\title{
Heinriel Semler
}

\section{Tropische und nordamerikanische \\ Waldwirtsehaft}

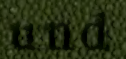

Holzkunde

UAVIVEลSIT

of

TORDNTO

Lenipr 


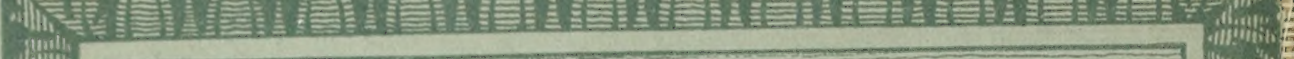

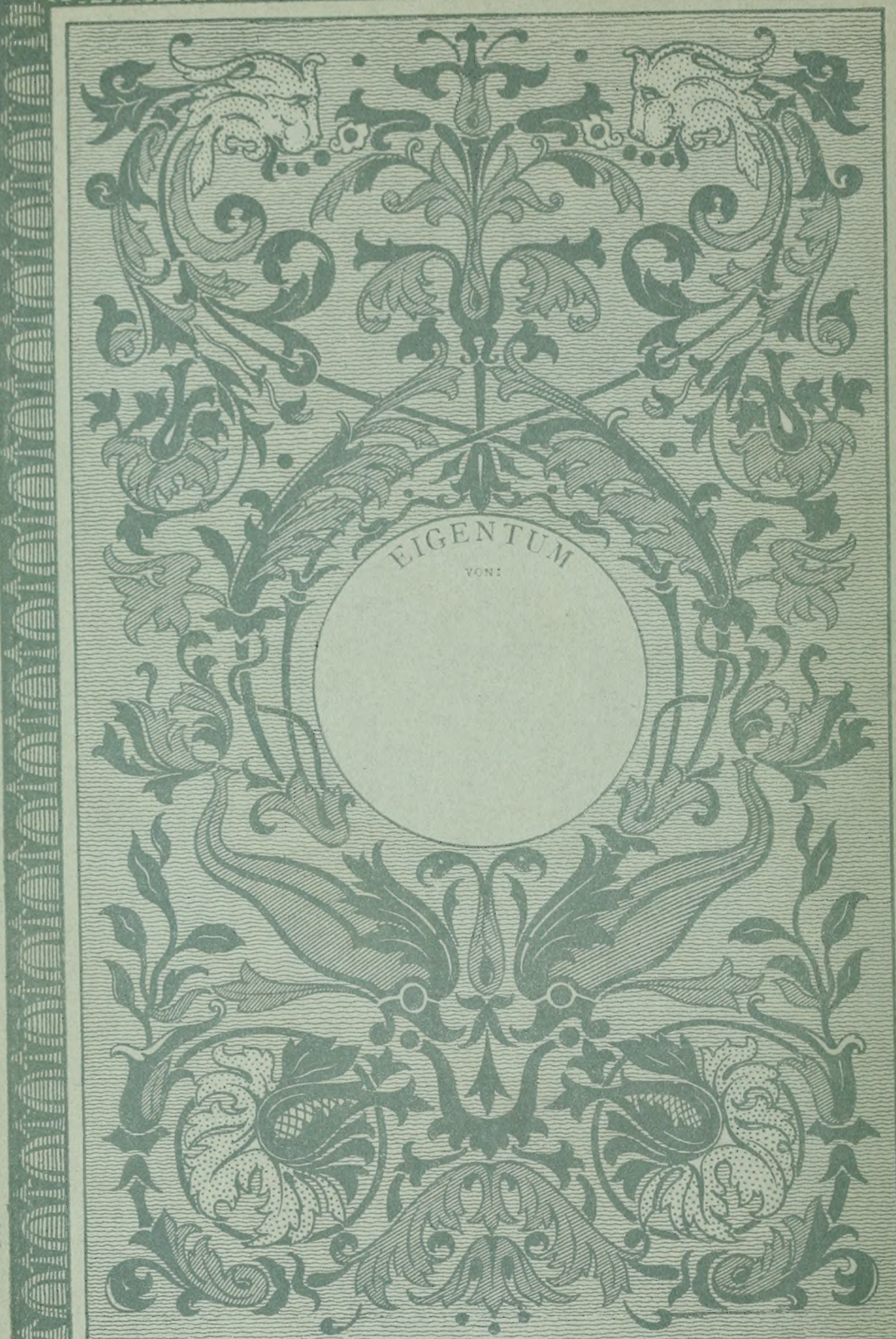






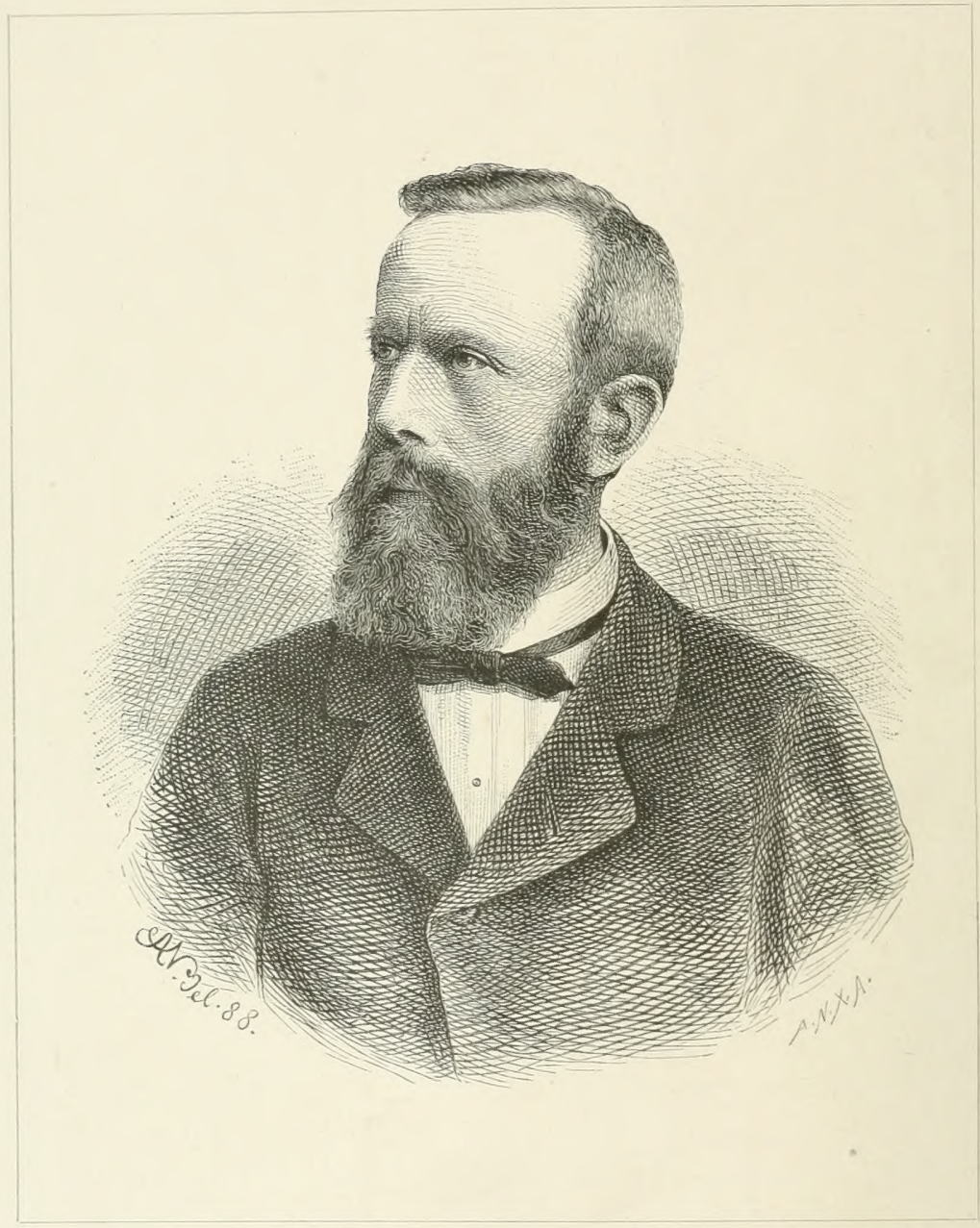

Heinrich Semler. 


\title{
Tropische und nordamerikanische Waldwitsschaft und Holzknnde.
}

\author{
Handbuch
}

für

Forstleute, Holz-Techniker und Händler in

Deutschland und im Auslande.

Von

Ieinrich Semler

in San Francisco.

\section{LIBRARY}
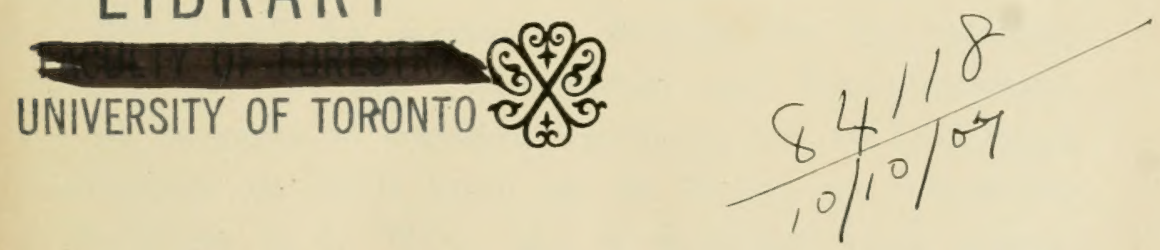

Mit einem Porträt und 62 Textabbildungen.

BERLIN.

VERLAG VON PAUL PAREY.

Terlagsbadluog fur Laedwirtschaft, Gartenbau und Forstuesea. 


$$
\begin{aligned}
& 50 \\
& 391 \\
& 54
\end{aligned}
$$




\section{Vorwort der Verlagshandlung.}

Zu. Beginn dieses Jahres erhielten wir von Herrn Heinrich Semler in San Francisco das Manuscript zu dem vorliegenden Werke mit dem Antrage, dasselbe in unserem Verlage erscheinen zu lassen. Da uns der Verfasser nicht nur durch sein bedeutendes Werk ,"Tropische Agrikultur" bekannt war, sondern wir uns auch überzeugten, dass dieses neue Werk des weit gereisten und erfahrenen Mannes, welcher sich sein ganzes Leben mit diesem Gegenstand eifrig beschäftigt hat, für unsere deutschen Forstwirte, Botaniker und Holzindustrielle von grossem Werte sei, glaubten wir diesem Antrage entsprechen zu können und entschlossen uns den Verlag zu übernehmen. -

Der Zweck des Werkes ist zunächst der, die Errungenschaften der modernen Forstwirtschaft und Forstwissenschaft, wie sie besonders im deutschen Vaterlande sich im Laufe dieses Jahrhunderts entwickelt haben, auf die Tropen und Nordamerika zu übertragen in der Weise, dass durch strenge Arbeit, gepaart mit Nachdenken und Vernunft, der dortigen systematischen Raubwirtschaft endlich ein wünschenswertes Ende bereitet werde und zum Wohle des gesamten Wirtschaftslebens rationelle Kultur und Ausnutzung an deren Stelle treten. Unseren deutschen Forstwirten und Holzindustriellen bietet das Werk mit besonderer Rücksicht darauf, dass man jetzt bemüht ist, nordamerikanische 
Waldbäume und amerikanisches Holz hier einzuführen, eine Fülle von Belehrung und Erfahrung.

Ein deutscher Fachmann, dem das Manuscript vorgelegen und der es mit grösstem Interesse gelesen hat, schreibt uns, dass der Verfasser in diesem Werke völlig neues Material von einem erfahrungsreichen, weitblickenden und vielseitigen Standpunkt behandelt und eine von vielen Fachleuten empfundene Lücke in der Kenntnis von den Bewaldungszuständen der Erde ausfüllt. - -

Noch bevor der Druck des Werkes begonnen, wurde Heinrich Semler von der Deutsch-Ostafrikanischen Gesellschaft nach Ostafrika zur Leitung ihrer Plantagen-Anlagen berufen. Aber schon nach kurzem Aufenthalte in Sansibar, nachdem er erst seit einigen Wochen eine vielversprechende Thätigkeit begonnen, erlag er am 7. Juli dieses Jahres einem Fieberanfalle.

Es war ihm leider nicht vergönnt, dieses Buch gedruckt zu sehen, obgleich es schon vor seinem Tode fertig vorlag. Infolge seiner Reise von San Francisco nach Sansibar, welche auf dem Umwege über Berlin erfolgen musste, war Herr Semler nicht in der Lage, die Korrektur des Buches selbst zu besorgen, aber Herr Hofmarschall von Saint Paul-Illaire, Vorsitzender der DeutschOstafrikanischen Gesellschaft und Herr Hermann Haché hatten die Güte, uns bei Drucklegung des Werkes zu unterstützen, wofür wir ihnen unsern Dank an dieser Stelle aussprechen.

In Heinrich Semler betrauern wir einen echten deutschen Nann, der, wenn auch von harten Schicksalsschlägen verfolgt, stets mit eiserner Kraft und Ausdauer gearbeitet und durch Wort und Schrift unendlich viel Gutes gewirkt hat. Es wird deshalb anch für unsere Leser von Interesse sein, seinen Lebensgang kennen zu lernen. Die nötigen Unterlagen verdanken wir einer im "Hamburgischen Correspondenten" veröffentlichten Biographie.

Heimich Semler ist am 18. Mai 1841 in Grünberg in Oberhessen als Sohn eines Landmannes geboren und erhielt in einem 


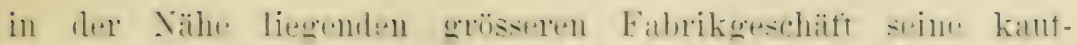

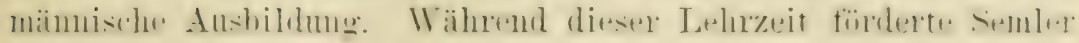

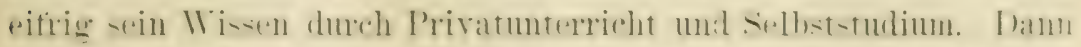

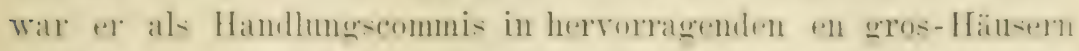

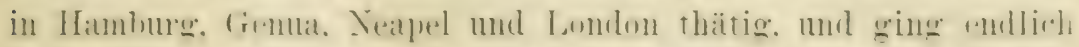

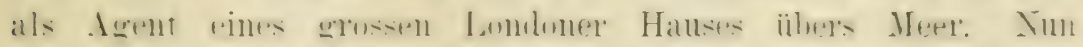

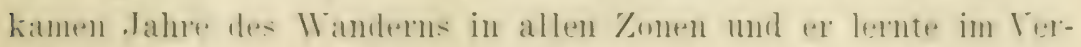

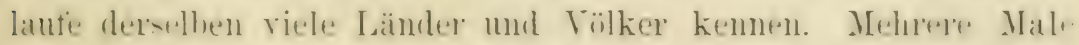
durchkrellzte er den firossen Uzean. mol wemn wir nicht irren. i-i

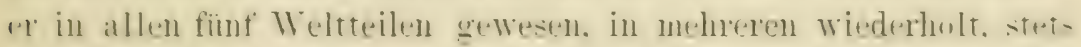

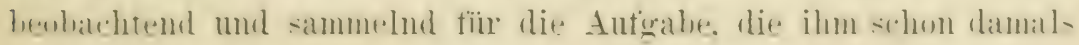
ver-hwebte: einst seinen dentschen Landslenten - die w - -

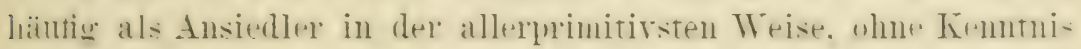
desern. was zu wisen nötig. mit Sichel nud spaten. dimen beiden Fraft- und Zeitverschwendern. hatte wirtschaften selon - ein. Anleitung zu shaffen, alls der sie lernen sollten. rinerspits, wir « druiben nicht gemarht werden müsse. mol anderseits. was zu henbarliten sei. wemn der in altem ererbten Aherelauben gar on häutiz noch für unerschöptich grohaltene tropische Beden da nernu nutzbar gemacht werden sollte.

Als semler nach vieler. Jahre langer Wanderschaft in sin. Heimat zurïkgekehrt war. übernahm er sein elterliches trütchen mul heiratete. Balil aber fand er. dass er in zu enge Terhältnisst getatell war und entschtoss sich. nach Amerika zu gehen. sich dont seshaft zu machen mor erst. nachilen ihm dies gelungen. seine Fanilie nachkommen zu lassen. Seit diesem Berimnen hatte cemler eine Reihe ron Tnglïtckschlägen und Enttäuschungen zu erleisn. E: gelang ihm nach mancherlei schwirrigheiten. im siirö-tlirhen Oregon eine Heimstätte zu finden. Er richtete sich ein. machte den Boden urbar. baute ein Haus für sich und dies Seinen. mol \&s schien srin Lnternehmen prächtig gelingen zu wollen. Ewar sine Lust. erzählte er. wie alles gerlieh! Xin war die Zrit 


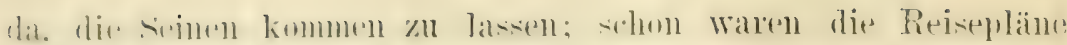

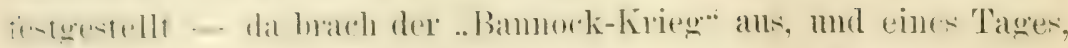

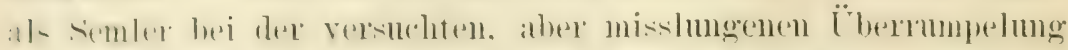

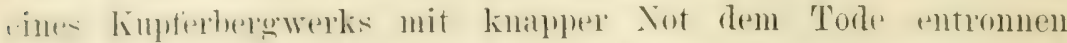
wat: whe sein Hats in Flammen anf. seine Felder woden verwiistrt. mnl anstatt seiner Fanilie entegegeneilen zu kïment trat

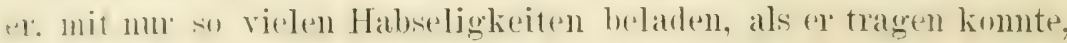
als armer Fliichtling an der Küiste ein.

syater siedelte semler sioh in einem Thale Kalifornions an. Es war rin prächtiges Fleckchen Erde. wie er berichtete, das sinen Mühen sohönen Lohn versprach. Fr wendete anf dieses Enternelumen alle Mittel, die ihm geblieben waren, trene Freunde halfen dazu. und wieder wuchsen seine Hoffnungen, wiedpr grediehen unte- seiner kundigen Hand die unternommenen Kulturen; ex wuchs md blühte, und in kürzerer Zeit, als er selbst gehofft, begamnen seine Felder Esträgnisse abzuwerfen. Nun glaubte er nicht länger zïgrern zu dïrten. die seinen zu sich kommen zu lassen - dnch abermals vertrieb ihn ein murhergesehenes Ungliick von seinem nenen Heim. Semler hatte bei dem Ankanf des Geländes in der Abfassmg des Vertrages alle üblichen Vorsichten angewendet, ex sclaubte sich vollkommen sicher in seinem Besitz; auch kümmerte sich niemand um ihn, solange das Land nicht urbar gemacht war; als aber Semler die Frïchte seiner Arbeit ernten wollte, da trat jö̈tzlich ein reicher Mann auf und sagte: „Das Land gehört mir." - Die aus mexikanischer Zeit ererbten unsicheren Bodenrechtsverhältnise und die jeder Schurkerei Thïr und Thor iffnenden fiesetze Kaliforniens gaben ihm leider Recht. Semler, der vermägenslose Mamn, komnte den Kampt gregen den Millionäı nicht weiter kämpfen, der ihm, die claim in her Hand, von deren Existenz dis dahin niemand eine Almung grehabt, von Haus und Hof reltrieb. Nur seine geringe bewegliche Habe blieb dem armen, abermals um die Fribchte seines schweisses betrogenen Mann. 


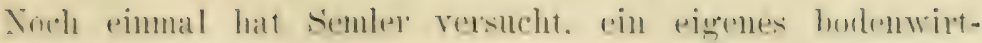
sohattiches Lnternedmen durhzusetzen. Whit einem \%writen zu-

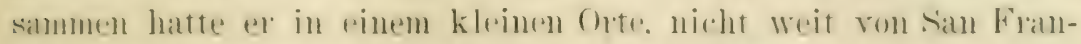

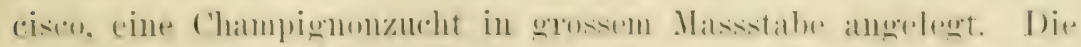

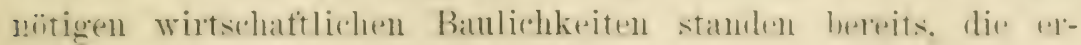

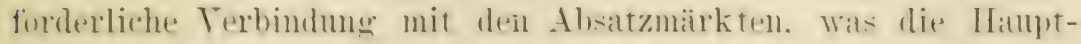
salche war, bot der kleine an einer Bahn gerlegene (1)t. den Tuter-

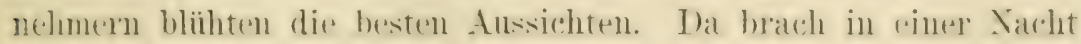

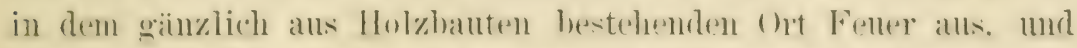

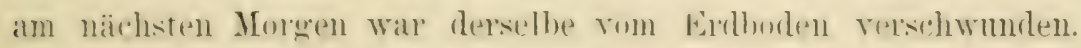

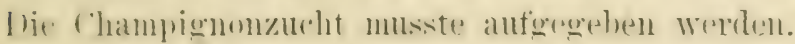

Sarh dem harten Verlust, den simler wolitt, als ihm seine Farm in Kalifomien genemmen worde. diurften ihm die Mittel getefehlt haben. sich noch rimmal anzukatufen. Fir liess sieh dautend in san Francisen als schriftsteller nieder. Mrehrere Male machte (') von dort aus grössere Ansflïge. eimmal anch nach Australien. un sich grössere Spezialkulturen anzusehen. wie ex dem anch zum Zwecke der Förderung seines Werkes: .. Ilie 'Trupische Agrikultur.*, an dem er vor nun zehn .Tahren zu arbeiten begamn. mit einer Reihe angesehener Pflanzer und Botaniker in lwhaftem schriftlichen Verkehr stand.

Mit tiefem schmerz muste dic Sachricht ron dem plïtzlichen Ende dieses Mammes berihren. Tahrzehnte lang hat er in tropischen und subtropischen Tändern geleht, hat allen klimatischen Einfliissen und mehrere Male auch Fipberanfällen gliirklich widerstanden, durch zahlreiche Fïhrlichkeiten. Unglïcksschläge und Enttäuschungen hat er sich hindurchgermogen. und mun, da er kaum ein Arbeitsfeld hetreten, welches so recht wie greschafien schien für seine Kenntnisie und Erfalmugen, seinen praktischen Blick und seinen ausdanternden Fleiss. win Arbeitsfeld, auf dem er nach allem menschlichen Ermessen mit reichem Erfolge gewirkt haben wïrde, num rafte ihn jäh der Tod hinweg, mat ex luht in der fernen fremden Erde - wieder einer der 
Braven, die hinanszogen für das Taterland und im IIrke'm tïi die Bedeltung und den Wohlstand Deutschlands in entlexpenen Zonen ihr Leben liessen.

\section{Ehre seinem Andenken!}

Berlin, im August 1888. 


\section{In ha l t.}

\section{Rundschau iiber die Walder der Erde}

seite

Jer Wald im Haushalte der Yatur . . . . . . . . . . 101

Der Einfluss des Waldes a uf die Luft . . . . . . 102

Der Wald als Wasserspeicher . . . . . . . 104

Der Einfluss des Waldes a uf das Klima . . . . . . 118

I)er Wald in beziehun zu den gesundheitlichen Ver.

hältnissen . . . . . . . . . . . . . 136

Verschiedene andere Dienste der Wä:der . . . . . 141)

I) ie Folcen der fintwaldnut . . . . . . . . . 14?

Grumdzïge der Forstkultur . . . . . . . . . . . . . 158

Pflanzenkunde . . . . . . . . . . . . 160

1. Die Pflanze im Allgemeinen . . . . . . . . 160

2. Die Wurzeln . . . . . . . . . . . 163

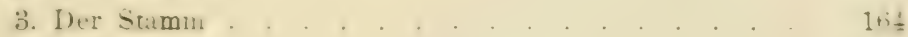

4. Iie Blitter . . . . . . . . . . . . . 16t

๖. Der Blütenstand . . . . . . . . . . . 168

6. Die Blüte im Allgemeinen . . . . . . . . 170

7. Der Kelch und die Blumenkrone . . . . . . . . 172

8. Die Staubgefässe . . . . . . . . . . . 114

9. Der Stempel . . . . . . . . . . . 175

10. Der Blütenboden . . . . . . . . . . . . 176

11. Die Frucht . . . . . . . . . . . 17

12. Her Samen . . . . . . . . . . . . 191

13. Jebenorgane . . . . . . . . . . . 133

Die Grundstoffe der Pflanzen . . . . . . . . 156

Die Klassifikation der Pflanzen . . . . . . . 188

Der Bau der Pflanzen . . . . . . . . . . 191

Das Wachstum der Pflanzen.......... . . 197 
Bodenkumbe

Die Behandlung des Samens . . . . . . . 227

bi, rersehiedenen Fortplanzungsmethoden der Wald-

bӓиme . . . . . . . . . . 2 230

Die Sat a uf die dauernden Standorte . . . . . . 231

Die Saat in die Baumschule . . . . . . . . . 237

l) bewurzelung ron Ablegern, stecklingen und

Schnittlingen . . . . . . . . . . . . . 248

Die Anpflanzung . . . . . . . . . . . . . 251

I) ie Plege des Waldes . . . . . . . . 263

Die Betriebssysteme . . . . . . . . . . 276

1. Der Lichtungsbetrieb . . . . . . . . . . 276

2. Der Schlagholzbetrieb . . . . . . . . . 277

3. Der Hochwaldsbetrieb . . . . . . . . . 280

Hilfsmittel fiir die Holzgewinnung . . . . . . . . . . . . . 284

Die Holzgewinnung im Territurium Washington . . 321

Die Holzflösserei in Kalifornien . . . . . . 329

Holzkunde

338

Die Struktur des Holzes . . . . . . . . . . 338

Die Zeit der Holzfällung . . . . . . . . . 352

Das Trocknen des Holzes... . . . . . . . 354

Die Charakteristik des Holzes . . . . . . . 364

Einteilung des Baublzes . . . . . . . . . . 372

a. Bauholzstämme . . . . . . . . . . . 372

b. Bearbeitetes Holz . . . . . . . . . . . 372

Unterweisungen von Queiroz, Moreia \& Comp. . . 373

Bretter . . . . . . . . . 373

Breite Bretter . . . . . . . . . . . . . 374

Schmale Bretter . . . . . . . . . . . . . $37 t$

Paos (Verbandholz) . . . . . . . . . . . $37 t$

Pernas (Verbandholz) . . . . . . . . . . . 374

Bohlen . . . . . . . . . . . . . 375

Bemerkungen . . . . . . . . . . . . . 375

Schluss . . . . . . . . . 375

Die Stärke des Holzes . . . . . . . . . . 376

Australische Hölzer . . . . . . . . . . . . 381

Resultate vom Oberst Ward . . . . . . . . 382

Resultate des Baron von Müller und J. (G. Lühmann . 382

Neuseeländische Hölzer . . . . . . . . . . . 383

Die Prüfungen von Thomas Laslett . . . . . . . . 384

Die nordamerikanischen Hölzer . . . . . . . . . . 389

Die Beurteilung der Farbhölzer . . . . . . . . . . 40;

Nebenprodukte des Waldes . . . . . . . . . . . . . . 410

Kohlen . . . . . . . . . . . . 410 


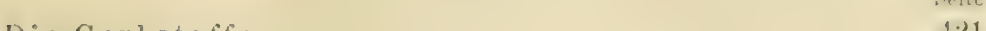

1. Gerberrinde . . . . . . . . . 421

2. Vallonea . . . . . . . . . . . 4 431

3. Galläpfel . . . . . . . . . . . . 4:31

4. Iyrabolane . . : . . . . . . . . . . 434

Pottasche . . . . . . . . . . . 435

Teer. . . . . . . . . . . . . 437

kientuss . . . . . . . . . . . . . . $43 k$

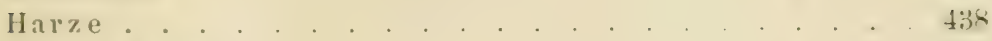

1. Kopal. . . . . . . . . . . . . 441

๖. Jammar . . . . . . . . . . . . . . . . . 444

3. liauri. . . . . . . . . . . . . 4tfi

4. Mastix . . . . . . . . . . . . 417

ј. Storax . . . . . . . . . . . . . . . 447

6. Sandarak . . . . . . . . . . . . it7

7. Benzoin . . . . . . . . . . . . 448

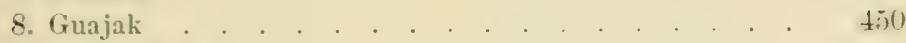

9. Gummilack . . . . . . . 4.51

10. Elemi . . . . . . . . . . . . . 4is

11. Balsame . . . . . . . . . . . . . . . this

12. Terpentin . . . . . . . . . . . $46 \pm$

13. Gummigutt . . . . . . . . . . . . . 474

14. Myrrhen . . . . . . . . . . . . 475

15. Weihrauch . . . . . . . . . . 488

16. Gummi . . . . . . . . . . . . . 481

Ahornzucker. . . . . . . . . . . . . . 4 . . . . . . . .

Querzitron . . . . . . . . . . . . . 442

kermes. . . . . . . . . . . . . . . $44 t$

Kino . . . . . . . . . . . . . 495

Farbhilzer . . . . . . . . . . . . . . . 497

Blauholz . . . . . . . . . . . . . . . . . . . . . . . . .

Brasilienholz . . . . . . . . . . . . . . . 499

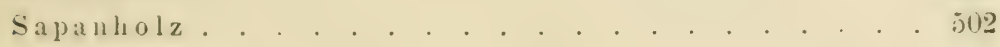

Caliaturholz . . . . . . . . . . . . . . 50弓

Camhol\%. . . . . . . . . . . . . . 507

Fustik. . . . . . . . . . . . . . . . 51

Fiset. . . . . . . . . . . . . . . . 508

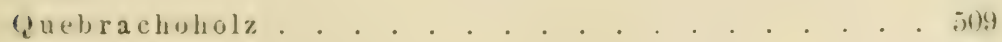

Grünes Ebenholz. . . . . . . . . . . . . . j11

Wohlriechende Hölzer . . . . . . . . . . . . . . . 511

Die kulturwirdigen Hölzer . . . . . . . . . . . . . . . . 521

Die nordamerikanischen Hölzer . . . . . . . . . . 52?

1. Eichenholz . . . . . . . . . . . . . 502 
a. Weisseiche . . . . . . . . . . 523

b. Posteiche, Eiseneiche . . . . . . . . 527

c. Lebenseiche . . . . . . . . . . . 528

d. Burreiche . . . . . . . . . . 530

e. Korbeiche . . . . . . . . . . 5 51

2. Buchenholz . . . . . . . . . . . 532

Nordamerikanische Buche . . . . . . . . . . 532

3. Kastanienholz . . . . . . . . . . . . . 534

Nordamerikanische Kastanie . . . . . . . . . 534

4. Birkenholz . . . . . . . . . . . . . 536

a. Gelbe Birke. . . . . . . . . . . . 536

b. Schwarze Birke . . . . . . . . . . . 537

5. Magnolienholz . . . . . . . . . . . . . 538

Grossblütige Magnolie . . . . . . . . . . 538

6. Tulpenholz . . . . . . . . . . . . . . . . . . . . . . . . . . .

Tulpeubaum . . . . . . . . . . . . . . 541

7. Stechpalmenholz . . . . . . . . . . . 542

Nordamerikanische Stechpalme . . . . . . . . 542

8. Ahornholz . . . . . . . . . . . . . 5

Zuckerahorn .. . . . . . . . . . . 544

9. Akazienholz . . . . . . . . . . . . . 547

10. Mesquithoiz . . . . . . . . . . . 550

11. Kirschholz . . . . . . . . . . . . 551

12. Hartriegelholz . . . . . . . . . . . . 553

13. Tupeloholz . . . . . . . . . . . . . 551

14. Virginisches Dattelpflaumenholz . . . . . . . 556

15. Schwarzes Dattelpflaumenholz . . . . . . . 557

16. Eschenholz . . . . . . . . . . . 557

Weisse Esche . . . . . . . . . . . 558

17. Catalpaholz . . . . . . . . . . . 562

18. Sassafrasholz . . . . . . . . . . 565

19. Californisches Lorbeerholz . . . . . . . . 567

20. Ulmenholz . . . . . . . . . . . . . 568

Felsenulme . . . . . . . . . . . 569

21. Macluraholz . . . . . . . . . . . 571

22. Wallnussholz . . . . . . . . . . . . 573

Schwarzer Wallnussbaum . . . . . . . . 573

23. Hickoryholz . . . . . . . . . . . . . 576

a. Weisser Hickorybaum . . . . . . . . . 577

b. Spötternussbaum . . . . . . . . . . 578

c. Muskatnusshickorybaum . . . . . . . . . 579

24. Oregoncedernholz . . . . . . . . . . . 584

Lawsonceder . . . . . . . . . . . . . 584

25. Weisses Cedernholz . . . . . . . . . 586

Weisse Ceder . . . . . . . . . . . 586

26. Rotes Cedernholz . . . . . . . . . . . 587 
Soite

Rote Ceder . . . . . . . . . . . . 587

27. Schwarzes Cypressenholz . . . . . . . . . . . . 589

Schwarze Cypresse . . . . . . . . . . . 58?

26. Kotholz . . . . . . . . . . . . . 590

Rotholzbaum . . . . . . . . . . . . . . 590

29. Weymouthskiefernholz . . . . . . . . . . . . . 593

31. Zuckerkiefernhol\%. . . . . . . . . . . . 598

31. Rotkiefernho!z . . . . . . . . . . . . . . . . 600

:32. Pechkiefernholz . . . . . . . . . . . . . 602

33. Wiesenkiefernholz . . . . . . . . . . . . . . $6(04$

34. Gelbkiefernholz . . . . . . . . . . . . 605

3i. Westliches Gelbhiefernhol\% . . . . . . . . . . . 607

3it. Schwartichtenholz. . . . . . . . . . . . 609

:37. Strandtichtenholz . . . . . . . . . . . . . . 6110

Strandfichte, Sitchafichte . . . . . . . . . . . 610

38. Douglastannenholz . . . . . . . . . . 612

39. Edelfichtenholz . . . . . . . . . . . . . 615

40. Tamarackholz . . . . . . . . . . . . 616

Verschiedene, nach dem Alphabet geordnete Hölzer. 618

1. Akazienhölzer . . . . . . . . . . . . . 618

a. Myallholz . . . . . . . . . . . . 619

b. Schwarzholz . . . . . . . . 620

c. Himbeerduftendes Holz . . . . . . . . . . . 620

d. Sabicuholz . . . . . . . . . . . . 620

2. Angeliqueholz . . . . . . . . . . . 622

3.) Araukarienhölzer . . . . . . . . . . . . . . . 622

t. Buchstabenholz. . . . . . . . . . . . 625

5. Buchsholz . . . . . . . . . . $626^{\circ}$

6. Calamanderholz . . . . . . . . . . . 629

7. Casuarinahölzer . . . . . . . . . . . . . . . 629

(Cedernhölzer s. Nr. 48 unter Z.)

\&. Chittagonyholz . . . . . . . . . . . . . 631

๕. Ebenhölzer . . . . . . . . . . . . . 631

10. Eisenhölzer . . . . . . . . . . . . 634

11. Eucalyptushölzer . . . . . . . . 636-666

12. Grünherz . . . . . . . . . . . . . . . . $67 \%$

13. Halmalilleholz . . . . . . . . . . . . . . . 674

14. Huontichtenhol7. . . . . . . . . . . . . 674

15. Jacarandaholz . . . . . . . . . . . . . 675

16. Kassou-Khayćholz . . . . . . . . . . . . . 676

17. Kaurifichtenholz . . . . . . . . . . 677

1\%. Kokraholz . . . . . . . . . . . . . 678

19. Lanzenholz . . . . . . . . . . . . . 678

211. Mahagoniholz . . . . . . . . . . . 679

21. Miroholz . . . . . . . . . . . . . . . 685

2.). Molaveholz. . . . . . . . . . . . (limi) 
2i. Moraholz

24. Niessholz

๑5. Pockholz

26. Porkupnienholz

27. Puririholz

28. Purpurholz

29. Pyengaduholz

30. Rataholz.

31. Rebhuhnholz

32. Rhodiumholz

33. Rimuholz

34. Rosenholz

35. Safranholz

36. Salholz

37 . St. Martinholz

38. Santalholz

694

39. Seidenholz

40. Tacamahacaholz

41. Tanekahaholz

42. Teakholz

43. Toonholz.

4t. Totaraholz.

45. Wallabaholz

46. Zebraholz

47. Zederachholz

48. Zederuhölzer

1. Eichenhölze⿺

2. Wallnussholz

3. Erlenholz.

4. Eschenholz

๖. Buchenholz

b. Birkenholz

7. Kastanienholz

8. Ulmenholz

4. Hainbuchenholz

10. Aspenholz

11. Ahornholz

12. Kiefernholz

13. Tannenholz

14. Fichtenholz

15. Tä̈rchenholz 


\section{Terzeichnis der Abbildungen.}

baumyr:iber

$\therefore: \therefore$

Englische Schmabelhaue

Iiaumschneider

Baumsägre, langstielige, amerikanische

Axt, nordamerikanisehe

Axtstiel

Schindelbeil, Handbeil, Spannsäge

Fuchsschwanzsïge

Blockisäze . .

Wheelers Wood Sawing Sïgemaschine

lieitersäge

Scheitholzsäge .

Bullsitge

Folding Sawing Machine.

Drag Saw Machine . . . . . . . . . . . . . . . . - . . . . . .

Kraftmaschine-Pferdetretmühle (Railroadhorsepower) . . . . . . . . 2.9?

Dampisägemaschine von Hill of Co. . . . . . . . . . . . . . . .

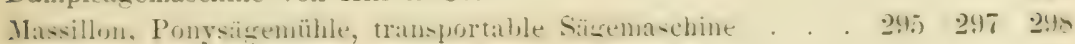

Green Jountain shingle of heading machine . . . . . . . . . . . . . . . .

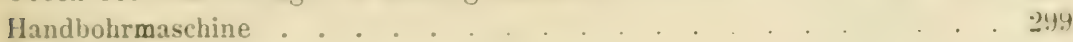

Windelbohrer (Breast drill borer). . . . . . . . . . . . 3ill

Hand windelbohrer oder Handdrillbohrer . . . . . . . . . . . . Bun

Blockwinde (timberjak) . . . . . . . . . . . . . . . 3ill

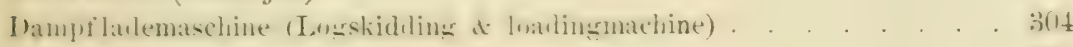

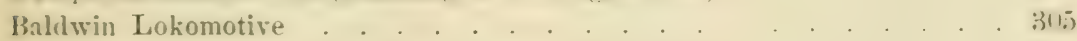

Rotholzblock . . . . . . . . . . . . . . 3111

Zug, beladen mit Rotholzblöcken . . . . . . . . . . . . . . . 307

Sïgremühle am Pugetsund . . . . . . . . . . . . . . . . . \$1⿴囗十

liutschbahn (Chute) . . . . . . . . . . . . . . . 311

langedger . . . . . . . . . . . . . . . . . . . 31:

Shepardson's Patent Latte Binder. . . . . . . . . . 31t

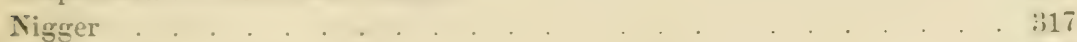

Bandsige . . . . . . . . . . . . . . . . . . 319

Einjähriger Zweig der Eiche . . . . . . . . . . . . 3:̈ч

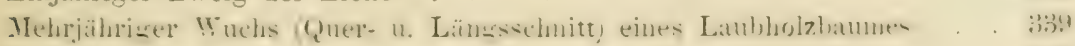

Kieilfömiges Stück Buchenholz aus einem Querschnitt . . . . . . . \$3̆丶

liernrissiøes $\mathrm{Holz}$. . . . . . . . . . . . . . . . . . . i4t!

Sternrissiges Holz . . . . . . . . . . . . . . . . 3in

Kireisrissiges oder tassenrissiges $\mathrm{Holz}$. . . . . . . . . . . . . 3il

Flechiges $\mathrm{Holz}$. . . . . . . . . . . . . . 3.il

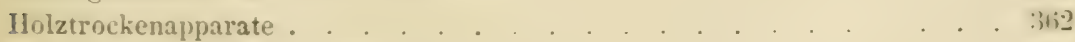

Trockenkammer mit Geleise . . . . . . . . . . . . . . . . 3 3

Crummi- (Stock-) Lack, Längsschnitt . . . . . . . . . . . . . 4.2 
Totes Insekt im Gummilack . . . . . . . . . . . . . 453

Weymouthskiefer, behauener Block . . . . . . . . . . . . 595

Rotkiefernholz, zur Ausfuhr gelangende Blöcke . . . . . . . . . . \$01

Zerlegung des Jarrahholzes . . . . . . . . . . . . . . . . . 668

Block rom spanischen Mahagoni . . . . . . . . . . . . (iא?

Block ron afrikanischen Teakholz . . . . . . . . . . . . . 712 


\section{Romdschlatu äleer die Wïlder der Erde.}

Die Kunlturgeschichte miseres Geschlechts lehrt mis die tran-

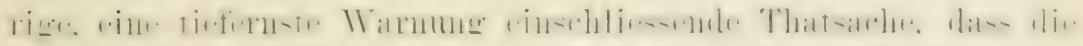

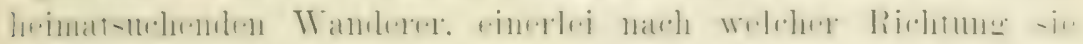

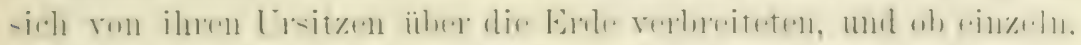

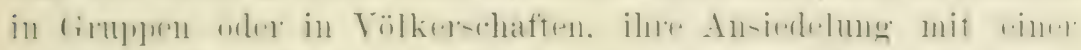

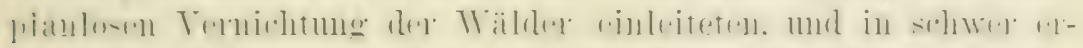

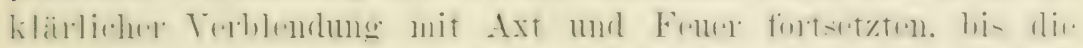

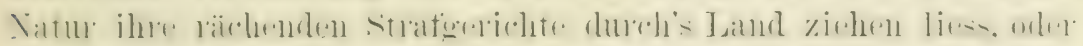
grar, bis es nichts melur zu rernichten gab. So ist es getresen

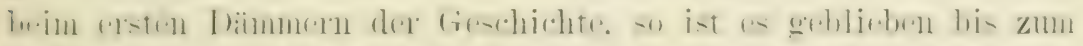

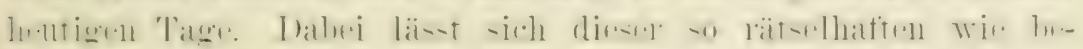

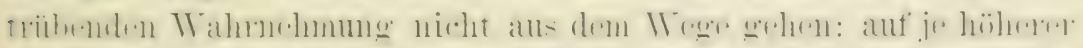

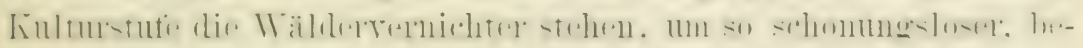

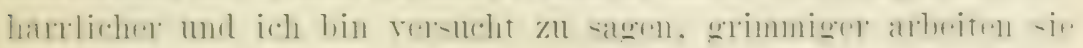

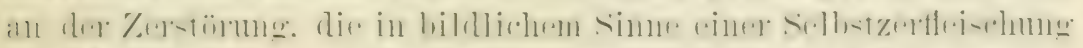

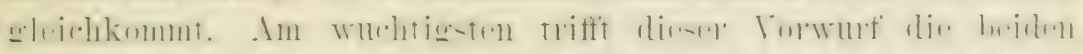

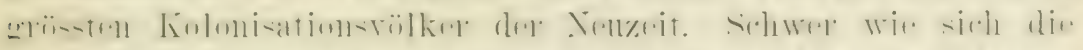

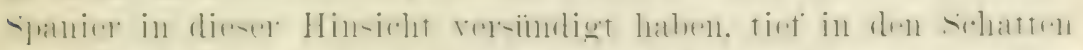

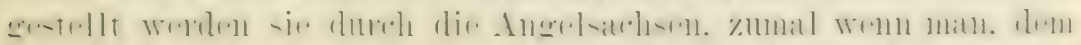

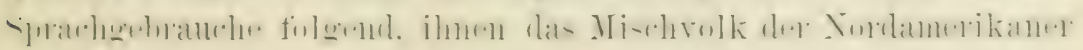
beizälntt.

Es wird eingewandt: der Ansiedler in der Wildnis milsse

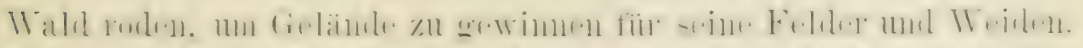

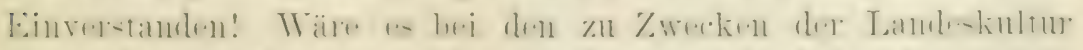

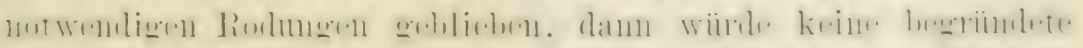

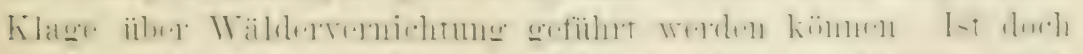

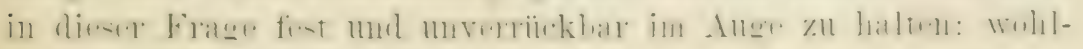




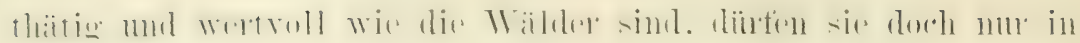

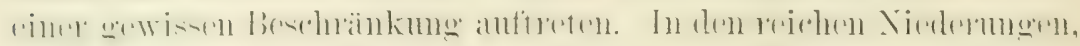

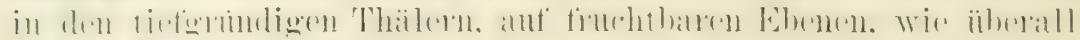

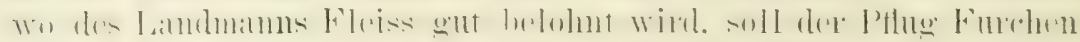

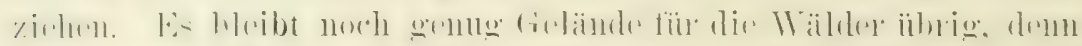

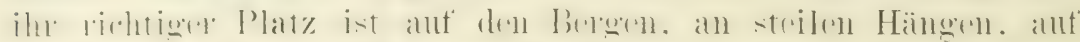

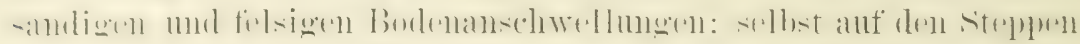

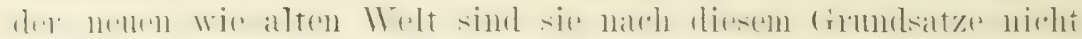

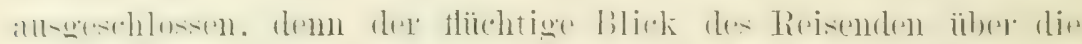

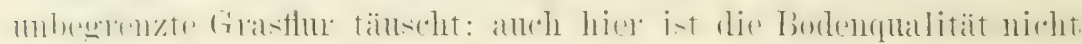

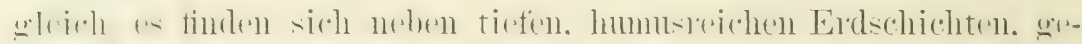

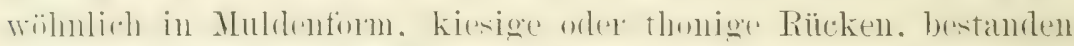

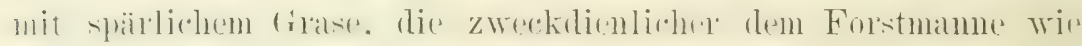
dem Ackerbatler über'wiesen werden.

Nein, es ist nicht die Terwandelung des Waldes zum Acker;

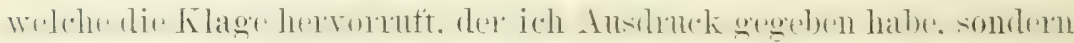

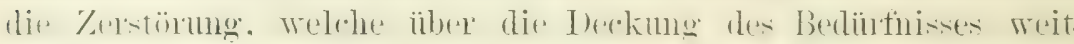

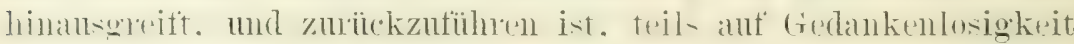

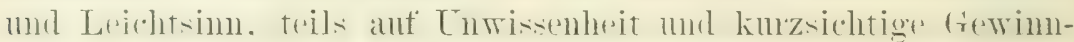

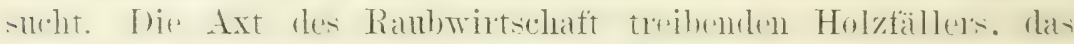

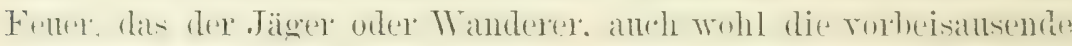
Lokomotion "ntfacht, die Herde des sehat- mol Ziegenhirten, dis

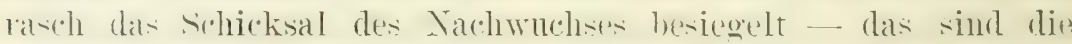
Terwioter im grossartigen stile. die das Lnheil stiften. Wolches zu schweren Vorwiurfen herausfordert.

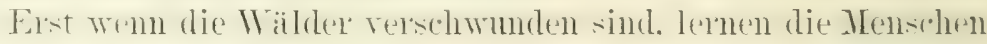

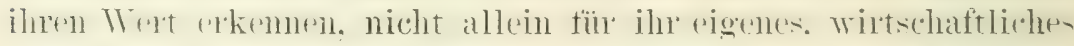

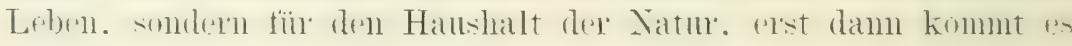

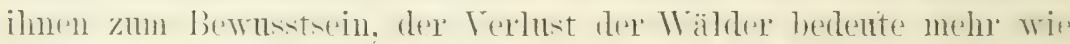

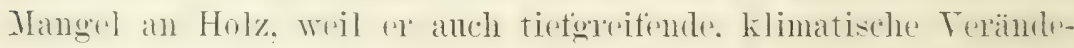
rungen in moinstiger Richtung zur Folge lat, die strömmenen

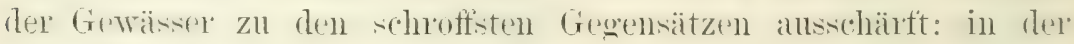
einem . Tahnesteit treten sie in verheerenden Toberschnemmungen ïber ihre Ltere in der andern versagen sie Lasten zu tragen mud das Rarl der Mïhle zu treiben. Ind es fïr den Flugsand hein Hindernis meln gibt. $10 \mathrm{~m}$ im spiele mit dem Wrinde todbringent g'egen die Felder des Ackerbaners vorzurïcken.

Völker, rle im Niedlergange sind. muterwerfen sich, die Händes

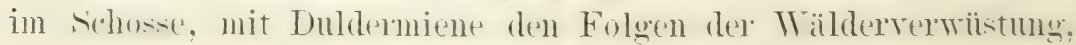




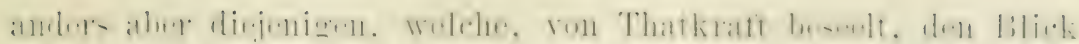

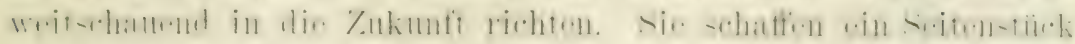

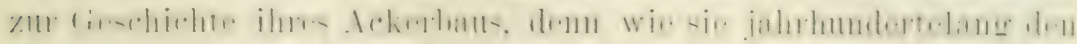

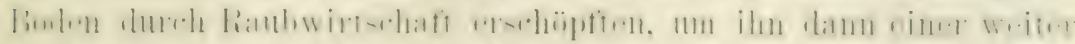

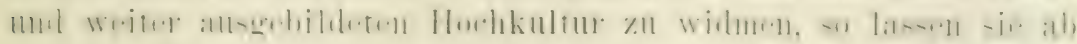
von der Wälderverwiistung, mu an ilne Stelle cine anf wissent-

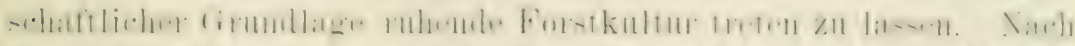

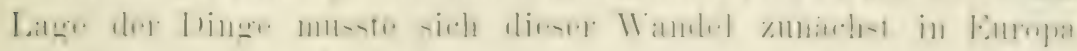
vollziehen. wo es hente keinen Kulturstant im wahlhaften Simm dieses Wortes qibt, der sich nicht zu dem Grondsatze bekennt:

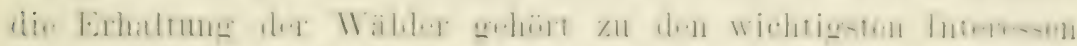

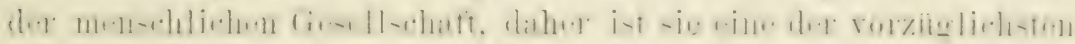

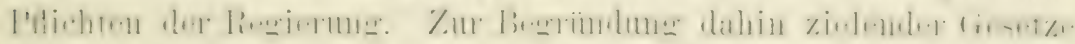

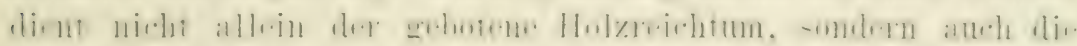

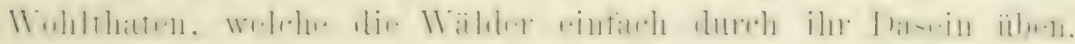

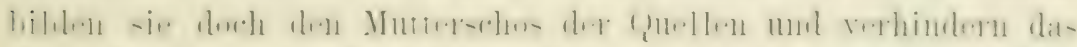

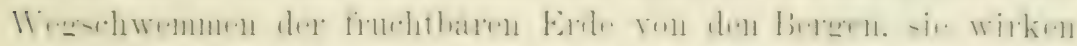

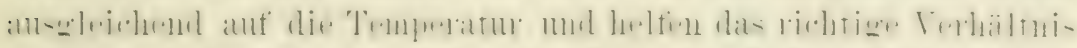

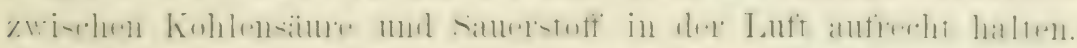

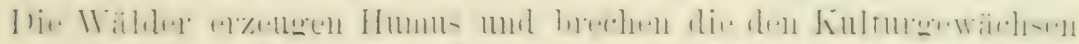

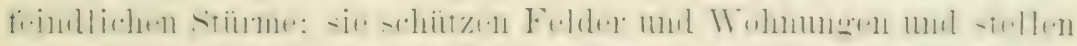

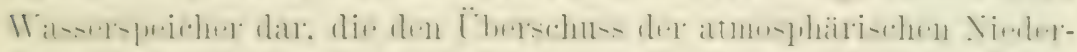

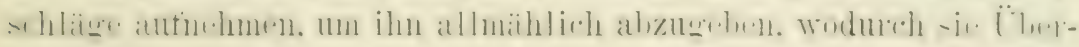

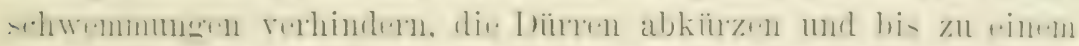
gewissen Grade die Fenchtigkeit der Luft regeln.

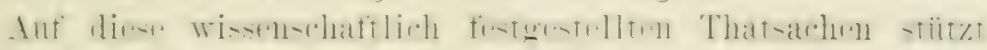

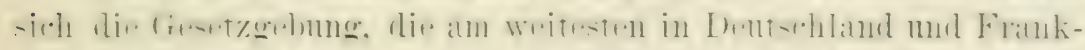

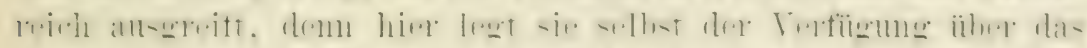

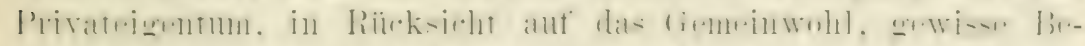

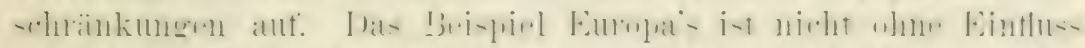

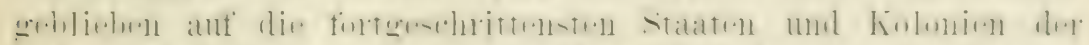

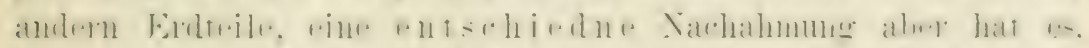

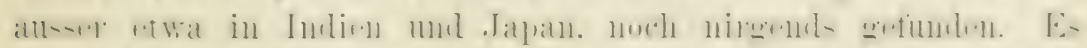

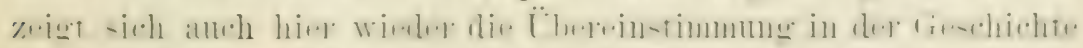

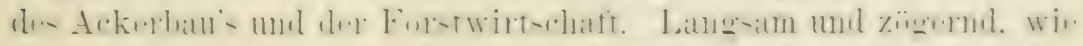

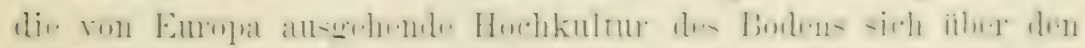

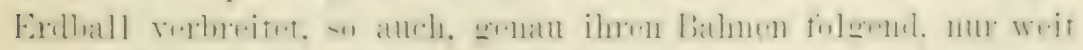
zurïckbleibend, die Líultur des Waldes.

Nordamerika setzt zwar seine in der iiltern wie neuern Ge- 


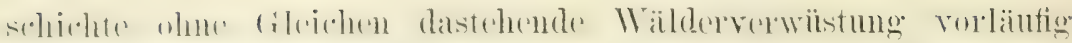

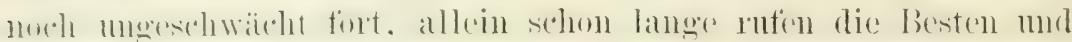

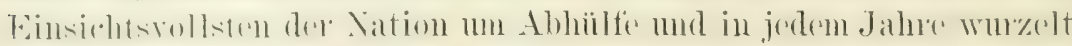

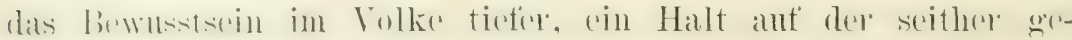

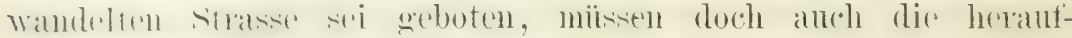

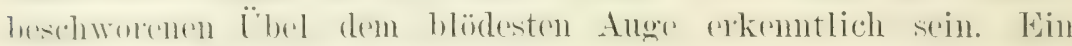

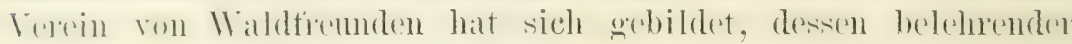

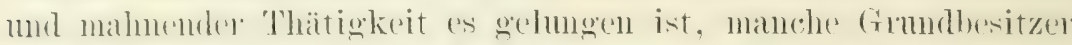

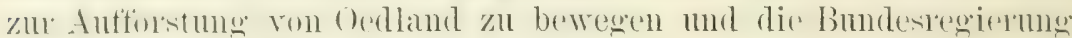

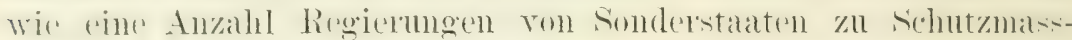

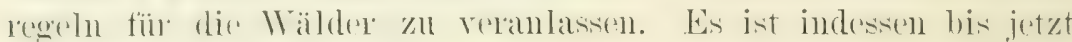

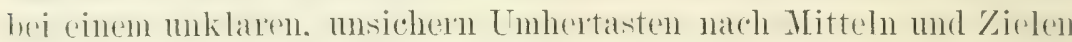
geblichen mol bei den herrsehenden Ansichten ïber die dem state.

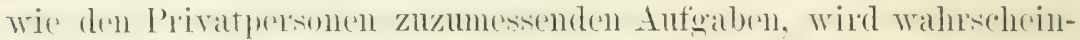

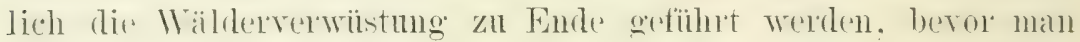
den Granben an die Heilwirkung einer starren, einseitigen Lehrmeinumg aufgibt.

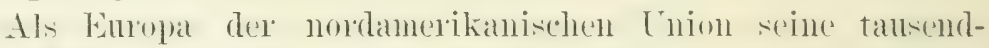
jïhrige Kultur als Wiegengeschenk überwichte, gab es allch soine Forswisenschaft mit und alle Erfahrmeren. welche sich an diesclbe kniipten. Irit diesem Femntnisschatze wäre es ihr leicht. mit sioherer Hand eine Forstkultur zu schaften. allein sie zield es vor, von eignem Gutdiuken geleitet, moherirend das Ziel zu suchen. Das in allen Tonarten besungene Gesetz iiber Land-

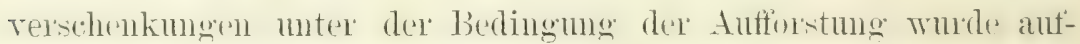

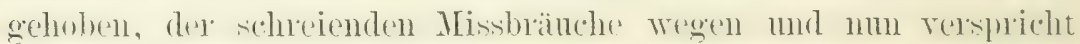
man sich alles Heil won den amtlichen Anordnumgen von jïhrlichern

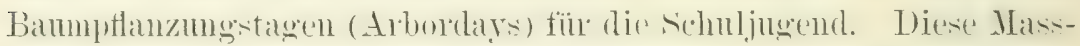

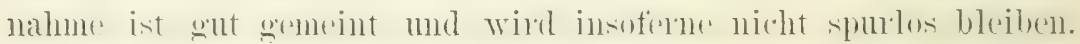

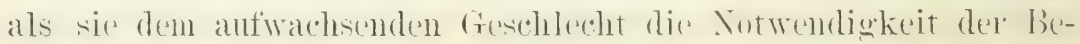
waldumg eines Teik des Bolens zum bewasterin bringt. Wer

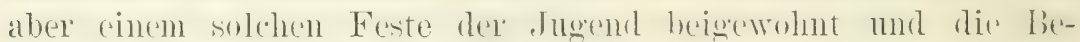

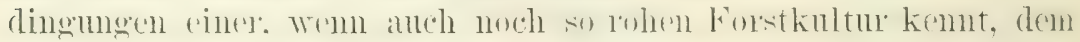

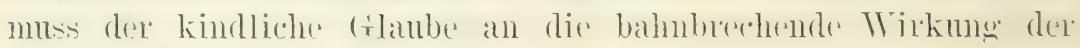
Baumpflanzungstage ein Lächeln abnötigen.

Australien hatte weder im Gesamt noch im Verhältnis so

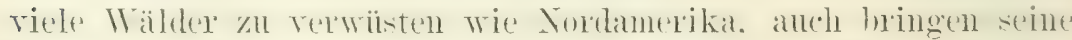
klimatischen Verhälnisse die störmeren. welche das Terschwinden

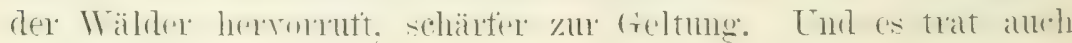


Finer fïr die Wäilder ein, vor dem sich alle achtungstonll verneigen: unser berïhnter Landsman baron von Mï̈llex in

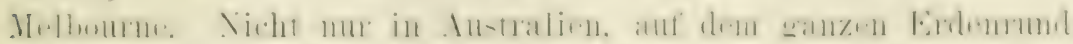

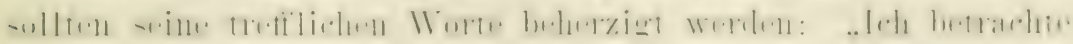

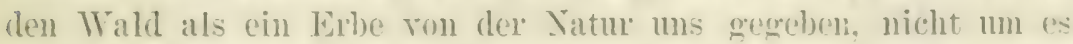
zu verderben oder zu verwiisten. sondern um es weise zu benutzen.

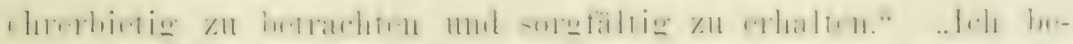

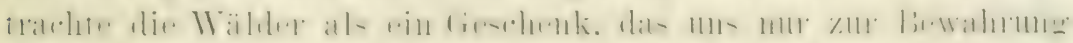

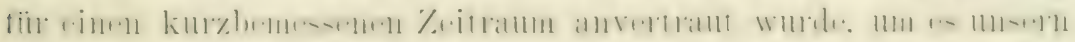

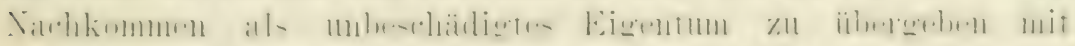

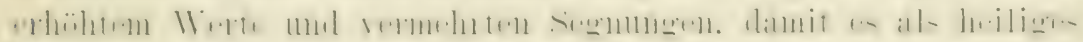
Erbgut von einer Generation zur andern iibergehe:"

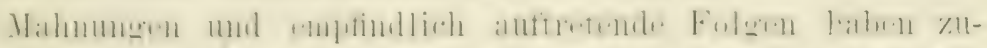

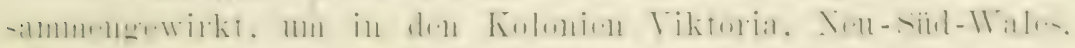

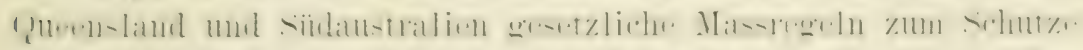

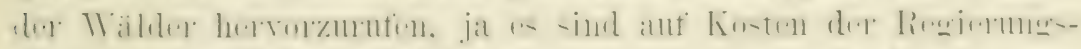

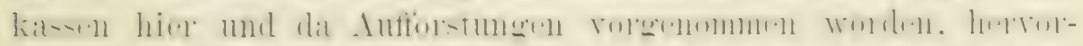

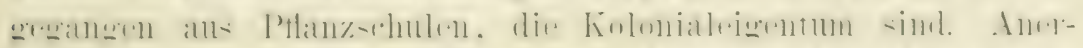

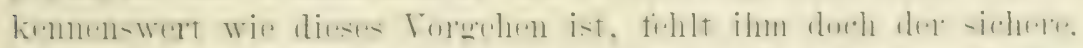

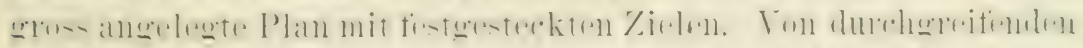

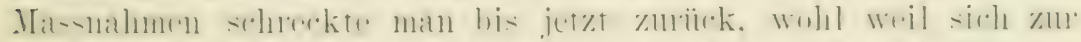

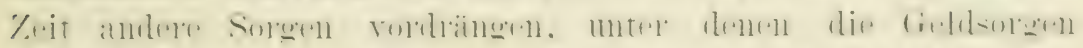

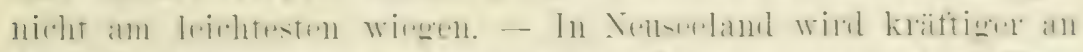

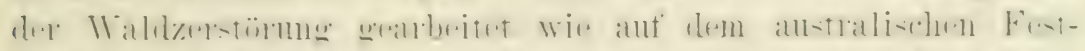

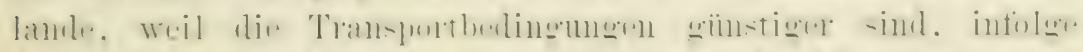

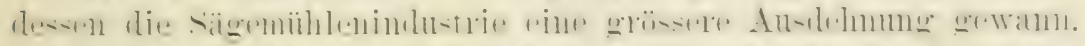

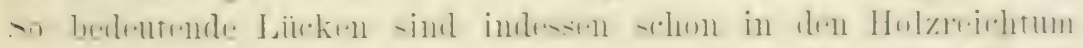

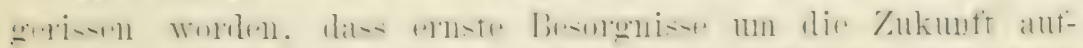

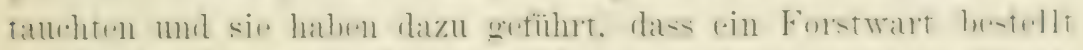

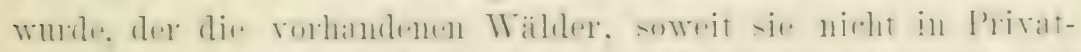

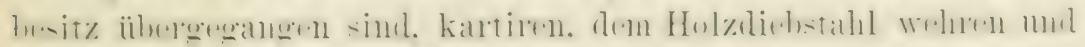

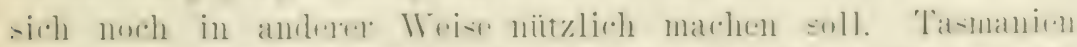

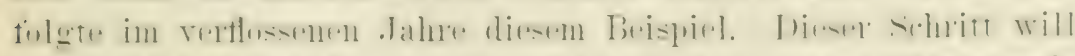

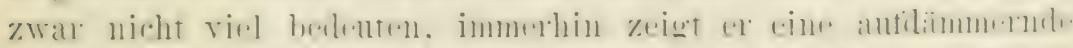

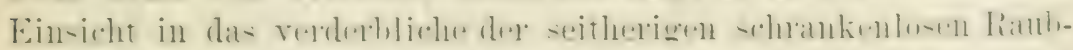

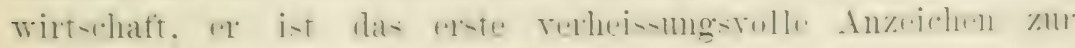
Umkehr auf dem abschiissigen Wege.

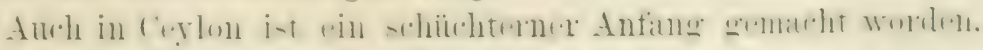

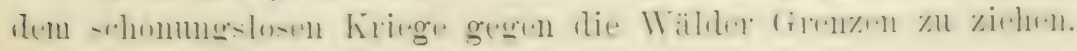




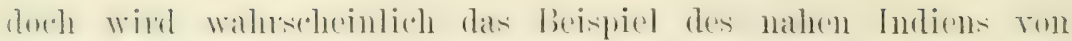

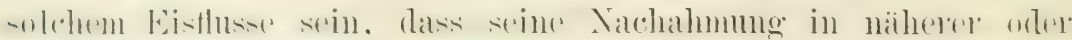
fernerer /nkmuft sicher zu erwarten ist. Tndien — das ist das

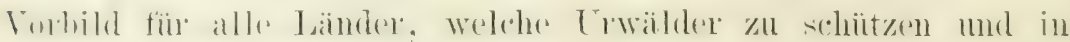
Linlumälder umzuwandeln hahen. Ansserhalb Europats hat man

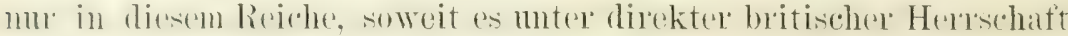
steht, erkannt, dass nur wenn der Staat die Wälderbewirth-

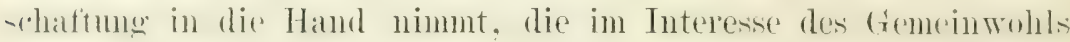
notwemdigerweise zal steckenden ziele erreichbar sind. Wo man -ich dieser Einsicht rerschliest. wird es bei gut gemeinten Tol-

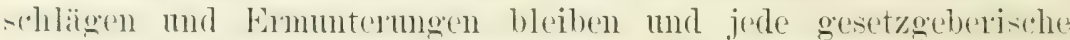
Mastregel rin schlag ins Wassel sein. Damit ist nicht geteagt, Forstkultur med Privatbesitz seien unverträglich; im fregenteil die Mitwirkmo rom Privatpersonem in der Erhaltme mol Pflege dere Wälder kamn nur prö̈nscht sein, allein dem stade mus- pin allseichender trmulstock ron Wäldern zufallen. um das Bediurfnis decken zu kömnen, mabhängig von dem Belieben und Können der Privateignentïmer des Bodens. Die Masse dex Letzteren zeigt, wie dir Erfahrung in allen Ländern lehrt, keine warme Anteilnahme an dex Forstkultur, wofür die Erklärung gesucht und erefundern wird: dex Wald wirft erst mehrere Tahrzehnte nach seiner Anptlanzung eine Rente ab; wohl kann der statat so lange warten. der Privateigentimer aber kamn oder will es nicht; fercere muss die Beschïtzung kleiner Waldflächen entweder unterbleiben. oder sie steht aluser Verhältnis zu den zu crhoffenden Frträgen. Auch die Lnsicherheit des Besitzes wird hervorgehoben. am häufigsten in Nordamerika. Hier werden mit zuverlässigster Regelmässigkeit jährlich viele tansend Hektar bewaldete Flächen durch Fenex zu öden Brandstäten verwandelt. Schwebt nicht mithin das Resultat jahnzehntelanger Wartmo und Zinsenanschwellung in stetel Gefahr, eines 'Tages in Rauch aufzugehen?

Der Nachweis wäre nicht schwierig, dass diese Darstellung in viel'n Fällen haltlos, in anderen übertrieben ist, allein sie herrscht und die indische Regierung that wohl daran. mit dieser Thatsache zu rechnen und anstatt kostbare Zeit zu vergenden. die Aufgabe der Furstkultur mwilligen Grundbesitzern auf die schultern zu wïlzen, selbst zu ïbernehnen. I'nd sie machte sich keiner Halbheit schuldig: nach breit angelegtem Plane ging sie "ntschlossen vor und der Lohn liess nicht anf sich warten 


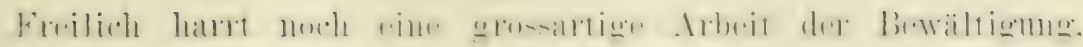

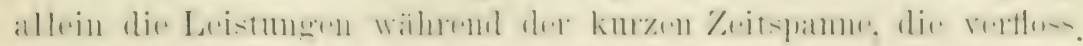

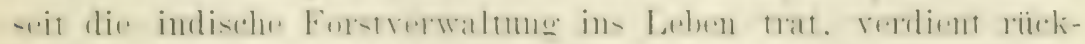
haltlose Anerkenumug.

Z/u nemen ist num noch hïchstens Britisch finiana. wo an

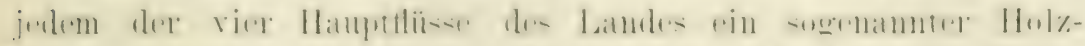
inspektor eingesetzt wurde, der sorgen soll, dass der IV'ald-

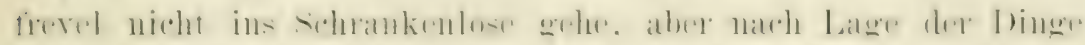

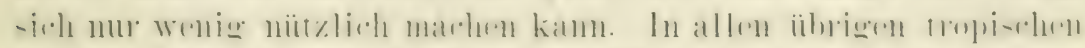

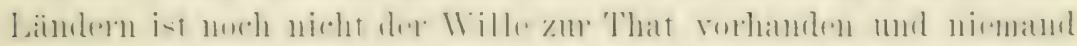

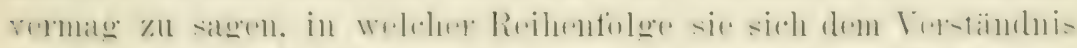

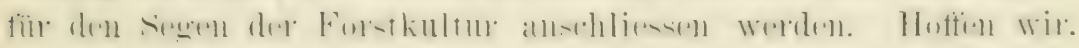
dass die dentschen Kolonien den Vortritt nehmen. Lommt es

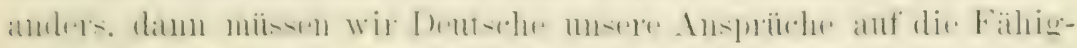

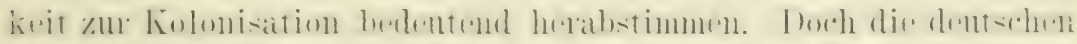

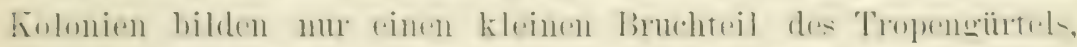

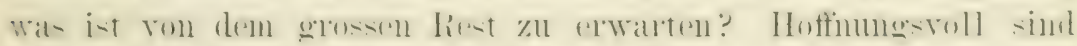

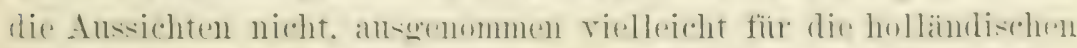

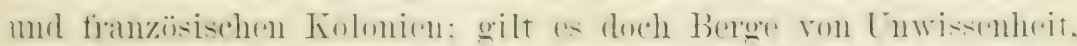

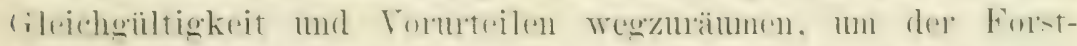

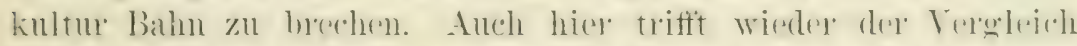

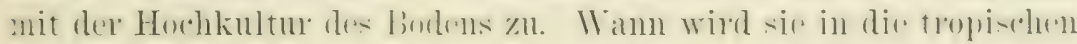

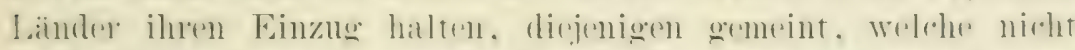

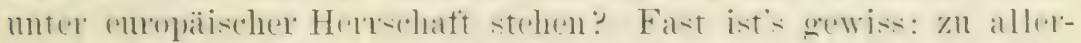

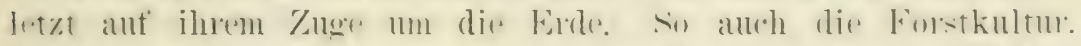

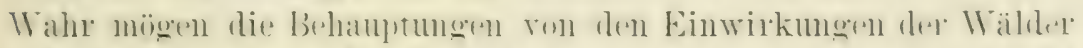

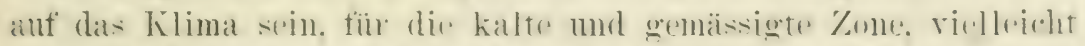

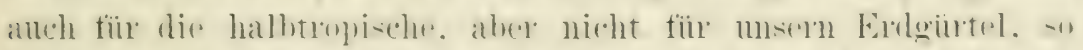

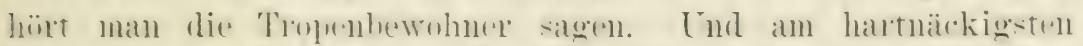
hängen sir an denn Wahne. fïl dir klimatisehene wir Arkerban-

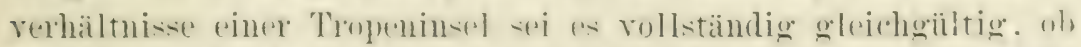
Wälder vorhanden wien where niteht. Als ob das westindiseles Simta lruz, als ob Mamitius mol Havaii nicht in scharfer wohrift ilas ferenteil leheten! Wartun sullen wir uns mit Wäldern ah-

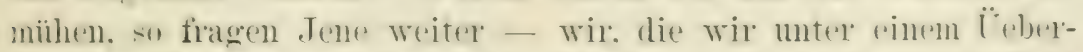

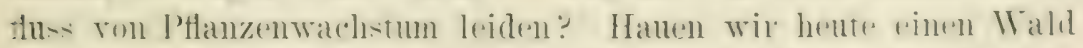

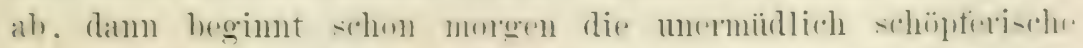

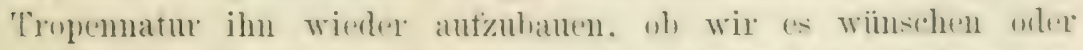

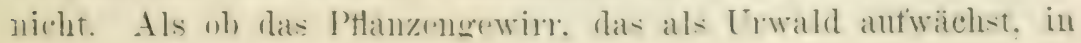




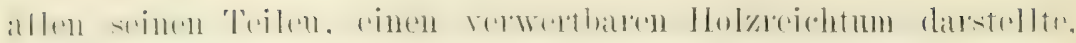

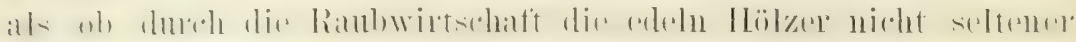
und seltner: werden und schliesslich rerschwinden mïssten!

Da rernichtet der Eine den Wald, weil ex wilde Tiere

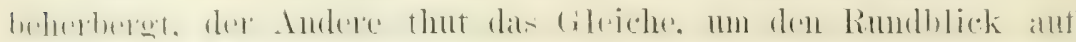

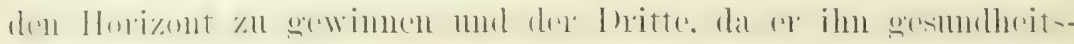

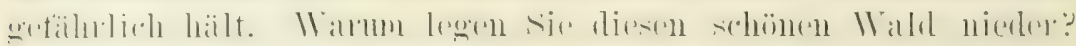
fragte ich einst einen Ansiedler. Weil die Wälder zu ihrer Er-

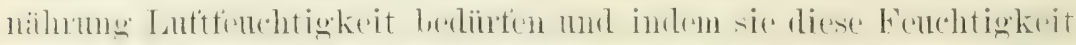

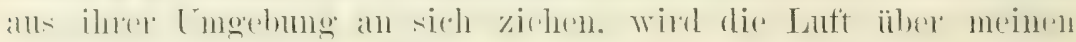

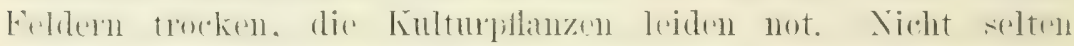

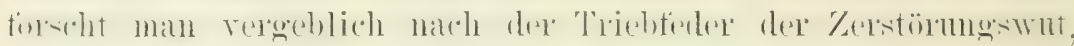

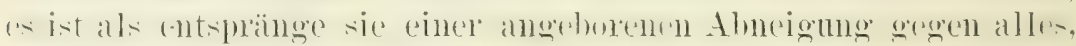

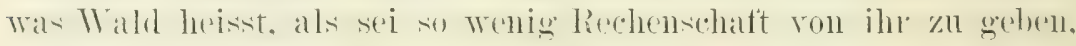

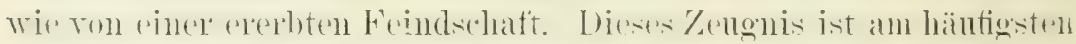

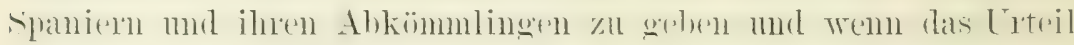
auch zu hart und weitgehend ist, welches dieser Rasse einen

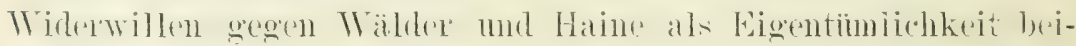
mi-st. so kamm es doch nicht witer endmildert merden. als dass

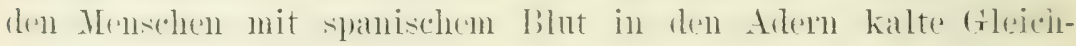

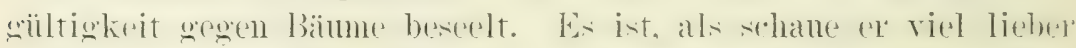
auf nackte, scharf umrissene Berge wie auf grime, bewaldete Höhenzïge.

Noch einer Ursache ist zu gedenken, welche hindert, dass die Forstkultur nicht überall dir verdiente Toürdigung findet.

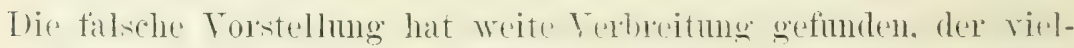
fältige und in jedem Jahr unfangredehere Estsatz des Holzes dureh

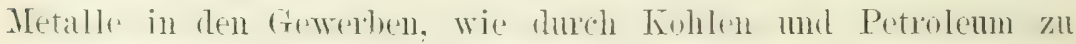

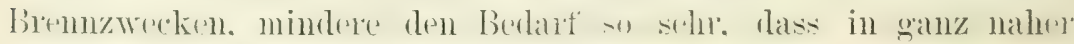
Zukunte die Holzproduktion nicht mehr hohnen kömne. Die Zait

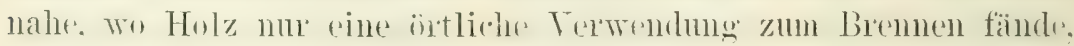

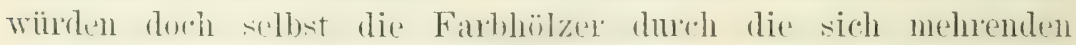
Darstellungen ron Farhstoften alls Mineralien, mamentlich allKohlen, übertlüssig werden. As vermentlich mantechtbarer Be-

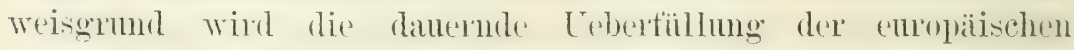
Holzmärkte und die darant gegrimdeten Klagen dere dentschen. isterreichischen und franzioischen Forstlente angeführt, die Wälder-

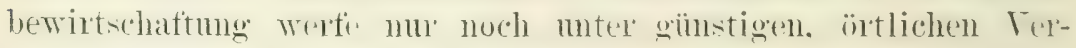
hältnissen eine schwache Rente ab. 
Weiter manten soll nachgewiesen werden, wie es sich mit der

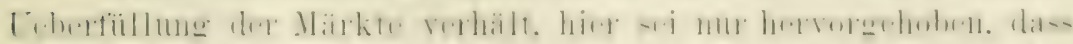

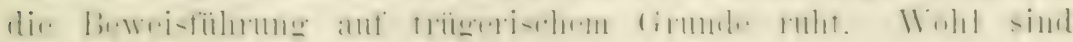

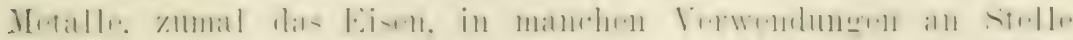

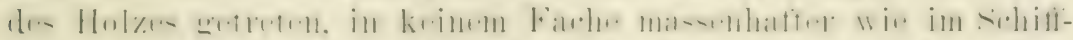

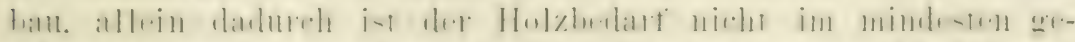

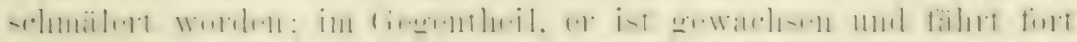

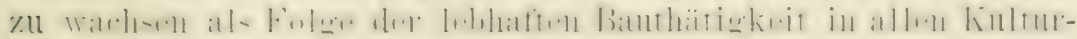

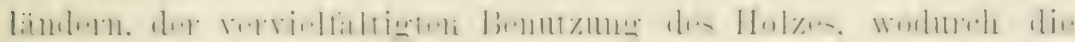

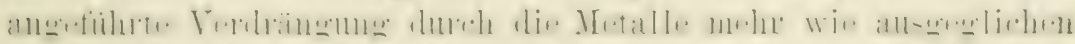

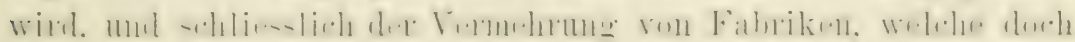

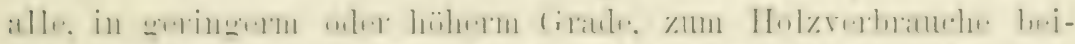

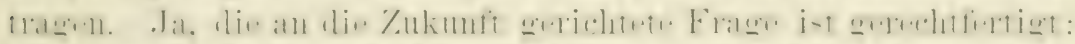

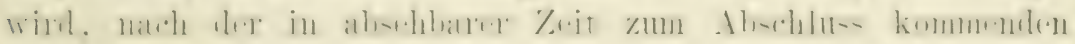

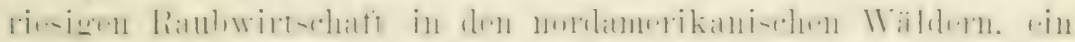

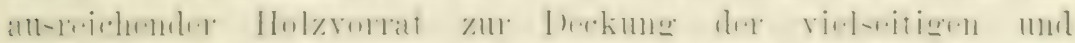

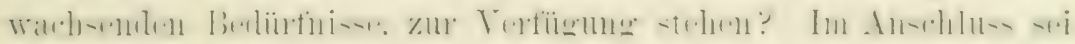

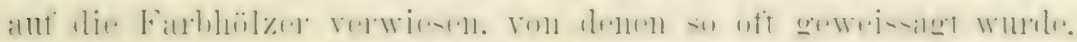

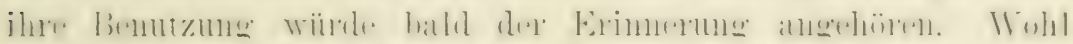

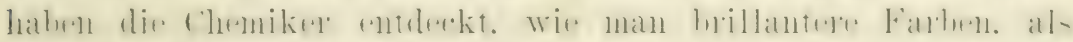

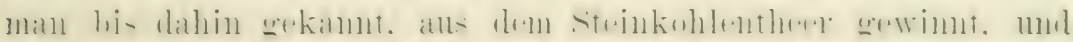

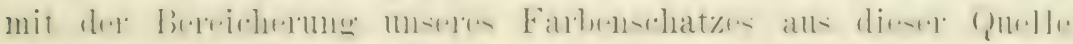

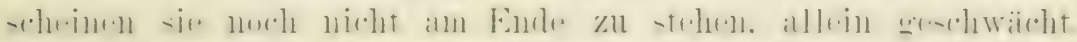

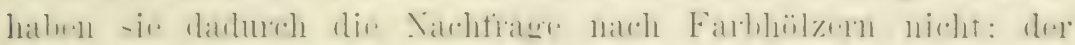

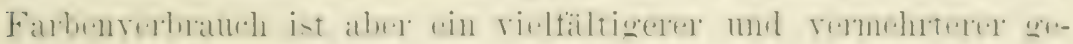

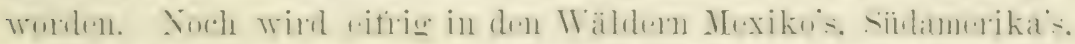

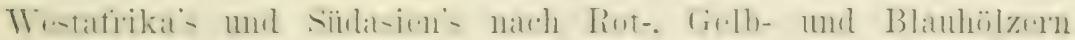

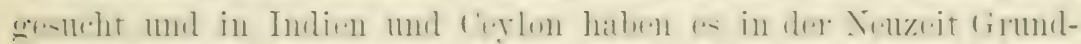

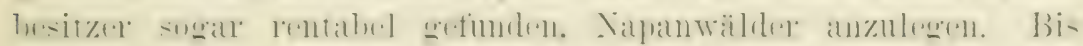

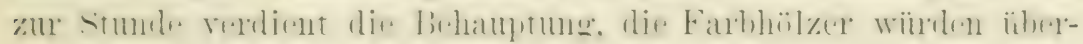
fliissig für die Gerrerbe werden, jeder Begrimdung:

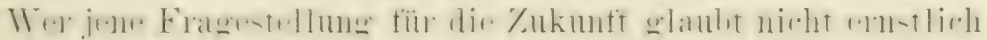

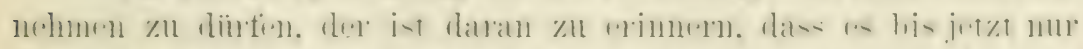

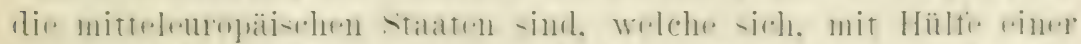

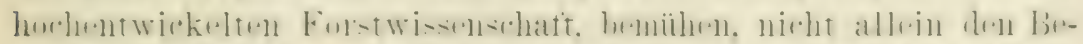

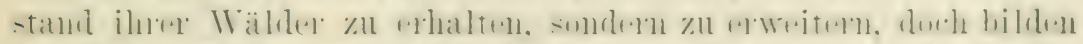

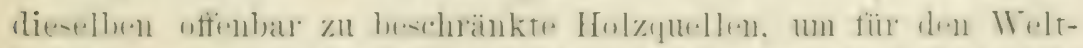

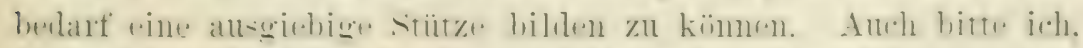

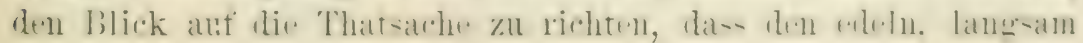




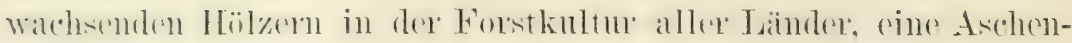

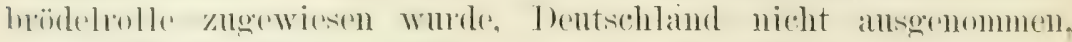

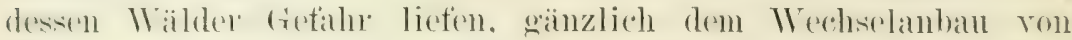
Kieferm mol buchen zu verfallen. ain beklagenswertes fieschick,

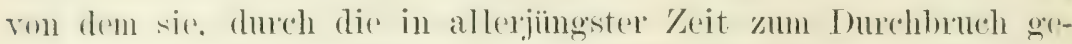
langten orlenchteteren Anschaumg, hoffentlich bewaht bleiben. Golegentlieh wird riel Lïrm gemacht von Anfforstungen in Nordamerika mol Australien, deren wahres Wext aber sehr herabsinkt im Lichte der 'Thatsache, dass, mit wenigen Ansmahmen, schnellwathrende, weiche Hölzer zur Anptlanzung gewählt werden, volzugsweise Pappenn. Teiden, Aspen, Tamnen, der silberlanbige und der eschenlaubige Ahorn, der T'ulpenbam, die Linde, und in geeignetem Kilima mit besonderer Toribue, der anstralische blane Gummibaum, desen Anbau sogar zur Manie ansartete, die aber nun im Erlöschen begriffen ist, weil sich die Teberzengung Bathn bricht, man habe sich riner Feschmackserintung schuldig gemacht, als man die schönheit dieses Bammes pries, er verdiene keinen Platz in Alleem mud larks. schon weil er das ganze Jahr durch Blätter abwirft. ex tange nicht zum schïtzenden Windbrecher für Obsthaine und Gärten, weil er selbst des Windschutzes bedarf und durch seine scicht lanfenden Wurzeln weithin die Erdkrume erschöpft, el sei als Waldbaum nicht lohnend, weil sein Holz weder zum Bauren noch in den Gerverben Beachtmo fände und nur einen mittleren Brennwert habe.

Höchst wichtig fïr die Znkunftsbetrachtung ist, den weit klaftenden Lnterschied zwischen Kulturwald und Lrwald im Auge zu behalten. Der Letztere bietet oft anf meilenlangen Strecken kein verwertbares Holz, selbst nicht eimmal rersprechenden dnwuchs, umfasst ausgedehnte Blössen, die in der Angabe seiner (rrösse einbegriffen sind und zeigt auch in seiner üp)pigsten Entfaltung einen stoffrorrat von buntestem Wertwechsel. Thd ferner: ein ganz bedentender Bruchteil der Trwälder muss fü lange Zeit himaus als der Ausbente sutriickt betrachtet werden, weil die Transportspesen nach aufnahmefähigen Märkten nicht in Einklang mit der Rentabilitat zu bringen sind. Die Tragweite dieser Verkehrsungunst beleuchtet das folgende Beispiel. Anstralien, noch so reich an Urwälder'n und dïm besicdelt, importiert beträchtliche Mengen Holz von der pazifischen Kïste Nordamerika's. trefüllt wird es an Buchten und Flussmïndungen der Küiste, wo seine 


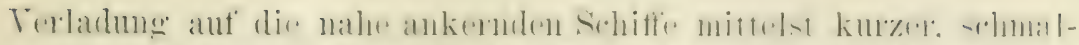

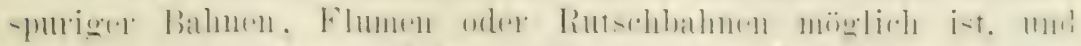

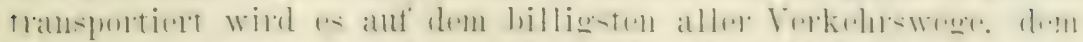

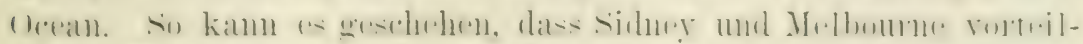

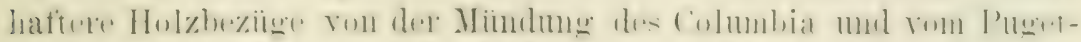

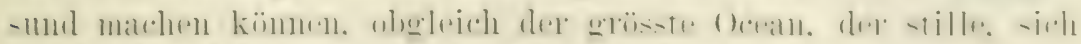

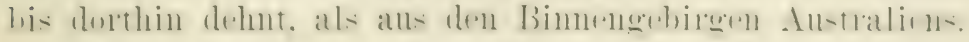

Doch liegt nicht dem Europäer ein Beispicl viel nälıc':

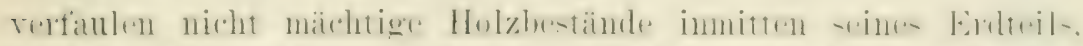

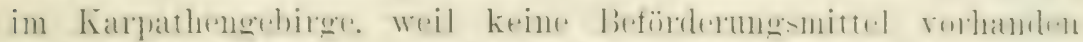

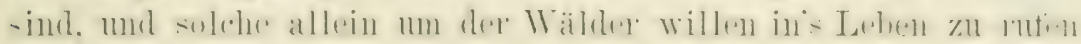
sich nicht lohnt?

Wohl berechtigt ist mithin die besorgte Frage nach der

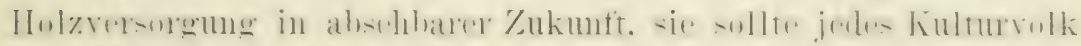

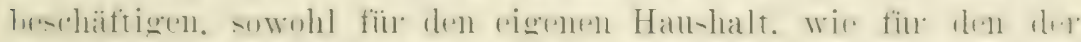

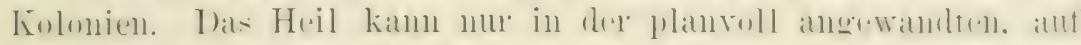

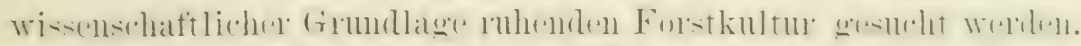

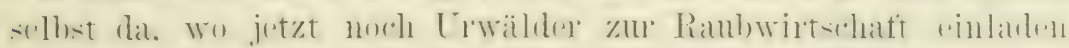

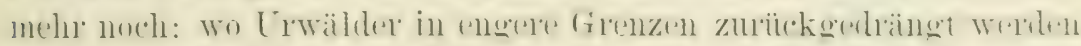

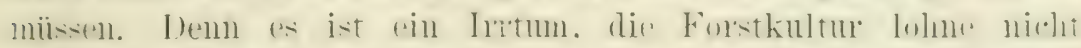

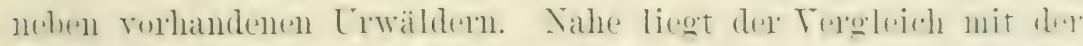

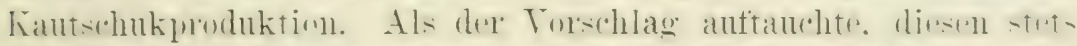

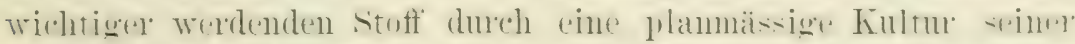

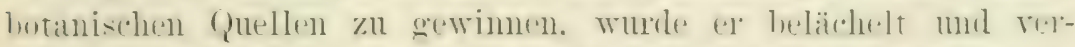

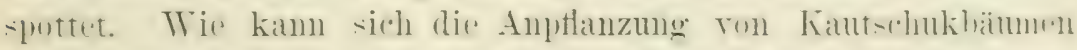

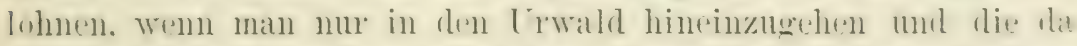

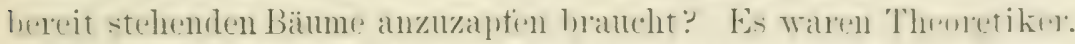

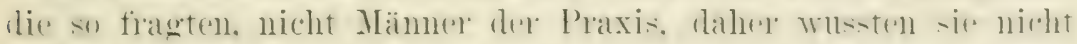

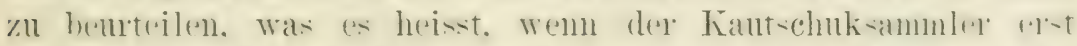

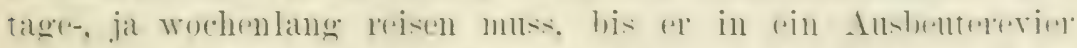

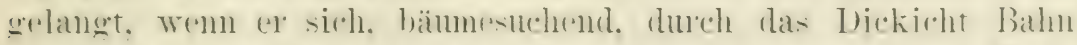

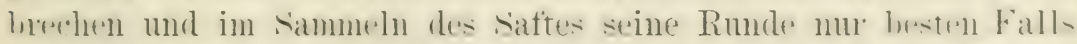

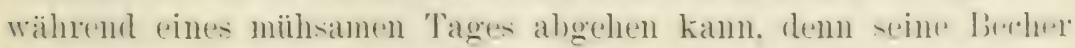

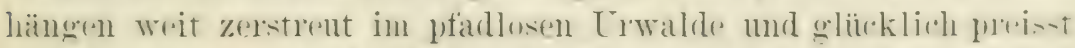

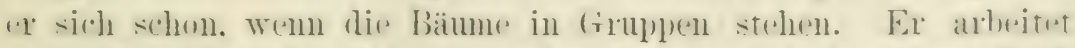

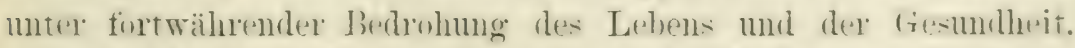

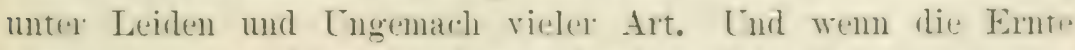
ringeheimst ist, folert die lange. heschwerliche Reise narle dem Markte. 
Welcher Zeit- rund Kraftgewimn lässt sich durch eine ge-

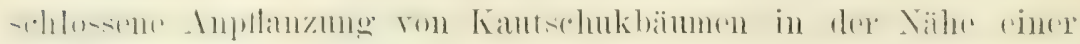

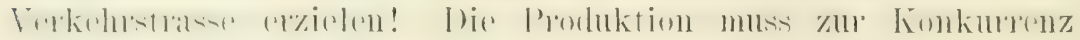

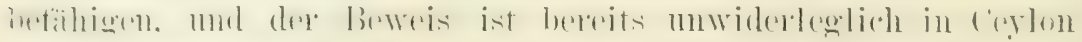
erbracht worden.

Wer jemals mit den Holzfällern in den Urwald eindrang;

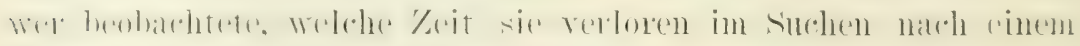

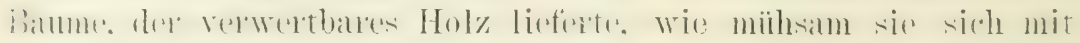
ihren Geräten zn ihm Bahn brechen mussten, welcher Torbe-

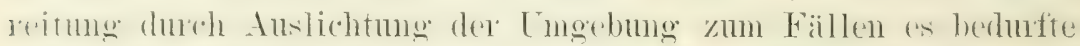

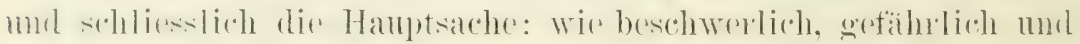

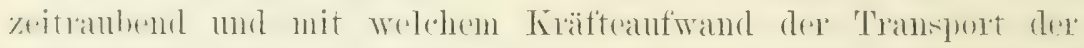
Blöcke nach dem Flusse stattfand - wer das sah und rechnen

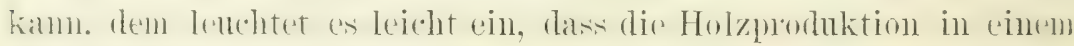

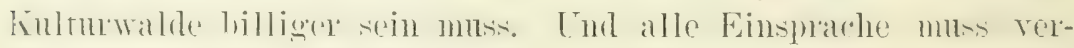

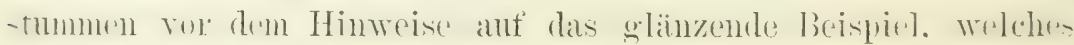
Indien bietet.

Entmutigen dart auch nicht die Bewohner der heisoren Zone:

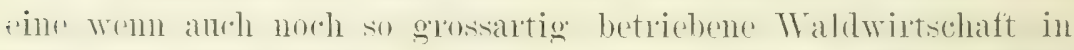

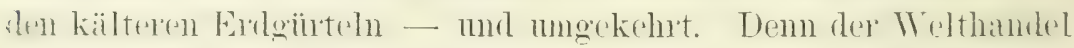
velangt Hälzer von rersehiedener physikaliseher Beschattenheit, mol da diese Eigenschaft anf klimatische Lrabche zurülokntïhnen i-t. sn steht die Notwendigkeit der Arbeitsteilung in dor Forst-

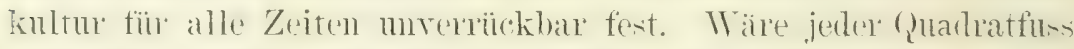
des 'Troperngintels mit Wald bedeckt, die Forstkultur in der

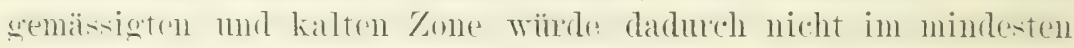

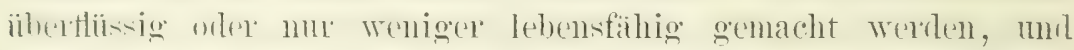
wem die nordisehen Forstlente weit über die Sachfrage hinats Holz moduzierten. es wïrle ohne Finfluss bleiben ant die tropische Waldwirtschaft.

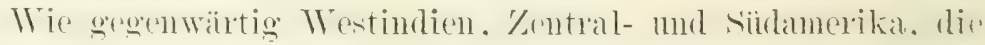

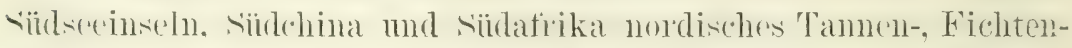

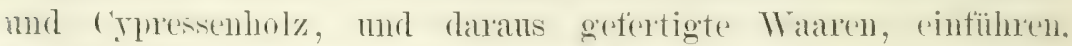
wie jetzt, Verfialdenngen in grossem Masstab ron Farbhölzern vel-chiedemer Art, von Ehen-, Rosen-, Jacaranda-, Mora- und Grimher\%hol\% ans tropischen Häfen nach nordischen Märkten stattinden, -o wird es immerdar bleiben. so lange es einen Wolthandel gibt, werden holzbefrachtete Flotten die Gzeane nach allen Richtungen der Windroses durchkrenzen, demn für die schöpferischen Eintlïsse 


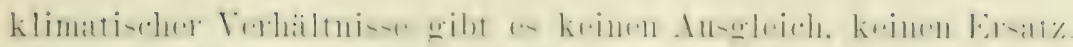

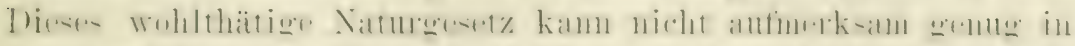

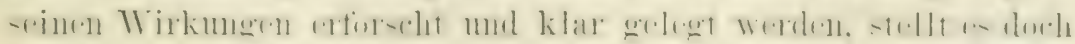

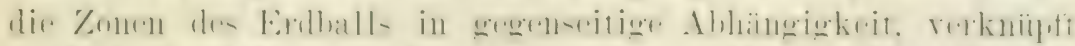

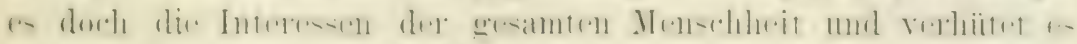

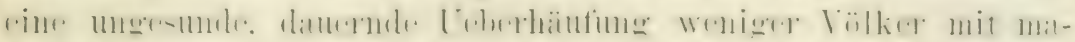

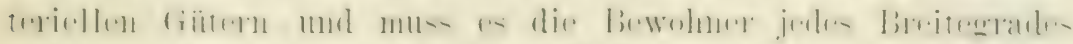

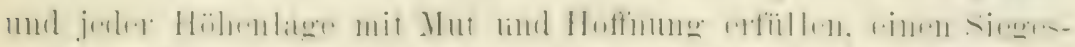

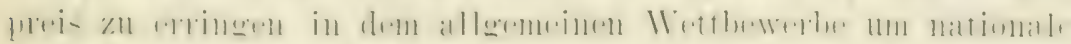

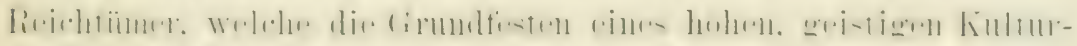
lebens sind und ewig bleiben werden.

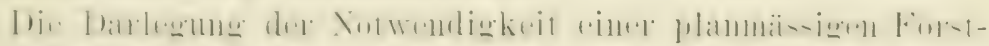
kulmo in allw \% \%

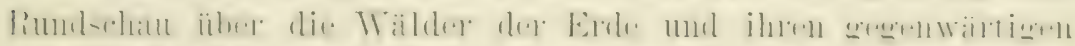

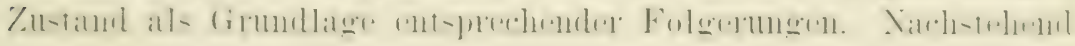
wird sie gegeben.

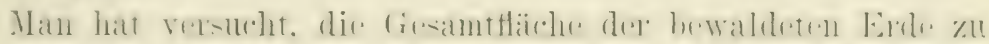

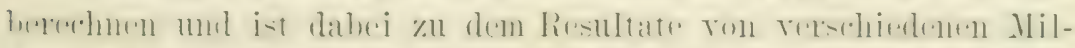

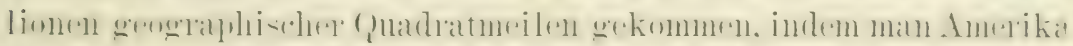

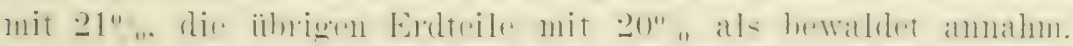

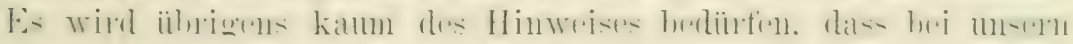

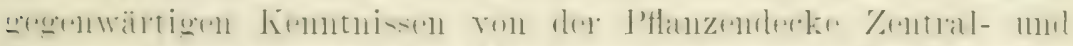

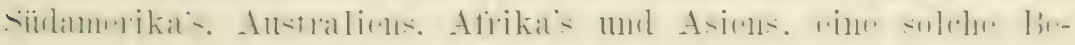

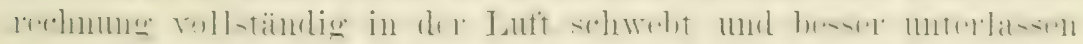
wird, da sie zu irrigen Torstellungen fiblut.

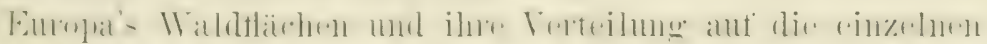

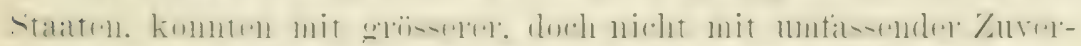

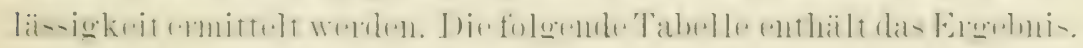

$$
\text { Hektar Wald Von der Gesamtfläche sind bewaldet, }
$$

Russland

Fimnland

$190,684,000$
$10.868,000$
$17,358.170$
$7.568,200$
$18.125,760$

in Prozenten.

Schweden

Jorwegen

Oesterreich

Deutschland

Türkè

Rumäniєn

Italien

$$
13,987,900
$$$$
\begin{array}{r}
8.201,300 \\
976.000 \\
5.1991 .590
\end{array}
$$

$3 \pm .1$

29,4

26,1

20.2

2.) 
Hektar Wald Von der Gesimtflïche sind bewaldet, in Prozenten.

\begin{tabular}{|c|c|c|}
\hline Stohweiz & 715,500 & 18 \\
\hline Frankleich & $9,075,100$ & 17,3 \\
\hline Giechenland & 688,400 & 14,3 \\
\hline Belgien & 200,500 & 13 \\
\hline s'panien & $3,133,450$ & 7.3 \\
\hline Holland & 227,600 & 7 \\
\hline Portugal & 466,100 & 5,1 \\
\hline rossbritammi & $1,004,100$ & 4,1 \\
\hline Dimemazk & 185,700 & 3.4 \\
\hline
\end{tabular}

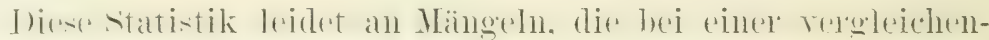

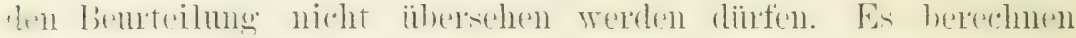

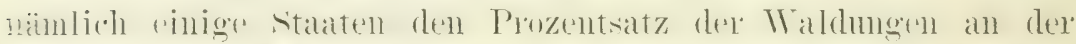

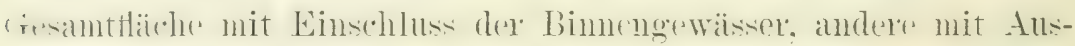

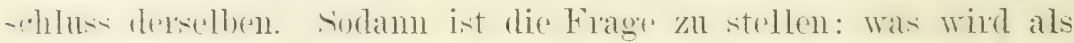

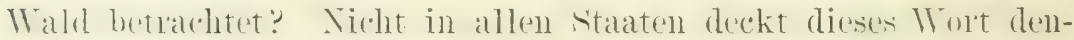

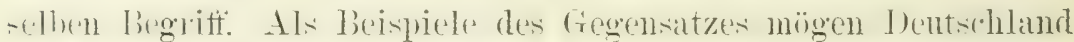

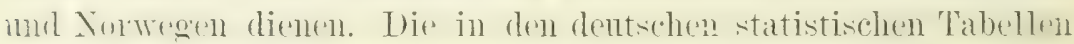

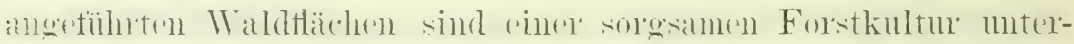

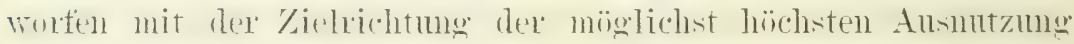

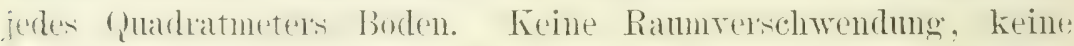

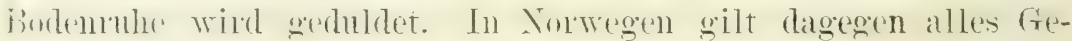
lände. das nicht als Acker, Miose oder M̈ildweide dient. als Mald.

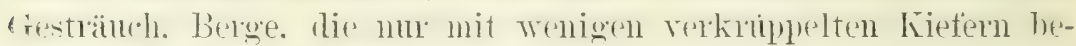

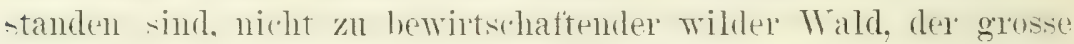

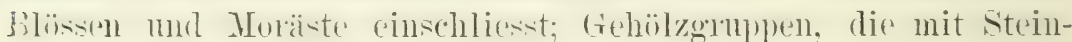

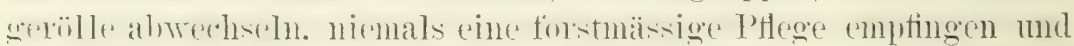

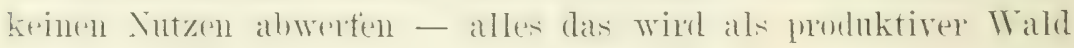

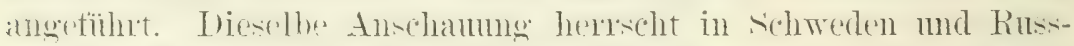

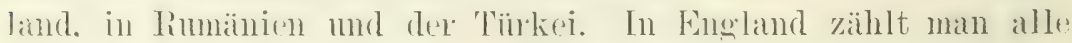

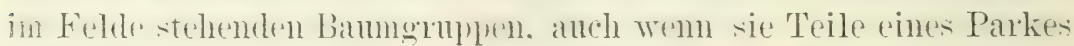

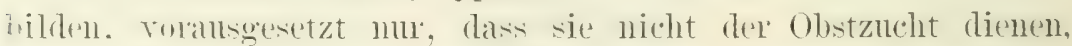
zul-ammen. mm dir bewaldeten Flächen des states zu berechnen. Eximmert man sich moch. Welehe weitem Wertabstände die Wälder

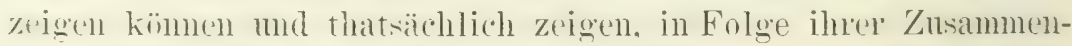
-rtzlung ats edleren oder gemeineren Hölzern, so wird man sich bei der vergledehenden Benteilung anf Grund der statistischen

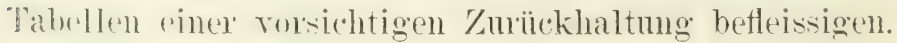




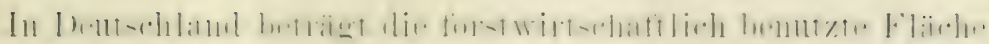

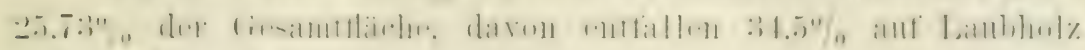
und $6.5,5 \%$ ant Sarlelhol\%.

Von der Lambleblafache kommen 10,1\% anf Eichen. 9.70':

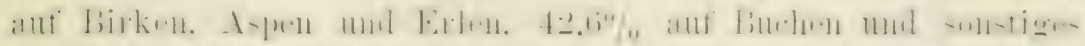

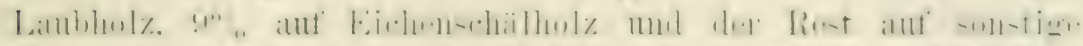

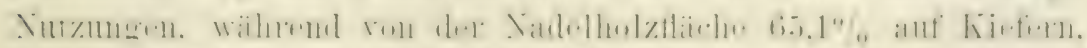

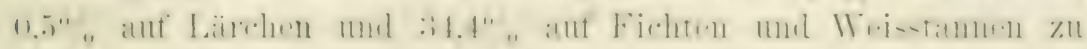
rechnell sind.

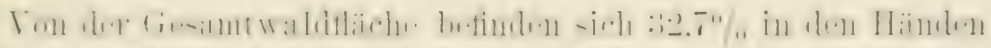

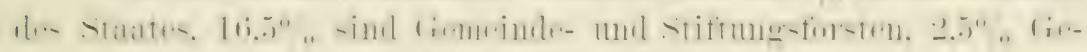
nossenschaftswilder und 48.30 \% Privatforsten.

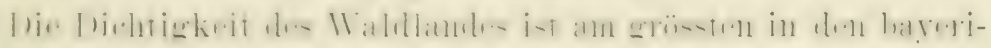

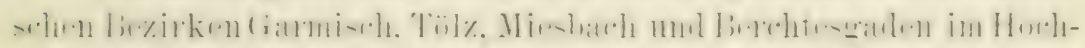

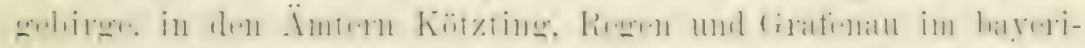

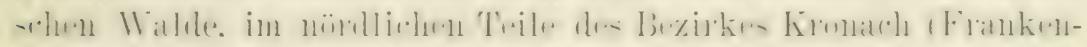

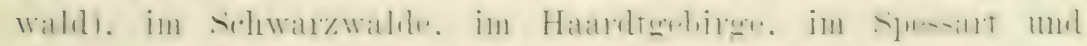

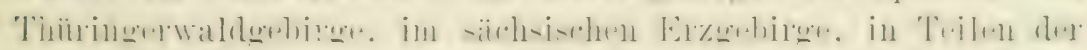

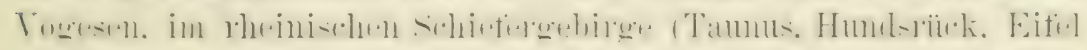

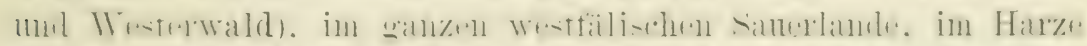

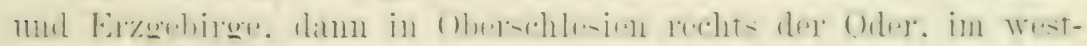

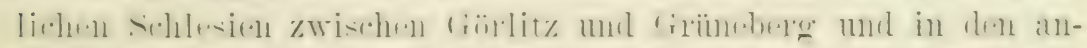

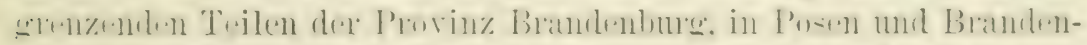

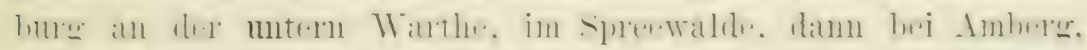

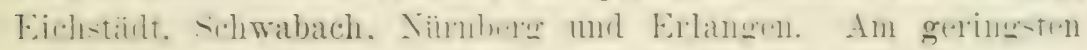

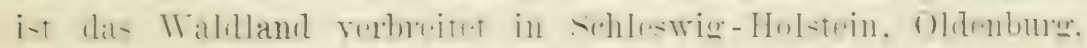

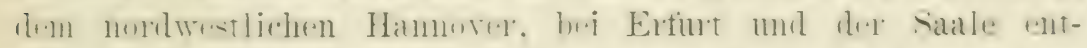

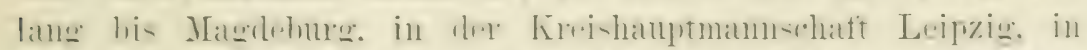

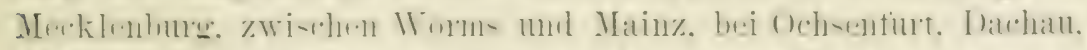

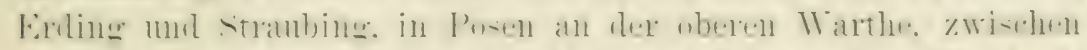

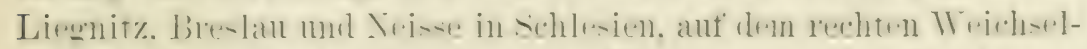

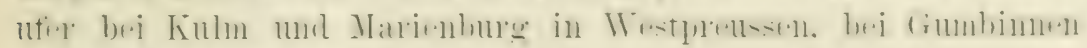
und Stallupönen in Ostpreussen.

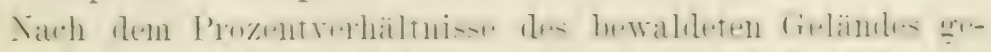

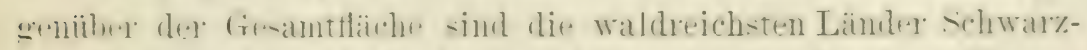

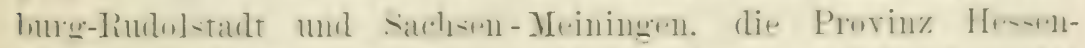

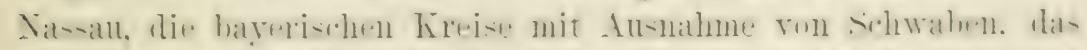

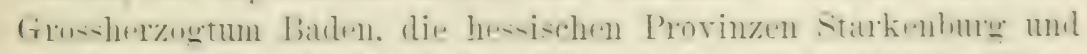

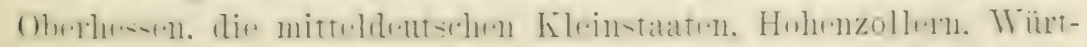




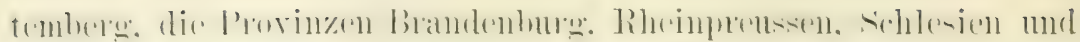

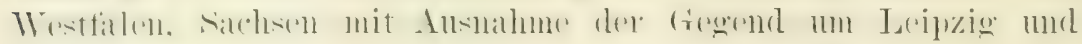
dis Elsass.

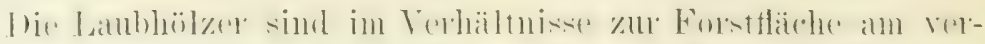

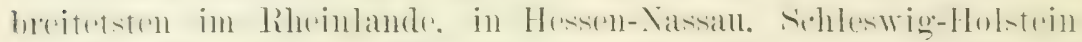

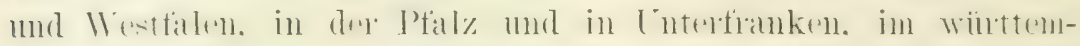

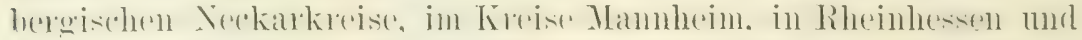

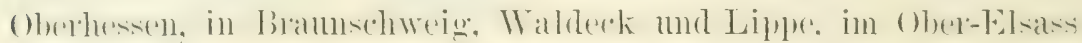

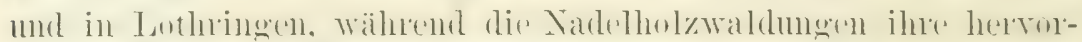

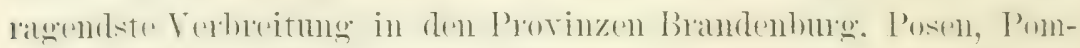

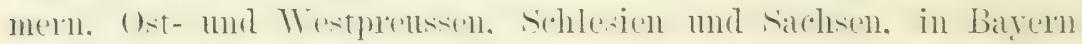

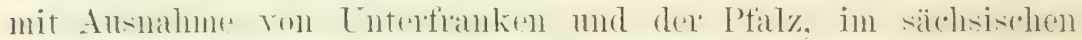

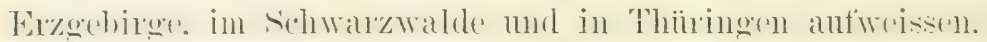

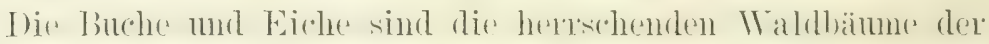

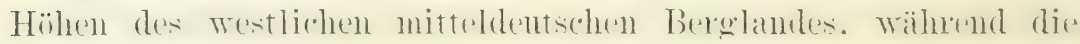

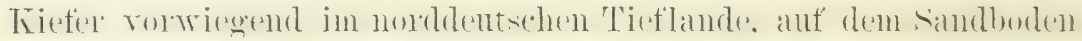

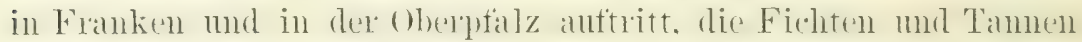
sind in den Alpen. dem sichwarwalde. dem bayerischen Walde,

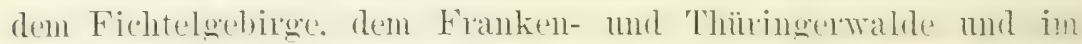

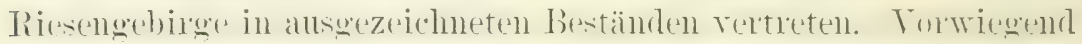

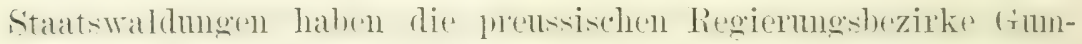

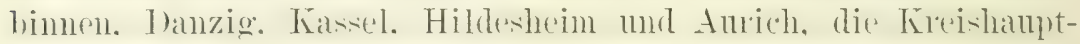

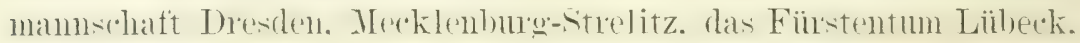

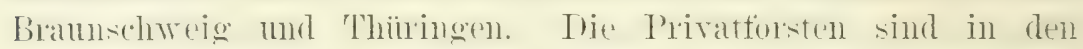

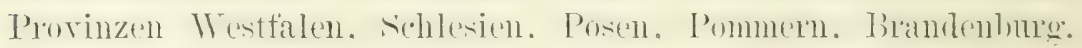

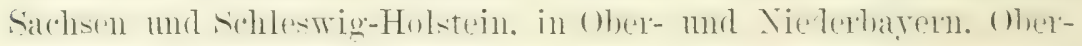
und Mittelfranken und in der Oberfalz rorherrschend.

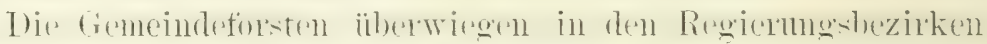

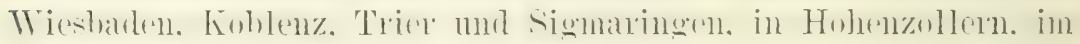

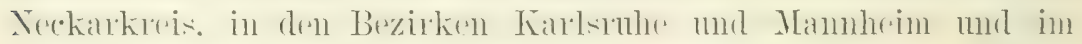

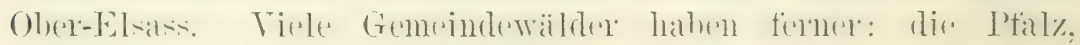
Unterfranken und das Grossherzogtum Hessen.

Die meisten Genossenschaftsforsten kommen vor in den Re-

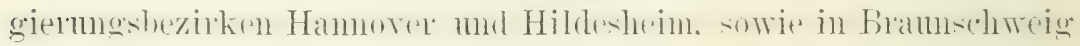
und Schwarzburg-Sondershansen.

In runder Zahl wird die Waldflïche Dentschlands mit

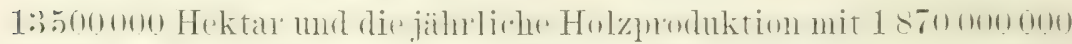

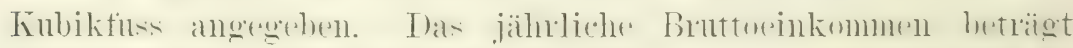

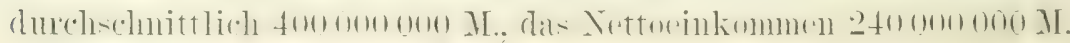




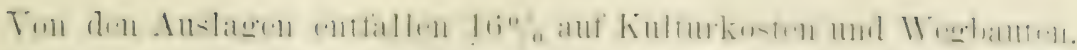

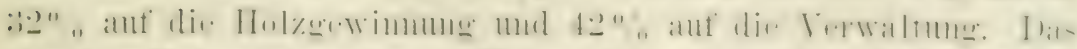

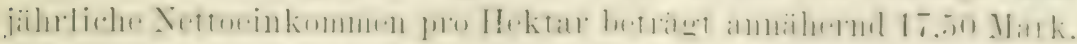

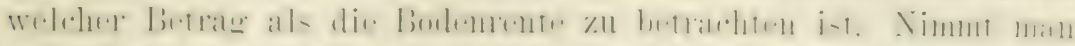

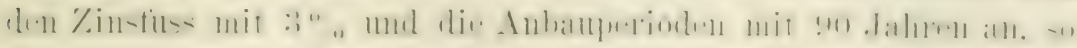
wiude sich der Tiapitalwert dex dentschen Tralder anf cetwa

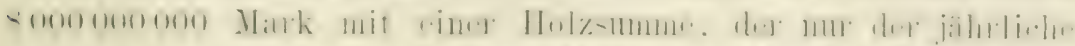

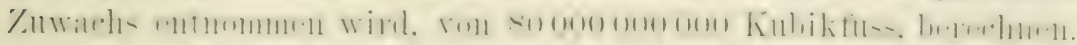

Fon dem Lapitalwert entfallen 1600000000 Mark auf de'll

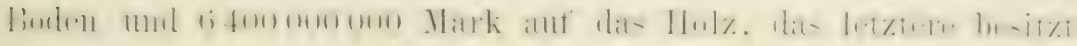
demuach den vierfachen TVert des ersteren.

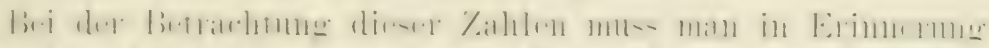

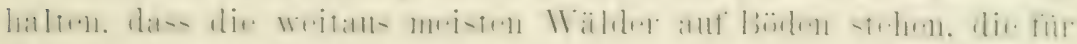
Ackerbanzwecke ungeeignet sind.

England hat sich unter den emopäischen staaten der voly-

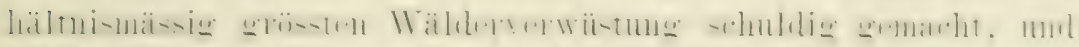

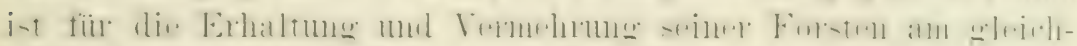

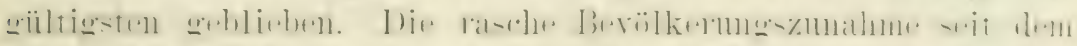

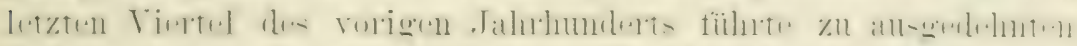

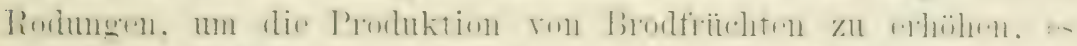

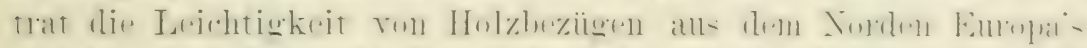

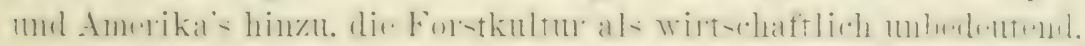

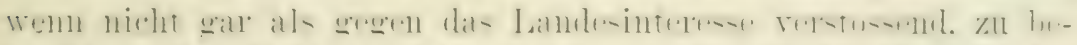

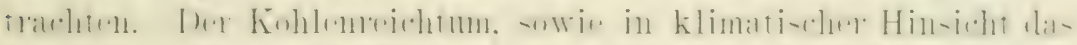

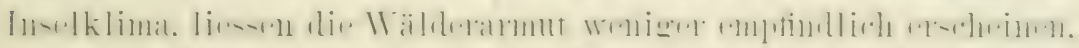

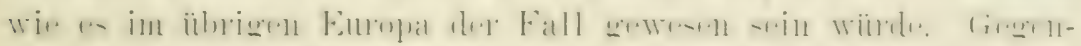

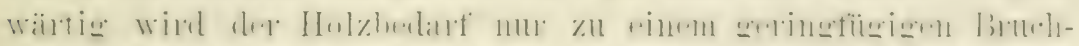

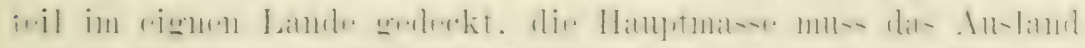

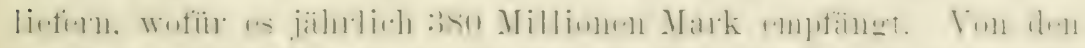

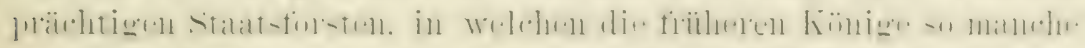

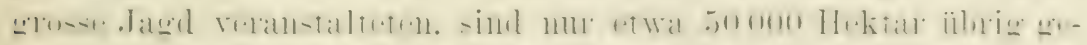

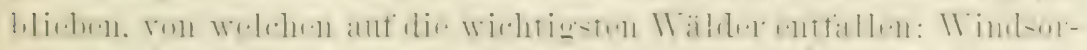

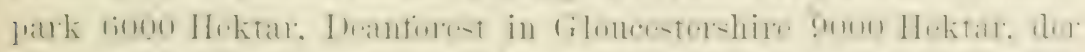

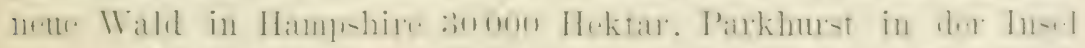

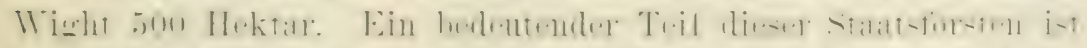

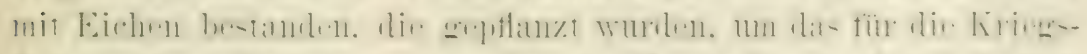

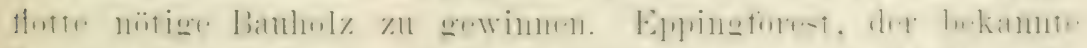

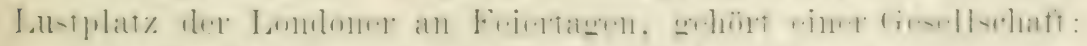

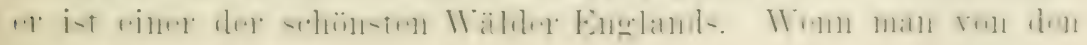




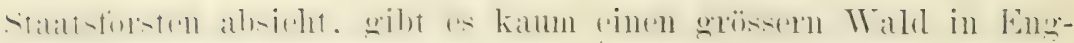

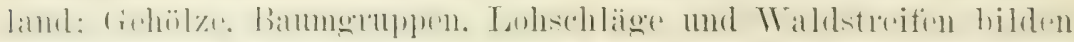

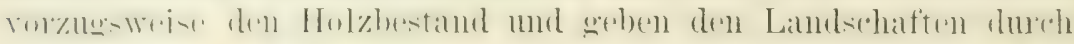

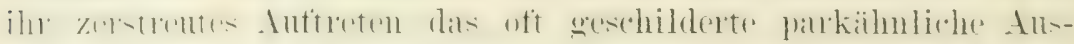

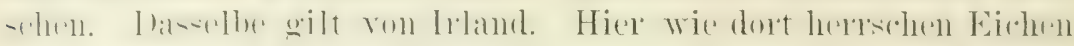

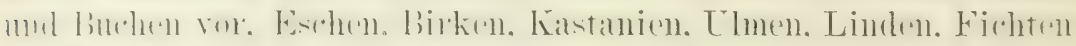

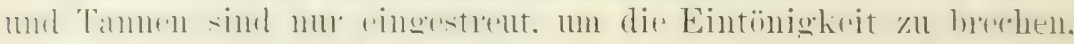

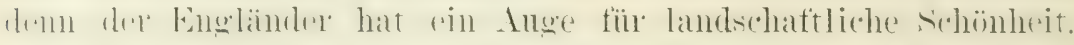

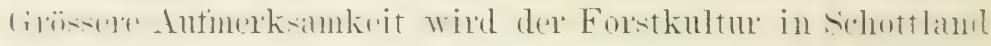

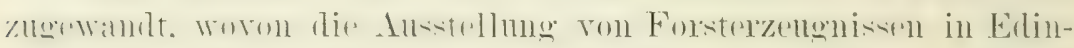

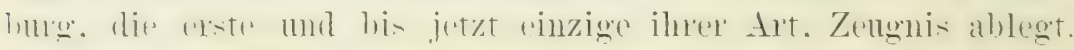

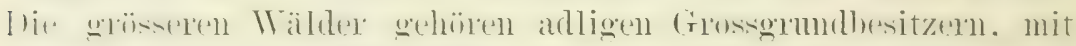

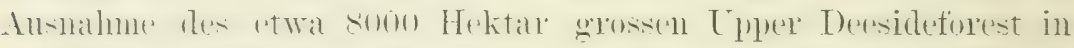

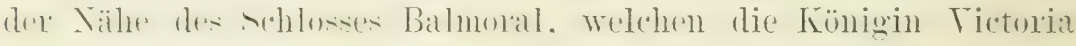

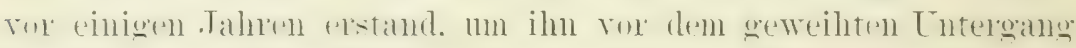

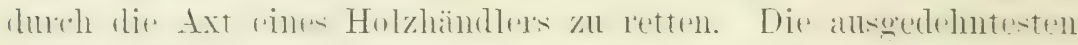

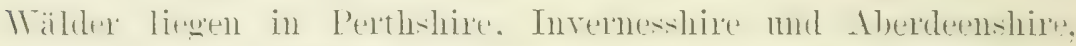

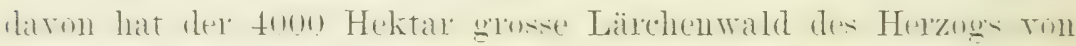

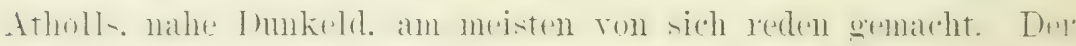

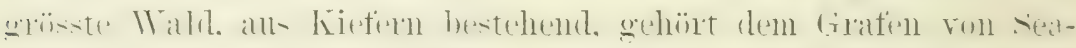

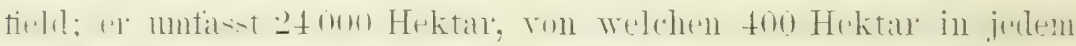

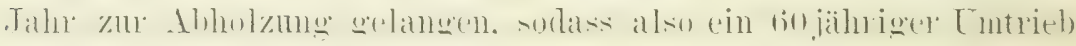
stattfindet.

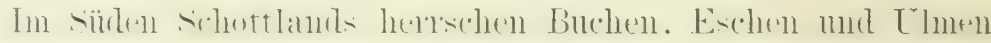

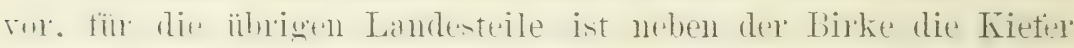

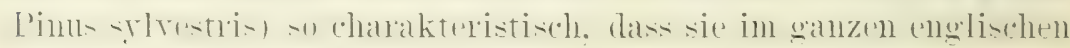
Sprachgebiet schottische Föhre (scotsch fir) g'enannt wird.

Ueber die Verteilumg der bewaldeten Flächen, mit Gegen-

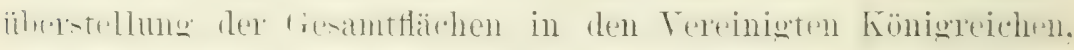
gibt die folgende amtliche Statistik Aufschluss.

Gesamtfläche in Helitar (einschliesslich Binnengewässer)

England

- 13038960

Trales

1888729

Schottland

7798452

Irland

8327930

31054071 bewaldete Flïche in Hektar 530306

50729

292996

130070

$100+101$

Nerh dieser Zusammenstellung würden die hewaldeten Fläthen mu 3.2.2". der Gramttläche betragen. der Rang tiur Groshritan- 


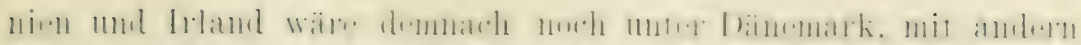

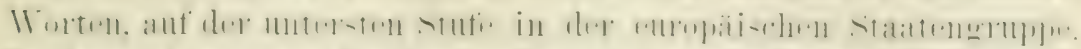

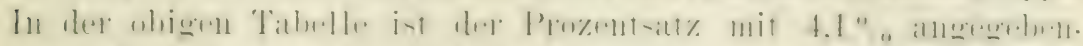

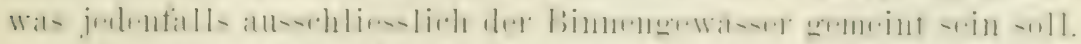

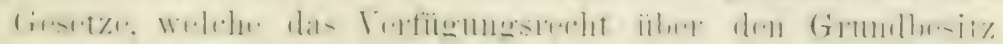

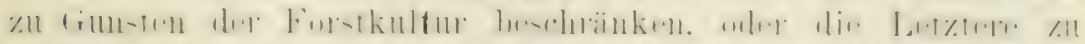

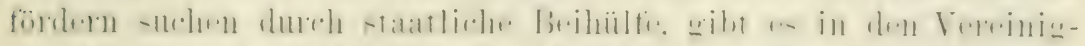

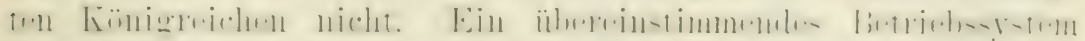

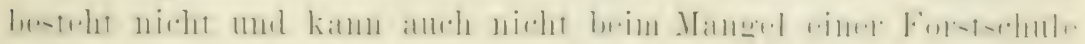
vorhanden gedacht werden.

schweden und Jorwegen sind immer noch stark bewaldet.

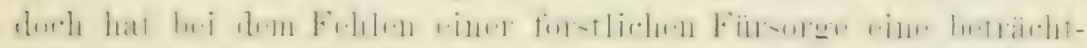

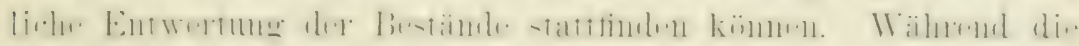

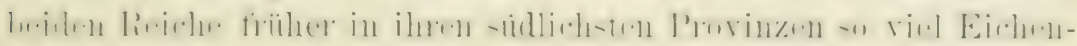

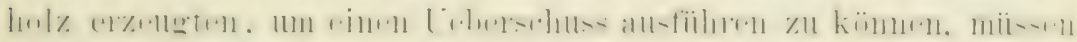

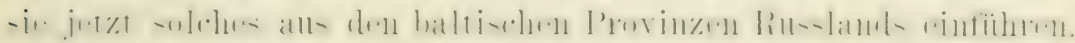

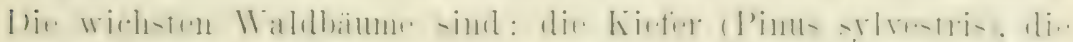

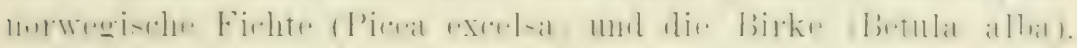
Die Letztere rückt fast bis zum Nordkap ror, wo an Stelle des

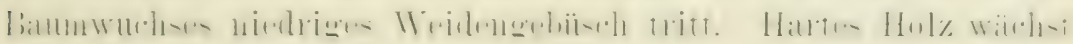
nur in den siidlichen Distrikten.

Dis westliche Jorwegen ist bereits stark entblösst ron Wiil-

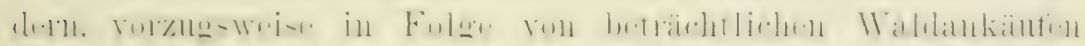

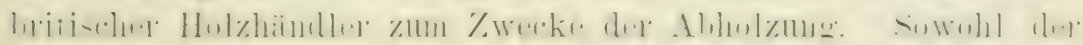
Bedart der Seekiste wie des Exports wird ron der östlichen

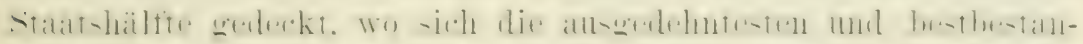

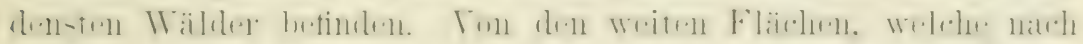

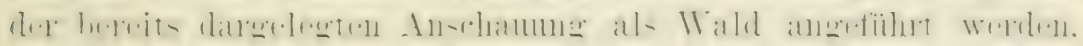

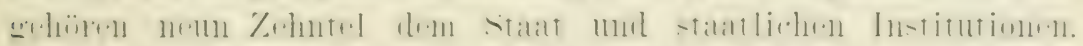

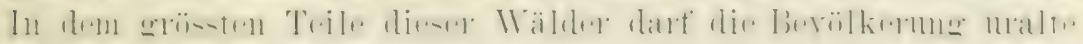

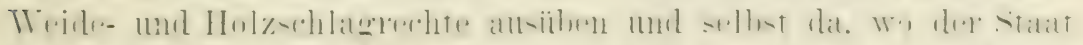

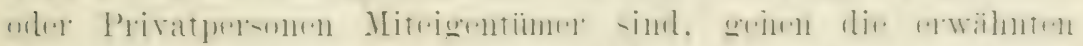

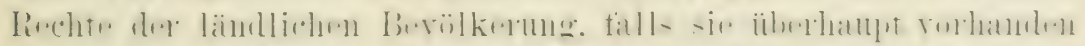

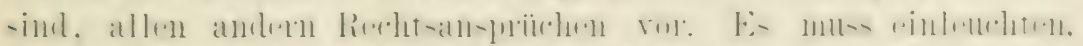

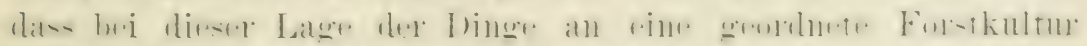

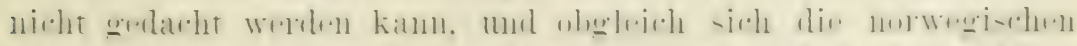

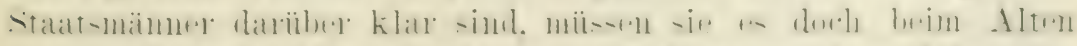

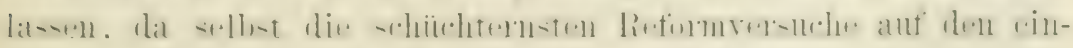
miitigen Widerstand der Landbevölkerung stiessen. 


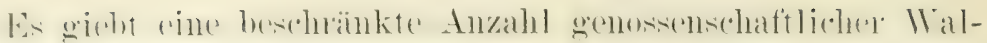

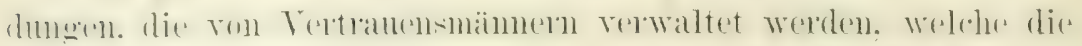

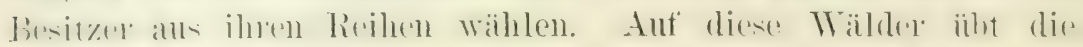

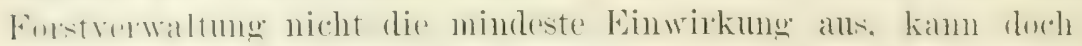

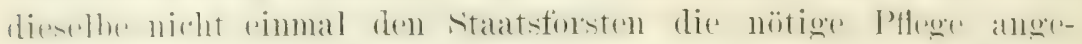

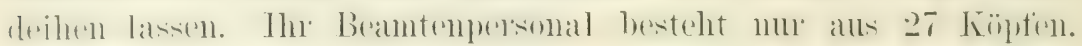

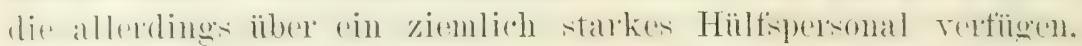

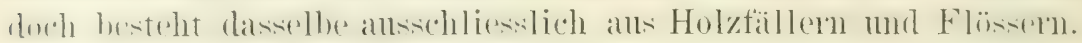

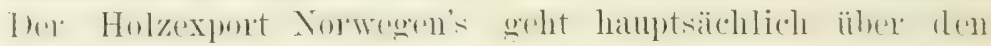

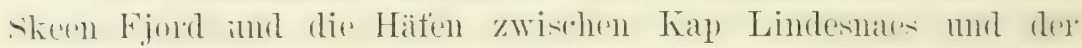

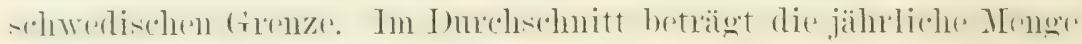
so Millomen Kubikfus: in Werte von 48 Millomen Mark. Davon nimnt mehr wie die Hälfte. nämlich tür 28 Millionen Mark. den Weg nach Grossbritamien und Irland.

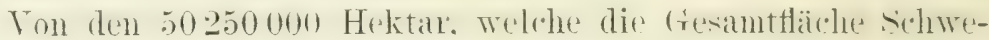
dens bilden. sollen nach antlicher Angabe 35020000 bewalelet

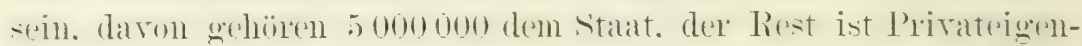
tum. In Wirklichkeit ist aber kamm die Hälfte dieser Fläche mit Waldbämmen bestanden. dir andere Hälfte sollte richtigere als

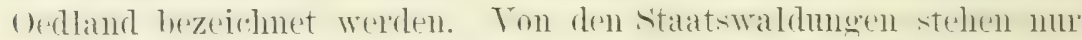

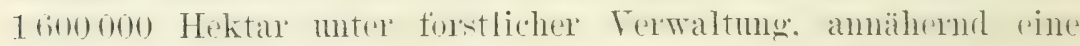

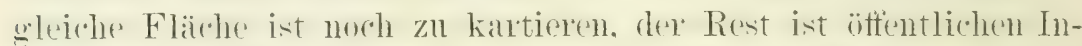
stitutionen zur Benutzung überwiesen oder zeitweilig verpachtet.

schwerlen besitzt dieselloen Wablhänme wie Norwegen, nul

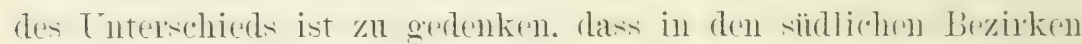

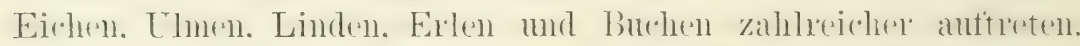

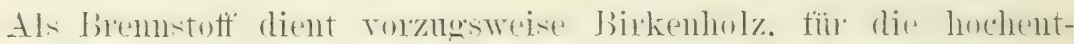

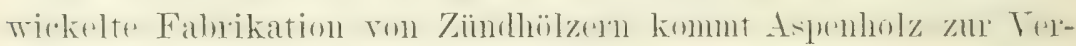
wendumg.

Die Forstbehörde besteht aus einem Direktor und etwa 700

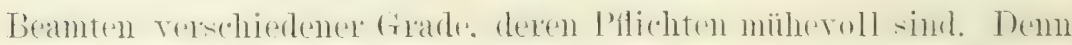
das wertvollste Holz steht tief im Innern des Landes, nach der

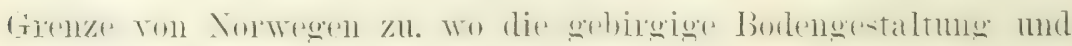

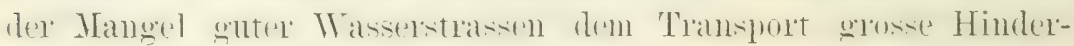

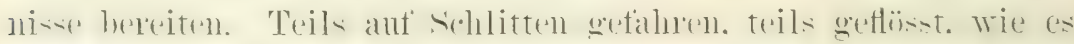

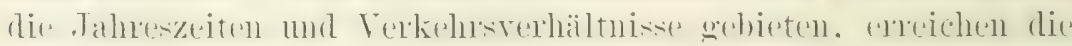

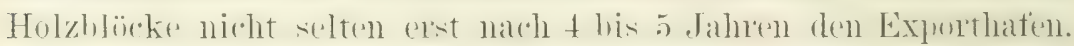

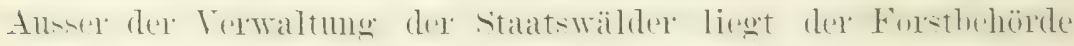

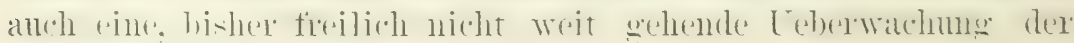


Privatwiblder ob. Lis steht aber za erwarten, dass die beateich-

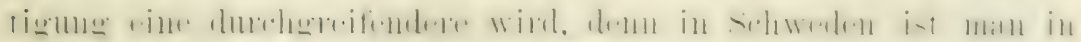

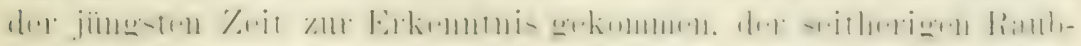

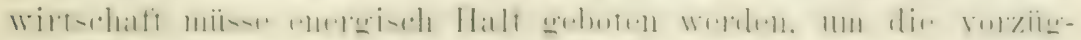

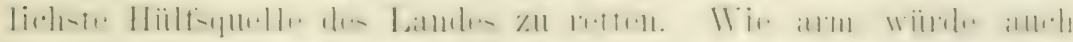
schweden sein. olne seine Wiildex!

Der durchschnittliche Holzexport Schweden's wird ant so

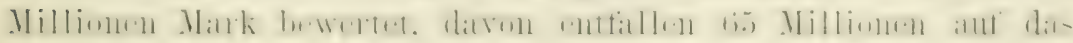

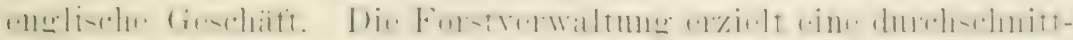

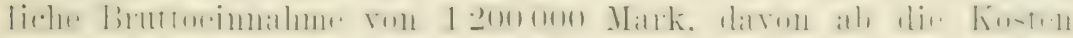
von 715000 Mark. bleibt ein Leberschuss von 485000 Mark.

sichweden besitzt cine Forstschule in Stockholm. der sich ij

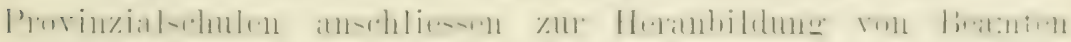
niederer Grade. Alsserdem ist eine Privatforstselute rorhanden. welche Staatsunterstïtzung empfängt.

In Dinnemark, das sich mit England um den Rang streitet.

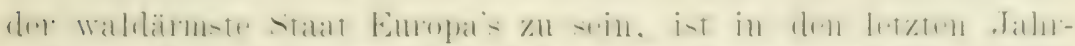

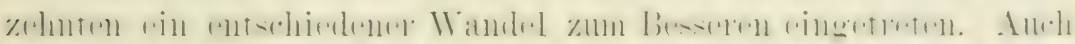

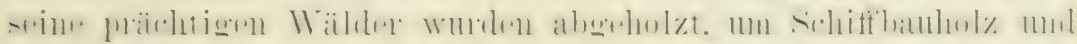

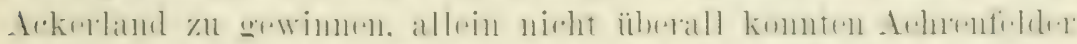

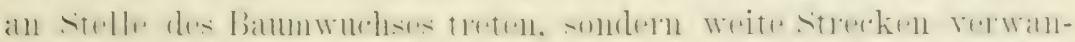

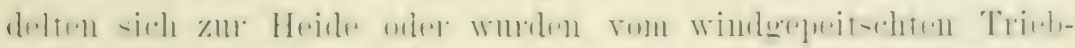

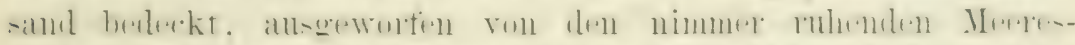

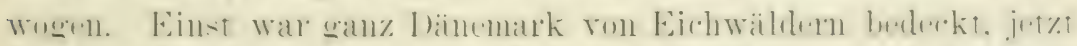

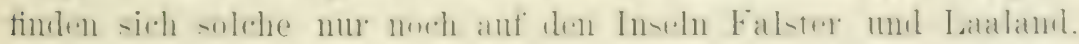

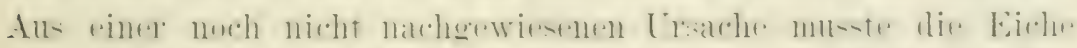

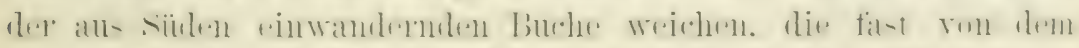

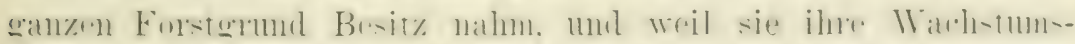

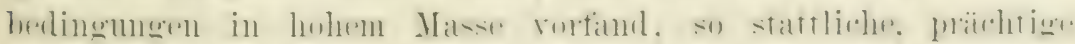

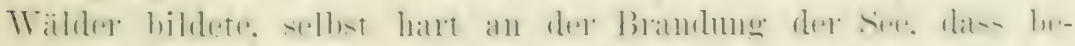

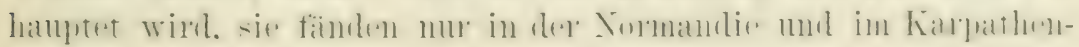
gebirge ihres Gleichen.

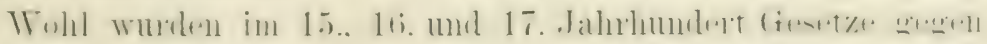

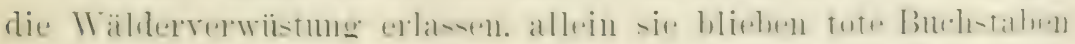

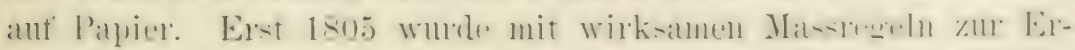

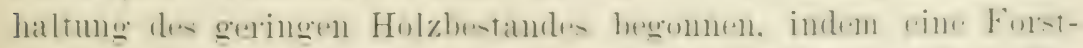

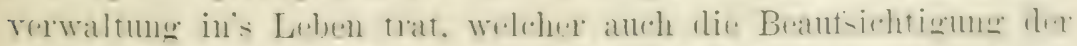

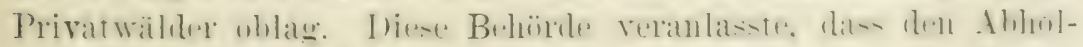

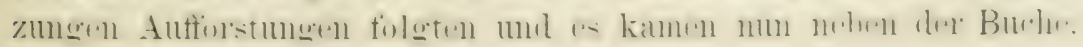




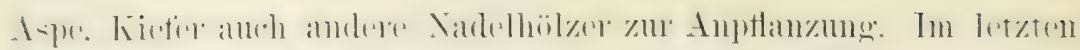

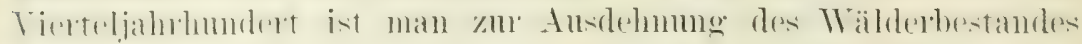

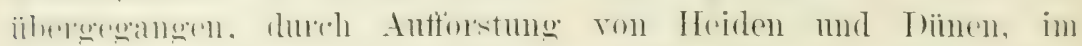

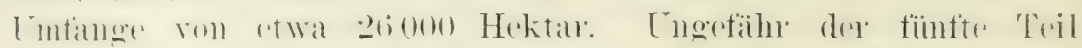

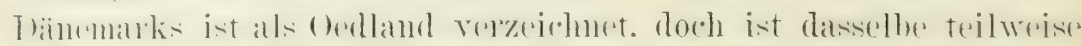

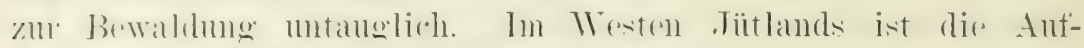

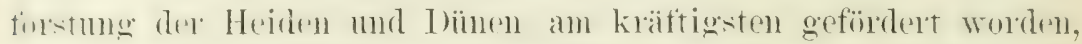

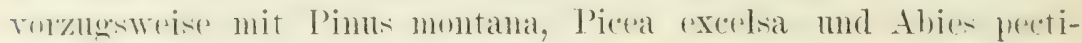
mata. In manchen Fällen forstete dex statat anf. indem ex die?

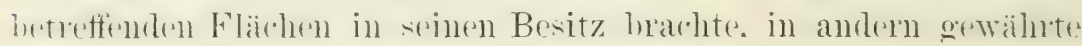
er Privatpersonen und Genossenschaften Beihülfe.

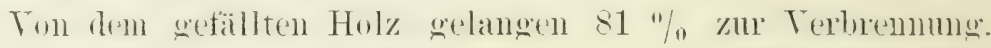

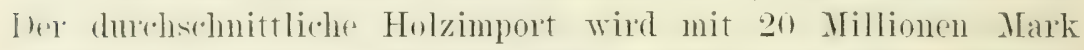
herertet. davon ist eine Wiederansfuh im Wrete von 2760600 Mark

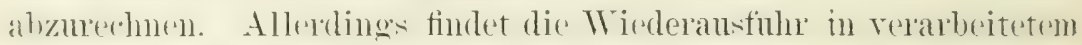
\%ustand statt. schliest also die Fabrikationskosten ein. Mit den butreftendell Artikeln, vorzugsweise Fäs-ex und andere Küferwaaren. beshickte Dianemark whe stark die Anstrollung in Edin-

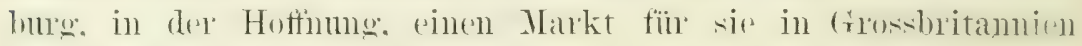
mol Irland zu finden.

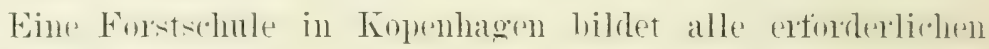
Beamten alls.

Holland besitzt nicht. Was wir Tälder zu bezeichnen ptlegen. In der Tmgelung von Amheim wie von Haag giebt es kleine Grë̈lze. was in C̈ebrigen als betraldete Flächen in der statistik rsheint. setzt sich als Baumgrupen und Baumstreifen zusammen, welche die strassen. Flüsse und zahlreichen Kanäle besämmen, anch auf den Deichen zu finden sind. Zur Anptlanzung kon!men Buchem. Pappehn. Weiden und Eschen. ant hohen Dïmmen anch die Thme. In ihrep Znsammenfasemg bilden diese Bestände immerhin einen ansehnlichen Holzvorrat. der aber so wenig genïgt, dass ein jährlicher Holzimport in Werte ron fo Millomen Mark stattinden muss. Es ist fast ïbertliissip hinzuzutïgen. dass es in Holland wedex oine Forstrerwaltung noch eine Forstechule gribt.

I) Budengestaltumg Belgiens ist, mit Answahme im nördlichon teile. ganz versohieden von derjenigen Hollands, daher auch ansogedehntere Waldungen anftreten kömnen. An dex siidgrenze zieht sich noch. wie ehedem. der alte berühnte Ardennenwald hin. in C̈unliơn sind die Provinzen Brabant mol Flandern 


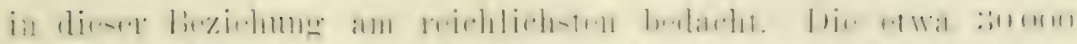

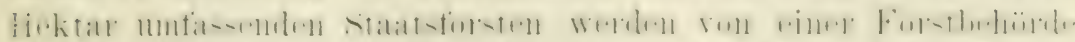

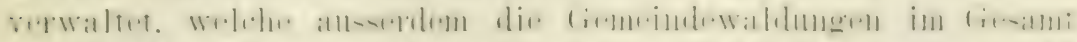

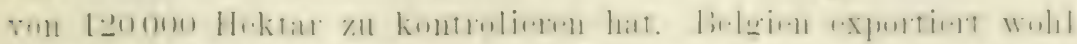

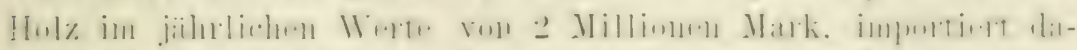

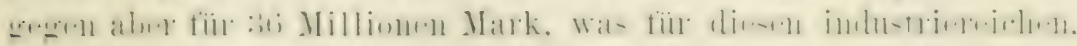

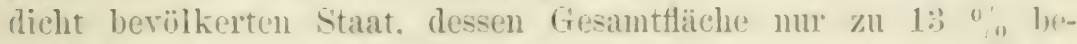
waldet ist. nicht autiallend erscheinen kann.

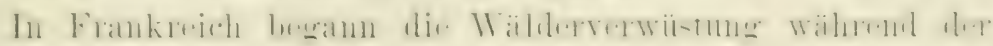

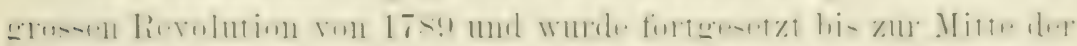

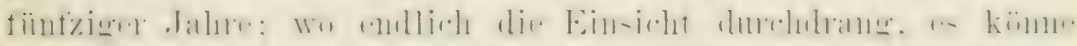

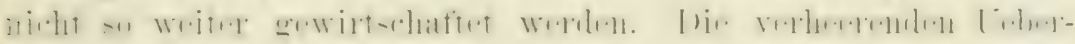

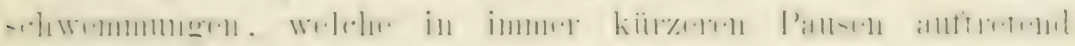

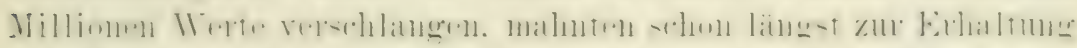

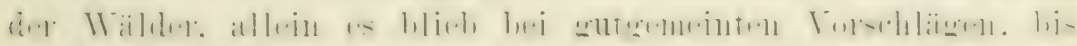

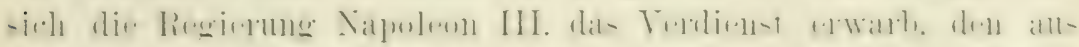

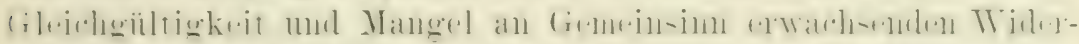

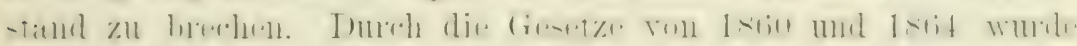

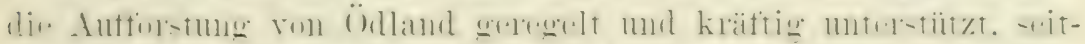

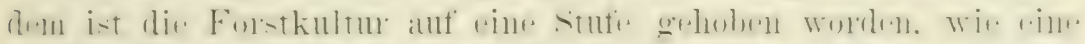

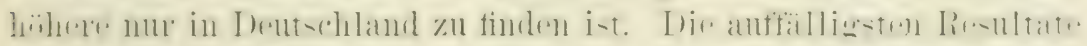

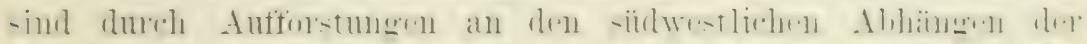

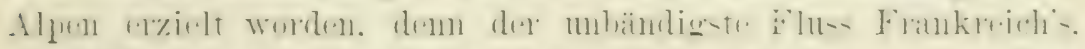

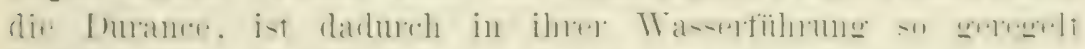

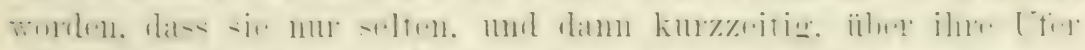

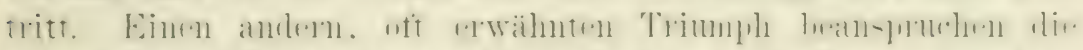

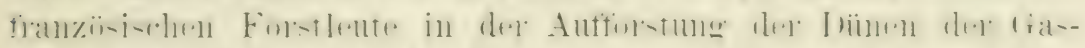

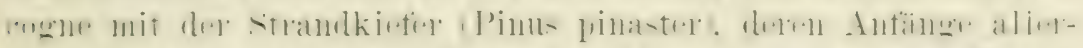

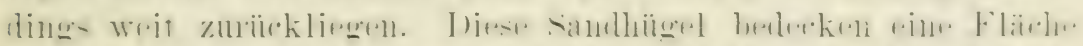

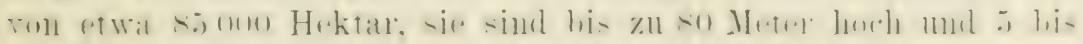

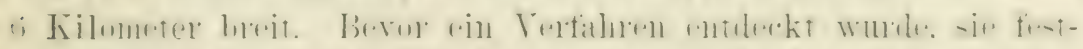

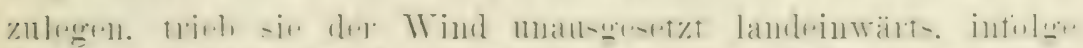

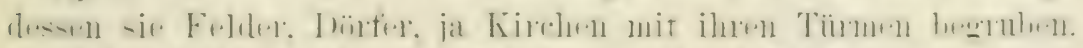

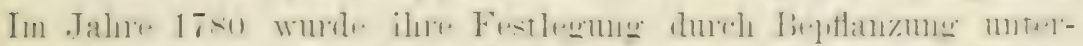

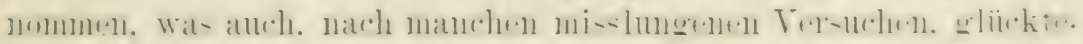

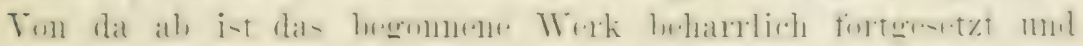

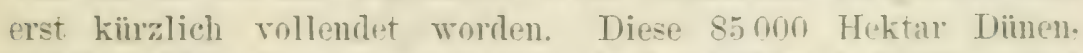

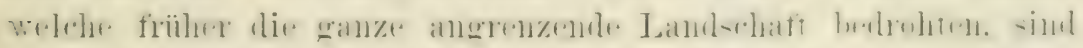

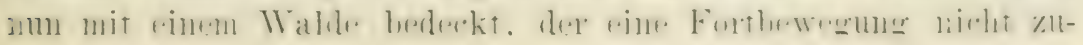




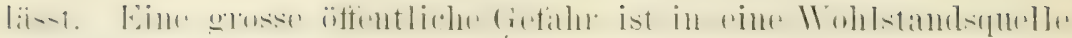
rerwandelt worden.

Nach dem Verluste von Eilsass-Lothringen find die erste

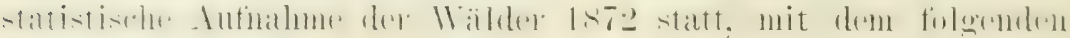
Resultat:

\begin{tabular}{lrr} 
Staatswaldungen & 900000 Hektar \\
Gemeindewaldungen & 2000000 & .. \\
Privatwaldungen & 6000000 & .. \\
\cline { 2 - 3 } & & 8900000 Hektar
\end{tabular}

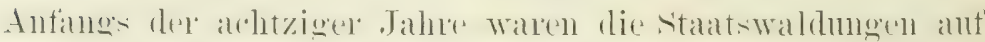

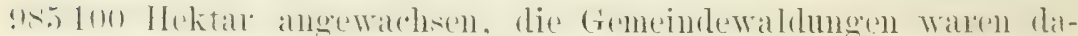

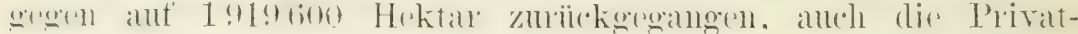

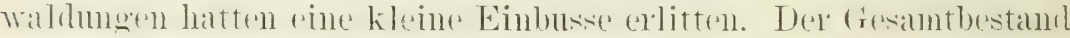

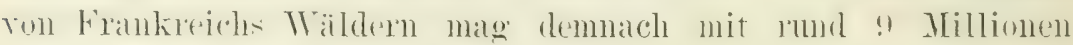

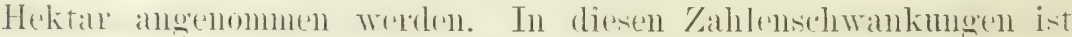

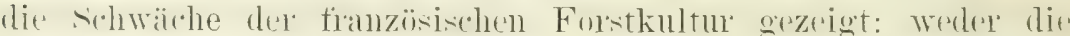

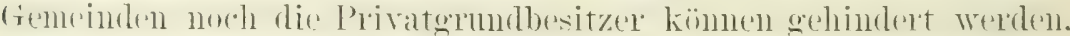

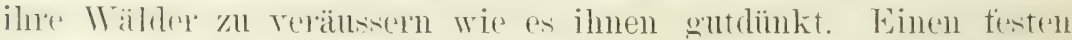

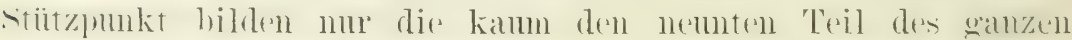

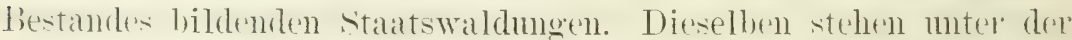

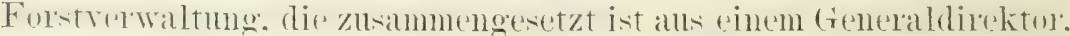

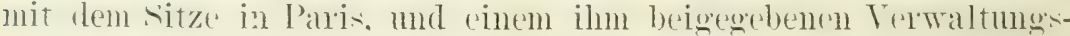
rat. del sirh zweimal wöchontlich versammelt. Im Betriebsplän. zul entwerten. von den Berichten des Beamtenpersonals Einsicht

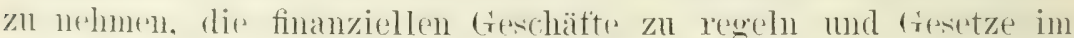
Interesere des Forstwesens vorzuschlagen. In den Provinzen sind

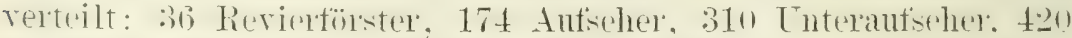
()herforstsehïtzen. Dir Zahl dex Forstschiitzen schwankt, je nach den Bedürfnissen des Dienstes.

Eine Furstlehamstalt, nach dentshem Mnster, bestelit in Nancr.

Als die voxzïglichsten Waldbämme Frankreichs sind za butrachten: dir Fiche in rexwhedenten tren. anch die Korkeiche wird inn sïden und in Corsika knltiviert: ferner die Buche, Eache. tome. Patplel. Birke und der Alorn; an den Küisten spielt die strandkiefer eine Rolle, withend die Aleppo- und Berokiefer ant den Hängen des Südens und Sïdostens vorherrscht.

Frankreichs jährlicher Holzexport wird mit 2:) Millionen Mark bewertet. der Holzimport dagegen nit 240 Millionen. Nieht 


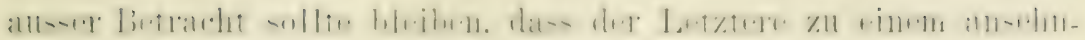
lichen 'Teile tropischer Herkunft ist.

Suanien ist, atsece Enoland. dor einzige westenophitische

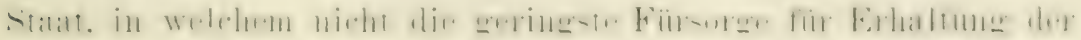

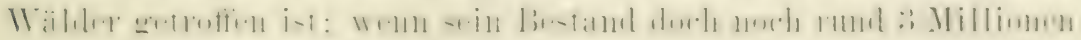

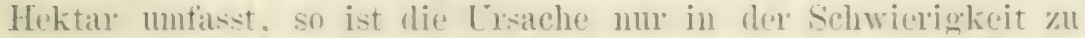
snchen. das Holz der vichen. einer Wasserstrasse wie ciner bistenbaln entbehrenden Gebiroseremden zin verwerten. An Bereit-

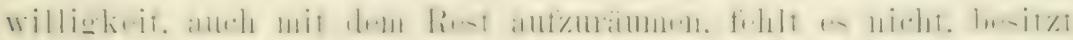

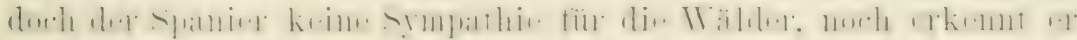

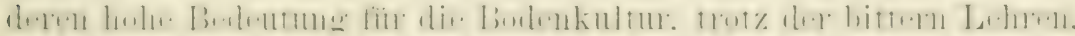

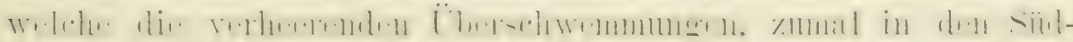
provinzen, wegeben haben. Es ist allen Emstes behauptet nurl

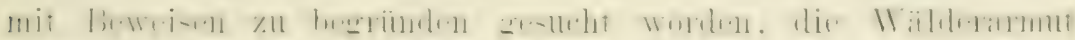
Spaniens in seinen mittlern und sïdlichen Provinzen sei ant

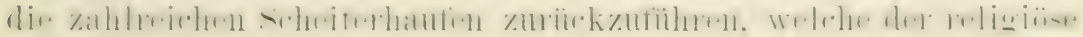
Fanatismus des Jittelalters cruchtete. IVas anch wahr an rlieser.

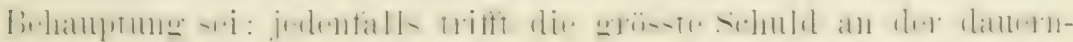

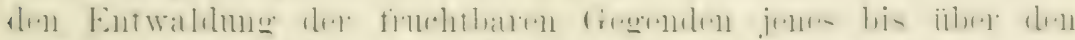

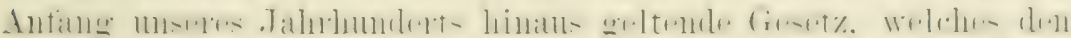

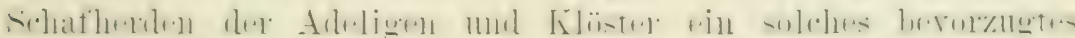

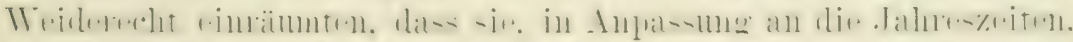

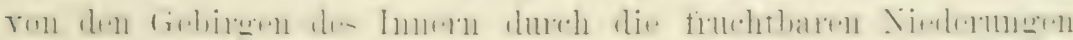

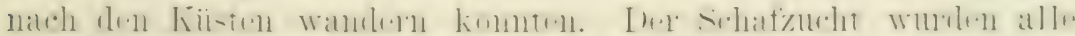

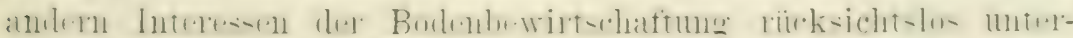

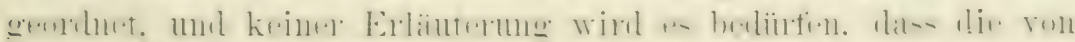

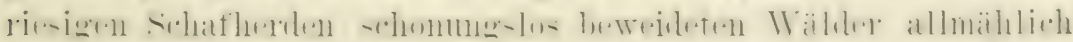

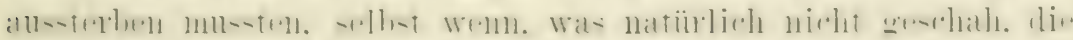

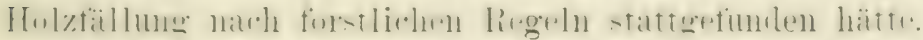

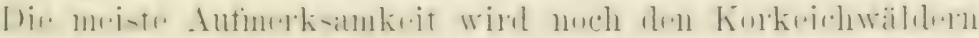

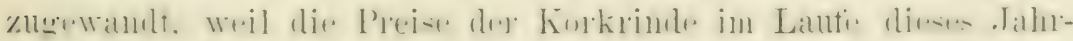

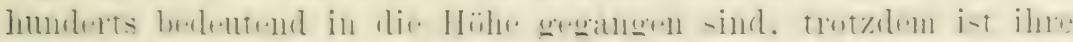

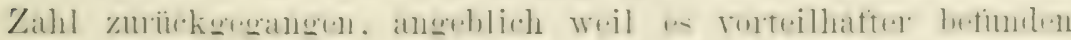

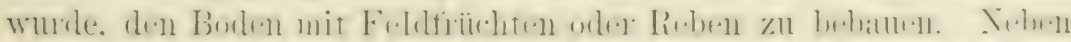

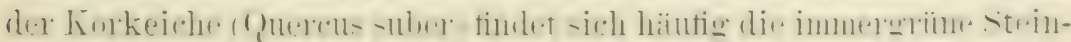

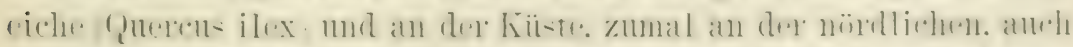

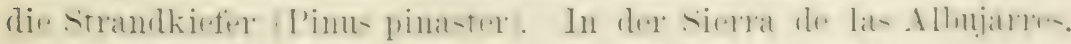

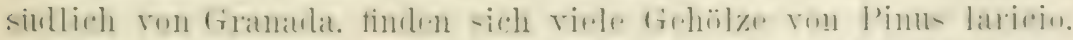

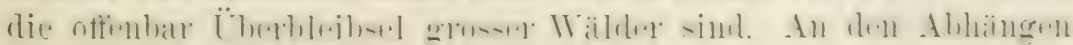




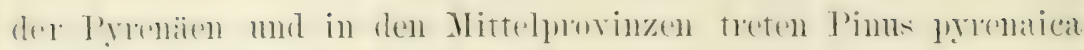
und Pinus halepensis (Aleppokiefer) lläufig auf.

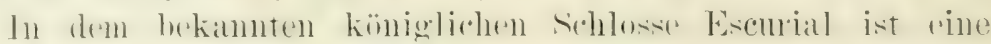

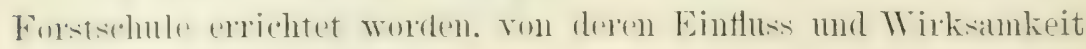
aber nicht viel verlautet.

Portugal ist verhältnismässig noch etwas waldärmer wie

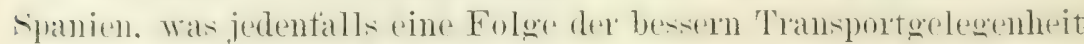

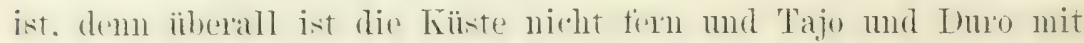

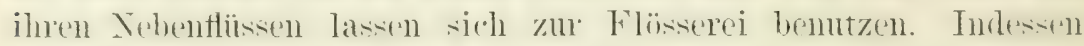

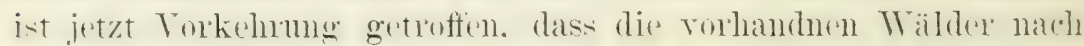

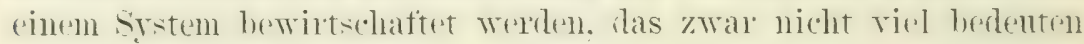
will. abere dorh immerhin ein systrm ist. das auf Erhaltmeg des Besitzes abzielt.

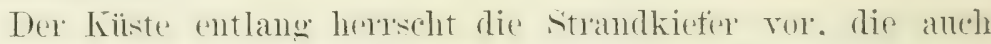

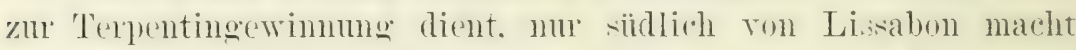

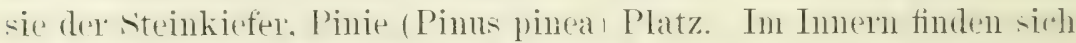
mehrere kleine Korkeichwälder. deren Rindenponduktion die ïbliche

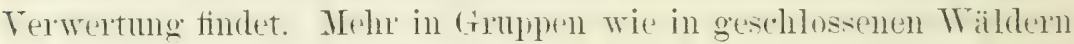
tritt die Steineiche anf.

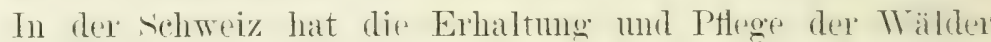
nicht ührall die Beachtung gefunden. Welche sie gerade in disem

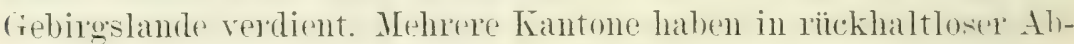

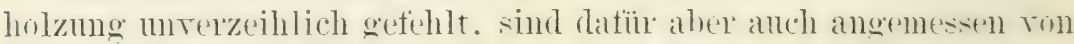

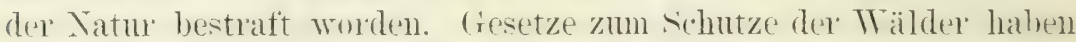

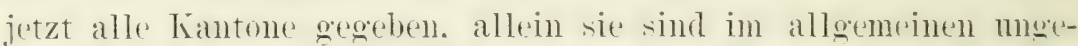

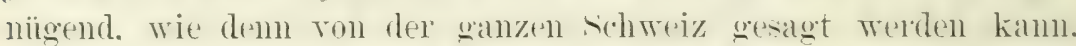
ihre Forstkultu liesse viel zu wïnschen ïhre. Nur einige Kanfone haben Anstrengmeg gemacht. (idland antzutonsten. namentlivh da. wo es gilt die Tasserfïhrung der Bärdue und Flüsse zu regeln.

Der vorherrschende WValdbaum der Schweiz ist die WTeisstamne Abies pectinata!. Welche bis zu Erhohnowgen von 1200 Meter grrosse Tälder bildet. Die Lärche kommt loäufig mit der Burhe

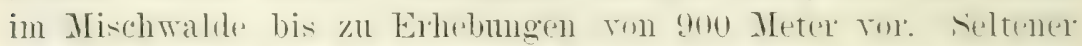

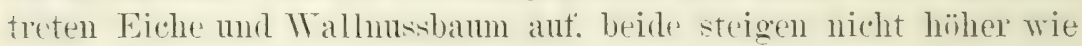

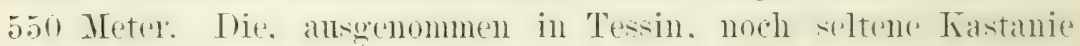
verschmäht höhere Standorte wie 250 Meter".

Italien bietet bei nährer Betrachtung kein erfenliches Bild. dem wrenn atlch soine amtliche statistik von iiber 5 Millionen Hektal Taldland spriclit. st) vergisst sir himzuzutügen. dass in 


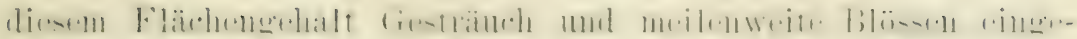

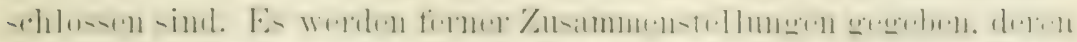

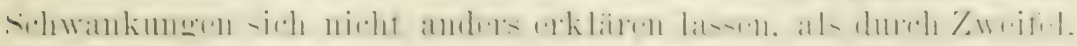
was als 11 ald zu betrachtem ist. So diese:

$$
1870 .
$$

Gemeindewaldumgen 2 169914 Hektal 1 580000

Privatwaldumgen $2662178 \quad$. 2040400

Statswaldungen $215801 \quad$.. durch Verlinufe starli loduziert.

Wie liesse sich. ohm jenc Ammane, eine so stathe Almuin-

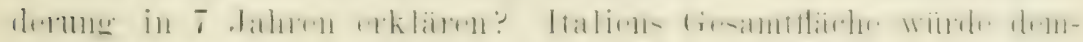
nach zu etwa 12"/n bewaldet sein. 'Tüchtioce Landeskennel bro-

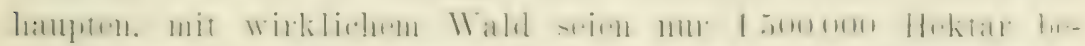
standen und so mage es sein. Tund nul weil dieser liest in mu11.2-

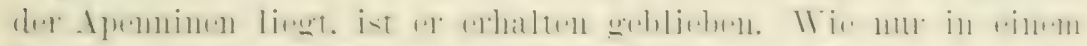

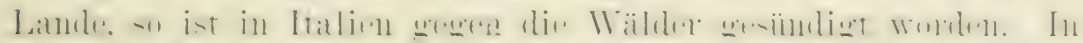

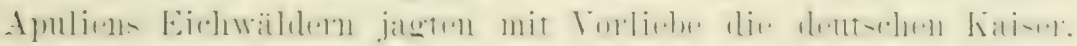
menn sie auf der Romfahrt mach Italien kamen. Tetzt ist di*

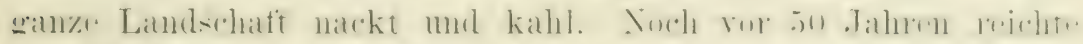

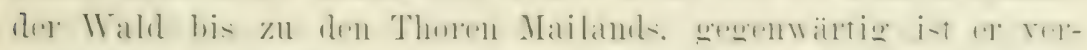

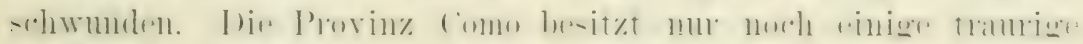

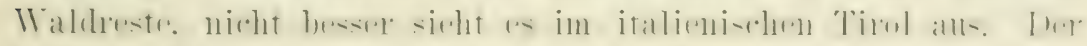

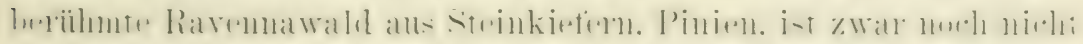

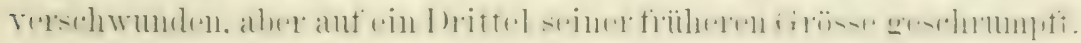

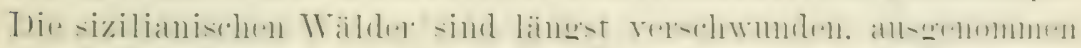

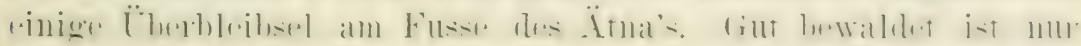

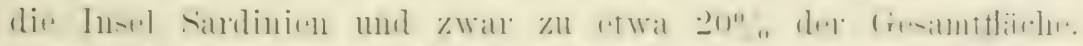

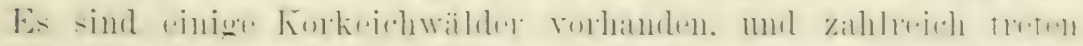

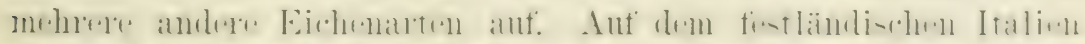

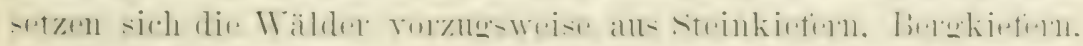

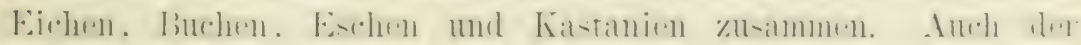

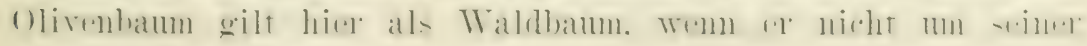
Frichte willen kultiviert wird

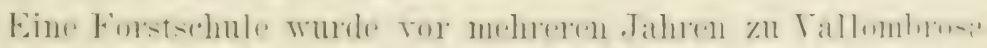

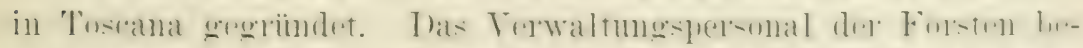

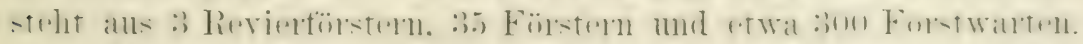

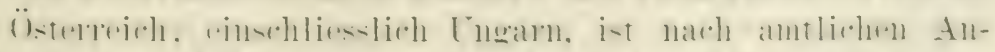

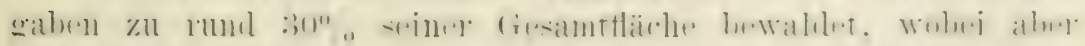

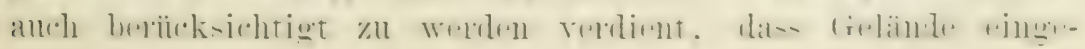




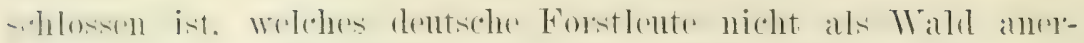

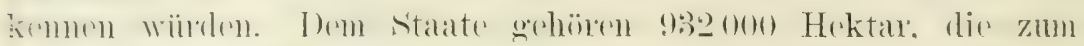

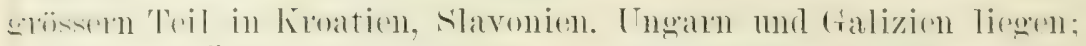

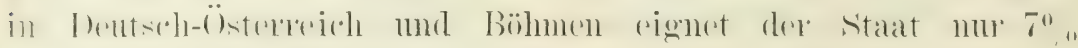
tes Wälderbestandes. Dalmatien, Istrien, Krain und das sitdliche 'lixol sind sehr holzarm und zwar, wie wir bestimmt

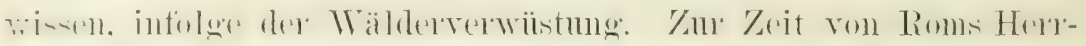

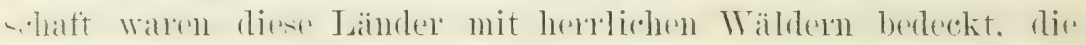

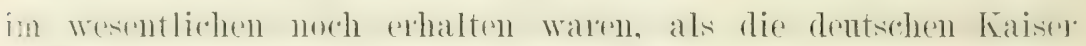

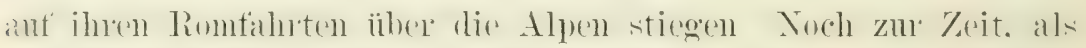

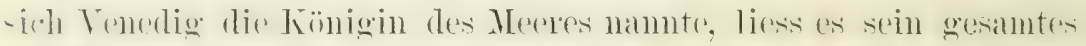
s.hifflanhol\% anf dem hinter Triest aufsteigenden Farst fällen.

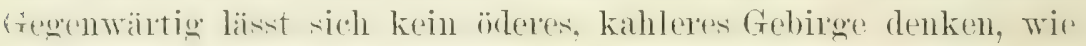

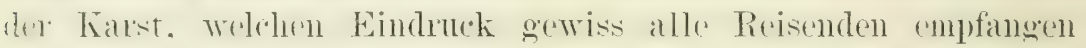

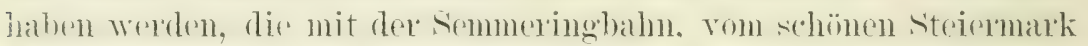

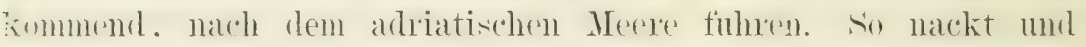

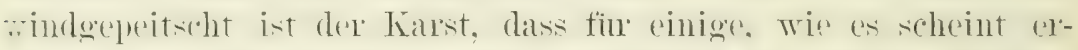

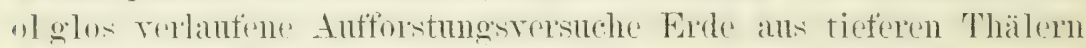

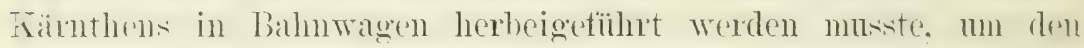

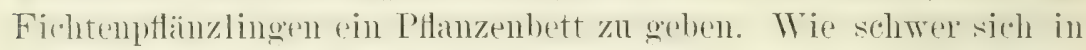

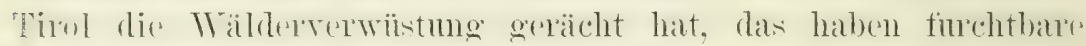

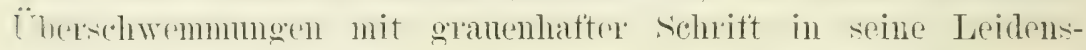
geschichte cingetragen.

Tiele Mäldere (isteredehs: wie namentlich die sehon erwähnten in den Kalpathem. sind wegen Mangel ar Verkehsmitteln dem

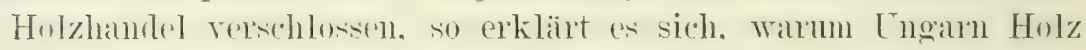
importiert. fieilich ans Bosnien, das man mun als einen damernden Bestandteil diesestadswesens betrachtren darf. Am besten sind

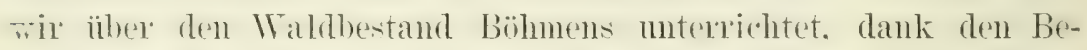
mahnugen ..des komités tïu die land- und torstwintschattiche statistik des Königueichs Böhmen*, das damit ein machahmmng-:wibdiges Bejspiel gegehen hat. Ioh lasse die wichtigsten Angaben folgen :

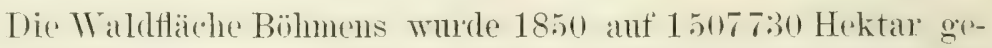

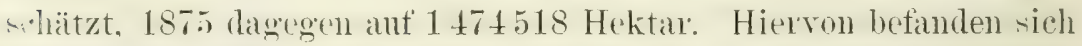
1850 in den Händen des Grossgrundbesitzes, wormuter alle FideiKommis und Lelngite's, somie alle jene Allodialgïter verstanden -ind, deren Gesantgröse 115,1 Hektar (200, Toch) und dariber be'trägt, 9.2018! Hektar oder $62,4^{\circ} / 0$. Der bezügliche Maldbesitz int 


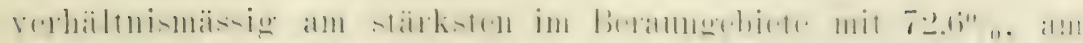

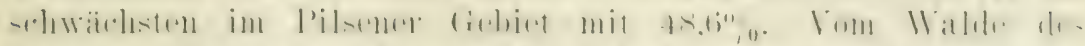

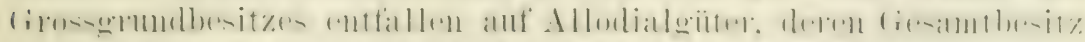

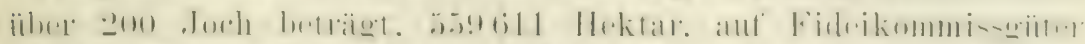

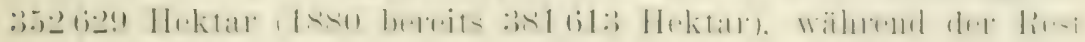
sich ant Lehngiter veleilt.

Die zweite Klasse der Maldbesitzer. die Gemeinden mur Gr. nossenschaften. Worunter alle Gemeinde-, Finchen-, sichul- und

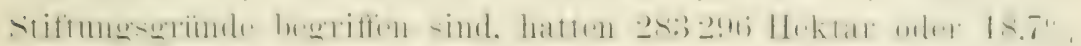
inne, und zwale die Gemeinden 18:3577 Hektal, die Bistiunn:

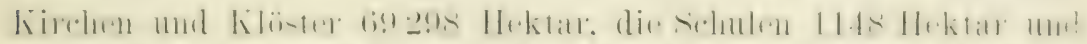

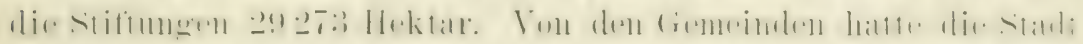

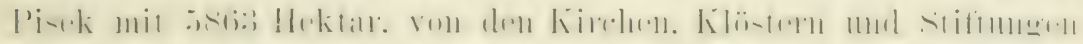

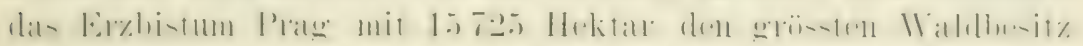

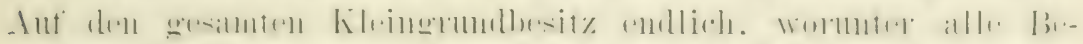

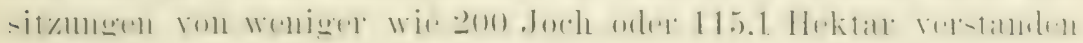
werden, entficl eine Waldtiäche von 306607 Hektal:

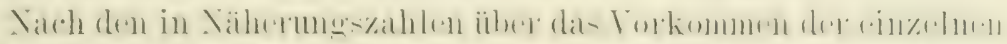

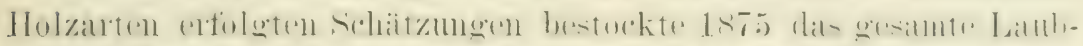

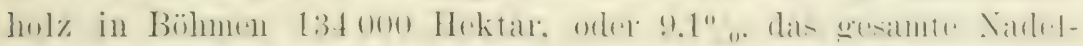

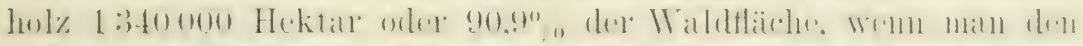

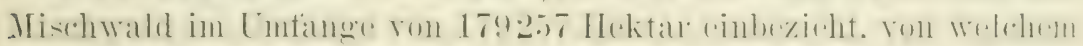

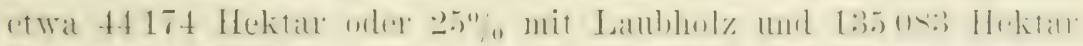

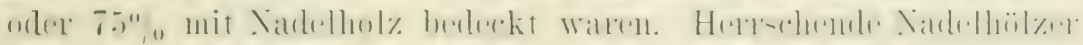

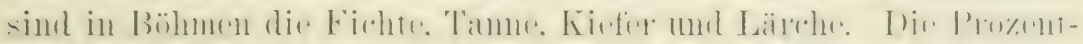

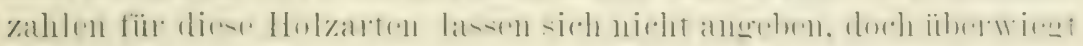

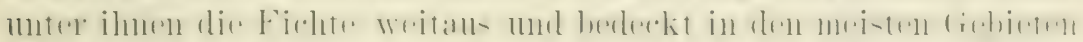

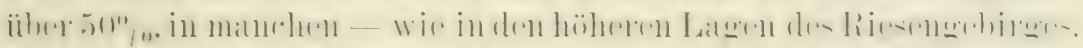

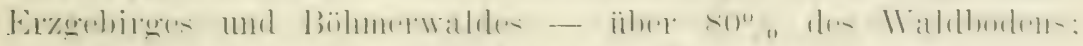

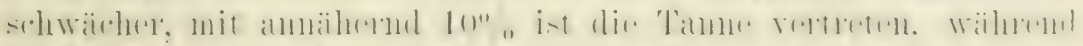

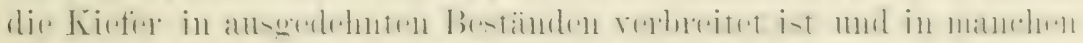
Gegenden 30 bis $35 \%$ oles $1 \mathrm{~V}$ aldbodens in Ansponch nimmt.

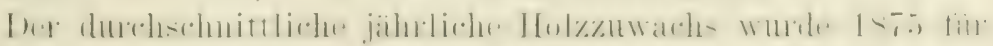
die Fläche voli 1474518 Hoktal in Ganzen ant 4 25:3 741 Fut-

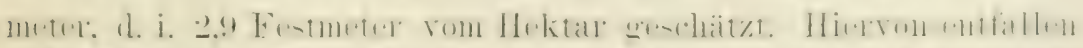

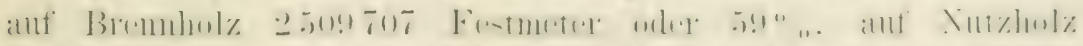

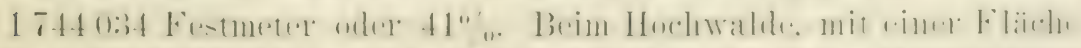

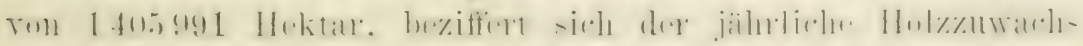

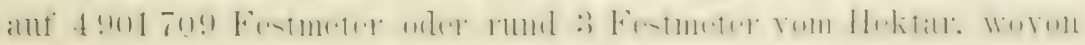




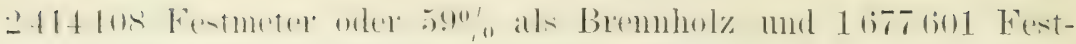

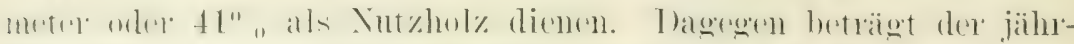

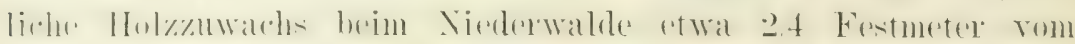

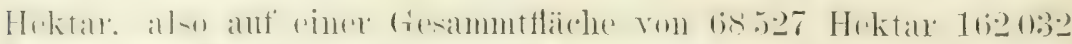

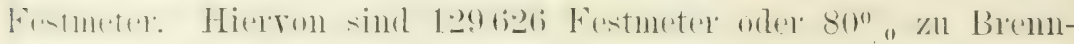
holz und 34206 Festmeter oder 20\% zu Nutzholz geeignet.

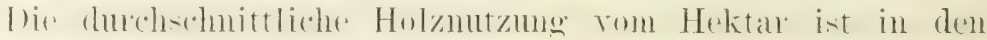

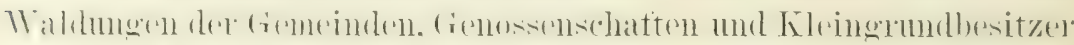

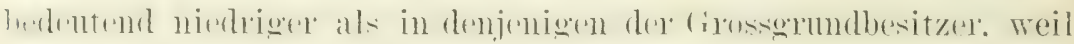

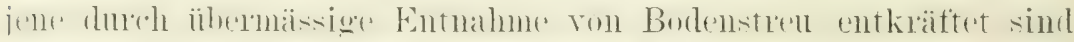

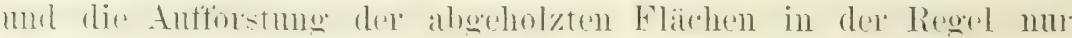

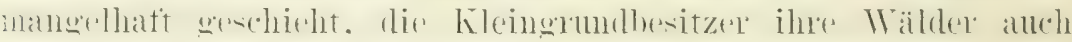

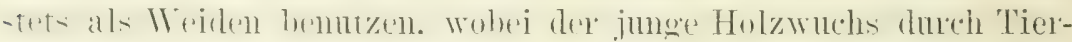

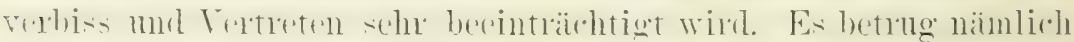
rie Terteilung nach Prozenten:

Gesamtholzproduktion. Holzprodultion vom Hektar.

\begin{tabular}{|c|c|c|c|}
\hline rundbesitz & $69,5 \%$ & 3,4 & Festmeter \\
\hline un. Genossenschaften & 16,6 & 2,7 & " \\
\hline Kleing'undbesitz & 13,9, & 2,2 & \\
\hline
\end{tabular}

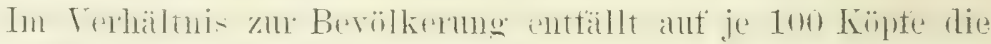

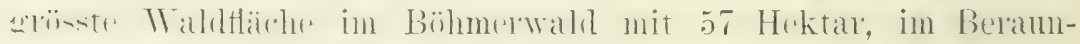

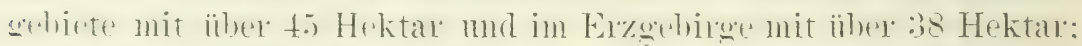

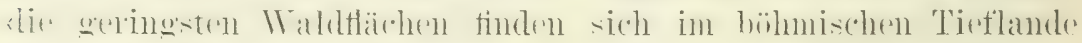

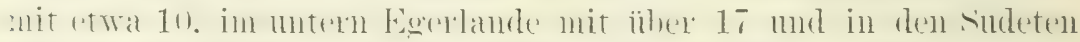

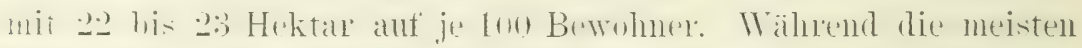

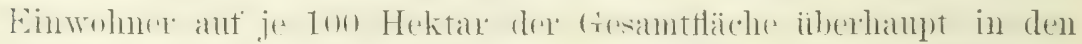

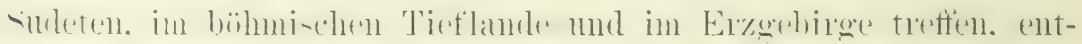

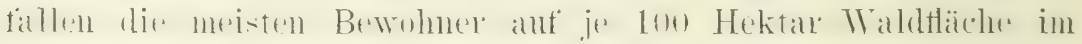

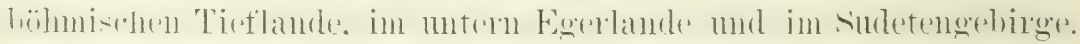

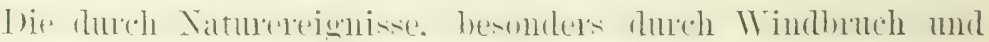

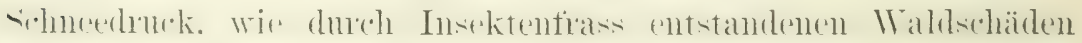

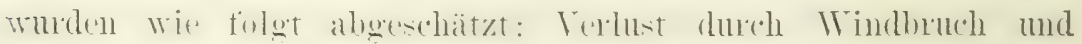

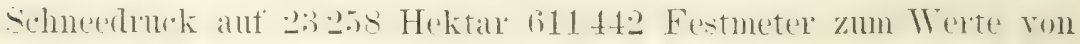

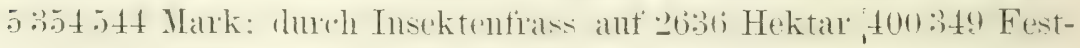
meter zum Werte ron 2049166 Mrark.

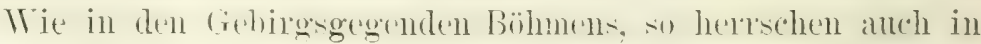

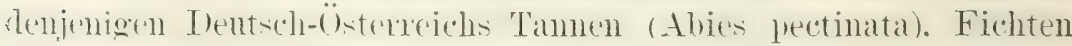

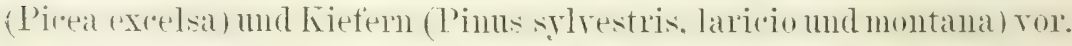
In den tieferm Latgen dre Alpens, in den Karpathen und den 


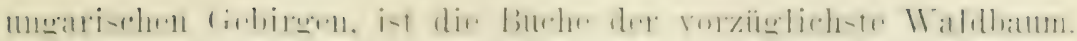

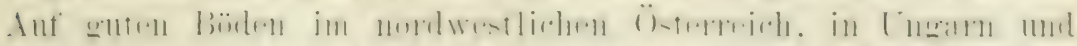

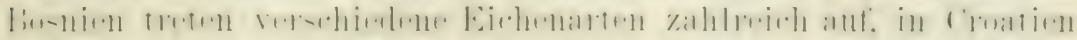

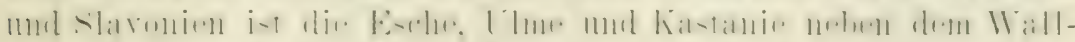
nussbanun ziennlich häutier zu finden.

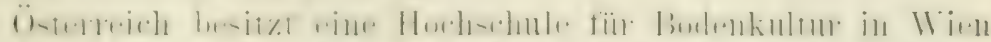

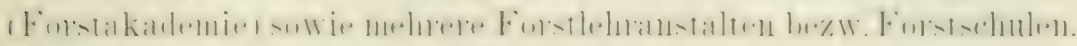
Lneralu eine Forstschule in s'chemuitz.

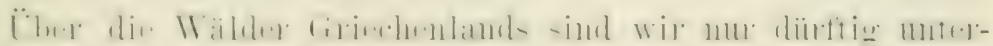

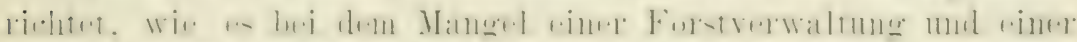

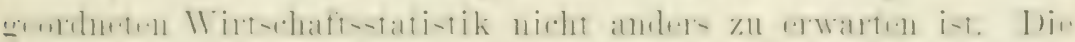

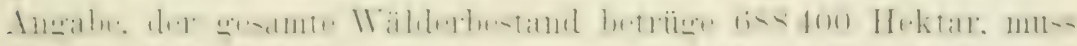

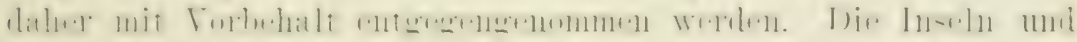

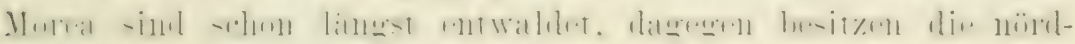

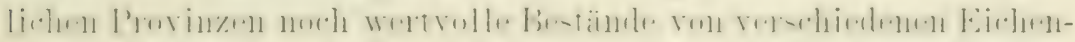

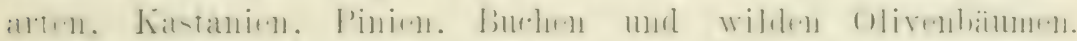

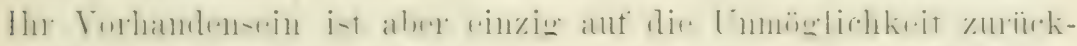

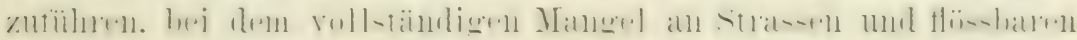

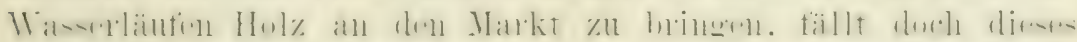

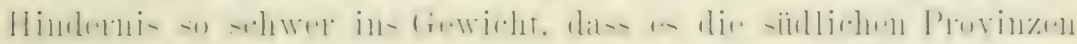

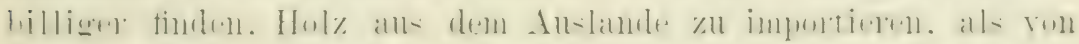
den nördlichen Plovinzen zu beziehen.

Fïr ganz Griechenland aber g'ilt, dass die Waldbestände

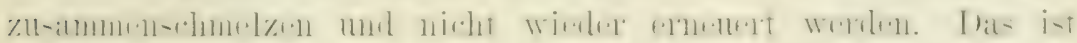

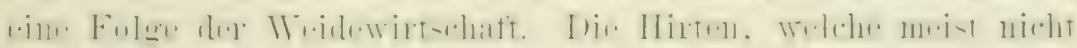

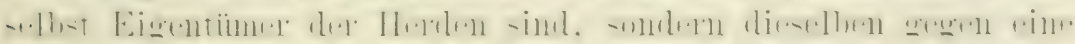

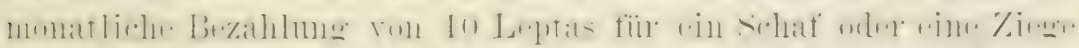

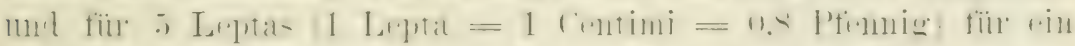

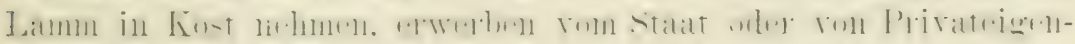

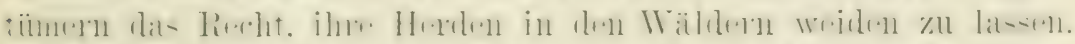

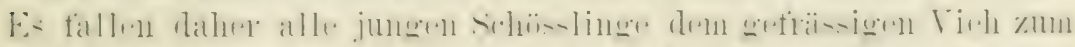

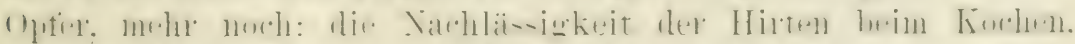

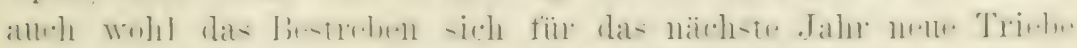
zu sichern, fïhnt zu weitansgreifenden Waldbränden.

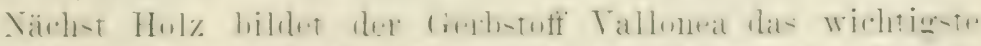

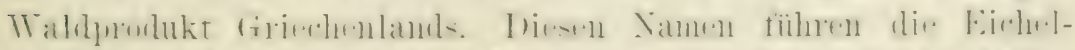

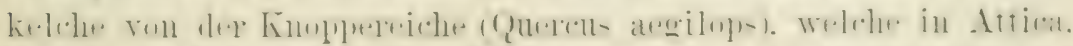

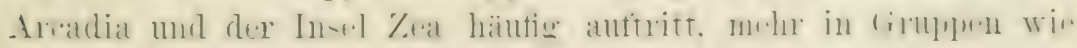
in zusammenhängenden Wäldern. 


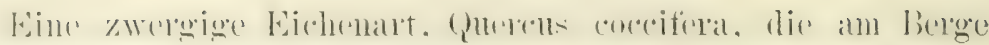

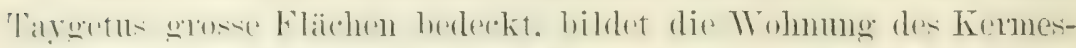

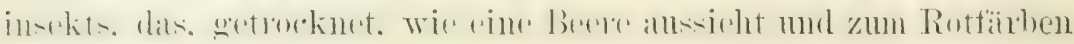
benutat wird.

Womöglich noch trauriger ist es in der 'Türkei mit der Er-

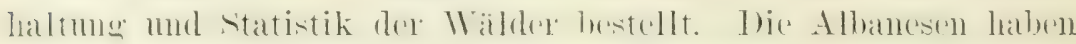

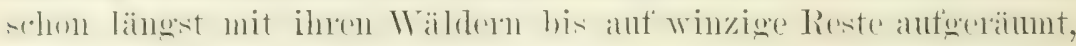

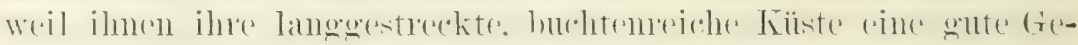

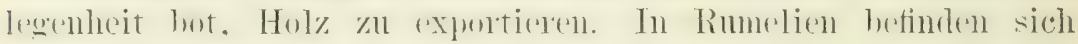

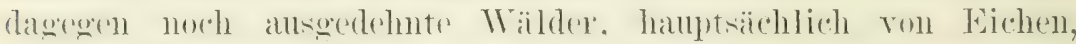

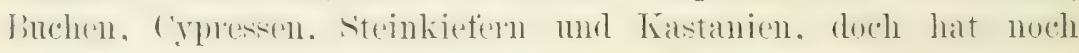
nicmand anch nur oine annähernde Emittelung gewagt. welchen

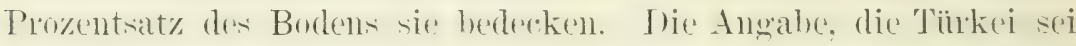

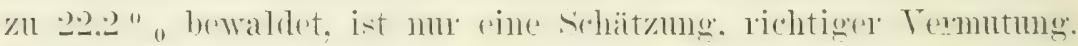

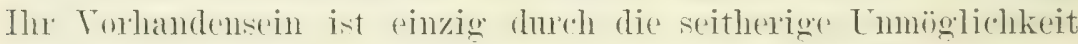

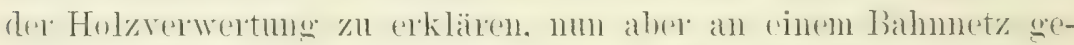
hatut wird, das Abatzoelegenlest nach Saloniki. Konstantinopel

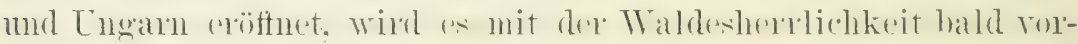

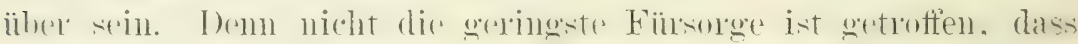
im Abholzen Mass wehalten oder nath bestimmten Regenn vertahren

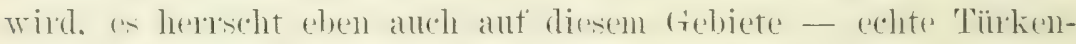

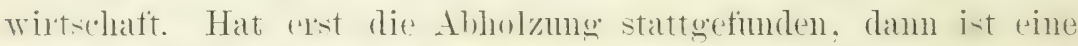

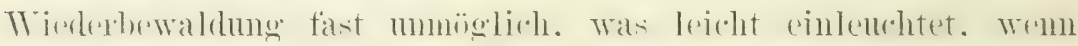

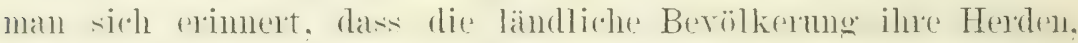
dic anen hohen Prozentsat\% Ziegen enthalten. halbmemadiseh anf den Weiden unherführt und als Wride wird alles Latnd betrachtet. das nicht mit dem Pflug bebaut wird. Aus derselben Ursache

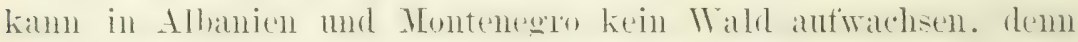

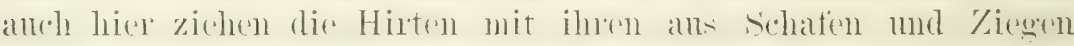

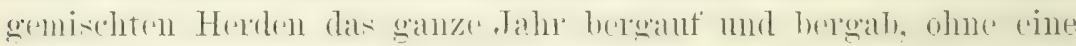

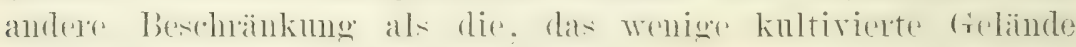
meiden zur mïssen.

Bulgarien ist, mit Am-nahme im Balkan. Wo sich alswerdehnte;

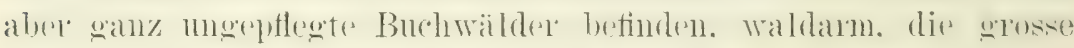

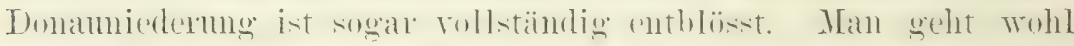

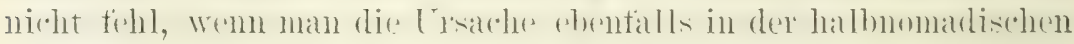
Viehzucht sucht.

Serbien ist im Vergleiche zu seinen Tachbarländern gut be-

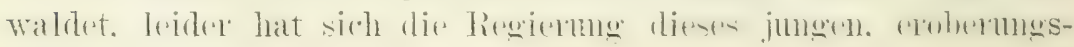




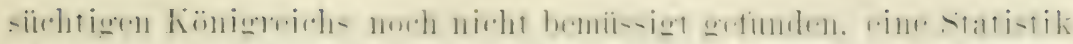

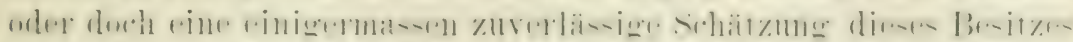

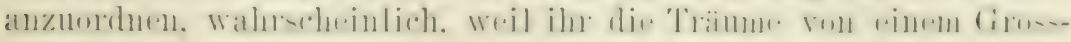

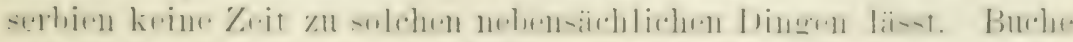

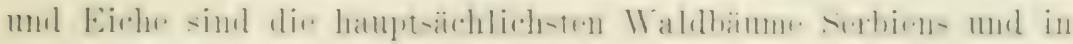

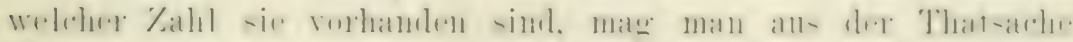

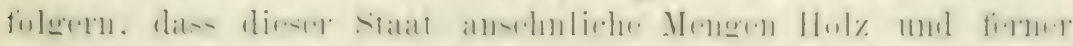

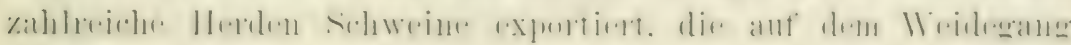

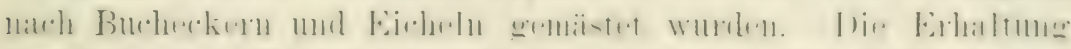

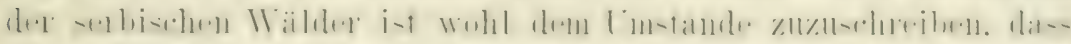

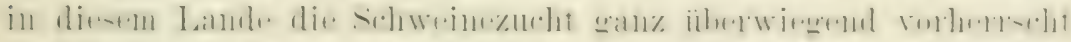

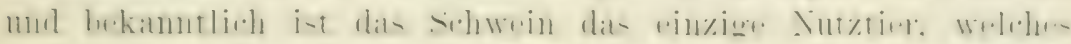

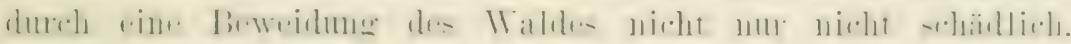
sondern entschieden vorteilhaft wirkt.

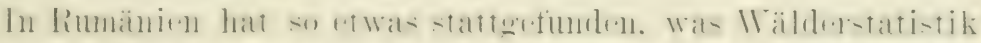

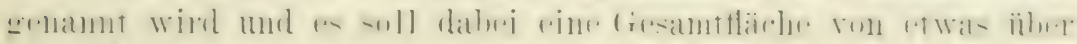

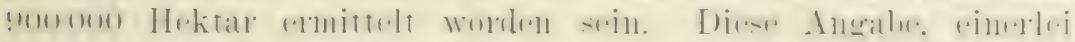

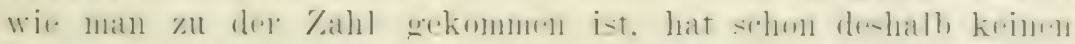

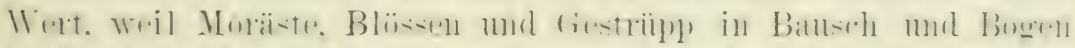

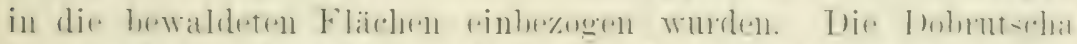

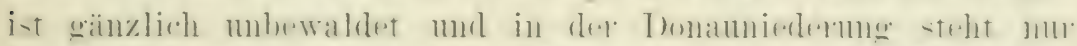

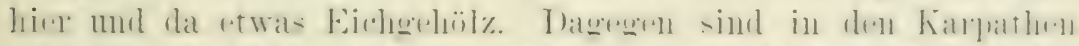

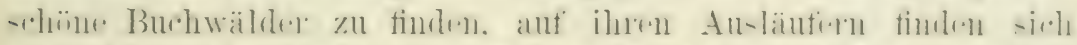

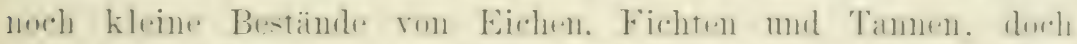

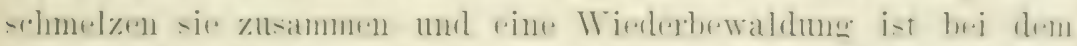

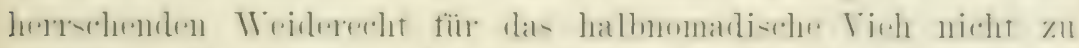

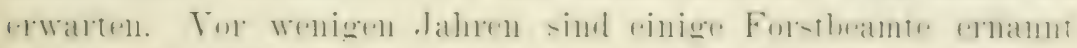

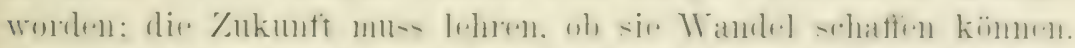

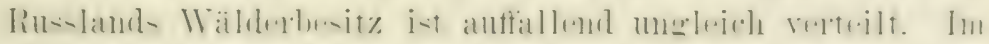

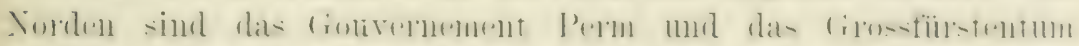

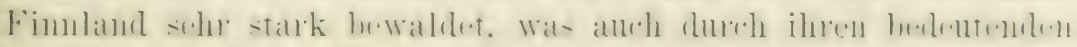

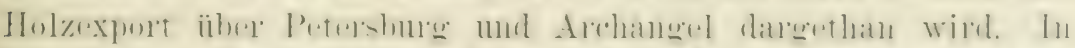

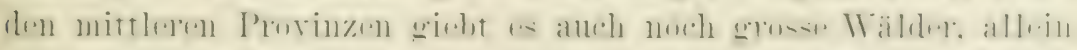

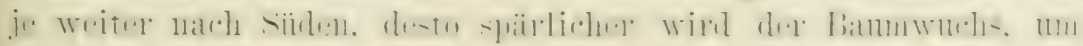

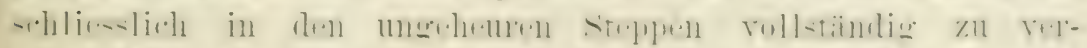

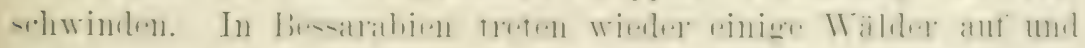

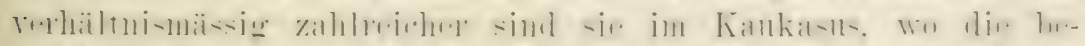

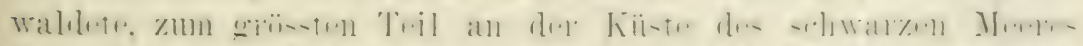

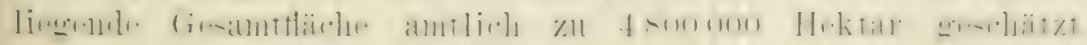




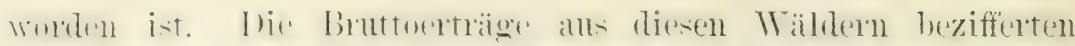

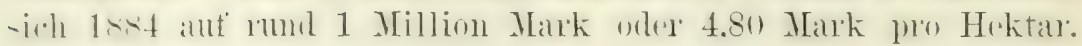

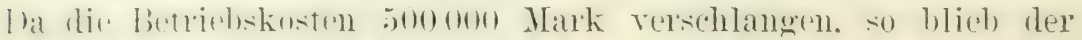
hescheidene Ueberschuss ron 2,40 Mark pro Hektar.

1)ir haltischent Provinzen wal'en einst stäres bewaldet wies

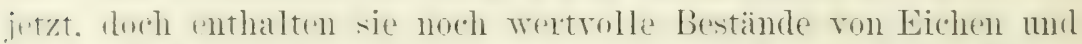

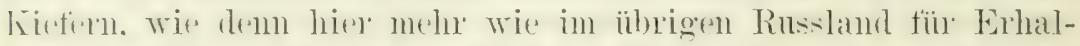

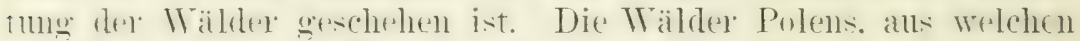

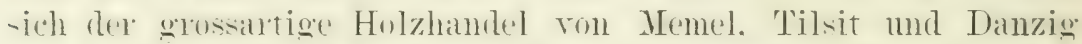
rexsurgt. sind stark exeschumptt und in manchen Gegenden sol] die Anstührung von Holzlieferungen bereits sth schwierig gor

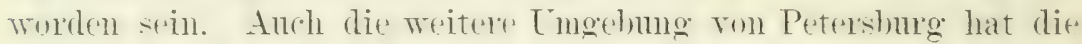
Axt entl)liisst. Wie re dement mit dem Wälderbestand Russlands

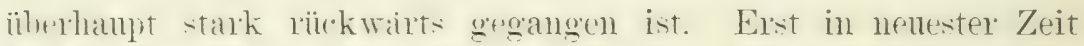

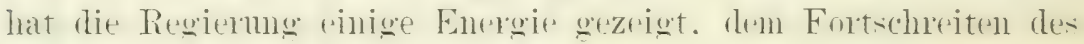
Uebels zu stenern.

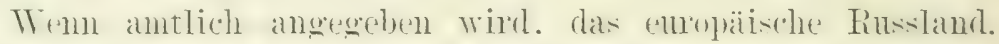

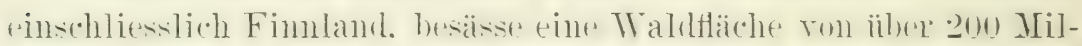

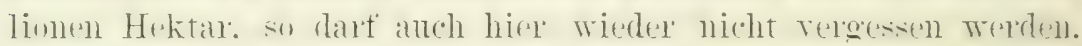

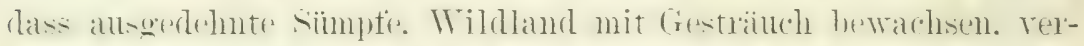

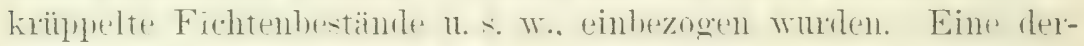
artign statistik hat wftenbar wenig Wert. Die nordietlichen

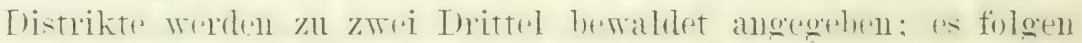
die norlwestiohen Distrikte mit 30 bis 5n " ". An de. mittlexn Trolgat. in dem haltischen und mestlichen Provinzen beträgt der

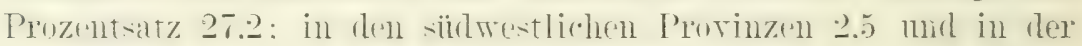
Tirim 0.7 .

Die Kiefer. Fichte und Lärche sind die rorherrschenden

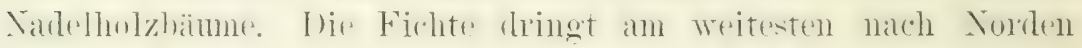

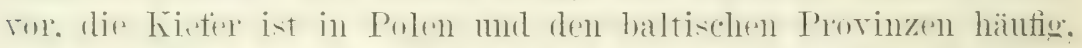

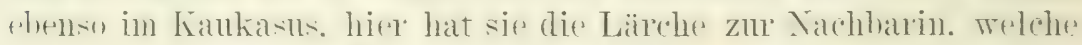

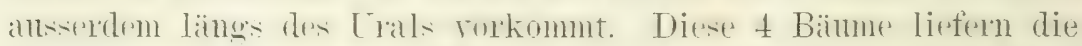

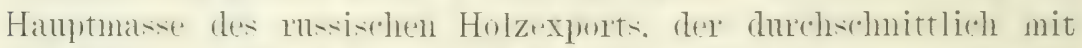
12.5 Millionem Jark bewertet wird. I)ie Birke ist rolzugweise im hohen Jorden zu tinden. site ist bis nach hamsehatka rer-

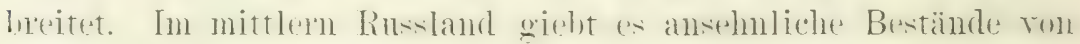

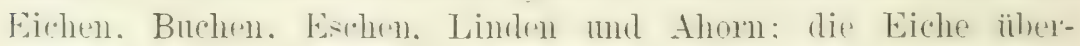

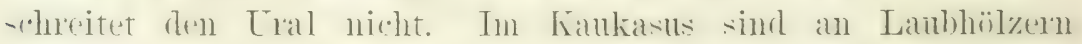

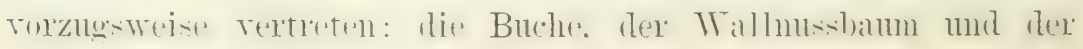




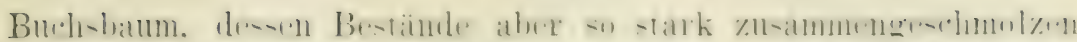

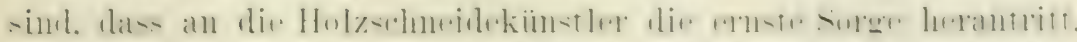

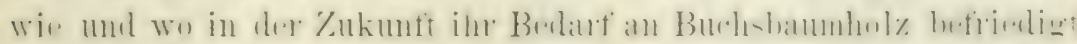
worden wird. Die hrim besitzt sehr wenig Laubholz, ihr

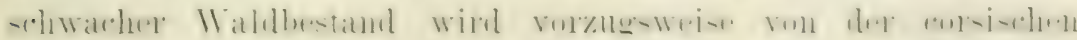
Meerstrands-Kiefer (Pinus laricio) gebildet.

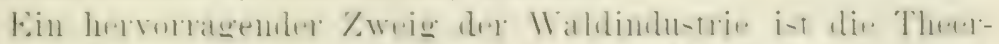

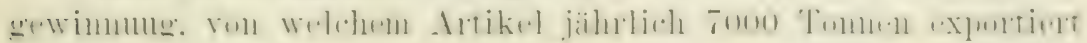
werden.

Russland besitzt eine Forstschule zu Towo Alexandria in Polen und eine andere zu Frois in Fimland.

Wenden wir uns nach dem asiatischen Russland. dann sind

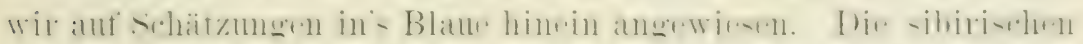

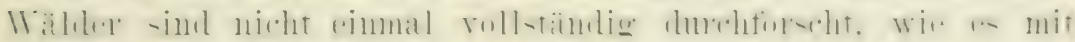

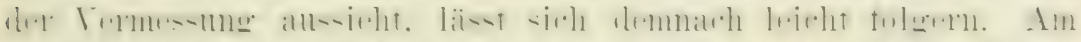

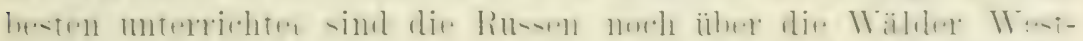

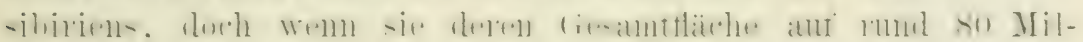

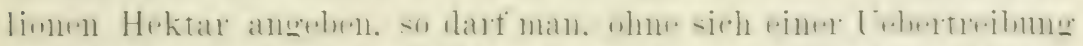

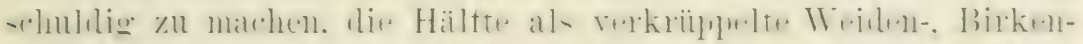

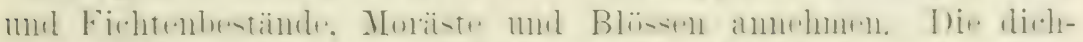

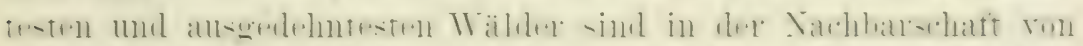

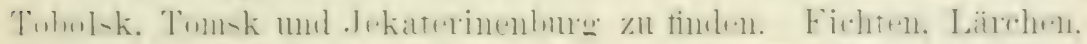

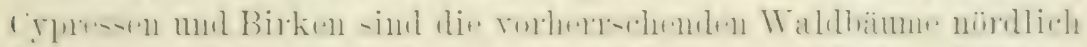

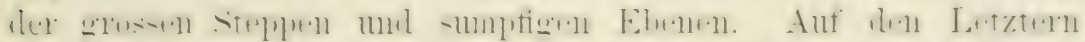

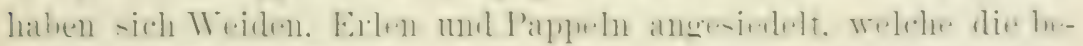

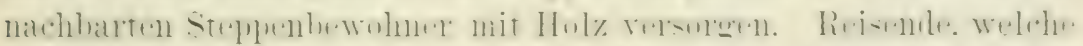

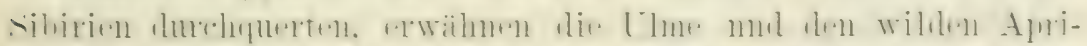

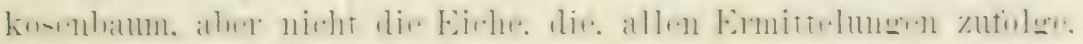
flort nicht heimisch ist.

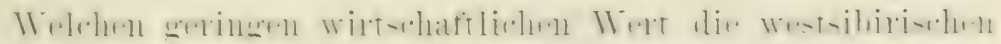

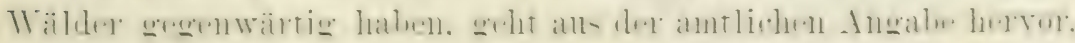

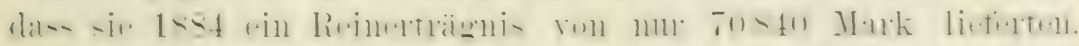

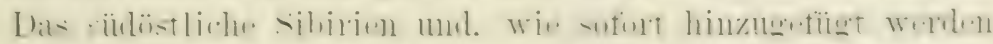

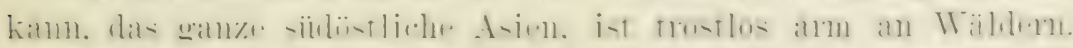

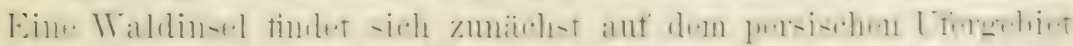

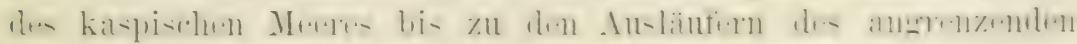
Gebirges. Diese Waldumgen werden als tropisch-ïppig be-

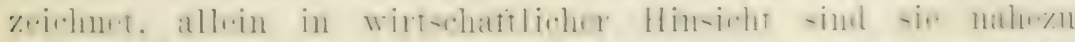

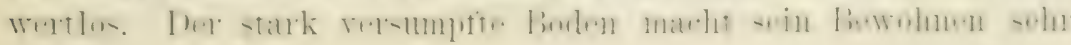




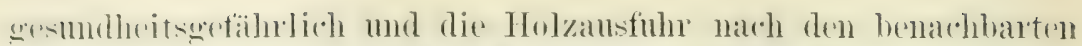
waldlusen fibleten stösst anf uniberwindiche Transportschwierigkeiten.

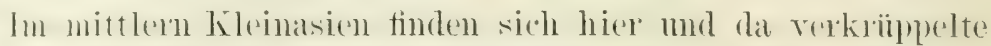
Fiehen- med Fichtenbestände. deren Vorhandensein Verwunderung

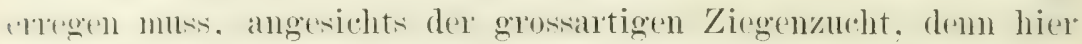
linet der Thistrikt Angora, der jener Ziegenart den Namen gab, welehr das Mohair liefert. Ansserdem durchziehen dir Finden. mit ihnen zalntreichen Herden gemener Ziegen. nomadisinend diese Gebixge.

Ant dem Libanon exzählen mehr oder minder misshandelte

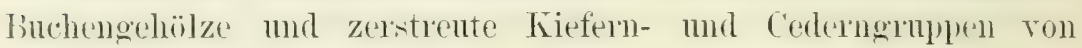
"instiger Waldesherlichkeit. Planloses Abholzen, Sorglosigkeit tïir die Zukuntt und weidende Ziegenherden in grosser Zahl, haben rereint diesen tranigen Zustand geschaffen. Geschiitzt wird von den Behörden nur die berïhmte, oft gexchildexte Gruppe c'edern in Palästina, von welcher man annimmt, sie sei das C̈berbleibsel fentes in der Bibel erwänten Waldes. in dem Salomo Holz fiur den Ban des 'Tempels schlagen liess. Ohne Schntz wiuden auch diese letzten Zengen einer reichen Bewaldung verschwnden sein. Erwähnenswert sind ansserdem noch die zerstrent stehenden Gruppen ron Qqueren aegilops, deren Eichelkelche den Gerbstoff Tallonea bilden.

Fin gleiches schickial wie Syrien mit seinem Libanon traf ('ypern, einst eine der fruchtbarsten Inseln des Dittelmeers. Als es in die Hände dex Türkei fiel, wurden seine Wälder riucksichtslos verwiistet. mit der traurigsten Wirkmng. Dex Regunfall wurde Treniger, Quellen mud Tasserläufe versiegten. dic Erdkrume wude ron den Feldern geschremmt und in den Niedermugen bildeten sich simpfe, die tödliche Fieberdiunste anshanchen. Als dir Engländer die Terwaltung dieser Tnsel zubernahmen. erachtete es der Gonvernem als este Pflicht. die wenigen vorhandenen Waldreste zu schïtzen und anstralische Grummibämme zu hunderttansenden in den versmoften Distrikten anptlanzen zu lassen. in der Absicht die gestmdheitlichen Verhältnisse zu bessern. ()beleich dieser Banmwahs erst 6 bis 7 Jahne alt ist. soll er doch schon einen Tohlthätigen Einflus üben. Crpern ghaubte auf des Anstellumg in Edinburg nicint moretreten sein zu diurfen, allein was es

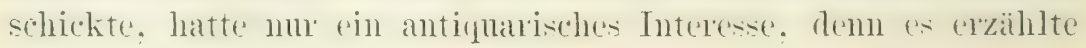




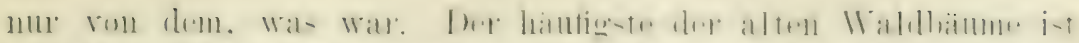

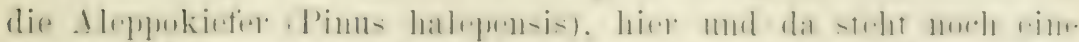

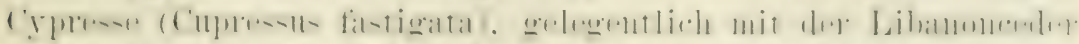

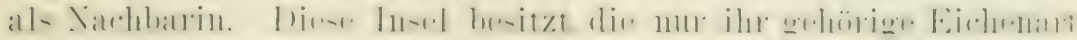
Quereus alnifolia.

Arabien besitzt keine Välder, ebenso nicht Mreopotanien

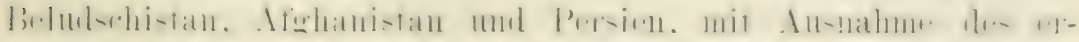

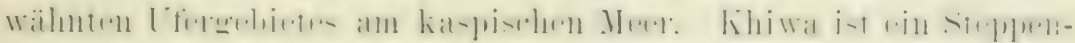

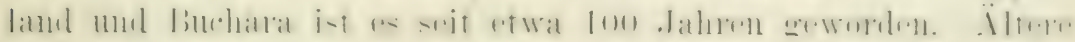

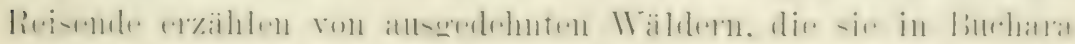

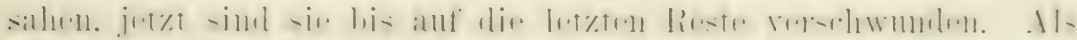

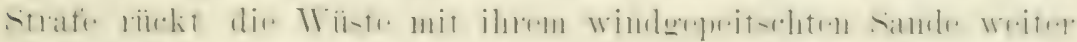

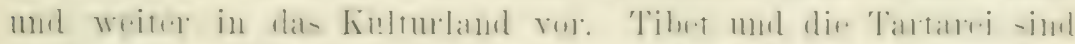

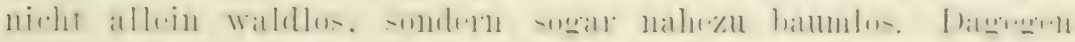

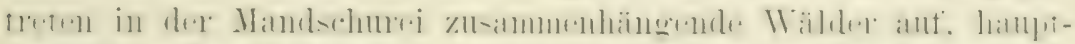

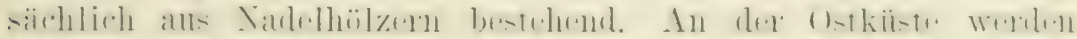

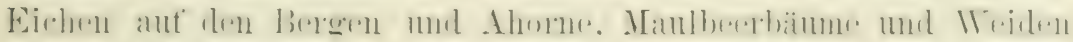

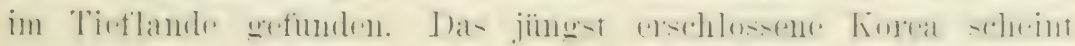

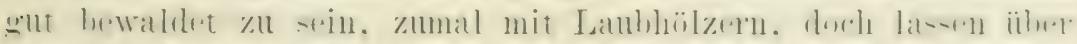

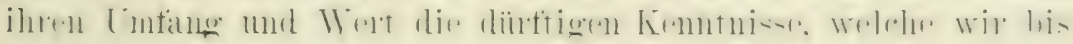
jetzt ïber dieses Land besitzen, ein Urteil nicht zu.

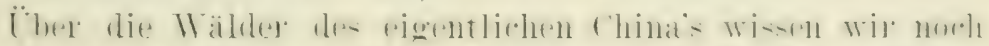

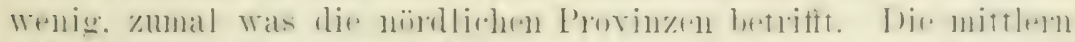

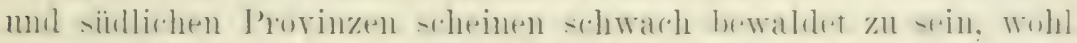

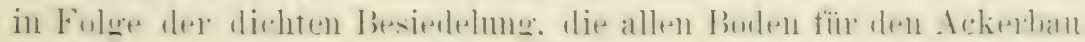

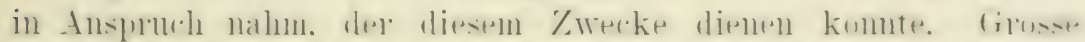

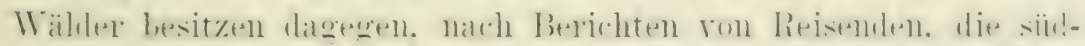

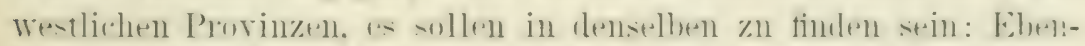

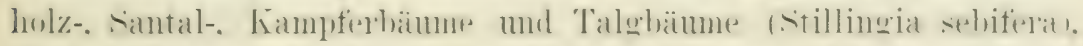

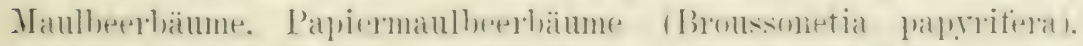

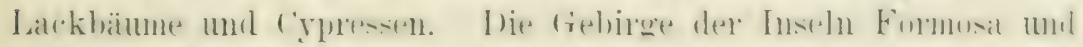

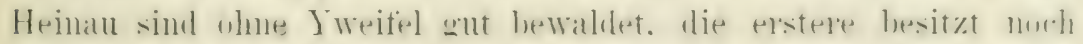

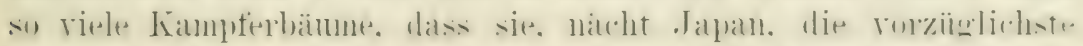

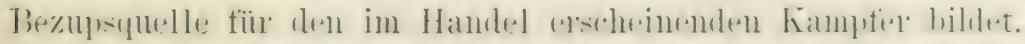

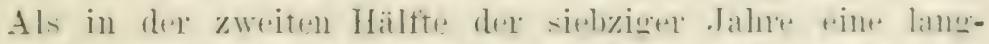

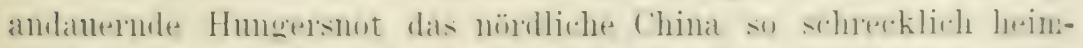

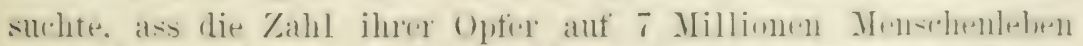

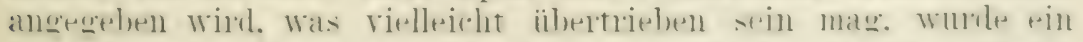

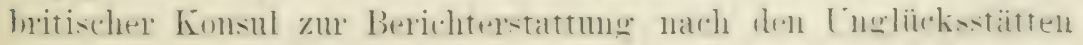




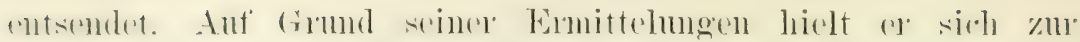

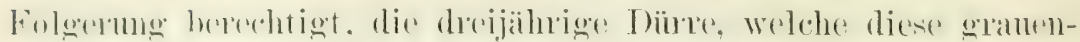

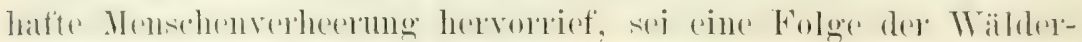

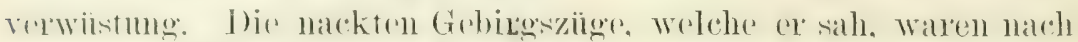
dent Ansiagene altere Lente triber dicht bewaldet; seit ihren rïrek-

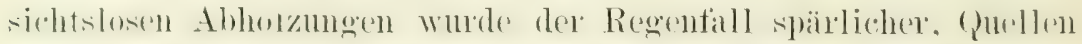
und II asserläufe versiegten. die alls den nördlich liegenden steplen

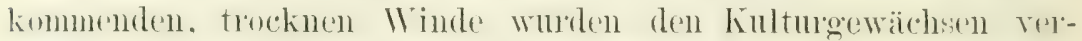

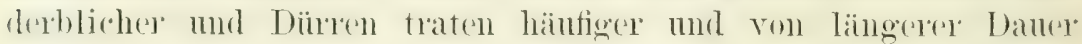
ant. Eiklärlich erscheint. dass im Tnneren des grössten Festlandes die schädlichen Wirkmegen der Fintwaldumg im denkhar schärf'sten Grade auftreten müssen.

Über die einschläglichen Terhälnisse in Anan, (ochinchina, Kambodscha und siam liegen so mogeniegende Berichte vor. dass sic hier ïbergangen werden können. Ton siam sei nur erwähnt. dass es die Ansstellumg in Edinburg mit 500 Holzmustem beschichte. ron welehen genannt zu werden verelienen: Teak, Eben-. Santalmol Adlerholz (Apuilaria agallocha). Anf dem asiatischen Festland bleiben mithin nur noch die Wälder Indiens zm Betrachlome iibrig.

Die der direkten hritischen Herschaft muterstehendern 'Teile Indiens wrden antlich mit rund 870000 englische (puadratmeilen

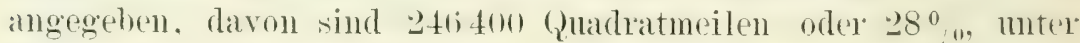

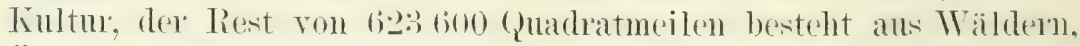
G̈dland und Wildweide. Welcher Anteil im besondern anf die Irälder entfällt, werden wir in naher Zukunft hören, da dexe'n Termesime krätig gefördert wird, gilt es doch auch lange Tersäuntes nachzuholen. Nicht allein unter der Hertschaft der mohamedanischen und Hindufürstern. sondern anch mes derjenigen der "nglich-ostindischen Handelsuesellschaft, blieb der wirtschaftliche

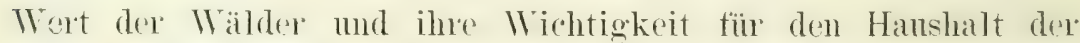
Natur vollstiundig unbeachtet. in Folge dessen ging ihne Zerstiurulig durch Holzfäller, Kohlenbremex, Viehherden und vor allem dureh die nomadisirenden, hallowilden Gebirgsstämme, mochindert volwärts. So lange die Handelsgevellschaft zu gebieten hatte, stand rlie Ausdehmug des Kulturlandes im Vorderorunde der Regierungsthätigkeit, wobei es ganz gleichgiltig blieb, ob sie anf Kosten der Wälder gder des Ödlandes geschah. Als aber manche Distriktes durch die ïblen Folgen der Wälderverwiistumg zu Wü̈sten zu 


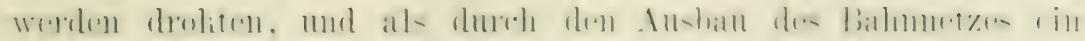

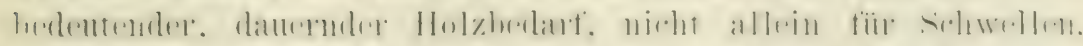

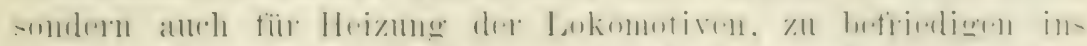

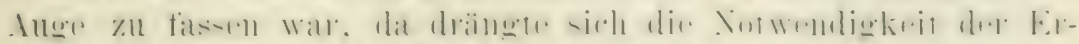

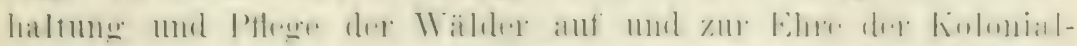

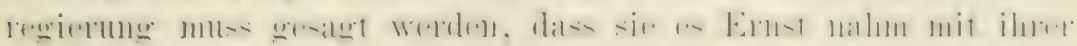

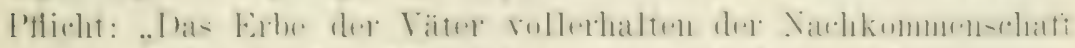

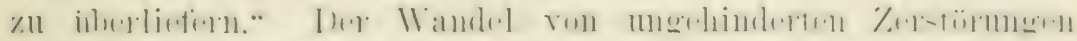

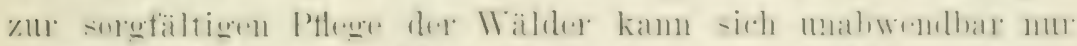

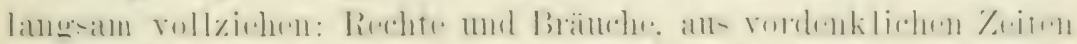

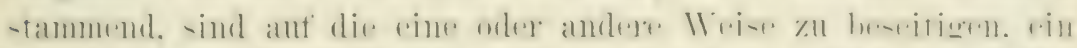

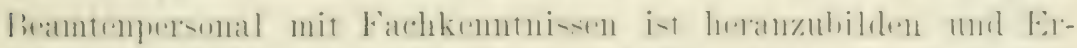

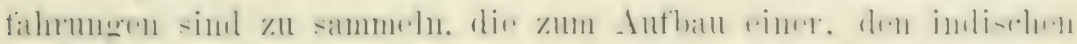
Verhältnissen angepassten Forstkultur dienen miissen.

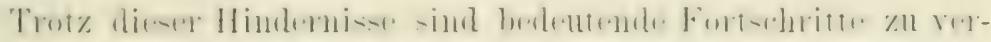

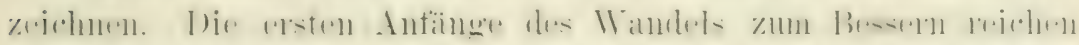

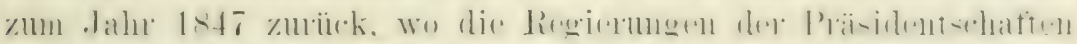

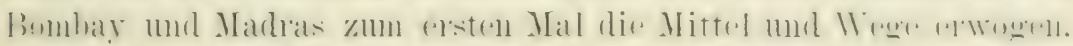

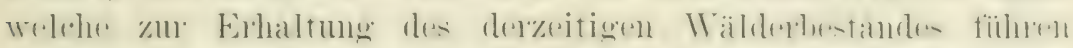

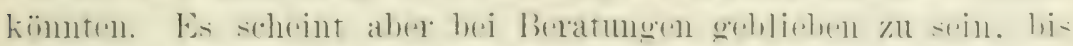

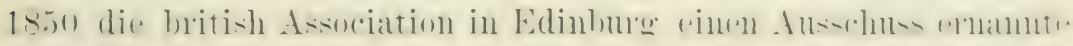

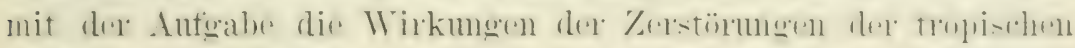

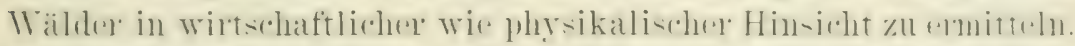

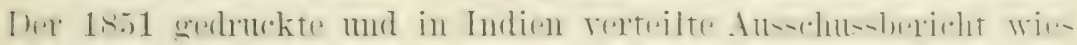

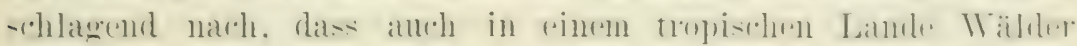

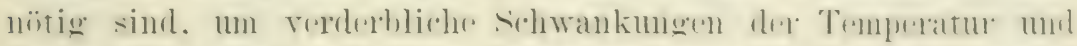

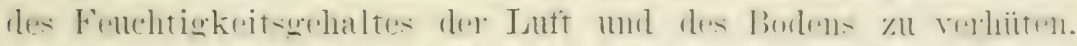

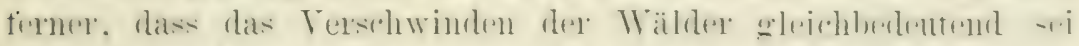

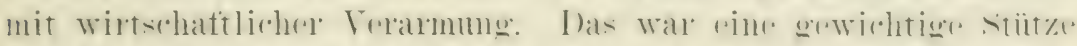

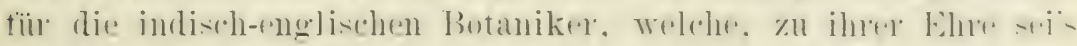

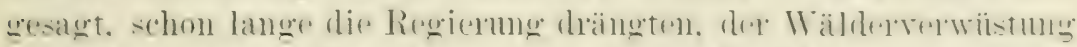

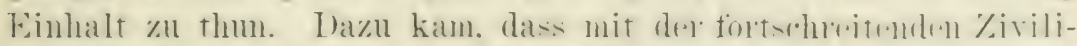

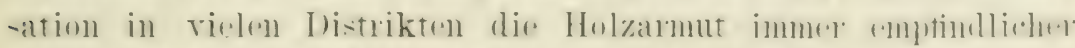

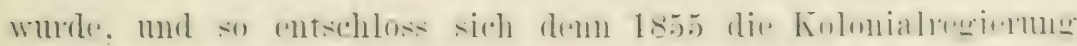

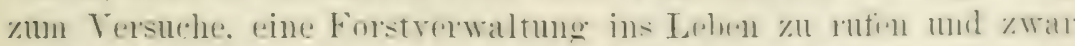

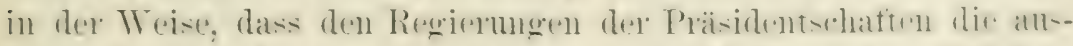

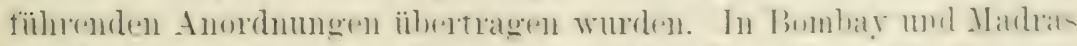

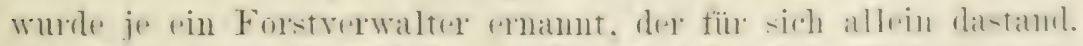

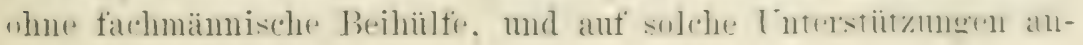




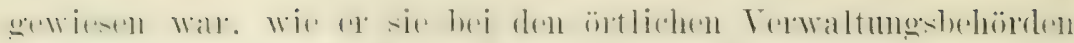

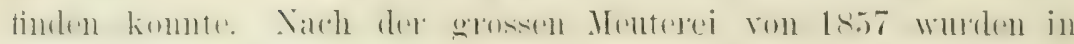

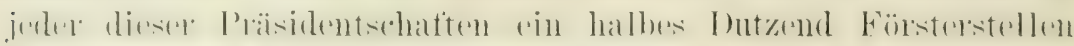

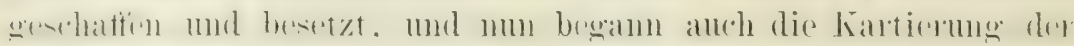

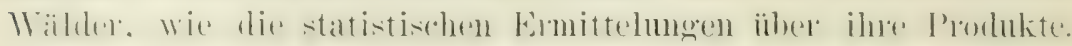

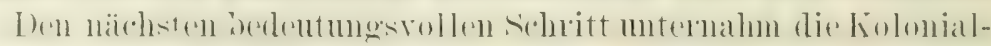

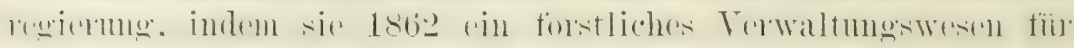

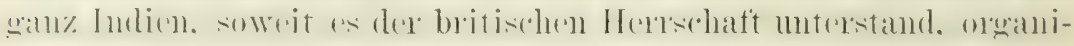

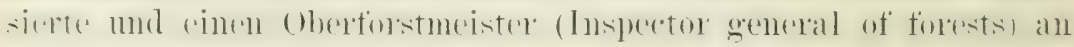

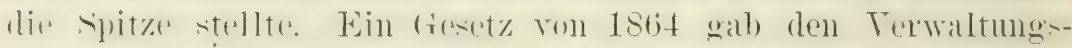

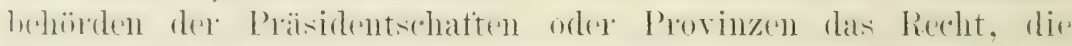

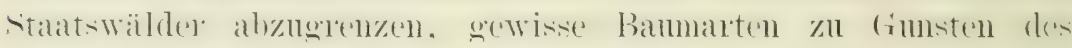

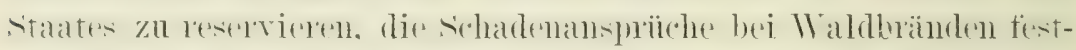

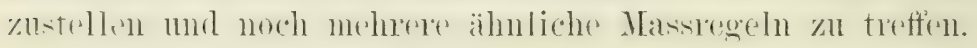

Nanche der ersten Forstbeamten waren ermannt worden, um

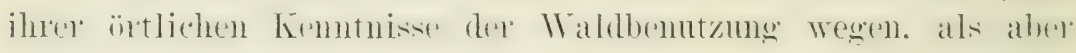

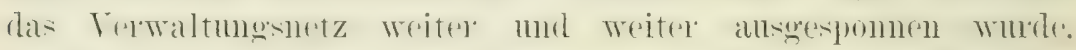

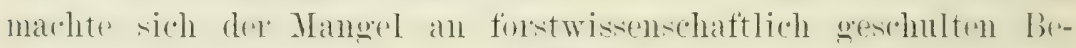
amten hald fïhlbar. Da es rine Forstschule wedere in Indion noch in Grossbritamien giebt, so wurden von 1867 an einige entsprechemd rorgebildete junge Männer zul Aushildung nach dedutschen Forstschulen gesendet. meit meln abt:r wuden der fiamzösischen

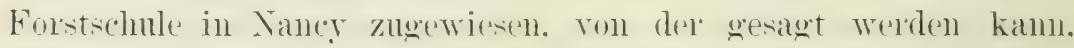
$\therefore$ ie sei in letzter Zait zugleich die Forstschule für Indien gerweren. Nateh einem Regierungsberchlusie von 1885, sollen fortab wedel nach Sancy noch nach dentschen Fehulen Forstzïglinge entsendet werden. da man sie in riner Ingenieuschnle, in der Nähe von Kew in England, ausbilden lassen will. Es bleibt abzuwarton. (1) bei dem Mangel eines Waldes zur praktischen belehrung dir gehegten Erwartungen in Erfïllung gehen können.

Gegenwiartig besteht das indische Forstpersonal ans 1 oberfinstmeister. 15 Revierfürster für die 15 Forstreviere, in relche Indien eingeteilt ist. Jeder Revier besteht ans eine' nicht uibereinstimmenden Anzahl Bezirke. welchen je ein Forstbeamter vorsteht. der' einen 'Titel trägt. welchen man mit Hülfsrevierförster übersetzen kimn. Die Brzirke sind in Kreise eingeteilt, dessen Grösis zwischen sono Hektar mo 30 englischen (2uadratmeilen schwankt mal welche je unter Anfsicht eines Fürsters stehen. Der Kreis ist eingeteilt in Distrikte. welche je ein Forstwart zu beant- 


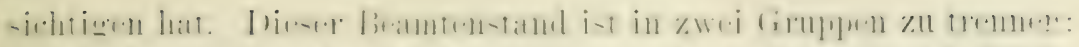

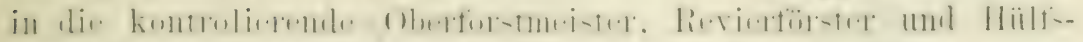
revierfüster) die vollziehende (Förster und Forstwarte).

Iur die kontrolierenden Beamten sind britischer Abkunt,

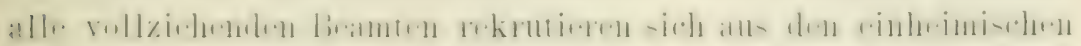
Tölkerschaften. Fiir die Heranbildung ron Förstern ist eine

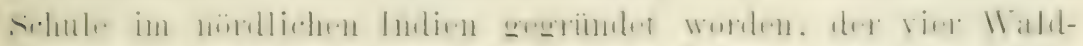

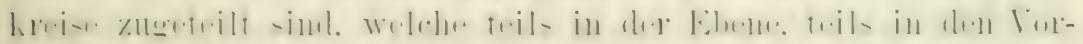

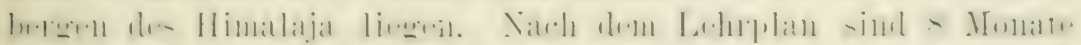

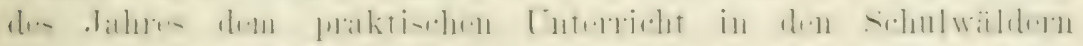

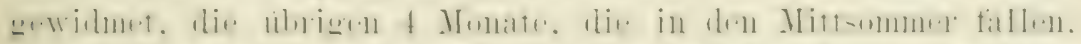

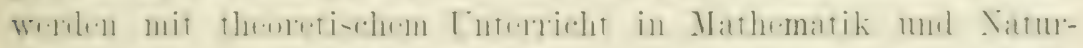

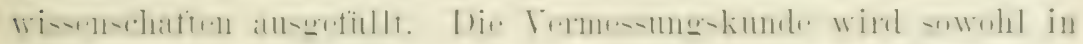
der Anstalt wie im Walde geleht. Alle Zöglinge werden im

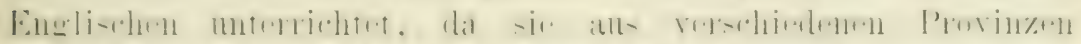

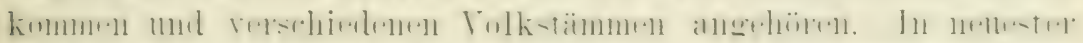

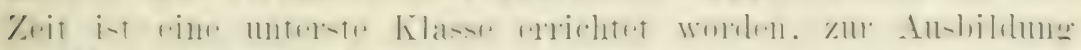

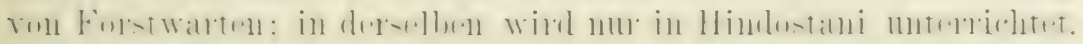

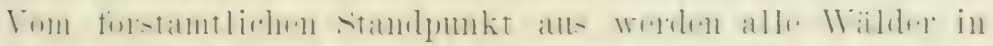
reservierte und oftene geteilt. Als reservierte Tialder gelten

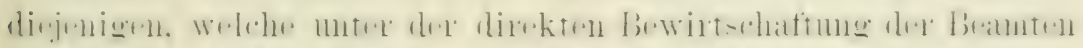

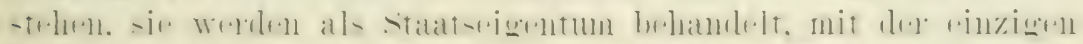

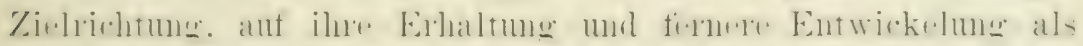

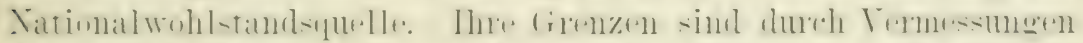

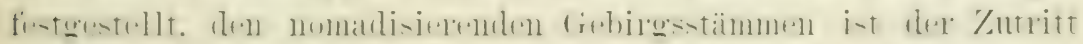

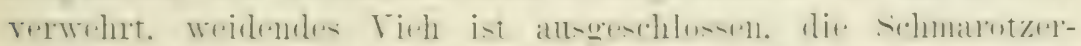

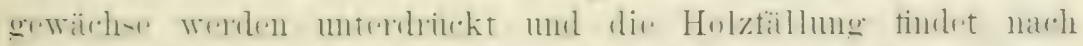

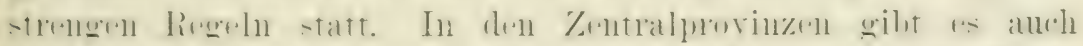

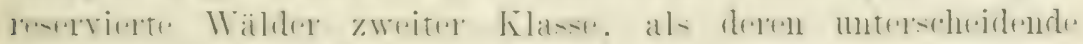

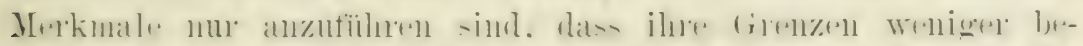

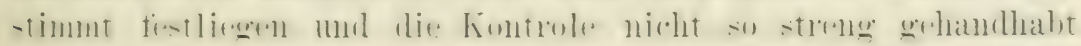

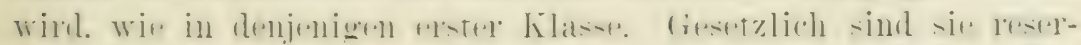
viente II

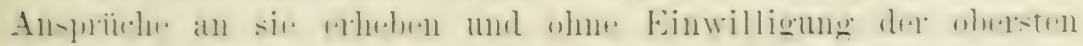

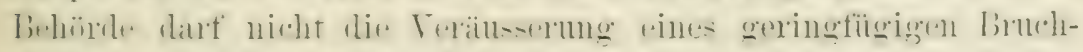

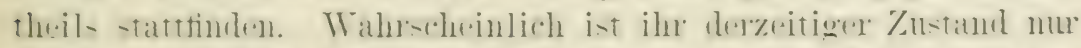

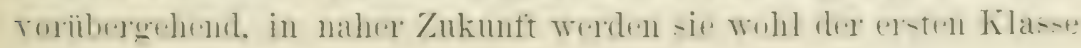
cinverleibt werden.

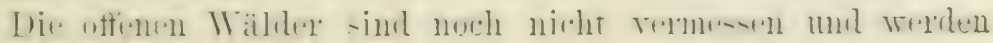




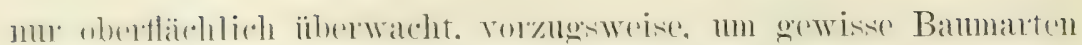

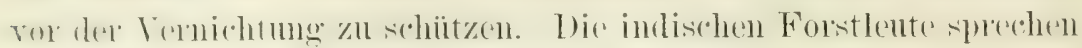

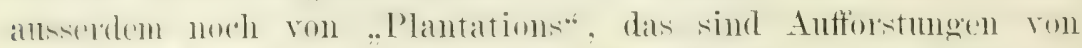

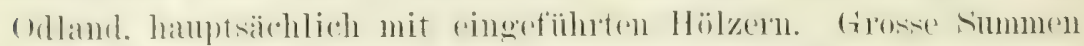

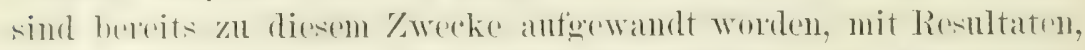
die namentlich an dex (i renze von beludsehistan und Afohanistan

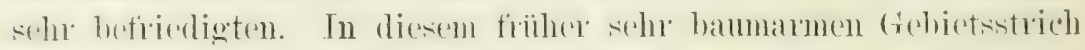

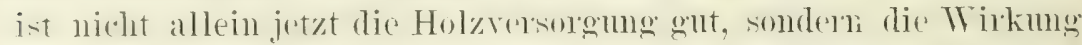
Aer bewaldung matht sich anch in roichlicherm Regenfall mol in

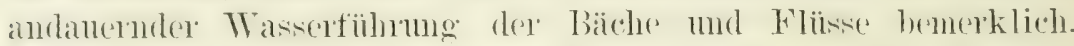
Trelche ehrenvolle. zivilisatonishe That wïnde es spin, die Bewaldung äber die Grenzen hinaus nach Boludschistan mod Afohanistan anszudehnen, damit in diesen halbwïsten Länderin dee Fleiss des Landmanns lohnte und ihe Bewohnex ans rohen Räubernomaden zu gesitteten sesshaften Ackerbauern wïrden!

Bis zum Schlusse von 1885 waren 29371 Quadratmeilen

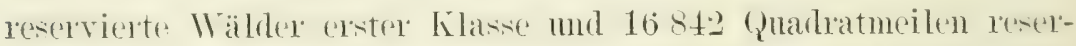
vierte Iälder zweiter Klasse vermessen. In jedem Jahre werelen fortab etwa 3000 Quarratmeilen vermessen und kaltiert, so krättig wird diese Autgabe gefordert. Wrehe Anstehmung die offeren Trälder besitzen. entzieht sich noch der sehätzung, sind doch nicht alle mvermessenen Wräler staatseigentum, sondem teilweises Privateigentum. Toranszugehen hat der Vermessung cine sorofaltige und oft langwierige Untersuchmg des Besitzrechtes, wis des Gewohnheitsrechtes der Weide mol ähnlicher Nutzniesmngen, welches ïber ganz Indien verbreitet ist. Begreiflich erscheint daher. dass die Forstbeamten mit viel Takt und grosser L'msicht landeln mussten. nm den gegenwärtigen Bestand an reservierten Wäldern zu sichern. Die grösiste schwierigkeit bot mud bietet noch jetzt die Tnterdrückmo des nomadenhaften Bodenban's der Gebirgsstämme. welcher als der gröste Feind der Wäldex zu betrachten ist.

In allen grosien Lrwäldern Indiens, die wir gewöhnlich als Dschmogeln bezeichnen hören. denn dieser Name bedentet nicht Röhricht oder Gesträuch wie häufig geglaubt wird. in Arakan, an der nordistlichen Grenze von Assan und Chitagong, in allen Zentralprovinzen und längs den westlichen Ghâts. züchten die Tr'bewohner Reis, Hirse u. s. w. nach dem urwïchsigsten Tertahren, von welchem uns die Kulturgeschichte der Menschheit erzählt. 
Gekamnt als 'T'omeya in Burmal, Jum an dex nordiostlichen

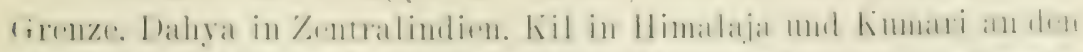

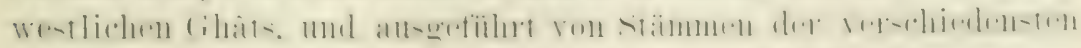

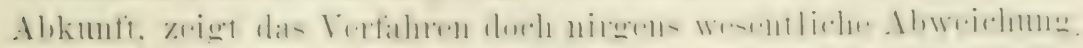

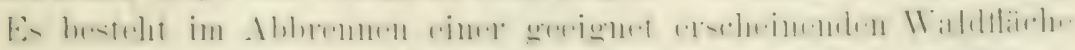

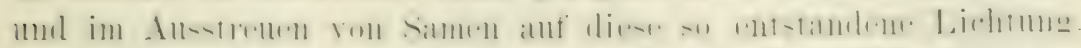

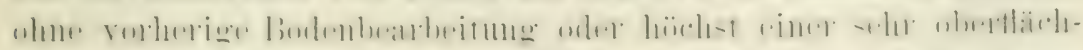

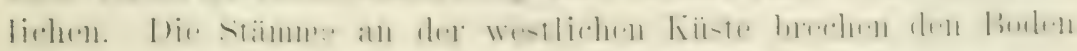
mit einer roben Hacke ant. die sie ans einem Ast schneiden, dey

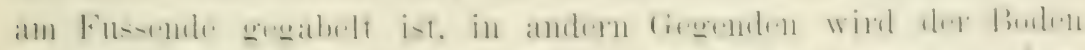

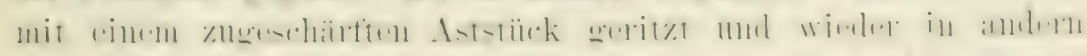

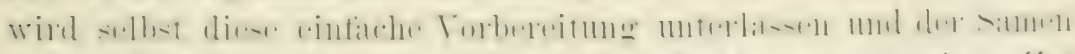

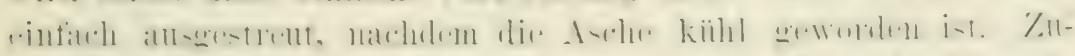

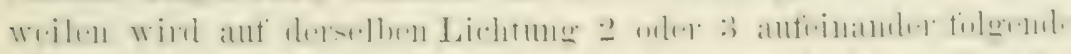

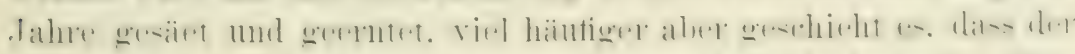

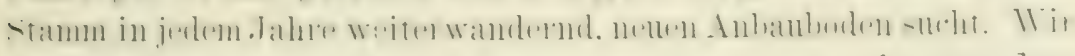
werden ein milderes Trteil fällen. wemn wir mons crimmern. das-

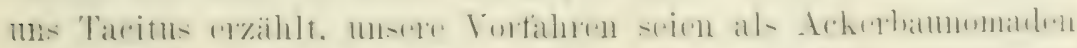

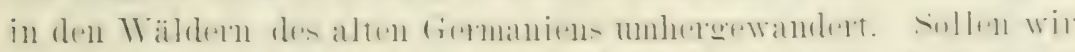

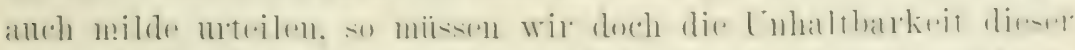

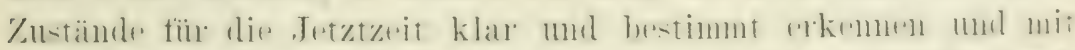

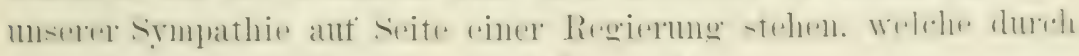
scheinbare Härte Wandel zu schaffen sucht.

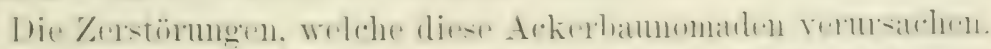

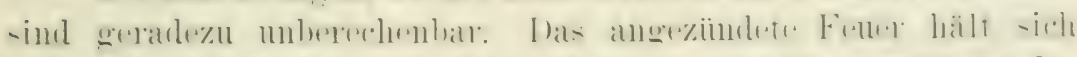

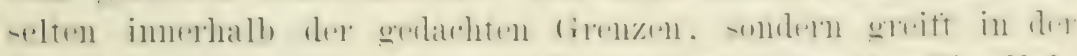

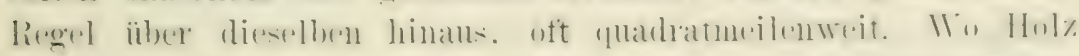
durch die Nähe eines Waldes Wert hat. lässt es dic Forstrel-

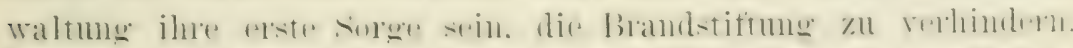

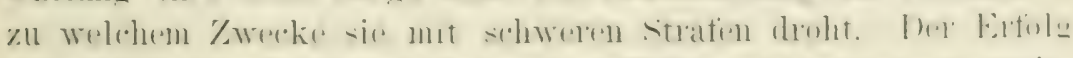

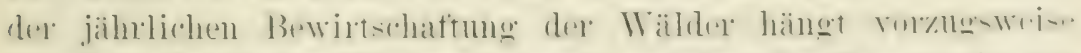

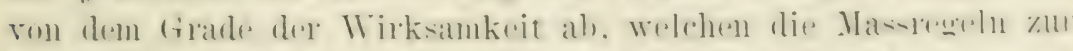

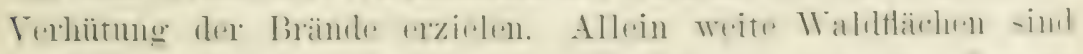

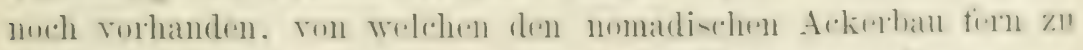

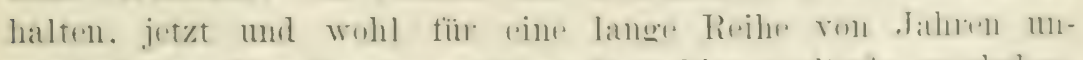

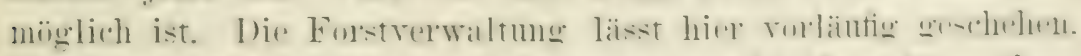

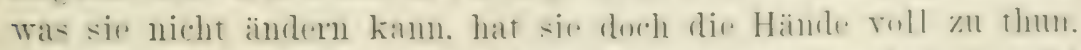

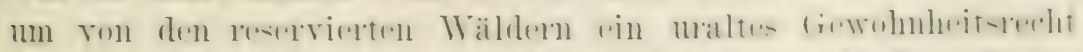

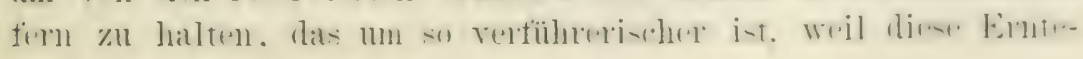




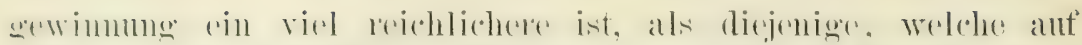

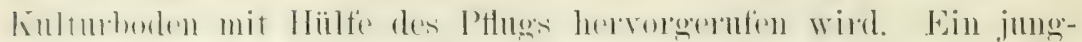

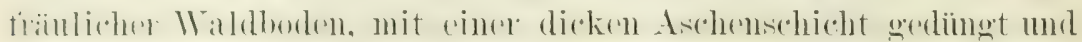

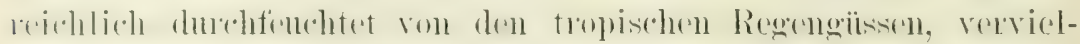
fixcht 40 bis 50 mal die ansgestrente Saat von Reis, der das

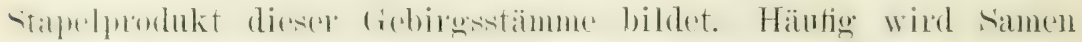

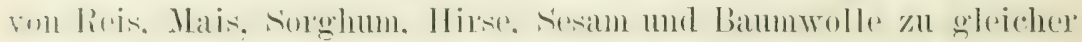

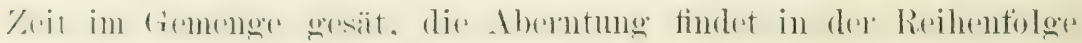
der Reihe dieser Nutzptlanzen statt.

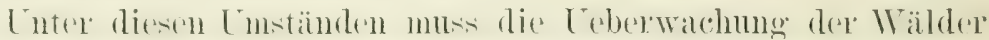

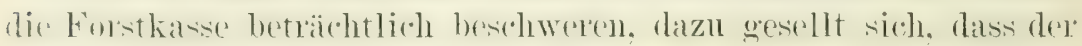

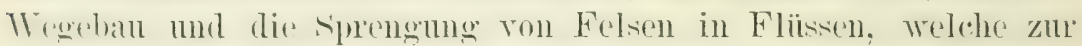

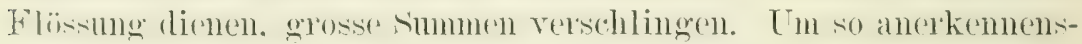
werter für dir indische Forstrerwaltumg; mod so beachtenswerter tü̈ dic Aubreitumg der tropischen Forstkultur, sind die jährlich

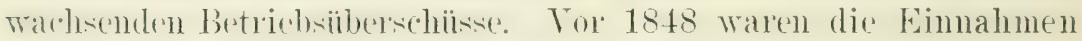
welehe den Regierungskascen ans den Wïldern zuflosene, kaum nennenswert. Für das Fiskaljahr 1872/7:) belief sich dex Über-

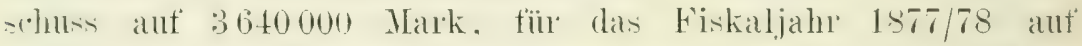
4282040 Mark. fïr das Fiskaljahr 1881,82 ant $6: 34000$ Mark.

In den abhängigen Fïstentiumern befinden sich ebenfalls

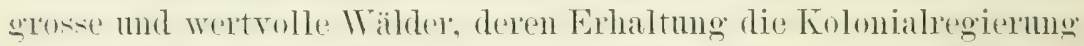
dureh Parehtung anst]eht. Fintweder bezahlt sie den Fïrsten, welehe sich zal dincm [̈bereinkommen bereit finden liessen, eine hestimmte jühliche Pachtsmmme, oder ein Entrelt für jeden getiallten Baum. Anch dieser Pachtbetrieb) hat Überschüsse geliefort. nanentlich in Mysore und Berar, sie sind indessen in den obigen Simmen enthalten.

Die Eimahmen dex Forstrerwaltme entstammen nicht allein von Holzverkäufen. sondern noch anderen Productionen. Tichtig ist der Kautschuk, den Fiens elastica liefert. Assam und Vikkim -ind die hauptsächlichsten Erzongmgsgebiete, in nenerer Zeit wird aurh in Burmah gesammelt. Um diese Nutzungsquelle zu vermehIen. Wmiten in Assam grosse Wälder mit dieser Feigenart angeIegrt. Im Fiskaljahn 188182 betrug die Kantschnkgewimmung 584000 Kilogramm im Werte ron 2176860 Mark. Kingellack und shellack sind andere Waldprodukte, sie bringen ein jährliches Bruttoerträgniss von rund 7 Millionen Mark. Catechu bringt $2^{3}, 2$ Millionen Mark und dee Gerbstoft Myrabolan 800000 Mark. 
An der spitze der Hölzer steht 'T'eak. dessen Austudn 182!

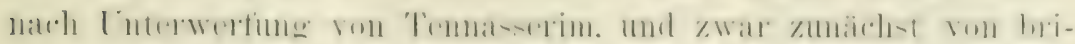

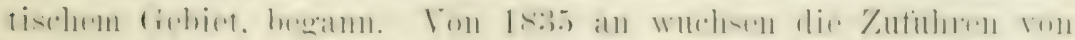

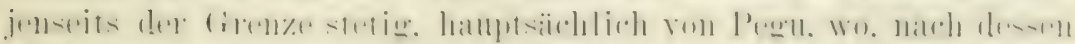

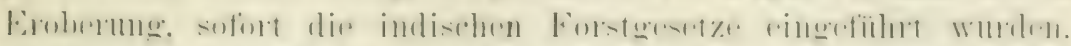

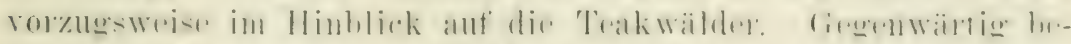

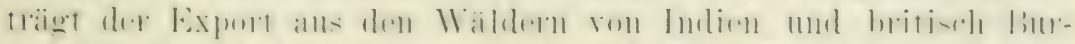

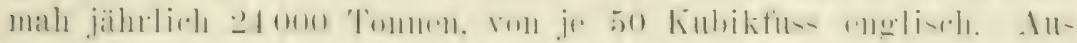

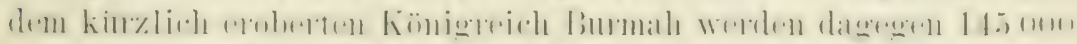

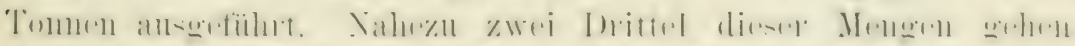

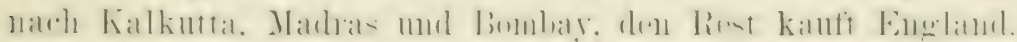

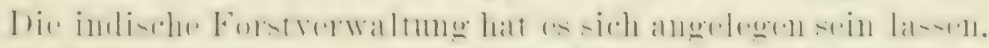

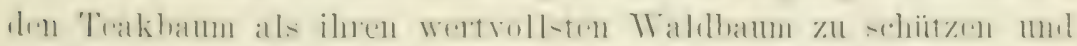

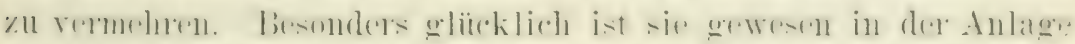

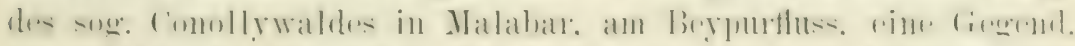

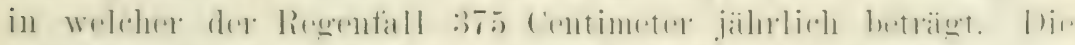

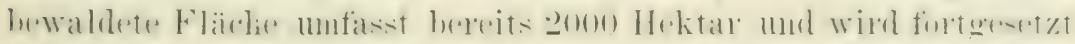

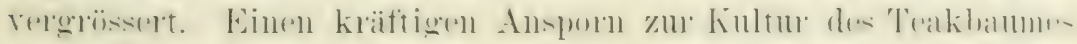

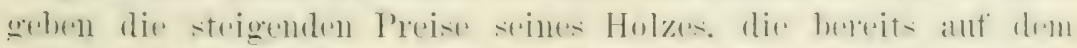

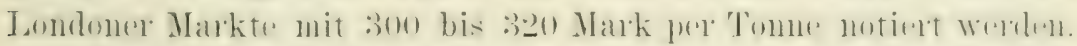

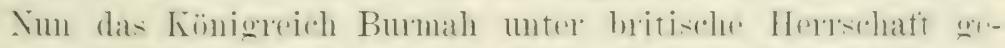

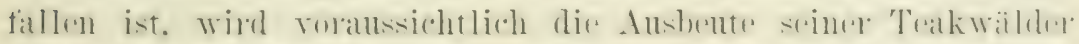
forstiahen Thereln unterstellt werlen. Wolche anf Erhaltume ath-

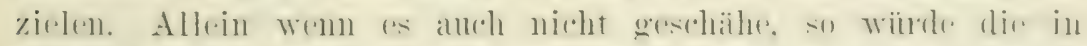

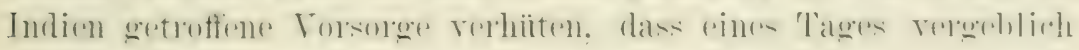
auf' den Handelsmärkten nach 'Teak gefragt wïrde.

Das Hol\% von Acacia catechn ist zu manchen / wrecken recht

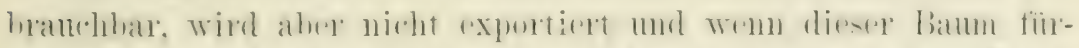

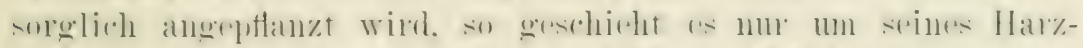

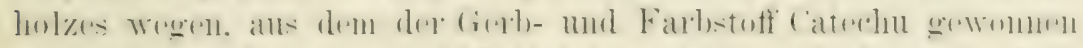

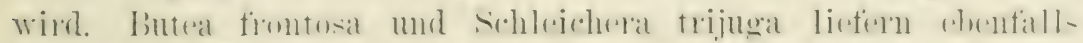

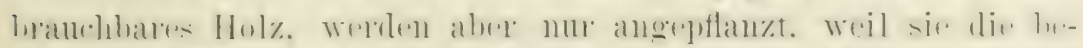

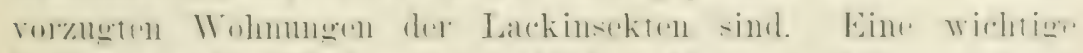

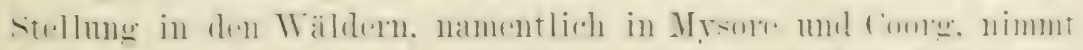

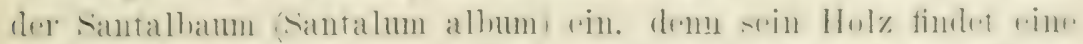

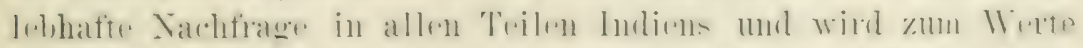

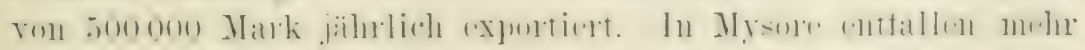
wie die Hälfte der Forsteinkïnfte auf diesen Baum.

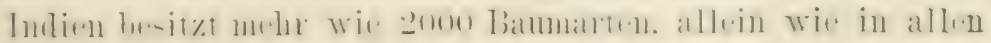




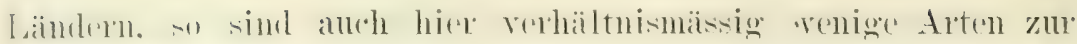

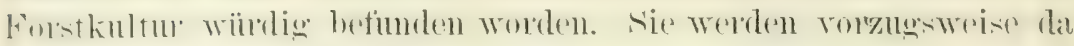
angepflanzt, wo sie ihr bestes Gedeihen finden und zwar:

In Bengalen: Toon und Teak;

.. Irysore und Curg: Teak und Santalbaum;

.. den nothwestlichen Provinzell: Deodar. Wallnuss mol Rosikastanie;

.. Berar: Teak und Babul (Acacia arabica);

.. Punjab: Deodar, Sissu, Kiksr, Ber und Haulbeere;

.. Ondh: Sal;

.. Burmalı: 'T'eak:

.. den Nilgiri: Chinchona, verschiedene Arten;

.. Assam: Kantschnkfeige;

.. Marlras: Teak. roter Sandersbaum, ('a-matina mol Eucalyptus. Iner Trakbamm (Tectona grandis) kamn der hänig der indi-rhen Waldbämme enenament werken. Heimisch ist ex in Hindostan. Burmalı und siam. Wo el gewöhnlich in Gesellschaft ron Bambus uder soldhen Bäumen wächst. die bei hoher Luftenchtigkeit einen

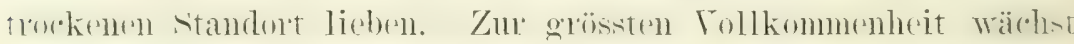
1. in Malabal und dem westlichen Bumall, weil hier der Regen-

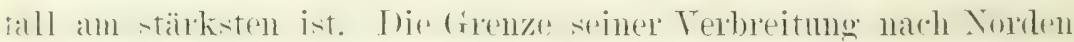
liegt merefihr heim 25. Breitegrad. Tas Hol\% dieses Bames wird in solitfban höher wife rin anderes geschätzt und ist namentlich da wertonll. wo sin Berïhrme mit Fisen verarbeitet werden soll. Fis anterendentlich daturhaft. verabeitet sich leicht. nimmt eine feine Politur an und wirft sich nicht.

Der Sal (Shorea robusta), ebenfalls ein wichtiger Baum,

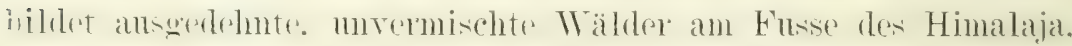
von Assan bis Sutlej, wie in den östlichen Teilen von Zentral-

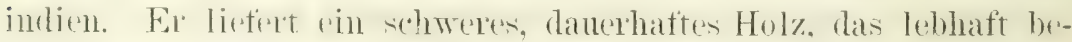
whet wird tïr Banzweke. Wagnerabeiten mol Bahnschwellen.

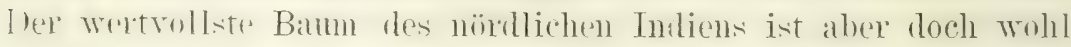

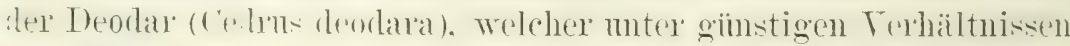
wine Höhe von ter Jeter exreicht und tïr die Danterhaftigkeit -rine Holzes berihent ist. Nur wenige Hölzer Indiens widestehen Itom Kilima und den Angriffen der Tnsekten lïnger wie wenigw Tahre nath ihrer Fällung. mon Deodar gehört zu diexen wenigen.

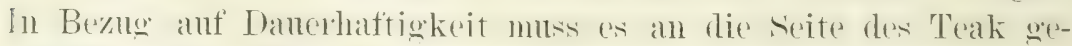
-tellt werden. Ilecer Balum ist heimisch in dem mordwestlichen 


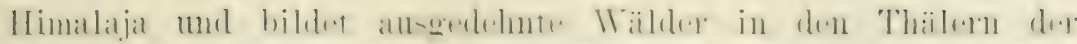

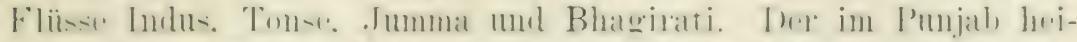

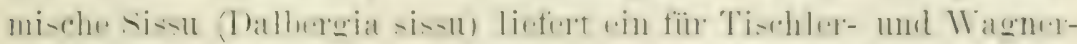

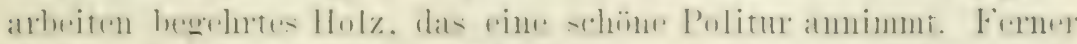

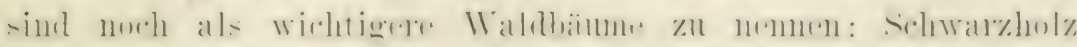

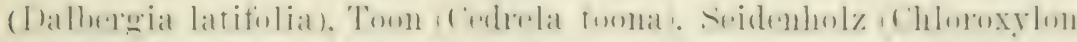

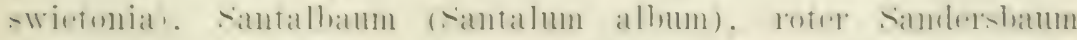

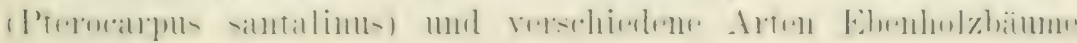
(Diospyros).

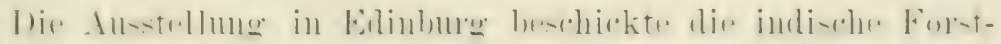

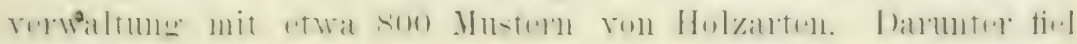

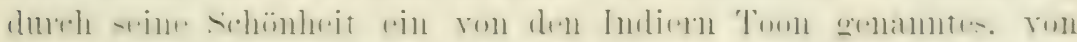

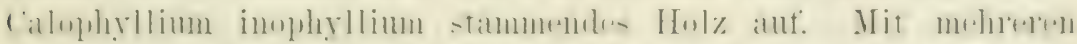

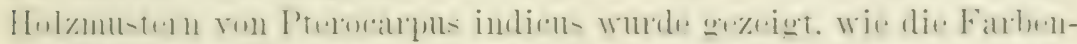

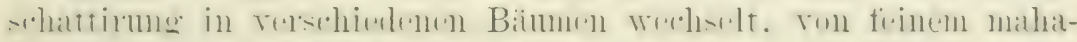

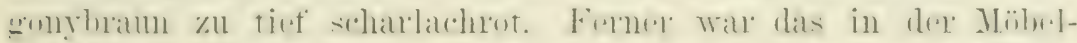

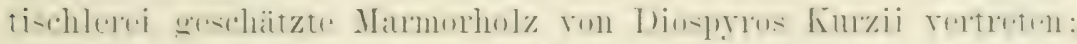

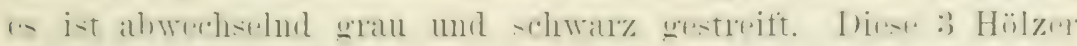

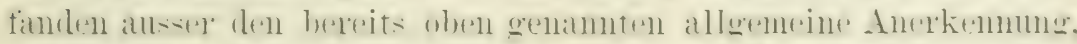

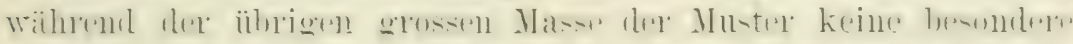

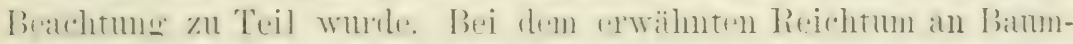

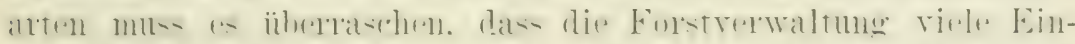

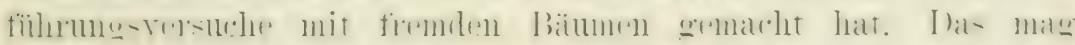

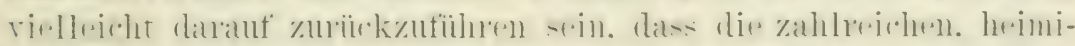

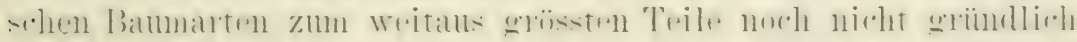

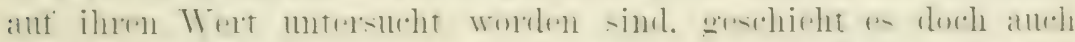

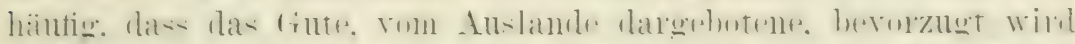

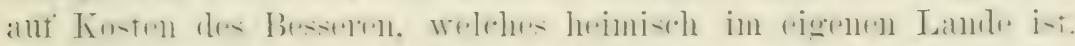

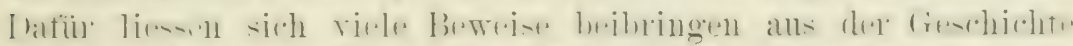

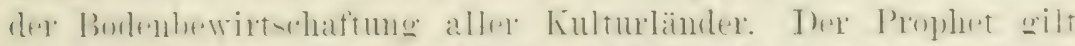

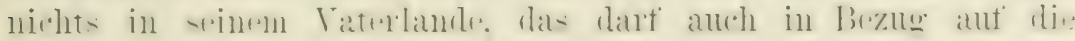

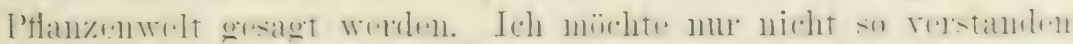

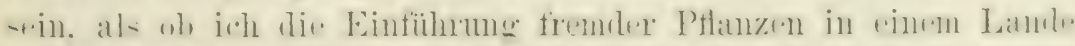

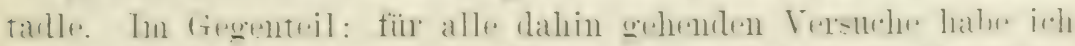

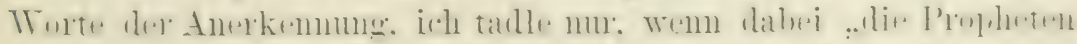

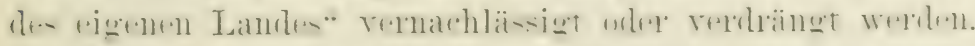

Indien war das erste Land. welches ron der Grmmibanm-

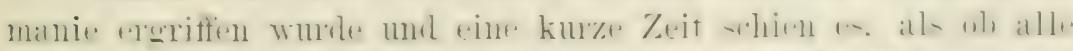
Anftorstungen ron 


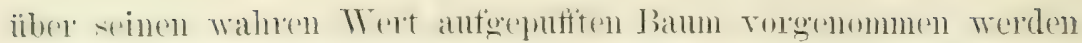

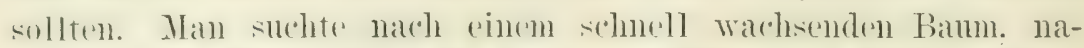

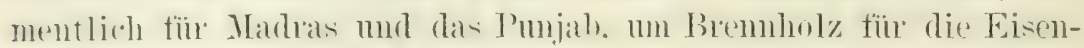

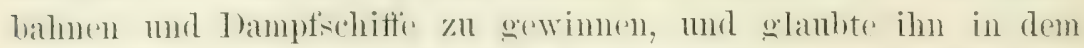

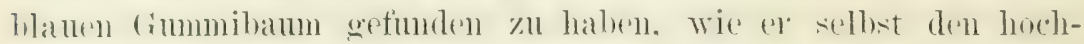

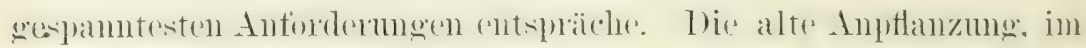

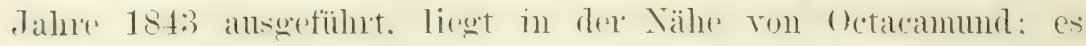
sollen dort Bäune von 3:3 Mreter Höhe und 3.8 Meter Lomfang zu finden sein. Indische Forstlente wollen berechnet hathen. der jähnliche Holzzuwarlss in dieser Anptlanzmo betrïge 2.) Tommen zu

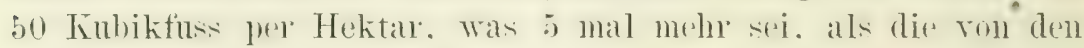
Taldbäumen Euroua's im Inuchschnitt erzengte Holzmenge. Wie?

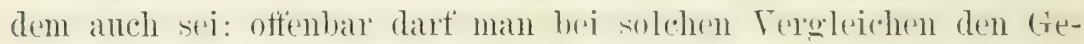
branchswert der verschiedenen Hölzer nicht unherürksichtigt lassen. Wie in andern Ländern, so ist anch in Indien in nenerer Zeit

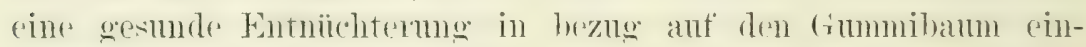
getreten.

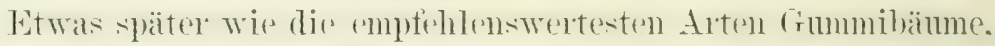
wouden die vershiedenen Gerherakazien ans Anstralien eingetihot. obgleich Indien bereits in dex nahe verwandten arabischen thazie

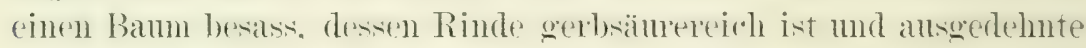

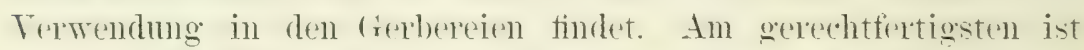

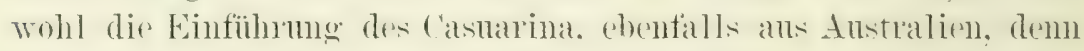
(1) dirnt zur Bepflanzmo öder, sandiger Küistenstrecken, also zu einen Zwecke, welchem nur wenige Bänme der brde dienen kënnen.

Aus Europa und Amerika, hier wie dort aus dem Norden, wurde eine Anzahl Waldbämme ringetïhnt, mit unbefriedigenden Erfolgen. Was wohl mit Recht aut klimatische resachen zuriek-

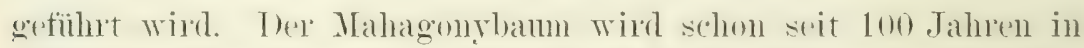
Indien als Parkbann angeptlanzt und in der Nähe von Kalkutta soll re Holz lieferen. das so whe wie das westindiscle ist. Die Forstrerwaltmug hat glosse Anstrengumgen emathe Mallagony-

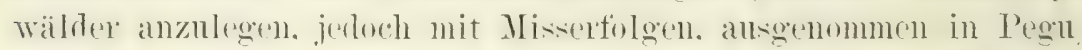

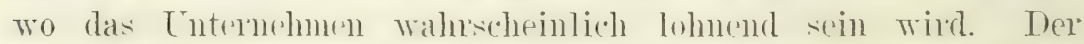
schnellwadesende Regenbaum (I'ithecolobium saman) ans dem tro-

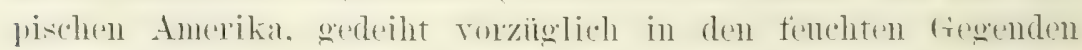
des tropischen Tndiens. T) ans Brasilien stammende Kantschuk-

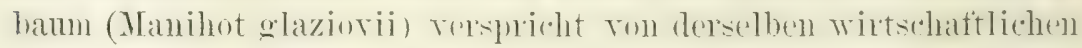

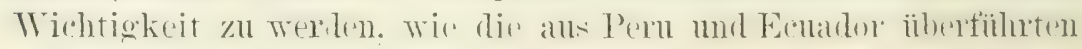




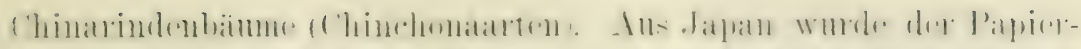

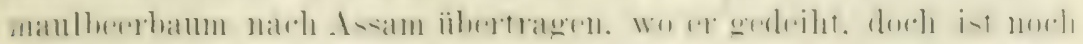

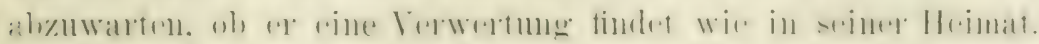

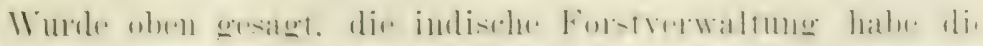
If

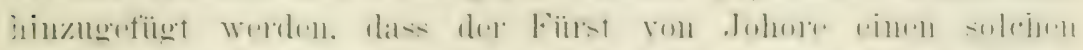

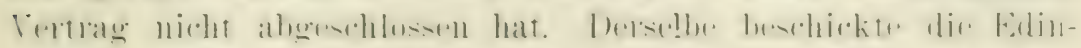

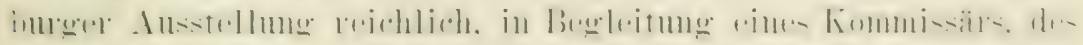

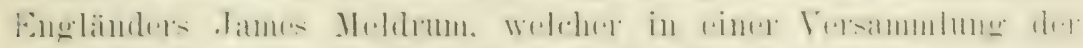

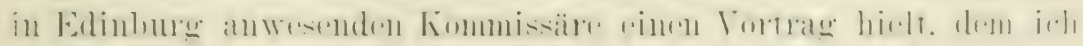

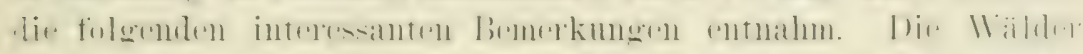

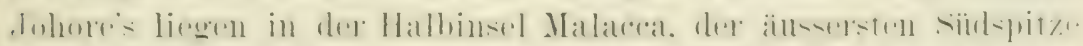

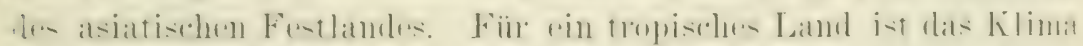

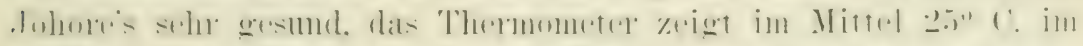

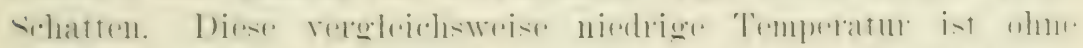

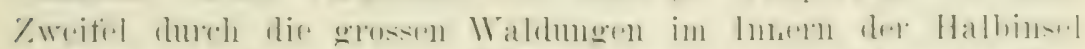

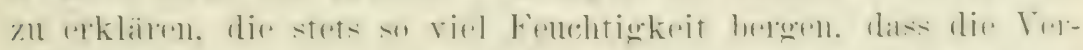

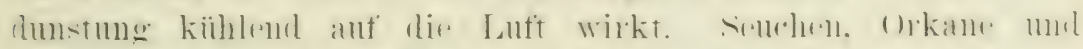

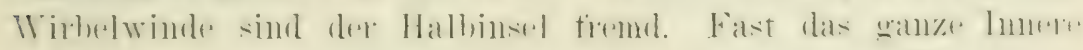
von Johore ist mit Urwald bedeckt. da aber keine Wege vol-

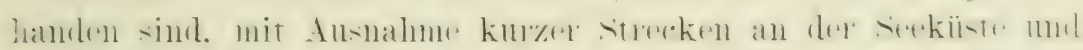

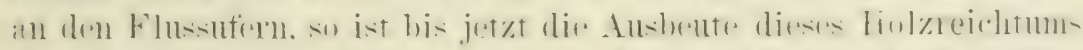

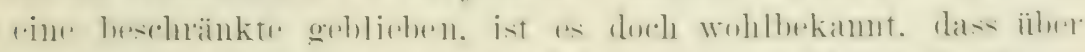

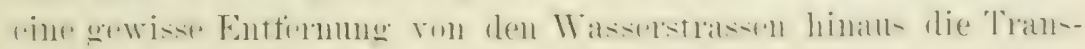
portkosten den Wert des Holzes iiberragen.

Ansgestellt waren in Edinburg 350 Holzarten aus den

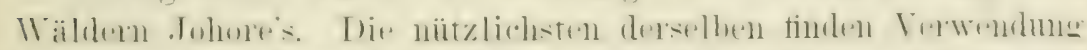

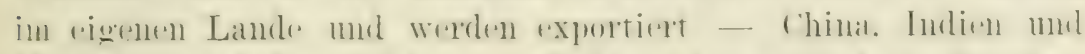

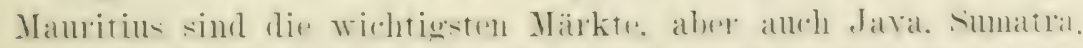

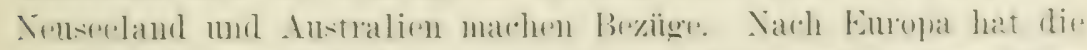

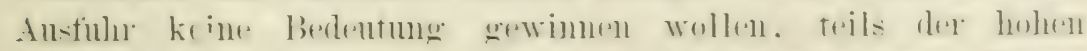

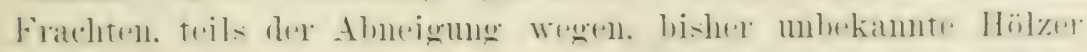

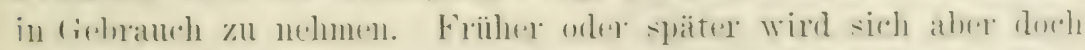

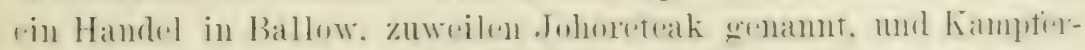

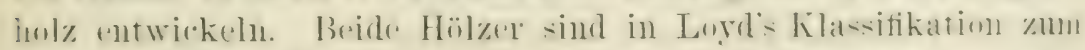

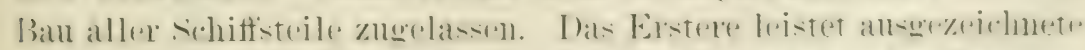

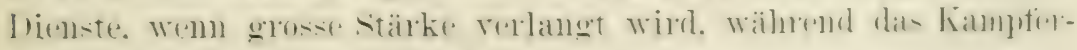
holz unibertreftlich dauerhatt ist. 


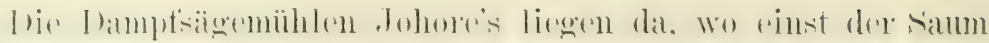

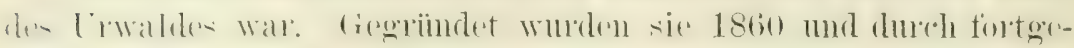

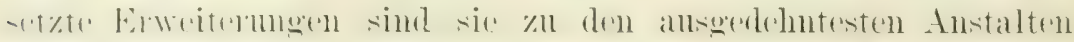

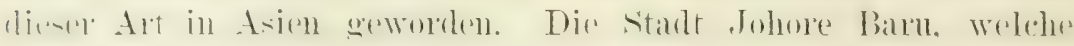

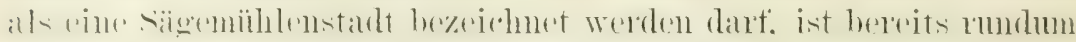
ron Wald entblöst und fängt an nuwichtig zn werden. Die

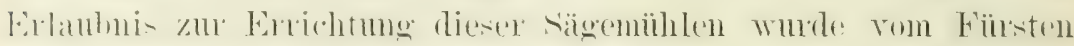

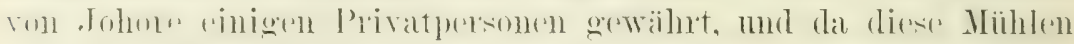

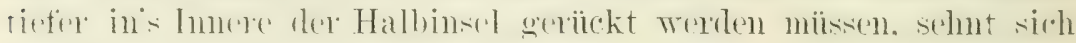
der Fürst, der ein erlenchteter Mamn sein soll, nach kapital-

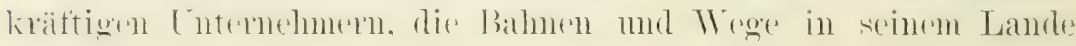
batlen.

Britisch Burmah besitzt eine eigene Forstverwaltung seit

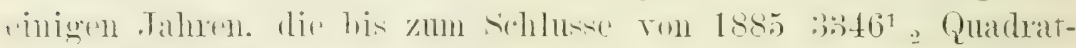

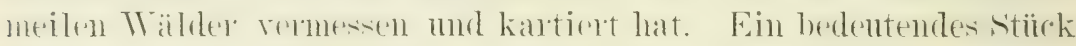
Arbeit bleibt aber noch zu thum. demn diese Kolonie umfasst

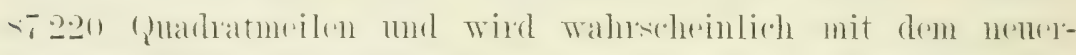

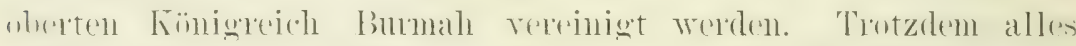

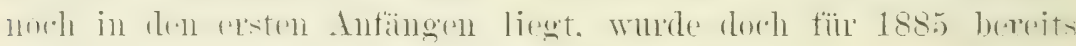
ein Betriebsïberschnss ron 32000 Mark erzielt.

Wie in Indien. so sind anch in britisch Burmah mit fremden

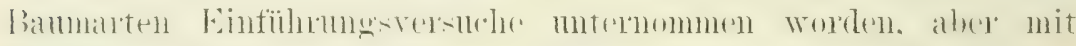

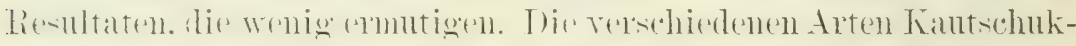

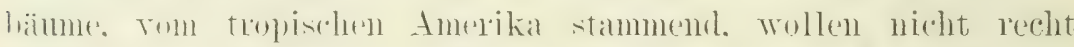

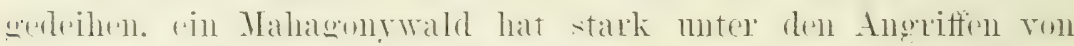

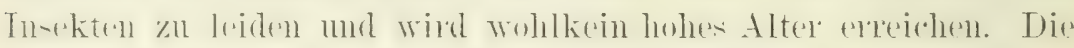

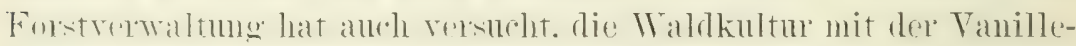
kultur zu verbinden, um jene rentabeler zu machen, allein die

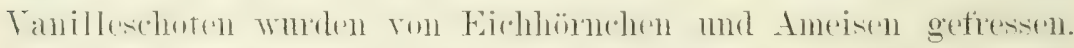

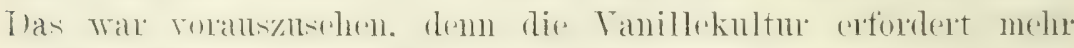

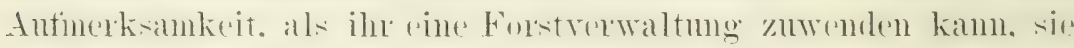

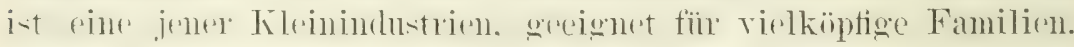

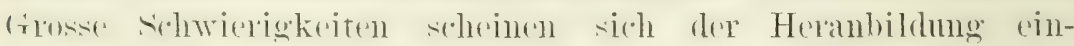

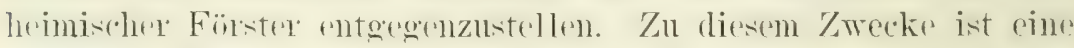

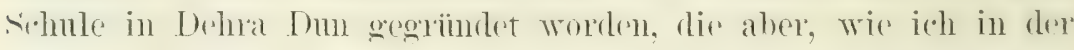

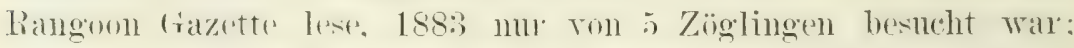

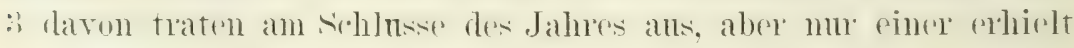
rin theangagengis. Dieser angenseheinliche Misserfolg ist violloicht in Bezithung zu hringen mit rem Ansppluche rines höhern 


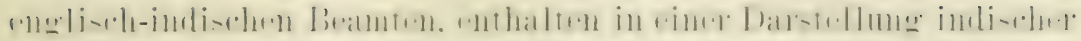

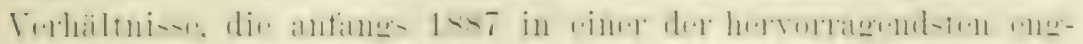

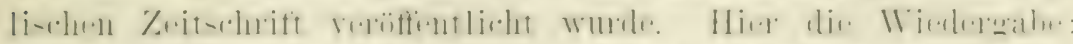

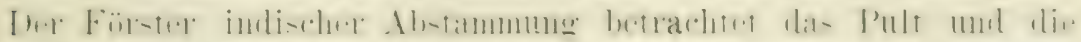

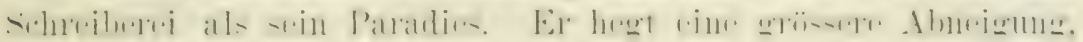

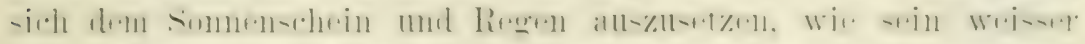
Kollege, dem er es daher gern überlässt, den Wald zu beautsichtigen, wo immer er nur ham.

Nim noch einen Blick auf den Himalaja, weil er in den

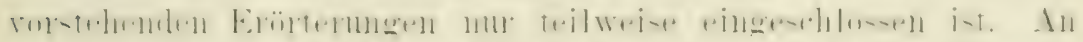

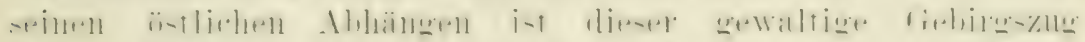
bis zu Erhebungen ron togo Meter fast überall mit dichtem

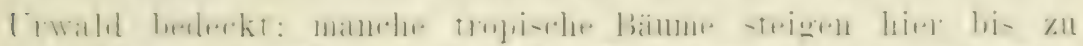

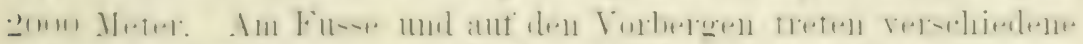

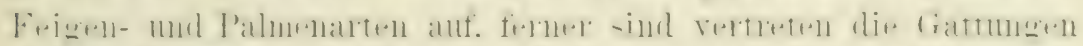

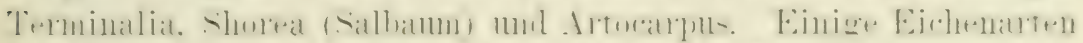

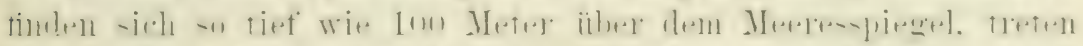

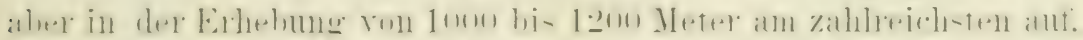

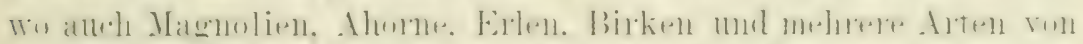

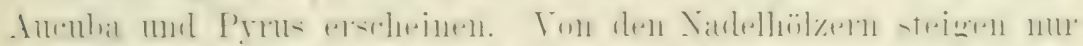

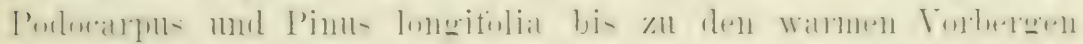

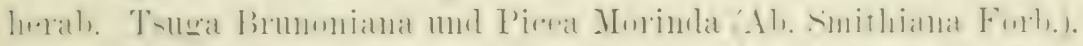

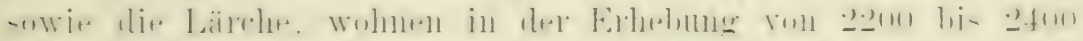

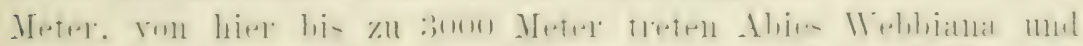

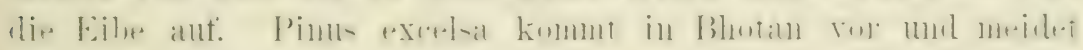
das feuchte Klima ron sikkim.

Die westliche Abdachmo ist spärlich bewaldet mol zwar

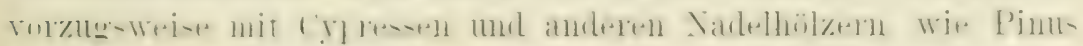

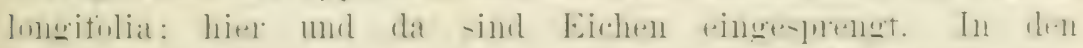

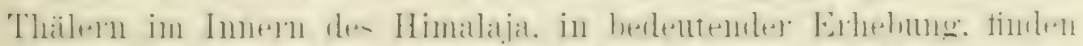

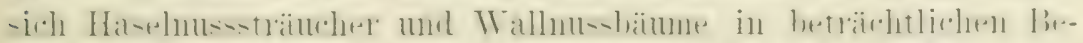

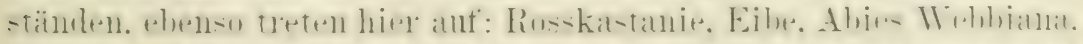

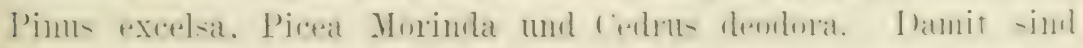

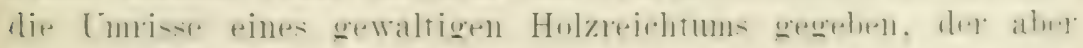

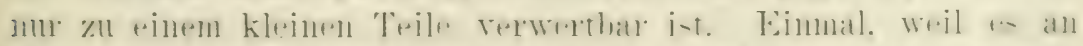

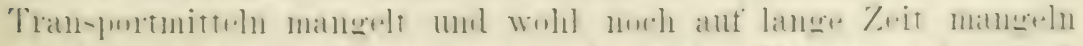

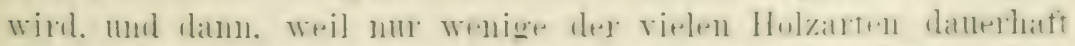

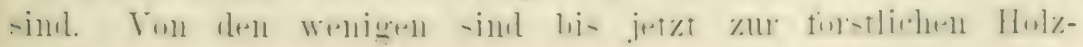




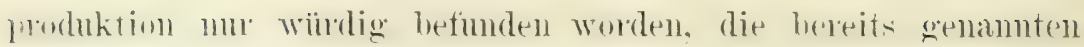
Arten: Sal, 'I'oon, Sissu und Deodar.

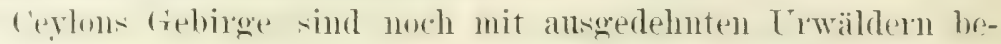
derkt. die sich. wie überall muter den Tropen, an zahleeichen Banmaten zusammensetzen. von welchen aber anftallend wenige Nutzholz lieferm. Dis Anzahl der nützlichen Waldbäume wird

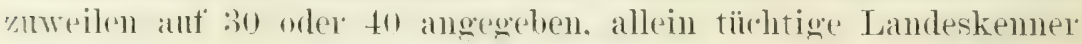
helaupten. es seien höchstens a Bammarten in rler Tnsel zu finden, welche als nïtzliche Waldbäume betrachtet mol der Kontur geewiudigt weden könnten. Ansser Betracht sind dabei geblieben

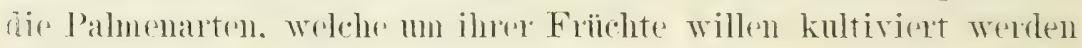
murl deren Holz nur Tebempodukt ist. Die wichtigsten Holzartull sind: Eben-, Seiden- mol ralamanderholz. Toak findet sich in Ceylon nicht.

Erst vor 2 oder 3 Jahren ist für Ceylon eine Forstverwaltung ins: Leben gerufen worden, welehe die seitherige Raubwirtsehaft heschränken. reservierte Wälder nach dem indischen Vorbild formicren und anch die Torfwäldex beaufsichtigen soll. Zur Tnter-

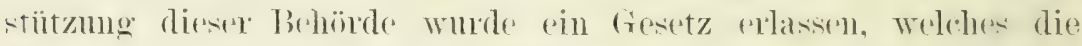

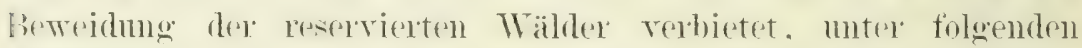

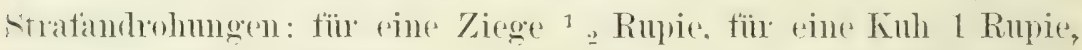
fïr (inc'n Büffel 2 Rupien und für einen Elephanten 10 Rupien.

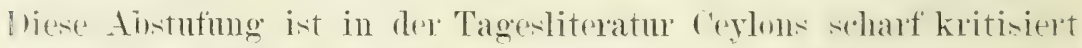
worden, mit Recht wurde hervorgehoben, die Ziege sei das dem

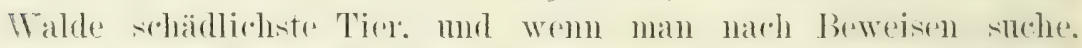
kïme: man sie in der. Präsirlenterhaft Mardras suchene, deren Träder-

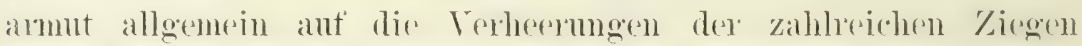

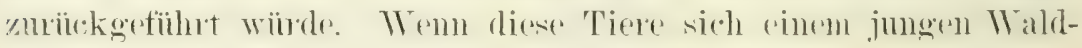
baume nahen kömnten, sei sein Schicksil besiegelt.

Java ist noch etwa zum vierten Teil bewaldet, trotz der

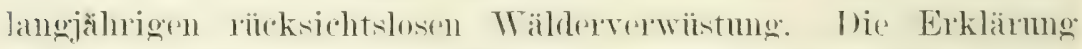

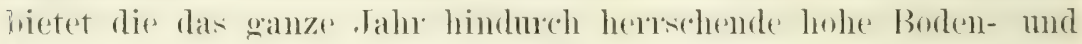
Luftfenchtigkeit. Welehe nicht allein das Warhstum allswendentlieh heginstigt. sondern auch die Ansbreitumg der Brände verhindert,

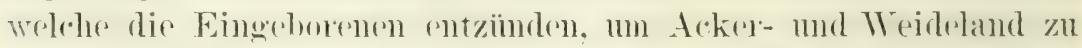
Erewimnen. Die erösten Wälder finden sich in den Bezirken Bantam, Preanger. Banyames, Pasmuan, Kediri, Besecki mol Banyuangi. Bis zur Erhebung von bon) Fusc bilden den Hauptbestandteil der Wädex Arten dere Familien Magnoliaceate und 


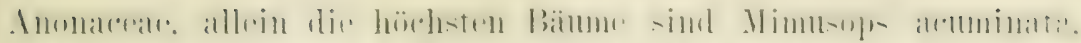

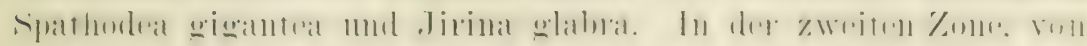

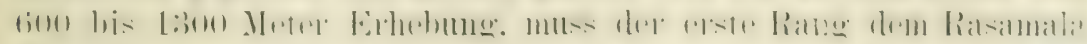

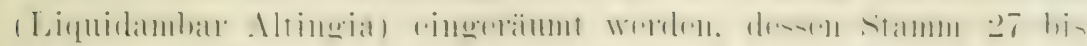
30 Meter astfrei bleibt. Ton seinen Nachbarn sind zu nennen:

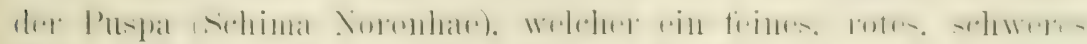

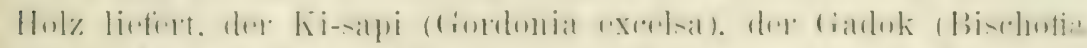

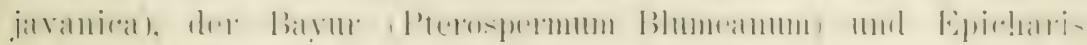

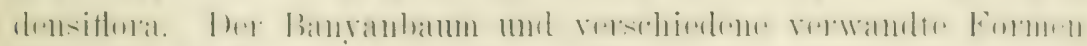
sind sehr häufig.

Bis jetzt ist der javanische Holzreichtum vergleichsweise wenig verwertet worken. Wenn die abhängigen Fiustentümer allsser Betracht bleiben, werden alle Wälder, welche nicht mit

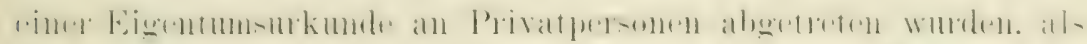

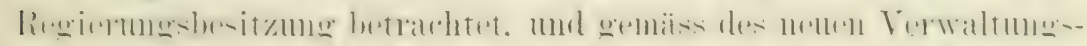

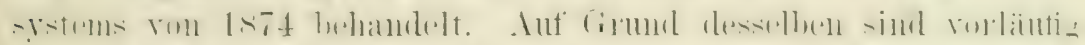

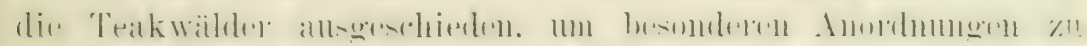

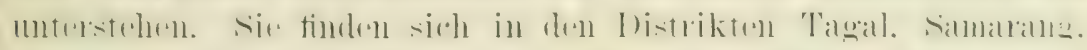

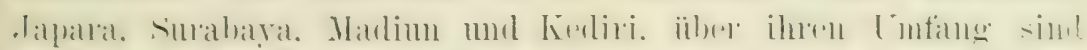

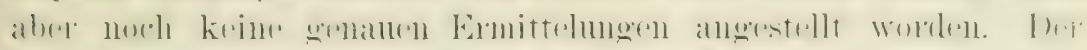

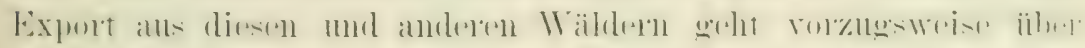

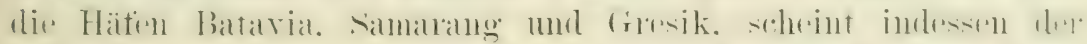

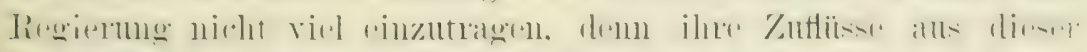
Quelle betrugen nur 1 bis $1^{1 / 2}$ Millionen Mark pro Jahr.

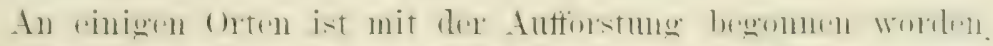

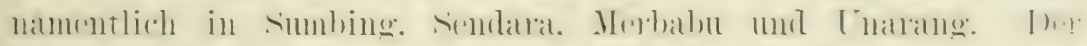

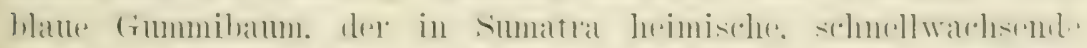

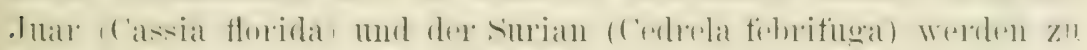
diesem $Z$ wecke berolzugt.

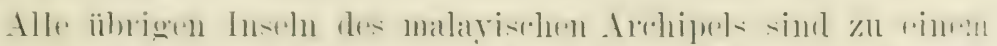

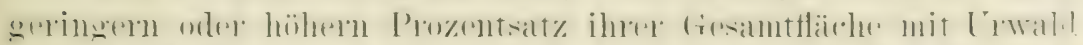

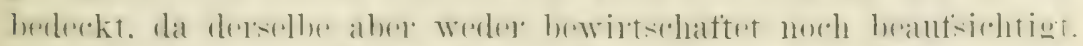

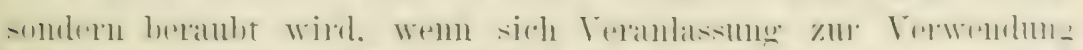

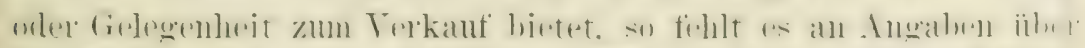

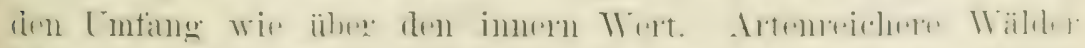

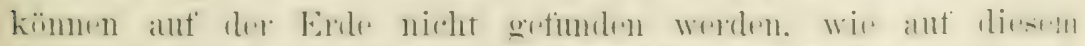

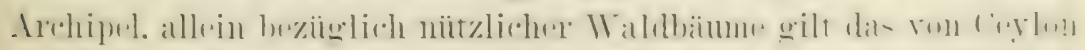

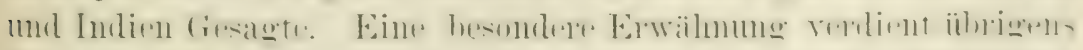

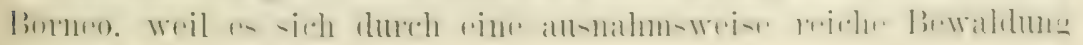




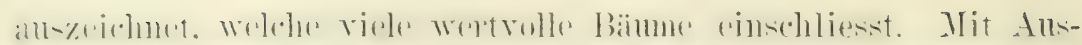

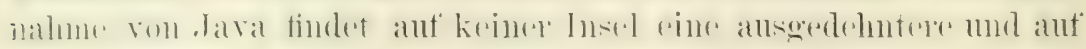

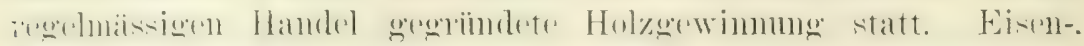

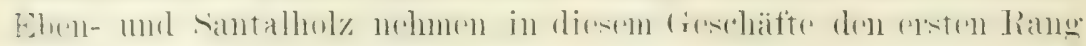

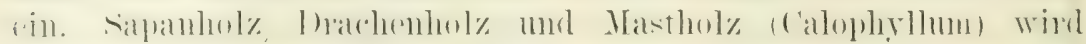

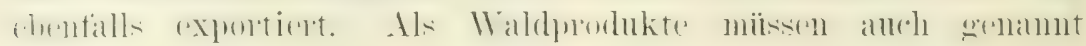

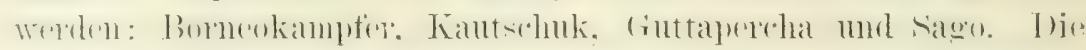

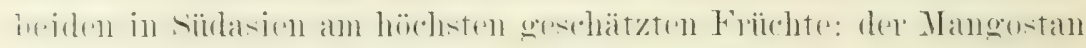
mond Durion kommen in diesen Wäldern wild vor.

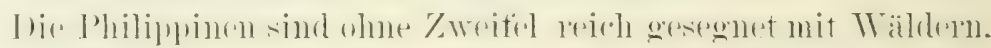

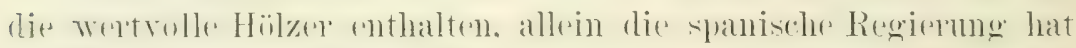

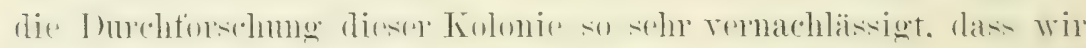

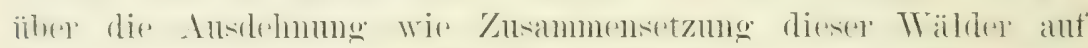

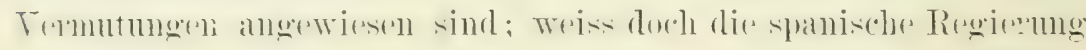
nitht rinmal genan anzngeren. ans wie vielen Inseln die Philippinen bestehen. Mindanan. Mindure und Palawan sind in Bezug

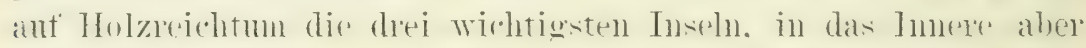

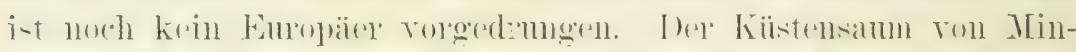

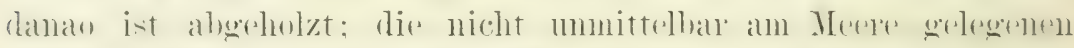

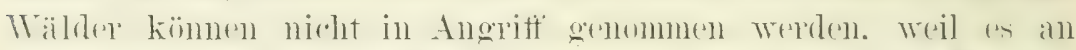

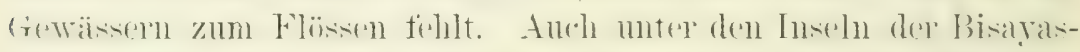
grmple sind viele dicht bewaldet. wa noch nie die Axt des Holzliamers geklungen hat.

Sach eine behauptung soll die baumwelt dex P'hiliphinen

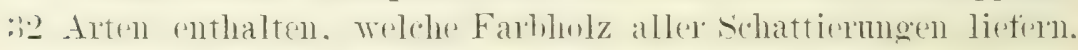

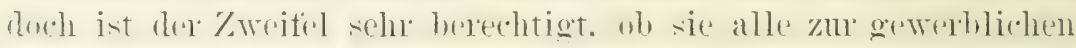

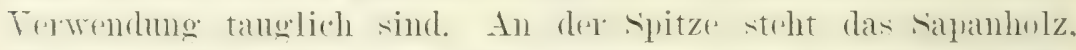

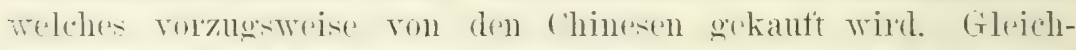

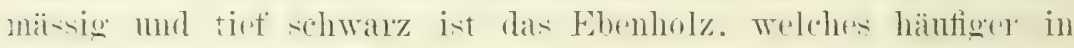
Luzon und Nogros wie in den ïhrigen Inseln getimnden wirl: es dient für feine Mäbelarbeiten und wird tener bezahlt. Ebentials

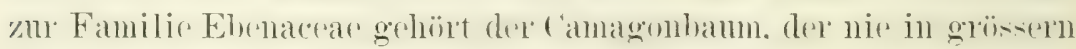

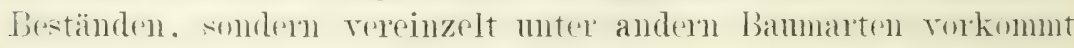

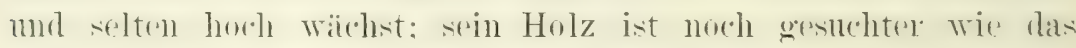

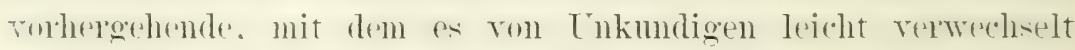
Werden kamm. Thas (amagonholz ist wohl schwarz aber nicht so

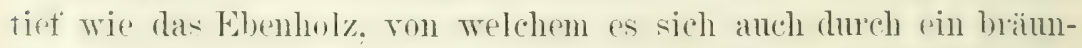
liehes oder rotgelles (reäder unterscheidet. D)iese schöne Färbung.

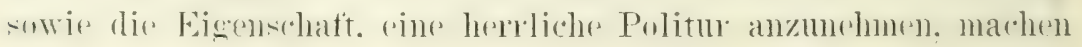




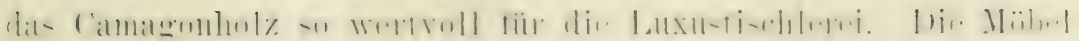
Manila's sind meist ans dem Holze der Vallal verfertiert. eines

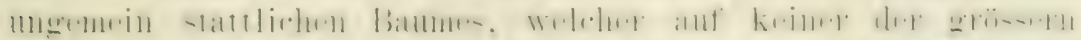

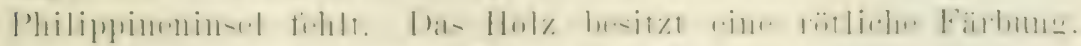
die sich mitunter bis zur Farbe dos Blutes vortiente Der an-

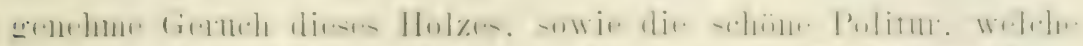

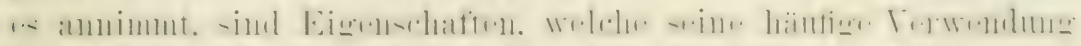

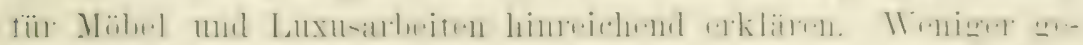

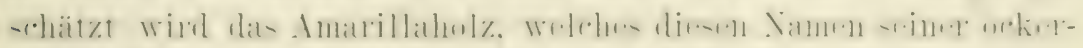
velben Farbe verdankt, die später nachdunkelt.

Tapau, dessen Gresamtläche rund :38 400000 Hektar beträgt.

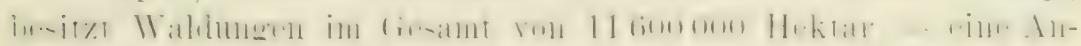
Eabe, ant rie wil uns verlassen diurten, - denn dieses Tolk bietet ein Lichthild in. Bezur ant Forstwirtschatt. schon die alten

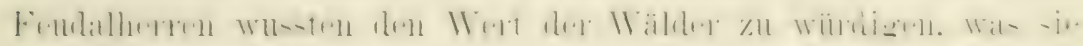

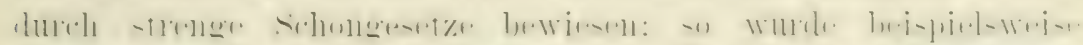

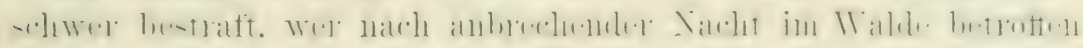

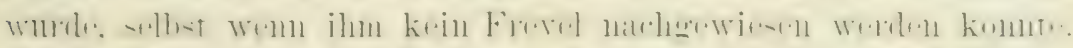

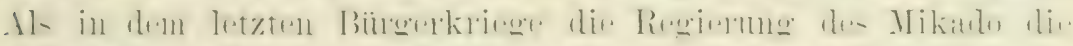

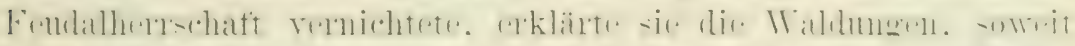

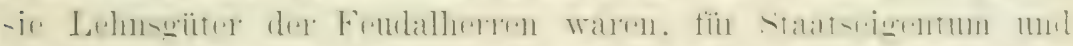

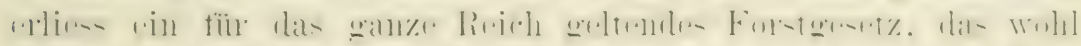

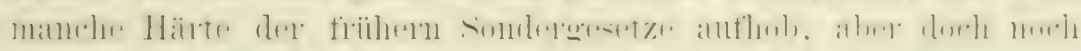

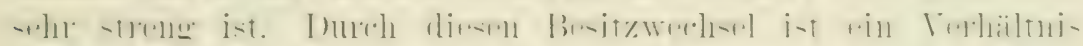

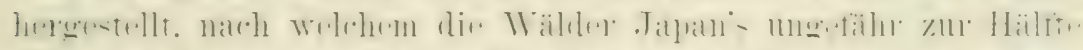

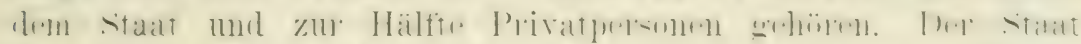

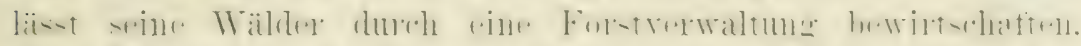

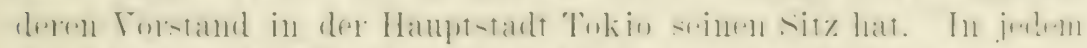

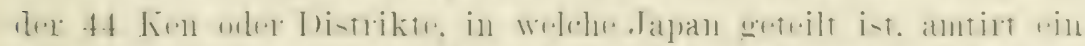

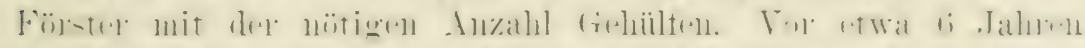

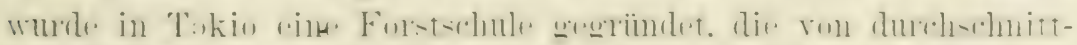

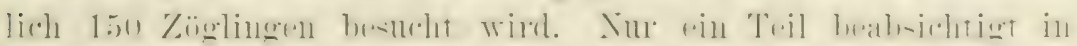

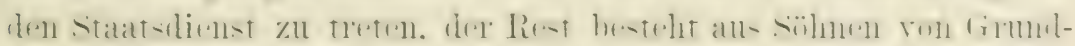

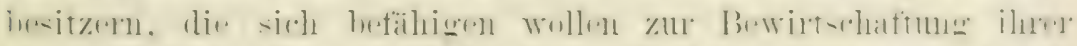

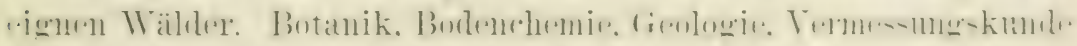

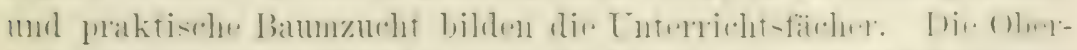

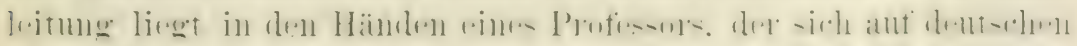
Forstechulen ausgebildet hat. 
Die Forstverwaltumg begnügt sich nicht mit dem derzeitigen

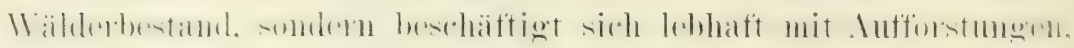

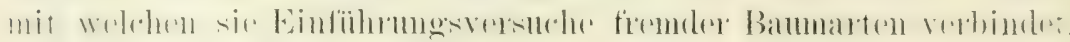

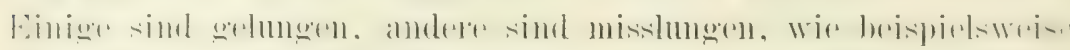

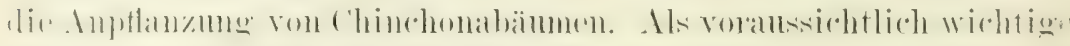

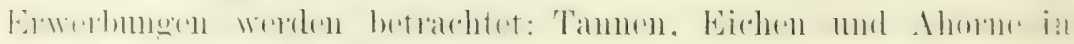

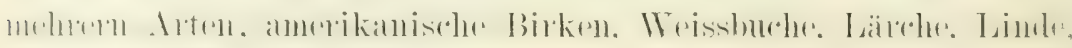
Esche und Abies Webbiana.

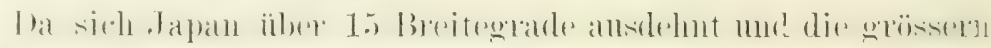

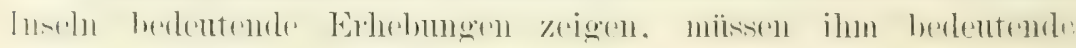
klimatische Unterschiede eigen sein und zwar ist dies so stark

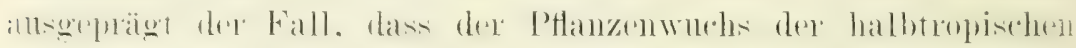

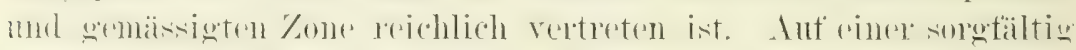

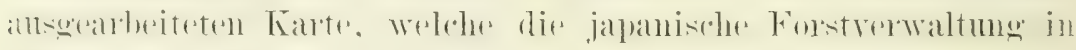

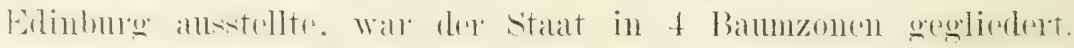
In der ersten ist die 'Temperatm' so hoch, dass die Wälder ans

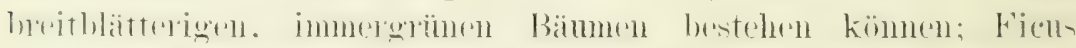

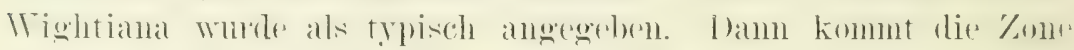

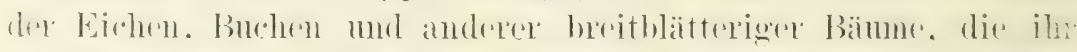

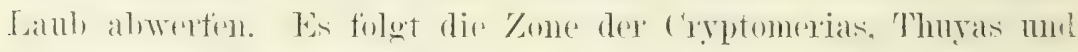

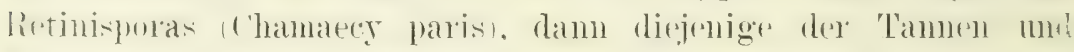
Finhten mit Ahies Veitrhii mol Picea Aleockiama als Typms. Hayt

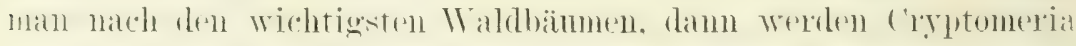

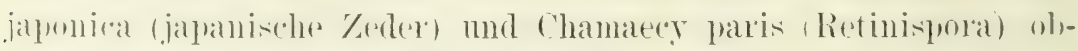

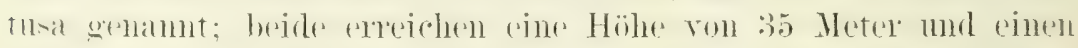
[mfang von 6 Neter. Ferner die lorbeerblätterigen Eichen

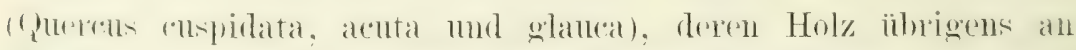

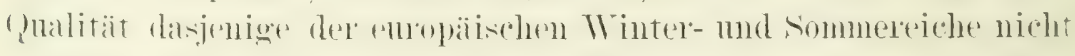

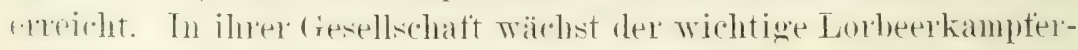

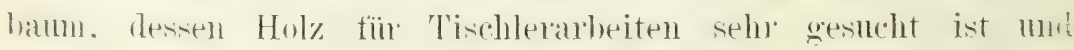

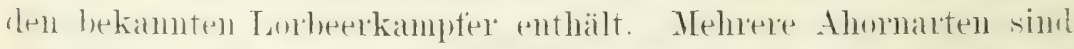
$\therefore$ shö̈n. dass sie in Nordamerika mod Europa als Zierbämunt-

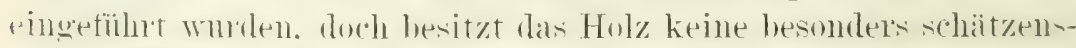
werten Figenschaften. Jas härteste Holz Japans liefert die atcoh in Enwpa bekannte Panlownia imperialis; es ist rötlich angehancht und dient viren \%weken, namentlich zu treräten. Soch zu nemenn sind: der Papiermatherethatum. ans dessen Rinde die Japaner ihn

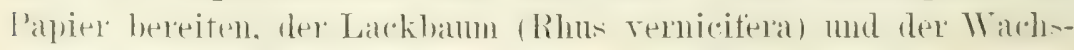
banm (Rhus succedanea). 
Ls mag noch erwilhnt werden, dass die Japaner hänfig. bevor

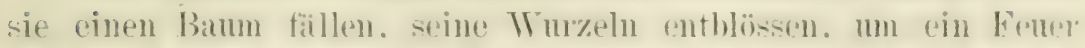

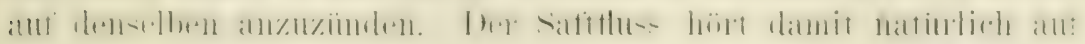
mud wenn der Stamm auf dem stand anstrockmet. Wird das Hol\% mateh Ansicht der olpaner fester und ranerhatter, als wemn es wiahrend eines. Wenn anch noch so unbedentenden saftflusses gerfailt wirk.

Wine andere bigentïmlichkeit zeigt die japanische Hol\%-

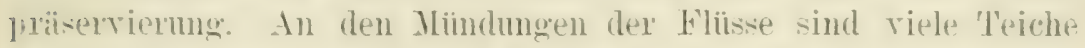
angelegt, Welche sowohl mit süsswasser wie Salzwasser qespeist werden künnen; es queschieht im Verhälnis: 6 T'eile salzwasser. med 4 Teile Süsswasser. Ein grösseres Übergewicht des Sal\%wasser's wiinde das Holz schwiizen, ein grössserer Anteil siisswassel kïmnte zur lolge haben. dass das Holz von Wiumern angegritten wiurle.

Die 'Teiche sind etwa $1 \frac{1}{2}$ Meter tief und häufig sind mehrere

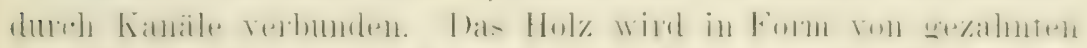

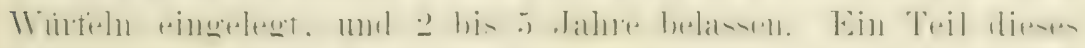

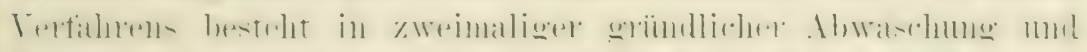

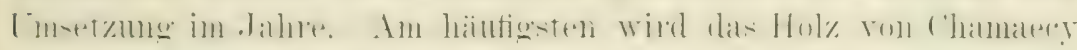

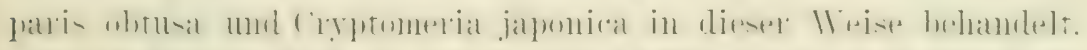

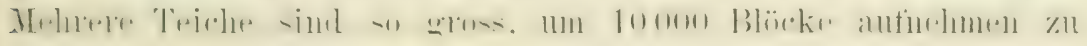
kiimnen.

Japan stellte in Edinburg 302 Holzmuster ans, davon 271

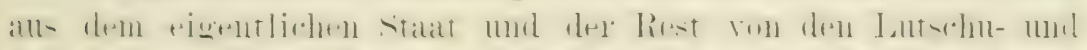

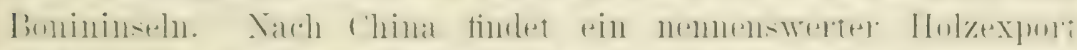

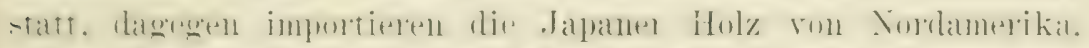

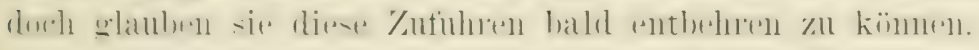

Von Atriña wissen wir, dass grosse Gebiete baumlos, andere

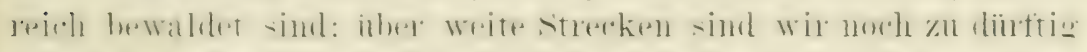

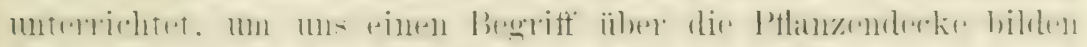

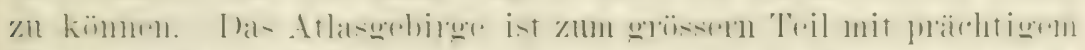

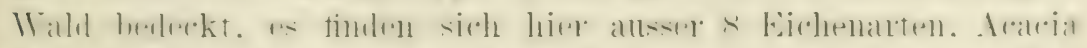

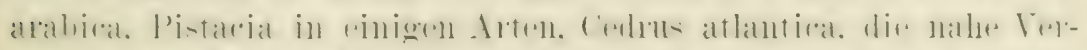

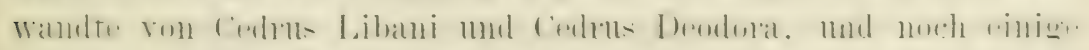
andere nuitzliche Waldhäume.

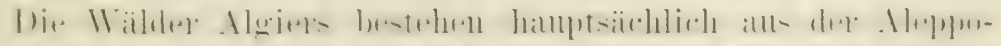

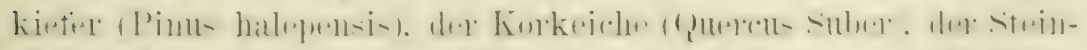

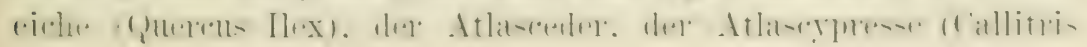




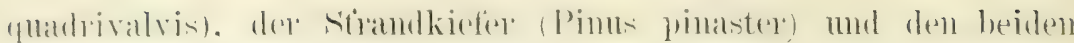

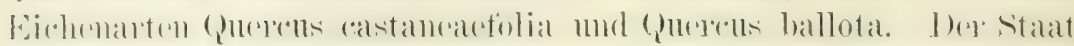

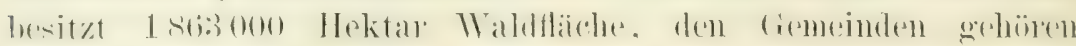

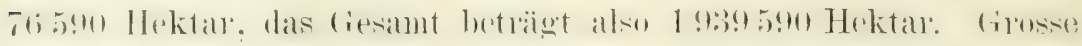

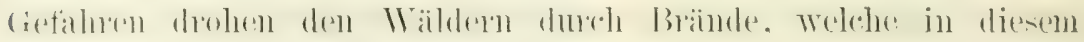

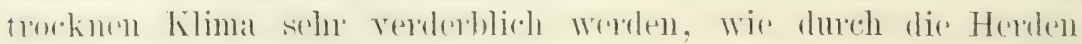

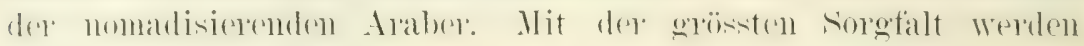

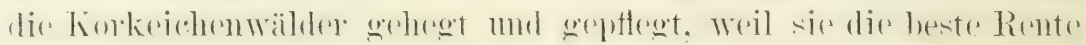
abwerten.

Reisende. welche ror etwa 100 Jahren 'T'mis besuchten. er-

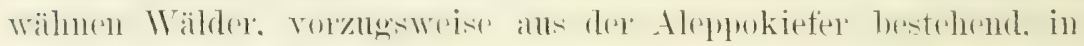

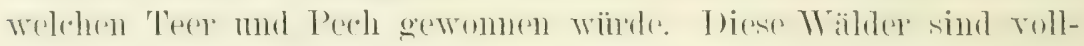

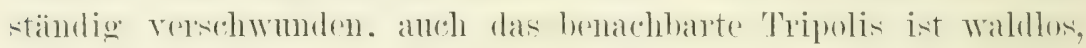
so ist es Egypten, die lybische Wüste und die Sahara. Das

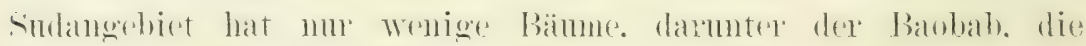

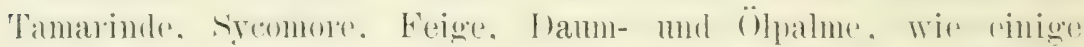

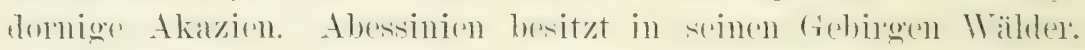

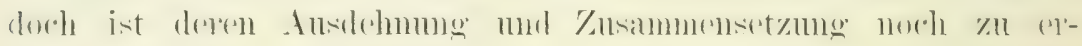
forschen.

Ueber die Bewaldung des tropischen Afrikas muss das end-

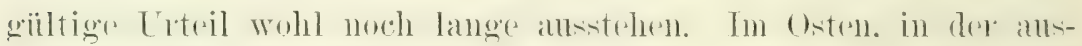

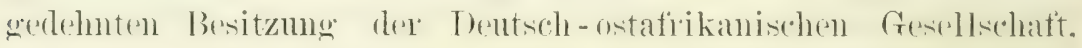
scheinen viele Uferwälder, aber nur wenige Urwälder oder

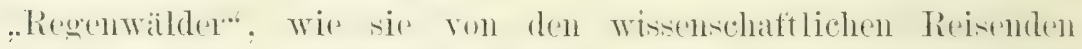
gernannt werden, vorhanden zul sein: noch waldärmer ist wahl-

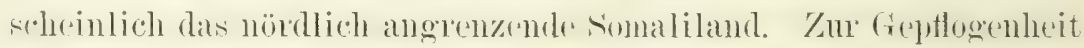
ist geworden, das congobecken als iipuig bewaldet darzustellen. weil es stanley so geschildert hat. Es ist im höchsten Grade auffallend, dass die Mämner der Wrisensehaft, welche doch somst ihne kritische sonde herzhaft und nicht selten bis zur Cielneltreibung gebrauchen, die Angaben stanley's kindlich-glänbig "ntgegemahmen, trotzdem sie sich bei kiihlex Teberlegung sagen mussten, sir lä̈ten es mit den bizählungen pines Visionärs zu thm. Das zeigt: wie die ührigen Irensehen, so werden anch die Gelehrten von dem Erfolg geblendet. Allen Respekt vor der l'ionierfaht stanley's, allein wemn ('r, der auf einem Kahn den Flus entlang reiste. ohne Rast, und dabei nichts sah wie die Ifex, uns von einex ippigen Bewaldung des comgolectens be-

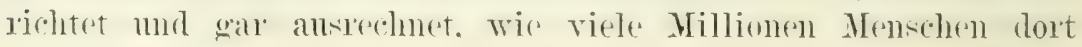




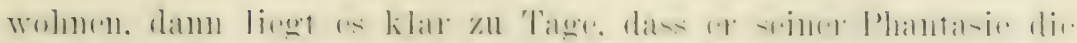

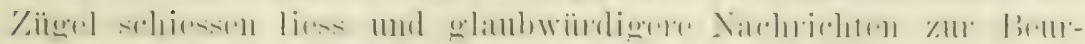

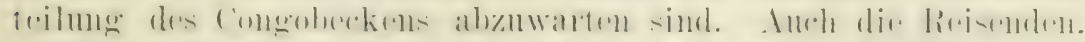

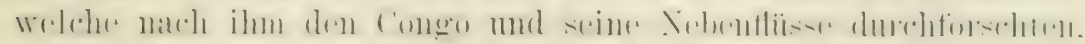

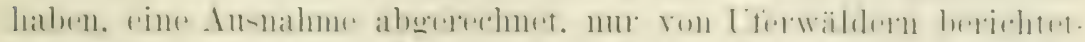

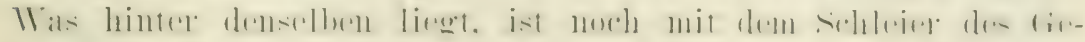
leimmisses bedeckt.

Die Westkinste des tropischen Afrika's ist munterbrochent

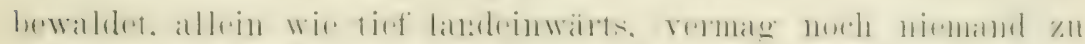

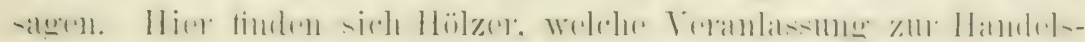

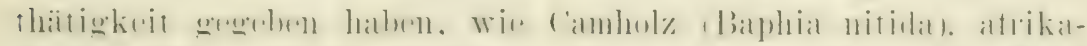

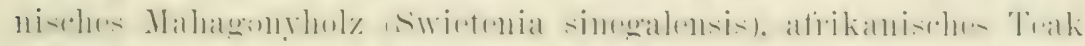

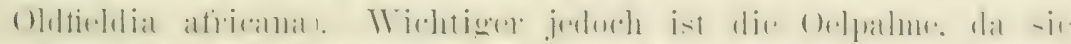

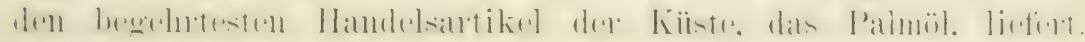

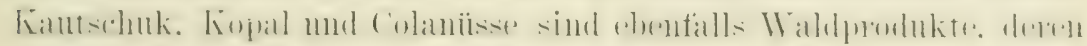
Belentung im Wachsen begriffen ist.

Sierra Leone und Gambia stellte in Elinburg cine Anzahl

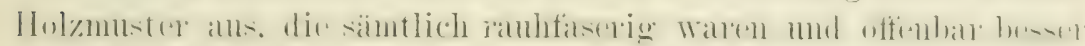

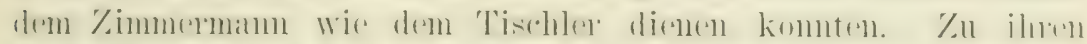

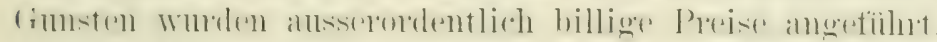

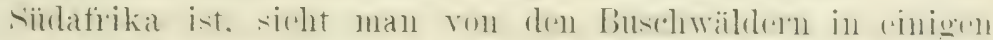

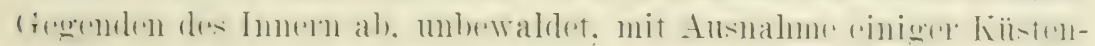

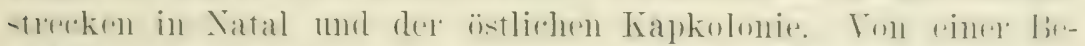

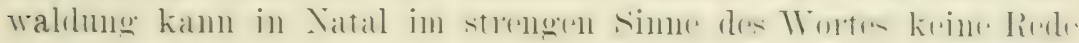

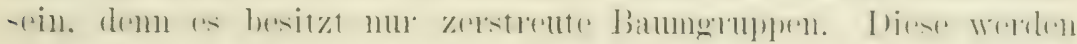

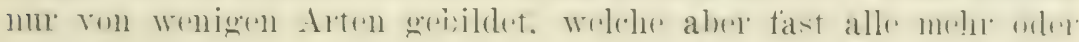
minder wertrolles Nutzholz liefer'n. Genannt zu werden ver-

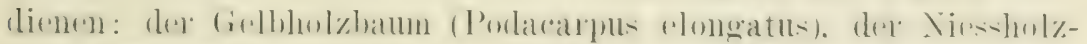

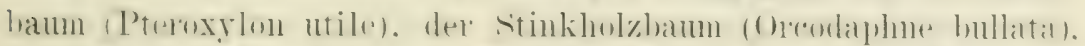

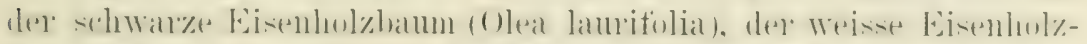

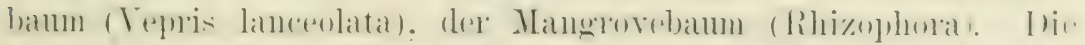

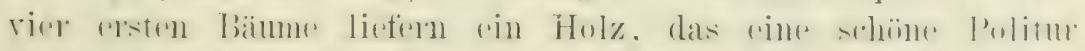

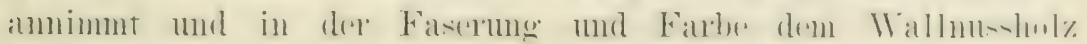
gleich steht.

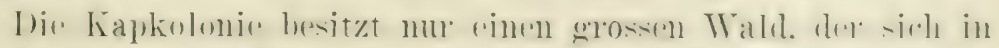

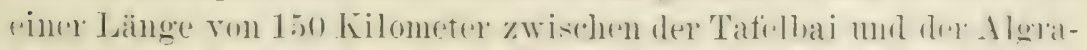

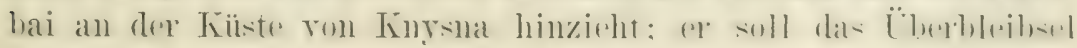

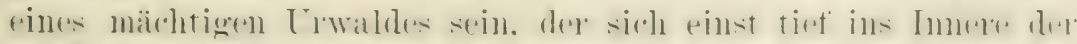

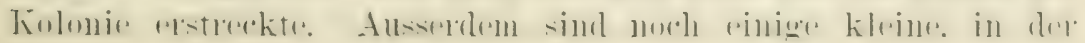




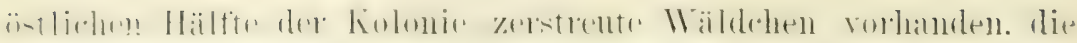

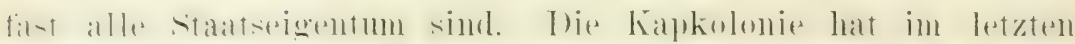

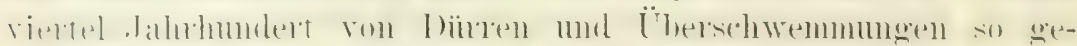

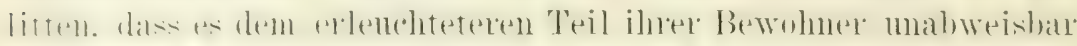

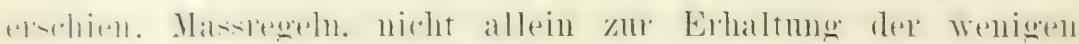

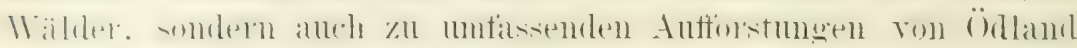

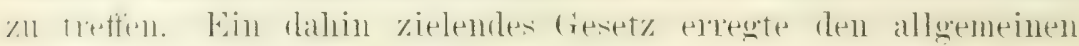

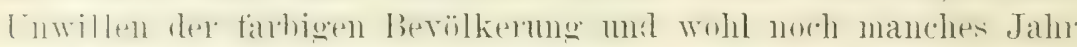

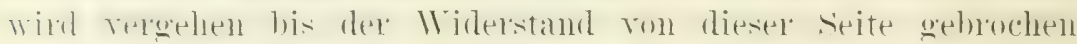
i-t. Hamnit das Gesetz kein toter Buchstahe bejhe, wuden Forst-

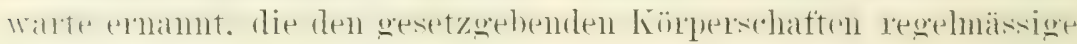

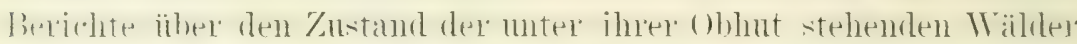

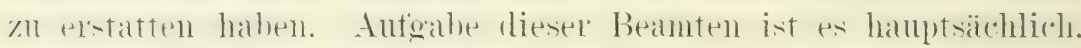

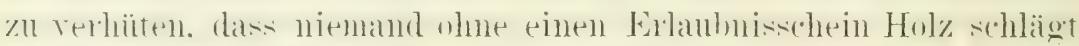

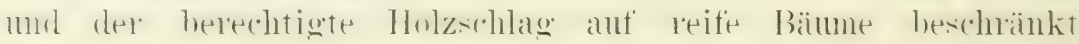

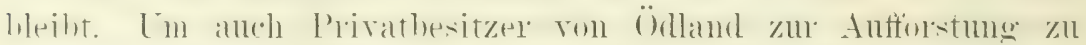

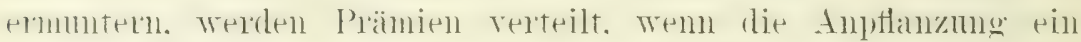

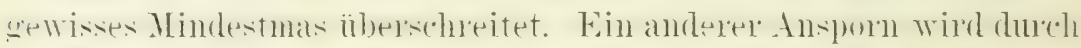

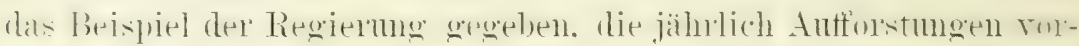
nelunen lässt. zu welehem \%wecke Pthanzschnlen gengündet wurden. an-

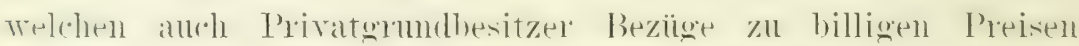

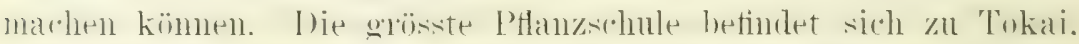

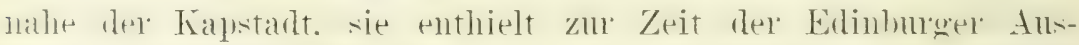

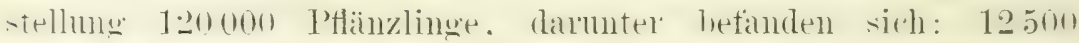

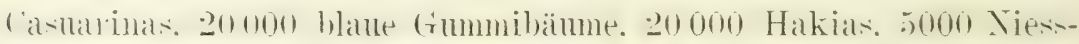

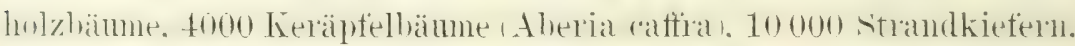

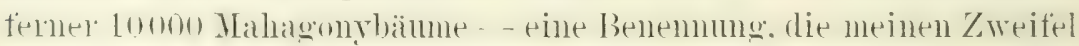

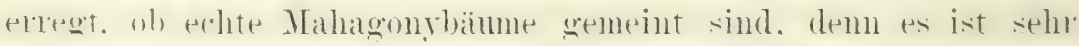
mwahreheinlich. dass dieselhen in dem Klima sïdafrikats eredeihen kïmen. Iter Name Mahagong ist in meherm halbtropischen

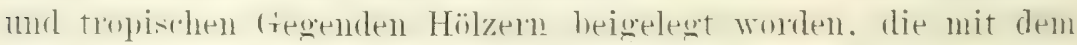
echten Mahagonyholz Ähnlichkeit besitzen.

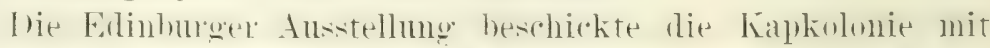
.n Holzmustern. davon worden ak die wertwollsten Stinkholz uml

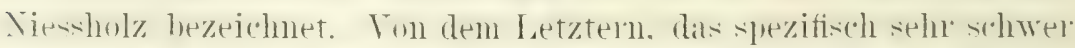

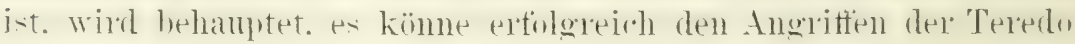
widerstehen.

lok Kapkolonie exportiert kein Holz. im tiegenteil. sie ist zu

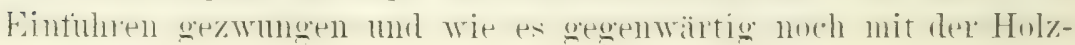




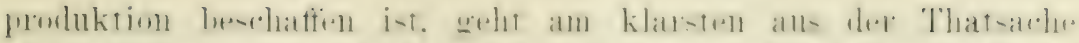

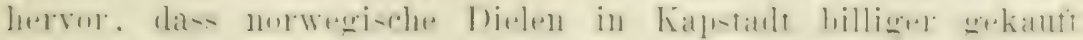
werden kömnen, wie Holz ans dem eigenen Lande.

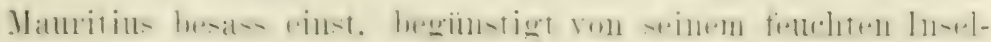

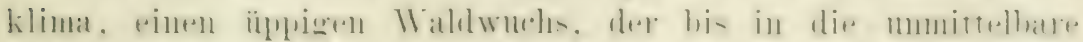

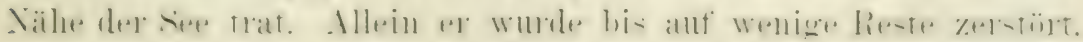

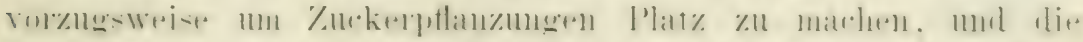

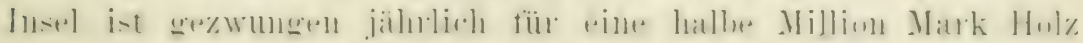

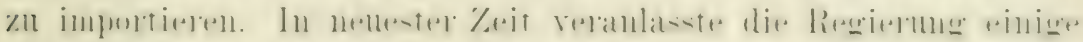

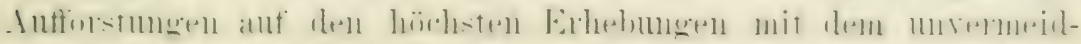

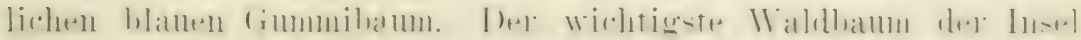

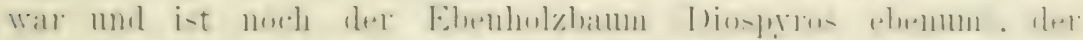

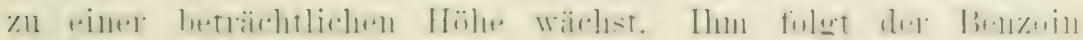
(croton Benzoe).

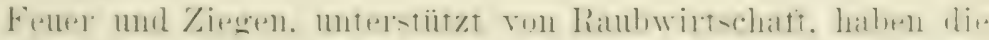

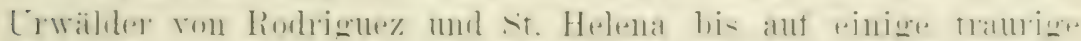
Überreste vernichtet.

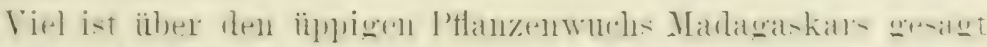

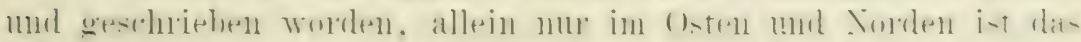

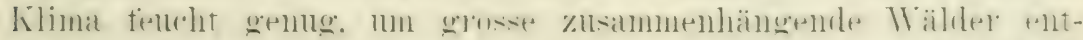

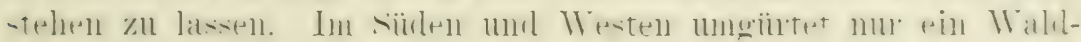

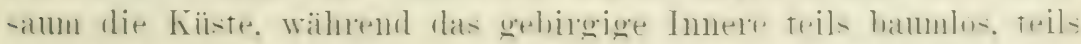

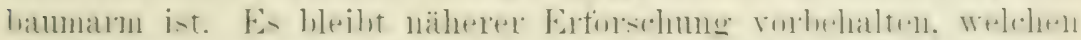

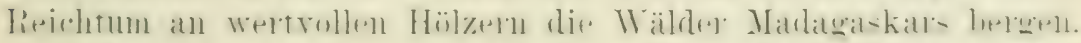

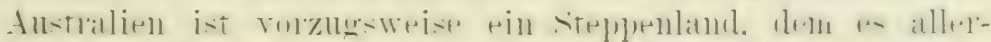

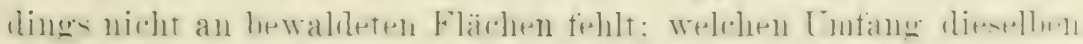

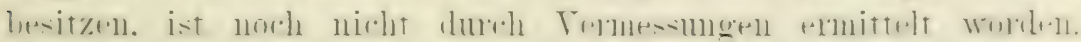

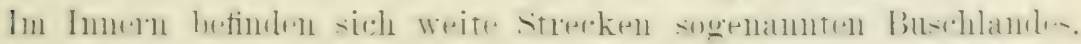

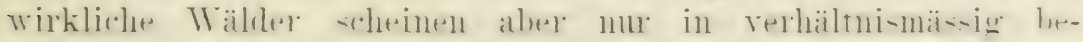

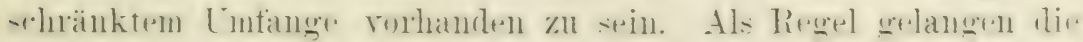

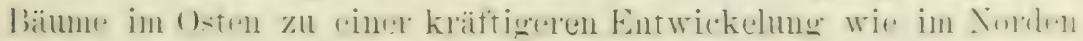

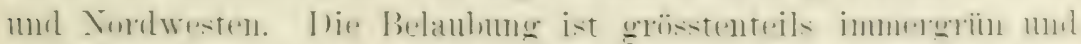

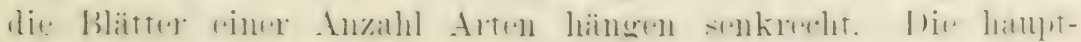

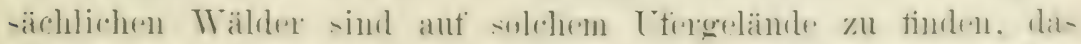

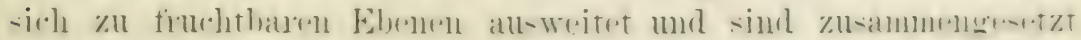

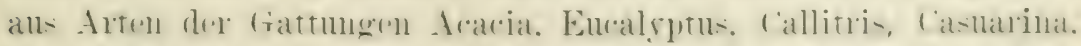

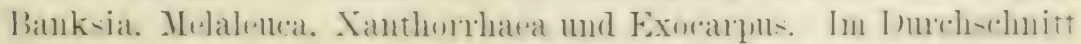

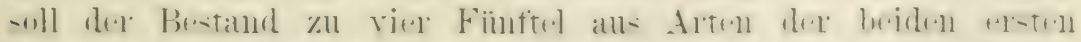
Gattungen gebildet sein. 


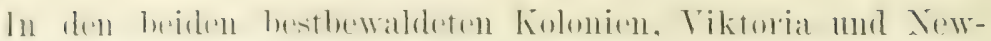

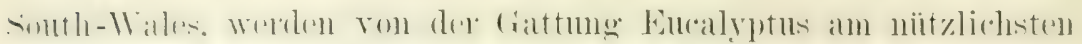

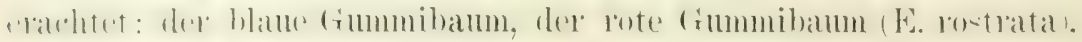

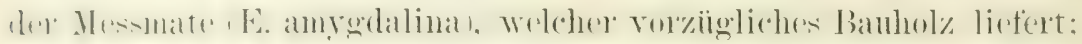

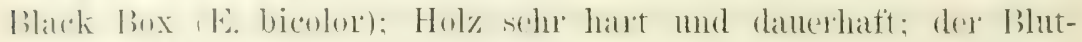

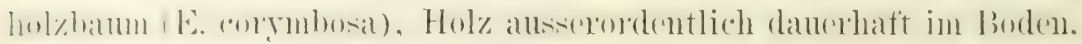

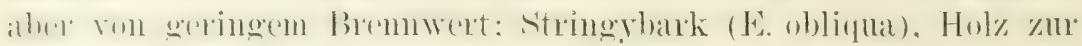

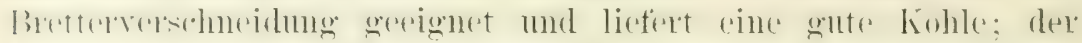

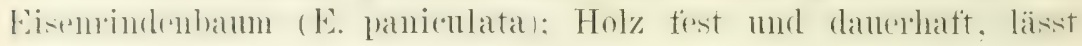

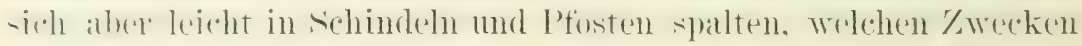

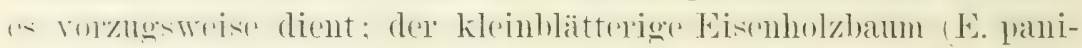
-nlatal val. myerophyllat) liefert ein Holz wie das voriges nur ron

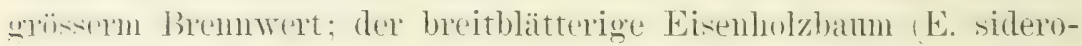

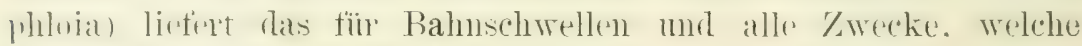

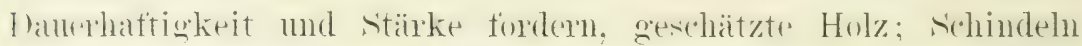

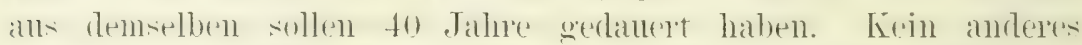
watustralisehes Holz kommt diesem an stäke gleich und keins

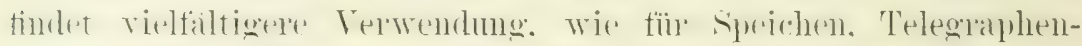
-tangen. Zämule. Wagmelarbeiten. Rartzähne u. s. w. alsserdem hat

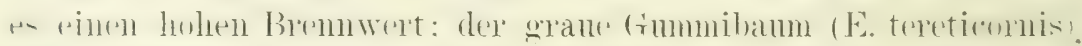

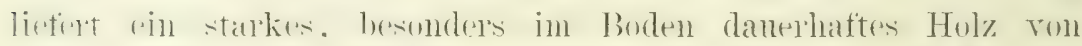

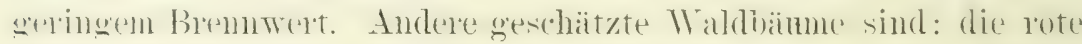

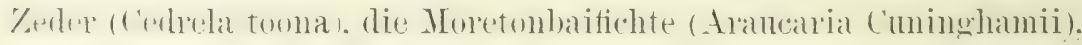

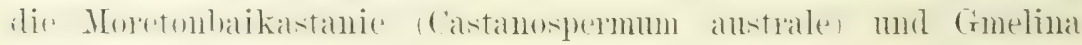
Leichardti.

Spärlich wie Westaustralien bewaldet ist, besitzt es doch

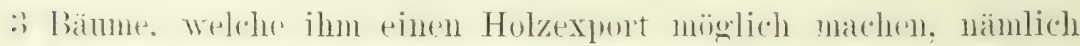

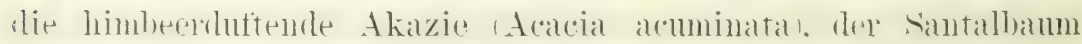

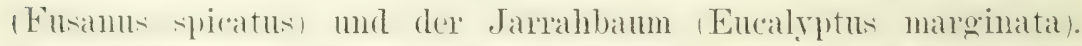

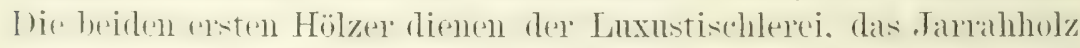
aher hat im lotzten Jahumht eine hohe Anerkennung im schiffbau gefiunden. Weil es eine berdentende Tragklatt besitzt. rom Terede nicht angegrifton wird und ausserordentlich danterhatt ist. In steigrnden Jfengen wird es nach England exportiert. wo es die crohiftbaner nu' dem 'Teak nachstehend schätzen. Indien macht (bornfalls Bezüge zu Bahnschwellen und 'Telegraphenstangen, weil das Jarahholz von den Termiten verschont bleibt molder Bodenfouchtigkeit sehr lange widersteht. Es scheint. im Jarrahbam soi der Tertrollste Waldbaum Australiens gefunden. 


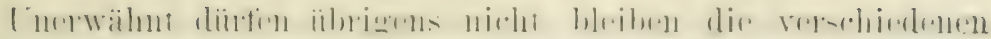

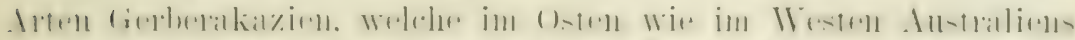

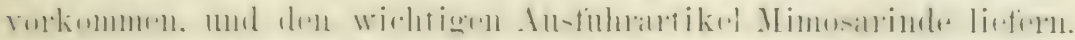

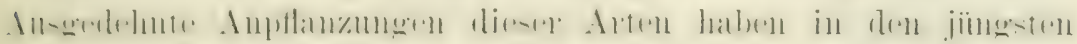
Talne'n stattgefmuden.

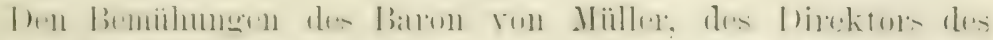

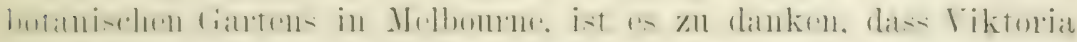

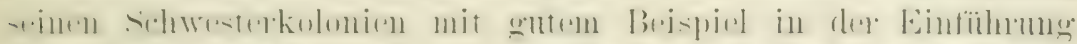

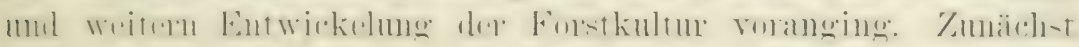

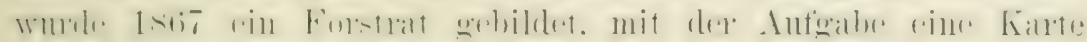

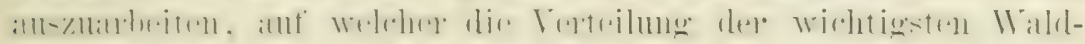

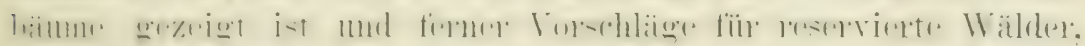

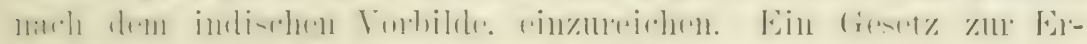

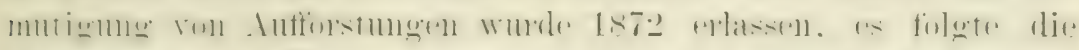

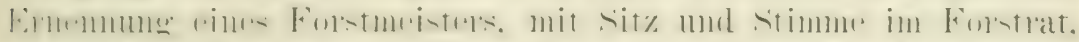

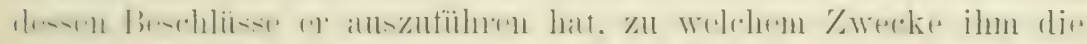

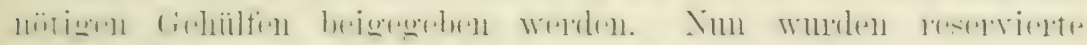

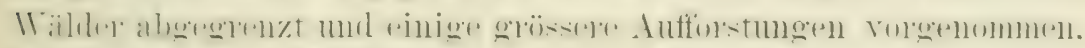

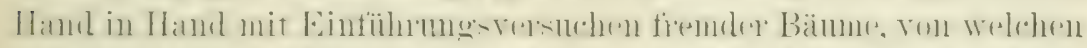

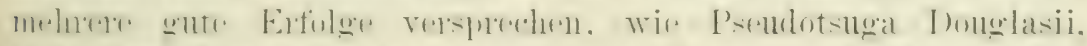

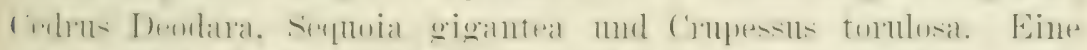

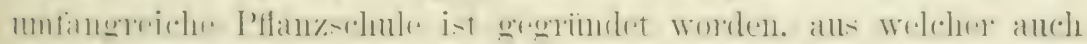
l'rivatermulm

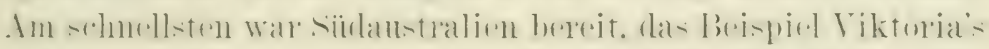

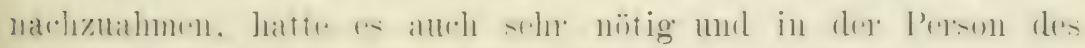

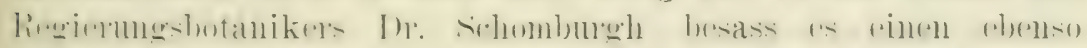

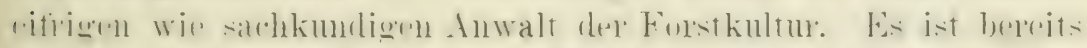

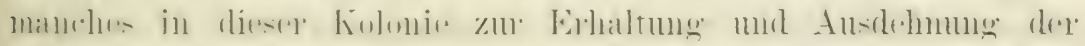
IV

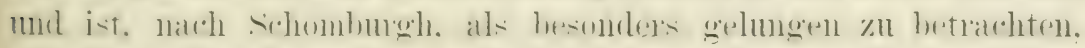

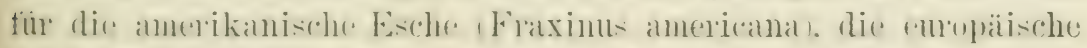

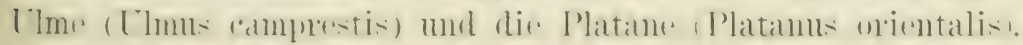

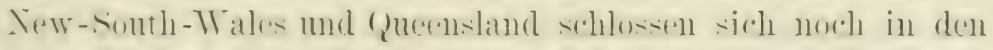

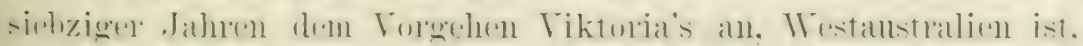

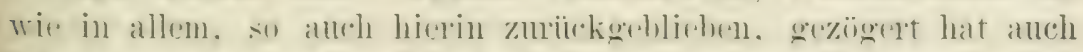

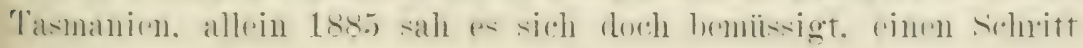
zu thun mit der Ernemnung eines Forstmeisters.

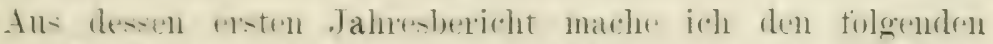

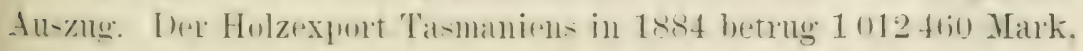




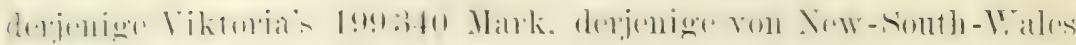

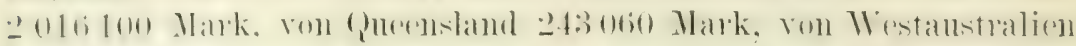

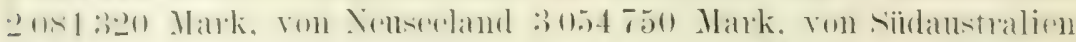

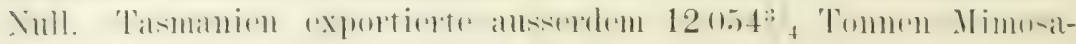
linde zum Werte von 1733780 Mark.

Lis sind 8 ieservierte Wälder abgegrenzt worden, mit einem

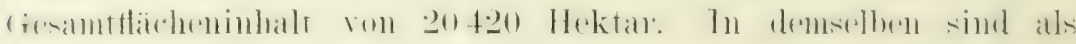

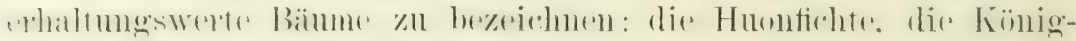

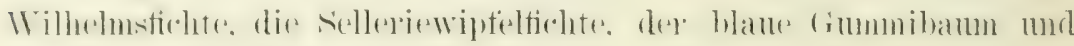
der Schwarzholzbaum.

Der blane Gummibanm ist anf' den siddichen 'T'eil der Insel

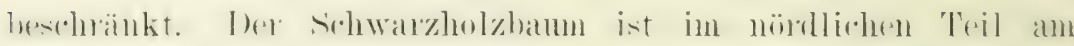

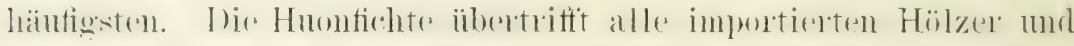
ist durchans olne einen Rivalen bezïglich dex Danterhattigheit

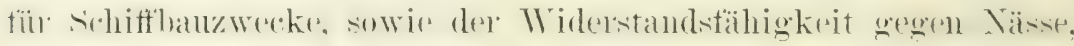

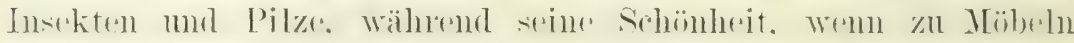

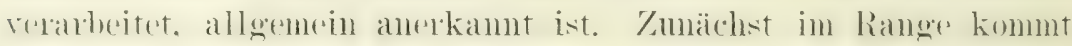
die Kïnig Wilhelnstichte - keine nützlichere Fichte ist in den anstralischen Kolonien zu finden; ihr Holz ist in jeder Hinsiclet

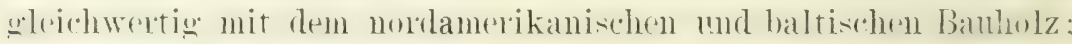

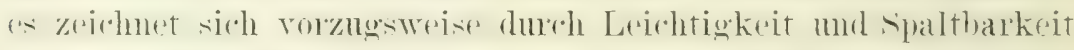
alts. Lot selleriewipfelfiehte ist in den nordiostlichen Distrikten an häutigsten: ihr Holz ist gratt und schrmupt nicht rin. Ein

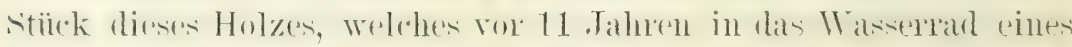

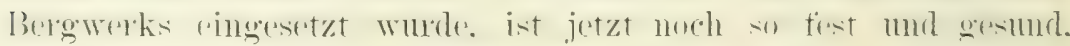
wie am Tage, wo es geschlagen wurde.

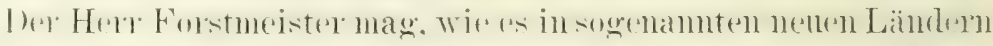

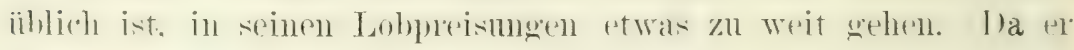

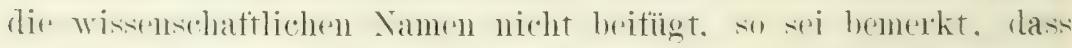
as seh keineswegs mu wirkliehe Fieleten handelt. Die Engländer

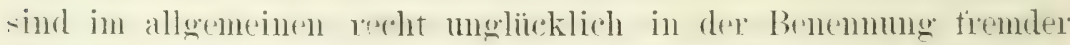

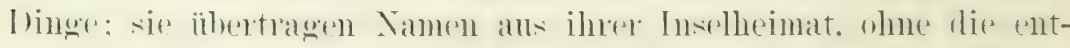

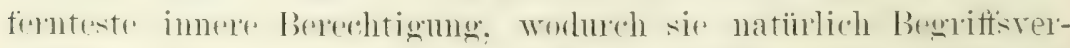

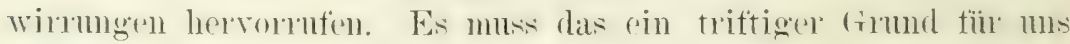

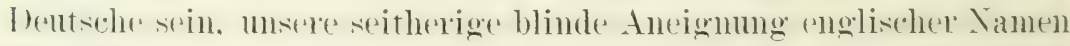

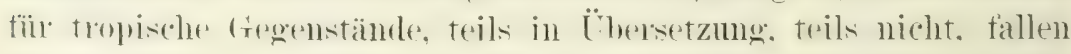

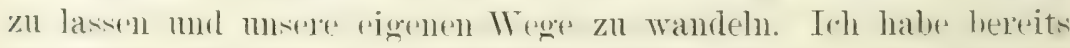

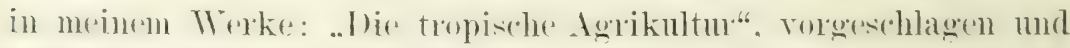

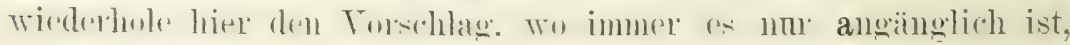




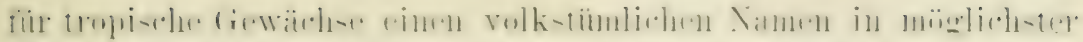

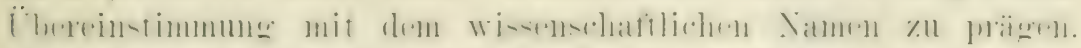

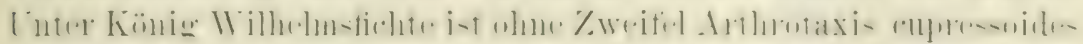

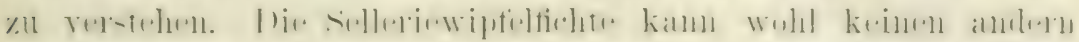

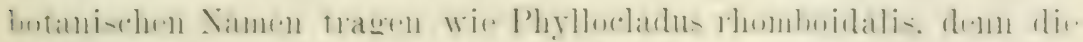

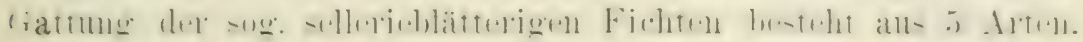
von welchen nul die genannte in 'Tasmanien hoimisch ist.

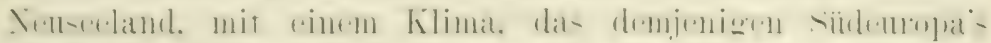

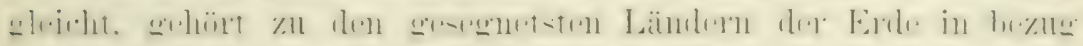

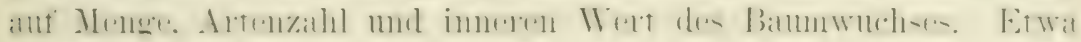

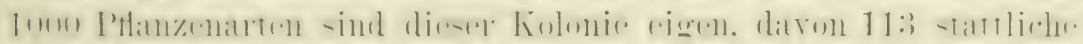

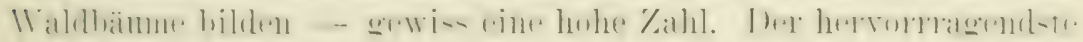

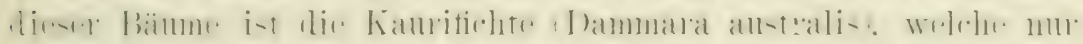

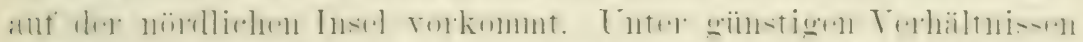

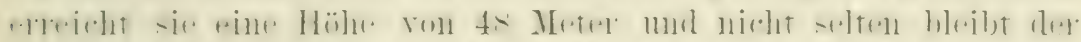

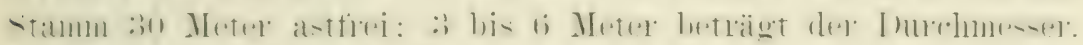

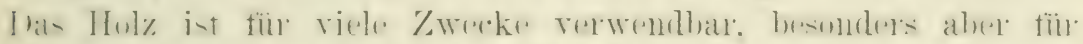

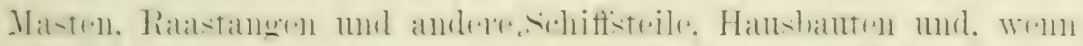

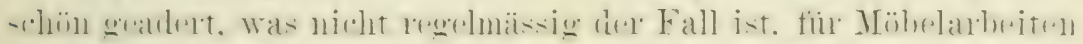

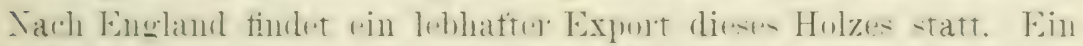

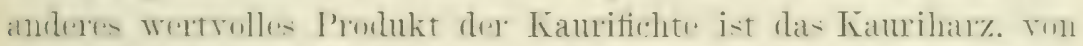

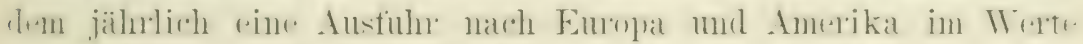
ron 6 Millionen Mark stattfindet.

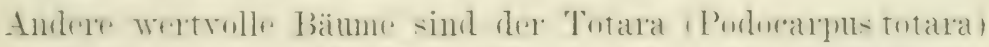

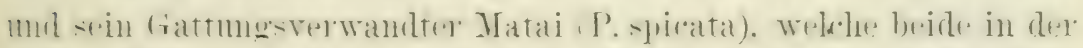

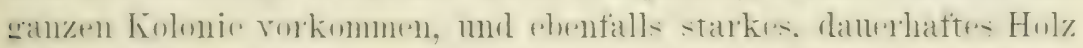

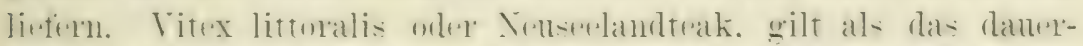

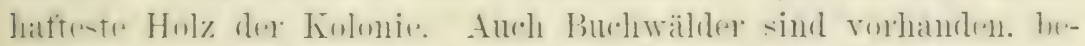

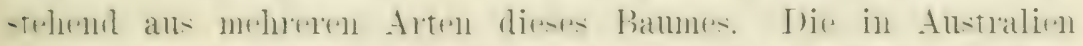

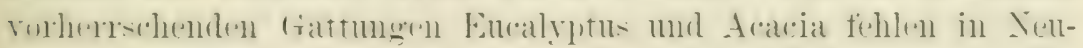
seeland gänzlich.

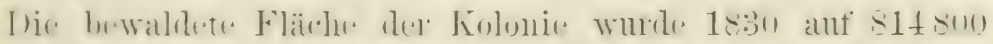

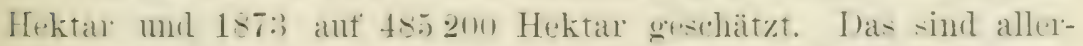

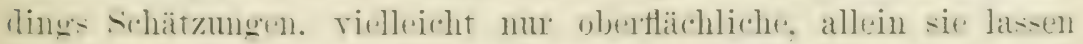

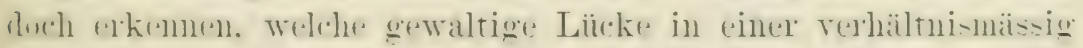

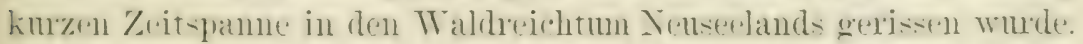

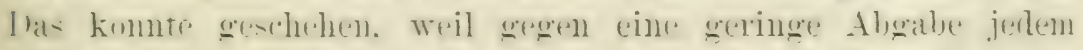

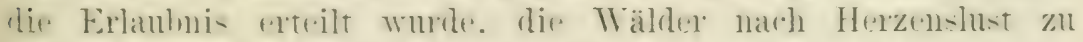

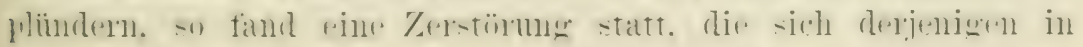




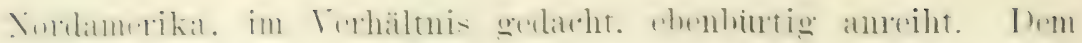

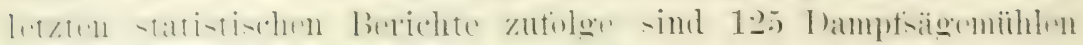

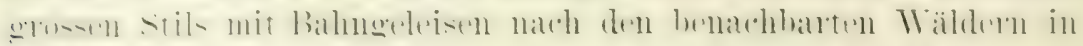

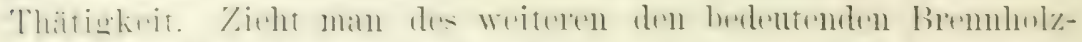

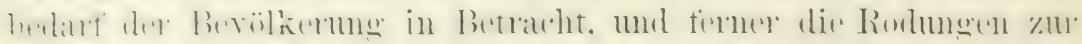

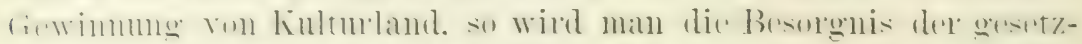

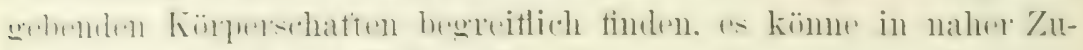

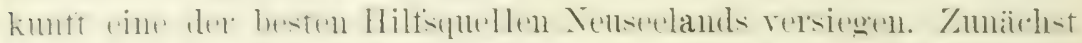

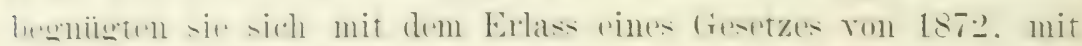

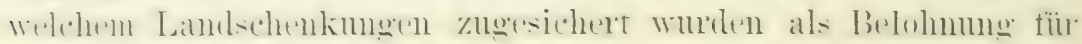

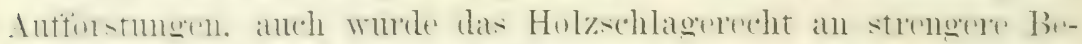

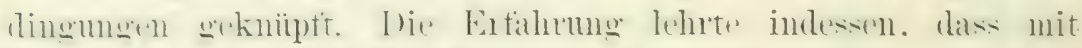

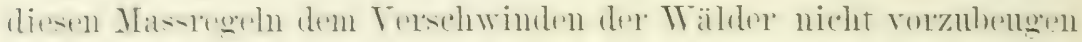

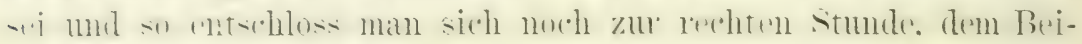

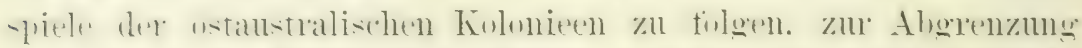

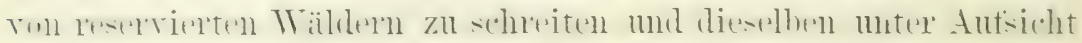

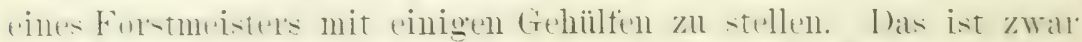

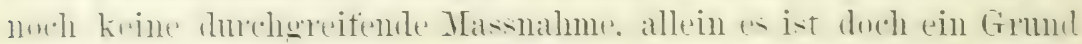

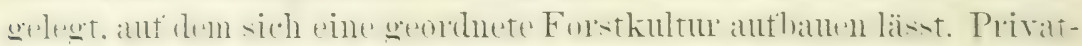

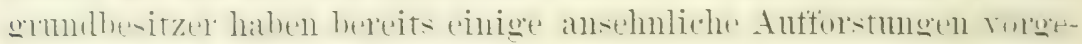

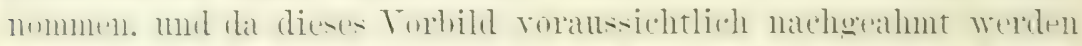

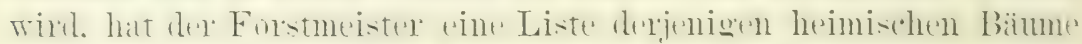

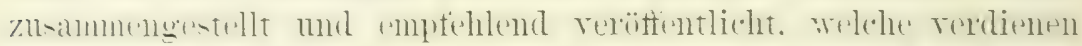

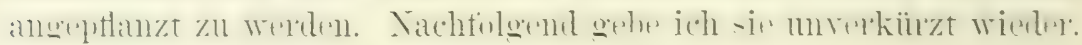
Kamifichte (Dammara australis)

Schiff- und Hausbau $36-48 \mathrm{~m}$ hoch $1.5-3 \mathrm{~m}$ Durchm. Totara (Podocarpus totara)

Pfosten und Schwellen $12-21$ $1,2-1,8 \quad$. Matai (Podocarpus spicata)

Pfosten und Schwellen $12-21$ $0,6-1,2$, Katraka (Libocedms Doniana)

Mübel und Züune

Pahantea (Libocedrus Bidwellii)

Brücken und Zïune Tamekaha (Phyllecladus trichonomoides)

Schwellen und Bretter $15-24$

Manoas (Dacrydium colensoi)

Pfosten und Hausbau (sehr dauerhaft) Manoas (Dacrydium restlandium)

Pfosten und Brūcken . $9-12$, $12-15, . . \quad 0,3-0,6,$. 
Manoas (Dacrydimn intermedium)

Pfosten und Brücken. . . . 12-15 $\mathrm{m}$ boch $0,3-0,6 \mathrm{~m}$ Durchn. 'Tawai (Fagus Menziesii)

schön zı Luxusarbeiten .

Puriri (Vitex littoralis)

Pfosten und Schwellen

$$
12-18, \quad, \quad 0,9-1,5, \quad, \quad,
$$$$
18-27, \quad, \quad 0,9-2,4,
$$

Hututawhai (Fagus fitsca)

Schiff- und Dockbau . . . . . kurzer, massiver Stamm.

Pohutukawa (Metrosideros tomentosa)

Schitt- und Dockbau .

Rata (Metrosideros robusta)

Schiff- und Jockbau, Schwellen . . 18-30 m hoch 1,5-3,6 m Durchm. Rata Metrosideros lueida)

shitf- und Decktau .

$$
4-1 \times \quad . . \quad 11.6-1.5, .
$$

Rawiri (Leptospermum ericoides)

Werftarbeiten

$12-15, \quad, \quad 0,3-0,6$,

Kowhai (Sophora tetrapera)

Pfosten und Schwellen

Maire-raumii (Olea apetala)

wertwoll aber wenig gekannt.

Maire-tawhake (Eugenia maire)

P'fisten und Zäme

$$
\begin{aligned}
& 15-21, \quad, \quad 0,6-1,2, \quad, \quad, \\
& 12-15 . . \quad . . \quad 0.3-0,6 \quad .
\end{aligned}
$$

Es wïrde zu weit tïhnen. die vielen Inseln des stillen unt

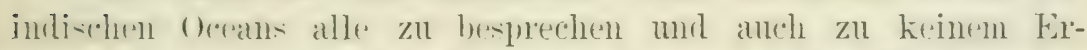

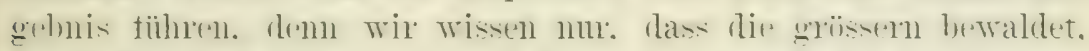
trilweise Therte dieser Wälder verhailt. ist eine noch mbeantwortete Frages.

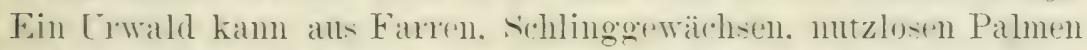
und vielartigem Gesträuch bestehen. ohne nur ein wertvolles Holz

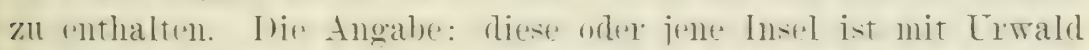

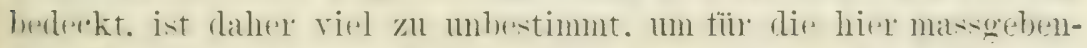

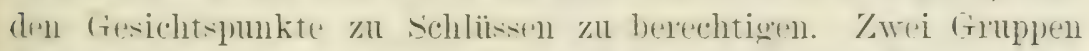
sollen aber doch eine kura. Erwähnme tinden. I)ie Firlechis be-

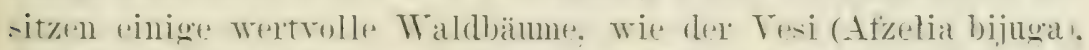
den I)ilo (Calophyllum inophylhum). dent T)akna (I)ammala Titiensis) den Jovi oder dir Tahitikastanit (Inocalpus edulist. den Papier-

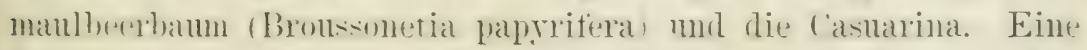

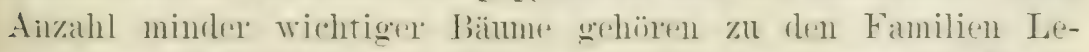

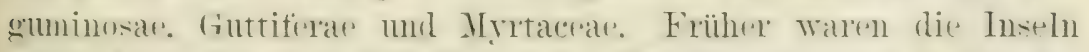
-tark bewaldet. seit Eintülumg des Plantagrnbanes ist abex dere 


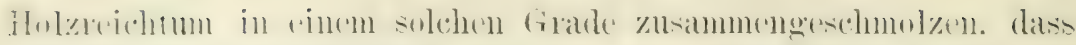

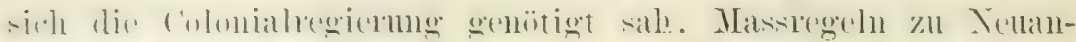

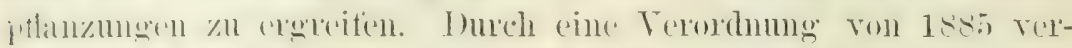

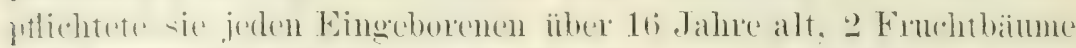

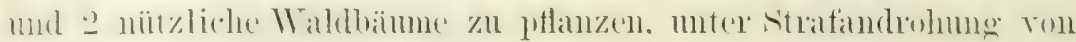
4 shilling oder 14 'lage tefängnis. Fs scheint, als labe das ihemalige Walderect\% von Japan zum Forbild gedient. nateh wel"hem jede ermolbesitzende Familie. je nach ilnem Ranges. to bis

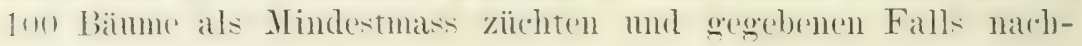
ptlanzen musste.

Auch die Wälder Hawaii's sind durch den Plantagenbau

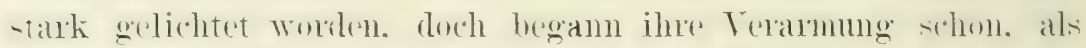
in der ..enten, alten Zeit" handeltreibende schiff-kaphitane kimen,

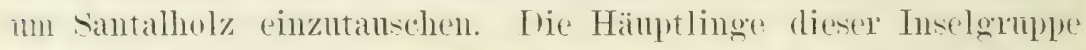
waren als die eifigisten santalholzkautleute bekannt und die meisten hahen anch ansehnliche Termögen in diesem Gechä̈t elwroben. Gegenwätig kamm der Waldbestand anf del gamzen sirupue als selewath bezeichnet werden. anf einigen Insehn herischt conar Holzmangel. trotzdem ist noch nichts geschehen, um dem writergreifenden Ø̈hel zu stenern. Ton den noch vorhmulenen Waldbämmen sind zu nennen: Alemites molnceana, Alphidoxia excelsa. Dodonaea viscosa. Cordia subcordata. Paritim tiliacsum, Broussonetia papyrifera.

serüchwörtlich ist der Waldreichtum sïdamerikas.s. mit Ausnahme der steperenstataten Lunguay und Argentinien. Lie ganze Anderkette ist mit Wäldern bekleidet. die je nach Bodenerhebung. Lage und Breitegrad eine wecheshde Zusammensetzmog habetl. Glosse Lïlken sind noch nirgends in diesen Reichtum gerissen worden, teils weil alle Länder suidamerikas noch düm besiedelt sind, teils - und dieser Grund wiegt schwer - weil verInaltnismässig Wenig Wassestrassen vorhanden sind. Welche sich zum Holztraneport nach der Fïste eignen. Toch in keinem staate ist der Lmfang der Wälder ermittelt oder ein anschanliches Bild ihres Wertes entworfen worden. Bei der grossen Verschiedenheit des Klima's mul der Bodengestaltumg müssen selbstrerständlich die Waldprodukte eine reiche Mamnigfaltigkeit zeigen.

Anf der istlichen seite Südamerika's. südlich rom Rio de la Plata bis zur Magellansstrase. ist der Bammwchs ausserordentlich spärlich. Nui hier und da finden sich einige dornige Akazien, 


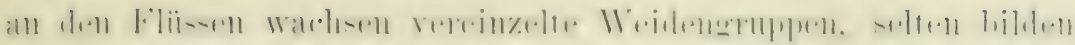

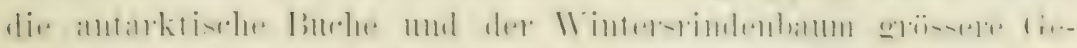

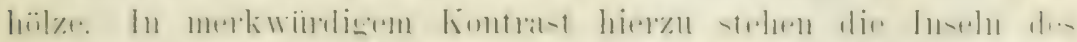

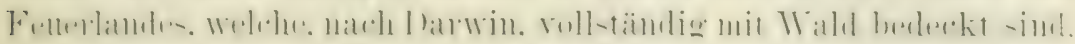

Sïrdlich vom Rio de la Plata stossen wir zunächst ant die

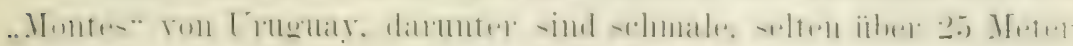

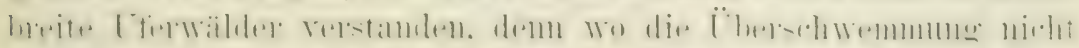

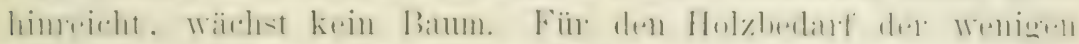

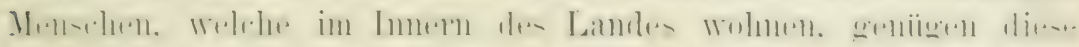

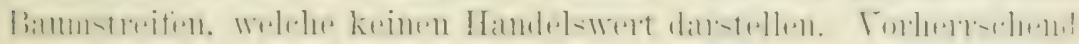
i-i d.

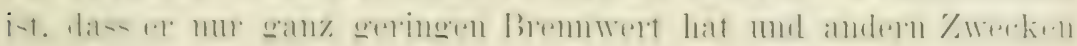
nicht diement kamm.

Ein ganz anderes Bill bietet Panguay, dessen Abrachumg

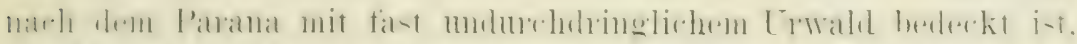

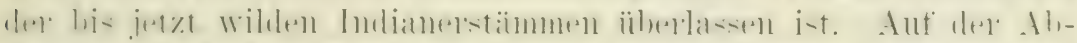

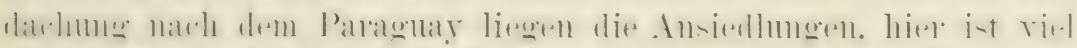

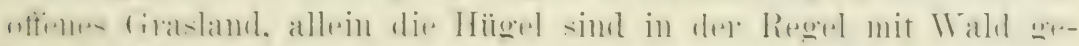

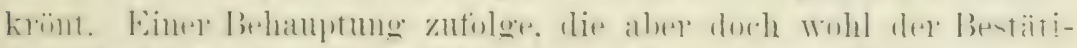

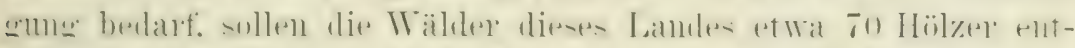

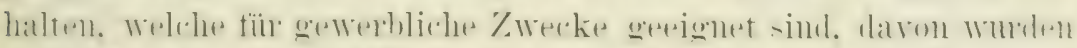

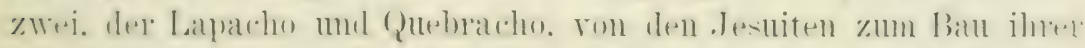

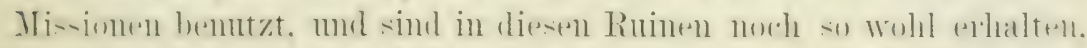

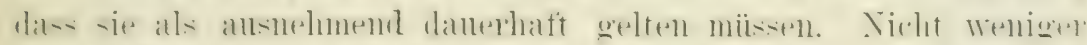

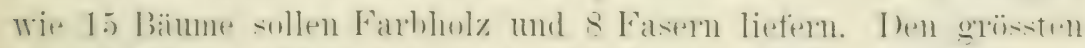

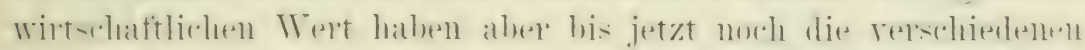

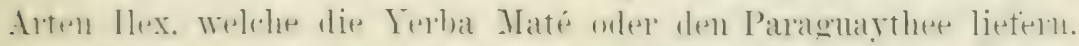

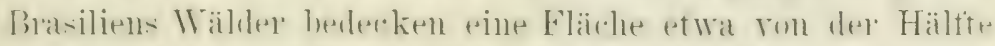

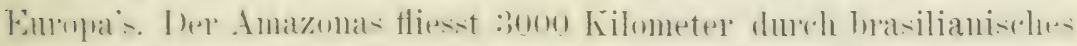

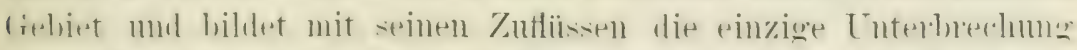

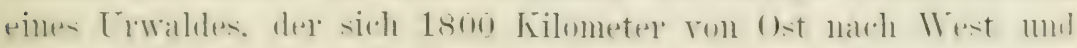

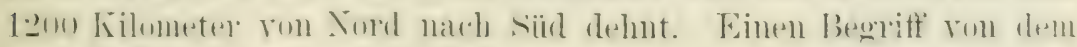

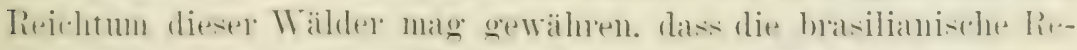

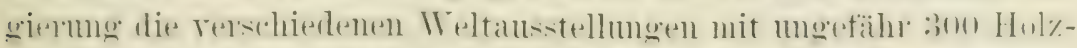

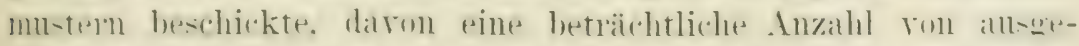

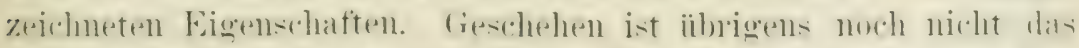

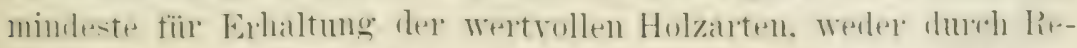

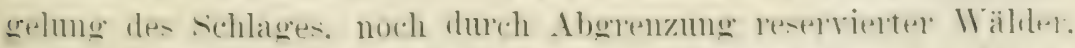

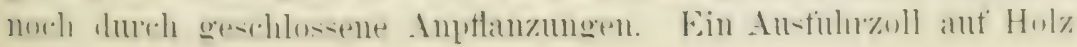




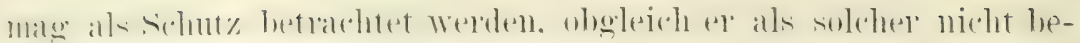

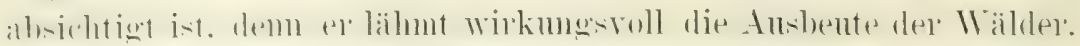

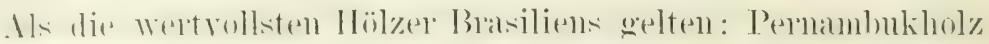

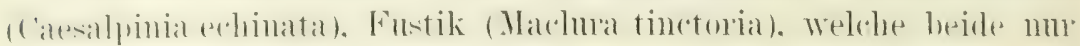

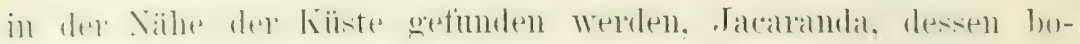

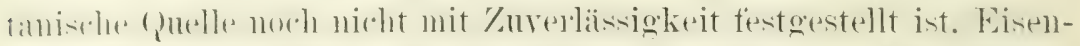

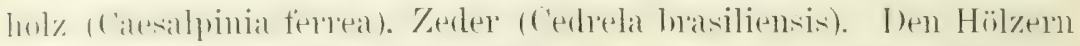

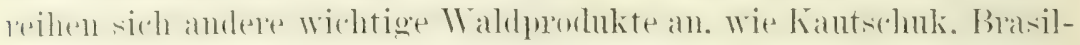

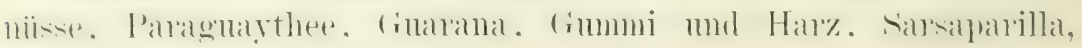
Ipecacuanha mo' Jalapa.

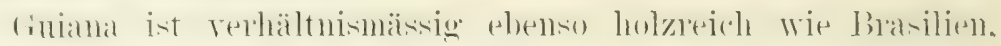

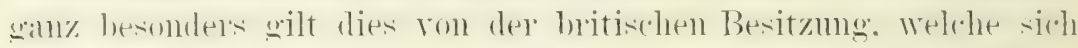

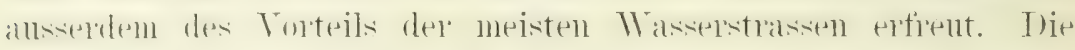
4 grossen Flïsse, ron welchen sie durchströmt wird: Corentyn,

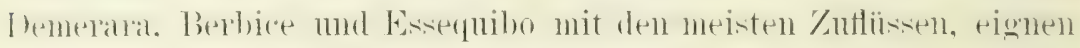

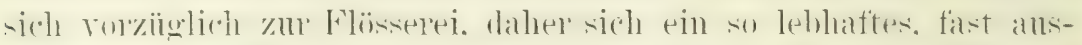

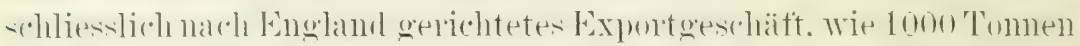

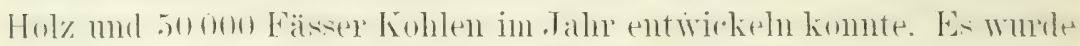

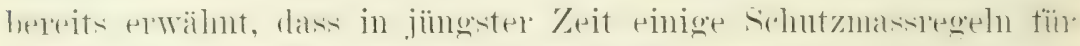

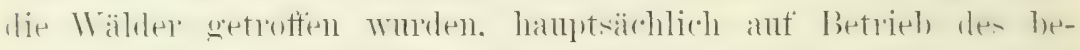

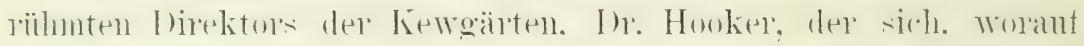
ich in anderen Arbeiten schon hingewiesen habe, um das wirt-

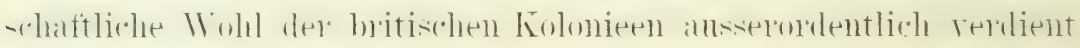
macht.

Britisch Gniana liefert zwei der wertvollsten Schiftbauhölzer:

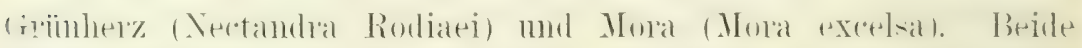

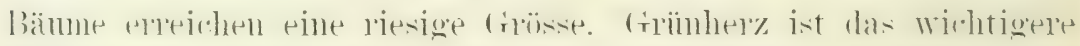

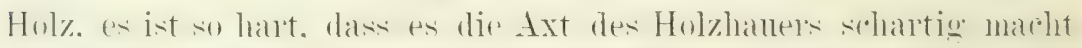

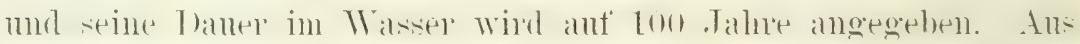

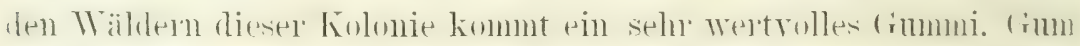

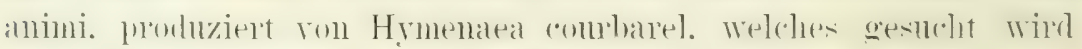
zur Herstellumg des feinsten Wagenlacks.

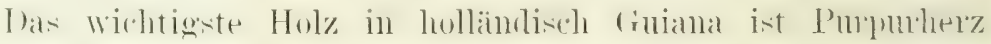

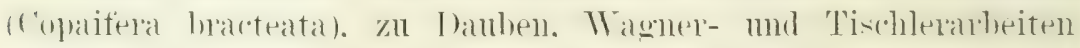

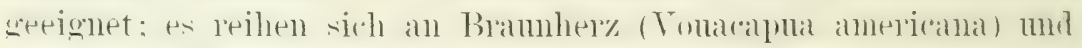

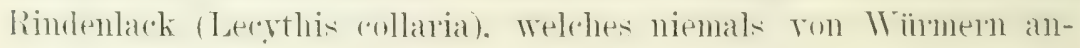
gegriften wird.

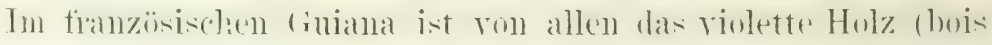

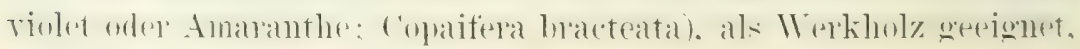




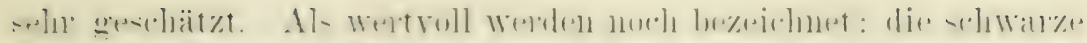

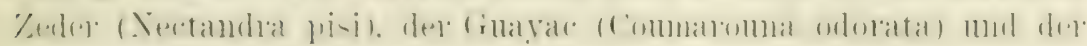
stattliche, 20 bis 24 Meter astfrei bleibende Combaril.

Dell drei Guiana's gemeinschaftlich ist der Balatabaum

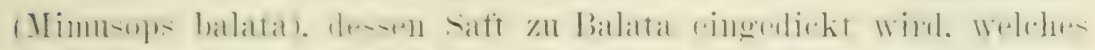

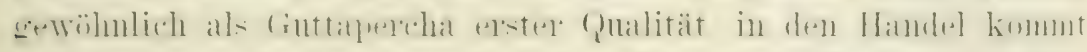

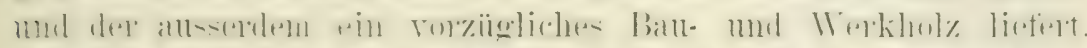

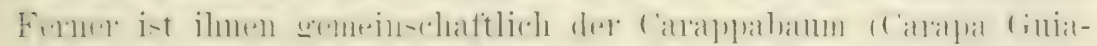

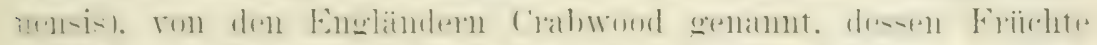

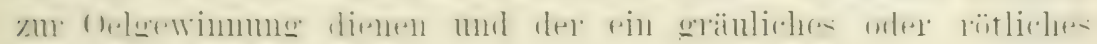

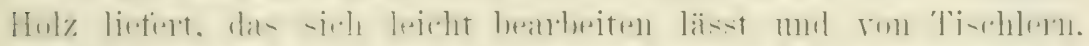

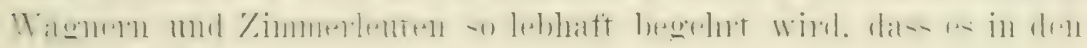
besiedelten I)istrikten bereits spärlich ist.

Venezucla ist zu einem grossen T'eile Stepuenstaat, seine

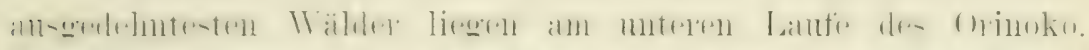

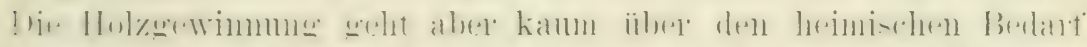

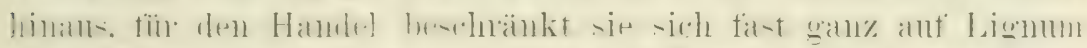

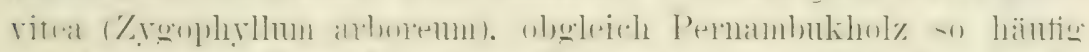

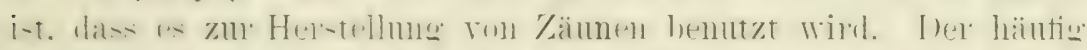

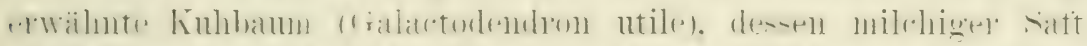

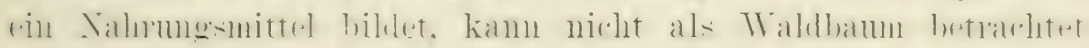

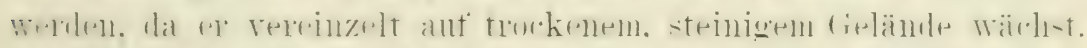

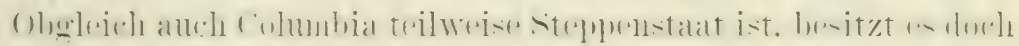

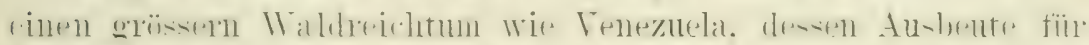

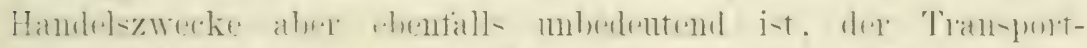

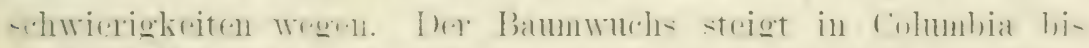

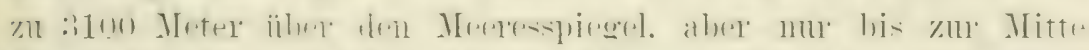

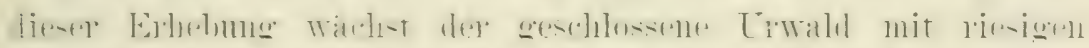

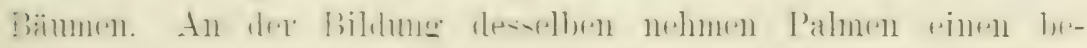

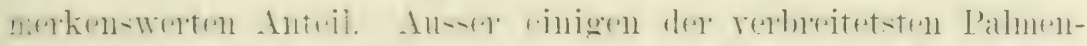

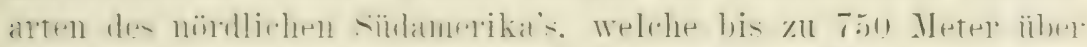

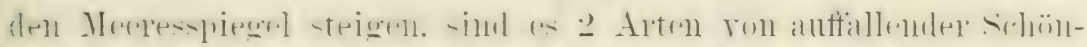

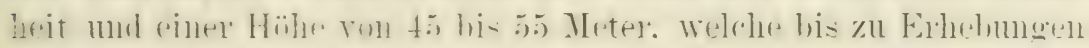

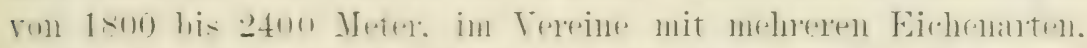

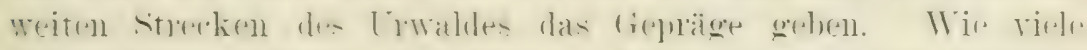

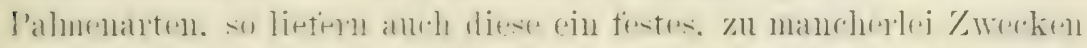

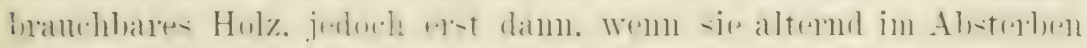

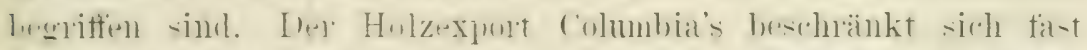

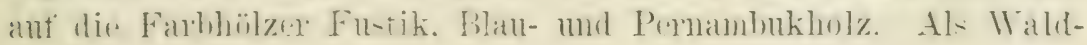


modulite habon ferner zu gelten und sind von Wichtigkeit:

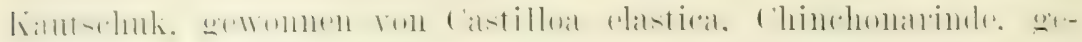
womnen ron 6 Arten, Balsan von 'Tolu, gewomnen von Myroxylon toluitel:at.

Eenador und Pertu sind in der Gebirgsegion der Andes mit

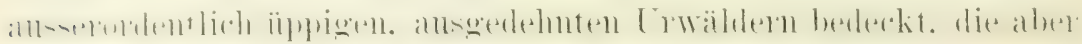

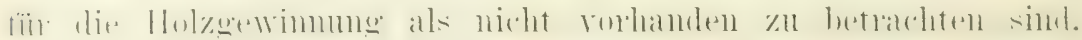
nenn man von dem geringen örthichen Bedarf absieht. Beirle

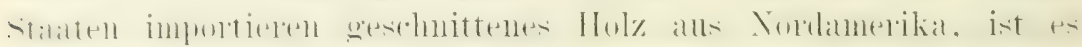

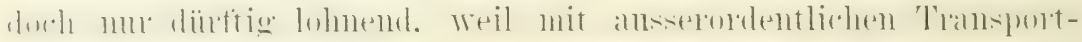

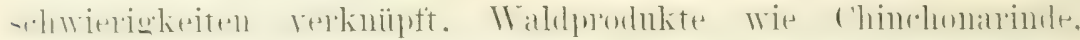

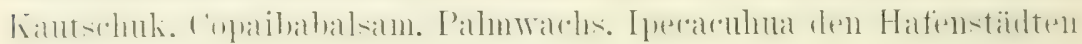
zuzutiihlen.

Chili ist im Norden ohne Wald, nur im Süden ron San Jago.

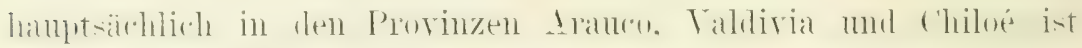

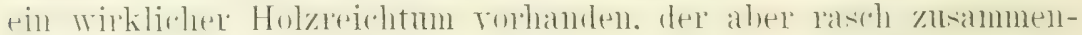

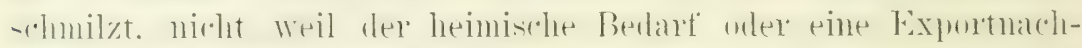

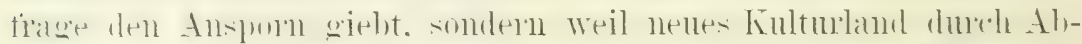

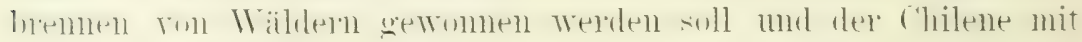
del dxt gegen alle wilden Bämme wiitet, als sei er von einem

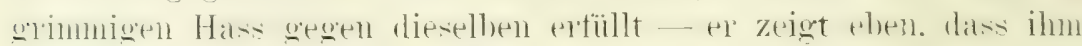
spanisches Blut in den Adern rollt. Die iblichen Folgen der

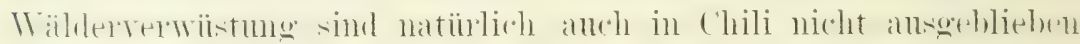

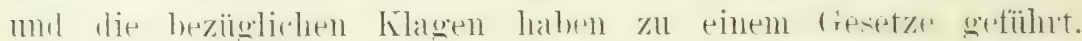

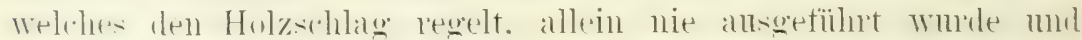

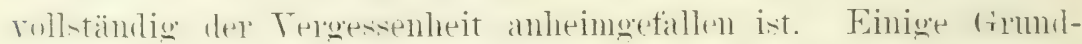

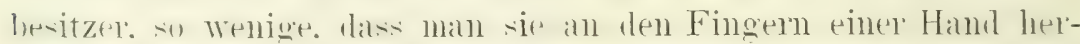

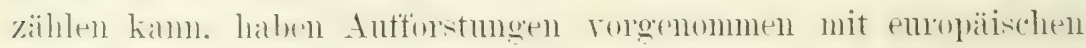

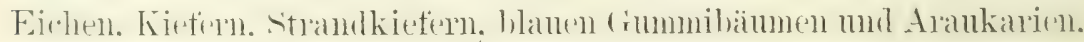

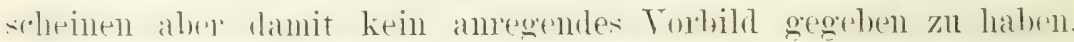

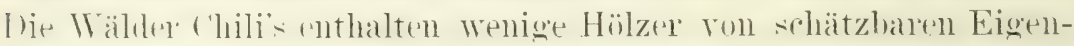

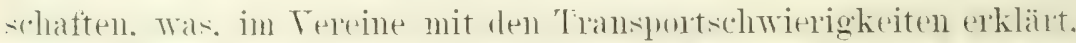

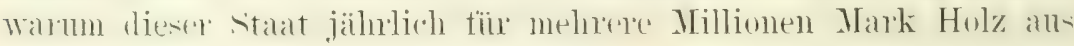
Noldamerika importiert.

Chili besitzt etwa 100 heimische Bäume, welche, mit Aus-

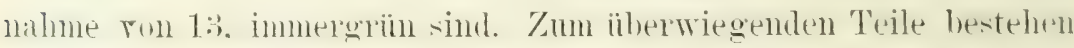

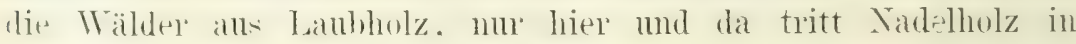
kleinen fruplen ant. Als der grösste und wichtigste Waldhaum

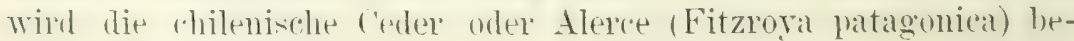




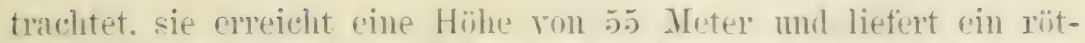
liches. weiches, aber dauerhaftes Holz, das sich nicht wirft. I)

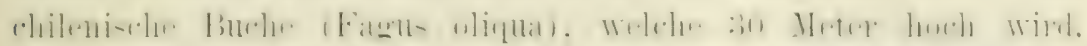

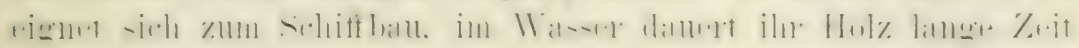

D)er Lingue (Persea lingue) lictert das beste Holz für Mö̈bel,

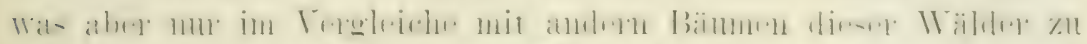

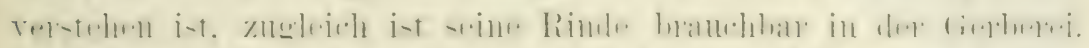

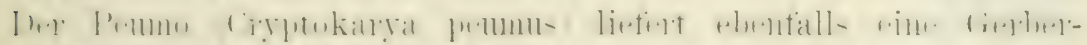

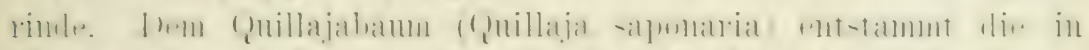

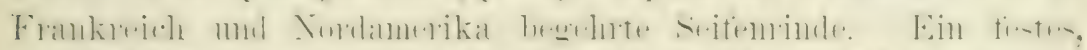

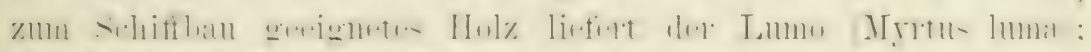

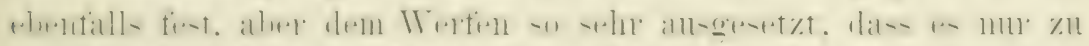

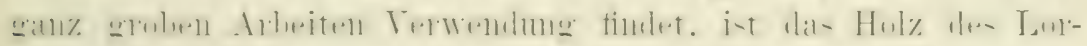
beers (Lametia aromatica). Die beiden Zypressen Libocedrus

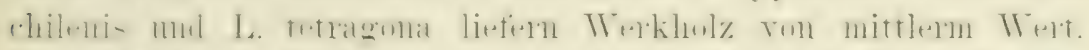

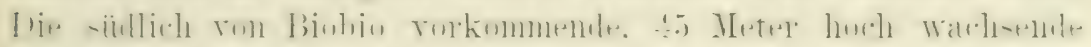

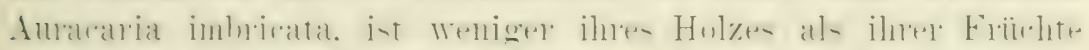

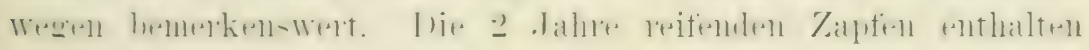
50 bis 100 etwa 5 Zentimeter lange Samen, welche gekocht, delikater wie Kastanien schmecken sollen.

Das allgemein gehaltene Trteil lantet: die Wäler Chili's

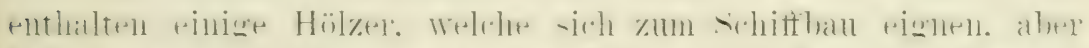

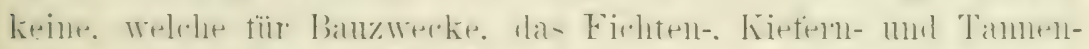

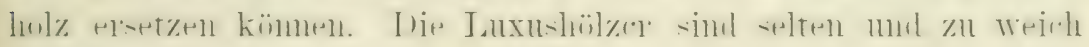
zur Herstellung ron danerhaften Möbeln.

Trestindien bietet durchaus ein tribes Bild der Wäldervel-

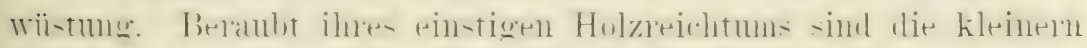

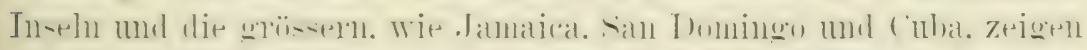

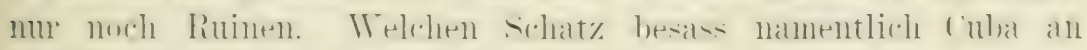

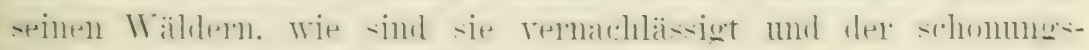

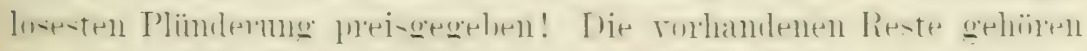

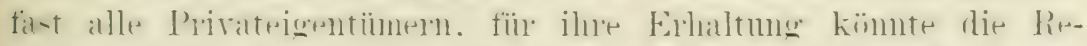

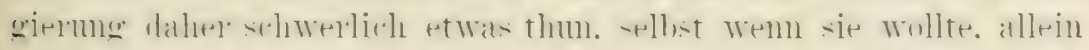
sir lat nueh nipmal- gewollt. Etwal- Mallaguny. Hu-tik mul

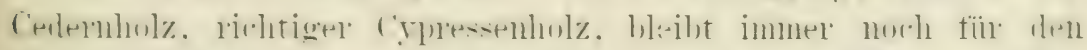

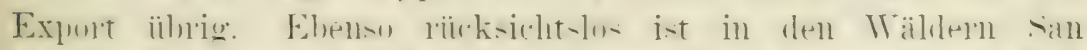

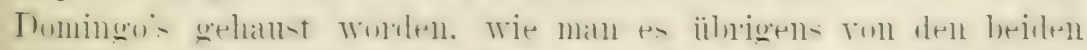

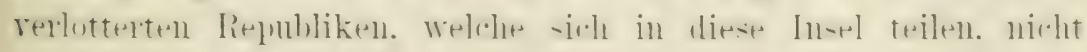




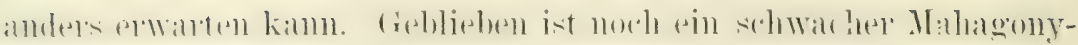
export.

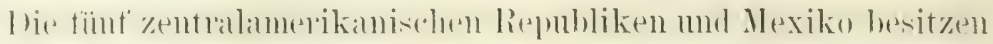
all-aredelunte II sind. dass weder der Flächengehalt noch der innere Wert an-

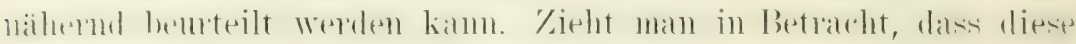

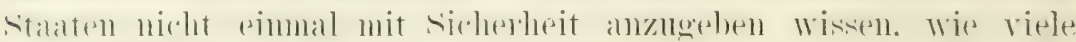
Bewohner sie haben. so wird man die herrschende Tnkemntnis

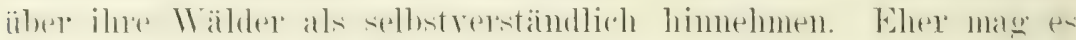

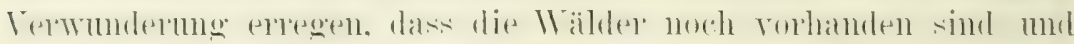

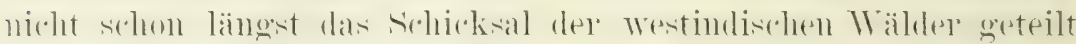
haben. Diese Thatsache mit der wirtschaftlichen Einsicht der

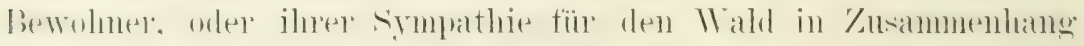
bringen zu wollen, wäre die denkbar irrigste Erklärung. An

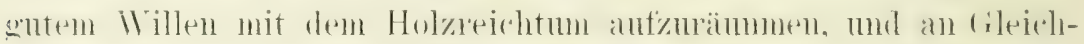

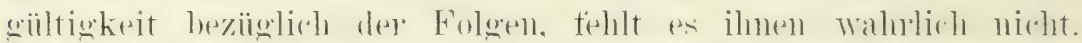

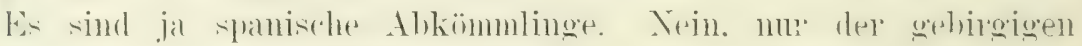

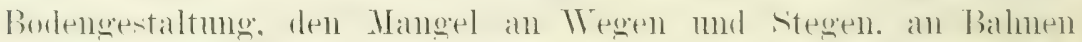

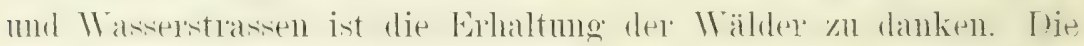
Natur hat der Verkelnshewegme in Mexika mol Zentralamerika

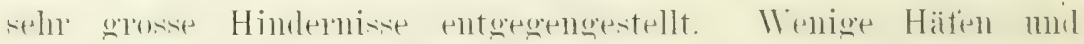

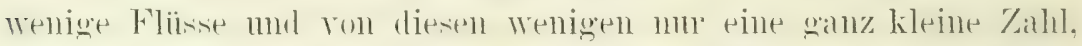

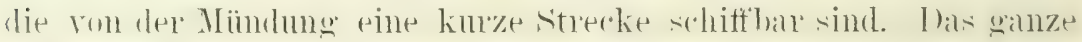

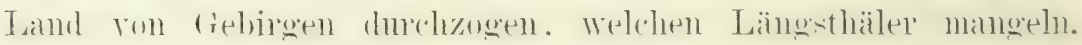

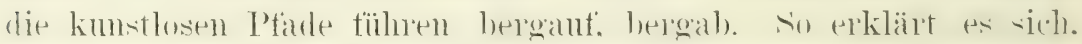
dass mur Hölzer vom hohem Wert, wie Mahagony mol Campeche.

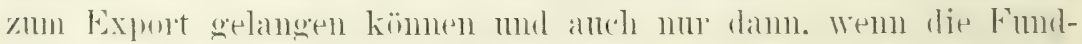
orte nicht entfernt von der Küste liegen.

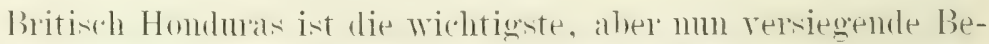

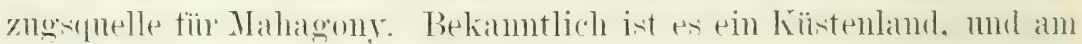

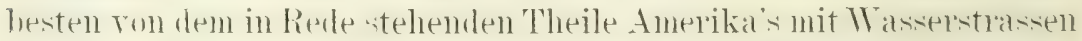
versellen. In miserem Zeit rersteht man es wohl. Terkehrshindernisse wie die elwihnten, zn besiegen und ein Anfang ist anch hereits in jenen Ländern semarht, allein der weite T'ransport mit der Bahn. helastet dem Verkantswert des Holzes so schwer, dass nicht anzumelment ist. Mexiko mol Zentralamerika werden jemals eine heträchtlich wichtigere Rolle als Bezuguquelle tör Holz spielen wie in der Gegenwart. Das ist um so wahrscheinlicher, weil die auflebende, tropicale Forstkultur fïr eine weite Terbreitume der 


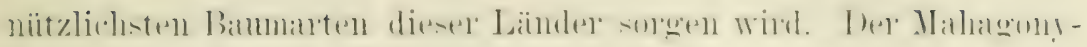
baum hat bereits die Wanderung angetreten.

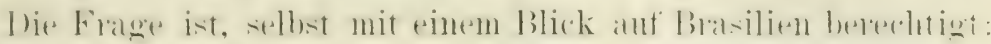

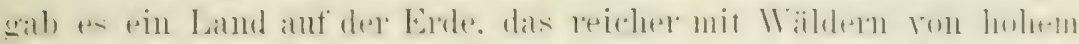

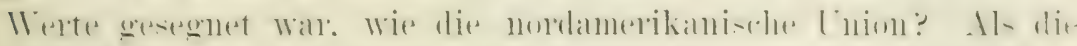

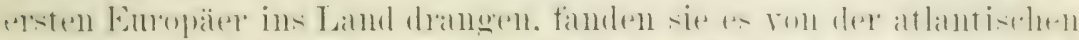

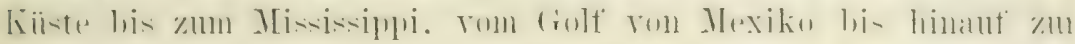

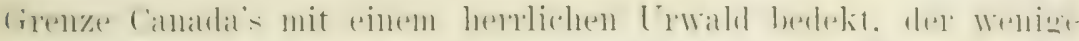
Lichtungen zeigte. An der entgegengesetzten Seite. an der

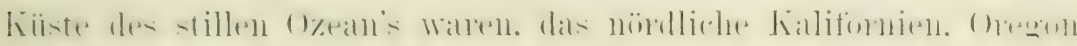

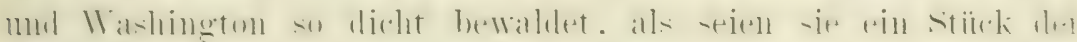

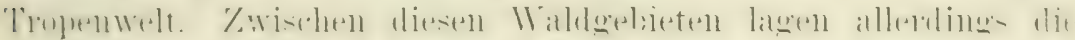

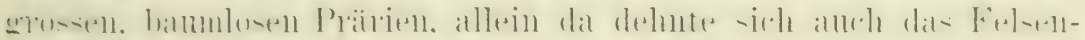

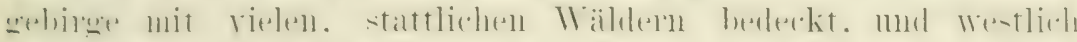

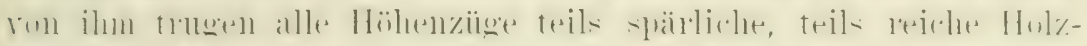

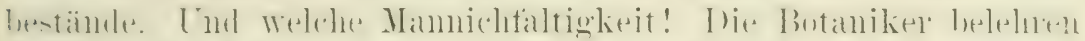

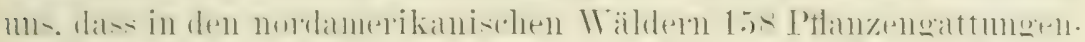

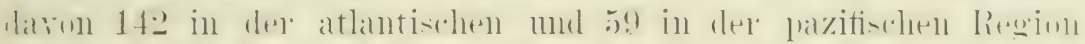
vertreten seien: ron den erstern werden 48 nicht anssprhall, dehalbtropischen Floridas gefunden.

An wirklichen Waldbämmen sind 412 Arten entrleckt worden.

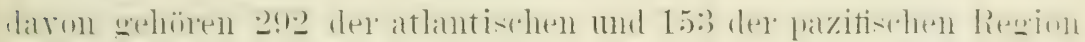

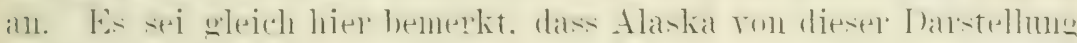

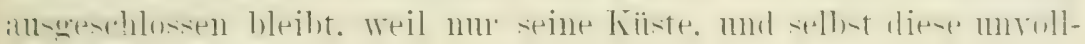
kommen, erforscht ist.

Das „Ruickgrat des nordamerikanischen Festlundes." das

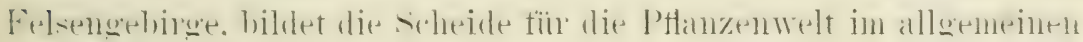

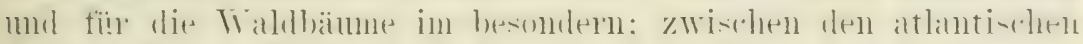

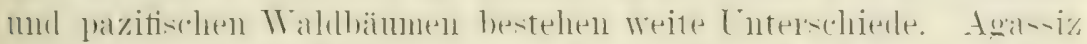

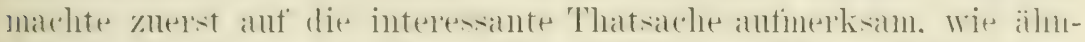

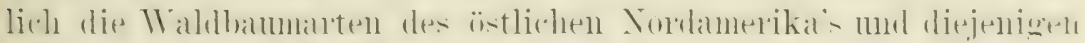

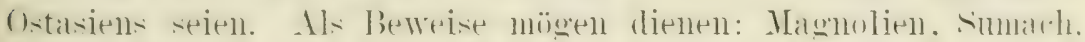

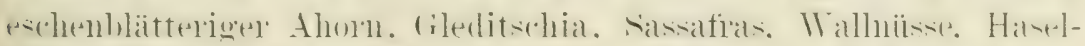

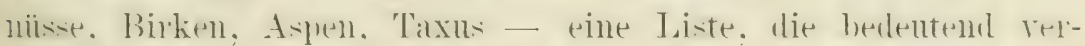

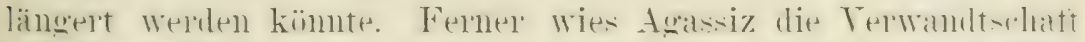
mit dem Pflanzenwachs der emopäischen Alpen nateh. durde Hin-

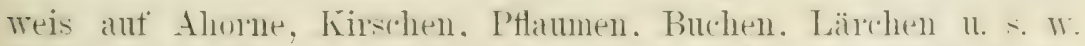

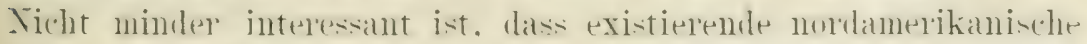

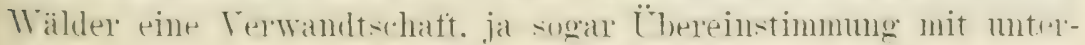




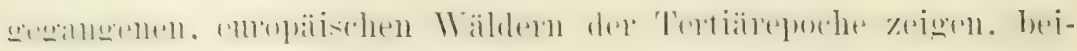

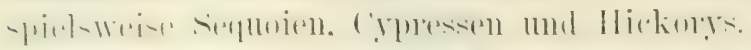

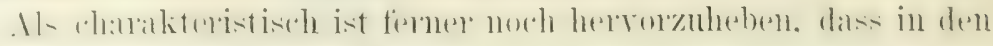

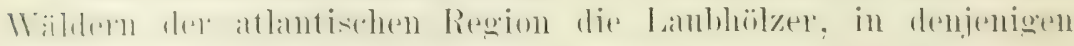
der parifischen Region die Nadelhölzer rorwiegen.

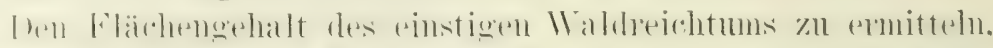

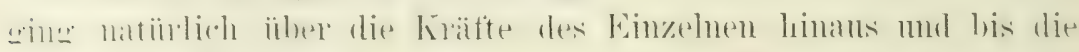

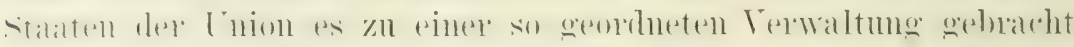

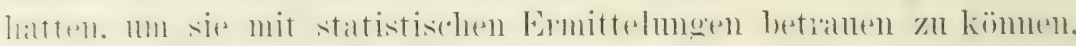

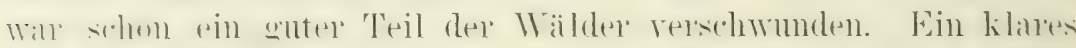

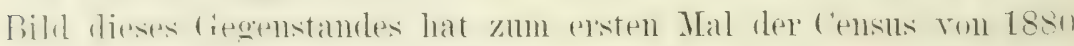

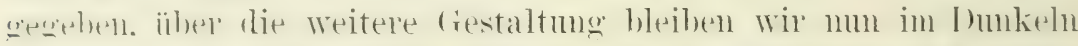

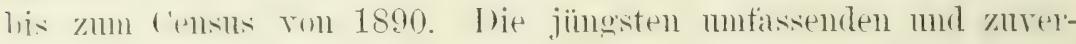

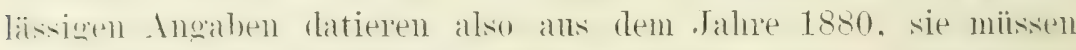

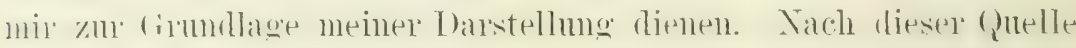

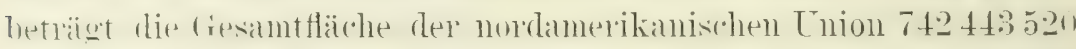

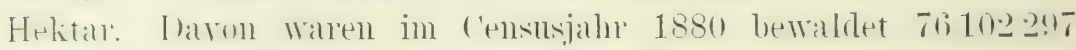

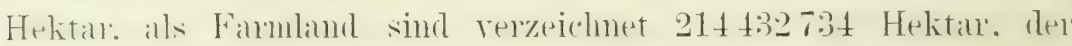
Re-t ron 4.51908 489 Hektar bestand ans Ödland. Wildweiden mut

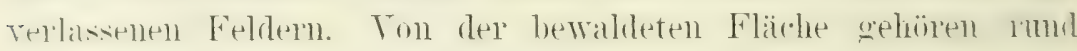
$\$ 4000000$ Hektar der Bundesregierung.

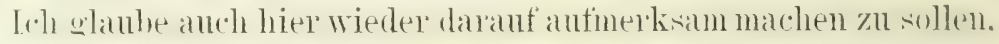
dass nuter be wableten Flächen nicht durchgehends Wähler im wahren sinne des IVortes rerstanden werden dïrfen. Tuter diesen Begrift fällt vielmeln alles Gelände. Welches. Wenm anch noch so spärlich. mit hulzigen dewädssen bestanden ist mol wer den Grwald kennt. Weiss. dass nicht selten ganze freviertmeilen keinen stamm entlaalten. der im Handel rerwertbar ist. Beisplelsweise sind an der Pazitikkiiste viele Berghänge mit einem huntscheckigen sträucherGemisch hedeckt, fiir welche der spanische Same Caparlal in die

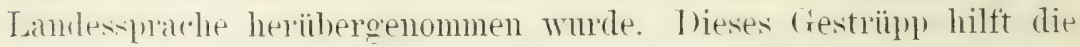
.,bewaldeten Flärhen" beträchtlich rermehren. allein del Holzhaner kïmnte da nur Reisigbündel machen. Selbst an den wirklichen Tahl dart nicht ein Gleichmass angelegt werden, da er in seinem vermertbaren tiehalt bedeutende Abweichmgen zeigt. wie the folgende fiegeniuherstellumg reransehaulicht. In den Wähldern Maine's. die viel whohtfhauholz lieferm, schätzt sich der Holztäller glïcklich. Trem er auf einen Acre $(40.47 \mathrm{Ar}) 15000-20000$ Kubikfiss Holz gewimlen kamn; el betrachtet das als das Hörchstmass. In den Rut- 


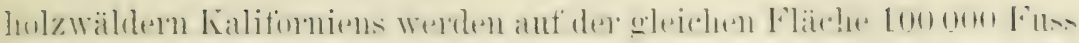

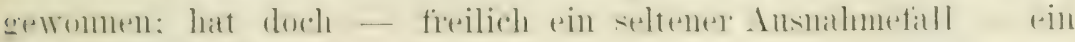
baum 75000 Fuss Holz geliefert.

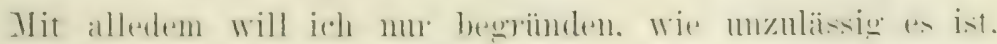

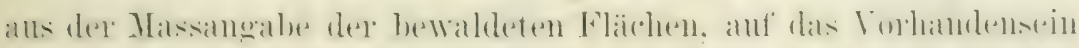

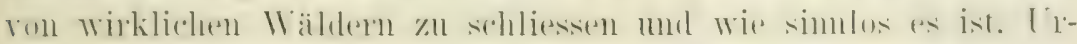
wälder mit Kulturwäldern in Vergleich zu bringen.

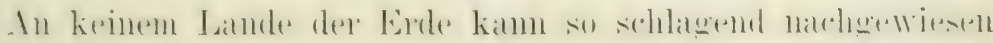

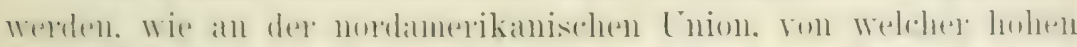

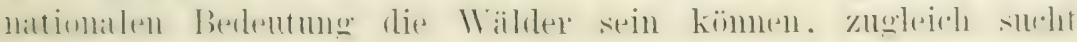

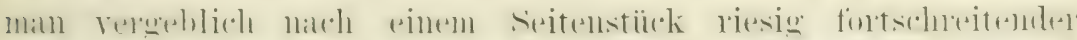

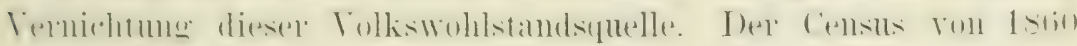

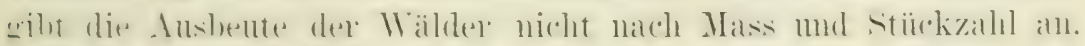

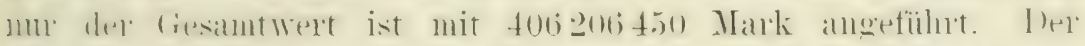

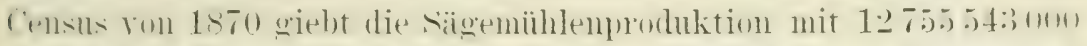

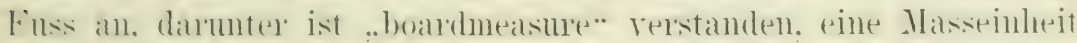
von 1 hadrattus 1 \%oll dick; ferner 3265516000 schindeln. I)ip

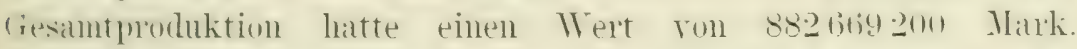

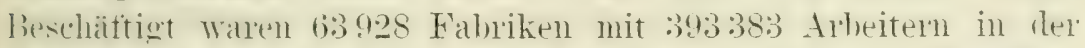
Anfeltigum ron Artikeh ganz ans Holz und 109512 Fabnikell mit 700915 Arbeitern mit Artikeln teilweise aus Holz.

Ine c'usus ron 1880 gibt die sägemühlemprohktion an mit 14041356000 Furs und 5 55.5046000 Schindeln. 1761788000 Latt'll. 1248206000 T)auben, in (iesamtwert rom 980154450 Mark. Das ist das Resultat von 25708 Sägemühlen.

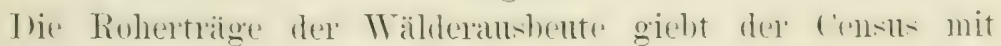
folgenden Zahlen an: gesägte Blöcke Brennholz für häuslichen Gebrauch

$587314800 \mathrm{Mk}$.

:. Eisenbahnen $1289290200 \quad$..

" Dampfboote .

21533100

." die Backstein

" die Wollfabrikation

7610800

16908800

986000

, die Salzfabrikation

511100

Holzverbrauch in der Edelmetallproduktion.

12073000,

zu andern Bergwerkszwecken

2729500 ,

zur Fabrikation vōn Stielen für Äxte,

Schaufeln u. s. w. 
Transport

Holzverbrauch zur Fabrikation von Wagenrädern . IJolzverbrauch zur Produktion von Holzpapier . IIolzverbrauch zur Fabrikation von Körben

"Booten u. Rudern

Molzverbrauch zur Fabrikation von Schuhnägeln . . Holzverbrauch zur Fabrikation von Schindeln handgemacht

Holzkohlenverbrauch 74008972 Bushels.
$1941925500 \mathrm{Mk}$. 6715700 8292100 ,"

1319300 972000 304000 ,

200000

$1981889900 \mathrm{Mk}$.

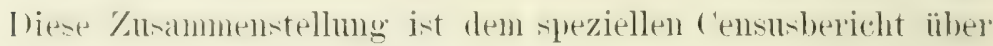
lie $\|$ älder entnonmmen, allein es ist klal, dass se movollständig ist,

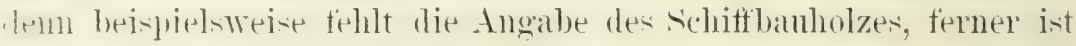

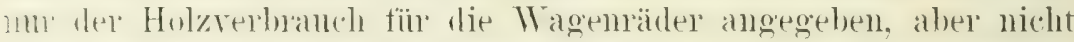
tiin die Arkelbangeräte in Ganzen. es wird nichts von 'Telegraphen-tangen. Bahmsalnwellen n. $\therefore$. W. gesant. Das Ackerbandepartement

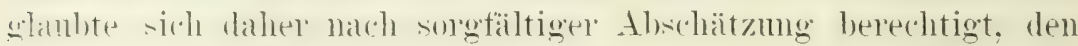

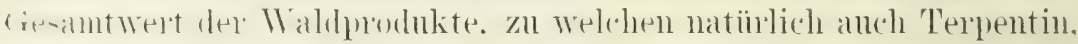
'Theег u. s. w. gehören, mit 2940000000 Mark annehmen zu

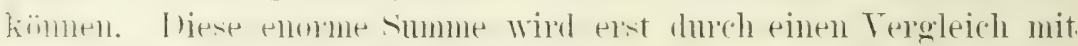

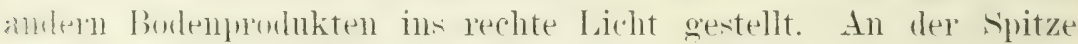

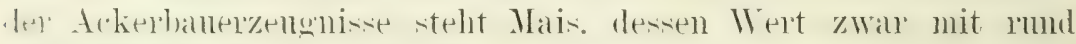

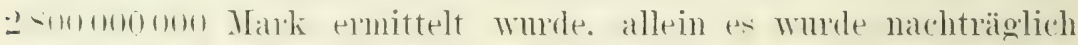

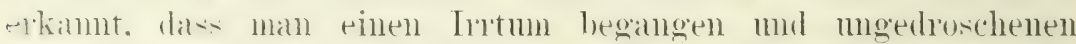

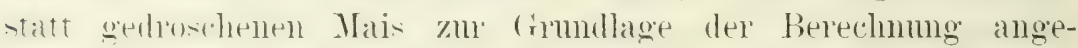
mommen hatte. Konärhst an Wichtigkeit kommt ileizen in

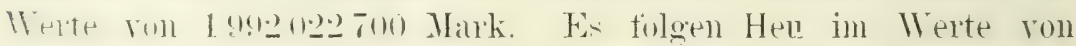

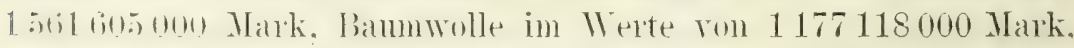

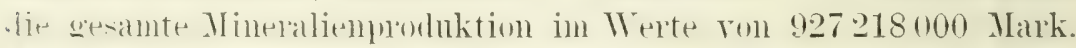

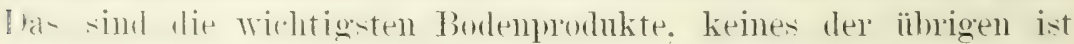
nit rinem hïher'n IIert wie Fon Millionen Mark rerzeichnet.

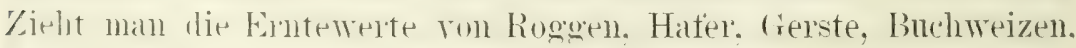
Kantufteln mud Tallak zu-immmen. damn erlält man noch nicht ganz Jie Hälfte der summe, Welche die Waldprodukte bringen. Wis

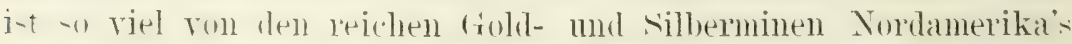

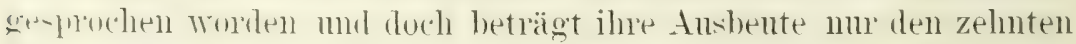
Treil derjenigen der II älder. Zelmmal wird anch die Wollernte vem der Holzernte ïbertroften. Toll elmessen lässt sich indessen 


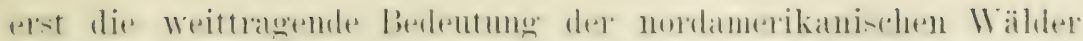

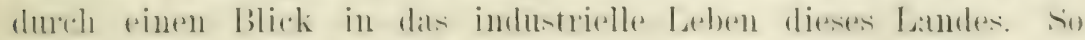

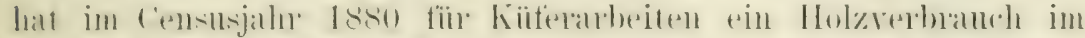

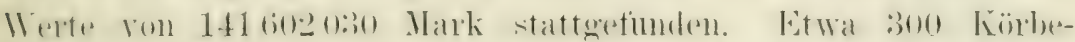

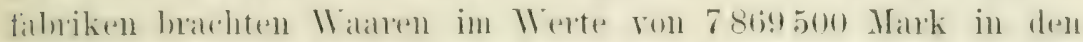

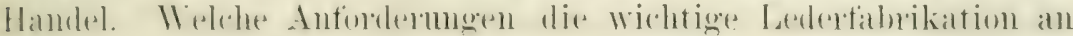

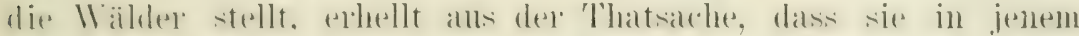

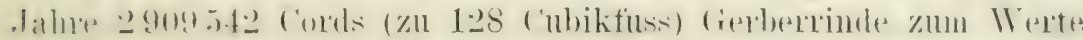

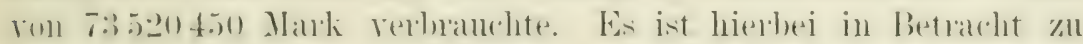

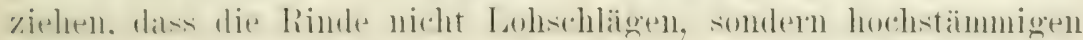

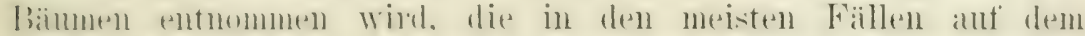

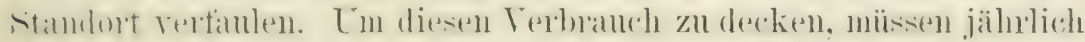

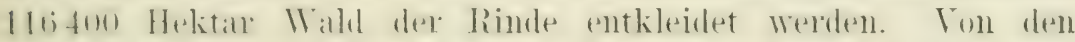
Ilemlorktament wird stets mur die Rimle reswertet, das Holz geht

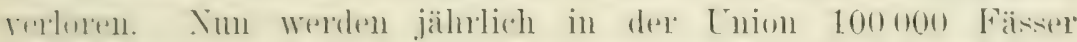
Hemlorkindenextrakt bereitet. davon entfallen 72000 anf eine

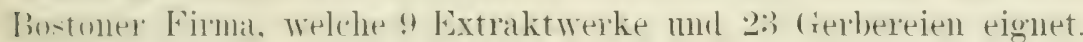

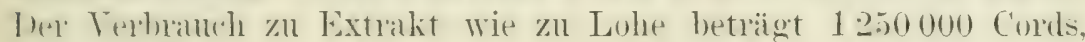
die in " Stalaten getwoment werden. Da anf einem Hektar etwa 17 comb Rinde getwomen werden. so gehen duch diese Industrie

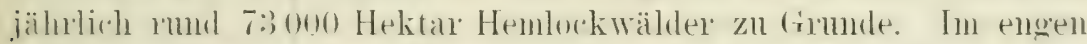

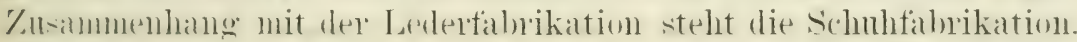
lip-alhe verlangt Leisten. mit deren Herstellumg sich 62 Anstalten berchäftigen: ihne fiesantproduktion ist mit 4000000 Wark be-

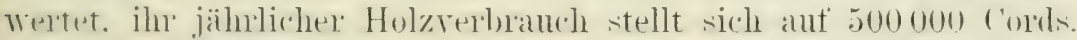

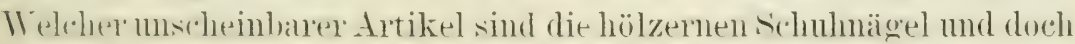
likelt er im letzten ('ensusjaln 26 Fabriken in Betrieb, die 100000 cords $^{\circ}$ Hol\%. grösstenteils Birken, verhatuchten. Tn der Fabrikation ron

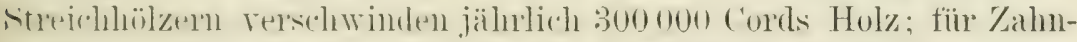

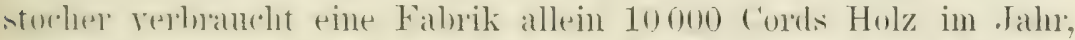

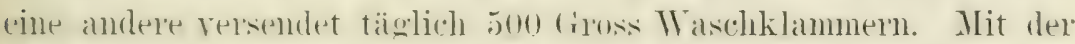
Antertigung gewöhnlicher Parkkisten beschäftigten sich 1880

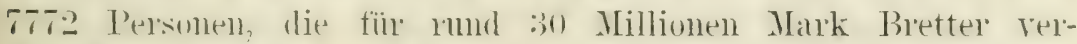
s.hnitten. Mit der Anfertigung ron Wagenteilen, wie speichen, Fegen. Naben 11 . $\therefore$ w. beschättigten sich 412 Fabriken, deren

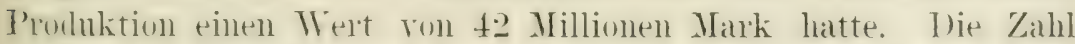

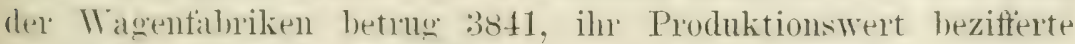
sich anf 27: 796500 Mark, wobei allerdings zu bericksichtigen ist, dass noch andere stofte wie Holz zur Terwendumg kament. immerhin 


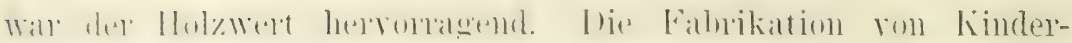

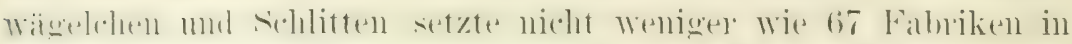

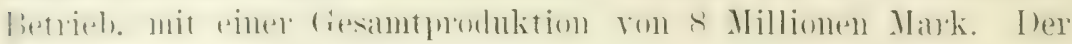

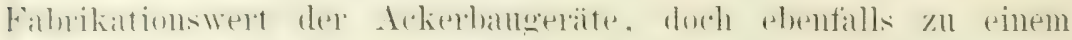

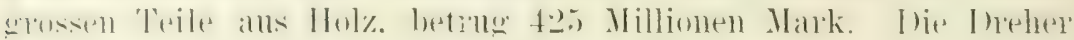

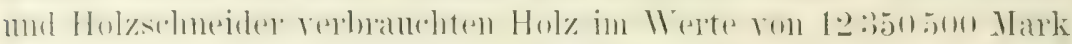

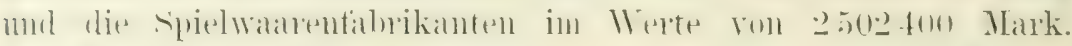

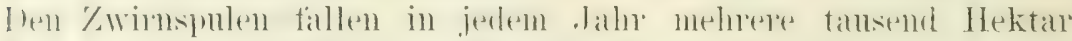

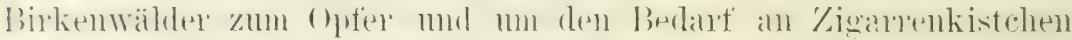

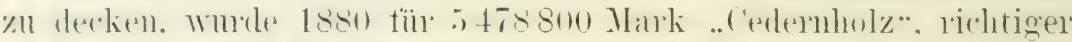

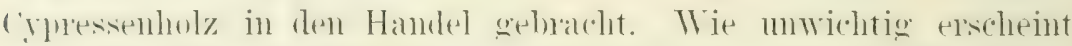
der Artikel sägemehl! Turl duch erient es allein in New-Tork

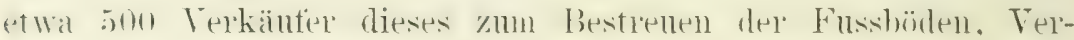

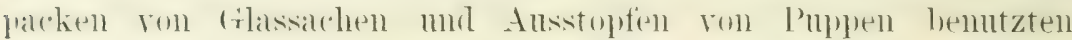
Stoftes. mit einem desamtereshätskaphital ron \& Millionen Mark Das ist nur ein Blick in das industrielle Leben, keine er-

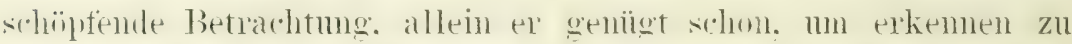
lasien. Welche hohe Wirhtigkeit den Wäldern tür ..die Entwickelumg ohne dielehen" del nordamerikanischen L'nion zngemessen werden

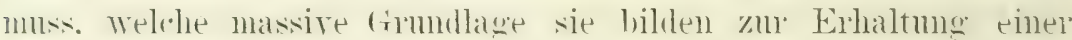
Fïwerlsthätigkeit. welche die Komkmpenz der Nordanerikaner in Ansande getïrehtet matht. Aber anch die Frage dräligt sich ant, was soll ans vielen der widhtigsten Tndustriezweige del Lnion

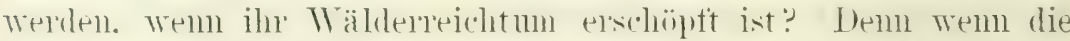
Vordanerikaner Holz importieren miissen. hören sie anf in HolzWablen concurrenzfähig zu sein. zumal sie in Verlegenheit kommen minssen. wo sie Ersat\% finden sollen. für ihre geschätztesten Hölzer. wie Hidkmy. schwarze Wallnuss. Gellhkiefer und crumesse. deren

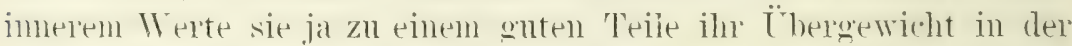
Fabrikation von Holzwaaren verdanken.

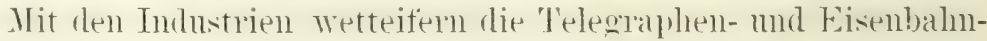

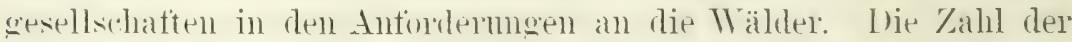
'Telegraphenstangen beträgt zur zeit etwa 1 Million und zum Fisatze missen jährlich 300000 Bämme geschlagen werden, Kastanien und (ripressen (gewöhnlich Cedem genamnt) merden berolzugt nud mit dem hä̈hsten Preis ron \& Mark das stïck hezahlt. Iboch dieser Bedart ist verschwindend gering. gegeniber demjenigen der Eisenbahmen. Cun diesen tiegenstand anfzuhellen, versendete das Ackerbandegaltement Fragebogen an die etwa 
300 Bahngesellschaften des landes, von welchen $63 \%$ beantwall zom das Gesamt berechnet mit folgendem liesultat.

Die Länge der schienengeleise beträgt 112000 Meilen \& 1 .

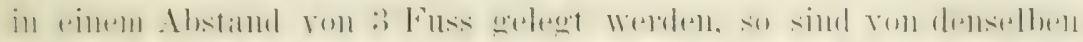

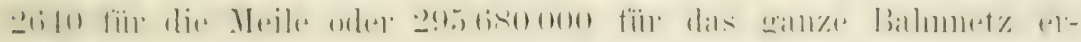

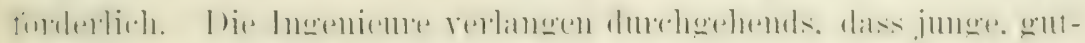

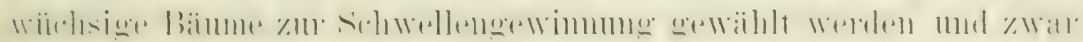

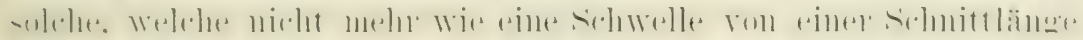

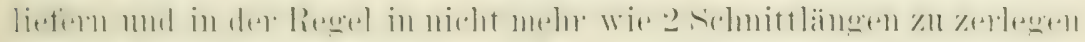

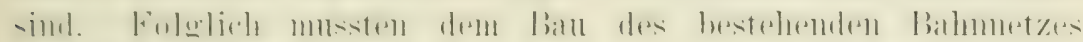

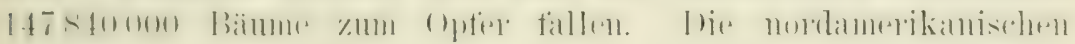
Erwälder liefern im Imrehschnitt nicht mehr wie 250 schwellen

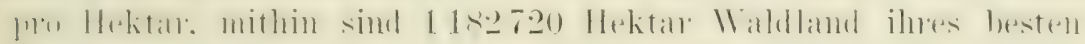
Holybestandes fïr diesen '/areck beraubt worden. Die Durch-

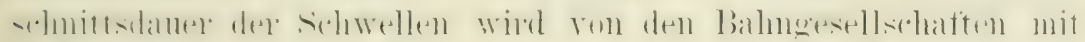

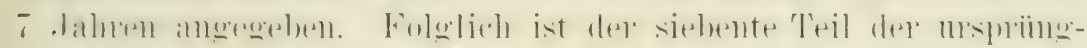

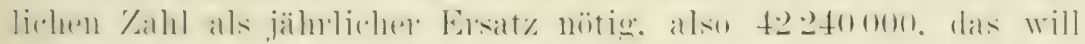

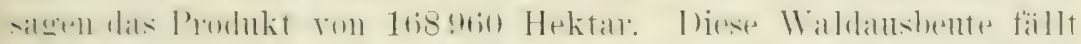

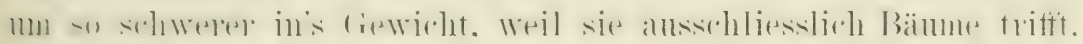

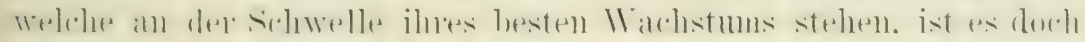

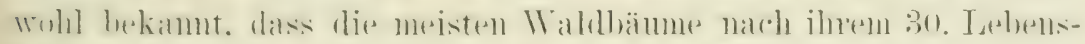

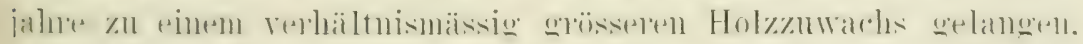

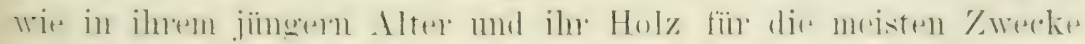

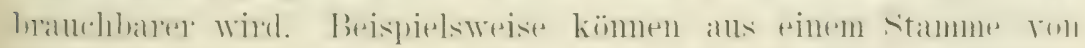

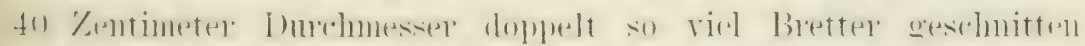

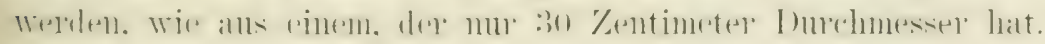

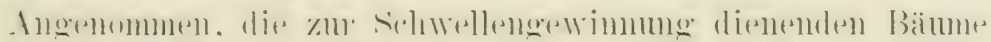

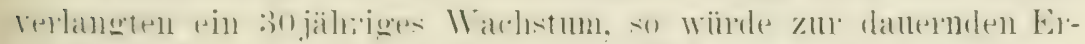

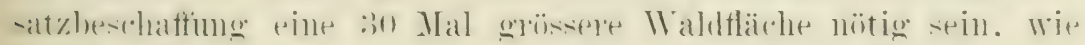

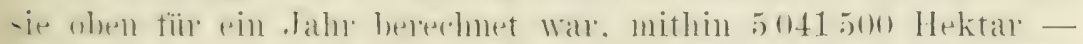

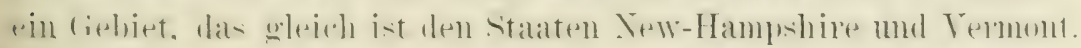

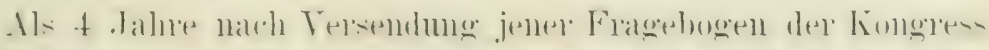

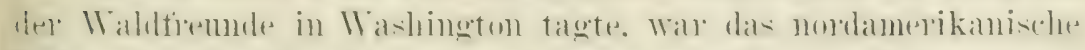

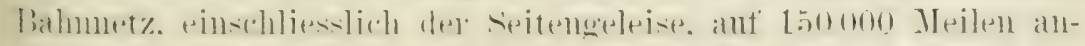

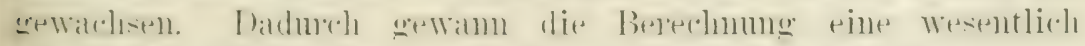

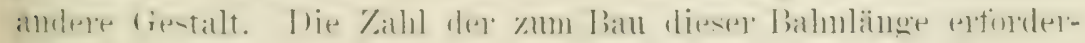




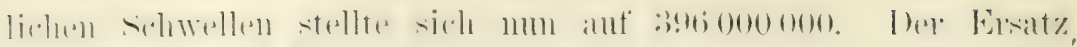

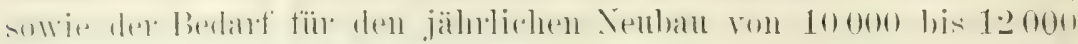

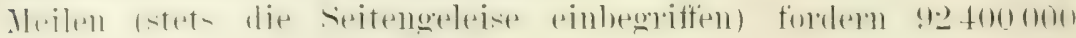

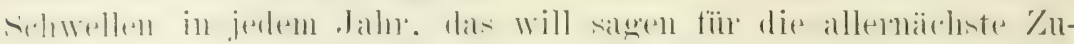
kunft. wie klar zu 'Tage liegt. Nimmt man selbst eine ståkere

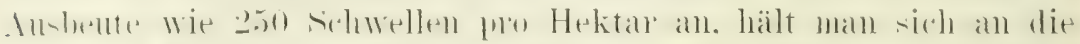

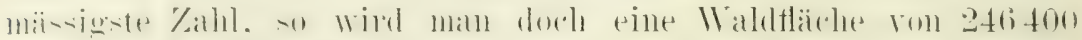

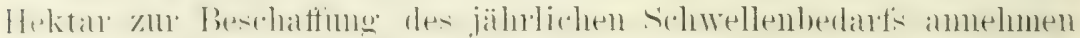

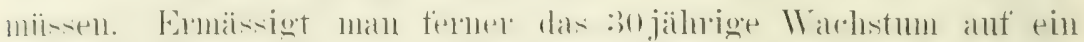

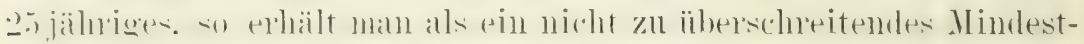

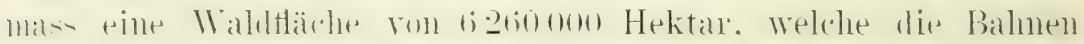

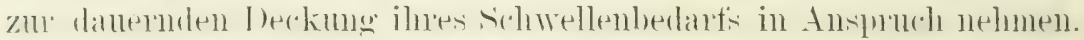

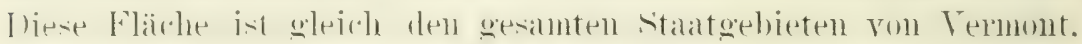

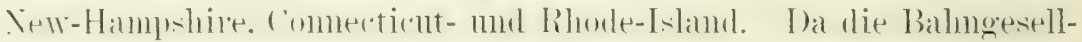

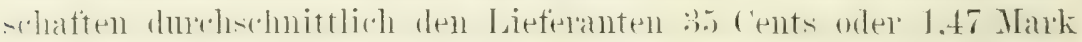

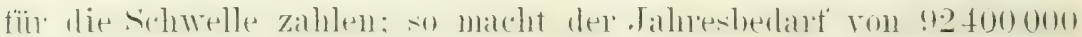

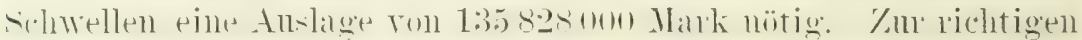

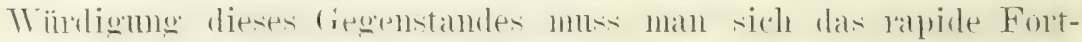

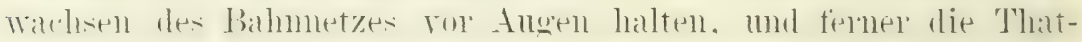

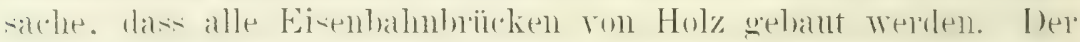

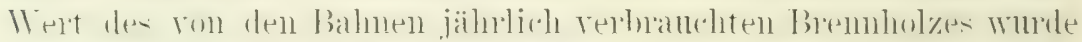

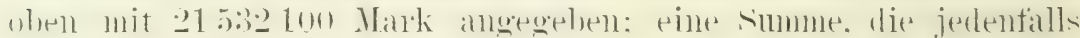
weit ïbertroften wird ron dem Werte des Holzes. das zum Bau

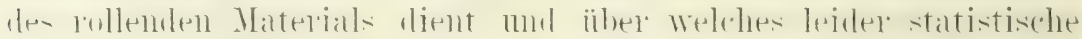

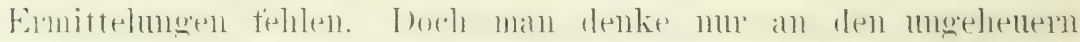

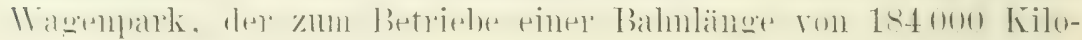
meter elforderlich ist!

Der ron der II elt angestame Bahmbau ist olne Frage eine

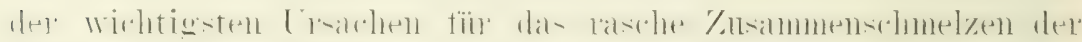

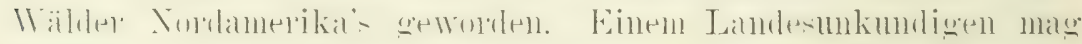

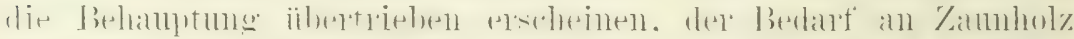

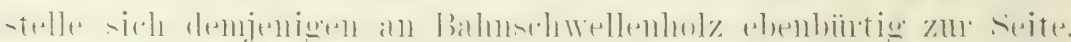
Ich bitte aber zu erwägen, dass in allen 'T'eilen der Union die ver-

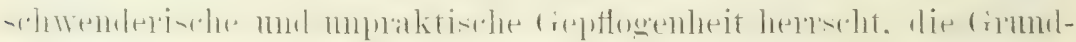

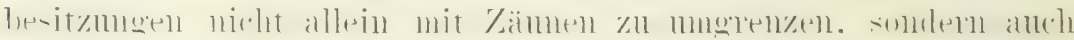
mehrfach abzuteilen. Und in den meisten Fällen sind die Zäune

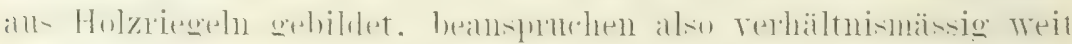

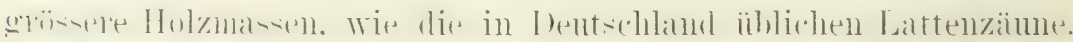

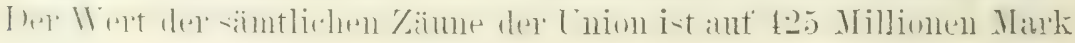




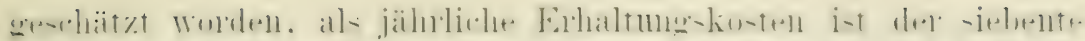

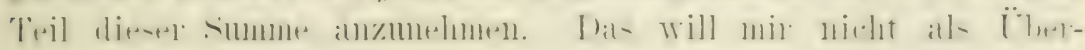
treibung erscheinen.

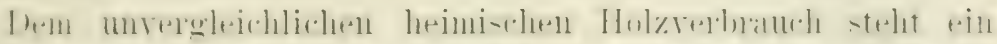

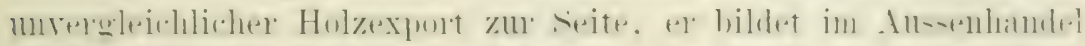

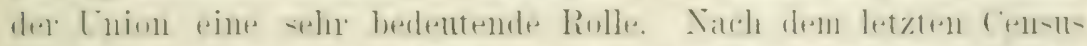

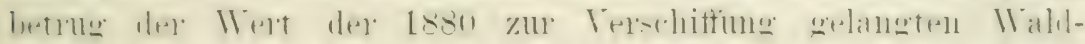

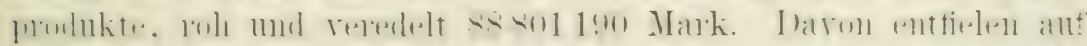

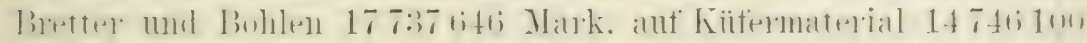

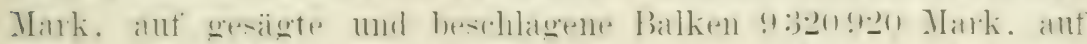

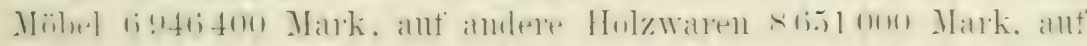

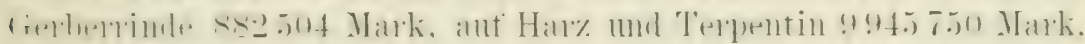

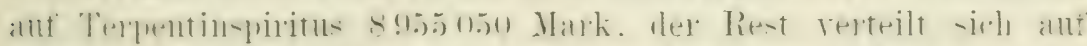

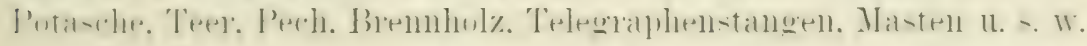

Die Waldausbente, wie sie bis hierher in rohen Zügen als

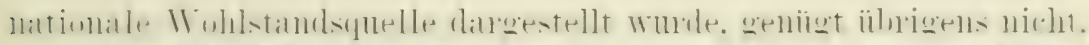

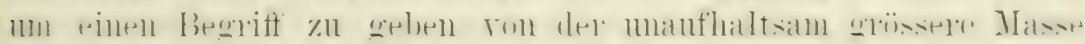

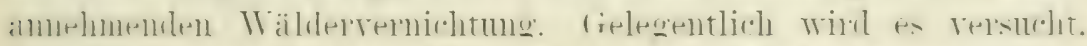

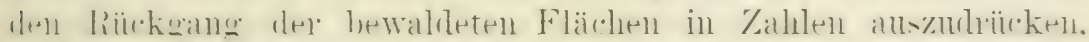

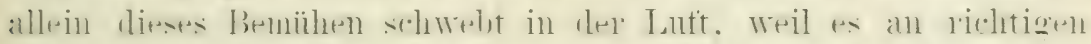

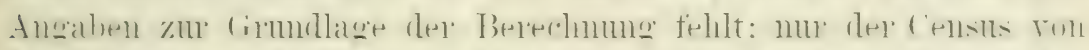

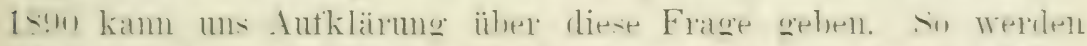

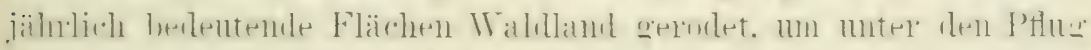

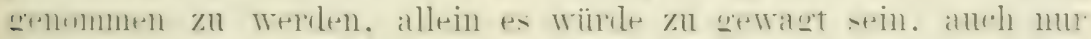

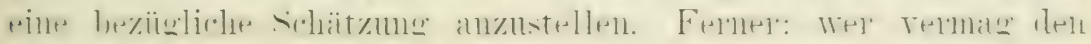

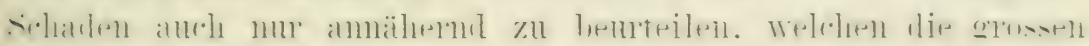

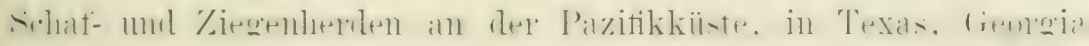
mad Ohio anstiften? Dagegen sind wir in der Lage die Ter-

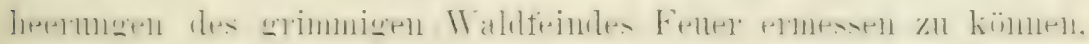

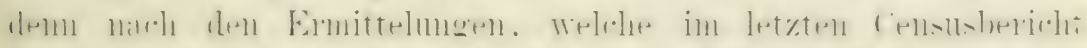

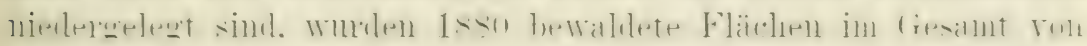

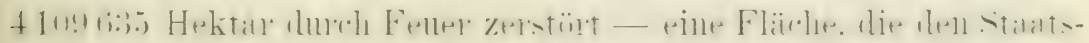

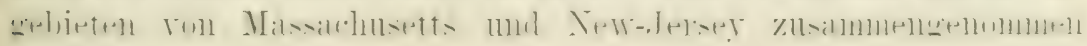
gleichkommint.

Major Powell, dessen Jame in wissenschaftlichen Féreisen

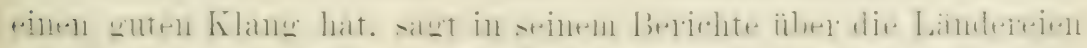

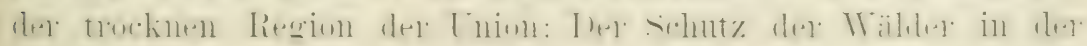

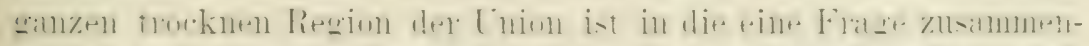

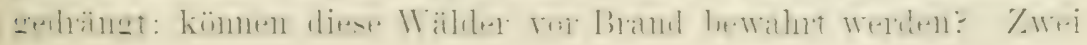




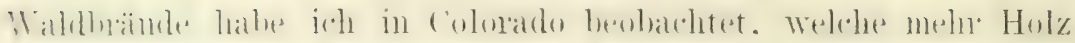

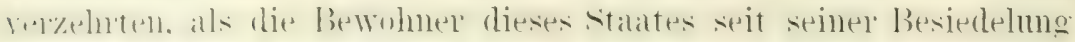

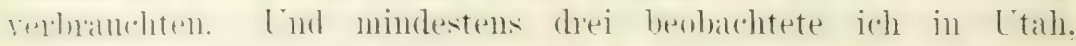

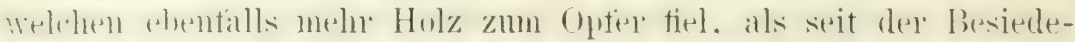

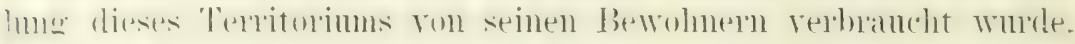

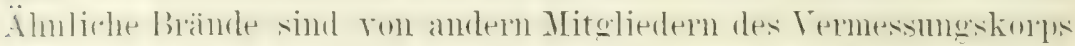

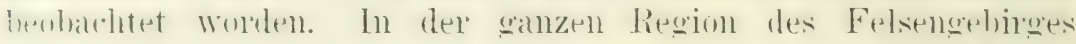

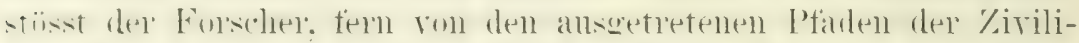

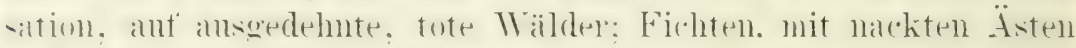

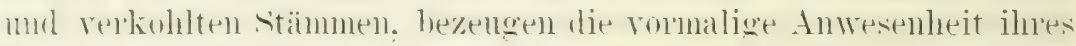

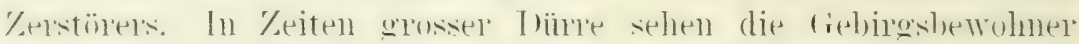
den Himmel mit Ranchwolken iberzogen. Soweit Powell.

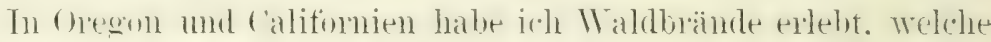

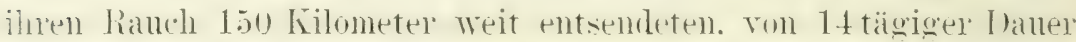

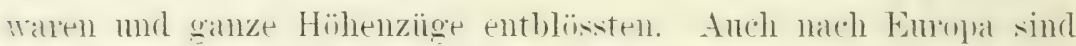
vie Berichte ïber die schrecklichen Waldbrände in Michigan mork Wisconsin gedlungen. die sich über viele fieviertmeilen rerbreiteten. städte. Farmen und Menschenleben vernichteten. und die some wochenlang verdunkelten.

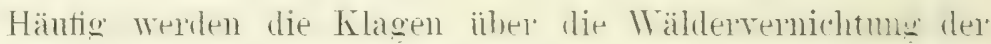
Thertreibung geziehen, mit der Betommg. der Ansbente stände ein falnrlicher Holzzuwarhs. der gänzlichen Vernichtmug. eine Anpflanzmng grtenenilber. Der jührliche Zuwachs ist sicherlich nicht zu lengnen,

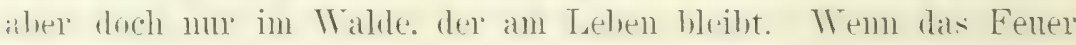

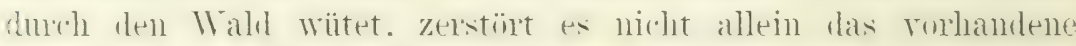
Holz, sondern auch auf viele Jahre - vielleicht auf 50 - die

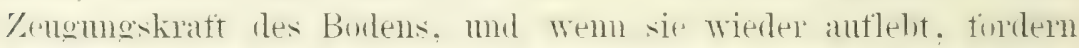

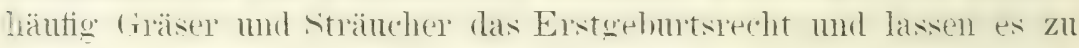
rinem Bammwols nicht kommen. In einem Iralle. Wo sehate

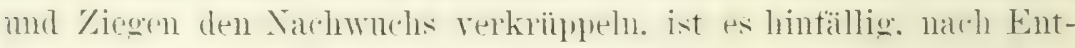

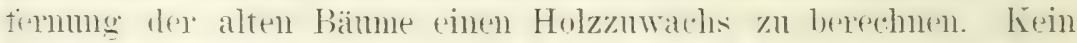

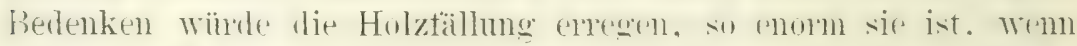
sie sich anf die reifen Bämme beschünkte. demn dex Wall ist da. banit el Vutan gewahre. I ie in Zahlen angegebene Holzgewimmng gilot keinen Massstal, tïm die Mädderternichtung. dem has Holzfallen ist begleitet rom einer so grossatigen Zerstönug

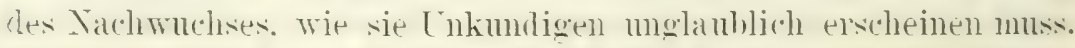
(ileich tuden habe ich das anfs schärtste rerurteilt. bis ich. im Erwatle lebend, dats Treiben der Holzfäller vol Angen hatte. Xum 


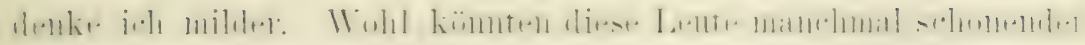
relfahren. es ist wahr. allein ändern kïnnen sie ilı Tevfahren nicht. Jan relogenwiutige sich nur immer den Lnterschierl zwischen Kulturwald und Lrwald. In dem letztern findet der Holzfiller auf einer Fläche. vielleicht ron riner Ar. nur einen Bamm. der ihm wert diukt. dass el die Axt an ihn legt. Die Lm-

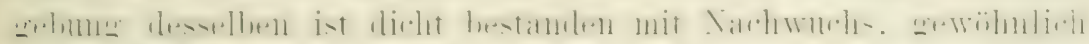

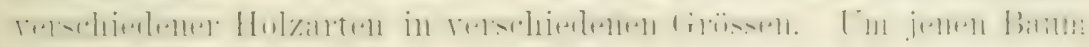
tiillen zu kïmnen. muss el sich durch Abhatlen ron Lunterholz gu-

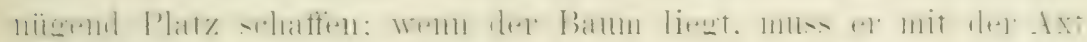

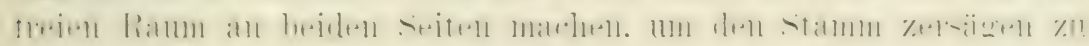
kïmen. Dam treften + bis 8 . Toch Ochsen ein. welche die an-

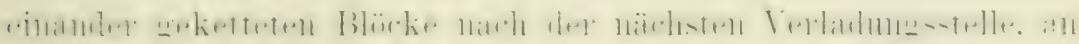
einer Bahm oder einem Wasserlanfe. schleifen sollen. Da qilt es

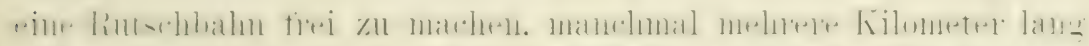

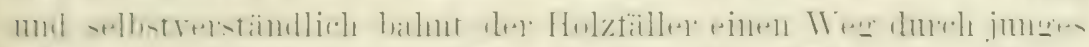

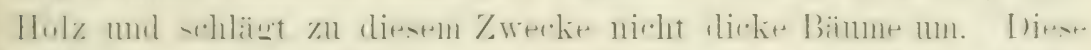

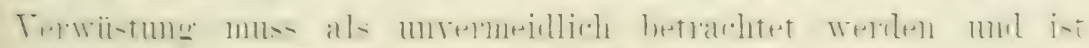
mulislich rerknïptt mit dem Mesen des Lrwaldes.

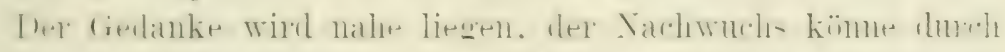
das thlhanen nicht fïr immer remichtet sein. Das mind ev zwar

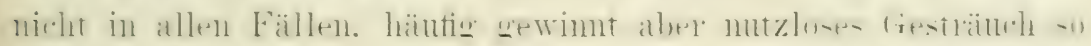

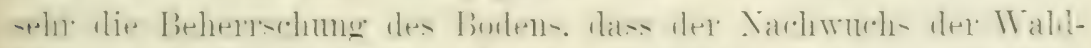

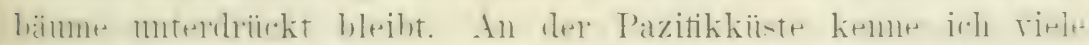

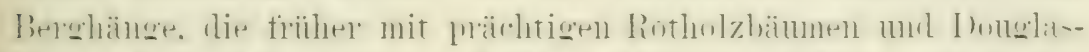

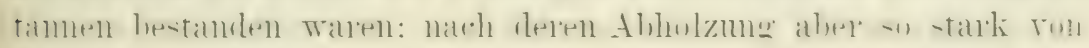

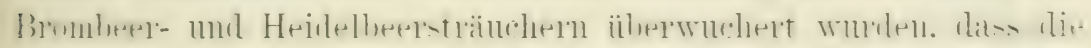

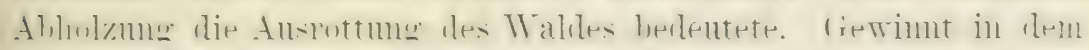

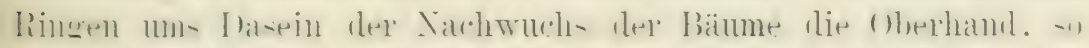

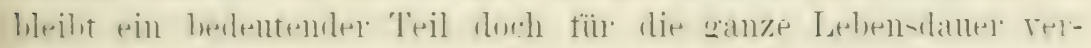

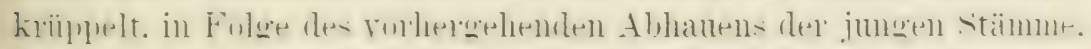

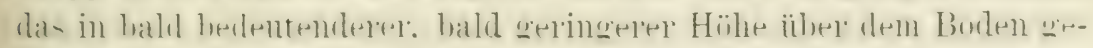

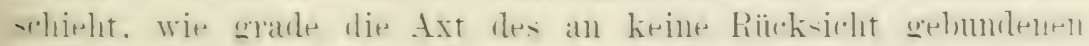

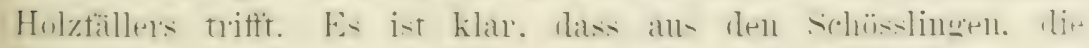

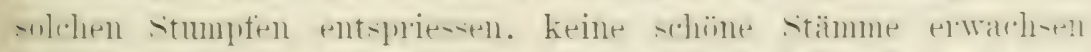

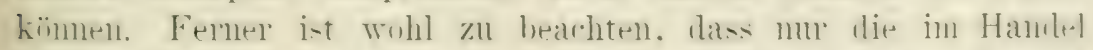

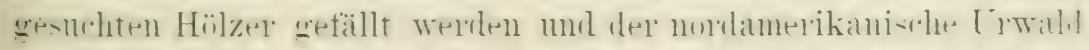

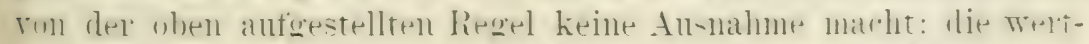

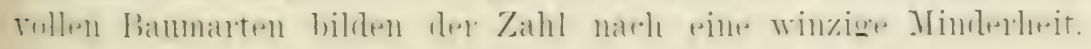




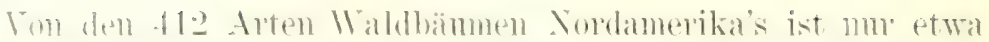

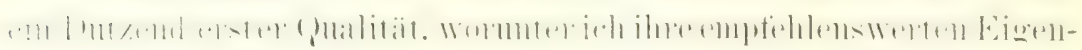
sohatton zur Forstkultur rerstanden wissen mörhte. Fin weiteres

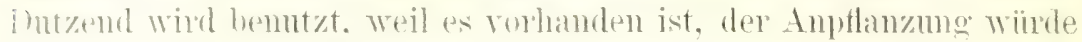

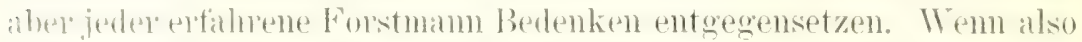
nicht eimes der wenigen falle vorliegt. Wo der Wald ans eined Holzat bestent. Wie beispielsweise die Rotholzwäder kalifonniens mond die Donolastannentribler IV ashingtons, damn nehmen die nutz-

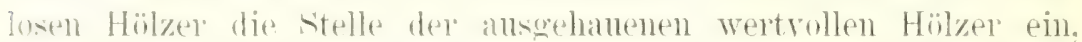
Was so natiolich ist. dass es anch dem Nichtkennel pinlenchten mnss. Dex Mald mag in seinem seitherigen Umfang bestehen bleiben, allein el verame bis zur Nutzlosigkeit.

IVas num die Anfforstmoen betrifft. von welchen so viel Lärm amamale wiol. so schaffen sie durchans keinen Ersatz tïr den Abgang alls den Wälden. so weit die Handelshölzer in Frage kommen. Anschliesslich Privatgrundbesitzer haben sich mit diesem fegenstamd beschäftiot mol ihmen ist es mm lasche fiewimmmg rom biennlonz zu thm. wie in den Probiestaten, oder nm eine baldige Rente. ant die. entsprechend dem Tolkschanakter. in Tordamerika ein noch smosseres fewicht gelegt wind, wie in anden Ländern. Ans diesem

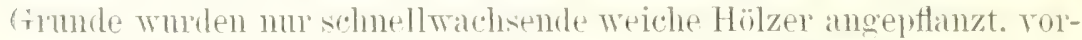
zugntreise die schwaze Pappel (Populus monilifera, das .Cottonmood" der Vordanerikaner), der silberhlatterige Ahorn (Acer dascrcarpum), der rote Ahorm (Acer r'ulbrum), der eschenblätterige thorn (Negundo arceroides). die Linde (Tilia americana), die Hemlockstanne ('Tsuga "anadensis). im siiden der monermeidliche fimmibann. in den Präriestaden ein von den russischen Mennoniten mitgebrachter Manlbeerhamm. allsiprlen verschiedene 11 eidenaten.

sieht das notdamerikanische Volk dem Terschwinden seiner

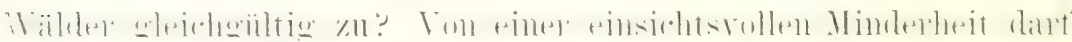
das wahlich nicht behamptet werden. dem dieselbe, mit dem Terein Rer IValdfremde an der spitze. ist mablassig bemiiht, die Regie-

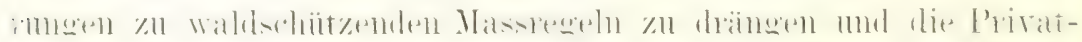

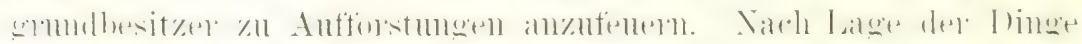
kamn nur die Bumlesregiermo wirksan helfen und sie glaubte geholfen zu haben mit dem viel erwälnten ,Limberlaw". welches

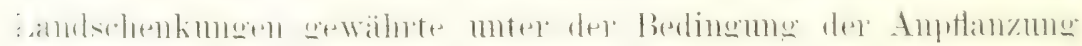
mit II aldhammen, allein der krasse Missbranch dieses Gesetzes hat zu s.rinem 11 iderout gefiihnt. Seitdem beschränkt sich die Bundes- 


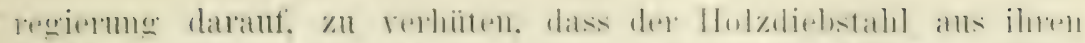

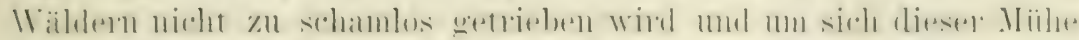

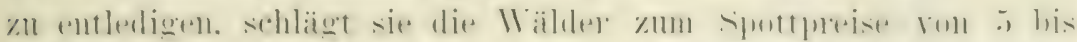

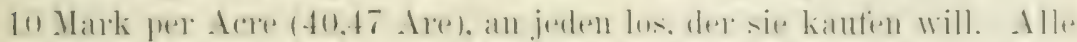

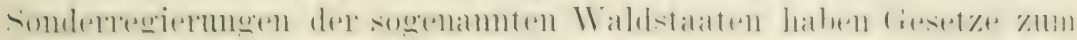
selunt\%

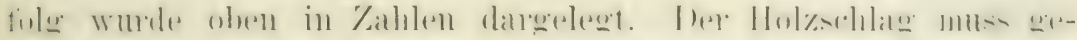

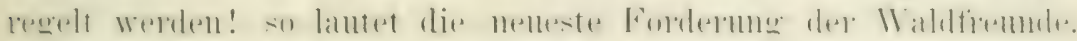

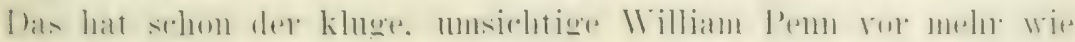

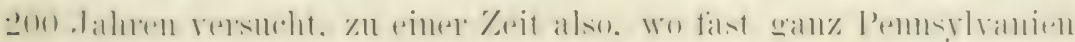

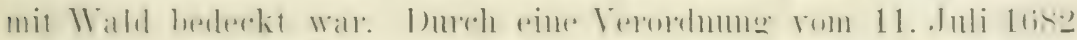
bestimmte er, dass vou je 6 Acre Wald mu 5 gerodet wremen

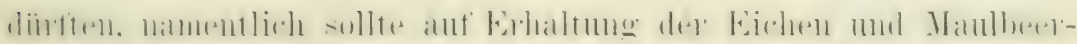

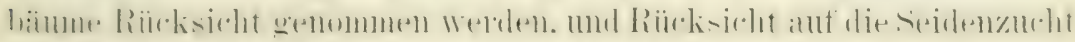

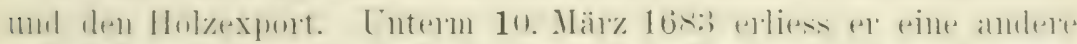

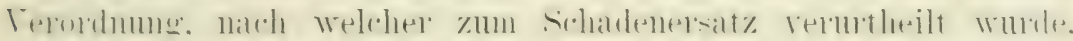

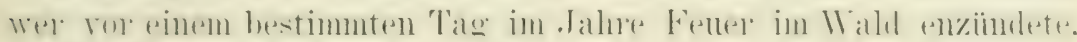

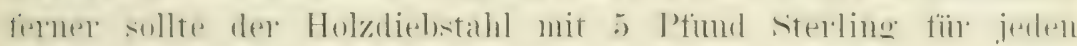

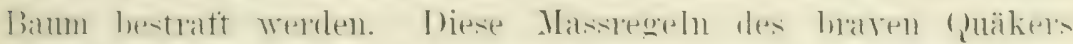

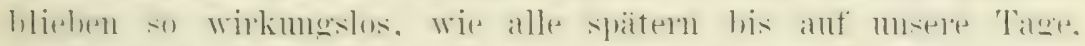

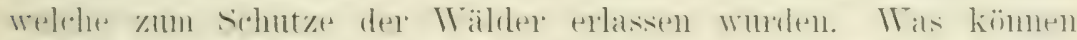

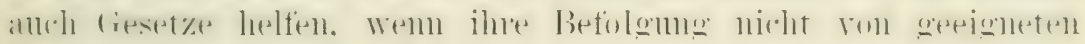

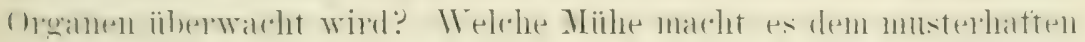

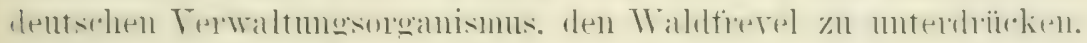
mol mun denke man sich Wälder ron einel Grösse. wie sie in

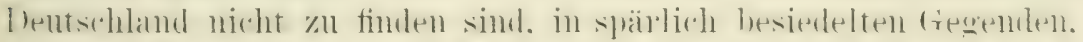

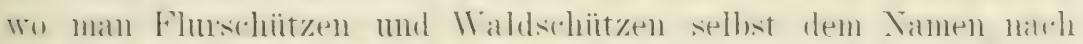

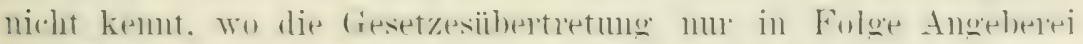

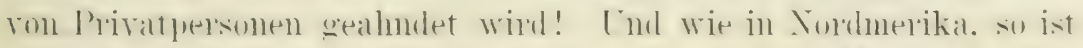

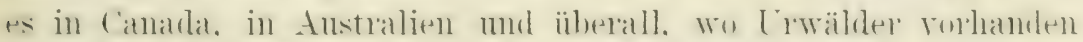

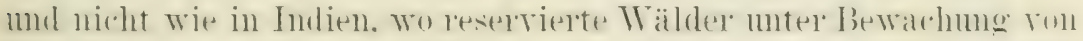
Furstenten gestellt sind. Alles. Was die Sordamelikanter his jetzt tïr

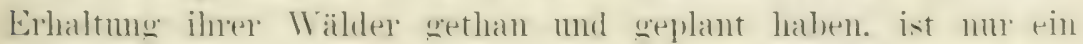

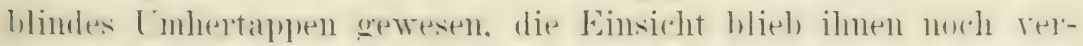

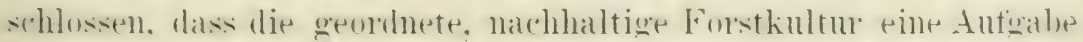

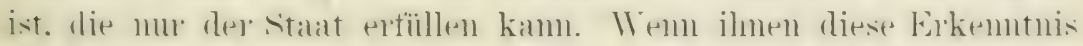

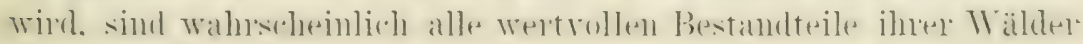
verschwunden. 
l)ann wird sich anch die Rene einstellen iblor die Selbst-

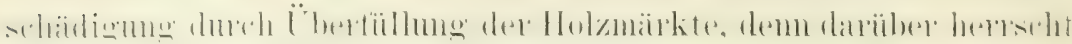
nu eine Stimme, dass die vielen tamsend Säigemïhlen weit iiber

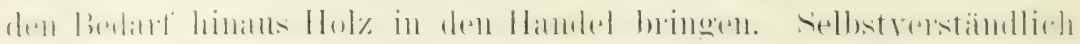
werden daduch die Preise gedrickt und Vorräte anoehäutt, die

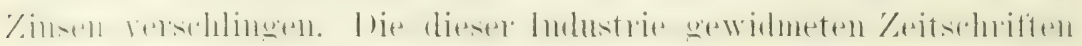

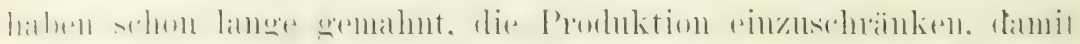

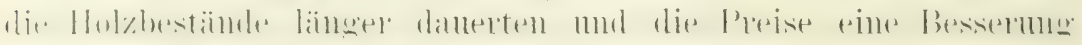

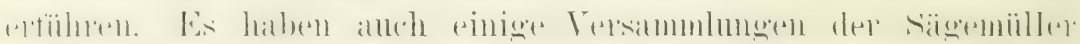

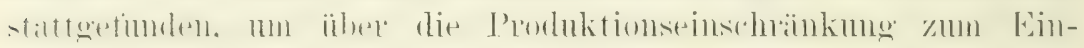
rentïndnis zu gelangen, allein es kam niemals zu einem andern Resultat als dem, an jeden Einzelnen gerichteten Rat, in seinem

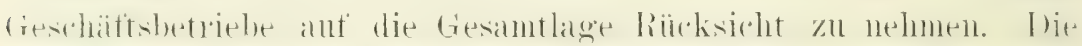

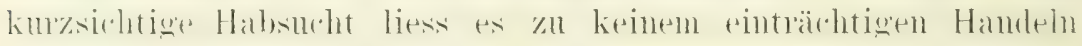
kommen. es wird in der alten Weise fortgewintschattet, bis die

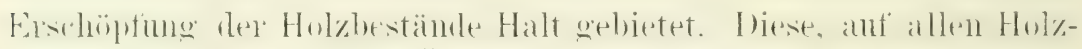

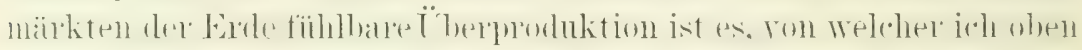

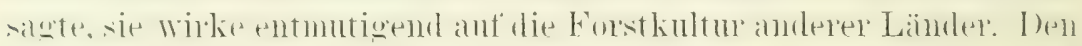

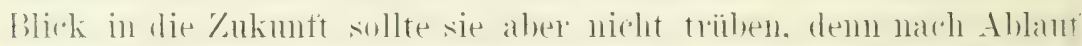

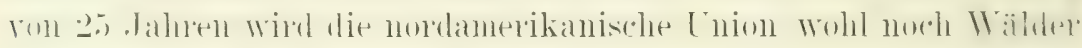

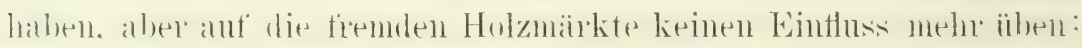

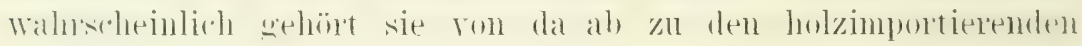
Länder'n, wormuter natiulich der Import von tropischen, der zur

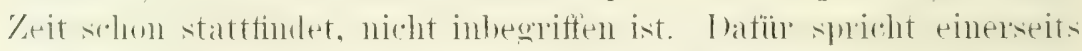

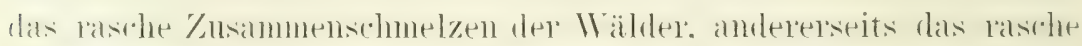

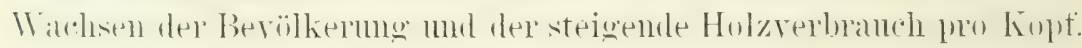

In vier Regionen liegt das Schwergewicht der nordamerika-

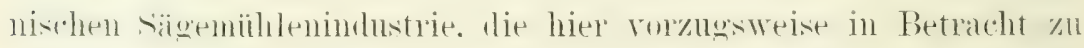

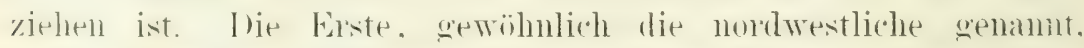

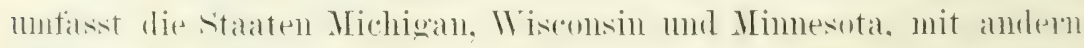
Morten das (puellengebiet mul den obern Lant des Mrssissipui. Hiel ist der tomangebende Bamm die Meisskiefer (Pinms strobus).

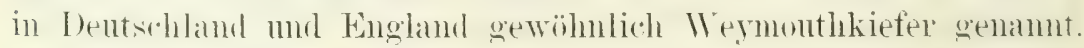

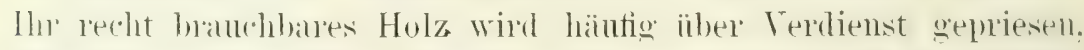
dem es ist weich, nicht besonders stark, mur datlerhaft in trockute Luft mol solowill und schrumptt stark bei einem bedentenden Fenohtigkeitswerlssel der Luft. Die Alowesenheit ron Astkmoten. die

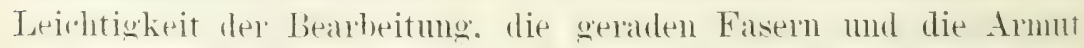

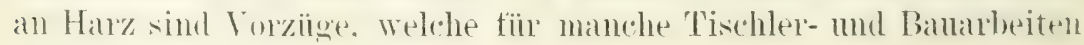


sehr geschäz sind. Es wimb irrig sein, zn folgerm, ein Holz,

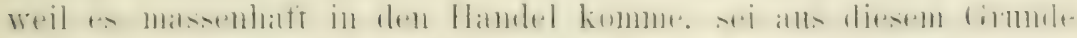

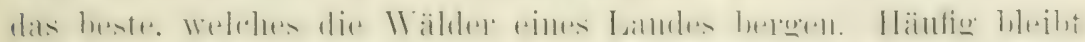

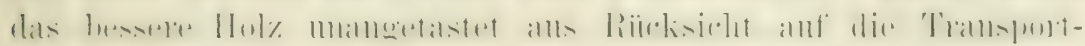

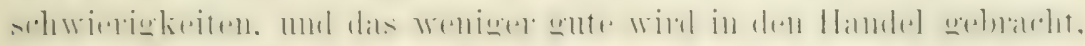
weil es in der Nähe einer Wasserstasse gewonnen werden kamn.

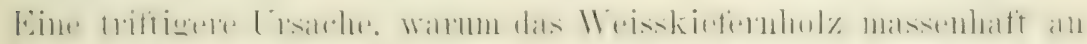

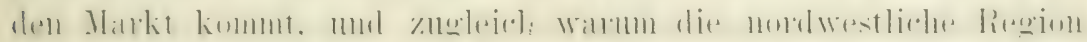

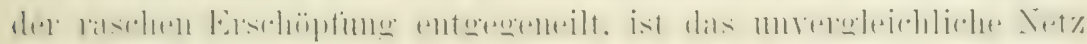

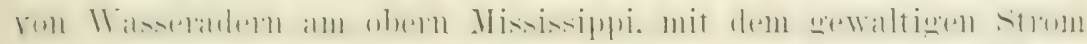

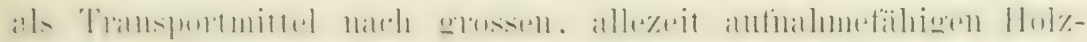

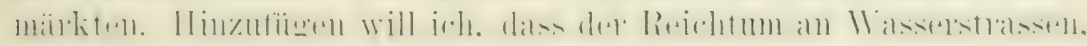

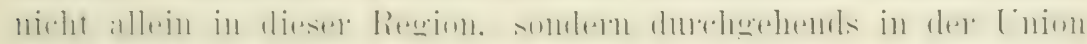

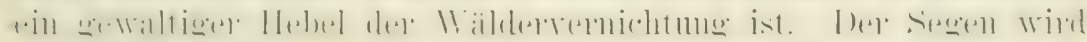

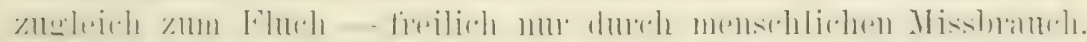

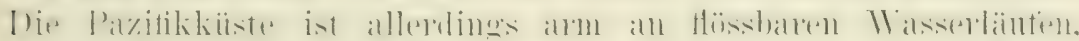

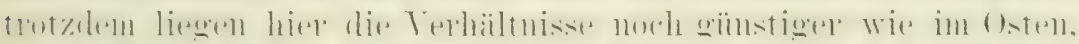
rla die wertvollsten Wïlder sich rer Küiste entlang ziehen. Am

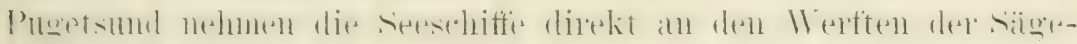

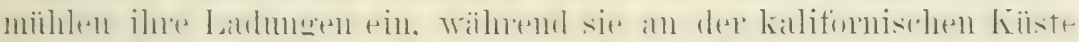

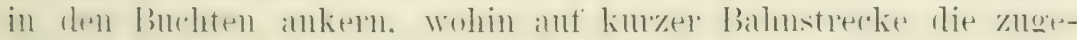

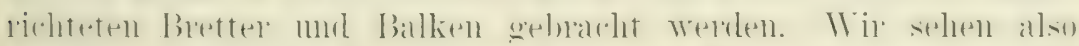

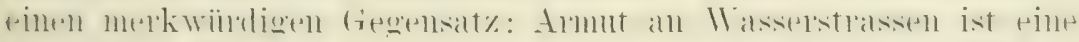

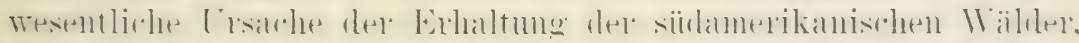

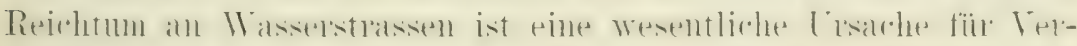
nichtung der nordamerikanischen Wälder.

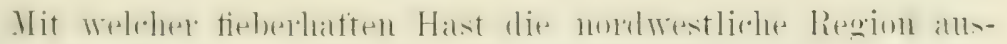
gebeutet wird, zeigt die folgende Gegeniiberstelltung:

$187: 3$

3993780000

2277433550
1883

7624789786

3964756639

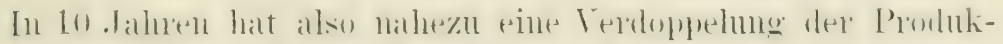

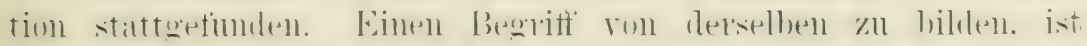

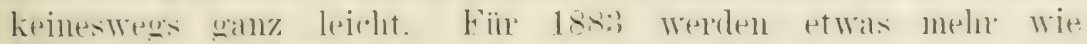

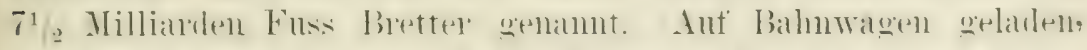

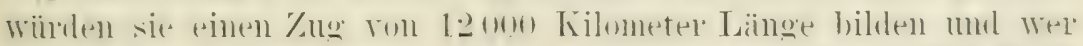
sie kantin wollte. milsste verfiigen. 


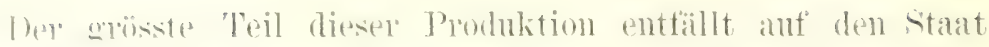
Jivhican. mit pinem Werte rom etwa 255000000 Mark; der Wert

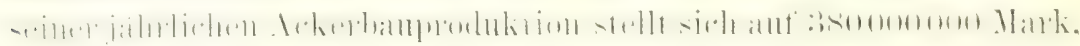

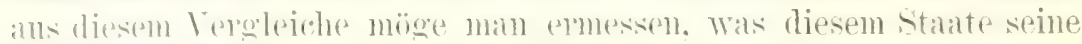
II

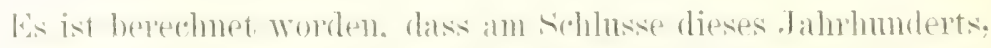

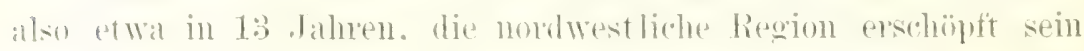

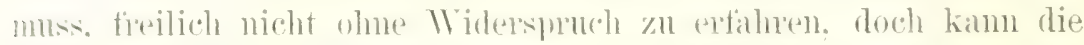

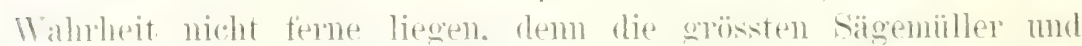
Holzspekulanten fangen hereits an. jene liegion zu verlassen, wie die Ratten das sinkende sidnift. mu sich der zweiten, der siddlichen Region zuzuwenden. Fine solche 1 andermo ist leichter ansfiblnbar, wie man in der Ferne denken mag. da die nordamerikanischen sägeninhlen. ansschliesslich ans Holy erbant. ein hablomadisches Gepräge tragen. Man sieht es ihnen anf den ersten Blick an. sie sind tiir Ortsveröndermoen. mit andern Worten fïr die Wälderherambuns. berechnet.

Die sildliche Region liegt mit ihrem schwergewicht in Nordfollolina und monfasst Teile dep stanten siidcatrolina, Georoia. Alabama. Mississippi nud Lomisiana. Hiel ist del geschätzteste

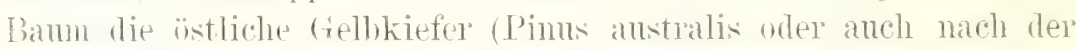
nenesten Klassifikation P. palustris). sie wiod sogal ron den meisten Kennern als das wertwollste Tadelholy Nordamerika's betrachtet. Fragt man mach der Ursache. warum die siddiche Region. trotz ilnes bessern Holzes, riel massoller ansebentetwmile. wie die nordmestliche. so wurde die Erklärmo hereits gegeben: die Transportverhältnisse liegen muginstiger. Jarin ist allerdings seit Ausban

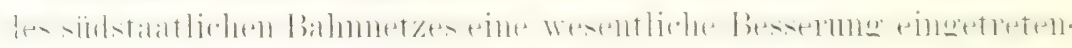
allein mescetzbal sind und bleiben die ansegeichneten Wasserstrassen des obern Mississippigebiets.

Die östliche frelbkicter hat num wenig sulint, das Kernholz ist rom seln gleicher Qualitit mul rom den harzigen stotten regelmässig durchsetzt. Kein anderes Nadelholz kommt diesem an Stäke. I anemaftigkeit und Härte gleich. Fs wird. wo Leichtigkeit mo Festigkeit vereint elwimscht sind. dem Holz der ITeisspiche roroezogen, desen Elastizität es zwal nicht besitzt. mit dem es aber eine gleiche Belastmo trägt. Torzugsweise findet das Crelbkiefermhol\% Terwendmo im schitt-. Hans- mol Brïckenbau. Del banm wird bis an t5 Meter hoch. bei einem Inuchmesser vom 


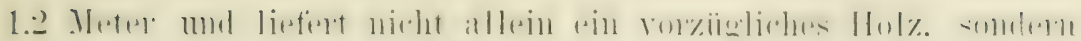

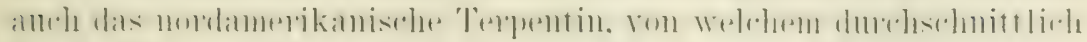
fiir 8 Millionen Mark jälnlich exportiert wirkl.

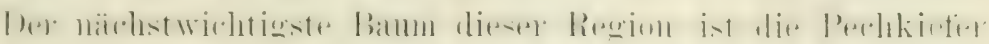

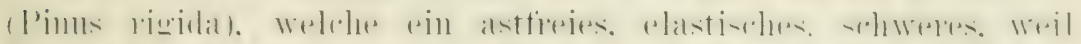
hal\%)

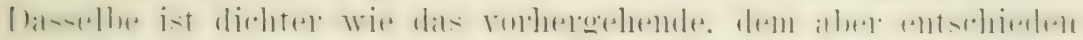
rev Vorzug gegeben wird, wenn ein farbiger Anstrich beahsichtigt ist.

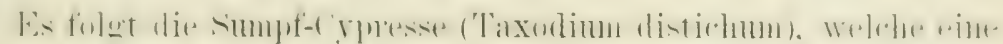

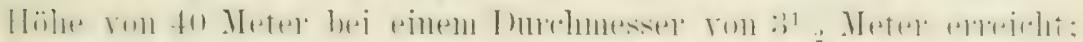

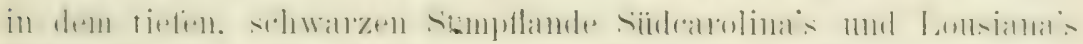

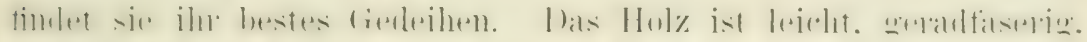

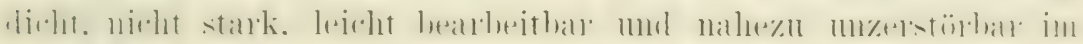

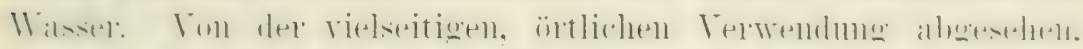

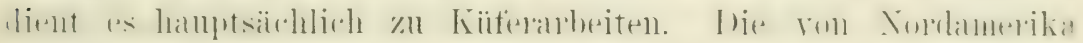

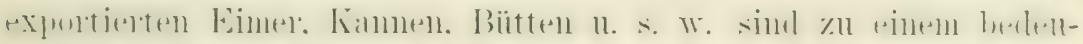
tenden 'leile aus diesem Holze oefertigt.

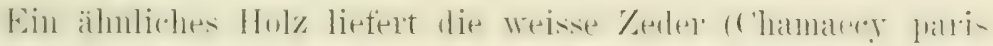

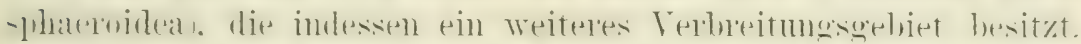

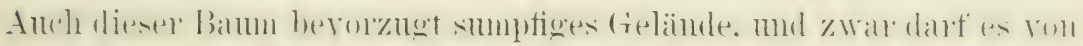

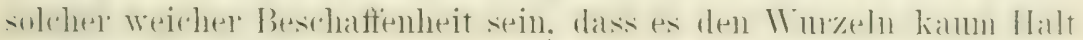

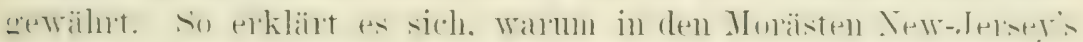

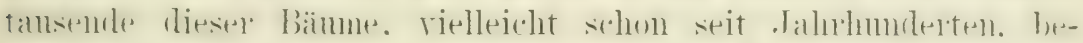

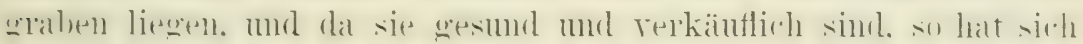

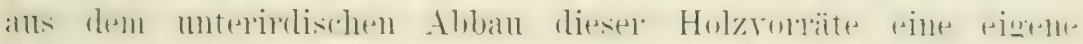

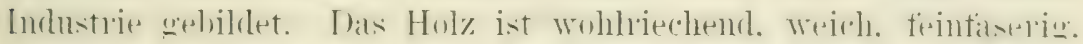

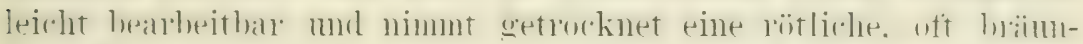

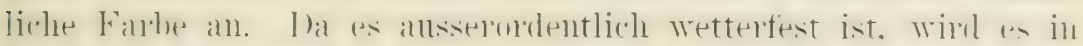

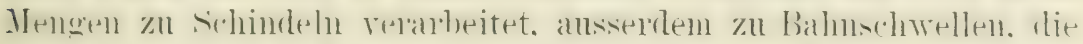

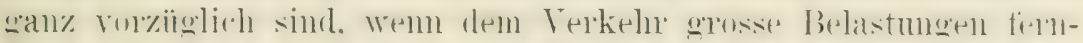

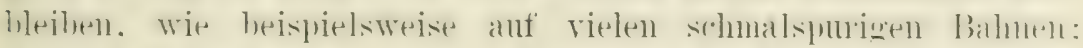

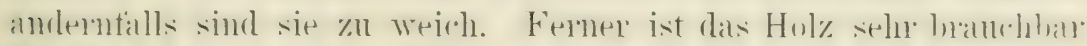

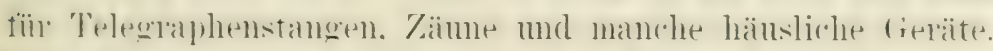

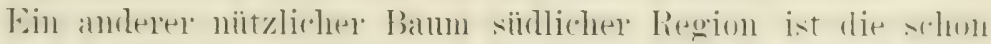

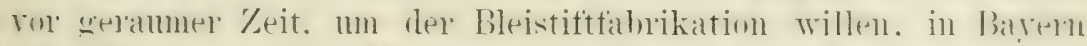

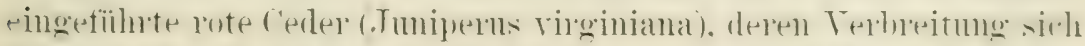

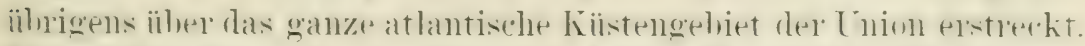

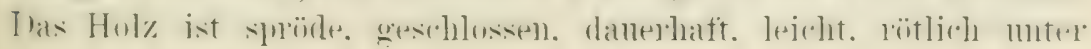


Tem weissen Splint. Es hat einen starken. charakteristischen

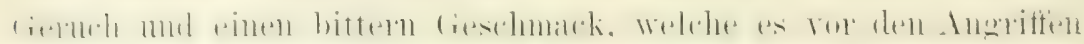

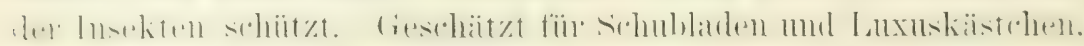

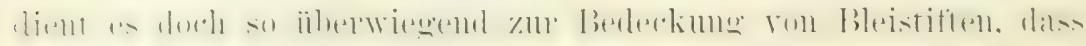
der Baum häufig Bleistiftzeder genamnt wird.

Die dritte Region mufasst das mittlere und nördliche Cali-

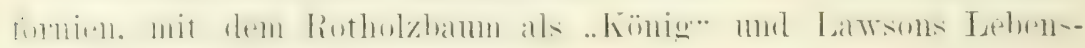

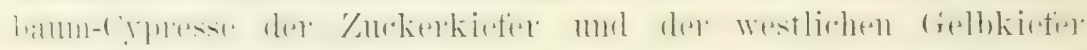
als Gefolgschaft. Das Rotholz wird, auf Grund seiner gegen-

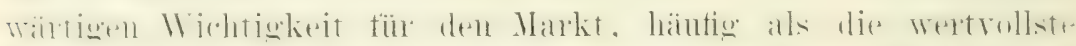

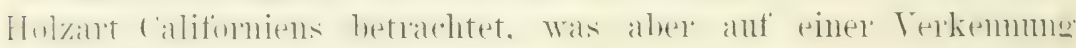
beruht. Das Holz der Edeltanne (Abies nobilis) zeigt für die

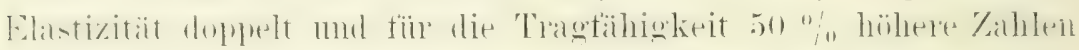
wie das Rothol\%. ansserdem ist es viel danerhafter. Kommt es

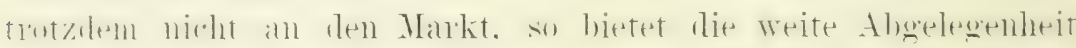

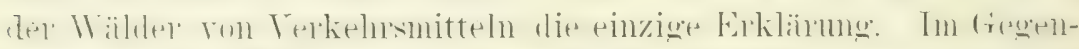

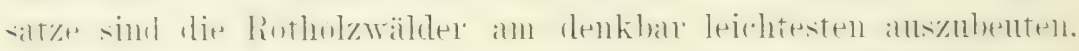

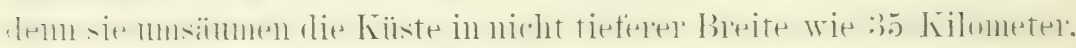

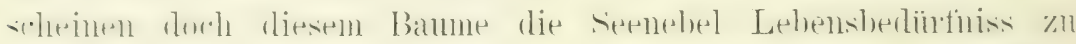

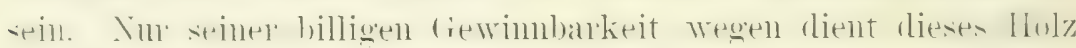

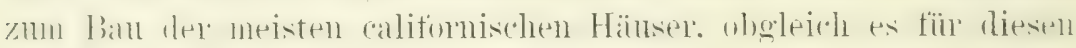

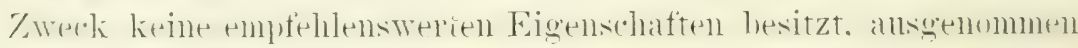
seine leichte Bearbeitbarkeit. Es ist leicht. weich. nicht stark.

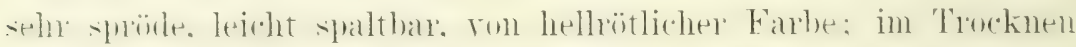

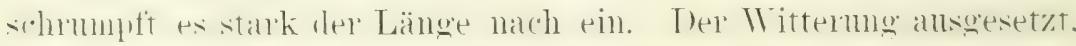

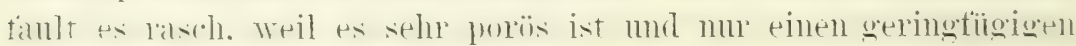

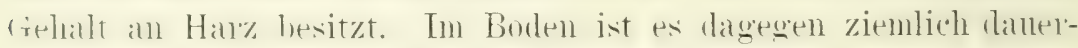
haft. Es nimmt eine schöne Politur an. Weshalb es in neuerer

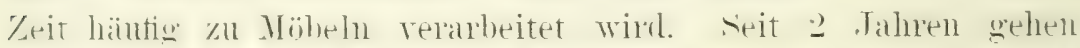

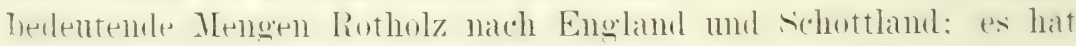
sich sogal eine sohottische fresellsehaft mit einem hapital rom 4) Millinnen Mark zur Ansbentung der "alifornischen Rotholzwälder gebildet. doch selueint man sich in dem teuchten Britamien norh nivht hlal za sein. welche massenhafte Telwendung man diesem Material geben will. (taubt man es zu Banzwecken benutzen zu kïmnen. damm wird die Enttänschung nicht lange ant sich warten lassen.

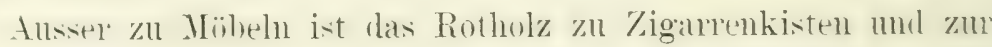

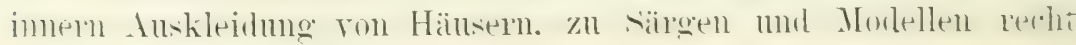


lnauchbar: In califurnien findet es anch zu Mieinfissonen nut

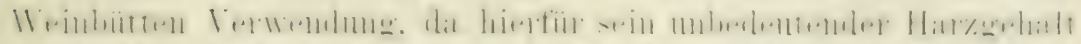

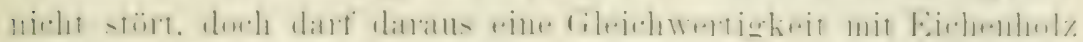
zil diesem '/weche nicht retolgert werden.

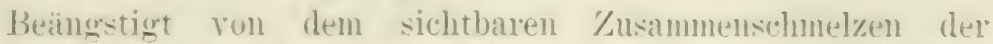
IV:ildel: setzte die californische Regierung 1880 eine Fon'st-

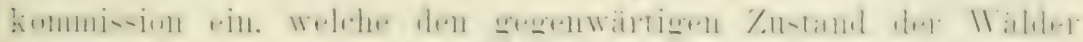

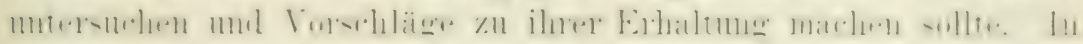

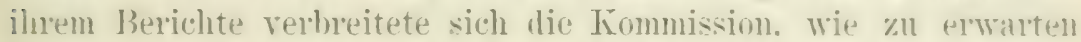

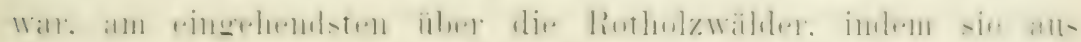

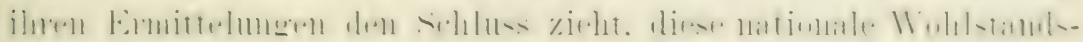
fuelle wiorde noch 100 dalne datern. wem sie nach dem del-

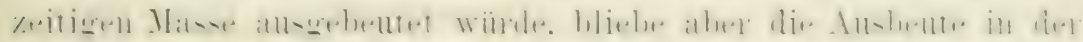

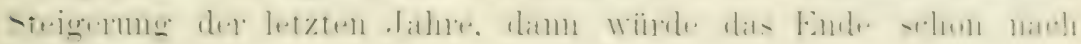
50) Jalluen eintreten.

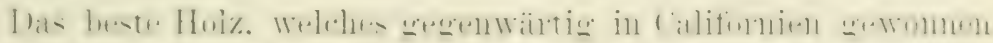

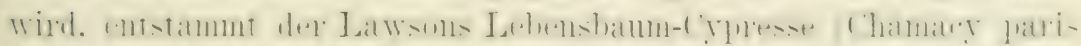

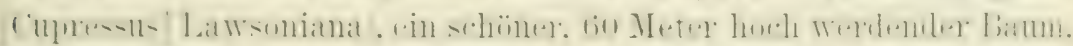

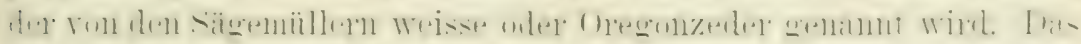

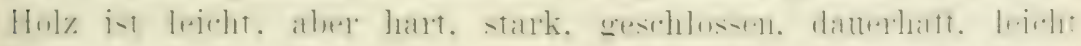

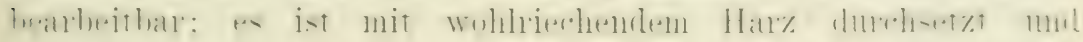

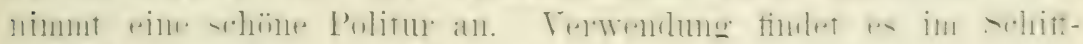

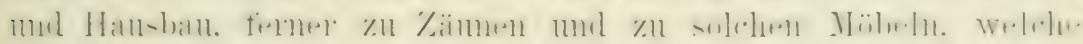

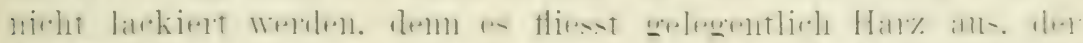

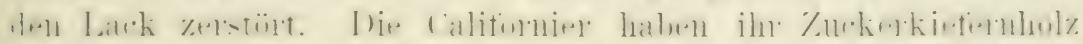
iblu

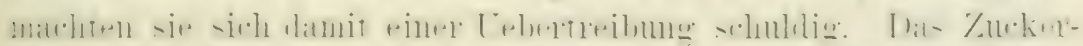

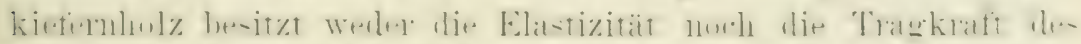

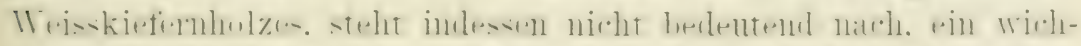

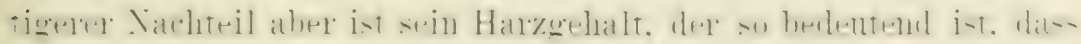

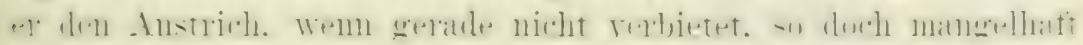

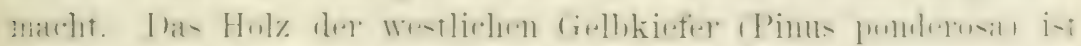

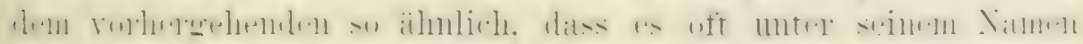

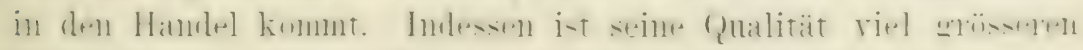
schwankungen unterworfen.

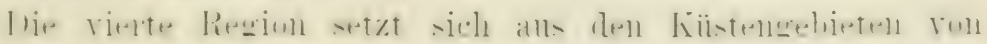

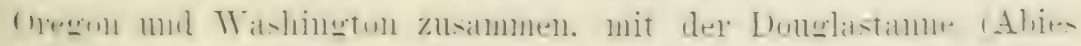

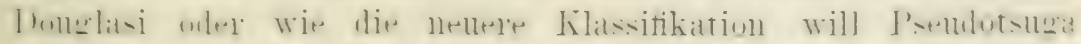

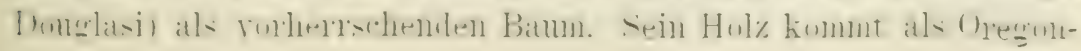




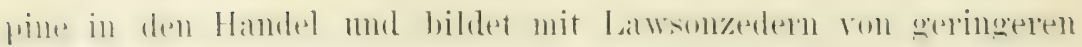

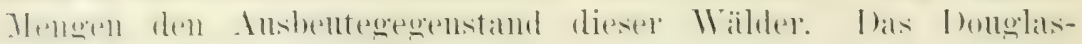

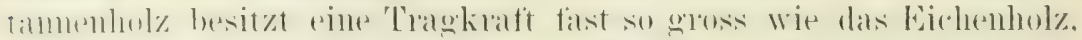

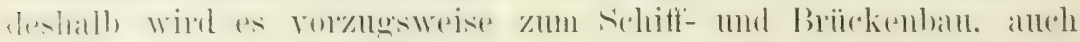

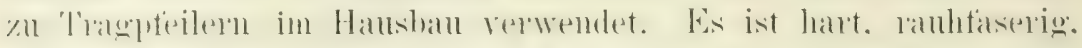

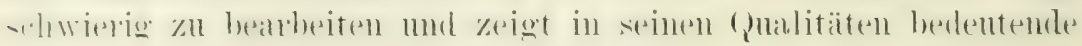
Abweichmgen, gemäiss Alter and Standort.

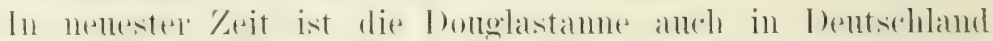

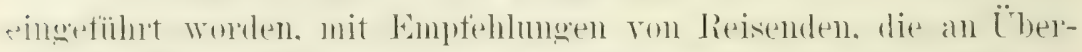

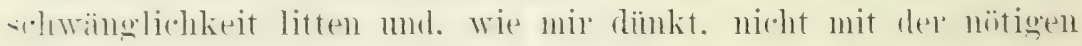
Vorsicht entgegengenommen wurden.

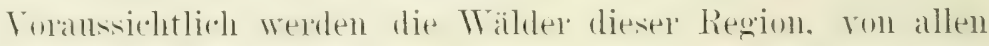

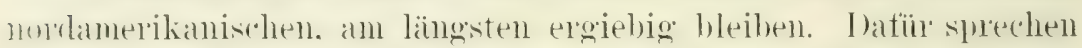
dis Beginstigmen des Wachstums vom Boden mol Klima, die

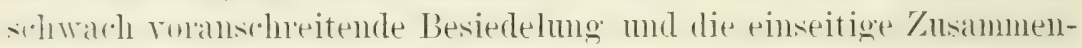

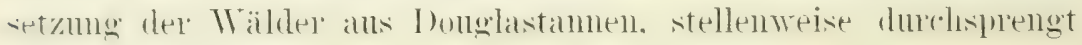
mit Lawsoncedern.

Holzreich wie die Pazifikküste ist. sieht sie sich doch zu

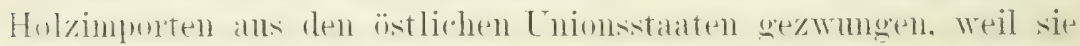

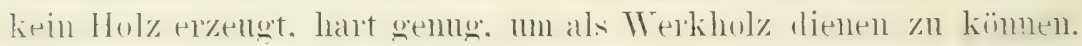
Lalifornien besitzt ein halbes Ibutzend Eibhenarten. es finden sich

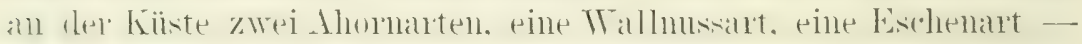

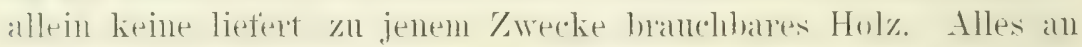

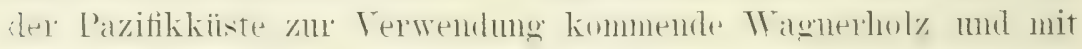

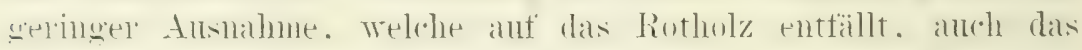

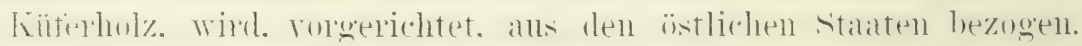

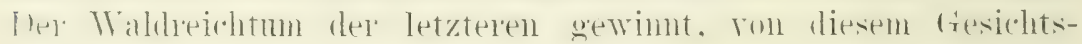

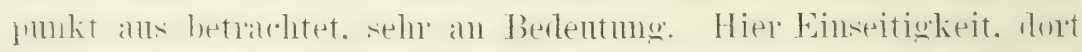

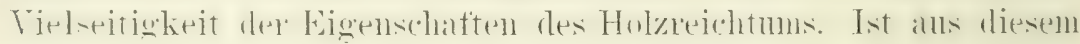
Grmde der immere Wert der östlichen Wälder ein höherer wie

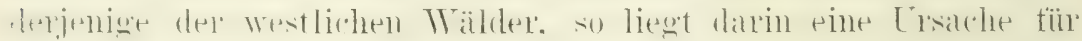
Jas rasche Verschwinden der ersteren. mïssen sie doch mit ihren

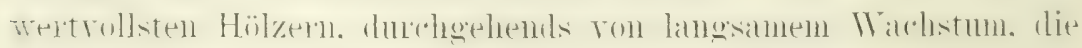
entsprechenden Bedürfnisse der ganzen Union decken.

Da ist zmä̈chst zu nemnen das für Wagnerarbeiten müber-

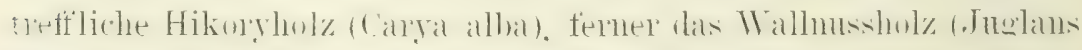

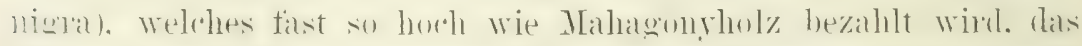

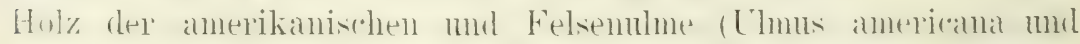

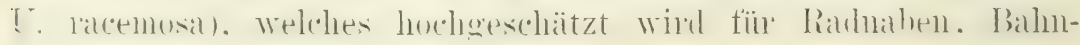




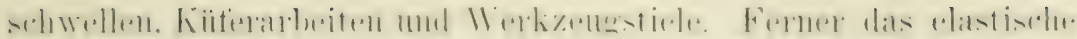

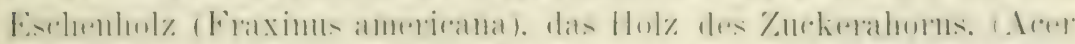

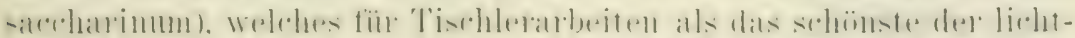

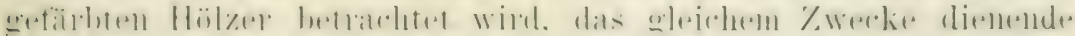

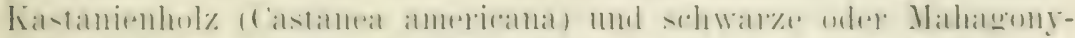

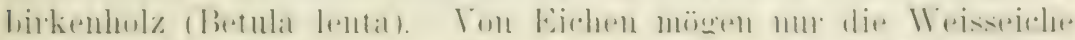

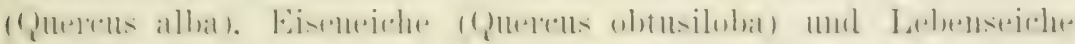
(1)

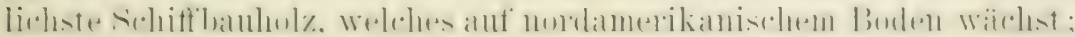

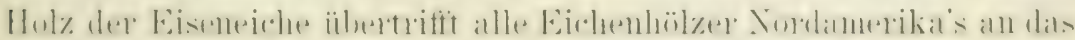

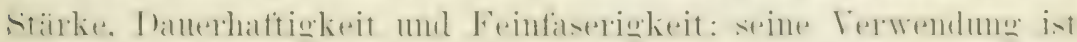

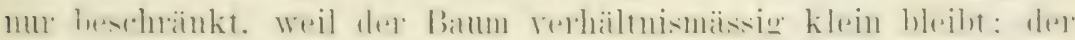

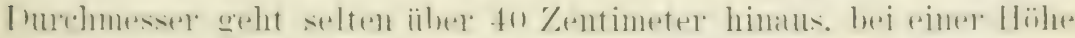

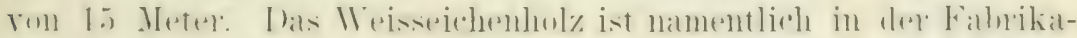

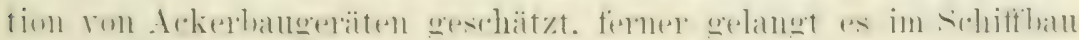
massenhatit zur Verwendung:

Vor dieser glänzenden Reihe ron edlen Hölzern mus die

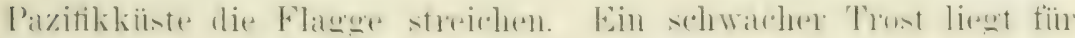

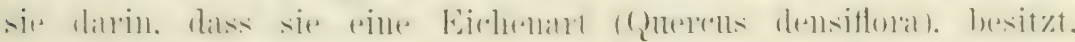

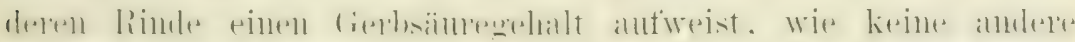

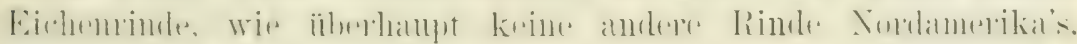
näimlich $16^{1} / 2^{0} \%$.

Dem letzten C'ensus wurde auch zur Anfgabe gestellt. zu el-

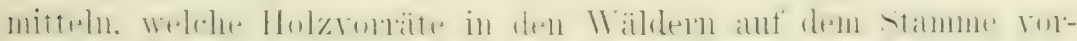
lamden wälen. Diesem 'I'eile des Berichts messe ich nu' einen

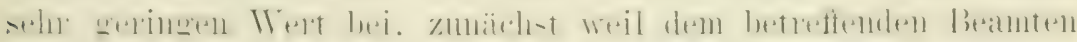
viel zu nenig Linäte beigegeben waren, nu diese ungeheme

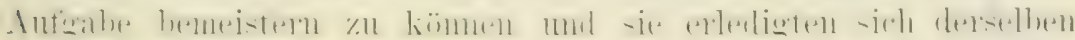
so zu sagen in Fluge. Tud damn: um die Holmmenge eines Ur-

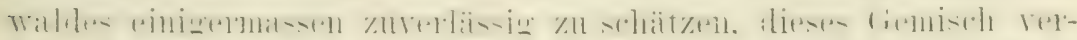

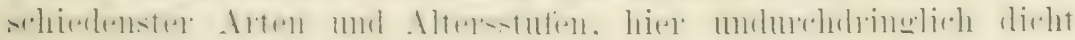

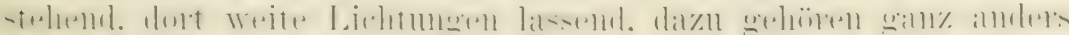

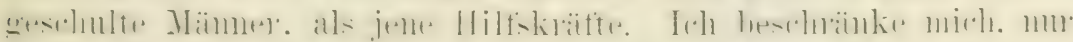
um die l'robe zu zeigen. anf die folgenden Angaben.

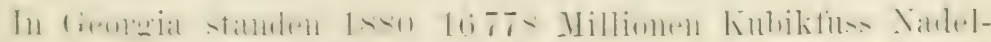

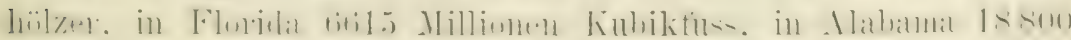

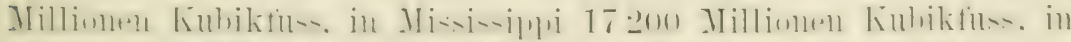

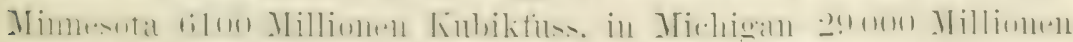

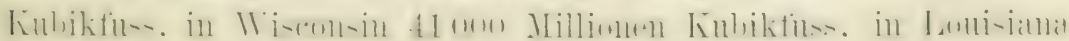




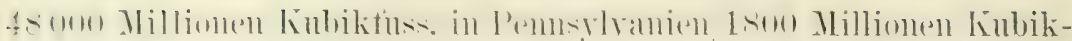

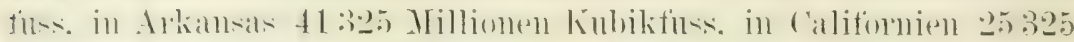

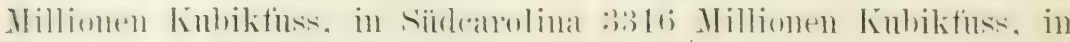
Maine 5000 Millionen Kúubikfuss.

Obgleich es ummöglich ist. den Holzwert eines weiten Ur-

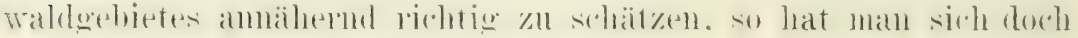

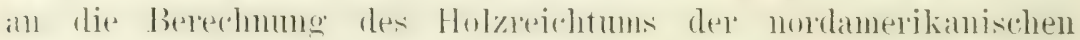

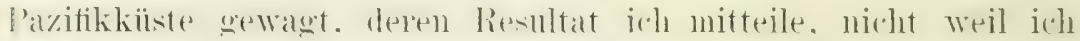

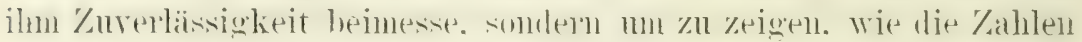

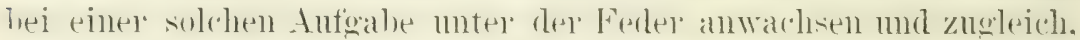

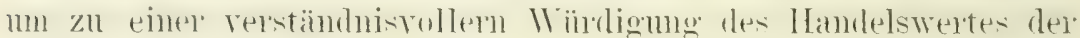
Wälder anzuregen.

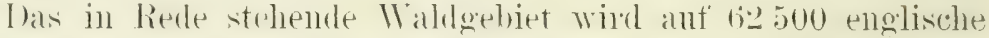
Gmadratmeilen geschätzt. mit einem durchsehnithlichen Holzhestande

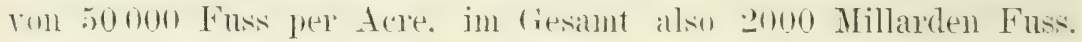

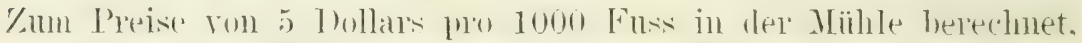
rowibt eine summe von lo Milliardem loblars orter t2 Milliarden Mark. Narh dem Bestimmmesorte enendrald und dort mit dem ïlnlichen Nutzen des Holzhändlers verkante lässt die Summe and

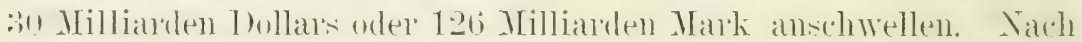
Timmanlelumg des Rohstoffes in Fabrikate. hat eine Wertsteigermeg

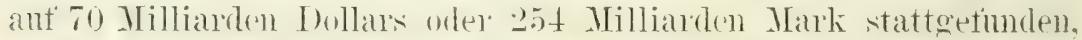
urler mahezu ant die doppelte summe, welche als ras gegenwätige, verstenterare Figentun der noldanerikanischen Lnion angegeben wird. Diexer Holzreichtum rerteilt sirh ant Arizona. C'alifornien.

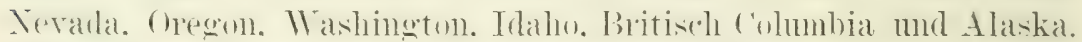

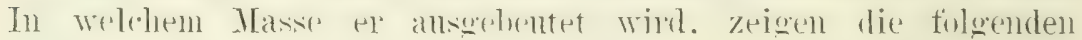
Tabellen.

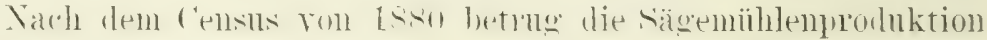
in jenem . Tahre:

In Californien
.. Oregon .
.. Washington
. . Iraho . .
.. Nevarla .
.. Arizona .

$\begin{array}{r}304795000 \text { Fuss } \\ 177170000 \quad " \\ 160176000 \quad " \\ 1 \times 204000 \quad . \\ 21545000 \quad " \\ 10715000 \quad " \\ \hline\end{array}$

692606000 Fuss.

Diese Produktion beschäftigte 4784 Arbeiter. 


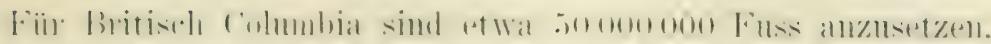

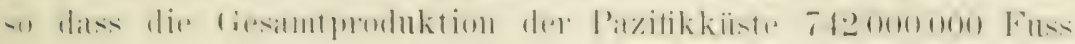
betrue.

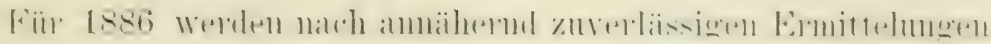
rinur Handelszeitung folgende Kahlen angegeben.

Washington . . . 500000000 Fuss
Oregon . . 550000000 ..
Californien . . . 550000000 ..
Der Rest . . . $\frac{50000000 \quad \text {.. }}{1160000000 \text { Fuss. }}$

Das wäre also eine Produktionserhöhung ron etwa $65 \%$ in

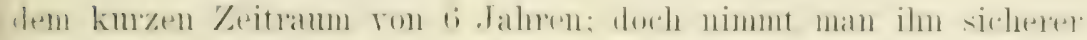

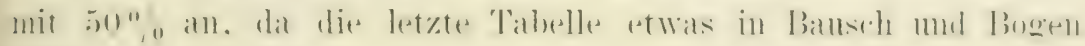
alu'gestellt ist.

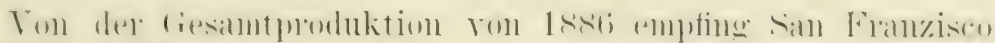

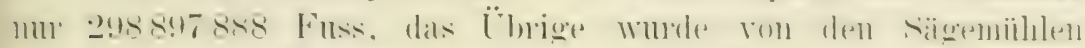
direkt nach den Konsumtionsplätzen verschifft.

Interessint ist ein Blick auf den Export nach fremden Laindern. Von der Pazifikkiiste. soweit sie zur nordamerikanischen

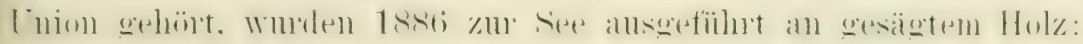

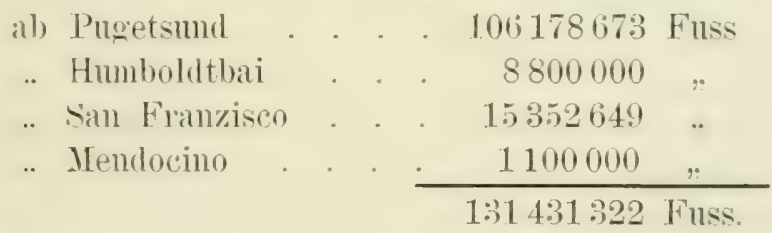

Davoll gingen:

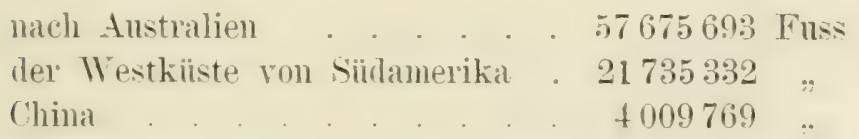

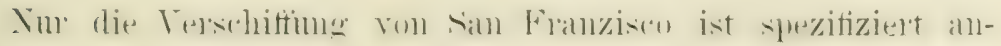
gregeben, nämlich :

Export yon Schindeln:

Hawaii

11172 Stiick

\%entralamerika

71

Latus 11243 Stiick

Serrler. Waldwirtscha?t. 


\section{'Pallsport 11243 stibek}

Mexiko

S64.

samoa

132 ..

Dellsthlamb

2460

Yew-berlforal

1647

Mangarewal

200

thili

Iatpall

1

Asiatisches Russland

40

Marselathinseln

100

Tahiti

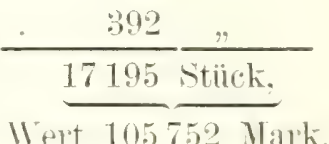

Export ron Brettern und Balken:

Marschallinseln

Mexiko

Centralamerika

( 'hina

Hawaii

Nenseeland

Britisch ('olumbia

Talpatu

Frankreich

belgien

Anstralien

bentsoliand

('hili

(olumbia

samoa

Englamel

riland

st. Denis

New-berlomil

Mangarewa

port Eilizabeth

(Fibralta
159142 Fiss 2745107

348689

5) 12 !

1583927

10610

1:391!

$84+95$

$59+000$

105000

1521510

15000

$360+2$

7.5 .565

$\$ 6.5000$

2.279000

2397000

17000

525944

$4+8.5$

2100()

\%) 


\section{'Transport 13719881 Fuss}

Cipstiald

Aslatisches Ruswind

Schottland

Marquesasinseln

Talliti

New-Tork

$$
\begin{aligned}
& \because 801 . \\
& 39000 \\
& 39000 \\
& : 38000 \\
& 11111 ! 5- \\
& 3000 \\
& 15352649 \text { Fuss. } \\
& \text { Wert } 1177612 \text { Jark. }
\end{aligned}
$$

Export ron 'Thiüren und Fensterläden:

Hawaii

Anstralien

China

Mexiko

Zentralamerika

Samoa

Asiatisches Russland Chili

Thahati
2031 Sitick

28830

88

468

201

137

$$
\begin{array}{rr}
12 & . . \\
30 & . . \\
288 & . .
\end{array}
$$

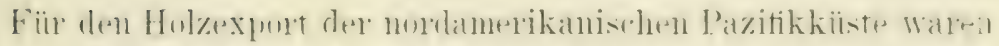

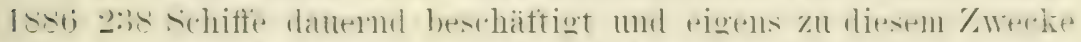

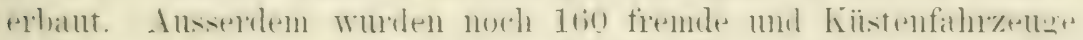

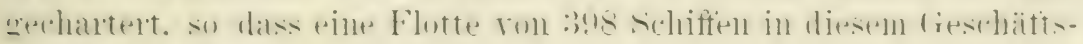
zweige thätig wal.

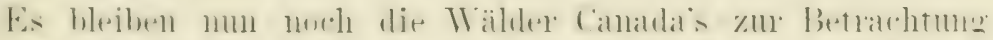

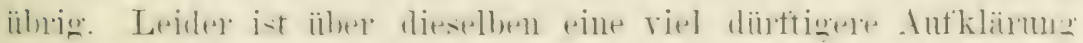

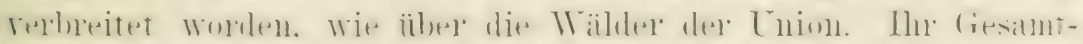

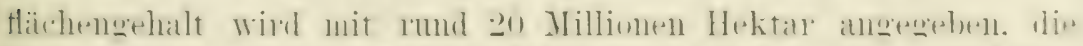

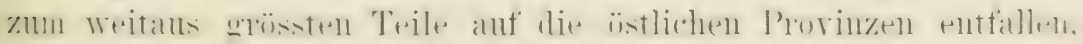

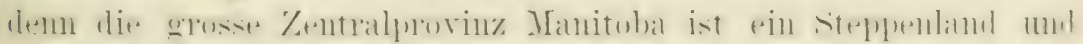

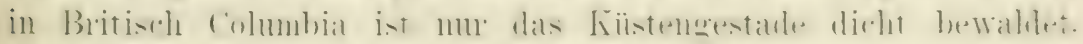

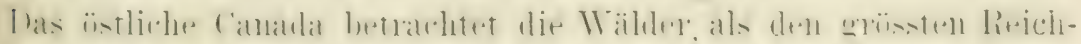

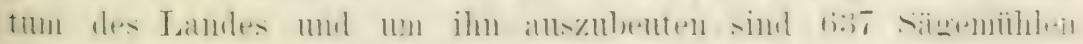

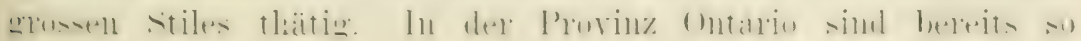




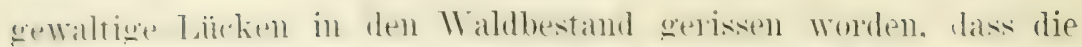

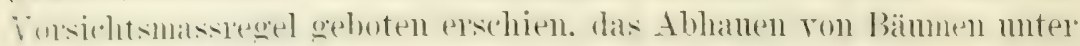

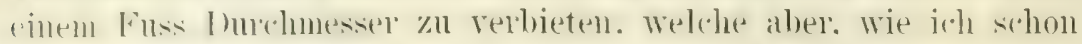

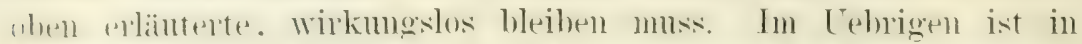

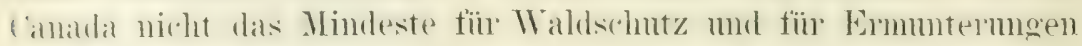

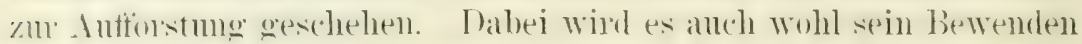

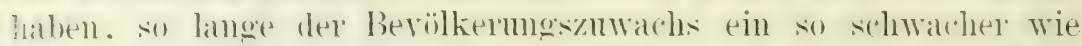
seither bleibt. Als die wiehtigsten Waldbämme ('andats sind zon betrathten: die canadische Rotkiefere (P'inms resinosa). deren feintilseriges. starkes. damerhaftes Holz in solifthan seschätzt ist.

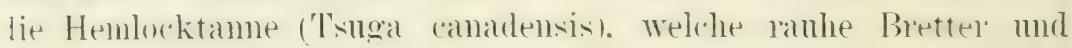
sine gerbainereiche Rinde liefert, die anerikanische Fiche die Felsenulme und der Zuckerahorn (Acer saccharinum). 


\section{Ier Wild im Haushlalte der Niatur.}

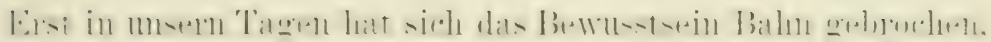

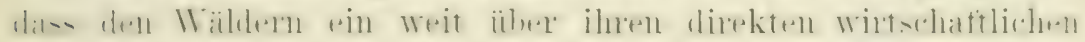

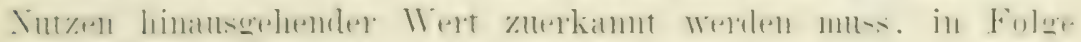

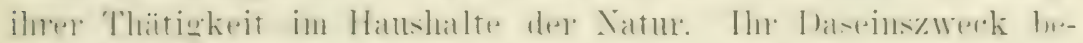

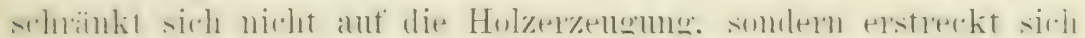

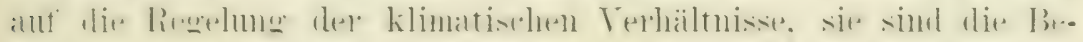

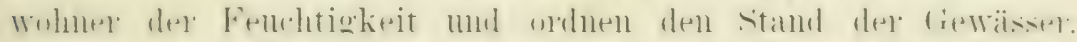

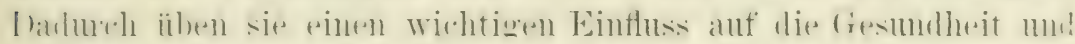

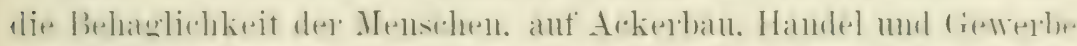

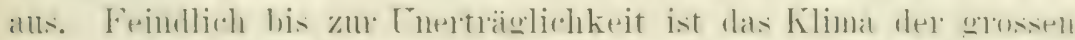

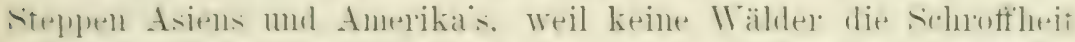

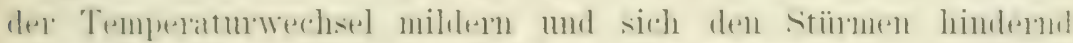

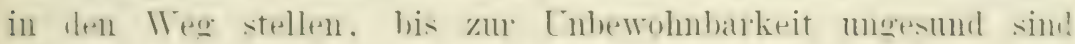

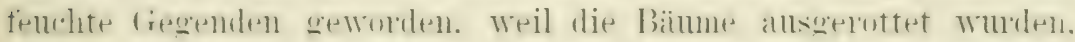

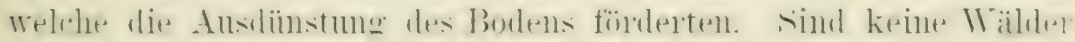

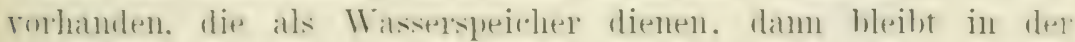

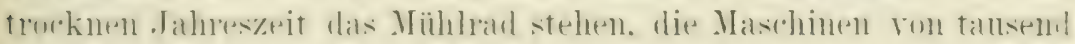

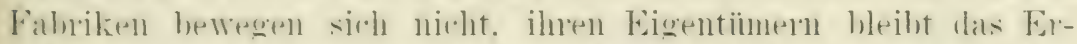

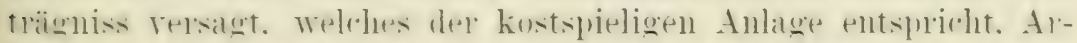

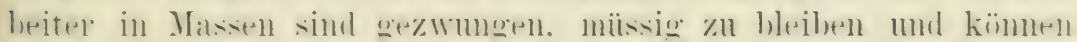

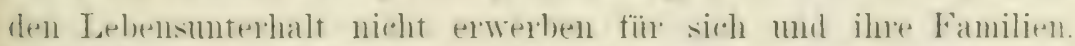

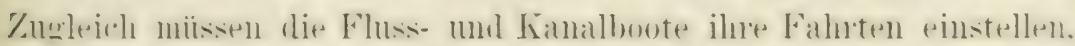

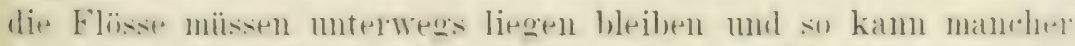
Vertlage nicht erfiillt werdent. manche Terbindlichkert nirht einge-

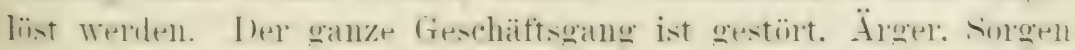

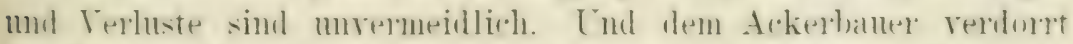

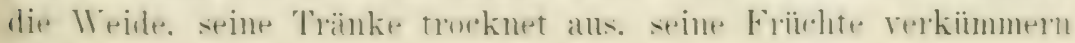




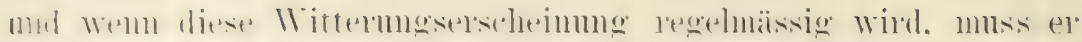

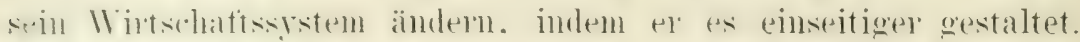

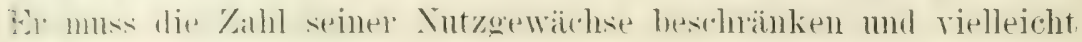

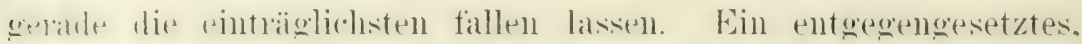

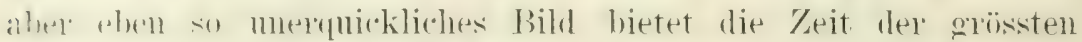

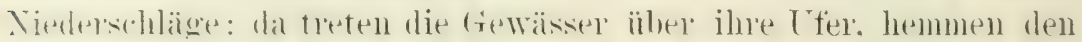

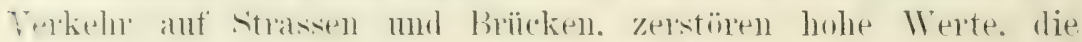

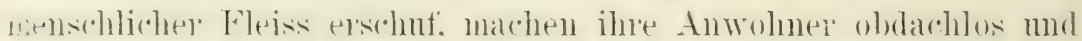

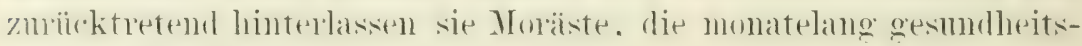
gefährlich bleiben.

Betribend wie diese Erscheinungen sind, ist es doch noch betrïbender, dass ihm Lehren wenig beherzigt. von den grosien Fulksmassen nidht eimmal verstanden werden. So nur ist es erklärlich,

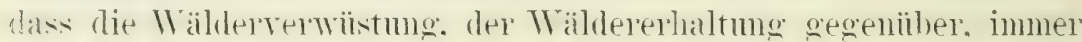
moch das C̈berowicht behamptet. Tud diese mlenghare Thatsache marht es zur erusten Notwendigkeit. die Terrichtungen der Wïlder in Haushalte der Natur so oft zu belenchten. bis sie in den weitesten Kreisen gekannt und gewïrdigt werden.

\section{Der Einfluss des Waldes auf die Luft.}

T'ie alle Pflanzen. so sind andh die Bämme aus vertremnlichen mid mrerbremlichen stoffen zusammengesetzt. Der rerbremende Teil ist eine rerschiedenartig zusammengesetzte Terbindung ron

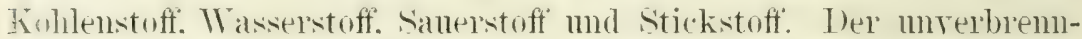
Tirhe 'Teil. welcher' als Asche iibrig bleiht. besteht ans mehreren frumdstoffen. Wie Kalimm. Calcium. Magnesium. Natrimm, Eisen. Inlsphor. Schwefel. Silicimm und Chlor. Stets gefmulen werden in dele Ashe: Phosphor. Schwefel. Kalium. Calcium. Magnesium und Eisen. es ist daher anzmehmen. dass diese (trmudstoffe nebst den erstgenamnten. zur Ernähmug der Pflanzen unerlässlich sind. and zwar minssen sie in flüssiger Form zugänglich sein, also wässerig oder gasförmig.

Der wichtigste dieser Stoffe ist der Kohlenstoff. der vorzugsweise rom Holz anfgenommen wird. Die Blätter saugen Kohlensäme. aus Kohlenstoff' und Sanerstoff bestehend. auf, scheiden. unter Mitwirkung des Blattgüus und des Sommenlichts. den Sanerstoff ans und behalten den Kohlenstoff zurizck. Im ihn den Ästen und dem Stamme zuzuführen. zu deren Aufban er dient. Selten finden wir in der mbelebten Xatur freien Kohlemstoff als I)iamant nud 


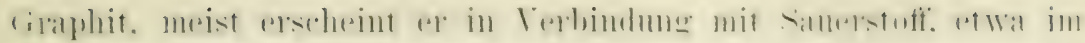
Terhältnis von $6: 16$ Gewichtsteilen.

Die Pflanze kamn nu ron freier Kohlensäme. wie sie die Luft.

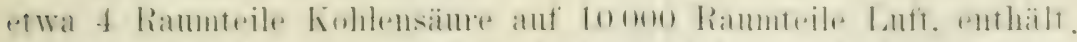

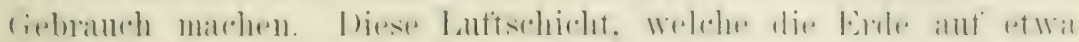

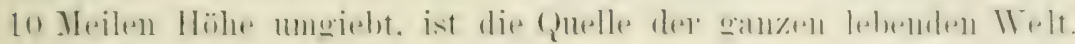

Wemn num die Pflanzenwelt. ganz besonders der Wald. ron

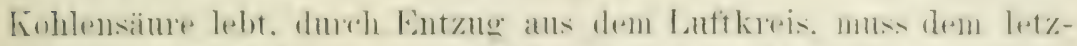

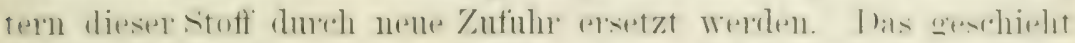

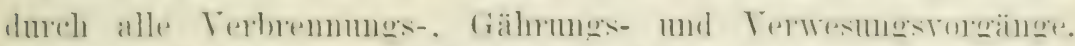

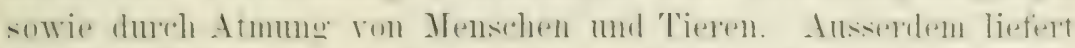

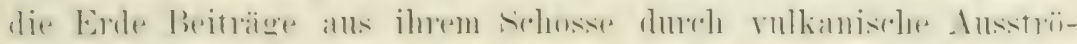

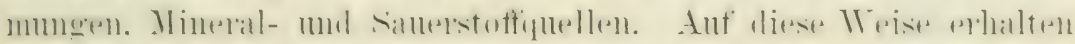

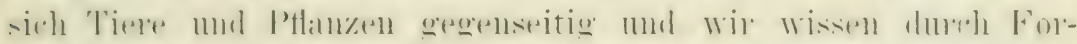

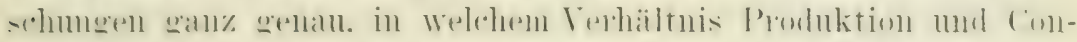

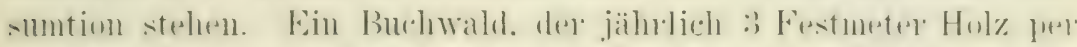

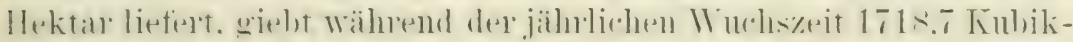

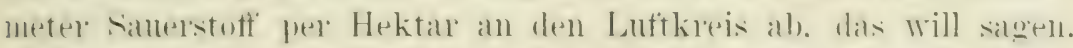

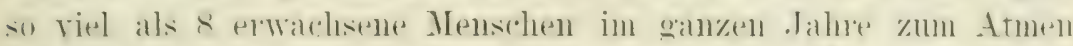

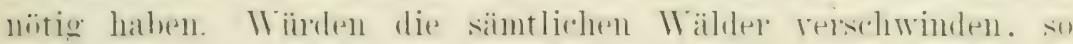
wïrde allein der menschliche Verbrande rom silleststoff etwa in

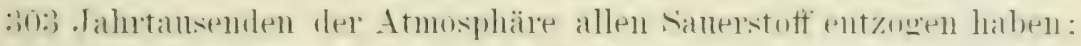
in einem \%eitram ron 1000 . Tahren wïrde der Kuhlensïmegehalt

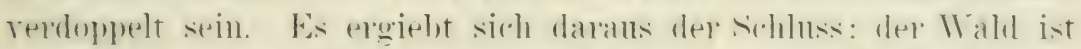

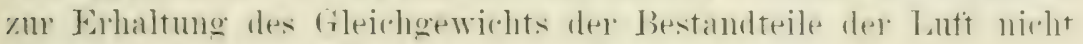
allein von erositer Wirhtigkeit. sondern menthelurlich.

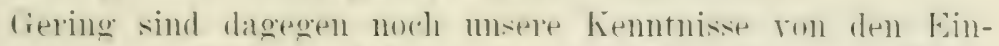
wirkmogen der Wälder ant die elektrischen Verhälnoisse der latt. Jeder Bamm ist ein elektrischer Iepiter in teils höherem. teils geringerem firad mol ex ist nicht anzmehment. dass Wolken. Welelye

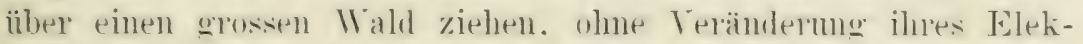

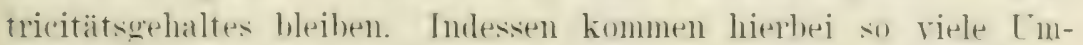
stände in lietracht. dass fine Klarstellumg dieses fiegrenstamdes stets seln solwierig bleiben wird. Cnerwähnt dart indessen nicht heiben. dass der Hagel. Weleher vom vielen Naturforschern als das Fizengnis einer besonderen elektrischen Thätgkeit betrateletet wird.

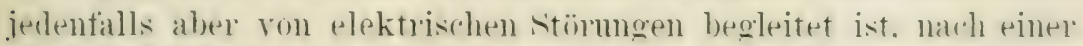
weitverbreiteten Annahme mit zmehmender Häutigkeit tällt. je weiter die Entwaldung einer Gegend fortsohreiter. Fin italienischere 


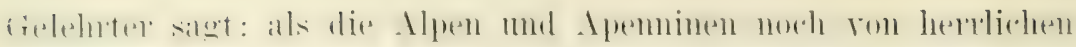

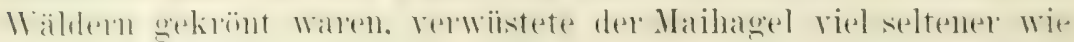

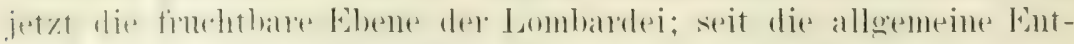

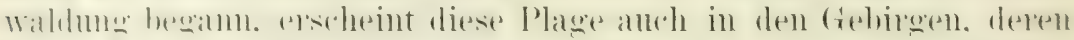

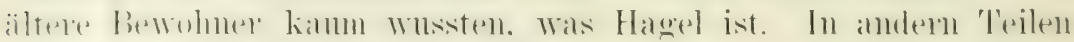

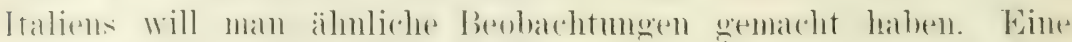

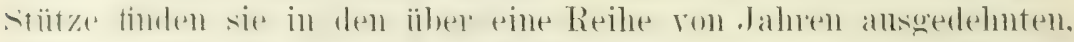

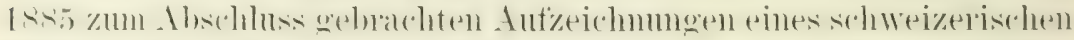

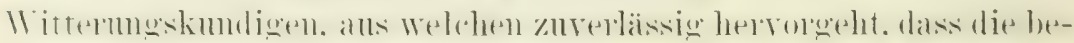

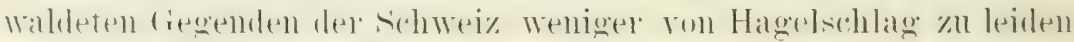

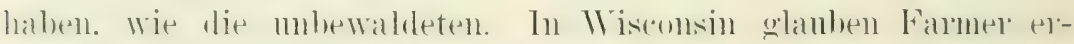

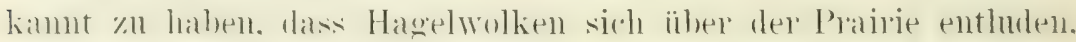

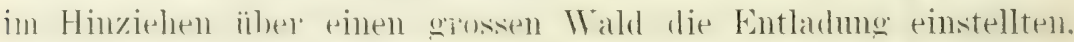
mu sie jenseits des Waldes fortzusetzen. dedenfalls sollte dieser hehauptete Hagelschutz der Wälder ron dem Natuforsehem aller ländel. mit Hülfe der in jedem . Jahne weiter ansegebildeten statistik.

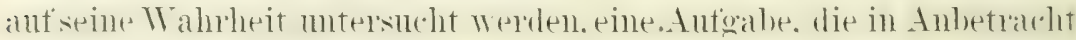
der moghemen Verwiistungen. Welde der Hagel bald in diesem. bald in jenem lande anrichtet. gewiss widhig erscheinen muss.

\section{Der Wald als Wasserspeicher.}

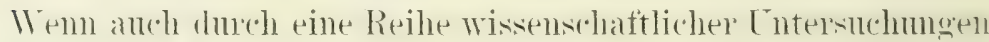

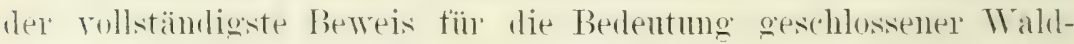
hestände in Bezule anf die Regelmo klimatischer Terhältniss grelietert ist. su muss die Fragere ob in den Waldumgen anf gleicher

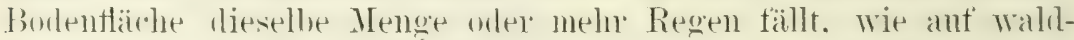
freiem Borlen. norld als offen betrachtet werden, dem die Ergebnisise hisheriger lntersuchumgen sind sich mehr oder weniger widelsprechend. Ibas aber ist zurerlässig: der Regenfall im waldigen (relände hleibt arisstenteils nutzbringent. zum kleinsten T'eil hleibt er es anf banmlosen oder nackten Flächen.

Es kamm nicht im mindesten bezweitelt werden. dass die gepsamten atmosphärischen Nienlerschläge anf mbedecktem. der somme mond dem trockenen Irimde preisgegebenen Boden in 1 sin si gefähnlicherer Iteise sich geltond machen. je schutzloser der Boclen und je stärker des Regenfall ist. Del wirklich in den Borlen dringende Regen fliesst entwedex nur durch denselben (sand- mul Kiesbolen). wher wird von dem Boden zurickgehalten (Thon-. 


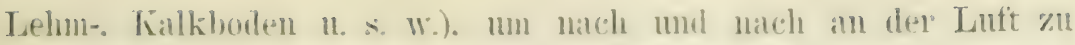
verdunsten whel pinzusickern.

Die einzelnen Bodenarten sind bekamtlich, je nach ihres.

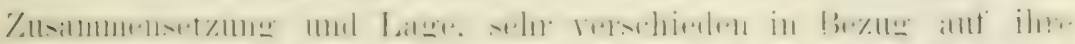

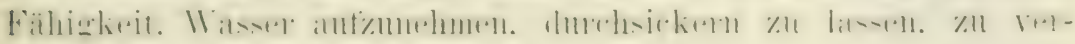
dunsten mol den Pflanzen zuzufiihren.

In IValdbolen wird aber der bei weitem gröste l'eil des

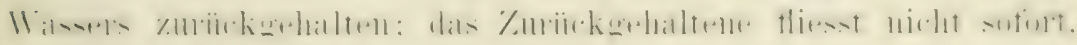
sondern nach und nach al): es verdumstet nicht so rasch wie ant

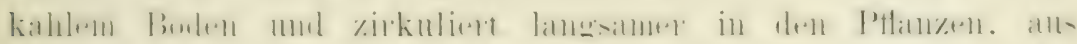
welchen es zum 'Teil nittels der Blaitter abenfalls wieder in die Lutt verdumstet.

Viekeitige Exmittelungen eroaben. dass ron den juihrlichen

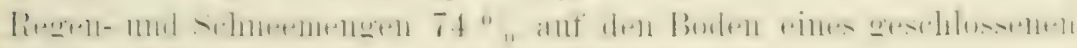

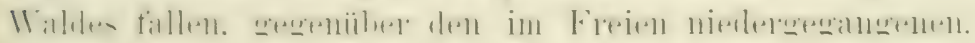

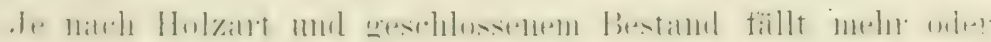

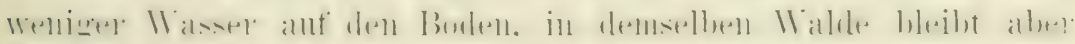

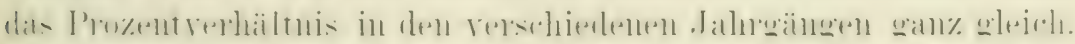

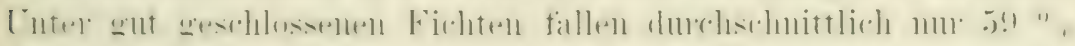

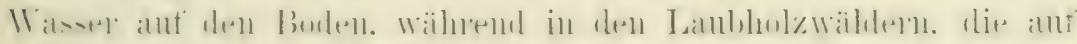

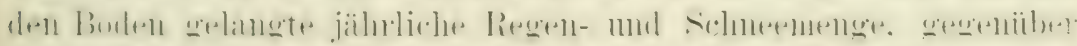

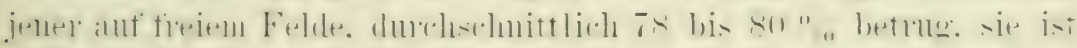

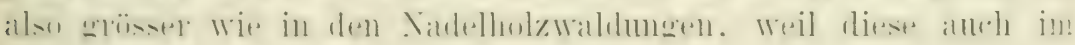
Winter ihre auftangenden Tarleln behalten.

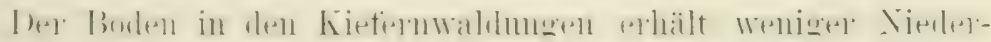

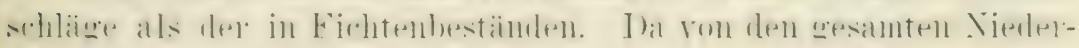

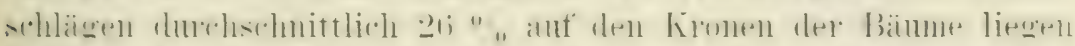

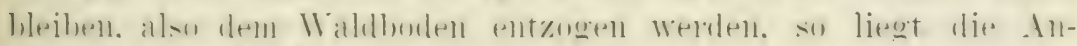

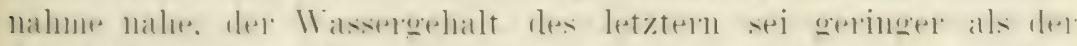

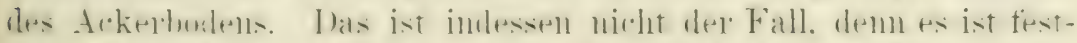

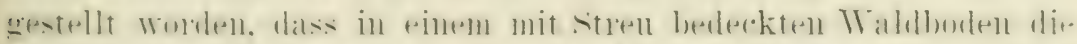

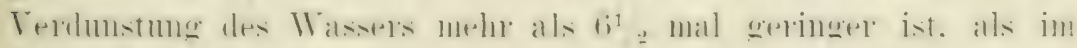
freien Feldboden.

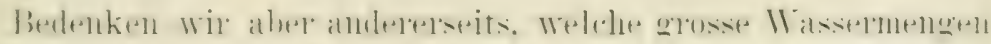

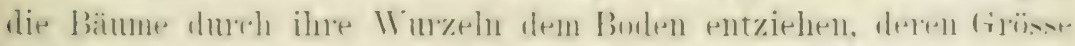

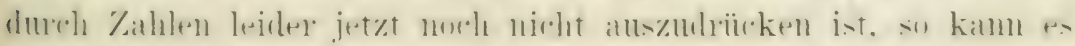

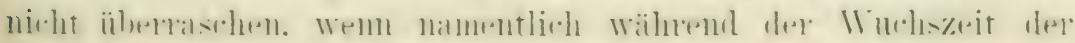




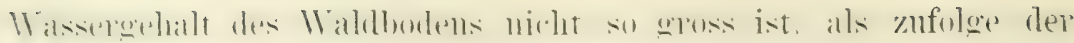
verminderten Verdunstung anzunehmen ist.

Die Hummsschicht im Walde kimm eine seln grosse Menge

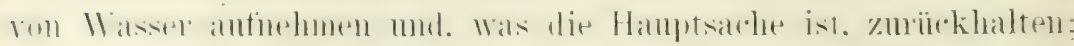

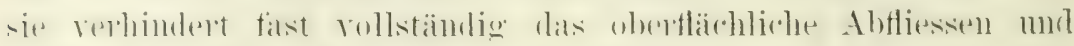

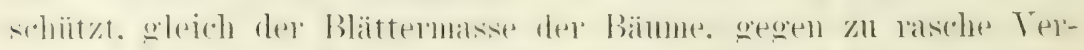

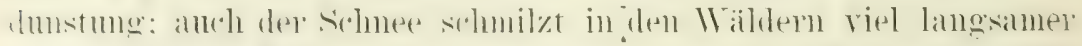

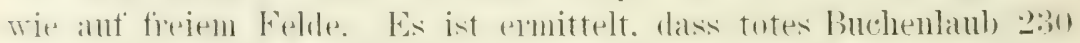

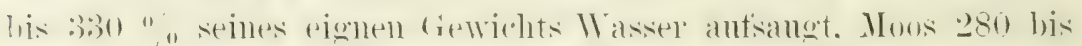

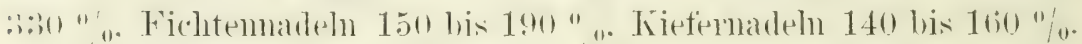
Ein Kubikmeter Burlemlanl, hailt fast 2 Hektoliter Wasser roll-

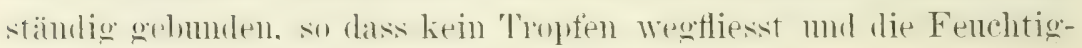
keit nur allmählich dem Borlen zugängig wird.

Sach M. Deherain. der in den Wäldern Algiels Forschmeren anstellte. enthailt 1 Litel Waldhumms im Inurchschnitt 0.935 Kilo-

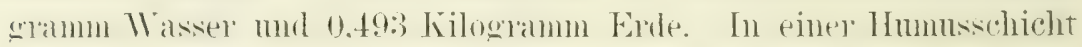
rom 10.05 Meter I)icke wiude also jedter (Quadratmeter so Liter mele 47.75 Kiloglanm Wasser und 24.65 Kilogramm Erde enthalteli. mul 1 Hektal dieser sinhoht wïnde 478 Knhikmeter Wasser festhalten. Wemn die 2000000 Hektal Wälder Algiers durohschlends ans Kulturwäldern heständen. so wïrden sie einen Wasserrorrat rom 956000000 Kobikmeter anfinehmen. Ximmt man eine Hummsehicht rom 0.10 Meter Iricke ans. so wiirde der Wasserrorrat nahezu 2000 Millionen Kubikmeter betragen. Es ist interessint. einen Vergleich amzustellen mit den grosien Sammelbecken. die zur Abwehr der Jiirmen erbant wurlen. beispielsweise mit demjenigen vom Hamiz. Dasselbe entlält. Wenn ganz gefüllt. 14000000 bis 15000000 Kubikmeter Wasser. es miisstem also 60 solcher Sammelbecken gebant werden. muso viel Wasser anfzuspeichern, als eine Humuschicht ron nur 0.05 Meter in den gesamten Wäldern Algiers auflowahrt. Fs entspricht aber mehr den thatsïchlichen Terhältnissen. eine Humnssohicht ron 0.10 Meter Tlicke anzmehmen. Eine solche hat dieselbe Fassmeskaft wie 135.5 Sammelbecken. erbaut nach dem riesigen Massstabe wie dasjenige ron Hamiz. Kaum schlagender kam die Bedentmo der Wälder fiur die regenarmen halbtropischen Länder. wie Algier. Wo ansiserdem die Niederschläge anf gewisse Monate im .Jahre beschänkt bleiben. quezeigt werden. als durch diesen Vergleich. 


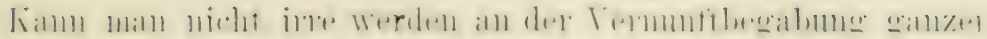
Välker, Wenn man sicht. Wie sie ihre Wälder zerstören. un sich

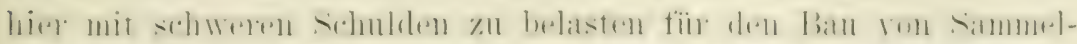

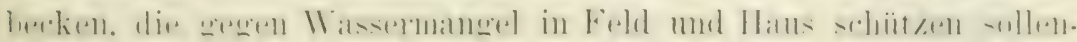

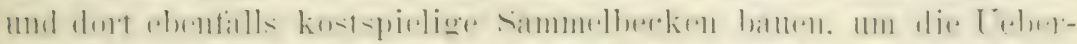

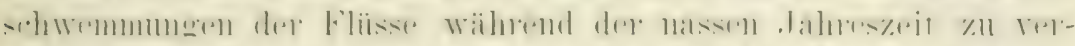

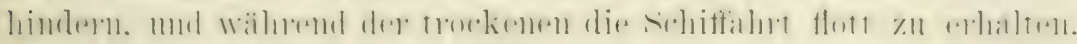
wie es gregenwärtig am obern Mississippi geschielıt?

Vorzugsweise ist es der Lanbwald, welcher geetonet ist.

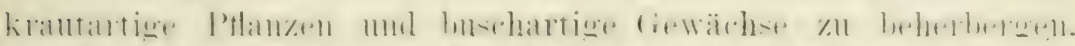

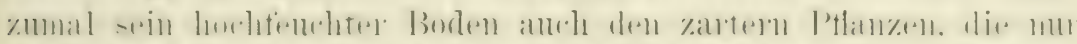

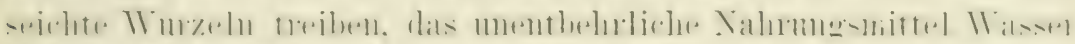

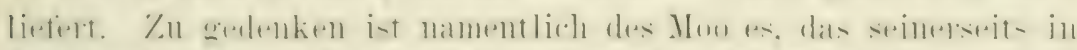

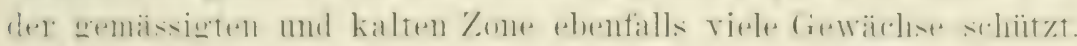

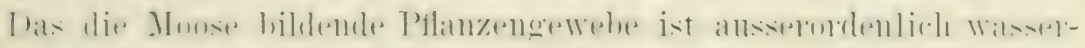

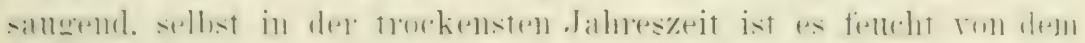

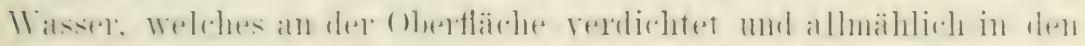

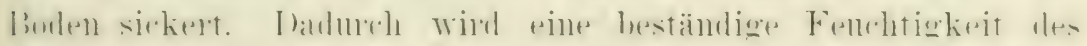

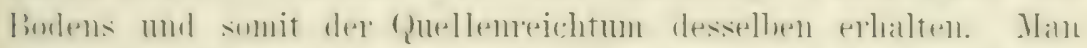

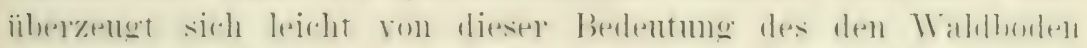

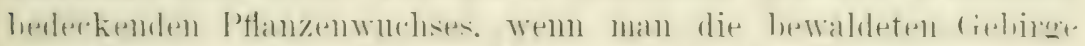

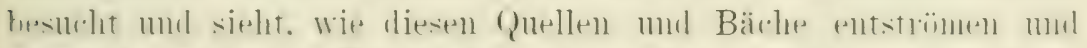

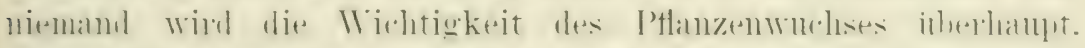

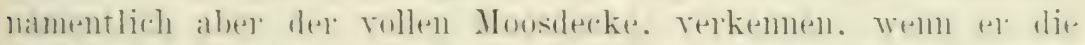

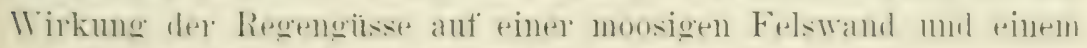

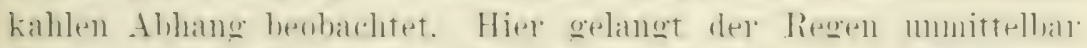

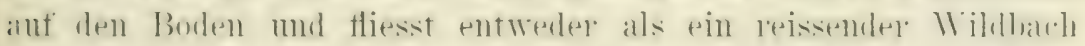

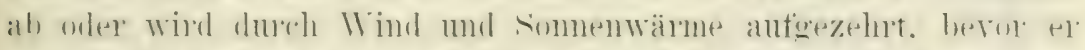

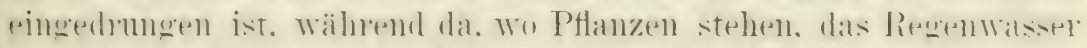

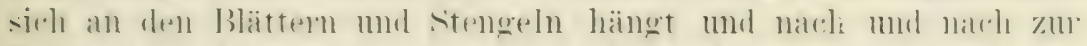

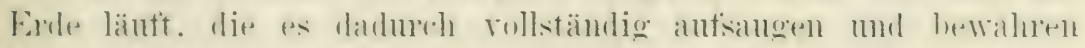
kamm. Jie gröste Whehtigkeit in dieser Hinsirht hesityen die

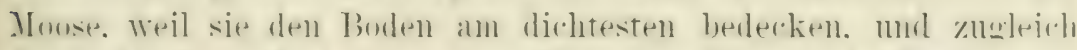

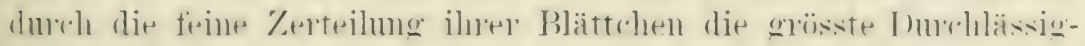
keit besitzen.

Die Moose leisten den Wäldern fiemere Thienste. indem sie den Boden ror dem zu starken Austrocknen dureh den Wind mud die sommenstrahlen betwalnen. das fallende Laub festhalten und mit

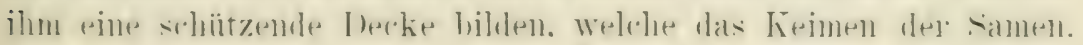




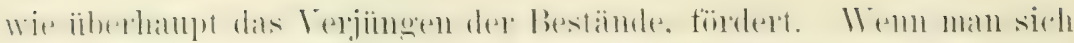

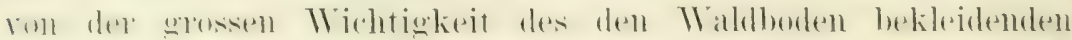
l'tlanzenw

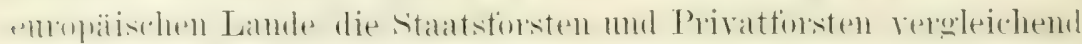

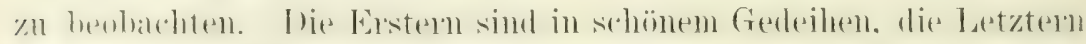

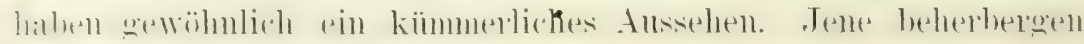

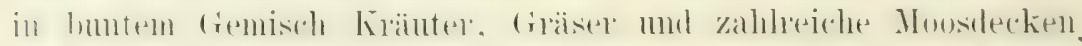

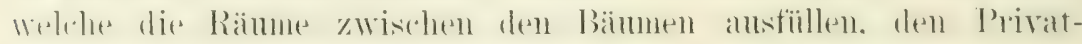

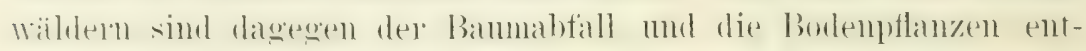
zonen worden.

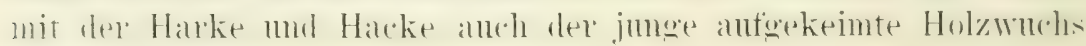
vernichtet.

Wie gross der Einfluss ist, den die Wälder auf die Bildung mul Erhaltumg der Fliisse ansiiben. lehrt ein Blick ant die Quellen-

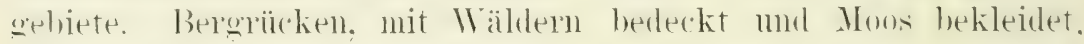

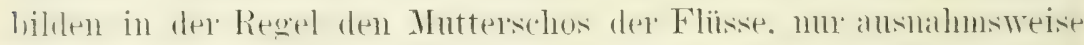

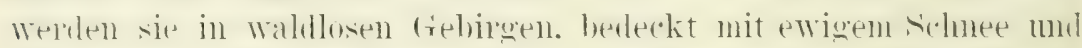

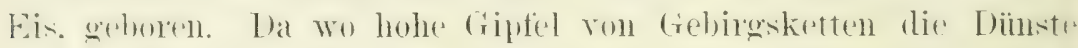
des Neeres aufhalten. wo man, wie auf der dem Neere zuge-

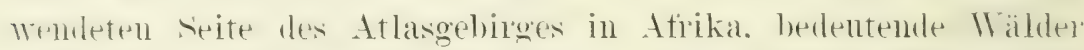

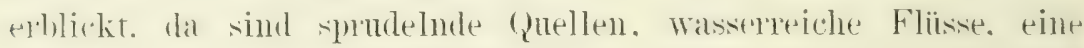

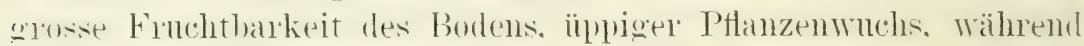
ant der entgegengesetzten seite diesel Gebirgskette fiast kein Hiessember IIasser zu tinden ist. da lier der Boden nackt mol kalle ist mel die Hitze der Wöiste die rasche Terdmstmo der Nimblahläge bewirkt. Ias scheint nicht immer so geweren zol

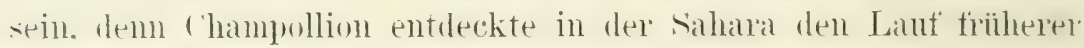
Flïsse und Bäche in Bodeneinschnitten und an der Form der

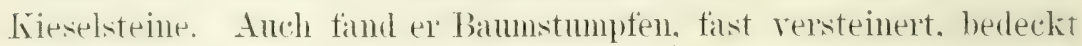
mit heissem sande. Fud so dämmert ms die erstamliche Wahrleeit ant. bemerkt er. dass diese Tlïste einst mit II älderne und ynellen gesegnet und die Wohmmg rom Millionen Menschen War.

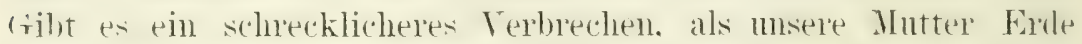
ihres Waldkleides zu berauben? Die Hand des Menschen hat

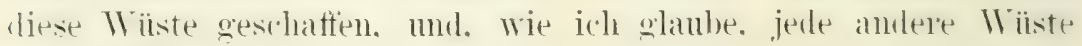
anf der Eirde.

I) Wolga kamm als Beweis angefüht werden, ilass nicht alle grositen Flïsse anf Gebirgen entspringen. Wohl wahr. allein 
iln Quellengebiet, die Waldaiebene, ist ron grosien Waildern berlecekt.

Niemand wird die Quellen des Xils in den kahlen Gebirgen

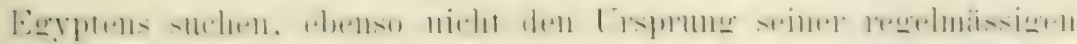

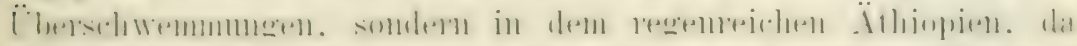

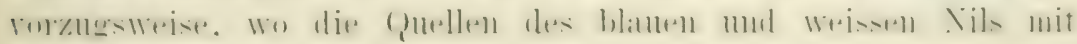
dichten Lrwäldern umgeben sind.

In so engen Zusammenhang stehen die Wälder mit den

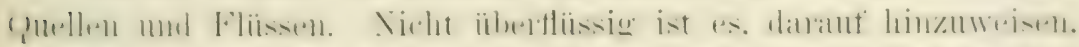

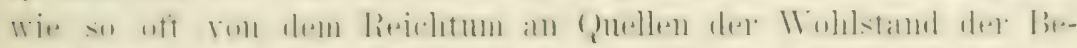

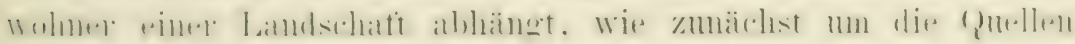
die Menschen sich anbauten und so an feste Wohnsitze und an

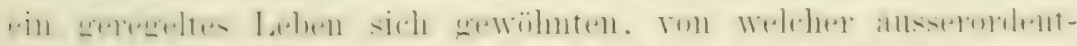

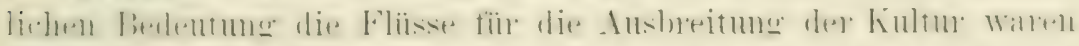

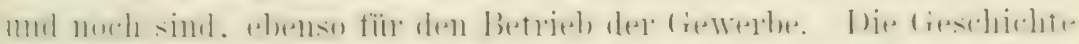

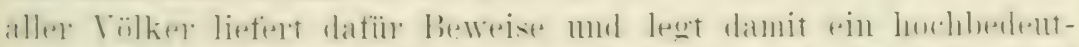

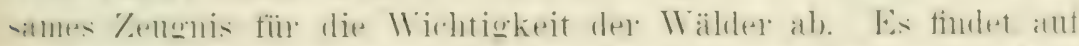

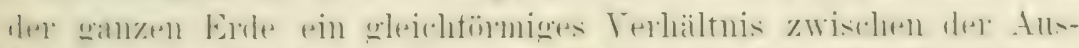
dehnume der II

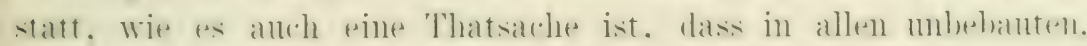

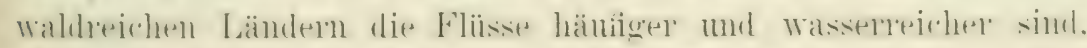

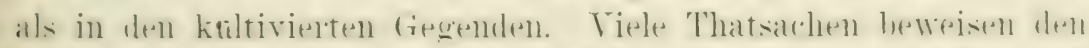

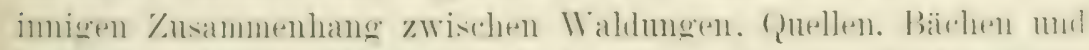

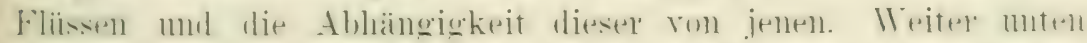

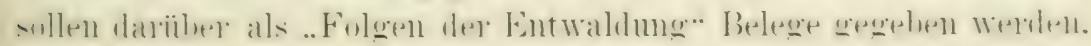
hier sei nm Spanien als Beispiel anfgestellt.

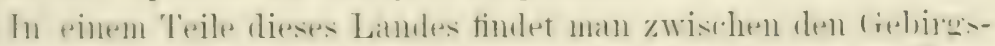

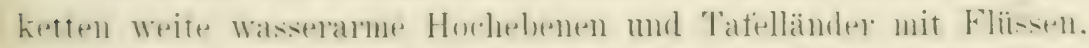

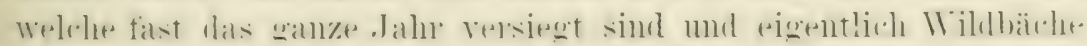

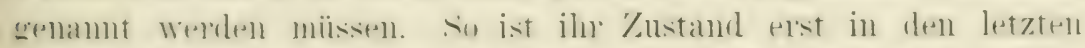

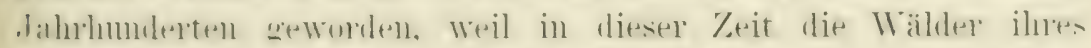

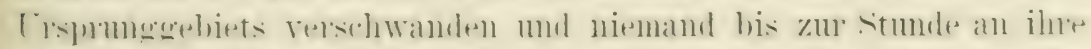

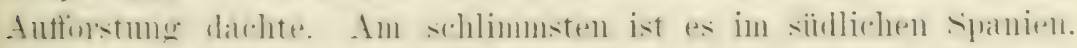

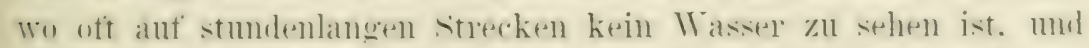

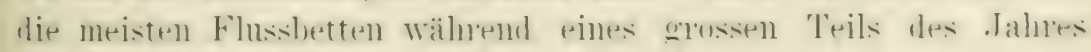
nocken liegen und nur nach längepln Regengiissen ren strümen

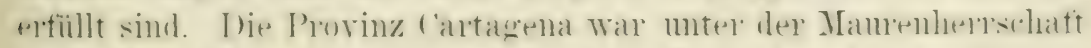

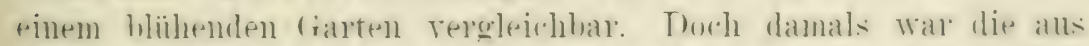

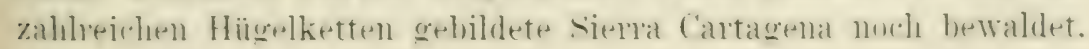




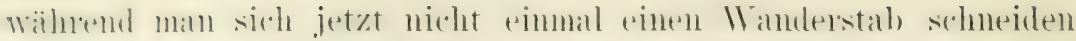

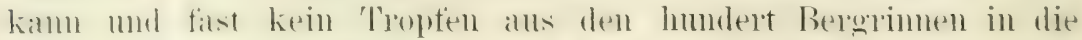

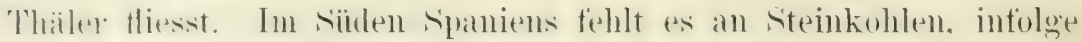

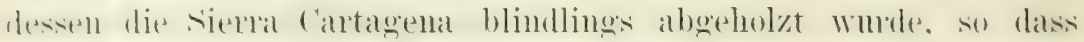

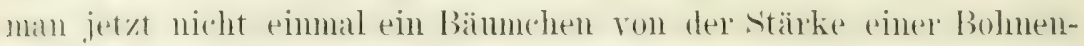
stange timbet. Kahl. von allem Bammondes entblösst, sind andeh die

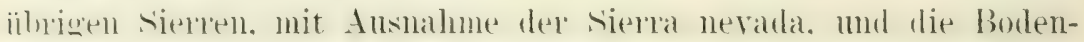
kultul ist mu' in den 'Thäler'n möglich und zwar tür alle NutzpHanzen. Welche nicht während der kurzen Regenzeit ihre Entwidkelmg alschliessen, nur mit Hülte künstlicher Bewässemo: lie spanische Regiermg wendet grate jetzt der Anslehnmg der Cinahetze pine besondere Antmerksimkeit zu - eine Aufqahe. die Millionen verschlingt. Wie wohl katun nötig ist hinzuzufïgen.

Besser sieht es im Norden Spaniens, in den baskischen Provinzen. ans. wo das Gebirge anssemondentlich zerstïckelt mul ron engen 'Thäler'n durehschnitten ist. ̈̈ber' die sich schofte Kalksteingiptel bis zur Höhe ron 1200 bis $15(0)$ Meter iiber den Ieeresplegel erheben. Terhältnismässig sanft ist das Autsteigen rom der Küste in den Thälern zu den P'ashöhen. als entziickenm schön wind das 'Thal ron Bilhao egeschiblert mol trefflicher dubau erhöht die Reize der Natur. Kastanien-. Buch- und Fichwälder

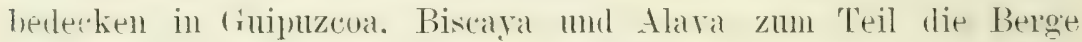
numl ïpliger lraswuchs schmilckt die Wiesen, so anch Westwärts in Asturen mul Galicien. längs der cantabrischen Kïste. ïberhant so) Weit. wie die ïher den biscayischen Meerbusen streidenden fenchten und verhältnismässig kühlen Winde reichen.

Der ganze Abfall ron Yordspanien steht unter dem Finflusie des reeklimas, daher Gleichtömmigkeit der Temperatme deren jähr-

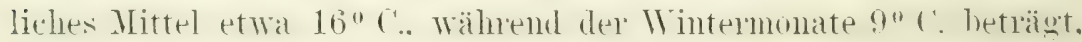
wem anch manchmal ant Stmolen strengere Winterkäle. bis zu (9" moter Null eintritt. Eine Folge dieser Terhälnisse ist reichlivher Niedershlag. der" anf diesen 'Teil syaniens beschränkt ist. Hier triftt man die ansehnlichsten Mälder sumiens. trotzdem sie. mit Ansmalnme im westlichen Asturien. ausserordentlich gelichtet.

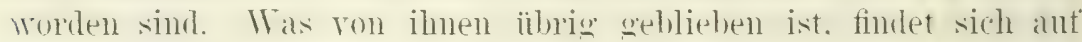
den mittern thhängen der (iebirate die höhern Erhehungen simd aber nicht kahl. hier wächst u. A. eine del schönsten Heidealten des sïllichen knropals. mit einer Mrenge kleiner. olokentümiger

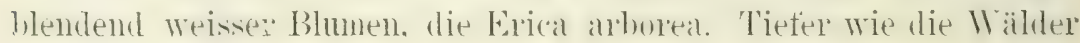




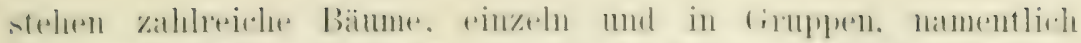

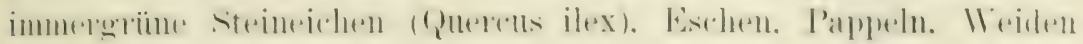
und Obstbaitume.

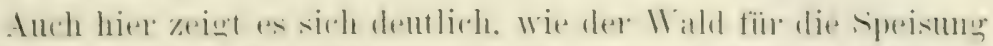

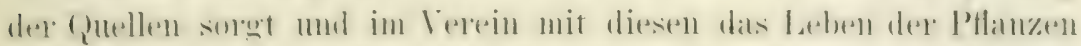

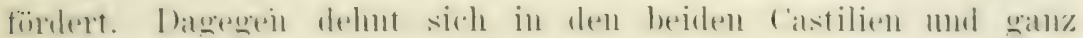

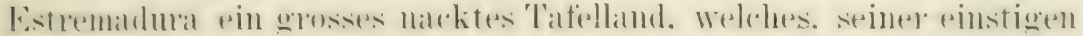

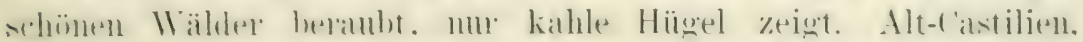

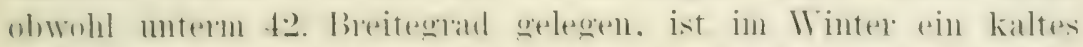

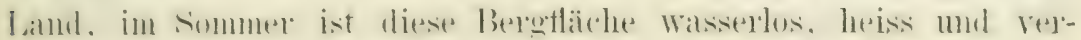

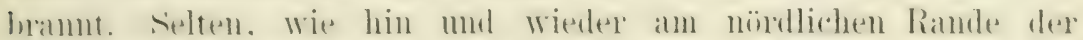

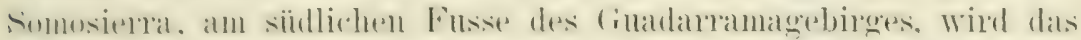

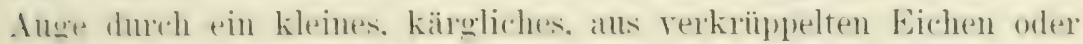

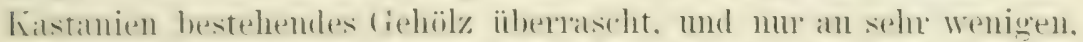

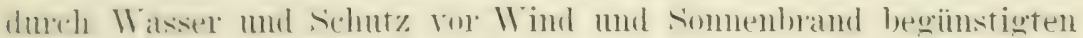
Stellen erfiest der Anhlick hoher. schlanker. mit byhen umankter

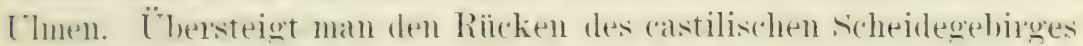

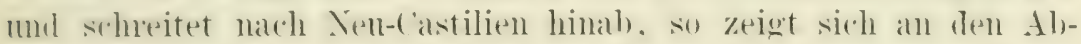
hängen dïmner Rasen mit zwiebelgewäd-hsen. An mbebanten Hügelhängen wäldst hier und da die busehige hermeseiche mol der Baden-

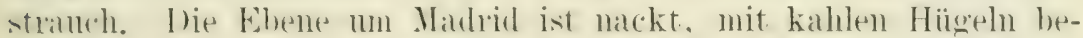

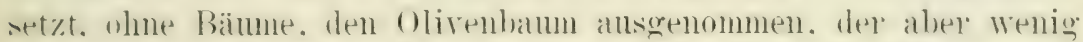

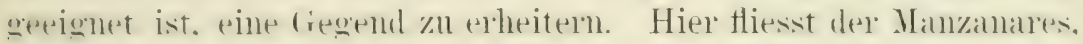

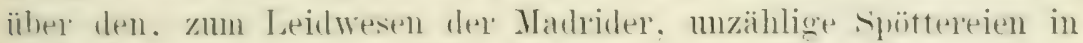

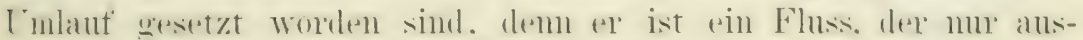

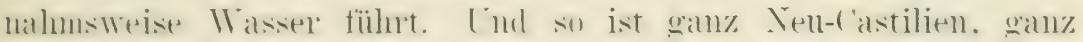

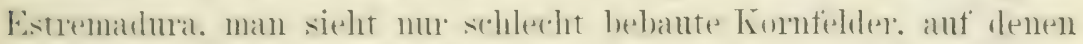

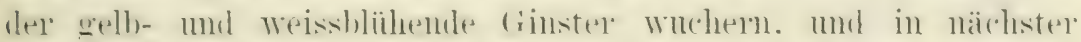

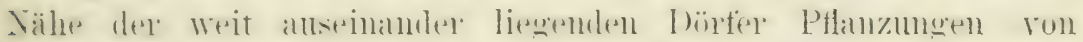

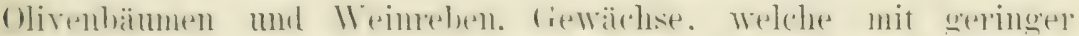

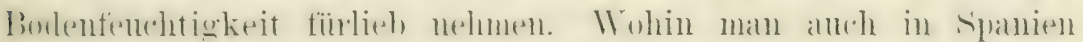

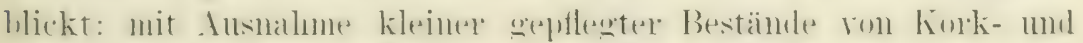

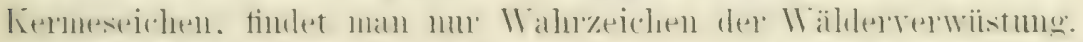

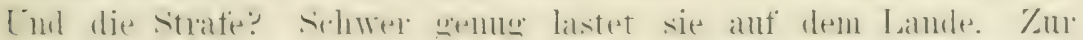

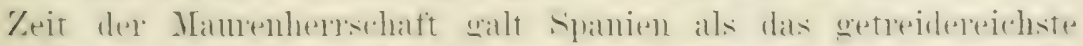

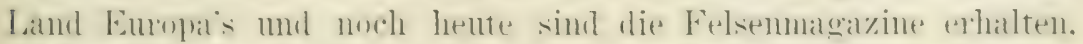

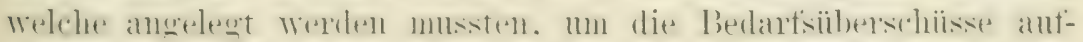

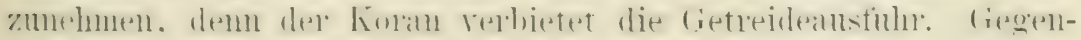

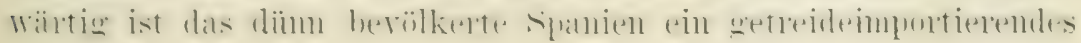




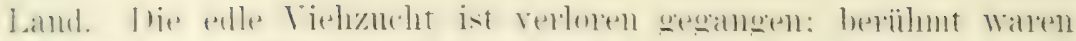

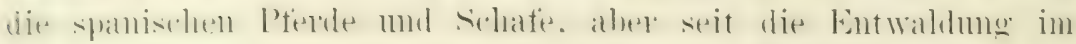

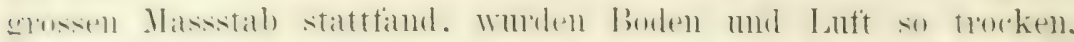

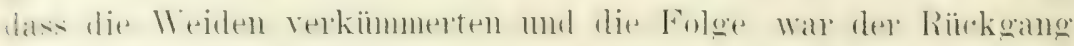
der Pferde- und schafizucht. An die Stelle des Pferdes is über-

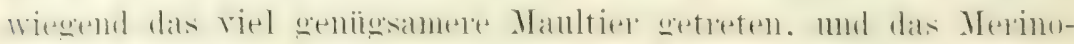

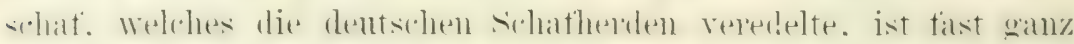

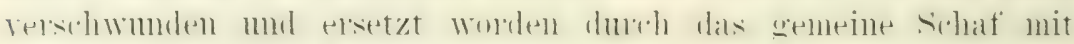

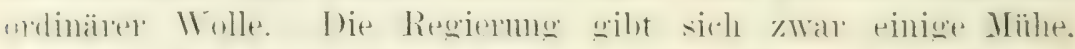

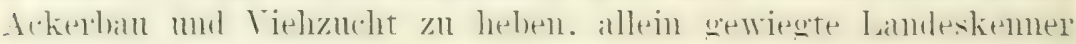

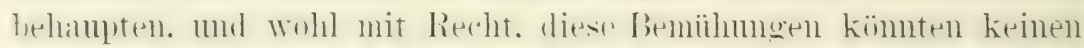

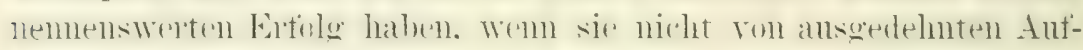
forstungen unterstiitzt wïrolen. Xorls fins: Syanien ist nicht allein

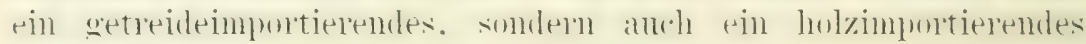
I.ind geworden.

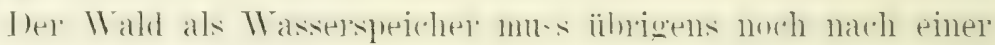

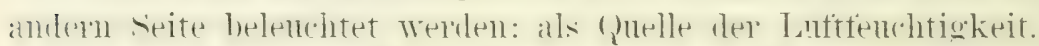

Wemn wir sagen, das Masser rerdmstet, so heisst das, es

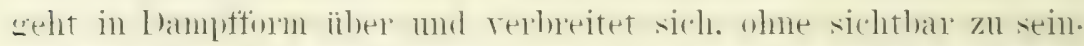

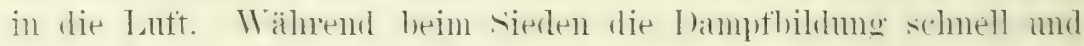

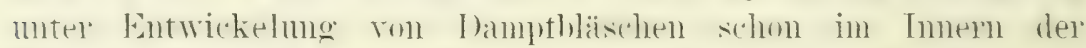

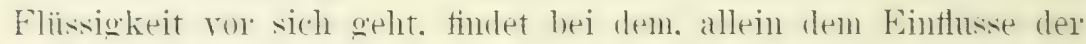

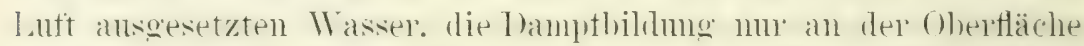

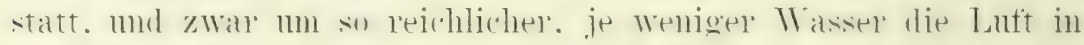

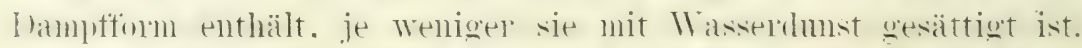

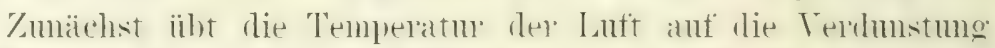

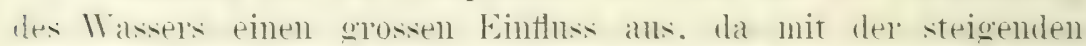

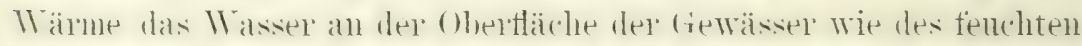
Borlens um so leichter verdunstet. Es muss also. unter sonst

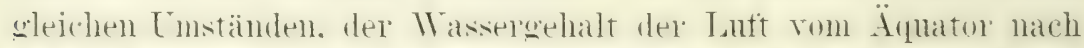
den Polen zu abnehmen. anch. Wenn mit dem Antonge der somme

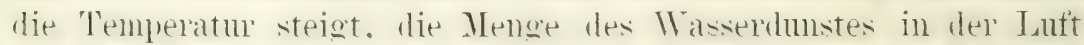
sich an Tage vermelnen. Ehenso sohwankt das Verhältnis in den

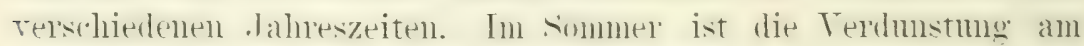
stähsten. särker ist sie in sommenschein wie im schatten. Ferner

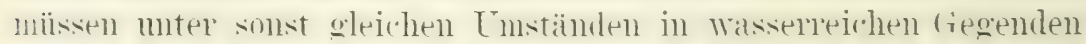

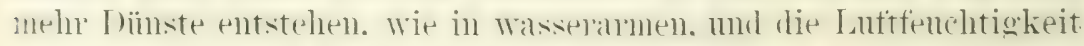

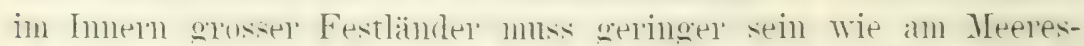

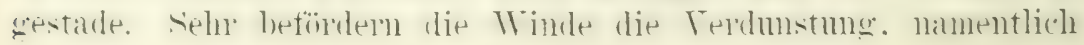




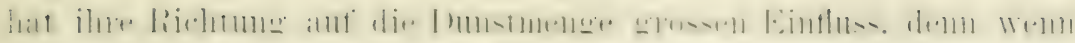

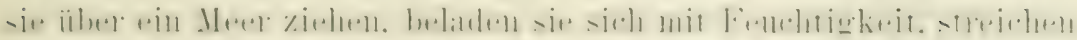

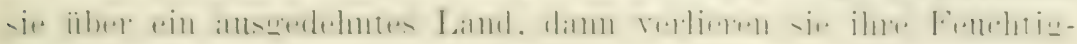
keit und werden trocken mol kalt.

Mithin steigen die meisten Diuste ant. wo lohe 'l'emperatur

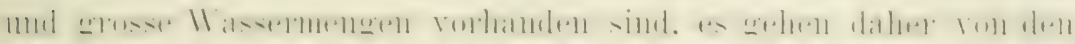

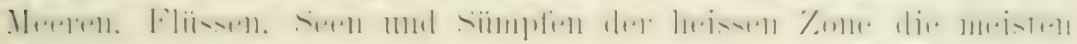
Diunste in die Luft über. Anch die bestandige Anwesenheit ron

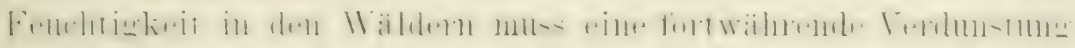

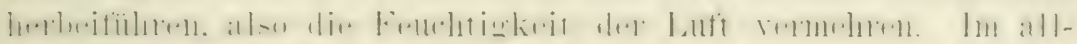

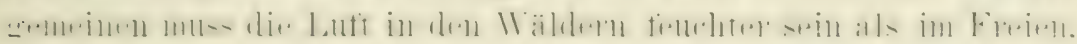
da dort das II assel nicht so solmell verdunsten kamm. demn es ist

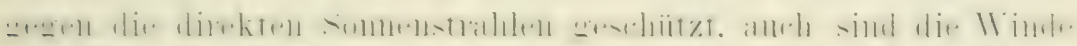

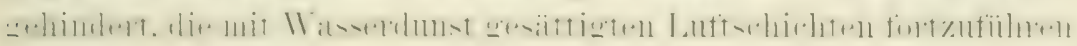
nund sie dumch trockene zu ersetzen.

Die Verolustung der vorlandenen Budenfenchtiokeit ist in-

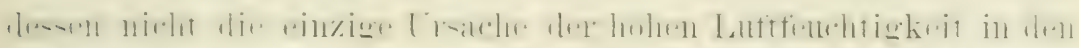

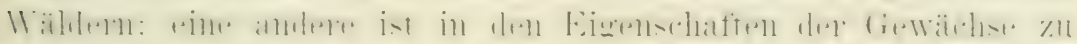

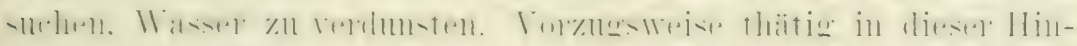

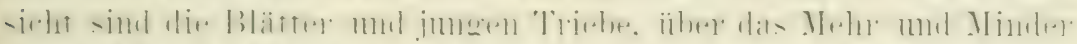

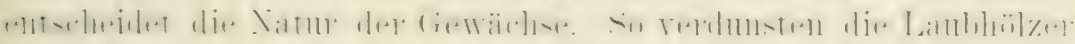
mehr Wassel wie die Sadelhïlzer. odel" in andern Worten: Jje

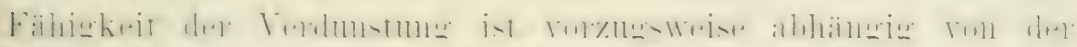

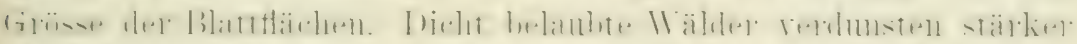

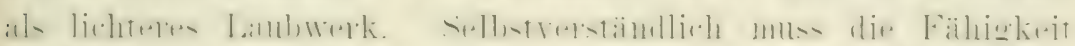

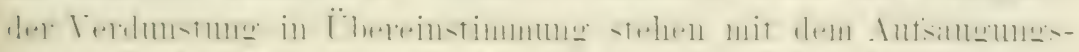

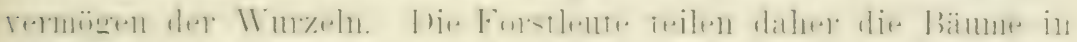

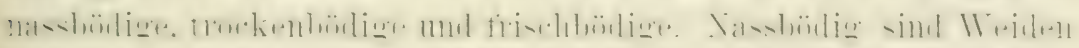

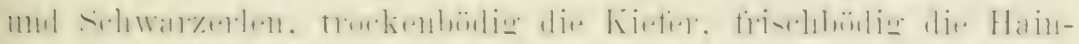

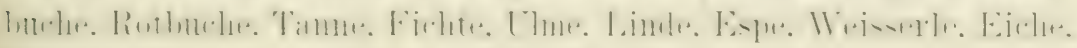
Papuel. Birke und Lärche. Sach Hartig verdunsten:

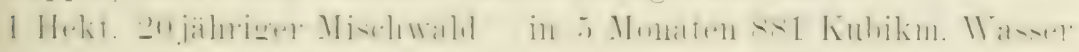

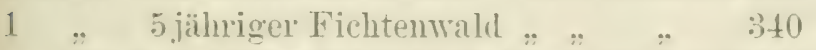

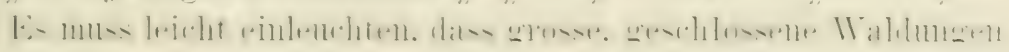
die Lutt einer Gegend fencht elhalten milssen. demn die in die

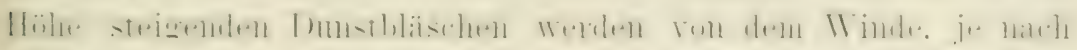

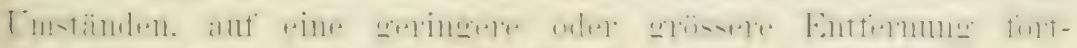

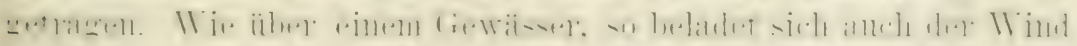

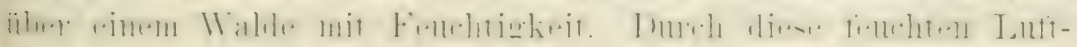




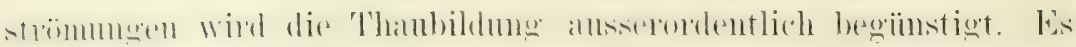

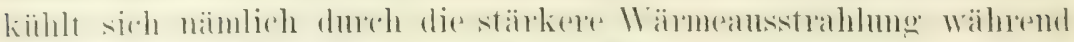

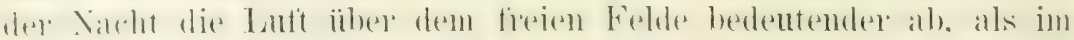

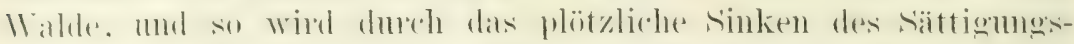
punktes rine Verdichtmeg rom Wassertropten bewirkt, die ats 'Than

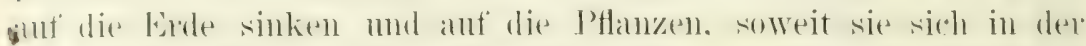

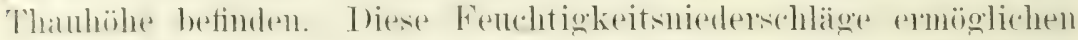

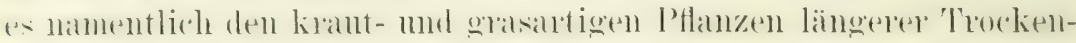

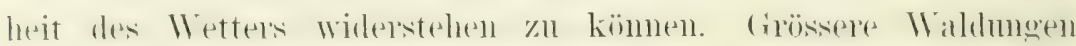

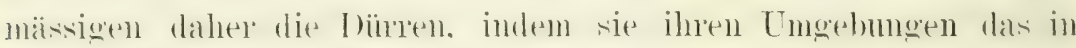
ihrem Schosse rerwahrte Wasser als Thau spenden.

lieser binfluss geht norh weiter. Wie oben nachorewiesen

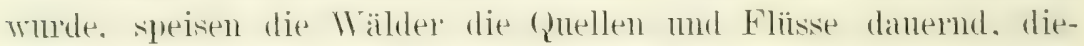
selhen kömnen daher anch mansqesetzt anf dem Laufe nach ilem

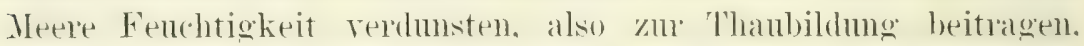
sie sind ferner jederzeit diensthar zur kïnstlichen Bewässerme del Felder und Gärten. sie bilden eine Tränke tür das Vieh und unterbrechen nicht die industrielle 'Thätigkeit. zu deren Hilfe sie heran-

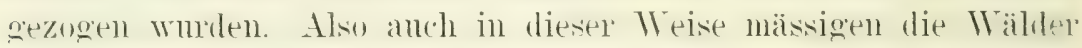
die Ibïren. Als Wasserspeicher leisten sie in der entgegengeseraten Richtumg katum mimler wichtige I)ienste: durch das berlentende Aufsangungstermögen ihrer Bodendecke. durch den mechanischen Triderstand. welden ihre stämme mond IIrzeln dem abfliessenden IV assere entgegensetzen. verhindern se die Teberschwemmung der Thäley und das Wegwaschen der Erdkitume von den Berohängen.

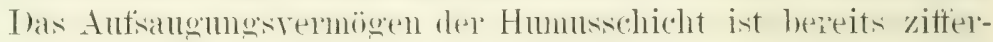
mässig dargelegt worden. doch ist hier noch daran zu erimern. dass

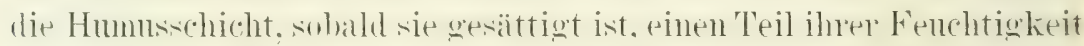
an den Boden abgibt und sirle damit zur weitern Aufiahme betähigt. Fallen stäkepe Regenmengen, als die Hummsehicht antsamgen kamm. so hindern die Stämme. das [nterhol\%, die Wromeh. das Moos und die vielen Unebenheiten des Bodens. welche in

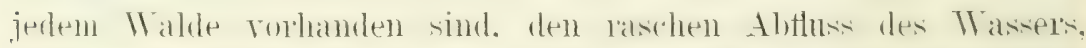
sie lassen es zu keinel staken strömung kommen, somblem teilen die Rimmen immer und immer wieder. so dass das Wasser die

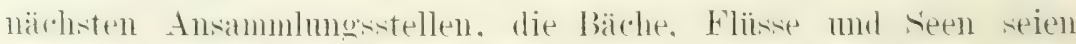
mögen, nur allmählich und gewaltlos erreichen kamm.

Die Provinz Brescia und die angrenzende Gegend der Provinz.

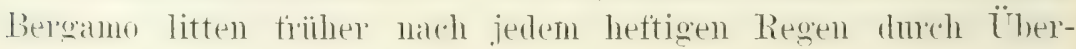




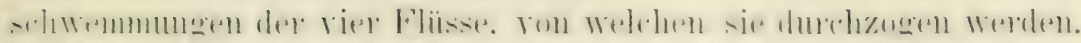

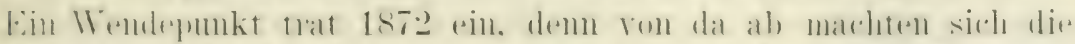

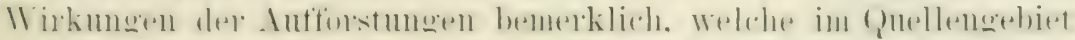

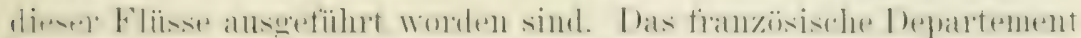

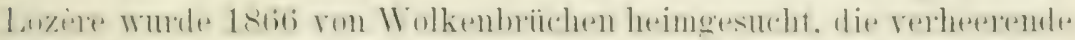

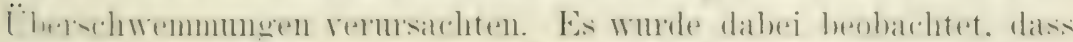

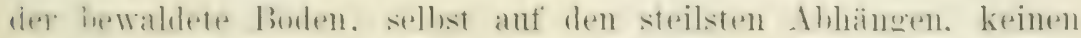

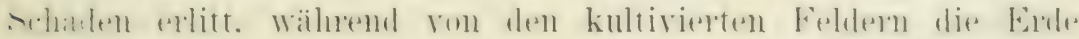

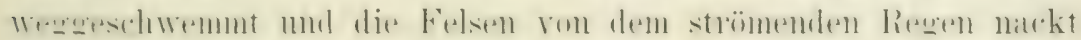
aelegt wurden.

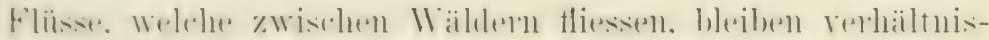

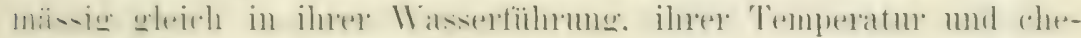
mis lex \%

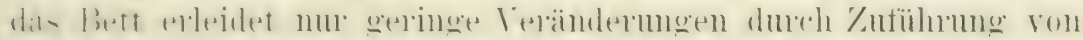

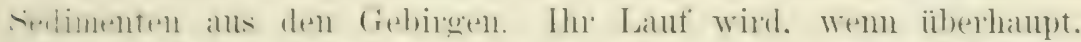

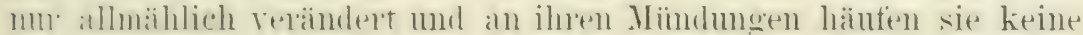

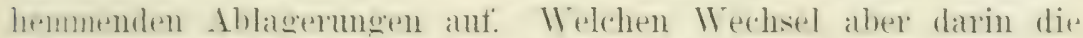

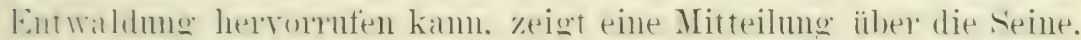

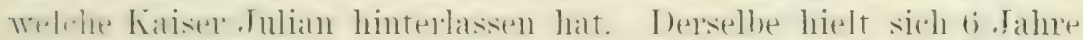

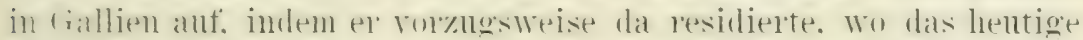
Paris steht. Ias war in 4. Jahmondert. zu einer Zeit also. wo

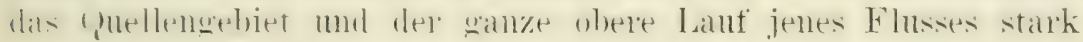
bewallet waren. Julian bemerkt, die Seine sei frei von Über-

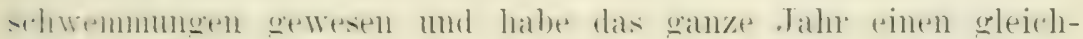

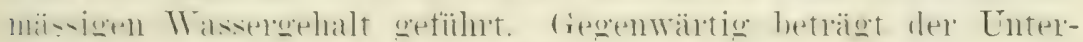

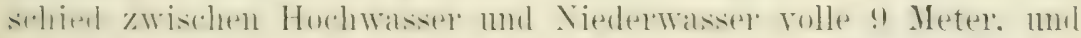

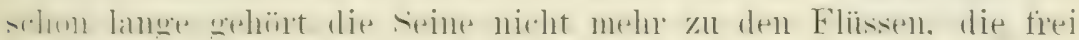
rom Übelschwemmungen sind.

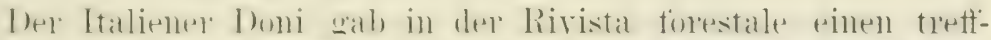

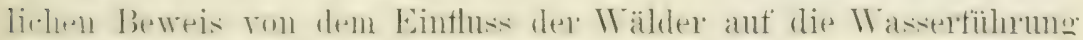
del Flïsse. Er sate: die Sestajone und die Lima sind zwei

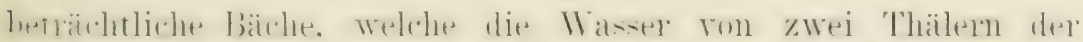

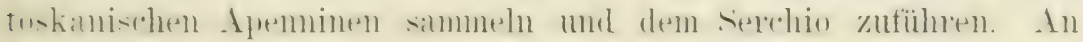

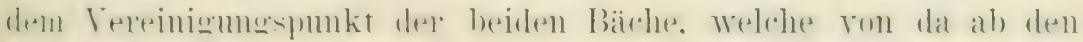

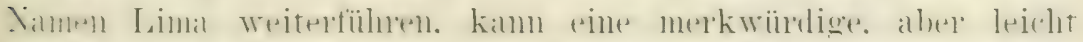

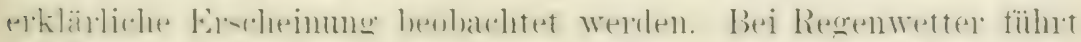

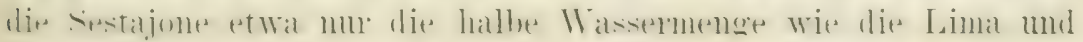

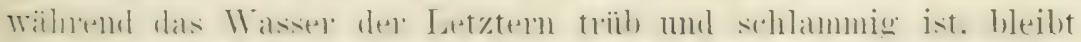

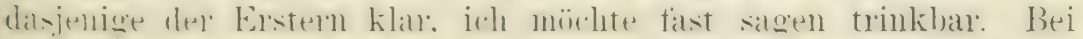




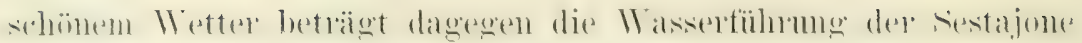

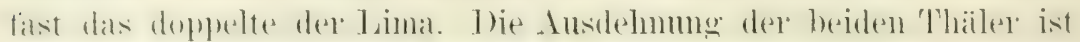

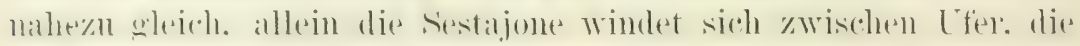

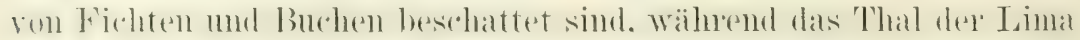

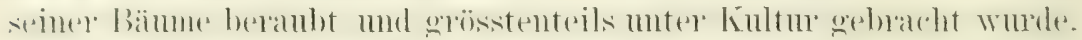

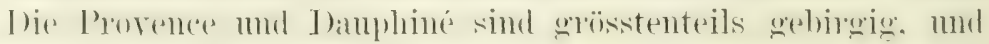

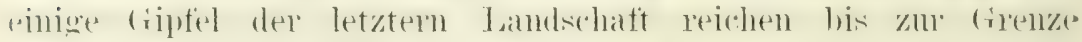
des ewigen sidneses. Die Hänge sind grösstenteils steil. also des

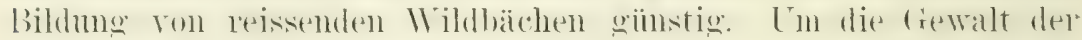

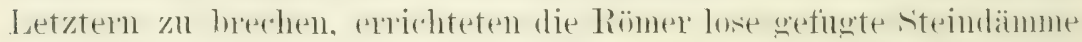

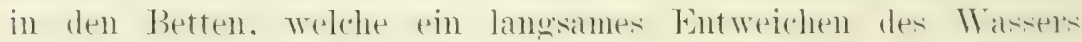
gestatteten und die mitgetïhrten gröberen sedimente anrïcklicelten. In einer suäterm zeit brachten die Kreuzfahrer. unter andern

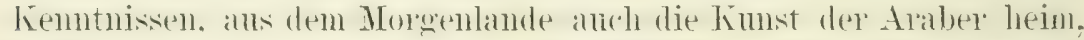
die Berogänge zu terassieren und mit Hülfe künstlichel Bewässermeg produktio zu machen. Die Wälder. Weldhe die Berge bedecktem.

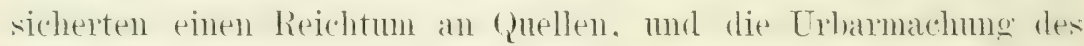

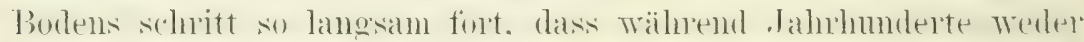
Holzmangel noch andere iible Folgen der Entwaldumg bemerkbar wholen. In ganzen Dittelalter Walen diese Provinzen stark he-

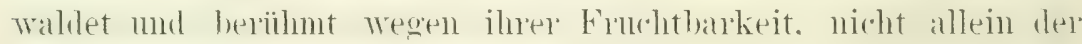
'Thäler, sondern auch der Berge.

Aus dem siebzehnten Jahrhmolert aber wird berichtet. dass

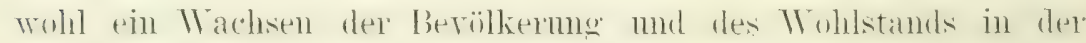

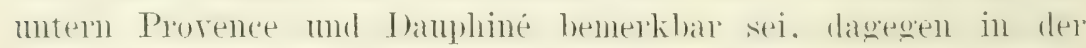

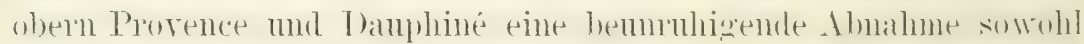

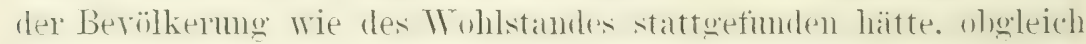
das Kulturland durch Rodumg rom Wäldern bedentemd anscentehnt

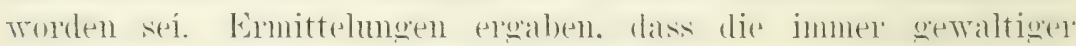
grewordenen Wildbäche mehr linturbolen wegreschwemmt mber mit sand mod Geröll beileckt hatten. als dureh die Rerlme ron

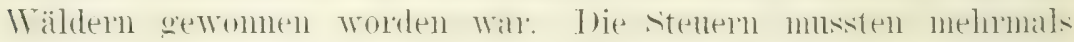

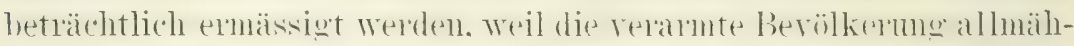
lich ilnen verwästeten Boden preisgal. An der Rhone und der Kï̈ste

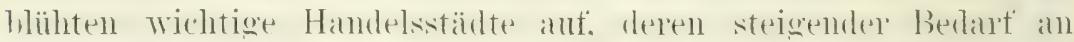

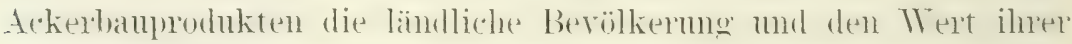
Ländereien hätte vermehnen mïssen, allein die Verwiistmogen in den

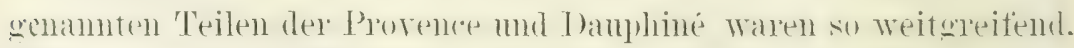
dass beträichtliche strecken vollständie entrïlkert womlens. 
Lm solche Zerstommgen begreiflich zu finden. muss man in Zahlen ror Angen laben. Welche Erdmassen ein Flus fortschremmen kamm. Del Po möge als Beispiel dienen. Plinius sigrt: Der Po. welcher keinem andern Flusse in der Raschheit -

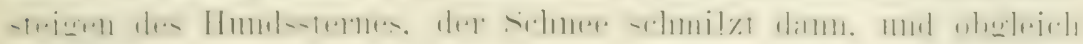
der Abfluss schmell ror sich greht. schwemmit er doch nichts rom

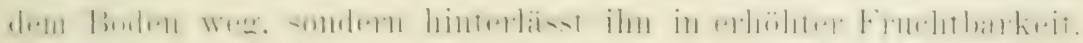

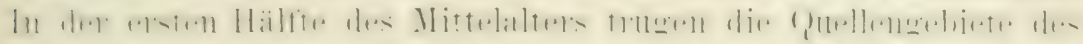

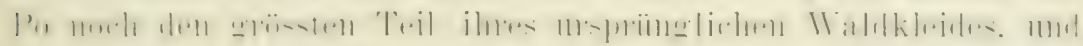

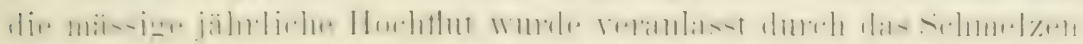

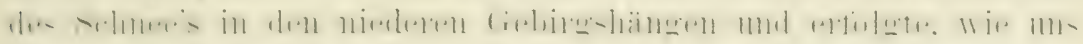
Cakso wissen läst. in Mai. In einem spätern Zeitalter fand eine

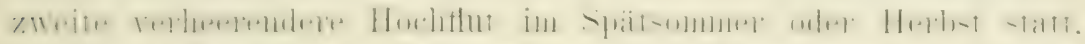

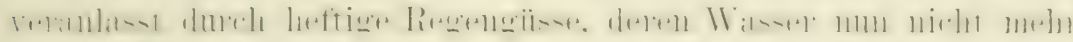

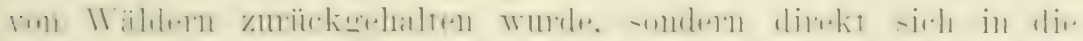
Zutlitsse des Po:s ergossen. Indessen bedurfte es bis etwa 1780

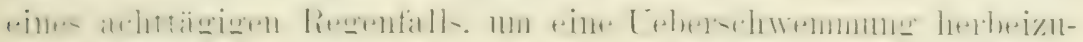

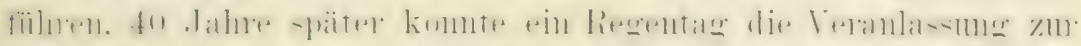

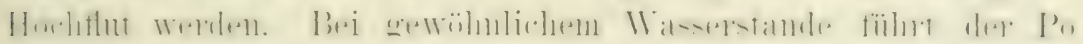

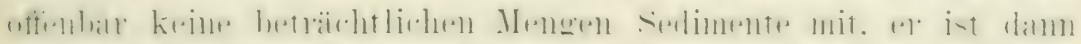
rerlältnismässig hlar. Anders aber wem er bis zur Hochflut

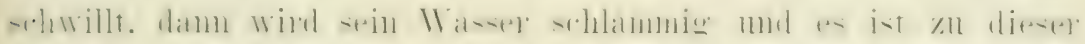

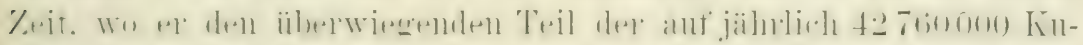

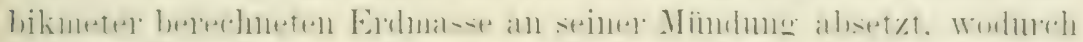

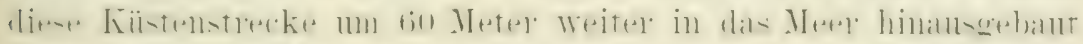

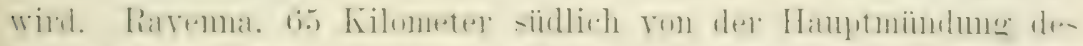

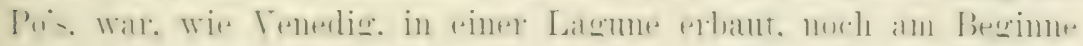

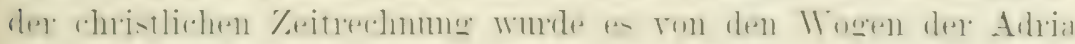

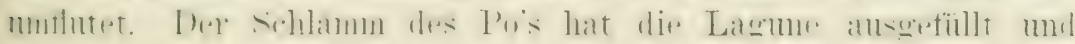

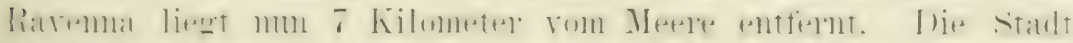

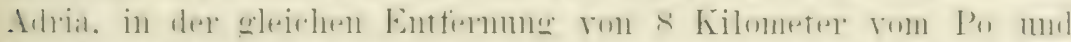

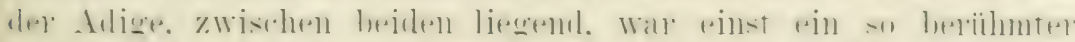

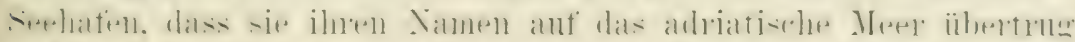

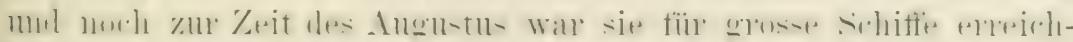

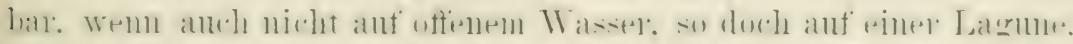

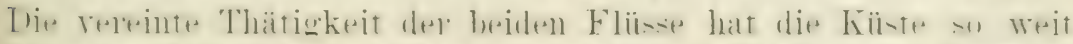

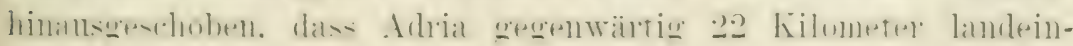
wïlts liegt. 
Nächst dem Po fülnt die Adige die gewaltigsten Erdmassen

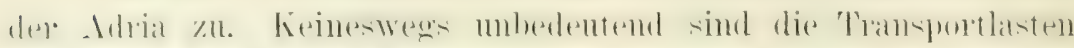

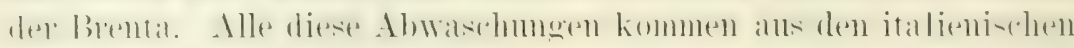

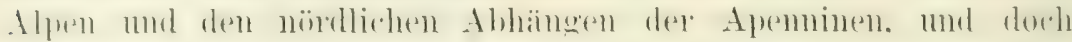

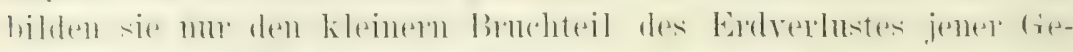

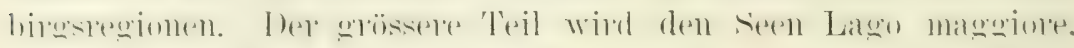

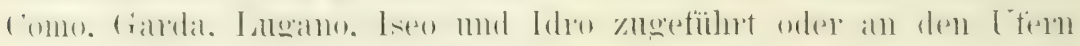

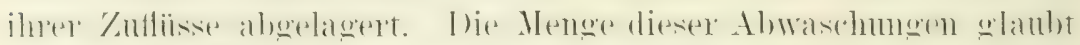

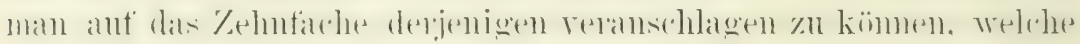

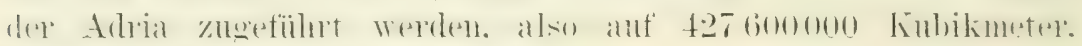
immer im Laufe eines Jahres gemeint.

Die Ablagerungen an der Mündme des Po's in ihrer gegen-

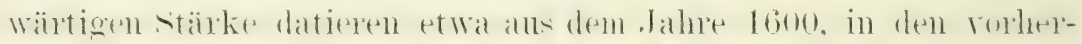

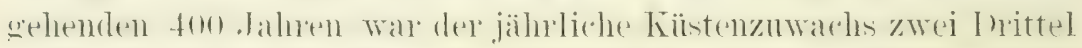

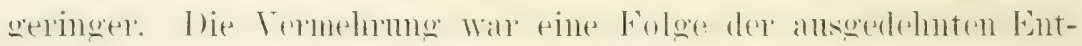

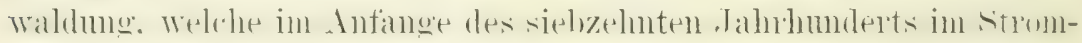

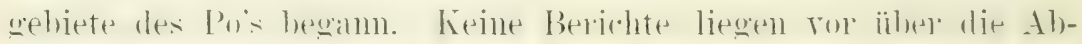

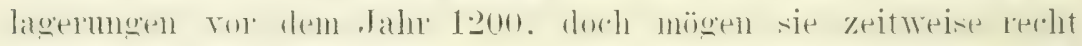
beträchtlich gewesen sein. Denn auch in den 'Tagen des alten Roms ist riel gegen die Wälder gesindigt worden, so wurlen

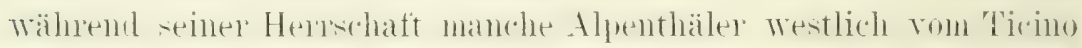

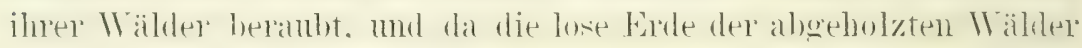
leicht wegesechwemmt wird, so mag damals der Po in den der

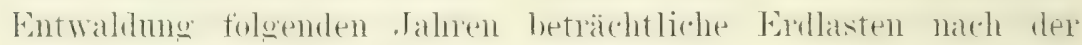

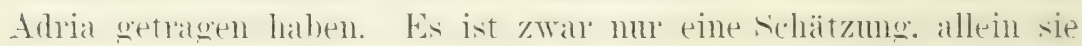
ist gut begründet. dass in den letzten 2000 dahren in dem strom-

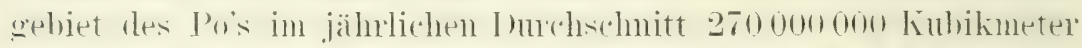

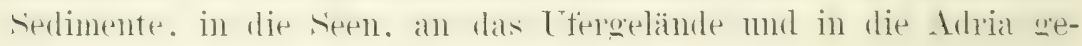
schwemmt worden sind, mithin im (iesant 540000000000 Kubikmeter. Iniese Masse wörde geniigen das stromgebiet des Pos. Weldes his Ponte Lagosemo - dem P'mkte des letzten Zufluses - 10938200

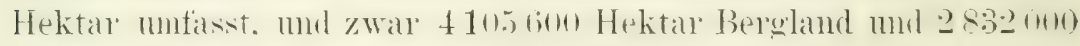
Hektar Eikene. mit einer estwa 14 Meter tiefen Frdschicht zu hedecken.

\section{Der Einfluss des Waldes auf das Kima.}

Fs mag. in Anbetracht der verhältnismässig geringen Flär.hen. welche die Wälder auf dem Erdball bedecken. fraglich er-cheinen. (1) sie die klimatisehen Verhälnisse der Fude in inner liesamtheit 


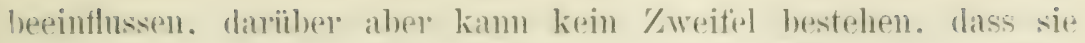
einen berlentenden örtlichen Einfluss auf das Kilima. unter Umständen sogar anf eine weite bintfernung hin. ausiuben. Wiirde

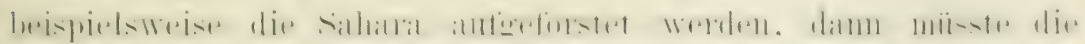

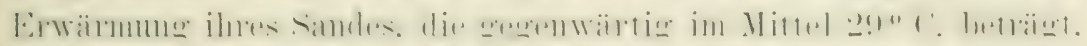

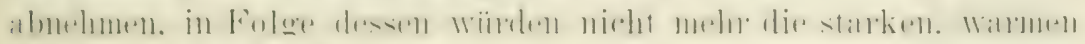

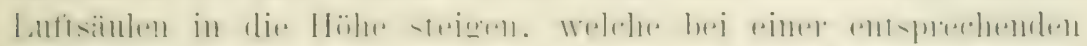

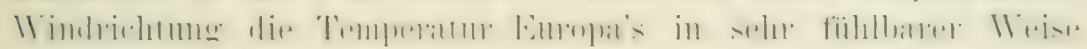
whiihen.

Die 'Temperatur wird vom den 11 äldern vorzugsweise durch 5 Lisichen beeinflusit:

durch die fortwilneme Verdunstung:

dureh die Hemmmg der Wämeansstrihlmg des Bodens mittels des Lambdaches:

durch die reminderte Besommmo der Errde:

duch den mechanischen Widerstand. Welchen die Wälder dem IVinde entregensetzen;

durch die Wärmeansstrahlumg der Bämme.

Eine Folge der Verdunstumg des Wasser's und der Anwesen-

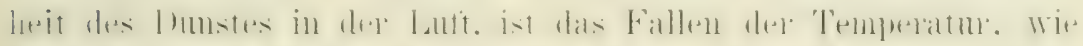
dem

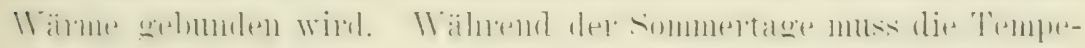
ratur im IValde kühler sein. wie im freien Felde. Weil die ror-

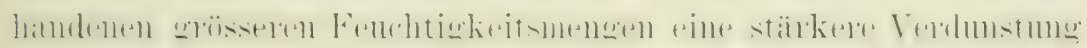

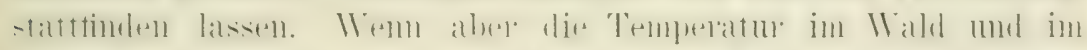

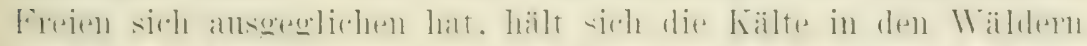

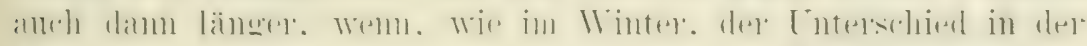

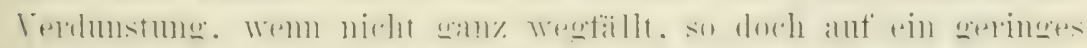

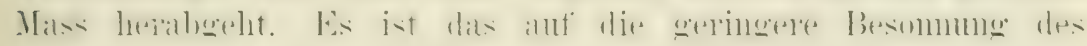

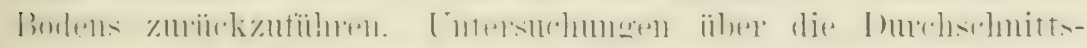

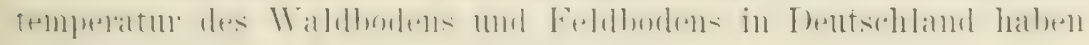
zit den folgenden Ergebnissen gefiihrt:

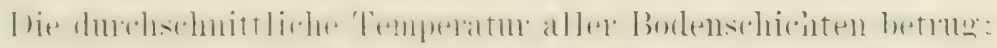

\begin{tabular}{|c|c|c|c|}
\hline & Im Freien & Im II ald & Unterschied \\
\hline im Friilhling & $5.84^{\circ}(\div$ & $4.250 \mathrm{C}$ & $1.59^{\circ} \mathrm{C} \vdots$ \\
\hline im sommer & 13.44 & 10.23 .. & $3.21 \quad .$. \\
\hline im Herbst & $8.07 .$. & $6.85 \quad$. & $1.22 \quad$ \\
\hline m Winter & $2.16 \ldots$ & $2.1+\ldots$ & 0.02 \\
\hline
\end{tabular}


Selbstroständlich mïssen in wärmelen orler kïlteren Tündern.

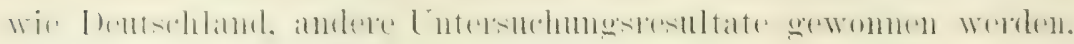

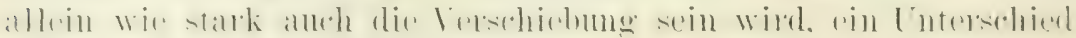
ist als moweifelhatit volauszusetzen.

In den Lanbwaldungen ist der Unterschied zwischen der

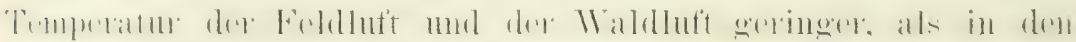

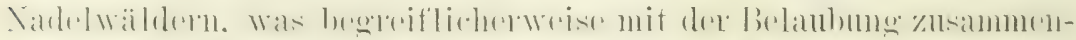

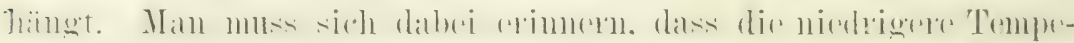

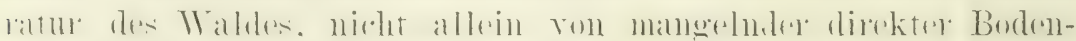

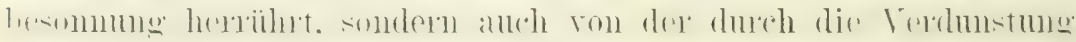

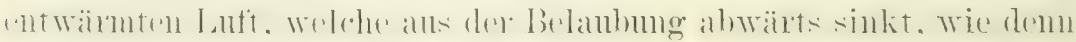

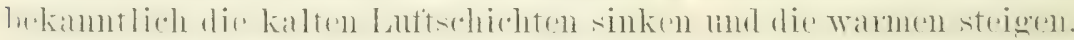

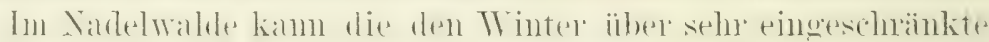

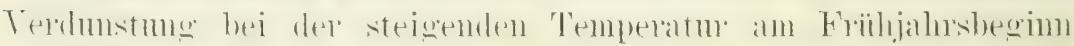
alsbald wieder anheben. weil el seine Terdunstungsorgane den Winter äber nicht rerloren hat. Der Lambwald dagegen kamu ron der \%eit. wo er seine Blaitter verliert. bis er sie erneuert, nicht

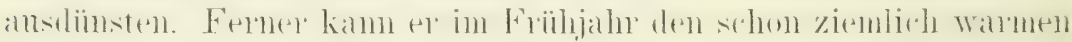

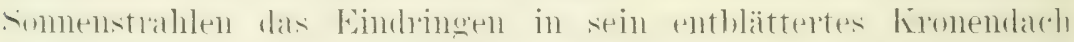

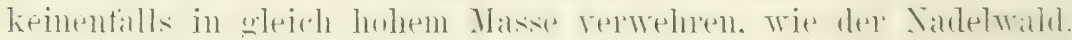

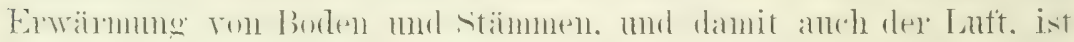

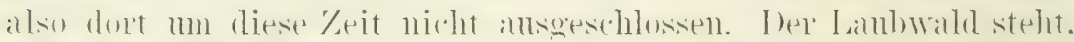

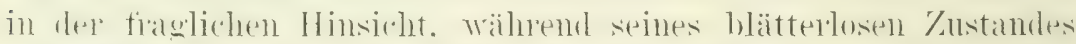

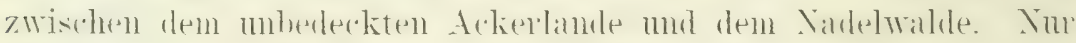

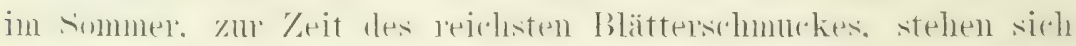

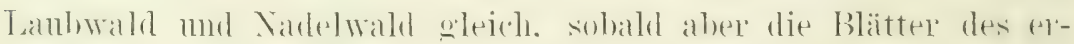
steren zu welken anfangen, begimnt die meh" und mehr sich ermeiternde Kluft.

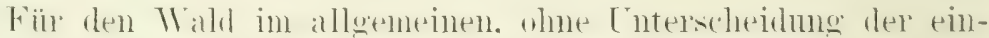

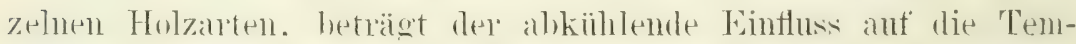

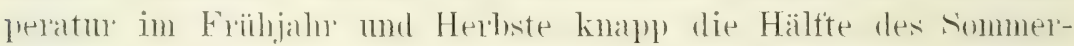
einflusses. Welder riermal so stark ist. wie der winterliche Temperatumemterschied zwischen der Feld- mol Waldluft.

Anster in maisiger Abkühlmng der 'T'emperatur bestelit eint

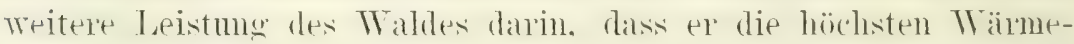
crate (bei 'Tag) mol die niedrigsten (bei Vacht) absolewäleht, mit amben Tronten die Temperatuextreme mäsiget. Thabei ist zu he-

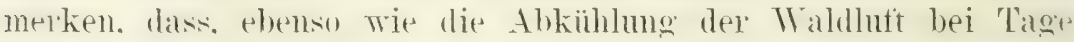
mumeriscle viel bedentender ist. als ihre nächtliche Fröammog. 


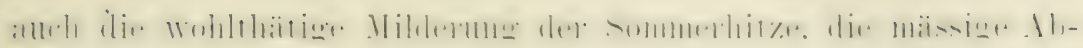
schwiichung der Winterkiilte iiberstejot.

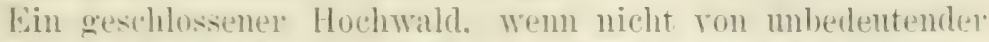

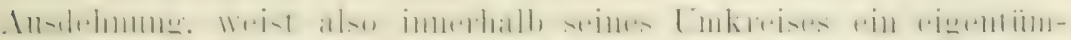
liches Klima ant. W' gleicht mit seinem Jinfluss ant die 'Temperatum einem Meere. wemn schon die Giviude der temperatur-

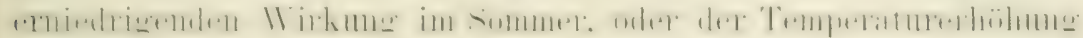

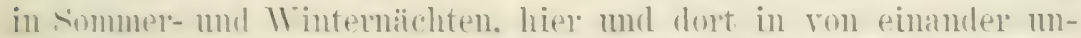

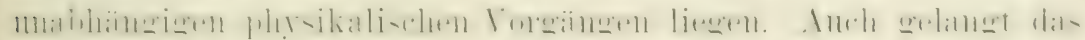

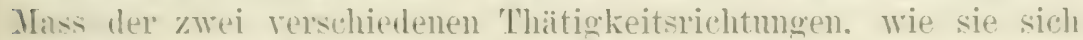

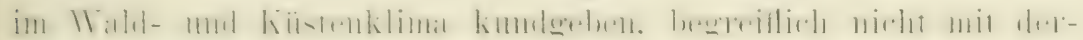

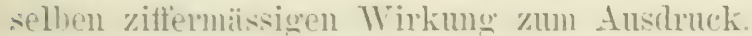

colange das erfonderliche Kahlemmaterial nicht zur Vexfiigung.

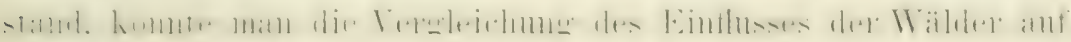

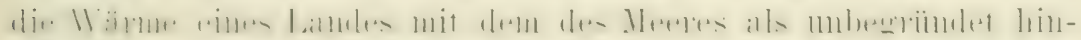
stellen. In msern 'l'agen ist das nicht meln möglich. Hente. "ro

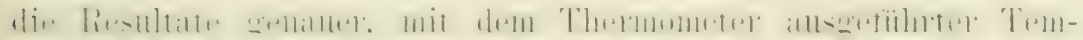

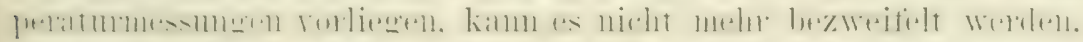

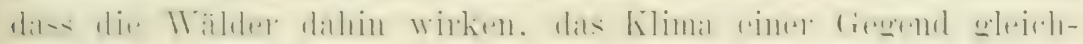
mäsign zu machen. ohne sie wirrlen die T'emperatmextreme griissel seill.

Bewaldung mässigt somach das schrofte Festlandklima einel

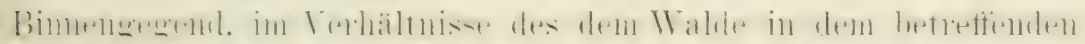

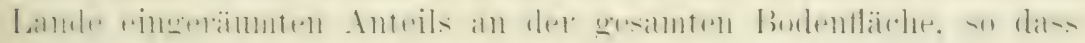

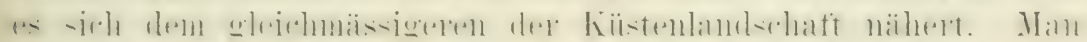

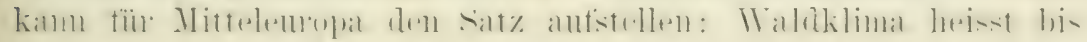
211 einem gewissen Grade Seeklima.

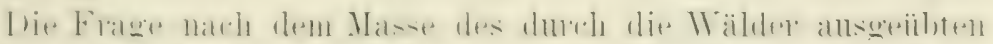

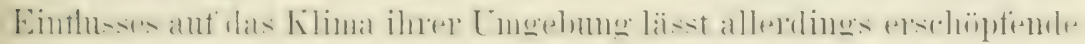

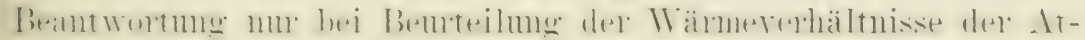

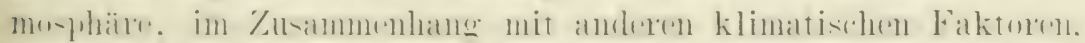

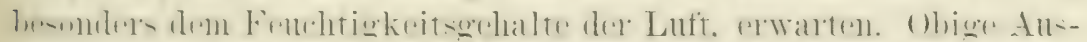

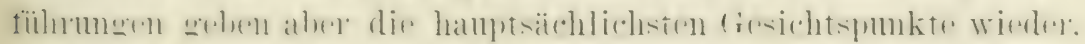

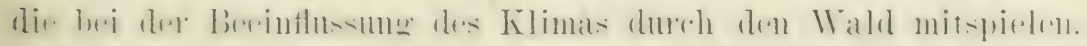

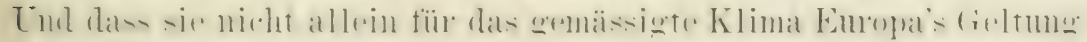

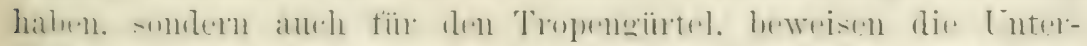

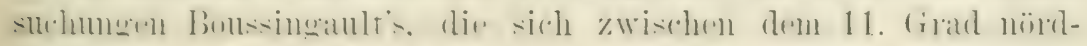

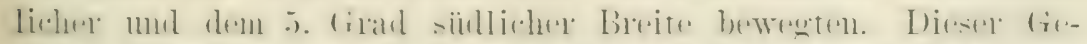

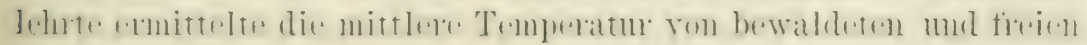




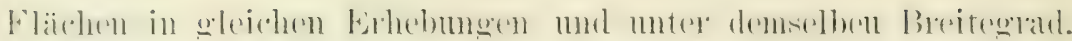

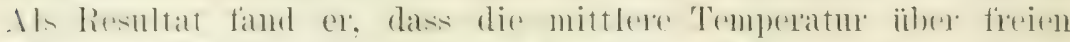

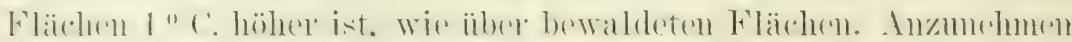

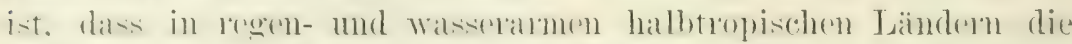

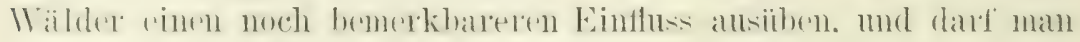

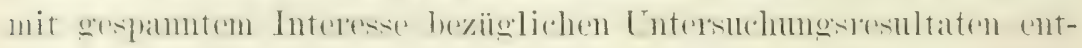

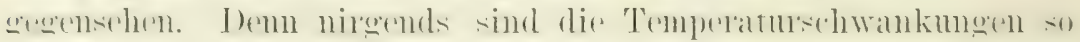

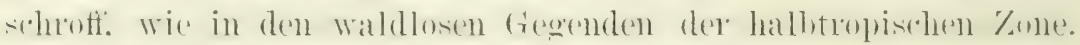

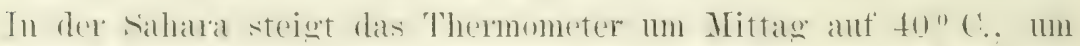

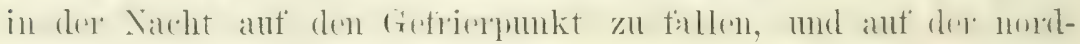
indischen Ebene tolget nicht selten rince Tageswälne von 3.5" ('.

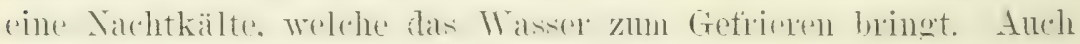

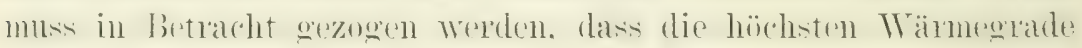

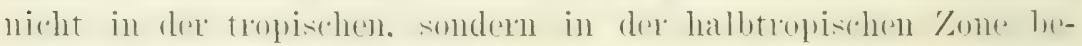

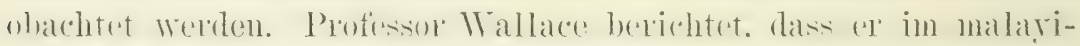

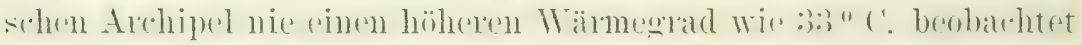

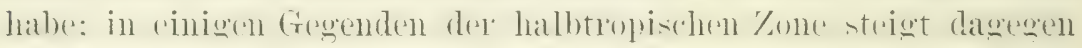

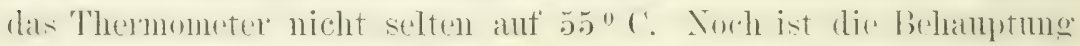

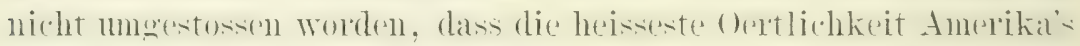
an der Mündung des Colorado in den Golf ron Kalifornicu zu suchen sei.

Am untern Laufe dieses Flusses, in Arizona, liegt Fort Tuma,

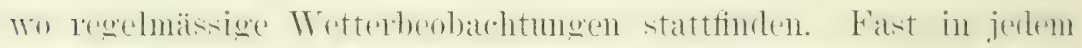
sommer wird von da für wenige Tage rin Thermemeterstand ron

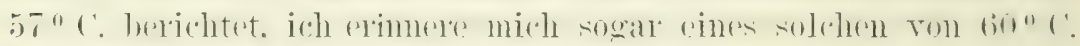

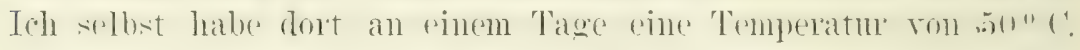
erlebt und denke heute noch mit Schander'n daran.

In Asien liegt die wärmste Gegend am persischen Golf, also ebenfalls in der habbtopischen Zone. Thert steigert sich die

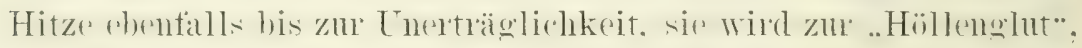
wie Reisende bexichtert haben. Es dart dabri nicht äbersehen

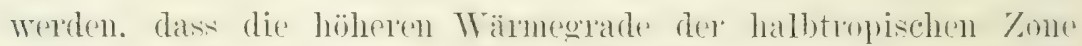

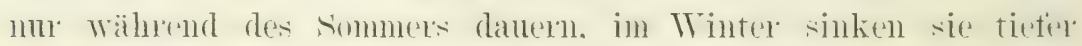
wie diejenion der tropischen Zone. I)iese Erschedume wird allerdings vorzugsweise durch stärkeren Regentall im Tropengintel

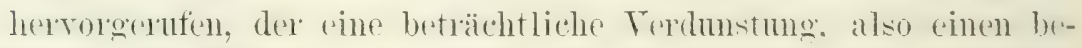
dentenderen Wärmererbranch. wie in der halbtropischen zome herdingt. allein wesentlich mitwirkend sind anch die ansqedehuten. ïppigen, tropischen Wälder, dureh eme Thätigkeit. die bereits "r- 


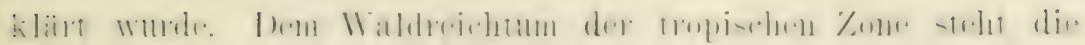

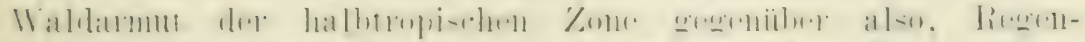

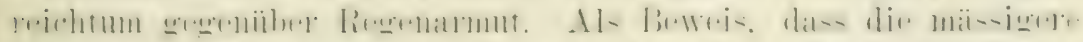

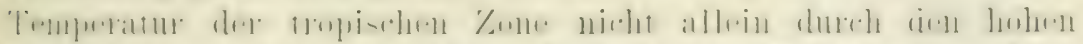

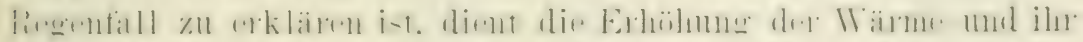

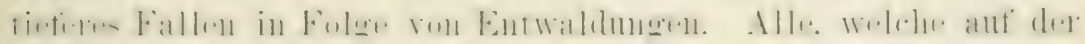

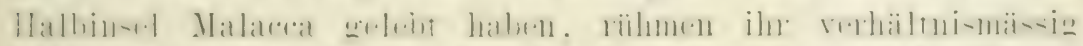

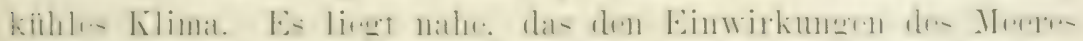

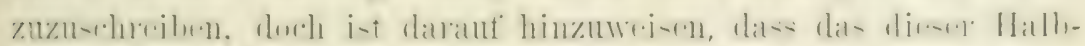

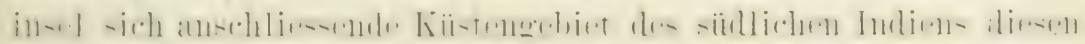

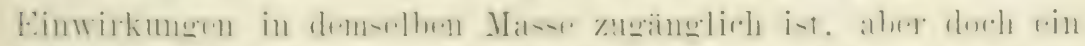

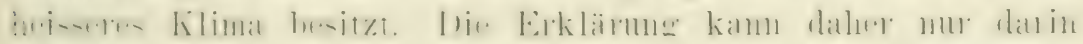

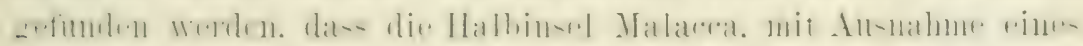

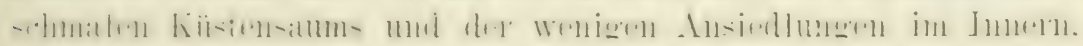

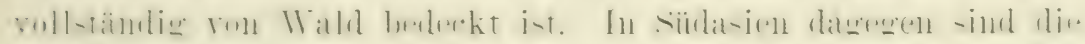

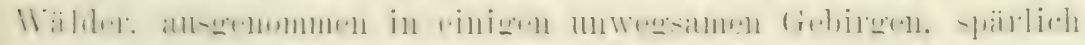

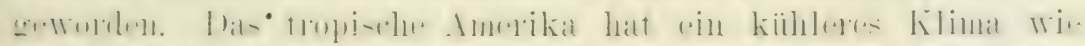

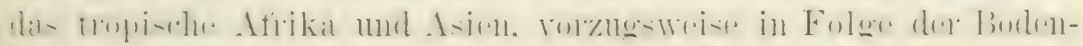

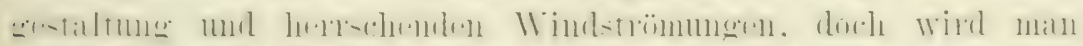

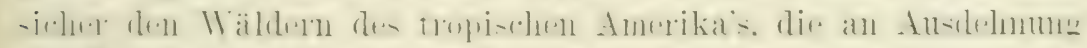

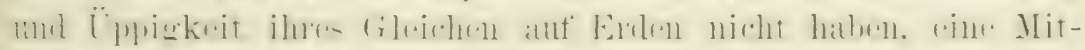
wirkung zusprechen müssen.

Die Beweisfïhrung wird unterstiitzt, wemn wir nach den

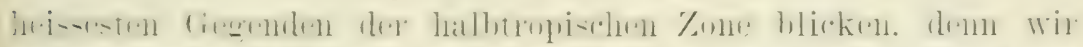

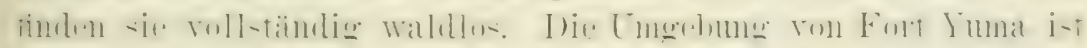

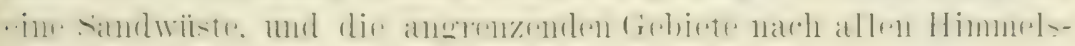

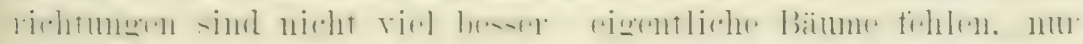

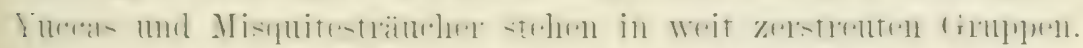

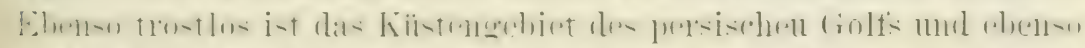

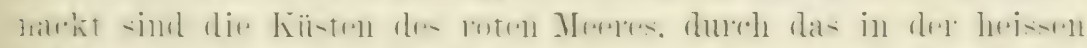

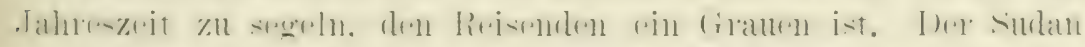

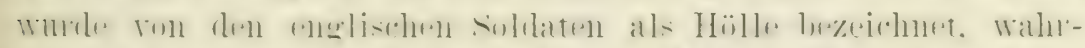

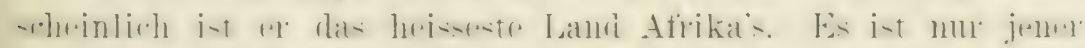

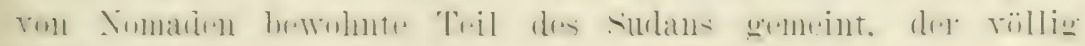
walilos ist.

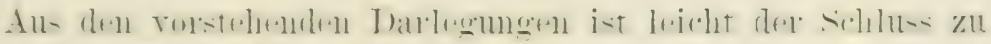

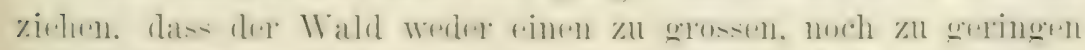

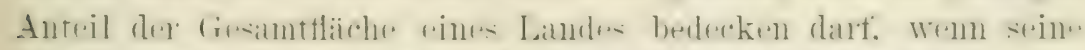

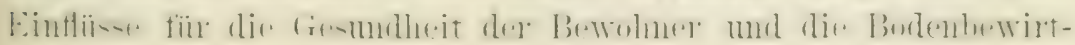




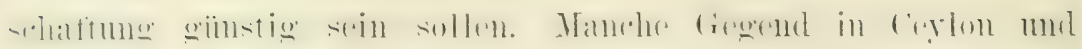
Indien. welche als „Grab des weissen Mannes“ verrufen war:

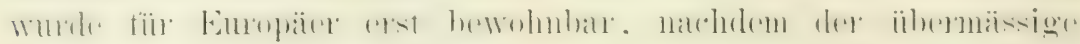

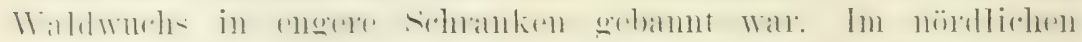
Oregon war, so lange es ein munterbrochener Wald bedeckte.

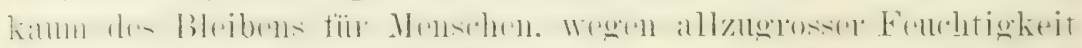
des Bodens und der Luft, das führte auch zu dem Spottnamen

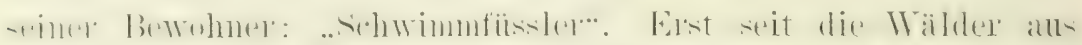

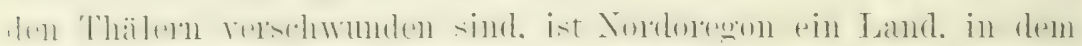

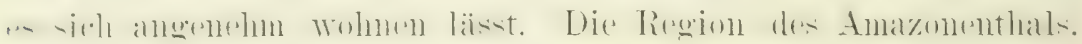

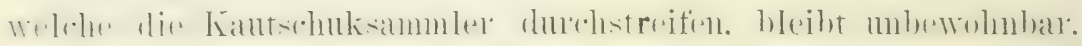
so lange sich dort ein munterbrochener Urwald dehnt. Selbst

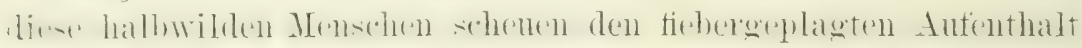

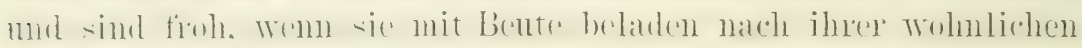

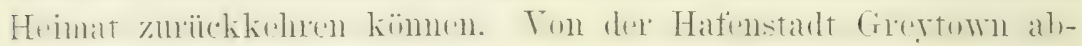

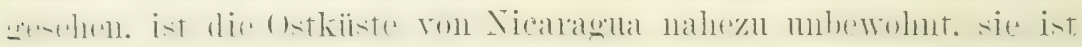
menschenarm, aber wald- und regenreich. Auch hier ist es nur

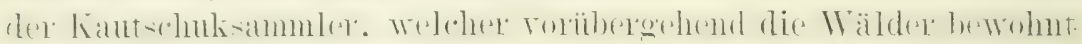

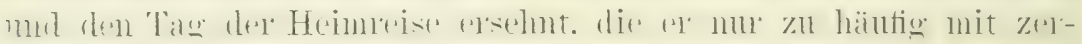
riitteter Gesundheit antreten muss.

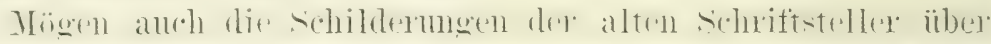

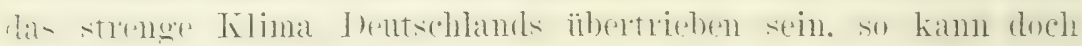
nicht bezweifelt werden. dass das alte Germanien mit seinen

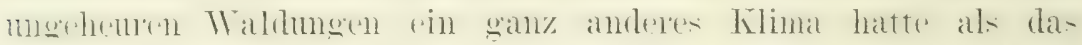

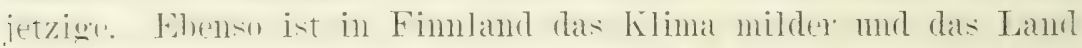

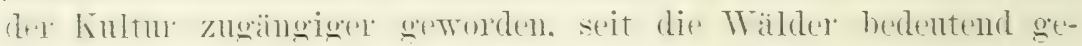

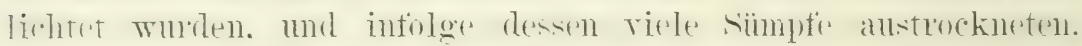
Amblelseds sind dureh masslose Encwaldungen schwere klimatische

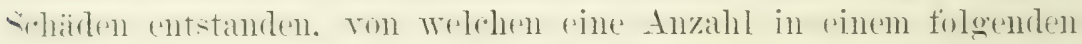
Abschnitt angefïhrt werden soll.

Detr Einflus des Waldes ant die Abiöhlung der Temperatur

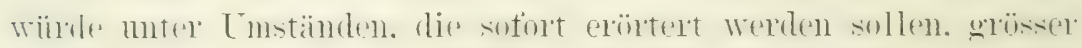

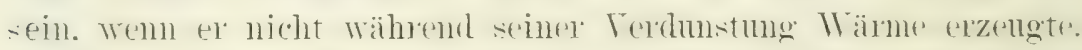
Der Bamn erzengt durchs seine Lebensthätigkeit Wärme in seinem

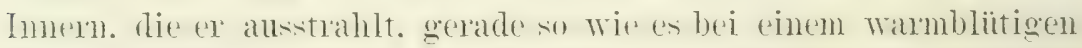
Tijere dere Fall ist. Dureh die Anwesenheit voll einem halhen Intzend Fïhe in einem stalle wird die Temperatur in demselben rluch Wärmeansstrahlung dieser 'Tiere erhöht. ebenso whöht vine fruple [Bäume, wemn anch vie]ledeht den simnen nicht wahl'nehmhar. 


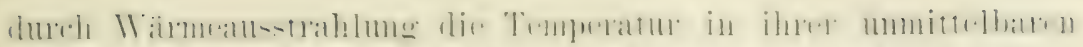

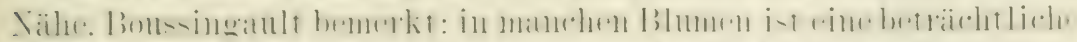
II worden. In gevissen Alumen stieg' die 'T'mperatur ant $\neq 0$ bis

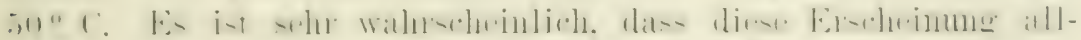

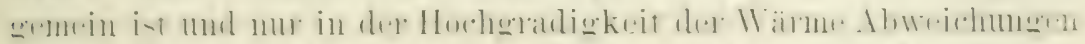

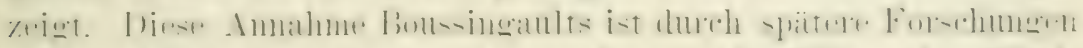

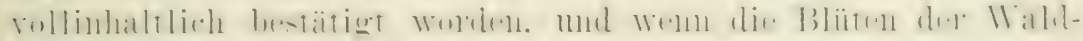

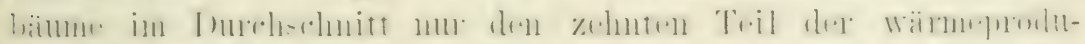

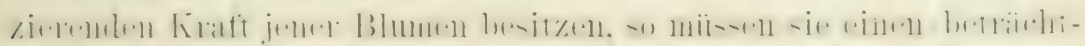

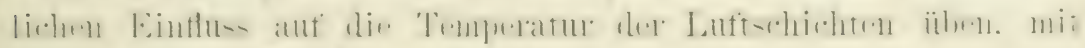
welchen sie in Berïhnung kommen.

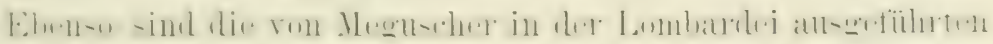

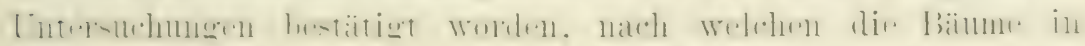

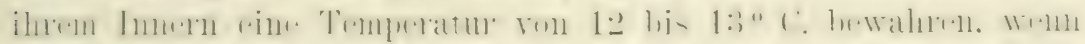

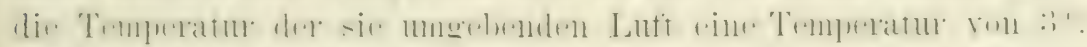

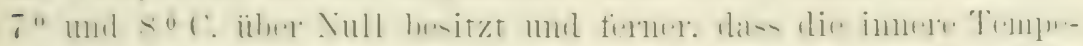

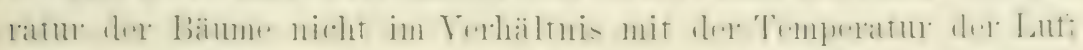

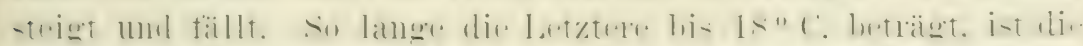

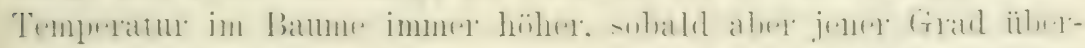

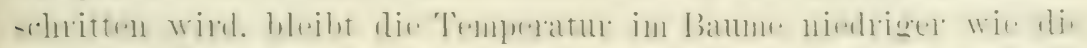

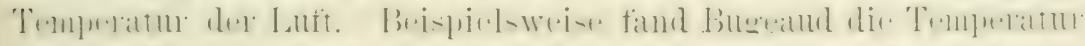

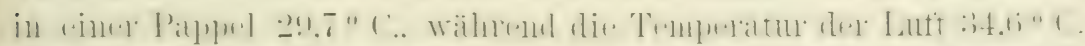

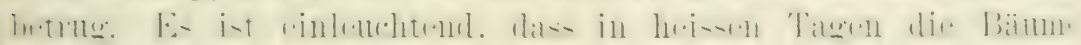

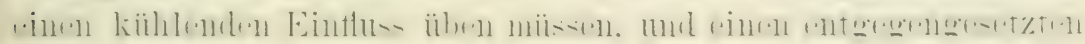

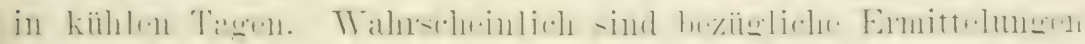

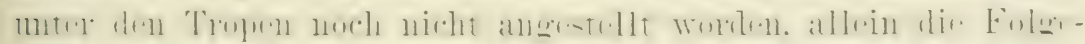

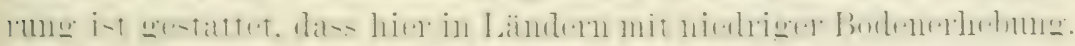

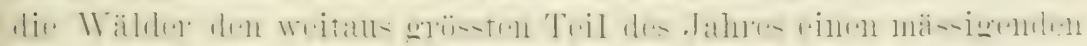

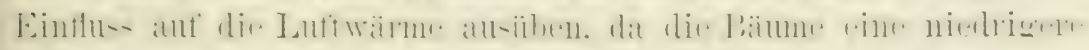

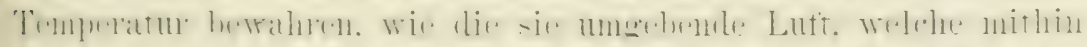

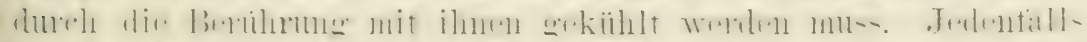

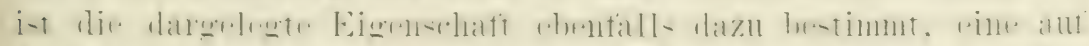

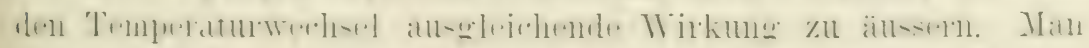

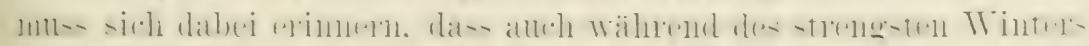

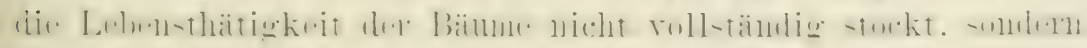

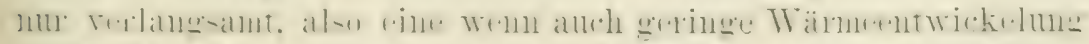

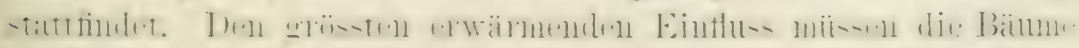

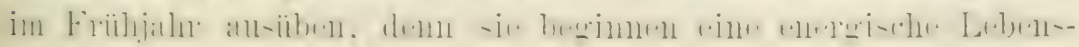




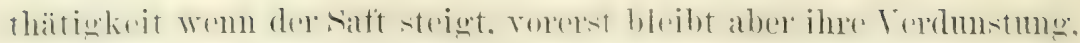

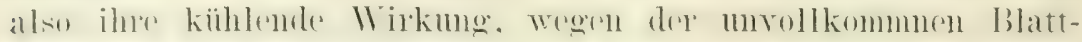

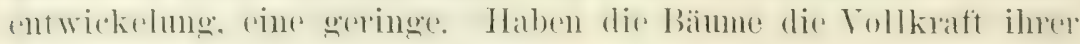

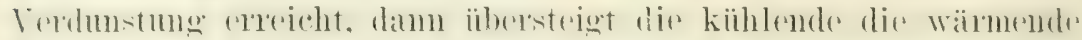

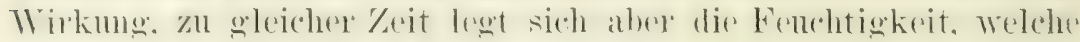

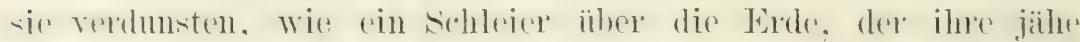

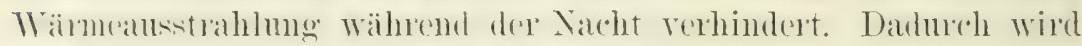

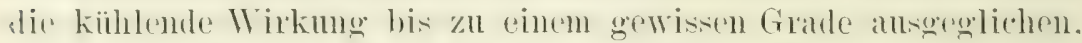

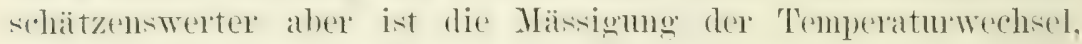

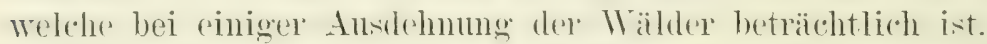

I) temperaturkïhlenden Einflusie der Wälder steht rin temperaturerhöhender entgegen. dex meines Erachtens noch nicht genug gew üdigt und in die wissmschaftichen Untersuchmgen hereingezogen worden ist. Ich meine den mechanischen Widerstand. Welchen die Wäldex den Winden entgegensetzen. Die Luft in den Wäldern ist nahezu ruhig mol bewegt sich nur. Wenu ïrtlicher Temperaturechsel die spezitische sechwere ihrer Atome ändert. Daher ist oft eine gïnzliche Wiudstille in einem Walde. wem in der angrenzenden freien Lambehatt ein heftiges stmm wiitet. Und während auf dem Felde der Schall in der Nähe

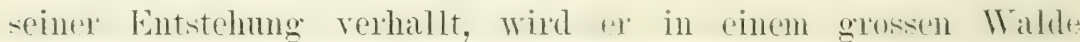
weithin fortgetragen, wats zwar nicht allschliestich, aber rorzug:Weise durch die Luftruhe zu arklären ist. Als Luterstiutzung ist die Abwesenheit von Gerånsch zu betrachten. Je dichter der Mald ist, namentlich mit je mehr Interholz er i)estockt ist. desto antfallender ist die Wrirkung der Windhemmumg. und zugleich der

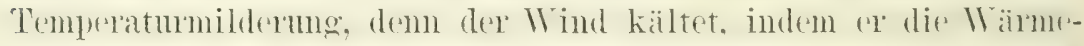
allsstrahlungen dex Lebewesen rasch enttiihnt und durch kïhlere Luft ersetzt. Der .. Wärmemantel". Welcher bei Luftrule jedes Lebewesen umgibt, kimm sich während des Windes nicht bilden.

Yiemand kann diesen Einfluss unbeachtet lassen, der an einem kïhlen. windigen Tage vom treien Folde in den Wald tritt. Recht bezedohnend ist oin sprichwort der schweden: dex Wald ist des armen Mammes . Tacke. E- ist wesentlich del Nonden. wo

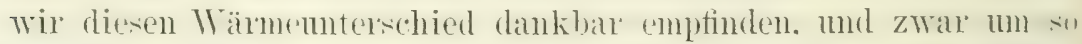
mehr. je näher wir der arktischen Region rücken. Fon den mannigfachen Beobachtungen, die in kalten Ländern von dem trmperatumildernden Einfluse der Wälder gemacht worden sind. diirfte keine beweiskrätiger sein. wie die, von welchen die Loco- 


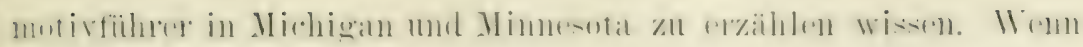
-ie während kaltex 'Tage von der Prärie in einen grossen

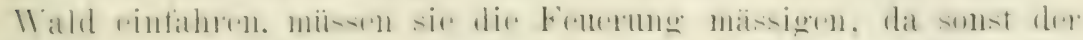

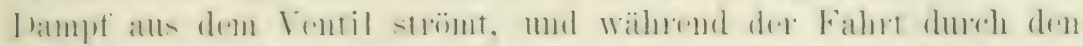

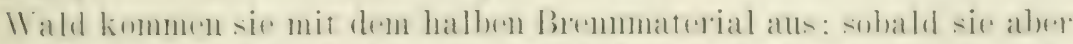

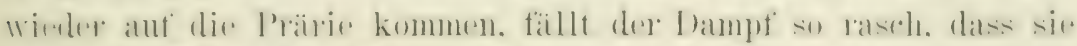

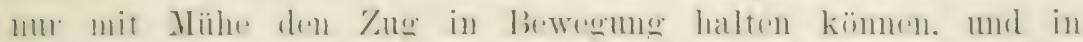

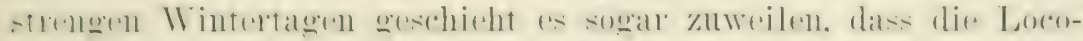

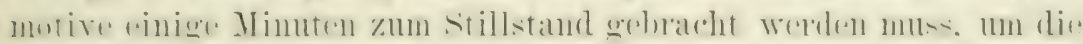

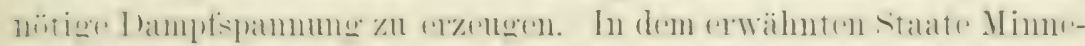

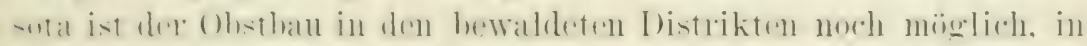

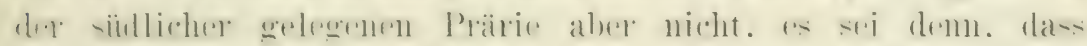

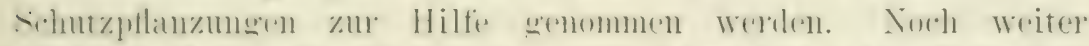

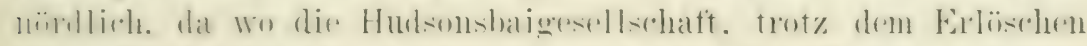

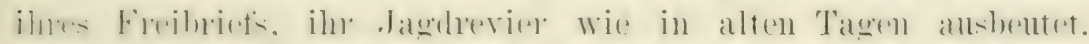

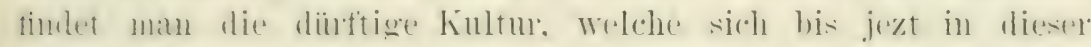

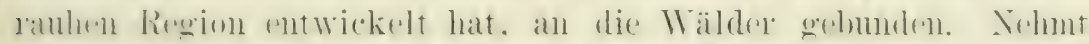
diese weg und es bleibt eine menschenleere Wildnis.

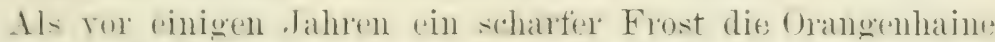

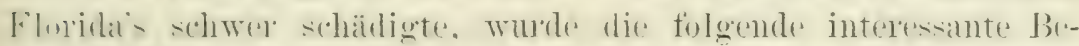

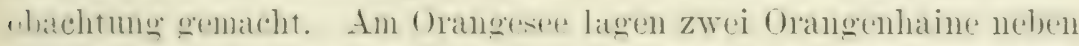

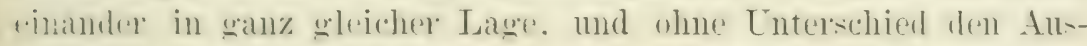

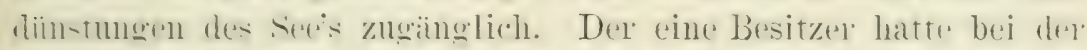

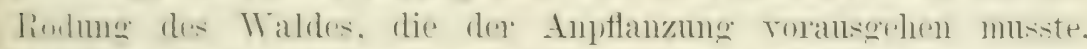

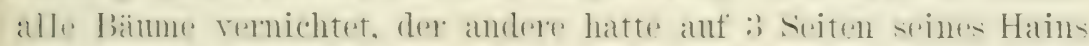

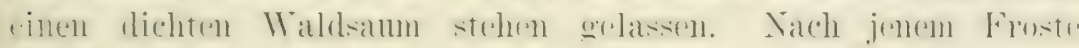

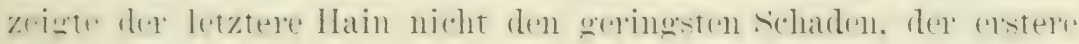

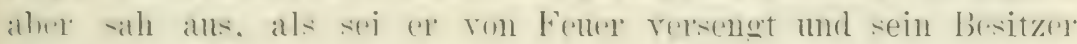

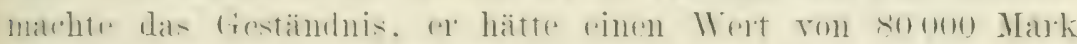

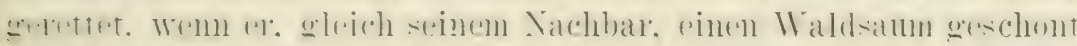

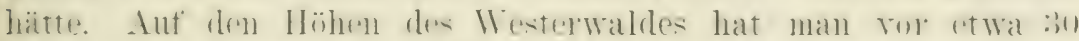

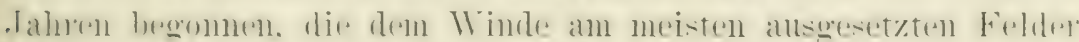

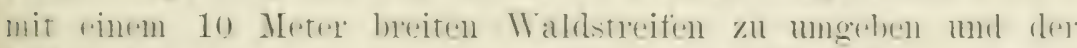

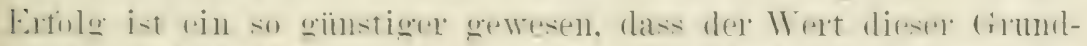

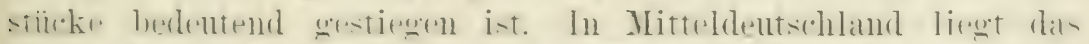

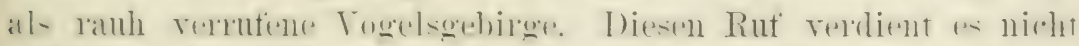

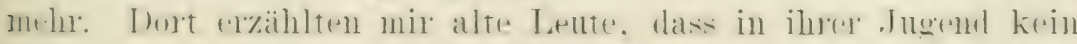

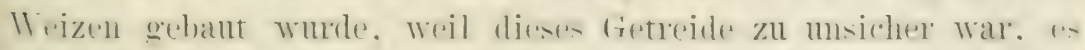

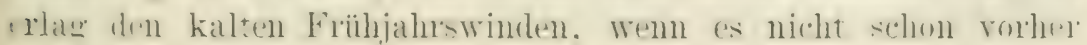




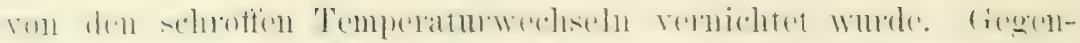

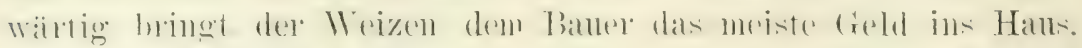

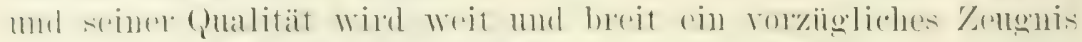

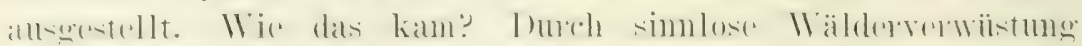

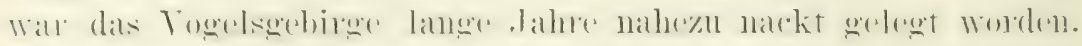

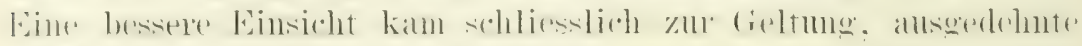

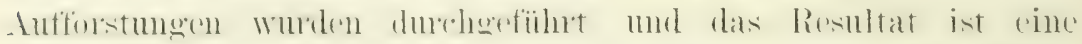

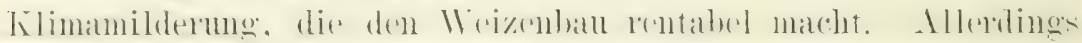

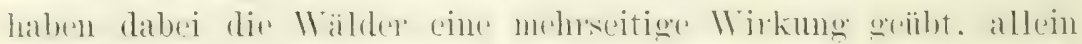

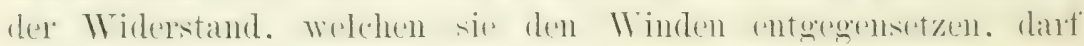
gerade in diesem Falle nicht unterschätzt werden.

Die Ebene von Cran im Departement Bouches-du-Rhône war

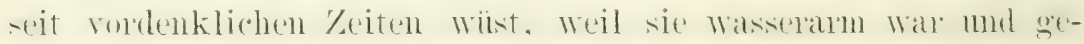

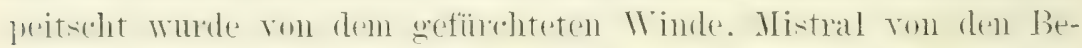

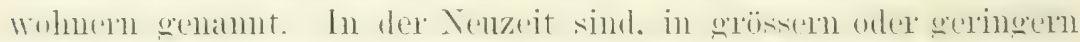

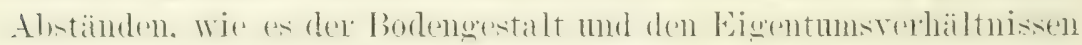

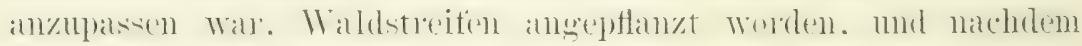

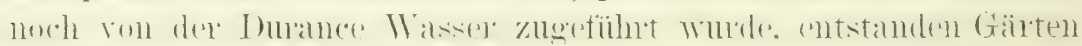
und Äcker mit üppig gedeihenden Nutzg'ewächsen.

In Italien ist bemerkt worden, dass seit der Entwaldung der

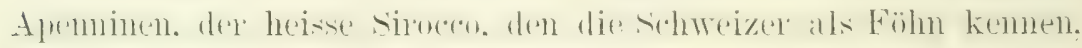

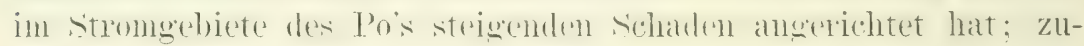

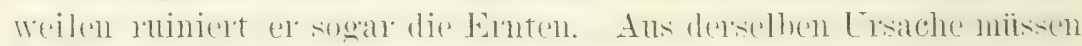

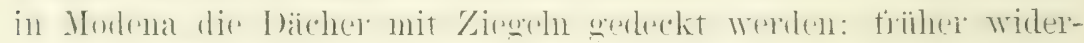

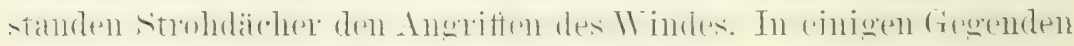

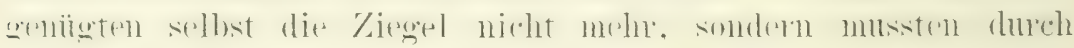
Steinplatten ersetzt werden. Nahe Porto bei Ravenna stand ein

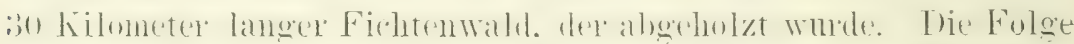

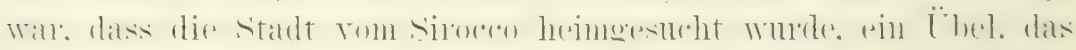

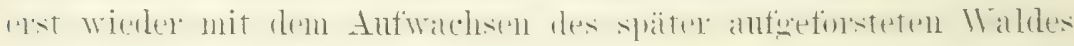
allmählich rerschwand.

In der schelde, Antwerpen gegenïber, dehnte sich frïher

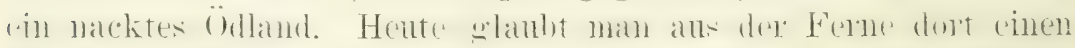

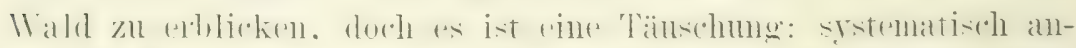

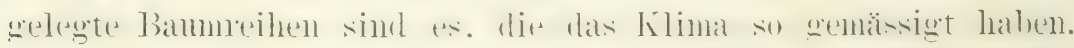

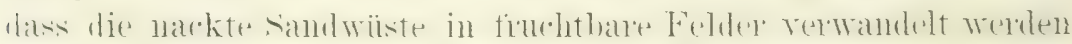
komnte. Wälrend der rom Meere kommende Wind die Wipfel

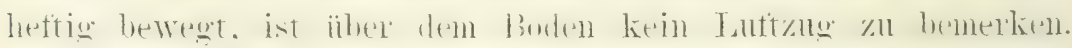

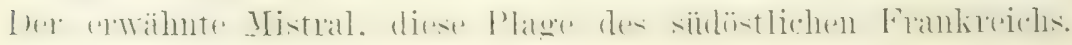


soll erst entstanden sein, als zur Zeit der römischen Herrschaft

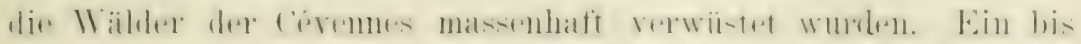

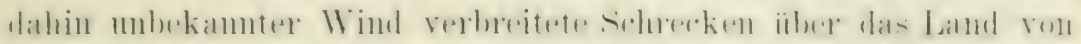

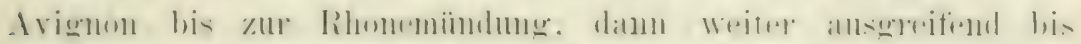

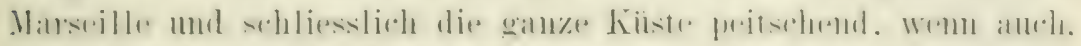

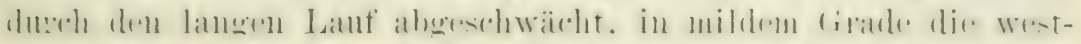

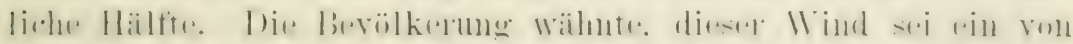

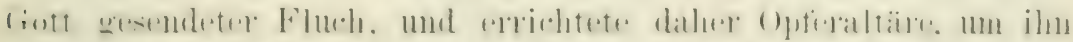

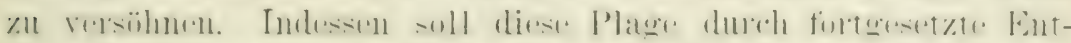

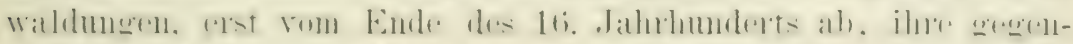

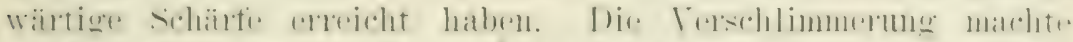

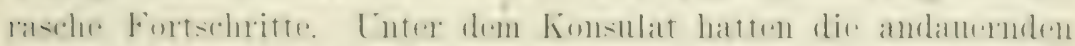

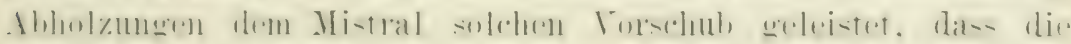

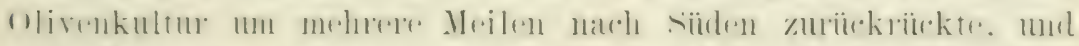

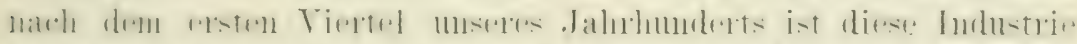

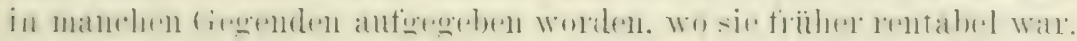

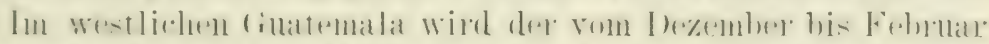

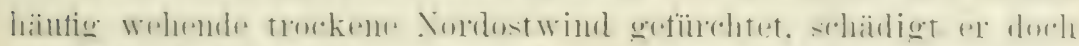
zow

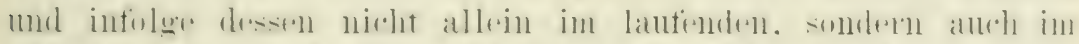

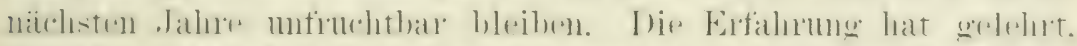

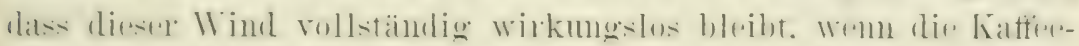

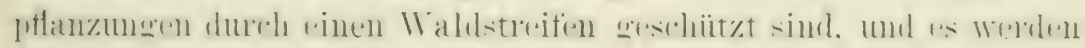

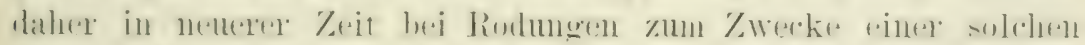

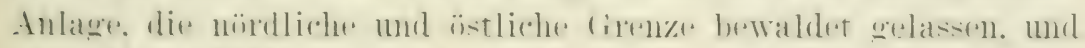

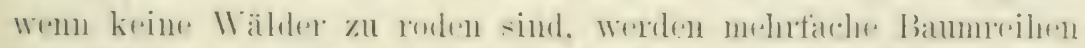

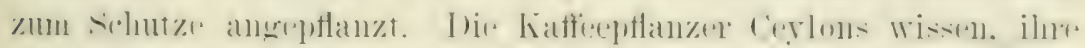

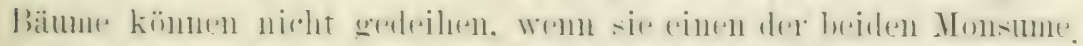

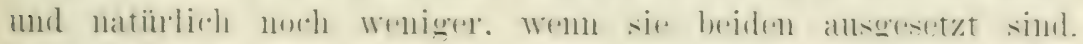

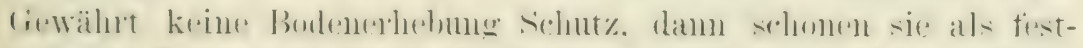

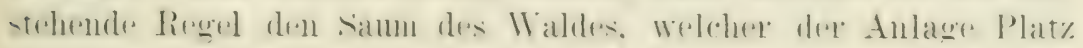
machen soll.

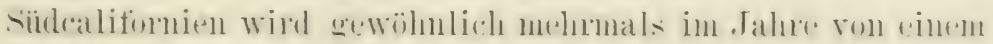
ats: der iloharewiiste kommenden Winle geplagt. dex so heiss mul trocken ist, lass ex sich wie eine Glutwelle über das Land rrofesst

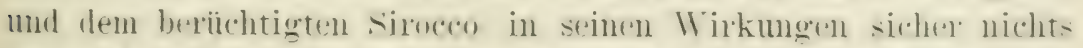
natehgiebt. I'm ihn ron den (iärten abzuwehren. ungielst man

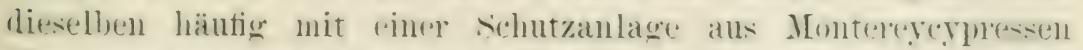

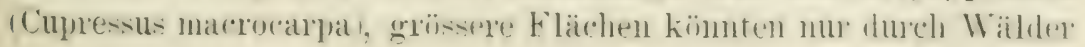


geschiitzt werden. die aber noch der Anptlanzmog harren. In Algier shiitzt man die Giarten vor dem Winde der Sahara ebenfalls dureh dichte baumeihen. enewöhnlich wïhlt man den schnell wachsenden. abre im C̈ehrigen schlecht geeigneten blanen Gimmibam. Genug. in tans'mel beispielen lassen sich die wohlthätigen Wirkmngen des Milder. und selbst nur ron Bammreihen, durch Hemmung des Windes nachweisen. Freilich gilt auch hier wieder die Bedingung: am rechten Ort und in rechter Ausdehnung.

In eschlostenen, fenchten 'Thälern, oder bei einer über das richtige Mass hinansehenden Ausdehnung, kann der Wald durch Verhindermong des Lnftwechsels, und die dadurch begiunstigte Triasmenbildung, krankheitserzengend werden. Tud in dumpfer Luft wollen die Nutzoewächse nicht freudig gedeihen.

Nicht zu hezweifoln sind die bis jetzt erörterten Einflissse des Waldes, dagegen hart die Frage noch der befriedigenden Antwort: stehen Regenfall und Wald in ursäehlichem Zusammenhang? Gebildet wird der Regen, wem die Temperatur der Luft so) weit sinkt. dass die in iln schwebenden Wasserdiunste nicht mehr hestehen können. oder wemn diese, vom Wind getragen. in kältere wrer schom mit Dïnstru gesättigte Luftschichten gelangen. Ist das Hächstmass der anfinelumbaren Feuchtigkeit erreicht und sinkt die 'Temperatur, so belalten die Dïnste nicht ilne unsichtbare frestalt. sit verdichten sich, erscheinen als hohle, mit Luft gefüllte IV asselhläschen mol werden pine Zeit lang von der Luft getragen. "ntweder als Vebel orler als Wolken - ein Unterschied, der nur durch dir Hëhe berlingt wird, denn die Wolken sind Nebel. die in hohe'n Luftechichten schwoen, andererseits sind die Tebel Wolken. die ummittelhar über der Erole längen. Tem bei furt-hueitender Terdichtmo die Dumstbläschen sich vergrössern mond schwer werden. Wenn einr kältere Luftschicht die Wolken lwrührt. damn nähern sich die Bläschen, fliessen znsanmen, bilden Tratrertropten mol fillem als Regen herab. vie verdichten, wegen ihnereringen 'T'emperatur. die Wasserdünste der Luftschichten, durch welche sie fallen, und werden dadurch grösser. Die Unterstchungen. von welchen Lmständen die Regenmenge abhängig ist. eroben. dass sie sich nicht gleichmässig anf die Tahreszeiten rertrilt, mol abhängig ist von der gerographischen Lage. der Bodengerestalt, den herrschenden Windströmungen, dem Dasein ron GeWä́-ern und - mas fireilich Widerspruch exfährt - von Waldungen. 


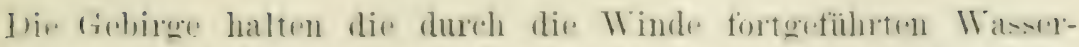

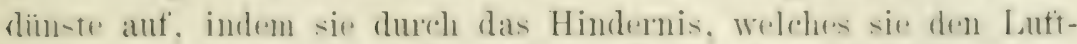

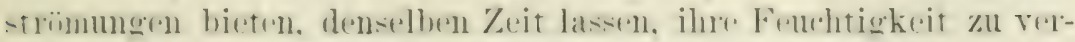
diebten und rine. Wolke zu bilden. Gefolgert darf nicht werelen.

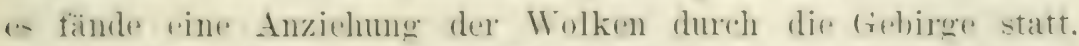
denn in Gegenden mit armer Pflanzendereke, namedelirh bei vos-

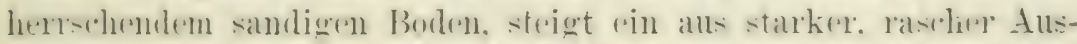

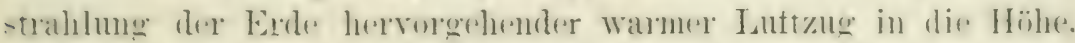

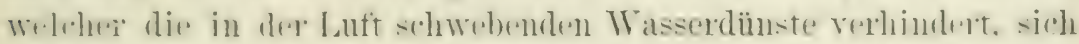

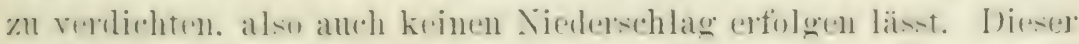

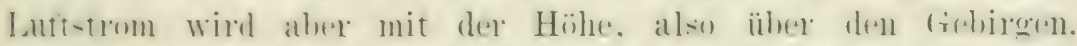

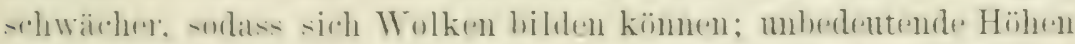

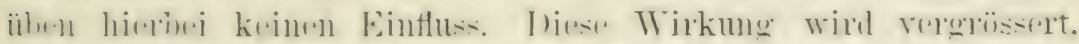

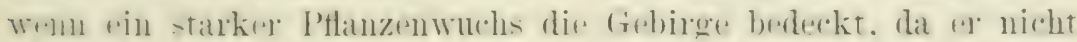
allein das den Luftetrimungen antgegenstellemde Hindernis ver-

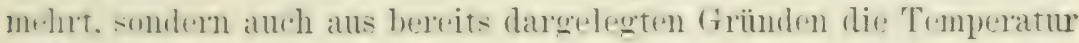
kiihlt, mithin dir. Vordirhtme der Thinste begünstigt.

Verelereht man die Tabellen iiber den Rergenfall in bewaldeten

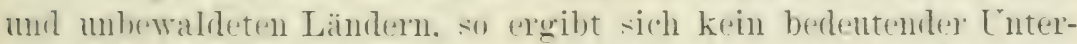

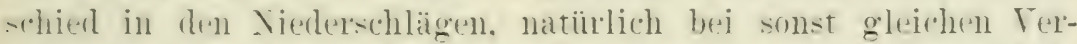
hailtnisen. In den waldreichen Gegenden Sorddeutschlands fällt keine gröscele lexpenmenge wie in den waldarmen. Ilasidbe find in in dem stark bewaldeten P'iemont und dem wenig bewaldeten

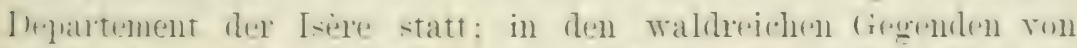

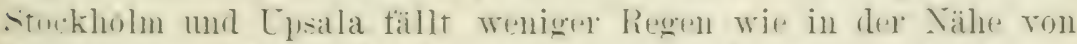

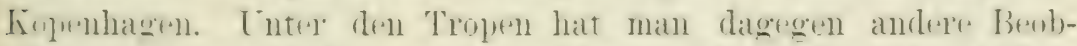

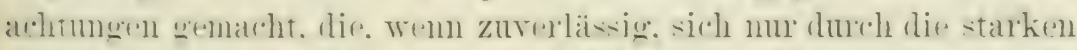
fiecensitze ron Eshitzung und Abkïhlung trklären lasen. In

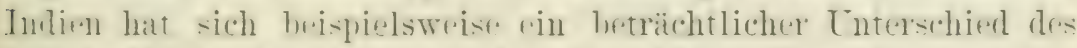

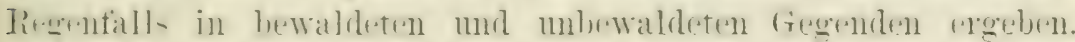

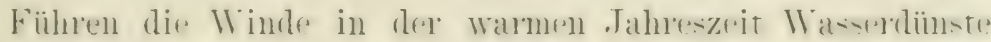

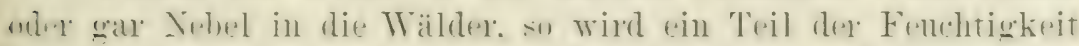

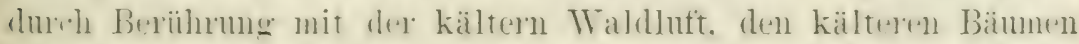

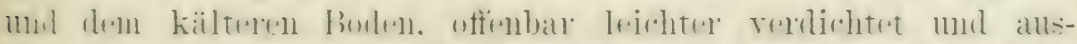

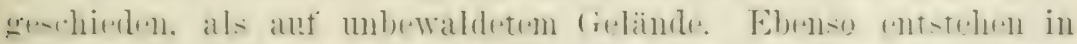

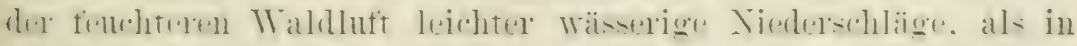

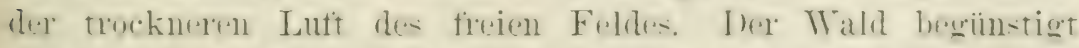

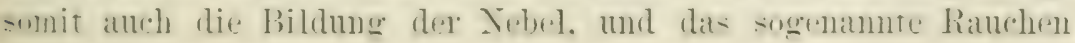


der Wiilder an 'Tagene mit unterbrechendem Regen erklät sieh von selbst.

Wer IIald mit soinen holeen Bämmen setzt in Gebiroen der Bewerme dex Wolken und feuchten Luftmassen ebenfalls ein Hindernis rntgegen. worlureh er seine mechanische Wirkme erhöht. Vorbeiziehende Wolken setzen einen 'Teil ihrer Fonchtigkeit im Walde ab. die Dunstblaschen. alls welchen die Molken bestehen, werden an den Bänmen verdichtet. sie Hiessen zusammen und fallen als Wassertropfen zur Frde. Besonders sind die Fichten- mod Kiefernbäume durch ihre rauhen, bürstenartigen Bimdeln von Nadeln greeignet, die kleinsten Wassertröptehen ans den vorbeiziehenden Wolken aufzufangen.

Ist anch der Eintluss des Wraldes auf den Regenfall nicht so bedentend. als häufig angenommen wird und wenn anch der Wald gegenïber dem frebirge in dieser Beziehmen nur eine untergeordnete Rolle spielt, so darf man ihm daher keineswegs jede Einwirkung anf die Niederschläge abspredhen. Bei der Abwägmo des Für und Trider diüfen wir einen wichtigen Cmstand nicht als den Angen lassen. Es ist nicht anzunehmen, dass die Luft den grösseren Teil ihrer Fenchtigkeit in verdichteter Form an die urspringlichen Empfangsstellen zurickgibt. Die Luft ist in fortwährender Bewegung und es ist daher wahrscheinlich, dass die Ansdünstungen eines see's, Flusses oder Waldes weniger in der nächsten Vähe des Anfstiegs, als in Entfernmgen, die nach Meilen, vielleicht nach Breitegraden zu bemessen sind, in Form von Regen niederfallen.

Die in der Luft schwebenden Wasserdiunste sind ror ihrer Terdichtmo unsichtbar und hinterlassen kein Merkmal auf den Bahnen, welche sie ziehen. Wir wissen daher nicht, woher sie kommen und wohin sie ziehen. Verdanken wir den Regen, der unsere Wiesen erfrischt, einem fernen M[eer, einem nahen Wald, oder beiden? Wo wird die heutige Ansdiunstung des See's niederfallen, auf dem sich unser Schiffehen schankelt - als schnee im Hochgebirg, als Wolkenbruch über einer durstigen Wïste? Weil wir auf diese Fragen keine Antworten gehen kïmnen, ist es unmöglich, den Einfluss des Waldes anf die Regenbildung klar und bestimmt festzustellen, aus demselben Grunde ist auch der Beweis hinfällig, mit welchem dieser Einfluss rollständig geleugnet werden soll: Durch Entwaldung sei der Regenfall einer Gegend nicht vermindert worden. Wer kamn sagen, ob die verschnundenen 


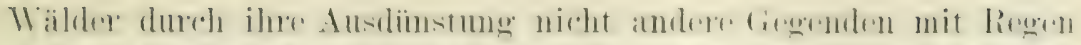

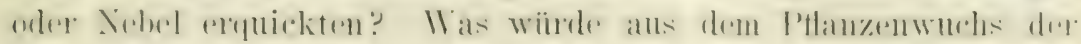

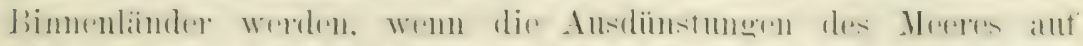

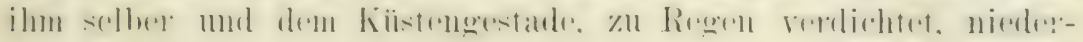
tielen ?

T'rotz dieser Lücke unseres Wissens ist die Ammahme be-

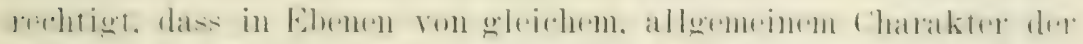

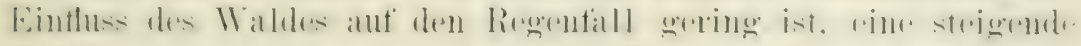

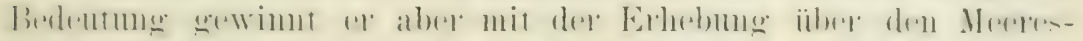

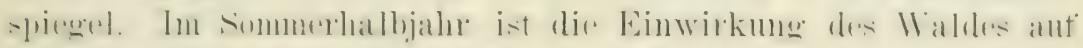

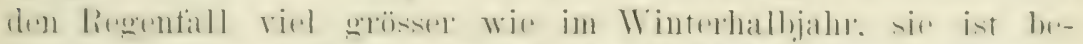

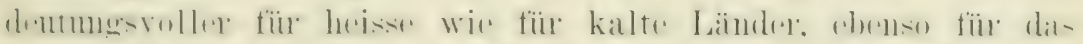

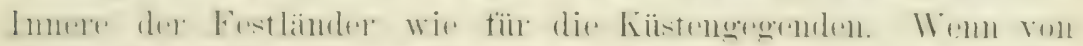

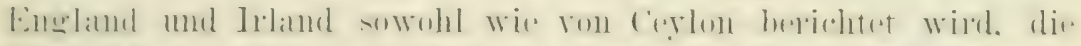

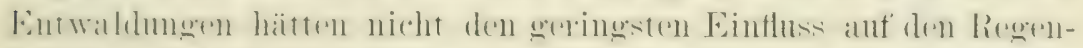

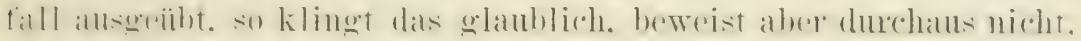

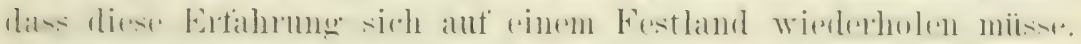

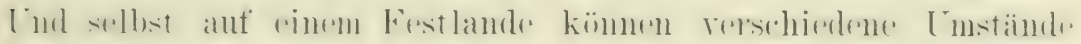

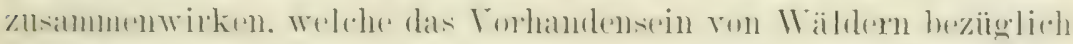

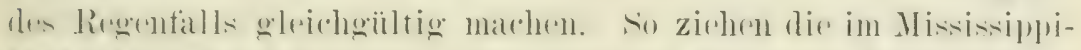

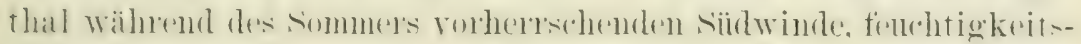

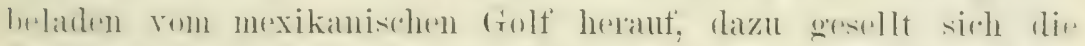

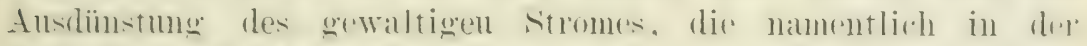
Zeit der tropischen Hitze ron Antang Juni bis Ende Angust

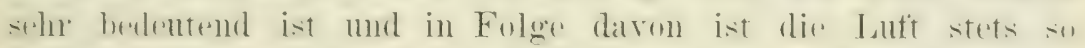

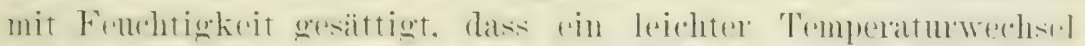

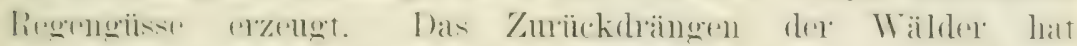

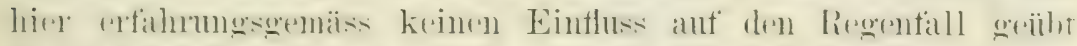

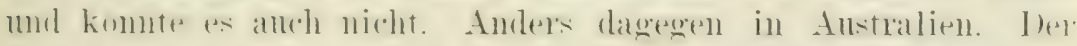

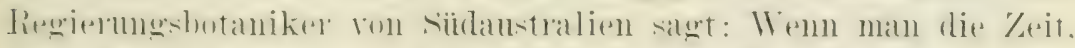

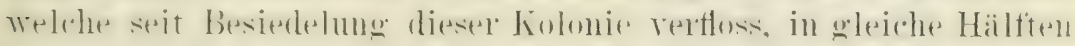
trennt. so findet man in der ersteren einen um 4 Zentimeter

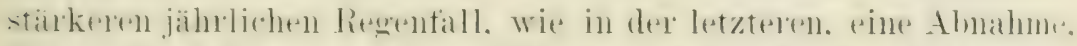

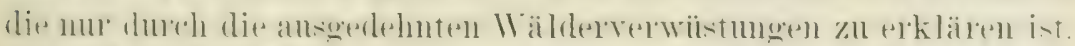

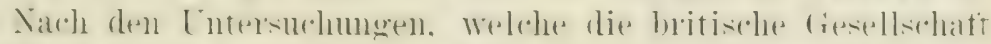

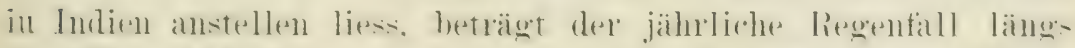

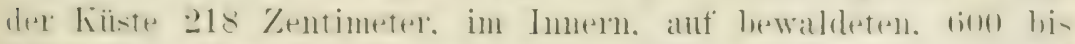

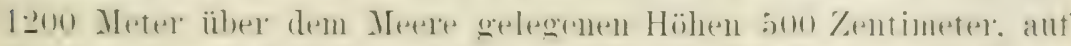

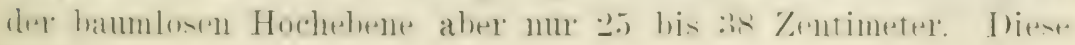


Ermittelungen waren es hauptsächlich, welche die Regierung veranlasste, gegen die Wälderverwüstmig einzuschreiten, eine erste Masinahme, ans welcher später die indische Forstkultur hervorging.

Californien ist ein langegestrecktes Küstenland und den cleichen Windströmmgen ansgesetzt. Im vollständig waldlosen südcalifornien fallen nur 20 bis 30 \%entimeter Regen, obgleich hier die Sierra Nevada zur höchsten Erhebung gelangt. Das mäsig bewaldete Mittelcalifornien hat einen Regenfall von jo) bis 60 Zentimeter, und das stark bewaldete Nordcalifornien rinen solchen von 100 bis 120 \%entimeter. Es folgt nordwärts las mässig bewaldete Südoregon. Wo der Regenfall selten 60 Zuntimeter iibersteigt. Die allgemeine Erhebung des Bodens und die Gestaltung der Bergrücken mag zu einem Teile diesen auffallenden Tnterschied erklären, allein eine Mitwirkmg der Wälder kamn man sich kaum als ausgeschlossen denken.

Zum Beweise, dass die Bäume regenbildend wirken kïmnen, ist schon oft die Insel Ferro angeführt worden. weil man auf ihren Höhen Baumgruppen sieht, die fortwährend ron Wolken pingehiillt sind, welchen sie die Fenchtigkeit so wirksam entziehen, dass den stämmen beständig Wasser horabfliesst. Liese Erscheinung habe ich übrigens häufig auf tropischen Inseln heobachtet, wemn sie auch nicht danernd waren. An sonnigen 'T'agen rerdichteten sich die Ausdünstungen des Meeres anf den Hühen, und zogen bei einiger Luftbewegung gleich weissen Riesinschlangen durch die Banmgrupuen hin. Da komnte ich wenau beobachten, wie die Dumstbläschen sich an den Zweigen mun Stämmen zu Wassex verdichteten, das niedertroff, um sich zu einem Rimnsal zu rereingen, das mumelnd nach dem Thale sprang. wo es die Felder befeuchtete.

Es ist zu bedanern, dass in Nordamerika. dem Lande dex grossartigsten Wälderverwïstung, die regelmässigen Wittermgsbeobachtungen noch so nenen Datums sind, dass weder bejaht nuch verneint werden kann, ob der Regenfall abgenommen hat. Das Hörensagen und schätzen müssen verbannt bleiben, wenn diese Frage zur Entscheidung gestellt wird. Nur die genau gemestenen Regenmengen während eines langen Zeitraumes, an mehreren orten eines Staates, dürfen als Beweis erbracht werden. 


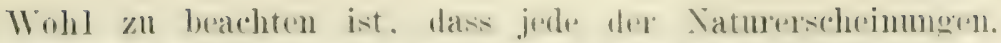

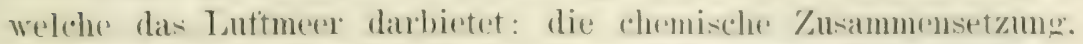

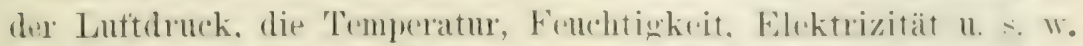

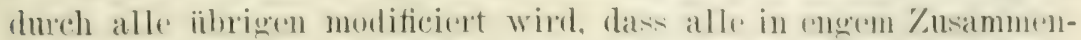

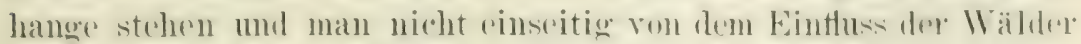

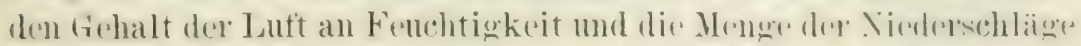

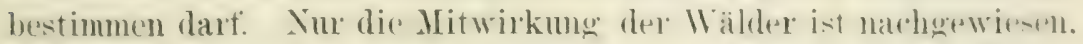
damit abre aluch ihre gerosse Bedelutumge im Hallshalte dre Natur.

Fines Einflusses der Wälder ant das Flima mus noch ger-

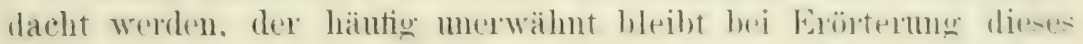

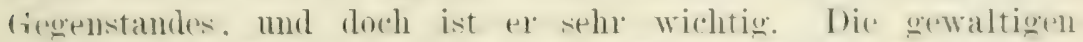

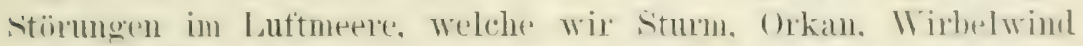

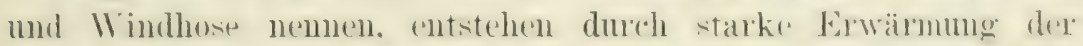

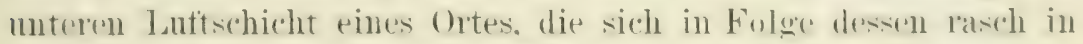

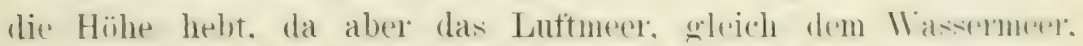

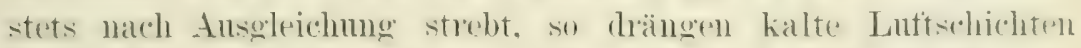
in den frei gowordenen haum. Je nach der Ausdehmung der erwärunten Luftschicht und der Heftigkeit, mit weleher die Fir-

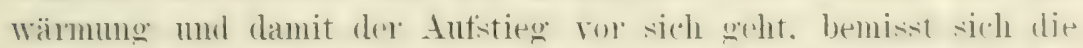

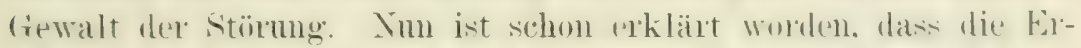
wärmmeg des Bodens in tieien Felde eine stäkese ist. wie in

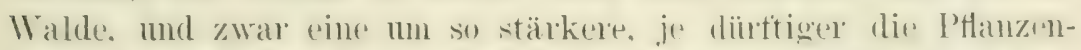

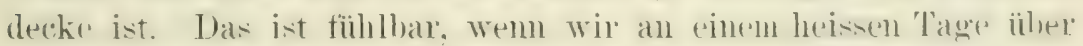

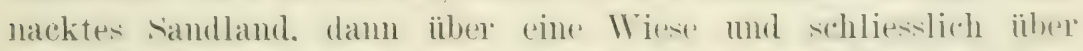

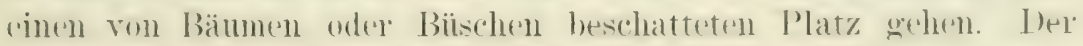

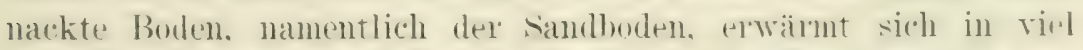

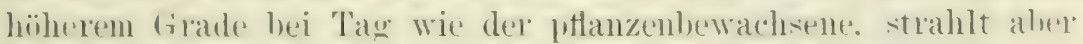
auch bei Nacht seine Wärme viel rascher aus.

E. ist num legereitlich, dass die Ammalume berechtigt int, bewaldete fiegenden seien niemals der lisplumesont lest-

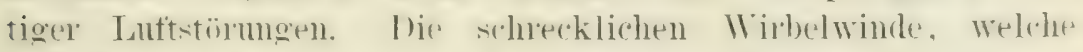
ant den morlamerikanischen Prärien mberelembare IVerte. virl

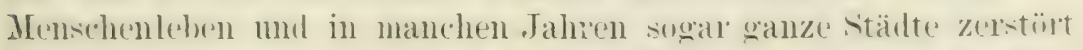

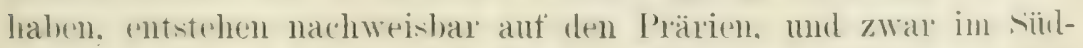

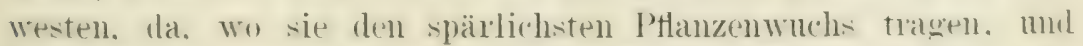
bewegen sich num anf der waldlosen Prälic. Fbenso sioher nach-

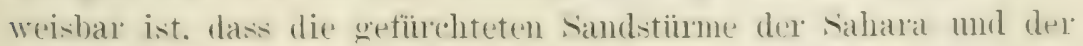

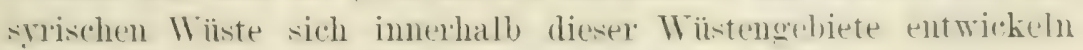
und da ihre grösste Heftigkeit bewahren. 


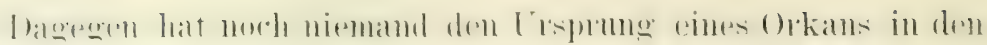

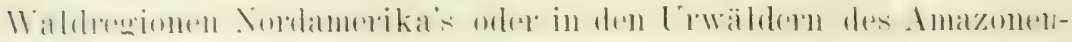
thats antspuinen kömmen.

\section{Der Wald in Bezichung zn den gesmulheitlichen Verhiltuissen.}

Ls ist in nenester Zeit so viel geschrieben und gesagt worden,

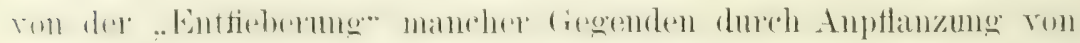

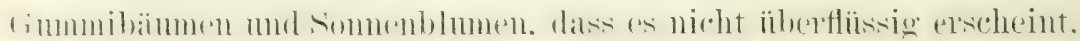

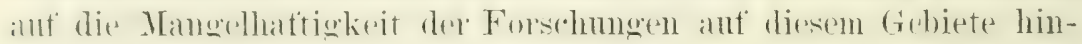
zuweisen. Wenig wissen wir bis jetzt iiber das Wesen des Fiehers - ich spreche rorzugsweise von dem Sumpffieber oder der

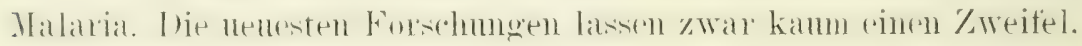
dass diese Krankheit durch Pilze. zu winzig. um dem unbe-

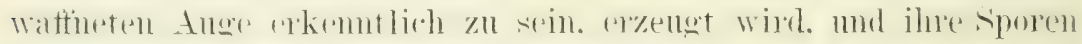

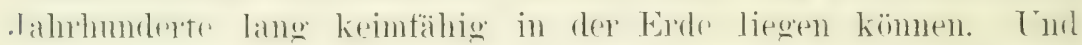

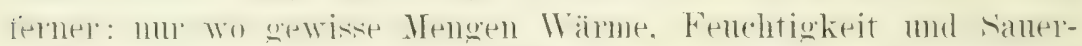

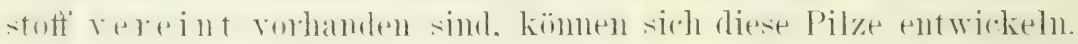
Das ist der Anfang der Erkenntnis - nicht mehr. Noch viele Anfhellungen zur vollen Erkenntnis sind nötig.

Der Franzose Bequerel, welcher sich viel mit klimatischen

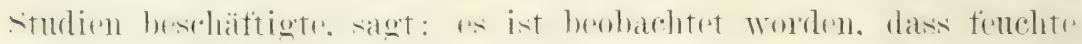
Tuft. mit Miasmen beladen. diese verlor. wenn sie durch einen

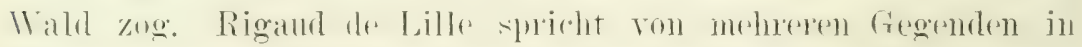
Italien. Wo rin Waldstreiten dio Anshreitung des Fiebers ver-

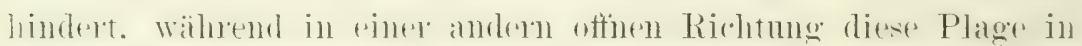

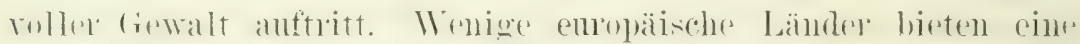

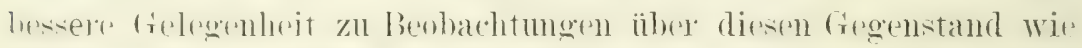

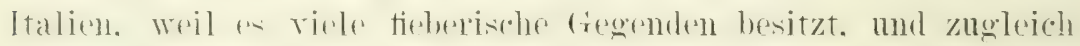

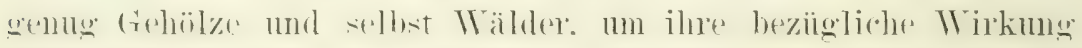

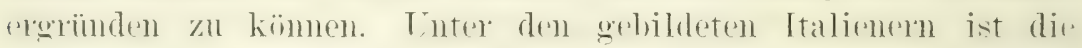

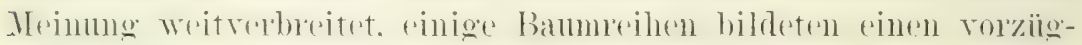

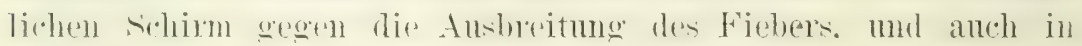

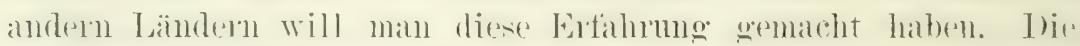

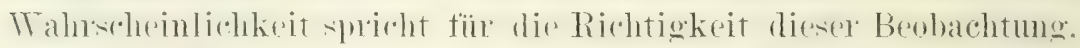

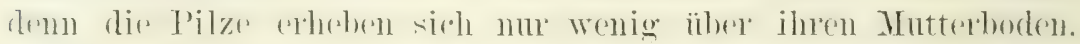

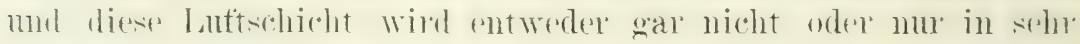

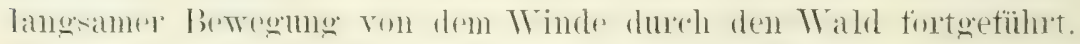

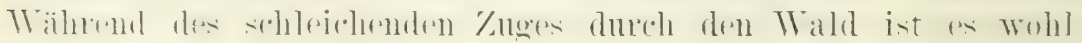


fieberwidrige Wirkmng nur in der starken Anfsangme von Bodenfenchtigkeit zu suchen ist. Wr leistet also in dieser Bezichung nicht mohr wie andere sehnellwachsende P'flanzen, beispielsteise Somnenblumen und Weiden.

Es kann keinem '/weifel unterliegen, dasss manche iuberfinchte Bodenart durch Bepflanzung so genïgend entwïssert werden kamn, dass sie ihre Gesmulheitsgefählichkeit rerliert. TTemn beispielsweise der Untergrund muduchlässig ist, mag sich ïber ihm ein Morast bilden. Durchbrechen starke Bammuzeln den C'nter'grund, dann schaffen sie dem Wasser eine Abzngsloahn nach poröseren Erdschichten. Diese Entwässerungsmethode steht in naher

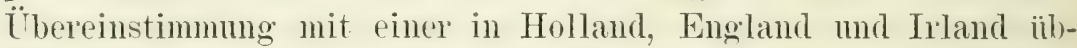
lichen, die darin besteht, dass mehrere hundert Pfähle auf jeden Hektar des zu nassen Geländes eingeschlagen werden. Das Wasser sickert an den Pfählen abwärts, mond in manchen Fällen sind mit diesem Verfahren so gute Erfolge erziclt worden. wie mit wagrecht gelegten Entwässerungsröhren.

In der französischen Landschaft La Breme liegt eine 80000) Hektar grosse Fläche mit undurchlässigem L'ntergrund, welche ror tausend Jahren ron einem Walde mit eingesprengten fruchtbaren Feldern bedeckt war. In Folge der Entwaldung ist dieses Gelände zu einem ungesunden Moraste geworden. In der Sologne wurden aus derselben Ursache 500000 Hektar gut bewaldetes und fruchtbares Land der Kultur entzogen, zugleich verschlimmerten sich die gesundheitlichen Verhältnisse auffallend. Ehenso anffallend verbesserten sich die Letzteren in Folge der Aufforstung:

Es ist eine wichtige Beobachtung, dass die Kunlturwälder eine grössere ('ntwïssernde Wirkung besitzen, wie die L'rwïlder. Als Erklärung ist anzuführen, dass in ersteren viel meln grose Bäume auf einer gegebenen Fläche stehen, wie in letzteren, also auch eine unverhältni-mässig bedentendere Anzahl Wurzeln abwärts treibt. Ferner treiben Bämme, wenn sie duch Zwischenräume getrennt sind, tiefere Wuzeln, als wemn sie geschlossen beieinander stehen, weil sie eines kräftigeren Haltes gegen den Wind bedürten. Anch ist die Wasserverdunstung des Bodens im Kulturwalde eine stärkere, wie im Urwald, neil in jenem das tote Holz und die selmmarotzergewächse weggeräunt werden. welche beide die verdunstminshemmende Bodendecke beträchtlich erhöhen. und dex Luftzug ein stärkerer ist. 


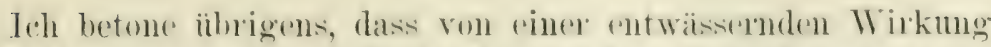
des IValdes nur in drm nicht häutigen Benden die Rede sein kamn. wo der Cntergrmend molurchlïssigg für Wasser und doch durehdringlich fïr Wurzeln ist. In den meisten Bodenarten wird dies

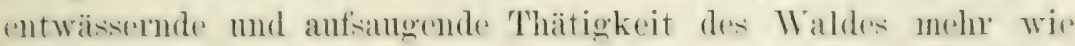

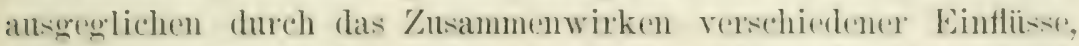
\&) dass als Reged der Boden dureh Bewaldung fenchter ludeilt. als or anderufalls sein würde. Es ist, sagt Matsh, in der mortamerikanischen I'niom beobachtet worden, dass die Entwaldung

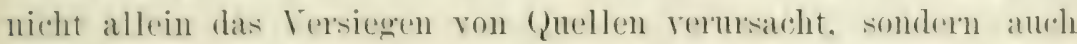
dats Vertrocknem stehender I'fützen und des selewammigen Ibulens:

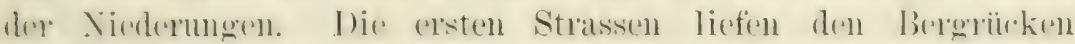

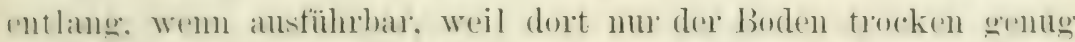

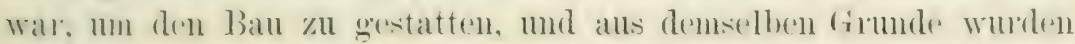

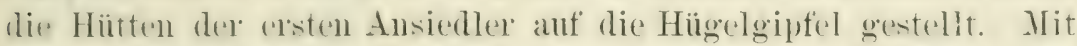

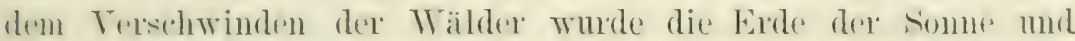

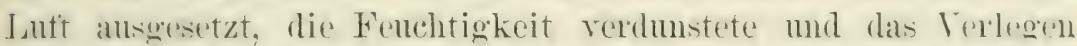
der Strassen und menschlichen Wohnungen von den raulen Biseren nach den geschützten Thälern ist eine dex angenehmsten der vielen liesermongen, welche die jüngeren Geschlechter im Tnmern Nordamerika's erlebt haben.

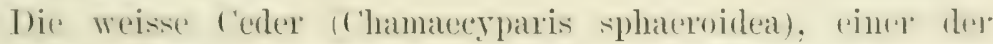
wertrollsten Bälume de's ästlichen Vordamerikats, wirl rorzues-

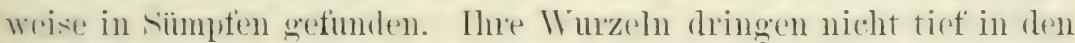
Boden. sondern breiten sich so seicht aus, dass der Baum nicht selten den Halt verliert und umfällt. Entwässernd wirken daher diese Bäume nicht, wohl aber verhindern sie durch Beschattumg das Vertrockne'n des sumptes, dex manchmal ohne andere als die gewöhnlichen

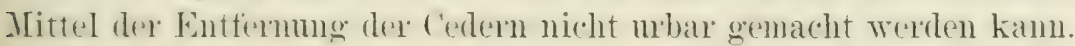

Das alles schliesst äbrigens nicht ans. dast nassen Böden duch Bäume ein Teil der Feuchtigkeit mittels Anfsangung entzoegen weden kamm. Je rascher diese Bäume wachsen, je meln Blitter als Terdunstumgsorgane sie besitzen, je dauternder diexelben thatig sind. immergrim bietet das erwünschte Höchstmass. Im so entschiedener wird dex Erfolg sein. Bedingmen aber bleibt. dass die bämme soweit auseinander geptlanzt werden. $1 \mathrm{~m}$ dem Trinde und selbst der some Jitwirkmng im Auftocknen zul gestatten. und firner die Bildmor viner Humuslecke duroh dir abtallenden Blätter nicht gestattet wird. 


\section{Verschiedene andere Dienste der Wailder.}

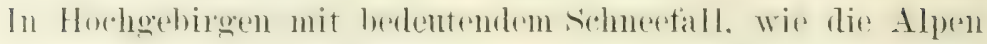

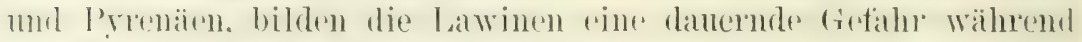
dere IInters für die Bewohner. Xiun kamm allerdings kein Wall rine woll entwickelte, im sturz begriftene Lawine anthalten, allein "l kimm dir bildung derselben verhindern, demu die bintstehme findet stets anf nackten Berehängen statt. Fis ist in den beiden fenammten Gebirgen vieltadh nachgewiesen worden, dass an orten verdexbliche Lawinenstiuge stattfanden, wo man sie früher nicht kilnnte. als Folgen rom Entwaldumgen. Tond häufig ist beobachtet worden. dass die sitherigen Lawinemstimze bedentend an Verderl)lichkeit zumehmen. nachdem sin Wald ahgeholzt worden war.

Eine'n ähnlichen Dienst leisten die Wälder im Festhalten ron Felsereöll. woron man sich leicht iiberzengen kann. wenn man winell trehirgwald betritt. Beispielsweise in der schweiz tïtet

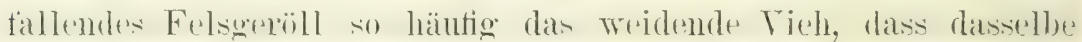
gegen diesen Lntall versichert zu werden ptlegt. Des erwähnt: Dienst ist mithin gebührend zu wirrdigen.

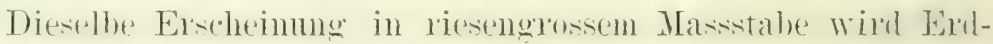
lutsch genamut. und ist bis jetzt ann häufigsten in den Alpen bewhachtet worden. I)ie stant Plus's in Maairathal worde 1618 mit

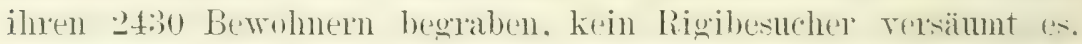

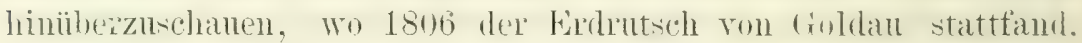
der das I) ref mit 450 Menschen ïberschüttete. Im lotzteren Faldr ist os bestimmt nadehgeriesen. dass der Abholzung eines IValdes berdentende Mitsohuld an dem Lngliicke zugrmessen werden musste. Hält doch das. Wurelgetlecht eines. Waldes die Erddecke fest zusanmen mol schiitzt die unterliegenden Felsen vor den Finwirkungen der Käle mol Hitze - die beiden Factoren, welche am wirkmo:rollsten an ihrer \%erstörung arbeiten. Ferner verhindern dit Wälder während eines Regens die Bildme von Giesolachen, welche den Fuss der Felsen unterminieren und damit ilneen Absturz beschlemigen. Nicht minder nïtzlich wie in Grobere zeigen sich die Wäder an der Küste. dem hier gebieten sie den Dimen Halt. damit sie nicht das angrenzende fruchthare cielande üherschiitten. E. ist sehr bemexkenswert, dass ans dem Altertum keine Berichte:

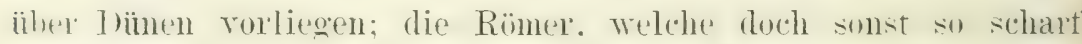

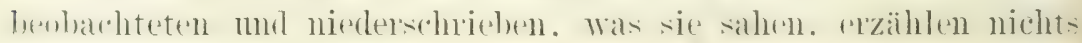




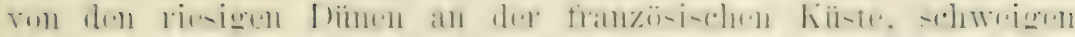

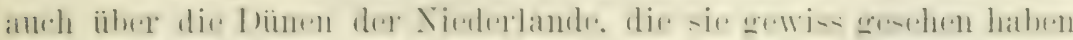

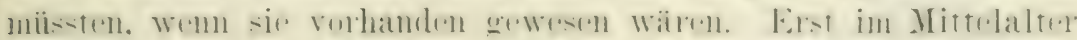

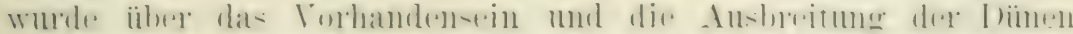

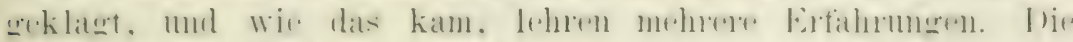

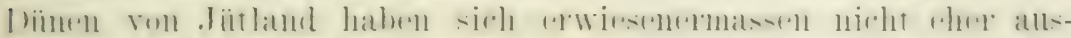

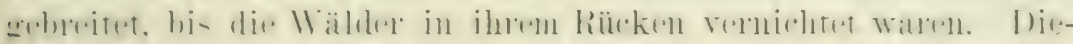

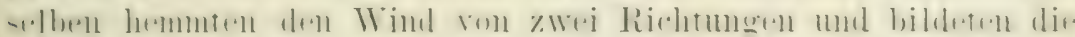

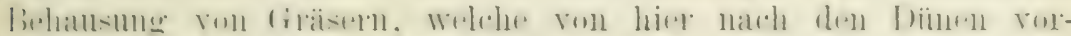

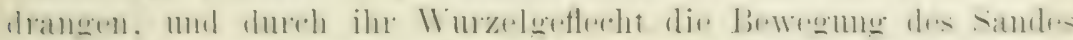

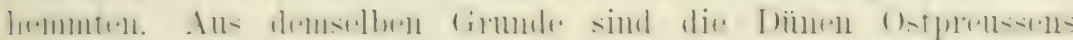

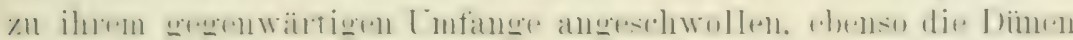

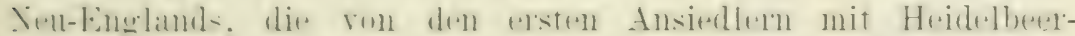

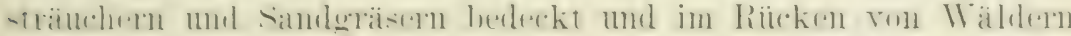

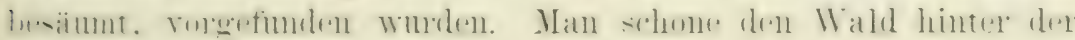

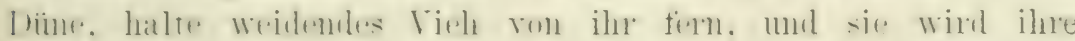

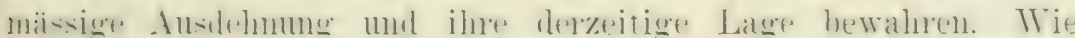

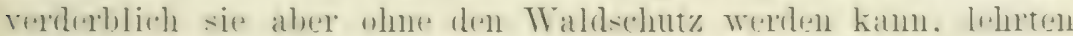

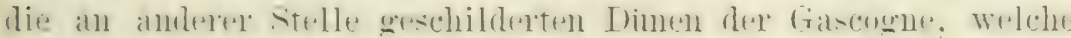

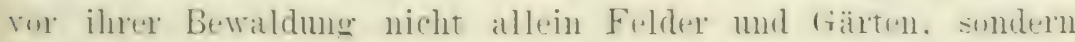

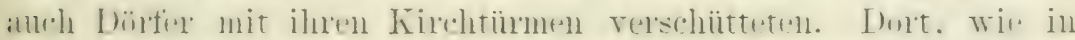

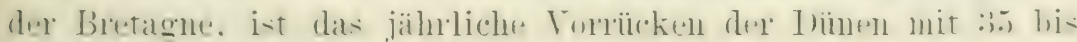
50 Meter gemessen worden.

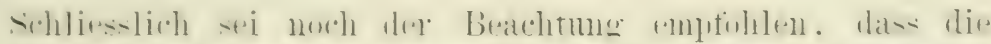

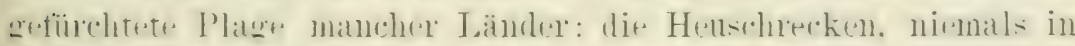

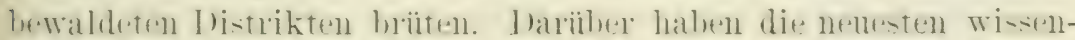

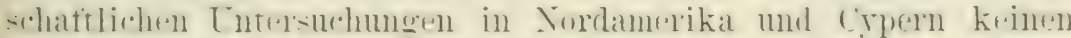

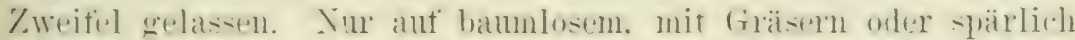

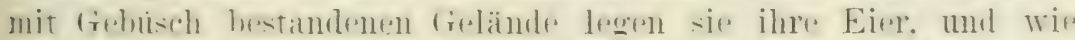

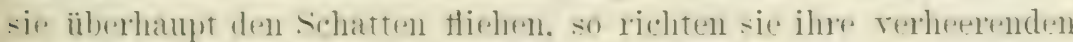

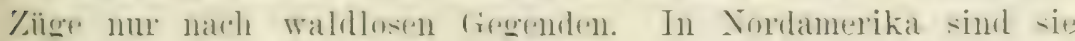

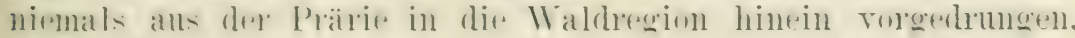

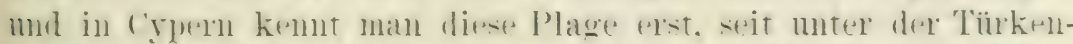
herrsehaft die Entwaldung legann. mol zwar hielt sie mit der-

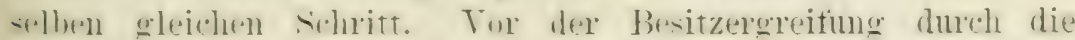
Engländer wollten die Bewohner melnmals in Verzwoitlung den

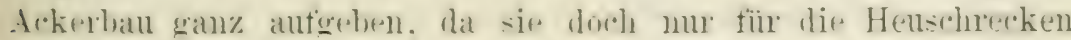
ihre Felder bestellten. 


\section{Die Folgen der Entwaldung.}

(iewöhnlich treten die Folgen der Entwaldung langsam ein, welkalb sie häufig geleugnet werden. Doch sie bleiben nicht ans nund rächen die Simde, das Gleichgewicht im Haushalte der Natu' gestärt zu haben. Zugestanden muss werden, dass die Folgen sich weit weniger fiihlbar machen, wemn an stelle des Waldes das geptliigte Feld tritt, anstatt die nackte (ide. I) mun der gepfliigte Boden ist fähig. eine viel bedentendere Fenchtigkeit anfzuspeichern, wie der ungeptliigte, kann also auch länger durch Verdunstung Fenchtigkeit an rie Luft abgeben, und eine viel stärkere Pflanzenderke crnähren, welche die Verdunstmo indirekt besorgt, zugleich aluex den Boden vor zu sehmellem Anstrocknen bewaht, indem sie ihm vor den Einwirknngen des Windes und der somne schützt. 'l'rotzdem rächt sich die Entwaldung fühlbar, immer in ihrer Plan- und Mas-losigkeit gemeint. Demn es heisst weit über das Ziel hinansschiessen. Wollte man alle Entwaldungen in Bansch und Bogen veruteilen. Nur ein gewisser, nach der geographischen Lage und der Bodengestalt schwankender Prozentsatz des Landes ist den Wäldern einzuräumen und zwar in möglichst gleichmässiger Terteilumg über das Gesammtgebiet.

Ina die Theorien gewöhmlich weniger belehend und mahnend wirk'n wie die 'Thatsachen. so stelle ich nachtolgend rine Reihe von Fälen zusammen, welche als Beweise fïl die nashteiligen Folgen der Entwaldung dienen sollen.

Mit berechtigtem Stolze diurfen wir Dentsche auf unsere Forstknltur blicken, rergessen sollten wir aber nicht, dass es eine Zeit gab, wo anch in Dentschland stark gegen die Wälder gesiindigt rurde, und die schäden immer noch nicht rollständig ansgeglichen sind. Wasserbaningenieme, die gehört zu werden verdienen, behaupten, dis Wasserführung dex deutschen ströme im sommer sei gegenwärtig eine geringere wie in früheren Zeiten, mod die verheerenden Öberschwemmungen dex Odex, des Rheins und ihrer Nebenfliise in den beiden letzten .Tahrzehnten, reden lant genng, dass die Bewaldung noch nicht so ist, wie sie sein sollte.

Von der Römerzeit bis ins 14. Jahrhundert war die Eifel fin mit schönen Waldungen bedecktes, gut kultiviertes GebirgsJand. In Folge der Wälderverwïstung, die während der Raubzïge 


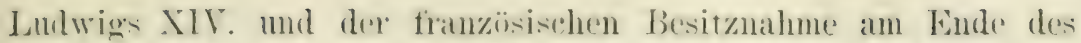

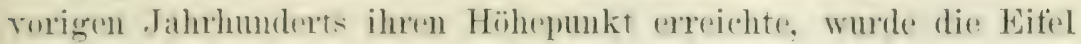
zum .rheinischen sibirien," wo kaum der Hater reif wurde. Ihre,

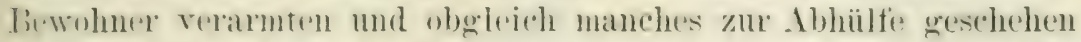
i-t. s) bleibt doch zur Wiederherstellune der früheren Zustande now manches Gilland aufzuforsten. Auf der hohen Vent trug die

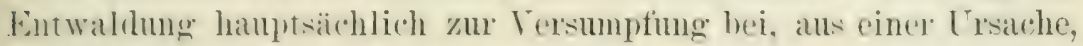
die oben schon durch Beispiele erläutert wurde.

bin Kiefernwald befestigte mit seinen Wirzehn den Dünensand und die Haide munterbrochen ron Lanzig bis Pillan; als

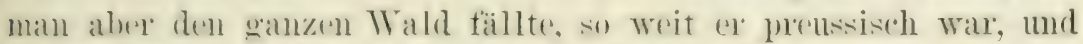
die Winde ïber die kahlgelegten Hügel wehten. versandete das Fri-che Haff zur Hälte. Gegenwärtig droht das weit über die

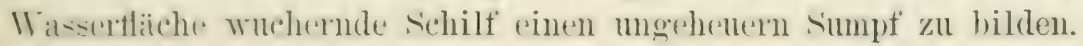
The Wascrstrase von Elbing und Künigsberg ist gefähdet, der Fischfang im frischen Haff beeinträchtigt.

11: Napoleon I. die Kontinentalsperre dekretierte, wurden die Hondiofen in der Xähe ron Bergamo erweitert, und bis zu ihrer äl--erstrn Leistung-fähigkeit in Betrieb) gehalten. Selbstrerständlirh wurle der Beelart an Bremnstoft bederltend erhöht, und er musste in sine \%eit. wo nan noch keine Eisenbahnen kannte und die

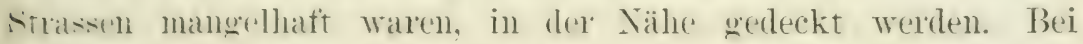

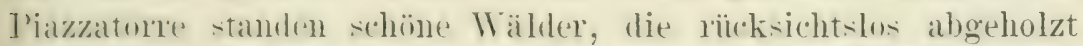
whrlen. Diexem Frevel folgte die strate anf dem Fusce. Das Filina jenter fiegend, die fortan nicht mehr gegen die eisigen

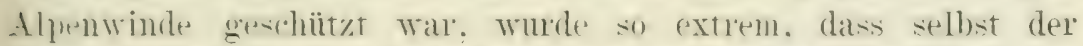

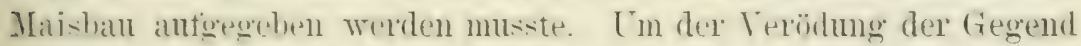

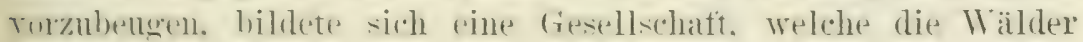

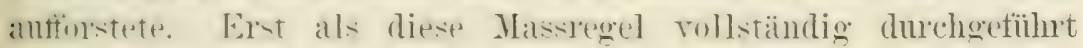

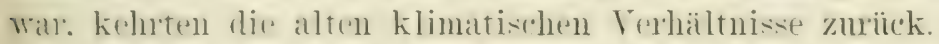

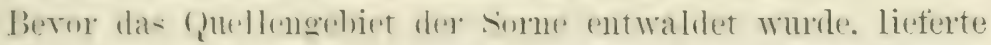

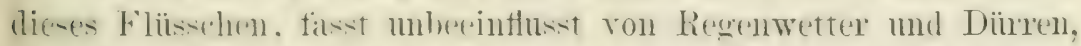
gronigendes llaser fïr dir kisenwerke von linterwyl. Die sorne

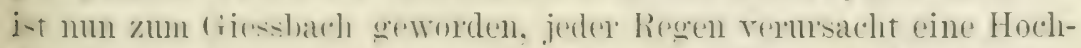

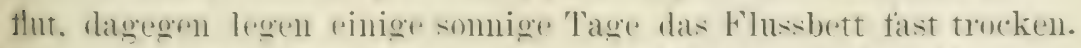

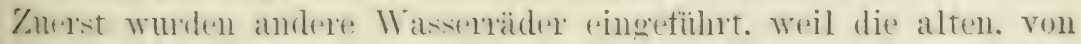
schwerfalliger Lonstruktion, dir Maschinen nicht mehr treiben kwnntull, schlieslich mussten aber Dampfimaschinen aufgestellt

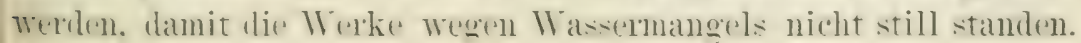




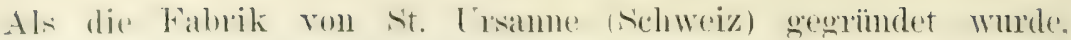
lieferte das rorbeiflessende Filisschen geniigende Wasserklatt und latte se bereits seit rordenklichen \%eiten für eine andere Fabrik

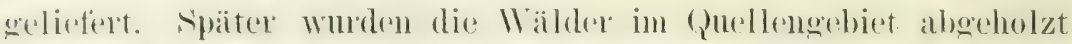
und die Folge war. dass dire Fabrik nur das halbe Jahr ITasied hatte und später anfgegeben werden musste.

¿̈ber die Folgen dex bintwaldume dex Alpen in dex loovence ätsuert sich der Franzose Blanqui: In dem enemäsigteren Kilima Vordfrankreichs kamn man sich krinen Begrift von diesen bremenden Berohängen machen, wo es nicht eimmal rine'th Busch gibt, um einen Vogel zu schützen. Wo der Reisende nur hier und da eine verwelkende Lavendelstande triffit, wo alle (puellen ressiegt sind und ein dïsteres, kaum vom summen der Insekten unterbrochenes Schweigen herrscht. Bricht ein Gewitter los, dann Wälzen sich von den Höhen IVassermassen in diese gebonstenen 'Thäler, welche verwïsten ohne zu begiessen. überschwemmen ohne zu erfrischen und den Boden durch ihre vorübersehende Lrscheinumg noch öder machen, als er aus Mangel an Fenchtigkeit war. SchliessJich zieht sich der Mensch ans dieser schrecklichen Wïste zurück, mol ich habe in diesem, Jahre (1843) nicht ein lobendes Wesen mehr getroffen, wo ich vor :30, Jahren (iastfremondschaft genossen zul haben, mich erinnere.

Zehn Jahre später richtete der Lnterprätekt des ron Blanqui geschilderten Gebiets eine Denkschrift an die Regierung, in welcher diese sätze standen: Es ist sicher, dass die fruchtbare Erdschicht der Alpen durch die strigende Gewalt des Fluches dieser Berge, der Giessbäche täglich mit schrecklicher schnelligkeit vermindert wird. Alle unsere Alpen sind entweder vollständig oder zum grössten Teile ihrer Wälder beraubt. Ihr Boden, berstend unter der sonne der Provence, zerstiickelt ron den Klanen der schafe, welche den Boden aufkratzen und benagen in Suchen nach Wirzeln. dia sie nicht genug Gras fiuden, um ihren Hunger zu stillen, wird von Zeit zu Zeit von dem schmelzenden schnee und dem Sommerregen weggeschwemmt. Ein indirekter Beweis von der Verminderung der fruchtbaren Erde kam in der Entvölkerung des Landes gefunden werden. Im .Jahre 1852 berichtete ich dem Generalrat, dass gemäss der Tolkszählmng jenes Jahres die Bevïlkerung des Departements der untern Alpen in den 5 Jahren zwischen 1840 und 1851 un nicht weniger wie 5000 seelen ab- 
sind rersient und die Bewässermugkanile trocken. Der treibendr Wïstrnsand, nicht mehr zurückgehalten von Wäldern, verbreiter. sirh jeden 'Tag weiter über das Land und wird dasselbe schliesslich in eine Wïste verwandehn. so z̈de wie diejenige ist, welche es ron Khiwa trennt.

\section{6.}

Die schönste Provinz dex Tartarei bleibt noch zu beschreiben. ir ist sewöhnlich unter dem Namen grosse Bucharei gekannt.

Der bemerkenswerteste und fruchtbarste Inistrikt heisst Sogd. $\therefore$ genamnt nach dem Flusse. welcher ihn durchströmt. Acht Tage: lang. sagt Than Hankol, mag man in dem Districte Sogd reisen und stets in einem prächtigen Garten bleiben. Dörfer, reiche Kornfelder, fruchthare (Obsthaine, Landhäuser, Gärten, Wiesen, von Bächen durchschnitten, Sammelbecken und Kanäle bieten an jeder seite ein lebensolles Bild von Fleiss und Glück. Das reiche Thal ron sogd erzengt eine solche Fülle von Tranben, Melonen, Birnen und Äptel. dass sie nach Persien und selbst nach Hindostan exportiert werden. Ich bin oft in Kohandis gewesen, der alten Hauptstart der Bucharei. Tiel habe ich mich umgesehen, aber niemals fand ich eine frischere, ippigere und ansgedehntere grime Landschaft. Der grïne Teppich rerschwamm am Horizont in das Blau des Himmels. Das Grün diente als eine Art selmiickender Intergrund für die Städte, welche in ihm standen. Zahlreiche Landhänser zierten die Felder. Laher bin ich nicht iiberrascht, dass von allen Bewohnern der Tartarei keine ein höheres Alter erreichen, wie diejenigen der Bucharei.

Mag auch anf beiden seiten einige Übertreibung unterlanfen, -1) bleilht doch noch wenme iibrig, um das Bild sehr trübe er'scheinen zll lassen.

Iie Entwaldungsmanie muss sich tohl von Buchara nach dem benachbarten nördlichen China verbreitet haben, denn anch hier ist im letzten Menschenalter mit Axt und Fener so lange gegen die Wälder gewiitet worden, bis alle Berge und Hügel nackt lagen. Als Rächer erschien der Würgengel Hunger in immer kiirzeren Pausen zu längerem Aufenthalt, und als er im vorigen Iahrzehnt :3 .Tahre lang verheerte, sollen ihm 7 Millionen Menschen zum Upter gefallen sein. Mag das nun zu hoch gegriffen - win oder nicht - grauenhaft ïber alle Begriffe war diese Leidenszeit der Bevölkerme. Einem britischen Konsul, der zur Bericht- 


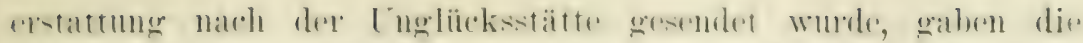

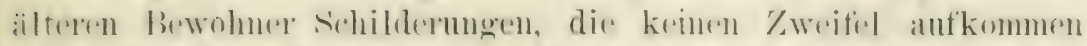

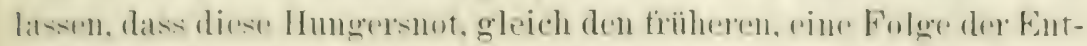

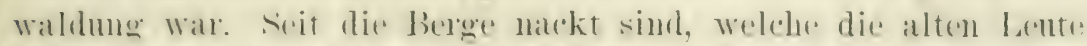

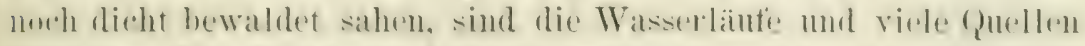

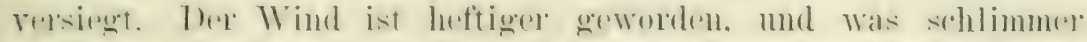

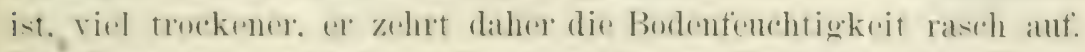

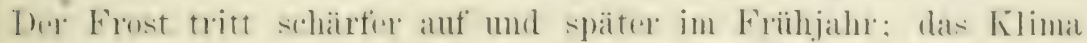

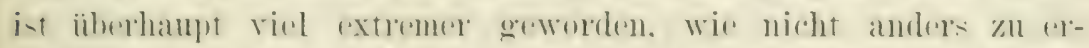

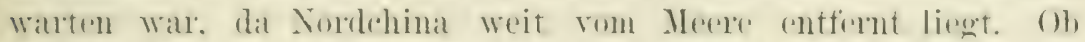
"due Abmalne des Regentalls stattfand. Wio behauptet wird. muss

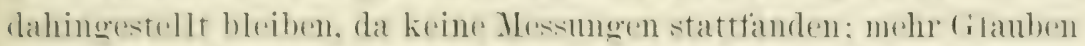

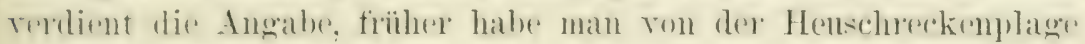
nichts gewusst, jetzt trete sie häntig anf.

seither trat regelmäsig zweimal in einem .Tahrolnt die Hungersnot in Indien anf. bald hier bald dort in dem erosisen

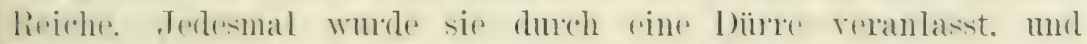
diese lounte waren die Foleren von Entwaldungen, wie die Enter-mehungen ergaben. welehe die lirgiermug nach jeder Hungersmot anstellte. Dats ist riner der triftigsten Grimde für die energischen

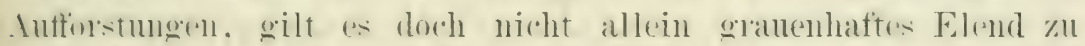

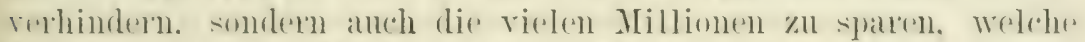

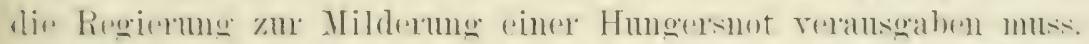

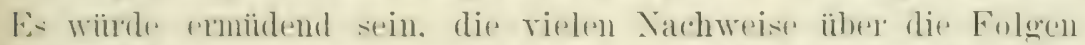

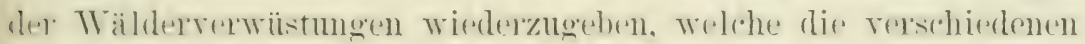

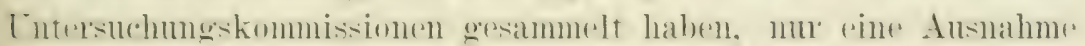
minge stattfinden. Weil sir pinen wenig gekamten fiecenstand

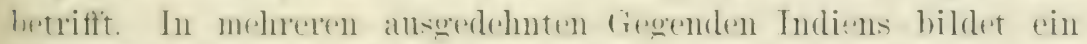

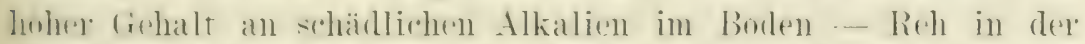

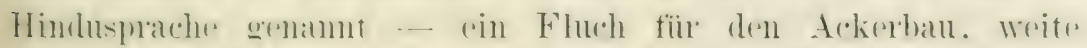

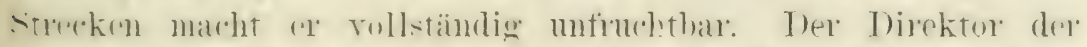

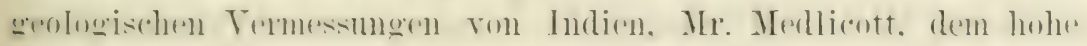

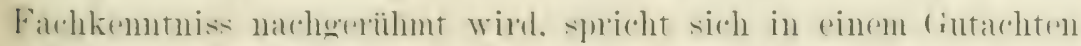
dahin aus. die Alkalien hätten sich in dere Bodenkrome num wegen

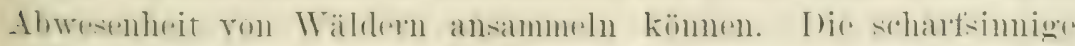

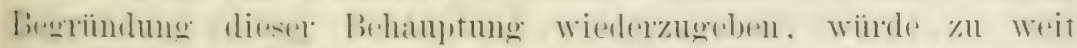

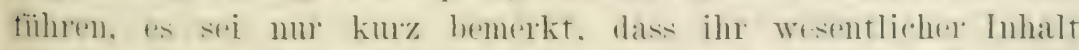
darin besteht, dats Regernwasser linte so ratsch. dass es nicht in

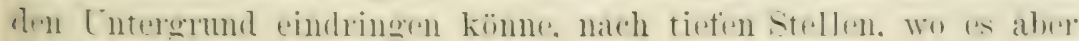




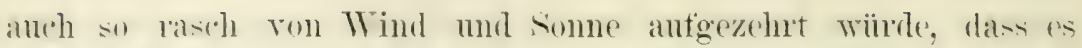
nicht tief einsickern kïmne. Als unverdunstbaren leil liesen es in Form einer weissen Limste das Produkt der Anslaugmo anf dem Wige nach den sammelstellen zurick. Als Beweistïhrung diont, dass ., Rehland" in gruser Ausdehmung nur auf den walulosen. somverbramten. windgepeitschten nordwestlichen Elyenen anftritt. Im es kurz zul fissen: Medlicott führt dieses Uebel auf die meunstige Beeinflusung des Klima's durch Entwaldungen zuriick. Was auch dagegen gesagt werden mag, beachtenswert ist e jedenfalls. dass anch die nordamerikanische Pazifikkïste an jenem Übel leidet, und es anch hier nur in waldlosen fregenden anftritt. Ich glaube dieselbe Erscheinmg lässt sich noch in anderen Ländern beobachten.

Auch in Australien haben die Entwaldungen manche ungiinstigen Teränderungen hervorgerufen. namentlich ist die Tascelfïhrung der Flüsse in der trockenen Tahreszeit geringer gewrorlen. Der Forstkommissär Brown von Südanstralien sagt in einem Bericht: der Torrensfluss sei wesentlich ron den Entraldungen beeinflusst worden. Früher führte er Wasser in allen Jahreszeitedi. gegenwärtig sind alle tiofen stellen von sand und Kies aufgetiillt und da. wo vor Tahren die Lente mit einem Fährbout übersetzten. hömnen sie jetzt die meiste Zeit trockenen Fusses krenzen. Ans demselben Frunde ist anch de' 'Thaufall in manchen Gegenden fast bis zur Unkenntlichkeit schwach geworden. Nicht die Holzfäller sind die Hauptzerstörer der Näalder in Anstralien, zumal in siidanstralien, sondern die schäf(x. demn dieselben ringeln die Bäume und stecken sie. wenn diur gerorden. in Brand, um mehr WTeideland für ihre Heerden zu gewinnen.

Es wird so oft behauptet. das Inselklima schïtze vor den Folgen der Entwaldungen, so dass es eine besondere Beachtung verdient, was man in Mauritius darüber weiss. Diese Insel war einst dicht bewaldet, allein schon gegen Ende des vorigen .Tahrhunderts exregte das Verschwinden der Wälder so exnste Besorgniss, dass eine Reihe ron schutzmassregeln erlassen wurden. so sollten nur steine zum Banen rerwendet werden. es wurde rerboten, Fenter in Feld und Tald anzulegen. die Eigentïmer einer Landfliche musten Erlaubnis einholen. wemn sie Wald roden wollten, mol niemal: durften sie ein Flussufer abholzen. Toch andere Verordnungen folgten, die letzte datiert von 1826. 


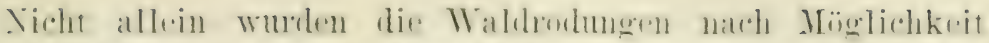

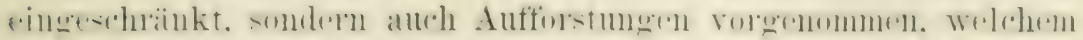

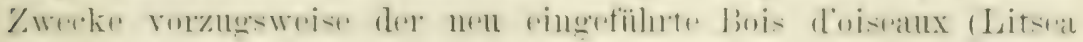
chinensis) diente.

so blieb es bis zum Begimn der fïnfziger Jahre, wo das

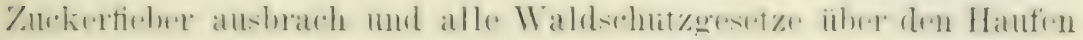

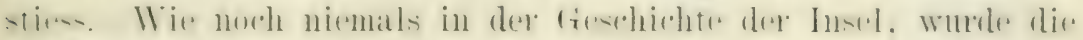

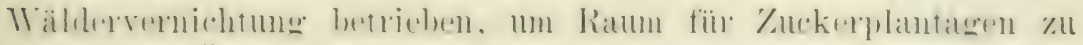

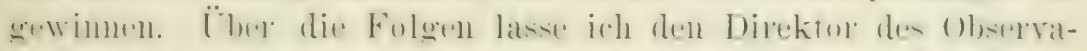
roriums ron Mauritius, Charles Meldrum, sprechen.

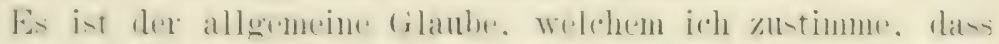

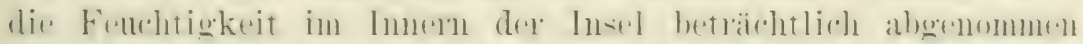

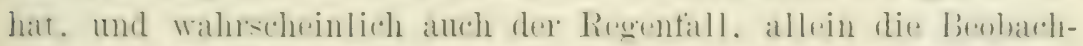

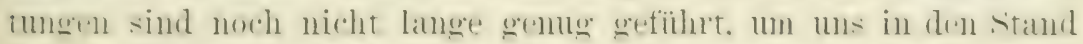

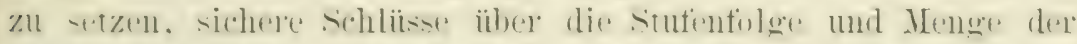

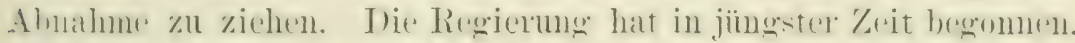

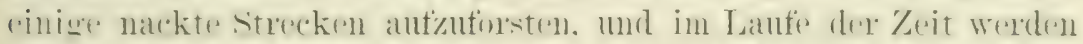
wir dir. Wirkme auf die Fenchtigkeit rom Luft und Bonden kement lernen.

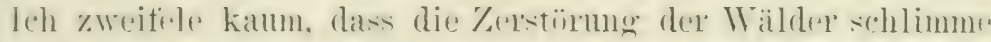

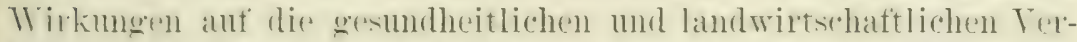

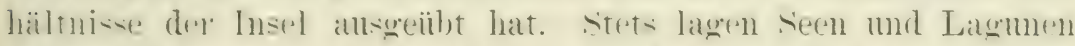
in den Viederungen an der Kü̈ste, get)ildet dureh rickerwasere an-

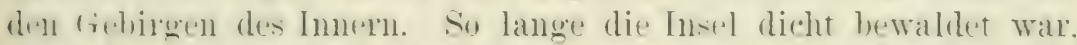
wurle ein grosier Teil des Regenwasser's zurückeghalten und die

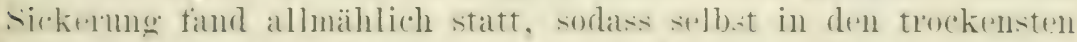

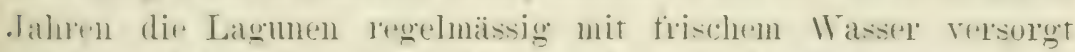

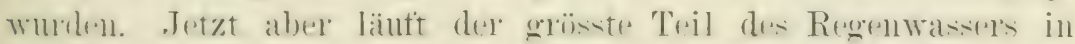
da- MEeer, und daher strahlt bei trockenem Wretter die somne ant

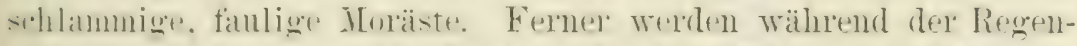

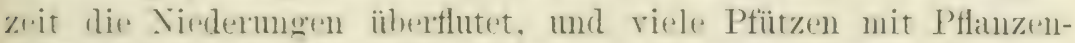
suffen bleiben zuritek. Ibie Fulge ist. dass eine Insel, die einst

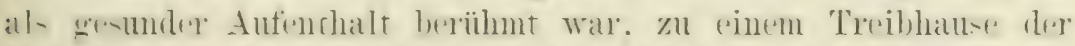
Malaria geworden ist. In dron letzten 10 , Jahren ist die storblichkeit durch Fieher sohr gross gewestn. Während nath schweren

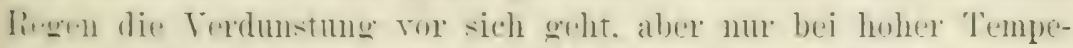

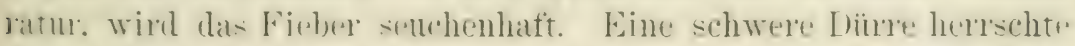
Tom Janlal bis April 18\%5, gefolgt rom starkm Rougen Endr

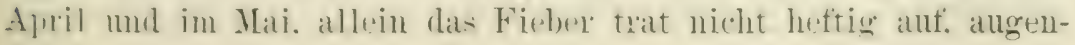


shemlinh, weil der Winter vinsetzte, bexor der Regen anthörte. Ambererseds wurde rine vom November bis danmar 1876 währende

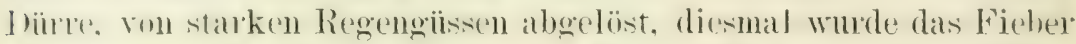
allexemein und wïtete wïhrend der Monate März, April mol MLai. Wibhend der letzten 15 . Tahre sind manche Zuckerplantagen an der Windwärtskïste aufgeceben worden, hauptsächlich weil a an geniigendem Regen fehlte.

Ähnliche Ertahrungen wie Mauritius hat auch seine Nathharinsel Rémion gemateht. Nachdem dir hewaldeten Hügel al)-

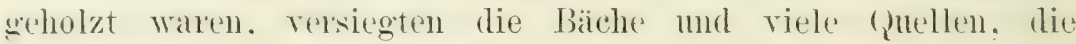
Regengiisse ïbertluteten das hulturland und die gesmalleitlichen Texhälnisse verschlimmerten sich. Noch zur rechten Zeit wurlen Massregeln getroffen. un die Bewaldung wenigstens teilweises wieder herzustellen.

Die (apkolonie leidet bald an einer Diure. bald an eines C̈berschwemmung, ein C̈belstand der von dem Regierungsbotaniker brown anf das Verschwinden von Wäldern zuriekgefïhrt wurde. Dieser Beamte reröftentlichte ein Buch ..Forests and Moisture., welches einen Brief enthält. der so interessant ist. dass ich ilm hier eine stelle rinrämme. Der schreiber sagt: .Dieser rommer ist an der Kü̈ste entlang ungewöhnlich heiss mol trocken geweren, und in der Tmgegend ron Grahamtown sind wir alls Mangel an Regen nicht in stande geweren etwas zu ernten, rersiegten doch alle Quellen. Vielleicht kemmen Sie den Platz ron J. J. Stone anf dem Hïgel an der cowiestrasise nach der see zu. Er ist weithin gekemuzelchnet durch eine Anzahl Gummibämme anf der seite nach Grahamtown. Während des Sommers hatten wir nur Tebel, gerade genug um das Gras anzufenchten, aber nicht genug mn den Boden zu benässen. allein jene Bäume verwandelten den Sebel in Regen. An ilnen ist die Trirkmng fast spurlos roriibel gegangen, dort whehsen anch die Blumen und das Gemüse den ganzen sommer ohne bewäsert zu werden, anch war die Tränke stets gefïllt. Das ist der einzige Platz imnerhalb 25 Meilen von (ijahamtown, von welchem ich diesen Zustand vernommen habe."

Schlimmer wie im siden ist im Torden Afrika's gegen die Wälder gewütet worden, standen doch auch hier mehr Irälder zur Ternichtung bereit. Tor tausend Jahren war das durch einen Gebirg-zug ron der Nahara getremnte Land. Weldess wir inelute 


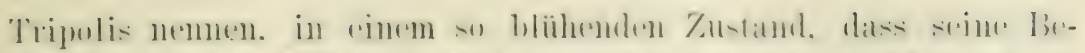

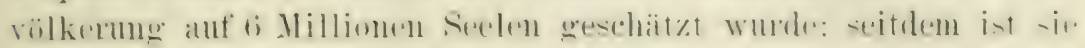
auf 45000 zusammengesehmolzen.

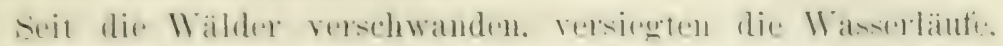

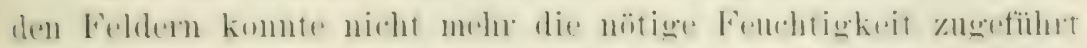

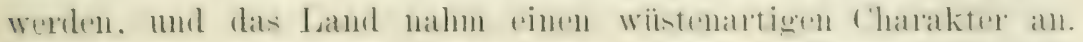

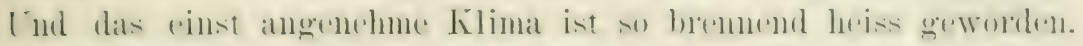

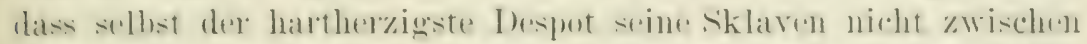

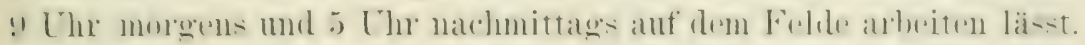

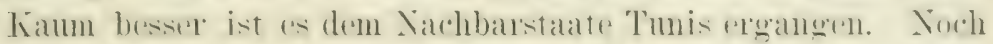

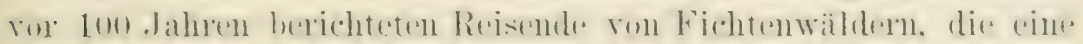

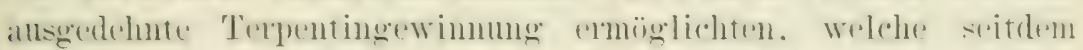

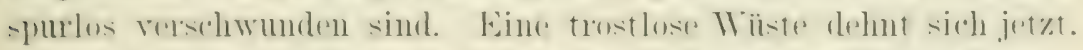

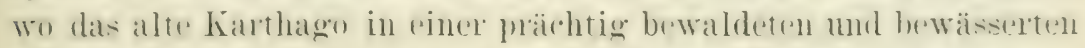

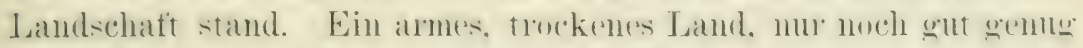

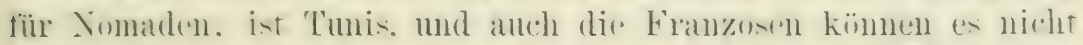

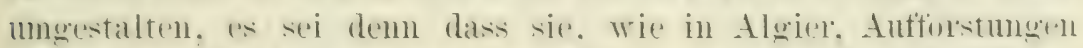
vornehment. Lud läsit man den Blick rund un das Mittelmere schweifen, so trifti er ibterall somnverbanntes, kahles frelände. Su War es nicht immere "inst War dieses schönste Mrea der Erde

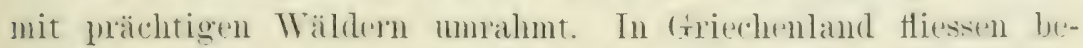
riihme Quellen nu noch im Lied. histmische Flïsese sind liäche

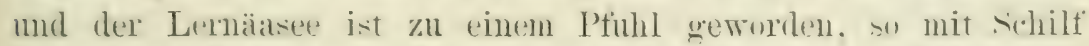
bewachsen, dass manche Reisende an ilm vorbeizogen und ilm nicht bemerkten. In Italien ist der berihmte Rubicon so mbedentend geworden. dass über seine Echtheit Zweifel nutstanden. Palästinat war ein Land der (Wuellen und Bäiche. Jie Lä̈ufe bestehen noch. allein sie: sind trocken. allsgenommen in der Regenzeit. Ladsen wir den blick abschweifen, dam bietet sich wenigstens ein Lichtbild: bei lionstantinnel. Etwa 2010 bis :30 hilometer ron diesere stadt entfernt, sind alle Hügel mit Eichen und Kastanien bederekt, die seit 1500 , dahen gesetzlich bechibtzt werden. Schon die alten griechischen kaisel erkannten ihre Wirhtigkeit, die aurh den tiurkischen sultanen nicht entging. Denm in diesen Hügeln entsuringen die (putellen, welche Konstantinopel mit Wasser versorgen. liur einmal wurde der sichut\% unterhrochens als sultan Mahmut

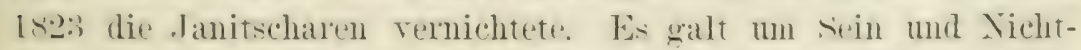
s.in und so wurden diese. Wälder in brand gesteckt, un die hierhere getlïchteten .Janitscharen zu rertreiben. Die Folge war s.jn emptind- 
licher Wassemangel in Konstantinopul. der in dem Masso verschwand, wie das junge Gehölz aufwuchs.

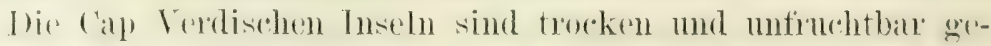
worden mit dem Verschwinden ihree Mälder. Nadeira war bei seiner Enteckung reich bewaldet, entstammt doch auch der Name dene portugiesischen Worte für Holz. Als die Europäter zur Be-

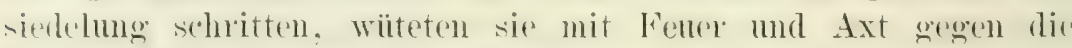
Iälder. Die portugiesische Regiermer wollte Einhalt thm rereghlich, das Verdangen nach nenen Weinbergen liess sich nicht muterdrïcken. Als die Bämme anf' den Bergen verschwomden waren. komnten sich nicht mehr Regen und Rimnsale in der oben geschilderten Wrise bilden; Madeira wude wasserarm und damit unfiuchtbarer, sein grösster Fluss, der socorridos, anf dem fribher Flösse nach der See trieben, ist ein Bach geworden.

Ebenfalls reich bewaldet war St. Helena, als es 1502 entdeckt morde. Die Lodungen, um Kinlturland zu gewinnen, mehr noch die vielen Ziegen entblössten die ganze Insel von Wrald. Es traten verherende Dörren und katm minder verheerende C̈berschwemmmgen ein, so verderblich wuden diese Übel, dass Ende der vorigen Jahrhunderts. der Gouvernenr V'rgïtungen für Aufforstungen gewähte und die schnellwachsonde Tiefer mit der Ermmerung zu Anptlanzung einfühte. Der Erfolg entsprach den Erwartungen: die alten klimatischen Zustände kehrten zurück. 1)ie englisch-ostindische (resellschaft muste 1836 diese Insel an das Mntterland übergeben, von da ab hörten die Vergütungen für dir Bewaldungen ant, die schutzgesetze geraten in Vergessenheit und allmählich scheinen die Wälder dem Tontergange sntgegen zı gehen.

Von den sïdamerikanischen Starten hat Chili am ärgsten gegeren die Wälder gestimdigt. Der nördliche Teil des states war. zum wenigsten in geschichtlicher Zeit, niemals bewaldet, wohl wan es aber der mittlere 'Teil, der jetzt nahezu entblöst ist. Im siiden sind zwar noch ansgedelnte Waldungen zn finden, die aber nach allen Mitteilungen wie schnee vor der Märzonne zusammenschmelzen. Hier sowohl wie im mittleren Chili, haben sich infolge der Tälderverwüstmengen Ïbelstände eingestellt, welche die geset\%gebenden Körperschatten zum Erlass ron Waldschutzgesetzen veranlasst haben, die indessen nux auf dem Papiere stehen. Erwirschermasisen sind viele Quellen rersiegt, Wasserlänfe sind zu 


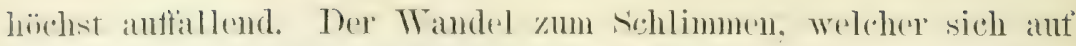
den kleineren rollzogen hat, ist ohne \%weifel dureh menschliche Vermittehug herbeigetührt. Fröher waren sio dicht bewaldet und die ilteren bewohner erimnern sich der Zeit, wo genïgender Regen firl. und dir Hügel und alle unkultivierten Plätze von Bäumen beschattet watren. Die Abholzume ist sicher die trasache des gegenwärtigen Ïbelstandes. Anf dem entblössten Boden sangen die senkrechten Sommenstrahlen die Fenchtigkeit raseh ant und rerhindern den Regen. nach den Wuzeln der Pflanzen zu sickern. I) Regenzeit in diesem Kilma besteht nicht ans einer Reihe bewölktel 'lage, sondern plitzliche Regenschauer wechseln mit heissem somnenschein ab. Anf unbeschatteten Boden wird in den Pausen des Regentalls die Fenchtigkeit rasch verdunstet; und aut jenen Insehn mussten daher die Quellen mol Tasserlänte einen Riickgang erleiden.

Bei Sensulipek in San Salvador wurden viele Wälder gerodet. um Land für die Indigokultur zu gewimnen. In Folge dessen litt diese Gegend so sehr ron Stürmen, dass Anptlanzungen mit den schnellwachsenden Gummibämmen ansgefüht' wurden. Im das Übel zu verbannen, was auch gelang.

Der Botaniker Berthold Seamamn berichtet von einer kleinen Insel, an der Küiste von Nicaragua: Das Kilima ist mlengbar warm, allein die Passatwinde machen es in einem grossen Teil des Jahres angenehm gleichmässig. Es ist eine merkwürdige Thatsache in Bezug anf den Regenfall, dass während dex Zeit, wo diese Insel eine grosse Baumwollpflanzung war, die Regenzeit ron 7 anf 5 Monate zurückging, 7 Monate waren trocken, 5 nass. Allein nun, wo die Bämme und sträucher den grössten Teil der Insel in ihren Natmzustand zuriickgewandelt, haben sich die Witterungsverhältnisse umgekehrt: 7 nasse Mronate ist jetzt die Regel.

Als in Guatemala zwischen San José und dex Hauptstadt Guatemala viele Wälder gerodet wurden, um Kínlturland zu gewimnen, wurde das Klima fieberischer und reränderlicher, die Stüme gerammen an Heftigkeit und in der Hauptstadt Guatemala fiel Schnee, ein Ereignis, das seit Menschengedenken nicht stattgefunden hatte. Erst als Kaffeebäme das meiste gerodete Land heschatteten, und manche Lichtung sich wieder bewaldet hatte, 


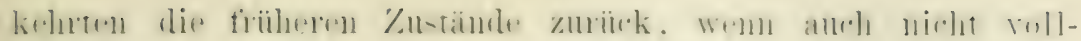
ständig.

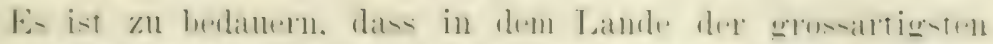

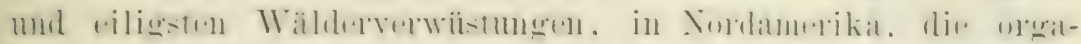

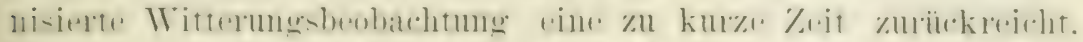

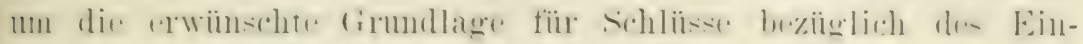

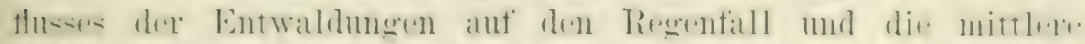

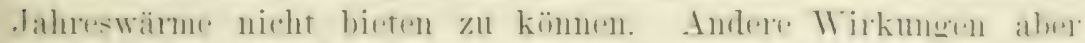

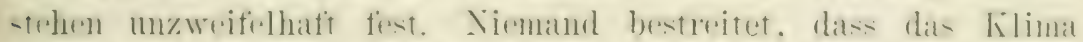

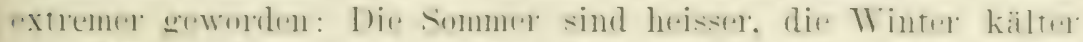

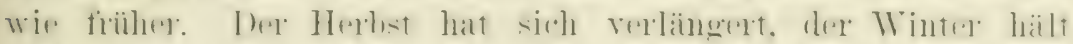

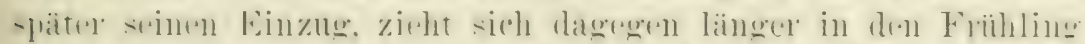

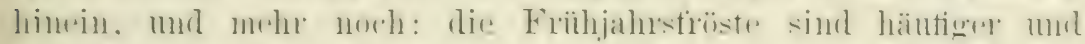

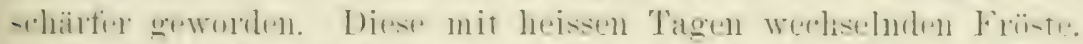

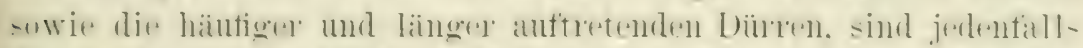

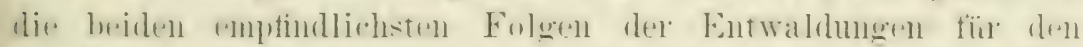

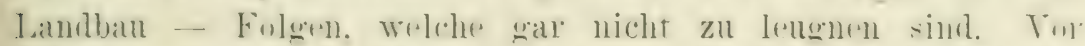
:an Jabren trat in Michigan von Antang Mai bis Ende (1ktulnel kein Frost auf. zuweilen blühten schon die Blumen in Fonnthar. Jetzt ist his Mitte Iuni die Frostgefahr nicht voruber. die I'tir-

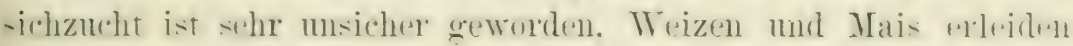

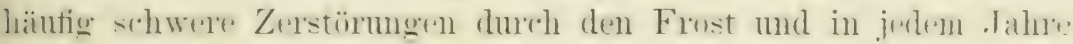

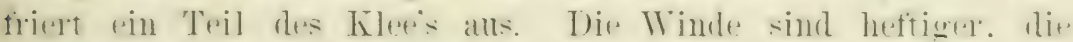
T'emperaturwechsel schroffer geworden.

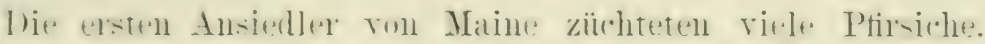

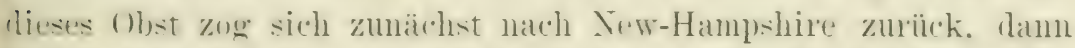

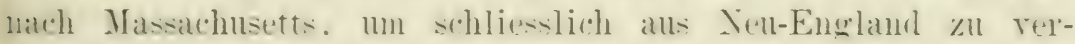

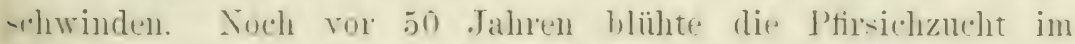

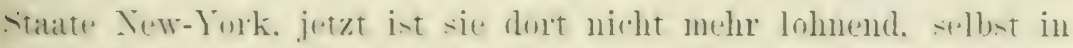

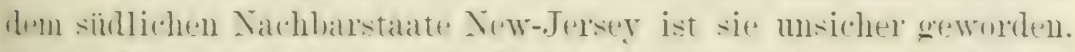

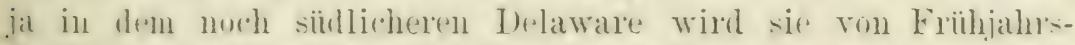

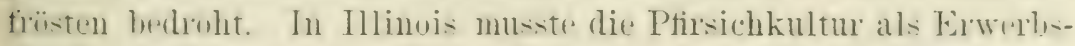

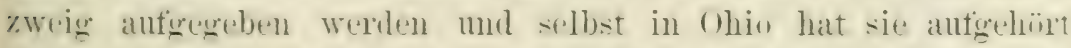
lohnend zu soin. Lnd als bezeirhnend füge ich hinzu: der Sekretär

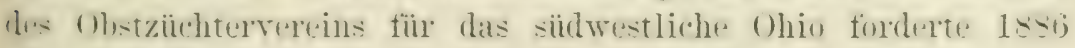
die Mitglieder durch ein hundsohreiben auf. sich mehr der Becerenuhithultur zuzuwemben. da dif Ohstkultur his zur Entmutigunge msicher geworden sei. 
In (Mntario, der bevölkertsten kanadischen Provinz, wo die Wälder starker gelichtet wurden, wit: im iibrigen Osten diestes Latudes, mïssen jetzt die Brumenscharehte 12 bis 15 Mreter tief ge-

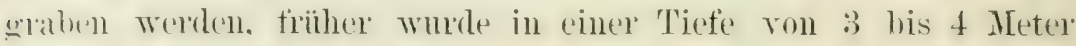
geniigend Wasser angetroffen.

In mittleden New-York sind die Bäche, welche vor 30 bif11 Jahen die Muihlteiche mit einem niemals fehlenden Wasservorat versorgten, $n$ im sommer trocken. mit Ausnahme einiger T'fïtzen, die Dïmme sind wegoewaschen, die Mühlen verschwunden und die Gegend trägt das Gepräge der Verödung:

Philadelphia wird rom Flüsschen Schuykill mit Wasser rersurgt, mod da es in den letaten .Tahren damit haperte, stellten die IVasserbanbeamten Untersuchungen an, welche ergaben, dass vor bo Jahren die Wasserfühmmg dieses Flusses im rommer 1900000000 Liter den 'Tag betrug, seitdem ist sie allmählich auf 90000000 Liters in anderen Worten auf die Hälfte zurückgegangen. Diese nummstössliche That-ache kamn nur durch dir Ternichtung dex Wälder im Qnellengebiete des Schnykill arklärt werden.

Ein ähnlicher Wasserrïckgang lässt sich noch an vielen anderen Flïssen nachweisen, beispielsweise war der cuyahoga. welcher sich in den Eriesee ergiesst, noch vor 50 .Tahren ein allezeit schiffbarex Fluss, gegenwärtig trägt ex im sommer keinen Kahu mehr. Dex Huronfluss in Michigan war einst bis Ypsylanti schiffbar; jetzt ist er bis zu seiner Mündung ein Mühlbach.

Als Oregon 1832 besiedelt wurde. war sein nordwestlicher 'Teil ron einem zusammenhängenden Walde bedeckt. In den folgende'n 40 . Tahre'n blïhten dort die Rosen noch um Weihnachten, rine Eisbildung fand nicht statt und der Temperatur blieb jeder schrofte Wrechsel fer'll. Dann aber machten sich die Folgen der fort-chreitenden Entwaldung bemerkbar. In jedem Jahre wurde der sererkehr Portland's, dex kommerziellen Hanptstadt Oregons, durch Eisgang auf dem Willametti und Columbia unterbrochen. die Bäche frieren zu, der Schmee bleibt längere \%eit liegen, die Stiimne richten schaden an, was sie frither nicht thaten mol Frïhjahrsföste, frïher eine unbekannte Erscheinung, bedrohen den Landban.

Die Regierung ron Californien setzte 1886 eine sogenamnte Furthommission ein. mit der Aufgabe. über den gegenwärtigen 


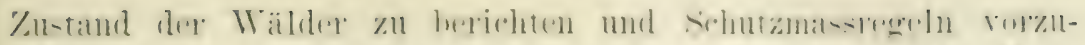

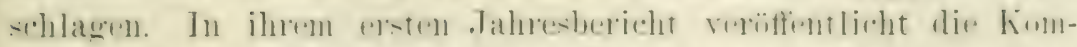

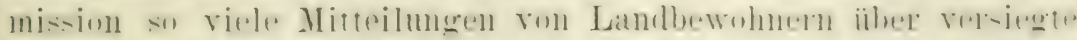

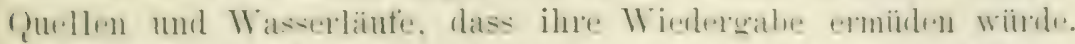

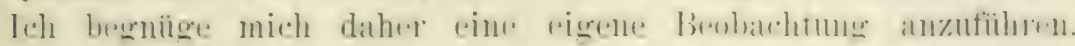

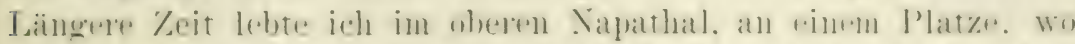

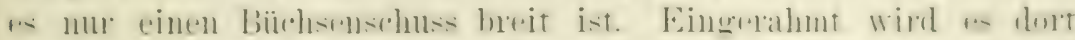

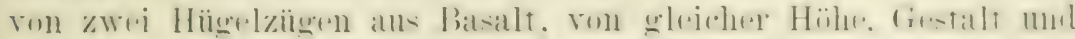

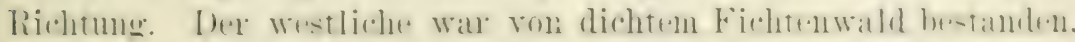

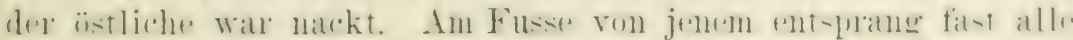

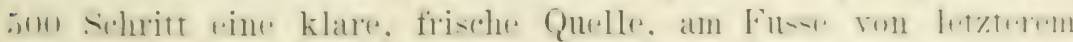

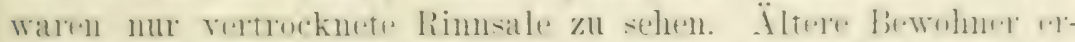

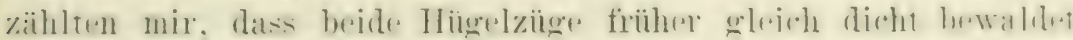

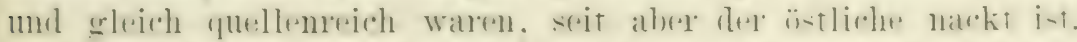

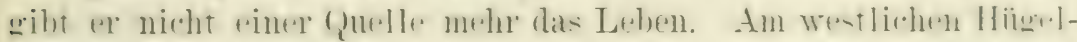

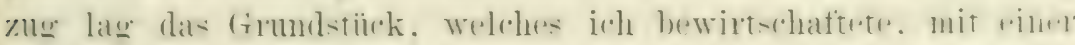

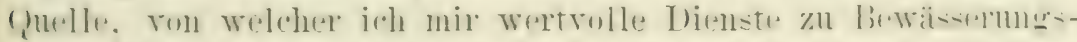

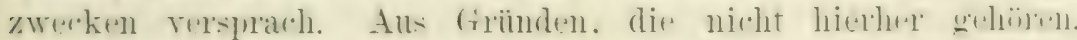

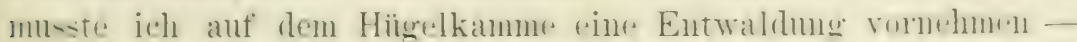

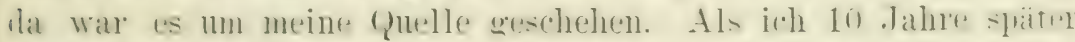

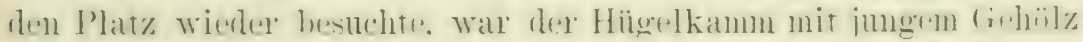

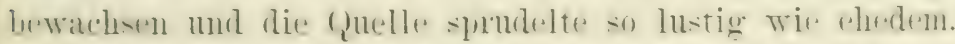

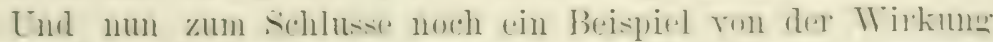

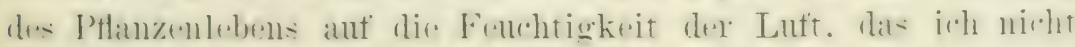

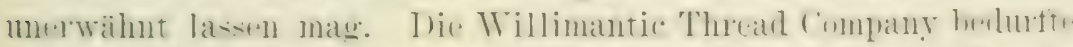

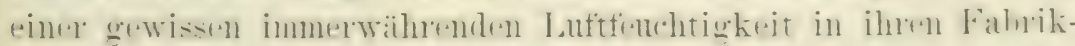

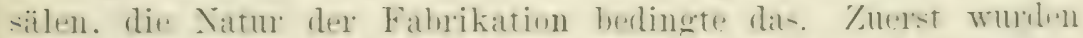

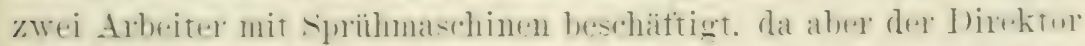

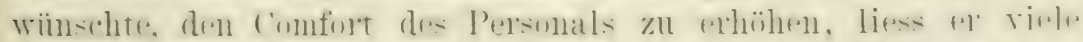

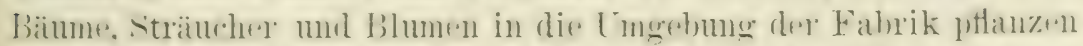

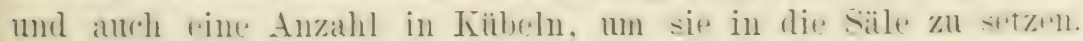

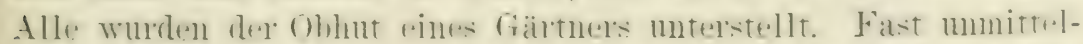

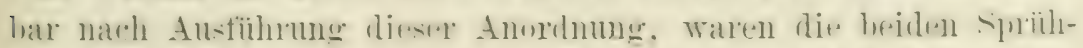
maschinen nicht mehr nötig: der Direktor sparte den Lohn rine-

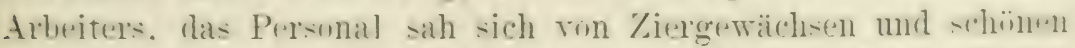

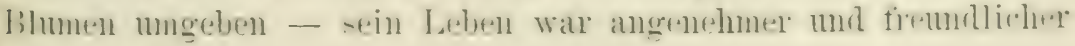
geworden. 


\section{I)ie (irundzüge der Forstkultur.}

Zur richtigen Anffassung der nachfolgenden gedrängten Alhandhung schicke ich diese beiden Bemerkungen voraus:

1) Klar möchte ich mich verstanden wissen, dass ich nicht tür amgehende Forstlente schreibe; geleitet werde ich nur von der Absicht, dem tropischen Pflanzer belehrend zur Seite zu stehen, wenn "L sich dir notwendigsten Kenntuisse zur forstwirtschaftlichen Benutzung eines 'Teils seines Besitztums aneignen will. Kein Forstmann möge deshalb, vom standpunkte seines Berufes ans, Kritik an dem hier Gebotenen üben.

2) Eine tropische Forstkultur gibt es bis jetzt kaum dem Samen nach, wissen wir doch nicht eimmal von manchen geschätzten Handelshölzern zurerlässig dif botanische Quelle, und wie es da mit den Kenntnissen rom Werden und Wachsen der tropischen Taldbäume bestellt sein muss, lässt sich leicht folgern. So berechtigt der Stolz ist. mit welchem wir Deutsche anf unsere For'stknltur blicken, so diunfen wir doch nie vergessen. dass sie mserem Taterlande, bildlich gesprochen, anf den Leib zugeschnitten ist nund daher anf andere Länder nu in kleineren oder grösseren Bruchstücken ïbertragen werden kann. Erwies sie sich schon zu finem beträchtlichen 'Teile nnanwendbar in dem nahen Italien. wie mangelhaft als Torbild mus sie sich demnach in tropischen Ländern erweisen. Indien ist bis jetzt das einzige tropische. Land, wo der Grund zu einer Forstkultur gelegt wurde, allein es sind doch erst nur Anfänge vorhanden, es fehlt selbst noch das rohe Geriist des Aufbanes. Und dam: schätzenswert wie die in Indien gesammelten Erfahrungen auch sind, Iassen sie sich doch nicht ohne weiteres auf andere tropische Länder iibertragen. 


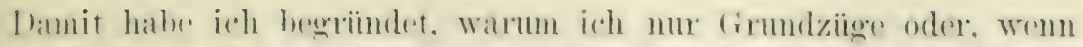

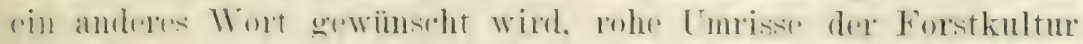

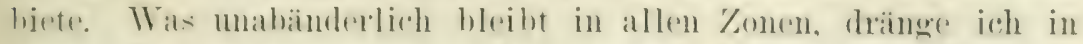

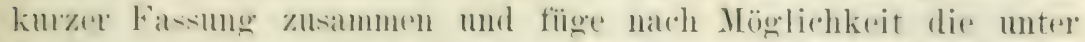

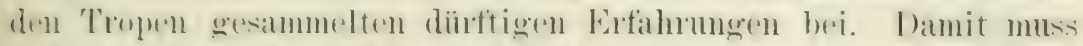

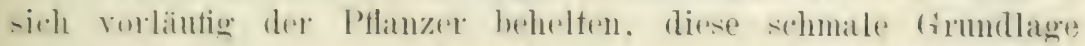

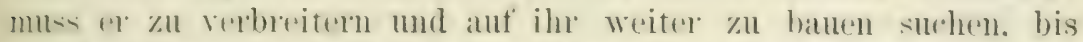

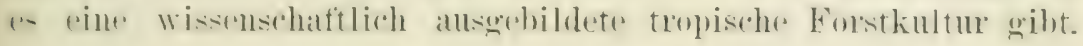

Die Furstaultur im weitesten simne des Wortes ist der Zweing

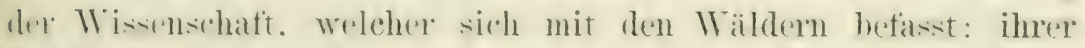

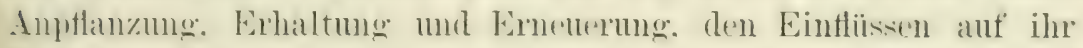

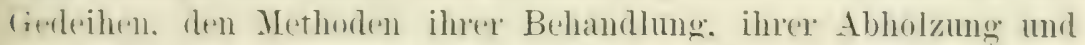
Verwertung. den Essparnisen. Wolche dureh eine umsichtige Brwirtschaftung erzielt werden können.

Hir Forstkultur stiityt sich ant verschiedene Wissensehaften :

1) Der Vatmoeschichte entnimmt sie die Beschneibung und Eintrihmg der Bänme. Wit der Tiere und Ptlanzen. Wolche Finfluss üben anf das Gedeihen der Bänme.

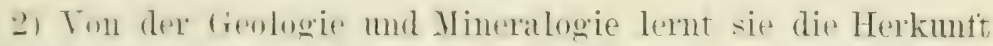
mul merhanisole Zusammensetzung des Bodens, wie der unterlagernden Felsgebilde.

(3) Von der chemie fordert sie: Anthlärmugen iiber die chemi-che Zn-immensetzung des budens und des Holzes. wie ïber dit

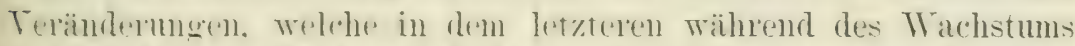

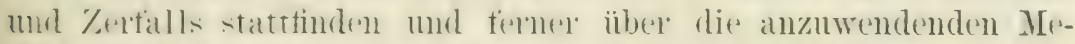
theden hei (itwinnmer von Vebenprordukten des Waldes.

4. Dir. Mathematik gewährt ihr Hülte bei allen Mesimgen

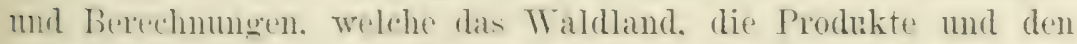
Betrieb ambelangen.

5) Die Mechanik lehrt sie die rerschiedenen Hiiltsmittel zum Fälen. Transportieren und Zubereiten des Holzes. wie zum Bearbeiten des Bodens und zur Pflege der Bäume.

(i) Phỵsik und Ifetenologit gewähren Aufklarung ïher die verehimbenen Fragen der Bergehungen des Kölimas zu den Wäldern, 


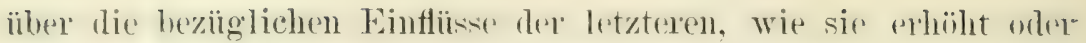
ermässigt werden kömmen.

7) Der Volkswirtschaft entlehnt sie die Lehsätze äbex Angebot und Nachfrage, über ätentliche Wohlfahrt und Nutzniessmeen. ihre gegenseitige Abhängigkeit, über die Wirkung, welche die allgemeine Geschätstage anf den Boden- und Produktenwert der Wälder ausibben. wie iiber alle wirtsehaftlichen Fragen, welche mit der Anlage oder Benutzung der Wailder in Beriehungen stehen.

Alle diese Hültswissenschaften hier in Anspruch zu nehmen, würde dem '/awecke dieser ku"zen Abhandlung nicht angemesen sein. Fragen der Volkswirtschaft, Physik, Meteorologie, Mechanik und Chemie sind an anderen Stellen dieses Buches, je nach ihrer Wichtigkeit, kürzer oder länger erörtert worden; ich beschränke mich daher, einen Abriss der Pflanzen- mo Bodenkunde zn qeben, bevor ich zur praktischen Forstkultur übergehe.

\section{Zur Pflanzenkunde.}

1. Die Pflanze.im a $1 \mathrm{~g}$ emeinen.

Als Pflanzen im wissenschaftlichen simme betrachtet man alle Gewächse, vom Pilze, der nur dem bewaffneten Ange sichthar ist, bis zum mächtigsten Bamme Fs sind Wesen, deren Lebensthätigkeit auf die Ernährung; das Wachstum und die Fortpflanzmng beschränkt ist; wohl wird auch einigen Pflanzen eine gewisse Empfindung und willkürliche Bewegung zugevprochen, doch thum dariber weitere Anfstellungen not, jedenfalls kommen diese Eigenschaften höchst ausnahmsweise vor:

Jeder 'Teil der Pflanze, dem eine besondere Verrichtung obliegt, wird als Organ (Werkzeng) bezeichnet.

I) Verrichtungen der Organe und die Wirkungen, welche sie hervorrufen, werden von der Pflanzenphysiologie ertorscht. Der Ban der Organe fält dagegen in's Bereich der Pflanzenanatomie. Die Grundstoffe, ihre verschiedenen Verbindungen und L'mwandslumgen, bilden den Gegenstand der ['ntersuchung für die Pflanzenchemie. Iit den äusseren Formen der Pflanzen beschättigt sich die beschreibende und systematische Botanik. 


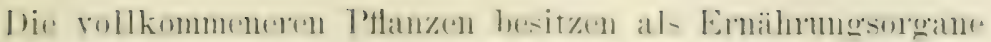

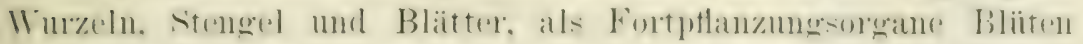

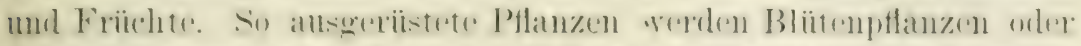

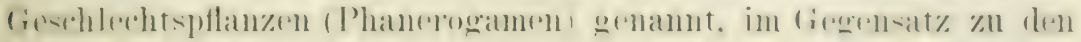

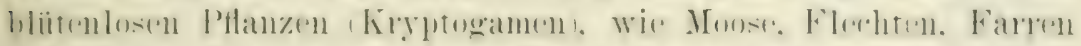

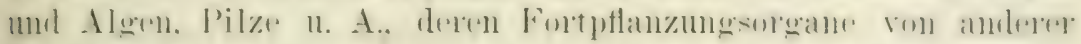

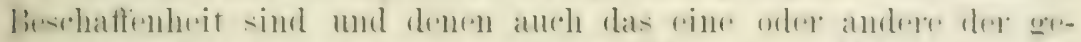

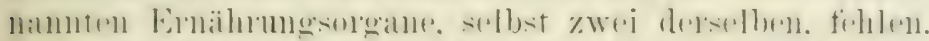

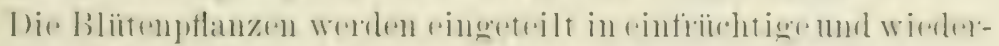

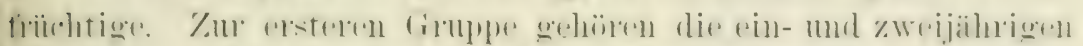

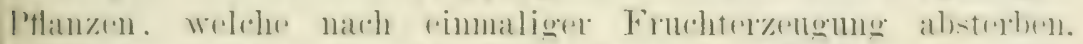

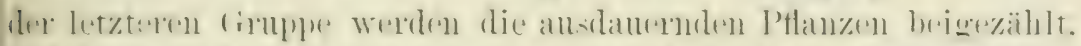

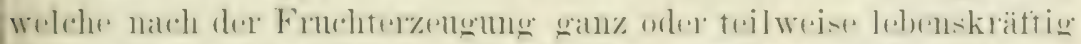

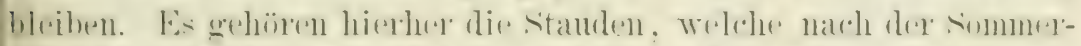

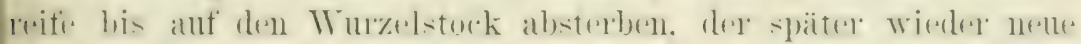

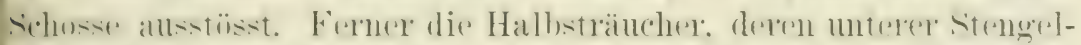

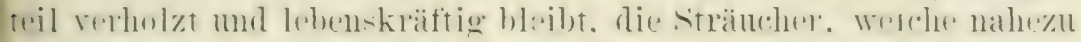

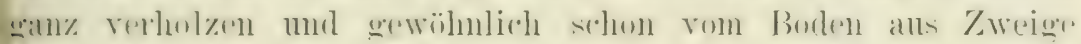

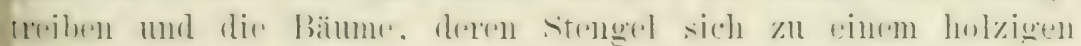

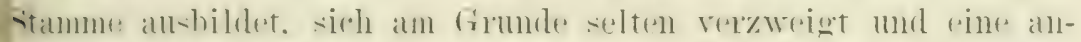

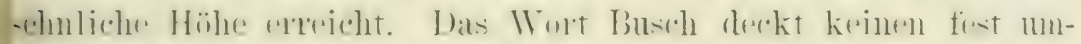

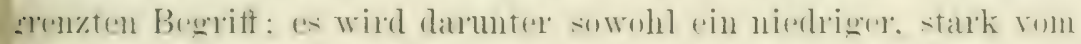

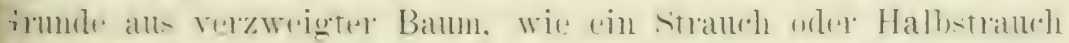

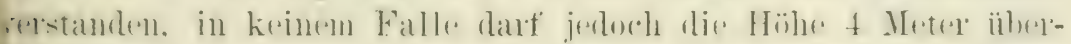
chreiten.

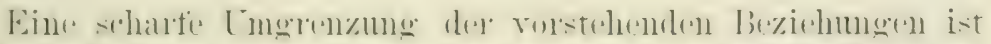

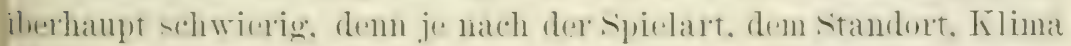

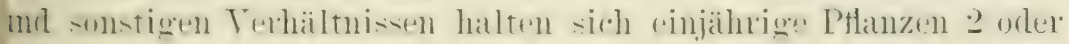

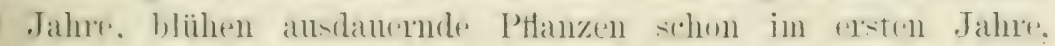

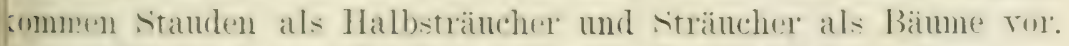
Gine andere Einteilmog der Blitenptlanzen geschieht in Einsanenappige (Aonokotyledomen) und zweisamenlappige (D)ikotyledoment. bi: erstren krimen mit rinem samenlaypen. die letzteren mit zwei.

Landpflanzen werden dir Pflanzen genannt. Welehe in der

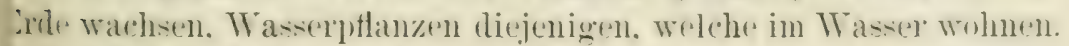

Als Epiphyten werden die Pflanzen bereichnet. welele sich it ihren Wurzeln an andere Pflanzen heften; sie sind wehte

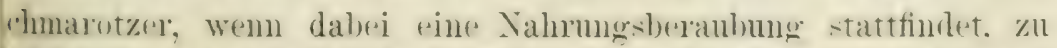
olchem Zwecke natiurlich die Wuzeln in die Pflanzen eindringen 


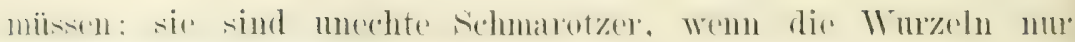
änsserlich anhängen.

Bätume und sträulher, um deren betrachtmon es sich fortan handeln soll, bestehen aus:

1. Dex Wurcel odex dex abwärts wachsenden Achse, die sich

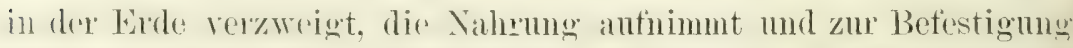
dient: sie ist bei den Blïtenpflanzen schon bei der Keimmon des Samens vorhanden.

2. I) Sum stamm odex der anfwärts wachsenden Achse, die sich vorzweigt. Bläter treibt und Blïten mod Frïchte hervorbringt.

3. Den Blättern, welehe meistens griun und wagerecht an den Zweigen in verschiedener Weise gentellt sind. Sie empfangen den aufsteignenden Saft, nehmen aus der Luft Kohlensäure auf, stosien den überflüssigen Samerstoff ans. verbinden den zurüickgehaltenen Kohlesustoft mit der Bodemnahrung und geben den si mugewandelten Saft an dir Zweige zurïck - eine Thätigkeit, rle im sewöhnlichen Leben atmen genament wird; daher bezeichnet man auch die Blätter als die Lunge der Pflanze.

t. I) Bn Blitten, die entweder an den Enden der Zweige, als Endblïten, oder an deren Seiten, als seitenblüten erscheinen. Blättex wie Bliiten entwickeln sich ans Knospen, die, in Tebereinstimmung mit vorstehender Einteilung, Fudknospen und stitenknospen genannt wriden. An anderen stellen anstretende Knospen werden Yebenknowen orlex Arlventirknospen genamnt. Achselknospen ist nur ein anderer Yame fïr seitenknospen. ex bezieht sich auf dis Blattallsiln orler Blattwinkel. an welchen die Knospen erscheinen. Tren Volnenknospen längere Zeit ihre Form bewahren, werden -ie zu schlatkunsprn. die sich gewöhnlich erst damn öfnen, wemn die ïhrigen Knospen zerstät wuden, durch Frost beispielsweise. Inzwischen nehnen sie jedoch an Grösse zu, muter Lmständen so sthr dass sie in dex Rinde dicke Kingeln bilden. Ans ihnen entwickeln sirh am stumpfe gefällter Bämme die Stockausschläge. Futstehen Knosuen durch eine Lmbildung der Blüten oder Früchte, $\therefore$ nennt man den Baum oder stranch sprossend oder lebendig gebärend.

Die Blüten kömnen getremntgeschlechtlich oder zwitterig sein.

In ihrer vollkommensten Ausbildung ist die Blïte zwitterig und besitzt die folgenden Bestandteile: 


\section{Der Stamm.}

Auferelst wird ein stamm genamt, wemn el anfstrebend in die Höhe wächst, niederliegend, wenn er ganz oder zum grö̈sten T'eil ant dem Boden liegt; treibt er zugleich an rinigen stellen Wurzeln aus, ist er kriechend. Treten mehrere diume stämme dicht beisammen ans dem Boden, wird die Bezeichnung bü-chelig angewendet. Schwache, unselbständige stämme heissen mindend, wemn sie sich schraubenförmig $10 m$ ihre stïtze legen; rechtswindend, wemn die stïtze zur Rechten, linkswindend, wenn sit: zur Linken bleibt. Kletternde stengel sind solche, welche, ohne zu winden, sich mit Blättern, T)ornen, stacheln, besonderen Rankin oder Klammerwurzeln festhalten.

Ausliuter oder surösslinge sind junge Bänme oder sträucher. welche aus dicht unter der Bodenoberfläche lanfenden Minzeln treten.

Die Stelle an dem stamme, stengel oder Zweige, wo ein orler mehrere Bläter oder Zweige entspringen, wird Knoten genannt. Der zwischen zwei ïbereinander liegenden linoten befindliche Teil heisst das stammglied, Zweigglied oder stengelolied.

Der Stamm gilt als Hauptachse, die Äste und Zweige als Tebenachsen erster und zweiter Ordnung. Die Richtmo der Äste und Zweige giebt der Tracht (Gesammtansehen, Habitns) fines Bames oder stranches im Tesentlichen das Gepräge.

Die zweige sind gegenständig. wenn zwei an demselbun Finoten an entgegengesetzten reiten entspringen; quirlständig oder wirtelig, wenn mehrere rings un denselben Knoten geordnet sind; büschelig, wemn zwei oder mehrere an einer teite eines Rnotens entpringen, wechselständig, wemn sie einzeln an den Knoten, aher abwechselnd an der entgegengesetzten seite entspringen; zerstrent, wenn sie anscheinend unregelmässig rerteilt aus den Ästen orler dem Stamme wachsen.

\section{Die Blätter.}

Was vorstehend ron der Anordumg der Zweige gesagt ist, grilt anch für die blätter. Es tritt noch hinzu: Kreuzständig werden die Blätter genamnt, wenn sie nicht allein gegenständig sind, sondern jedes Paar mit den vorhergehenden und nachfolgenden einen rechten Winkel bildet. Zweireihig sind die B]ätter: wenn sie in zwei entgegengesetzten Reihen regelmässig geordnet sind; 


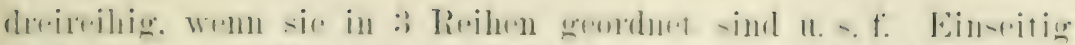

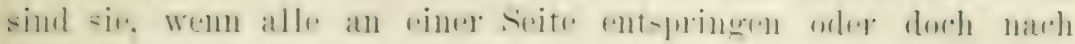
einer seite hin gerichtet sind.

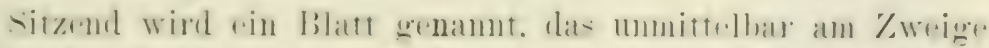

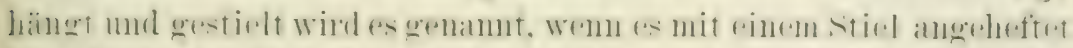

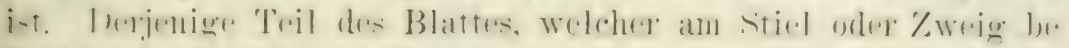

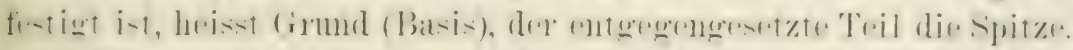

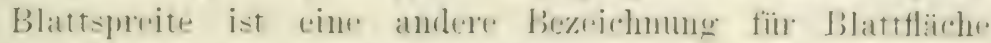
cine solche besitzt nur das Laubblatt.

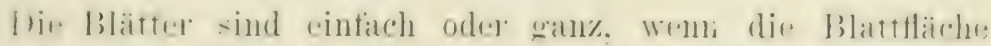

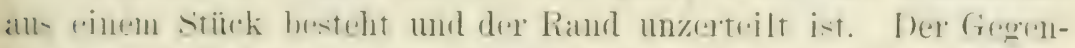
silt\% von einfach ist zusammengestzt. derjenige von ganz: groalnnt,

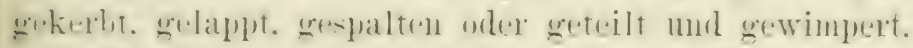

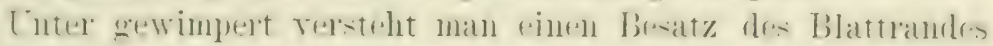
mit starken Haaren oder harähnlichen Kähhnen.

lrozahnt wird ein Blatt genannt, wronn der liand mit

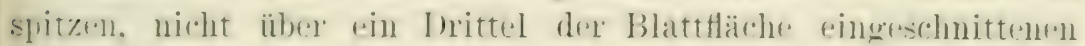
Ziilnem besetzt ist.

sind /ähne und Winkel scharf, ähnlich wie dir. Zälne ciner Säge, ist das Blatt gesïgt.

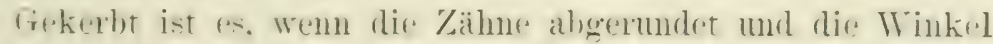
schart sind.

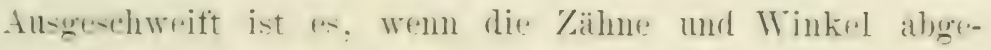
rundet sind.

Wellig ist es, wem der Rand nirht in gleicher Flärehe licgt, sonderm abwechselnd gehoben und gesenkt ist.

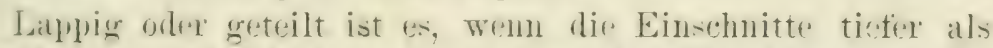

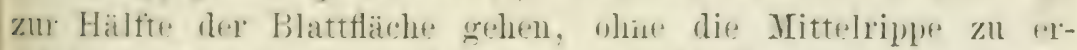
relohen. Dir einzeluen Abtrilungen werden Lappen grenannt oder

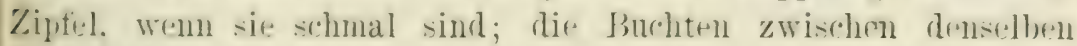
heissen Alusschnitte.

\%erteilt oder zersohnitten ist es. wem die Einschnitte anf dir. Iittelripe: oder den Blattstiel gehene, dis Teile jodnch am Grunde rethunden bleiben, mit sich oder ohne beronderen stim mit der Mittelrippe oder dem Blattstiel.

befiedert wher zusammengesetzt ist as. wenn es ans muge-tielien oder gestielten Fiederbüttchen grebildet wirl. Ton dem

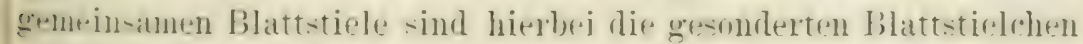
zil unterscheiden. 
Dem Bhatstiele entepringen Rippen oder Adern, die sich in

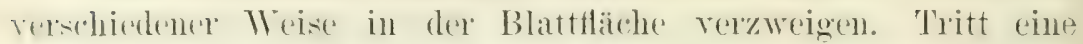
derselben in der Mitte des Blattes stark hervor, wird sie Mittelriple wemant. Ihre scitemiplen veristeh sich und wem sie fein anslaufen. bilden sie ein Adernetz. Mrehere gleich starke, dem Blattstiel contsuringende Riplen werden finger- oder handnervig grenannt.

Der Form nach können die Blätter sein:

lincalisch. wemn sie lang. schmal. cincen Lineal ähnlich sind;

lanzettlich. wenn sie drei- oder mehrmal länger als breit, in des:

Mitte am breitesten sind und nach beiden Enden sich verschmälern, ähnlich einer Lanzenspitze;

keiltörmig, wenn sie oberhalb der Mitte am breitesten mond nach dem Grunde schmäler sind; wenn dabei sehr breit an der Spitze und abgermdet, sind sie fächerförmig;

slatelfömig, wemn die breiteste stelle an oder bei dex spitze nud kurz ist. rom da bis zum Grumde eine Terschmälerumg stattfindet;

firund. Wemn sie rotwa doppelt so lang als breit mol muterhalb der Mitte am breitesten sind. ähnlich dem Längshorchschnitt eines Eies.

rerkelurteirund ist dieselbe Form, nur mit der breitesten stelle oberhalb der Mitte;

sichelförmig, wemn sie gekrïmmt sind, wie dir Finge einer Sichel;

kreissund, langrund, rantentörmig entspechen den grleichnamigen mathematischen Figuren;

ICittelformen bezeichnet man durch Verbindung der beiden in Betracht kommenden Haulfformen, beispielsweise lineal-lanzettlich ist lang und schmal, gegen die Mitte breiter wie an beiden Enden; linealisch-langrund ist nicht so schmal um linealisch, nicht so breit um langrund zu sein, nach beiden Fnden findet keine Verschmälerung statt.

Die Blattspitze kann sein:

rpitz, wemn sie tinen spitzen Winkel bildet oder sich zu einem Punkte verschmälert;

-tumpf. wenn sif einen stmmpten Trinkel bildet oder abgermet ist; 


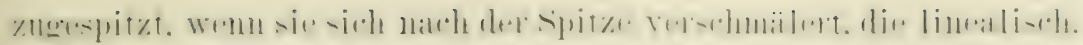
spitz oder stumpl sein kann;

abgestumpft, wemn die Spitze eckig ausläuft;

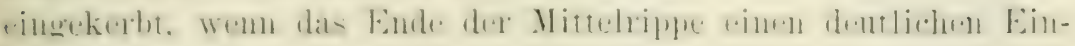
schnitt zeigt:

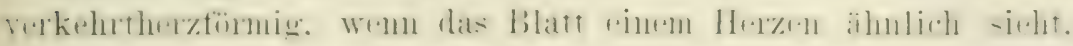
das an der Spitze befestigt ist;

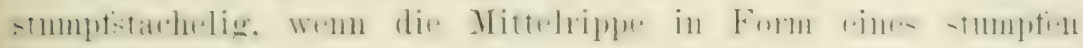

Stachels über die Spitze hinaustritt;

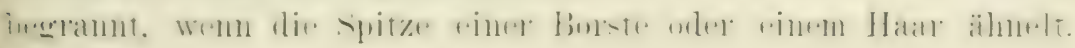

Der Blattgrund kann sein:

keilförmig, wenn er schmal zuläuft;

abgerundet, wem er sich einfach abrundet;

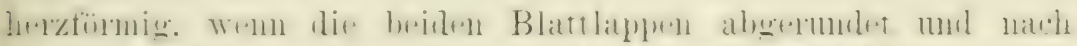

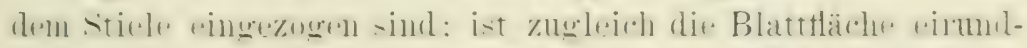

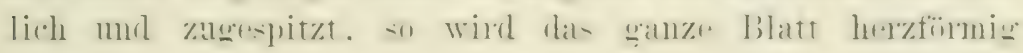
genannt;

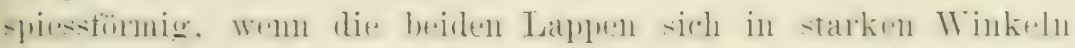

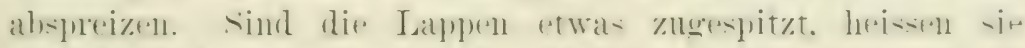

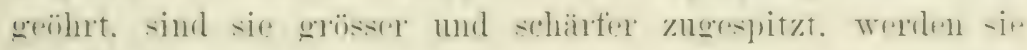
pfeilförmig genannt;

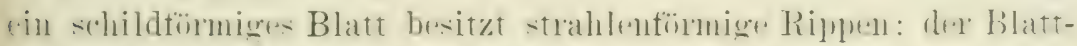

stiel entsuringt alls der Witte rer motern Blattlache:

nierentïmig wird cin Blatt genamnt. das hreiter als langr. an

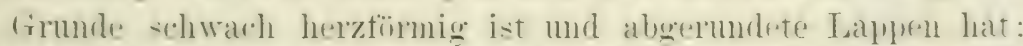
barlelfümig ist rin Blatt, das schlank mol zugleinh zugespitzt i-t. :ihnlich einer Nadel.

Alle diese Formen quhen inderen so ineinander ibluer. dars uft schmer hält. dir richtige Benemunng zu finden.

schuppen hïmen als relkiummerte Blitter hetrachter werden:

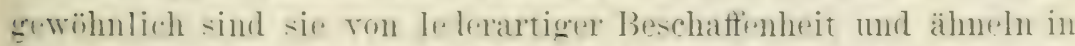

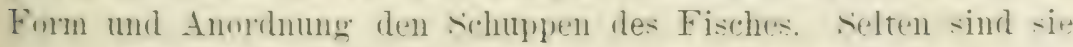

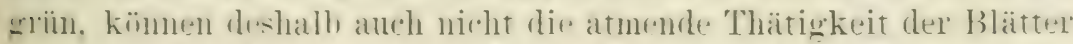

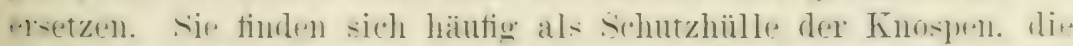

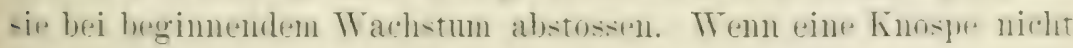
mit Schuppen bedeckt ist, wird sie nackt genannt.

Inekblätter werden dir oberen Blätter einer blühemelen I'flanze erenannt. sif sitzen an den Blïtenzweigen und weichen in Form.

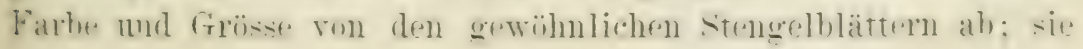


sind wewïnlieh kleiner und mehe sitzend, sind nicht immer sriü. sondern anch blumenartig gefärbt.

Vebenbläter sind blatt- oder schuppenähnliche Anhängsel am Cirmude der Blätter. Mreist sitzt rins an jeder Seite des Blatter. Hne Bestimmmg ist häutig. das junge Blatt vor seinel Entfaltumg \%u schüt\%en. '/uweilen sind sie den achten Blättern vollständien ännlich, nur dass sie keine Knospen in ihren Winkeln bilden. häutiger sind sie den Fiederblätrhen eines zusammengesetzten Blattes ähnlich. In den meisten Fällen sind sie schmal und klein. mitunter verkimmert zu schupen. Knötchen. Dornen oder diitenförmige, stengelumfassende Gebilde.

\section{Der Blïtenstand.}

Inter dem Blïtenstand einer Pflanze versteht man die Anordmung ihrer Bliitenzweige und Blüten. Es ist die blïhende spitze eines $/$ weiges. oberhalb der lotzten stengelblätter, mit Deckblättern, Blüten und Zweigen.

Gipfelständig ist ein Blïtenstand, wenn er sich an der spitze eimes Zweiges befindet; achselständig, wemn in der Achsel (dem Tinkel) (ints Zweighlattes stehend, blattgegenstandig, wem el sich einem Zweigblatte gegeniiber befindet. Begrenzt wird ein Bliitenstand genannt. wenn er an seiner spitze mit einer Blïte abschliesst, mbegrenzt, wenn die Blüten achselständig sind und mit Blättern enden.

Blïtenstiel nemnt man nicht allein den besonderen stiel einel Bliite. sondern anch den gemeinsamen Stiel eines Blïtenstandes. das will sagen, den obern Teil des blühenden Zweiges vom letzten Zweigblatte an. Das stiick des Zweiges, welches durch den Bliitenstand geht. bezeichnet man als seine Achse oder Spindel.

Die Zweige eines Blütenstandes können wie die übrigen Zweige sein: gegenständig, wechselständig u. s. w., sind jedoch oft in abweichender Weise wie die Bann- oder stranchzweige geordnet.

Der Bliitenstand ist:

zentrifugal, wenn sich seine oberste Bliite zuerst offnet, dir tieferstehenden später;

zentripetal, wemn sich die untersten Blïten zuerst öffnen, der Hauptstiel inzwischen weiter wächst und Bliiten entwickelt. die sich später entfalten. 


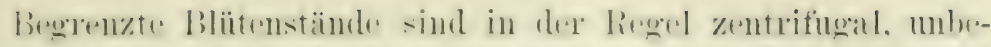

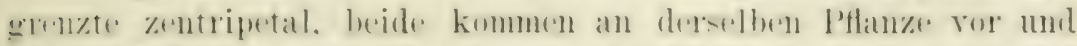
zwat häufig. dass der Hauptzweige des Bliitenstandes \%entrijetal ist und die Seitenzweige zentrifugal sind.

Der Bliitenstand kamn sein:

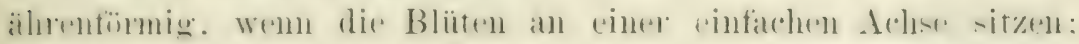

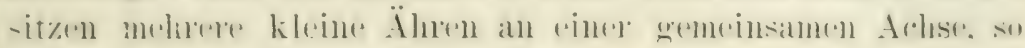
(ninteht die zusammengesetzte Ähre;

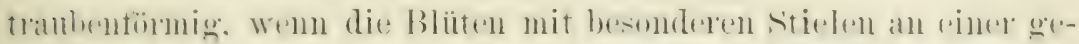

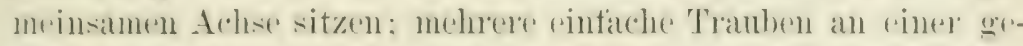
meinsamen Achse sitzend, bilden eine zusammengestzte Traube: ri-penformig. wenn die Achse in \%weige getrilt ist. von welehen

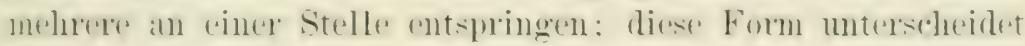
sich kaum ron der zusammengesetzten 'l'raube;

koptfirmig. wemn melnere beieinanter sitzende libiten zu •-inem keptähnliehe'n Büschel zusammengedrängt sind. Dir kurze. rerdickte. gewölbte oder kegrelfömige Achse, anf welcher die Blïten sitzen, wird dex gemeinsame Blütenboden genamt. w. wird zum Blätenkuchen, wie bei der Feige. wenn ex fleischig ist und die Blüten eingesenkt trägt;

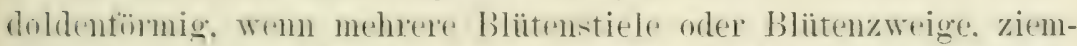
lirh von delselben Länge, an rinem Punkte zu entspringen scheinen.

Einfach ist eine Dolde. wenn jeder Zweig nur eine Blüte trä̈rt: zusammengesetzt, wenn jeder Zweig ein I)öldchen trägt. Fom Konft unterscheidet sich die Dolde, rass ihne einzehen Bliiten gestielt sind.

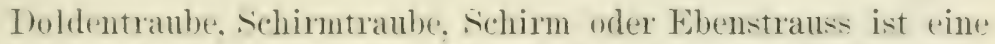
verweigte: ahgestuzte Traube. Die tiefer stehenden Blitenstiele verlängern sch sn weit, dass ihre spitzen mit den obersten in (inex Linie stelene die Blüten also eine Fläche bilden.

Eine 'Trugdolde ist eine verzweigte und zentrifugale Traube wher loblentratbe, deren mittelste Blïte sich zutert öftnet. diejenigen del seitenzweige folgen nach und nach; gewöhnlich sind die Letzteren gabelig oder gegenständig verästelt.

In zahlreichen Fällen hält der Blitenstand die Mitte zwischen zwei der genamten Formen und werden dam mit Bezoichnumgen belegt wie ährenähnliche Trauben u. s. w.

be Kätzhen der Kätrhenblitter sind eine Form der Achre. 
Deckblitter sitzen gewöhnlich unter jedem '/aweige eines

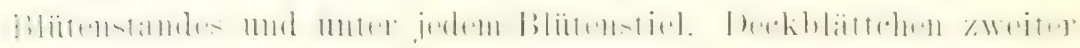
Ordnung sitzen in der hegel parrweise, eins an jeder seite des Bliitenstils. minter einer Blïte oder aut dem Kelche selbst. Diese

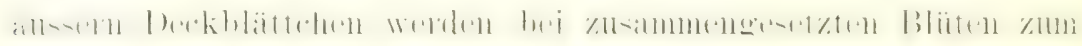

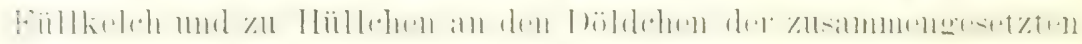
milden.

\section{Die Blïte im Allemeinell.}

Als vollständige Blïte bezeichnet man eine solche, welche ans Kelch, Blumenkrone, Staubgetässen und stempel besteht, und als eine rollkommene eine solche, in welcher alle diese Organe

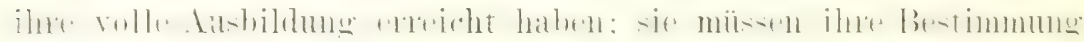

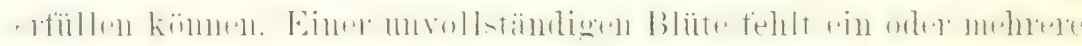
jener Organe, eine unvollkommene besitzt ein oder mehrere jener Organe, die so rerkiummert sind, dass sie für ihren Zweck untauglich sind. Solche Organe werden anch als fehlgeschlagene bezeichnet, wem sie in Grösse und Gestalt rerkitippelt und als spurenhafi, wenn sie kam bemerkbar sind.

Die Blïte kamn sein:

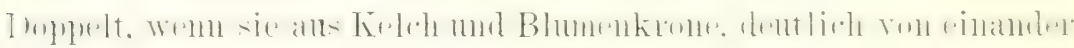
getremnt. besteht;

einfach. wemn Kelch und Blumenkrone rertachsen sind oder eins

ron beiden fehlt; fehlen beide. so ist die Bliite nackt;

zweigeschlechtig oder zwitterblïtig, wenn sowohl Stempel wie Staubgetässe vorhanden sind;

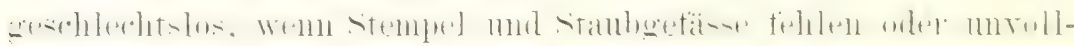
kommen ansgebildet sind:

unfruchtbar: wem sie aus irgend einer Ursache keinen Samen elzengen; fruchtbar. wenn sie Samen erzengen.

Eine mämnliche oder staubblïte besitzt ein oder mehrere Staubgefasse, aber keine oder verkimmerte Stempel.

Eine weibliche oder Stempelblüte besitzt nur stempel, aber keine oder rerkiummerte Staubgetässe.

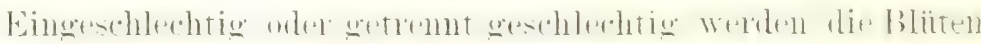

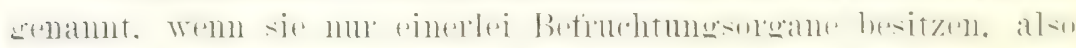
männlich oder weiblich sind.

Einhänsig heissen sie, Tenn die mämnlichen und weiblichen

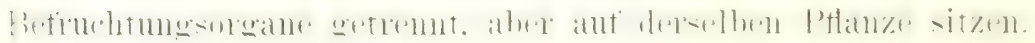




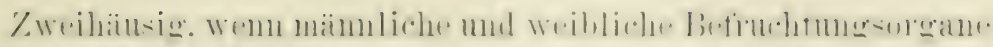
anf verschiedenen Pflamzen sitzen.

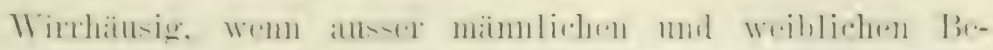

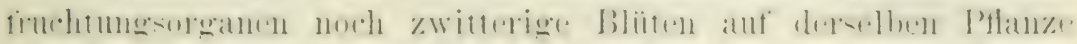
(oder aut verschiedenen Pflanzen vorkommen.

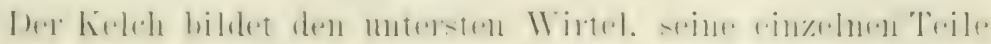
heissen Kelchblätter.

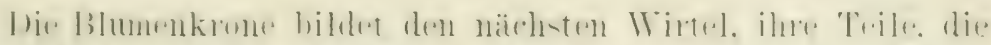

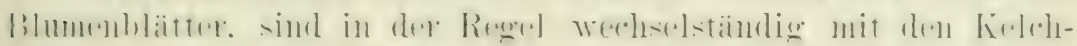

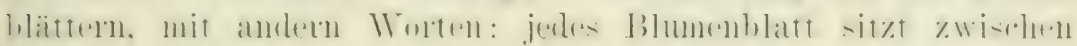
\%wei Kelchblättern.

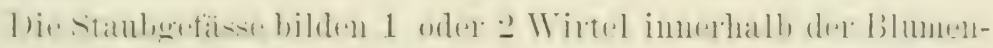

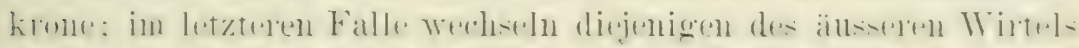

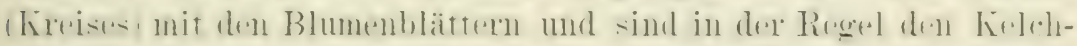

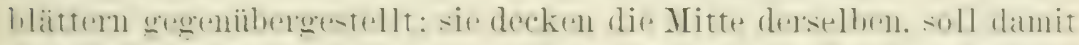

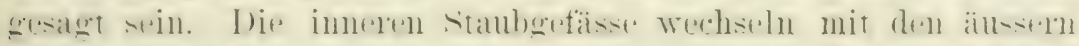

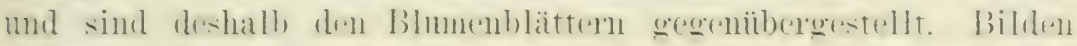

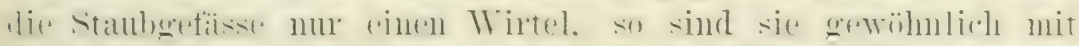

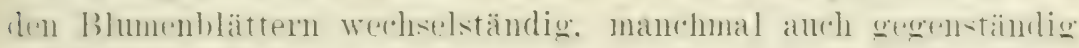
mnd mit den Kelchblättern gegenständig.

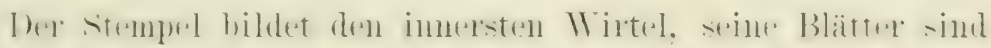

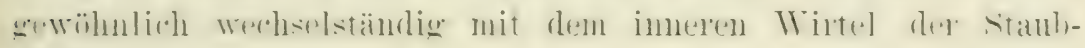
grefässe.

I) Ar Anzahl, in weleher die verschiedenen blätentede rorhanden sind. macht man ron 1 bis 10 namlatt. grässele Ifengen

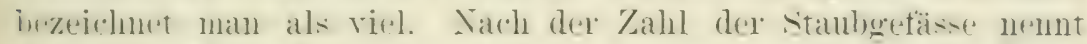

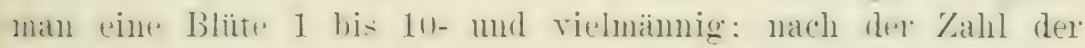

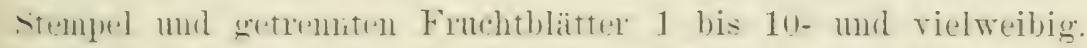
Sach dem Vorherrschen winer bestimmten Zahl in riner Blïte wird diese 2-3-4-5-6zählig genannt.

Lnegelmäsige wird eine Bliite genamnt. wem die Teile pines

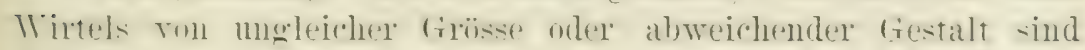

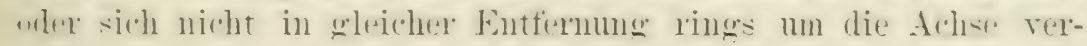
ailen. Bri unrexelmäsiger Allsbildmeg der Blumenkrone wendet

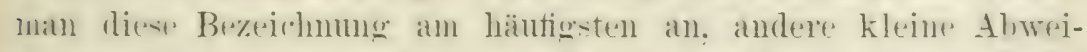

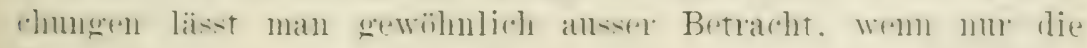
Blumenkrone regelmässig ist. 
7. Der Keleh und die Blumenkrone.

Ter Felde ist in der Regel kleiner wie die Blumenkrone mol wlin. zuweilen sche klein oder verkümmert, nicht selten fehlt er. In manchen Fällen bildet ex zwei Virtel, in andern gar keinen. noch in andern einen undentlichen, wieder in anderen besteht ex ans vielen Kelehblätern, von denen die änsseren in Deckblätter: die immeren in Blumenblätter übergehen.

Die Blumenkrone ist gewöhnlich von zarterer Beschaffenheit wie del Kelch und gefürbt. Ist sie dabei von ansehnlicher Grösse: so wird im gewöhnlichen Leben die ganze Blüte Blume genannt. I) Blumenblätter stehen selten in 2 Wirteln oder sind in unbestimmter Zahl vorhanden. Die gefüllten Blumen mit ihren zahlruchen Wirteln sind als Missbildungen zu betrachten; vermeht Inaben sich die Blumenblätter auf Kosten der Kelchblätter, Staubgetässe und Fruchtblätter, anch wohl durch Zerteilung der Blumenbiatter. Wie dir Kelchblätter, so fehlen anch die Blumenblätter in manchen Fällen, oder sind sehr klein oder rerkümmert.

Kelch und Blunenkrone bilden die Blïtenhïlle(Perianthemum). welche doppelt genannt wird, wenn beide vorhanden sind und einfach. wenn nur der Kelch oder die Blumenkrone da ist. Nanchen Bliiten wird eine einfache Blütenhülle zugeschrieben, weil Kelch und Blumenblätter von gleicher Form und Beschaffenheit sind und scheinbar einen Wirtel darstellen. Häufig zeigt indessen eine Tntersuchmo der jungen Kinospe, dass die Hälfte der Teile mehr ansserhalb steht und kleine Abweichungen in der Beschaffenheit zeigt. Die Beschreibungen der Botaniker weichen daher von einander ab. die einen sprechen von einer einfachen, die andern von einer doppelten Blütenhille.

I) Be Blitenhïllen werden einblätterig oder verwachsenblätterig genannt, wenn die Blumenteile verwachsen sind, entweder vollständig oder nur auf dem Grunde zu einer Glocke, Röhre oder Scheibe - mehrblätterig oder freiblätterig, wenn sie rom Grunde an frei sind.

sind die Blumenblätter nur teilweise verwachsen, so wird der verwachsene Teil Röhre genannt, die freien Teile bezeichnet man je nach ihrer Grösse als Zähne oder Lappen. Fine sehr kurze Rïhre rutt auf den ersten Blick die Täuschung hervor, die Blumenblätter seien frei; ihre niedrige Terbindung am Grunde verdient 


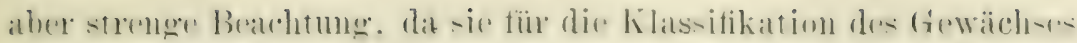
wichtig ist.

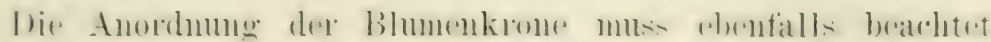

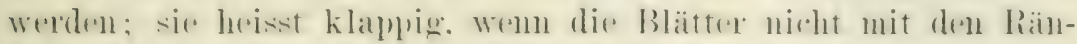

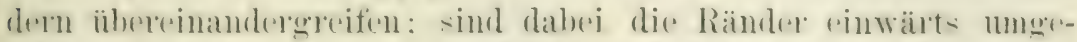

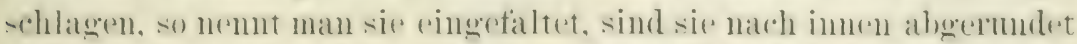

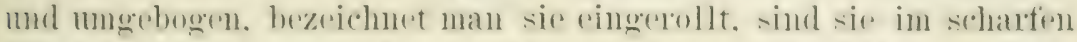

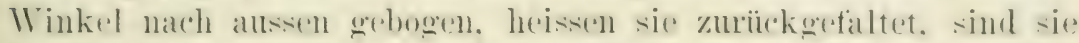

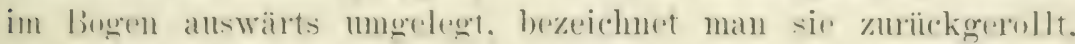

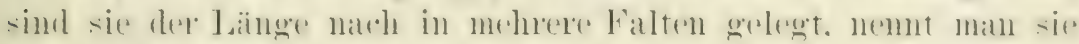

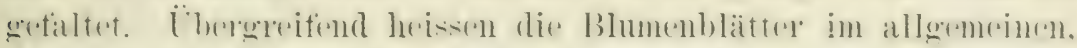

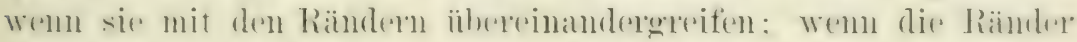

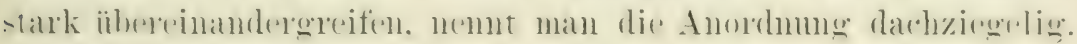

Die Blumenkrone kam der Gestalt nach sein:

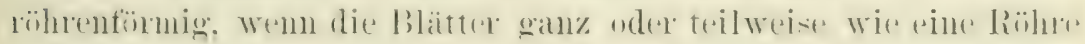
geformt sind;

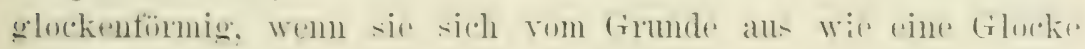
el'weitert;

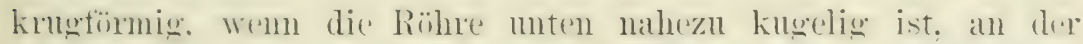

spitze sich etwas zusimmenzieht, um sich wieder zu rewoiterll;

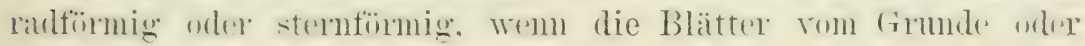
fast rom Grunde ans wagrecht ausgebreitet sind;

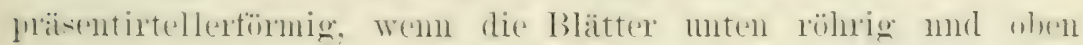
allswebreitet sind: der satum mag ganz odere geteilt sein: die

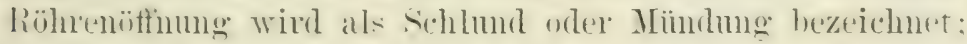

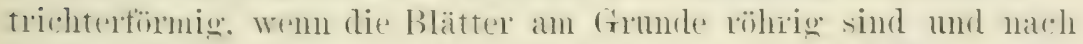
dem hande hin sich allnählich exweitern; die stelle. Wo die Erweiterung merklich wird. wilt als dex selnlund. weldher indessen häufig schwierig zu bestimmen ist.

Auscrem gibt es eine Anzahl muregehnassiger Formen. die nicht von allen Botanikern geleichmäsig benamnt werden. Am cheten welten als allgemeine: Bezeichnumen: zweilippig. wrin bei riner 4 oder 5teiligen Blume 2 oder 3 Lappen weiter ausstehen und den ïbrigen. die als Interlippe bezeichnet werden, frereniberstehen. Ist der schlund der zweilippigen blüte weshlorsen durch einen Gaumen. das ist eine Leiste an der oberen uder unteren lipje, so entsteht die Maskenblïte oder Larvenblïte. strhen die beiden Lippen weit altemander und ist die Röhre 
offen. so hejsit die Bhmenkrone rateneörmig. Hat die Röhre oder. der untere Tril cines Blumenblattes eine kegrelförmige, hohle Verlängerung. ähnlich einem Hahmensporn, so ist sie geepornt. Ist dex sporn kurz mol abererumlet. "ntsteht die Sackform, höckerign ist die Benemmeng, wemn ex nur in ciner schwachen Ansehwellung hesteht. Der ansgehreitete Treil eines Thumenblattes heisst eine Platte und der stilartige Teil der Nagel. Ein gestieltes Blumenblatt wird ein genageltes genannt.

\section{Die Stanbgefässe.}

Die Stanbgefäise in ihrer gewöhnlichsten Form bestehen aus einem Stiel. dem Staubfaden (Filament), welcher den Staubbeutel idnthere) trägt. Der letztere ist in der Regel in 2 Fächer geteilt, in welchen der Blütenstanb (Pollen) greborgen ist, der aus kleinen, staubförmigen, meist gelben Körnchen besteht, welche beim öfthen der staubbentel ansfallen. Sind dit beiden stanbbentelfächer dicht rerwachsen, so nennt man den rerbindenden Teil Mittelband. Der Stanbfaden darf fehlen. der sitzende Staul)berutel bildet deshalb doch ein rollkommenes Befiuchtungsorgan. tehlt dagegen dem stanbfaden der Staubbeutel oder enthält dersclbe keinen Blütenstanb. \&o ist das Stanbgefüss unvollkommen oder fehlgeschlagen, also unfruchtbar.

Eimmannig ist eine Blüte. wem sie num cin stanbgefäss "nthält, vielmämnig. we'nn sie meh" wie 10 besitzt. Brïderig. sind die Staubgefüsse, wenn mehrere mittels der Fäden rerwachsen sind. Finbrüderig (monadelphisch) sind sie. wenn ihre Fäden zu einem Bündel rerwachsen sind, der eine Röhre um den stempel bildet oder, nenn derselbe fehlt. die Mitte der Blïte

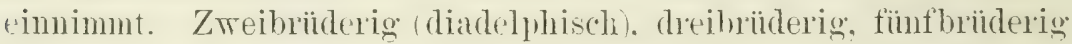
ı. s. f. sind sie, wenn die Fäden zı 2, 3, 5 u. s. f. Bündeln verwachsen sind.

Angeheftet orler ansitzend ist ein Staubbeutel. wenn er der ganzen Länge nach am Stanbfaden angewachsen ist; anfsitzend. wemn er nur mit seinem Grunde auf der spitze des Staubfadens sitzt, und beweglich, wemn er mit dem Rücken so auf der Syitze des stambfadens befestigt ist, dass er sich leicht bewegt.

Die Fiacher des Stanbbentels sind entweder gleichlanfend oder anseinanderfahrend, wemn sie fast eine gerade Linie bilden, indem sie sich nur an einem Ende beriihren. Ansgespreizt sind sie. 


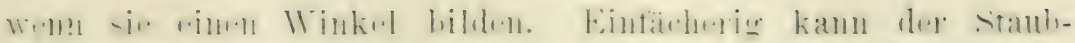

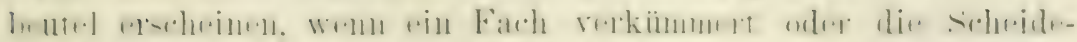
wand verselewindet.

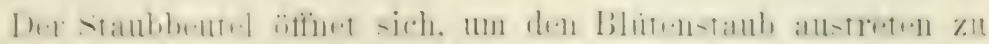

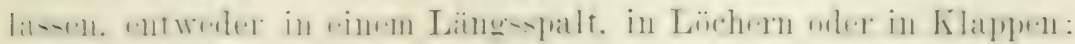

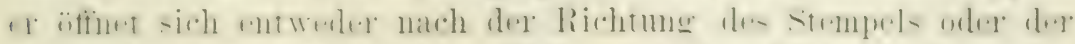

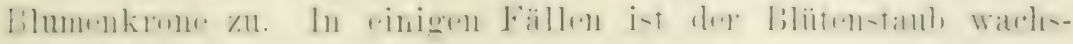
ähnlich, nicht staubfömig:

\section{Der stempel.}

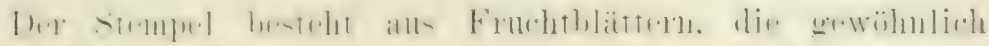

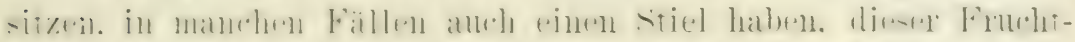

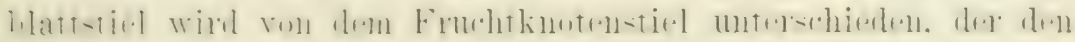
Tireis der Fruchtblätter, also den Stempel trägt.

Das Fruchtblatt besteht aus 3 Teilen:

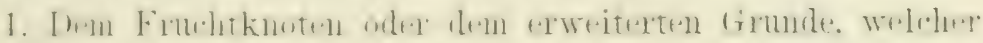

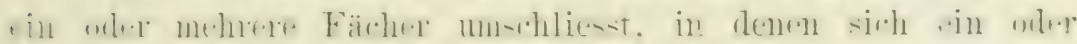

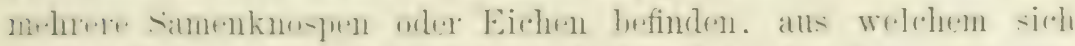

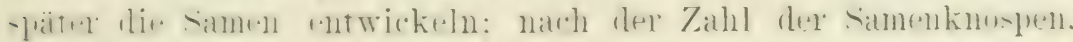

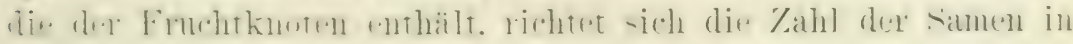
der Frucht, er erzengt ihrer nie mehr, wohl aber weniger;

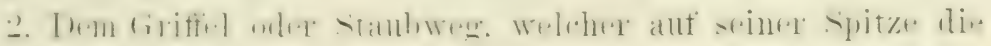
Jarbe trägt:

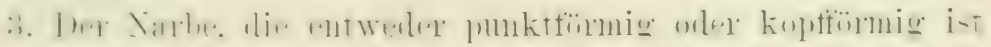

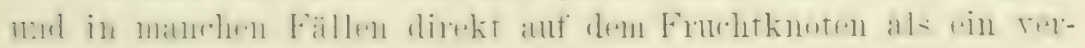
hreiterter und rerschieden gestalteter Teil sitzt.

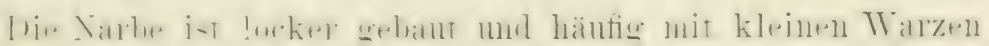

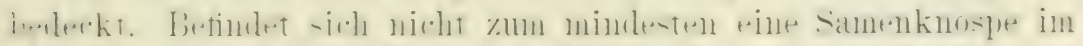

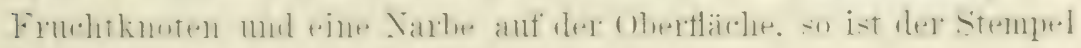
fehlgeschlagen, also unfuchtbar.

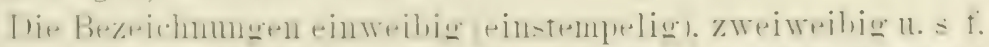

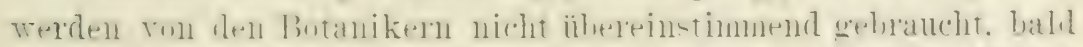

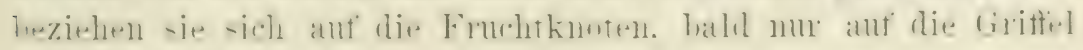
oder Tarben.

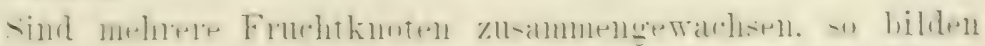

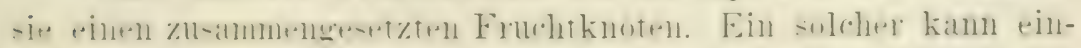

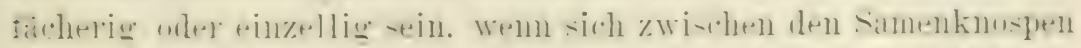

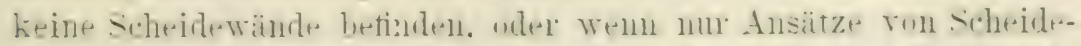

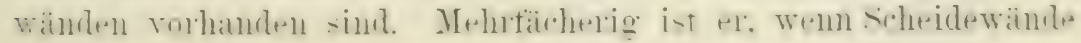


von dex Mitte des Fruchtknotens ans strahlenförmig nach dem L'm-

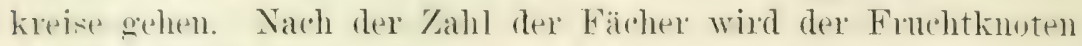
2, 3 bis vielficherig genamnt.

In den meisten Fällen ist die Zahl der Fä̈cher aibereinstimmend mit derjenigen der Fruchthläter', welche den stempel bilden.

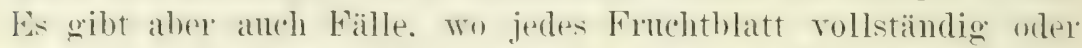
unvollstandig in zwei Fächer geteilt ist oder 2) Reihen Fichen trägt, es erscheint dam die Zahl der Fruchtblätter dopledt in gross wie sie in Wirklichkeit ist: andererseits gibt es stempel, die scheinbar ans einem Fruchelblatte bestehen, so imnig sind mehrere Finchtbläter verwachsen: sie bilden ein Fach mit eines. Samenknospe.

Verwachsenblätterige Stempel können haben:

einen einfachenGriffel mit einer gekerbten. gezahnten. gelannten oder ganzen Narbe;

einen einfachen Griftel mit melneren Narben. Wenn die (rriftel bis

zur Narbe vereinigt sind, diese sich aber trennt; mehrere Griftel. wem diese rom firmete an frei bleiben.

Als Als-nalume ron der Regel gelten: die zahl der Narhen und tiriffel ist grösser wie die der Fruchtblätter: die Varben sind zweigabelig oder fiederig verzweigt oder anch pinselförmig. Diese Anwahmen erschweren oft die Zahl der Fuchtblatter zu bestimmen. melche den Fruchthnoten zusammensetzen: ein regenstand. der abel wichtig ist, weil er die natüliche Verwandschaft der PHanzen bestimmen hilft.

Als ramenleiste bezeichnet man diejenige stelle im Immern des Fruchtknotens, wo die samenknospen angeheftet sind.

Jede rollkommen entwickelte iamenknospe besteht gewöhnlich ans dem Eikern oder Knospenkern, welcher in die Eihülle, an: 2 sackförmigen Hänten bestehend, eingeschlossen ist. die als änsere und imnere bezeichnet werden. Der Eigrimd oder Knospensrund ist derjenige Teil dex samenknospe. an welchem der Eiker'n oder Knospenkern mit den Eihäutchen rerwachsen ist. Der Eimund ist eine kleine Oeftumng in den Eihäutchen über der syitze des Eikerns.

\section{Der Blïtenborlen.}

Das oberste Ende des Blütensticls. ïber dem Kelche. auf welchem die Blumenkrone. Stauhgefïsse und Fruchtknoten befestiot 


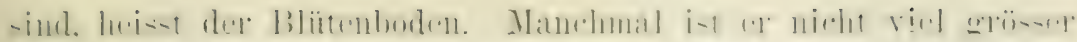

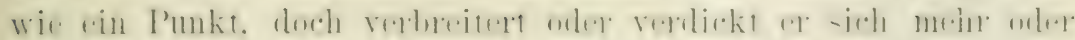

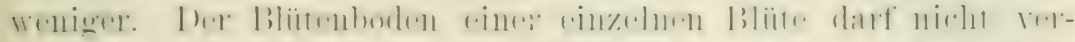

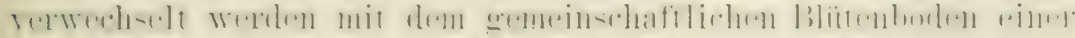

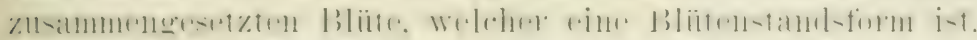

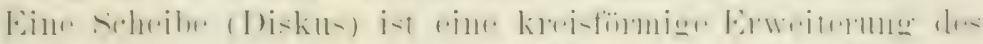

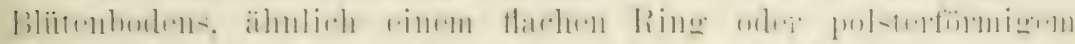

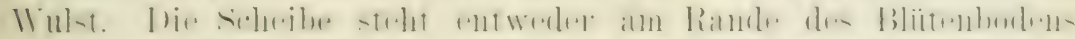

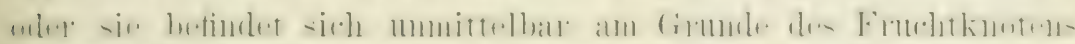

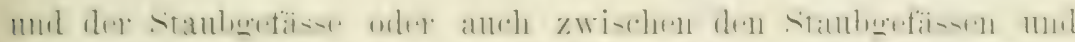

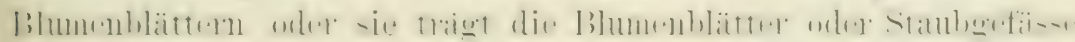

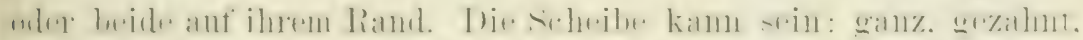

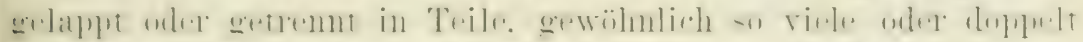

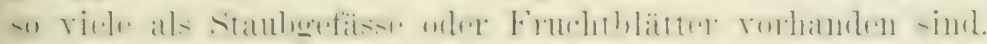

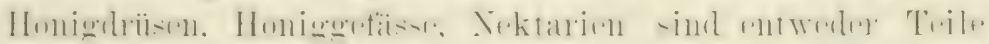

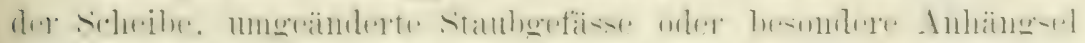

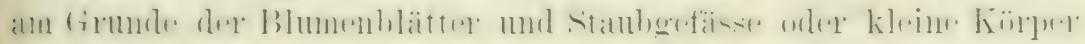

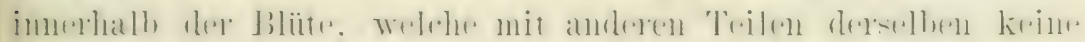

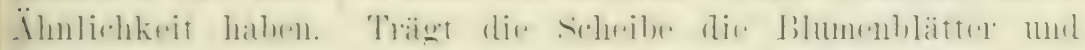

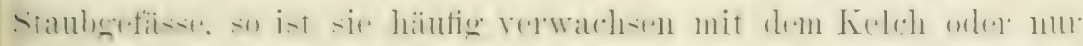

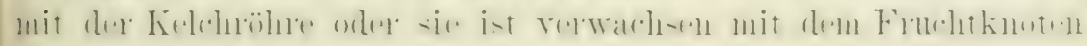
oder mit der Kelchröhı'e mud dem Fruchtknoten.

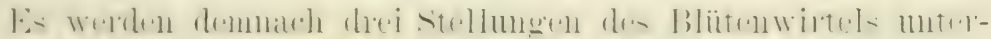
schieden :

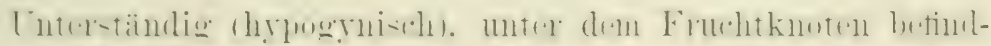

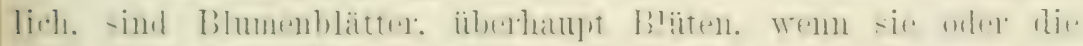

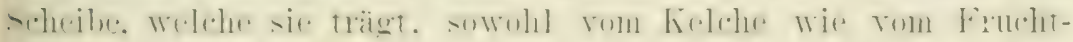

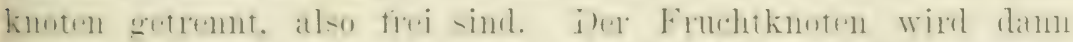

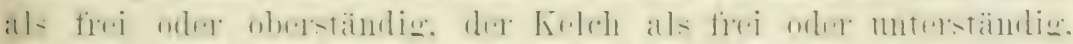

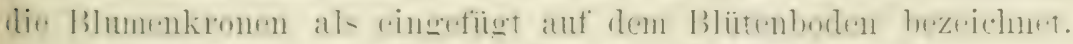

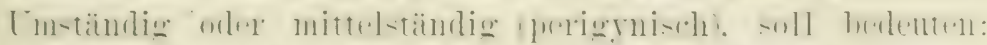

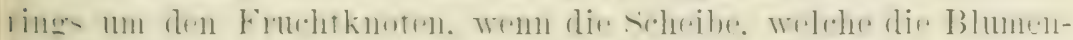

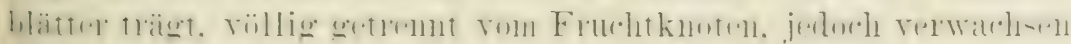

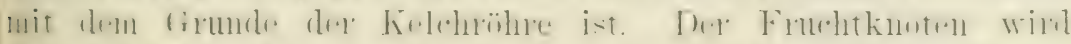

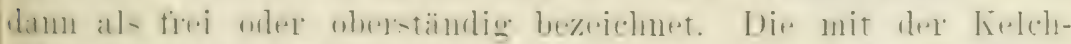

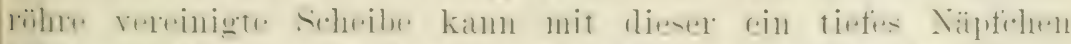

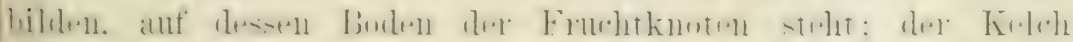

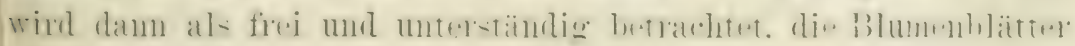
als dem Kelche eingefïgt. 
(Hherstïndig (eppognisch) soll bedeuten: auf dem Frucht-

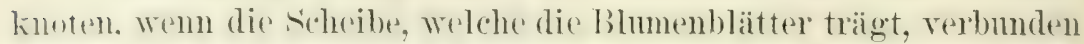

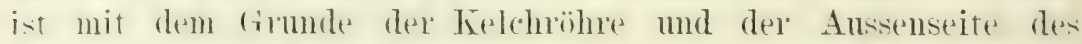
Fruchthnotens. Fntwedre schlinst sie sich oberhall des Frucht-

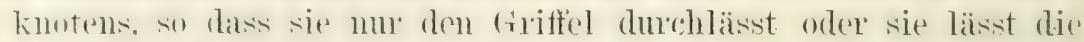
spitze des Frudithotens mehr oder weniger frei, ist aber mit lotzterem unterhalh der Höhe der untersten Samenknospe verhmulen. Wenige Fälle ansqenommen, wo die samenknospen an den spitzen dex Fächer hängen. Der Fruchtknoten wird hier als angerathen oder unterstindig. der Kelch als angewachsen und oberstandig, die Blumenblätter als eingefingt anf und oberhalb des Fruchtknotens bezeichnet.

In einigen Fällen kann nicht sicher entschieden werden, ol) die Blïten oberständig oder umständig, umständig oder unterständig sind.

Folnen die Bhmenhlätter in einer Blïte, so wird die Einfïgung der staubgetisse benutzt, um die rorstehenden Bezeichnungen festzustellen.

Ein Fruchtknotenstiel entsteht, wemn sich der Blütenboden deutlich unter dem Fruchtkuten verlängert. Findet eine solche Verlängermg innerhalb des Staubgefäsi- oder Blumenblattwirtels statt. so bezeichmet man die staubgefässe und Blumenblätter als eingefuigt in den Fruchtknotenstiel.

Eine oberständige scheibe nemnt man gewöhnlich die verdickte spitze der Fruchtknot'n bei oberständigen Blïten, selten bezeichnet man so die wirkliche Scheibe des Blütenbodens. welche sich über dem Funchtknoten zusammenschliesst.

\section{Die Frucht.}

l) Frome unschliesst die oder den Samen bis zur Tollreife derselhen. um sich damn zu öffnen und den Samen austreten zu lassen oder mit lutzteren zugleich ahzufallen. Sie geht hervor all: den Fruchtknoten und anderen nach der Befruchtung bleibenden Teilen ater Blïte.

Die Frucht kamn sitzend sein oder an dem Fruchtstiel hängen.

Die Einzelfincht entsteht ans einer Bliite, sie bildet den tregensatz zu den Sammelfirichten, die sich aus mehreren dicht zusammenstehenden Blüt'n mit einblätterigen Stempeln entwickeln. 


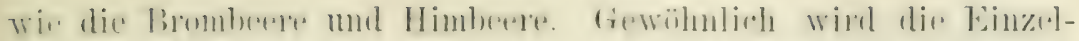

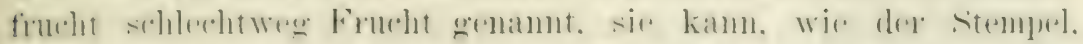

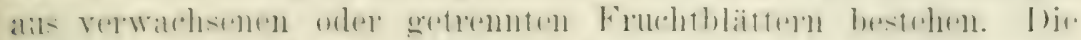

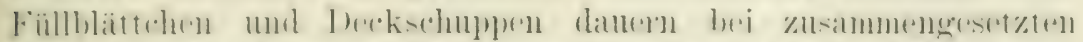

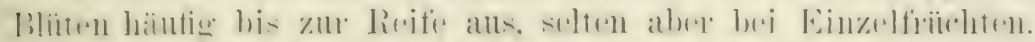

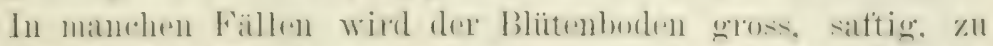

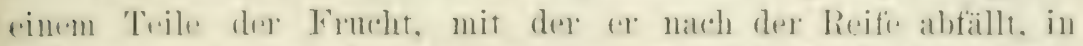

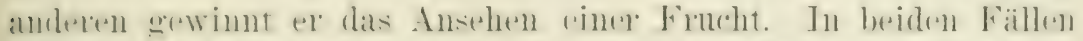

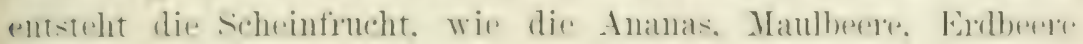
und Feige.

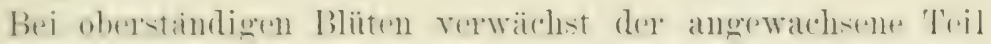

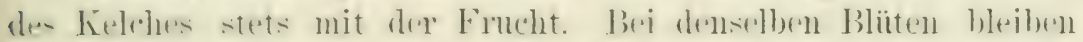

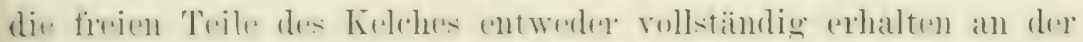

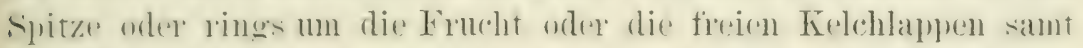

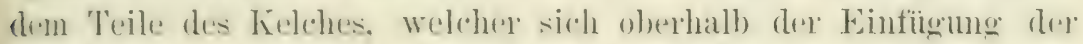

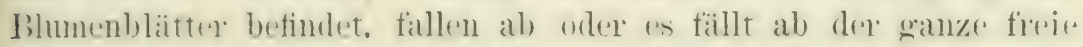

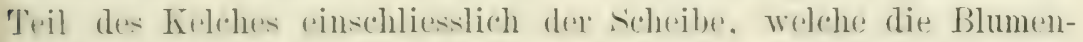

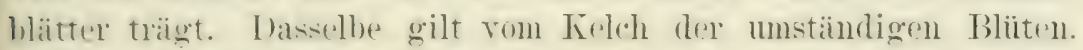

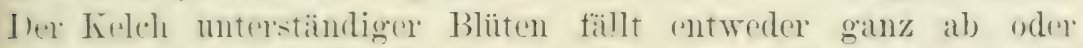
hleibt vollständig rhalten. Ein Kelch wird abfallend gemamnt. Tren w wanz wer trilweise abfält. Ist er bleibend, damn rergrörisert ar sich entweder unter oder um die Frucht oder ar verschrumpft.

1) it Blumenkrone tällt gewöhnlich vollständig ab. bleibt sie. sn verschrumptt sir. nur in sehr wenigen Fällen vergmiscent sie sich um die Frucht.

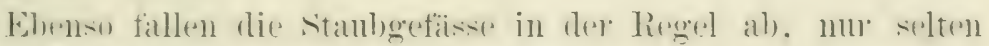
bleiben 'Teile zurück, die rerschumpfen.

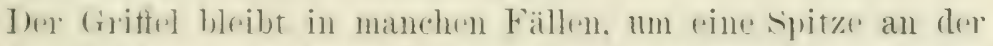

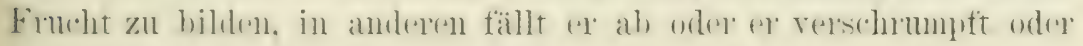
er verlängert sich zu einem Anhängsel der Frucht.

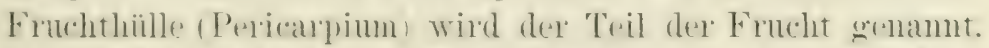

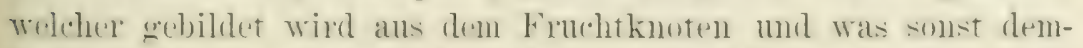

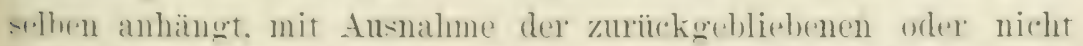

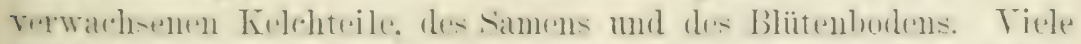

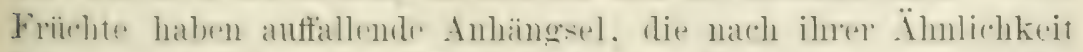

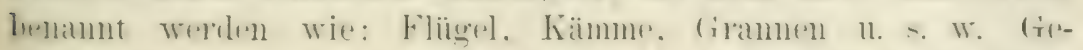

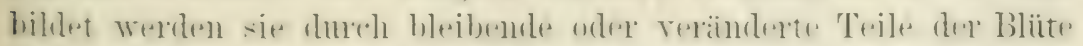

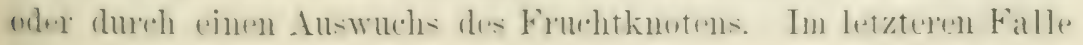




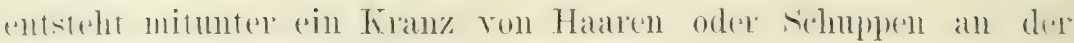
Spitze de: Frucht, welcher Krone genannt wird.

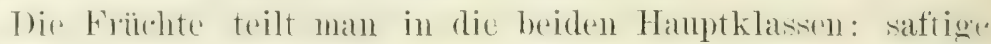

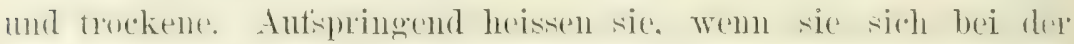

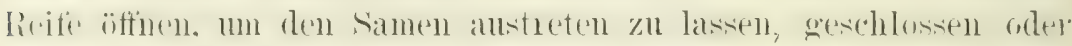
schliesfrithte. wem sie samt dem samen abfallen. Saltiger Früchte bleiben gewöhnlich geschlossen.

Die wichtigsten Arten der sattigen Früchte sind: Die Bestre. bei welchere die ganze Masse der Fruchthiille sattig oder fleischige ist. mit Ausuahne dex äuseren Fruchthant (Epicarpium); die sinnen sind gewöhnlich eingebettet in das Fuchtlleisch. bei

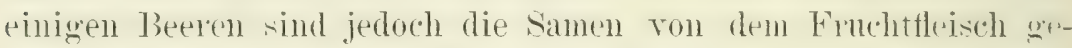
trennt durch die imnere Fruchthatut (Endoscatrpium), welche dit Fächer des Fruchtknotens aliskleidet. Zu dieser Fruchtat gehören : die Heidelbeere, Weintraube, Johanistraube, Orange und citrone.

Die Steinfucht (Drupa), bei welcher die Fruchthiulle anzwei dentlich unterscheidbaren Bestandteilen besteht: der änseren. Heischigen, sattigen Masie, dem Fruchtfleisch (Sarcocarbium), das anssen ähnlich wie die Beere überzogen ist. von der änsserren Fruchthant (Evicarpium) und einex imneren. trockenen, harten Fruchtschicht odex Fruchthaut (Putamen), welche entreder pergamentartig oder holzig ist; in letzterem Falle heisst sie ein tein und die Frucht eine Steinfrucht im engeren simne des Wortes.

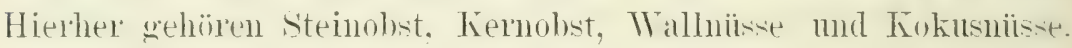

Die wichtigsten Arten der trockenen Früchte sind:

Die Kapsel, wann sie-sich bei der Reife öffnet. In diesem Falle besitzt sie geröhnlich so viele Klatpen als sie Fächer be-

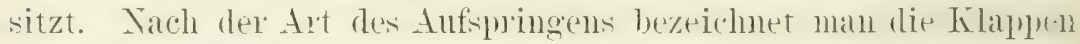
als scheidewandlösend, wem die scheidewände stehen bleiben unt die Kapselwand sich völlig ron ihnen tremnt; als fachspaltig. Wem die scheidewände in der Mitte der Kilappen stelnen bleiben und samt diesen abfallen; scheidewandsualtig. Weme sich die scheidewände in der Mitte tremnen. an den Rändern der Klatpren stehes bleiben und mit diesen abfallen.

In manchen Fällen hat die Kapsel Löcher. rlureh welche der samen austritt. oder sie offnet sich in einem wagerechten spalt und zerfialt dadurch in '2 Teile; sie ist damn umschnitten. antspringend und heisst eine Büchsenfiucht.

Die Schliessfincht (Nuss, Achene). welche nicht anfepringt 


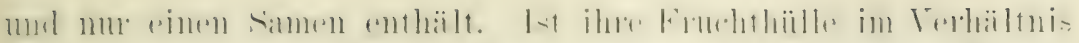

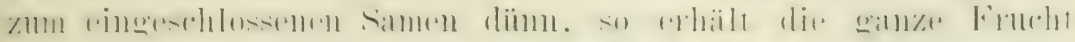
odel ilne einzelnen 'Teile das Ansehen eines Samenkorns mor

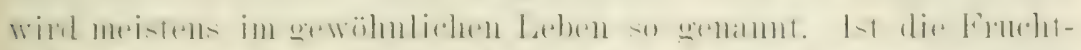

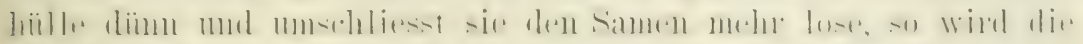

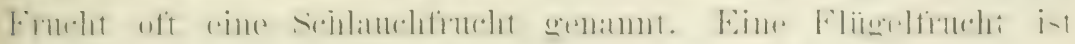
pine Nuss mit einem Flügel an ihrem oberen Ende.

sind die Fruchtblätter der Frucht getremnt, so kümnen sie.

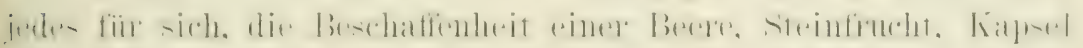

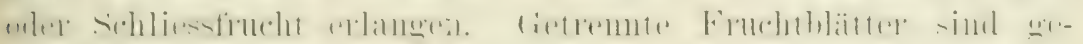

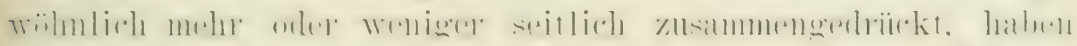

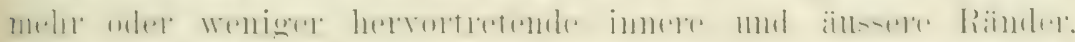

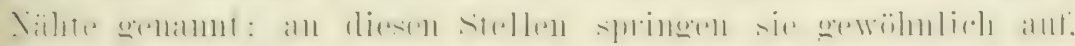
fills sie sich überhanpt offhen.

Eine Balgfincht ist cine Kapsel, welche sich auf eincr

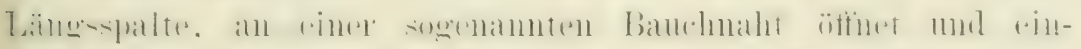

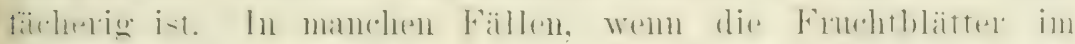

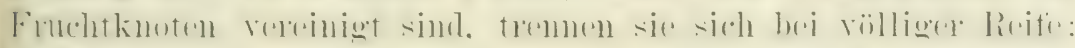

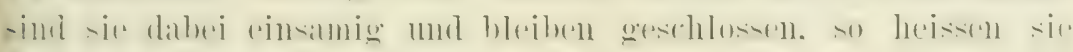
haiutig' Körner' oder 'Teilfriichte.

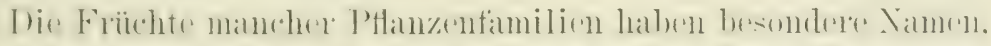

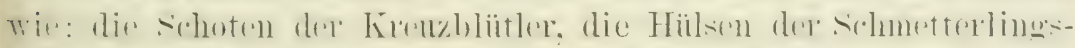

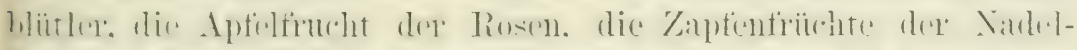

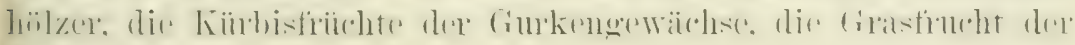
Grïisel" 11. S. $\pi$.

\section{Der Samen.}

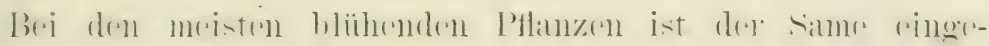

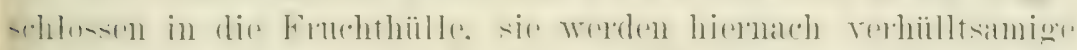

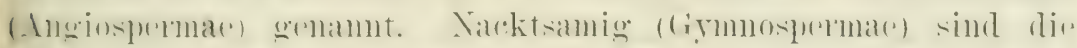

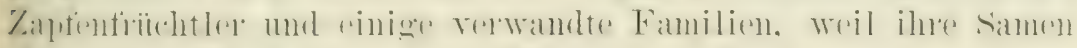

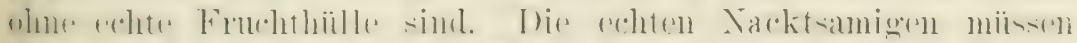

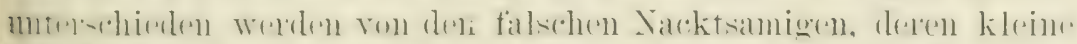

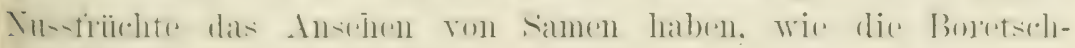
geräichse und Lippenblütler.

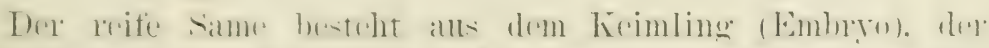

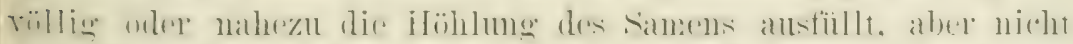

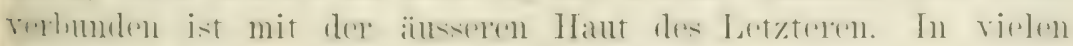

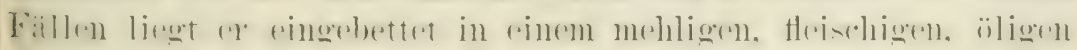

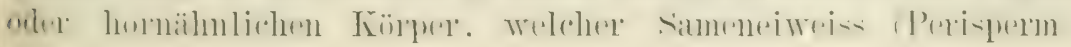




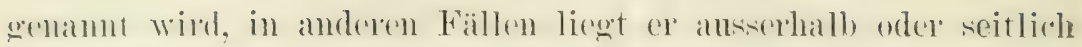

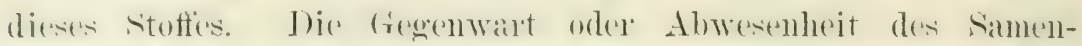

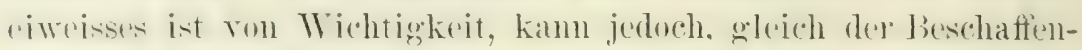
heit mancher heimlinge, bei mehreren samen wrot dentlich wiallrend der Keimumg erkamnt werden.

Die sidale des samens besteht gewöhnlich alls zwei trennbaren Hänten. Die Äuscere (Festa) ist in der Regel do wichtigste, in manchen Fällen wird sie nur allein bei der beschreibung dex:

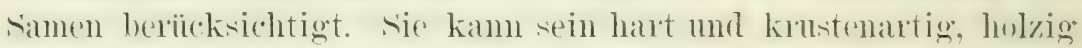
oder knochenïhnlich, dünn oder zalthäutig, trocken oder fleischig

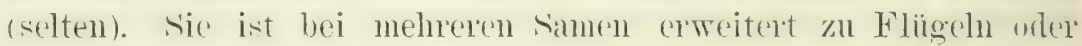
trägt ein Bäischel Haare oder Fasern. die Samenwolle. I)ie innere samenschale wird ron den Botanikern Tegmen gemannt.

Samenträger wird der stiel genamnt, mit dem der sianten befestigt ist. Er wird zum Samemmantel, wenn er. zu rinem laintigen, saftigen oder fleischigen Anhang verbreitert, sich über (inen ansehnlichen Teil des samens ansdehnt vder denedben fest. umschliesst. Keimwiilstchen wird rin einfacher. Walzenähnlicher tuhang an der samenhant an de: seite oder in der Tähe des Samenträgers genamnt. Sabel nemnt man die Sarbe, welche bei Abtrennung rom samenträger an samen zurückbleibt. Ter Livinmund ist am reifen samen gewöhnlich als feiner. nadelstichartiger Prunkt bemerkbar, der bald in der Nïhe des Nabels, bald ihm gerenüber liegt, je nachdem der Same gradlautig, krummäiutig oder gegenläufig ist.

Der Keimling besteht ans dem Wiinzelchen oder dem Anhange dex kïnftigen Wurzel, aus 1 oder உ Keimblätern oder samenlappen und aus der Stammknospe oder dem Blattfederchen. dem Anfange zum kinntigen stengel. In manchen samen. besonders in solchen, die kein Eiweiss enthalten, sind die verschiedenen Teile sehr deutlich, in anderen dagegen schwierig zu erkemen mo werden mitunter elst bemerkbar, wem der samen zu keimen begimnt. Ihre Beachtung ist jedoch ron Wichtigkeit, da sich auf die Terschiedenheit des Keimling's, ob derselbe 1 oder 2 Samenlappen besitzt, die beiden Hamptklassen des P'llanzemreichs: Einsamenlappige (Jonokotyledonen) und zweisamenlappige (Dikotỵledonen) gründen. Bei den einsamenlappigen Pflanzen, kürzer spitzkeimer genannt, besitzt der Keimling nur einen samenlappen, 


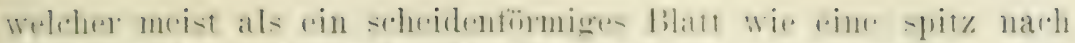

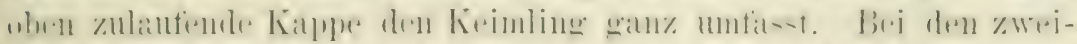

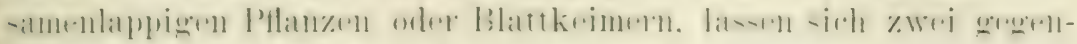
iiberstehende Samenlappen ganz bestimmt erkemen.

13. Nebenorgane.

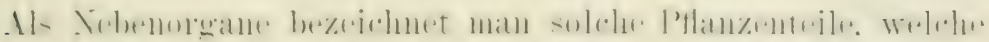

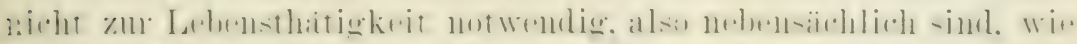

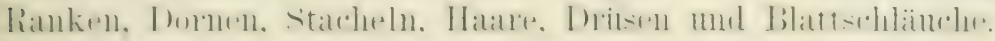

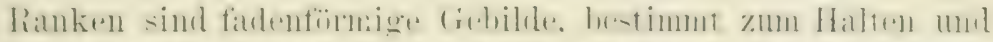

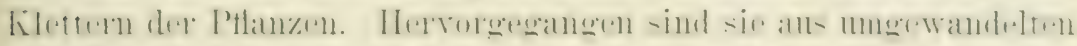

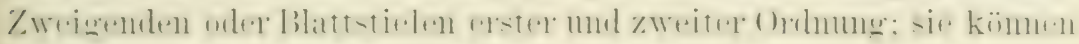
sein einfach oder veristelt.

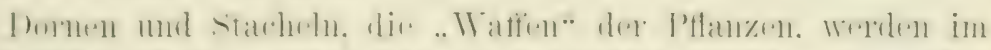

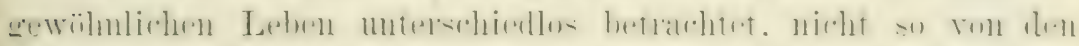

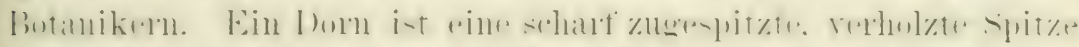

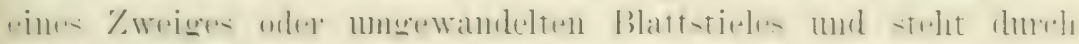

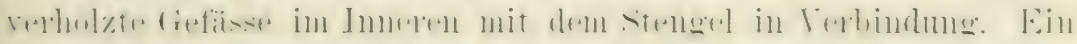

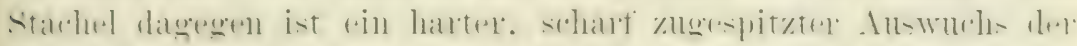

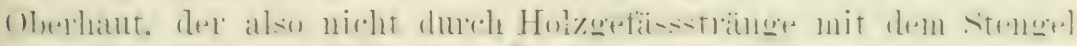

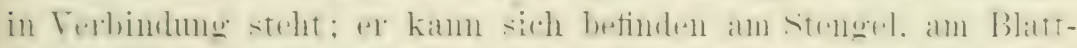

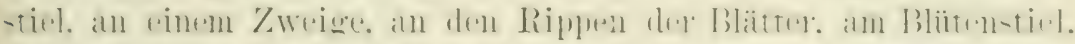

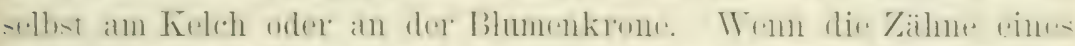

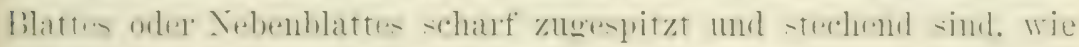
bei den Disteln, werden sie anch Stacheln genamnt.

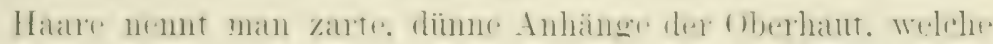

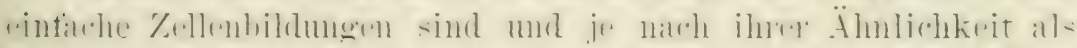

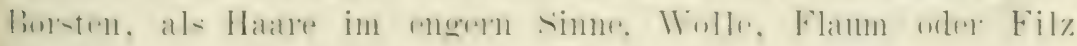

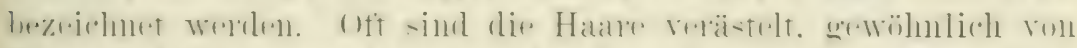

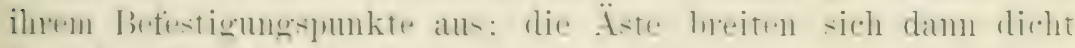

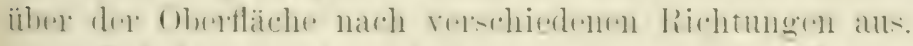

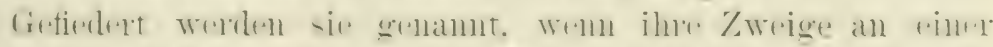

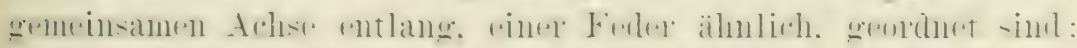

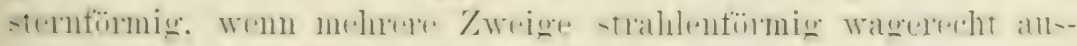

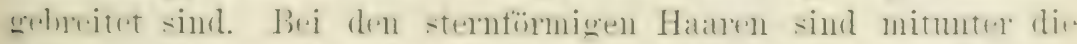

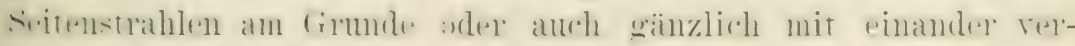

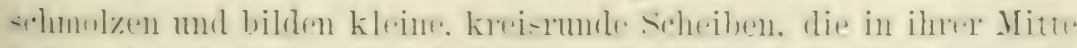

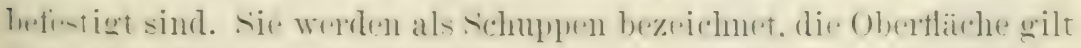

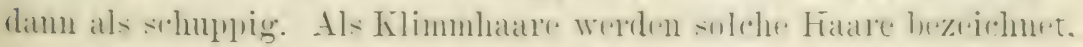




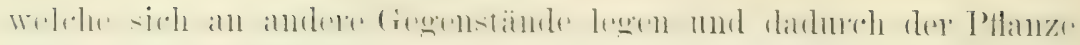
beim klettern helfen.

Die Oberfliche cines Pflanzenteils ist:

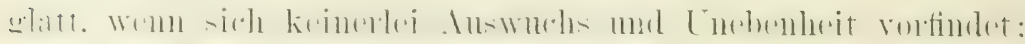

kahl, wenn sie keinerlei Behaarmo hat;

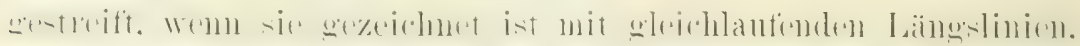

die nur einfach erhaben oder zugleich verschieden gefürbt sind:

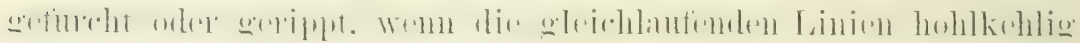
und dentlich erhaben sind:

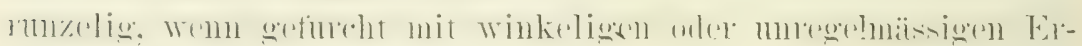
hebungen und Vertiefungen:

eingefressen, wenn versehen mit sehr umregehmïssigen, tiefen. gedehnten Aushöhlungen;

punktiert, wenn rersehen mit sehr kleinen, kreisrumden Vertiefungen ;

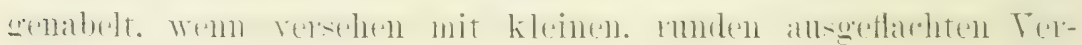
tiefingell;

klebrig;, renn bedeckt mit klebrigen Ansscheidungen; rauh, wem sie sich rauh anfühlt:

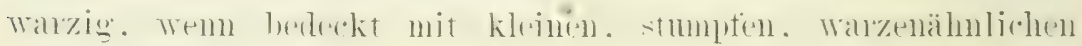
Auswïchsell;

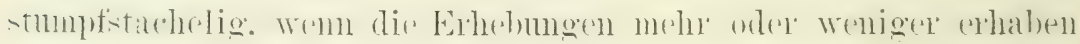
und zugespitzt, dabei kurz und hart sind;

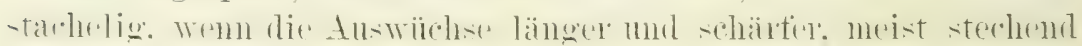
sind;

borstig, wenn bedeckt mit steifen, geraden Haaren;

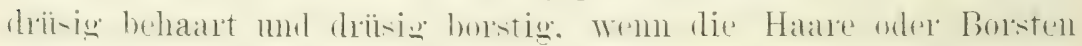

an der Spitze ein kleines, klebriges Köpfchen tragen;

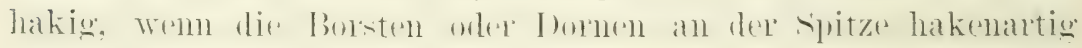
gebogen sind;

haarig, wenn besetzt mit langen, etwas straffen und entfernt -tehenden Hataren. Woldhe dir Flïrhe nicht völlig bedechen:

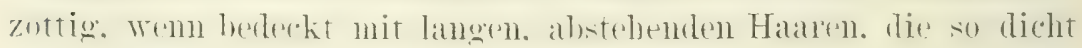
stehen, dass sie die Oberfläche verdecken;

km\%horstig. Wran bederkt mit km\%n. zerstrenten. oft rabeligen oder dreizackigen Borstenhaaren;

langhorstig. Wem bederkt mit ziemlich langen. nicht selne cutfernt stehenden Borstenhaaren; 


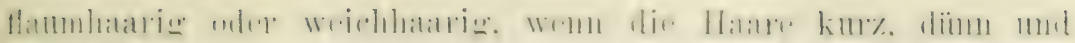
weich sind, dabei so rerteilt, dass sie die Oberfläche nicht vïllig verdecken :

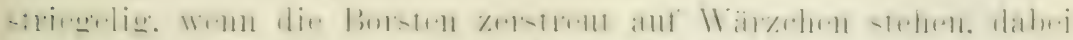

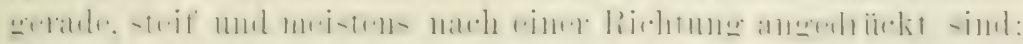

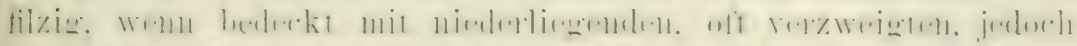

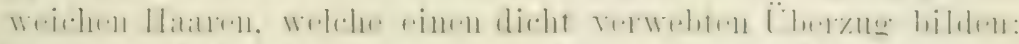

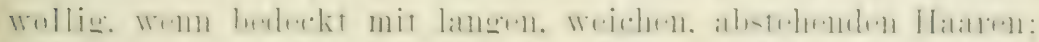

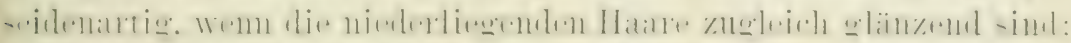

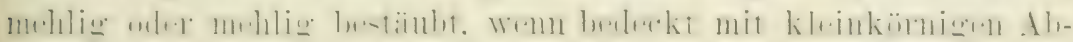

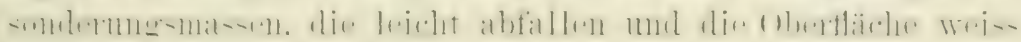
bestäntot eracheinen lassen;

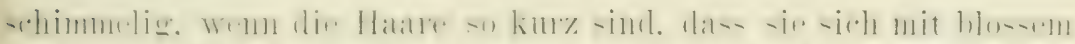

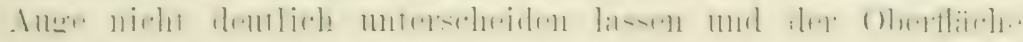
einen weisslichen Schimmer verleihen:

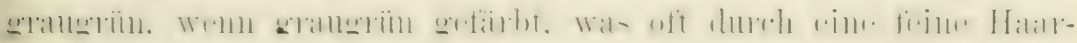
bedeckung geschieht.

lie Do\%

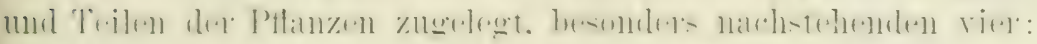

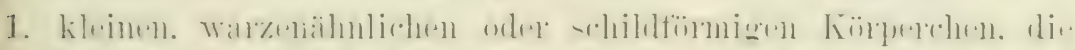

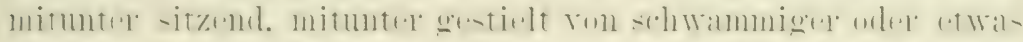

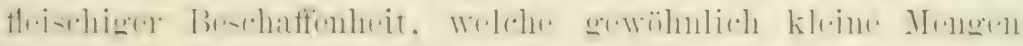

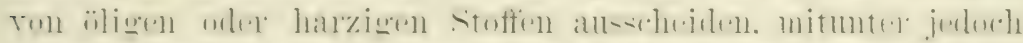

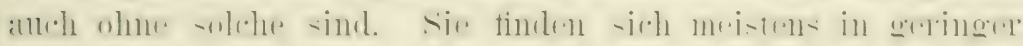

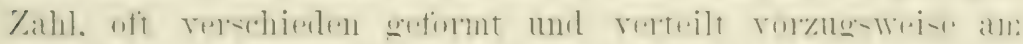

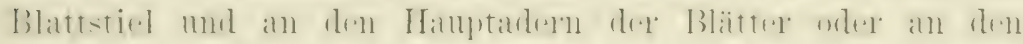

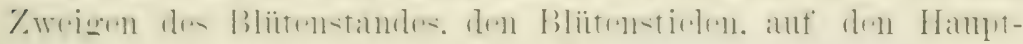
rippen der Deckblätter, Kelch- und Blumenblätter.

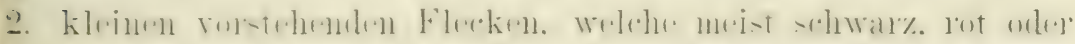

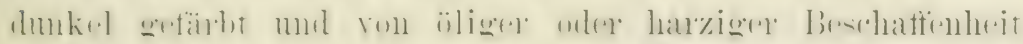

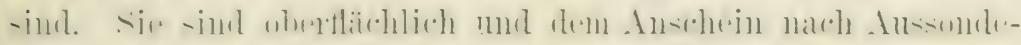

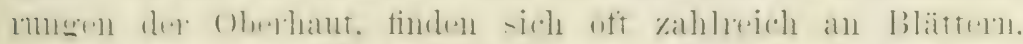

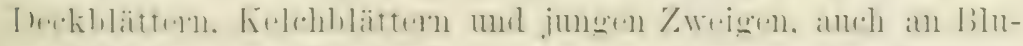

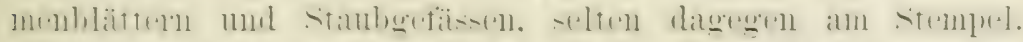

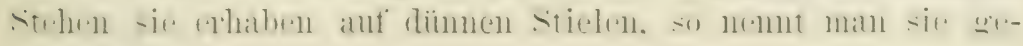
stielte Drïsen :

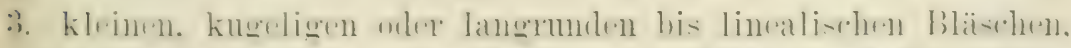

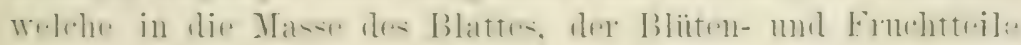


sclbst ringebettet sind. Sie sind oft selu zahlueich vorhanden, ähneln durchsichtigen Filecken, mitunter finden sio sich auch nü zon wenigen mol in verschiedenatiger Verteilung. Tn dre Fuchthïllo dor boldengewäichse sind sie anffallend regehmissig und in dir Angen fallend und werden striemen genamnt; sie werden besonders beim Querschnitt und bei einiger Vergrösserung sichtbar"; 4. Lappen der Blïtenscheibe oder kleinen fleischigen Answächsen imnerhalb der Bliite, entweder der am Blïtenboden, Kelch, der Blumenkrone, an den Staubgefässen oder am Stempel.

Der Blattsehlauth ist rine schlauchtörmige Bildung. die an der spitze cines rankenartigen Teiles, dex Fortsetzmg cines Blattes, sitzt. Der Schlanch ist an seinem Ende abgestutzt, often und mit einer Art Deckel verschen. Im Imner'n entsteht eine schwath sïssliche Fliussigkeit, welche die Insekten anlockt.

Es diunkt mir eine Pflicht, zu erklüren, dass ich mich in meinen vorstehenden Darlegungen vorzugsweise an Hermann Wagner's .. Floxa rou Dentichland" angeschlossen habe, weil mir die Verdentschung del botanischen Kunstatsdritcke und die Beschreibung form in dimen trefflichen Werke mustergitig coscheint.

\section{Die Grundstoffe der Pflamzen.}

Weme dir Chemiker pine Pflanze in ihre Grundbestandteile zerlegen, finden sie stets Kohlenstoft, Wasserstoff, Sanerstoft mol stickstoff, das sind dio sogenamnten organogeen oder organische Grundstofte. In einzelnen Pflanzenteilen kamn der Stickstoff fehlen. sie heissen dann stickstofffeie, im Gegensatz zu den stickstofthaltigen, welche alle vier Grundstofte enthalten. Nur sehr wenige Pflanzenstoffe bestehen aus zwei Elementen oder Grundstoffen, keinem aber fehlt der Kohlenstoff', deshalb bezeichnet man die oroanische Chemie anch als ('hemie der natürlichen und kïnstlichen Kohlenstoftrer'bindungen. Ansserdem finden sich stets 6 Mineralien oder morganische firundstofte in schwachen Mengen vor: Kalium, Magnesium, Calcium, Eisen, Phosphor und schwefel. Diese Mineralien, welche 
meistens in Form von salzen, das will satgens. in Verthindung von

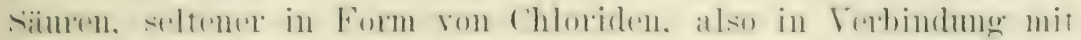

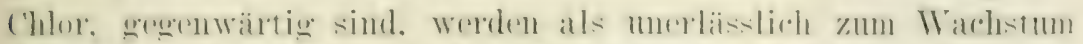

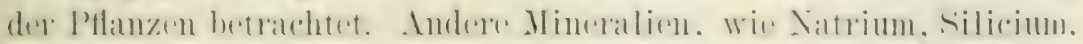

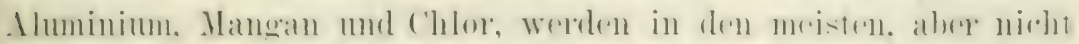

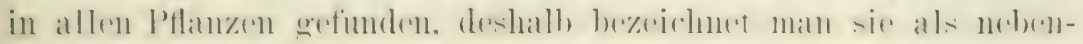

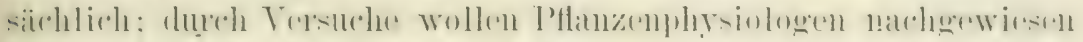

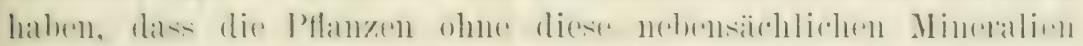

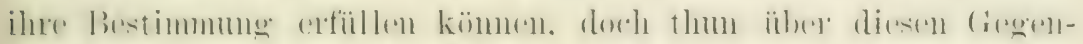

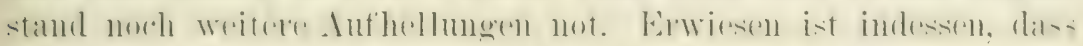

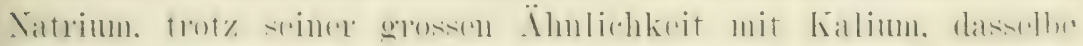
nicht ersetzen kimn.

Ans diesen wenigen Grundstoften also, denen einige unor-

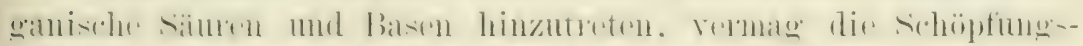

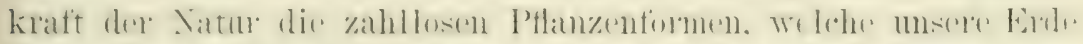

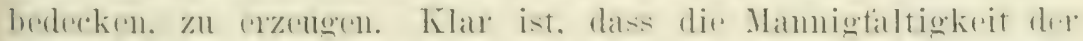

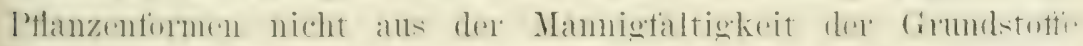

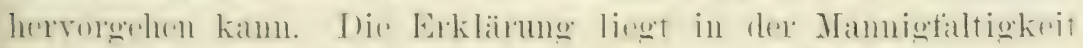

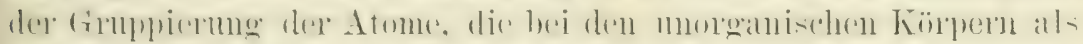

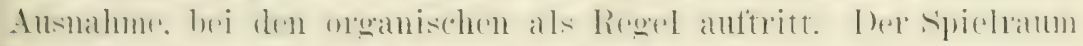

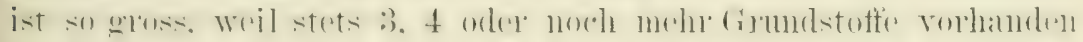

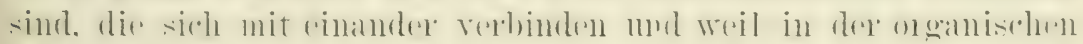

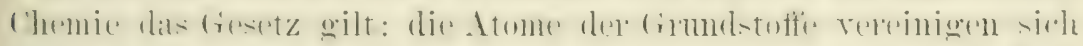

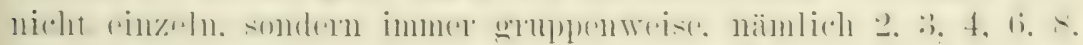
10 und meln Atome von dem einen Grundstoff mit 2. 3. 4 n. s. w.

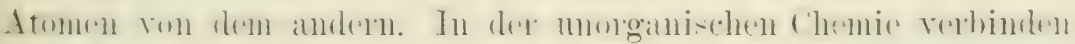

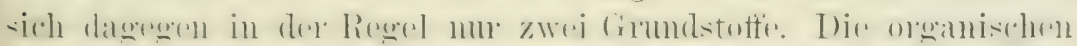

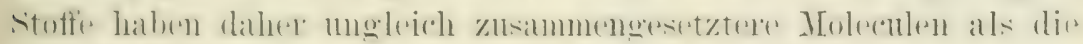
morganischen.

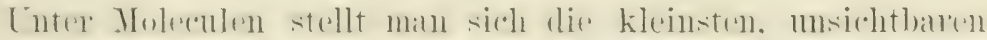

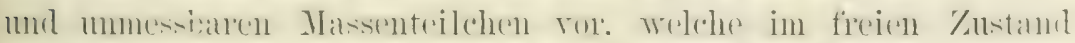

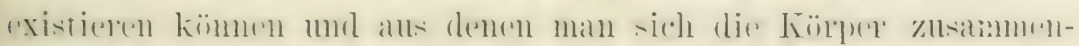

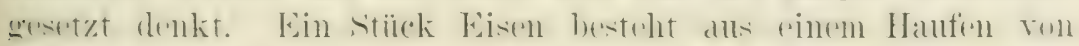

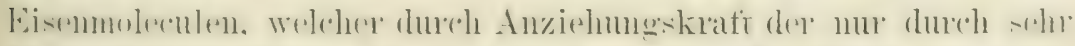

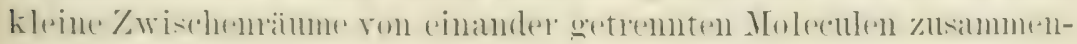
gehalten wircl.

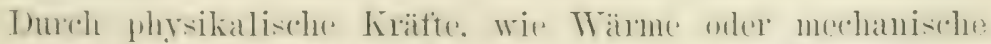
finwalt. latsich sich die. Mfoleculen nicht weiter zerteden, woul aber

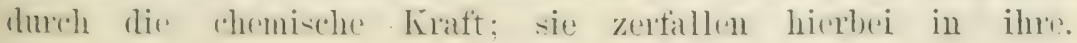




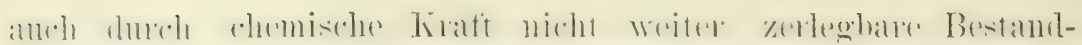
teile, in Atome, die man sich also noch kleiner zu denken hat, wie die Moleculen. Einzelne Atome kömmen für sich nicht be-

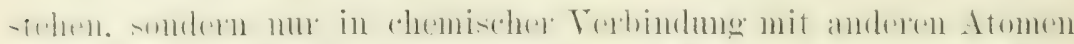

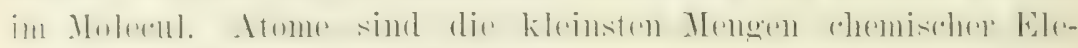

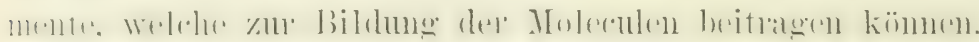

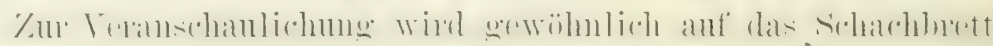
rerwiesen. Auf demselben kömmen wir durch Tersetzung der

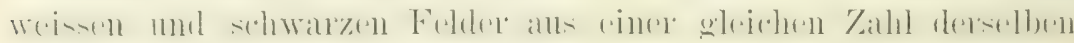

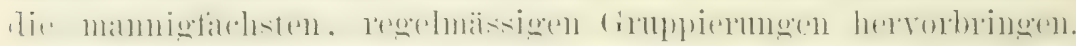

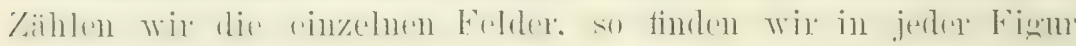
S schwarze und 8 weisse. die wirkliche Zahl ist also gleich

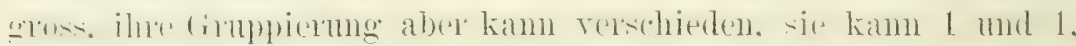
2 und 2. 4 und 4 r. s. f. sein. Denken wir uns statt der Felder

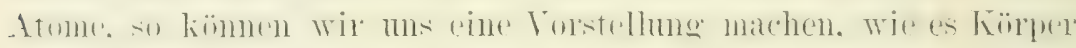

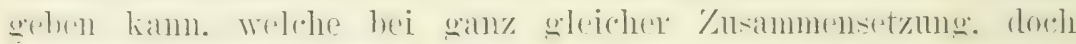

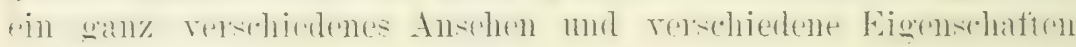
haben.

\section{Die Klassifikation der Pflanzen.}

Um eine Übersicht über die etra 100000 Pflanzenarten der

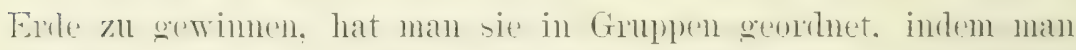

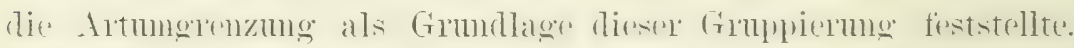
Alle Ptlanzen. Welche in ilnen wesentleleen Merkmalen iiberein-timmen mor deren ans Samen herrorgehender Nachkommen ein trentes Ehombild werden, betrarlitet man als Alt. Lie mwesent-

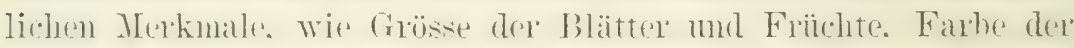
Bliiten. Beharamg der Zweige köment wedseln. ohne die trtun-

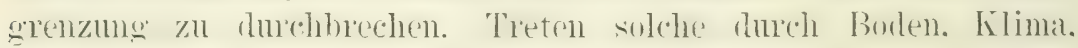

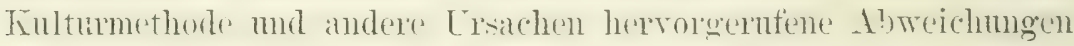
hei cinel Anzahl Individuen dersclben Alt (species) ant, so hretrachtet man sio als eine spielart (Varietät). ('halakteristisch ist « tör die splelart. dass sie anf lingere Zeit durch samen nirht tren menbildlich fortgepflanzt werem kamm, dil die Nachkommen

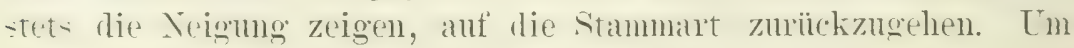




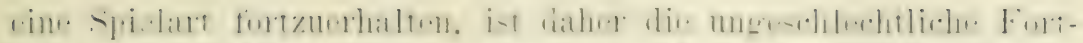

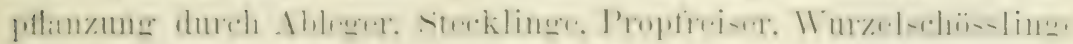

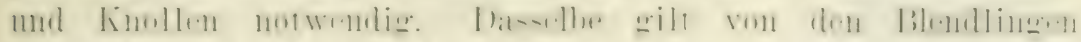

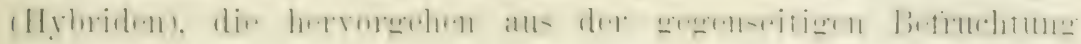
ron zwei Arten und nicht verwechselt werden diurfen mit don

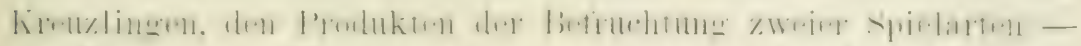

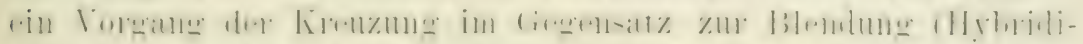

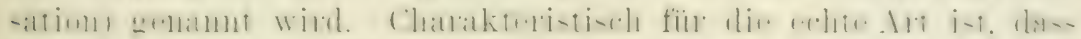
sie sich durch Samen stets wieder mit ihnen wesentlichen Irerknialen erzengt.

Einflïsse des Bodens, Klimas, Standorts, der Salurungrg. der

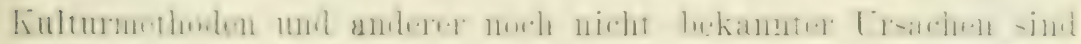

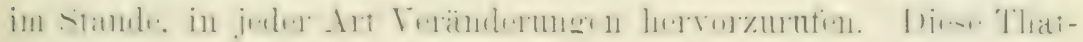

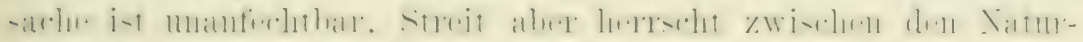

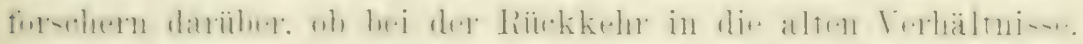

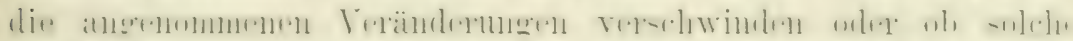

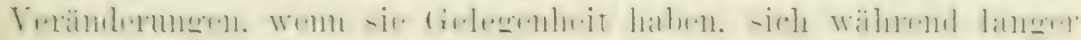

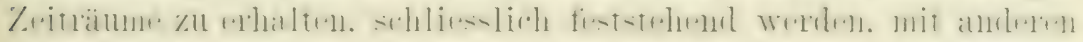

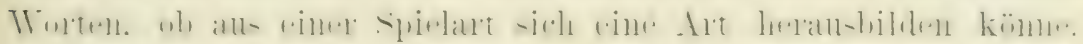

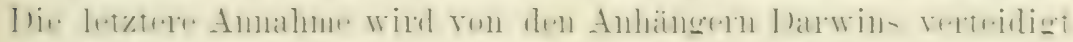

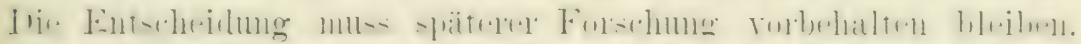

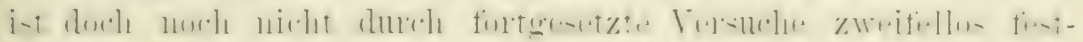

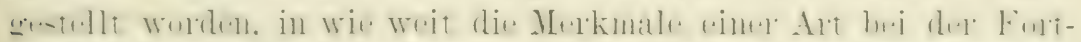

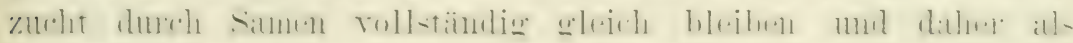
wesentliche I[erkmale zu betrachten sind.

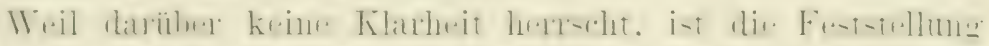

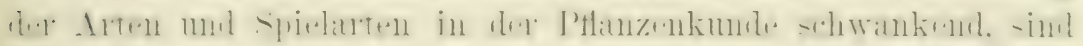

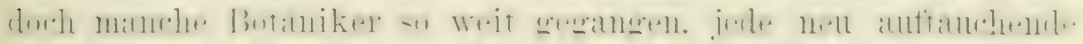

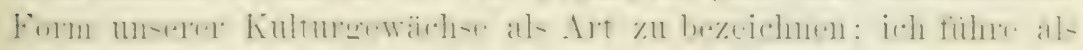

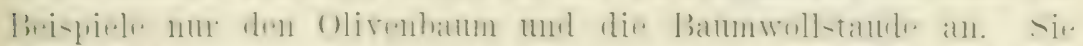

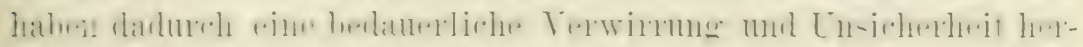

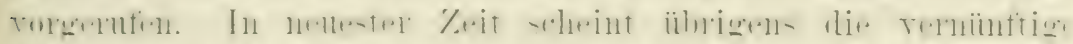

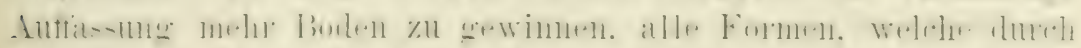

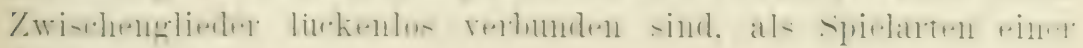
Art zur betrachten.

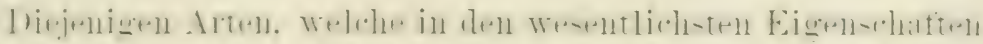

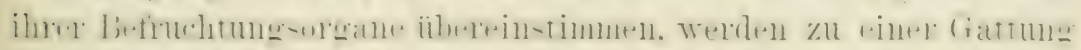

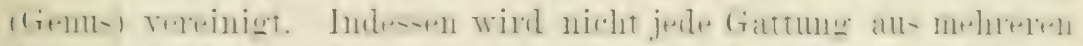

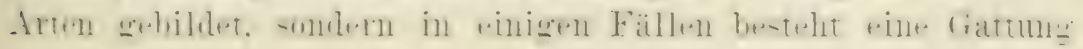


mul alls einere Art, weil andere Alten nicht vorhanden sind, oder his jetzt noch nicht entreckt wurden, wolche gleichgeartete Befiruchtungsorgane besitzen. Taweilen wird eine Einteilung in I"ntergattungen vorgenommen. un die nähere und weitere Verwandtschaft zu sonder'n. Fine Pflanze bezeichnet man mit dem gemeinsamen Gattungsnamen, dem der betreffende Artname zugetï̈nt wird. Die heiden Vanen sind gewöhnlich dem Griechischen oder. Lateinischen entnommen und bezeichnen häufig hervorragende Eigenschaften. Der (tattmgsmame ist ofter dem Griechischen wie dem Lateinischen entlehnt. das Lmgekehrte ist bei den Artnamen der Fall. Ine elstere beginnt stets mit einem grossen Bucistaben, der letztere nur damn, wem er aus einem Eigemmamen gebildet i-t. beispielsweise ans dem Namen des Entdecker's oder ersten Botaniker's. welcher die betreftende Pflanze beschrieb. Solchem Namen wird eine lateinische Endung angehängt. Nerden mehrere Arten hintereinander erwähnt. so schreibt man nur den ersten trattungsnamen roll ans. die folgenden bezcichnet man mit dem Anfangsbuchstaben. Beispinlsweise: Pinus strestris, P. strobus, P. rigida.

Der Gattumgen hat man etwa 6000 gebildet: um dis Übersicht noch meln zu mleichtern. oruppierte man sie in Familien oder luatiurliche Ordnumgen. je nach ihrer Ähnlichkeit im Ban der Betiduhtumgsorgane. Auch die Familien werden zuweilen in Unterfamilien geteilt. Der Faniliemame ist gewöhnlich aus den Yamen derjenigen Gattumg gebildet. welche die Familienmerkmale am dentlichsten besitzt. Etwa fon Familien sind antgestellt worden, whlche in Klassen gruppiert sind, doch begnïgt man sich gewöhnIich damit. Familie. Gattung und Art einer Pflamze anzugeben. da dadurch ihre Zugeshörekeit hinreichend klar gestellt wird.

Wird die Klasifikation vorenenmmen anf Grond der Gesamtheit aller Ähnlichkeiten mul Verschiedenheiten. sn nemnt man sie die naturliche. in (iegensat\% zur künstlichen, die begriundet ist auf einem Merkmale oder wenigen.

Was when in bezug anf die Feststellung des Artbegriffs ge-agt wurde, gilt anch für die Gattungs- nul Familienbegriffe. vicht selten wird dieselbe Art ron verschiedenen Botanikern zu verschiedenen Gattungen. dieselbe Gattumg zu verschiedenen Familien gezählt. Nicht allein. dass ein Botaniker die Klassifikation des andern umstïnt. veroüssern sie die Terwirmung anch noch 


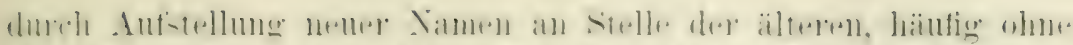

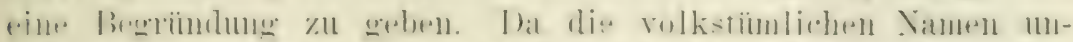

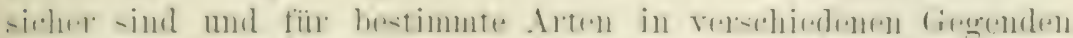

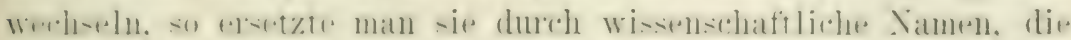

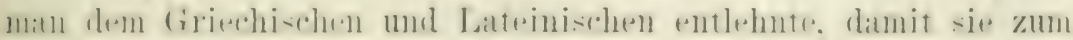

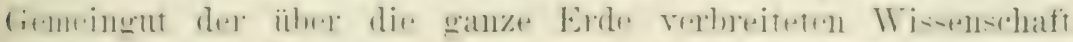

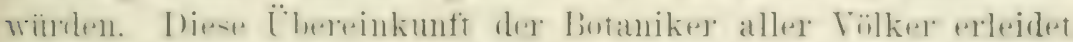

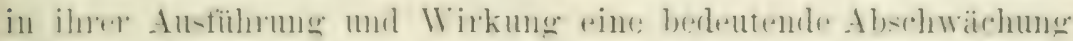

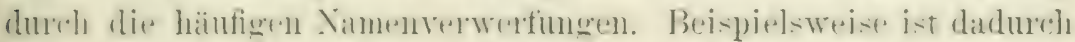
für dir mondanerikani-chen Wallbäme ein soleher Vimenwirrwar Hevorgerufen worden, dats es eines eingehenden stuliums bedart,

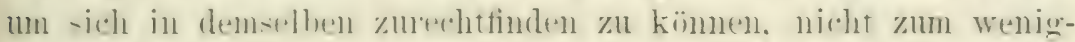

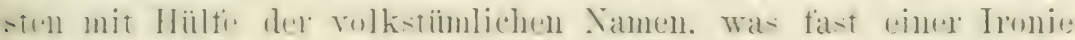
gleichkommt.

Wril s von br-mblerem Interesse für die Forsthultur ist. sei bencert. dass sich dir Botaniker auch noch nicht haben einigen kiinnen. welchr. Pflanzenfamilien als Tardellölzer gelten sollen. Bentlam und Hooker führen in inrer frenera Plantarum diess sechan: runtesinease, Taxodieas. Taxeare Podococarpear: Arancariear und thietineae.

\section{Der Bau der Pflanzen.}

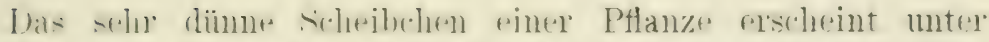

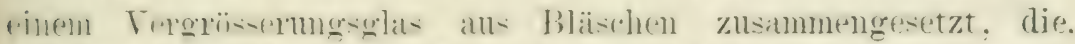

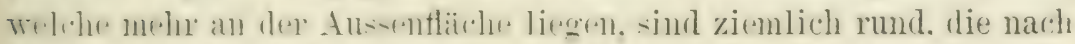

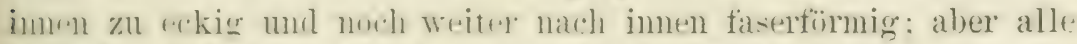

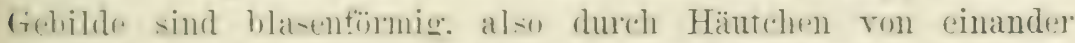

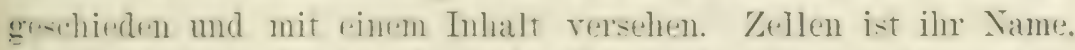

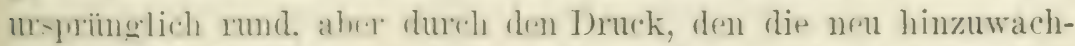

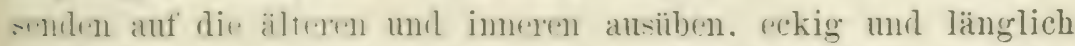

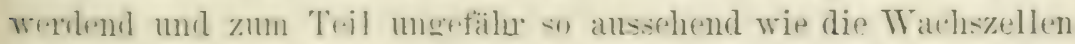

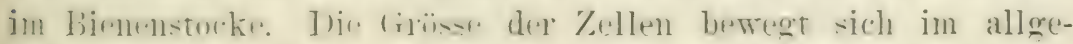

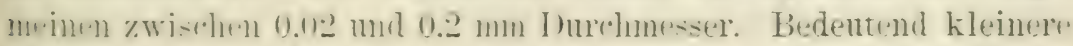
Z.Hen timbn sirh in den Bakterien, dagegen sind die langgu-trektrin Holz- unl Batzellen im Durchschnitt 2 mm lang und 


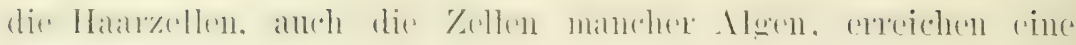
Liange bis zll $2 \mathrm{~cm}$.

Aus solchen Zellen besteht alles, was wächlst. Das Wachs-

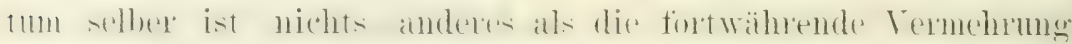

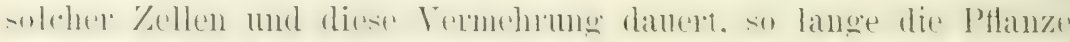

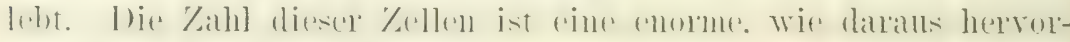

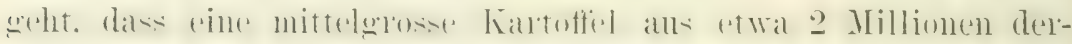

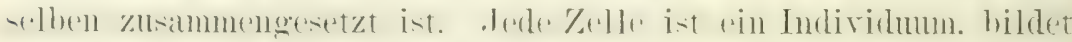

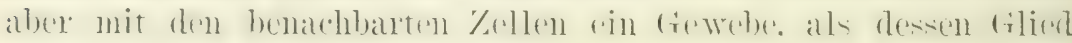
es an der Lebensthätigkeit der Pflanze teil nimmt.

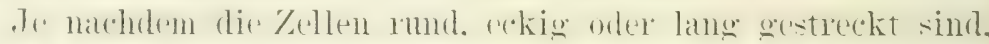

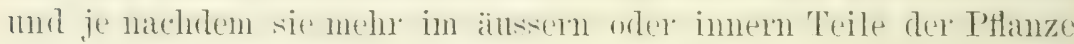
liegen, nemnt man dies Zellgewebe:

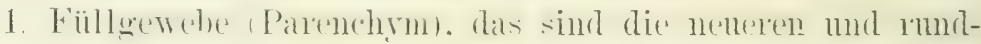

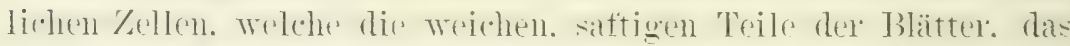
Mark des stromgels. das Fleisch der Frükhte und alle jungen,

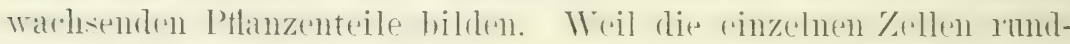

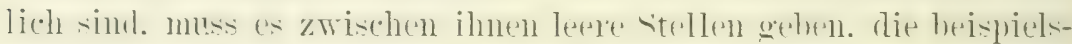
weise beim bitatt als Polren in die Luft mïnden und ron welchen noch unten die Rede ist.

2. Fasergexelue oler Holgowebe (Prosenchym) ans langen,

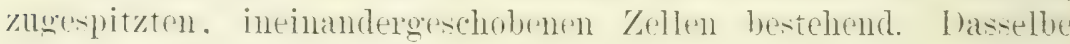
bildet das Geribst der Pflanze. dats härtere Holz, die Ripnen der Blätter 11. S. w. Die Wand dieser Zellen ist dick, stark und clastisch.

3. Gefüssgewebe oder röhrige Gewebe; da, wo der Saft am stäksten ah)

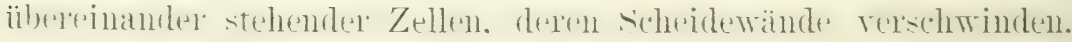

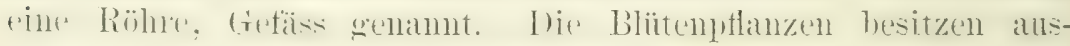

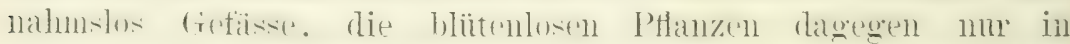
rinigen vollkmmenen Fanilien: diese wie jont werden daher

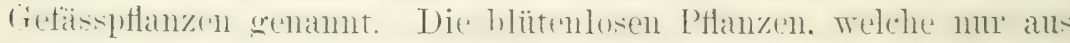

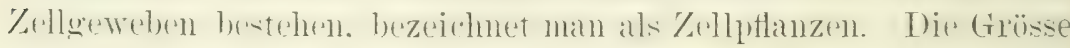

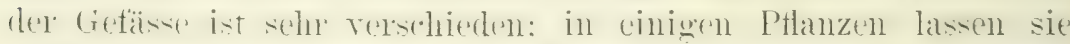
sich mit nacktem Aluge aut dem (purechnitt rektmen, in anderem

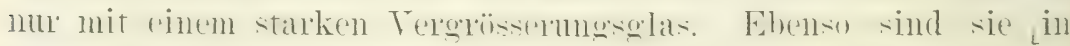
ihrem Aussehen sehr verschieden.

Zwischen den Faser- und Gefässgeweben liegen Räume

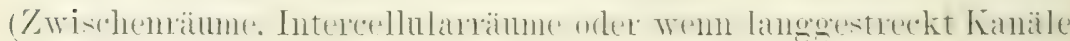




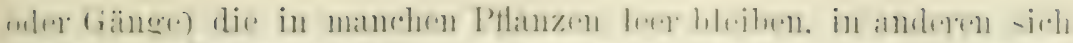

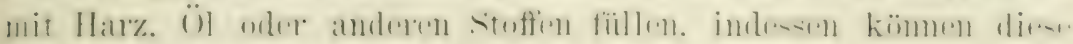

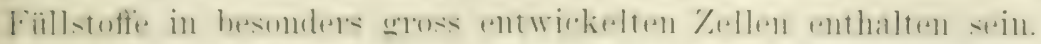

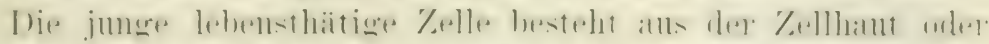

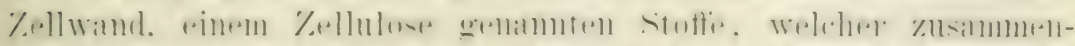

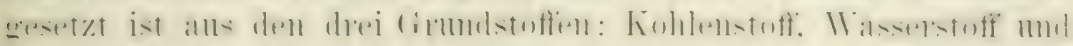

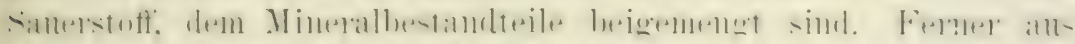

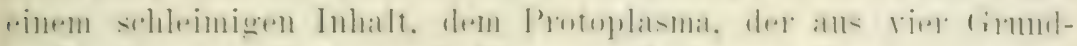

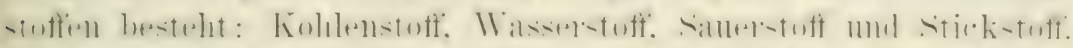

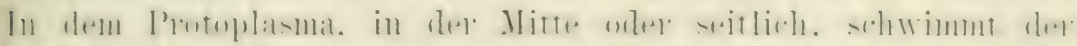

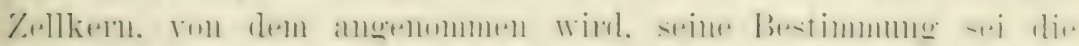

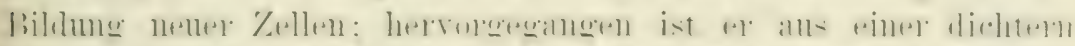

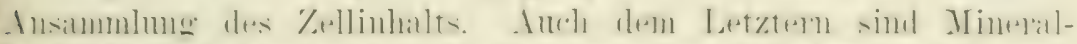

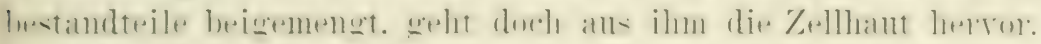

Ans Zellen baut sich also die Pflanze auf. doch ist ihr ana-

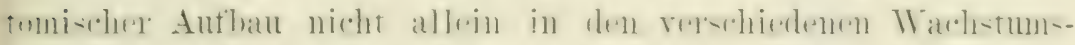

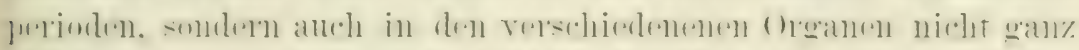

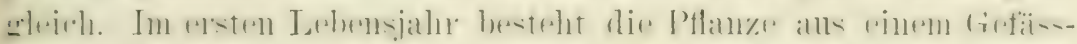

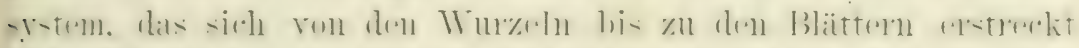

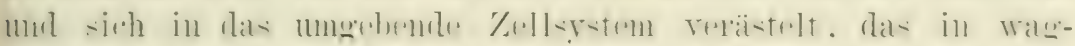

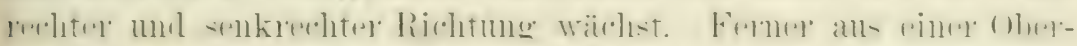

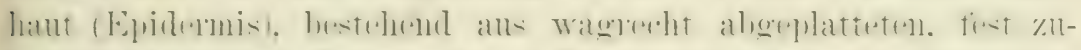

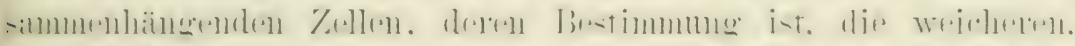
inne?

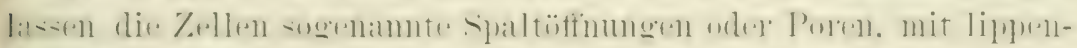

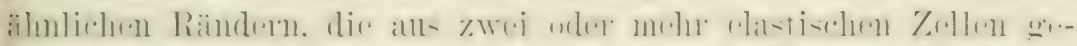

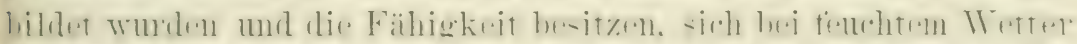

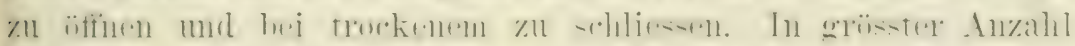

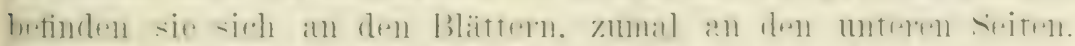

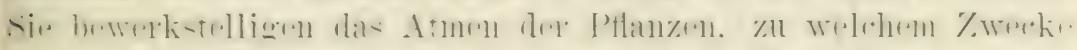

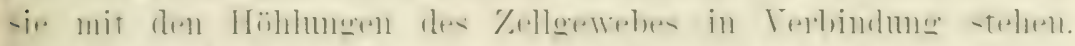

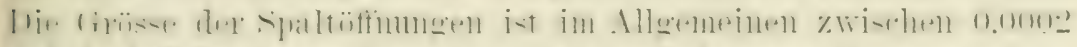

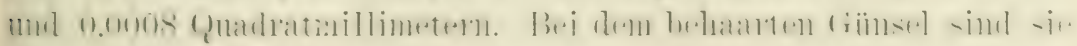
mur 0.0000137 Quadratmillimeter gross.

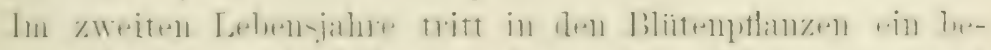

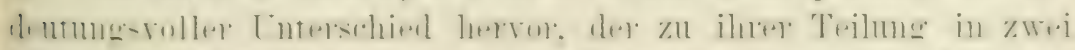

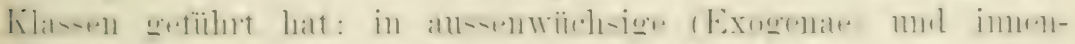

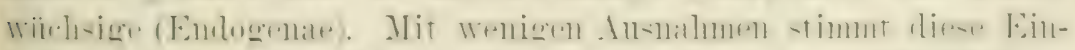

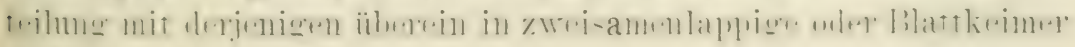


, likotyledomeni) mol rimsamenlappige oder Spitzkeimer (Donokotyledenen). I) aе anscenwüchsigen (zweisamenlappigen) Pflanzen setzen nerus tellgewebe an ihrem jeweiligen änsseren T'mfange an, sir wachsen in die 1)icke rom her'n nach aussen, wie es am klarsten an den Holzringen vines Bammstammes beobachtet werden kamn. l) innenwïchsigen (einsanenbläterigen) Pflanzen kömnen ihren Inuchmesser nicht merklich rermehren. dem ilne \%ellenbildungen finden imnerhall, des eimmal angenommenen Unfanges des Stengels wler Stammes statt. mol zwar se lange, bis derselbe gänzlich ausgefïllt ist und eine Veubildumg von Zellen nicht mehr stattfinden kamn. Das Absterhen der imnenwïchsigen Pflanzen pflegt man treffend als einen Fustickmostod zn bezeichnen. Hänfig besitzen sie weder ein zentrales Mark noch eine besondere Rinde.

Die IInzel hat keine Poren und .Jahresringe sind gar nicht wer kamm bemerkbar. die Anordnumg der Zellen ist umregelmässiger, wie in den ïhrigen Organen, oft hervorgerufen durch Anhäufung rom stïrke und andelen stotten. I)ie Wurzeln enden in den Wurzelhatrent kleine. länglichrunde Zellen, welche den nährenden Saft ans den boulen anfinehnen und durch Ansscheidung einer frein sïne die Mineralbestandtheile des Borlens anfzulöson im stande sind: ie ungehen sich nit einer Fiill, von Bodenteilehen, wolche sich selbst durch Schuitteln nicht entfernen lassen.

Iner stengel bder Stamm der ansenwïchsigen Pflanze besteht nach dem ersten Lebensjahre ans:

dem cylinderfmonigen Mak. Welches genam in der Mitte liegt, mu in den jungen stengeln mul Zweigen an der Lebensthätigkeit teil nimmt. suäter vertrocknet und in älteren Bammstämmen vollstïndig verschwindet;

der Markscheide. Welche ähnlich dem Mark suäter rertrocknet und verschwindet; sie steht in der Jugend mit dem Gefässsystem in Verbindung;

dem Hol\%, welches die Markisheile momgibt mol gebildet wird ans holzigen rewebe durch das defässe in verschiedener Anordnung ziehen. ansotmonmen hei den Nadelhölzern. Es ist in kreisähnlichen Ringen gendnet, welche mu einige Jahre lebensthätig bleiben, damn hart, dicht, dunkel mud mnthätig werden; in diesem zostande bilden sie das Herz- oder Kernholz, im Gegensitz zи dem gewöhnlich heller gefärbten, thätigen Splint- oder Saftholz; 


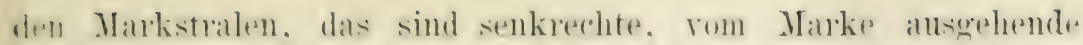

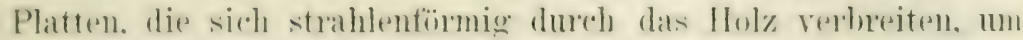

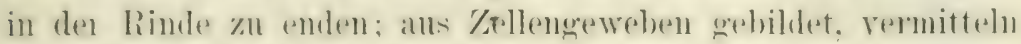
-ie den saftallstallsidh zwischen den noch thatigen mittleren 'Peilen des Stengeds mul den äusseren. Wird das Kernholy muthitig. Werten es alleh die Markitralen, so weit sie rom

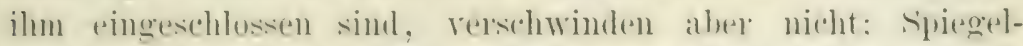

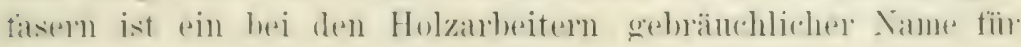
Markstrahlen;

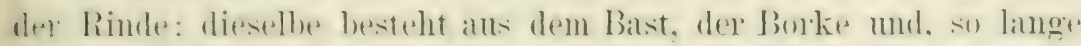

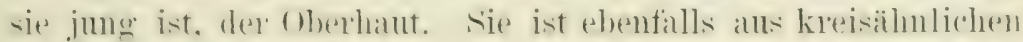

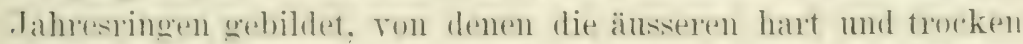
werden, beim I) idierwerelen des stammes zerreisen mol allmählich abfallen:

dem Bildungsing (Kambiumbing), der zwischen der Rinde umd dem

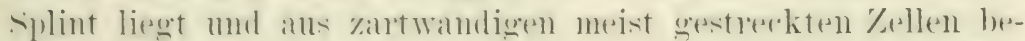
-teltt. die mit klarem were kinnigen Zellsalt strotzen. Des

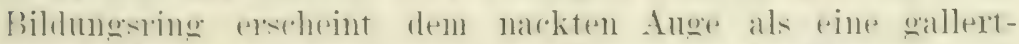

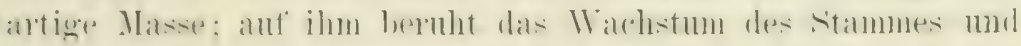
der Äste, wie weiter unten erklärt wird.

lep immenwolsige stamm zeigt niemals in seinem Immern

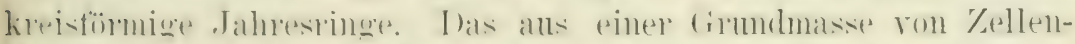

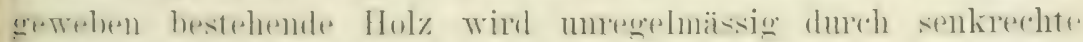

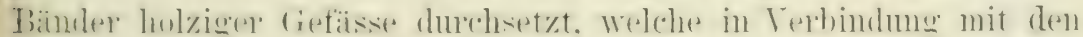

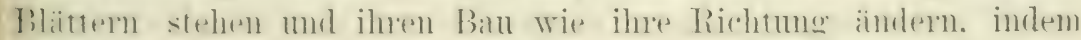

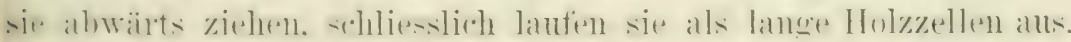

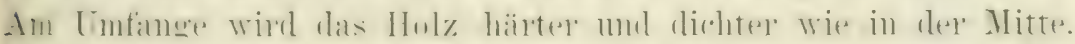

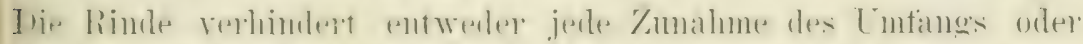

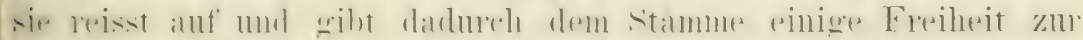
Ansdehnung, die er ibrigens wenig beniitzt.

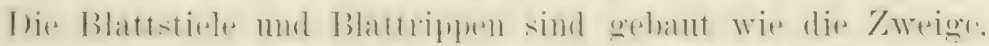

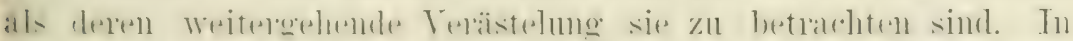

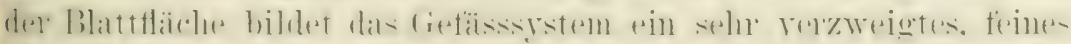

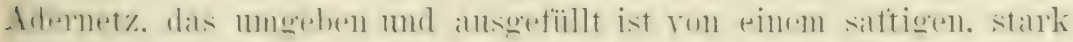

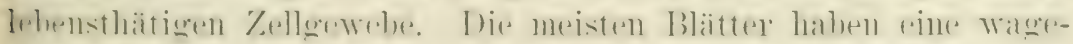

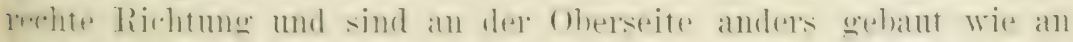

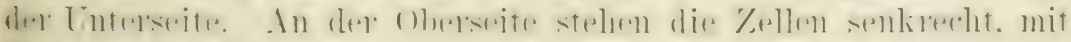

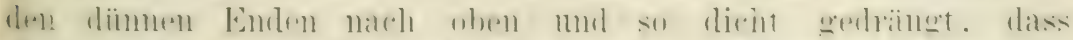

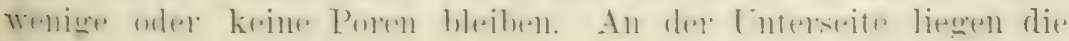


Zellen mohr uler weniger wagerecht, sind so locker gefïgt, das. sie Hohlränne zwischen sich lassen. die mit den zahlreichen Poren der ()herhant der Lnterseite in Ferbindung stehen. Bei den senkrecht gestellten Blättern, wie sie viele anstralische Pflanzen besitzen. sind beide seiten ron ambähernd gleichem Bau. Die Blattripuen dienen zur Zutührme von Nährwasser in die Blattfläche, sowie dex Rïckleitung der umgewandelten Bildungsstofte in den Blattstiel und den Bildungring. selbstrerstandlich in gesonderten Kanïlen.

Die schupen sind nach derselben (irmdanlage wie die Blätter irebant, sind sie doch. wie oben erwähnt, als rerkümmerte Blätter zu betrachten. allein die Anordnumg ist sehr vereinfacht. Poren fehlen gewöhmlich orler sind nur spärlich vorhanden. das Zellwewebe ist ziemlich gleichartig und die crefüste sind wenig relzweigt.

Temn die Ireckblätter und Blütenhüllen grïn und stark entwickelt sind. ähneln sie in ihrem Bau deil Blättern, je mehr sit aber zu Schnppen rerkïmmern oder zu Blunenblättern werden. desto mehr verschwinden die Poren. das Zellsystem wie die Gefä-s+r werden einfacher, dümer und zarter.

Die Stanbgetisse und stempel sind fast gleichartig gehaut. In den staubfäden und Griffeln ist das ron dem Zellgewebe umgebene und ausgetïllte Gefässstem einfach. dagegen mehr verzweigt in den Hächenförmigen Teilen, den Fruchtblättern. Stanhbenteln u. s. w. Der Blïtenstanb besteht ans kïmigen Zellen. in versobiedenten Formen gruppiert und ïbereiustimmend bei derselhen Art. zuweilen sellost bei derselben Gattmog und Fanilie. Die Narlu res stempels besteht ans lockerem Zellgewobe whe oberhant mol ist gewöhnlich rephunden mit einer höhre. die zu den samenknospen führt.

Die Drü̈ren bestehen, gleich der Xarbe. ans lockerem Zellgetwebe ohne (bberhant. die Hatre werden ans mehreren iibereinanderstehemden Zellen gethildet. selhst damn. Wem sie sich zu Bursten und stacheln rerhärten. Niemals besitzen sie detaisse. wodmech sie sich ron den Ibormen nuterschedilen. die mit dem

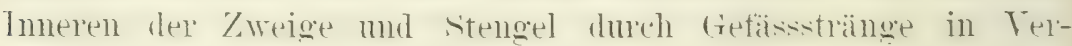
bindung stehen.

Thas sameneiweiss. die dicktleischigen teile des heimlines. die fleischigen oder holzigen Teile der Frucht. die fleischigen Ter-

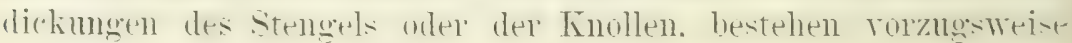


Keimsats. wir die grosse, in samenknospen liegende Zelle genamnt wird. ertuppiert sich in bosondere Abteilungen, die sich mit einel Zellhatut mogeteen. Das ist freie Zellenbildung im Gegensatz zur Zellenteilung. Die hegimende Entwickelung der Pflanze, whelle man heimmog nemnt, monterscheidet sich anch dadurch vom spätren Wachstum, dass keine Vährstoffe vom allsesen zugeführt werden. da -ie in den Samenkïmen, Knollen. Twiehehn mol ansdanemiten Wurzelstöcken vorhanden sind.

Sie alle enthalten eine rerhältnismässig hedentende Menge rom stickstofthaltigen Terbindungen. welche dem Hühnereiweiss. dem Blutfibrin und dem Käsestoff grleichen und Eiweisitufte (Albuminoide) genannt werden. Ansserdem sind noch andere stutte zur Ernährung des sirh bildenden Keimes rorhanden, entweder gross Mengen von stärke und kleinere ron Fett, wie in den Hülsenfrïchten und Getreidekömern oder umgekehrt: grosise Mrengen Fett allein vder gemengt mit stärke, Zucker u. derol. Dass es diese Stoffe sind, aus welchen die junge Keimpflanze ihre ersten Turzehn. Stengelteile und Blätter aufbaut, folgt ans der leicht zu machenden Beobachtung. dass sie sich. in dem Masse, wie das Wachstum fortschreitet, rerändern, indem sie dir Form ron Zellneweben amehmen. Anch das Austreiben der Holzptlanzen im Friihjahr ist ein Keimmesrorgang derselben Art; die Winterknospen der Bäume und Sträncher enthalten Eiweissistofte. Stärke und Fett in grosser Menge, dieselben Nährstoffe sind absserdem in der Rinde mo im jünceren Holze der Zweige und Stämme wïhrend des Winters abgelagert, sie bilden die sogenamnten Reservestofte, welche rerschwinden in dem Masse, wie die Frühlingstriebe und die Früchte sich vergrössem.

Die Keimung danert nur, bis die vorhandenen Nährstoffe rerhrancht sind. Da sie ansreichten. un die Organe zur weiteren Ernährmo der jungen Pflanze, die Wrurzeln und Blätter, als:zubilden, so ist dieselbe jetzt im Stande, sich aus ihrer Umgehmung die zum Wachstum notwendigen stoffe zu verschaffen. Die Frag't, woher diese erste Grundlage zur Keimbildung und Entwickelung. stammt, wird durch die Erfahrung beantwortet. Die Mutterpflanze hat in der vorhergehenden Wachstumsperiode mehr Nährstoffe aufgenommen und ungewandelt, als ihre Lebensbedürfnisse erheischten, den Überschuss speicherte sie in den Samen, Zwiebeln und Wurzelstöcken auf, gewissermassen als Erbschaft oder Mitgift für die 
junge I’tlanze - ein kleine- Katpital, mit derm die letztere su lange

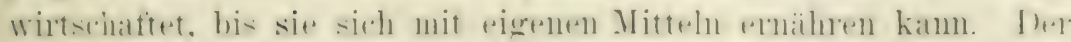

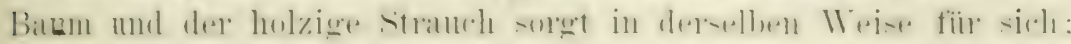

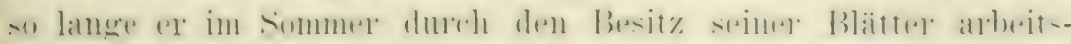

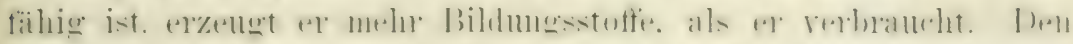

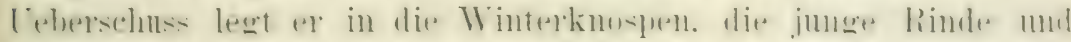

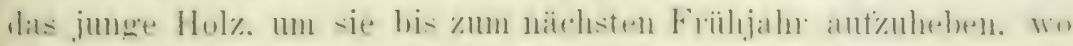

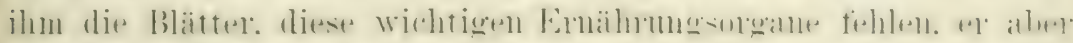
dennoch weiter wachsen will.

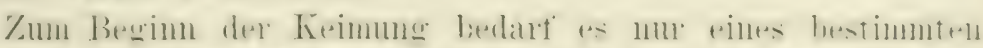

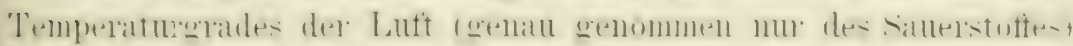

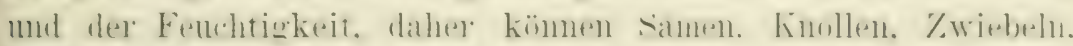

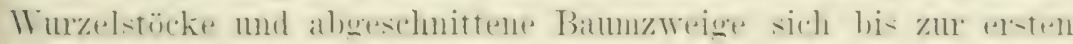

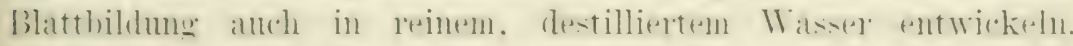

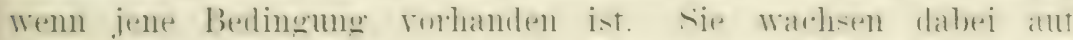

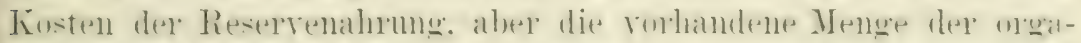

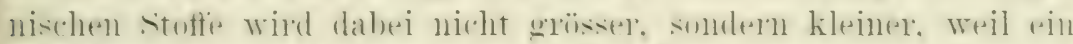

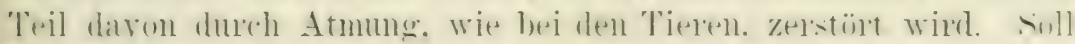

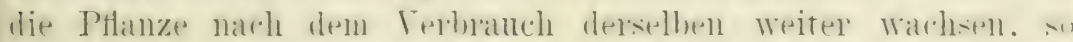

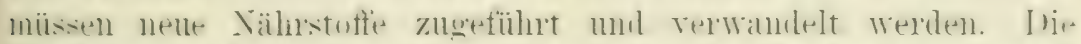

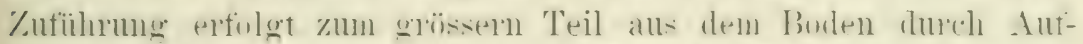

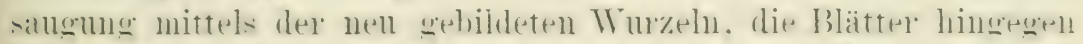

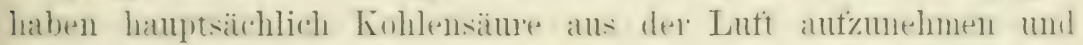

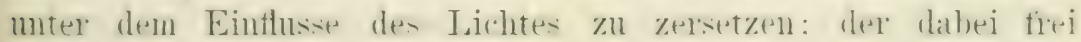

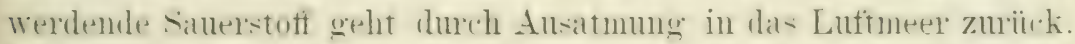

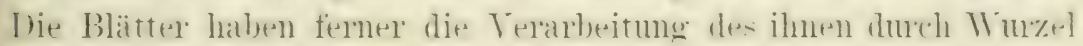

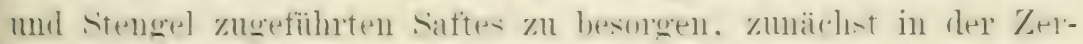

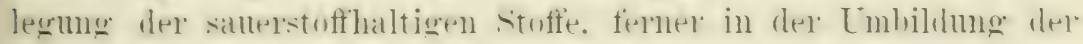
[bestandteile des rohen saftes in urganishos stoffe. Welche zum dutbau der Pflanzen dienen. T)iese I mulhildung findet statt in dent

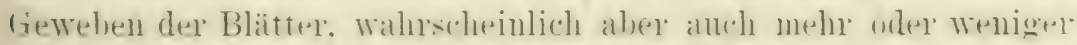
in allen lehensthatigen 'Teilen res J'flanze. Ibabei wird ein ver-

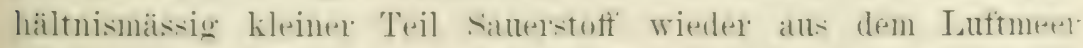

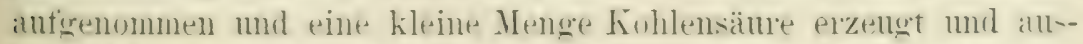

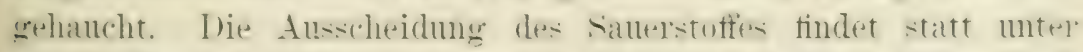

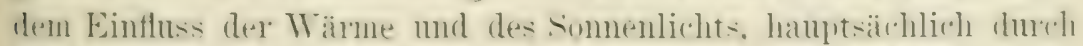
die Poren an dex Lntersedte der blätter. Lie Anfiahme ron

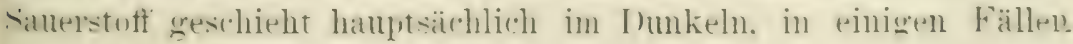
anch während des lages. 
I'ie wichtig die Einwirkmm des Lichtes, welches bei dem

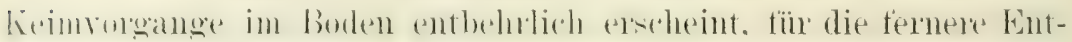

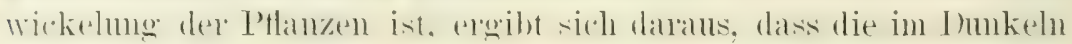

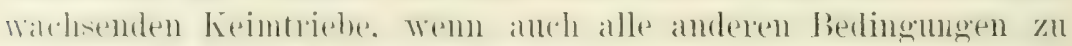

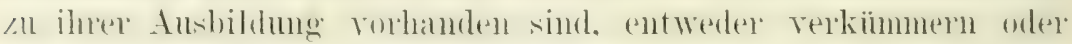

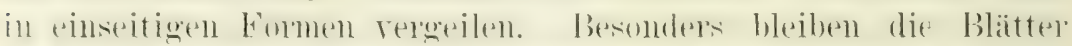

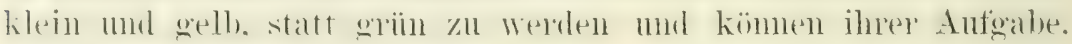

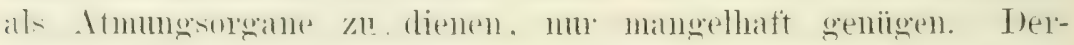

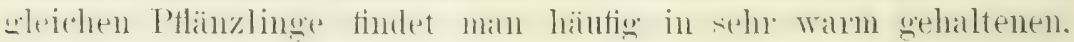

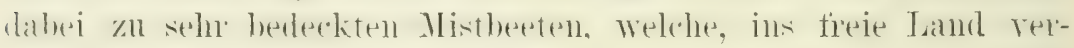
setzt. lange kränkelı oder bald zu Grunde gehen.

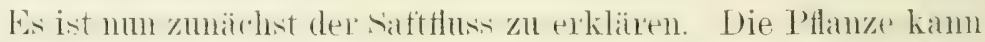

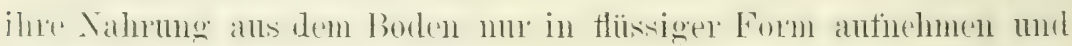
diese Aufnahne geschieht durch dic jumgsten. Watchenden Enden der

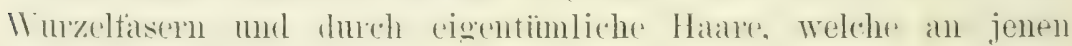

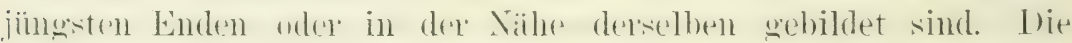
auferemmene Vahrung besteht ans Waster, in welchem mineralische

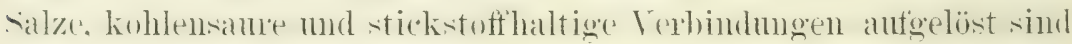

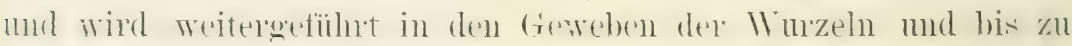

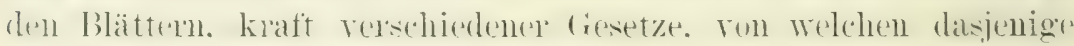

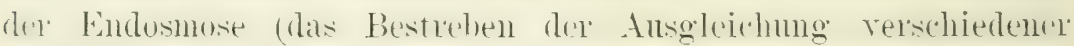
dichter Säfte) an erster Stelle genamnt zu werden pflegt.

Diese hiaft kamn durch einen einfachen Verstch anschanlich getmateht werten. lerschliest man whe lange mit einer skala rersehene

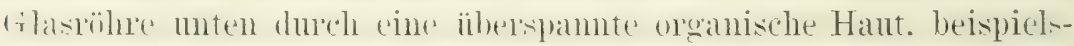

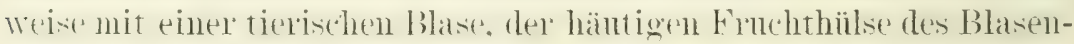

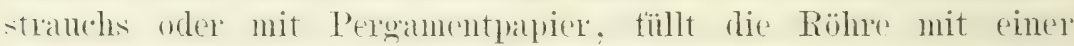
laïnng ron zucker. crmmmi obler dergleichen teilweise an, tancht sie mit ihnem muteren Ende in ein weites mit Wasser getiilltes

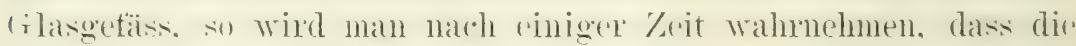
Fliis-igheit in der Röhre gestiegen ist mol zwar geselah es mit ciner beträchtlichen Kraft. dir messbar ist. Inuch diesen Tersuch lässt sich erwerisen. dass von dem Wasser beständig ein 'Teil durch di. Hant in die Löisung strönt. Was als Endosmose bezeichnet wird. Alle Bedingungen einer krätigen Endosmose finden wir in der lebenden Ptlanze, zmmal in den Momzelspitzen, deren sich

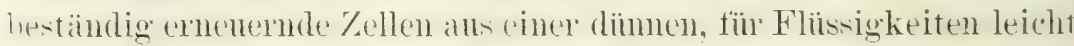
durchrlingharen Hant gebildet und mit einer meln oder weniger honzentrierten Lösmng von timmmi, Dextrin. Stärke und Eiweiss- 


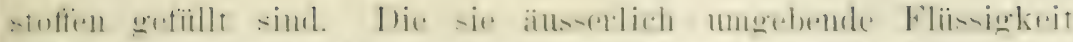

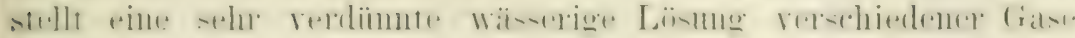
mud salze dar.

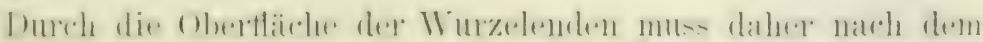

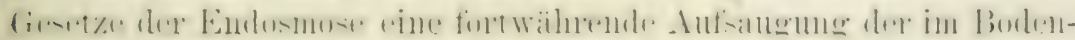

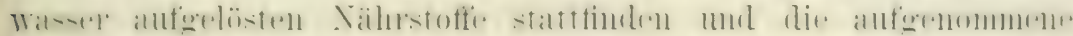

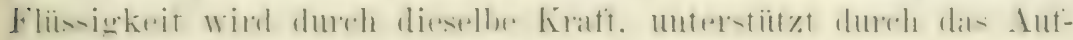

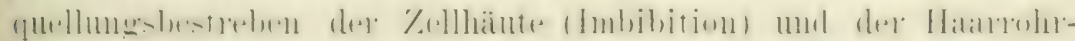

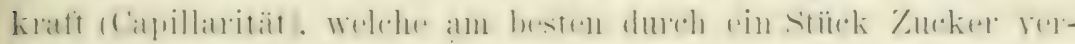

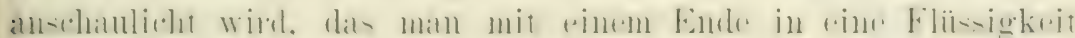

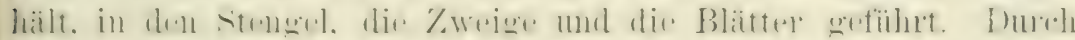

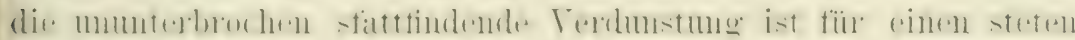

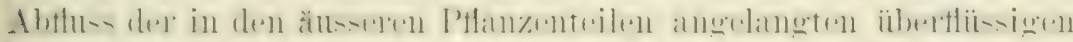

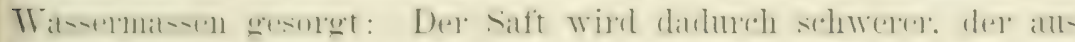

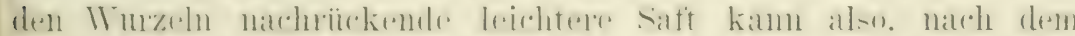

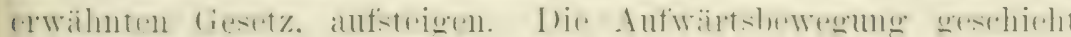

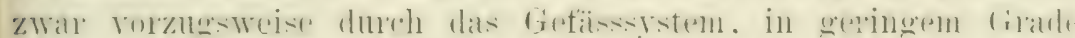

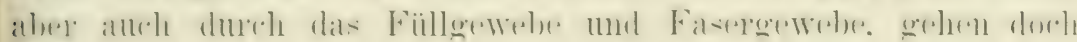

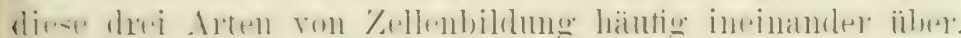

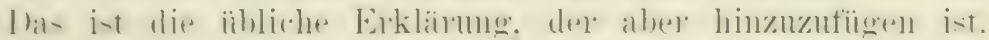

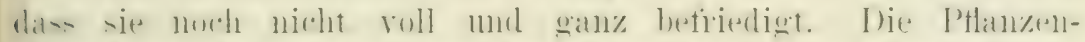

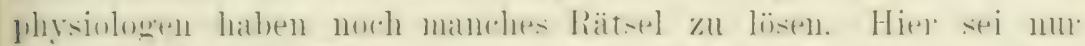

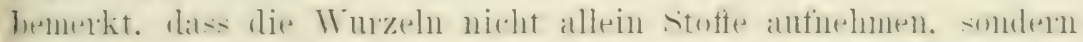

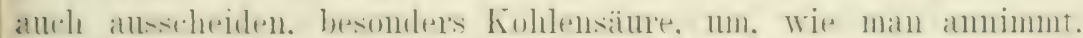

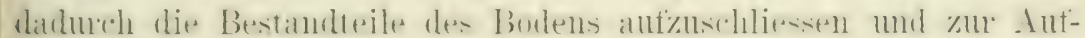
nahme befähigter zu machen.

Vim in in allerjüngster \%eit mit Hülte selne starker Ver-

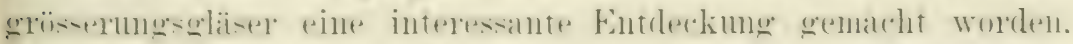

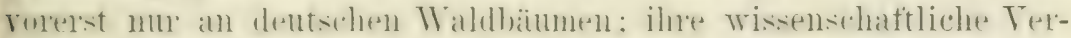

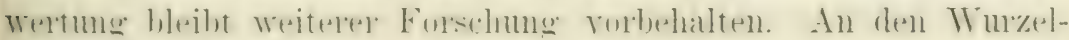

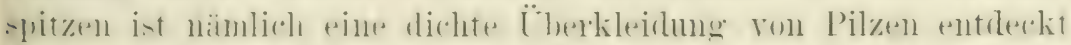

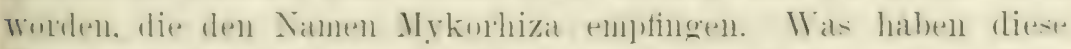

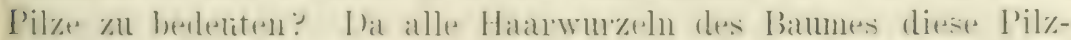

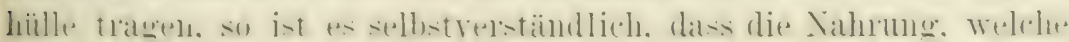

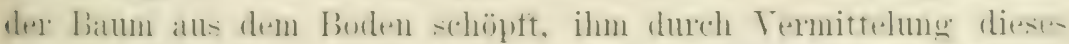

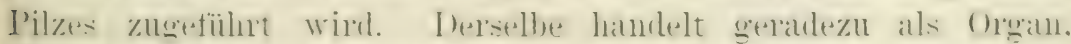

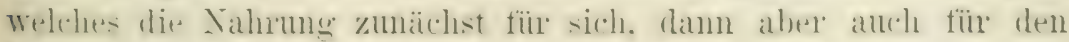

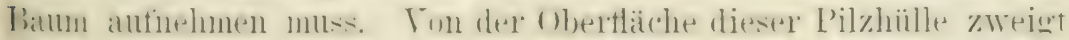
sieh eine grese Anzahl ron teinen Pilztialen in den bonlen hinein. 
Wo sie die Rolle der Murelhare spielen. Die Frage drängt sich ant: leisten sie blos eine 'Thätigkeit. Welche der Baum vermöge siner eigenen Wurelhare ansfïlnen kam oder rerrichten sie winen Dienst besonderer Art? Ris weitere Forschmgen Aufklämungen gegeben laben. ist die Termutmog statthaft: Ter Humms ist bekamelich ein Zersetzungsprodukt von pflanzlichen Stoffen, aber noch nicht die letzte stufe dieser Zersetzung. Wir wissen num, dass viele Pilze im stande sind. den Humus als Nahrung zu rerwenden. während derselbe für die höheren Pflanzen arst nach weiterer \%ersetzung in Betracht kommt. Es. ist nicht monahscheinlich, dass die Mykorhiza den Humus so rerwandelt, dass "'r für die Bamwurzeln aufhehmbar ist und als eine Begründung hamn gelten, dass diese Pilzbildung in humusfreiem Boden fehlt. Temn dem so wäre, winde sich die pflanzliche Ermähnungslehre etwas anders gestalten.

I)er ron den Blättern umgewandelte zähe Saft geht als sogenamnter Bildungsisaft von den Blattzellen durch den Blattstiel wieder in die Zweige. Äste. den stamm und die Wurzeln. abel nicht anf dem Wege durch den splint. denn dessen Gefäsisistem ist mit antisteigendem Saft und waihrend der Trachstumssuhe mit Luft sefüllt. somdern er steigt als imnerhalb des Bildungsringes (Cambium). einer Lage sehr dimmandiger Zellen. Welche das Holz mit der Rinde rerbinden. I)ie Zellen des Bildungssinges rermehren sich durch Teilung und dehmen sich ans; dabei sondern sie sich in zwei schichten, deren immere den neuen Holzring; deren äussel't eine neue Bastschicht ergibt.

Der Lmfang des Bammes muss. wemn so splint und Bast Zumachs erhalten, zunehmen mo zwar in allen seinen Teilen, demn der Bildungsaft steigt bis zn den feinsten Wrzeln hinab. Wird an einer Stelle des Stammes ein mur fingerbreiter Ring der Rinde bis auf den Splint abgelöst. muss der Baum sterben. Der Nahrungsatt -teigt in diesem Falle wohl noch in die Blätter. allein der Bildung'saft kamn nicht ïber den Ring hinunter, weil seine Hauptbahn, der Bast, hier ringsum eine Lïcke hat: der mntere Teil des Stammes und die Wurzeh können sich nicht mehr weiter bilden, namentlich rerstopfen sich alhnählich die Haarwuzehn, sie kömnen wegen des ausbleibenden Bildungssaftes keine nenen Zellen bilden. damit fällt ihre Fähigkeit fort. Bodemnahumg anfzunehmen. Der Baum stirbt Hungers und somit ist der alte spruch berechtigt: in den immersten 


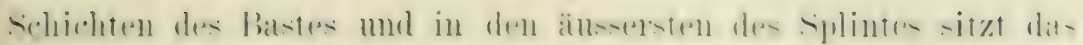

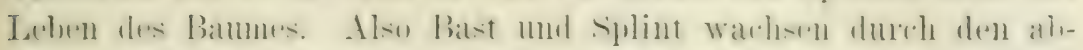

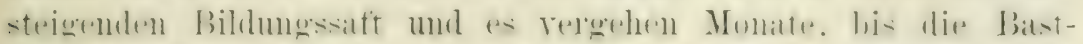

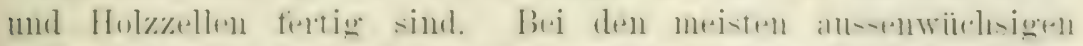

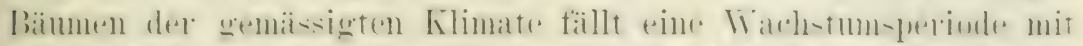

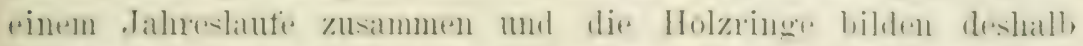

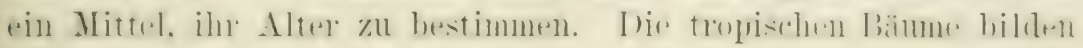
dagegen zwei und selbst mehr Ringe im Jahr.

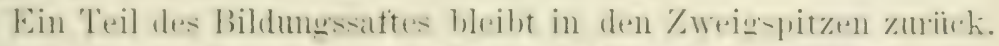

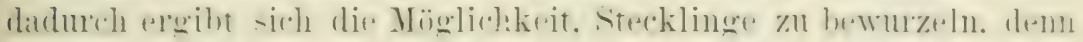

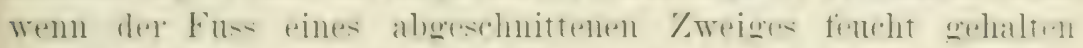

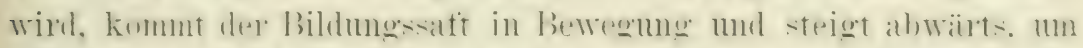

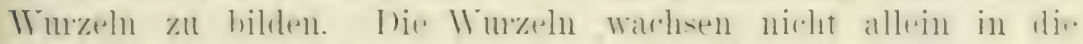

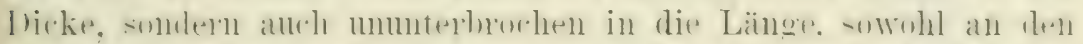

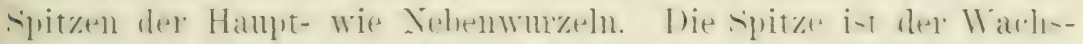

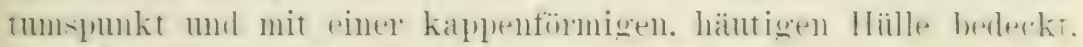
die Wurzelhaube oder Wurzelmütze genannt wird.

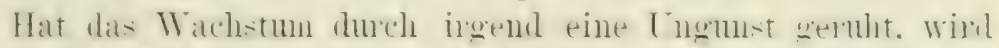

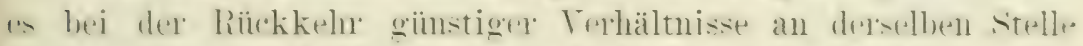

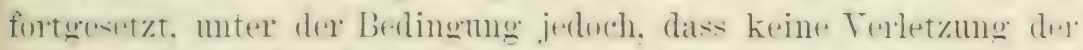

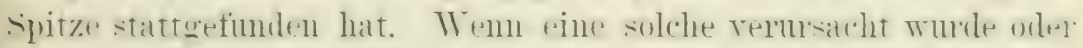

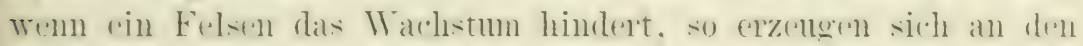

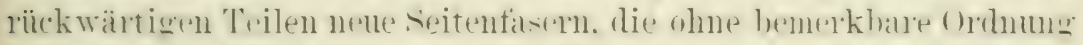

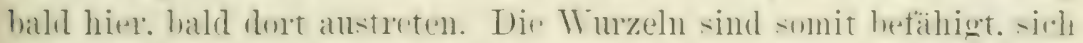

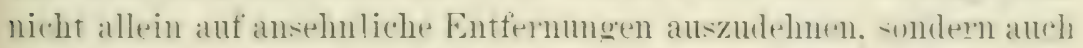

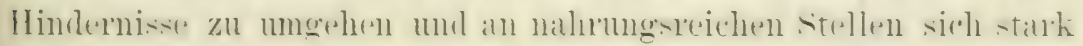
zil entwickeln.

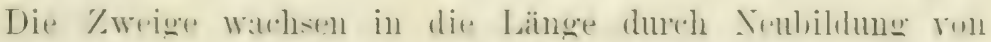

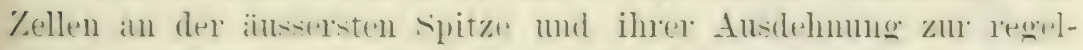

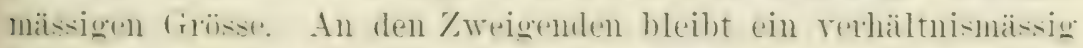

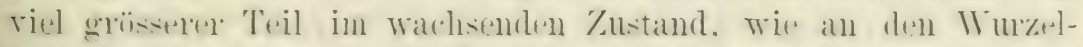

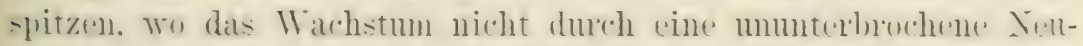
hildung ron Zellen und Ansdehume zur rollen Gröse stattfind re Es vertrocknen nämlich häutig die Zellen. welche zutest an eine-1 Wurzelfitser gehildet werden. die ihr Wachstum beginnt: sie bilde-n in dipsem \%nsande einen schutzmantel für die unter ilnu'n zur Ausbildung gelangenden Zellen.

Die Blätter und blattahnlichen Blütenteile wachsesn an iln'em firmer durh zellenvermehrung. Sie treten mit ilner splitze? 
zulest alls ihtem sitze, während an ihrem (irunde die Veubildung

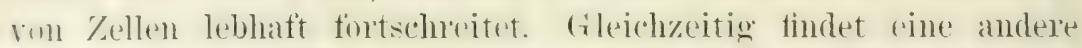

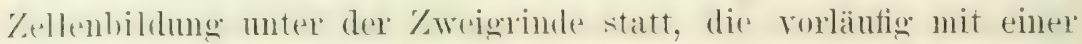

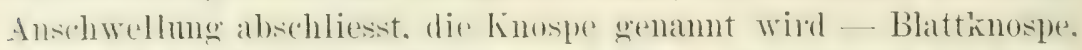
Wrm sie die Anlage zu einem nemen Blatt, gleichzeitig zu einem

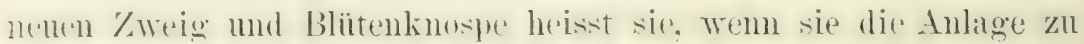

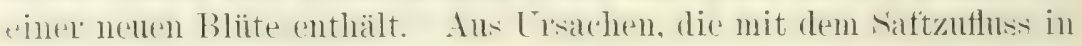

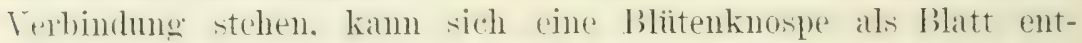

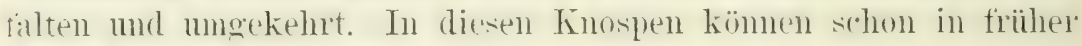
Fugend manche biätter mit allen Einzelleiten deutlich erkimnt werden. In dieser kleinen Gestalt ruhen sie bis zur nächsten Walchstmmseriode. Wo sofort die Torgrössermg durch eine lebhatfe Yeubildung rom Zellen stattfindet. seltener sind bei den Keimlingen die Blätter dentlich erkembar. Welche sie in ihres. Anlage enthalten. Der Same mit seinem Keimling ist gleichzeitign Init der Knospe in ähnlicher '/enlengruppierung gebildet worden.

Mancher 'T'eile der Blïte. Welche spaiter miteinander verwachsen. sind in ersten hinospenzustand getreme, andere, die später ron meleicher frösse und Gestalt sind. rscheinen in frïhester Jugend ron übereinstimmender Beschatfenheit. noch andere sind dentlich rkemular. kommen aber nicht zur weiteren Entwickelung.

Die Bliitezeit wähnt ron dem beginnenden (̈)ftnen der. Bliitenhiillen bis zum Terwelken und Abfallen der Stanbgefässe und stempel oder in manchen Fälen bis zur anhebenden Tergrösserung ler stempel. Ton da ab wird der vergrösserte Fruchthoten junge Frucht genannt.

In manchen Pflanzen finden sich in oder nahe bei den Knospen vder samen beträchtliche Vahrungsvorräte. ronzugstreise ans stärke bestehend. Sie dienen in vielen Fällen. wie in den Sartoffeln. in vielen Wurelstöckens. in den schuppen und dem rerdickten cirmde der Zwiebehn. in Eiweiss oder in den Keinnlappen des samens augenscheinlich dazu. um in wieder Hössig gemachter. Form den zu bildenden Zweigen und Keimlingen als erste Xahrung zn dienen. In anderen Fällen. wie bei den fleischigen Anschwellungen mancher stengel und Blattstiele. der Fruchthiille mancher Früchte. welche lange ror der Keimmog des samens rershrinden. ist der Zweck dieser Torräte noch nicht erkamnt.

Die Blïte wirkt nicht bei der Eruährung der Pthanzen mit. ihre Thätigkeit ist ausschliesslich der Erzengung ron Früchten 


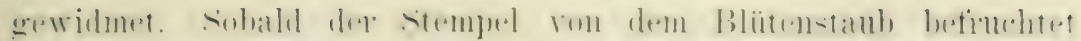

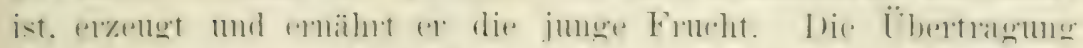

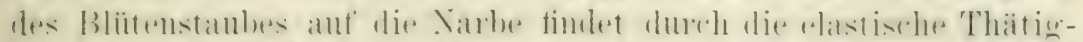

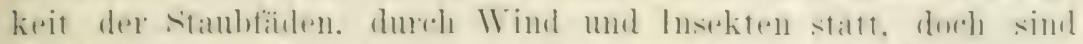

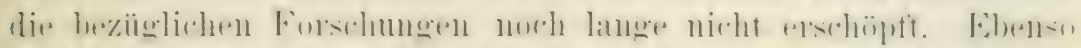

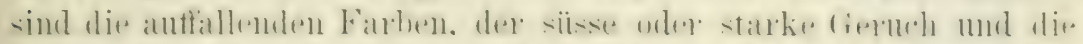

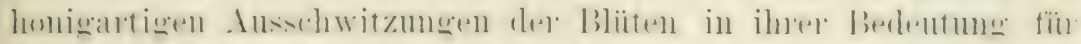

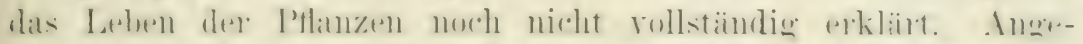
nommen wirl. sie bilden Anzielnung-mittel für die Inscktent.

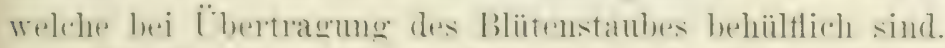

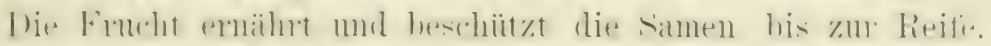

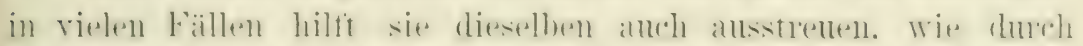

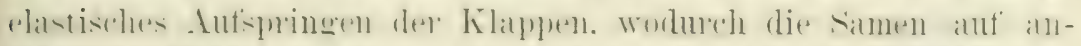

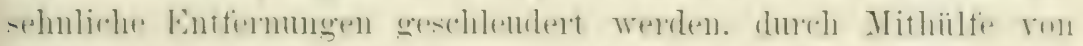

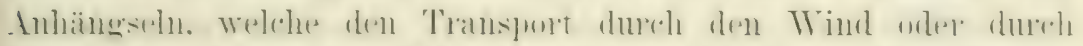

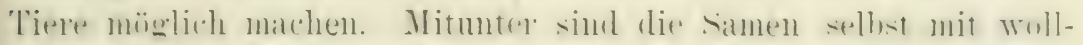

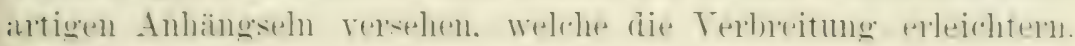

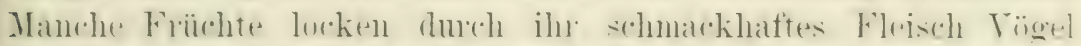

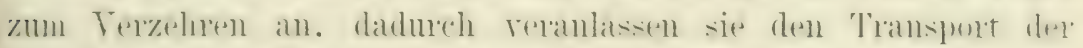

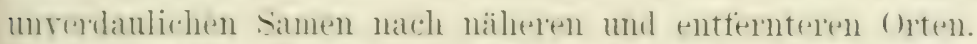

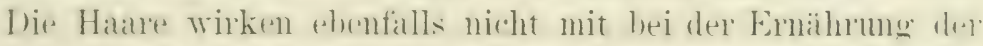

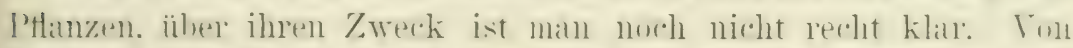

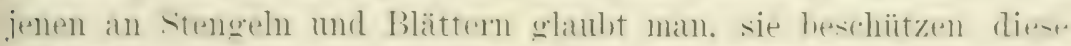

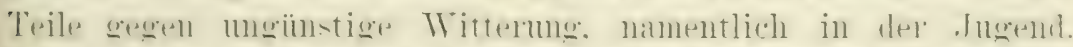

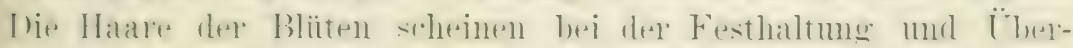

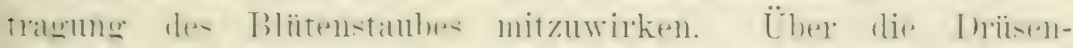

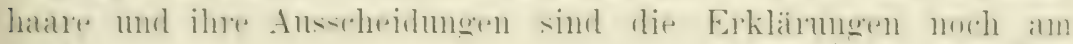
diirftigsten.

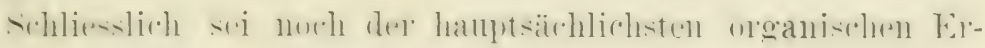
zengnisse der Zellen während des Wachstums gedacht.

Zucker, ron dem drei Arten mnterschieden werden: Roh-

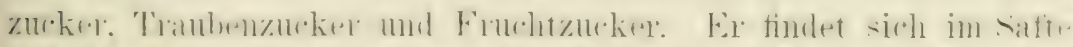

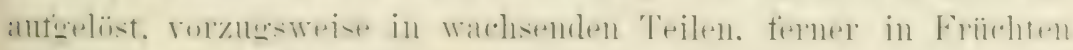
und keimenden Samen.

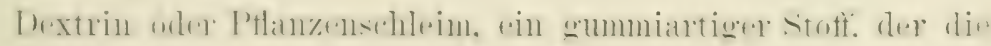
Mitte liält zwischen Zucker und Stärke.

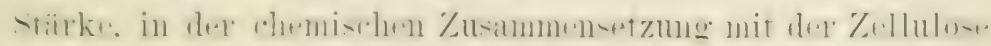

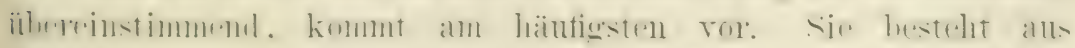

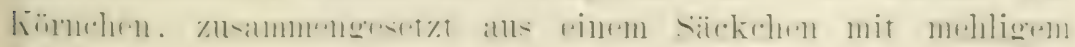


Inhalt und ressehieden gestaltet, je nach der Pflanzenat. Werden die Säckchern in heissem Wasser gesprengt, so entsteht stärkekleistry. der nicht zu königer stäre zuriickverwandelt werden kamm. Jas charakteristische Erkemmngszeichen fïr Stärke ist, dass sie sich bei Anwendung von Jod blau färbt.

Blattgrün oder Chlorophyll besteht ans sehr kleinen stickstoffhaltigen Kïrnchen, die sich muter der Wirkung des somnenlichtes färben. Die grime Farbe lässt sich durch Alkohol ausziehen. zuriick bleiben farblose Körnchen. Gewöhnlich liegt das Blattgrün unmittelbar unter der ()berhant der Bläter und jungen Rinde. Es hat wichtige Dienste zu verrichten, denn es ist der Apparat. in welchem, unter dem Einflusse des Lichtes. Kohlensäure und Wasser in organische Troindungen umgerandelt werden. Daraus folgt. dass Pflanzen ohne Blattgriü keinen Kohlenstoff aus dem Luftmeer beziehen können, sondern von vorluandenen Kohlenstofiverbindungen leben mïssen. Daher finden wir sie auf Fäulnisprodukten wachsen oder sie treten als Schmarntzer auf.

Ausserdem finden sich noch andere Farbstoffe in vielen Pflanzen vor. Fette und ätherische öle, harzigr Stoffe, Gerbstoffe und verschiedene Bitterstofte sind onthalten in zellen onter in Ränmen zwischen den Zellen, ebenso liegen da ruschiedene mineralische stofte. entweder formlos oder in testalt ron hrystallen. 


\section{Zur Bodenkunde.}

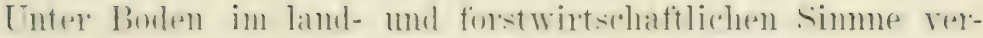

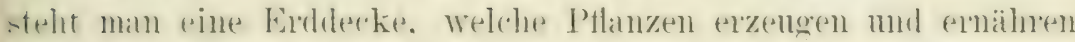
kamm: se zerfallt in die Litume. Welche man nach allecemeines

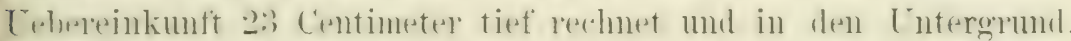

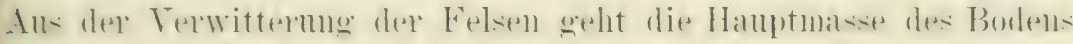

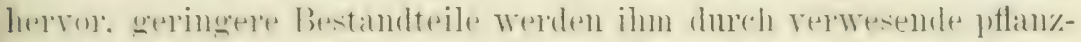

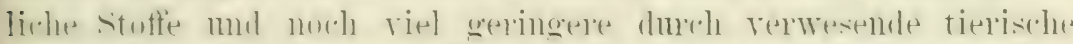

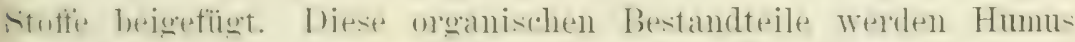

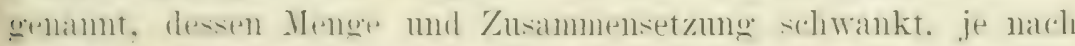

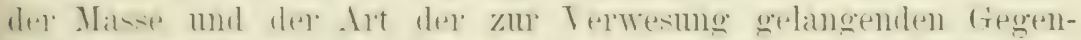

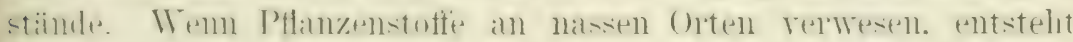

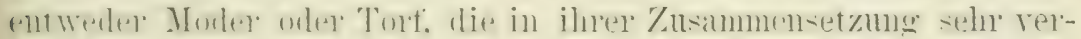

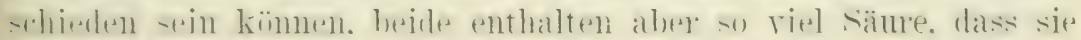

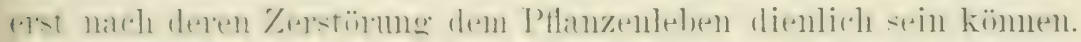

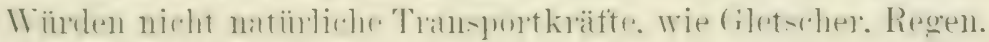

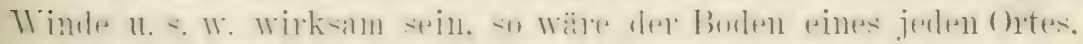

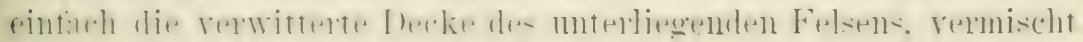

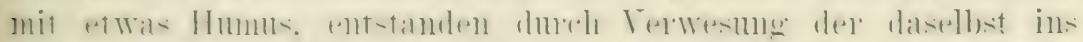

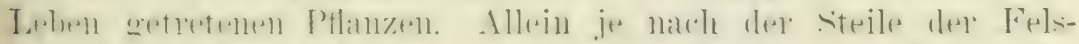

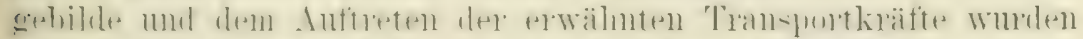

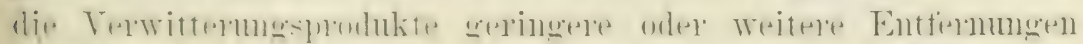

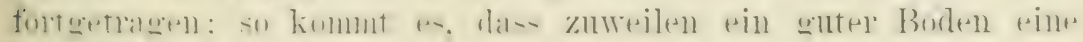

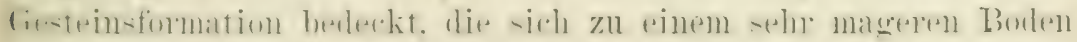
zersetzt.

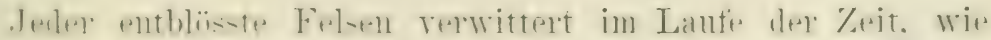

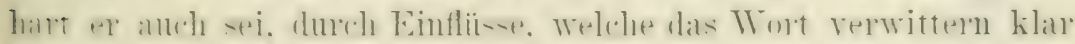

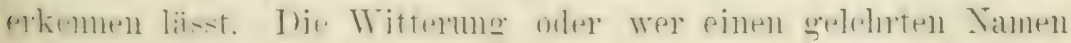




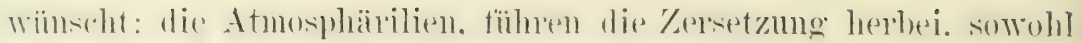
ant chemischem, wie medhanischem Wege. Dex Regen, welcher Kohlensïure in der Luft anfinimmt, wirkt durch diesen stoft' antlïsond, ferner anch dureh seinen santerstoft. der Oxidationen herbei-

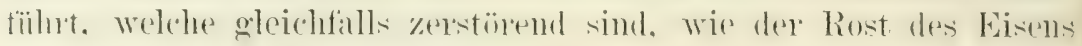
als bekamntestes Beispiel darthut. Die mechanische Thätigkeit des

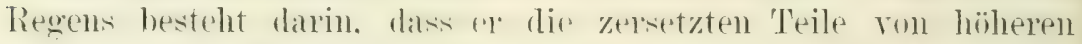
natch nioderen stellen trä̈gt. Wobed sir häufig in Folge von An-

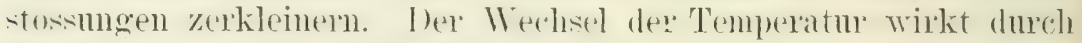

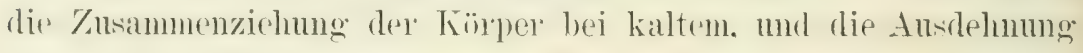
hei warmem Wetter zerstiarend. D) Luft selbst wirkt (chemisch anf das Gestein, dureh langsame oxydation derjenigen Mineralien, welche Sanerstoff aufzunehmen rermögen. Ein sehr krätiger Zerstïrer ist der Frost. demn wem das in die Felsemrisere cindringende Wasser friert. dehnt es sich mit ansserordentlicher Gewalt. und ruft sprengungen hervor: durch welche grössere Flächen den Einflïssen des Regens, der Luft und der Thmperaturwerhsel zugängig gemacht werden.

Nach Darwin verwittern die Felsen auch in Gegenden, wo es selten regnet und niemals Frost anftritt. I iese Thatsache slaubt der belgische fieologe de Koninck durch die im Than anfoelöste Kohlensäure und Salpetersäure erklären zu können.

Die Wittermg wirl in ihrer bodenbildenden 'Thätigkeit nicht selten unterstiitzt durch Wurzeh. Welche in Felsenrisse eindringen mul sie watchsend anseinanderdrängen, wie durch P’flanzensämen, die sich in Humus bilden und sehliesslich durch tierische Erdhewolner. Wie ms Darwin durch seine jahrelangen. interessinten Intersuchungen gezeigt hat. lejsten die Regenwiumer erstamliche I benste bei der Bodenbildung. indem sie Erde fressien und in ant-

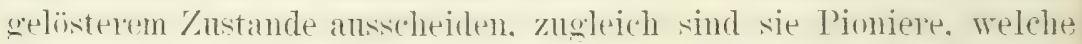
dem Regen und der Inft mansqeretzt neute Bahnen ïthen. Also nicht tin Feind, wie triiher geglanht worde. sondern ein Fremnd dre Landmamms ist del Rexenwurm. Ähnliche wiohtige I'ionierdienste leisten unter den Tropen die T'ermiten.

Die Felsen. welche am leichtesten verwittern. sind nicht immer mit der dicksten Bbolensohicht bedeckt. I)as (iegenteil ist: hänfig der Fall. Reines kalkgestein remag beispielsweise kamm pine Bodendecke zu bilden. Weil die lolnlensiume des liegens fast.

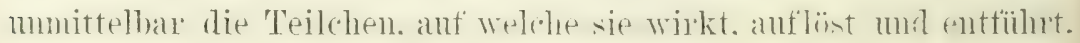




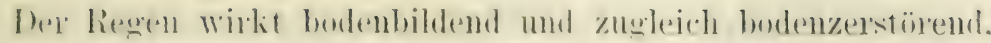

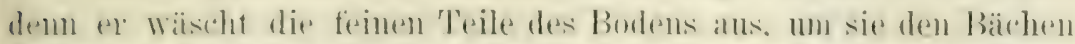

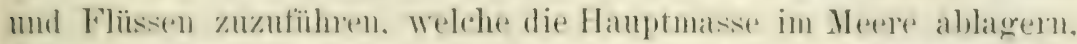

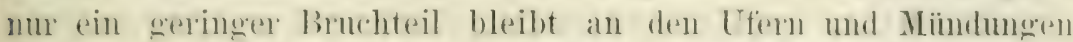

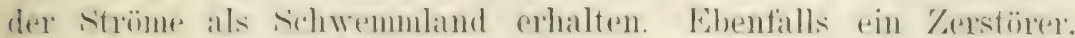

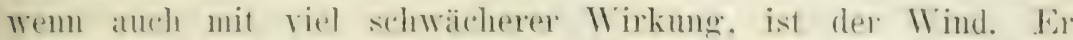

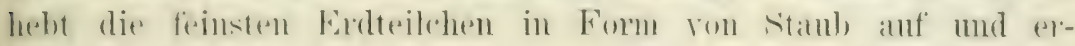

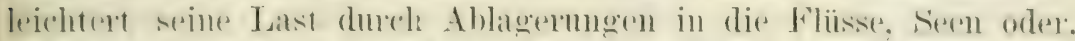

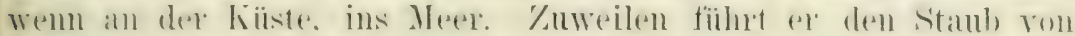

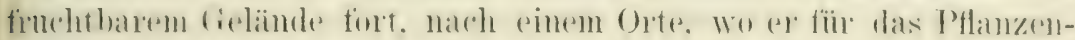
leben unverwertbar ist.

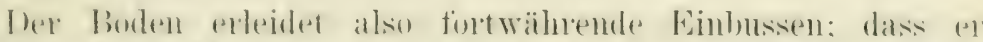

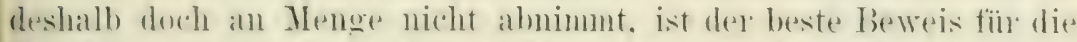

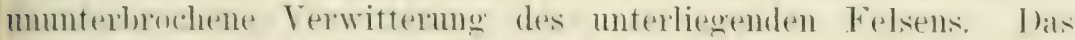

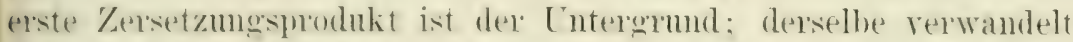
sich durch Zerbrörkelung und chemische Auflisung seiner listandteile in kirume. Anf diese Weise wird stets für den Abgang Frsatz geschatiten. Inuch Bebatumg des Bodens wird diese Umbildunggefördert. Was wohl keiner weiteren barlegumg bedarf.

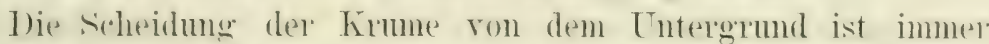

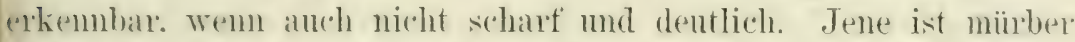
mol. infolge der Beimischumg von Humus, dunkler gefärbt wie des zähere. dichtere. crobkïrnigere T'nterermond, dessen Farbe gewöhnlieh geelh. rot oder bläulich ist, je natch dem Auftesten der färbende'ln Eiselnsalze. Anf bebautem Buden wind, wie oben erwähnt.

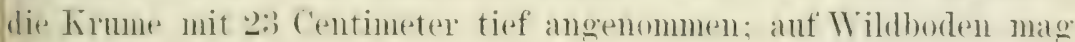

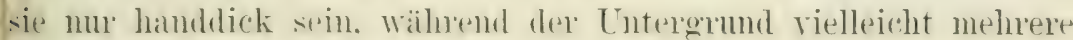
Ieter tief ist.

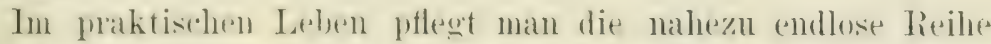
von Bodenarten in diese อ̆ Gruppen zu sondern:

1. die sandigen bïden. deren Hauptbestandteil ans Kies oder sima besteht. mol die num eine geringe Fenchtigkeit bewahremde Kraft hesitzente es sei denn. dass ein bündiger Intergrund vorhanden ist;

2. die Kalkböden. welche viel Kalk hesitzen. hervorgegangen aus der Verwittermg ron Kalkgestein oder aus dem juingeren Mergel. dessen Kalkgehalt organischer Abkunft ist. Dlesen Bïdell wohnt in hohem Grade die Eigenschaft bei. Fenchtiokeit antzumehmen und zurïckzuhalten: sellset wem sio durehSemler, Waldwirtschaft. 
tränkt sind. ist del Inft das Eindringen gestattet und wemm mit dem I'flug gewendet. zerfallen sie zu Pulver, namentlich wemn der Frost thätig war. Nit Säme in Berïhrung gebracht, bransen sie anf, was ein bequemes aber nicht in allen Fällen zuverlässiges Untersuchungsmittel ist;

3. die Thonböden, in welchen kieselsanres Aluminium in Form von Thon der vorwiegende Bestandteil bildet. Diese Böden haben eine starke wasseraufuehmende und bewahrende Kiraft, sind aber bei trockener Witterung leicht geneigt zu bersten. Herrscht der 'Thon bei Abwesenheit ron Sand sehr vor, so wird der Boden undurchlässig für Fenchtigkeit und bietet den wachsenden Wurzeln grossen Widerstand;

4. die Alkaliböden. in welchen die alkalischen Salze in solchen Mengen auftreten. dass nur sogenamite Salzgräser ihr Fortkommen finden oder eine vollständige Unfruchtbarkeit die Folge ist. Sind die Alkalien kohlensaure Verbindungen, also kohlensaures Kali oder kohlensamres Tatron (Soda) und nicht in sehr starkem Anteil rorhanden, so kömen sie durch eine 7ufuhr von Crips unschädlich gemacht werden. Es bilden sich schwefelsanre Verbindungen, wobei die atzende Kohlensäure frei wird und sich verfluchtigt. Andernfalls muss zu einer Anslangung des Bodens mit siissem Wasser geschritten werden, natiinlich nem die Lmstände dieses Verfahren gestatten;

๖. die Moorbüden. Welche vorzugsweise aus rerwesten PHanzenstoffen bestehen. Wenig Mineralien enthalten und so stark mit Fenchtigkeit durchtränkt sind, dass sie ohne vorherige Entwiassermo nicht anbaubar sind. Ihr starker Gehalt an Hummsämre ist dem Pflanzenleben feindlich und muss deshalb durch Kalkzufuhren zerstört werden.

Ans dieser Gruppierung treten als wichtigste Bodenarten hervor: der sand, der lehmige Sand, der sandige Lehm, der thonige Lehm, der kalkhaltige Lehm, der bündige Thon, der Mergel und der Moder.

Die hervorragendste Stelle gebührt dem Lehm, der aus einer Mischmeg rom Sand, Thon und Humus besteht. Er wird sandig oder leicht genamnt, wemn der Sand ïberwiegt und thonig oder steif, wenn der 'Thon vorherrscht. Trägt er eine entschieden dunkle Färbung, so heisst er humoser Lehm, besitzt er einen Kalkgehalt. der ihn weisslich und miube macht, so wird er als 


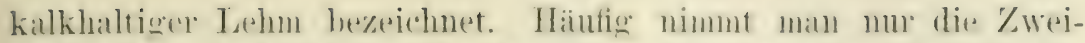

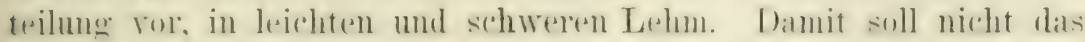

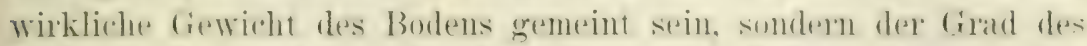

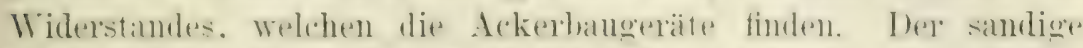

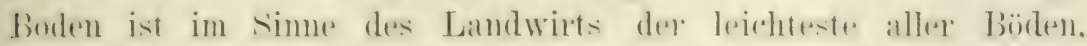

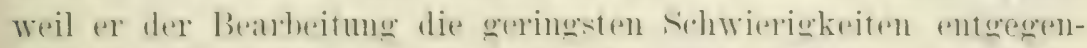

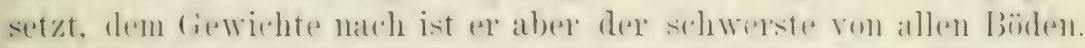

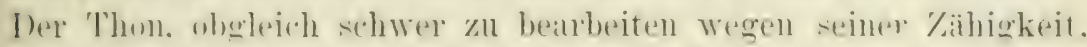

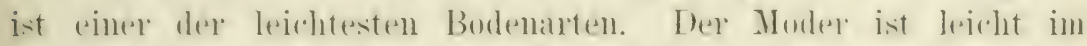

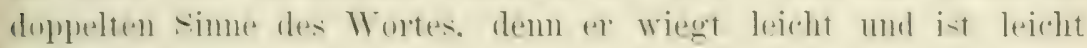
zu bearbeiten.

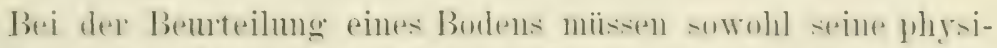

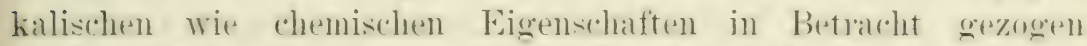
werden. Unter den ersteren sind inbegriften: die 'Textm: Tremper-

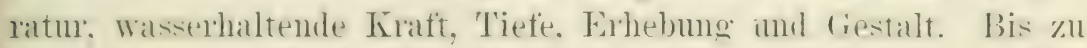
rinem gewisen Grate können wir diese ligenschaften muwandeln

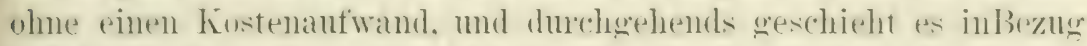

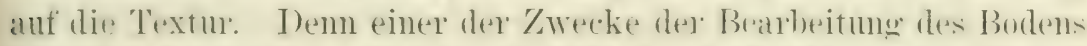

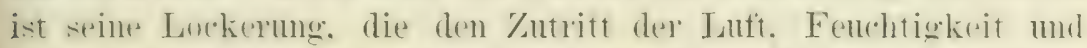
Täme erledehtern soll. Die chemische Beschaffenheit des Bodens hat vinen sehr geringen Finflus anf die heimmeg. vinen mu su

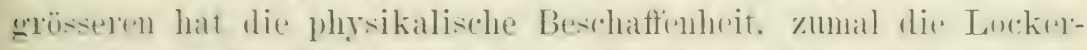

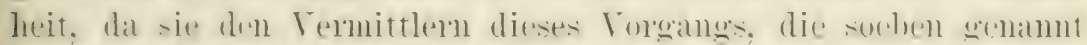

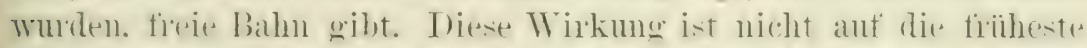
Entwickelung der Pflanze+n beschänkt, smolem drehnt sich ïher

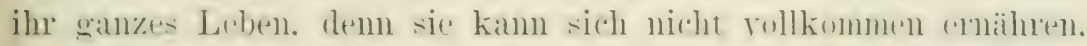
wem nicht Luft und Fenchtigkeit fieien Zugang in droll Buden haben und rie Haarwurzeln sich megehindert nach allon lichotmegen ausbreiten kimmen. Die Lockerung ist. nach der Terschiedenheit des Bulens, mehr orler minder notwendig. Zäher. hindieger Boden verlangt selhstverstiandlich eine sorgfältigere mo eriundlicheres

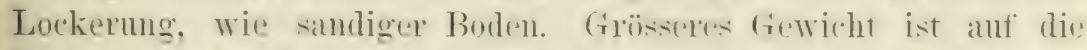
Lockerung des Bodens in einem kalten wie in eine-un warmen

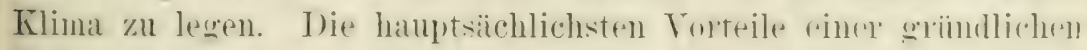
Bodenlockerung sind so zusammenzufassen:

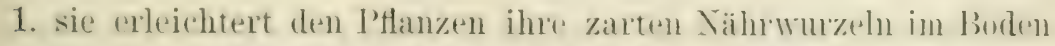
zu verbreiten und macht es ihnen dadureh mïglich. im gamzen Wurzelbereich Nahrung aufzunehmen; 
2. der I unt: wird freiex Zutritt in den Boden gegeben; dadurch wird die Terwittermo und die Verwesmg der pflanzlichen Stofte beschleunigt:

3. das in der hrume ïhershbiussige Wasser dringt raseh in den Untergrund;

4. die Harrohrkiaft des Buhtens wird bedentend gehoben, indem sich viele feme Hamröhen bilden, welche die Fenchtigkeit ans dem Cutergrund nach der Kirune leiten, sie den PflanzenTwüh zur Terfügung stellen und ferner die Wasserdämpfe der eindringenden Luft rerdichten. Inuch letztere Wirkme wird eine ginstige Regelung des Wämeverhältnisses in der Krume herbeigeführt. Bei der in den Haaröhren des Bodens stattfindenden Terdichtmong der Wasserdämpfe wird nämlich eine rhebliche Mrenge Wärme fier. die in den Wasserdunstbläschen eingeschlossen war; der Reichtum an Haaroüren ist also der Bodenwïrme förderlich. Nebenbei deckt das DampfWasser einen beträchtlichen Teil des Bedarfs der Pflanzen an Feuchtigkeit. Bei anhaltender Trockenheit wiurden alle scichtwmzelnden Pflanzen absterben. wenn sie lediglich auf die Niederschläge angewiesen wären.

Eine ïbertriebene Lockermo matht den Boden ..tot". er verliert seinen ,.schlus:" damit will nan sagen. seine Hamrohrkraft sei zerstört, die Fenchtigkeit der tieferen Schichten kann nicht meh' nach höheren gehoben werden. 'Tutgelockerter Boden muss einige Zeit liegen. um sich so sacken zu kömnen. dass sich seint Haarü̈nen wieder zur Leistumgstähigkeit zusammenschliessen.

Nicht allein durch unsere Ackerbangeräte kïnnen wir den Boden lockerm, sundern auch durch Mischmng mit leichteren Bodenarten. So wind steifer Thon durch aine Termengung mit Sand rerbessert. Humns wint elentalls lockermd. Am hänfigsten wird 'I'honboden durch zugefïhrten Kalk gelockert. Was aher auf chemischen, nicht mochanischem ITege gaschicht. Andererseits Kann zu lockerer Boden durch eine Vermischmo mit bindigem Boden schliessender und damit forderlicher für's PHanzenleben gemacht werden.

Wenn zwei Böden in nichts anderem wie in der Textur verschieden wären. wïrde der den Torzug verdienen, welcher am feinkörnigsten ist, weil seine wasserafuehmende und bewahrende 


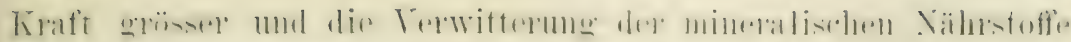
weiter fortgeschritten ist.

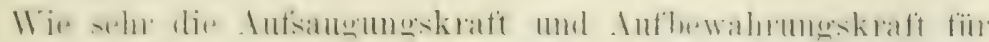

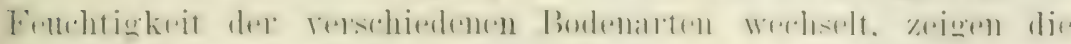

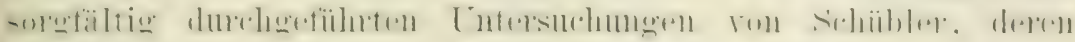
Resultate in der folgenden 'Tabelle niedergelegt sind.

Die Waszeraufsaugung betrug Die Verdunstung in 4 Stunden in Prozenten

Ruarzsand

Kalksteinsand

25

29

40

51

วิ2

61

85

89

181 betrug in Prozenten

88,4

75,9

52,0

45,7

32,0

34,6

28,0

24,3

$2.5, \overline{5}$

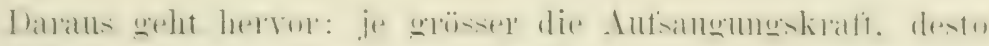
grösser ist auch die Aufbewahrungskraft.

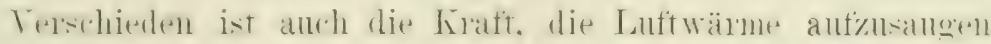

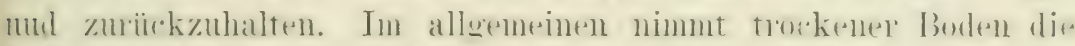

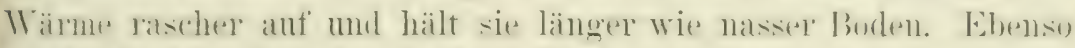

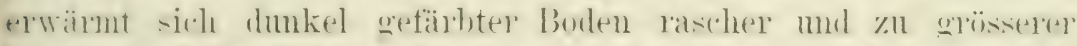

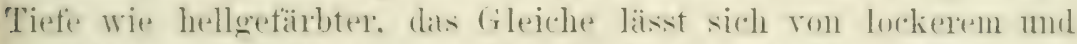

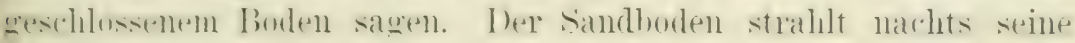

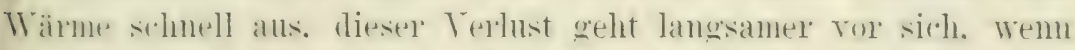

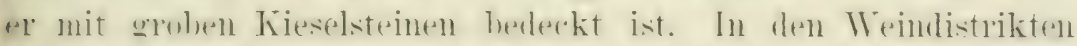

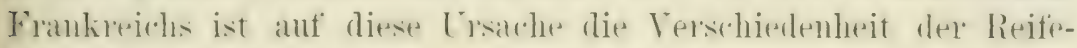
zeit zuruickgeführt worden.

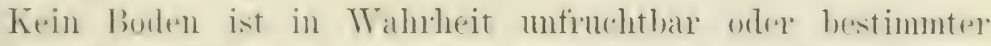

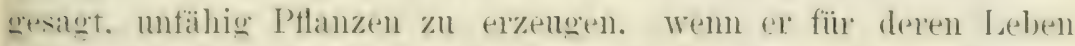
nicht schädliche stofte enthailt. wio schwefelsaures Fisent. Humnssilme und Alkalien über ein gewisses Mass hinaus r. s. w. In simne des Landwirts aber ist derjenige Boden unfruchtbar. anf welchem dir Nutgewärhse aus irgend einem firunde nicht gedeihen. Er kamm im lnaktisidhen Leben fïr wertlos gelten. wenn er nicht mit einem hostentantwand anhanwïrdig gemacht werden kamn. der die Rentabilitäs nicht ansochliesst. Indessen sollte ror jeder kostopieligen Bodenbeserung sorgfaltig erwogen werden. ob anf dem Borlen. wie w. gegeben ist. irgend rine PHanze mit Nutzen gezüchtet werden 
kimm. sed es an hescheidenes Futtereras oder ein stattlicher Waldbatum. Die Fruththatreit des Bodens hängt von dem Vorhandenstin allere erforderlichen Xährstofte ab) der noch so reiche Gehalt an den meisten kamm das Fehlen eines derselben nicht anfwiegen.

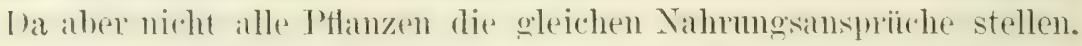

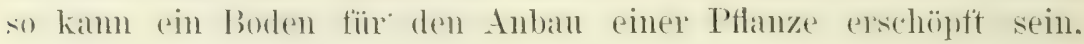
einer andere $n$ aber moch anf Jahre hinaus hinreichende Mittel zur Lebensthätigkeit lidenen. Fs ist dabei zn beachten. dass in Inuchschmitt dex Boden mur 1" " mineralische Nährstofte in sofort von den Pflanzen aufnehmbarem Zustamb enthält. fïr viel grössete Irengen ist die zersetzung bis zu diesem Punkte noch nicht fortgeschritten, da sie aber andanrad ror sich geht, so erhellt, dass es mur einer läneren Ruhe oder gar nur eines Anbauwechsels bedarf, un einen für tine gewisse Pflanze erschöptten Boden wieder zengungstähig zll machen.

Un den Boden mechanisch zu analysieren. das heisst. ihn in seine Bestandteile: Sand, Thon. Humus u. s. w.. zu zerlegen. sind mehrere Instrumente elfunden worden, und es gall ane Zeit, wo die Behanptmo viele Anhänger hatte, die mechanische Analyse sei wichtiger wie die chemische. Man hat sich aber inzwischen iiberzengt. dass die mechanische Analyse keine zurerläsigen Resultate gibt, weichen doch dieselben für denselben Boden mit demselben Instrumente ab. da eine genaue Scheidung ummöglich ist. Dagegen sind leicht ansführbare schlemmungen emptehlenswert, sie gewähren für das praktische Leben einen guten Anhaltsjunkt zur Beurteilung der mechanischen Zusammensetzung eines Bodens.

Nötig sind: einige Spitzgläser, ein Reibschälchen mit Pistille, ein Stiick Lackmuspapier, eine kleine Wage, ein Fläschchen Ammoniak, ein Fläschchen Oxalsäure mit Wasser rersetzt, ein Fläschchen phosphorsaures Natron mo Filtrierpapier - alles Dinge, die man sich in jeder Apotheke verschaffen kamn. die Wage vielleicht ausgenommen.

Will man Erde anf die beiden wichtigen Bestandteile Sand und Thon prïfen, so nimmt man eine 50 Gramm schwere Probe, reibt sie stark angefenchtet mit der Pistille im Schälchen. bis sie zu einem gleichmässigen Brei geworden ist. Taucht man in denselben ein Stiick Lackmuspapier und es rötet sich, so liegt der Beweis vor. dass Humussäure in dem Boden enthalten ist und daher 


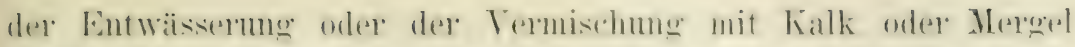

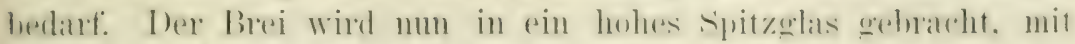

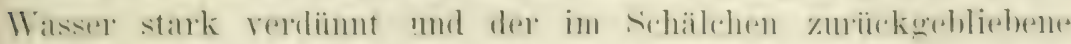

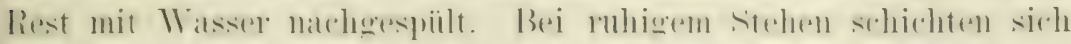

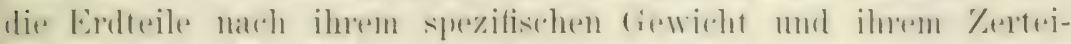

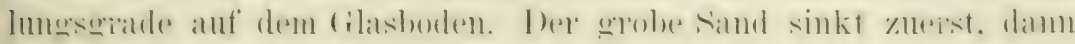

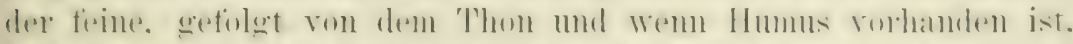

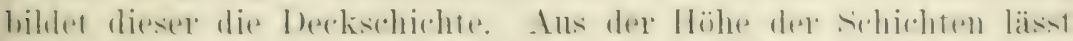

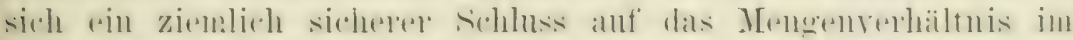

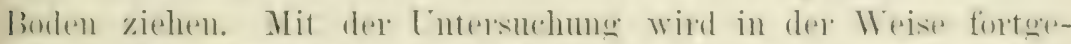

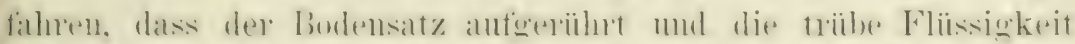

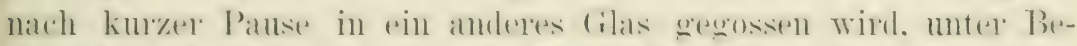

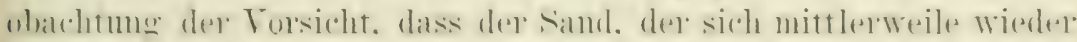

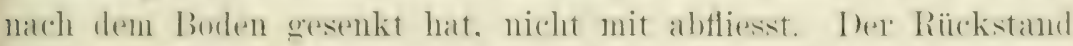

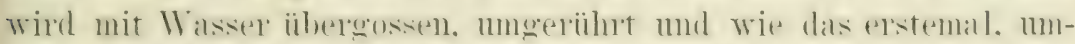

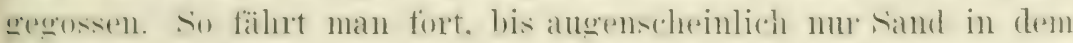

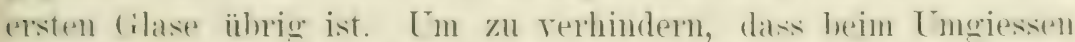

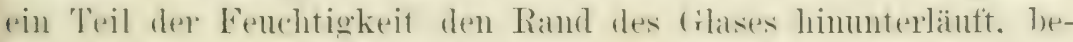
streidht man denselhen an der Answenseite mit Talge oder man hält pin stiblhen an die Ramblelle. wo die Flössigkeit abtliesst. Der simel wird mum anf Filtrierpapier getrocknet. damm gewogens: Was an 50 (iramm fehlt. Wird als feinerdige Masse (Thom. Hunns) in Rechumg gebracht.

Die Prüfung anf den Kalk und Magnesiagehalt kamm in der tolgemelen Weise geschehen. Man wiont on Gramm trockene Erde

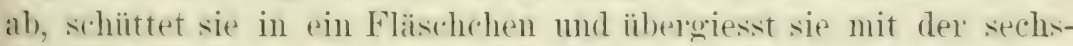
fachen Massmenge Wasser: damn fü̈gt man nach und nach 5 bis 10 Gramm salzsime hinzu und stellt das Fläschehen einige Stunden an einen warmen Grt. Wem beim /usat\% der salzialure ein merkliches Bransen eintritt. ist bewiesen. dass der Boden reich an Kalk ist. Follständig zur Ruhe gekommen. wird der Inhalt des Fläsch"hems anf Filtrierpapier gegossen mo der Rückstand mit warmem Wasser nachgespiilt. Die durchlaufene geelbe Fliissigkeit, welche: natiirlich in einem Glas aufgefangen werden muss. wird so lange mit Ammoniak ressetzt, his sie deutlich darnach riecht. Scheiden sich brame Flocken ab. so mïssen diese als Eisenoxydhydrat mo Thonerdehydrat, nebst Phosphorsäme, betrachtet werden. I)ie Flüssigkeit wird abermals filtriert und dann, in ilnem wasserhellen Zustand. so lange mit einer Lösumg von Oxalsäme in Wasser ver- 


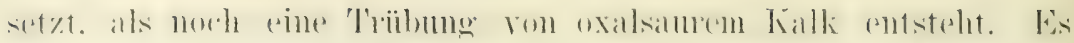

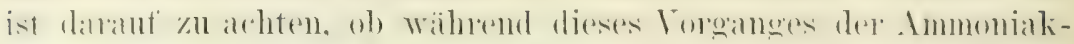

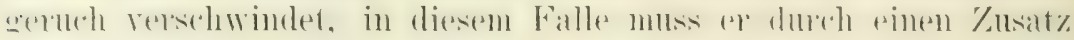

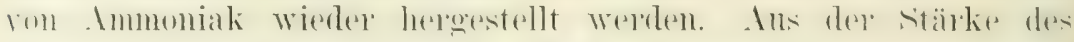

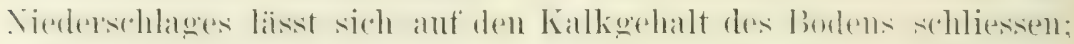

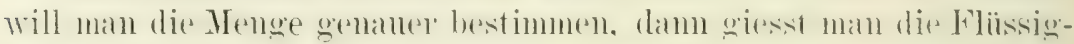

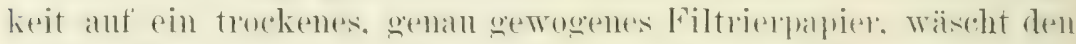

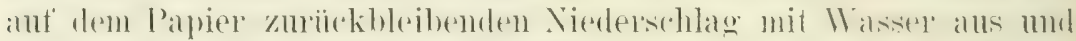

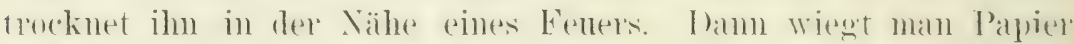
mol Niederschlag mol das Mehroewicht des Palpiers ist als oxalsanter Kalk anzunehmen. Derselbe lässt sich dureh bohitzmong in kohlensampen Kalk reptrandeln. allein dieses Tertalnen ist mun̈tig. weil man weiss. dass 100 Teile oxalsamen Kalk $68^{1}$; Teilen kohlensamem Kalks entsprechem. Die Magnesia wmole nicht mit Eefällt. Exmitteln kam man den Gehalt alls der von dem oxal-

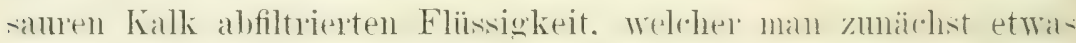
Ammoniak zusetzt. Dann löst man etwat phosphomalles Natrom in der Flïssigkeit ant mol ribrt sie mit einem filastäbehen 1 m. Sach einer kleinen Panse wird sich bei hedentemdem Mangesiagehalt ein krystallinischer Niedlersohlag bihlen. der aus phusphorsimer Ammoniak-Magnesia besteht. Ein mbentententer Niederschlag. und erst nach längerem stehen. erzengt sich, wenn der Gehalt gering ist.

sioll der Boden anf seine wasserhaltende Kratt oreprifft merden. wiegt man 100 tramm trockene Frde ab. zerreiht sie im schälchen mol sohüttet sie in ein Glas, dessen Gewicht man. samt spinem Inhalt ermittelt. Damn giesst man soriel Wasere ins (ilas. dass dir Erde rollstandig bedeckt ist und roranssichtlich nicht alles Wassel rerschlucken kamn. Nach 24 Stunden giesst man das ibberstehende Masser vorsichtig al, und wiegt das Glas abermals. Die Zunahme des Gewichts cribt die Massermenge in Prozenten an. welche die Erde anthehmen kann. Diese Fähigkeit steigt hei Thom auf $80^{\circ}$... bei Humus anf $100 \%$ und noch höher. bei sand und Fies bleibt sie auf 20 bis 2.50 , o stehen. Diese Zahlen lassen anch ammähemd zurerlässige Schlïsse auf die mechanische Zusammensetzung de Bodens ziehen. Eine einfachere, obertächlichere Prïfung anf die wasserhaltende Kraft des Bodens, die aber nur ansführbar ist bei fregenwart von Thon, besteht darin. dass man ein stiuckchen ganz trockener Erde an die Lippen bringt. Ist der Thongehalt bedeu- 


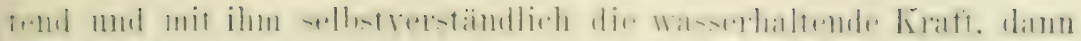

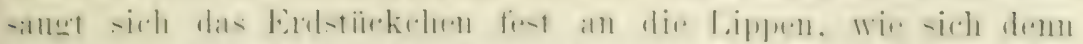

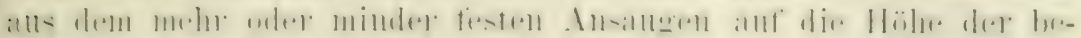

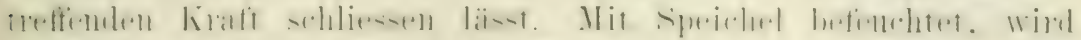

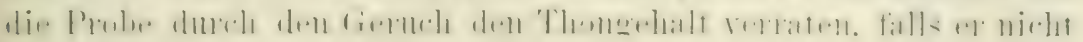
zu unbedentend ist.

Die chomische Lntersuchung des Bodens ist bache eines el-

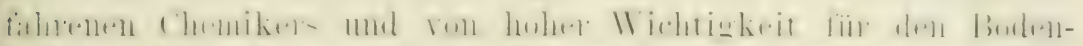

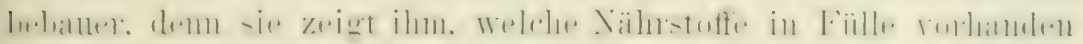

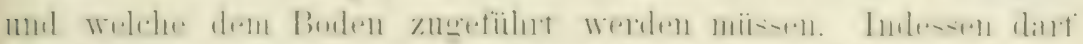

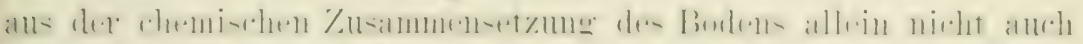

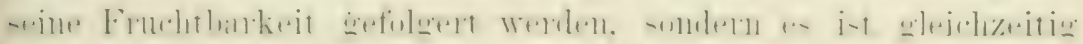

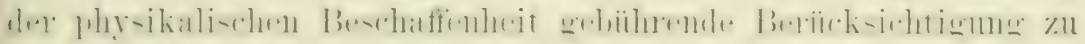

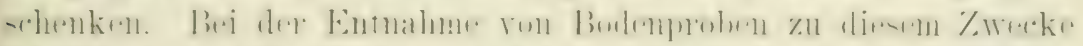

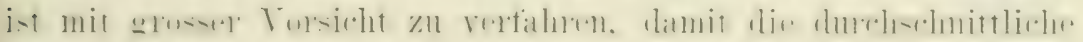

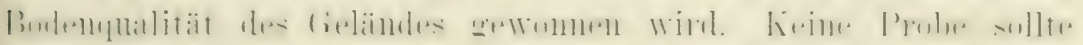

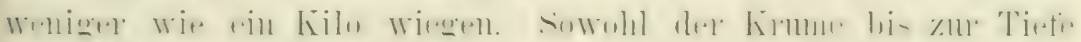

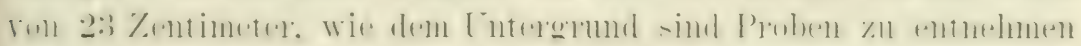

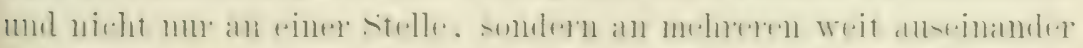

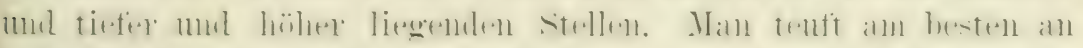

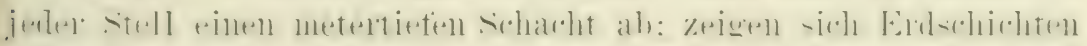

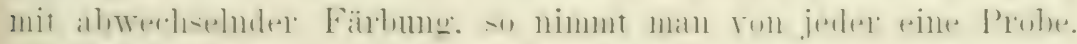

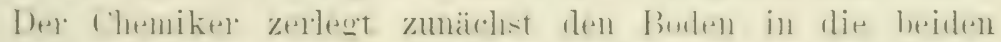

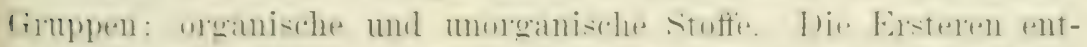

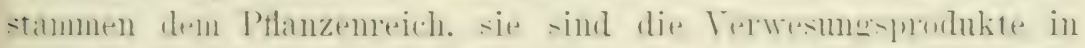

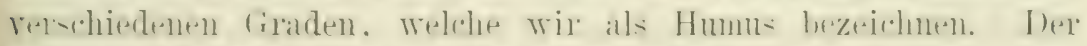

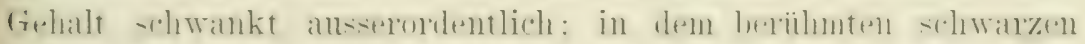

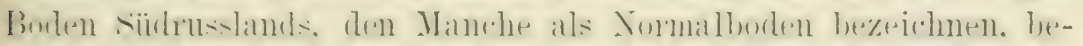

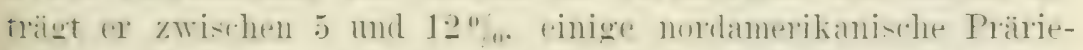

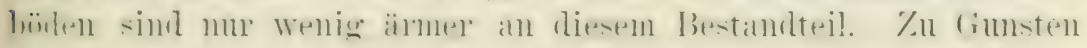

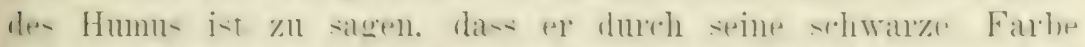

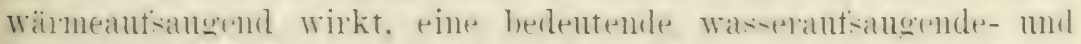

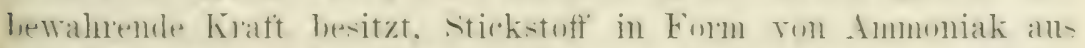

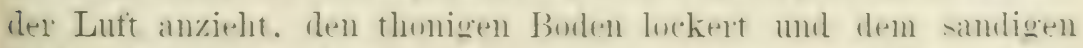

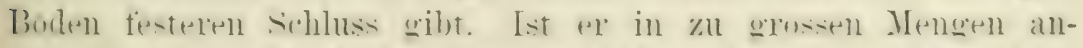

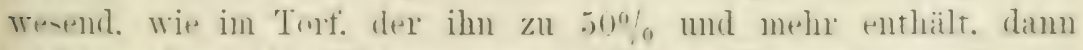

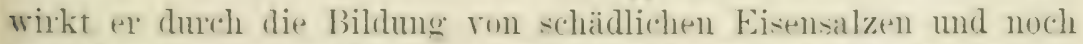

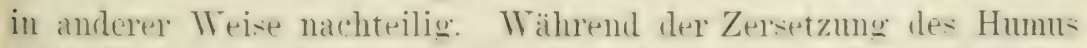

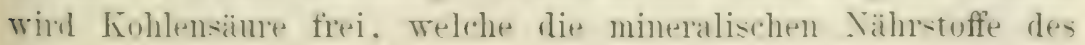


Bodens anfichliessen hilft, es wird aber anch Stickstoff in Verbindumg ron Wasterstoff als Ammoniak frei; durch Ausscheidung des

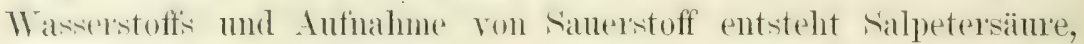
die pinzige Form. in weldhe die Pflanzen den stickstoft als Naltl'mug anfinehmen kömnen. Inteh die atmosphärischen Niederschläge wird dem Boden Stickstoft ans der Luft zugefïhrt; die Frage, ob die Pflanzen anch in stande reien, durch ihne Blätter Stickstoff aus der Luft antzunehmen. in welchem Maasse und ob sie es alle kömmen - harrt noch der endgiiltigen Beantwortung.

Da der Humbs mehr wit sein Eigengewicht an Wassel aufnehmen kitnn und heträdhtliche Nengen Ammoniak ans der Luft autsangt. so muss einlenchten, wie wichtig es ist. dem leichten mo trockenen Boden reichlich Humus zuznfïhren, sei es in Form ron Kompost oder durch Düngumg mit (trünzeng. Dagegen ist dem Thonboden nur dam Humus einzuverleiben. wenn er natiulich oder künstlich gut entwässert ist, da sonst der. Wassergehalt in schädlicher Treise vermelı't wïıde. Bei geniigender Entwässermg dieser Bodenart ist die Humuszufuhr. sowohl wegen stïkeser Erwärmung wie besserer Lockerming, empfehlenswert.

Der C'hemiker wendet sich dam zur. Ermittelung der unorganischen oder mineralischen Bestandteile des Bodens, die er wie folgt zergliedert: Kieselsäure, Aluminimm, Calcium. Eisenoxyd, Phosphorsäure. Kali. Natron. Magnesia, Chlor, Schwefelsämre. Diese Stofte treten in sehr mgleichen Anteilen anf. I)ie meisten Böden werden zu 90\% aus Kieselsäure (Sand). Aluminimm (Thon) und Kalk gebildet, die wichtigsten Nährstoffe: Kali. Phosphorsänre und Schwefelsäure sind in verhältnismässig sehr schwachen Mengen vorhanden, ebenso wie die minder wichtigen: (hlor, Natron und Magnesia.

Kieselsäure (die Terbindung von Silicium und Sanerstoff) ist in schwankenden Anteilmengen in den verschiedenen Böden vorhanden. grösstenteils in unaufgeschlossenem, das will sagen, für die Pflanzen nicht aufnehmbarem Zustand. Tornehmlich ist dies in den ärmsten Sandböden der Fall. Fruchtbarer Boden enthält gewöhnlich einen kleinen Prozentsatz in aufgeschlossenem Zustand. Sandiger Boden enthält 70 bis $90 \%$ Kieselsäme. Thonböden von 40 bis $70 \%$ und Kalkböden von 20 bis $30 \%$.

Als Nährstoff hat Kieselsäure nur Wert, wenn sie in der Form von löslichen Silikaten anftritt. In unlöslichem Zustand, wie Quarzsand, wixkt sie nu mechanisch, indem sie den Boden lockert 


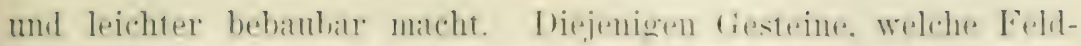
spat ruthalten. lieferm in ihrem Verwittermestrodukte wats

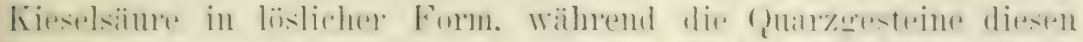

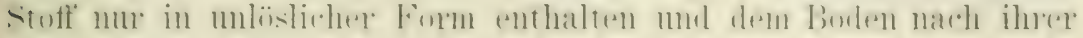
Zersetzung zufüihren.

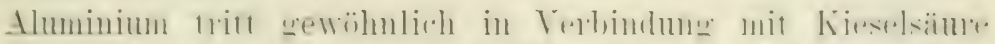

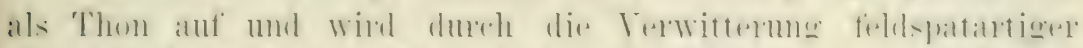

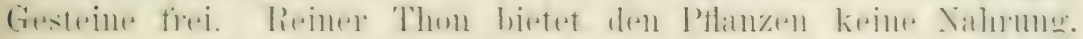

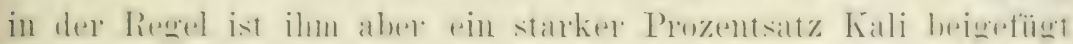

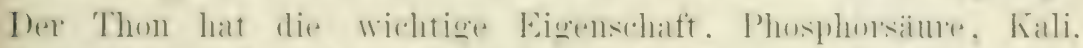

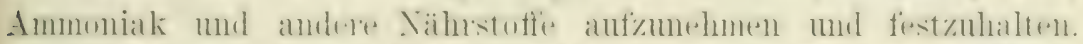

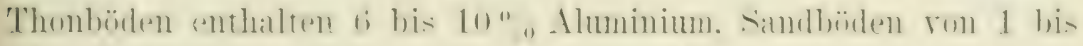
$4 \%$, Kalkböden und Humusböden 1 bis $6 \%$.

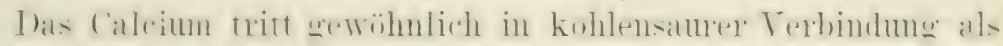

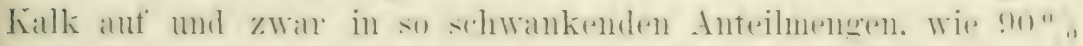

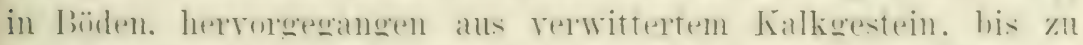

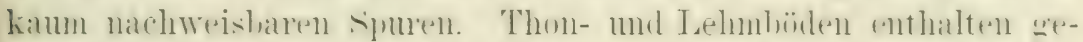

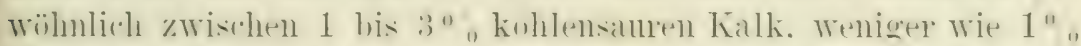

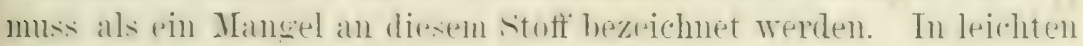

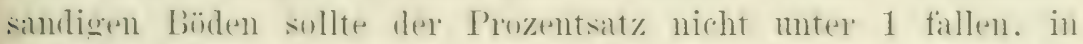

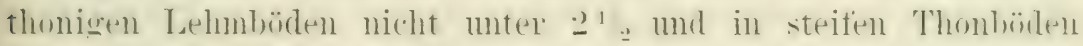
nicht unter 5. Ein an Kalk armer Buden tenthält das Wrnige in

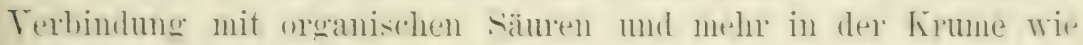
in Cntererund gelagert. Wer Kalk ist nieht allein eine l'flanzen-

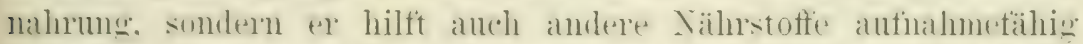
machen. Er wirkt zersetzend anf die Mineralien wie den Humus und fördert die Bildumg von salpetersüure. von der oben die Rede war. Aus diesem cirunde kommen die Pflanzen anf kalkarmem Boden zu keinem ferleihen. trotrden ror der Anssat krätig gedïngt wurde. Jie kalkreichen Bïden sind reich an Kalk umb Magnesia, dagegen. als Regel. arm an Phosphorsiume und Tali.

Fistenoxyd wird in allen Bäden gefunden und rerursacht ihre rölliche Färbung. wemn in starkem Prozentsatze anwesend. Ton dem Zustande seiner ()xỵlation hängt der schädliche oder grünstige Einfluss auf den Boden al). Das Terhälmis ron 2 Teilen Eisen und 3 Teilen Saluerstoff. eine Terbindung. welche in grewïhnlichen Leben als Eisenrost gekamnt ist. muss als das günstigste betrachtet werden. Ein geringeres Anteilverhälmis ron samerstoff gibt die Verbindung. welche Eisenoxydul heisst und dem Pflanzenleben schäd- 
lich isl. Eisenoxydul finded sich rolzhesweise im Untergrmule, wo

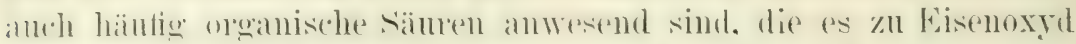

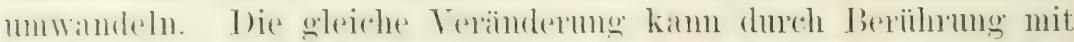

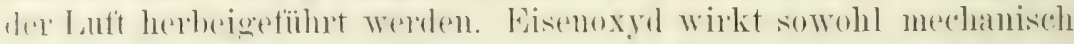

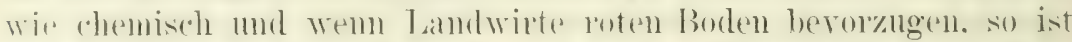

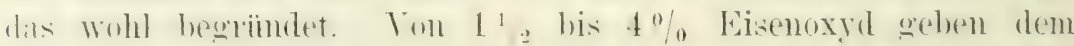

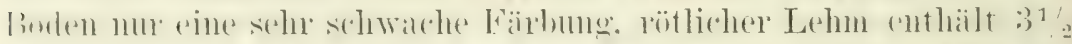

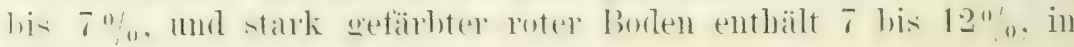
manchen Fällen sogar $20 \%$.

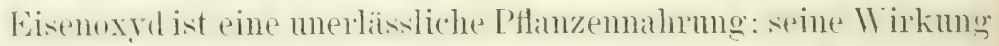
ant den borlen hängt rom seiner mechanischen Beschatfenheit ah.

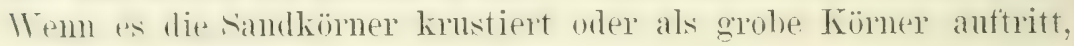
nato die chemische Analyse einen hohem Gehalt nachweisen. der Fintluss ant den Boden ist aber sehr gering. Wemn nicht gleich Sull: rorteilhat wirkt es dagegen in tein zerteiltem Zustande. Bïden mit einem hohen Gehalt an Eisenoxyd sind gewöhnlich arm an organischen Stoffen. trotzlem zeichnen sie sich durch Fruchtlarkeit ans. Die dmble Fürbmg. relche dais Eisenoxyd dem Boden gibt. ist der Wämmeanfsangung gümstig, seine lockernde Wirkung ist namentlich den Thonbörlen sehr wohlthätig. Seine fairbende Wirkung üht das Eisenoxyd auch aus. nachdem es ron den Pffanzen anfgenommen wude: ohne seine Termittelung wiirden Bliiten mol Friichte farblos sein.

Phosphorsäure ist in allen guten Böden enthalten. aber im Terhiätnis zn den anderen Xährstoffen in sehr geringen Mengen. mud mus wher an ehesten in Form ron Dinger ersetzt werden. Am hänfigsten tritt es in Terbindmg mit Kalk. als phosphorsamer Falk anf. viel seltener in Terbindung mit Eisen lond Aluminium. selbst in sehr fruchtbaren Böden wird es in einer kam höheren Anteilmenge wie $1 / 2 \%$ gefunden, $1 / 40$, wird schon als ein guter (rehalt betrachtet und nux in Thonböden steigt der Gehalt anf $1^{0}{ }^{\circ}$. Phosphorsiume kommt in allen Böden ror, welche aus der Terwitterung von Granit. (mneis, Kalkgestein. Dolomit und namentlich von jüngerem vulkanischen Gestein hervorgegangen sind. Schwemmböden sind dagegen in der Regel arm an diesem Stoffe. Tem er in finem geringeren Anteilverhältnis wie $0.05^{\circ}$ o rorhanden ist, bleibt der Boden unfuchtbar, es sei demn. dass er einen hohen Kalkgehalt besitzt. Freie Phosphorsäure nehmen die Pflanzen nicht auf; nach 


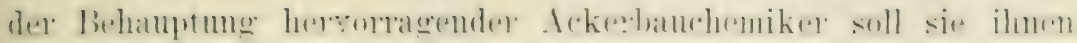
sogar Gift sein.

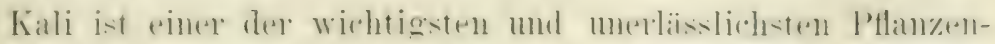

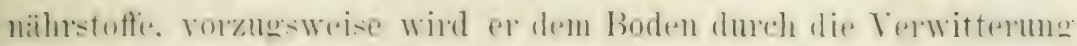

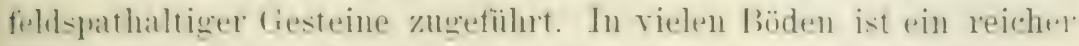
Vorrat ron hali antgespeichert. allein nur ein geringer Prozent-

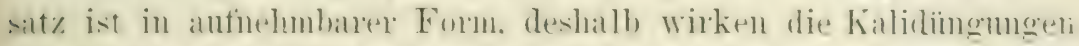

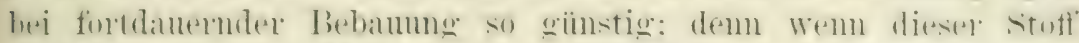

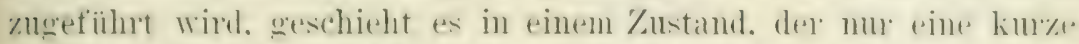

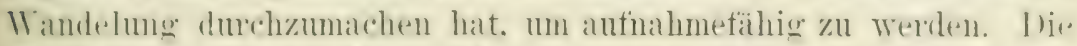
C'hemiker der alten schule behampten zwar. die meisten bïden budiurften keiner halidiungme. allein die Erfalnemgen des praktischen

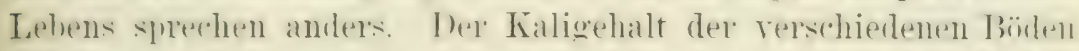

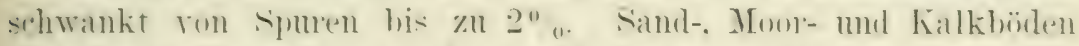
sind in dere Regel arm an diesem Stott. reich aber sind die 'Thmobirden. In Bocken tritt Kali in Terbindung nit Kieselsiume ant mo billet ein silikat. das schwarh lïslich in Wasser ist. Eim hoher haligehalt scheint in Bezug auf Fruchtharkeit einen niesligen Kalkgelalt auszogleichen. mogekehrt mag ein Boden, der reich an Kalk und Phosphorsäure ist. shre firchtbar sein. Wenn er alleh renig Kali enthält.

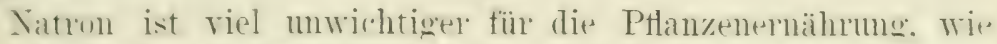

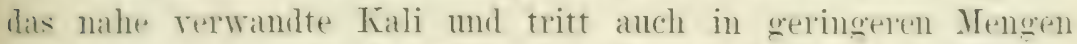
anf. anternommen in der Nähe des Meeres. Tritt es in hïherem Prozentsaty wie 0.1 in Terhindung nnit Follemsiume als Forla.

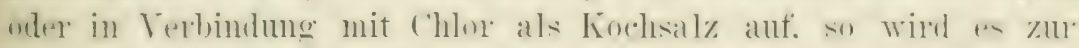
Ursache der Unfruchtbarkeit.

Matgesia wird in allen fruchthaten Bëden in sedn sohwankenden Anteilmengen gefunden. Es ist ein Begleiter des halks, dent

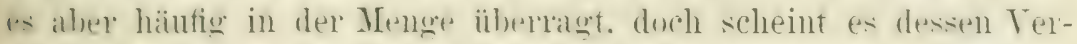

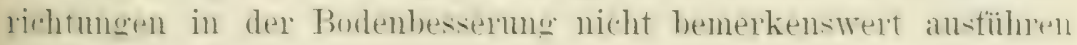
zil können.

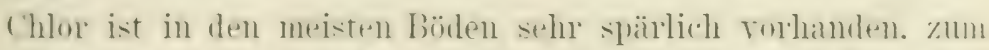
I'tlanzenleben scheint es nicht durchaus notwendig zu suin.

s.hwefelsiture ist in der liegel num zul 0.2 bis 10.5 ". im buklen vorhanden. seine (iecenwart ist aber fïr das Planzenleben unerläslich. Am stärksten tritt sie in den Gipsböilen anf. am

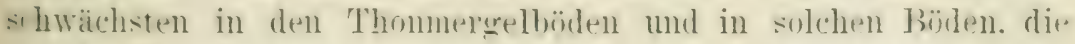
aus der Verwitterung ron huntem sandstein herrorgegangen sind 
Den Bedalf der Planzen an Schwefelsiume ist viel geringer wie

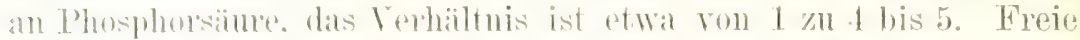

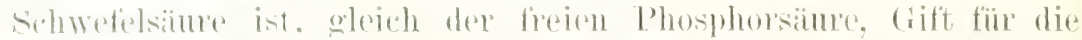
ptlanzen. Gewöhnlich tritt die sichwefelsiume in Verbindumg mit den Alkalien ant.

Ans diesen Angaben gent hervor, dass die Pflanzemnïhrstoffe mur anen geringen Inteil des bodems. selbst des sehr fruchtbaren. biden. allein das dewicht der (Bherflache oines Hektar Landes ist

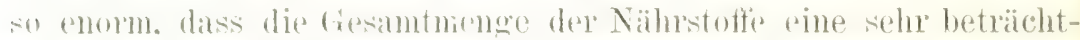
liche ist. selbst bei niedrigem l'rozentsat\%. Selbstverstandlich wechselt das fiewidht der verschiedenen bodenaten, je nachdem sie locker. sandig und humos sind. Nach Protessor Schübler wiegt dere Boden eines Hektar Landes. 23 '/entimeter tief gedacht:

$3992000 \mathrm{Kg}$. in trockenem \%astand. $5295000 \mathrm{Kg}$. in fenchtem Zustand. wemn ans sandigem Thon bestehend (45\%, Sand. $55 \%$ Thom);

: $450000 \mathrm{~K}$. in trockenem Zustand. $4862000 \mathrm{~K}$. in feuchtem Zustand. wenn ans gewöhnlichem Ackerboden bestehend.

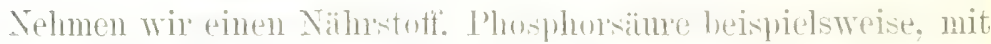
$0.1 \%$, vorhanden an. su wirrde die (isamtmenge in einem Hektar Land 3 t50 bis 3992 Kilogramm betragen. Den Pflanzen, welche

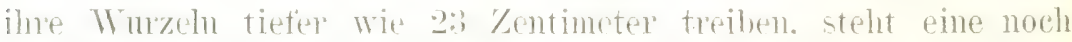
hedentemdere Trenge Phosphorsure zur Tertügug.

Lehmeich wie cine budenanalyo ist. sind ilne liesultate doch nur. verwerthat innerhall, gewisere Grenzen, ïber welche sich Dr. Tälcker folgendermasipn ansspricht. Ihe Resultate des Bodenamalyse geben häutig befricdigende Antworten anf folgende Fragen:

1. Ob die Unfuchtbakeit reranlast wird durch die Gegentrart

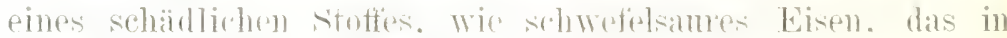
torfigen mnd thonigen böden rorkommet

2. ob Alkalien rorhanden sind, die in cteringen Nengen den

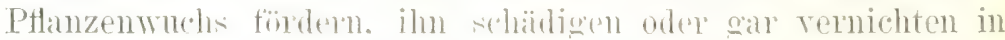
bedentenden Ilengur

3. ob Unfruchtbatkeit veranlasit wird dureh Mangel an Kalk, Phosphorsäme oder andere wichtige Nähstofte:

4. ob Thonböden wirklich unfiuchthar sind und durch Bearbeitumg nicht rerbesiert werden kömnen. oder ob sie die er-

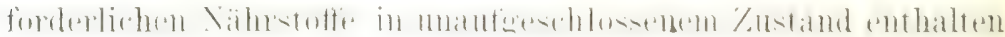


oder ob site durch 'Tiefkultur und ähnliehe mechanische Mittel fruchtbar gemacht werden können;

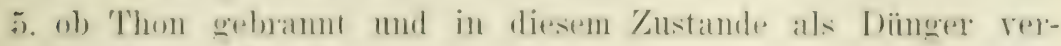
wendet werden kam:

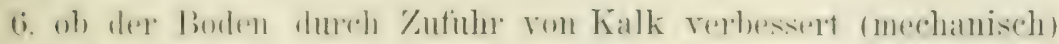
werden kam:

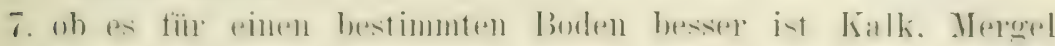
oder 'Thon zuzuführen;

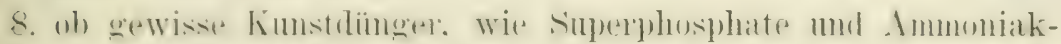

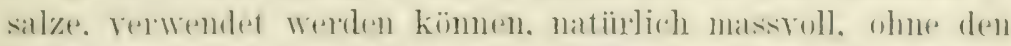

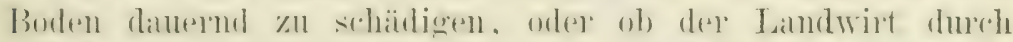

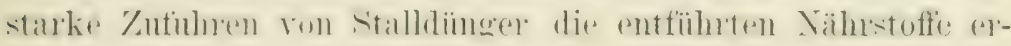
setzen soll;

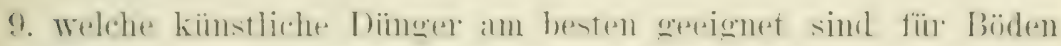
verschiedener Zusammensetzung:

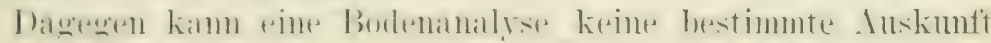
geben :

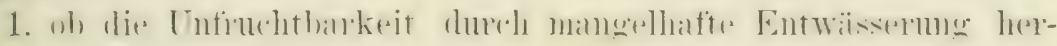
beigefiilnt ist;

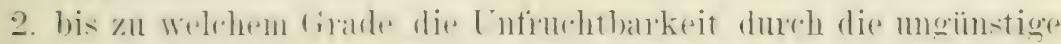

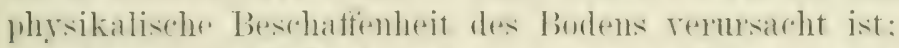

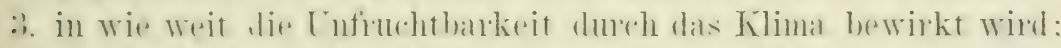

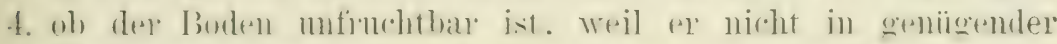
Menge vorhanden ist;

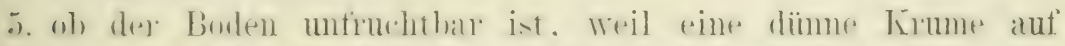

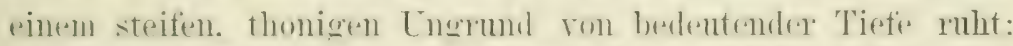

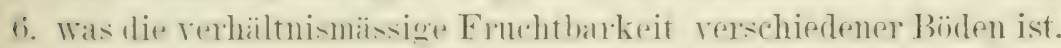

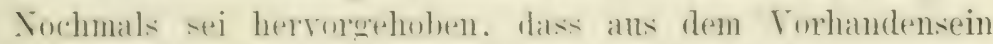

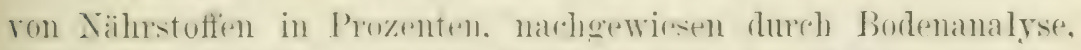

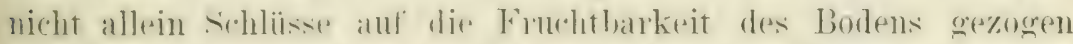

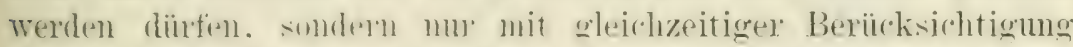
der phrsikalisehen Beschaftemheit. Jn einem lorkeren Boden kam pine I'flamze ihre Wumeln viel Weitre ansbeiten. wie in pinem

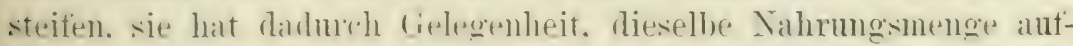

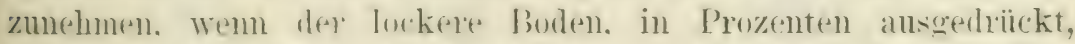
arner an Xahrstoffen ist. Wie der steife. Auch ist die Wurzelkraft der verschiedenen Pflanzen in Betratht zu ziehen. Manche Pflanzen treiben zufolge ihrer Natu kurze Wruzeln. sis kimmen auf einem Boden rerderben, auf welchem andere Pflanzen mit weitstreichenden 


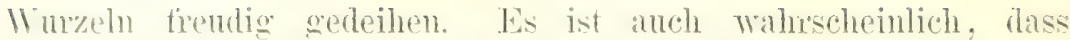
manche l'thuzen die Katt besitzen. Nihlostofte in nahezu anfuehm-

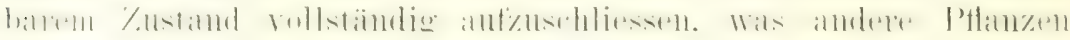
nicht vermögen. Die I'flanzenphysiologie muss ms über diese interesante Frage noch Autklärung verschaften.

Kiehen wil als diesen allgemeinen I)aregmoen schliisse tïr dic Maldbämme. so eroiebt sich. dass ihr tiedeihen abhängig sein mlltss:

1. ron del chemischen '/astmmensetamg des bodens:

2. Von seinen physikalischen Higenschaften:

3. von der Natur des Untergrunds in hölerem Grade wie fïm seichtwmelnde Ptlanzen.

Selbstrerstänllich ist das Gedeihen anch abhängig von den klimatischen Verhältnissen. die aber hier nicht in Rede stehen.

IVenn ein Baun verbramnt wird. bleiben seine mineralischen Bestandteile in Form ron Asche zurick; einen so geringen Prozentsatz rom Gesant sie anch bilden, ïben sie doch einen entscheidenden Einfluss anf das Wachstum ans. und zrral in dem Masse, dass fïl bestimmte Gebirgsformationen aemisse Pflanzen charakteristisch sind. so merden kalireiche böden ron der Ulme bevorzugt, Kalkböden sind dem IVachstum des Ahorns giunstig. nicht aber der. Fichte. welche auf kieselsämereichen Büden ihr bestes (iedeihen findet. Das Alles wind vollständig klax. Wenn man die Resultate verschiedener Aschenanalysen seite an Seite stellt. nach dem folgenden Beispicl:

Zuckerahorn

(Acer saccharinum)

Kieselsturc

liali

Tatron

Kalk

Irgmesia

Phosphorsiures Eisen

Phosphorsamer Kalli

I'hosphorsane Magnesia

Schwefelsïture

Kohlensïnte
(), 40

4,62

2.90

$\pm 1,33$

6. 42

0,78

4.64

1). $7 t$

1,29

$\frac{36,45}{100,00}$
Pechliefer

(Pinus rigida)

7,00

If,10

20,75

13,60

4,35

11,10

2.75

(1,90

3,45

$\frac{21,50}{100,00}$

Die Buchenasche enthält 22.11\% Kali, also über $17 \%$ mehr wie die thomasche; sie enthält $25 \%$ "Kalk. 3,32 \% Natron, $5.520 \%$ Kieselsäme und $7.64 \%$ sichwefelsäme. 


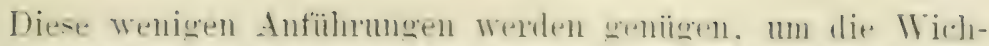

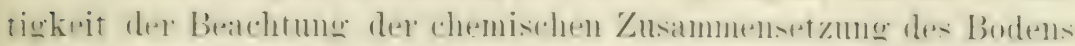

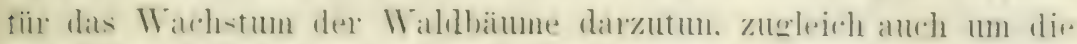

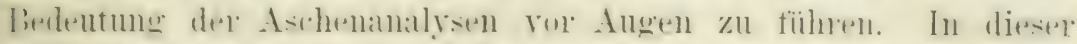
Hensirht ist tïr die tropische Furstkultu fast nuch alles zu thun: diese Lïcke des Wissens allsufullen. muss als eine der wirhtigsten

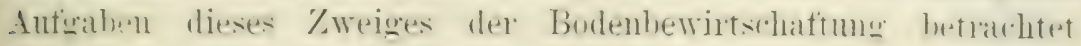
werden.

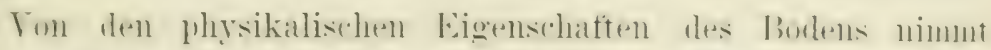

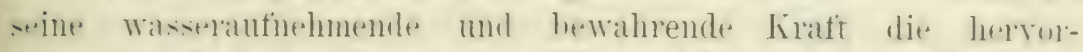
bagendste stelle ein, dem der Wasserbedart pines Waldes im

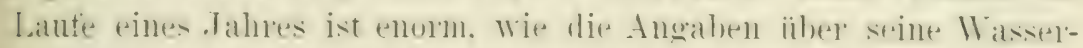

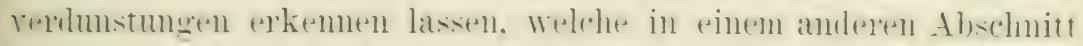

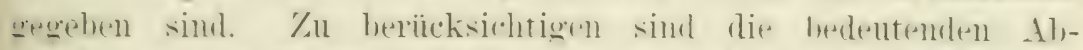

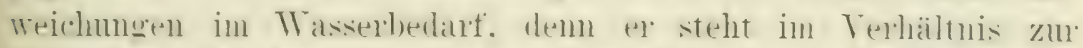

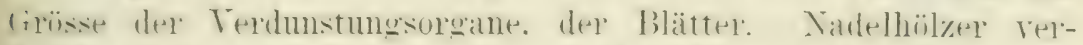

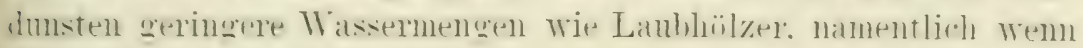
diese immergriun sind.

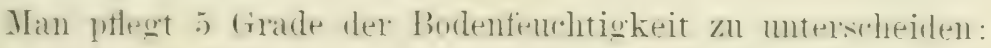

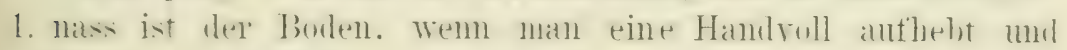
'T'ropten niederfallen;

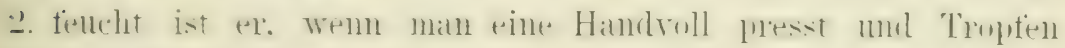
niederfallen:

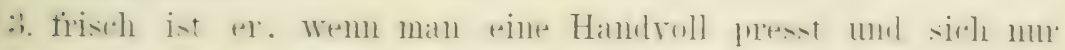
Spuren ron Feuchtigkeit an den Fingern zeigen:

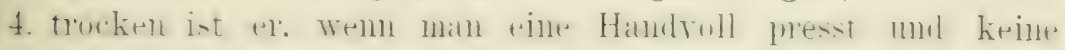
Spur von Fenchtigkeit an den Fingern bemerklich ist;

5. durr ist er: wenn er durch Reibung als Staub zerfällt.

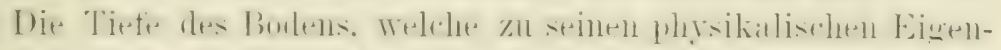

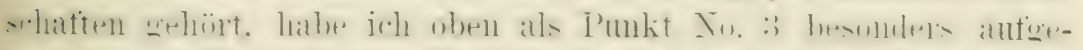

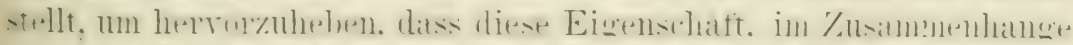

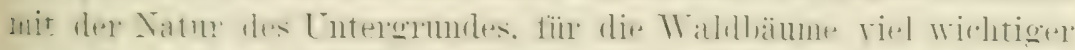

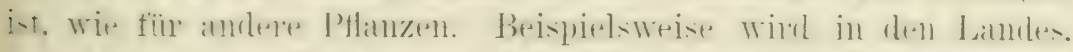

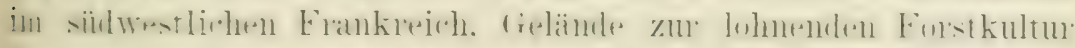

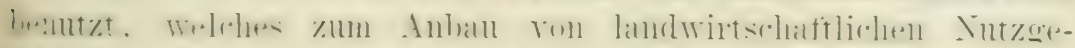

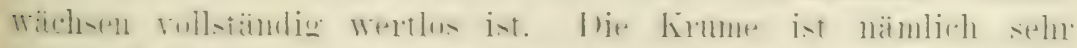

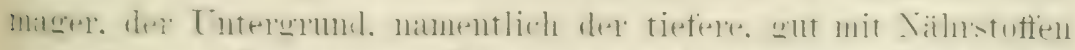

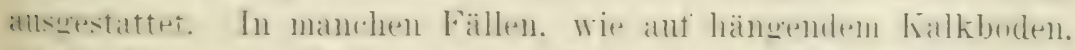

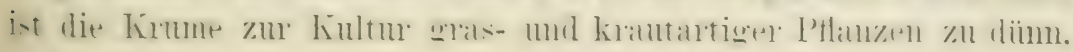




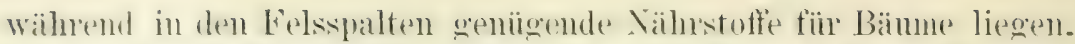
die von ihren Irumeln anfoenommen werden kömen. Diese Wrumeln lassen bei ihrer Verwesme organische Stofte zuriick, die nachtolgenden biumen zur Sahrung dienen kïnnen; ferner ïffhen sie nene spalten und erweitern bestehende. dadurch fördern sie die

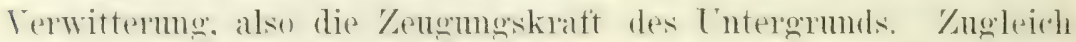

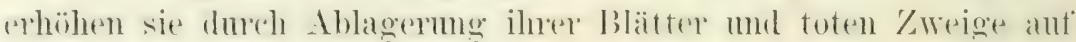
der Krume deren Fruchtbarkeit.

Wie die Bodenfeuchtigkeit. pflecet man anch die Bonlentiefe in 5 Grade zu sondern, nämlich:

1. sehr reicht ist der Boden. Wem seine Tiefe nicht über 15 \%entimeter geht;

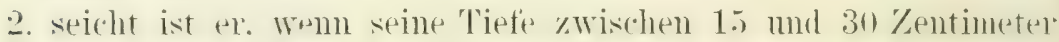
beträgt;

:3. mitteltiet ist er. Wenm seine Tiefe zwischen 30 mol tio zentimeter betrïgt:

t. tief ist er. Wenn seine Tiefe 60 bis 120 Zentimeter heträgt:

5 5. sehr tief ist er. Wem seine Tiefe ïber 120 Zentimeter beträgt.

In Bezug anf die Lage des Bodens kommen in Betracht:

1. die Erhebung iiber dem Neeresspiegel;

2. die Neigung nach einem Punte des Kompasses;

3. der Neigungsgrad gegen den Horizont.

Die Höhengrenzen für das Anfstergen der Bäune ïher dem Meeresspiegel wechsehn sehr, je nach der Natur der Bämme, der klimatischen Terhältnisse und der Bodengestalt. Für den Waldwuchs im allgemeinen. wie ïberhaupt fïr den I'flanzenwuchs. liegt der höchste P’unkt der Höhengrenze am Äquator. ron da fällt sie nach beiden Polen hin - als Regel gemeint. die örtliche Ansnahmen zuläst. So wird das Aufsteigen der Bämme im Gebirge beeinflusst durch die Xeigung der Hänges nach einem gewissen Punkte des fompasses. Allgemein lekamnt ist. dass anf der nördlichen Erdhälfte die sïdwestlichen Hänge am wärmsten sind. weil sie die meisten somnenstrahlen emptangen und am geschiitztesten ror den kalten Winden sind. Keineswegs darf aber als ansmahmsweise Regel aufgestellt werden, der Bammuchs steige an sïdwestlichen Gebirgshängen hïher wie an Bodemneigungen nach andereil Punkten des Kompasses, demn die erwähnte Gunst wird häufg ausgeglichen durch moünstige Fenchtigkeitsverhältnisse. wie durch starke Abwaschungen des Bodens. Aus ähnlichen 


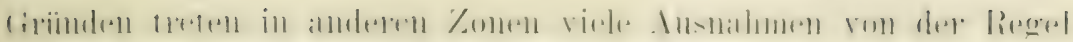
ein, welche man glaubte anfistellen zu können.

Der Veigungswinkel des Bodens hat ebenfialls einen be-

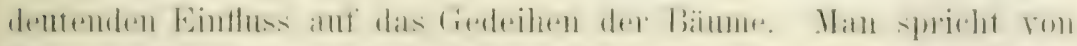

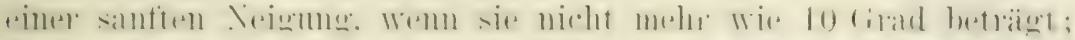

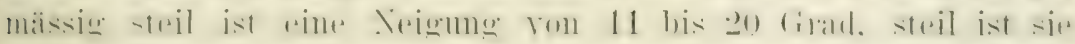
ron 21 bis 30 Grad und sehr steil. wem sie iber 30 Grad ist.

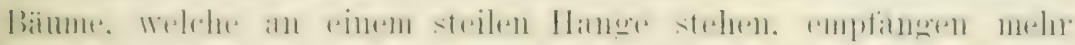

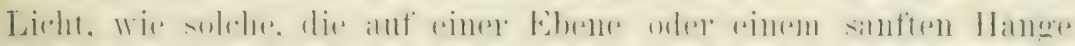

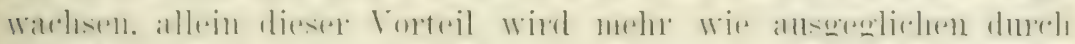

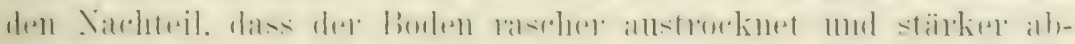

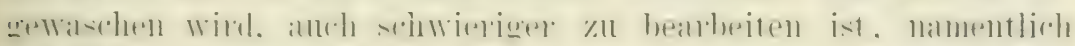

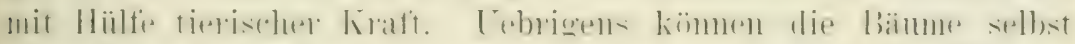

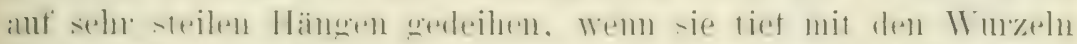

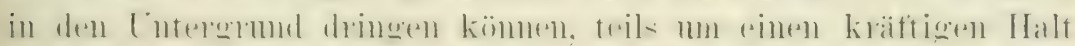

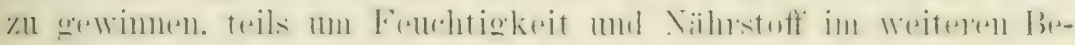
reiche aufzusuchen.

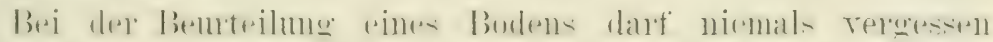

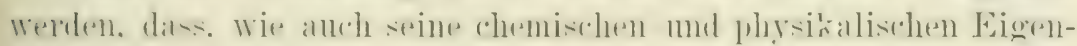

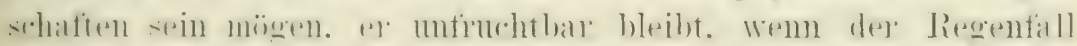

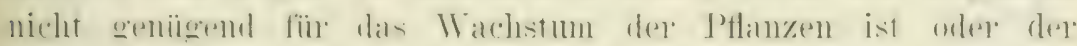

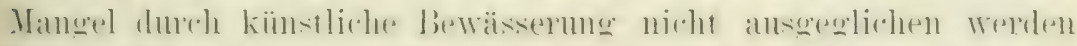

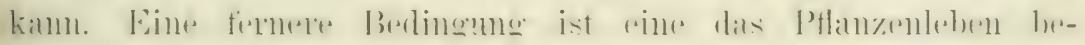
guinstigende Luftwärme.

\section{Die Behamdlung des Samens.}

Leider ist es nicht immer ausfïhrbar, nur solchen Wald-

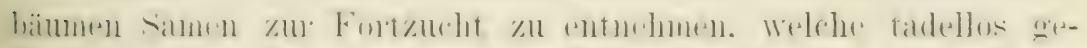

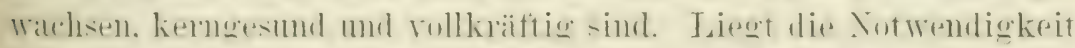

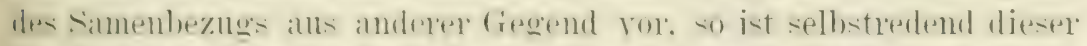
wichtige liegenstand roll-tïndig der hontrole antrïckt. Lmmerhin

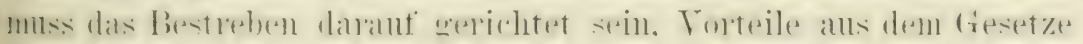

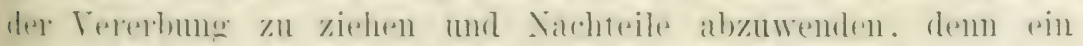

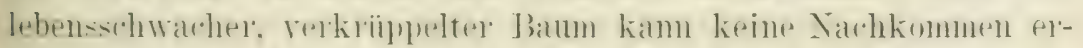

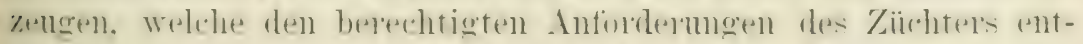

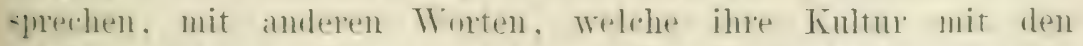

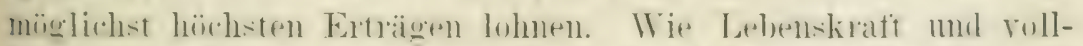

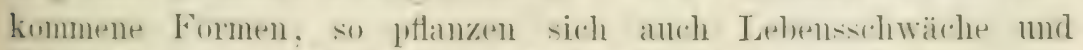
Fehlerformen von den Eltern anf dit Salhkmumen fort. einerlei 
(1) die Eltern Memschen, There oder Lflanzen sind. dem das ciesetz

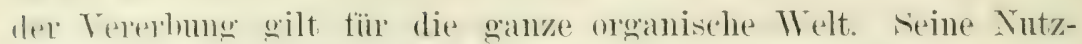
anwemdung in der Pflanzenkultur ist merkwindigerweise noch rehr venachläsigt - merkwindigerweise. sage ich. im Hinblick ant die enlänzenden Erfolge der 'Tierzucht. welche in erster Linie diesen Mittel zu danken sind. Was mzählige Mal betont mu zum Allgemeinwissen gemacht wurde.

Der Baumsamen soll als Regel gesammelt werden, sobald el: reif ist: Wem nicht früher möglich, muss es ohne Zeitrerlust nach dem Alfallen geschehen. Und wemn irgend thunlich. soll die Natur nachgeahnt und die saat mmittelbar nach der Ernte stattfinden, dem manche simnen rerlieren bald ihre Keimkraft, andere sind währemd der Aufbewahme schwierig ror dem Verderben zu schïtzen.

Fiur die Anthewahmo lassen sich nur allgemeine Vorsichtsmassegen aufstellen: Der same darf keiner hohen Temperatur. ahex anch keiner unter den Gefrierpunkt fallenden. ausgesetzt sein, kiihl und gleichmässig sind die bezïglichen Bedingungen. Tere Same darf terner nicht fencht, aber anch nicht zu trocken werden. Ist ex äreich, wie Bucheckern, so exhitzt we sich leicht, wem ex gehäut lagert: selbst wemn man ihn in diunen schichten anshreitet. darf ein ifteres Lmschaufeln nicht moterdssen werden.

Der Same und solcher, der ihm ähnlich ist, ron den folfrenden Arten: Esche. Ailanthus. Linde, falsche Akazie. Catalpa, Ahorn. Thme. Kiefer. Tamme und Hemlock werden am besten in siacken. schwebend in kiihlen trockenen Rämmen, autbewahrt. In sircken. weil die Erfahrung gelehrt hat. dass ein rollständiger Luftalschluss. Wie er in irdenen Gefässen oder wasserdichten Fïstern stattfinder. nicht zweckdienlich ist. Achwehend. weil der silntr dadurch den Angriffen des Lngeziefers entrïckt wird.

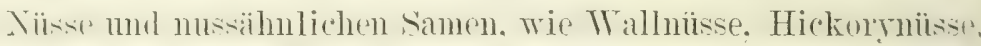
Firholn und Fastanien verlieren ihre Keimklatt, wemn sie stark anstrocknen oder schimmelig werden; bei dinem hohen Grad ron Befenchtume mögren sie rorzeitig keimen. wodmeh sie natiulich Wentalls tö̈ dir saat untauglich werden. Tm einem Terluste rorzubengen. legt man diese samen schichtenteise in sand ein. den man einigenal mit Wasier besprenkelt. Der sand soll niemals vollständig trocken werden, demn in diesem Zustande entzieht en dem silmen Furbtigkeit. er muss aber anch vor einer zu starken Benïsome hemahrt bleiben. damit ex nicht zur Keimung amegt. 


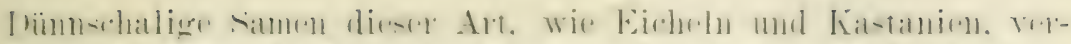

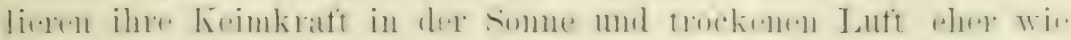

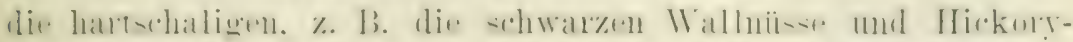

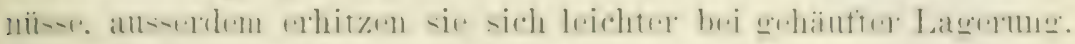
sie sind also rorsichtiger zu behandeln.

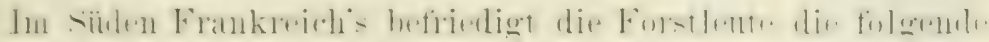

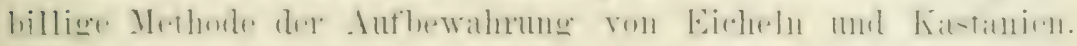

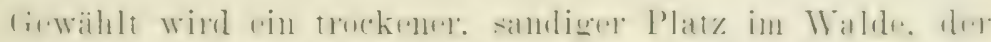

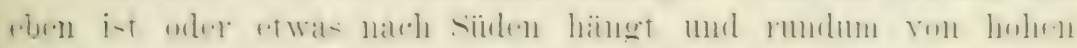

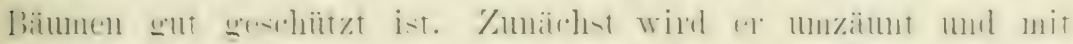

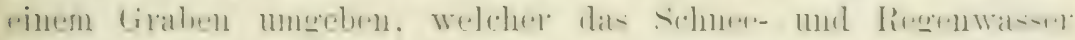

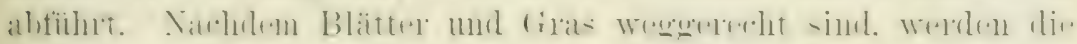

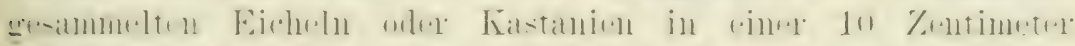

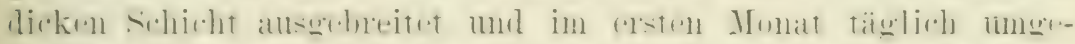

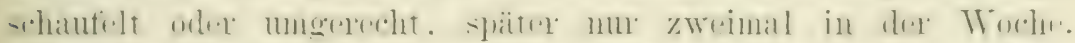

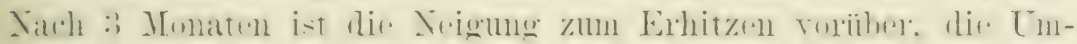

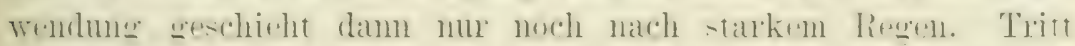

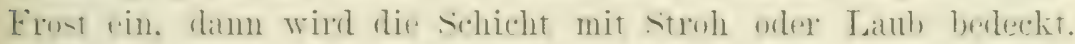

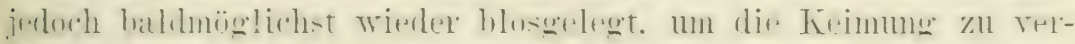

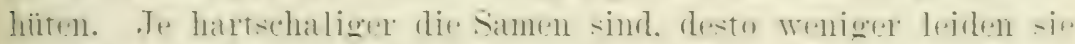

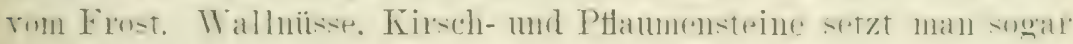

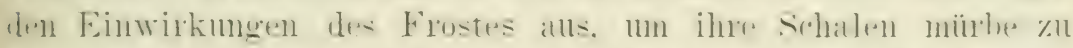

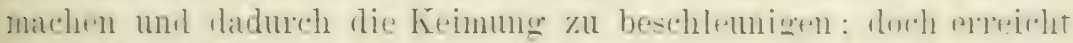

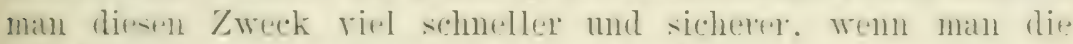

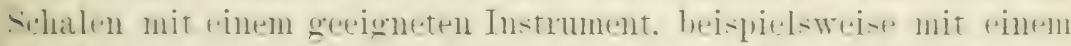

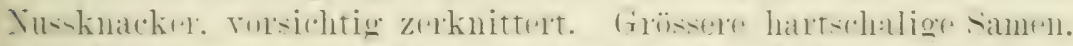

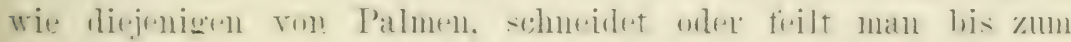
lielue an.

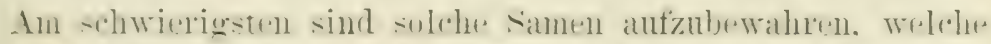

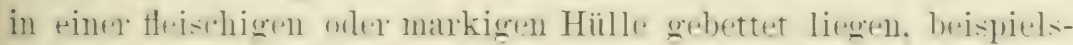

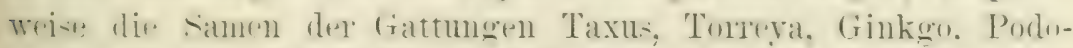

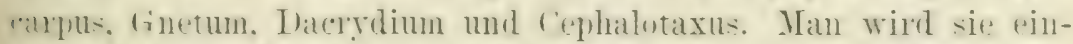

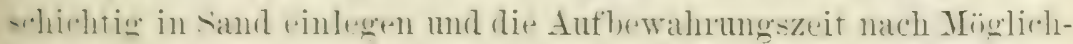

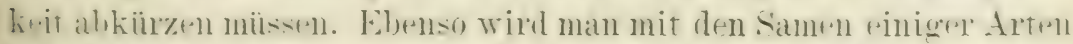

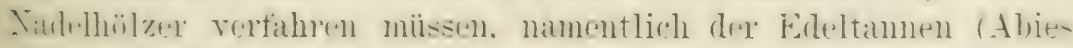

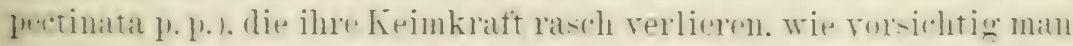

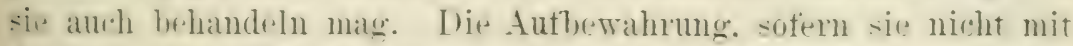
dem Tersand in Terlindung steht. ist num in Gerenden notwendieg. 


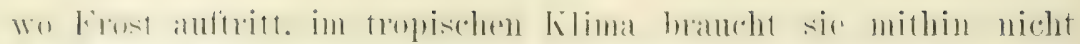

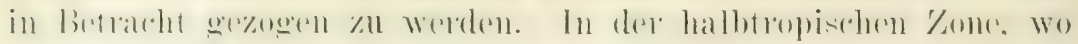

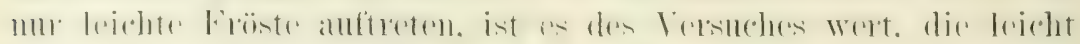

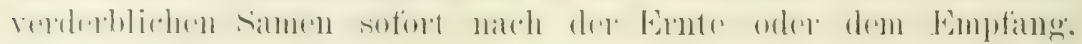
wenn sic ats anderen Gegenden bezogen werden, zu säen

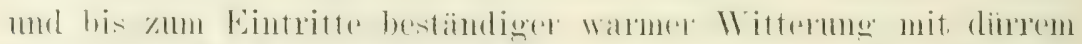

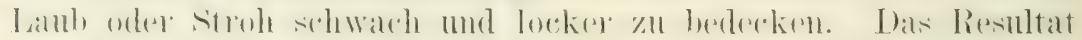

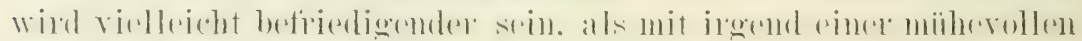
Aufbewahrungsmethode.

Samen, der iiber See, iberhaupt auf weite kntfernungen,

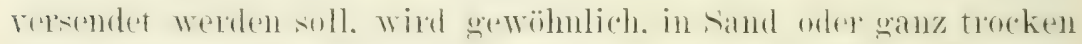

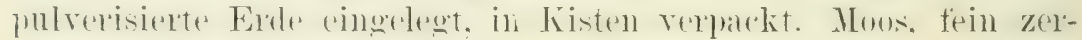

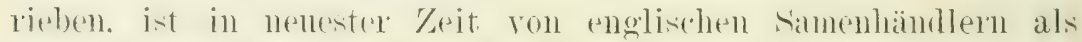

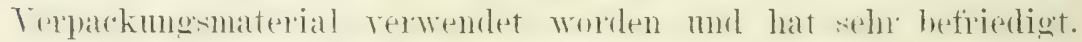

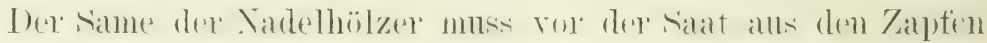

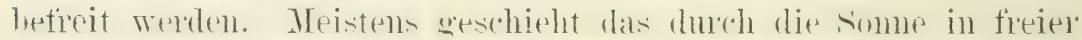

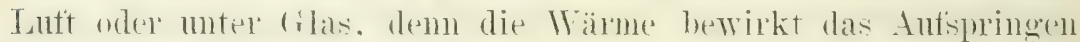

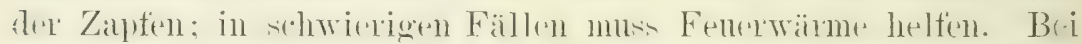

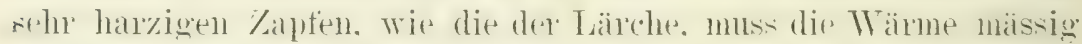

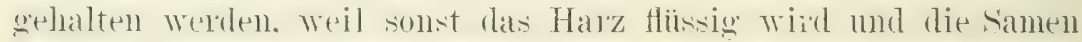
festhäl. Wenn die simmen von sehn festliegenden sichmples bedeckt sind, wie in den 7ayten der Codern. bufreit man sie durch Als-

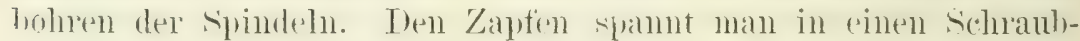

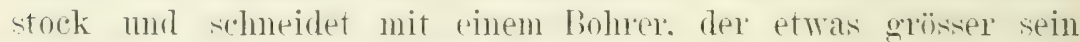

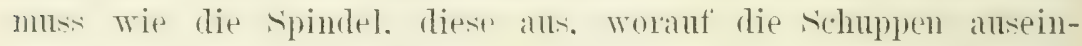
anderfallen.

\section{Die verschiedenen Fortpflanzungsmethoden der Waldbämme.}

Nach einem der drei folgenden Verfahren iamn die Fortptlanzung stattfinden:

1. durch Sat auf die danernden Standorte;

2. durch Saat in die Bammelnule. oder natiuliche sat und Terpflanzung anf die dauernden Standorte;

3. durch Ableger. schnittlinge und stecklinge, die in der Bammschule bewurzelt und ron da anf die danermden Standorte verpflanzt werden.

Iede dieser Methoden erfordert eine gesonderte Bespreshumg. 


\section{Die Saat auf die damernden Standorte.}

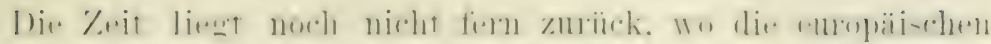

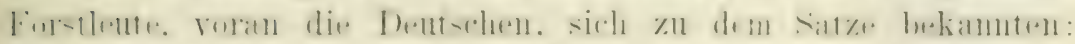

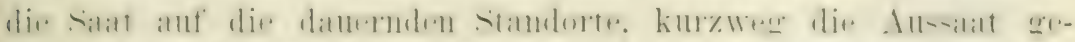

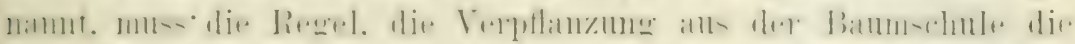

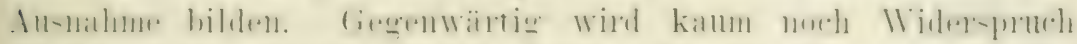

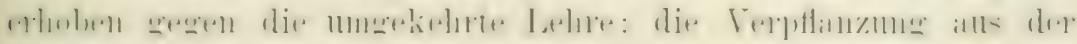

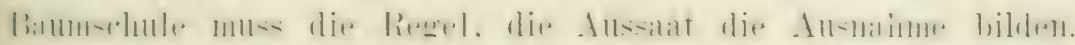

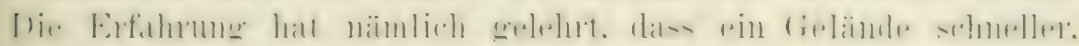

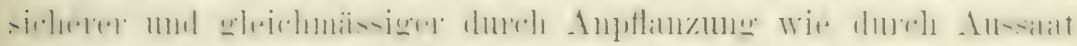

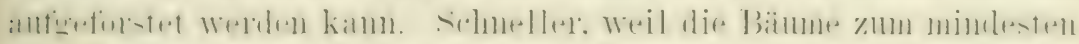

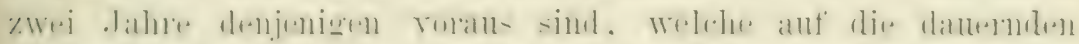

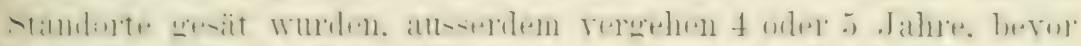

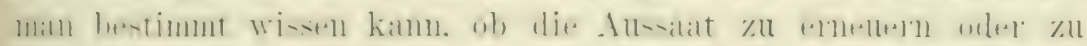

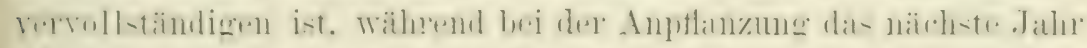

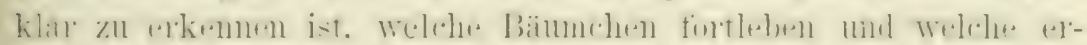

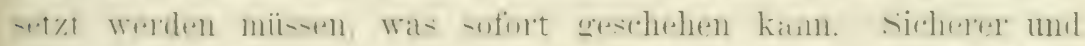

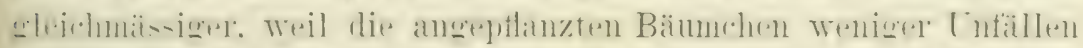

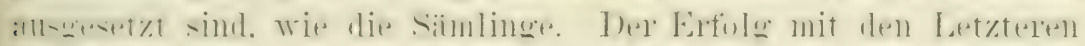

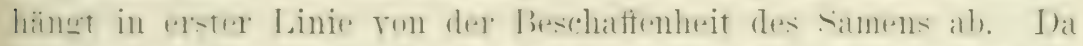

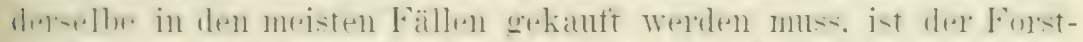

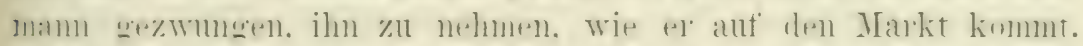

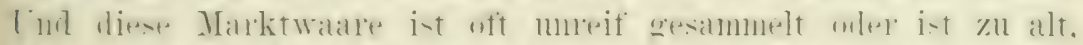

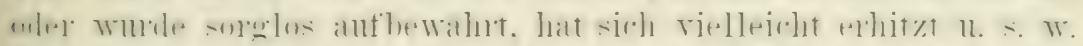

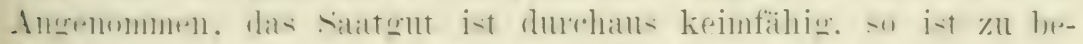

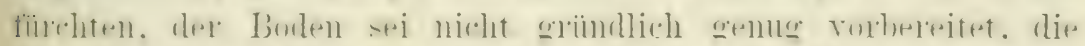

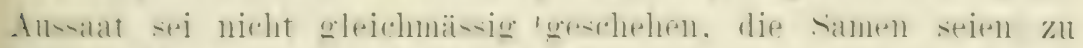

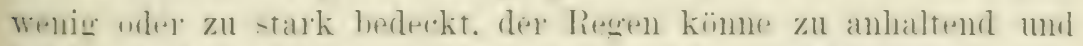

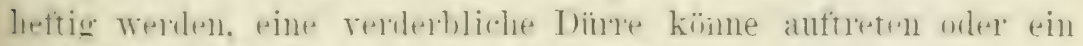

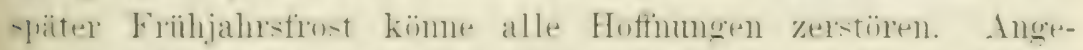
mumnen. die Wittermes sei günstig und Vügel und Mänse hätten

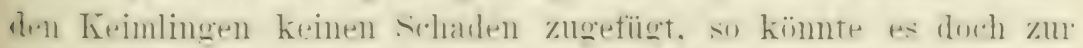
higteren Täushumg werden. den Erfolg sicher zu glauluen. War dip IVittrung günstig für das Warchstum der sämlinge -1) War

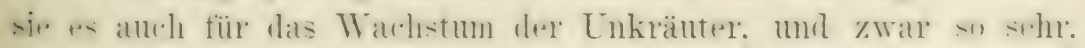
da- die winzigen Bäunchen kanm in dem sie bedpekenden und

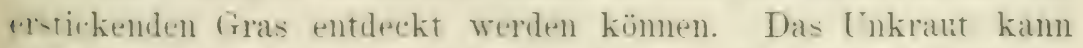

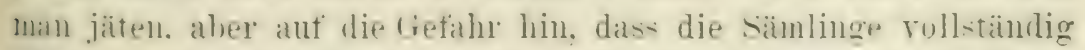

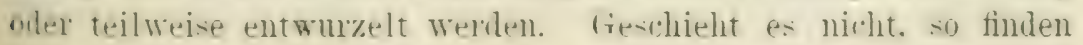




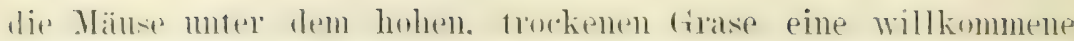

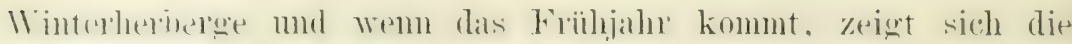

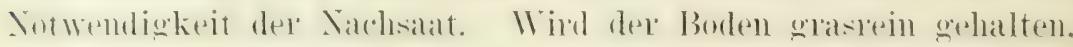

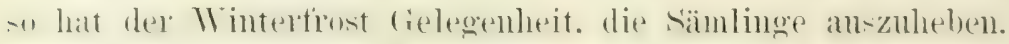

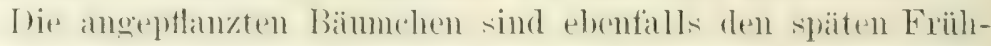

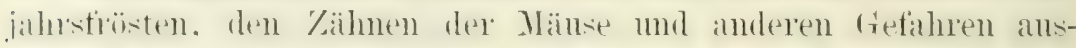

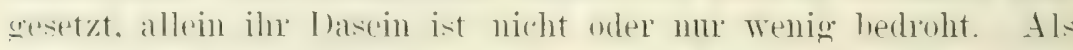

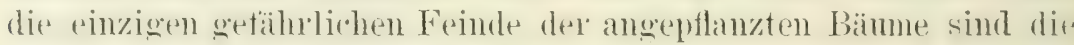
Insekten mol ihne Lanven zu hetrachten. die natiurlich anch dir. angesïeten Bäme nicht relschomen. Erfahrene Forstlente nehmen an dass die Anptlanzmo billiger ist. wie die Ansalat. Die erstjïhrigen Kosten sind zwar etwas geringer für die Anssat. Wie tiï die Anjtlanzmg. allein in den folgenden Jahren sinkt die Tagschale zu Tngunsten der Aussaat durch die Auslagen, welche das Yachsïen und das Auspflanzen rom Lücken relusarht. Alles in Rechnung gerogen, diurte somit der gröscre Torteil auf Seite der Amptlanzung liegen.

Diese für die gemässigte: Zone anseinandergesetzte: Darlegme. kamn mit einer Verschärfung auf die tropische Zone übertracen werden. dem hier sind die sämlinge grösseren Gefahren ausgesetzt: ron dem wnchernden Tnkiant, den zahlneichen tierischen Feinden und dex rersengenden Dïrre. Toch darf nicht vergessen werden, dass w sich um eine Regel handelt, die Ansmahmen zulüsst in allen Zonen. [nmöglich ist es, alle Ansuahmen anzutühren, da die triunde für und wider in buntem Wechsel auftreten kömnen. Nur die trichtigsten könmen Erwähnumg finden.

In sinem trockenen Klima wie anf einem freien steppenborlen, ist die Terpflanzung der Nussbämme und Eichen mit bedeutender ('efaln rerknüpft, denn gewöhnlich sterben sie sofort oder nach längerem Kränkeln; es empfichlt sich deshalb die Saat auf die damernden standorte. mit der For'sichtsmassregel. schnell wachsende Schutzbäume nicht allein in den Reihen. sondern auch den Grenzen entlang. hier dicht gedrängt, anzupflanzen.

Wemn es sich um die Bewaldung der Dünen mit Nadelhölzem handelt, ist die Aussaat die zurerlässigste Methode. In Frankreich, wo man in diesem Zweige der Forstkultur die grösste Erfahrung besitzt und die glänzendsten Erfolge erzielt lat, verfährt man wie folgt: Zumächst wird für rinen schutzwall gesorgt und zwar wird der Wind gezwungen, einen sochen zu banen. Etwa 


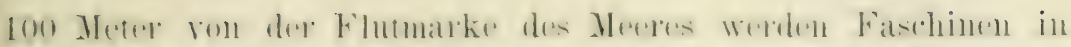

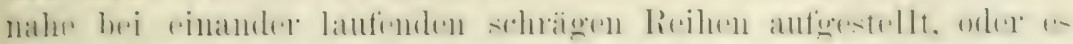

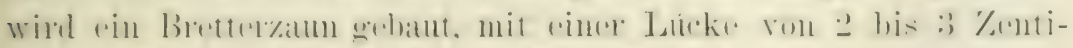

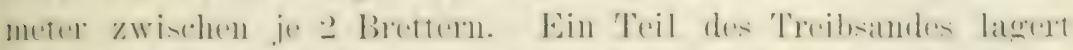

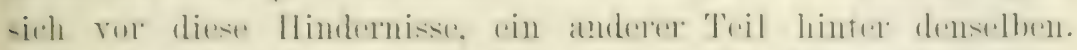

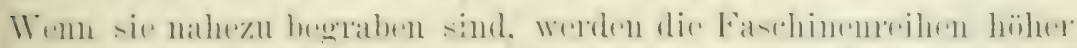

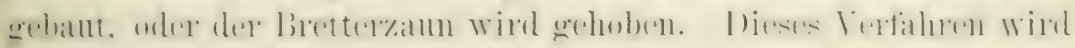

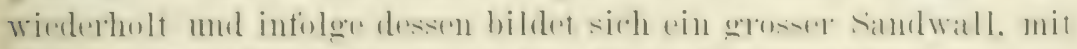

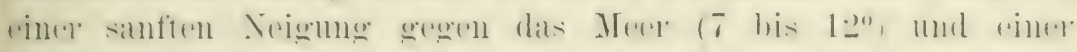

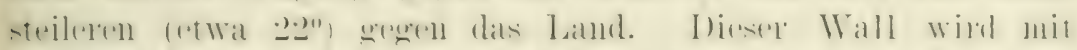

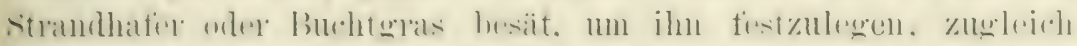

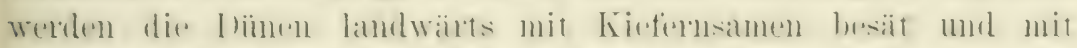

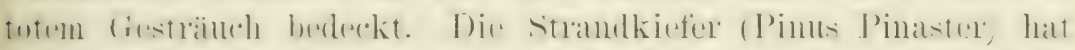

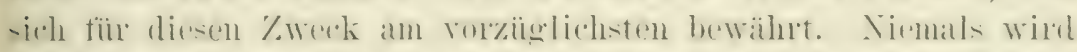

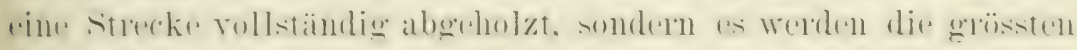

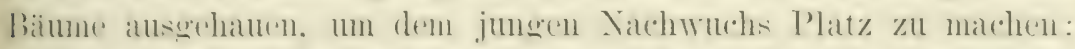

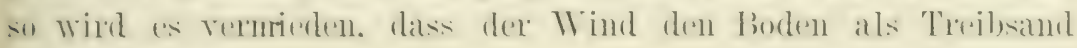
wegtragen kamn.

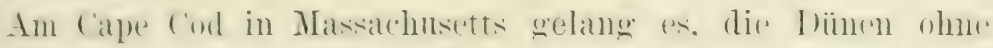

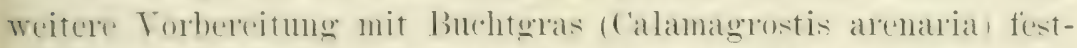

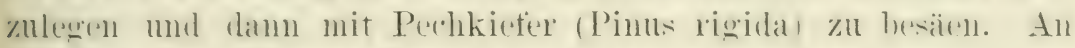

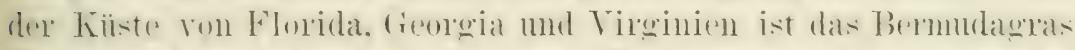

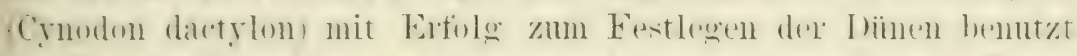
worden. zur Bewaldung wählte man den tilanthus. dir rote cedele (Juniperus virginiana) und die Tamariske.

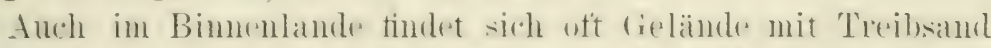
berleckt. das man an besten besit, heror es bewaldet wreden soll.

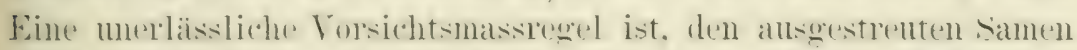
mit lockeren fiesträuch zu hedecken. das eingeschlagene l'fähle festhatten. Wemn es den sïmlingren gerlingt, sich unter dieser schntzdecke zu bewurzeln, ist der Erfolg gesichert.

Die Aussaat ist auch dex Auptlanzung vorzuziehere fïr die Anfforstung steiler (ipbirge. nur mit wenig Erde bedecht mol spärlich mit ciras bestanden. Das Verfahren wird gewöhnlich mit de.j. mehrfachen Abdämmmg der Wildbäthe eingreleitet, mu ilseren reissenden lant zu mässigen, dex bedentende Alwaschungen in Gobirge und Therschwemmmoren im Tieflande rerursacht. An fasienden Stellen werden ans schweren steinen, ohne jedes Bindemittel. Welne crbaut. die auf breitem Fundamente ruhend. dachtörmigr auslaufen 


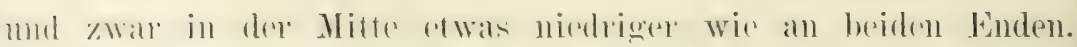

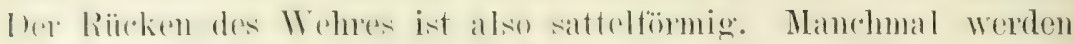

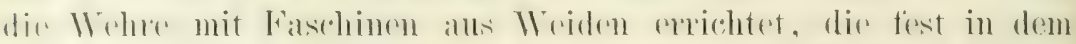

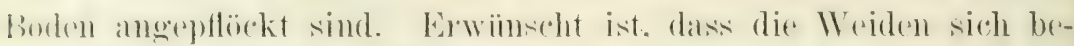

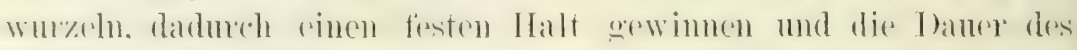
IVehres verlängeru.

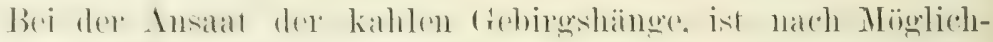

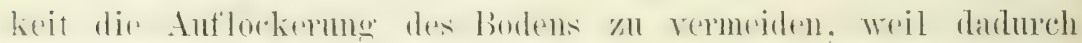
srint II

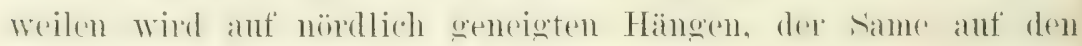

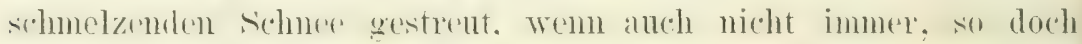

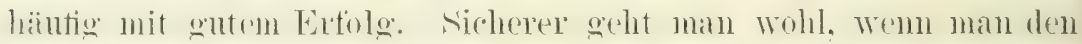
Boden leiroht mit cince Harke anfkatzt, den samen mit der Eode

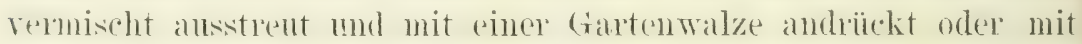

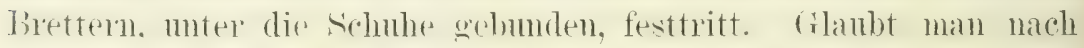

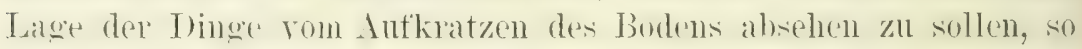

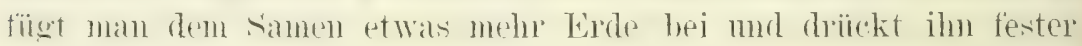
anf den Borlen.

Sowohl anf 'den Dimen, wie auf den steilen Gebirgshängen slent man an besten den samen breitwiufig mol dicht aus. Fö̈ die Besämng anderel böblen ist zumächst zul betomen. dass sie nicht allein mit den gewiihnlichen PHug. sonden anch mit dem Lnter-

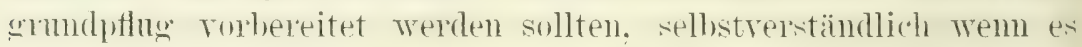
die Ansaat gestatten. Gestatten sie es, dann lohnt sich eine solvlue grimolliche Torbereitung in hohem Grade, zumal sie verhähnismässigg geringe Kosten relusacht. Inas sei dn dieser stelle hofont: in der europäischen Forstrirtschaft werden, gleichwie in d+l Landwirtscluaft. die Hacke, Harke, schantel und der spaten zu läufig in Fällen angewendet. wo sie durch vollkommenere Geräite ersetzt werden kïmuten. Anch in der Forstwirtschatt mïssen Pflug. Tontergrundpflue. Kultivator, sämaschine. Banmơaber u. s. w. zur mäglichst atl-gedehnten Anwendung gelangen. um die Rentabilitat zu sichern oder zu erhöhen.

Wenn der Boden nicht tief' genug tïn die Terwendmeg des PHuges ist, mag er mit dem Kultiratol gelockelt werden. Liegt der 7wang ror, ein Handgeräte zu benutzen, was stets der Fall ist. wemn kleine Waldichtungen zn besäen sind, damn empfiehlt sich eine kräftige Harke, die man sich wie eine Mistgabel denken nüge, deren drei Zinken abwärts gebogen sind. Welches Instru- 


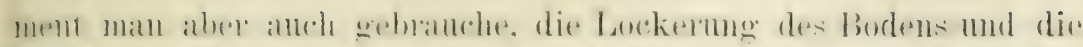

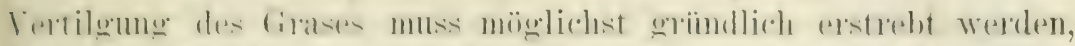

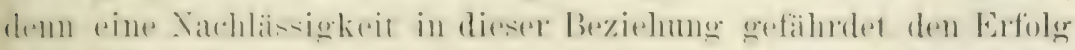

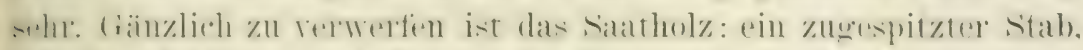

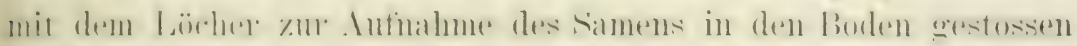

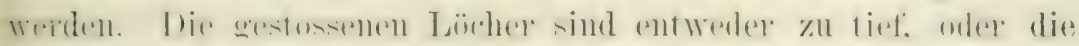

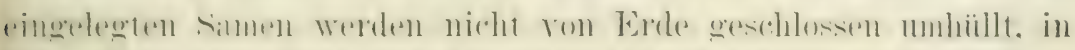

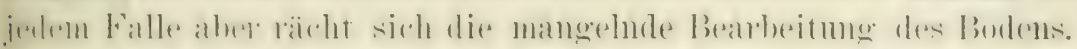

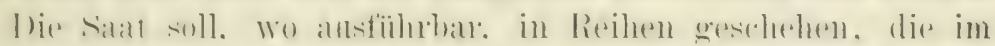

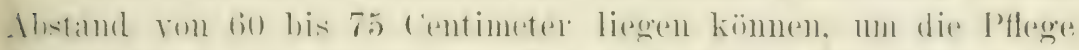

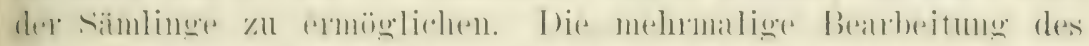

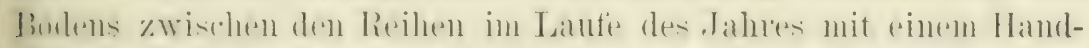

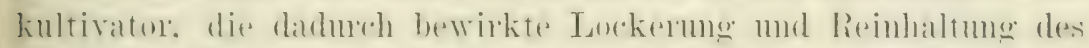

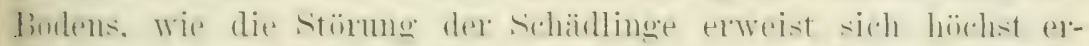

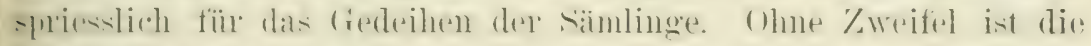

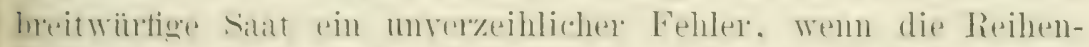

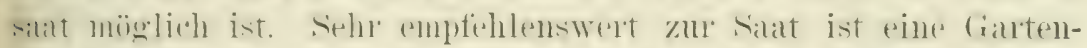

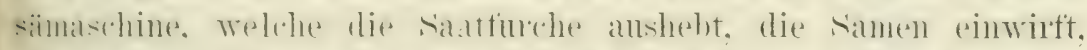

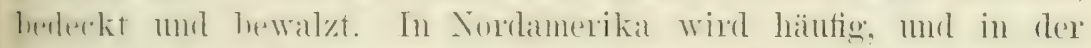

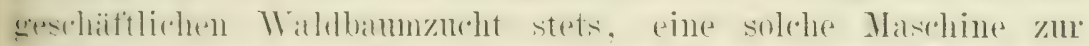

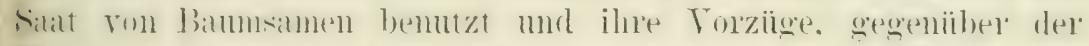
Hamel. sind aluch su klan, daks sie selbst ron einem blöden Auge

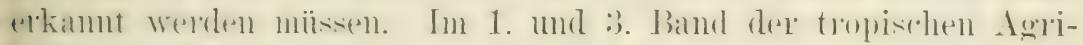

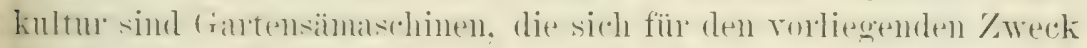

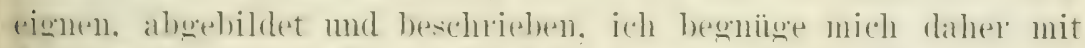
dem Hinweise. Anfï̈gen will iels. dass in diesen bänden noch

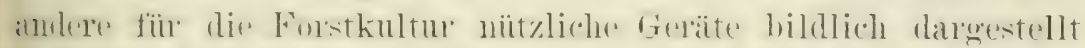

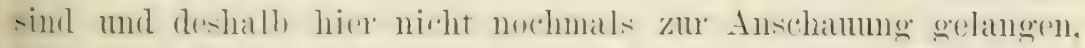

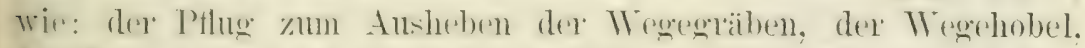

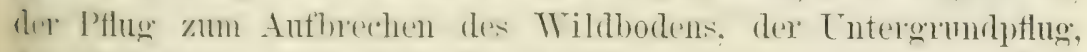
de. Foldkultivator mol dor Handkultivator. in verschierlenen construktionen, und die Obsthainegge.

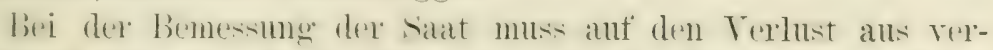

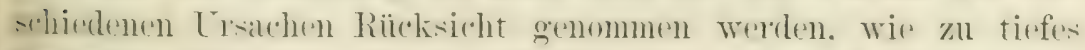

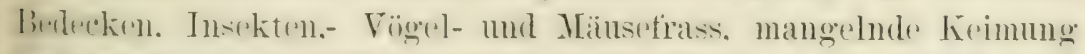

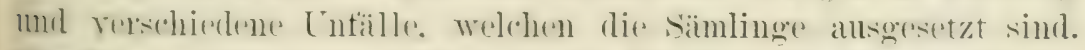

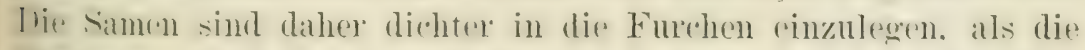

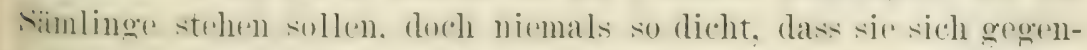

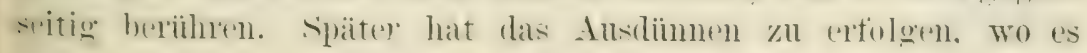




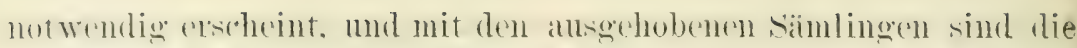

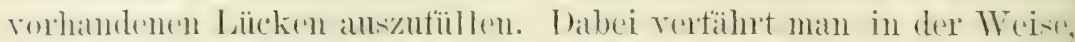

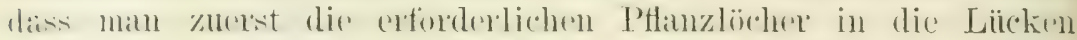

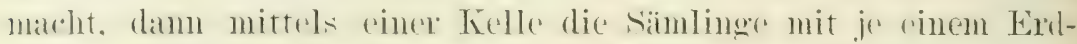

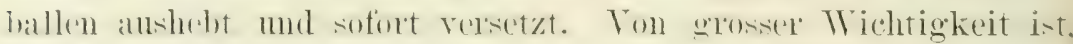
die Silmen weder zu seicht noch zu tief mit Erde zu bedecken. Fingehende Virsuche deutscher Forsteute zederten. dass Bucheckem

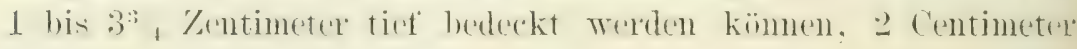
war die vorteilhafteste 'l'iefe.

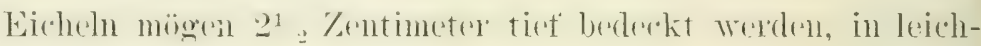
tem Boden bis zu 5 Zentimeter.

Ahornsamen mag 1 bis 2 Zentimeter tief bedeckt werden, tiefer wit T contimeter keint or nicht. Dieser same treibt seht lange Samenlappen. die. Wrenn tief bedeckt oder wenn die Bodenwherfläche hat rexkrtstet ist, das Hindernis nicht beseitigen kömnen, aber zu warlsen fortfahren. bis sie abbrechen und so der Keimling verloren geht.

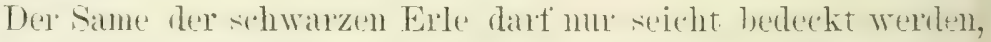
als beste Tiefe zeigte sich 1 Zentimeter. In einer Tiefe ron $1^{1}$.

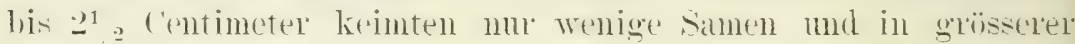
Tiefe gar keine.

Der Kiefernsame keimt am besten in einer Tiefe ron 1 bis $1 \%$ centimeter, in wösserer Tiefe wie 3 Zentimeter wude heine Keimmg erzielt. Ebense verhielt sich der same der T'annen, mit Alsmahme dexenigen dex Weisstanne. Welcher eine geringfïgig tiefere Bedeckung vertrug.

In allowmeinen geht man ziemlich sicher, wenn man sich an die alte Gärtnerregel hält. den Sianen dreifach so tief zu bedecken. als sein Durchmesser beträgt. Das ist für gewöhnlichen Gartenbolen gemeint. In schwererem, fenchterem Boden muss die Bedeckmy etwas seichter, in trockenem, leichtem Boden etwas tiefer sein.

C̈hrigens sribt es auch Ausuahmen ron der Regel. so muss der same der falschen Akazie (Robinia Pseudoacacia) so tief wie die Eichel bedeckt werden. wie vergleichende Versuche in Dentschland lehrten. I as berechtigt zu der Ammahme, dass dieser Baum vorteilhaft zur Aufforstung benutzt wird. von solchen trockenen Gelände. in welchen dimm bedeckter same ans Mangel an Fenchtigkeit nicht keimen kann. 
Hartsehalige simmen. wie von der falsehen Akazie. dent ant-

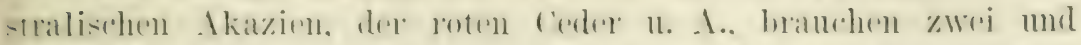

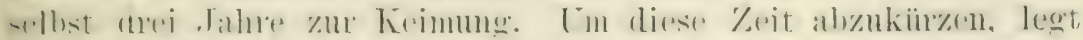

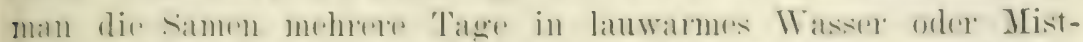

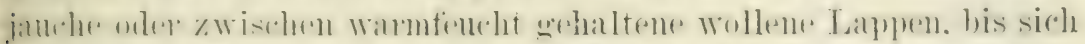

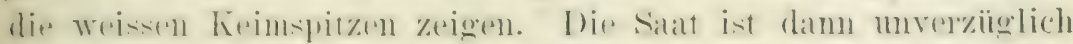

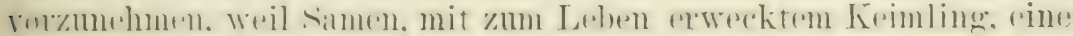

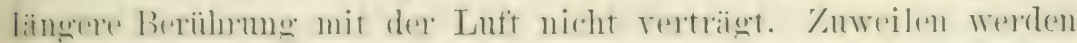

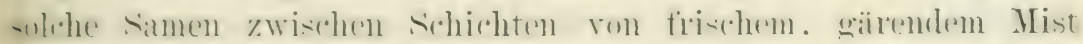

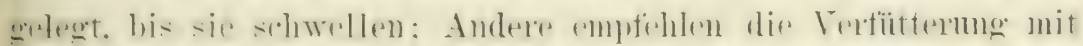

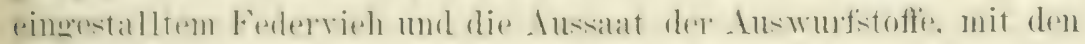

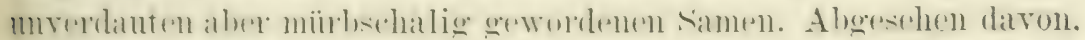

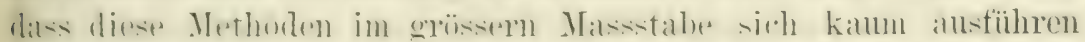

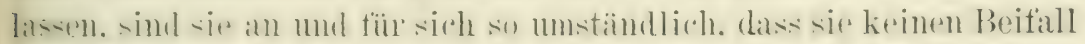

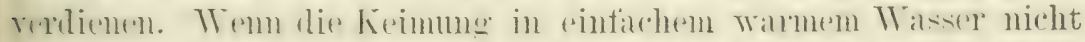

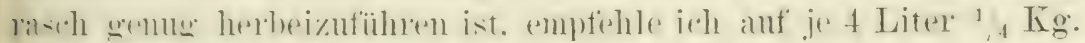

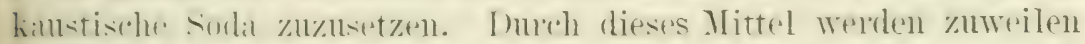

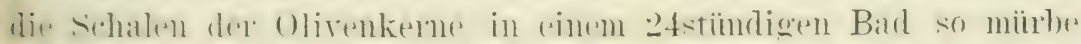

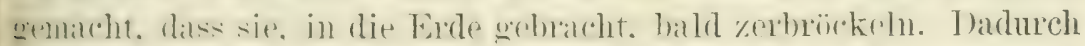

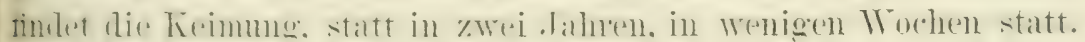

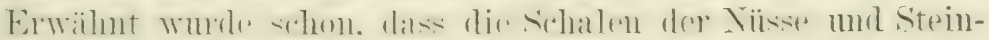

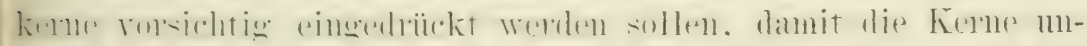
rerletzt bleiben, beror man sie in die Erde bringt.

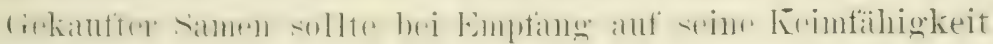

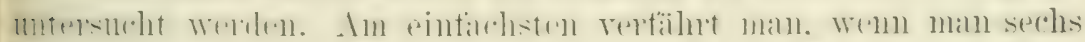

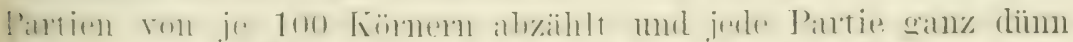

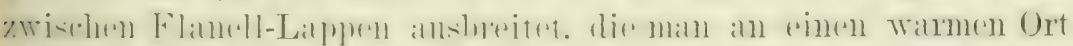

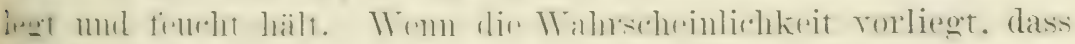

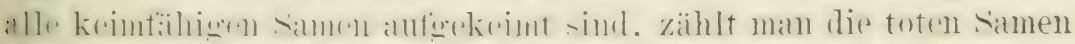

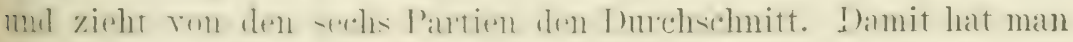

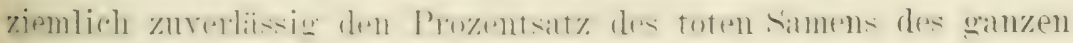
Pnstens elmittelt.

\section{Die Sat in die Bammschule.}

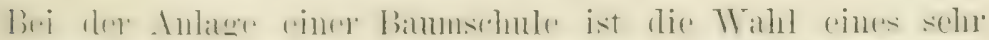

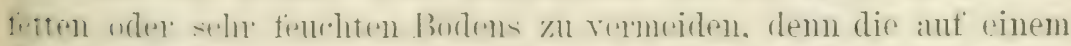

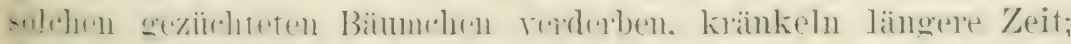

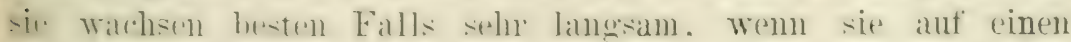

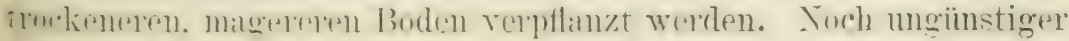




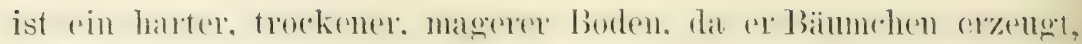

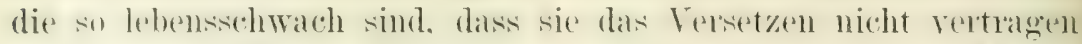

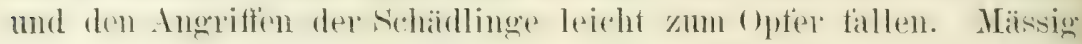

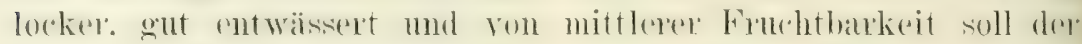

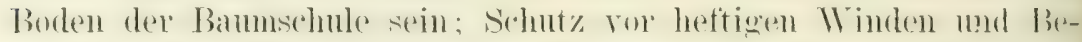

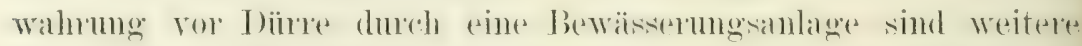
Bedingungen, die mit dem geringstens Anfwand von Mühe mul Kosten zu erfïllen sind. Wemn die Anlage in einrm 11 alilsamm mul

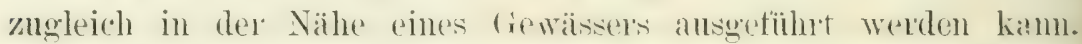
Der Boden muss tief bearbeitet werden, entweder mit dem suaten

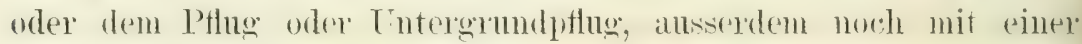
feinzinkigen Egoe, die alle siteine und Wuzeln alshebt. \%oigt, sich dex boden nach rieser Burbeitumg nirht so krïnelig wie rwïnscht, so empfiehlt es sich, ihn zunächst mit Hackfrïchten, Mais. Sorghum oder anderen Kultuptlanzen zu bebaten. wolche eines mehrmalign Bodenbeabeitung wähend ihres Wachstums bediü fen

Rätlich ist es, sclon vor der Errichtung der Baumschule Komposthanfen anzulegen. Man wählt dazn rincen scollattigen. der Luft moghinderten Zutritt gestattenden Plat\%. Aus diurlen Lanb, Moos, Famen und anderens saftigen Pflanzen, die nicht mit reifen Same'n behangen sind. bildet man finen Hanten. der 1 bis $1^{1}$. Meter hoch sein mag. Einom anderen Haution bildet man atls Rasene oder wemn ex nicht rorhanden ist. aus Gras mul solchen feincren Pflanzen, die rasch verwesen. denn der Zwerk dieses Hantens soll sein, eher Humus zu lirfern. Wie der andele. Fine Mischmos von Laub- und Vadelblättern geibt den bestron Kompost für die Bamschule und in späteren , Tahren sollte ex nu ats diesen stoften zusammengesetzt werden, falls sic zur Verfïgung stehen. Dio Haufen miissen zweimal im . Jaht mmgestochen und bei trockrnen Wetter begossen werden. Sicheitet die Vermesmeg nicht nach Wunsch font. so mag man dem Giessmassole ctwas salzsïme zusetzen. orler man mag webrannten, pulverisierten Falk in den Hanfen strenen, während er umgestochen wird. Indessen ist die Zugabe ron Kalk sulu massvoll zu halten, da sonst die Zersetzung schneller, wie erwïnscht sein kann, vor sich geht.

Dieser Kompost wird über die samenbecte ansocbreitet und seicht untergebracht. Legrt man vor jeder ternoren saat eine dïmne Kompostschicht ïber die Beete, so rezden dieselben in gleicher Zengungskraft erhalten mol die Verlegung der Baum- 
betont werden. dass dureh ein hänfiges Lockern des Bodens, mit

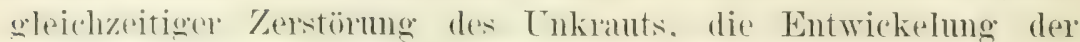
simlinge allserordentlich gefürdert wird, was noch viel zu wenig Bearehtung findet. Cund wem es begriffen wird. schenchen vor der Befolgung die hohen Kostrn zurïrk. welche entstehen, wenn die Bearbeitung mit der zeitraubenden, kraftrerschwenderischen Hacke stattfindet. Daher stelle ich den Handkultivator so scharf in den Tordergund und empfehle. Im seine Anwendung zn ermöglichen, nicht mit dem Ram zu geizen. sondern die Reihen in entsprechend hreitem Alstande zu legen. Was. im Veroleich mit der alten Tethode. an Raum verloren geht. wird mehr wie anfgewogen durch die raschere und kräftigere Entwickelmo der Sämlinge.

Die dichte saat wurde oben angeraten. weil rlie samlinge in den Reihen so gedrängt stehen sollen, dass kein Cnkraut zwischen ilnen aufkommen kann. Das . Täten in den Reihen muss mit der Hand ansoefïhrt werden. ist also zeitraubend und kostspielig. ausserdem wirkt es schädlich, weil beim Ansreissen des Unkrautes die Wurzeln der Sämlinge gelüftet werden.

Im C̈brigen gilt fiir diese saat, was hereits fiir die saat auf die dauernden standorte gesagt wurde. Hinzuzufügen ist nur noch. dass die samenheete bis zum Erscheinen der Keimlinge mit Zweigen zu bederen siml. Wem die Gefahr vorliegt, dass der samen ron

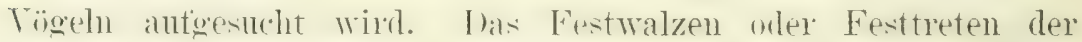

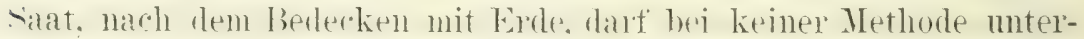

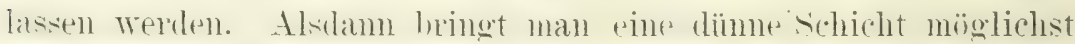

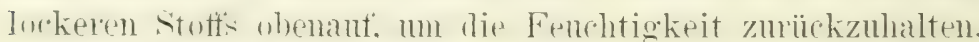

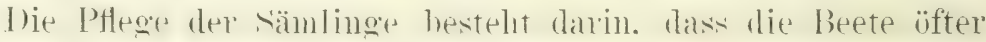

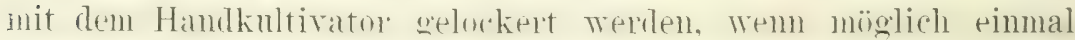

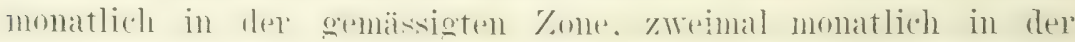

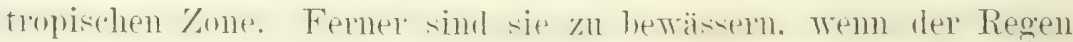

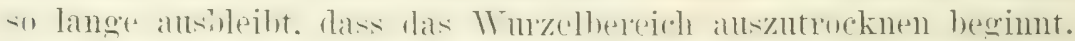

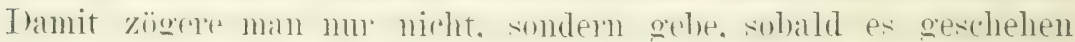

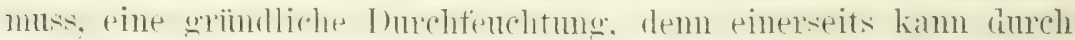

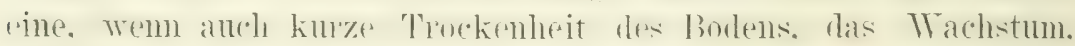

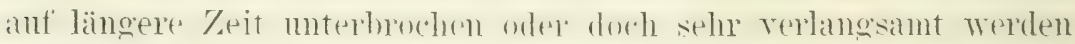

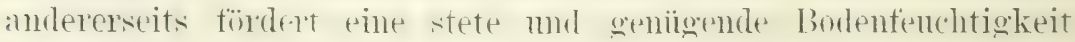
dif Entwickelung der Sämlinge im hohen Grade. In Frimnermo ist zu halten. dass eine häutige bodenlockerung. wie vorstelend moptohlen. der Frhaltung mo Bildumg von Fenchtigkeit sehr 


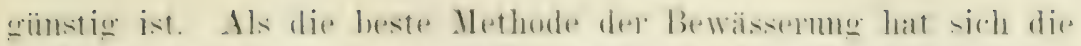

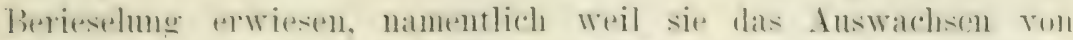

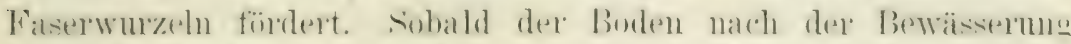

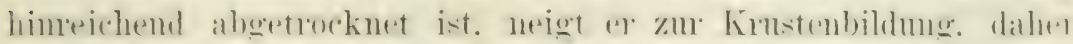
er sofort mit dem Handkultivator zu bearbeiten ist.

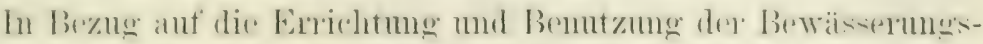

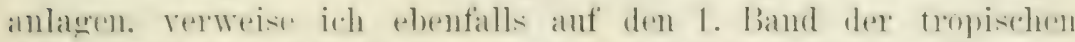

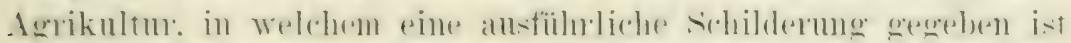

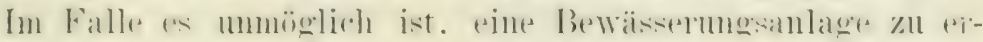

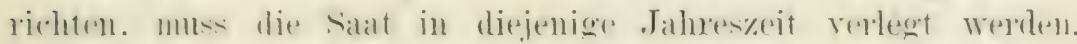

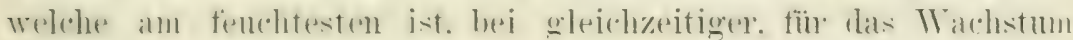

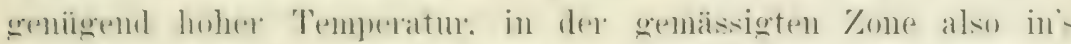

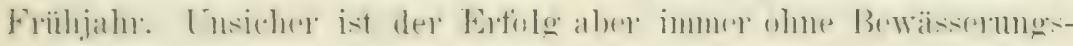
anlage.

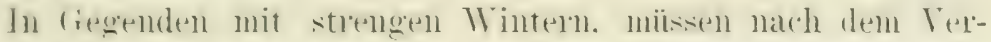
schwinden des Frostes die Sämlinge genan besichtigt und alle.

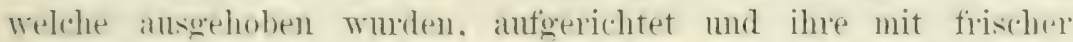
Frde bedeckten Wurzeln sorosam mit der Hand niedergepresit werden.

Fiir Eichens:ämlinge ist pine besomdere Behandlung anzu-

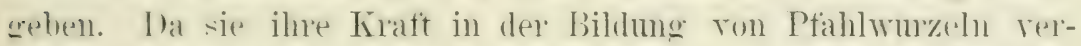

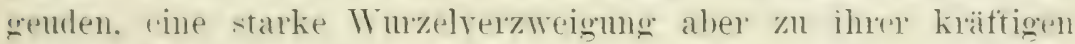

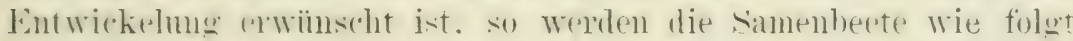
herererielitet : anf eine Lage zerbrochener steme werden die Ficheh

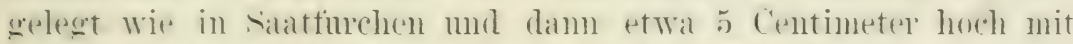

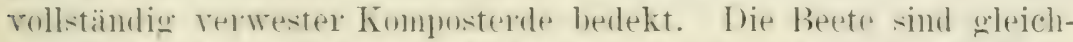
mässige fentht zu halten und das Resultat ist. dass die sämlinge

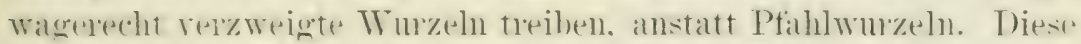

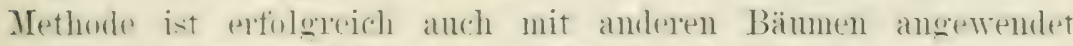
worden. dir ihne Pfahluwrehn auf Kusten dex Faserwurzeln atlszubilden pflegen.

Wenn die sämlinge etwa pin Tahn alt simb. sollten sie ant"

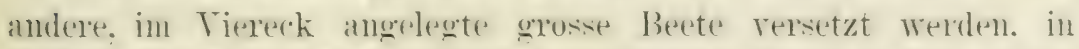
Reihen. die 80 bis 100 centimeter anseinander liegen und in einem Abstand von 25 Centimeter in den Reihen. Diese Pflanzweite ermönglicht die Anwendung des Pferdekultivator's für die Bearbeitung lles Bodens. loie Arten. welche ihr Laub abwerfen, miissen im bläterlosen Znstand versetzt werden. fïr die immerorimen Arten gibt es wohl auch eine \%eit geringeren saftlusses allein man 
brande discolloe nicht abzuwarten; $10 m$ so wichtiger ist a. ihm THzeln nidht trocken werden zu lassen. Sind die Wurzeln eines immereriinen Bämmchens trocken geworden. da darf man es verloren erachten. Die emopäischen Forstlente halten die Verpflanzung der Vadelhölzer am zuverlässigsten, wemn sie im Frihjahr ih: Tiachstum fortzusetzen begomem haben, was sie durch Austreiben von gelben Zweigspitzen bekunden.

Beim Verpflanzen der Sämlinge muss man bestrebt sin, mïglichst viel Erde an den Wruzeln zu lassen. und da es bei ihrem dichten stande nicht angänglich ist, einen Erdballen mit auszıheben. so tancht man die Wurehn unmittelbar nach dem Ansheben in einen bereit stehenden Kübel mit zähem Schlamm. Dic so behandelten Sämlinge werden in einem mit einem nassen Tuch iiherdachten Korb gestellt, der sofort nach den Pflanzstellen getragen wird. Wem er gefiillt ist. Möglichst rasches Tersetzen der sämlinge. einerlei von welcher Art. ist als streng zu befolgende Regel zı botrachten. Tergessen darf aber nicht ein wichtiger 7weck der Verpflanzung werden: das Pikieren der Wrurzeln. das heisst das Abscheiden der Spitzen der stärsten Wurzeln mit einer sharfen scheere. Das Bäumchen ist dadurch gezwungen, seine Wuzeln zu rerzeigen und je mehr es dieselben rorzweigt. desto besser ist es mit Nährorganen ausgestattet.

Auch die aus fremden Baumschulen bezogenen Bäunchen sollen. Wem irgend möglich, mmittelbar nach Empfang angepflanzt, werden. Kam es nicht geschehen. so sind sie zeitweilig in einen (traben zu stellen, der so hoch mit schlamm angetüllt wirrt. dass die Wmzeln bedeckt sind.

Fiur die Anptlanzung sei der Beachtung emptohlen. dass ts die Reabeitung des Bodens mit dem Knltivator sehr erleichtert, wenn die Reihen shommgerade sind. Die Benutzmg der Gartenshmur ist daher athoten. Bei der Anpflanzung im grossen Massstab nag man durch einen geschickten Pflüger seichte Furchen in dem bezeichneten Abstand ziehen lassen: ïber die Mitte jeder' Furche winl die Gatenschnur gespannt, welche mit angekniupten Händchen in Ab-tande ron 25 Centimeter behangen ist. Bei be-hränkteren Anptlanzungen spannt man erst die Gartenschnm und luht dann mit einer Schanfel ihrem Lante entlang eine Furche ans. Tem diese Torbereitung getroffen ist, legt ein Arbeiter wri jertem Bändchen der Gartenschnur einen Pflinzling. ander 
Arbeiter heschiftigen sir.h mit dem setzen. Es is dabei zul he-

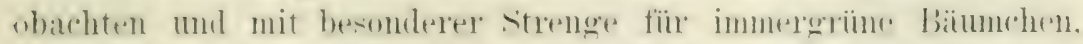

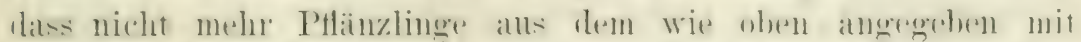

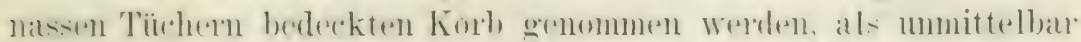

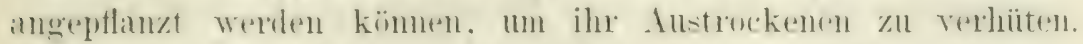
llesem \%werke phtspridht alloh trïhes, feuchtes Wetter, das mall

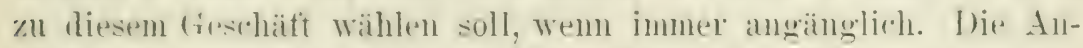
ftlanzung geschieht, indem dio linke Hand rinen P'tlänzling in dir.

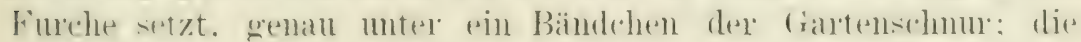
rechte Hatnel fiillt die Furehe an dieser stelle mit Erole ans.

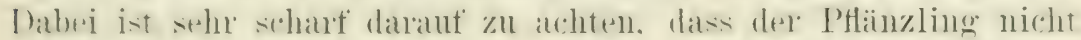

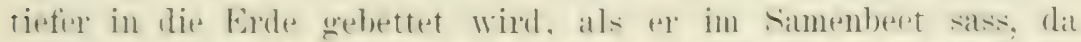
sonst die Rinde äber dem Wuredhals tanlt. Woduch dats Absterben erfolert. Ther Pflänzling muss daher mit der linken Hand während der Erdeinschïtung sante aber mit zuckender Bewergug geliiftet werden. sowohl damit er in die richtige Höhe zu sitzen kommt. als anch um zu vermediden, dass sich Hohlräume unter de'n Wirzelı bilden, demn dieselben sind dem Leben des Pflänzlings getährlich.

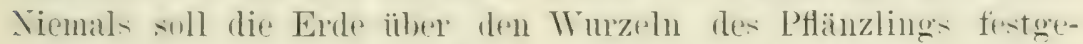
treten, somdern nurmit der Hand niedergedriickt werden.

Wrum dex Anptlanzung nicht längreses trübes Wetter tolgrt. miissen dir Pflinzlinge eine leichte Beschattmeg fiir mehreres

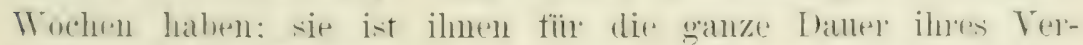

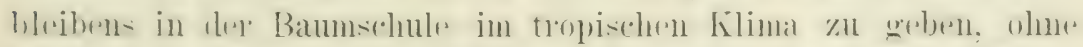

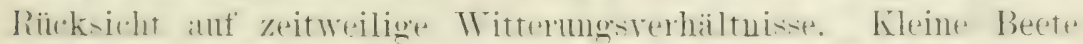

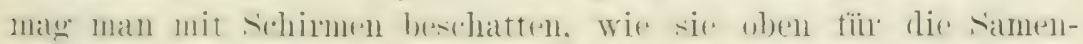

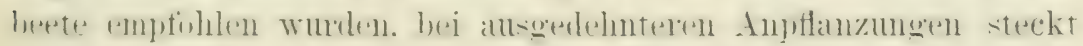
matn an elie somesnseite eine jeden P'tlanzling: rinen \%weig. ein

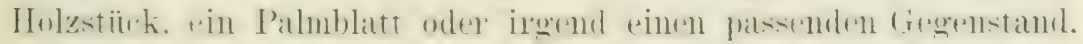

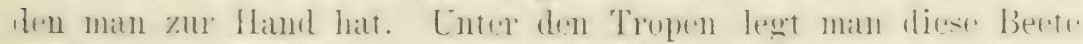

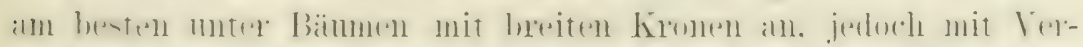

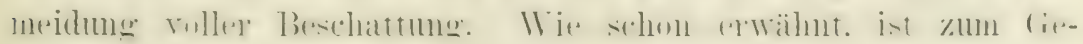

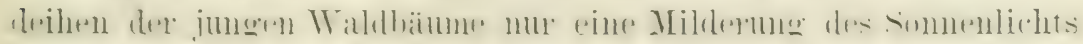
anzustreben.

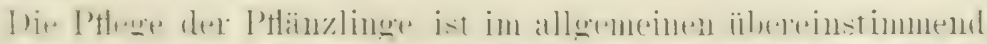

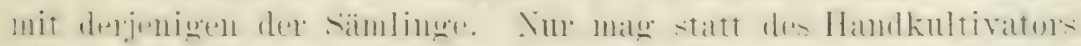

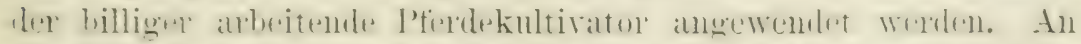

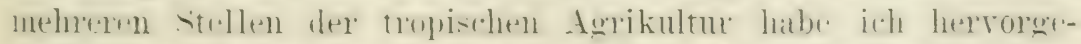

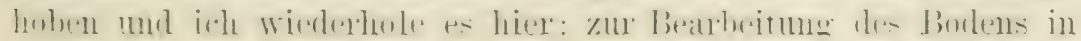




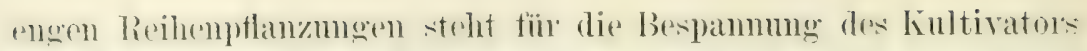
dass Manttier mü̈hertroften da. In der nächsten TTmgebung der P'thinzlinge mus: der Boden mit der Kratzhand oder Hacke gelockelt und erereinigt werden und zwar jedesmal, nachden der Kultivator zwishen den Reiben durchgefahren ist. Ein Arheiter: der den hultivator geschickt zn fïhren versteht, lässt fïr die Hacke mur wenie zu thm iibrig. doch hat er daranf zu achten, dass dex. kintirator so sedeht läuft. Im nicht die Wurzehn der Pflänzlinge in ilurer Lage zu stören.

Ohme \%weifol ist es rorteilhaft, ein zweites Mal zu pikieren. num die Nïhorgane dex Bäumehen noch weiter zn rervielfachen und damit ihre schnellere und kräftigere Entwickelung herbeizufïhren. In dre gemässigten und kalten Zone fïhst man diece Handlumg gewöhnlich ans. indem man die Pflänzlinge im folgenden Tahre inrer Verpflanzmig auf ein anderes Beet versetzt, wo man sie nochmals ein Jahr stehen lässt. Dieses Verfahren hat jedenfalls die Schattenseite, dass das Wachstum der Pflänzlinge eine Fiubusse erfäht, wemn auch die Terpflanzung während der Satttuhe geschicht. ann nachteiligsten und gefährlichsten ist es für die immergrünen Bäume, also in diesem Falle für die Nadelhölzer.

In wamen Tändern hat man sich mit der Versetzung del Pflänzlinge, zum \%wecke des Pikierens, ans zutreffenden Grinden niemals befremdet. Hier wiegen die immergrünen Bänme weit ror: die Saftuthe ist teils eine kïzere, teils fällt sie ganz wey und das heisse Klima macht die Terpflanzung gefährlicher wie in der gemässigten mo kalten Zone. Es wird daher ein einfacheres und sicheres Terfahren rorgezogen, das im Pikieren mit einem scharfen Spaten besteht, während die Pflänzlinge anf ihrem Standorte beiben. Man forscht, wie weit sich die Wurzeln im Durchschnitt rerbreitet haben. damm sticht man in einem Abstand rom Pflänzling. Wo man die Nurzelspitzen zu treffen glaubt, mit dem spaten senkrecht in den Boden mil zwar an den vier seiten. In Tordamerika hat man zu diesem Zwecke, wie zmm Abschmeiden der Erdbeerranken, ein Instrument erfunden, das man sich wie einen Schubkarren mit messerscharfem Rad denken möge. Je nachdem man den Karren leichter oder schwerer belastet, sinkt das Schneidrad seicht oder tief in den Boden. Mit diesem Instrument fährt man kreuzweise ïber die Beete, in beiden Richtungen 


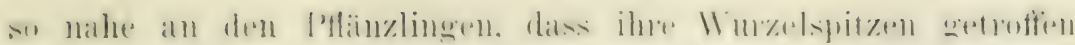
weriten.

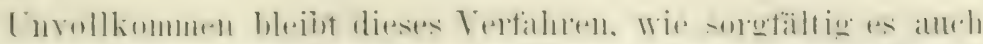

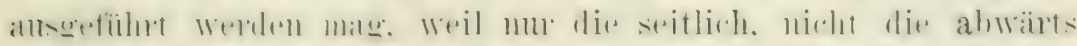

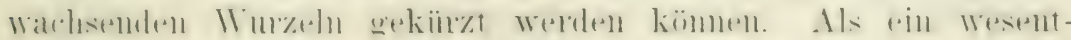

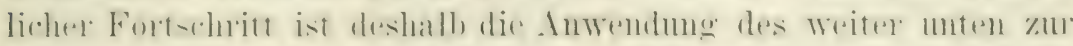

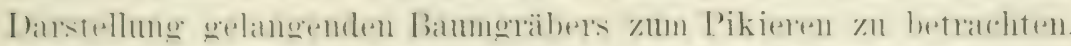

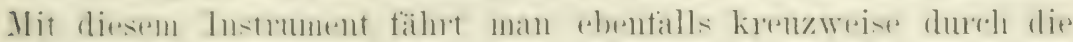

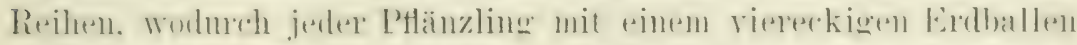

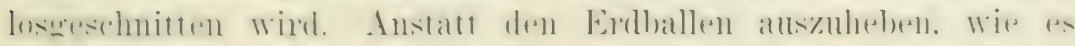

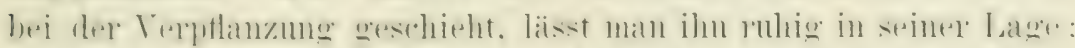

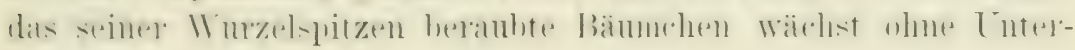
brechmmg weiter:

Zu bemerken bleibt noch, dass es tropische Bämme gibt,

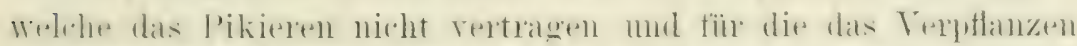

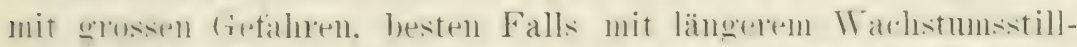

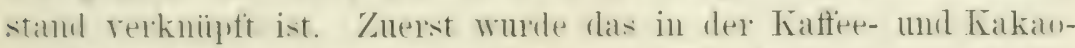
kultur erkannt, suater in der Teak- mol chinehomakultur. La die Silat anf die bleibenden standorte ans reschehedemen Grimden nicht

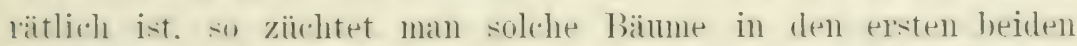
Jahnen einzeln in Getaisien. Im sie nit denselben in die Erde zu setzen oder un sie nit den vollen Errballen heranszmelnen und auf die bleibenden standorte zu repptlanzen. T)ie indische Forstrerwaltme hat ihre Teakwälder und teilweiste anch ihne chinchonat

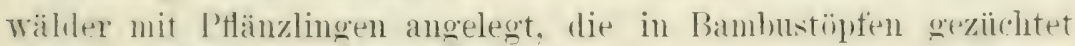
wurden. Sur die where Hälfte des Bambuscohs wird zu Tïpten vershohitten, weil es noch weich genug ist. un. in die Eole gehratht, bald zu verwesen und damit den Wuzeln der bäunchen Dhurchange zu gestatten. Jedes stengelglied des Bambusohrs motel dem hinoten alogeschnitten, gibt eines Topt rom 15 bis: 20 \%entimeter Länge und \& bis 10 Zentimeter. Inurehmesser, dem pin Loch in den boden geschlagen wird. Die Fassmgsklaft qenügt rollständig für das zweijährige Wachstum des Pflänzlings. Dis Töpti werden mit reicher Erole getëillt. die vorher in einem

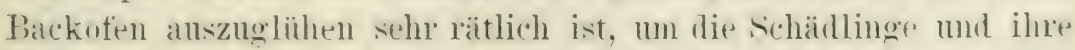
Eier zu vernichten. Welche sie wa enthält. In jeden Topt werden drei samen gelegt. die antisurosicenden sämlinge werden bis aut den kräftigsten entfernt. sobald sie sich so weit entwickelt haben. um pinen sicheren Vergleich zu gestatten. Die Taiphe werden in 


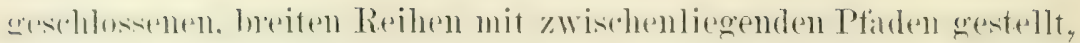

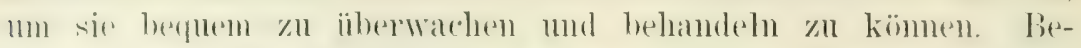

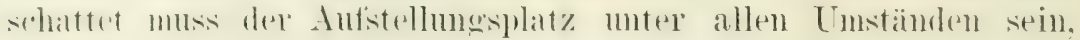
rin Hain ron breitästigen Bämmen ist rorgïglieh für diesen t/week

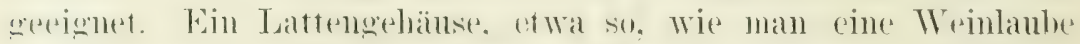

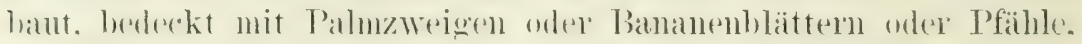

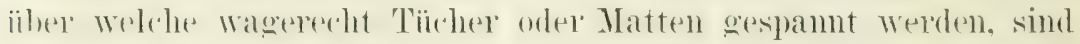
andere häution angevendete Beschattumgsmittel. Nicht zu empfeblen

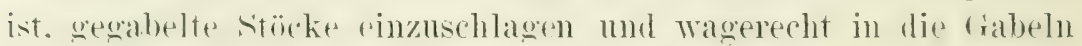
welegte störke mit Bananenhlättern oder Zweigen zu bedecken. Weil diese lose Bedarhung vom Wind Weggerissen nond anf die Pftänzlinge geworfen wird. Welche dadurch zu Schaden kommen.

Elhenso widhtig wie die Beschattmo. ist die danernde Fenchthaltung der Erele in den Töpfen. Zritranbend mond mühsam ist es, die Befenchtumg täglich mit der (ijeskame vorzunehmen, arbeitsfördernder ist die Gartenspritze. Wenn eine wie im 1. Bande der tropischen Agrikultur beschriebene Wasseröhrenleitung vorhanden ist. geht das Begiessen mittels eines angeschaubten schlauches lassh und milhelos rom statten. Als der beste Plan aber hat sich "rwieven, eimen sanft geneigten Aufstellungsplatz zu wählen. der wie eine Teme gestampft wird. Ceber diesen Platz wird ein sich iiber die ganze Breite ausdehnender, dauemder Wasserstrom geleitet. Termöge der Haarohrkraft steigt das Wasser in die Erde der Töpfe, nachdem es das Bodenloch durchdrungen.

Bekauntlich wird in dex Blumengärtnerei hänfig das Wasser nur in die Tntersätze der Töpfe gegossen, von wo aus es zu den Truzeln der Blumen dringt. I)eses Vorbild ist mit geeigneter Abändermg nachgeahmt worden in jenem Plan, der sich vorzïglich bewährt hat. Die Erde trocknet nicht aus durch die Nachlässigkeit in der Überwachmg. sie wird aber anch nicht mit Feuchtigkeit übersättigt, sondern empfängt ohne Lnterbrechung die für das Wachstum günstigste Wasserzufuhr.

Wemm die Bäumchen etwa 2 Tahr alt sind, werden sie mit den Bambustöpfen an ihre danernden standorte gesetzt. Wie bereits angedentet, rerwesen die Töpfe rasch und die Wureh können sich ungehindert ausbreiten.

In anderen tropischen Gegenden hat man gliicklicke Versuche gemacht, Kürbchen aus Schilf, Binsen. Span oder ähnlichem 


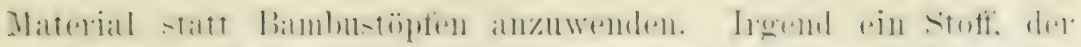

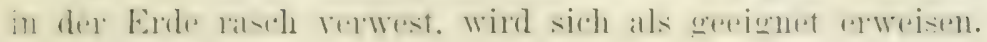

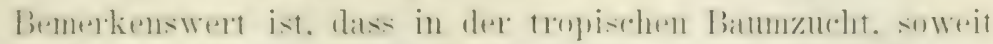

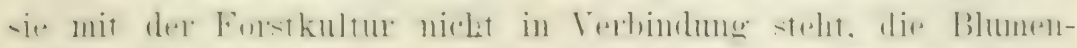

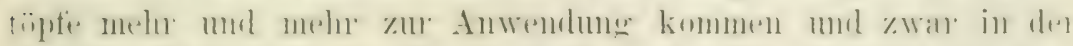

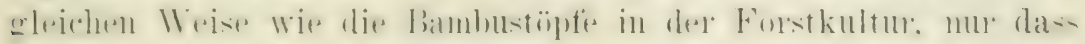

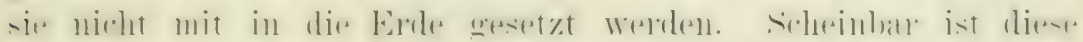

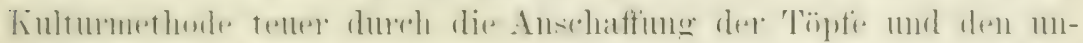

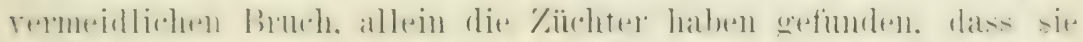

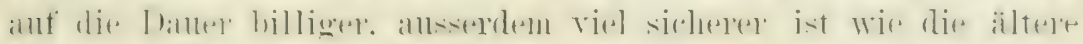

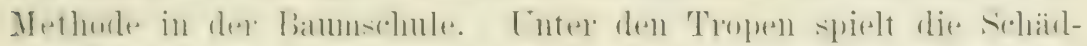

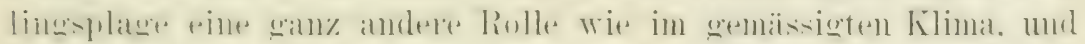

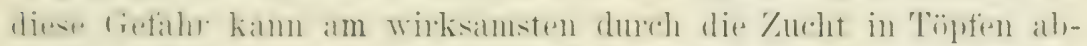

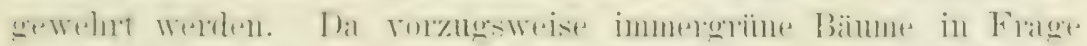

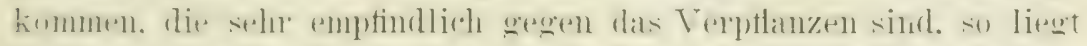

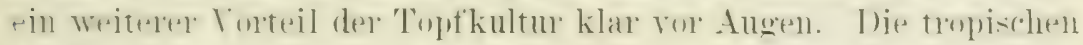

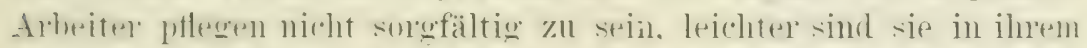

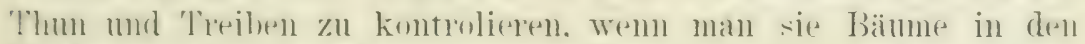

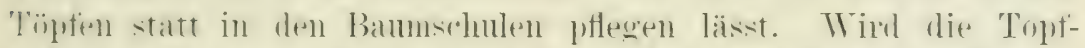

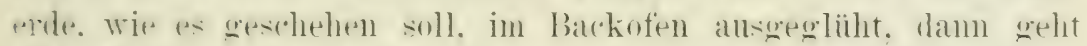

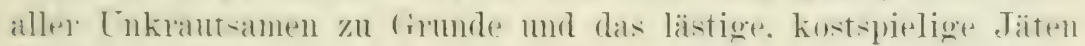
fallt wer. das in einer tropischen banumsebule mindestens ein-

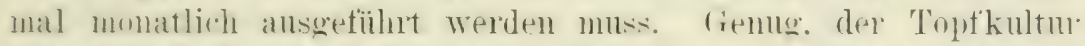

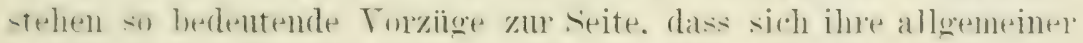
werdende Beliebtheit wohl begreifen lässt.

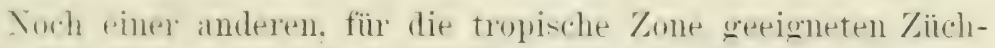
mugrmethule ist zu gedenken. Tistchen. su gross. dass sie hequem getragens werden kïmnen. etwa 10 \%entimeter tief und mit

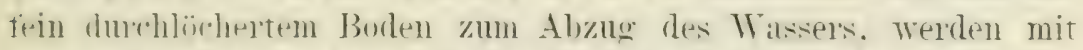

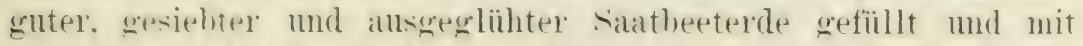
Holzs änem wher Papplecteln in Abteilungen getrennt. von welchen

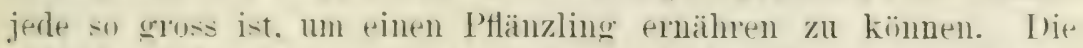
siheidewände sollen verhindern. dass sich die Wurzeln der PHlänlinge inander rerwickeln und das Ausheben jedes Pflanzlings nit rine-ln wohlerhaltenen Erdhallen sicher und schnell vom statten greht. Ile saat und Behandlmgg erfolgt genan so wie oben fïr die 'Töpteangegeben: zur Versetzung trägt man die Kistchen nach den Pflanzstellen. hebt mittels einer Kelle Pflänzling fïr l’flänzling mit 


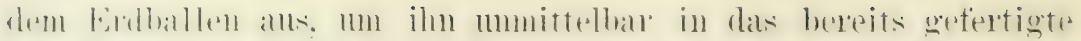
Ptlamzloch zul setzen.

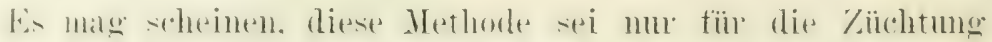

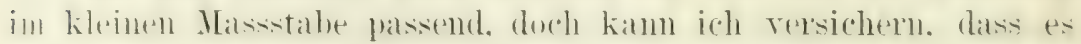
fiannschulen wiht. wo jührlich rinige hundertausend Bäunchen - nantentlich anstralische Gummibämmehen - in solehen Kistchen

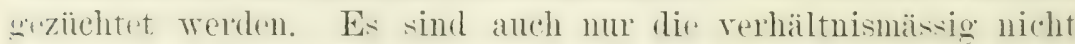
Bredeutenden Anschatfiungsosten der Kistrhen. welche in Betracht kimmen. dem der beanspruchte Ram ist nicht grössen als bei der Zürohtme anf Saatbeeten, das .Täten fällt weg und die Terptlanzmer ist billiger. Bei dem Setzen anf die danemden stand-

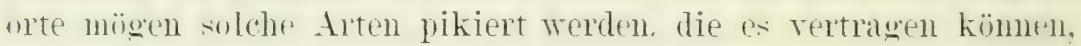
indem man ohme beriihrung des Errballens die äberstehenden Wuzelspitzen abschneidet. Hält man ein zweimaliges Pikieren erwimscht. mnd will man diese Zuchtmethode beibehalten. daun ist das erste Pikieren bei einer Terpflanzuny in tiefere Kisten mit yraiseren Abtrilungen vorzunehnen. dem die I'flänzlinge beduiufen num einer lïngeren Zeit bis sie auf die daternden standorte iibertragbar sind. Wohl ausfïhrbar. aber wrenger zu empfinleu ist. die PHänzlinge nach dem Pikieren in die nämlichen Kistchen zuyiuckzusetzen. Ein ähnliches Verfahren ist bei der Topfkultur finzuhalten, mit der Beachtung: dass die Töpfe nicht nö̈ser sein sollen. als durchans notwendig ist und zwar alls zwei Gründen: die nicht von Wurzehn durchzogene Erde neigt zum Versautern mond an der Toptwand pflegen sich die meisten Wruzeln zu bilden. Es mird num begreiflich sein. watum nach gärtnerischer Regel, dex Same in kleine Blumentöpfe gesit und den sämlingen crest beim Pikieren grössere 'Töpfe gegeben werden.

\section{Die Bewurzelung ron Ablegern, Stecklingen und Schnittlingen.}

Dieser Fortphlanzungsmethode bedient sich der Forstmann mur selten, sie bleibt gewöhnlich anf die Gattungen der Weide min Pappel beschränkt. Ansführbar ist sie zwar noch mit manchen anderen Waldbäumen, kann aber nicht empfehlenswert er'scheinen, weil die Bewurelung mangelhaft ist und bleibt, die Bämme daher nicht nu in der Entwickelung zuriickbleiben. sondern anch eher absterben wie solche, die aus samen geziuchtet wurden. 


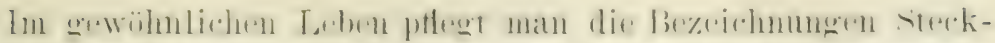

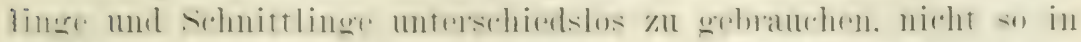

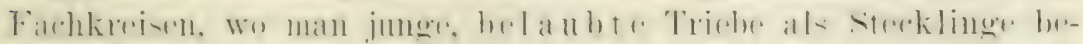

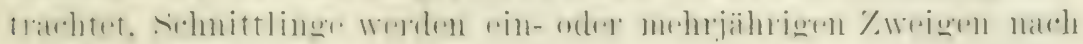
dem Blattfall entnommen.

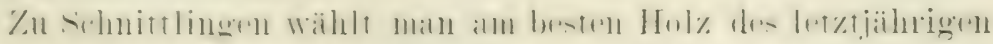
Tinchses, zur Zeit wenn es blatterlos ist. Wolıl bewmyeln sich

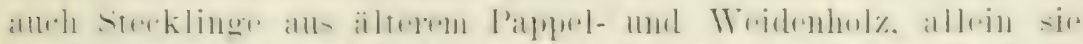

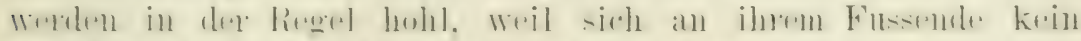

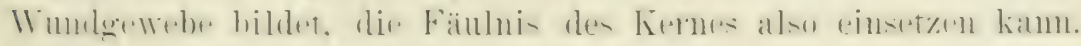
Selhstrerständlich ist die Lebensdaner kur.

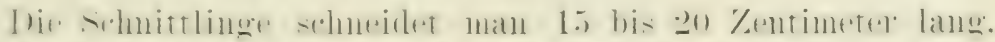

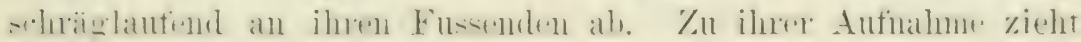

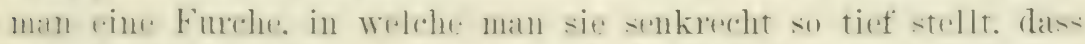

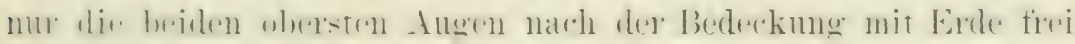

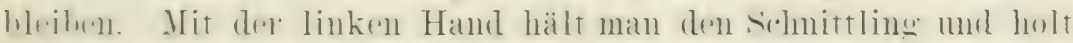
mit dex reeliten Halid Erde herbei.

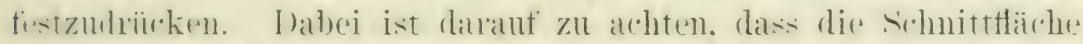

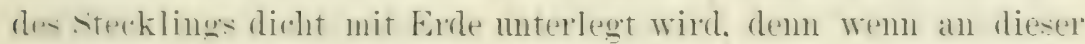
Strlle pin Hohlraum hleibt. bildet sich in der Regel hein Wind-

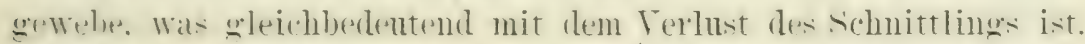

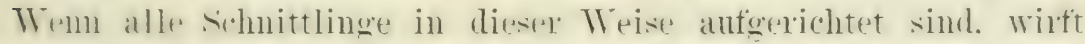

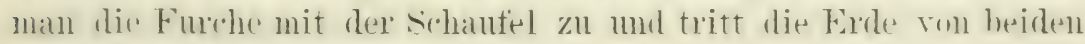
Seiten gegen die Schnittlinge fest.

1) ie behandlung dex schnittlinge stimnt mit dejenigen iblerein. welch. when fïr dir sämlinge angegeben worde.

Wrom man sinhittlinge in Herbst schneitet, muss man sie Währeml dis Winter's an einem frostfreim Orte. monter. einer passenden Bedeckung aufbewahren. Tas empfehlenswerteste Terfahren ist, sir in einem Keller in feuchtem sand zu betten. Fs begimnt sich damn shon während der Lagerung das Windgewelue zu bilden. wodureh rie Bewuzelung im Frïhjalu beschlemigt wird.

sterklinge kïmen mit Aussicht auf Erfolg nur in Kasten orler Täpfen bewurzelt werlen. die mit reinem sand gefïllt sind. der gleichmässig fencht und warm zu halten ist. Dieses Vertahren ist fül dir Forstkultur zu umständlich, 1 in in Betrareht konmen zul kïmnen.

Soch seltener kummt die Bewurzelung von tblegen in der Furstkultur vor. tür die Sardelhölzer ist sie sogar vollständig aus- 


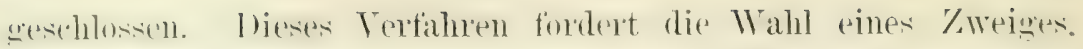
der sich zum mindesten mit seiner oberen Hälfte zur Erde nieder-

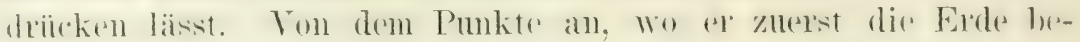

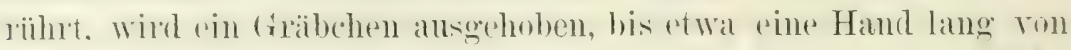

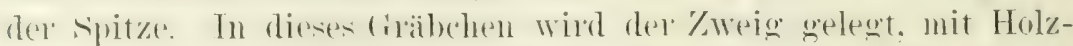
haken befistigt und mit feinem Humbs hoch bodeckt. Tateh rinem

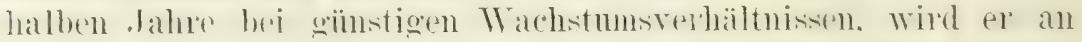

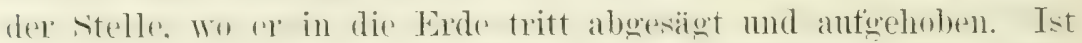
die eingebettet gewresene stelle lang, so schneidet man einen theil ab. damit die bewtuzelumg nicht länger ist. als bei cincm gheirh-

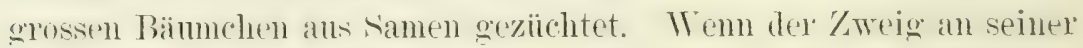
biegestelle hall durohschnitten werden muss. ist ex mindestms muter den 'Tropen notwendig. den Saft aufzusangen. da er sonst

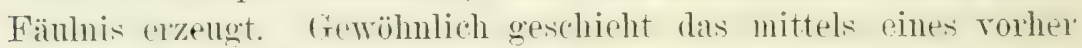
im ofen getrockneten Backsteins. der ant die schnittläche grebunden wird. Lnter den Tropen macht man zuweilen an Bämmen, ron wethen schwierig samen zu gewinnen ist. in langen. schmalen. mit Erde gefüllten Kistchen Absenker. In der Krone. wo Gelegrilheit gebuten ist einen schönen Zweig abzusenken, hindet man das Kistchen fest und vertäht im C̈brigen wie bereits angegeben. Tn der Mitte der Regenzeit ist die meiste Ansideht fïr das Gelingen dieses Verfahrens vorhanden. Nach 3 bis + Monaten haben die Absenker Wurzeln grtrieben und werden nun abgeschnitten, häufig um als ,stockpflanzen" zu dienen. Im Treihhanse wird ein 50 Zentimeter tiefes Beet ans selur fruchtbarer Erde hergestellt. dem man grelegentlich etwas Bodenwärme geben kann, doch ist es nicht durchans nötig. In dieses Beet werden die Stockptlanzen in Abständen ron 15 \%entimeter gesetzt und sobald sie fest angewurzelt sind, dienen ihre Triebe als Stecklinge. Auf diese Weise kamm man sich eine lang anhaltende Quelle ron Stecklingen rerschaften, die gerade so behandelt werden, wie die ron den Bäumen geschnittenen stecklinge. Zuweilen wird auch ron der Fortuflanzung gewisser Waldbäume durch Teredelung auf passende Tnterlagen gesprochen, doch sind in der Regel Zierbäume gemeint, welche in der Landschaftsgärtnerei dienen sollen. Fiir die Forstkultur kamm dieses Verfahren ausser Betracht bleiben. 


\section{Die Anpflanzung.}

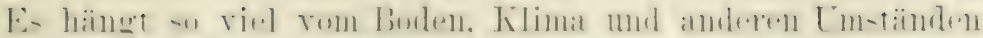

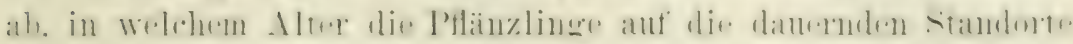

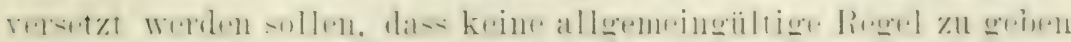

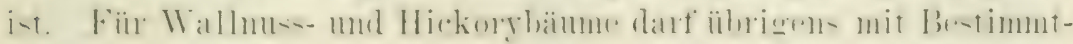

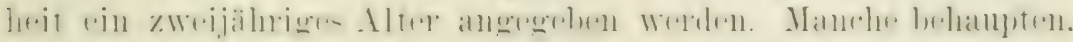

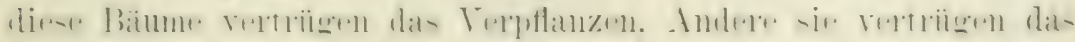

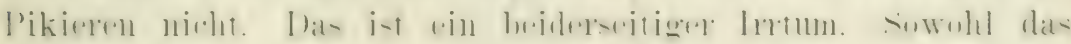

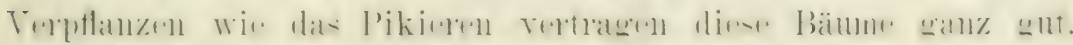

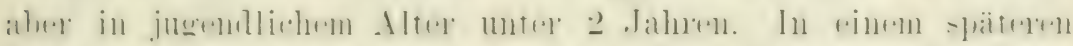

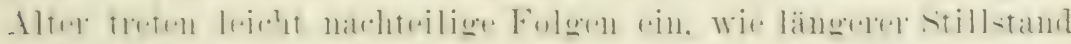

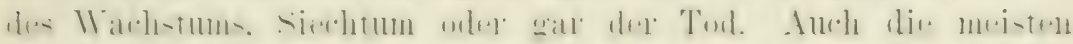

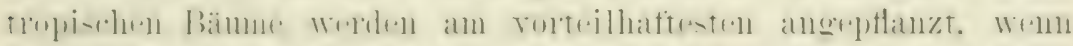

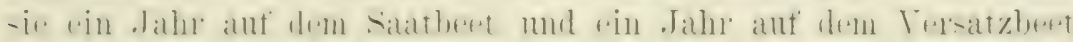

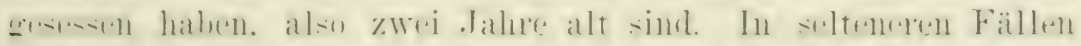

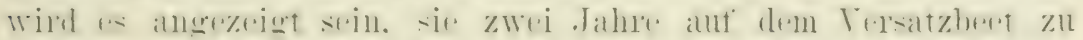

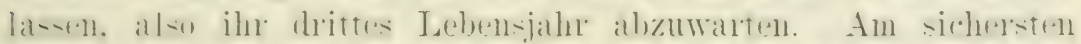

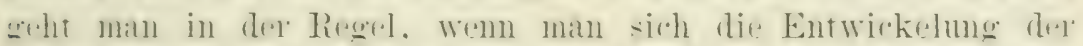

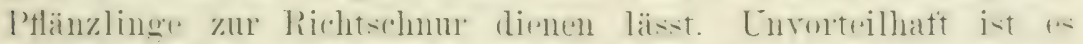

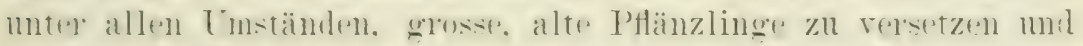

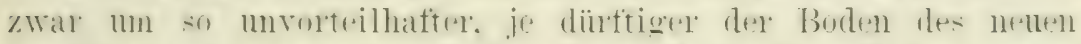

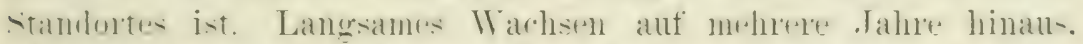
mler andautemder Warh-tumstill-tand siml dir. Folgen. In all-

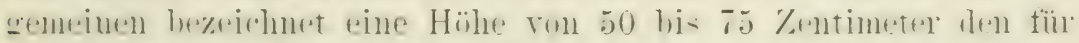

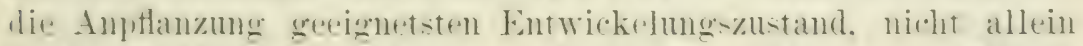

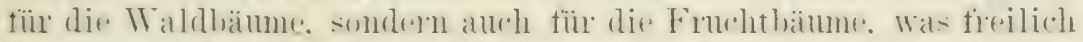
die europäischen Züchter nicht einsehen wollen.

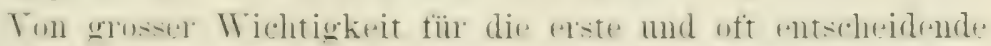
Entwickelung der Bäune ist sine melumalige Bearbeitunge des Bodens mit dem Pflug nud Contergrmelpflug. moter dor sellsetrel-

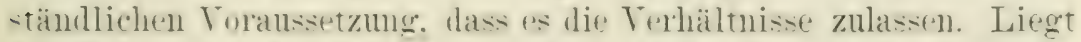

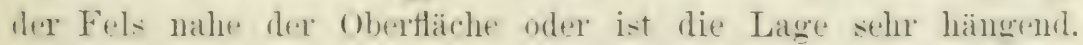
lam kamm dex Pflug nirht zur Anwemdung kommen, allein es wird läufig versäunt, iln anzuwenden. Wo die Möglichkeit vorliegt und das ist tadelnswert. Die griundliche Bodenbearbeitmer macht sich ïherreichlich bezahlt durch tine um Jahre eher herbeigetiihrte Finte. in vielen Fablen auch noch durch mehr und wertrolleres Holz.

Eluenso hat als Beslingung zu gelten, dass die Bäume in schnurgerade Reihen zu setzen sind. Wemn ansführbar. Auf felsigem. 


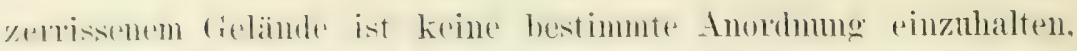

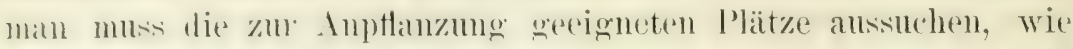

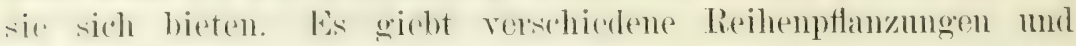
jerle hat ihe Mnhänger. Man kamn die Bätume so pflanzen, das: je vier ein rechtwinkeliges Viereck bilden. indem man die Reihen in sleichweiten lbstinden krenzweise iiber das crelände zieht. Nitch einem andern l'lane Werden dio Bänme in entegengesetzte Refihen ereptlanzt. das heisst. die Reihen werden wohl in gledehen Absänden gezogen. jedoch so. dass die Bämme der zweiten lieihe desn ILittelpumkten der Lä̈cken der crsten Reihe gegenïber stehen. dir Bäıme der dritten Reihe stehen den Iittelpunkten der Lüicken der zrreiten Reihe gegeniuber, also mit den Bämmen der ersten lieihe in einel Linie. So wird fortgefahren. Drei Bämme bilden rin Dreierk und jerler Bamm steht im Mittelpunkte eines rechsecks. Ku Gunsten diestr. Anordnung wiod gesagt, anf derselben Fläche

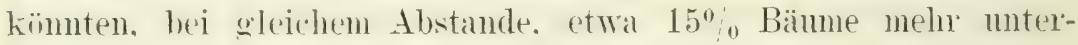
sebracht werden. wie bei der rechtwinkeligen Pflanzmo und doch sfi den Wurzeln eine ungehindertere Ansbreitung und den Kronen pine grössere Lichtfïlle gegönnt. Damit ist eine unlengbare Wahrheit ausgesprochen. die jedoch fiur die Waldbaumzucht eine weit geringere Bedeutumg besitzt. wie für die Obstbanmzucht. Nach einem dritten Plan kïnnen die Reihen einen weiteren Abstand hahen, als die Bäume in den Reihen gepflanzt sind. Diese Anordnung bin ich geneigt. für die tropische \%one als die empfehlenswerteste zu halten aus den folgenden Grïnden. Wrerden die Reihen 1 Neter ron einandex gezogen und die Bäume in einem Abstand rom 50 Centimeter in den Reihen gesetzt, so ist die Möglichkeit gegeben. den Boden die beiden ersten Jahre mit dem Pferdekultivator zu bearbeiten, was zwar in allen \%onen, ganz besonder's aber in der tropischen, ron hervorragendem Nutzen ist, weil hier das Lnkraut am üppigsten whchert und der Boden am härtesten von Regengiissen festgesehlagen wird. Gleichzeitig findet eine enge Pflanzumg statt und eine solche ist in der Forstkultm nach Möglichkeit zu erstreben. Es gilt. den Boden bald so zu beschatten. dass die Terdunstung der Fenchtigkeit gehemmt ist und kein Lnkrant antkounmen kann. die Bäumchen sollen sich gegenseitig vor dem Wind und zu heisser Besonnumg ihrer stämme schïtzen, der wichtigste frund aber ist. gerade, hohe, astfreie Stämme zu erzielen. Als Regel sind alle Bämme viel leichter geneigt, eine niedrige. breite 


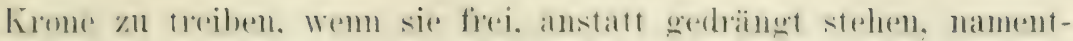
lirh in einem trockenen. Windigen Kimas. Dire Forstlente pflegen

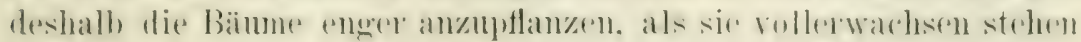

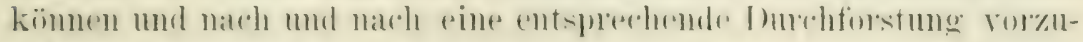
nehmen.

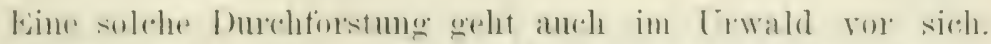

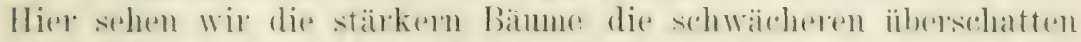

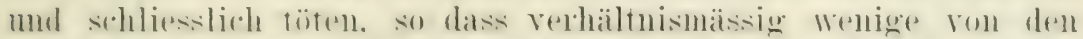

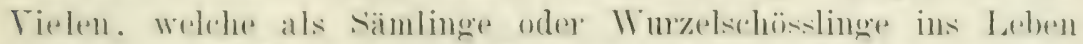

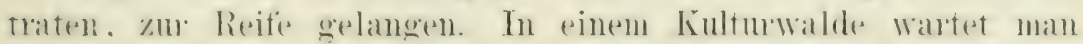

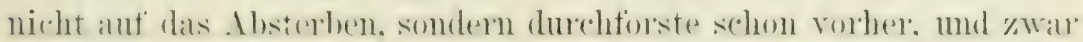
an bestimnten zeitpunkten und in der ganzen Anptlanzmen. Wind

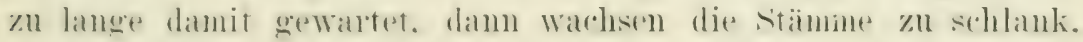

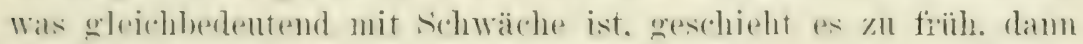

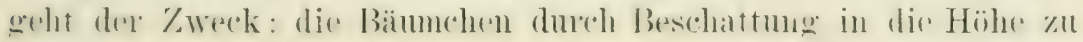
treiben. verloren. Wine bestimmte Regel. Wamn durehforstet werden

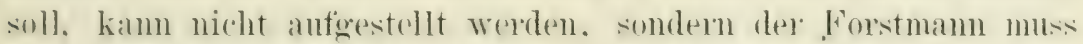
nath den vorliegenden Lmstanden sich ein Loteil ibler den richtigen

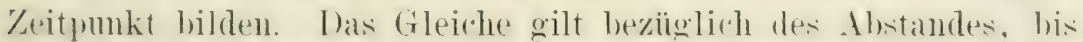

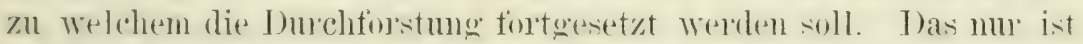

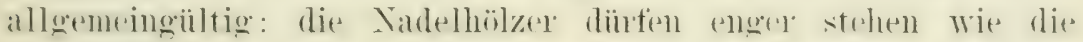
Laubhölzer.

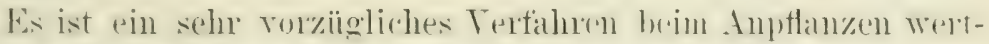

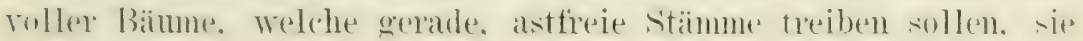

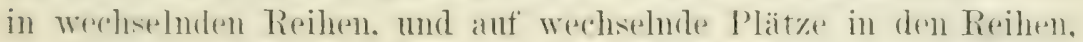

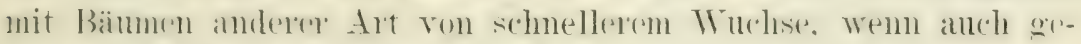
ringerem Wert zu setzen. Die Letzteren sind abzuholzen. Wem

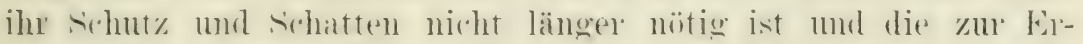
haltumg bestimmten Bäume desl ganzen Boden beschatten. Sio

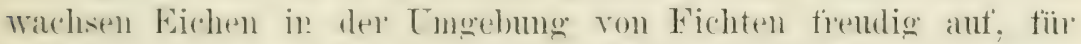
Wallnus:bämme und Eschen bilden Weiden mol Pappeln ansgerzeichnete schut\%hämone. T)er schnellwachende ('atalpa (Catalpal

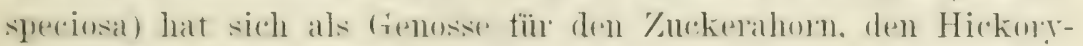
und Mahagonibaum bewährt.

Um die Anpflanzung möglichst rentabel zu matchen. ist solchen schutzbäumen der Vorzugr zu gehen, welche in jugendlichem \%astande zu einem bustimmten /wecke Terwendung finden können. heispielsweise zи Fasserefen, Hopfenstangen. Rebenpfählen, Telegraphenstangen, oder welche in ihrer Rinde einen gesuchten Gerl,- 
stoft lieteru. Pappeln und Weiden sind zu Fassreifen rerwendbar. dex' datalpar dient zu Hopfen- und 'Telegraphenstangen und die shwarze thazie Austaliens kam schon rom ihrem 5. Tahre al)

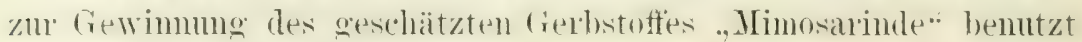
werden.

Die gemischte Amptlanzmng sollte überhampt die Regel, die monemischte dic Ansmahme bilden. Die Torteile der gemischten Auptlanzmng bestehen darin, dass die Bänme licht zu gleichex Zeit reifen, der Boden also stets beschattet gehalten werden kam.

Ferner kömnen atuf einer bestimmten Fläche mehr Bämus ernährt werden. weil die rerschiedenen Bammarten rerschiedente Ansprïche an den Boden als Tahrungsquelle stellen, und ihre Bermzehungen in teils seichteren. teils tieferen Erdschichten Nahrung snchen. Anch bietet die gemischte Anptlanzung einen gewissen sichntz gegen Stmm. Fener, pflanzliche und tierische Schädlinge.

Lngemischte Anpflanzungen sollen nur mit solchen Arten ansqefiihnt werden. welche während ihres ganzen Lebens eine dichte Belaubung bewahren. und den Boden durch eine starke Latub- oder Vadeldecke bereichern. Verhältnismässig wenige Arten hesitzen diest Eigens.haften. zn ihmen gehören die Buche, die Nadelhölzer und der Catalpa.

Es ist dabei wohl zu beachene dass die meisten Bammarten in ihrer . Jugend eine dichtere Belanhung haben. wie im zmehmenden Alter.

Auch die Verhältnisse des Bonlenss namentlich die Tiefe umd

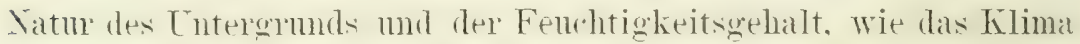

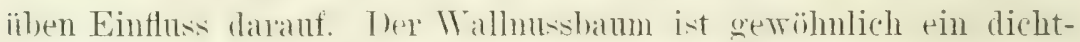
shattiger Banm. anf seivhtem Bulen nimnt er aber bald eine

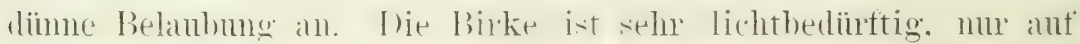
fenchtem Humusbeden vertä̈t sie beträchlichen schatten.

Anf tiefenn. ron Natur fielchtem boulen hrancht selbstrerständlich die Bodentenchtigkeit nicht durch eine eremischte Anpflanzung orler durch die Anptlanzune dirhtschattiger Bämme gewaht zu werden. Hier diirten dimmschattige Bämme angeptlanzt werden. namentlich für den Schlagholzbetrieb.

Es würde ein schwerel Misogrift sin. zu einer gemischten Anptlanzmg mehrere Bammarten anfs deratewohl zu wählen, denn es ist hierbei in Rïcksicht zu ziehen: 


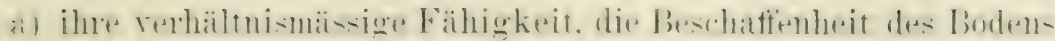
zu bewahen oder zu bessern;

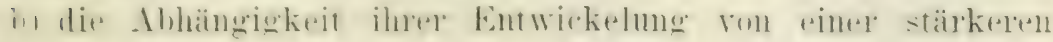
oder geringeren gegenseitigen Beschattung:

(c) der Fortschritt ihres Wachstums;

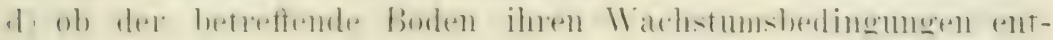
spricht.

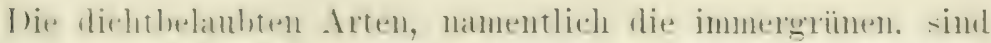

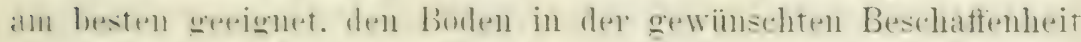

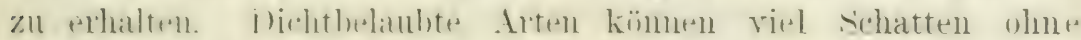

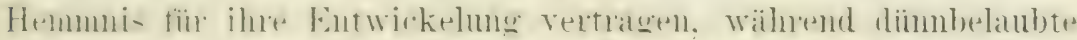

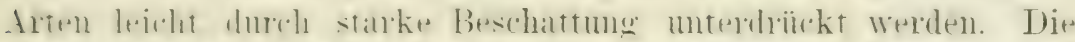

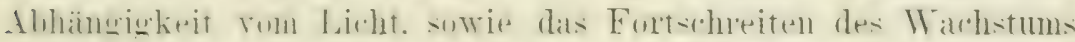

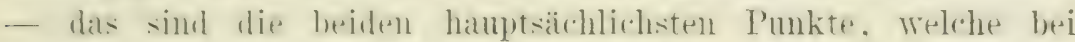

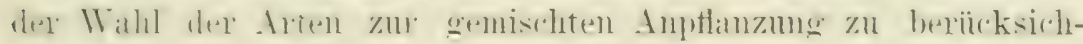
tigen sind.

In Einklange mit den rorstehemelen Bemerkmgens, stehen die tolgenden allgemeinen Regeln:

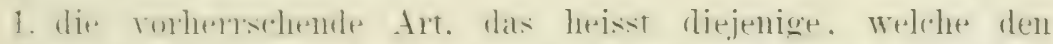

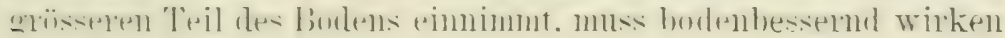
also dicht belanht sein:

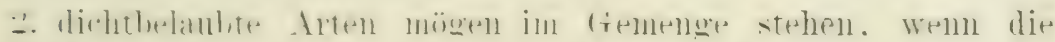

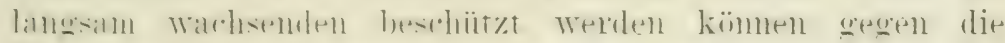

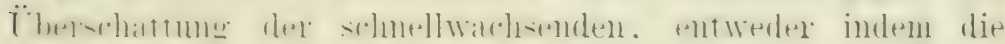
ersteren eher oder in grösserer '/ahl gepflanzt oder die letzteren zuriick- oder frühzeitig ausgehauen werden;

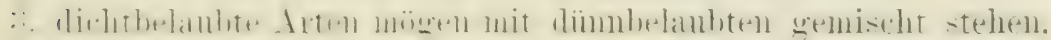
wem die letzteren eher gepflanzt werden oder scheller wachsen wie die ersteren:

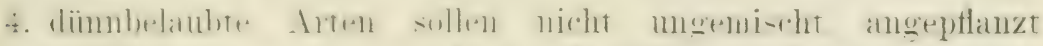

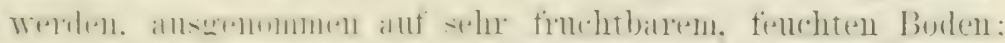

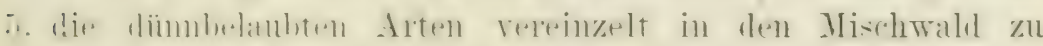

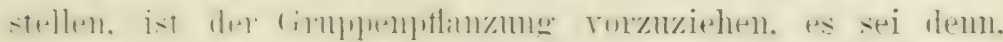

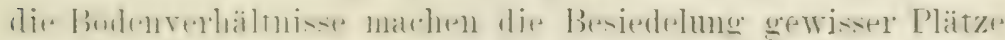

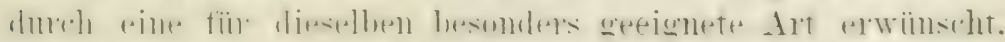

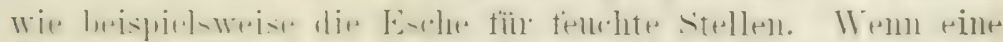

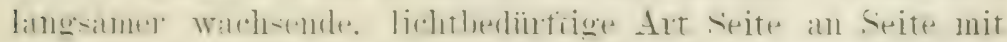

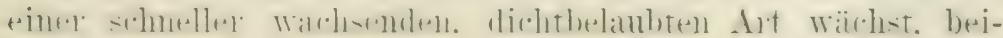




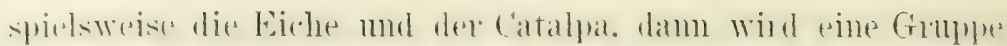

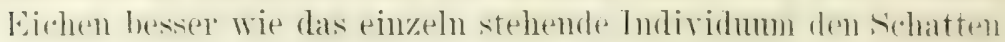
des dichtbelaubten Catalpa ertragen.

Angenommen. der Boden sei in der angeratenen Weise ror-

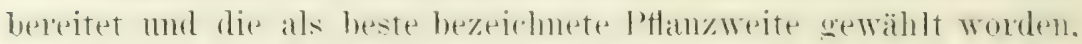

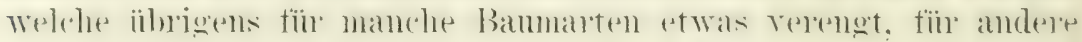
vereqüsert werden kann. dam sind die Reihen in dem thstand

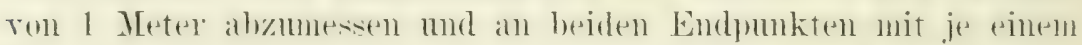

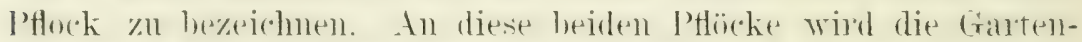

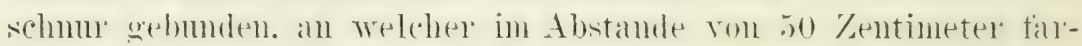

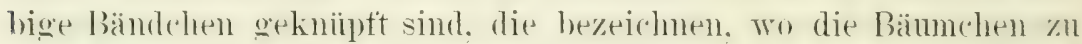
setzen sind. Des sichnu entlang wird eine Fuche gezogen. wie oben fiir die Versetzumg der Pflänzlinge angegethen. mur muss sies entsperehend tiefer und breiter sein. Ich mache daraut anfimerksan.

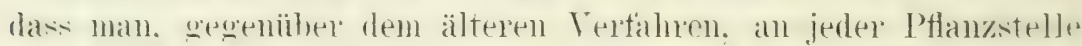

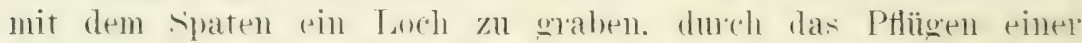
Furche eine beträchtliche Kratt- mol zeitersparnis erzielt. I)a quilt in ribühem Masse für den Anptlanzmesplan in rechtwinke-

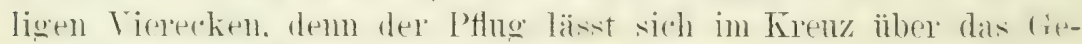
lände fiihnen mud jeder Krenzmospmkt ist pine Pflanzstelle. Nath-

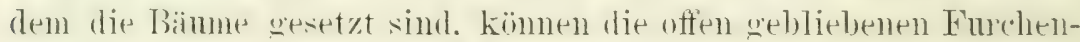

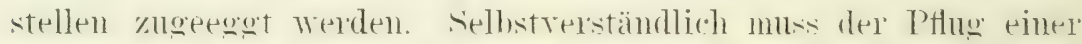
wespannten schnu entlang getiihnt werdem. dem die P’flïger sind ansserondentlich selten. Welche eine Furche ziehen kömmen. so gerade. wie der vorstehende Zweck erheischt.

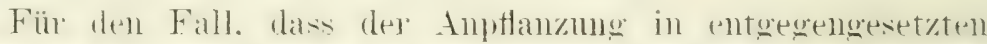

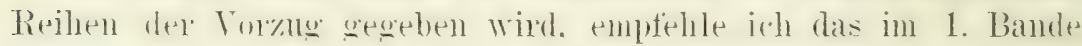

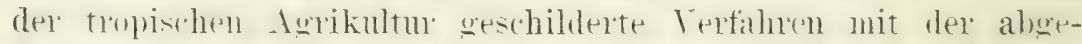
bildeten Triangel. Dasselbe hat zwar den Xachteil. dass die Ptanzstellen mit dem l'fluge nicht allscehoben werden kömmen, dageegen steht ihm der Torteil zu seite. dass jeder Baum den ihm zugemessenen l'lat\% mit der grössten (imanigkeit eimmimmt. die Reilen mithin mlsterhaft gerade werden. Anf geborochenem Gelände wird man rielledoht diesen Anpflanzmesplan am zusagendsten finden.

Es ist zumärhst der Behandlung des Pflanzemmaterials zu getdenken. Wo ältere Tälder vorhanden sind. wird man die wilden Nämlinge zur Auftorstung benutzen wollen. Dagegen ist rom forstwirtschaftlichen Standpunkte ans nichts einzuwenden, nur die Vorsicht ist anzuraten. solche sämlinge anszuheben. welche nicht sehr 


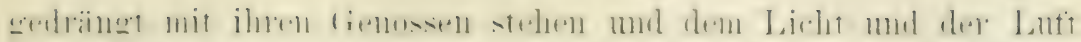

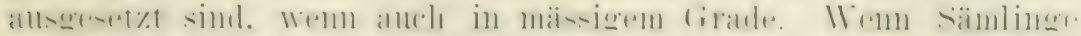

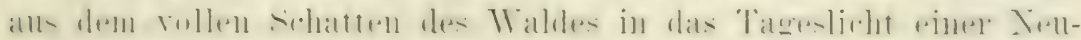

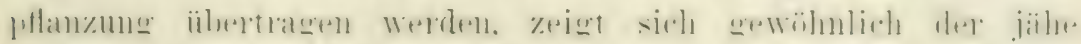

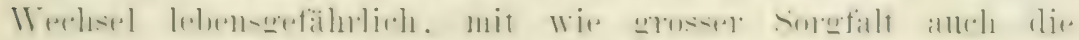

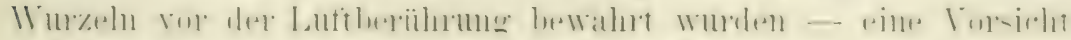
die nicht ernst genng heachtet werden kann.

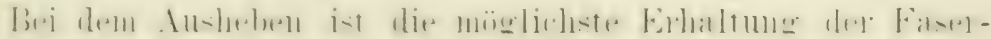

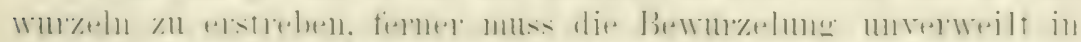

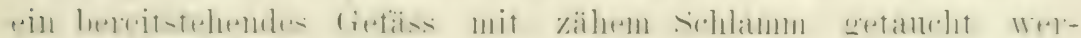
den. einerlei ob die Sämlinge den Nadelhölzern oder Laub-

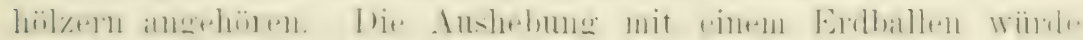
rorteilhatter sein, allein sie ist bei der in einem Walde herr-

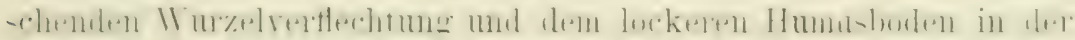

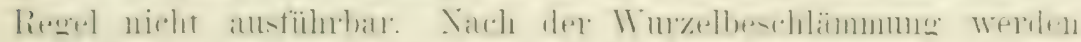

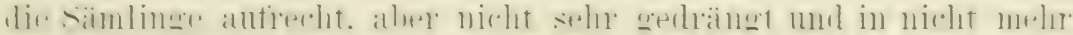

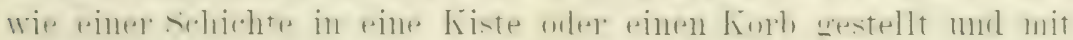

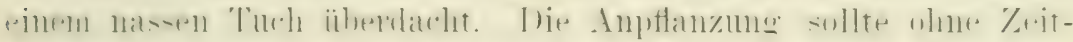

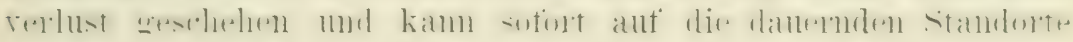

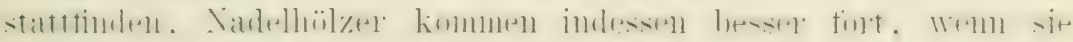

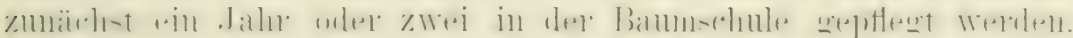

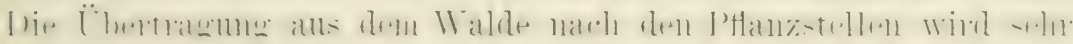

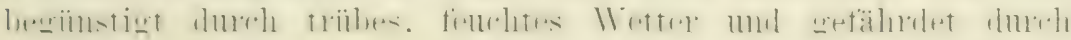
trockenen Wind. Samentlich ist der trockene. heisse Trind.

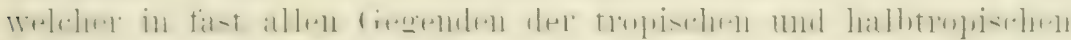

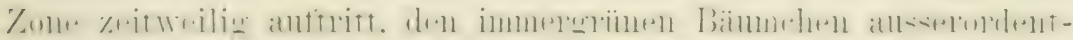

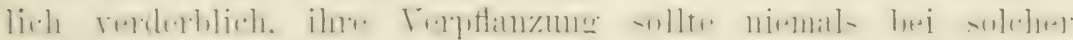
Tritterung unternommen werden.

Auch das ist zu beachten, dass die Sümlinge in dem Alter ron 1 bis 2 . Tahren dem Walde entnommen werden sollen. denn ihre

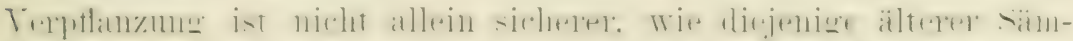

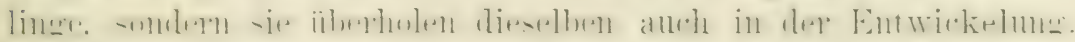
Die Praxis hat sich erhalten und wird sogar noch oft in

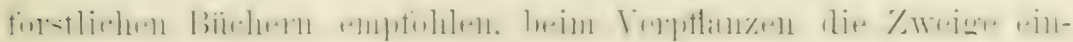

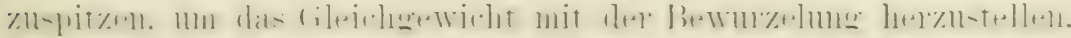

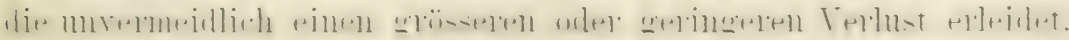

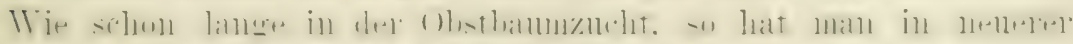

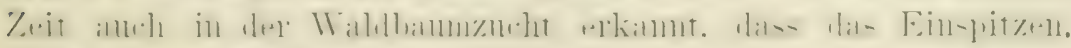
semler, Waldwirtschaft. 


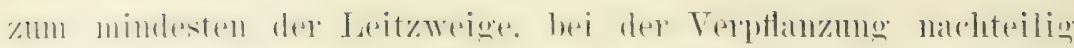

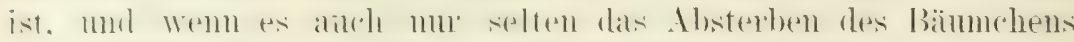

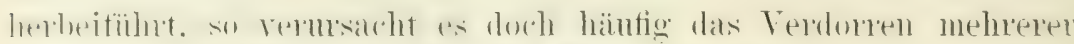

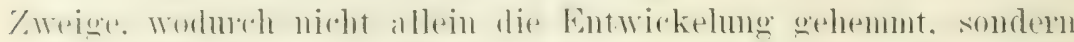

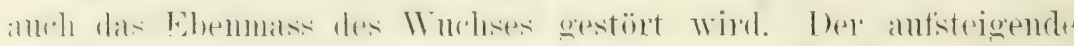

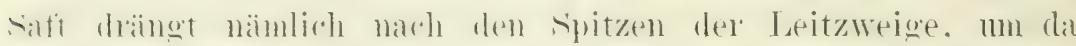

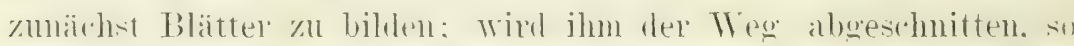

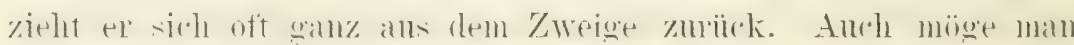

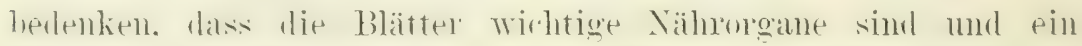
Bämuchen derselhen teilweise durch Finspitzen zu berabben, zu einer Zeit. wo es an der Bewurzelumg einen Verlust an Nähr-

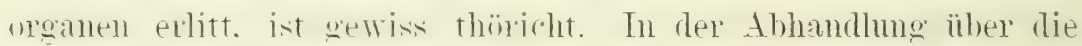

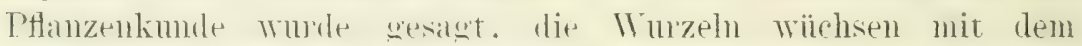

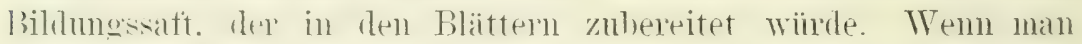

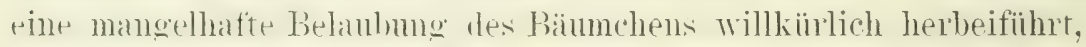
wie kamm ex da im stande sein. den hei der Velphtluzung erlittenen

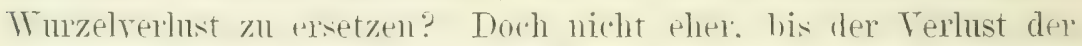

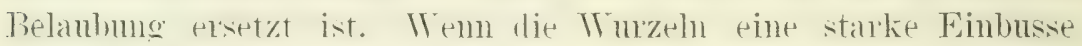

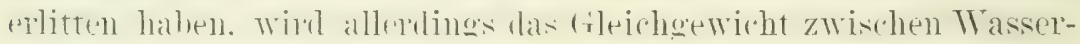
zufuhr und Verlunstung estët. lewzutellen ist es in diesem Falle

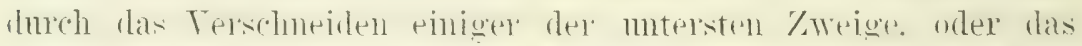

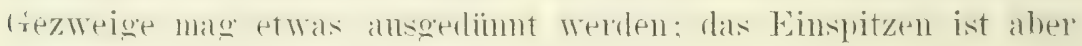
unter allen Umständen verwerflich.

Fermer soll das Zuriickschneiden bis iiber den Wurzelhals

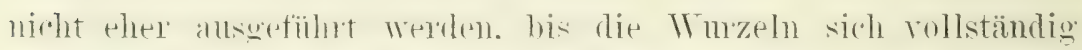
angesierlelt haben. Es giht nämliols Bämne. namentlich zu nemmen sind die Fiche mul Kastanie. Welche einen stäthelen Schössling

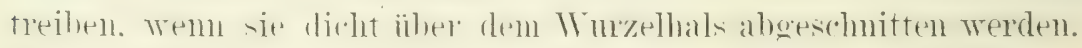

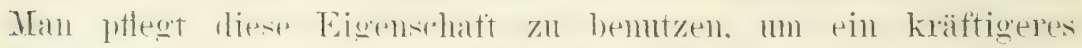
Stämmchen zu elrielen. Wenn das elste schwach anfwächst. Das

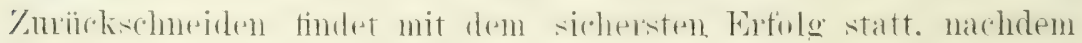
die Blätter abgefallen sind.

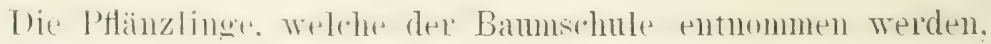
sind ebenfalls in ihne. Bewmoplung möglichst zu schomen. Die mremeidlichen Whudstellen del letzteren mögen mit 'Teer bestrichen werten, os sei demm, sir hetinden sioh an den spitzen und haben

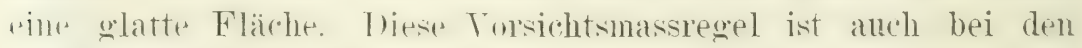
vämlingen des Waldis anzuwenden. sie empfiehlt sich ganz busonders fiur tropische Bäume mit weichen Wurzeln. 


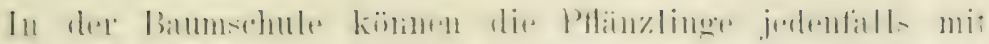

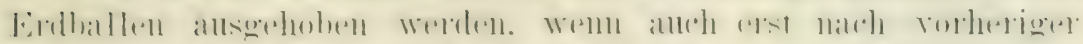

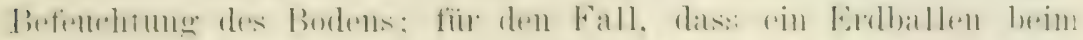

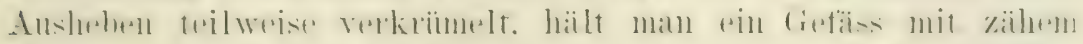

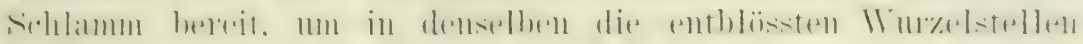
zil tanchen.

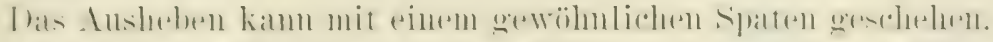

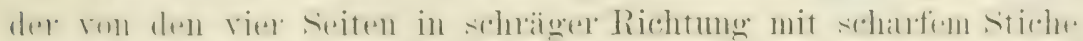

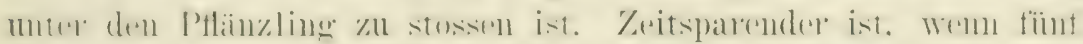

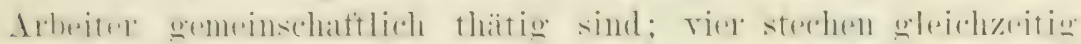

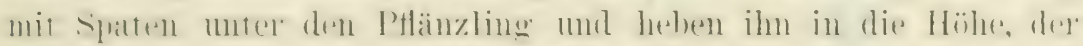

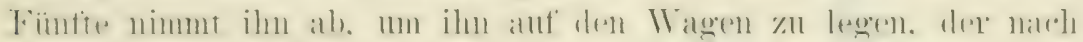

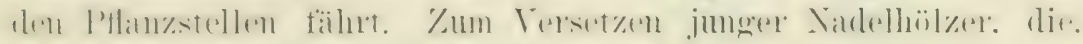

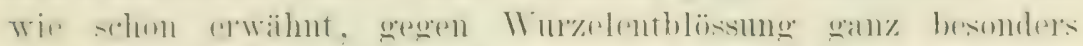

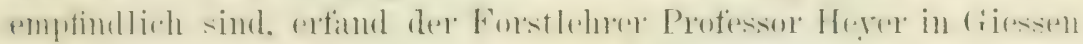

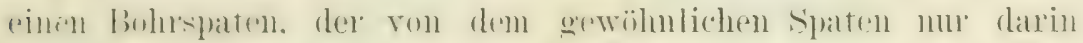

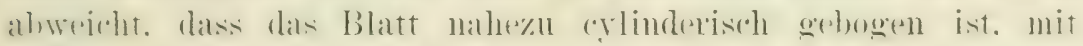

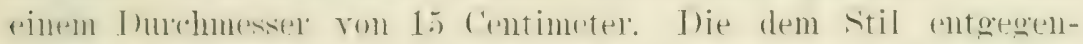

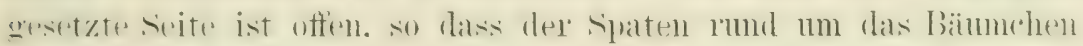

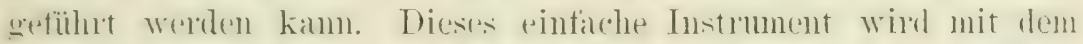

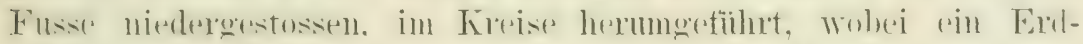

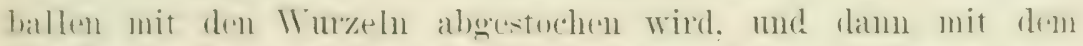

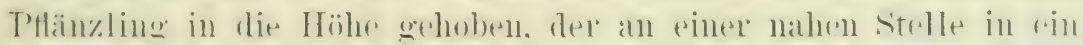

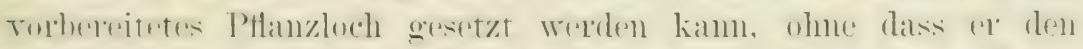

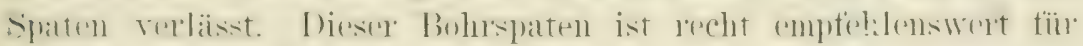

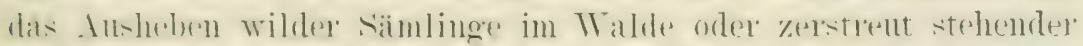

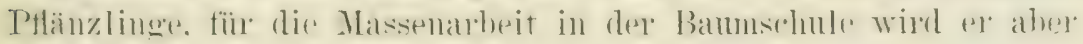

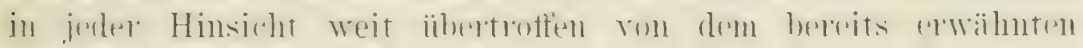
Baumgräber:

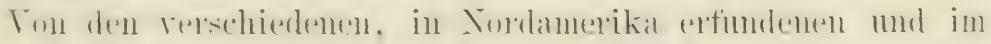

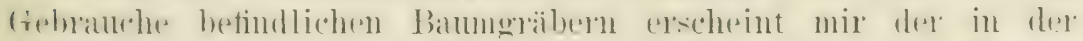

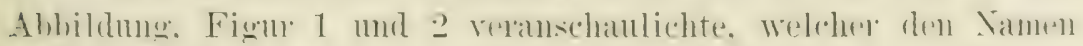

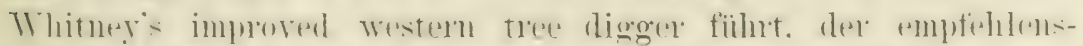

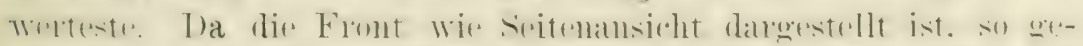

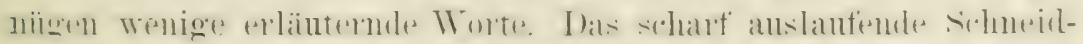

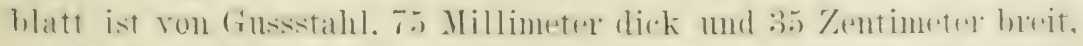

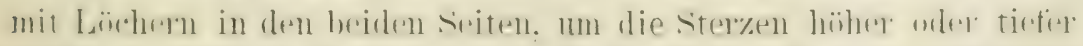

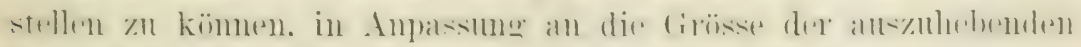

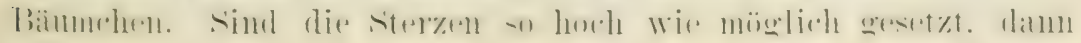




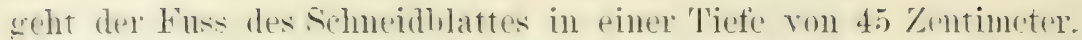
Zur Bespanmug sind zwei Pferde erforderlich, die olme Zugscheit angeschint werden mol die P'flanzlingsereihe zwischen sich lassent,

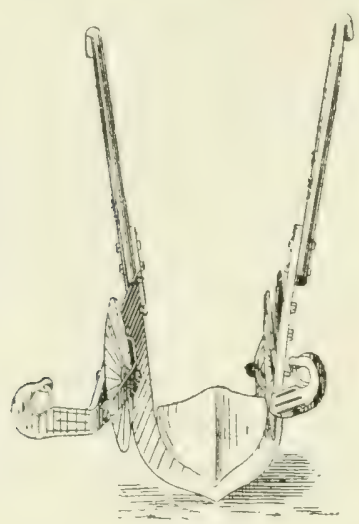

Figur 1.

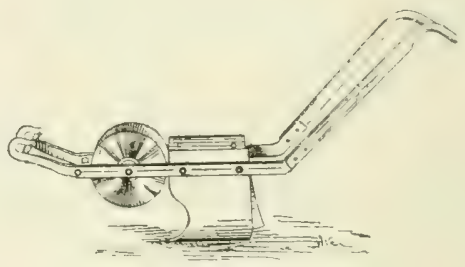

Figur 2.

vorwäts gehen. Zugscheite sind oftenhar nicht am Platze. Waher miissen die. natiulich zu verlängernden Zngketten direkt in dip Zugringe des Baumgräbers gehängt werden. Es gibt iubrigens auch in für diesen Zweck brauchbares /ugscheit. das halbkreisfïmig gebogen und mit den Zugriemen des Geschims. etwa landbreit hinter dem Schwanze hängend, verbunden wird.

Der Banmoräber wird krenzweise durch die Prihen der Batumschule gefiihrt. Wodurch er jeden Ptlänzling mit einem rierrekigen Erdballen glatt abschneidet. mul nul das Ansheben zu

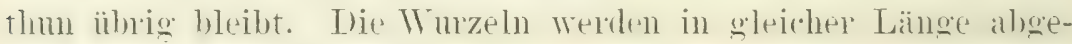
schnitten. nicht in ungleicher wie mit dem spaten. Was für den

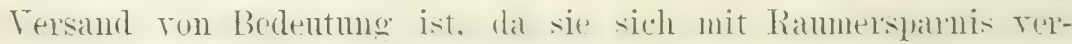
farken lassen. Ferner werden dir Wruzeln niemals zernissen

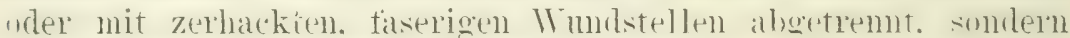
stets glatt abgeschnitten. Füge ich noch hinzu. dats rin Bamm-

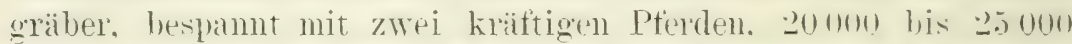
Plänzlinge den 'Tag zum Aushelen fertig luschneiden kamm. so wird einlenchten. dass dieses foräte einen beachtenstredten Fortschritt darstellt.

Der Preis des abgebildeten Bammgräbers beträgt l:u Mark. in Europa muss eq viel billiger herzustellen sein. 


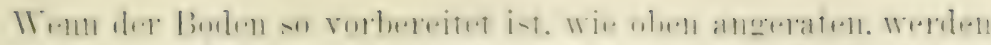

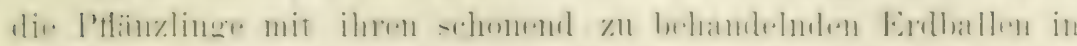

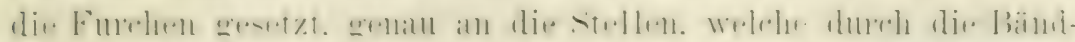

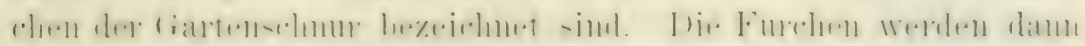

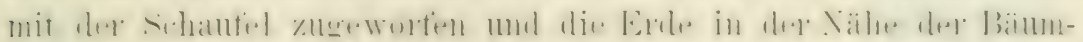

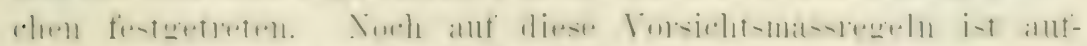

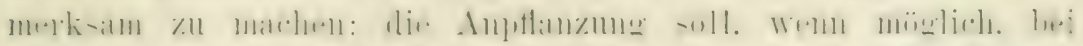

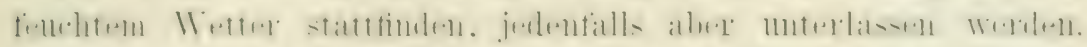

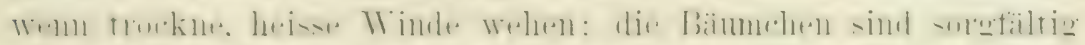

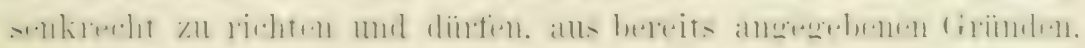
nicht tiefer wie der Wurelhals in der Erde stehen. Die letzte

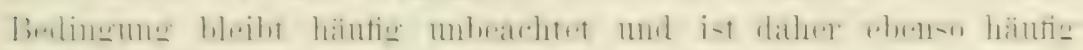

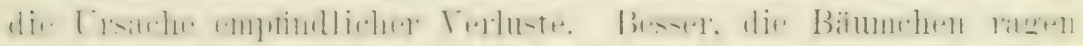
mit dem Wuzelhals ans der Erde als dass sie iiber denselben hinaus eingebettet sind.

Nicht immer steht aber ein Borlen zur Tertïgumg: den man

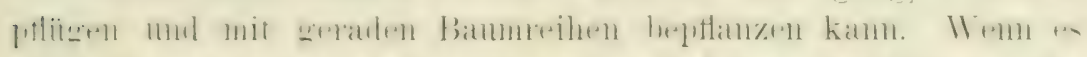

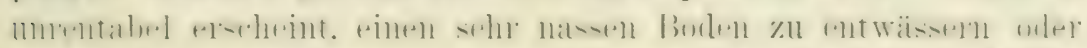

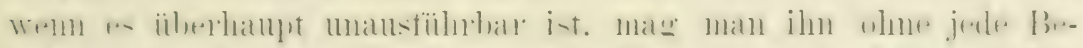

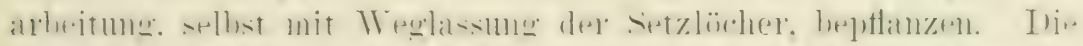

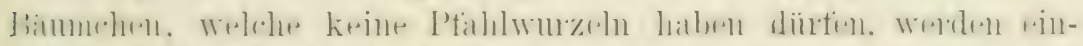

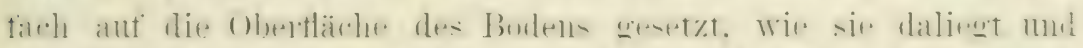

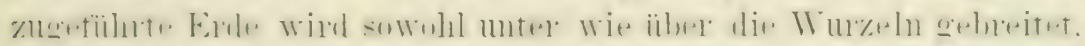

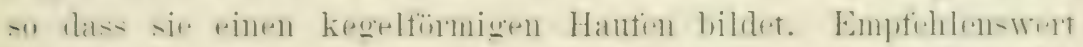

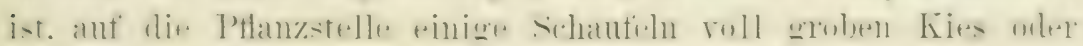

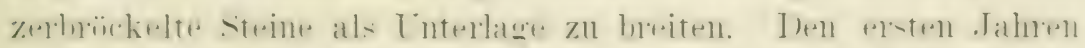

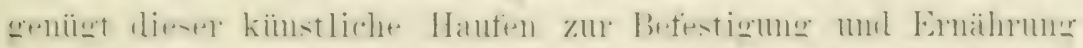

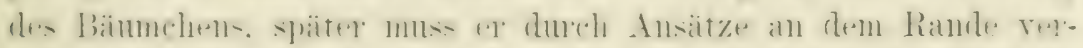

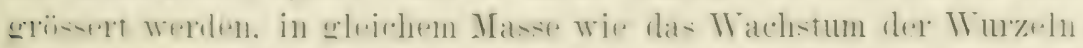

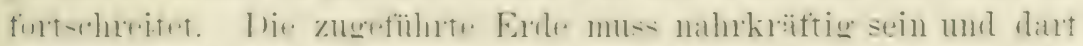

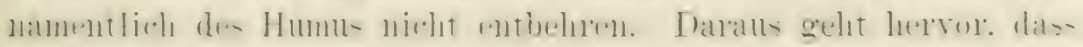

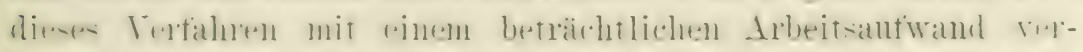

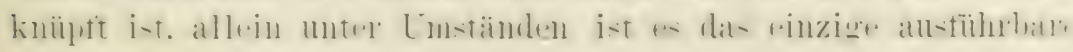
und mag sich recht gut rentieren.

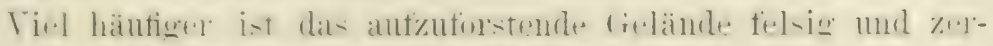

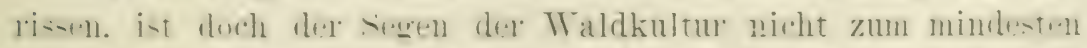

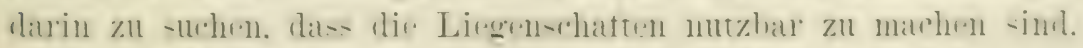

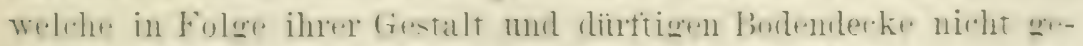

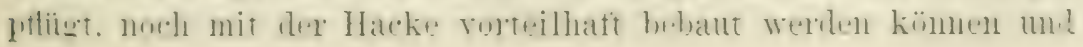




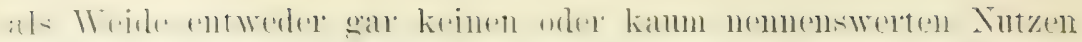

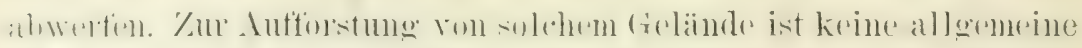

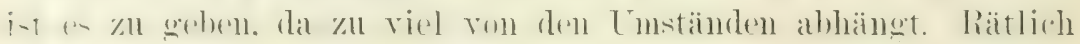

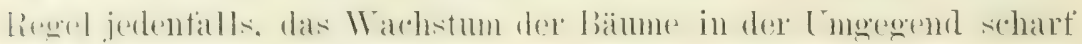

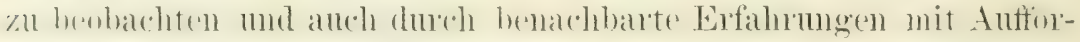

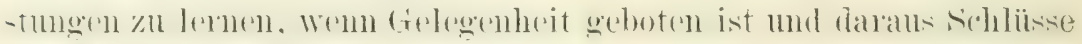

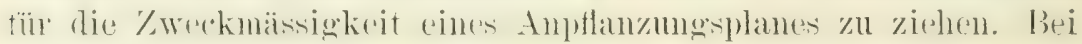
musichtigrem Handeln ist es demkbar, dass ant folsigem tiebirgs-

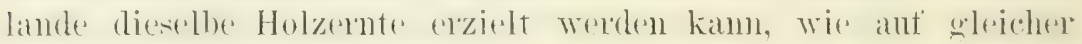

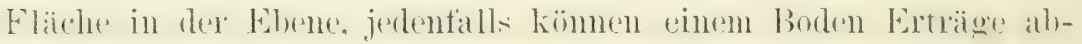
extungen werden. dex anderweitig keinen Nutzen weräht.

Weme ein Hang ron mäsiger Strile zu beptlanzen und eine Bublubeabeitung möglich ist. zieht man mit dem Pflig Furchen materecht mit dem Fusse des Hangs mod in disere Richtmog setzt mall auch die Bïmme. Bezweckt soll damit werdens, den boden vor dem Tegwaschen duch den Regen zu bewahren mol dem larehen Abthsse der Feuchtigkeit entgegenzurirken. Diese Furchen-

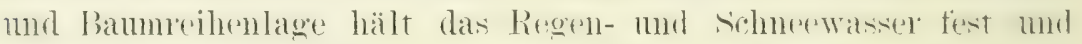
zwingt es in die Erde zu sickelm.

Auf steilem frelände beschränkt man sich ann bestell diraut, PHanzlöcher atszuhuben und de'l ̈̈brigen Bonlen mberiilıt zu lassen.

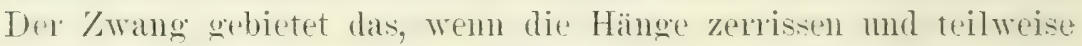
nackt sind, so dass von einer Reihtenordnung der Bämme alogesthen umd die Anptlanzung mongehnäsigg stattfinden mus. In solehem Falle sind die Pflanzlöcher möglichst wagerecht auszuheben. durch Einhanen in den Bergrïcken; jedes soll gewisermassen eine kleine Terrase bilden. Wem ein seln steiler Hang alls mïrbem Felsen besteht, mag es rätlich erscheinen. den Bammwzehn genügenden Boden zu schaffen, durch Anlage ron Terrassen oder nu Kerben, die an äusseren Rande mit tiestränch, festgehalten durch eingegreschlagene Pfähle. gesichert werden. Je nach der vorgeschnittenen Terwitterung des Eelsens, sind diese Terrassen und Ferben in tinem Jahı oder zwei durch Abwaschungen ron oben geniügend mit Erde bedeckt, un die Amptlanzung von Bäumchen zu gestatten. Zu diesem Verfahren wird man greifen mïssen, wem Gehirge anfgeforstet werden sollen. deren Erdknume. vielleicht in Folge ron mrerständiger Entwaldung. rom Regen- und schmeewassic wegoewaschen wurde, oder wenn vorgebengt werden soll, dass Gerillmassen von nackten Hängen anf Bahmbämme. Wege odex Feldex Itutschen 
Wemn anf trockenem. felsigen Gelände die Bätunchen nicht

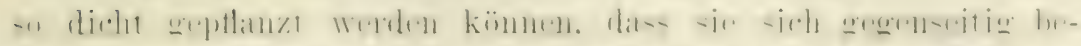

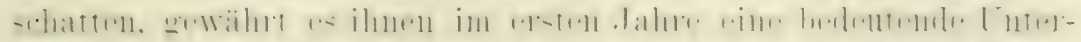

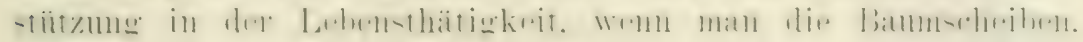
also das Bereich der Wureln. mit Stroh. Mons, diurrem Laul,

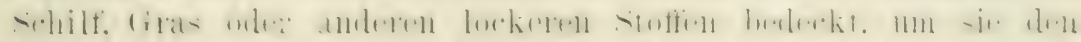

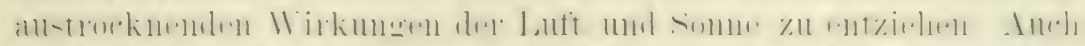

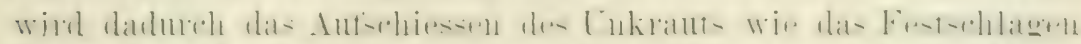

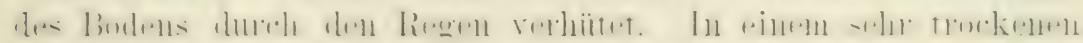

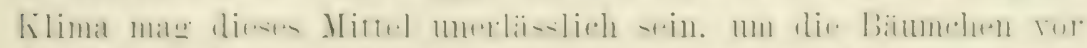

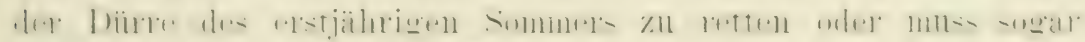
fortgesetzt werden. bis der Boden gut buschattet ist.

Unter Umstanden ist anch das Verfahren der russischen Forst-

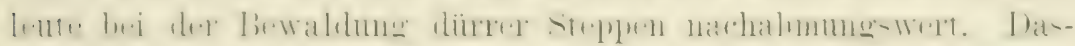

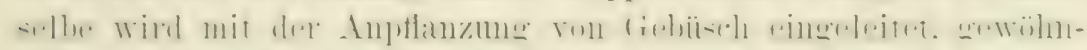

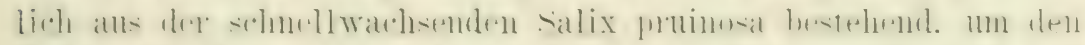

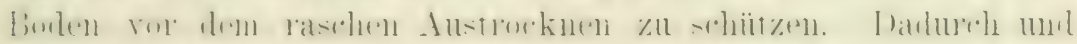

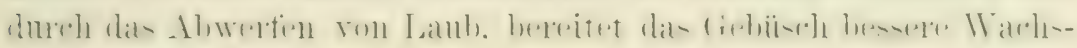
tumsverhältnisse rol:

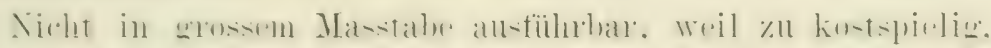

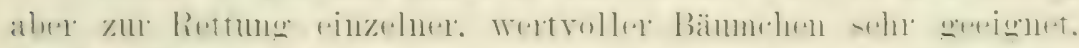

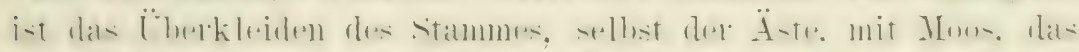

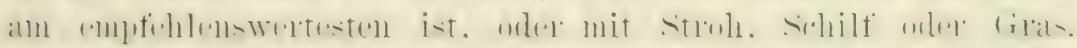

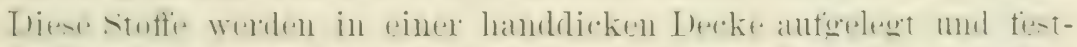

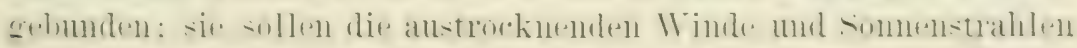

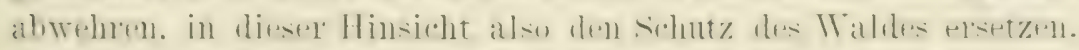

\section{Die Pflege des Waldes.}

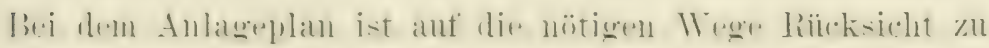

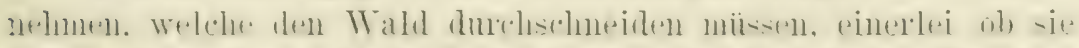

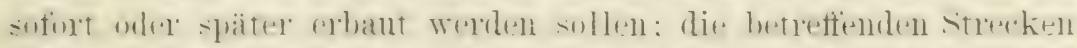

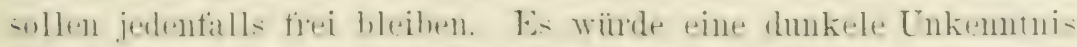

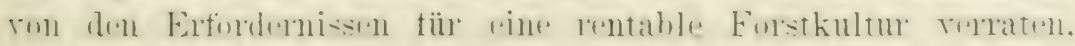

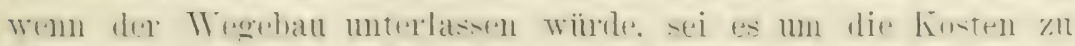

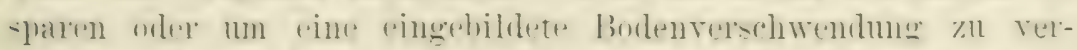
meiden. Fs wird rinlenchten. dass sich keine Anleitung geluen

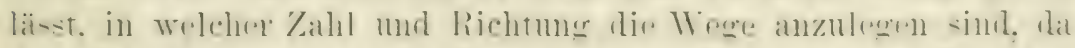

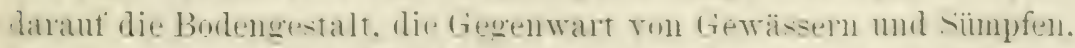

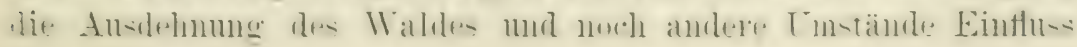




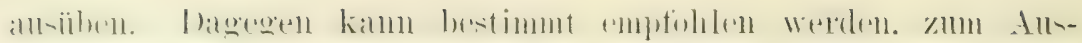

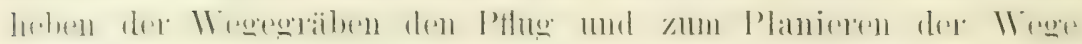

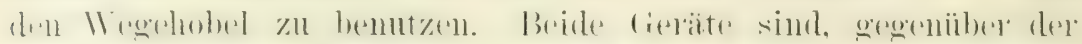

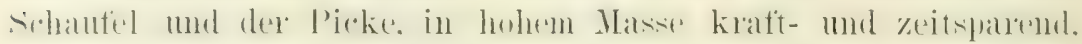

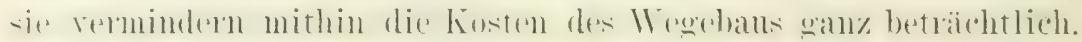

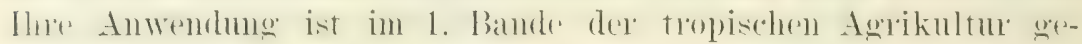

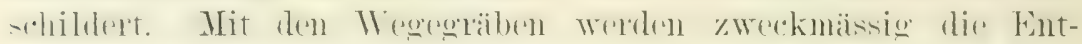

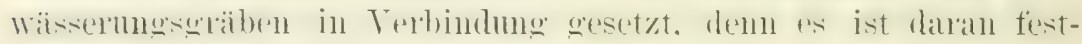

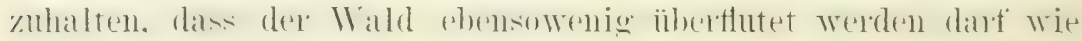

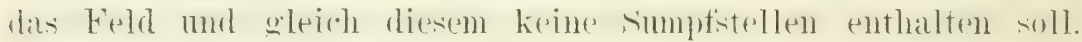

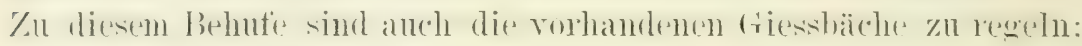
da wo sie ihr Masser über die Ufer treten lassen. sind sie einzudianmen, an stellen wo dieströmung so stark ist. dass sie Erle

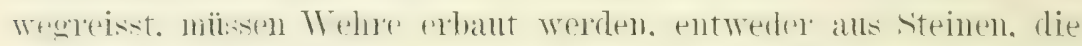
math in Darroform lose anfeinander legt, onles ans Pfahlen. dir man in das Bachlett solulaget und mit schwanken roweigen vereflicht.

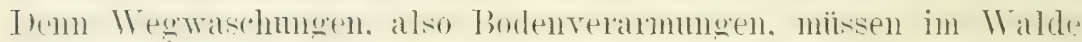
mit derselben sorofalt rethindert werden wie in Felde. bald durels

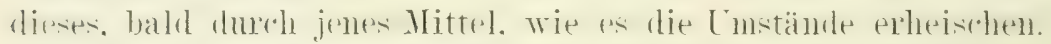

Wenn oben gesagt wurde, die Bearbeitung des Bodens mit

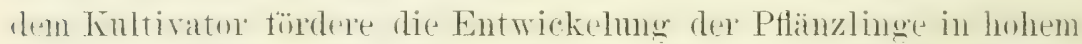

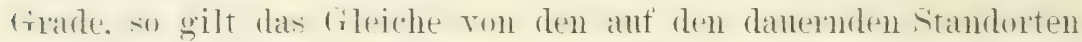
sitzenden Bälunchen. Fs hat meine Verwunderme eroegt. dass irh in den heirlen Iändern. Wo die Forstkultur ant höchster stufe

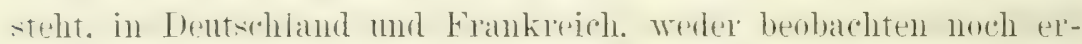

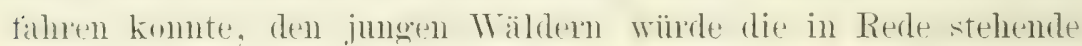

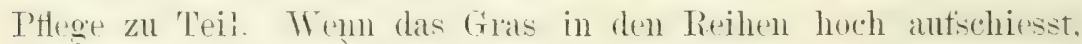

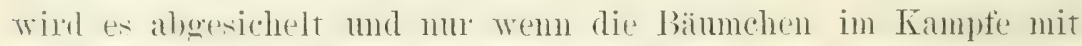
denn Cnkrant zu muterliegen drohen. lässt der Forstmann den borlen auflacken. Kostspielign und mangelhatt! muss das [utei] lanten. Ta. anch mangelhaft — sehr mangelhaft, demn die plmme Arbeit der Harke hät keinen Terobeleh ans mit der Leistmo des leichten eng gesetzten l'ferdeknltivaturs. Jent hebt in dem Terunkrauteten Bodtu mur schollen ab, daduch wird meder das Tuklaut wirkmostoll bekimptt. noch die Fenchtigkeit des Borlens erhalten, im Gegenteil, ihre Verdunstung gefördert.

Verwunderung muss diese Behandlumg deshalb erregen. Weil

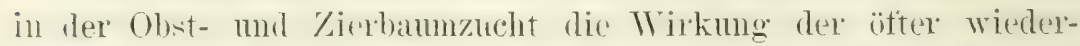

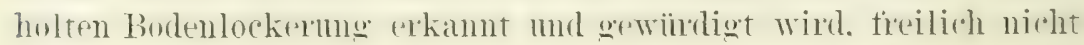




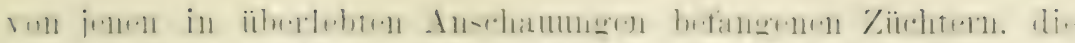

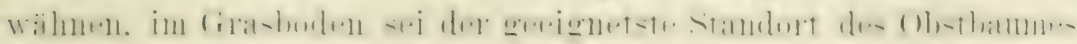

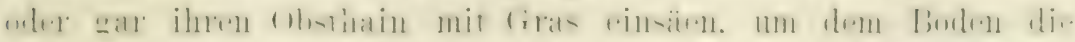

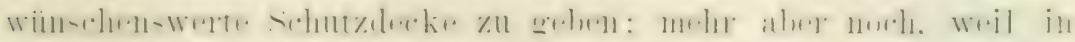

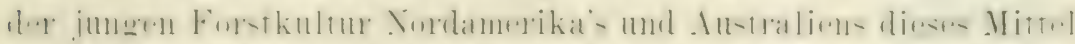

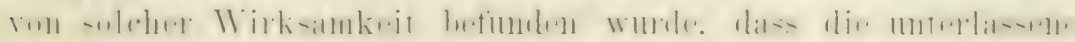

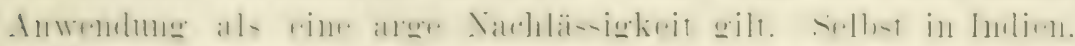

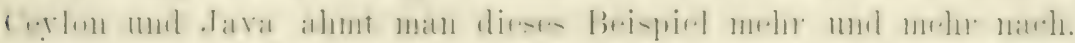

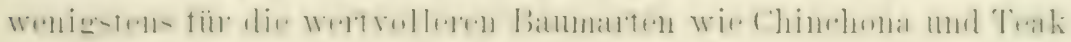

II ie aber die Forstleute der gemässigten und kalten Zone

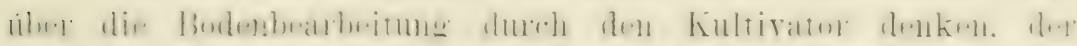

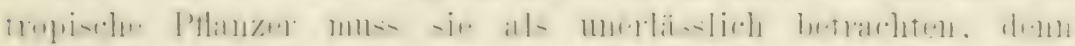

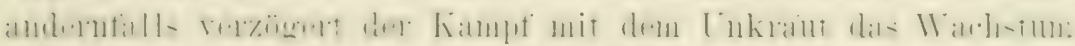

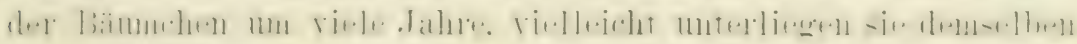

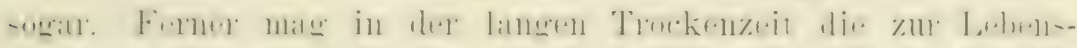

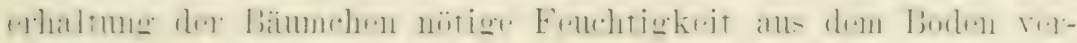

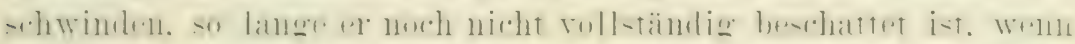

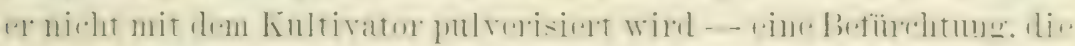

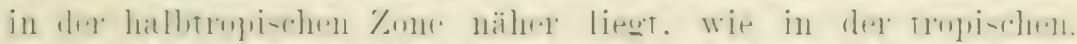

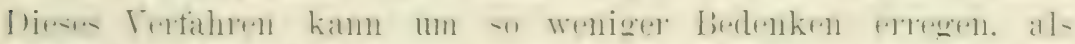

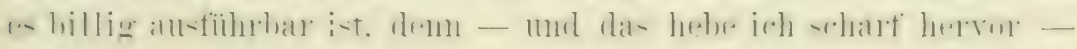

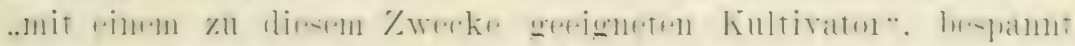

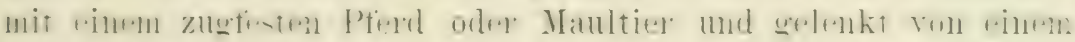

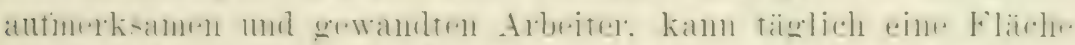

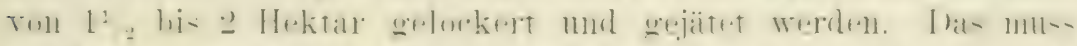

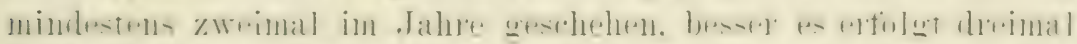

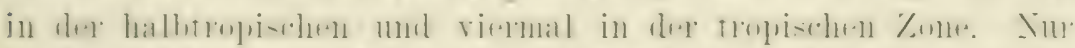

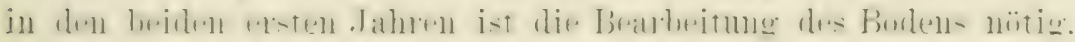
da el von da ab so reichlich beschattet ist. dass das Unkrant

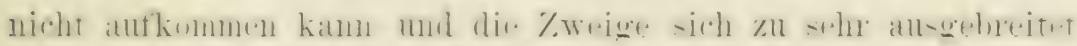

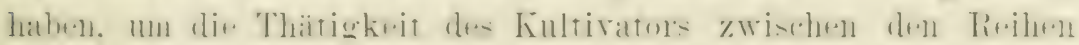

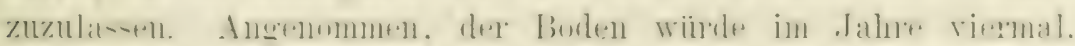

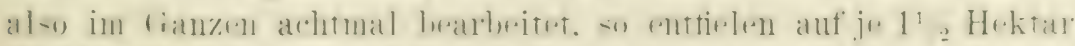

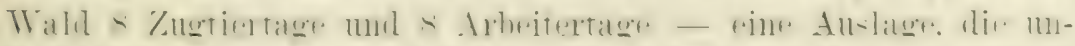

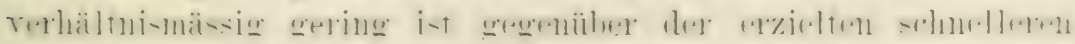
und krätigeren Entwickelung der Bäume.

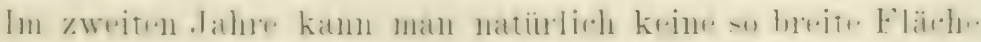

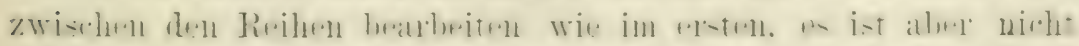

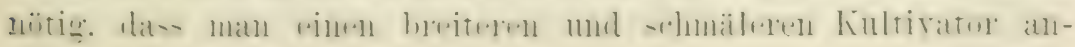




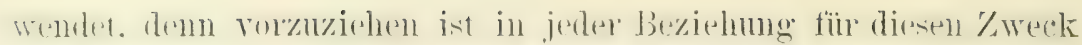
in liultivator. der breiter und enger gestelt werden kimm und

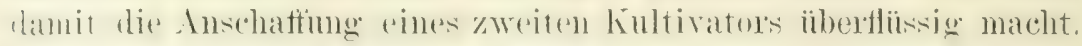

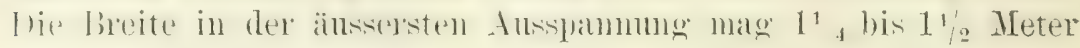

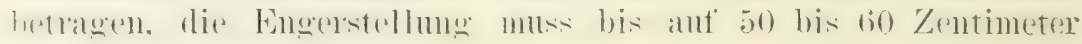
zurïckzutïhren sein.

Irh mö̈hte nicht misverstanden sein: nur tüir solchen Boden muntehle ich die Anwendmeg des hultivators, dere ror der An-

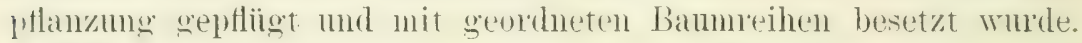
Auf felsigem, zerrissenten oder rehr strilem Ge?ände. Wo man sich daranf heschä̈nken musste, Pflanzlächer altszuheben, unterläst man jode Bodenberbeitung. es sei demn, es wiirde nötig befunden. das

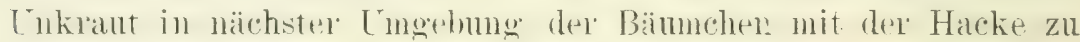
vertilgen.

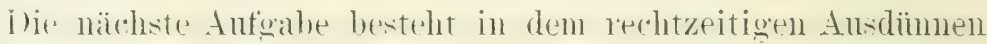
[urchforstens. I)ie Zweige diirfen sich den Ram nicht streitig machen. der Boden aber muss ent beschattet bleiben - darïber lnnan kamn keine allgemein gïltige Anleitmo gegeben weren, in jerlem einzelnen Falle mus dex Zeitpunkt der Durchforstme dem Ermesen des Forstmanns anheimerestellt beiben. Wie bei der Durchforstumg ropzugehen ist. lehrt das folgende beispiel. Wemn die angeratene Pflanzweite ron ${ }^{1}$. Weter in den Reihen mo 1 Meter zwischen den Reihen eingehalten wurde, so ist bei der ersten Durchforstung jedes zweite bämnchen in den Reihen zu entfernen. Alle verbleibenden Bäunchen stehen dann in gleichmässigem Abstande von 1 Meter. Bei der zweiten Intehtorstung wird jede zweite Reihe abgeholzt, in den verbleibenden Reihen wird hei der dritten Durchforstmg jeder zweite Banm entfernt. Die verbleibenden Bämme stehen nun in gleichem Abstande vom 2 Meter. Bei der vierten Jurchforstung wird wieder jede zweite Reihe und bei der fiunften Durchforstung jeder zweite Bam in den rerbliebenen Reihen abgeholzt. Die Bämme stehem nm in g-leichem Abstande von 4 Metel und dabei hat es sein Bewenden.

Dieses Beispiel trifft für viele, abex nicht für alle Taldhäume zu, was ich scharf betome. Es wurde oben bexeits gesagt, dass sich für diese Frage keine allgemein gïltige Regel anf-tellen liesse. dem das Rammbedürfnis der Waldbammanten ist nicht äbereinstimmend. Wie sthon erwähnt. vertragen die Vadelhiilzex rinen engeren Stand wie die Lamblö̈zer und fiur die 


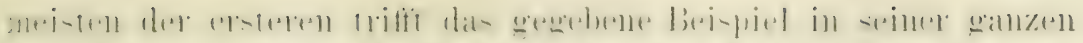

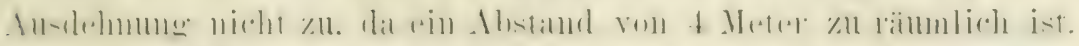

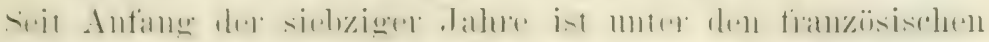

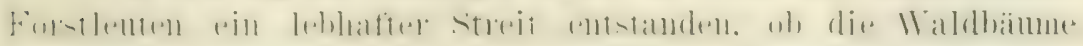
heschitten werden sollen oder nicht - ein Streit. bei dem die

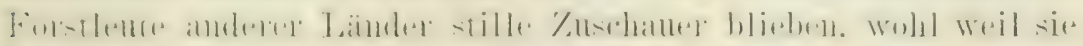

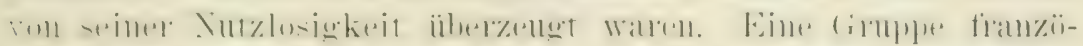

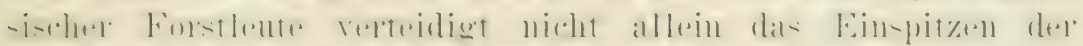

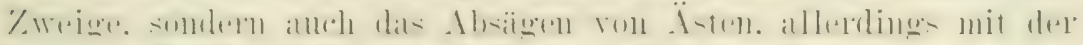

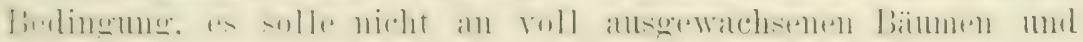

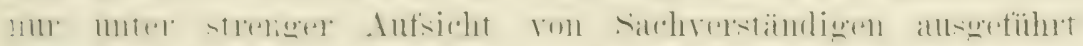

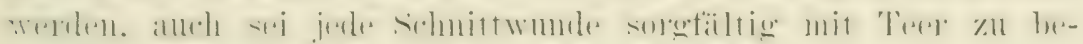

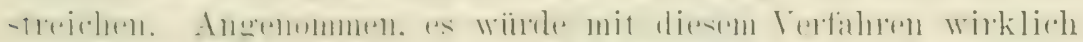

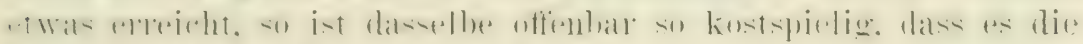

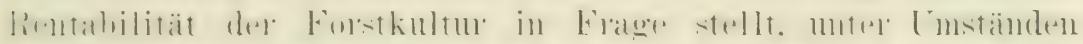

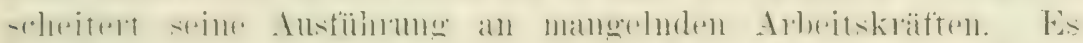

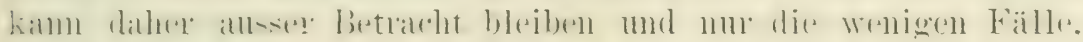

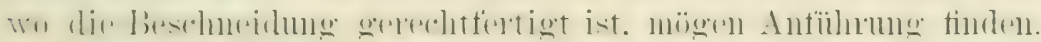

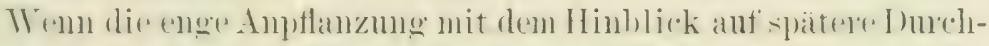

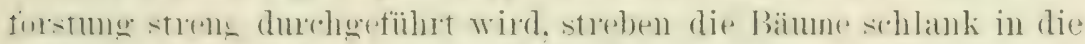

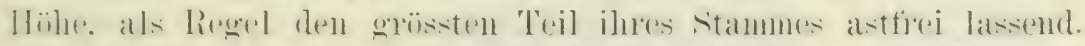

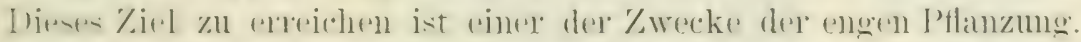

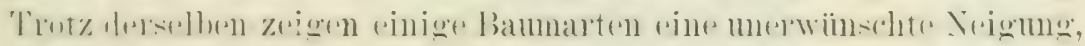

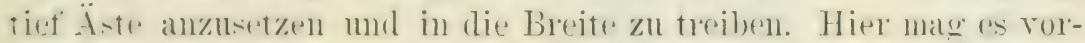

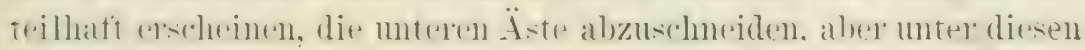

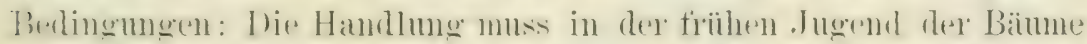

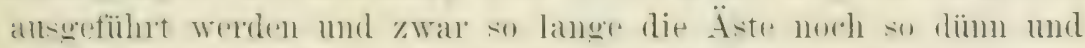
weich sincl. $13 n$ sich mit dem diartemmesser hart und glatt am stamme

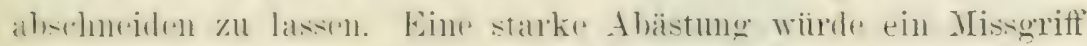

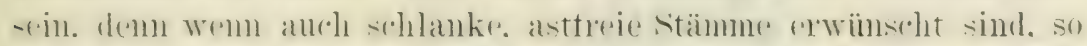

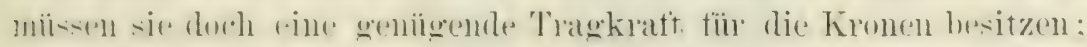

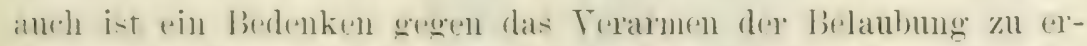

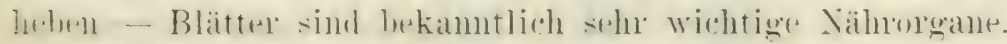

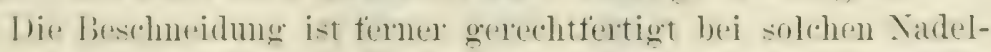

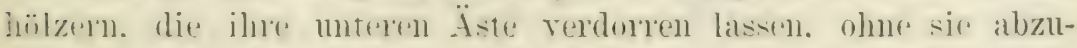
werten. sobald die $\ddot{A}-t e$ rollständig diur gewordent sind. werden

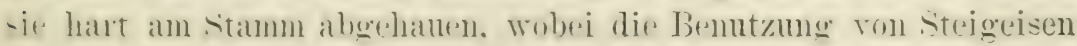

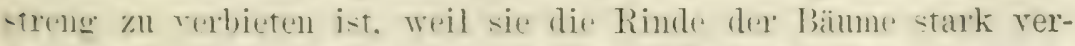

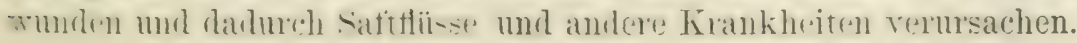




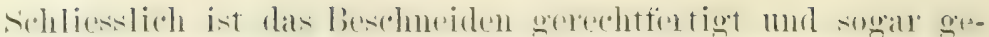

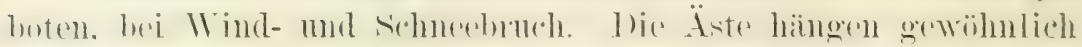

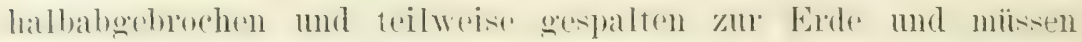
möglichst hart ann stamme aberesiogt werden. da sonst Fanlstedlen 'ntstehen, die bis in das stamminnere side allmählich allsdehnen. Zur Torsicht sollte jede sehnittwunde mit Holatere oder dem besern strinkohlentere dick bestrichen werden. Dex 'Tees mus möglichst diek sein und ist hei kaltem Wetter zu w'wärmen. Auf

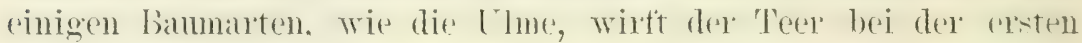
Bestreichmog leicht Blasen. es ist deshalh in einigen Tagen narbl-

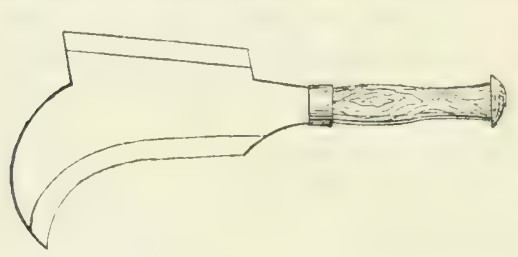
zusehen und erforderlichen Falls eine zweite Bestreichung zu geben.

Die für die erwähnten Beschmeidungen empfehlenswerten Instrumente sind: Das Gartenmesser: ron der bekannten Form. Die englische Figur 3 Schnabelhane, dargestellt in der Figur 3, welche in

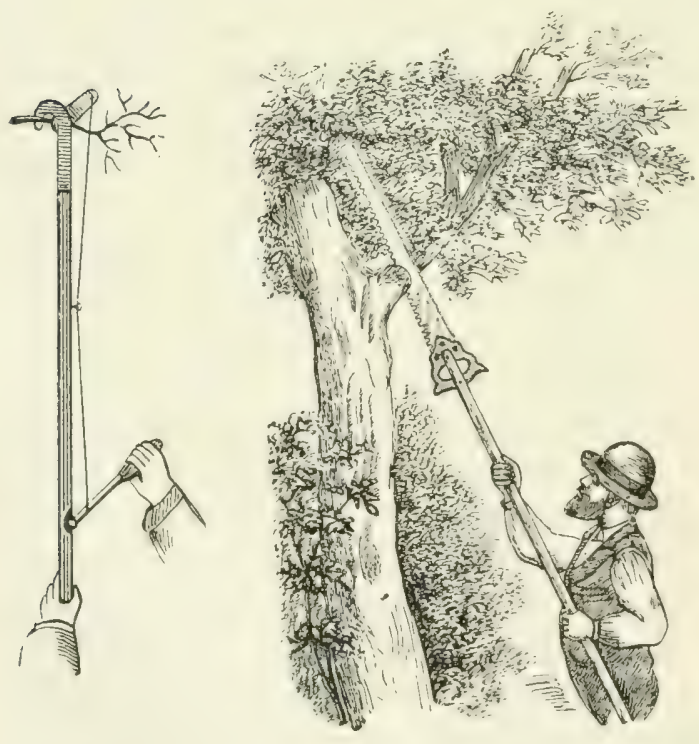

Figur 4. Figur 5. den britischen TioIonien viel verwendet wird und wirklich rolzüglich ist.

Der Baumschneider (Figur 4), mit welchem man nur diumne Zweige in der veranschanlichten Teise abschneiden kann. Er wird weniger für eigentliche Waldbäume gebrancht, als fïr freistehende Bäume, deren Kronen man eine regelmässige Form geben will.

Schliesslich dit langsticlige, amerikanische Bammages (Figur 5), mit der man, bei einem festen Stand auf dem Boden, Äste in beträchtlicher Höhe absägen kann. I) Vorsicht 


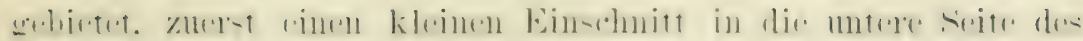

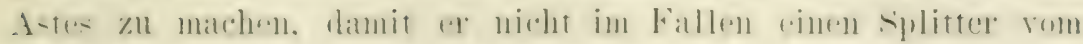
Stamm mitreisst.

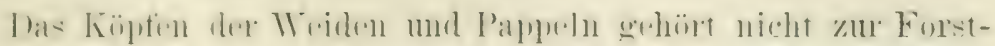

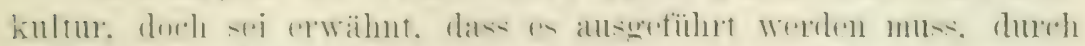
Al-itgen de.

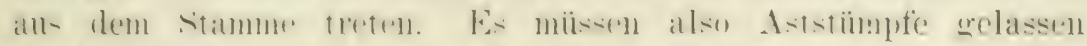

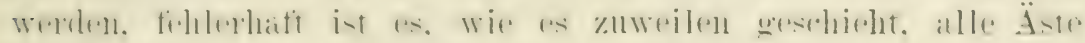
hart am Stamm abzuschneiden.

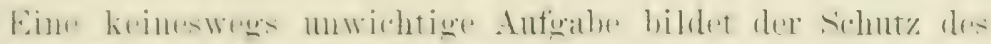

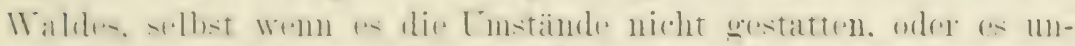

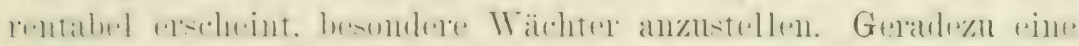

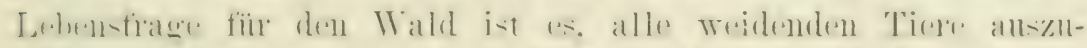

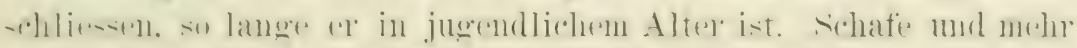

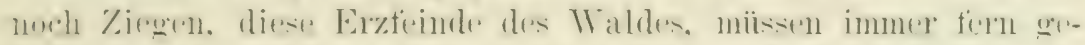

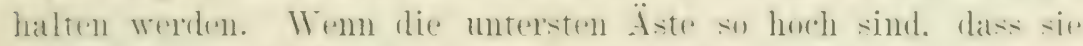

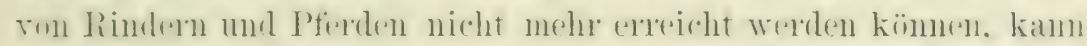

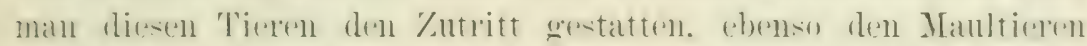

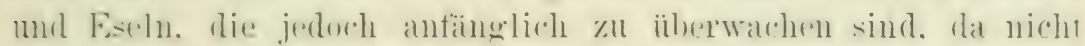

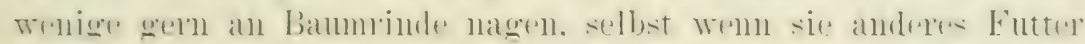

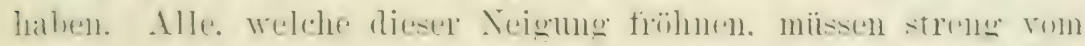
IValle allsegerhlosen hleiben. Entschiedenen Nutzen bringt die

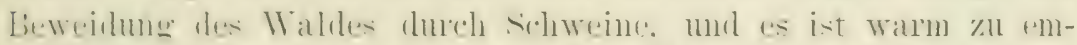

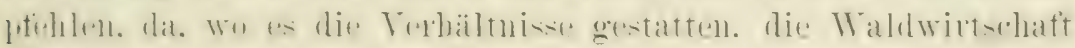

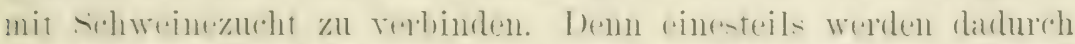

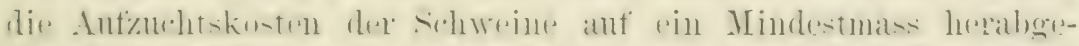

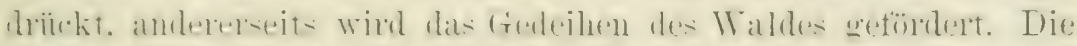

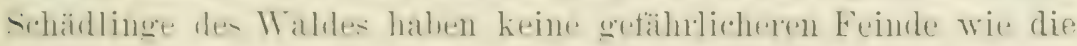

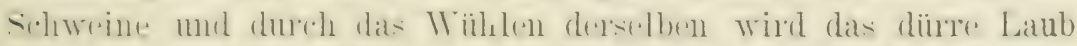

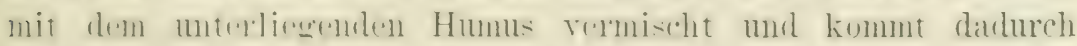

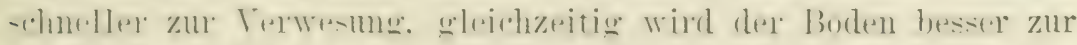

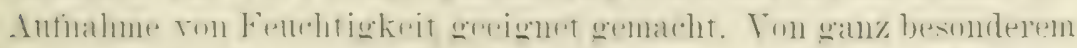

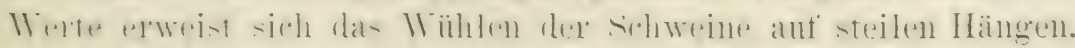

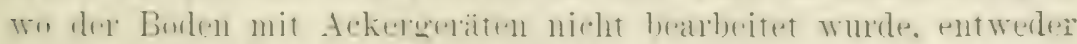

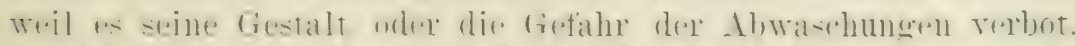

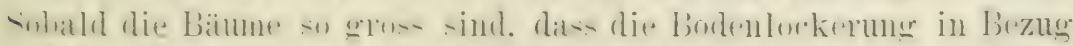

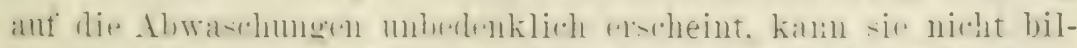

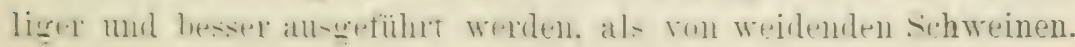




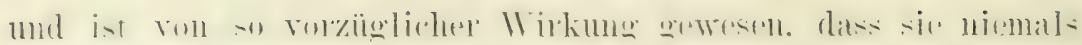

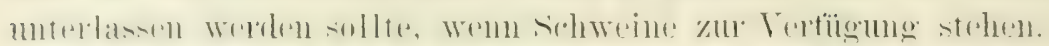

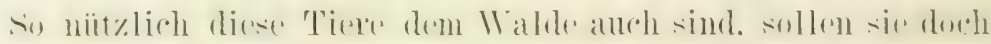

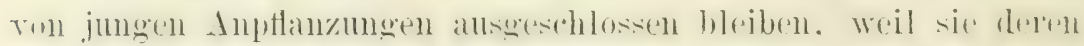
Trumelbefestigung beim Wühlen zerstören.

Häntio richtet das Wild beträchtlichen sohaden in den Wäl-

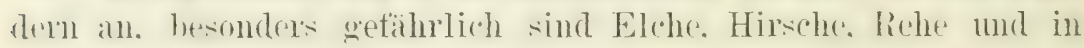
manchen tropischen fiegenden Elephanten mo Giraffen. IV emn anch keine Anstottme dieser Tiere zu hefürworten ist. so muss doch der Waldbesitzer suchen, ihre Zahl durch Pulver und Blei in beschränkten Grenzen zu halten. Am sicherst'n geht er übrigens, auch den Haustieren gegeniber, wemn er seine Anpflanzungen \&n lange umzämut hält. bis ihnen weidende Tiere keinen sidaden mehr thun kämnen. Ich bratuche wohl kamm hinzuzufügen. dass dieser Rat fïr andere Länder. wie die emonäischen hulturstalten. gemiinzt ist.

Gegen das ïbrige Heer der Waldfeinde. alls Insckten und ihren Larren bestchend. wibt es leider kein durchereitendes schntznoch Bekämptumgsmittel. In dem dicht bevölkerten Destschland und Frankreich versucht man es wohl, die Burkenkäfer durch Abschaben dex Borke zu rernichten. allein in anderen Ländern. namentlich in tropischen mod halbtropischen. ist an die Anwendung ron Mitteh dieser Ant nicht zu denkens. teils weil es an geniigenden Arbeitskrätten fehlt, teils weil der hostenanfand ansscr Terlältnis zu dem Erfolge steht. Nur zu thum bleibt. die insektenfiessenden Tögel möglichst wirksann zu schiitzen und die oben emptohlene schweineweide in geregelter Anordnmo einzufïhren. Das Übrige muss den Feinden der Insekten ans dem vigenen lieiche ïberlassen bleiben und gereis ist as ein beruhigender Trost. dass jedes schüdliche Tnsekt Toulteinde in der Insktenwelt hat. dif seine Termehrung in gerissen trenzen halten.

C̈ber die Tertilgme der Schädlinge im allgrmeinen gibt ein besonderer thechnitt im 1. Band der ropischell Agrikultur Autschluss. Wichtiger wie gegen tierische Feinde ist der Schut\% des Waldes gegen das Foner. demn dassolbe richtet nicht allein einen brdeutenden numittelbaren Scharden durch dir Vernirhtung von

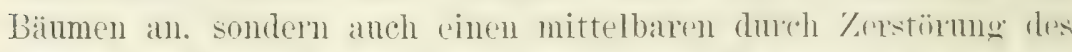
Humus im Boden. In Folge desen kann sich nicht oher nenes Ptlanzenleben entfalten. his dieser Terlust trilwaif ersetzt ist. 


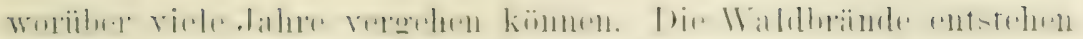
gewöhnlich aus folgenden Ursachen:

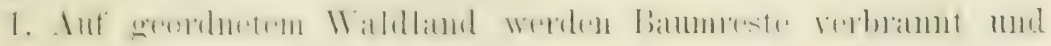
das Fener springt ïber nach dem angrenzenden Wald;

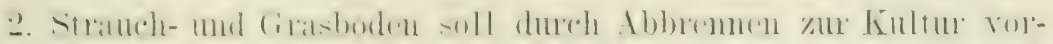

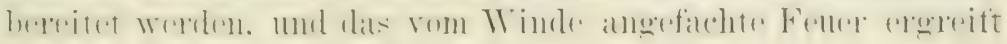
den Wald:

$\therefore$.

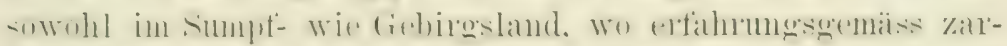

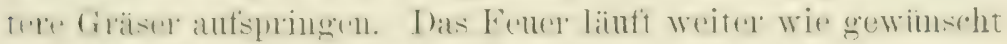
mol ergreift schliesslich den Wald:

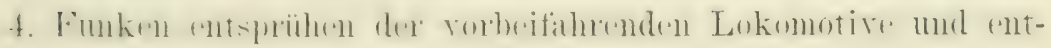
ziinden einen Waldbrand;

万. . I

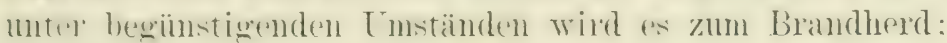

6. bremende streichlö̈lzer, glimmende Tabakasele mol Cigaren werden leichtsinnig ins diurre Latuh geworfen. das sich entzïndet: auch alogeschosene Elintenpfropten kümen einen Waldbrand erzengen;

7. dex Blitz entzindet oinen Banm. der zum Brandherd wird:

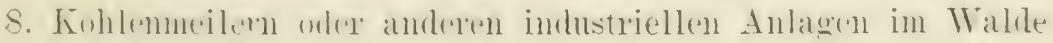
entspringt Fener und breitet sich aus:

9. böswilliger Brandstiftung.

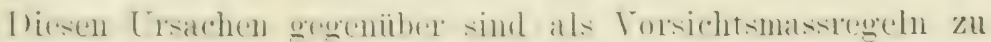
emptehlen: bei der Anlage cines Lagertenters sind alle brembare

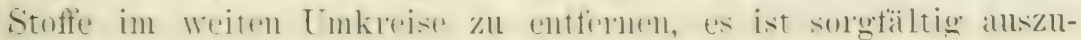

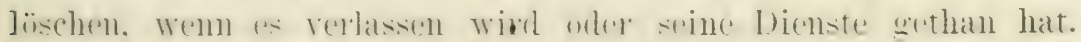

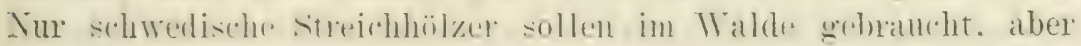
niemals bremend fortererten werlen. Es geihn Flintenptiopten.

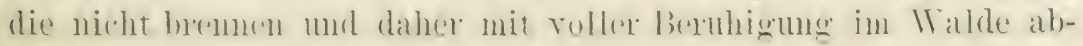

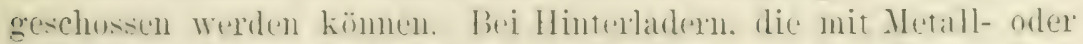

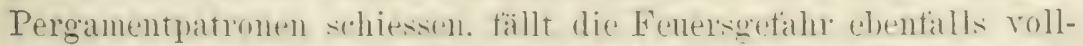
ständig fort. Cigargenstummel und l'feitullasche sollen vorsichtig aut Plätze geworten werlens, wo sir umschällich bleiben müssen. Die ron den Lokonutiven drohende Fenersgetahr kann wesentlich

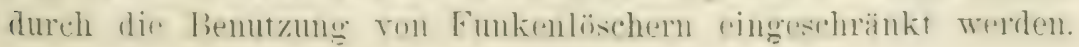




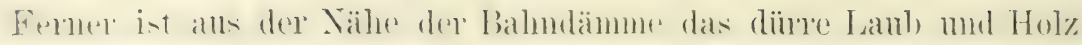

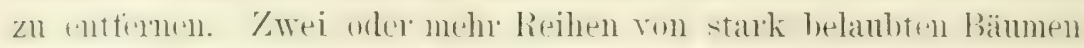
solltem an jeder seite des Bahmdammes weptlanzt werden. Wem de durch einen Nadelwald fïhrt.

Wenn der Wald an eine Grasflur stösst. kann die von daher

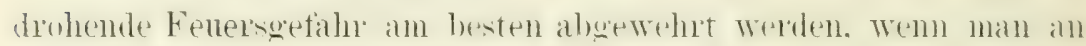

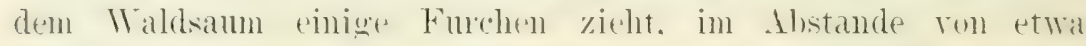

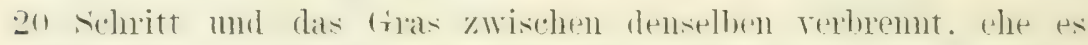

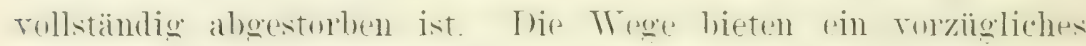
Hemmmis tïl die Verbreitung des Feners mul sind daher solon ans dipsen filmode als merlässlich zu betrachten. sichmale Tege

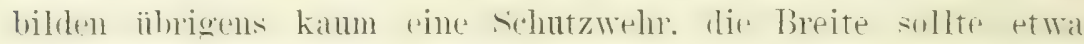

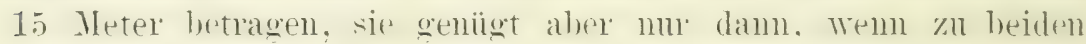
reiten des Weges an mindestems 5 Meter hreiter Streifen rom Gestripp und Unterholz freigehalten wird.

Wem ein Gewässer durch den Wald fliesst, mag es in der Weise abgedänme werden. dass es eine Reihe ron Teiclen hillet.

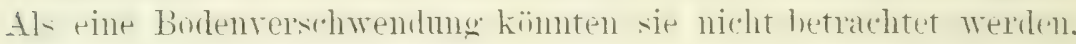
da sie zur Fischzucht benutzhar sind. zugleich rermögen sie als

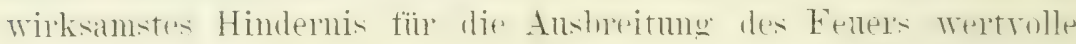

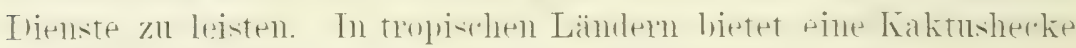
eine gute Schutzwehr gegen die Ausbreitung des Feners.

Dem Aufwuchern von Gesträuch. Gebüsch und Schmarotzer-

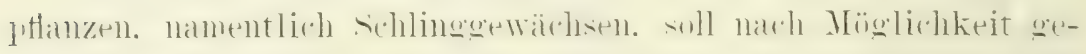

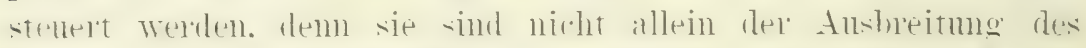

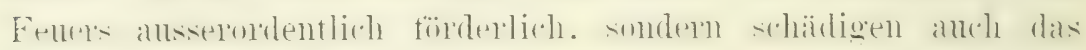
Tichstum der Bäume.

Diese Gewächse sammelt man anf Haufen und rerbrennt sie,

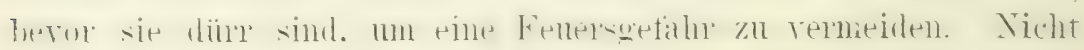

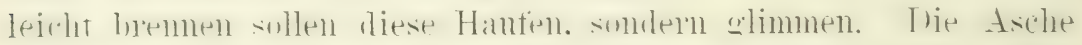
wird als Thinger antopstrent. Tiele Tnsektenlatren finden bei solcher Terbremnumg ihren Tod.

Vom den Mitteln. Weldhe zur Bekimprime des Mildhrandes dienell. sind die widhtigstens die bienze des Fellers wird stark

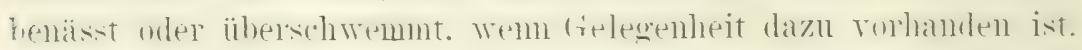
Fast ebenson mirkmesoll iot das bewerten des Femerambes mit Erde. Weldhes $u m$ sn melne in Betraht kommt. Weil es aiberall

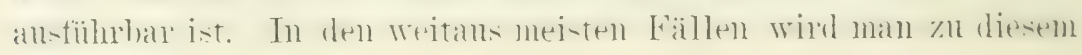




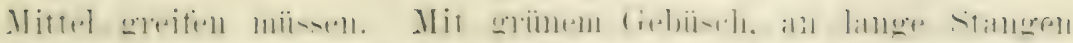

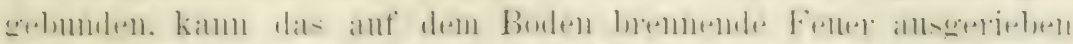

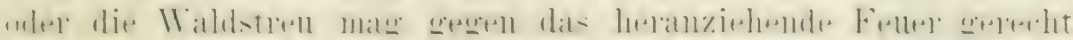

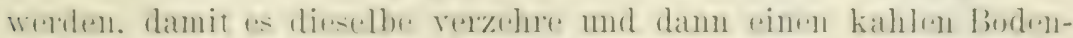

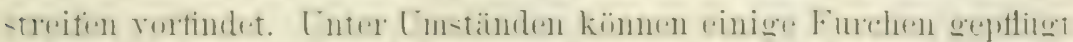

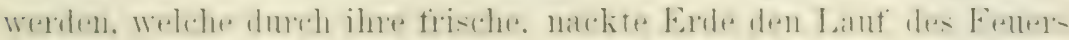
anthalten.

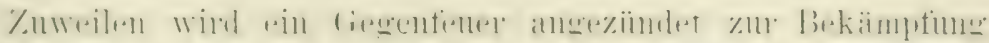

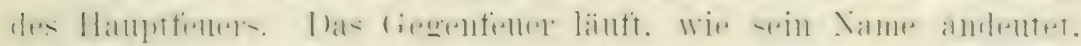

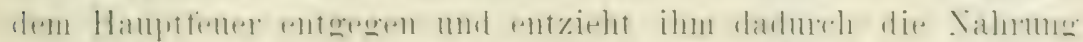

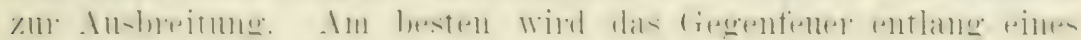

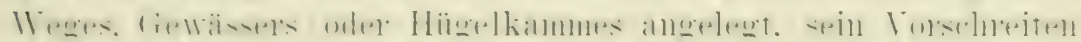

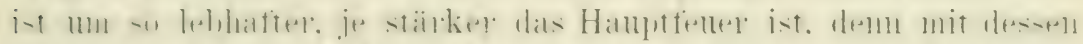

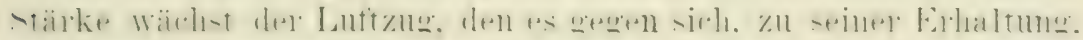
in Bewegung setzt.

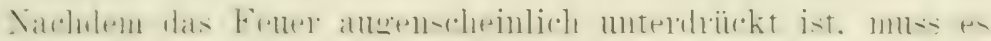

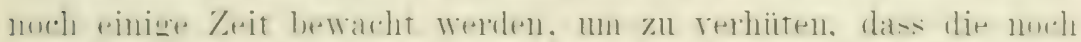

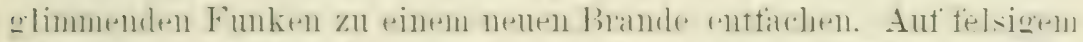

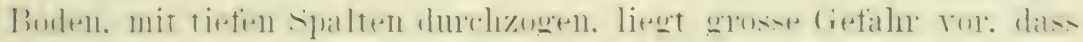
sich noch nach geraumer Zeit rerborgenes Fener belebt.

Wenn anch nicht im wörtlichen sime, gehört es doch zul

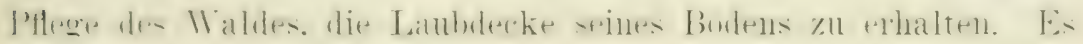
ist eine selir rerwerfliche Praxis. zu der die Privatbesitzer ron

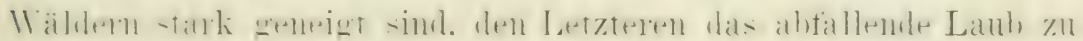

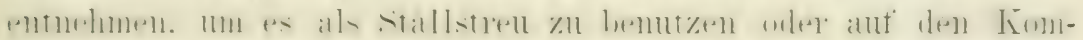

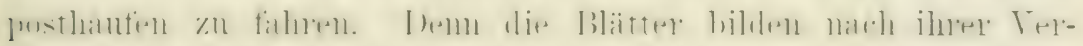

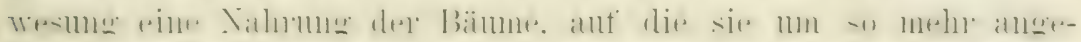
wiesen sind. je ämer der Boden ron Natur ist. Tnd als Regel

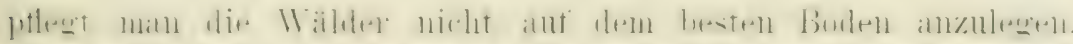

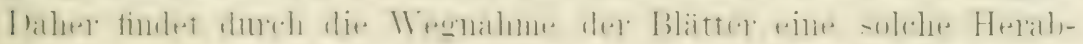

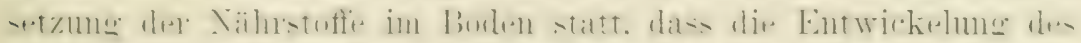

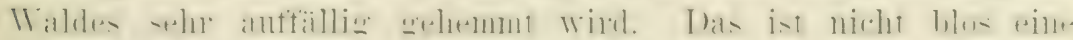

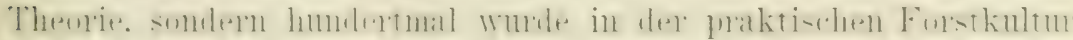

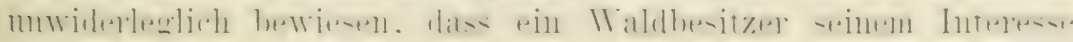

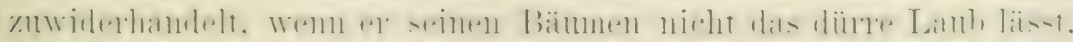

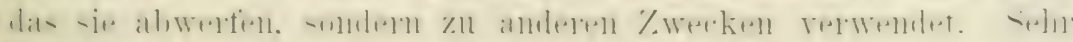

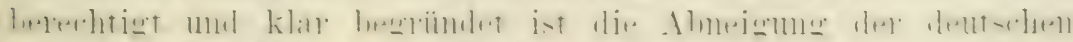

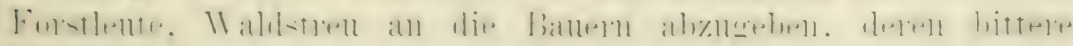
Feindschaft sie sich dadurch bekanntich zugezogen. 
Finige Resultate der nenesten Forschungen ïber das verweikende und gefallene Jaub finden hier einen geeigneten Platz.

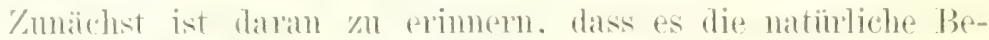
stimmung jeder Ptlanze ist. vollkommene samen zu erzengen und

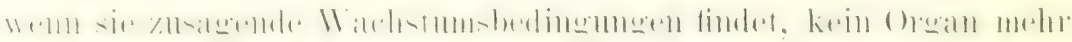
all-hihe ah \% IVenn das Bhatt seine Anforabe ertüllt hat, werden die in flm

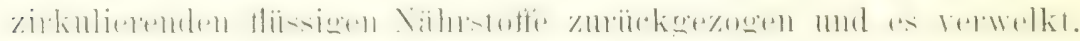
um nach einer gewisen heit ernenert zu werden. wem es nicht. wie bei den immergrinen Bämmen. durch einen jungen Nachschub ersetzt wurde.

Interessante Untersuchungen von Yöller und Rissmiiller haben ergeben, dass die Blätter im Frühsommer beträchtliche Mengen stichistoff. Kali und Phosphorsämre enthalten und gegen Herbst der grösste 'l'eil dieser Stoffe in den Bam zur Deckung des späteren Berlarfes zurïcktritt. die Bläter also. beror sie verwelken. an ihren wertrollsten Bestandteilen stark verarmen. In Buchenblättern wurde nachgeriesen, dass sie den höchsten Prozentsatz an Stickstoff, Kali mo Phosphorsäme besitzen. Wem sie sich im Mai öfhen und dieser Prozentsaty stetig zurickgeht bis zum Absterben. allein die wirk-

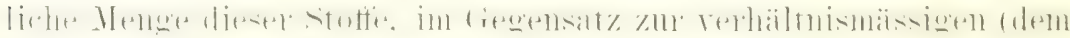
Prozentsatz). ist am höchsten im .Juli und vermindert sich ron da ab.

Anf der Ackerbanstation ron Comnecticnt wuden 1884 ron einer Eiche und einer Kastanie Blätterproben an den folgenden Tagen geptliuckt: 16. Oktoher und 13. November und der Analyse nnterworfen. Am 16. Oktober waren die Blätter hellgrim ohne Anzeichen pines Farbenwechsels. am 13. November waren sie bram mul hatten den rötlichen Hanch fast vollständig verloren. Die Blïtter fielen bereits an diesem t'age von den Bäumen, aber nicht zalilieichl.

\section{Allalyse der Blätter.}

Eiche

Kastanie

16. Olitoher 13. Norember 16. Olitober 13. November

Trasser:

Eiweissstoffe:

Rohiasern

Stickstofffreie Extraktstofle

Aetherextrakte

Asche
56,6

5,3

9.3

$2+9$

1.6

2,3

100,0
29,7

3,4

20,4

39.3

3.4

3.8

100,0
60,2

4,3

6,7

23,5

3,5

1,8

100,0
31,7

4, 2

13,4

42,3

5,4

3,0

100,0 
A nalyse der" Asche.

Eiche

16. Oktober 13. Norember

Kali

Fatron

Iialk

Magnesia

Eisenoxyd

Phosphorsäure

Schwefelsäure

Iiohlensia ure

Fieselsiume u.s. w.

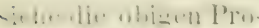

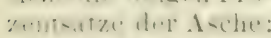

\section{0,326}

0,015

0,688

0,162

0,081

0,263

0,060

0,418

0,317

2.8311

\begin{abstract}
0,173
\end{abstract}
0,029

1,426

0,288

0,077

0,260

0,090

0,815

$0,6 \pm 2$
3,51111
Li:istanie

16. Oktober 13. Norember $0,3533 \quad 0,384$ $0,016 \quad 0,021$ $0,404 \quad 0,864$ $0,928 \quad 0,443$ $0,181 \quad 0,16 t$ $0,186 \quad 0,230$ $0,086 \quad 0,14 y$ $0,259 \quad 0,512$ $0,100 \quad 0,208$ 1.8:3 2.97 .5

Dic an 16. Oktober gepfliuckten Blätter hatten ilne Ver-

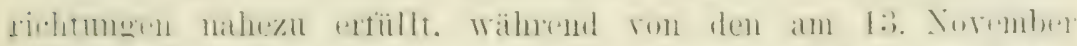

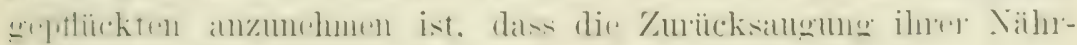
stotie nach den Zweigen abgeschlossen war.

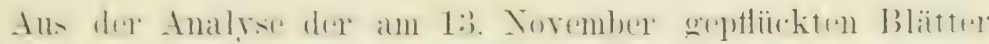

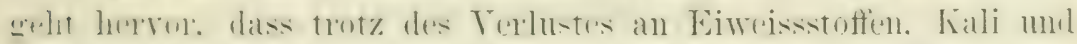

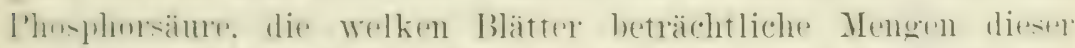

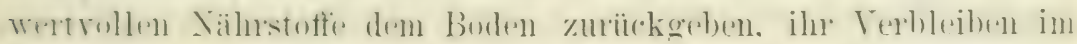

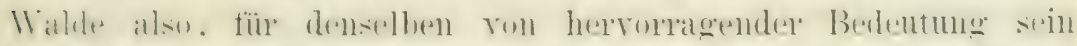

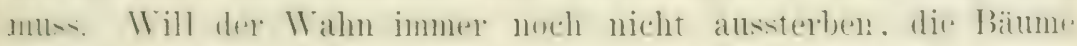

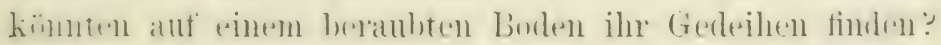

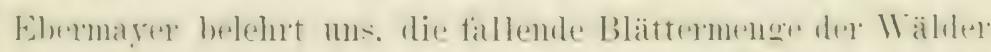

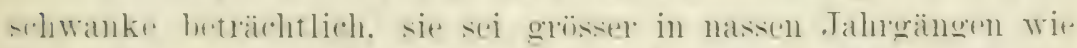

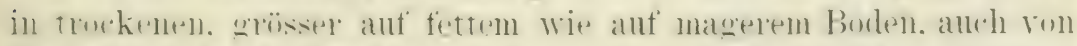

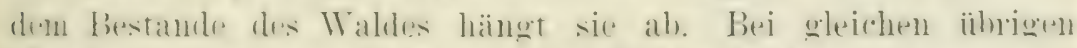

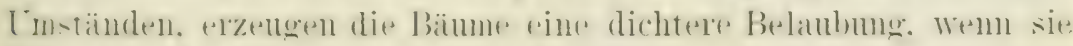
frei, anstatt gedrängt stehen.

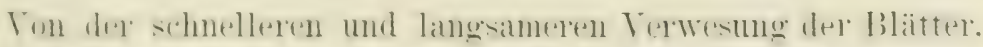

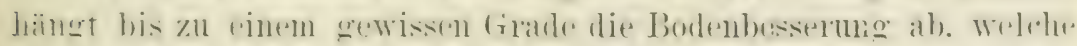

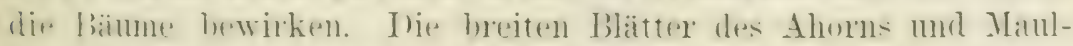

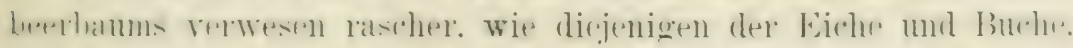

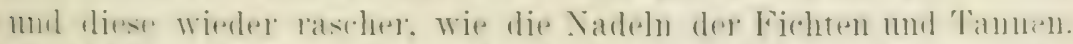

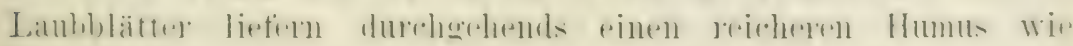
Nadelbliitter:

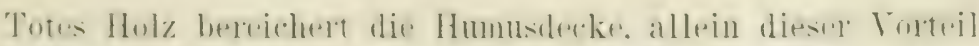

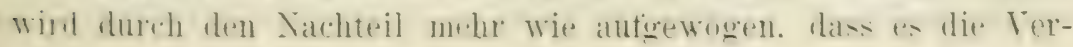




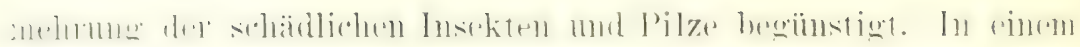

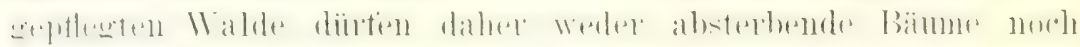
totes Holz zu finden sein.

Jie mineralischen Stotte (Asche) nehmen im Holze wie in der Rinde von oben nach muten ab, ihre Menge ist verlältnis-

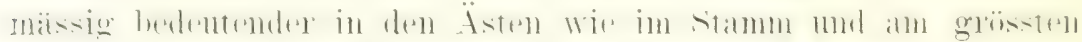
in den Zweigen und Blättern. Der Bildungsing und der Bast

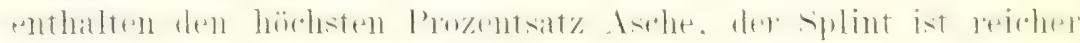
in dieser Beziehmo wie das Kernholz. Es scheint, dass das Zellensystem. sobald es aufhört thätig zu sein, seine Alkalien

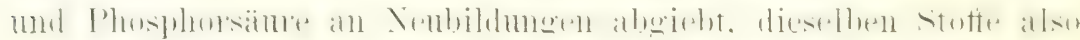

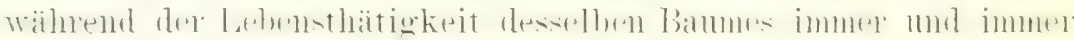
wieder: zur T'erwendung kommen. Es folgt daraus. dass der Baum

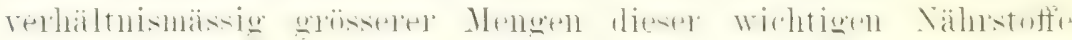
bedarf. wem er jung als wenn er alt ist, und der Boden einer

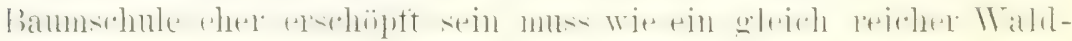
boden.

\section{Die Betriebssysteme.}

In der Forstkultur sind verschiedene Betriebsssteme ausgebildet worden, von welchen jedes, am richtigen Ort und unter

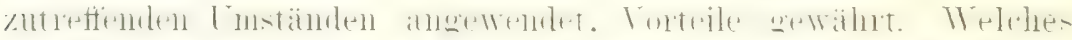

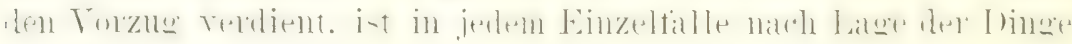
zu entscheiden.

Die bekamntesten und michtigsten syoteme sind:

\section{Der Lichtungsetrieb.}

Das Wesen desselben besteht darin. dass die in ilner Ent-

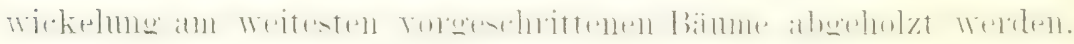
hier und da wo sie sich finden und den übriern reit zur Reife gregönnt wird. Zur Ansfïllumg der Lücken dienen die wilden samlinge und so kommt es. dass der Wald ans Bänmen aller Altersstuten besteht und einen geringeren Holzbestand umfiast, als gewöhnlich auf derselben Fläche steht. wem alle bäume gleich gross sind. Durch das jährliche Abholzen dev alten Bämme wird der Nachwuchs beschädigt, es bihlen sich leicht blösen, ganz besonders wenn weidendem Vieh der Zutritt gestattet ist. ferner richtet der Stum in solchem unregelmäsigen Walde grössere Verwiistungen an. wie in einem regelmässigen, anch das $\mathrm{Holz}$ ist in der hegel weniger wertroll, weil es in seinem jugend- 


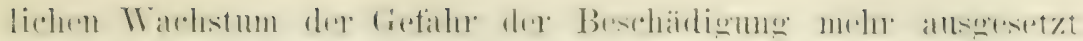

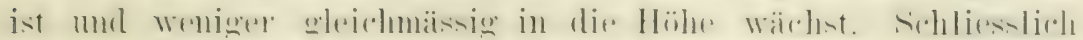

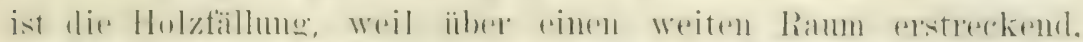

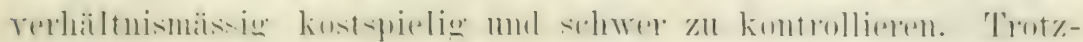

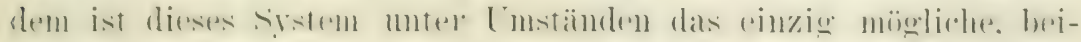

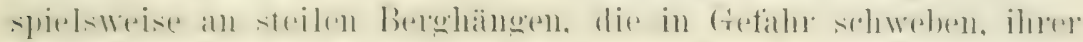

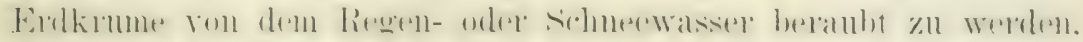

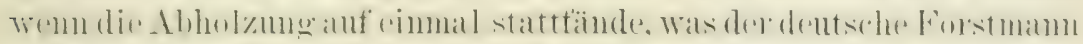

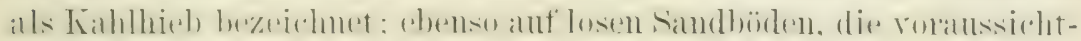

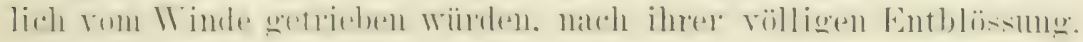

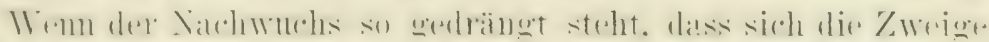

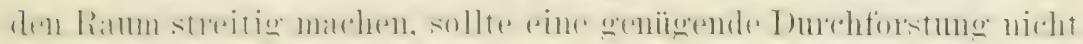

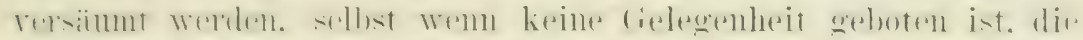

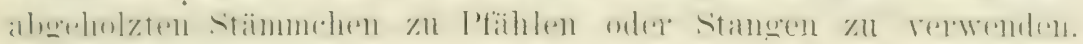

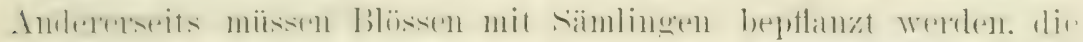
an Stellen ausgehoben wurden, wo sie zu dicht standen.

$$
\text { 2. Dex Schlagholzbetrieb. }
$$

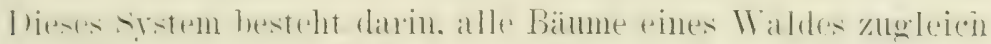

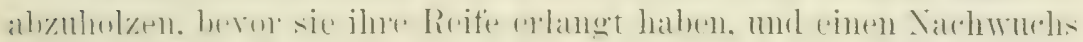

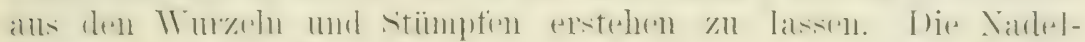

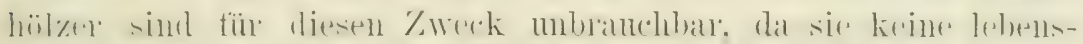

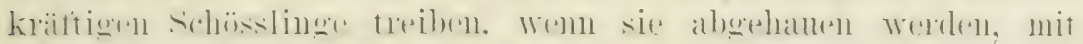

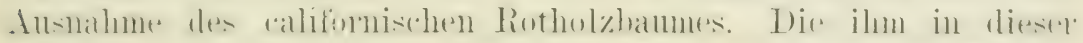

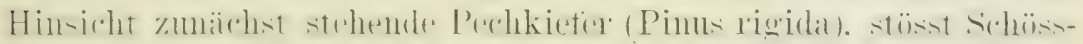

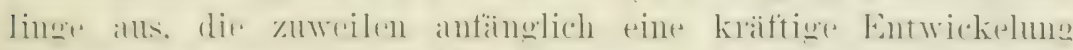

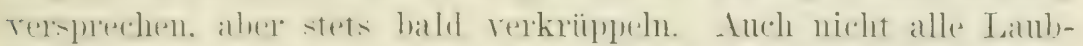

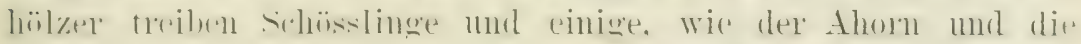

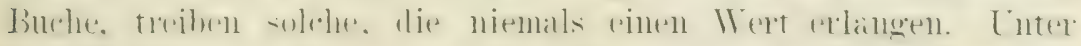

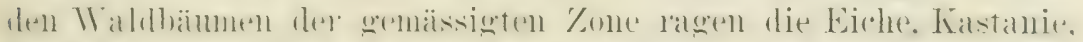

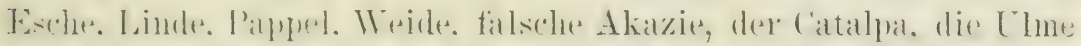

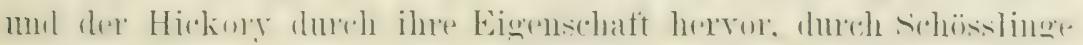
einen kräftigen Xachmuchs zu erzengen.

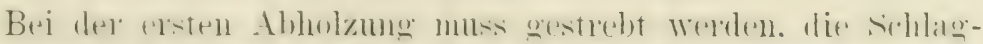

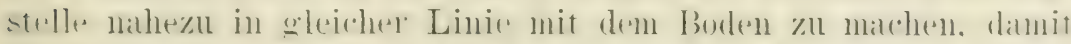

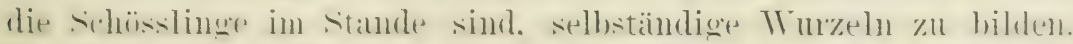

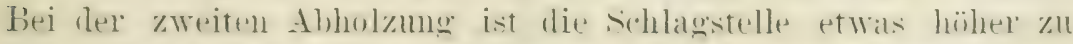

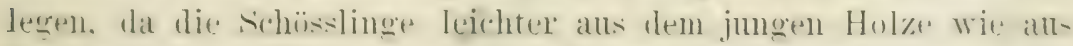

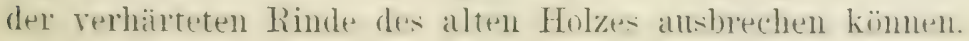


Lm Erfolg mit diesem System zu erzielen, muss die Al)-

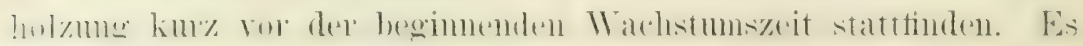

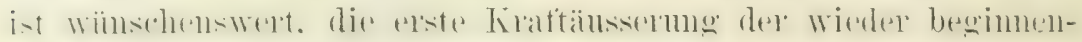

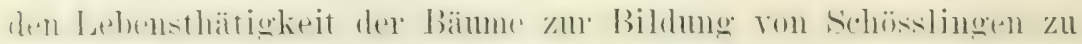

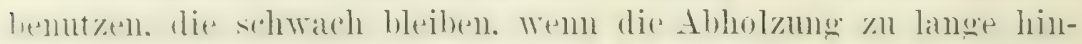

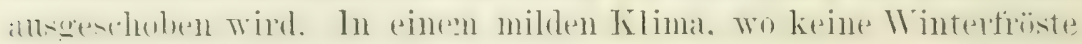

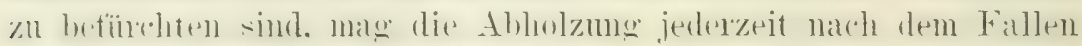

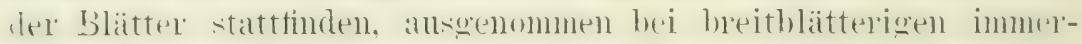

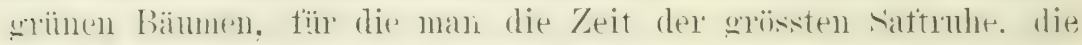

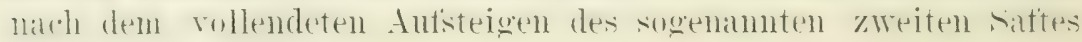
eintritt. abwarten muss.

Bei der Abholzung ist streng daranf zu achten, dass die

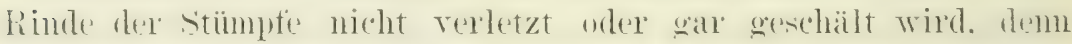
zwischen del Rinde und dem splint, ans dem bildungsing. entwickeh sich schösslinge. aber nur an unheschädigten strhlen. sehr emptehlenswert ist. nach dem Abholzen mit einem scharten

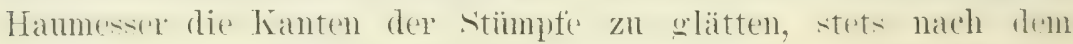
Mittelpunkte schlagend, der höher stehen soll wie die hituten.

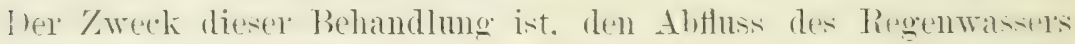

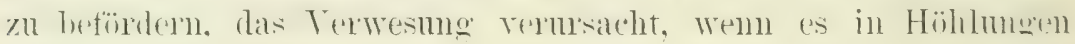
stehen bleibt.

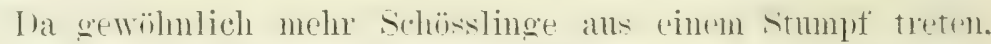
als aufwachsen diurfen, ist eine Durchforstung roozunelumen mul zwar frihzeitig. demn die Terschiehnug anf spätere zeit bedentet einen staken Thätigkeitsverhst des Stumptes. Gelegentlich ist es wön-chenswert, Lücken im Bestand auszutïllen. Was an leichtrsten nit abouenten sichösslingen geschieht. Wie die Absenk zu helandeln sind, wurde oben angegeben. Einige Bämme. wis die falche Akazie und einige Pappelarten. haben eine starke Veigung. Wuzelschiosinge zu treiben, oft in grosser Entfernung ron dem ILutterbatum. Diese Schöslinge entwickeh sich zu krättigen Bämmen und wemn ihre Termehrung erwiunscht ist, duchschneidet man die Wurzelauslänfer und bringt die Enden an die Bolenoberfläche: denselben entspringen zuverlässig schösslinge.

Es ist kitum nötig, daraut hinzumeisen, dass weidendes Tifh zu keiner Zeit und unter keinen Linständen den Niederwald betreten dart. Lnd nur unter ganz besonderen Cinständen ist die nicht selten geübte Praxis gerechtfertigt, in den ersten beilen Tahren nach der Abholzung zwischen den stimnten Kulturge- 
witchse, namentlich Liatotieln, anzubanen. In dor liegel ist der Vachteil einer solchen Bodenbenutzung grösser wie der Vorteil. Die Abholzmosperiode hängt ron dem Gobranchszweck mol den gegebenen Wachstumsbedingungen al). Nicmals ist sie ibber to Jahre anszudehnen. ermaissigt kann sie

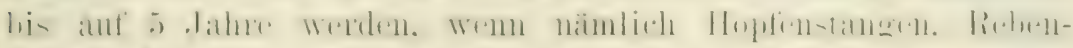

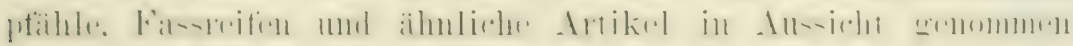
sind. Für Liohlen, 'Telegraphenstangen, Lohe u. s. w. wird die

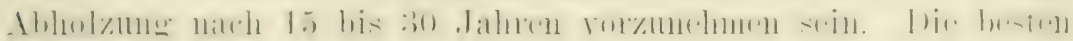

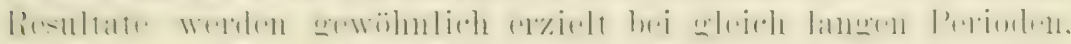

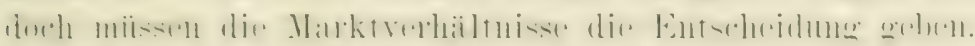

Nateh dem Abholzen sind die Stämme, nebst den abge-

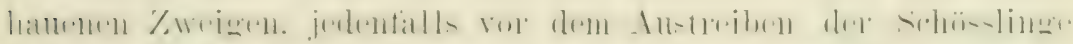

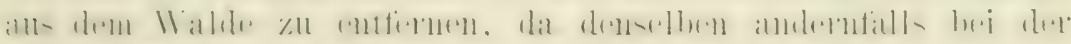
Wegschatfung schaden zugetügt wird.

Mit zumehmendem Alter verlieren die Stimufe die Lratt,

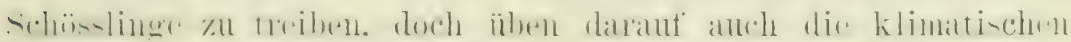

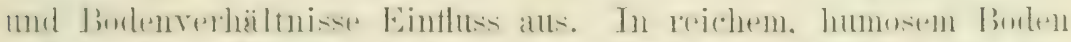

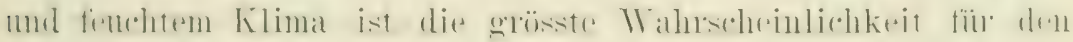

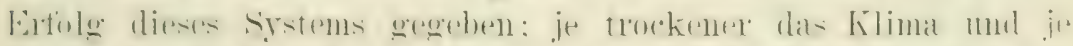

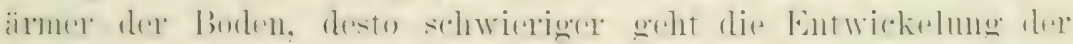

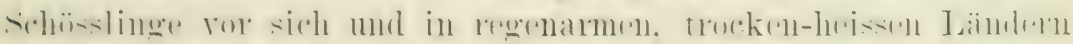

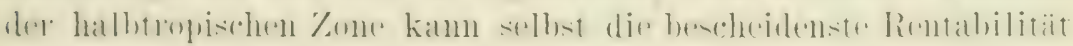
rieses systems nicht exhoftt werden.

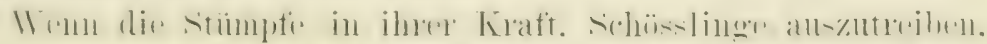

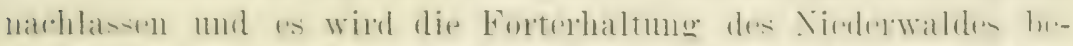

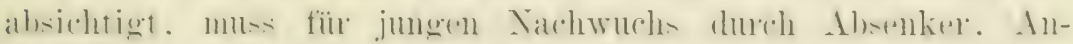

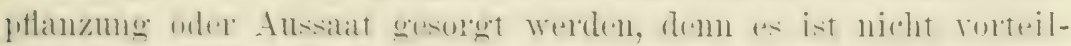

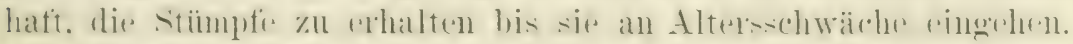

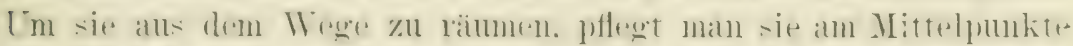

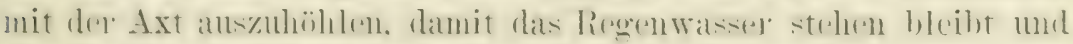
die limele an ringen stellen abzuschlagen. sobald ihre rin-

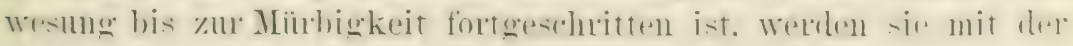
Axt auseinandergeschlagen.

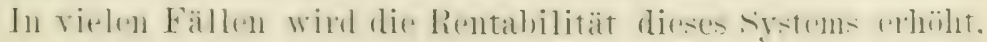

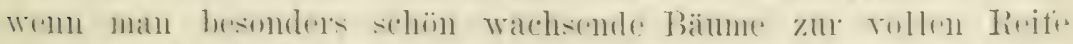

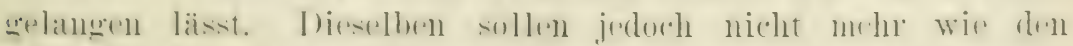

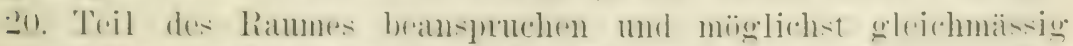

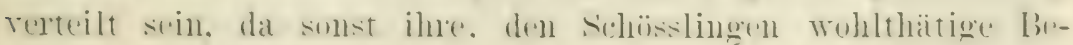




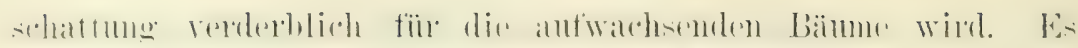
entsteht damit aus dem Niederwald der Mittelwald.

Eichen, die man im Hittelwalde zur Reife kommen lisst,

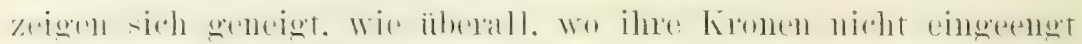

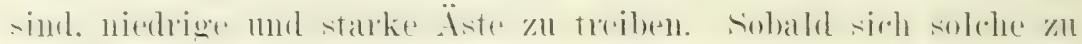

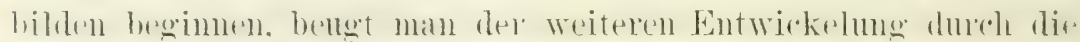

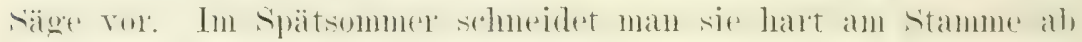
and rerstreicht die Wunde mit 'Teer. Es ist das einer der Ausnalmefialle. Welehe das Bechneiden vom Waldhämmen als wirtschaftich richtig erscheinen lassen.

Zu Erzielung eines Mittelwaldes lïsst man bei der ersten

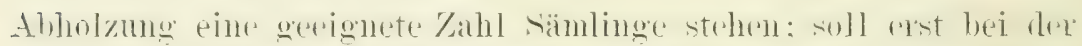

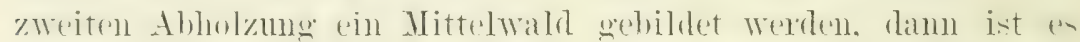

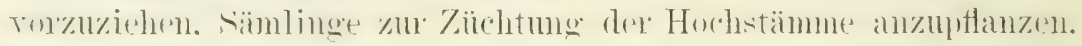

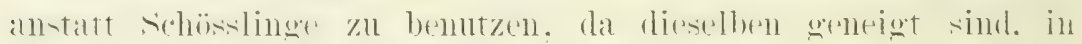
späteren Jahren zul rerkümmern.

Zu. Hochstämmen sind nur solche Baumarten zu wählen,

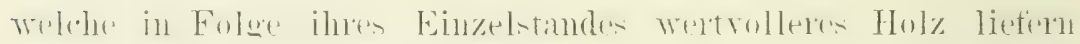
nud dabei das Unterholz nicht stark beschatten. Diese Voraus-

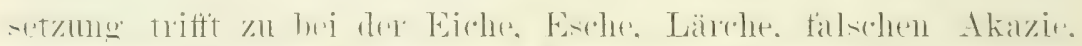

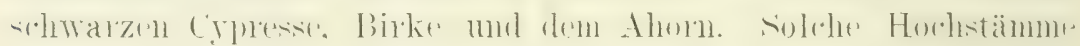

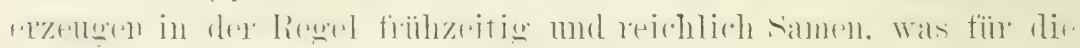
Terjung'ung des Waldes ein beachtenswerter Vorteil ist.

Das Unterholz des Mittelraldes muss ans schattenliebenden Baumarten gebildet werden.

3. Der Hochwaldsbetrieb.

Dieses System wird mit der Anpflanzung eingeleitet, wie sie

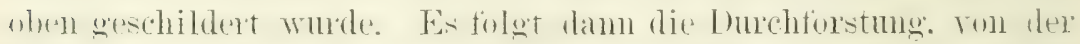

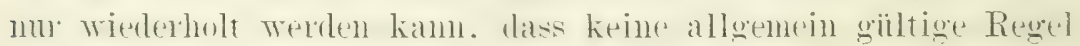
zu geben ist. da dit: Entscheidung wemäss dex wechsehelen Terhältnisse zu treften ist. Nur als Beispiel sei angeführt. dass in I) nutchland din aut gutem Borden stehender Buchwald wewähnlich vom 30. Jahre ab wie folgt durchforstet wird:

Vom 30. bis 40. Jahre bleiben 3200 bis 4000 Bäume auf dem Helitar.

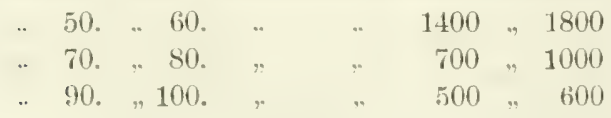


Sadelhölzer können in grösserer Kahl stchen bleiben, wio

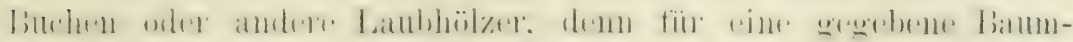

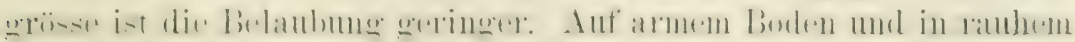

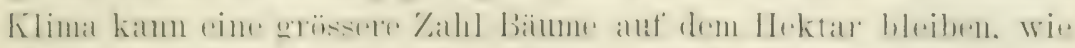

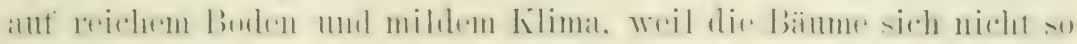

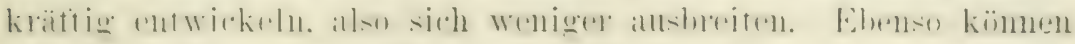

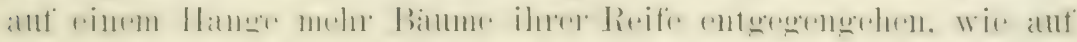

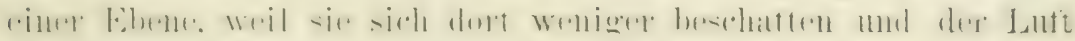
bessel ausgeset\%t siud.

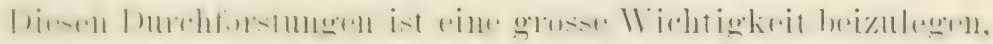

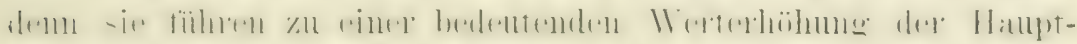

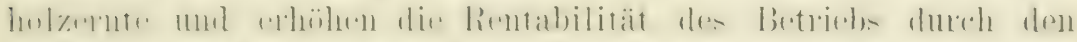

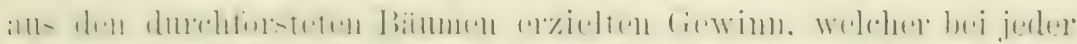

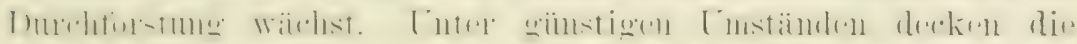

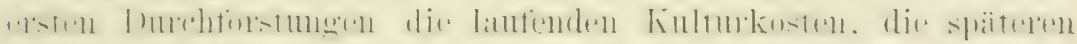

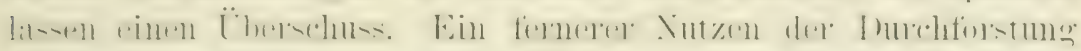

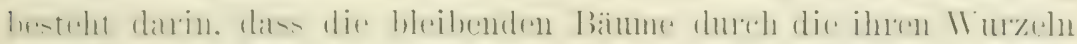

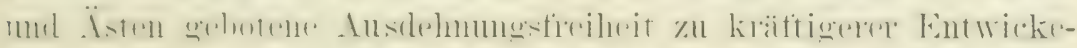

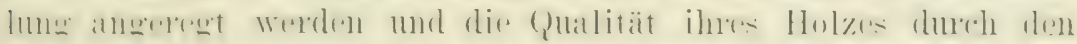

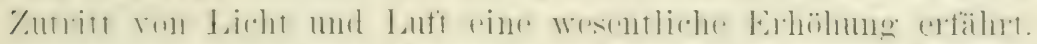

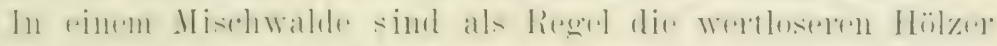

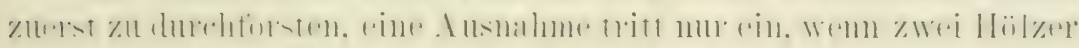

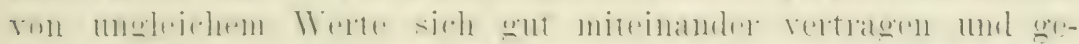

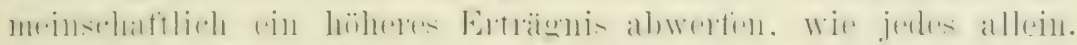

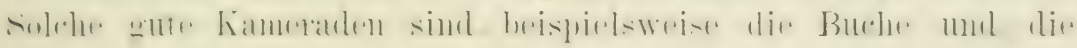
Kiefer mul die Fiche und die Buche.

IV emu die zeit del Abholzung herammaht, muss füi jumgen

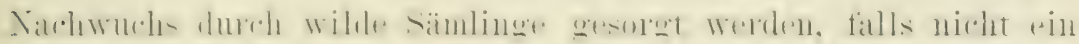

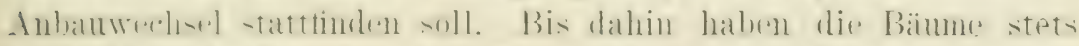

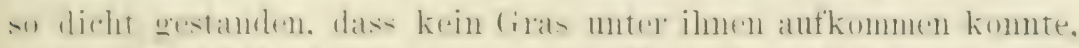

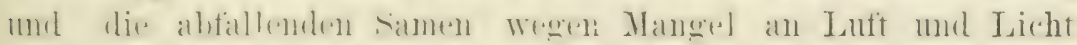

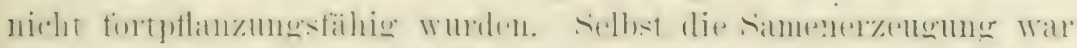

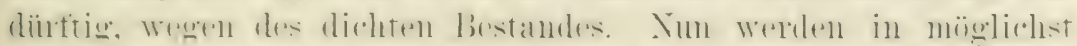

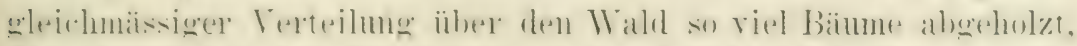

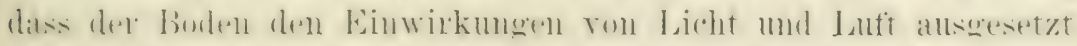

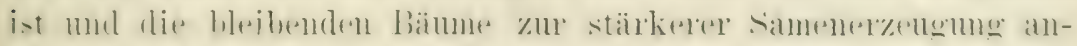

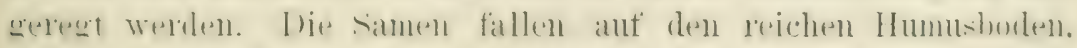

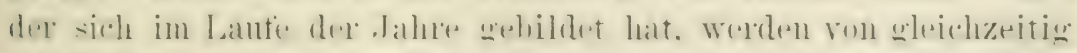

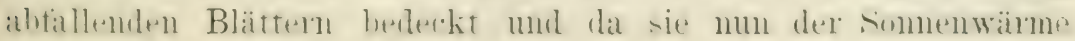




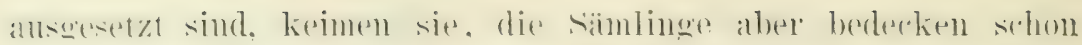

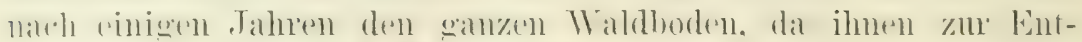

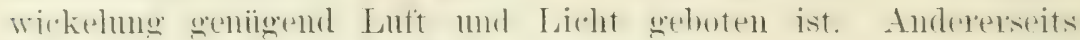

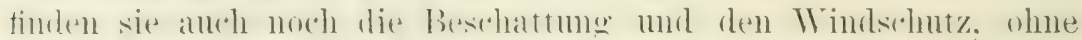

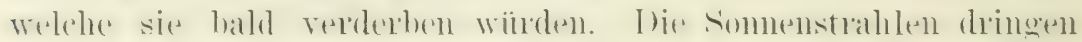

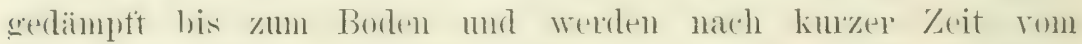

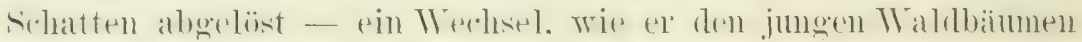
am besten zusagt.

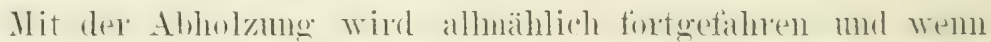

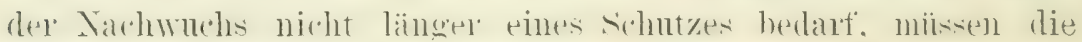
Iroten Bälme fillen. Fs ist nicht zu elwatell, dass die natill-

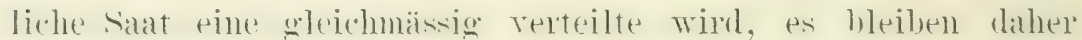

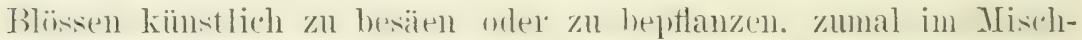

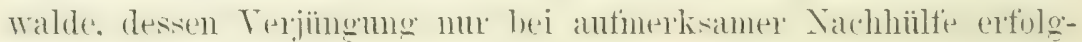
reich vor sich geht.

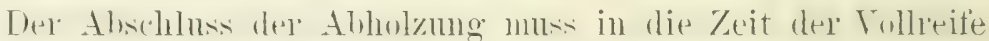

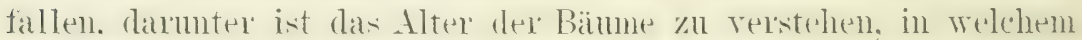

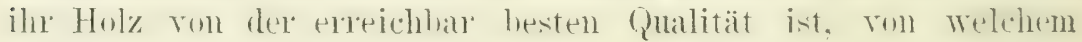
Höhepunkte es langsam zur Verwesung herabsteigt.

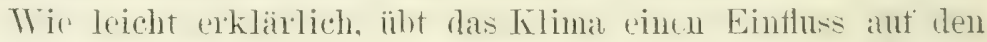
Eintritt der Roiti als. In der wemäsigen Zone eropichen Lärehe und Birke ilne Reite in sol his bu Talnen, die falsche thazie. dir cossische mol Aleppokieter in bo bis to Jahren, dir Kieter in su his 90 Jahren. die Buche in 80 his 120 Jahren, die Fseohr in

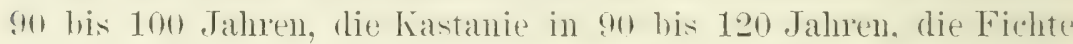
in 100 bis 140 Jahren. die Unme in 100 bis 120 Jahren, die Eiche in 120 bis 200 Jahren.

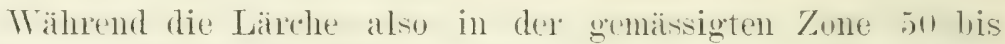
(j) Tahe zur Reife ihres Holzes brancht. nimmt sie in der kalten Zone. beispielsweise im Torden schottlands. 80 selbst 100 . Tahre in Auspruch.

Diese langen /eitabsehnitte entmutigen nicht selten zum Hochwaldshetrieb, deshalb sei angefïhrt. dass Hajtig. cine dentsche Autorität ersten Ranges. "rint vergleichende Berechmumg anstellte, mit der "r nachwies, dass ein Hochwalr, abgeholzt nach 120 Jahren, und ein Niederwald, abgeloolzt alle :30. Tahre, wälnend des Zeitraumes von 120 .Jahren Erträgnise lieferm. wolvhe wie 7 zu 4 regeniiberstehen. In Rechnung gebracht wurden aut beiden seiten die sämtlichen Ausgaben und Eimmahmen. 


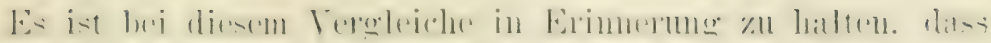

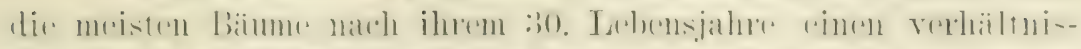

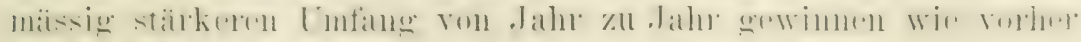

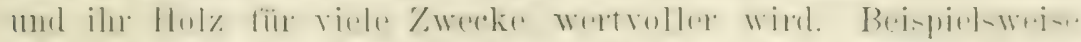

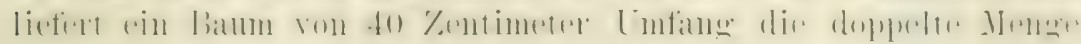
Bretter, wie ein solcher von 30 Zentimeter Unfang:

Der Wert des jührlichen Holzzuwachses der Eiche ist in

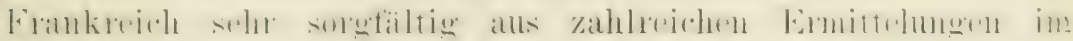
Durchschnitt wie tolgt berechnet worden.

Mark. Pfennig.

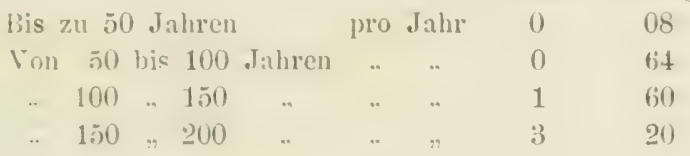




\section{Hilfsmittel für die Holzgewimmma.}

Damit die nachfolgenden Darstellungen im rechten Lielote betrachet werden. schicke ich voralls. dass sie nicht für die Holz-

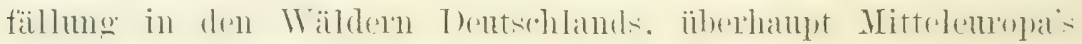

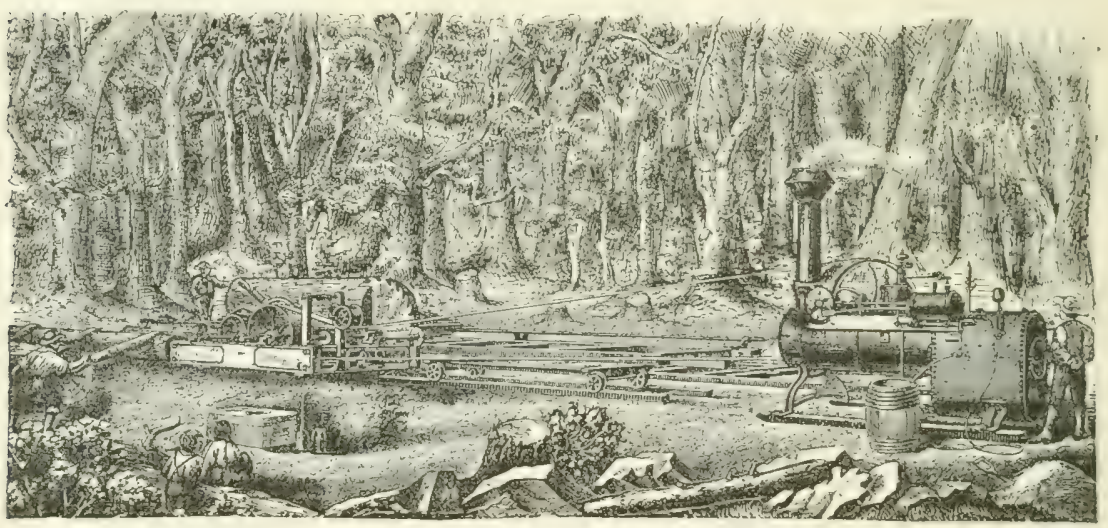

Figur 6.

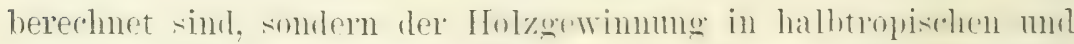
tropischen Täldern gelten. Für jene litgen ganz andere Tribältnisse vor. wie för diese, das bedingt abweichende Emtemethoden. Fs wird keiner weitschweifigen Begründung beduffen. warmu ich nur nordamerikanische ifaschinen und freäte zur Abhildung hringe. stehen doch die Tereinigten Staaten ohne Crleichen da in der Grossartigkeit der Wälderausbeute, ist doch, um für dirsen $/$ weck zeitund kraftsparende Hilfsmittel zu ersimen, der ganze .. Tankeewitz.

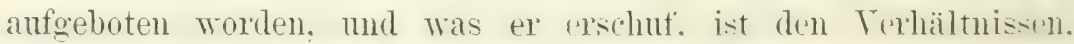
welche hier in Betracht kommen, ganz besmders angepast. Zum 


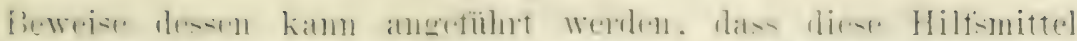

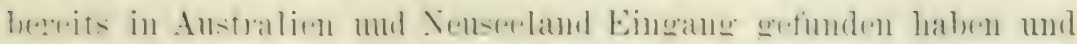

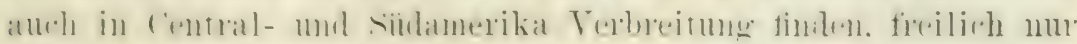

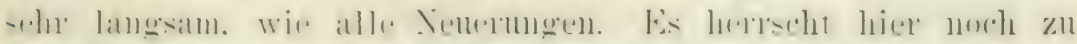

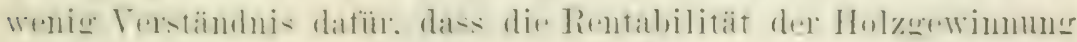

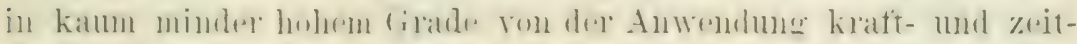

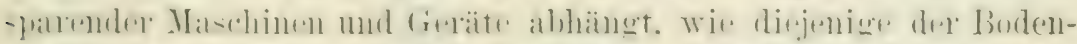

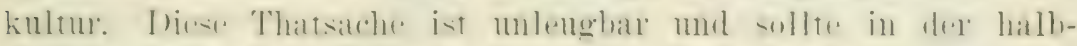

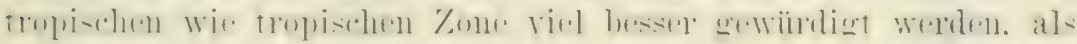

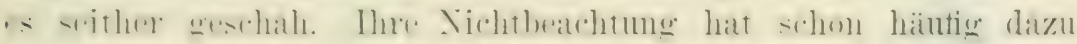

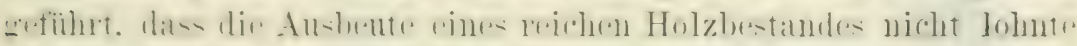

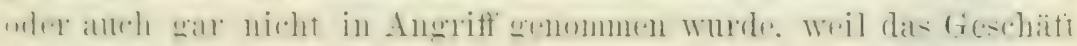
ron vornherein rerlustbringend erschien.

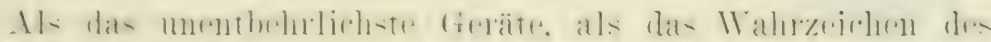

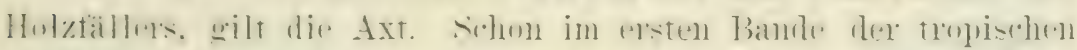

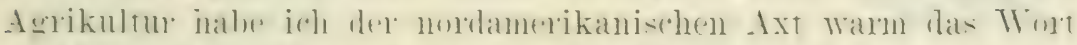

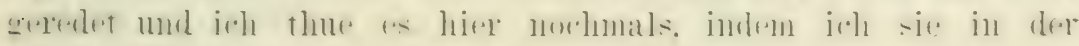
Figur 7 zur Anschaumg bringe. Der gebogene, nur in

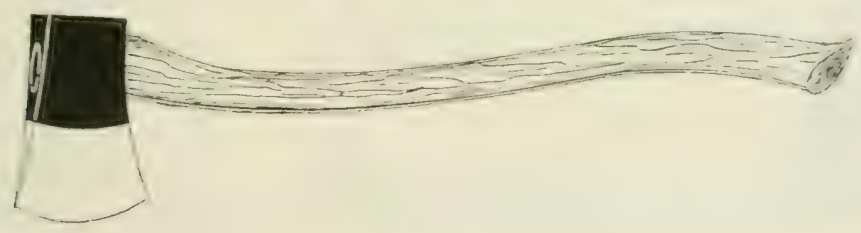

Fi:..... $\div$.

Fabriken mit den nötigen Apparaten herstellbare Stiel, Figur 8 . ist gewöhnlich aus dem

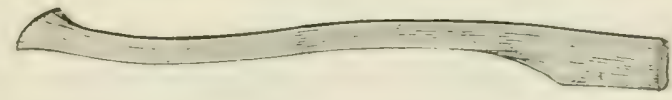

Figur 5 .

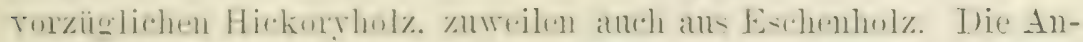

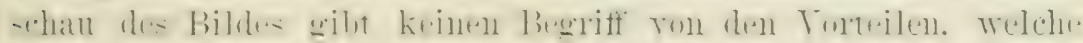

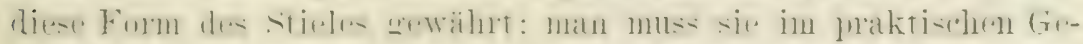

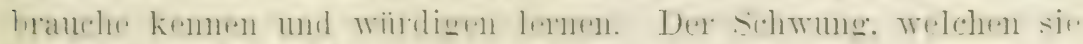

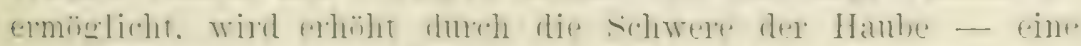

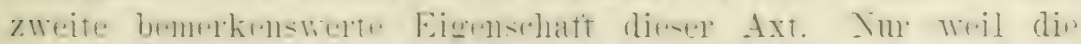

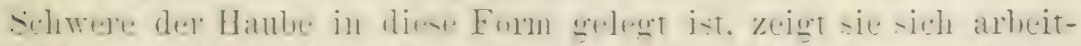

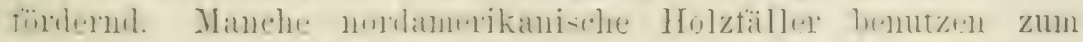

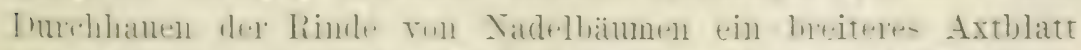

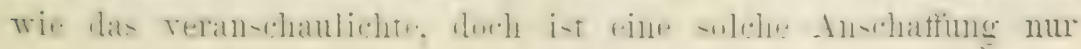


multhlenswert. Wenn die Rinde dex regelmässign zu fällenden Halume dick ist. Als Beispiele mögen dienen: die Rinde des Innglatamen ist häufg $10 \%$ /ntimeter, diejenige der californischen Rotholzbäume 15 bis 25 Zentimeter dick.

Gewöhnlich rüsten sich die nordamerikanischen Holzfäller ynit einem schweren und einem leichten Beile ans. Das Erstere wird schindelbeil genamnt. dargestellt ist es in der Figur 9.

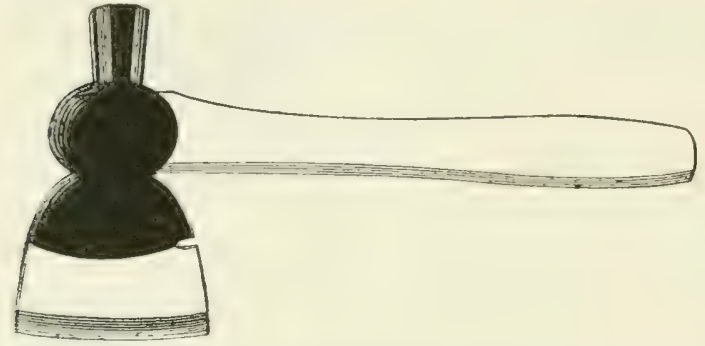

Figur 9.

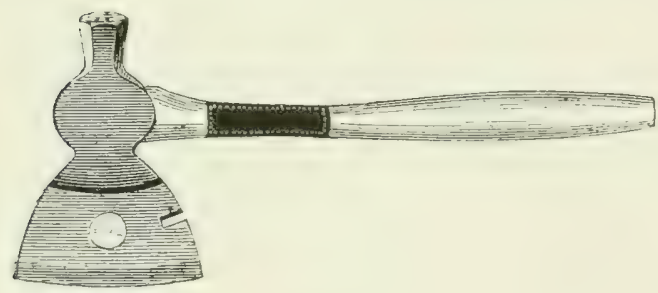

Figur 10. Dasselbe dient zur Ausführung von Arbeiten, für welche die Axt zu lang und unbequem, das Handbeil aber zu leicht ist. Das Letztere veranschanlicht die Figur 10; gebraucht wird es zu leichten Arbeiten, auch als Hammer und Nagelzange.

Bei diesen beiden Beilen bitte ich die Form derStiele wohl 7ı beachten. Die Anschwellung gewährt einen festen (trift ohne das Werkzeng schwertälig zu machen. Es sind oft nur solche kleine Torzüge, welche bei rlex Anschan übersehen werden und erst im praktischen Gebrand heroutreten. die den amerikanischen Geräten eine solehe Beliebtheit sellst in den fuglischen Kolonien rerschatft haben. dass sio die Guäte des Mntterlandes mehr und mehr verdrängen. Ferner lenkr ich die Autmerksamkeit anf die Beilblätter, welche, stark nach mntell verIneitert, eine lange sichlagstelle treften. I)abei sind sie verhälnisznässig leicht und doch kräfti@. weil aus gutem stahl geftertigt.

Nächst dex Axt bedarf der Holzfäller einer sprmmsäge. In der Figur 11 ist die nordamerikanische Form veranschanlicht, die jch ebenfalls ans eigener Erfahrung warm empfehlen kamn. Ther den Gebranch ist zu sagen: der Sägebock ist etwas nierlriger wie der in Deutschland übliche: die säge fasst man am 


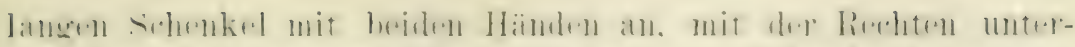

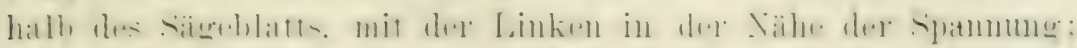

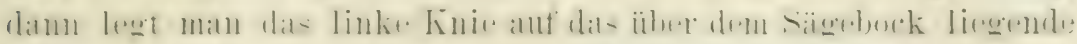
Holz; manche finden es bequemer: den linken Fuss aufzusetzen, und heginnt zu sïgen. Ich kam rersichern, dass mit diesem Instrument, in dieser Handhabung eim Mam das Doppelteleisten kimm, wie mit der europaiischen Spann-

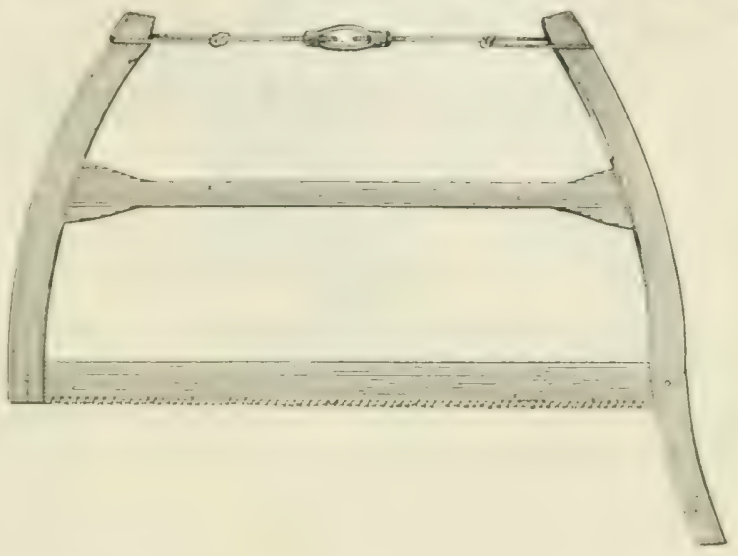

Figur 11.

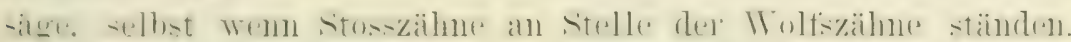

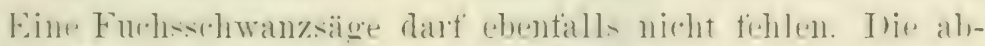

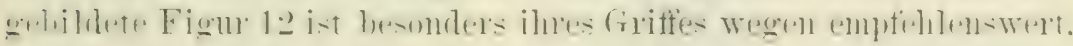
demu er gestattet mit beiden Händen anzufassen: mit der Rechten im Loen. mit der Linken am Horn : es wird damit

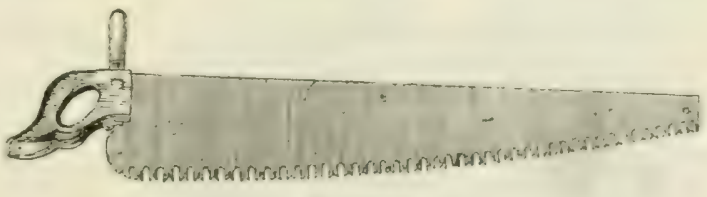

Figur 12.

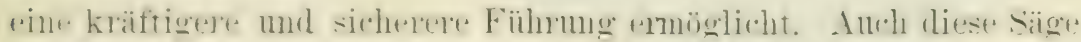
hat IVolt-zailhwe oder .. Blitzzïhne." wir sie ron den Anerikanern genlannt werden. deren Forzug darin besteht. in Zir.hen und stossen

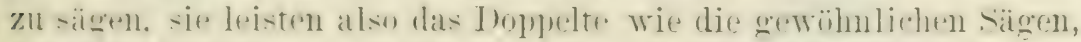
die lukanntlich nur im str-sen sägrn. Dite Wolfoühn machen

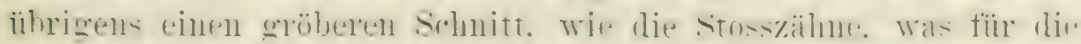

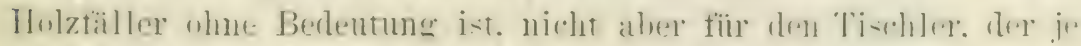
nach der Arbeit eine Wahl zu treften lat.

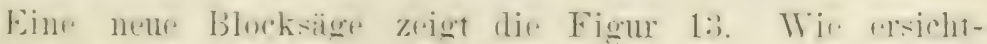

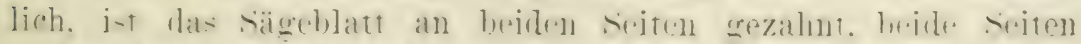

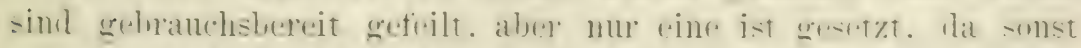
selb-trerständich die andere beim sïgen hindern wionde. Irem 


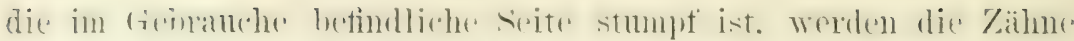

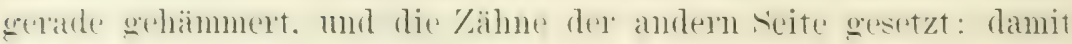

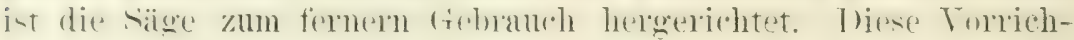

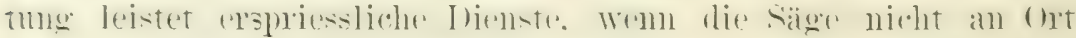

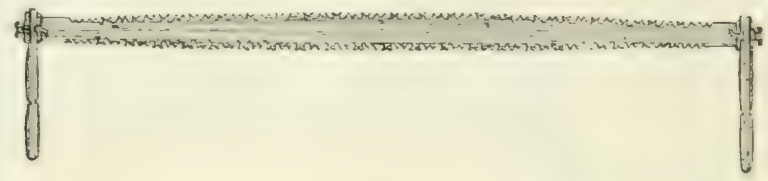

Figur. 13.

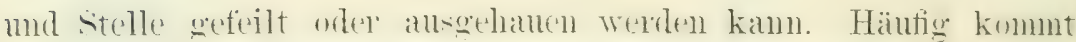
die Sïge nicht in die Hände cines geshohten sägenhaners. mol ihre früheren Dienste leistet sir damn nicht mehr. In solchem fialle ist die säge länger branchloar. Wip eint. die nur anf einer reite gezahnt ist. Tie beiden (iviffe sind relstellbar. so dass die säge sowohl zum Tmsägren stehender Bämune. Wie zum Zersägen liegender Stämme benntzt werden kann.

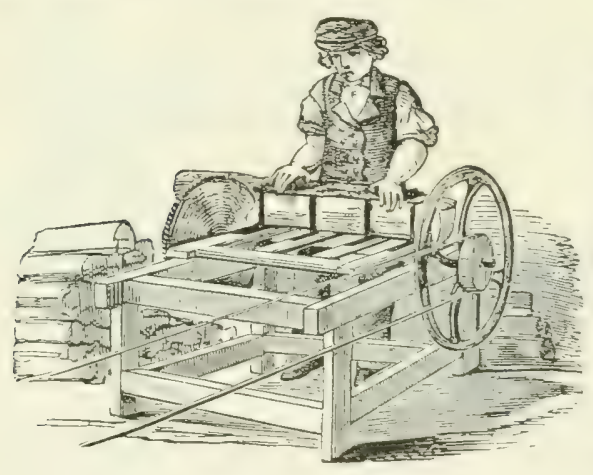

Figur 14.

Wenn bei der Holzgewinnung eine Dampfmaschine im Betrieb ist, rerdient die in der Figur 14 dargestellte. Wheelers Tood Sawing Maschine zum Sägen des Bremuholze: Beachtmo: Ditelbe wind in rerschiedenen (irisisen angetertigt. die 200 bis 300 Mark kosten. ILan kann rechnen, dass eine solche Maschine 5 Arbeiter

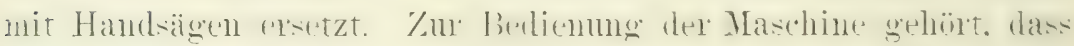

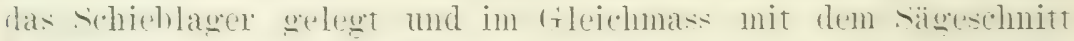
fintereshoben wird. Xach Vollendung des schnittes wird das schieh-

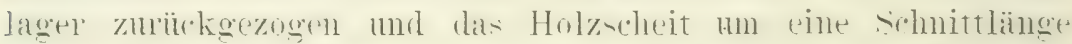

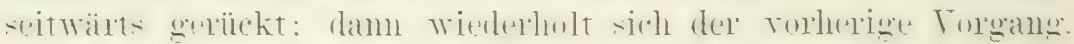

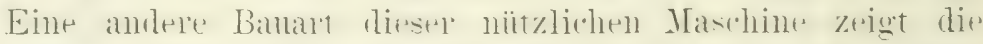
Figur 15. Der Preis, einschliesslich der 60 Zentimeter

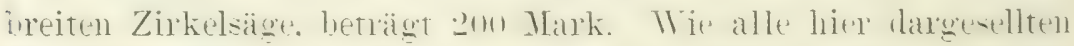

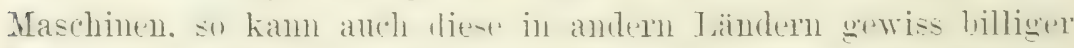

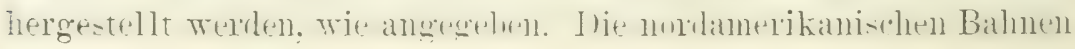




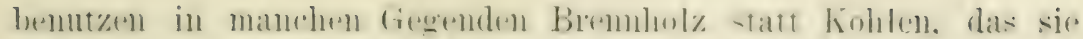

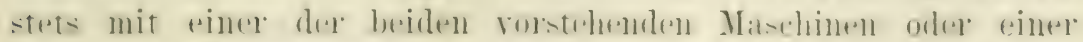
ïhnlichen Bauart sägen lissen.

Der Gebranch der hier abgebildeten Maschine wird nach dem Gesagten kitum einer Erklärung bediurfen. Der' 'Träger' des Scheitholzes ist so beweglich, dass er bis an seinen Rücken an die Süge geschoben werden kann. 1)er

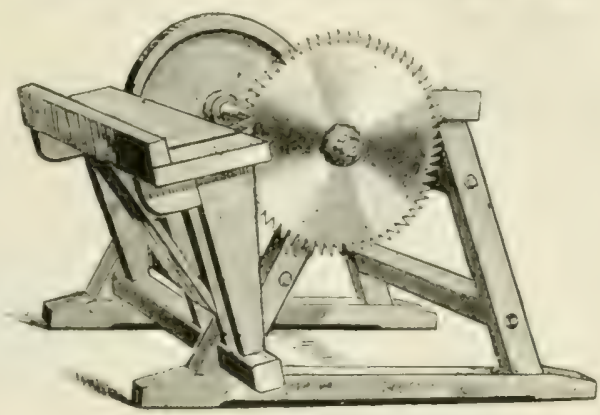

Figur 15.

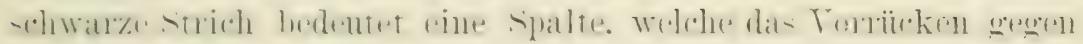
die sü̈ge ermöglicht.

Alich fiir das Zersägen der blïcke hat man die Handarbeit zn ersetzen oder zn erleichtern gesucht. Diese letztere Absicht hat in der Reitersäge Verkörperung gefunden, die in der Figur 16 veranschaulicht ist. Eine Gebranchserklärung wixd iiberfliissig sein. Der Preis beträgt 100 Mark.

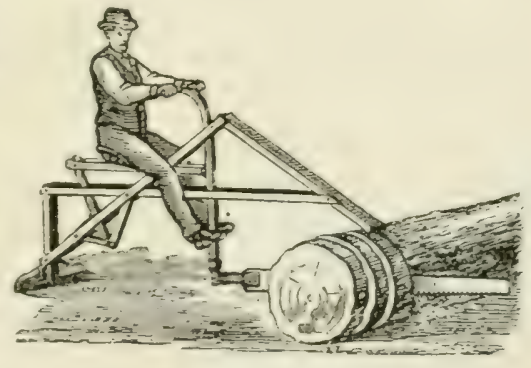

Fi:mr 11i

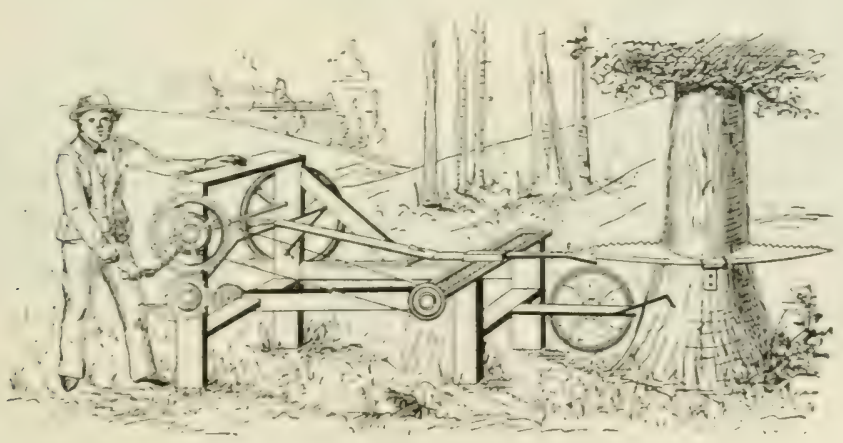

Figur 17.

Eine andere Marehine dieser Art ist an dex I'azifikhïste im

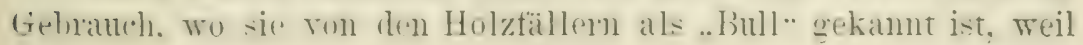


die Firma Grorge Bull u. ('ie. in San Franziseo die Patentinhaber mol Fabrikanten sind. Veranschanlicht wird sie in den Figuren 17 rind 18 .

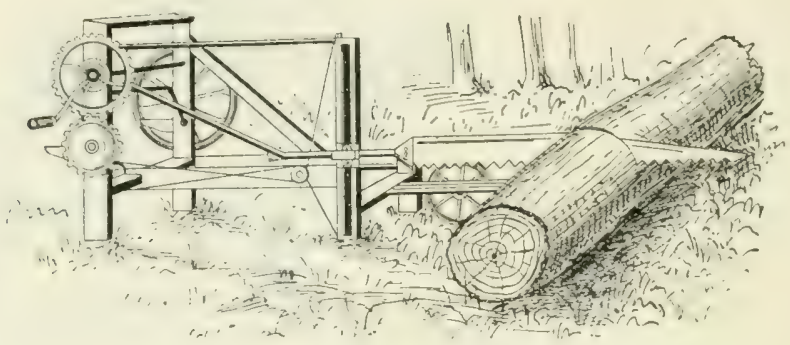

Figur 18.

Tie erstere zeigt sie in del Thätigkeit. einen stehenden banm unzuägen. die letztere. wie sie einen liegenden Stamm zerlegt. Der Butriel) erfordert nur eine geringe Kraftünssermo des bedienenden Arbeiteds. trotzdem bertegt das einfache Hebelwerk dir. Siige latsh hin mol her. Die bedentende Kraftersparnis ist

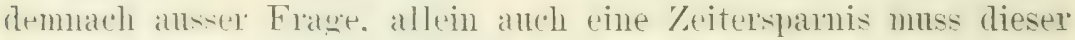

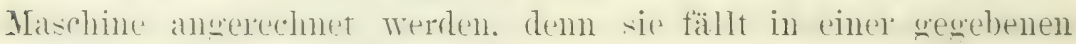
Zeit mehr Bäme wite ein Holzhatue mit einer Axt. Ihrer allge-

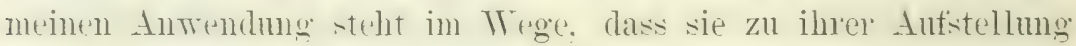
pines Trammes bedart. dex in einem dicht bestandenen Walde nicht rorhanden ist. Nor in einem Lrwalde, wo die L'mgebung eines Baumes leicht gelichtet werden kann oder in einem Fulturwalde. der zur voliständigen Abholzumg bestimmt ist, kamn sie in Gebrauch kommen.

Die Anwendum piner Sägemaschine zum Fällen der Bäume wird in Tordamerika immer gebräuchlicher, hauptsächlich ats rifesen beiden Grimden: « findlet. dem Axthieb gegenüber, eine Ersparnis an Holz statt und zwar am wertrollsten Holze des Stammes und fermer ...pringt der Stamm klarer rom Stumpt", eine Ausdncksweise, die kiner Erläutermg bedüren wird.

Eine einfachere, weniger Raum in Anspruch nehmende Maschine wird von der Folding 'sawing Machine Company in Chicago fahriziert und ist zmächst in den Waldstaaten Michigan und Wirconsin in Gebratuch genommen worden. Zwar habe ich diese Haschine noch nicht gesehen, doch hörte ich ron verschiedenen Seiten so gïnstige Beurteilungen, dass ich nicht anstehe, sie der 


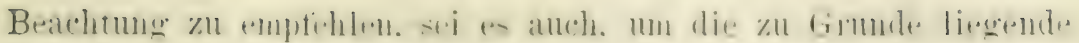
Idee weiter anszubanen.

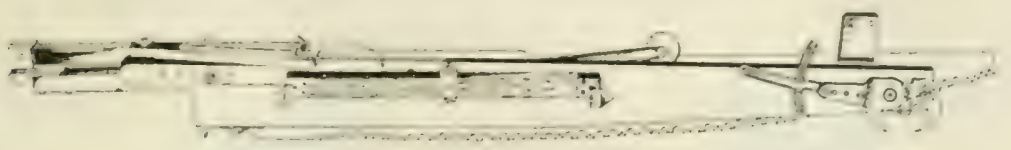

Figur 19.

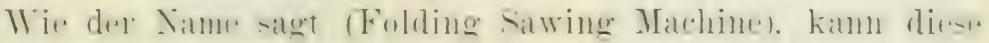
Masthine zu-itmmengetaltet werden. in Welchem Zutande se di. Furn be-ita. welehe die Figur l! wiedergibt. Da das Gewicht

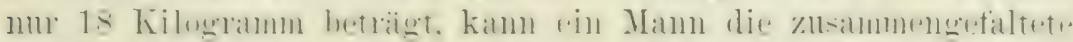

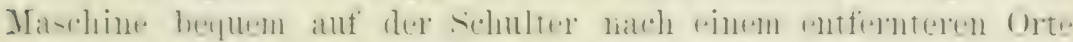

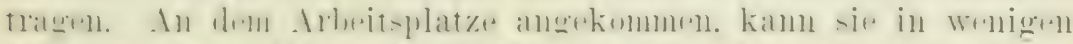

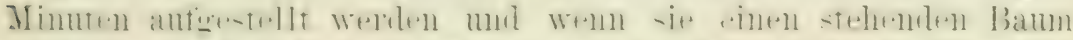

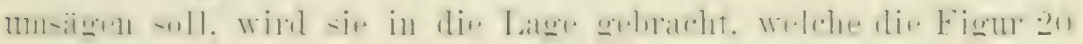
zeigt.

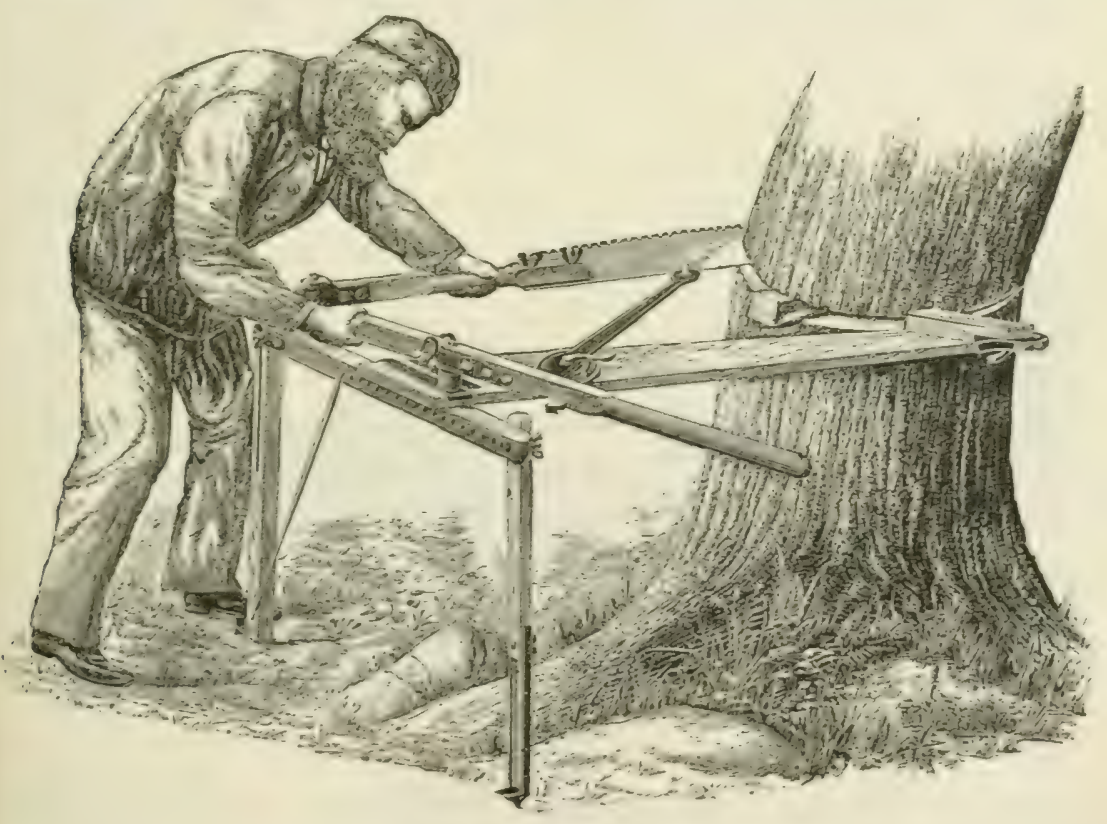

Fignu 20.

Der Baum darf einen Durchmessel ron 11/: Metel haben.

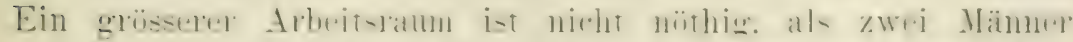

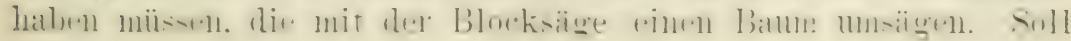


der Baum hart ïber dem Boden abgesägt werden, dam legt man die Fïsse der Maschine um, sie nimmt dann eine Lage ein, welche die Figur 21 darstellt.

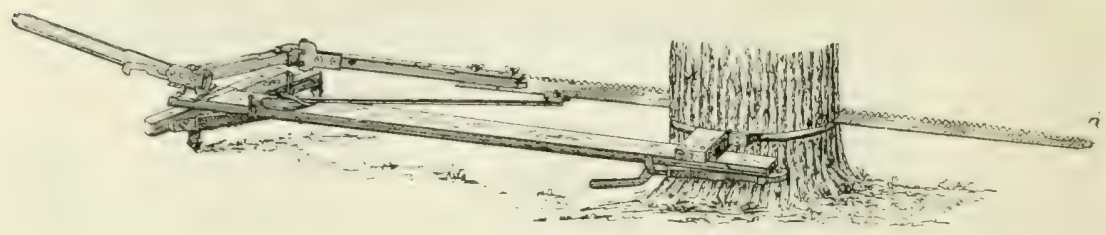

Figur 21.

Wemu der Stamm liegt, wird die Maschine aufgestellt. wie die Figur 22 zeigt, um die Blöcke abzusägen.

Liegt der Stamm auf einem Hange, so versetzt man den Hebel etwas seitlich, damit ex bequem in Bewegung gesetzt werden kann. Übrigeus kann die Maschine hängendem oder holperigem Boden leicht angepasst werden, da die Füsse verstellbar sind.

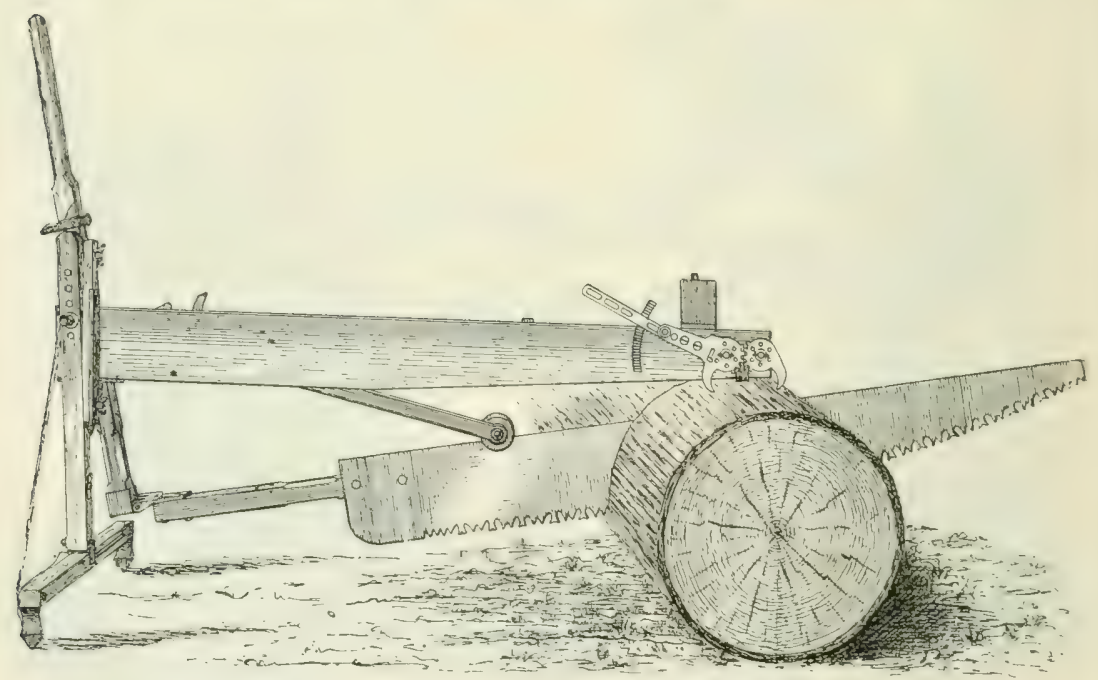

Figur 2s.

Den Vorzug besitzt diese Maschine jedenfalls, dass sie mässige Anschaffungskosten verursacht, die vor einem Versuche nicht zuriickschrecken, demn sie wird frei ab Chicago für 63 Mark geliefert; eine Extrasäge kostet 17 Mark.

Eine Sägemaschine, welche nicht von Menschen, sondern ron 
Pferden in Bewegung geretzt wird. zeigt die Figur 28. Sic fühnt den Xamen Drag solw Machine von Griftings in Nel-Vork und kotet 2-t0 Mark, ansomommen die Trotmiihle. die mit 5on Mark

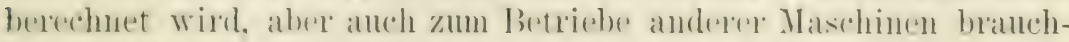
bar ist.

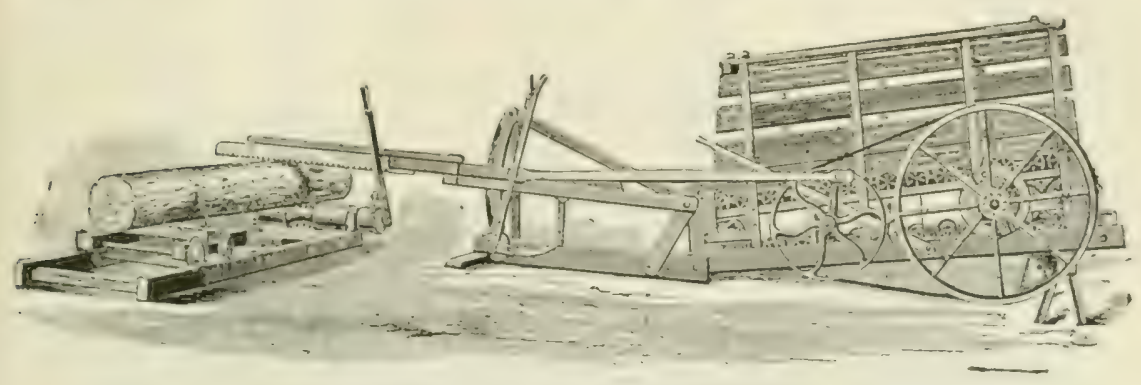

Figur 23 .

Wer den 1. aler :3. Band der ..'Tropischen Agrikultu” geleven hat. bedaref der Erklärmug nicht. dass die ron nir warm

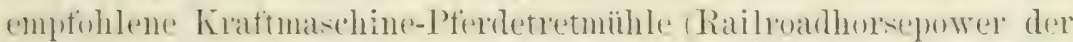
Nordamerikaner) in diesem Falle dazn verwendet wird, eine sïge-

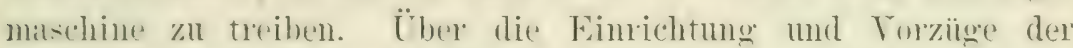
'Tretmïhle habe ich mich in der ..'Trophischen Agrikultur" ausfïhlich verbeitet und indem ich daranf verweise. fïhne ich nur kurz an. dass zum Betricbe der in Rede stchenden Maschine ein schweres Iferd genïgt, das in der Tretmühle die Bewegung des Gelens matcht. dabei immer auf derselben stelle bleibt. Diese Arheit ist durchates nicht crmüdend, weil das Pferd durch sein Gewicht anf die rollende Briiche wirkt. anf welcher es steht und die anf das sehwungrad die treibende Kraft fortpflanzt. Der bedienende Arbeiter stellt sich so anf. dass er die beiden sichtbaren Hehel ereichzeitig erfassen kamm. Mit dem linken schiebt ar den Stamm fort. mit dem rechten setzt ex das Sohwungrad ausser Wirksamkeit.

Bei der Anwendung ron tierischen Krriften zun Treiben der sägemaschine ist man nicht stehen gebliebent. sondern hat anch den Dampf zur Hilfe genommen, wie Figur 24 zeigt. Diese Dampfsïgemaschine wird ron $\mathbb{W}$. E. Hill if co. in Kalamazon in Michigan fabriziert. die ihr den uncomfortabel langen Vamen Patent improred directacting steam dragsaw marhine gegeben 
haben. Ther Preis stellt sich auf 1.t50 Mark. Terbertme hat

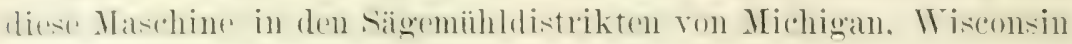
und Tlinnesotal gefunden.

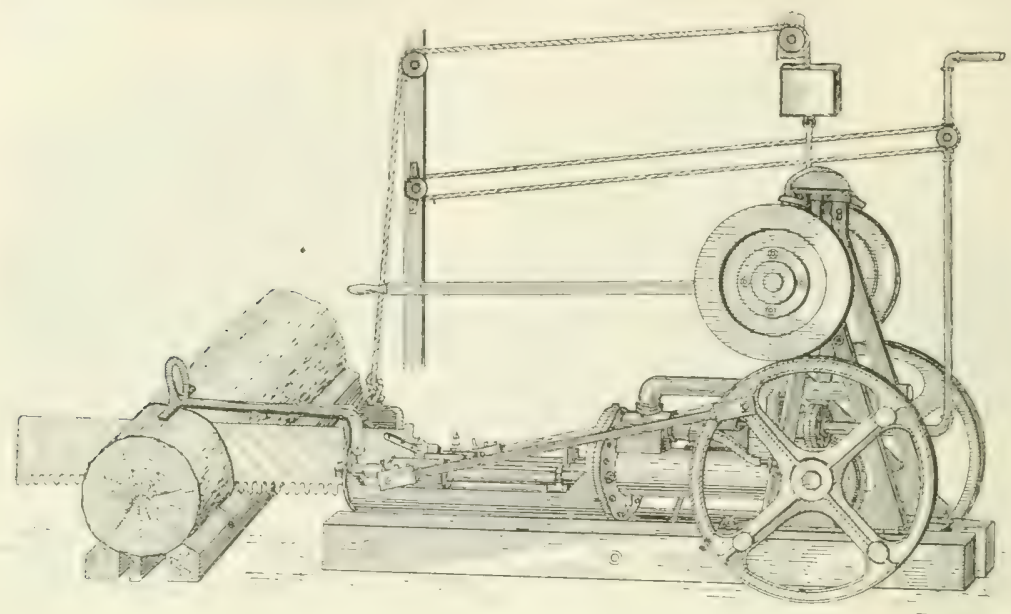

Figur: 24.

Wie der Name sagt, so wirkt die Dampfkraft direkt auf die säge. worlureh die stossende Bewegmeg verminden wird. Welche

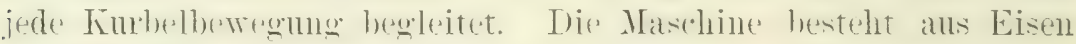
mud stahl, answenommen allein die hölzerne Hebelvorrichtme, werche zum Heben der säge und anch der Maschine dient. damit sie einen stamm ron jedem beliebigen Durehmesere zersägen kamn. Anf Winsoh wird die Maschine fïr zwei siigen eingrerichter, welche 40 bis by Zentimeter im Abstand sitzen end also zwei Blïcke in finer Zeit abtremen. Die Anschan der Abbildung lehrt, dass der Maschine Dampt aus einem besonder's autzustellenden Kessel geliefert werden muss und das ist jedenfalls ein Yarhteil bei der Benutzung im Walde. Fïr desn letzteren Zweck sollte der grnten frrundidee eine abgeänderte Gestalt gegeben werden.

Bis jetzt sind nur solche sägemaschinen gezeigt worden, welche die stämme in Blöcke zerlegen; kraft- und zeitsparend, wie sie sind, kïmnen sie doch nicht die grosse Schwierigkeit heben nder mindern, welche sich in wegelosen Wäldern dem Transporte der Blöcke entgegenstellen. Es ist emlenchtend, dass durch das Zerschneiden der Blöcke in Bretter in nächster Nähe des Gewimnungsortes eine ansserordentliche Transporterleichterung her- 


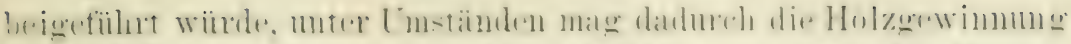

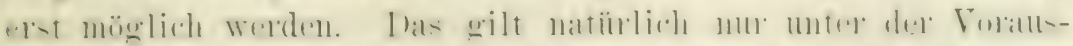

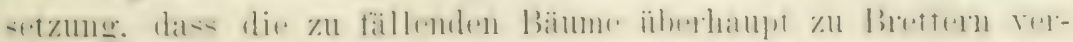

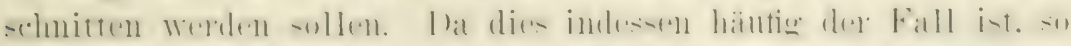

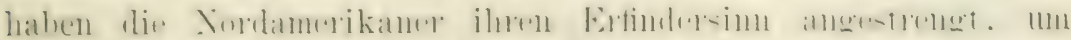

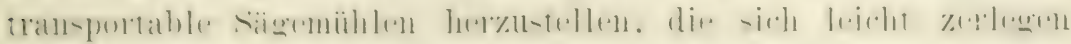

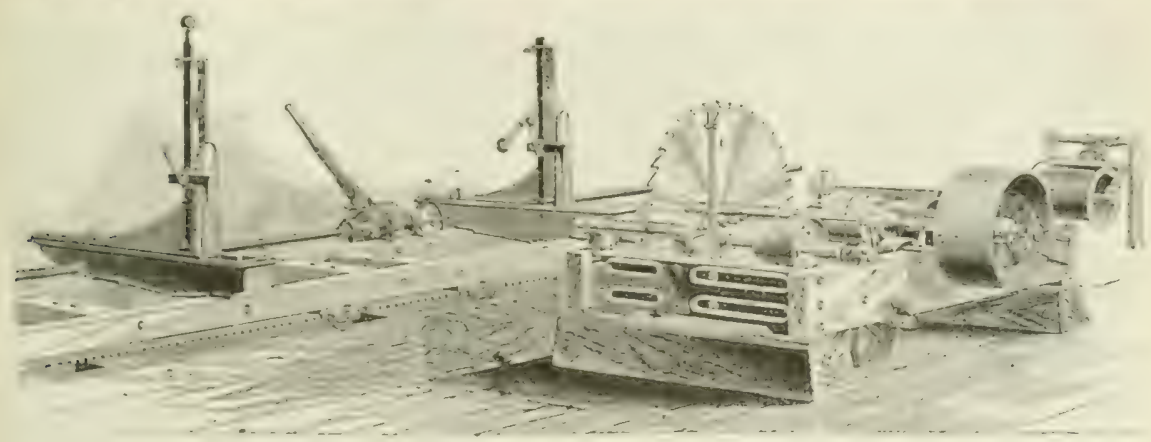

Figm :-5.

und an einem anderen Orte wieder zusammenstellen lassen. Be-

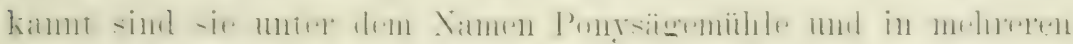

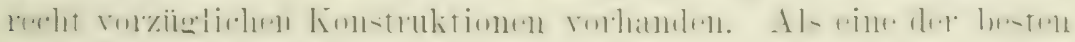
gilt die in der Figur 25 gezeigte .Massillon:"

Russell if Co. in Massillon. Ohio. sind die Fabrikanten und

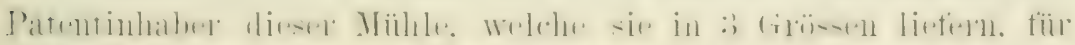

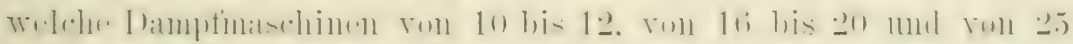

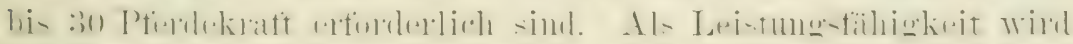
angegeben :

für 10 Pferdeliraft 90 bis 120 Meter Bretter, 21/2 Zentimeter dick pro Stunde.

$\begin{array}{llllll}-20 \quad . \quad 240 & \ldots & 300\end{array}$

"30 " $360 \quad 400 \quad$,

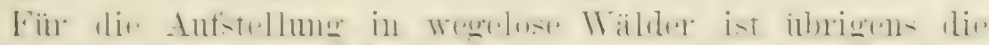

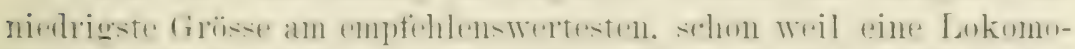

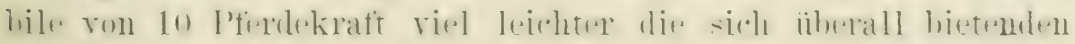

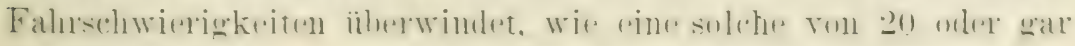
30 Pferdekraft.

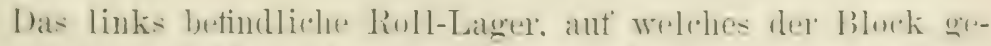

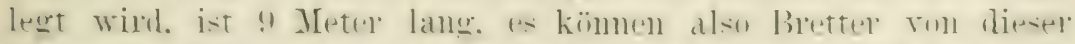

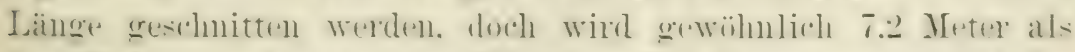
das Hëchstmass betrachtet. Mit einer Holbelvordehtme wird der 
Block ant das Lalger gehoinen und mit den beiden sichtbarem Winkelhaken festeklammert. Ein Teil des Blocks bleibt weit-

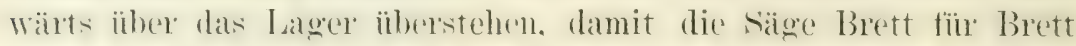
absehneden kann. Sobald der Block festgeklammert ist, hat sich dex bedienemele Arbeiter an den Hebel zu stellen. mit dem er sowohl den Block, samt dem Roll-Lager, langsan rorwäls schiebt, um dex sïge danternd Albeitsstoft zu bieten mol natiolich daun anch ant dem alten P'unkt zurtick. wie auch seitlich, sobald cin

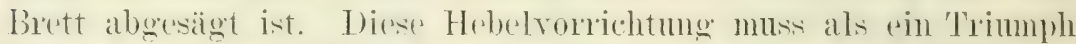
des menschlichen Erfindungsereistes betrachtet werden, sie ist bewondernswert, lïst sich aber leider nicht anschanlich sohildern. selbst mit Beigabe riner Abhildung. Man muss sie in Thätigkeit sehen. um ihre Irirkung zu begreifen. man muss erprobt haben. dass mit ilner Hilte cin Kind den sehtresten Block lenken kamn,

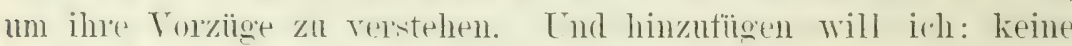
Torrichtmo der nordamerikanischen sägemiihlen hat so schr mein

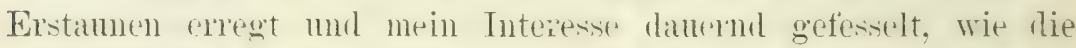
scharfsimnig erdachten Herhelwerke. Manchmal bin ich in den Gebirgswäldern Californiens Blöcken getolgt. $7^{1}$. Ifeter lamg und $1^{1}$ a Mreter dick, wie sie über scharfe Hänge nach de bach geschleift. dam wieder ans Land gohoben, abermals in die Bach gewortem mur schliesslich an der sägemiihle dem Wraser entnomment wurden, um vor die säge gelegt zu werden. Tedesmal wenn es galt. die Blöcke zu hroben. wurle die Aufgabe spielend überwunden, zumal in der Sägemïhle, wo anf beschränktem Raum eine genalu begrenzte Terrïckmo stattfinden musste. Eine leichte Handhewegme ind der gewaltige Block hol, oder senkt sich. rückte rechts oder links. vorwärts oder rückwärts, ganz nach dem Belieben des Lenkers. Man kann sich beim Anblick dieser Errungenschaften des Gedankens nicht erwehren. dass ein unberechenbarer, menschlicher hraftrerbratch in allen Erwerbsweigen erspart werden könnte, durch Anwendung dem Zwecke angepasster Hebelvorrichtumgen. In liegt noch ein mabsehbar weites Feld fiur die Erfinder offen.

Noch ist zn elwihnen, dass die Winkelhaken an dem sogenamnten Hund hängen. der verstellbar ist mol bewirkt, dass die Bretter ron gleichmäsiger I)icke geschnitten werden. Die Länge der eigentlichen sägemühle beträgt $2^{1 / 2}$ Meter, die Breite $1^{1}$, a Meter. 
Die Preise der obigen Sïgemiihle bewegen sich zwischen

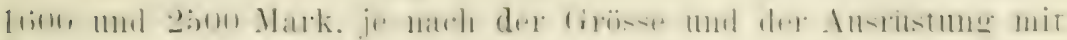
Extrasägen ul. s. w.

Wie eine solche Ponysägemülle im Walde anfyestellt wird. zeigt die Figur 26. ebenso das Titeibild.

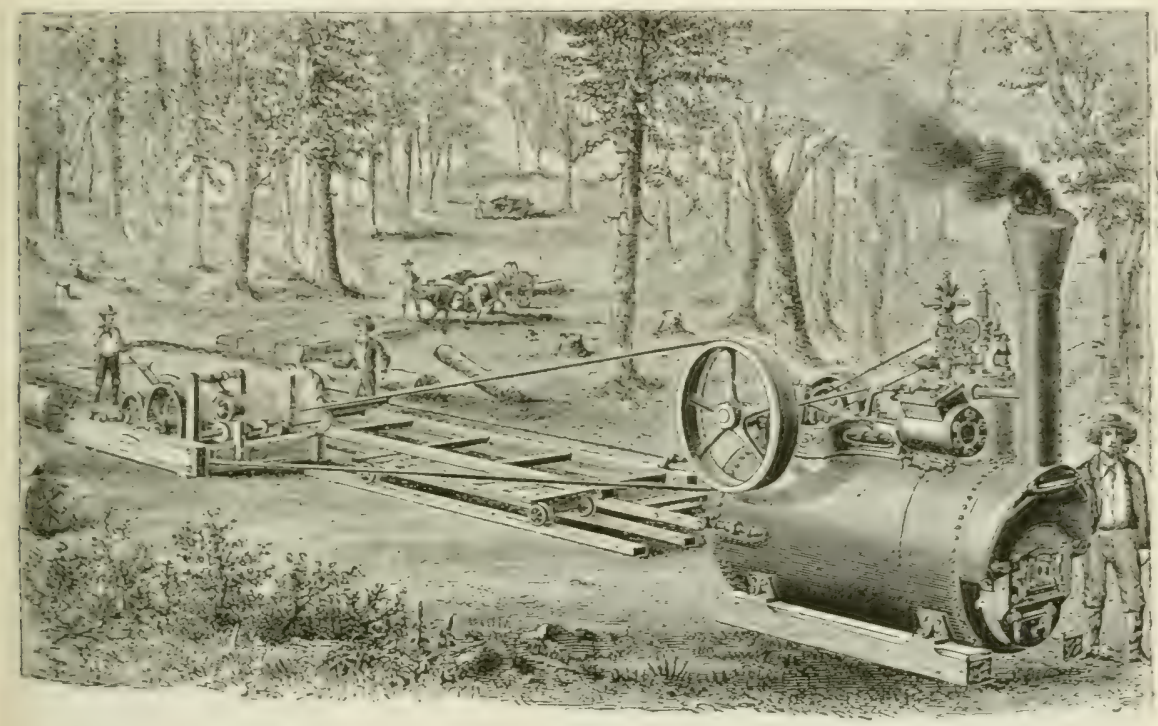

Figur ํㅜ.

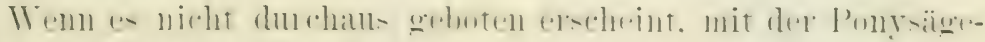

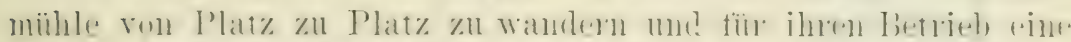

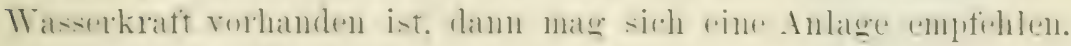
wie sie in der Figur 27 reranschaulicht ist.

Hier ist. oben auf den Bergen, ein Bach, ganz oder teil-

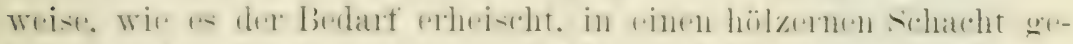

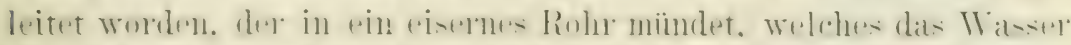

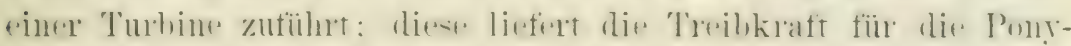

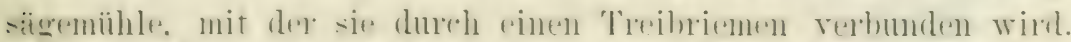

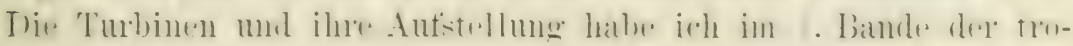

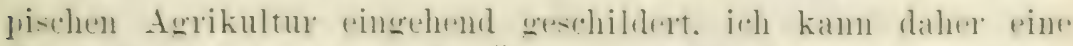

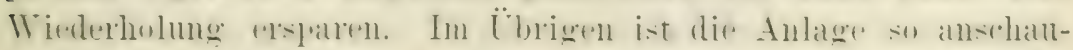
lich dargestellt. dass sie einer Erlänterung nirht berlart. In

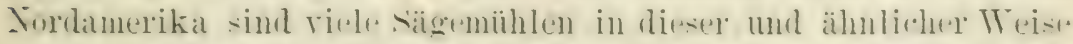

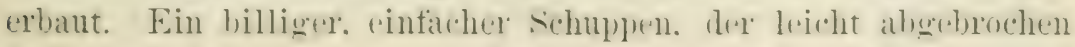




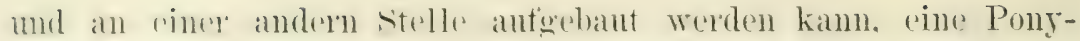

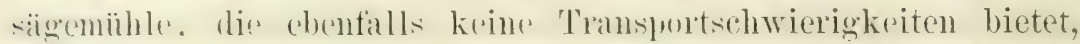

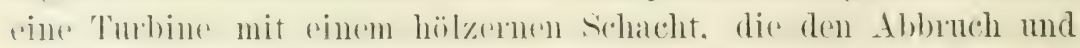
II iederanthan nieht kostspiolien matehen - das sind die bestand-

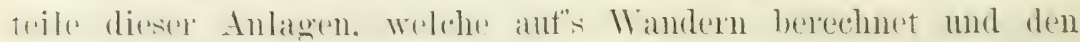
gegebenen Verhältnissen ganz gut angepasst sind.

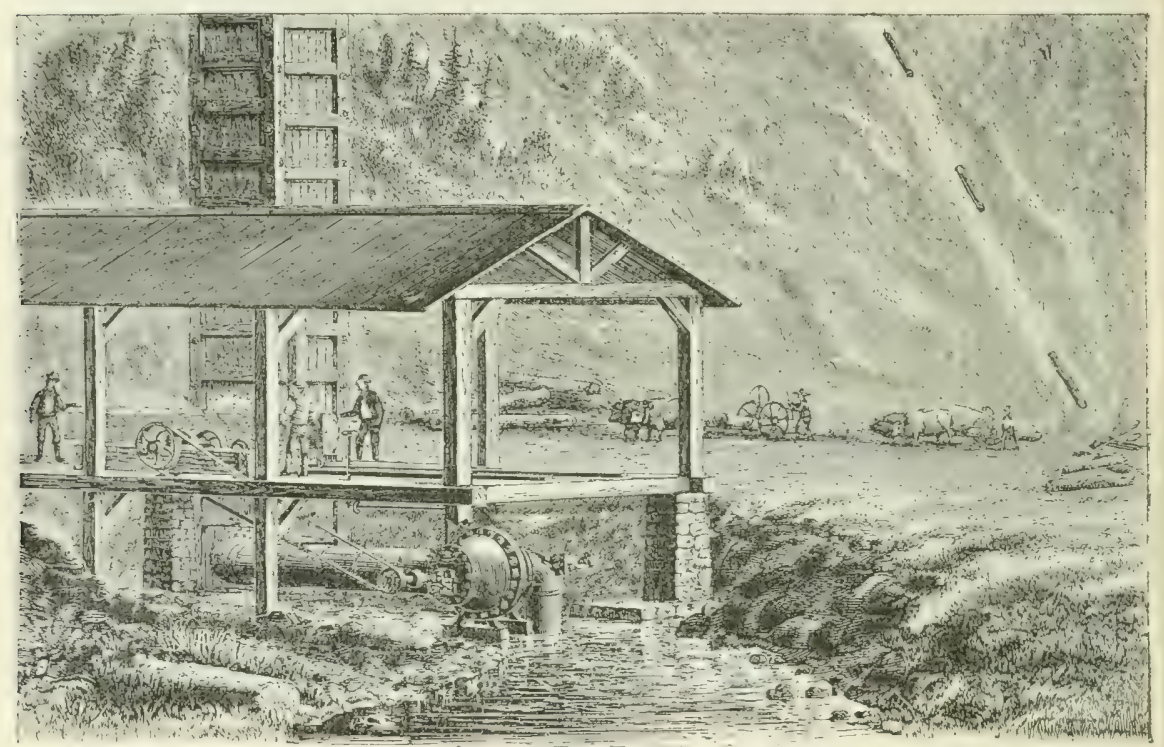

Fizur 27 .

Zureilen wird im Walde neben der Ponysägemïhle eine schindelmaschine anforestelt. Wulche nicht allein schindeln. sondern

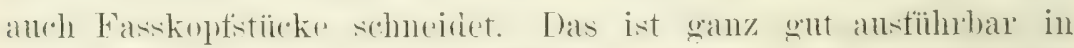
(inem Klima, wo es melnere Nonate nicht reguet und gewäht natiulich dem Holztransporte eine weitere bedentende Erleichterung.

Die in dor Figu 28 gezeigre Maschine dieser Art, ist untel rem Samen firen Momntain shingle o heading machine hekannt and kostet 630 Mark. Toie Bedienmog diesere Maschine kimn nicht verständlich geschildert, abere leicht rrernt werden. I)ie Angabe möge geniigen. dass vermöge der beiden Hebelarme die Brettstücke zu Schindeln mo Fasskoptstiuken in jerler beliebigen Dicke geschnitten werden können.

Wo die vorstehenden Maschinen im fiebranche sind. darf es dem Holzfïller an Bohrinstrumenten nicht fehlen, sie gehören zu 


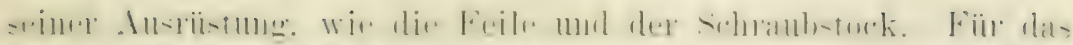

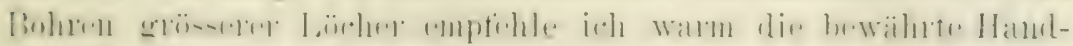

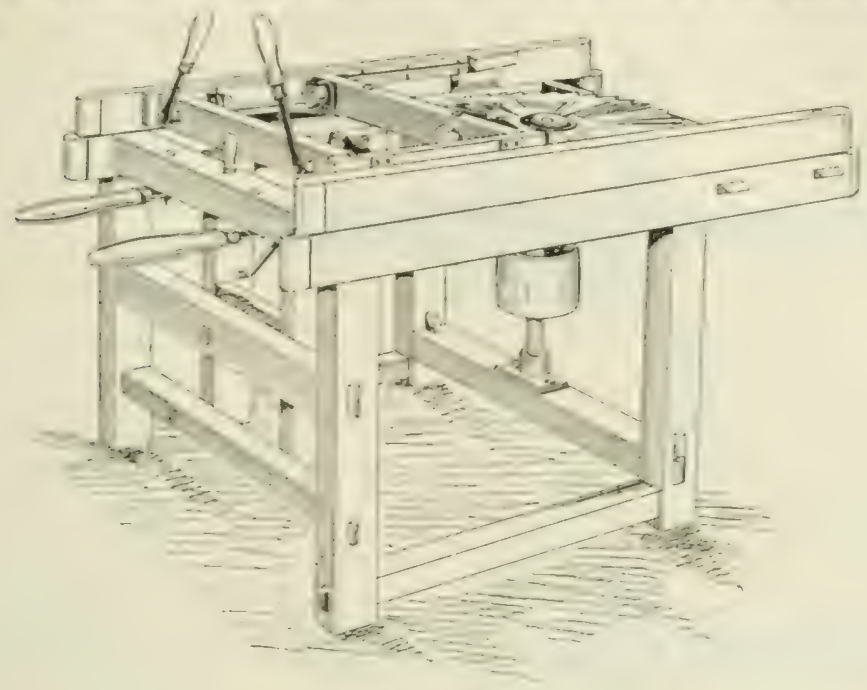

Himur 28.

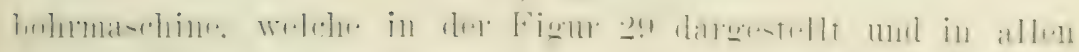
grösseren Werkzeughandlungen Nordamerika's fïr etwa 45 Mark zu haben ist. Nachdem die Maschine aufgesetzt ist, fasst der Arbeiter den rechten und linken Grift zugleich an und dreht. Im Nu ist ein glosses Loch gebohrt mit einem unvergleichlich geringeren Kraftaufwand, als wie ihn der Handschneckenbohrer erfordert. So kraft- und zeitsparend ist dieses vortreftliche Maschinchen, dass ich nicht begreifen kann, warum es noch nicht den $W_{\text {eg }}$ zu allen Holzarbeitern gefunden hat, die den Anspruch erheben, Ǩulturmenschen zu sein.

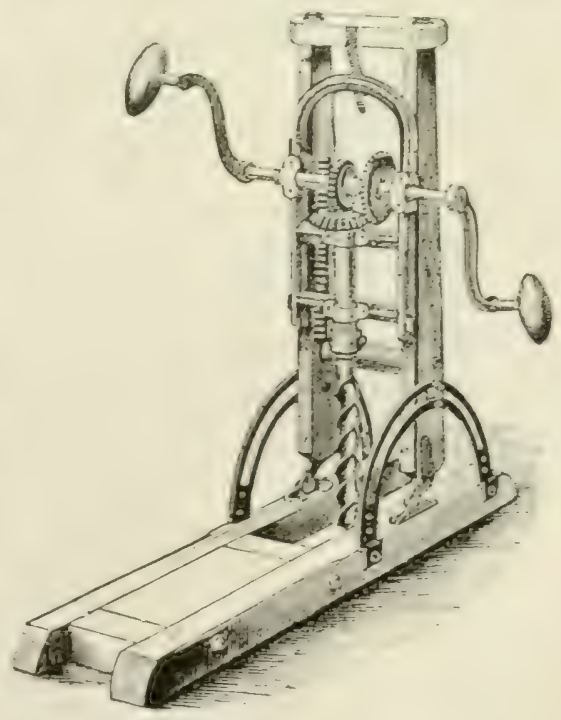

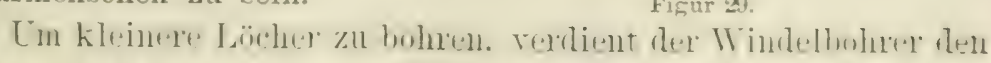

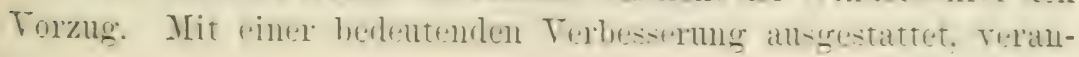


schutulicht ihn die Figur 30. Fr wird gegen die Brust gestemmt, wïlnend die linke Hand den oberen Grift fasst, die rechte dagegen

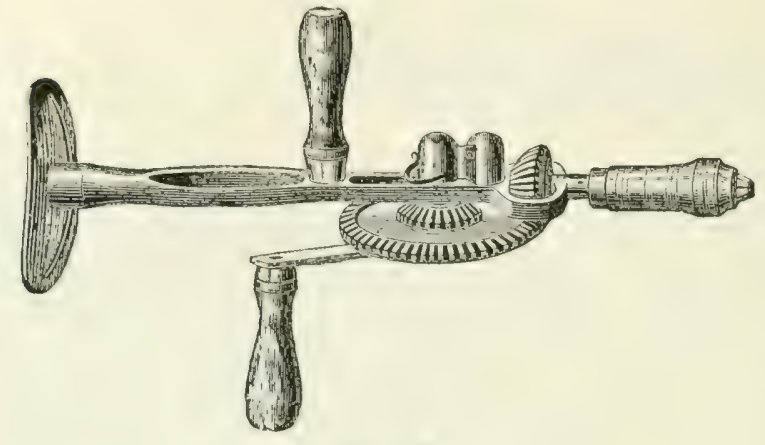

ligul :30.

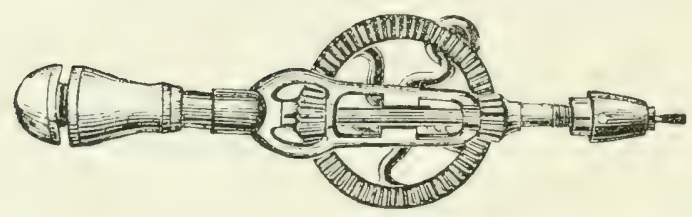

Figur 31. mit dem untern Griff dreht. Man muss sich in der Praxis überzengen, wie sehr diese Verbesserung die Arbeit erleichtert. Der Preis beträgt 11 Nark. „Breast drill" ist der englische Name.

Sehr enge Löcher bolnt man mit dem in der Figur 31 dargestellten Handwindelbohrer(Handdrillbohrer der Nord-

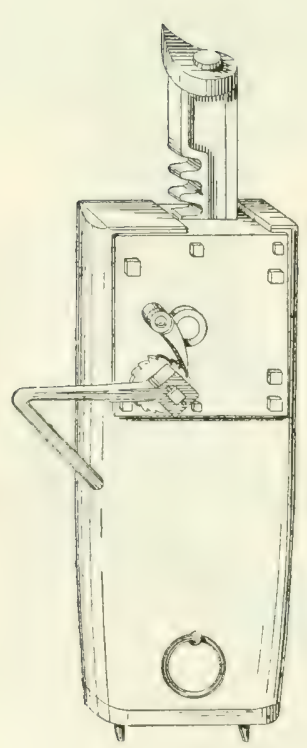

Figur 32.

amerikaner). Derselbe wird mit der linken Hand auf der betreffenden Stelle festgehalten, während die rechte die Kurbel des Rädchens dreht. Unscheinbar wie dieser F'ortschritt erscheinen mag, bedentet er doch eine Arbeitserleichterung. Preis: 6 Mark.

Ein unerlässliches Hilfsmittel für den Holzfäller ist oder sollte die Blockwinde sein (timberjak der Nordamerikaner), wie sie in der Figur 32 veranschanlicht ist. Dieselbe ist ganz von Stahl und nach dem Prinzip der bekannten Wagenwinden konstruirt. Mit den Fuss-Stacheln findet sie Halt im Boden, wenu man sie seitlich an den Stamm legt, um ihn zu verruicken. Das kann ein Arbeiter mit diesem Instrument schneller und mïheloser vollziehen, wie sechs, welche Stangen zu Hilfe nehmen. 
Die wichtigste Frage fïr die Holgorwimmmg in Wrialdern, wie sie hier in's Ange zu fassen ist, bleibt aber immer, wie der

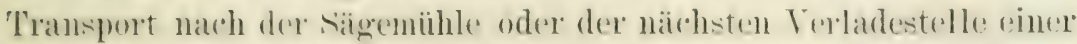

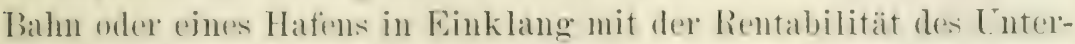
nehmens getnateht worden kam. Wohl kam dureh Anfitellung riner

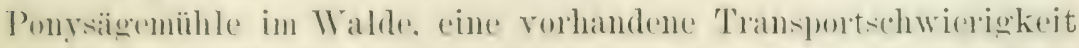
gemindert, nicht abere vollstandig beseitigt werden. (b) das Holz in Form von Blïcken wher Bretteren fortznsehatfen ist — in beiden Fälen tordere die enestellte Frage erusteste Erwägme. Wemm

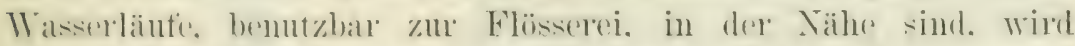

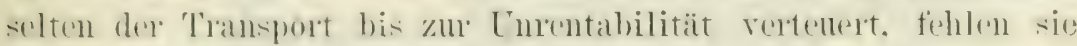
aber. dam mage dir Ausbente des Waldes mit fowimn zweifelhatt. werm nicht allsichtslos erscheinen. jedenfalls bedalf es eines hedentenderen Anlagekapitals zur Beschatfmeg der nötigen 'T'ranspertmittel. Write strecken tropischer Lrwitlel sind bis jetzt

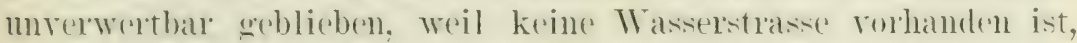
und es entweder an Kapital und Internehmung shoudigkeit fehlte, andere 'Transportmittel herzustellen, oder eine Berechmung (rogah, dass sich ein solcher hostenaufwand nicht lohnen kïmne. British Guiana ist eines der bevolzugtesten tropischen Länder, wenn nicht gall das hevorzueteste, was Artenzahl, deschätztheit und Verschiffbarkeit von Handelshölzen anbetrift. Trotz dieser Vorteile ist

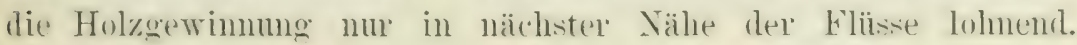
Hinzutügen musis ich indersen, dass sich das ferchät in Händen von Leduten befindet. denen es an allem fehlt, 1 m das Terkehrsnotz dureh Nathahmung fiemder Torbilder anszudehnen.

Wo crelegenheit rorhamben ist, kleine Wasierläufe in cinem sanmelhecken zu vereinigen, mag die Anlage einer Flume rätlich erscheinen - rin in californien erfundenes 'Transportmittel. das als pin bedentender Fortschritt zu betrachten ist. In einer dex folgenden skizzen wird die nähere beschreihung gegeben. Duch halte man in Erinnermog, dass in einem febirge die Anlage pincle Flume kostepielige ist mol sieh nur dame lolmen kimn, ween in

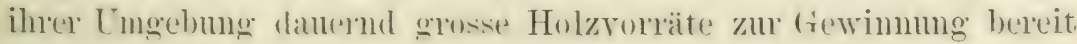
stehen.

Eim anderes 'Transportmittel, desen Frffundmo in die Neuzeit fillt und der Forstwirtschaft erspriessliche Dienste leistet, ist die transportable Eisenhahn. Eine Art derselben emptehle ich ganz besonders der Aufmerksamkeit, demn sie ist am billigsten und hat 
sich seit 20 dahren in den nordanerikanischen Wäldern sehr nitzlich erwiesen. Merkwiurdiger Weise kemut man sie trotz ihrer Verdienste fast mu im engen Fachkreise, daribler hinaus wissen wenige. dass 1886383 ,.stangeneisenbahnen" (Polerailroads) in in einer Gesamtlänge von 3600 Kilometer mit 428 Lokomotiven und 5182 Wagen rorhanden waren.

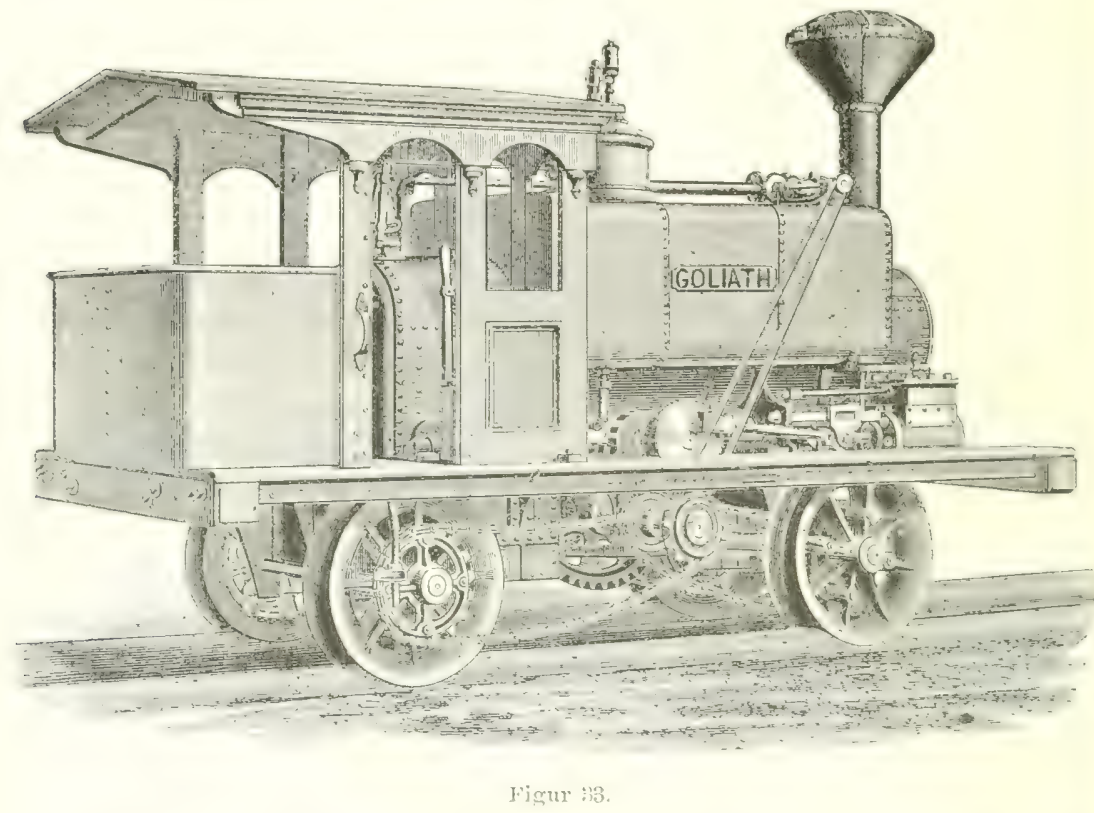

Die beiden Figuren sis und it lasen klar erkemen. wie man sich eine stangenbahn rorzustellen hat.

An der Lokomotive ist bemerkenswert. dass ihre Räder mittels Kettein getrieben werden nud zwar wird jedes Rad unabhängig ron den anderen bewegt, damit, wemn eine Kette bricht oder in Unordnme gerät. die Fahrt keine Tnterbrechung erleidet. Versehen ist die Lokomotive mit einem Masserbehälter, der 2000 Liter fasst; die Plattform ruht anf einem elastischen Gestell, damit die Maschine. ohme Schaden zu nehmen, iber holperige Stellen fahren kam. Die /ugkraft ist fuir 6 Wagen bemessen, beladen mit 3000 Meter Bretter. Bei einer Steigung ron 40 Meter

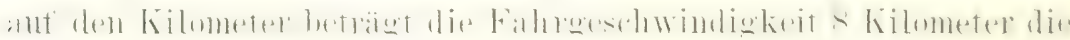
Stunde. Es giebt Bahnen, wo eine Steigung von 130 Meter auf den Kilometer rorkommt. Hier wird die Lokomotive in die Mitte 


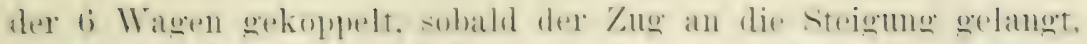

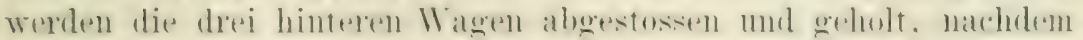
die drei vorderen über die Anhöhe geschoben sind.

Wie der Name sagt, wird diese Bahn mit Stangen statt

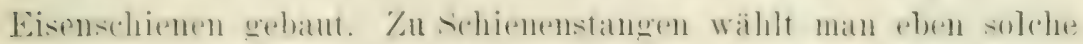

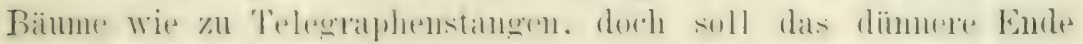

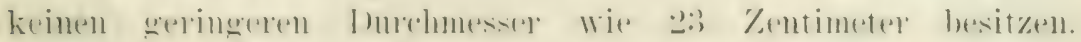

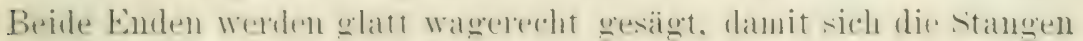

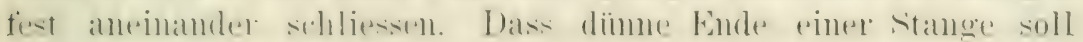

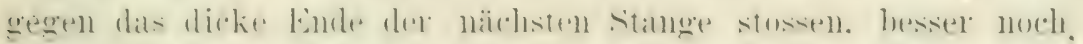

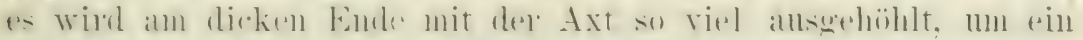

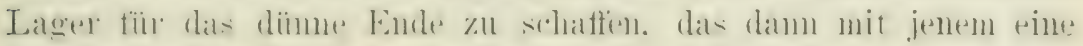
goleiche Riickenlinie bildet.

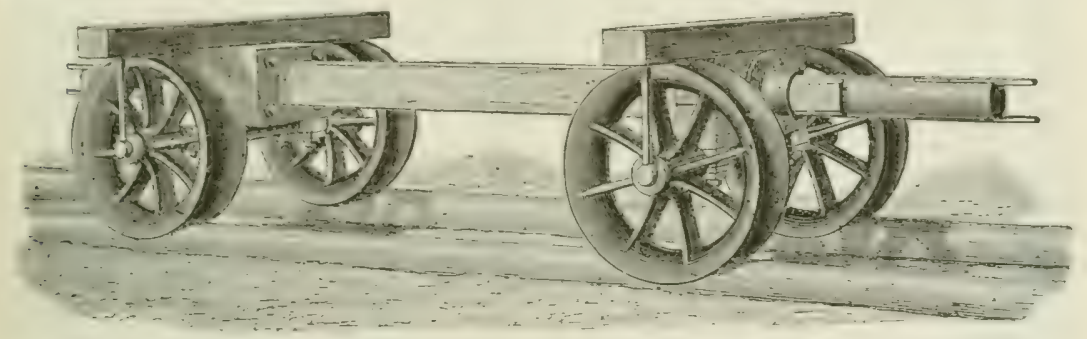

Finur 34 .

Die Stangen werden einfach auf den Boden gelegt, wenn

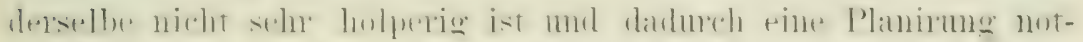

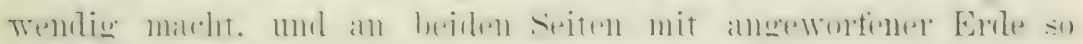

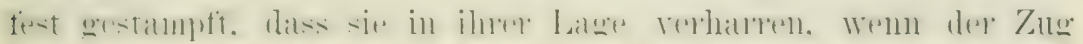

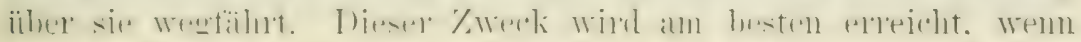

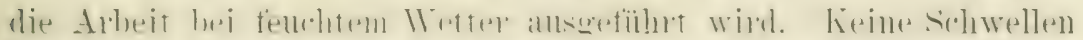

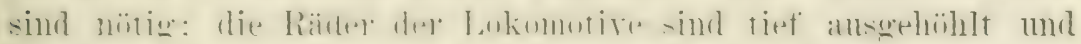

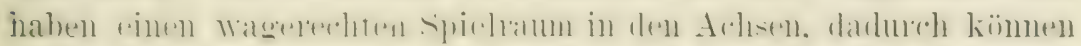

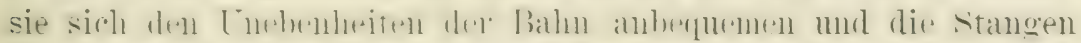

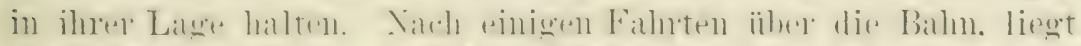

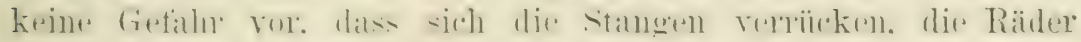

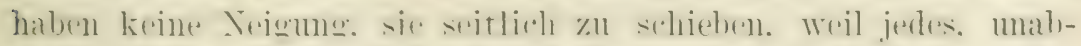

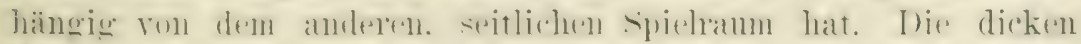

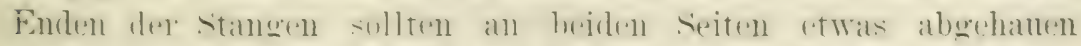

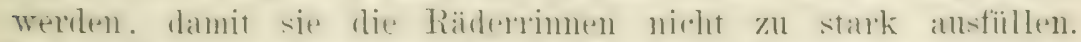
Trun Kurven zu machen sind. Weralen kury stangen aneinandergelegt, immer in der bushribenen Weise. Hitr grilt es cranz 
besonders daranf zx achtem, dass die stangenenden eine goleiche Rï̈ckenlinie bilden. Der L'auptlinien kïmnen sich \%weiglinien anschliescen. der Ïbergang kamn ohne Weichenanlage stattfinden; die /weiglinte muss nu im Bogen in die Hanptlinis einlaufen. Ein Arbeiter kamn rinte strecke vom :) Lilometer in Ordnung halten.

I) Be Bakosten hetragen. je nach der Beschaffenheit des: Bodens, der Höhe der Arbeitslïne n. s. w. 200 bis 400 Nark pro Kilometer. in einem zemissenten trebirge steigen sie jerloch auf 600

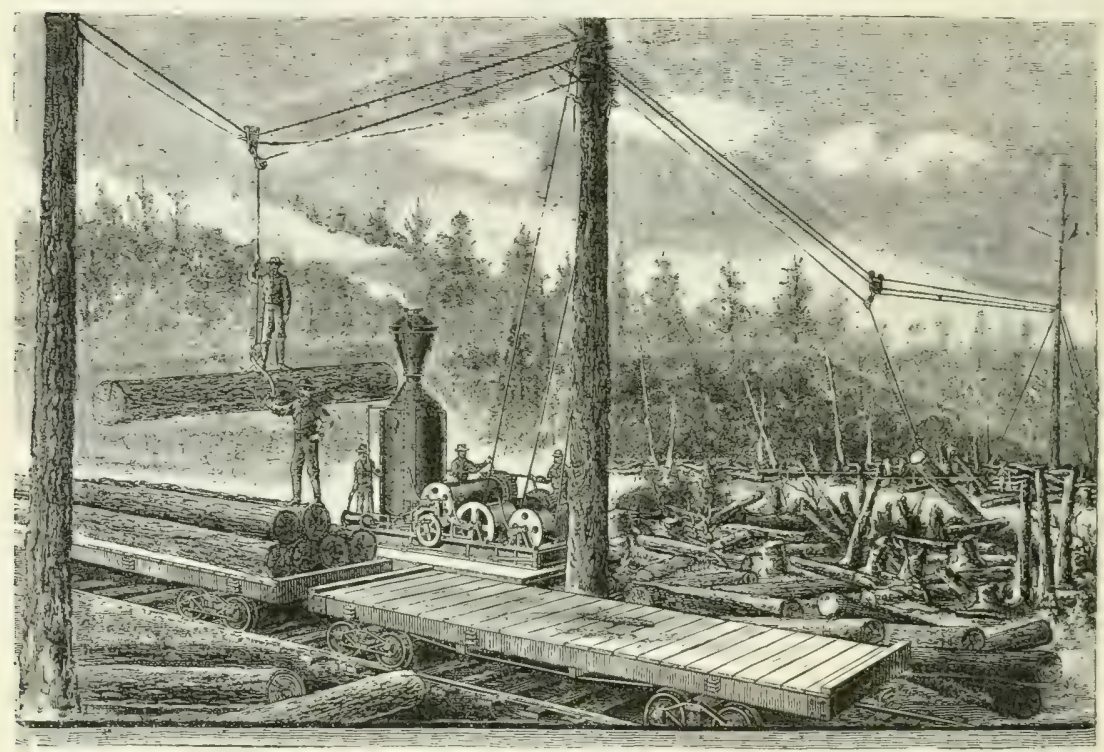

Figur 25.

bis 700 Mark - immer in Nordamerika gemeint, wo die Arbeitslïhne bekanntlich sehr hoch sind. Die Lokomotive kostet 12600 Mark (3000 Dollars) mond der Wagen 525 Mark (125 Dollars). Geliefert werden beide von der 'Tanner of Delany Engine Company in Richmond, Virginien.

Auf manchen Balmen wird die Lokomotive durch Zugtieve ersetzt. was allerdings ein geringeres Anlagekapital erfordert, allein der Betrieb ist langsamer und kostspieliger.

Die Stangeneisenbahnen sind in Tordamerika bis jetzt nur üstlich der Felsengebirge gebränchlich geworden, gewöhnlich mit Beihilfe einer Dampflademaschine, wie sie die Figur 35 reran- 


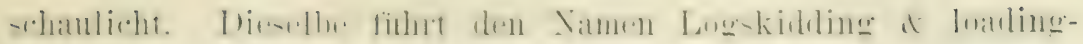

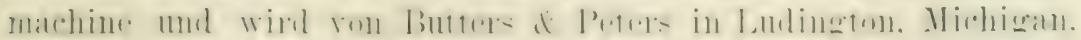
fabriziert.

Weil an der Pazifikküste anf einer gegeben Fläche viel

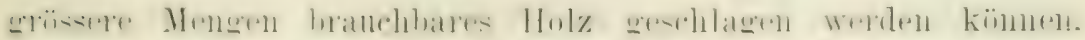

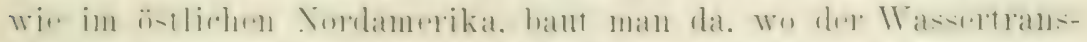

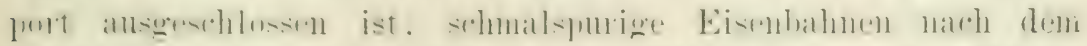

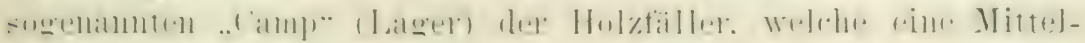

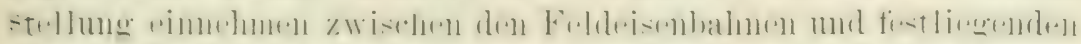

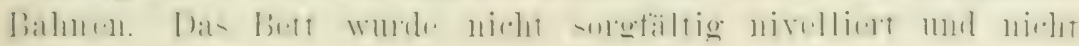

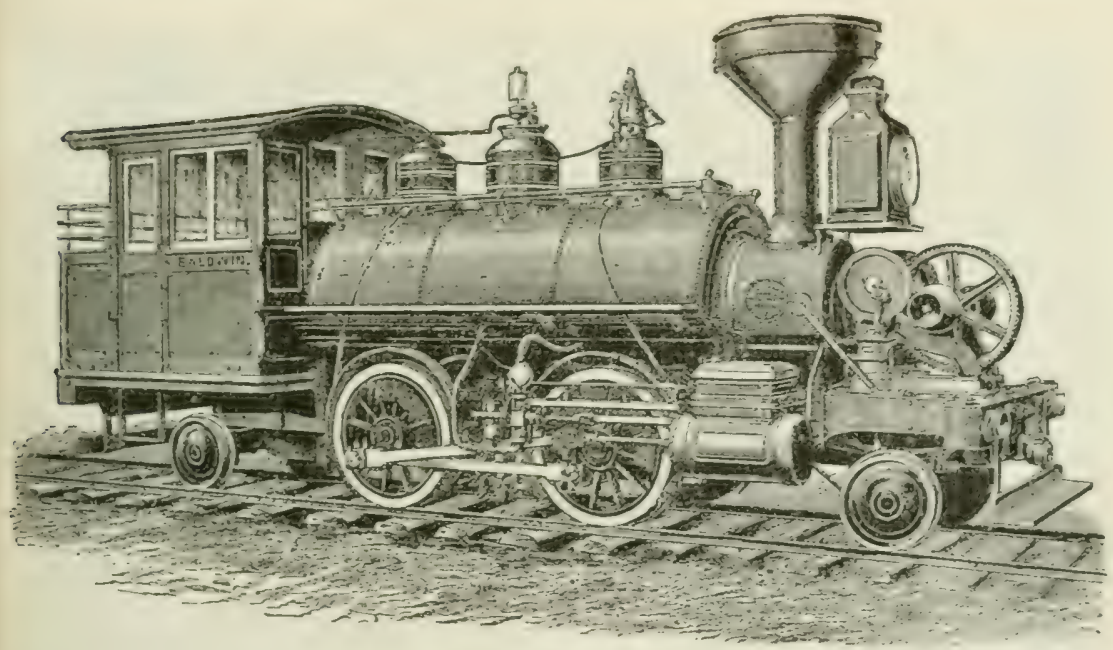

Figur 3j.

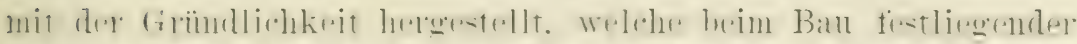

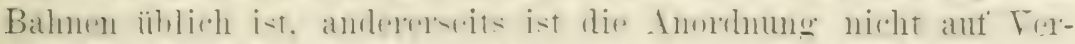

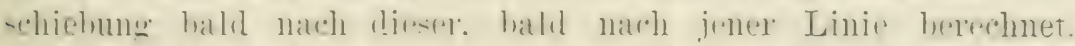

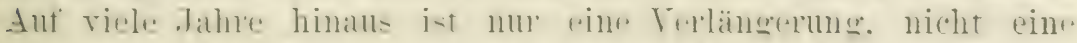

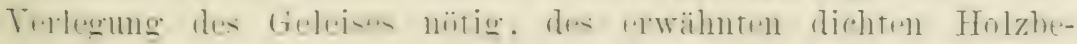
standes wegen.

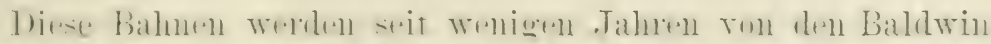

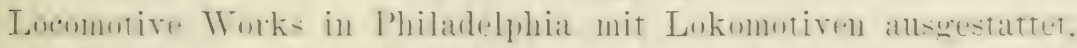

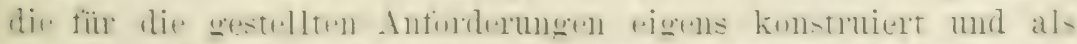

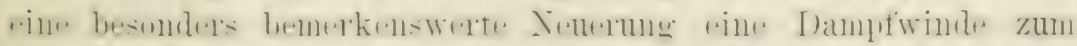

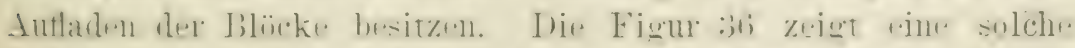

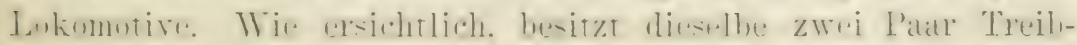




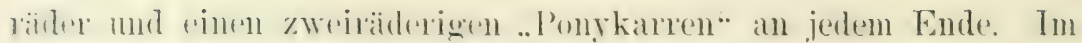
sittelkessel ist der nitige Wasservorat mol der Halbwagen enthïlt das Bremulnolz. Dex vordere Ponvkarren trägt anf seinem

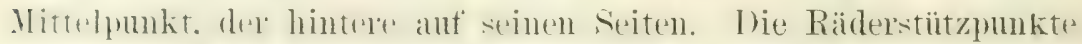
sind su whit anseinandel gelegt. um das frewicht der Lokomotive

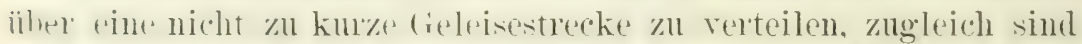

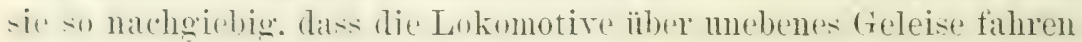
und kurze Kuren üherwinden kamm. ohne sich selbst oder dem Bahnbett sohaden zuzufïnen. Eine kraftige Damptbrense. die anf

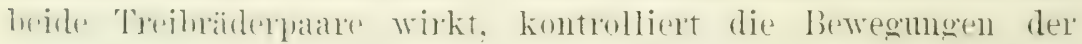

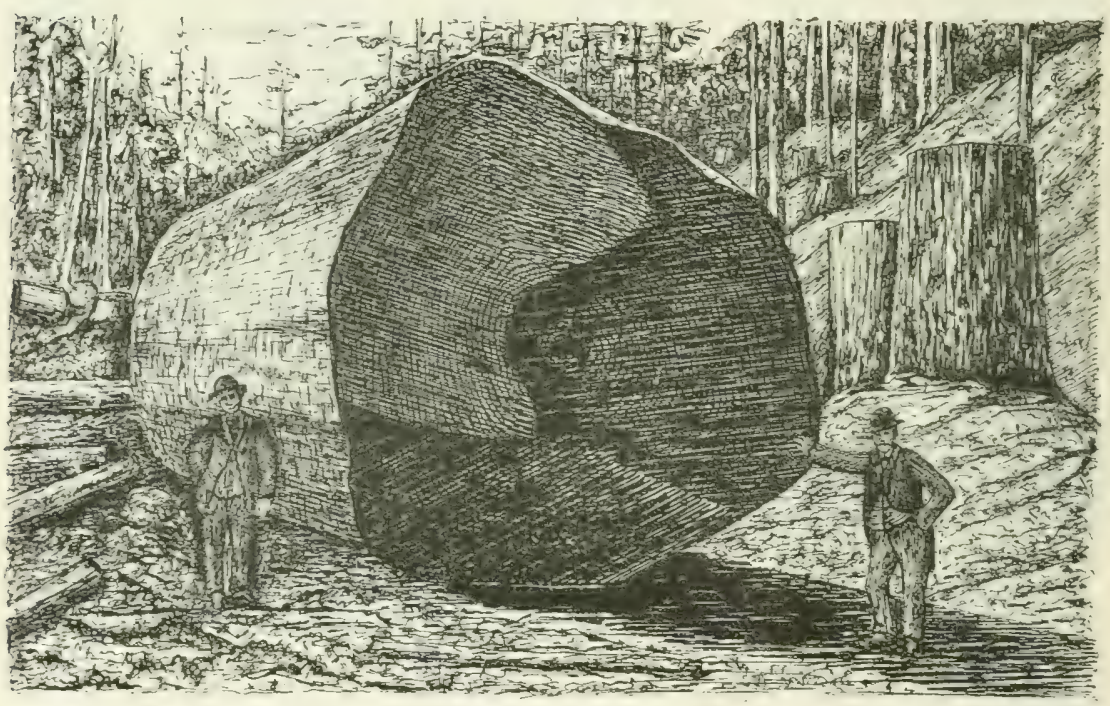

Figur $3 \overline{\text {. }}$.

Lokmutive anf ahschuibsiger Faht mul stellt sie fest. wem die Winde in Thätokeit ist. Die letztere. Welche. Wie ich kaum zu wähnen banche. patentiert ist. kamn mit den Treibrädern in Terbindmg weetzt werden. un diese treiben zu helfen. sie kamn aber anch an rorgerichter werden. dass sie nur ihrem eigentlichen Zmerke den Aut- und Abladen dex Blöcke dient. Zuweilen hat dit Winde enume Lasten zu beregen. giebt es doch Blöcke, die 201 his 30 Tommen wituren. Allenfalsige \%weifel bringt gewiss die Finur 37 zum schweigen, die einer Photographie nachgearbeitet ist. Dieser Rotholzblock mass 4.8 Meter im Durchmesere und der ganze Baum lieferte 41000 Fuss Bretter. (1 Zoll dick. 1 Fuss breit.) 


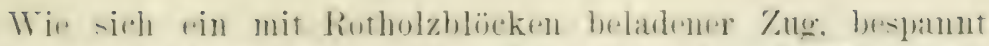

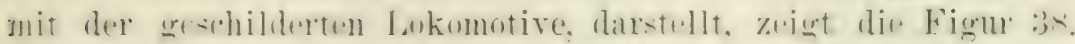

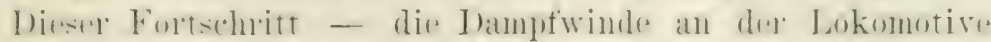

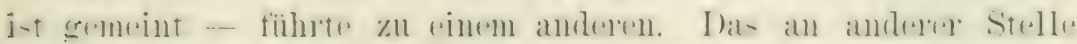

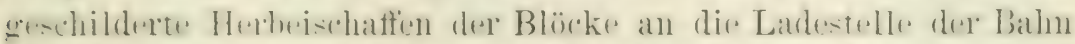

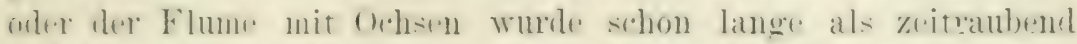

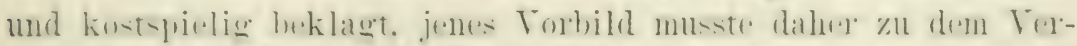

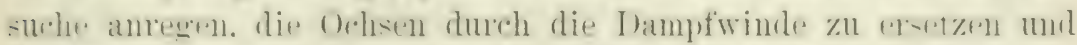

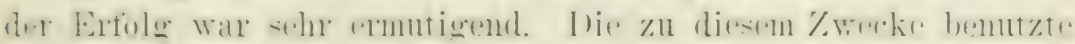

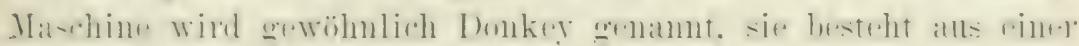

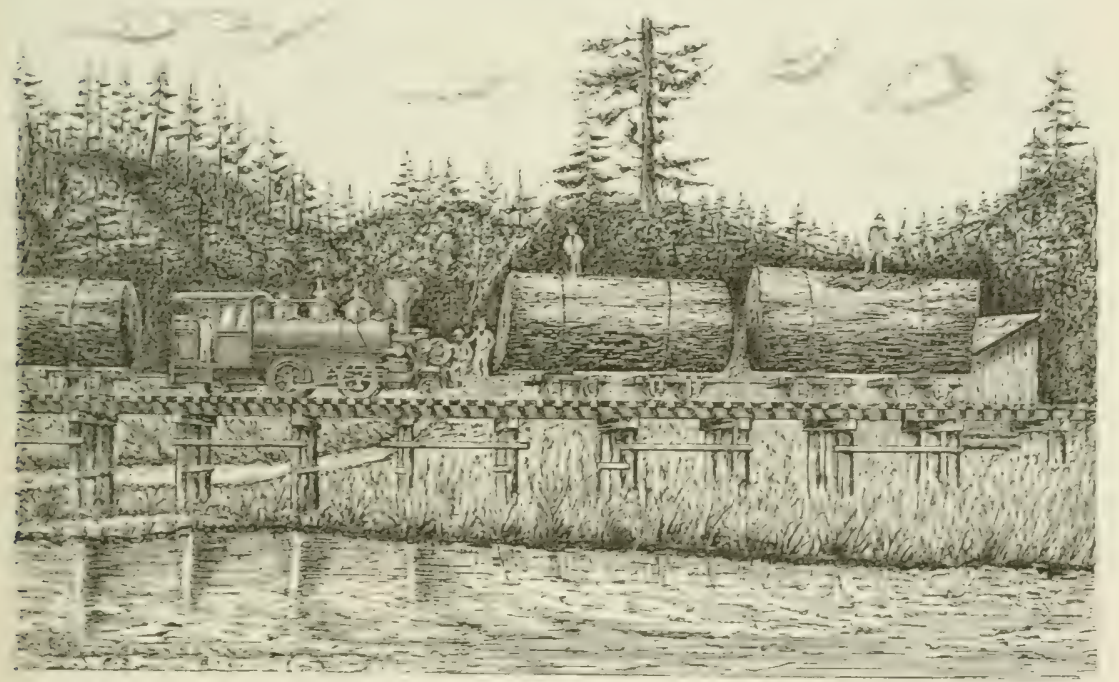

Figux 3y.

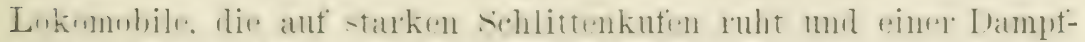

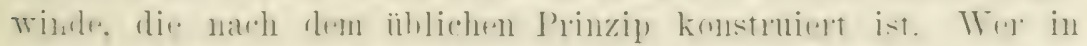

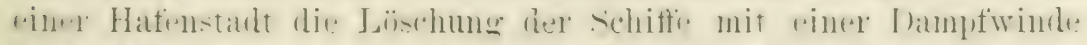

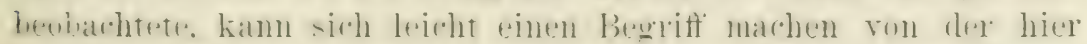

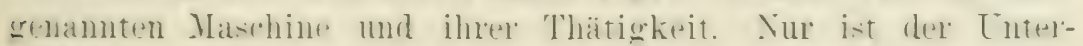

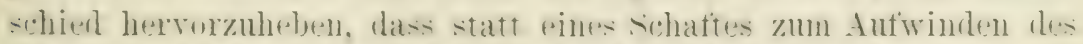
s.ils. zwei Haspel an jedem Ende lles scohattes vorhandere sind.

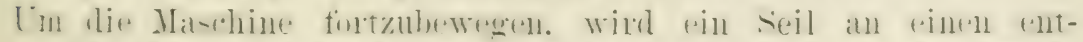

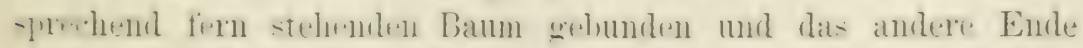

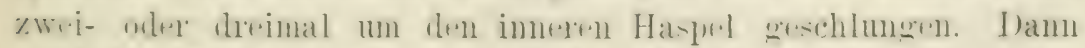

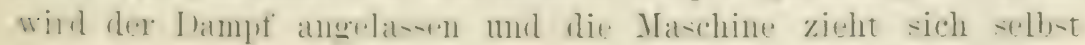


fort. Int diene 11 rise transportient sie sich selbst dahin. Wohin man sie wïnscht. Wrenn sie an den Bestimmungsort angelangt ist. wind sie an einem baum oder Stumpe festgemacht mud das suil mit einem Haken in den Block befestignt, welcher transportiert werden soll. Was mit Hilfe von schnaplestangen nach

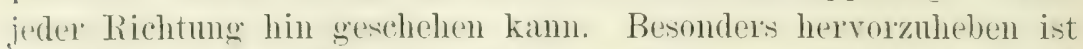
der Torteil dieser Maschine. dass sie Blöcke ans sichluchten und anderen schwer zuginglichen ()rten wegschaft, die ron ochsen gar nicht oder mur mit susser Lebensgefahr broteten werden können.

Obgleich cine I)arstellumg der sägemïhlenindustrite nicht im Plane dieses Mrekes liegt, so mind die ku"ze schilderung der sägeniihle nach fortgeschrittenstem System doch am I'latze sein. Zugestanden wird allseitig, dass sich die Nordamerikiner an elfolgreichsten bemüht inaben, die Leistungsfähigkeit ihrer sägemühlen zu erhöhen. und die Tordamerikaner erkennen einstinmig don Sägemühlen an der Pazifikküste die Paalme zu. Thol es kinn rewiss kein Zweifel darïber bestehen, dass an Pugetsund im 'Territorium Washington und an der Rotholzkïste Kaliforniens nicht allein die grössten, sondern auch die vorzüglichst eingerichteten, mit allen nenen technischen Erfindungen in diestm Fache alsgestatteten Sägemühlen zu finden sind. Das wird gewöhnlich durch den erstamnlichen Holzreichtun zu erklären gesucht. Gewiss, der Holzreichtum ist da, doch ich frage: warum spricht man von den natiulichen Reichtum Tordamerika's als Regel mo mu als Ausnalnue ron der Energie seiner Benohner? Nicht der natiirliche Reichtum eines Landes führt zu einer .. Entwickelume olne Gleichen*" sondern die Thatkraft, die Tnternehmmosnendigkeit und die Intelligenz seiner Bewohner. Besitzen nicht andere Länder wertvolle Tälder, die sich an Ansdehnmmg mit denen Kaliforniens oder Washingtons messen kömnen? Warmm ist ihre sägemibhlenindustrie unbedentend geblieben, warum lassen sie sich Holz von der l'azifikkiiste zufïhren?

Somit glaube ich berechtigt zu sein, mein Torbild an der Pazifikküiste zu suchen.

In den meisten Fïllen steht die sägemiilhle an Cté eines

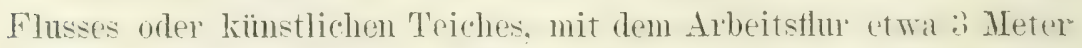

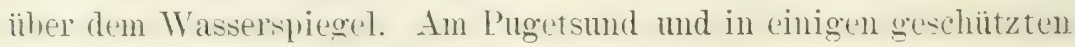




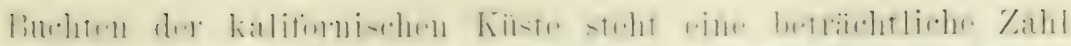

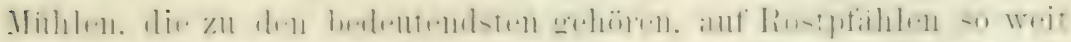

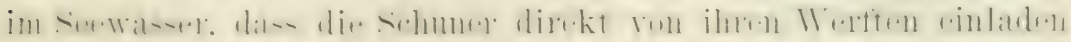

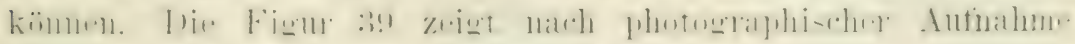
eine solche am I'ucetsund gelegene Mühle.

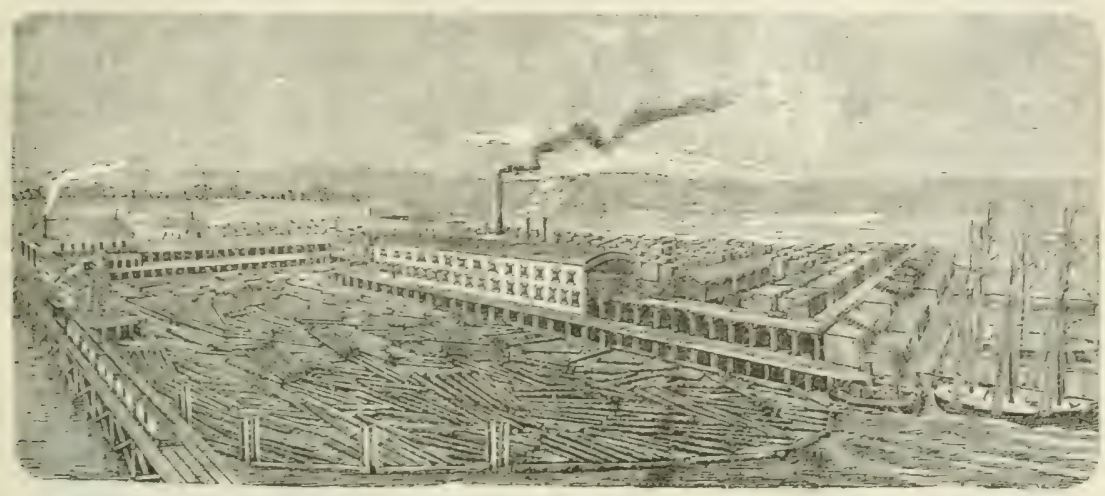

Figur 3 .

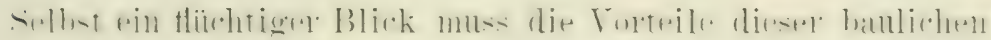

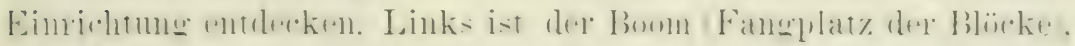

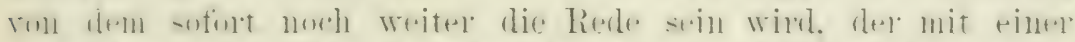

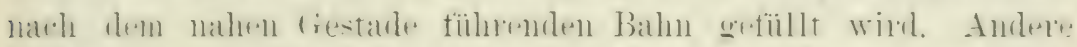

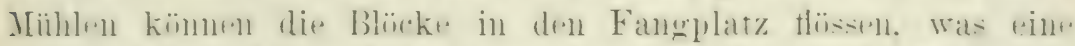

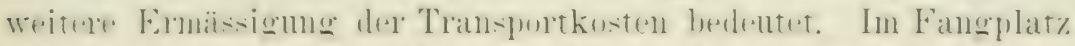

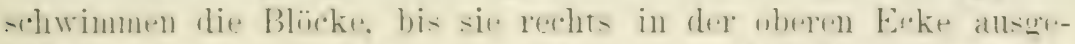

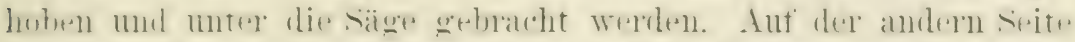

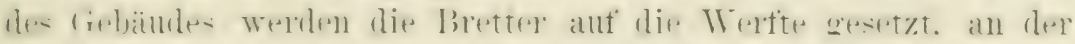

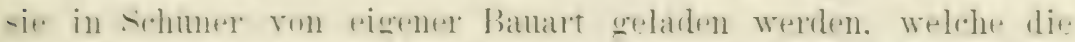

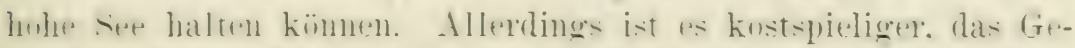

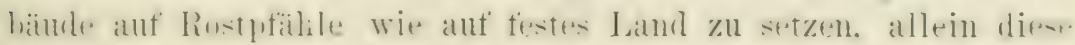

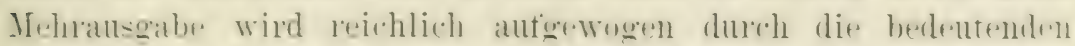

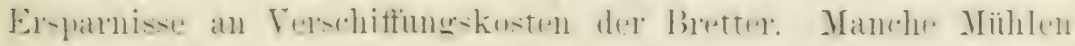

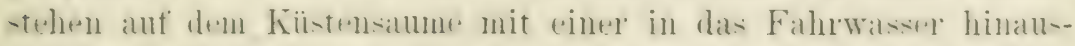

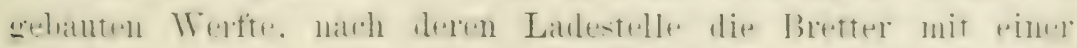

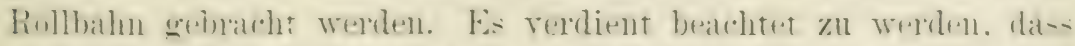

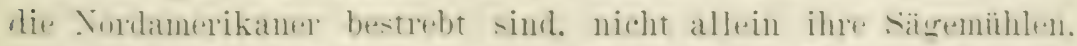

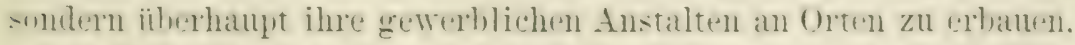

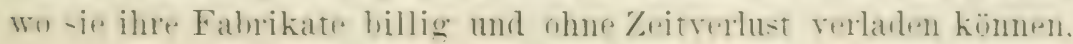




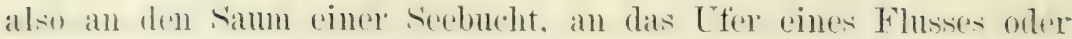
an den Knotenpunkt einer Eisenbahn.

zanweilen findet sich in der Nähe der Küste eine rortreftliche

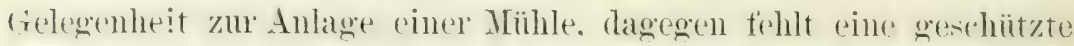
Bucht zur Errichtumg einer Landungsbrücke. Tn diesem Falle werden nicht die Mühlenprodnkte nach dem nächsten, vielledoht mehree hemdert Kilometer entfernten Hafen transportiert, somlern s wird in möglichst gerader Linie von der Sägemiïhle ein Ankerplatz gesscht mol narle diexem von dex Küste ab eine cluntes (Rutschbahn) gebant. wie sie Figm to zeigt. I) Batusten sind

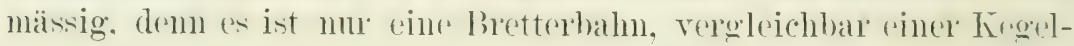

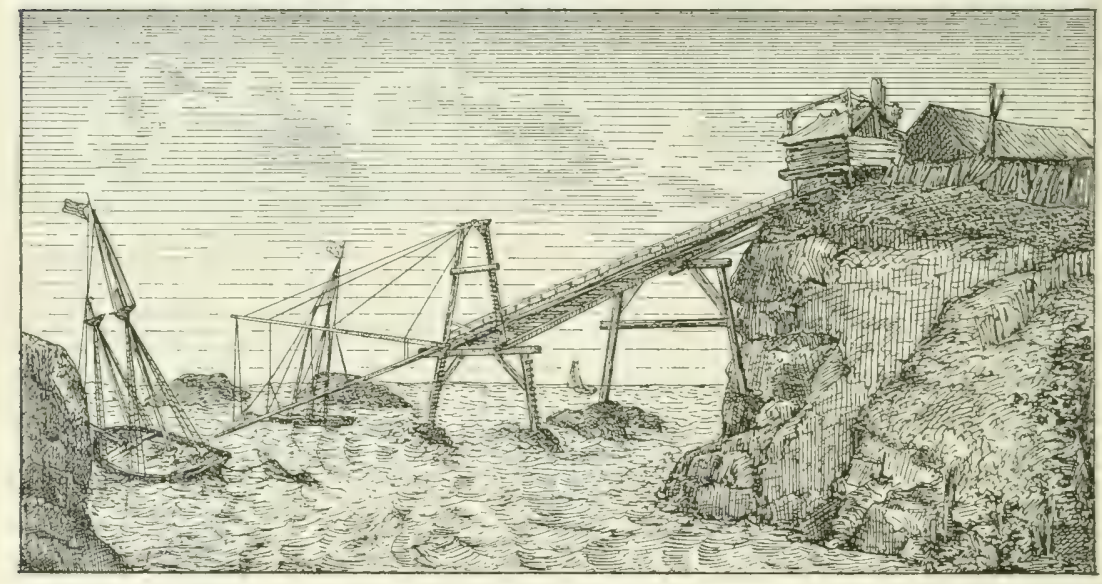

Figur 40 .

bahn, mit seitengeländer, trotzdem erfüllt sice ihnen Zwerk sanz

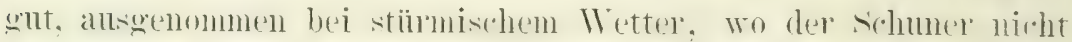

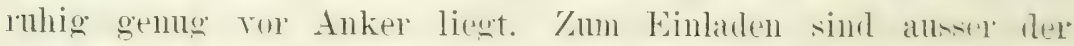

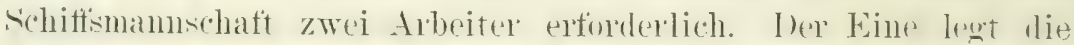
Hölzer auf den Kopt der Rutschbahn, ler andere steht an ihlem Fusse und handhabt die Bremse, eine Art rangriucke. damit die in rasender Eile herabschiessenden Hölzer sanft auf das Derok des schuners gleiten. An einer hafenamen Küste. wie der kalifornischen, muss dieste Finnichtung eine wesentliche Bedeutumg für das Verkehrswesen erringen. Legen doch manchmal die Dampiter an die Rutshbahnen an. Iun ihre Passagiere anszuschiften, dite hart an den Seitengeländern. wo kurze Qnerleisten anf dem IBoden an- 


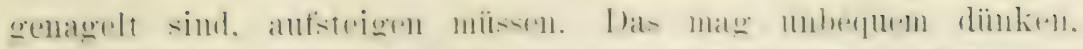

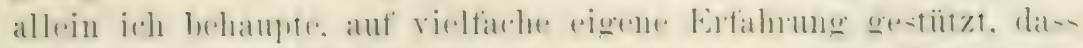
lui ...

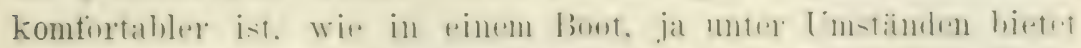

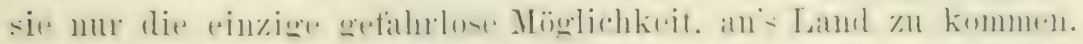

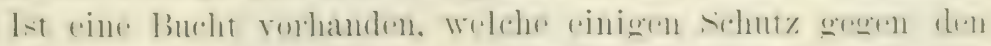

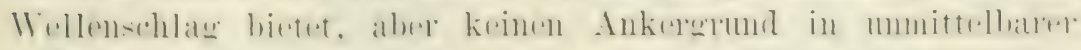

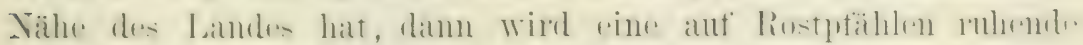

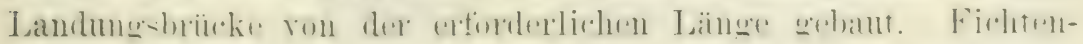

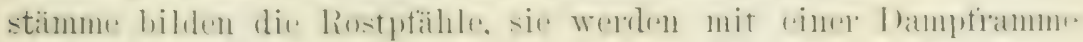

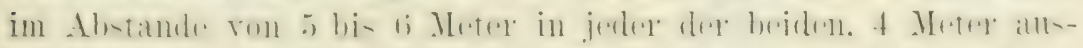

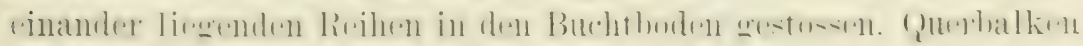

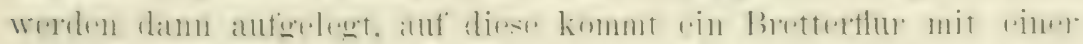

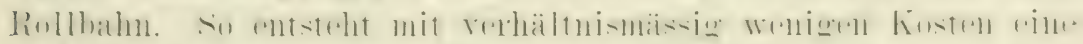
Ladestelle. die 20 bis 25 . Jahne danert.

Wie die Blöcke nach den Mïhlen tiansportiert werden, ist

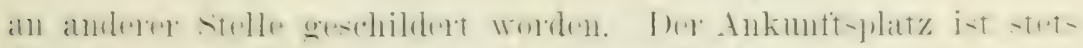

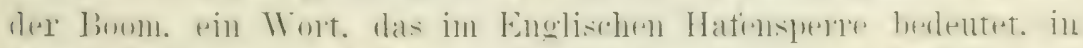

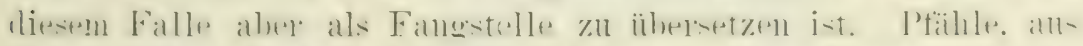

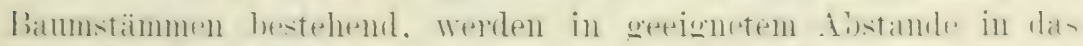

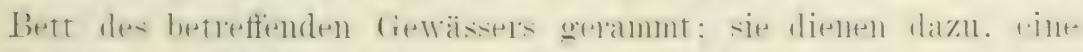

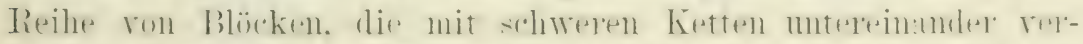

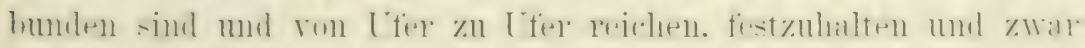

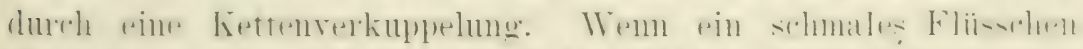

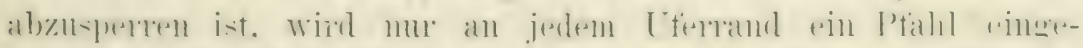

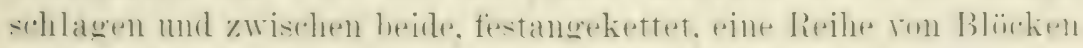

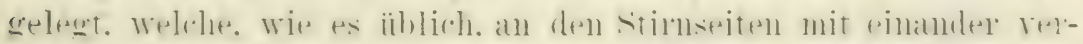

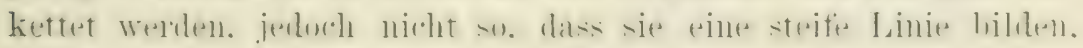
sondern einige Bewegungstieiheit behalten.

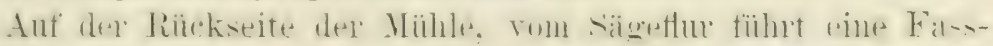

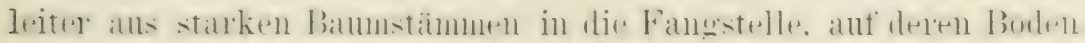

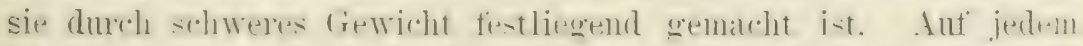

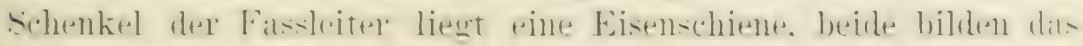

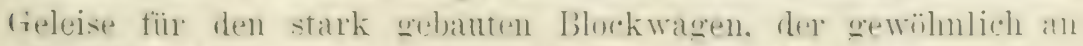

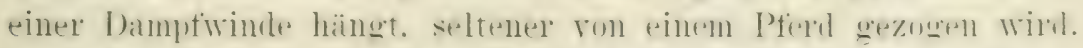

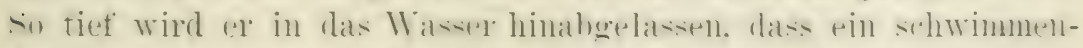

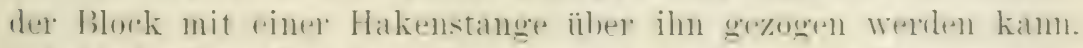

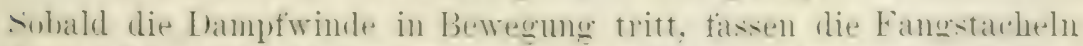

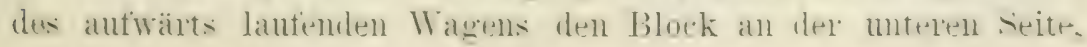




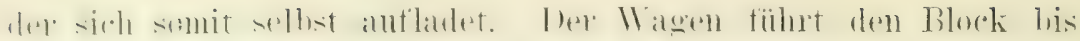

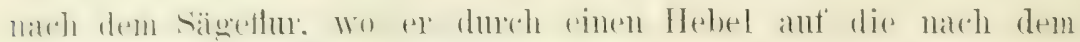

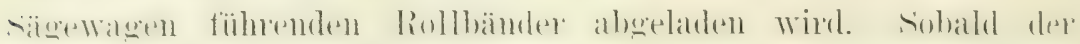

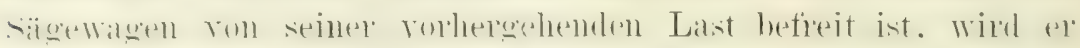

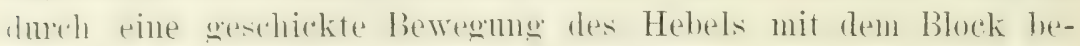

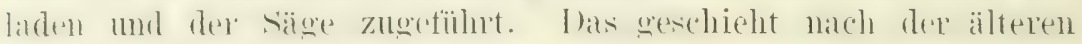

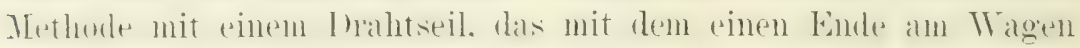

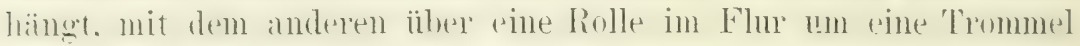
muter dem Flur länt. so eingerichtet. dass der bedienende trbeiter

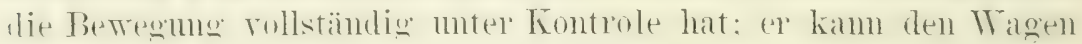

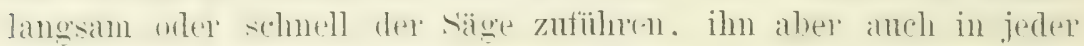

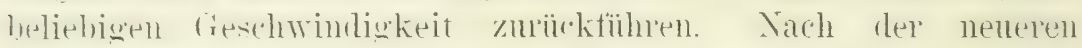
Jethode wird ant die Bahn des sïgewagens ein Dalnpteylinder. ron 20! Zentimeter Durdmesser gelegt. desien Kubem mit dem II agen in Vorbindung steht. Die Länge des Cylinders steht in C̈bereinstimmmo mit der Länge der zu sägenden Blöcke. Gliedter kïnne'l nach Belieben angehängt oder abgenommen werden. Wird Thampt dem treibuten Ende des Cylinder's zugetinht, damm geht der Wagen mit .. Blitzessihnelle" daher der Tame lightningfeed

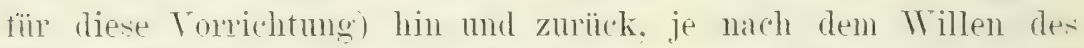
sägers. Da die Begrenzung der Leistmo einer Zirkelsïge in der Praxis ron der schnelligkeit abhängt, mit welcher die gesägton stiicke entfernt werden kïmen. so ist die Fertigstellung ron. (i) ofo0 bis 70000 Fuss Bretter im Tag. mit diesem Apparat zu einer gewöhnlichen Leistung gerorden. für eine kmze Zeit ist sulbst die Leistung ron 100 onn Fuss erreicht worden. immer mit einer Zirkelsäge gemeint.

Die abgesägten Bretter tallen auf ..lebende Rollen"; eine Fieihe von eisernen oder lö̈zernen Rollen. die durch eine Treil)kette mit einander verbunden sind, eine Einrichtung. Welche eine starke Ähnlichkeit mit den Transportemen der Dreschmaschine hat. Die ..lebenden Rollen" tragen die Bretter einem Arbeiter zu, welcher Edger (wörtlich ïbersetzt Kanter) genamnt wird, der sip durch die Tantenmaschine lanfen lässt, welche, wie iln Name andeutet. die Kanten gerade und zugleich die Bretter ron gleicher Breite schmeidet, auch die hreiten Bretter, die ron Blöcken, die mehrere Meter im Durdumeser haben, kommen. in die handelsïhlichen Breiten zerlegt. Dit nenesten Terbesserungen diespr Iaschine zeigt der in Figur 41 veranschanlichter Vangerger. 


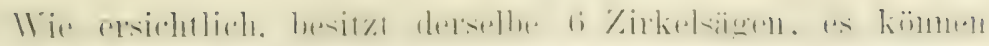

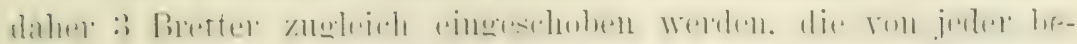

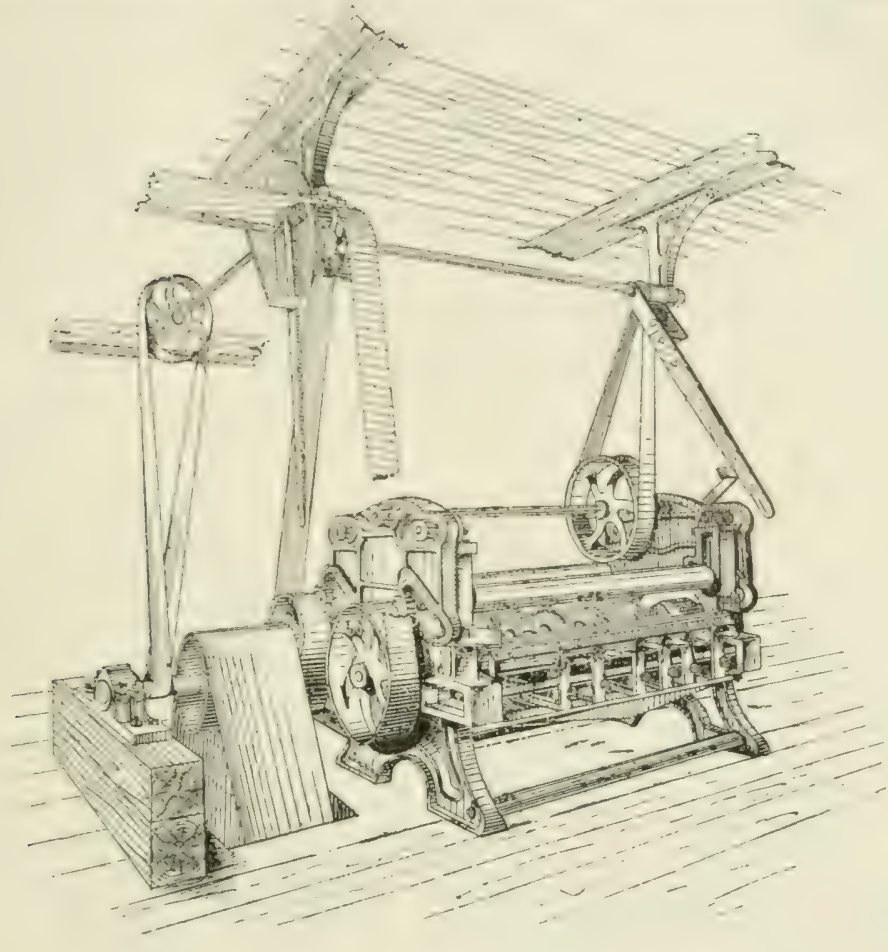

Figur 41.

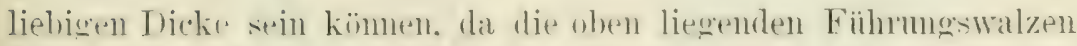

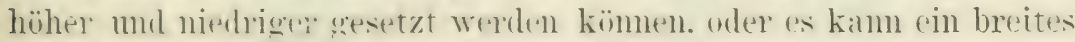
Brett in is shmale Bretter zersehnitten werden. Die Bretter werden anf der Vorderseite eingelegt. gehen damn ron selbst durch die Maschine und fallen anf einen Rollwagent, mit dem sie narh dem Holzhof hetürdent werken. In manehen Mühlen. Wo die Fabrikation ron Thïren. Fensterahenten u. $\therefore$ w. stattfindet. fallem die Bretter nivht anf rinen Rollwagen. sondern anf eine andere? Reihe .. lebender Rullen". wrehe sie dem 'Trimmer (Abstutzel') zuführen - eine schartsimig. Einrichtme von 'Tischen. unter welchen verschiedene Sügen rorwairts odex rückwïts gehen. ganz nach dem Belieben des bedienemden Arbeiters. Die sägen schneiden die Bretter zu gleidhmäsigen Lïngen und entfirmon alle Schadstellen. 
Welche sich an den Enden befinden. Die ïblichen Längenmasse fïr Bretter sind 12. 14. 16 und 18 Fuss (3.6; 4,2; 4,8; 5.4 Meter) und Aufgabe des Abstutzers ist es. genau diese Längen herzustellen. Die Abfälle an del säge und der Kantenmaschine werden sorgfailtig untersucht und, soweit sie sich dazu eignen. nach der Lattenmaschine gebracht, wclche sie in Streifen ron 4 Fuss Länge, s/s Zoll Dicke mi 1\% Zoll Breite schmeidet. Diese Latten dienen zur Überkleidung der inneren Hanswände; sie empfangen tinen Überzug von Gipsbrei - cine Baumethode. welche, wie ich glaube, nur in Nordamerika ïblich ist.

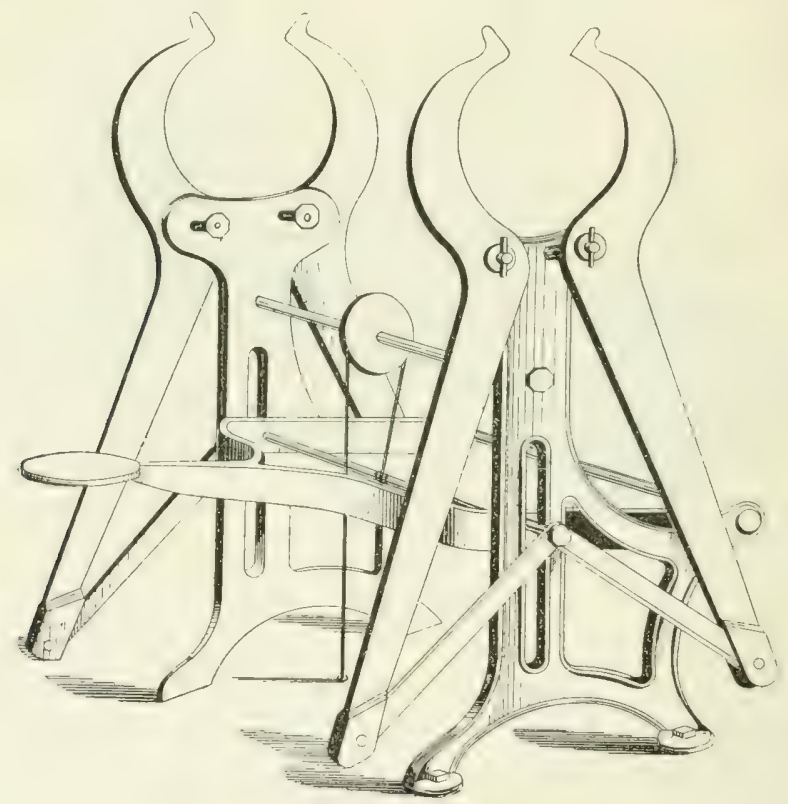

Figur 42.

Zur Terpackung aller Lattensorten bedient man sieh in den Sägemïhlen eines Apparates. der in verschiedenen Fonstruktionen fabriziert wird. Am bekanntesten ist wohl der in der Figur 42 veranschanlichte Shepardson's Patent Latten-Binder, den TV. E. Hill \& Co. in Kalamazoo, Nichigan, fïr 120 Nark liefern.

Mit diesem ganz ans Eisen gefertigten Apparat kamm jeder Bündel von demselben Lmfinge, und was wichtiger ist, sehr test geschnürt werden. Mittels des Hebels ist ein ansserordentlich 


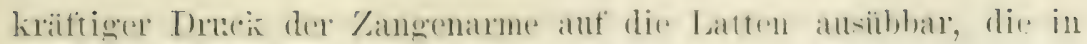

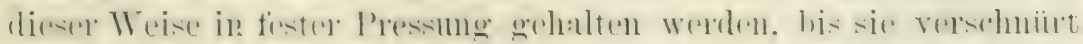
-int. Lis ist leideter mit dieseme Appanat die Isatten fent als

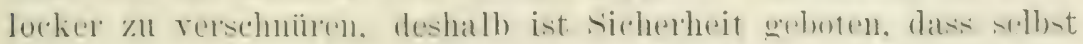

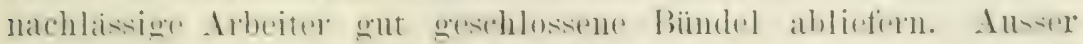

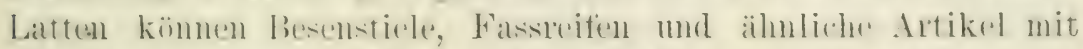
diexem mechanisehen Hiltsmittel in bündel verjalekt werden.

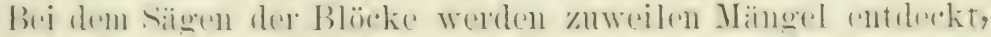

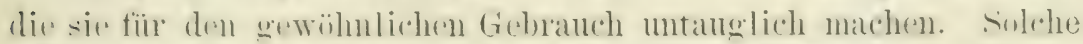

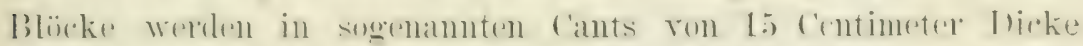

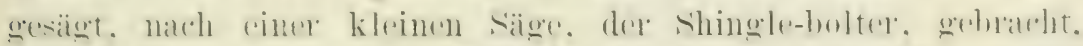

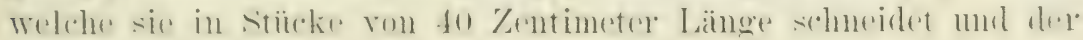
Schindelsige zufüilıt.

Wie ein Shinglebolter beschatten ist. zeigt die Figm 43, eine Konstruktion darstellend, die ans der Fabrik ron W. E. Hill 11. Co. in Kalamazoo, Michigan, zum Preise roll $8(00)$ Mark hervorgeht. Das Holzstiick wird anf die Sägetafel gelegt, welche anf einem Geleise und an einer Führumgsstange lïuft. Der Zweck des Geleises ist zu klax. nm einer Erklärmng

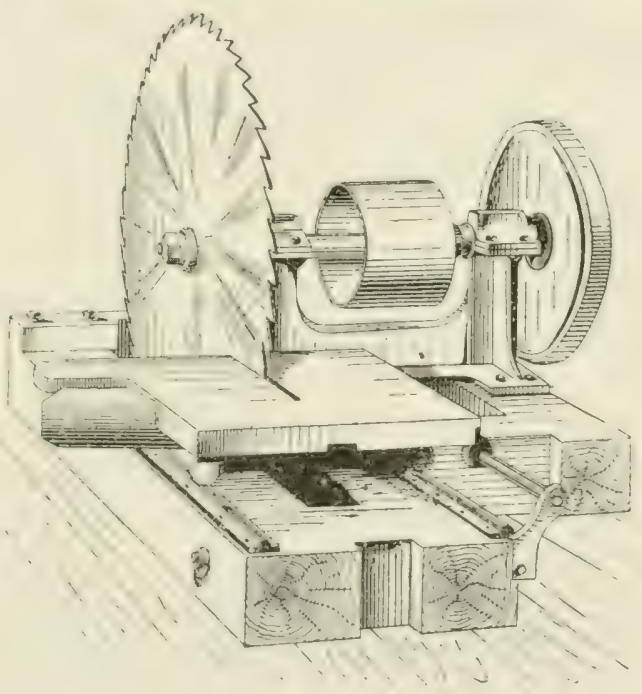

Figur 43.

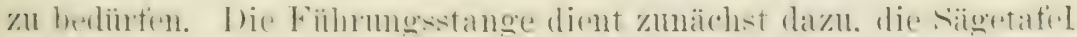

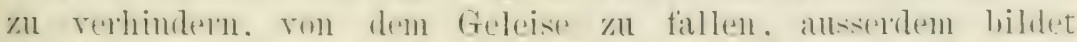

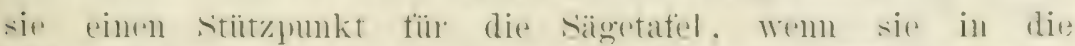

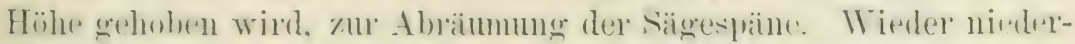

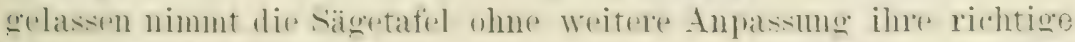
Stelle anf dem Geleise ein.

sirhindeln sind verjüngt anslantemde stiileke. " " Zoll an dem

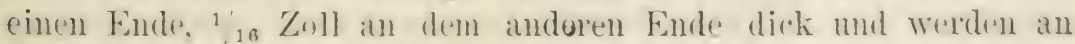
stelle dex Ziegel zum Bedecken der I)ädher gebraucht. Sie werden 


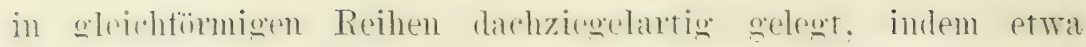
12 Centimeter des dicken Endes iiberdeckt werden.!

An häutigsten wird noch die Zirkelsäge angenrendet. oft mit

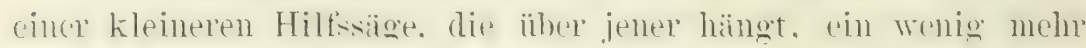

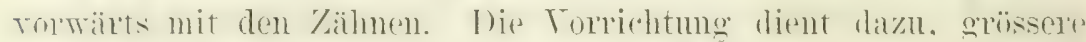
Blïcke zu sïgen. als der Durchmesser einer gewïhnlichen Zirkel-

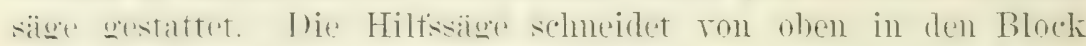

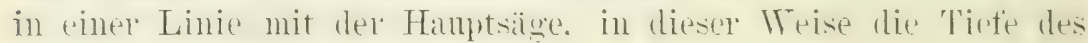
Schnitts rermehrend.

In Californien gibt es Mühlen ron 3 und selbst 4 Zirkel-

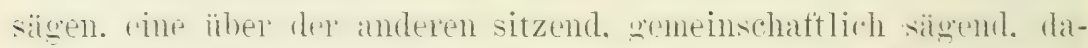

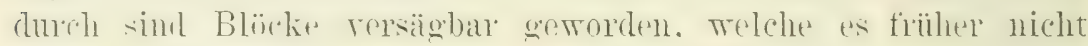
walren. Es werlen aber doch manchmal Bläcke in die Mïhlen

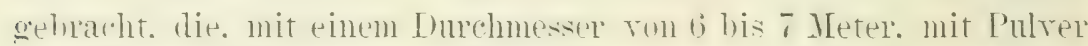
oder I rnamit gesprengt werden mïssen. um rersïglar zu werden. Thise sprengungen merdon ebenfalls als ein Fortschitt der Nerzeit bezeichnet.

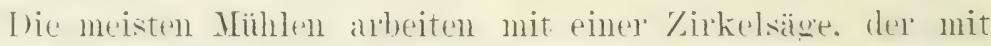
Wr+nigen Ansmahmen eine Hilfsägt heigegeben ist. Die crrïsten Anstalten lassen zmei siggen lauten. eine an ferler seite des Flurs. Die Blockbahn münlet in der Mitte des Flurs und dir Bliicke werden nach links orler rechts abgeladen. je nach Bediirfini:. These Mühlen sind mit allen nenen patentierten Erfindungen ansgestattet. Die Blöcke werden mit einer endlosen Kettr ans dem Wasser gezogen. welche in einer $\mathbf{V}$ fömigen Balkenschleiflahn länft und mit Zähnen rersehen ist. welche das Zurücholeiten der Blörke rerhindern. Ein Block folgt dem anderen in endloser Reihe. Bei der Ankunft anf dem sägeflur wird der Block durch eiselne Arme. relche in Folge einer Hebelbewegung aus dem Flur treten und ihn an der einen Seite fassen. mit beträchtlicher stärke anf die Rollbahn geworten. welche nach dem Sägewagen fïhrt.

Trenn ein Block zersägt ist, wird ein anderer auf den sägewagen geladen. durch die einfache Berïhrung eines Hebels mit der Hand des säger's. In Folge dieser Berïhrung tret:n eiserne Arme aus der Rollbahn nuter den Block und heben ihn auf den Tragen. den der bereits geschilderte Dampfapparat nach der sägせ schiebt. Nach dem ersten Schnitt beriihnt der säger einen Hebel. 


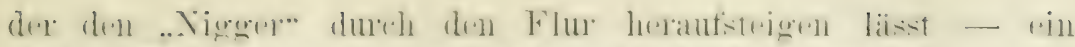

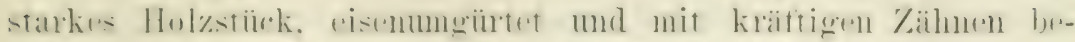

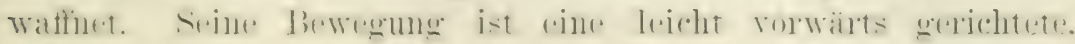

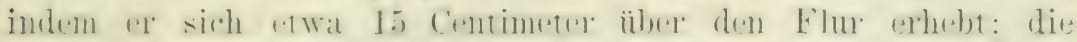

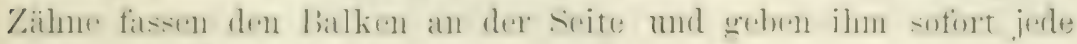
gewiinschte Lage.

Dieser ausgezeichnete Apparat, welcher in keiner gut. ansgestatteten Sïgemiihle fehlt. wird in der Figm 14 reranschaulicht. Wie er hier dargestellt ist, geht er aus der Fabrik von TV. E. Hill \& Co. in Kalamazoo, Michigan, hervor; welche ihn in vielen verschiedenen Grössen liefern, deren Preise sich zwischen 1200 und 2500 Mark berregen.

Wie dieser Apparat arbeitet, lässt sich ans der Abbildung leicht erkennen, doch sei noch

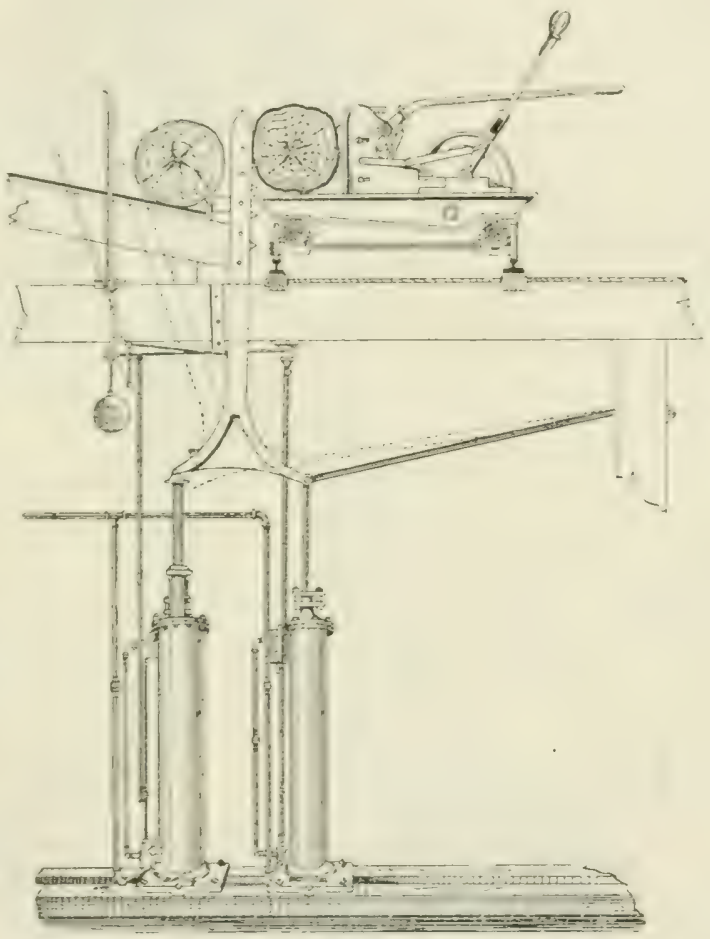

Figur 41.

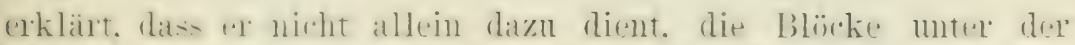

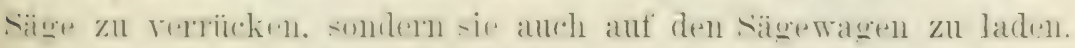
Zuwrilen werlens die Blïrke von der einen sïge nur ..gekanter". eine andere schmeidet sie in Brotter. In diesem Falle wird narh der firtigen Kantung eine an einem Balken hiugerme

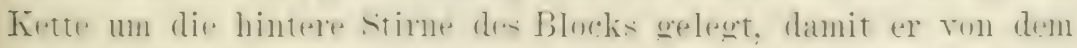

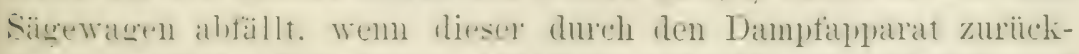

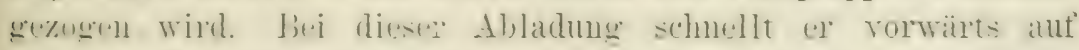

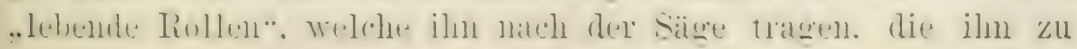


Burtern versehmeden soll. Selbstrerständlich werden die ., lebenden Rollen". wie alle andere Apparate der Miihle, dureh die im Frdgeschoss stehende Dampfmaschine getrieben.

Bis die Bretter die Sïger relassen, branchte keine Hand den Block zn berïhren. Maschinen. gelenkt ron menschlicher Goscheklichkeit. haben alle Arbeit gethan. Wem der Block den Sägewagen erreichte. wurde er rerklammert, nicht durch die altmondische Hebelklammer, eingeschlagen mit einem Hammer, sondern durch die einfache Berïhrumg pines Hebels. Er worde in die richtige Lage ror die säge grebracht, durch einen Mechamismus. Welcher die Lagt anf Wunsch mit einer (tenaugkeit von 25 Millimeter anderte. Sach dem ersten Schnitte lief der Sägewagen mit Blitzesshonelle zurick. In wirder die Stirne des Blocks ror die

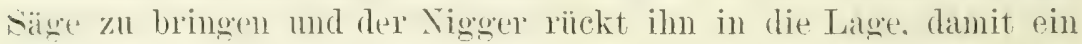

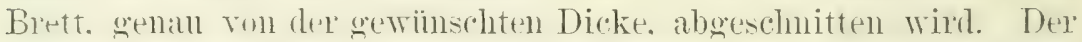
Sïgeragen wird. wie bereits erklät. mittels eines Dampferlinder getrieben, der auf seiner Bahn liegt.

Von der Fangstelle bis zum Holzhofe wal es nur notwendig, dar Holz in die Hanel zu nehmen an der Kantemarerhine. am Al)stutzer und beim Sortieren und Anfsetzen der Bretter. Alle

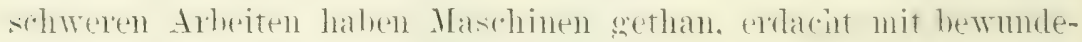
rungswïrdigem Scharfsinn.

sind weitere Torollkommmmgen möglich! Fin heherztes Ta muss die Antwort sein. denn wo ist die Grenze des menschlichen Könnens?

Ton anserendentlicher Leistmestähigkeit, wis sir dit Zirkelsiige hesitzt, ron oft 2 Meter Durchmesser mit ihrer Hilfssäge onter gar die vier ïbereinander arbeitenden Zirkelsägen erscheinen mii-en. ist dennoch ihre Glanzy+t schom roriber: sie werden allmählich aber manfhaltsam verdrängt von der Bandsigne. Welche als die Säge der Zukunft zu betrachten ist.

Eine Bandsige ist ein langes gezahntes stahlband, 15 bis 20 Zentimeter breit. an den beiden Enden mit Messingschlagloth zu-ammengelöthet: sie länt über 2 grosse, ïbereinander senkrecht sitzende Riemscheiben. welche sie gleich eincm 'Treibriemen rerbindet. anf die obere wirkt sie als treibende Kratt. Die Zähne stehen bei der Arbeit stets gegen das Holz.

Die Bandsägen sind rehr diimn und besitzen eine Leistungstiahokeit ron 30000 bis 40000 Fuss Brettermass den Tag. mit 


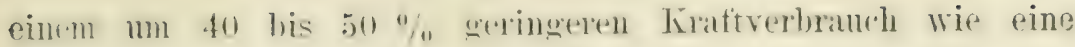
Zirkelsäge von gleicher Leistungstähigkeit.

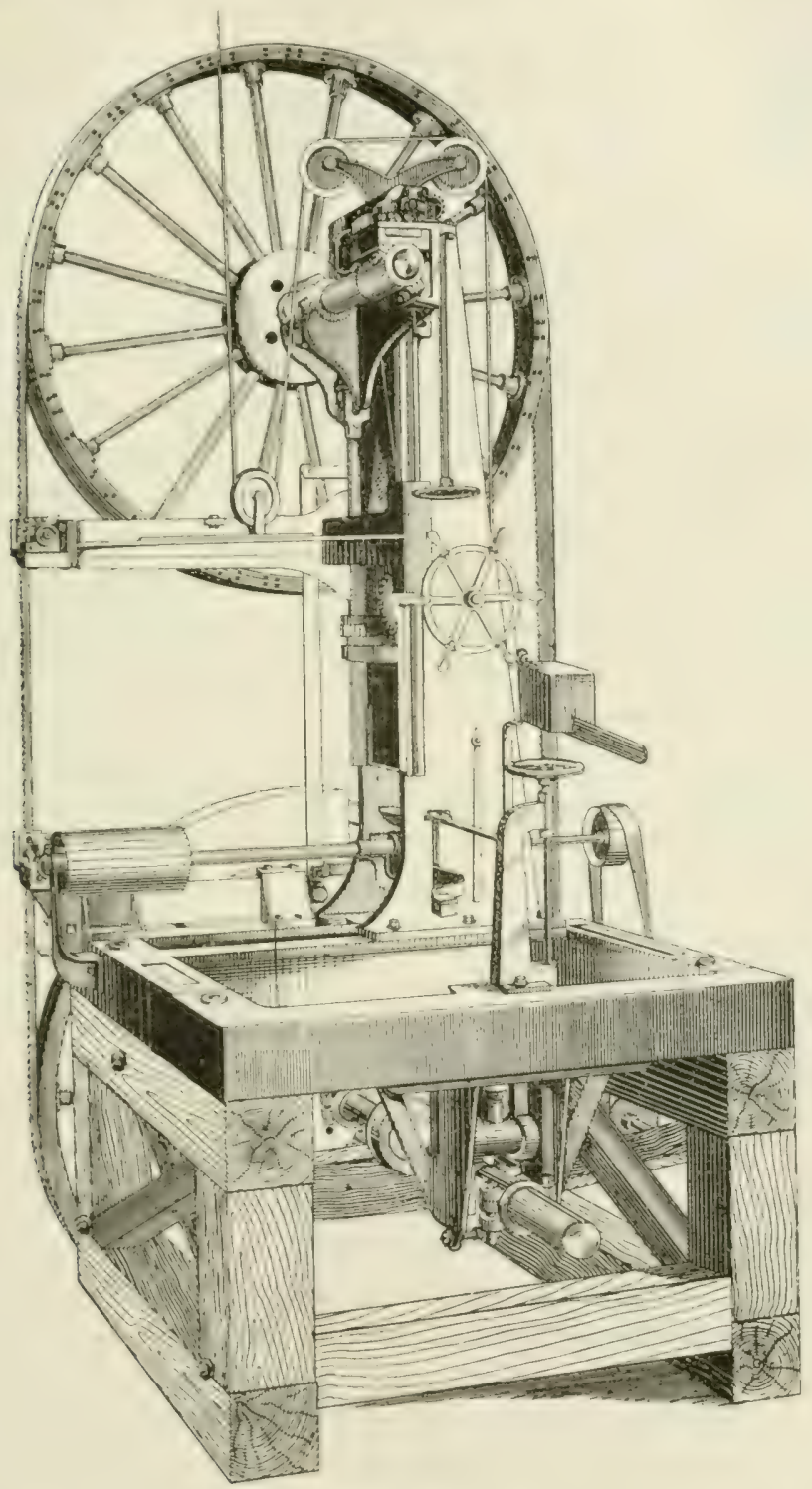

Figur 45.

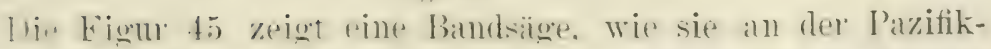

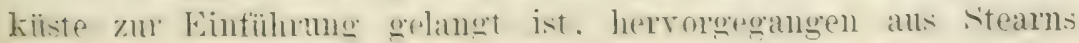


Manufacturing ('o. in San Franzisko. Der ganze Mechanismus wird so klar veranschaulicht. dass eine Frlauterumg nach dem bereits Gesagten gewiss iiberflüssig ist.

schliessich möge einer Torrichtmg sedacht werden, welche viele Mühlen zmm Verbremen ihner überschüssigen sïgespäne besitzen. Es ist ein grosser. kreismuler Backsteinofen, oft 15 Meter hoch. bei einem imneren Inuchmesser ron 7.5 Neter, so nahe an der Mïhle erbant, dass die sïgespäne auf einem Transportent. wie er an den Dreschmaschinem hängt mod der ebenfall:; ron der Dampfimaschine getrieben wird. nach einer in genïgender Höhe angebrachten Öffnumg getragen und da in den Ofen abgeladen werden können - alles ohne menschliche Termittelung. Alle unbrauchbaren Abtalle. soweit sie nicht zur Heizung der Dampfmaschine dienen. Nerden in diesen Ofen ron munterbrochen bremnendem Fener verzehrt.

Auch in Bezug auf die (u) ulität der Arbeit liegt der Torteil entechieden auf seiten der Bandsäge, demn ummöglich ist es. cime grose Zirkelsäge ohme einen gewissen Grad ron Erzittermg schnell laufen zu lassen, wodurch eince was ranhe schneidefliache erzengt wird; die oben und mten festgreührte Bandsäge läuft dagegen in grader, ruhiger Linis durch den Block nnd dia ïberdies ihre Zähne beträchtlich teine sind, wie diejenign der Zirkelsäge. schneidet sie eine glattere Fläche.

Nicht die unwichtigste Frage bei diescm Teroleiche bezieht sich auf den Holzabfall, und auch darin gibt die Bandsäge die besten Resnltate. Wenn die Bretter zu 1 \%oll Dicke geschnitten werten, gehen mit der Zirkelsäge bei jedem sohnitt ${ }^{5 / 16}$ Zoll Holz als Sägemehl verloren, der Terlust beträgt 22.6\%. Eine Bandsäge verursacht höchstens ${ }^{1 /}$ s Zoll Abfall pro schnitt. oder wemn einzällige Bretter schneident, 11 " „Ferner gehen beim Hobeln der ron der Yirkelsäge geschnittenen Bretter auf jeder Seite ${ }^{1 / 16}$ Zoll rerloren, während nu: 1/: Zoll verloren weht, vem die Bretter ron der Bandsäge geschnitten wurden, das ist also ein fernerer Gewim von $1 / 16$ Zoll pro schnitt. Das ergiebt cinen tresamtgeminn ron ${ }_{4}^{1}$ Zoll pro Schnitt, bei dem Gebranche der Bandsägre.

Fïr den vorstehenden Tergleich sind Blöcke gedacht, nelche su eross sind, un mit riner Zirkelsige ron 2 Meter Durchmesser rerschnitten werden zu kïmnen. Fün erössere Blöcke ist es not-

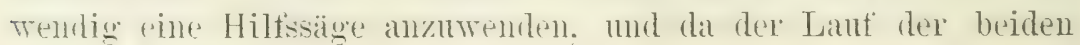




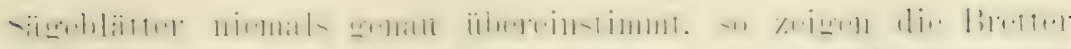

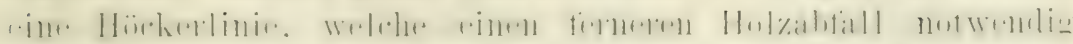

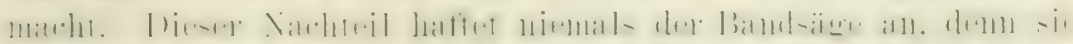

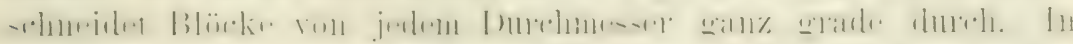

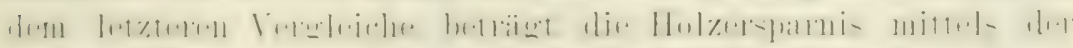

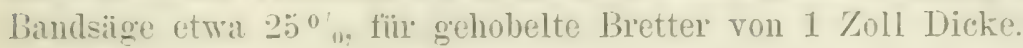

Die Vorteile der Bandsäge sind selbstrerständich um so

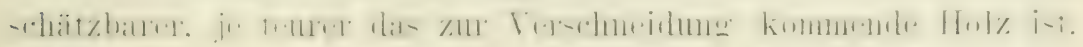

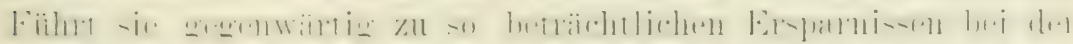

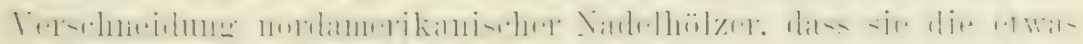

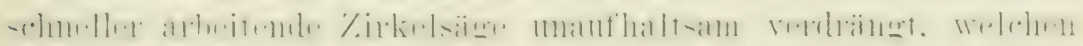

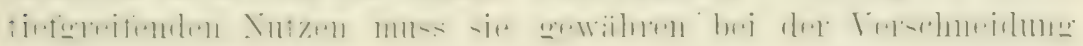
mopischer Luxushölzer - ein Dienst. den sic sicher in naher /ukunft antreten muss!

Eine Änderung dex Betriebseinrichtung macht del Ersatz der Zirkelsäge duch die Banisäge nicht nütig.

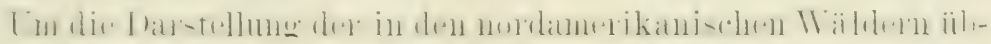

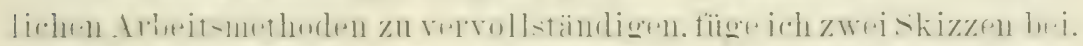

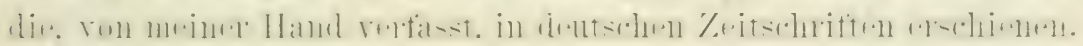

\section{Die Itolgewinmung im Territorium Washington.}

S̈egelt man durch die schmale, tief' in das 'Ternitorim

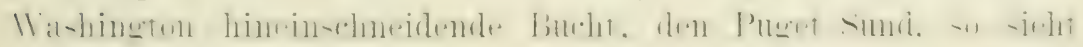

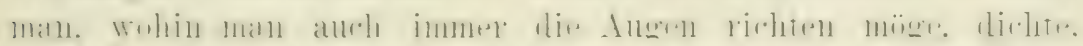

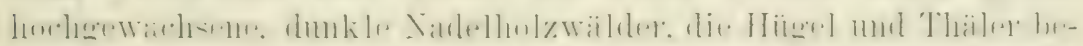

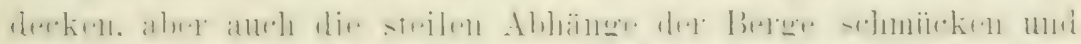

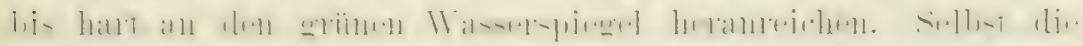

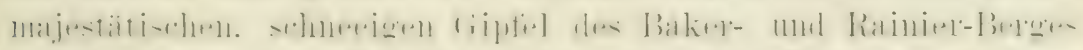

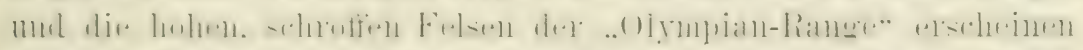

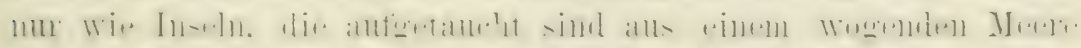

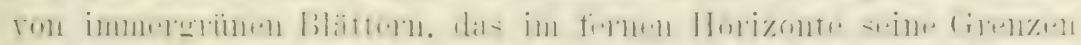

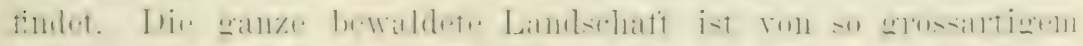

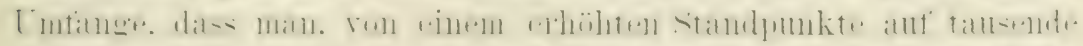

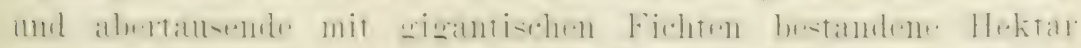

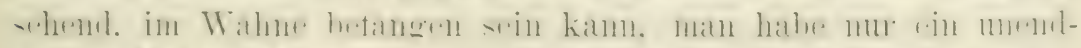

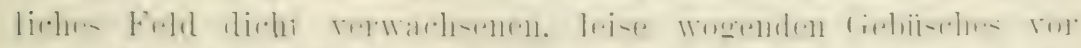

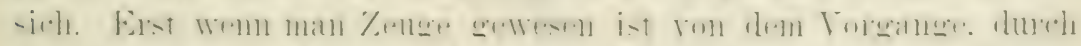

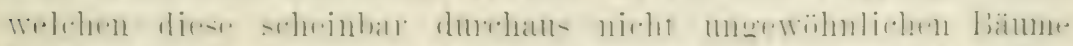

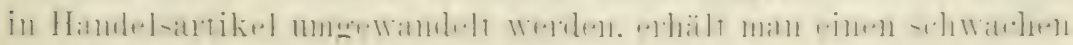




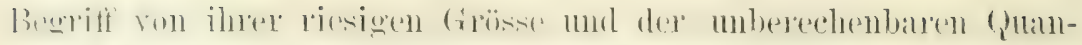

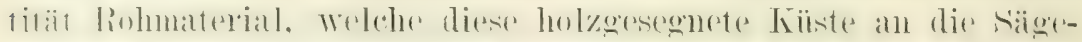

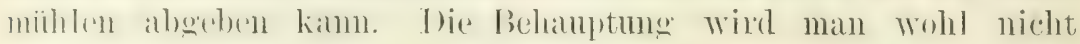

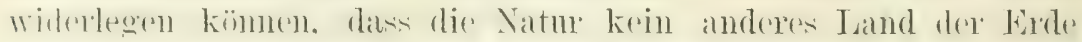

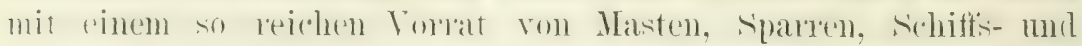

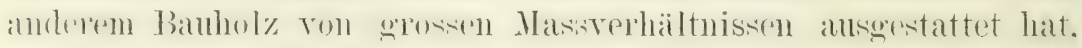
wie denjenigen 'Teil vom 'Territorium Washington. der an den Ttern von Jubu de Fucastrasise, Admiralty Tnlet. Possesion simul. Puget Sund und deren Hauptarmen liegt.

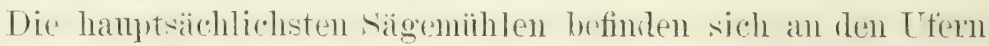
der Pobressom sund und des Puget sund zerstrent, und das Rohmaterial, welches sie beiliurfen. beziehem sie aus dem ihnen zunichst gelfogenen Kïstengebiat. Links mol rechts an den schmalen, beshatteden Buchten. findet man die Lagerplätze der Holzfäller. von

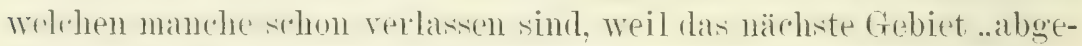
wirtschaftet" worden ist. Wo aber das raule Tölkchen der Holztaillere noch thätig ist. da hört man den schall dere Axt, das dumple

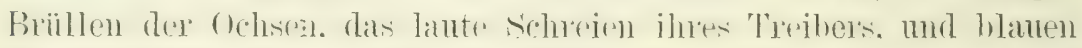

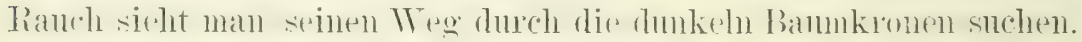

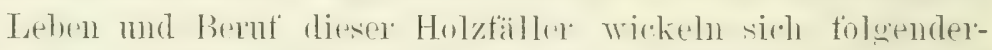

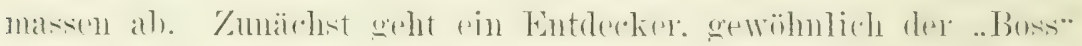
selber, auf die Suche aus, und wenn er eine g'ute ,chance" getroffen hat, dam holt we seine ..orew. die ihe Thätigkeit sofort

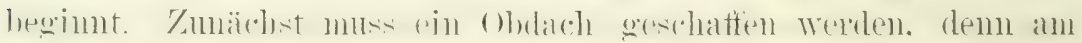

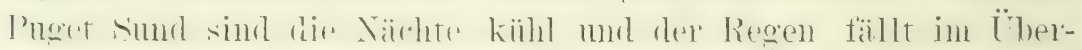

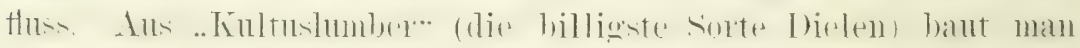

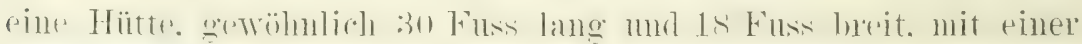

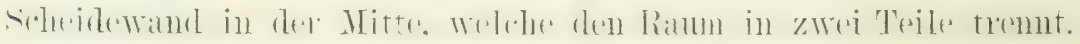
Den einen besetzt der Koch mit seinem Geschirr, der andere wird zum Schlafgelass der Lente bestimmt. Das Letztere ist,

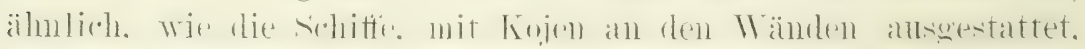

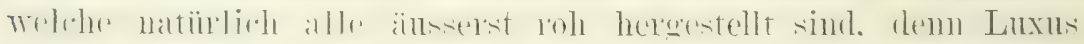

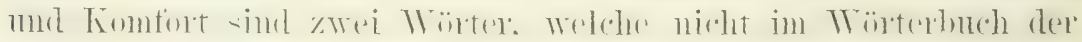

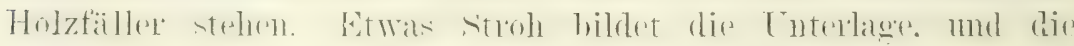

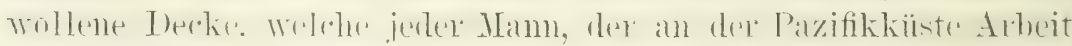

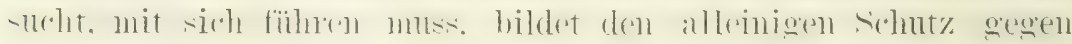
die Kälte. In der Mitte des Raumes, der oft nicht eimmal rauh

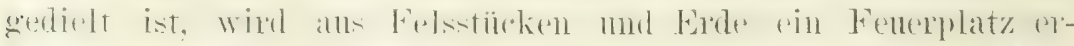

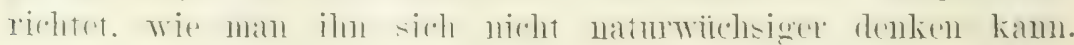




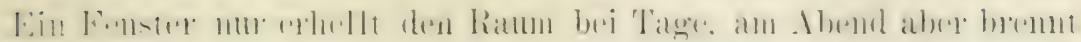

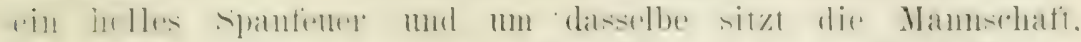

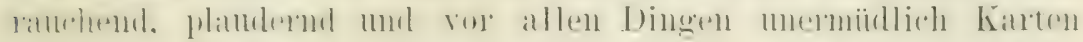

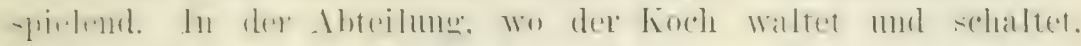

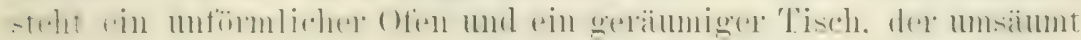

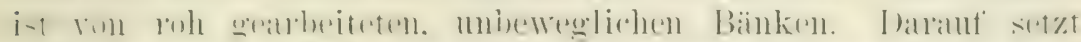

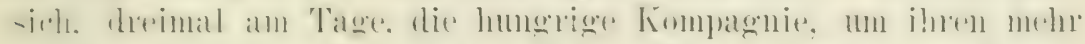

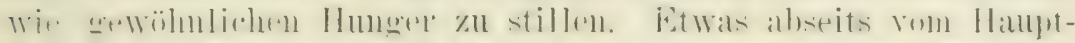

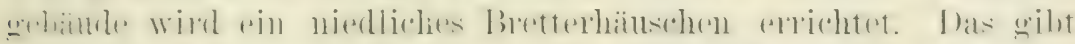

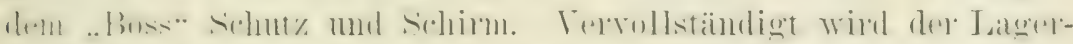

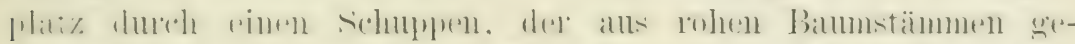

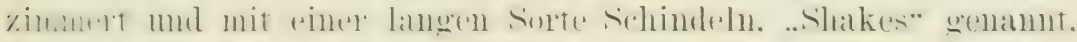

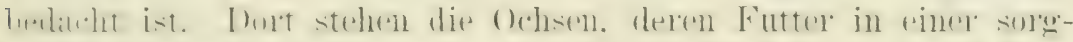

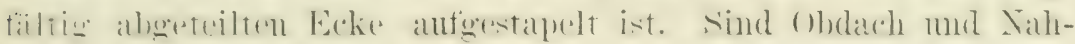

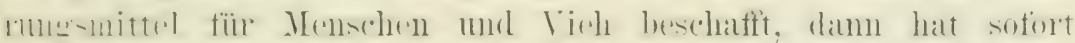

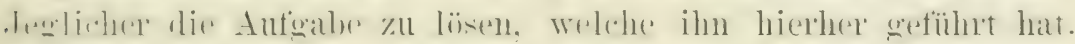

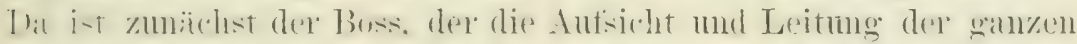

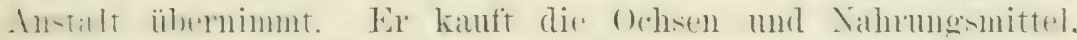

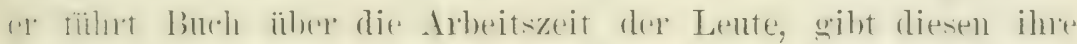

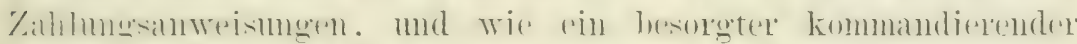

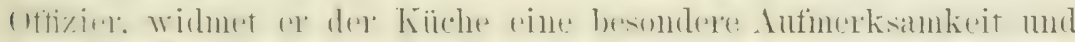

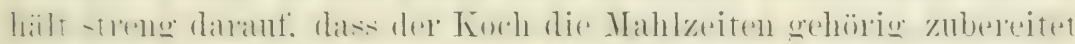

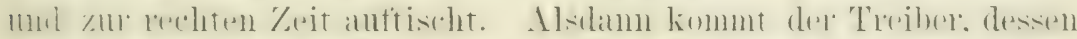

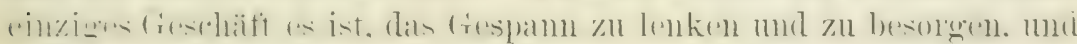

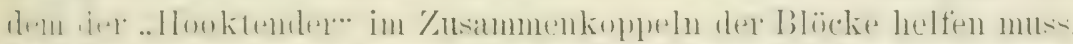

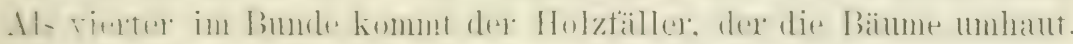

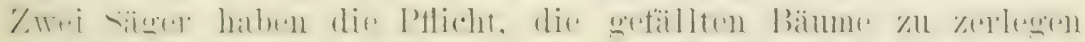

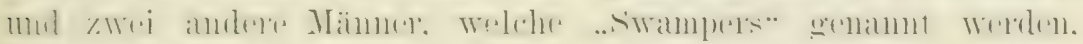

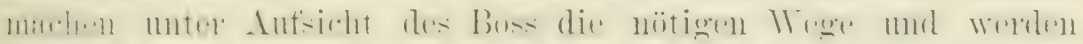
darin vom ..skidder" muterstiitzt, der ihnen das Rauhe erst aus

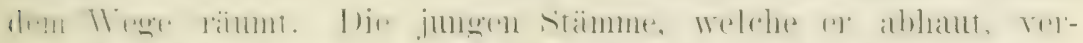

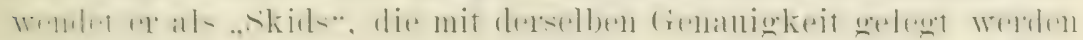

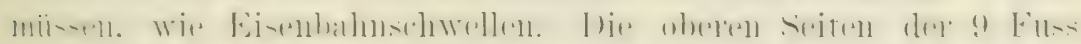

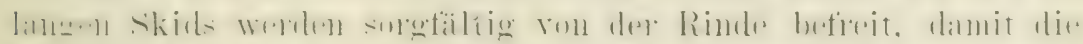

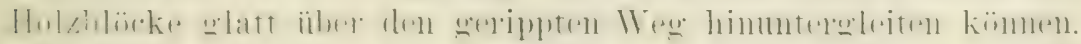

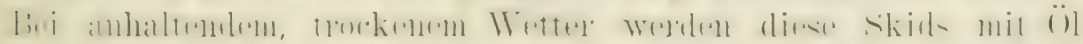

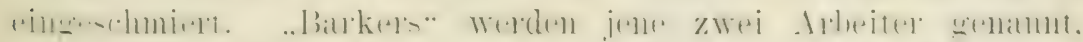
welche die Rinde der zersägten Banmstämme mit eigens

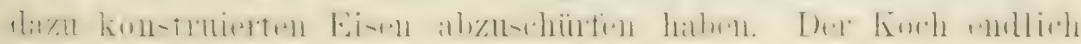




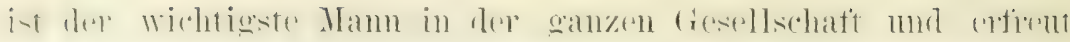

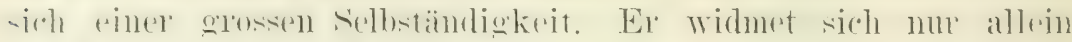

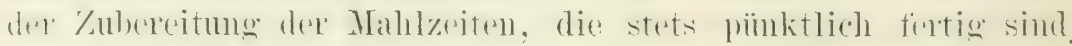
Friih Dorgens, - um vier Uhr schon, - hat der Koch sein

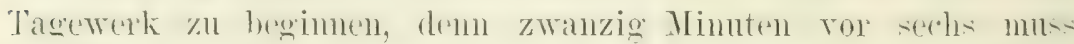
das Frühstïck fertig soin. Lmo halb sechs tritt ex ans der Thüu

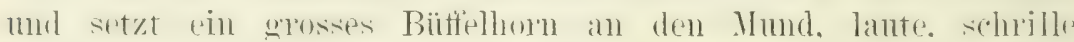
Töne blasend. Das weckt die Schläfer auf, die sich rasch an-

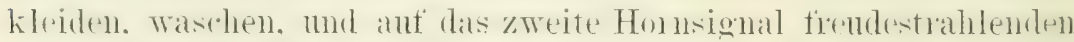

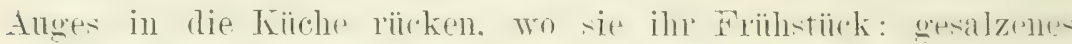
(Ichsentleisch. Kartofteln, gehackene Bohnen. Pfannkurhen. Biscuit.

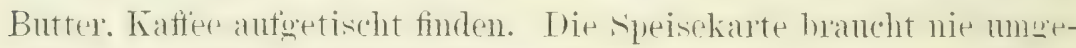
shloben zu werden. sie bleibt sich immer gleich: dreimal an Tage mol siebemal in der Worhe. Ist die angenelume Pflicht des Frïhstückens erloligt, dam geht Teder an weine trbeit. Ther Holzfaller nimmt zwei Äxte. die eine. nm die dicke Rinde zu durchhanten. die andere. schmal mel schart. wird anf dem reinell Holz ihre Antrendune finden. Das Fällen eines Bammes nird

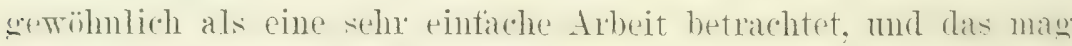
es auch anderswo sein, nur für Oregon und das Territorim Washington trift diese Ansicht nicht zut. Dort sind die Bämme

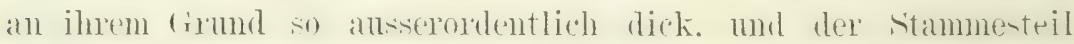
äber den Wuzeln ist gewöhnlich schon etwis mïrbe und anguyefresell. sn dass man es als einen Arbeitogewimn betrachtet. wemm man den Bamm in einex gewissen Höhe, wt füntzehn Fus̈̈bre der Erde. abhant. L'm dies bewerkstelligen zu können. liaut der Holzfäller. so hoch als es ilım nur zur Hand steht, ein vier-

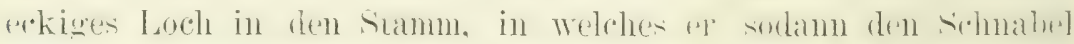
eimes soliden Brettes steckt. das 5 Fuss lang mol a Zull breit

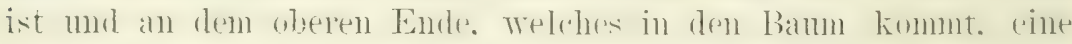

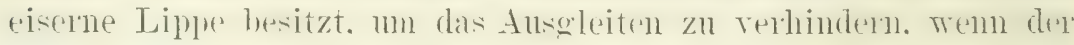
Mann darauf steht. Der Holztialles suringt num anf das Brett mud

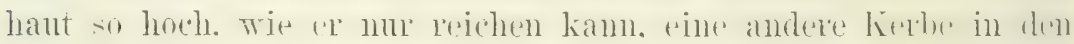

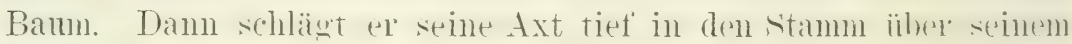
Kopt. hält sich mit dep einen Hand am stiel fest mul sureht mit der anderen Hand ein zweites Brett einzusetzend. dats er. halh kletternd, halb springend. erreicht. Im ant diesem stehemil dir. Fällung des Baumes sellest rorzunehmen. \%oust nimmt er dir scharer Axt und entfermt die Rinde an der sichlagstelle. dir el 


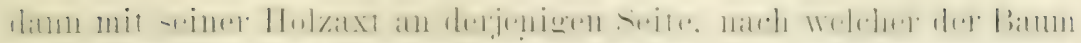

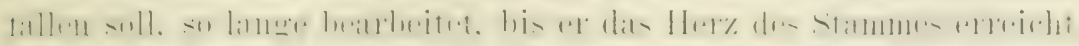

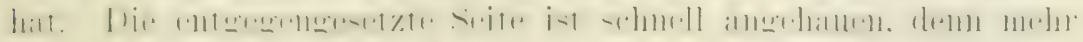
bedarf es nicht. mu den Baum zum Fallen zu bringen. „Under! [mele!: ruft ex als Warumgssignal, wirft seine Axt weit fort

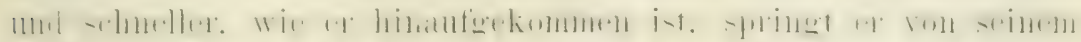

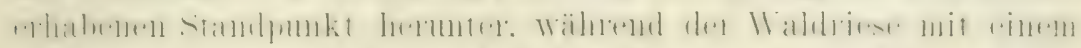

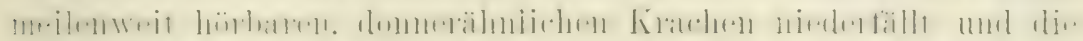
Äeste semer Vachbarn in jülem Sturze mit sicln reisst. Num kommen die beiden siiger mit einer mächtigen säge mo einer

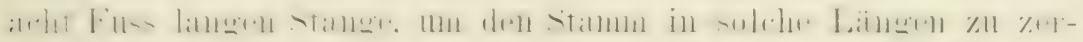
leren. wie es der Boss angeordnet hat. Tierundzwanzig Fuss ist

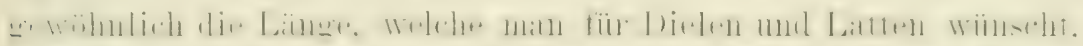

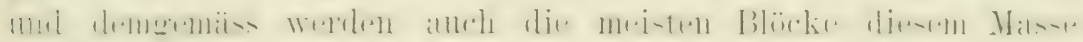
entsprechend geschnitten.

Äste sind den Sägern nicht im TWege, dem diese beginmen

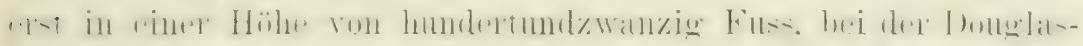

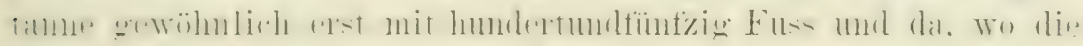

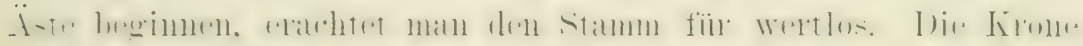

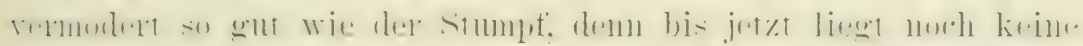

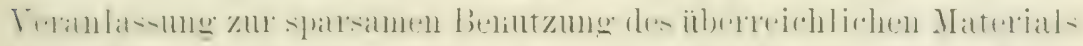

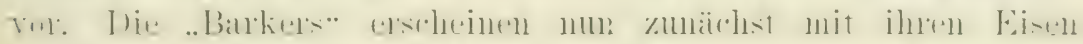

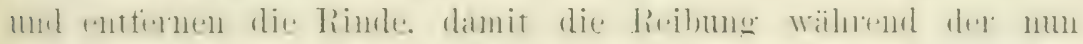

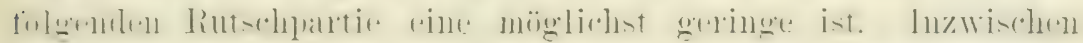
hahe:ll die ...

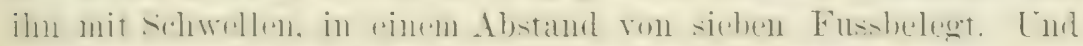

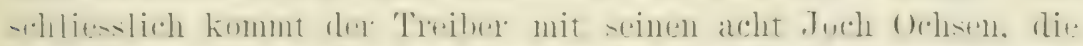

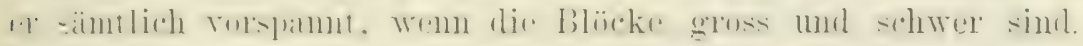
Andernfalls rerwendet er nur ein oder zwei Joch. Ein Kom-

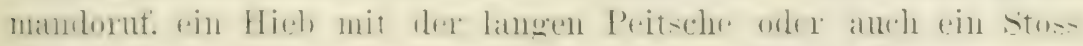

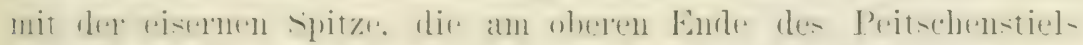

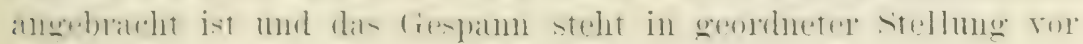
den Blöcken, an die es nun angekettet wird.

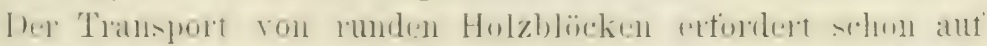

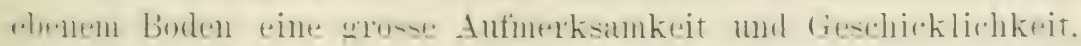

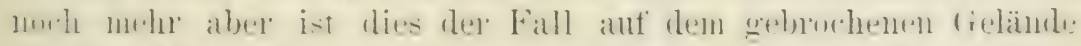

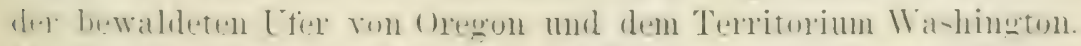

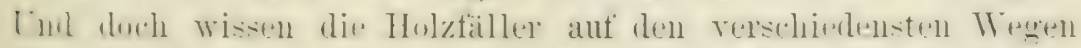

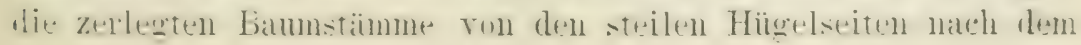




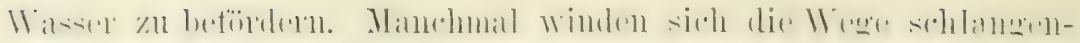

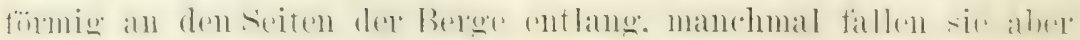

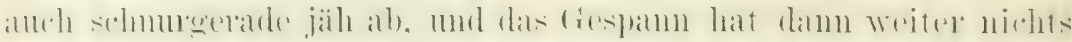

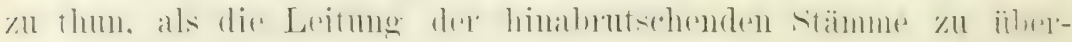
nehmen. Oft werden zehn oder zwölf Blöcke mit kurzer Tiette

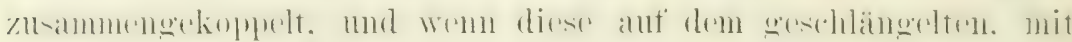

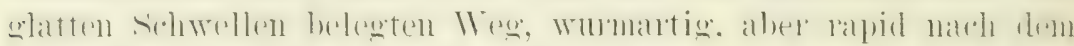

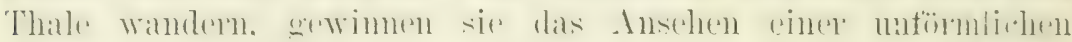

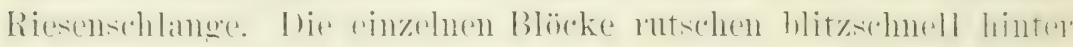
einander her und stossen sich gegenseitig an, was eine immer

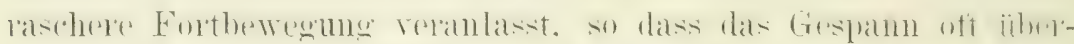
holt und schwer verletzt oder gar getödtet wird. Ein anderes Mal gleiten sie ohne Unfall bis dahin, wo der Weg zu steigen

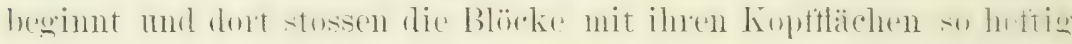
und mit einem solchen Getöse an, dass man glaubt, das Fenern

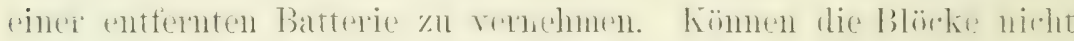
weiter gezogen werden, so tremnt man sie und schiebt sie einzeln

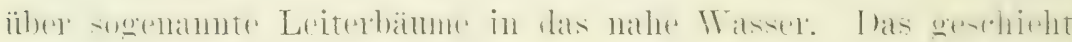
oft aus einer Höhe von fünfzig bis humdert Fuss, and es ist ein

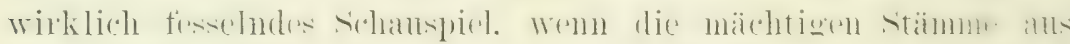

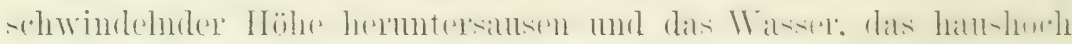

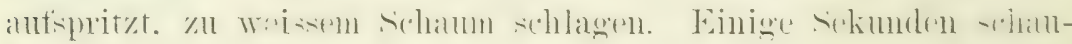
keln sie sich noch in allerhand phantastischen Formen an der

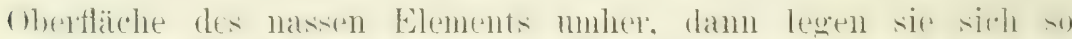

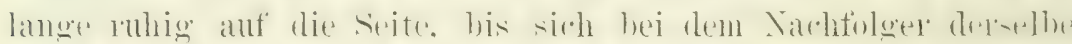

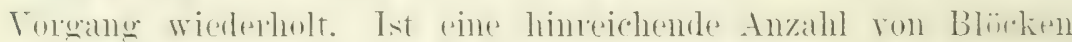
im Wasser versammelt. so werden sie zu einem Floss zusammen-

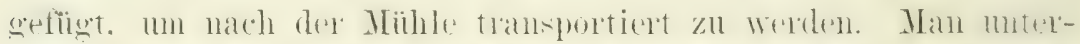

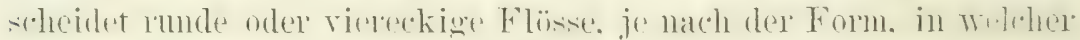

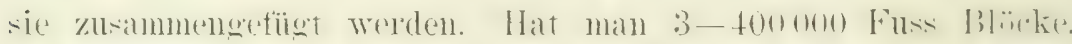

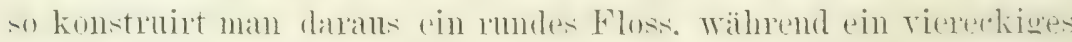

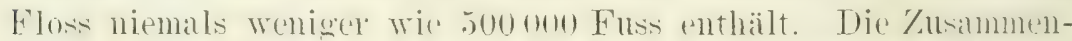

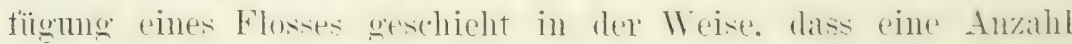

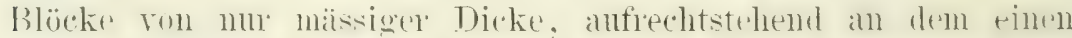
Ende durehboht und mit einer starken Kette zusammengetïgt werden. oft worden die stämme atuch mur rumbun seckerbt umi

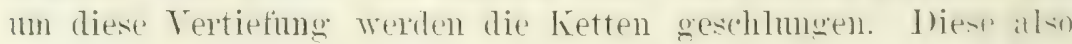
repbundenen Blökte bilden den Rahmen. der num mit dem anderm Material ausgefiillt und of horeh anfegbant wird. Ifit hetten und 
Sparren sucht man alsham das Ganze noch so gut wie möglich

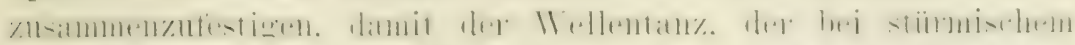

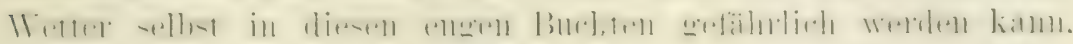
dias kmstlose Machwerk nieht auseinanderstosse. Ist das Floss

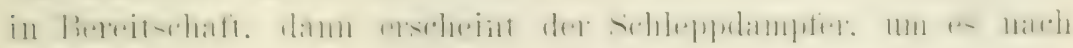
der Miihle zu bugsieren. Win Dampfer, der cin so ungelenkes

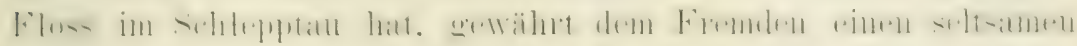
Anblick, dem el sieht in einiger Entfernung das Boot, wie es

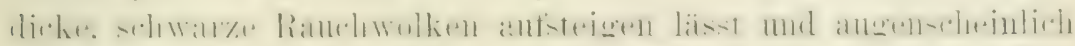

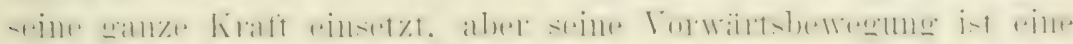

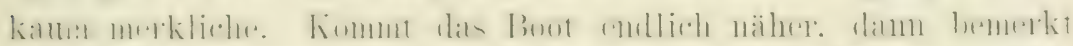

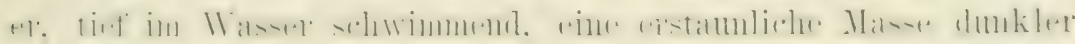

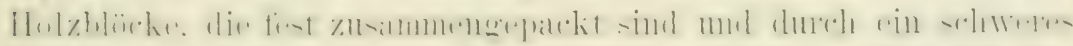

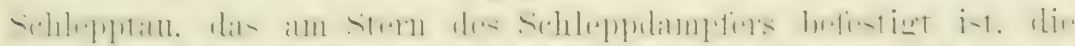

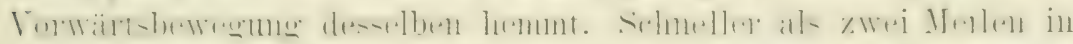

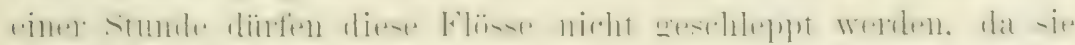

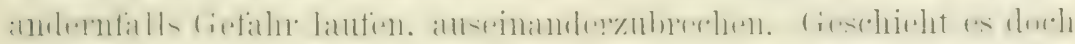

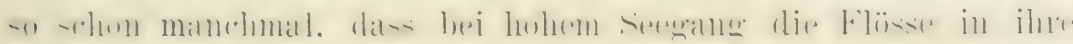

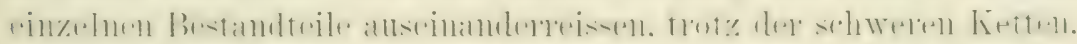

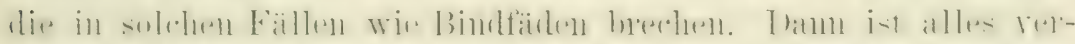

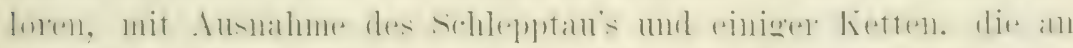

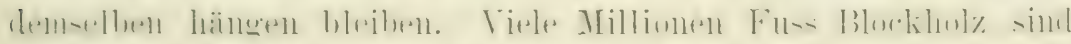

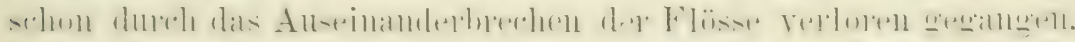

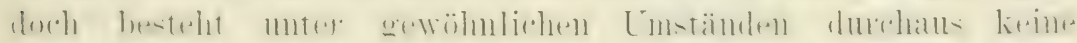

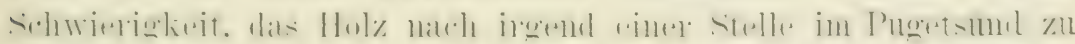

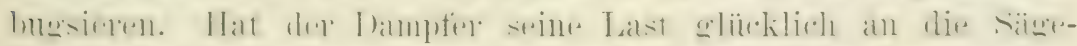

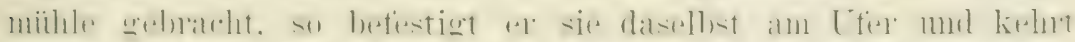

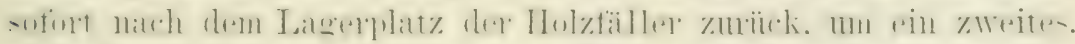

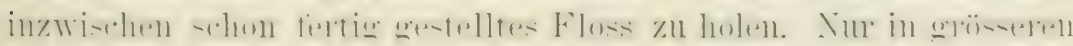

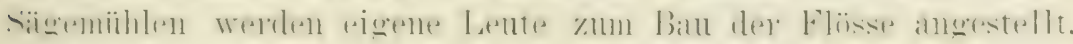

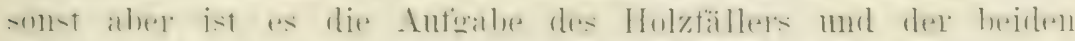

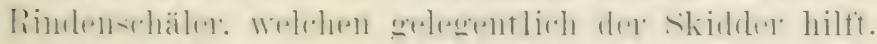

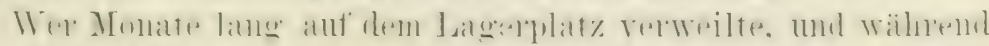

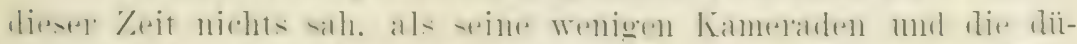

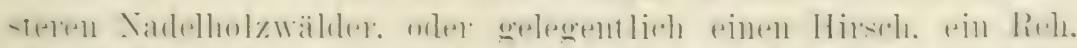

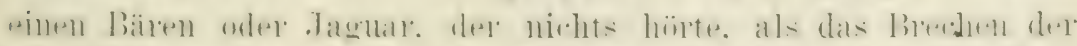

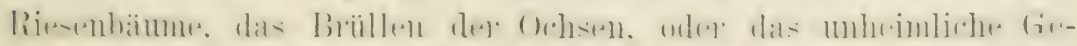

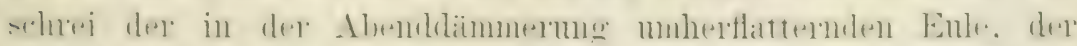

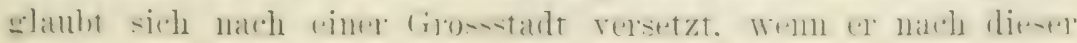


lingen Abwesenheit wieder nach der Mühle kommt. Dort trägt das ganze Leben den stempel der Eile und Geschäftiokeit. Da

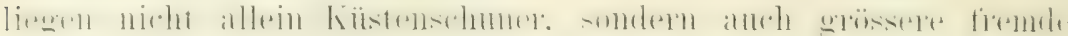

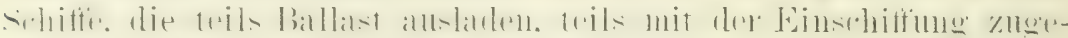

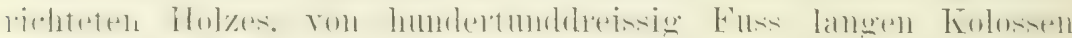
schreven Bauholzes bis zu Latten. von welchen hundert erst ein

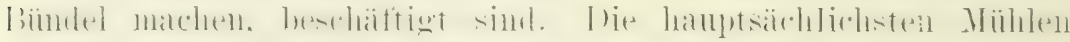

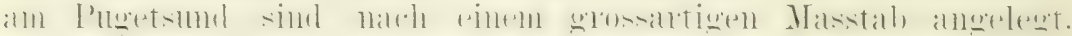

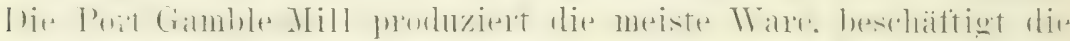

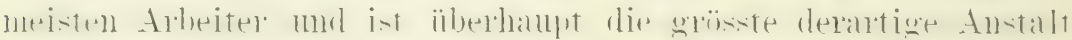

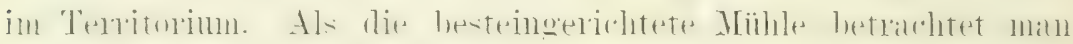

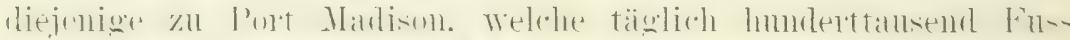

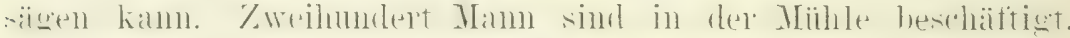

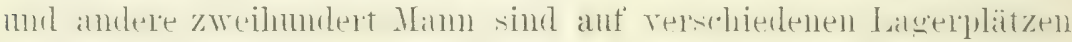
im Wald rertheilt. Sämtliche Mühlen werden mit Dampf ge-

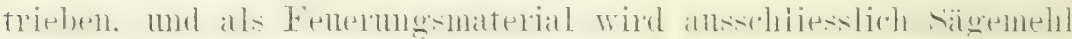

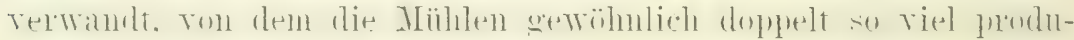

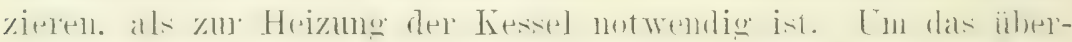

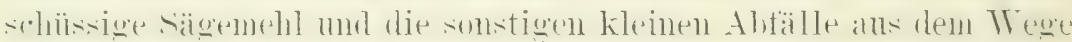

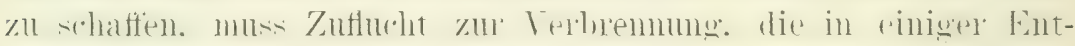

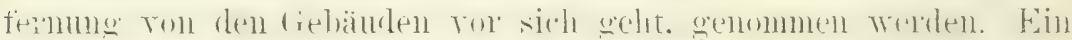

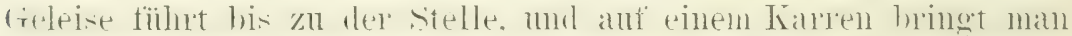

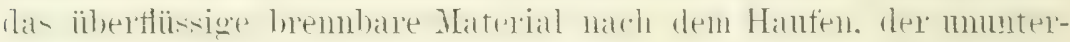
brochen Jahre lang brennt.

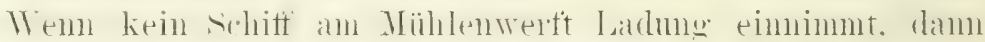

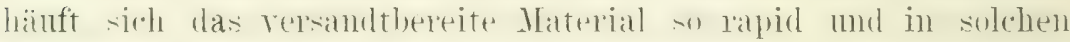

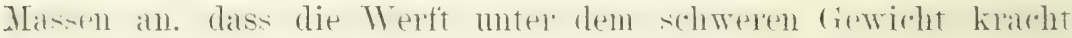

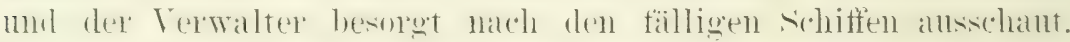
schwere veloel. heftige. wirlerwärtige Irinde verusachen nicht selten solche Verzügermegen. Endlich erscheint hintel dem nätchsten Torgebirge ein segel. und wirklich. as ist der lang elsehnte Bote: Eine stunde spätex liegt dat firendig begribste schift an der Werft. wo se rine Leine wirtt. um herangehnlt zu werden. Nieder gehen The segel und nieder geht der Anker. Die Laufbretter aber hat man inzwischen schon von der Werti nach dem schifte gelegt. dem die Arbeit des Einschiftens muss sofort beginnen. I)ie Lente werden in Partieen eingeteilt. und dex erste stenermann stellt sich an Backbord. der zreite an Stemerbord. Die Arbeiter, welche dats

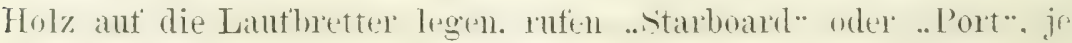


nach rlue Beite. an welcher es verladen werden soll. Ist der

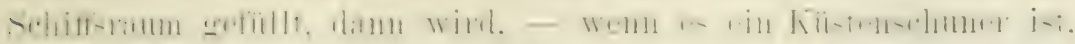
- das Deck moch zuhn bis elf Fuss hoch beladen. was abor bei

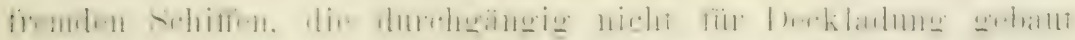

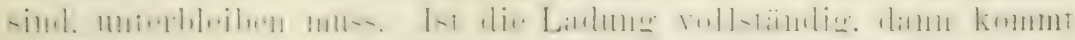

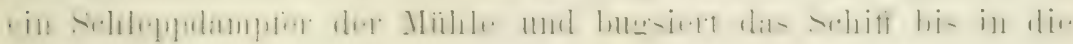
Strasse ron Juan de Fuca, wo es dam seine segel nach einem leinischen Hatun der Pazifikkïste setzt. odel nach Australien.

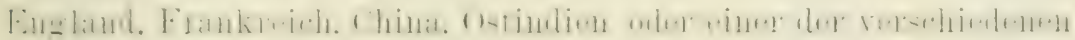
Inselormpen der siidsee.

Glaubwirdigen Angaben zufolge liefert das Territorium

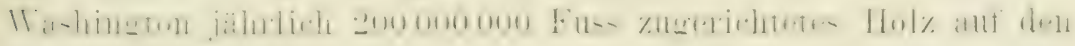
Markt. Daton guht der güsste 'Teil nach San Francisko, das

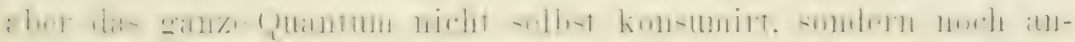

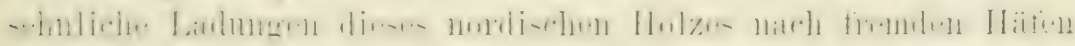

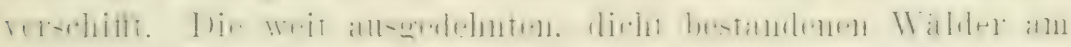

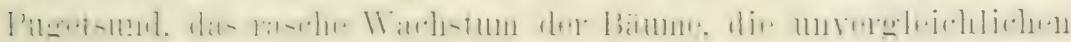
11 i - r r

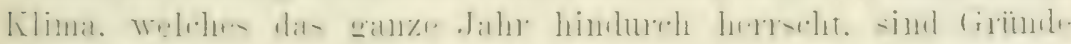

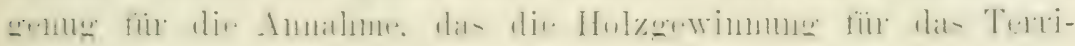
torium Washington das bleiben wird. Was es seither war: die Hatutguelle seines Mohlstandes.

\section{Jie Holaflösserei in Californien.}

Es war im April, dem lieblichsten Jonat für Californien.

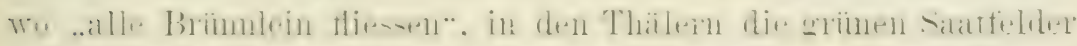

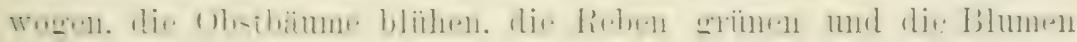

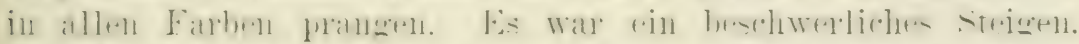

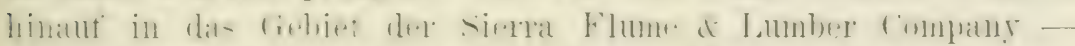

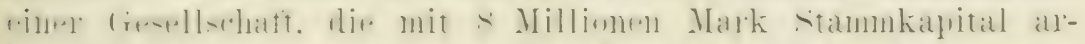

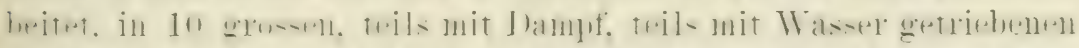

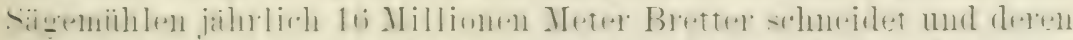

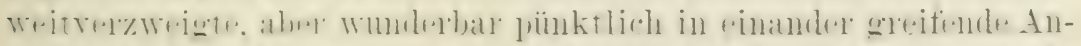

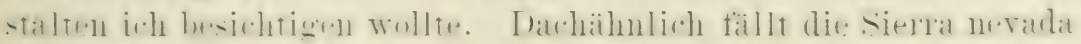

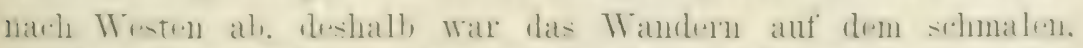

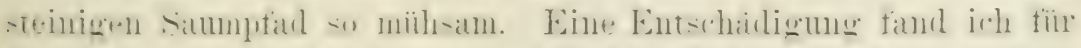

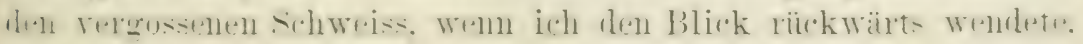

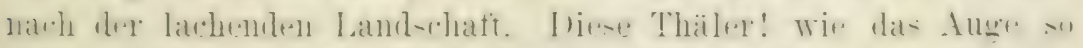

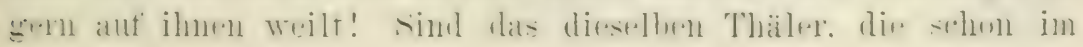




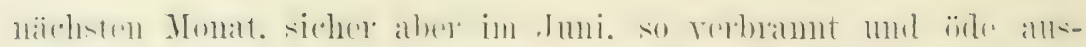

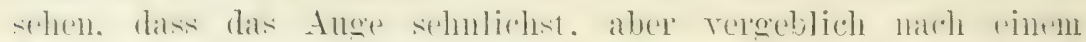

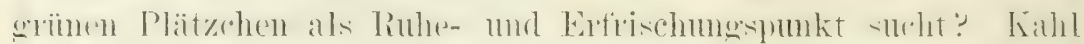

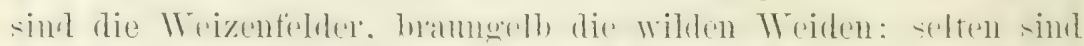

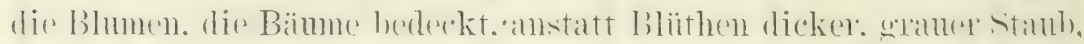

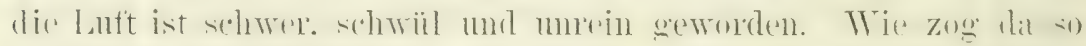

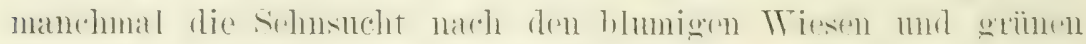
Gärten des dentschen Yateriandes ins Herz! - Doch hente waz

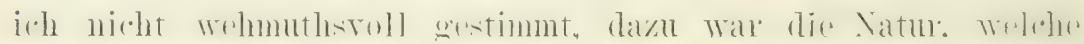

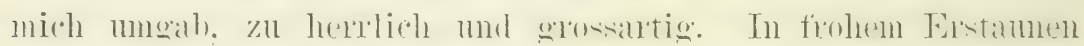
wendete sich der Blick anfwärts, nach den mächtigen Fels-

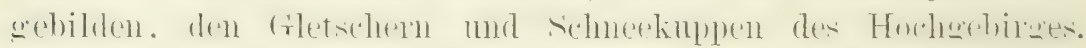

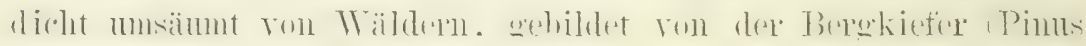
monticola).

Doch ich muss höher steig'en: Das zunächst zul er'eichende

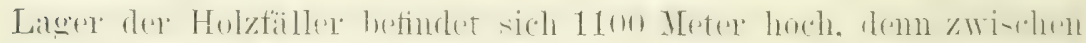

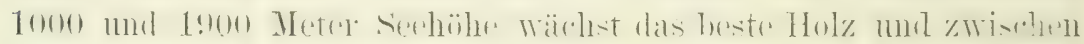

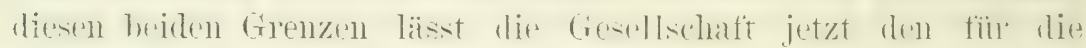

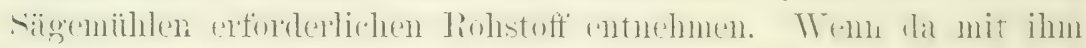
aufgeränmt ist, nun - damn geht sie tiefer und rielleicht auch

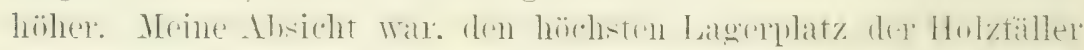

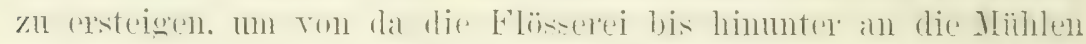

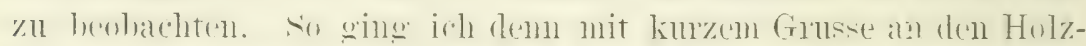

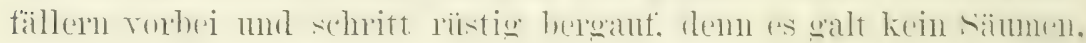

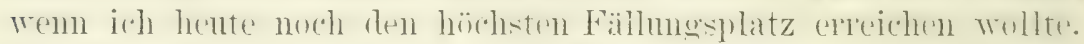

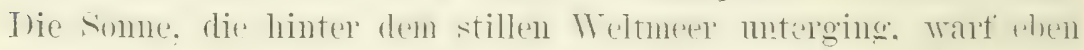

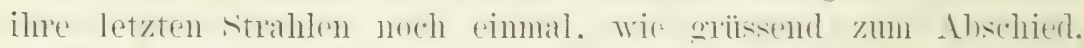

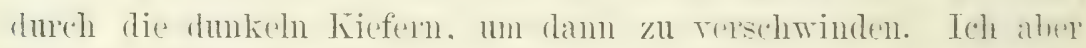
betrat ins Dïmmerlicht vine flache Lichtung. den Taigerpulatz der Holzfällex: die schon hesehättient waren. an hellthakremiten

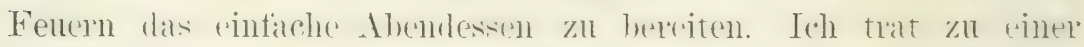
Gruphe: mol nin ihne Bekanntschatt zu mathen, liess ich die Mhi-ky-

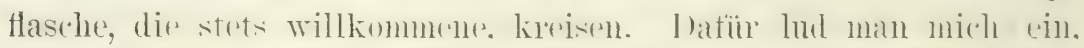

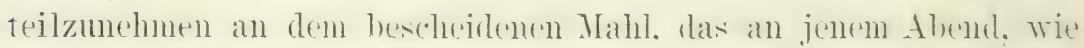

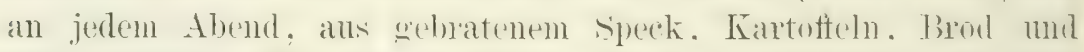
Thee bestand. Es Waren Mexikanel. d. h. Ahkïmmlinge iener

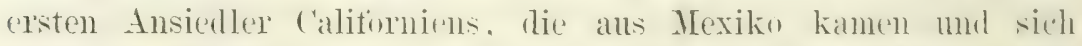
selten mit Germanen mul Romanen, desto häutiger mit Tndianten

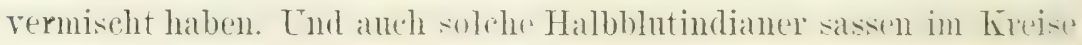




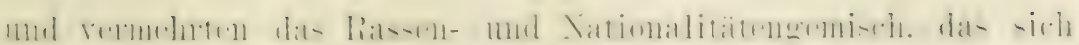

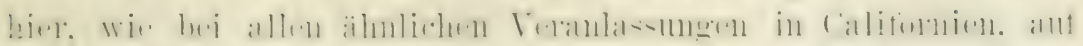
kleincm Ramme zusammendrïngt.

Zutällig war ich an's Lagerfener der Mexikaner geraten. dic wie ihre Alnen, die Spanier - .Castiliancr" nennen sie sich hente noch mit Torliebe. Wenn sic reinen Blutes sind - ausser-

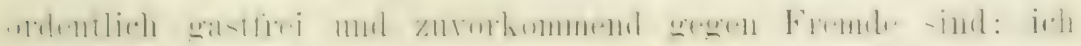

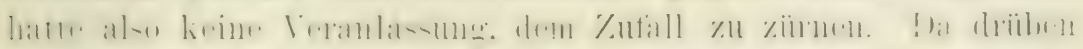

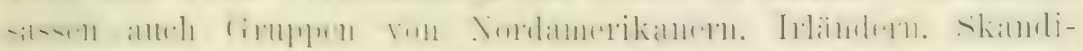

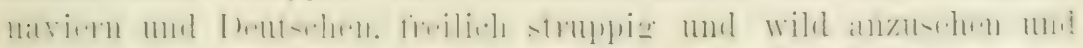

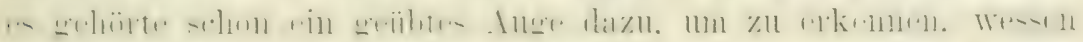

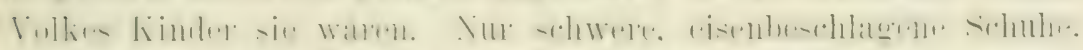

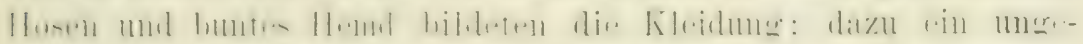

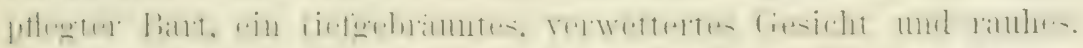

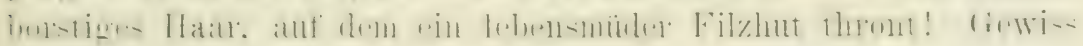
kein schmeichellattes Bild, aber es kann nicht anders sein.

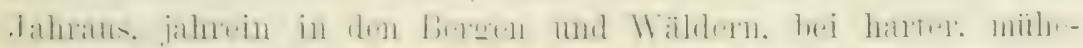

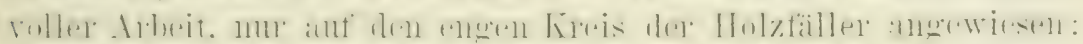

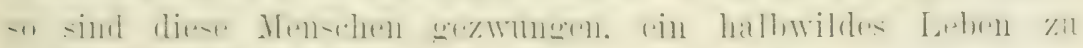

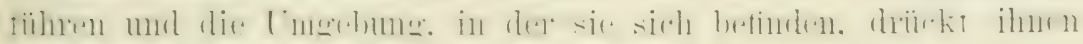
ilne (iepräge ant.

1)as Abendbrod wal verzelnt. die kurzen Pfeifen wuden an-

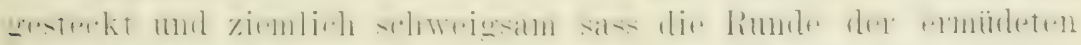
l.

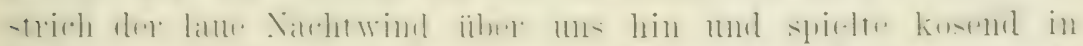

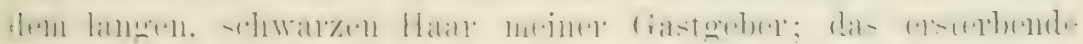

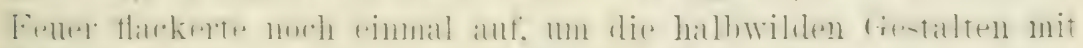

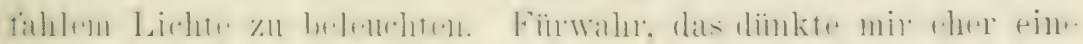

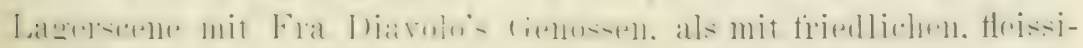
šen Holztailleru!

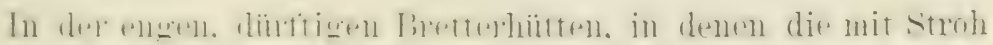

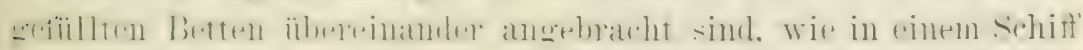

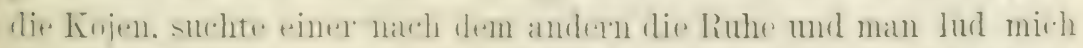

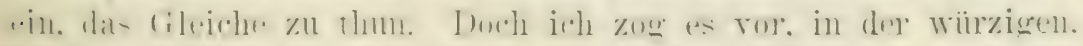

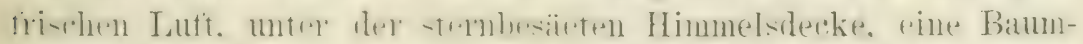

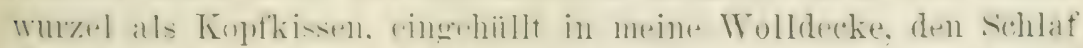

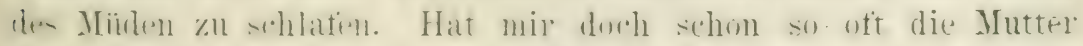

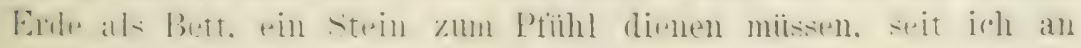
dieser Kiiste ein unstätes Leben führen musste. 
Die ersten Sonnenstrahlen trafen eben die höchsten Gipfel der Sievra nevada, als es rege turde im Lager. Man bereitete

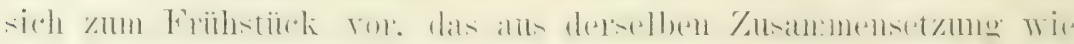

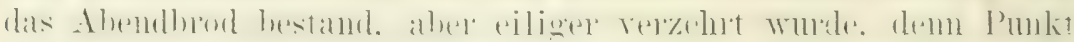

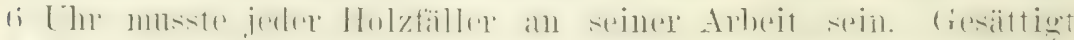

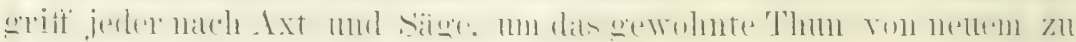

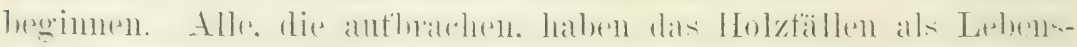
beruf erwählt, dem sie trotz seiner Gefährlichkeit, so treu an-

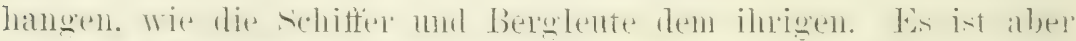

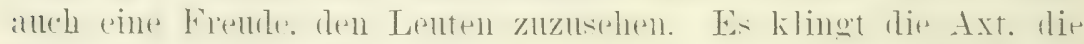

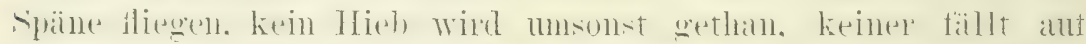

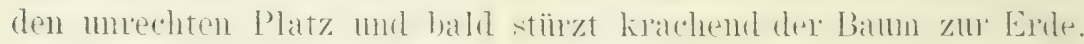

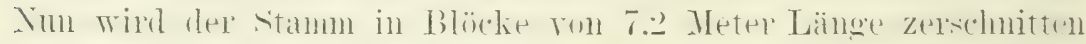
und, remn der Durchmesser über 1\%, Neter beträgt, auch gespalten. Die grosse Bammsäge - Specksäge ist in einigen

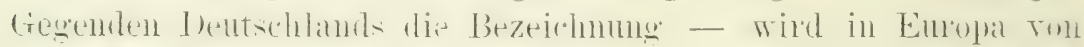

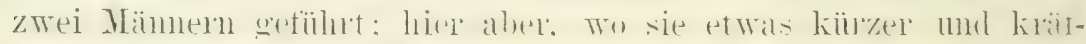

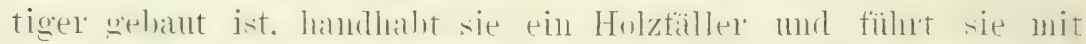

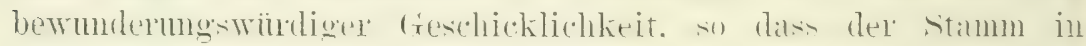
kurzer Frist zerlegt ist. Damit ist das Geschäft des Holz-

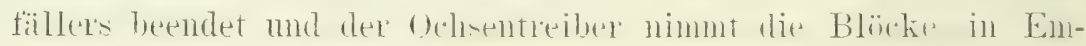
pfang, um sie fortzuschaffen.

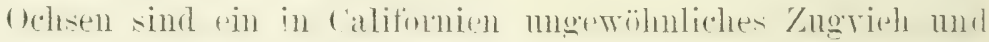
meines Wissens werden sie nur zu dem einen Zwecke in's Joch grespannt. grefälltes Holz in Gebilge zu transportieren. Langsim

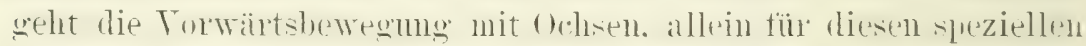
Dienst haben sie sich besser erprobt, wie Pferde mol Manltiere: sie wïrden sonst nicht ansmahmshos in allen siigenuïhlen benutzt werden.

Je nach der Beschaffenheit des Geländes erscheint der Uchsentreiber mit einem massir gebanten IVagen oder mit einer Anzahl hetten. in beiden Fällen bringt ex \& Juch odsen mit. Der Wagen wird selten gehratucht. mu dann. wenn ein Vaturwey nach dem Einschiffungsplatz vorhanden ist. Häufiger werden die Blöcke in der Anzahl ron 10 his 18 anemandergekettet, mit je einem Zwischenraum ron etwa 1/2 Meter. Jede der schweren Ketten wird mit den Endhaken tief in die beiden Blïcke ofeschlagen. welche sie verbibden soll. Tenn diese Torbereitung rollendet ist, spannt der Ochsentreiber seine Tiere ror, indem er. 
den Haken der lingen rangkette des hinterstun Joches in den

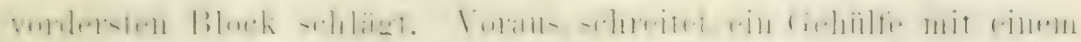
gefüllten IIassereinel: un die zu trockenen Werstellen zu be-

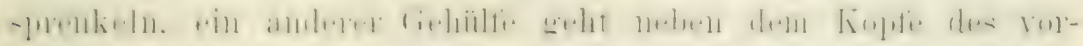

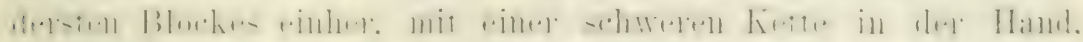
die er als Bremse vor den vordersten Block wirft. wenn er den

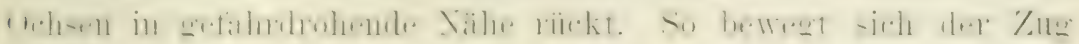

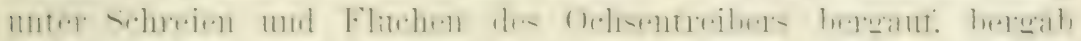

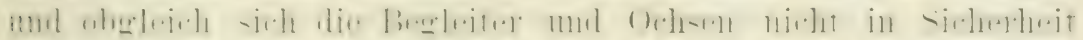

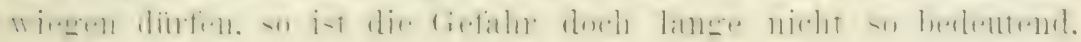
wie sie auf den ersten Blick erscheint. In der Länge des Zuges liegt die sicherheit. je länger desto sicherer. Denn es ist damit

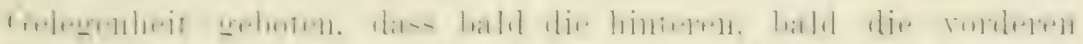

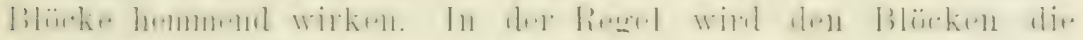
Rinde gelassen, damit sie bergal) nicht so rasch rutschen, ein

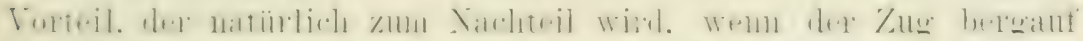

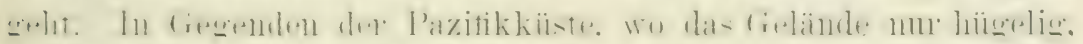

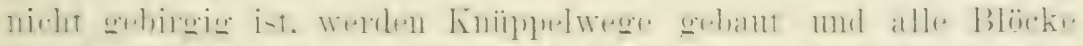

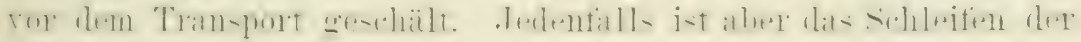

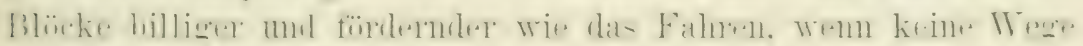
rorhanden sind unci häufig mu allein ausführljar.

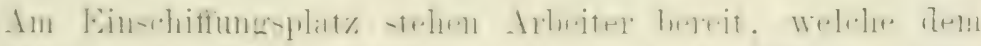

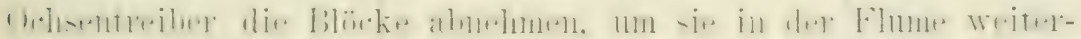

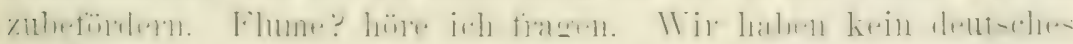

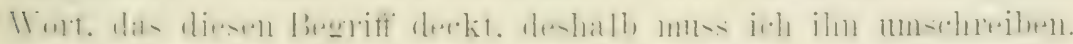

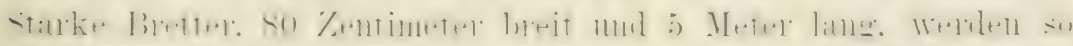

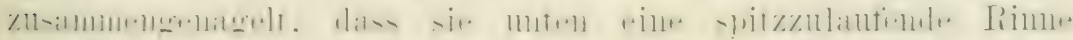

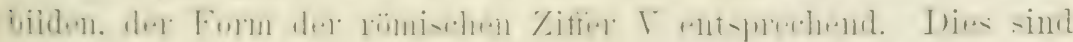

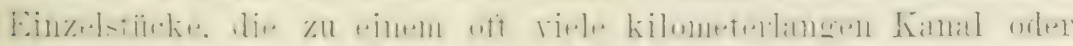

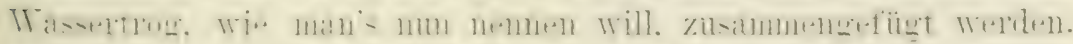

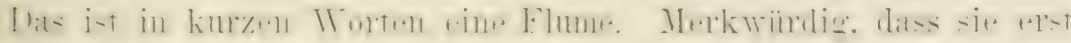
in der Venzeit erfunden wurde. Lange rorher versuchte man

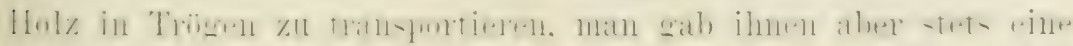

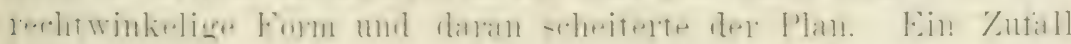

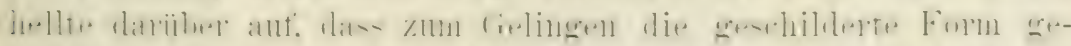

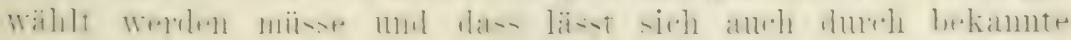

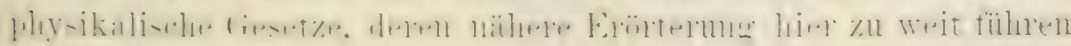
wiirde, begriinden. 


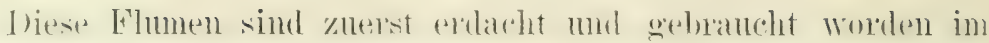

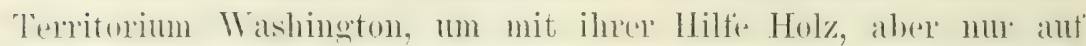

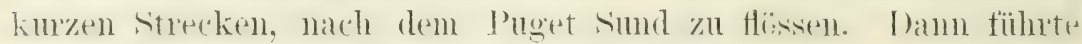
man die Ertindung an der östlichen Abdachung der sierra nevala ein, un dem täglich 1000 Klafter Holz verblatchenden Virginia ('ity, wo die weltberihhnte Comstockader answhentet wind, den Bedarf wenigstens eine Strecke weit zuzuführen. I as answedehnteste Flumentmetzaber besitzt dio Gesellschaft, welche ich oben name. Die Anlage einer Flume ist nicht so leicht, als man sich denken mag; sie fordent die ganze limst des Ingeniens heran. namentlich in einem zerrissen febirge und riele behamptem, eint Fisenbahn sei leichter zu planen und anszuführen, wie cine Flumenanlage. Zunächst muss das Augemmerk anf die nötige Wasserrelsorgmg gelenkt werden. die angefïht wird duch den Ban fines Sammelbeckens. Gleichzeitig wird mit der Jegung der Flume begonnen. Virgends, das ist selbstrestamdlich. darf sie scharf. Biegungen oder kure Windungen haben. An der eindn Stelle mus das Lagex tief' in den Felsen dingehanen, an der anderen Stelle muss die Anlage ïber sichluchten ron so his 7o Mreter Tiefe wegseteiihrt werken. In letzterem Falle muss win sehr kraitriges Holy-

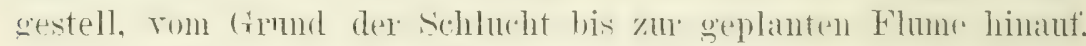
«bant nul mit eisernen stangen an den Felswinden betestigt

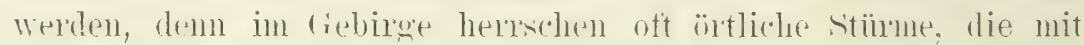

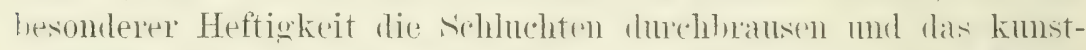

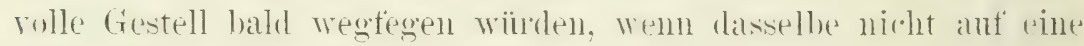

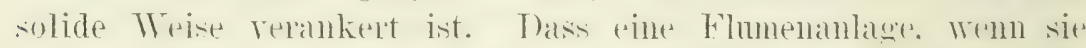

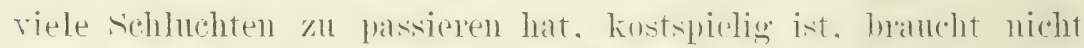

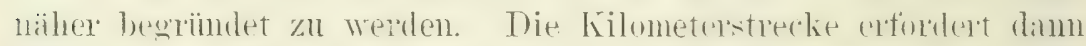

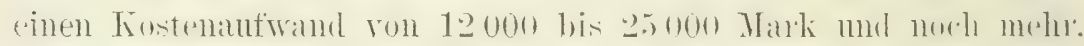

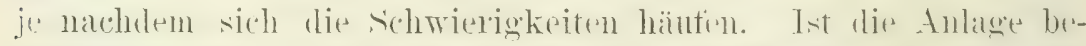

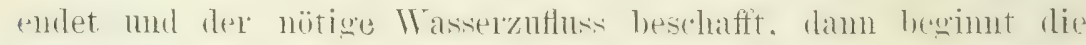

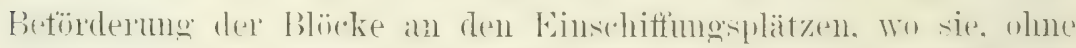

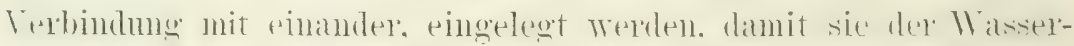

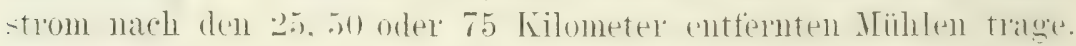

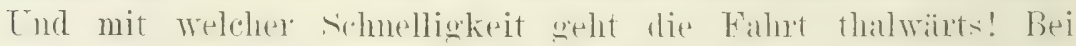
einem Fall von 1 zn 192 beträgt die Geschwindigkeit :3 bis

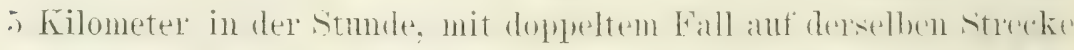
Terdreifacht sich die Schnelligkeit mol ein Fall rom lo his 12 zu 192 bringt das Holz 30 mud meln Gilometer in der stmule ror- 


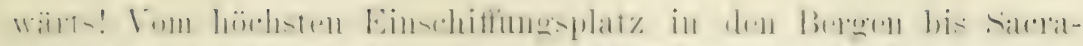

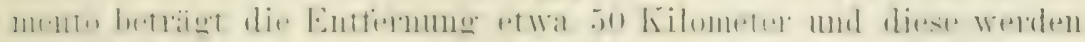

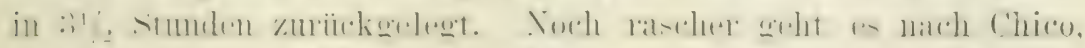

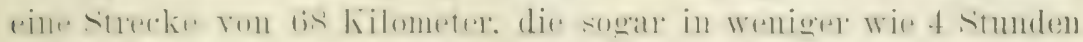

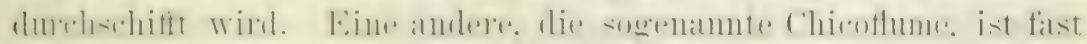

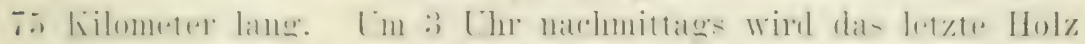

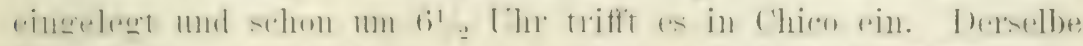

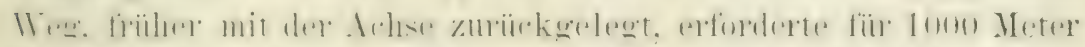

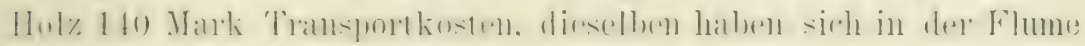
ant kaum 10 Mark rermindert.

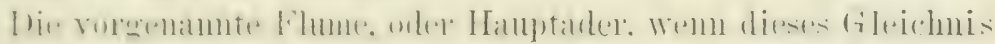

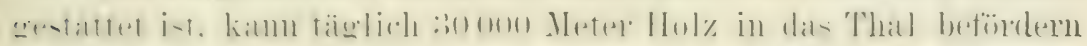

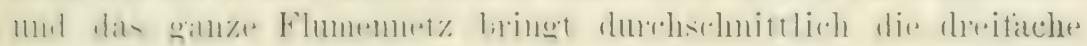
Jenge den 'Tag in die Sägemiihllen.

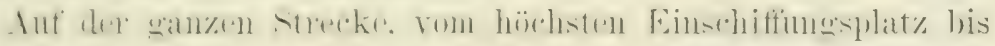

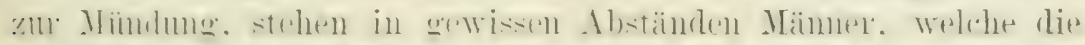

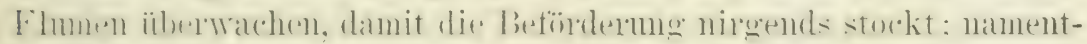

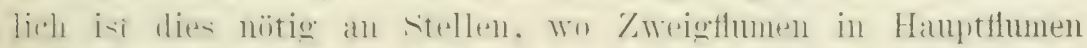

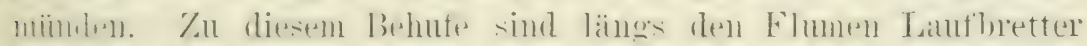

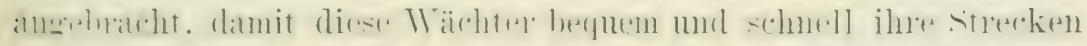

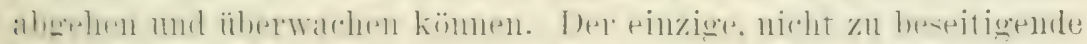

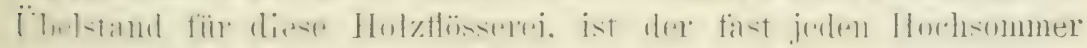

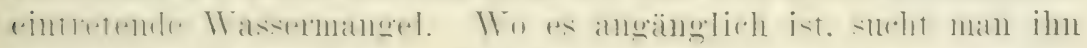

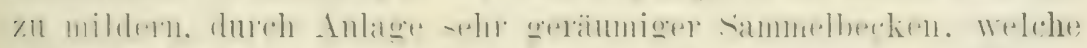

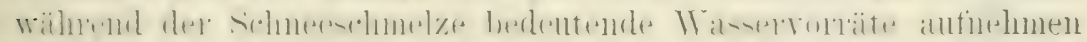

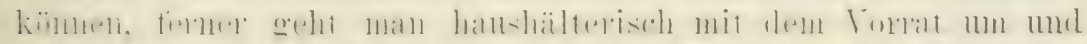

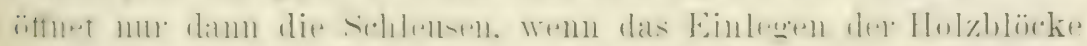

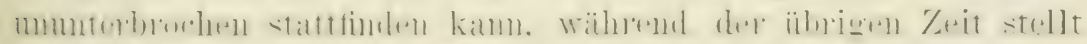

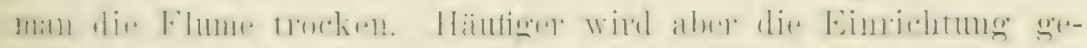

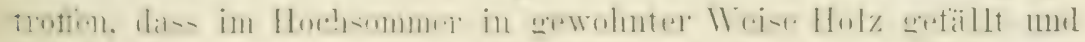

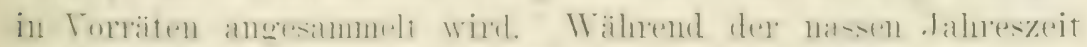

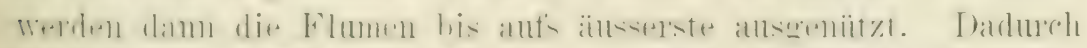

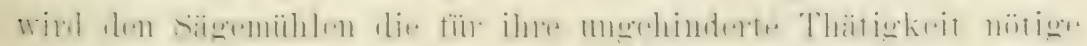
Rohstofimenge zugefuilurt.

So stieg ich denn wieder die Berge hinab, diesmal an der

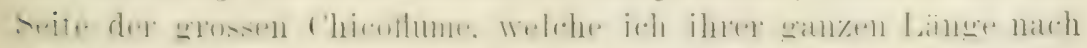

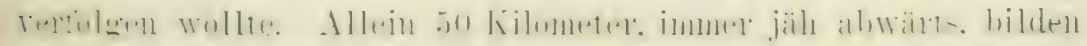

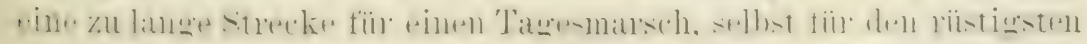

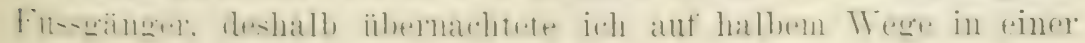




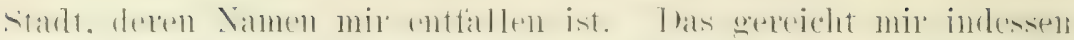

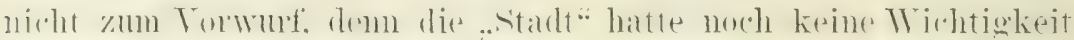

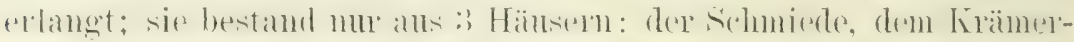

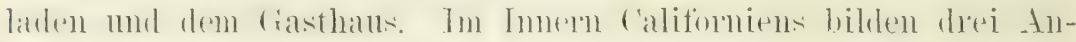

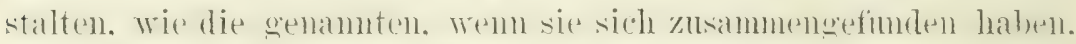

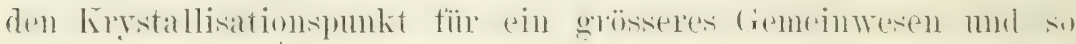

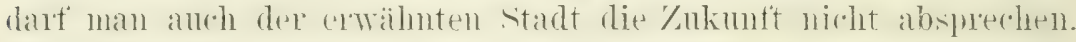

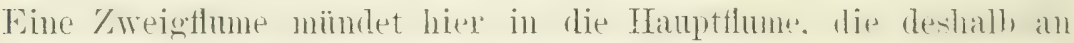

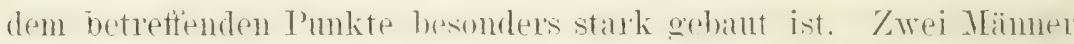
standen da mol hiolten die kommenden Bläcke in (Tronmg. damit ohne Stockmo einer nach dem andern die Reise fortsetzen komnte.

Das beobachtete ich, als ich am frühen MForgen die Weiter-

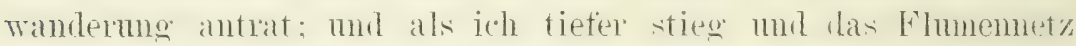
immer besser zu übersehen war, da überkam mich ein tief'er Respekt

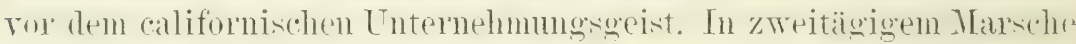
hatte ich on Kilometer alogegangen. Währeld das wante Flumennetz eine Gesantlänge ron fast 200 Kilometre hat und immes.

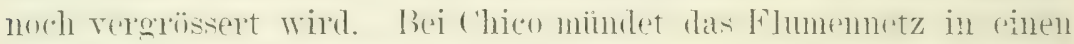

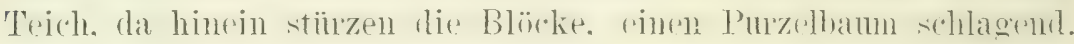

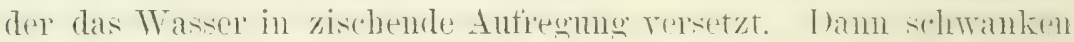

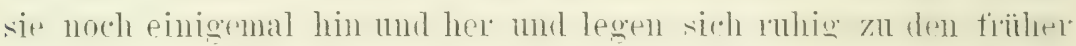

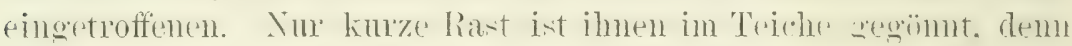

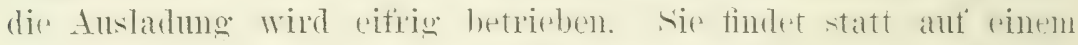
niedligen Rollwagen. dex auf rehiene+n läuft. the sich auf eintel

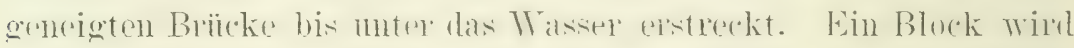

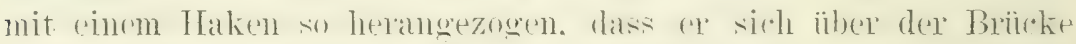

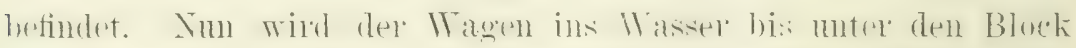

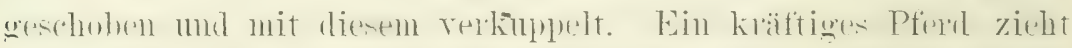

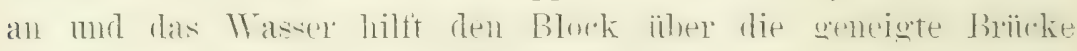
tragen.

In nächster Nähe ist der gewaltige Holzhof, dort kamn man

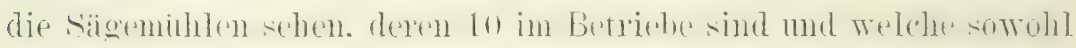

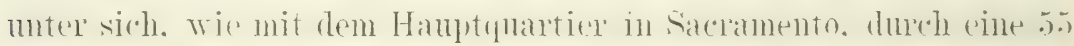

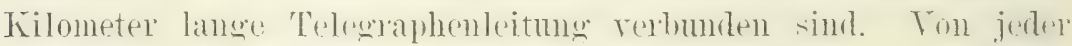

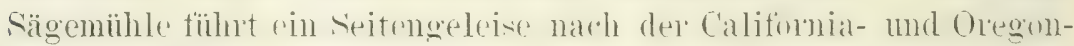

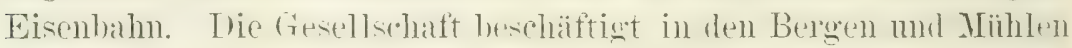

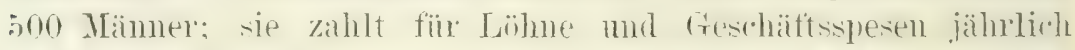
2 Millionen Mark: 500 ()chsen. 100 Pterde mol Manltiere. mit

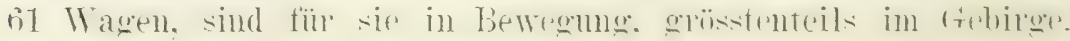




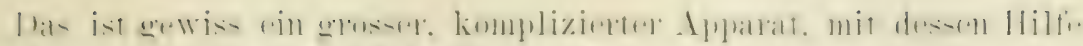

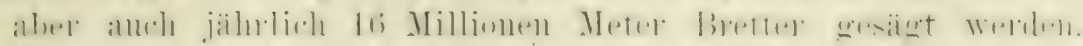

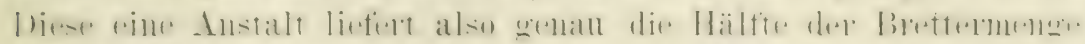
auf den Markt, wie der ganze holzreiche Stat Oregon.

In Californien hat sich die Holzindustrie in der Treise

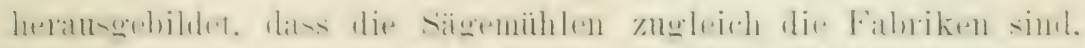

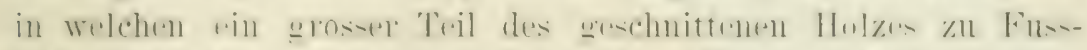

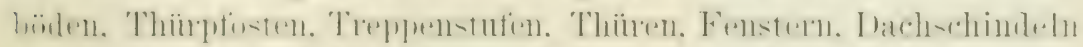

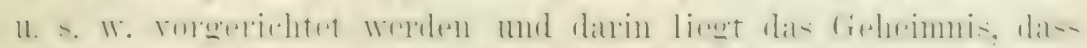

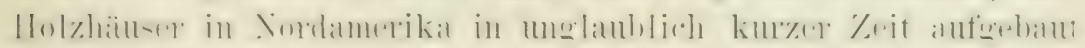

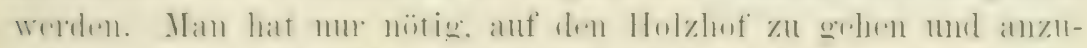

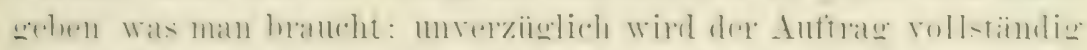
- die Fenster mit Glas, die 'Thüren mit Beschlag u. s. w. - ans-

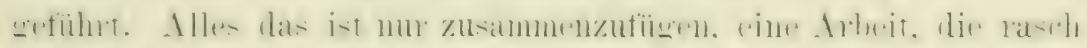

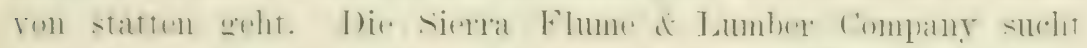

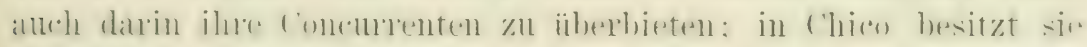

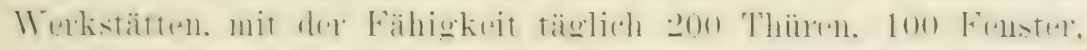

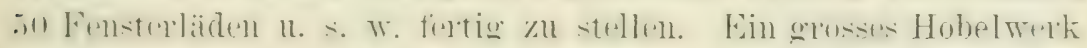

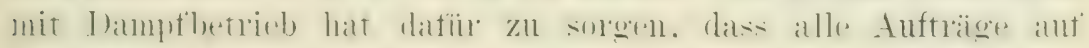

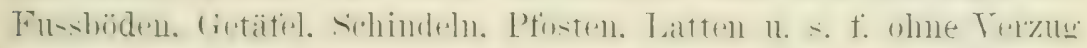
erledigt werden. 


\section{Zur Holzkunde.}

\section{Die Strulitur des Holzes.}

Das völlig trockene Holz besteht zu etwa $96 \%$ aus reiner

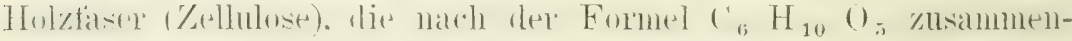

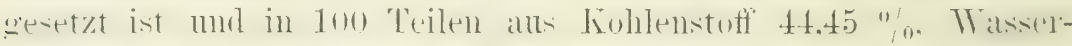
stoff $6,17 \%$ und Samerstoff $49,38 \%$ besteht.

In dem Holze eines Bammes ist bezïglich der Struktur

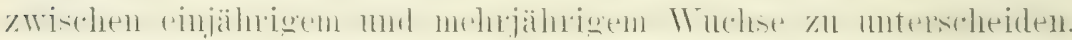

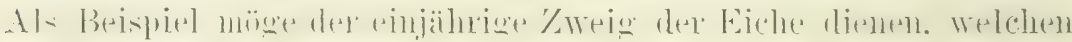
die Figur 46 im Querschnitt zeig't.

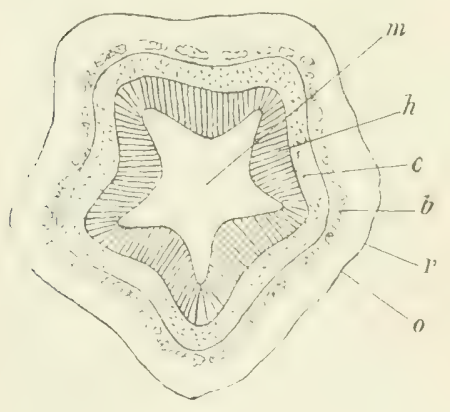

Figux fit.

Das Innere ist mit dem Mark $m$ ausgefiillt, einem ausserordentlich leichten Zellgervebe, welches stets in einem belaubten Zweige rorhanden ist und fiir seine Fortentwickelung ron wesentlicher Wichtigkeit zu sein scheint. Im Stamme verschwindet es fast oder ganz ohne Nachteil für den TIuchs des Baumes.

Die änsserste Zellenwand des Markes ist etwas härter wie das

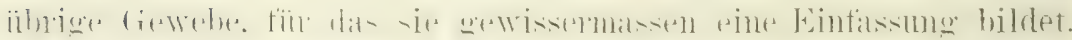

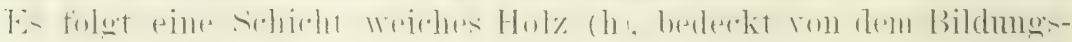
rine (c), aus dem nach imnen ein Holzring, nach aussen ein Bastring sich bilden. Der letztere ist durch b bezeichnet, ihn um-

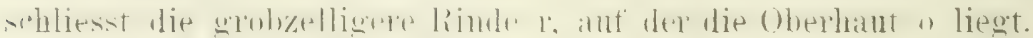


Der mehrjilnige 1 'uchs ist in der Figur 47 und zwar in

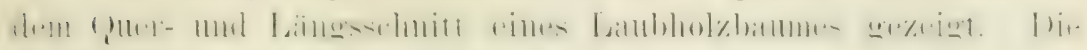
Markstrahlen oder Spiegelfasern d lauten strahlenartig von der Markyinhe $c$ ans bis zur Rincle a. velbinden also die Mankröhre mit dre Rinde. Sie durchkrenzen ant dem (Querschnitte die Jahresringe f' miter rechtem IIinkel mo bilden aut diese Weise riereckige Felder. Die ă Schichten des Kernholzes a mol die 5 schichten des splintes b lassen anf ein zehn-

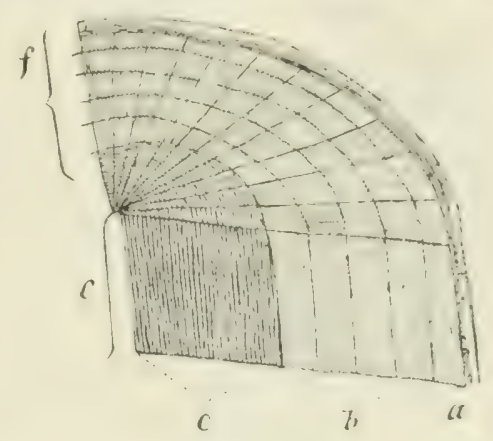

Fignil 47. jilluriges Alter dieses Stammes schliessen.

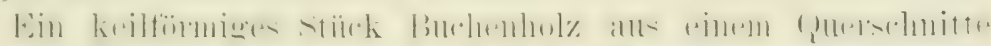

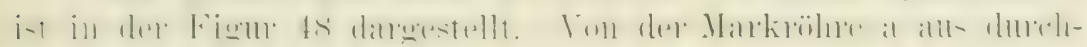
schneiden die Narkstrahlen die Jahresringe, wolurch sie viereckige Felder anf dem (Guerschnitte bilden. Mit b sind die Flächen der Markstrahlen bezeichmet, welche auf der oberen (querschnittlläche ilme Decke zeigen mond an der Anssenseite d. wo die Rinde abwelöt ist, ihro elliptischen Endigungen. Bei c liegen die Grenzen der J Jahrestinge. ant deren Querschnitte durch runde Löcher rie durchschnittenen Getässbiundel angedentet.

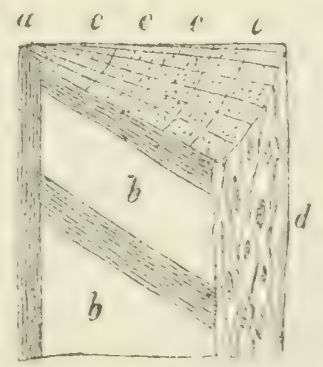

Figur 1s.

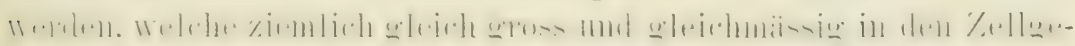

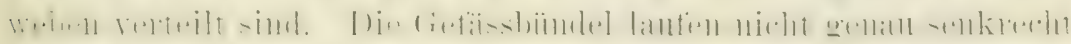

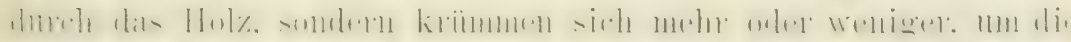
rom a zu d lautenden Markstrahlen durchzulasson. Die letzteren

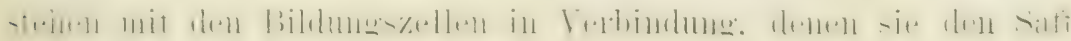
zur Weiterbilaumg zufïhren.

Das Mark, ans weiten, in längliche Reihen geordneten

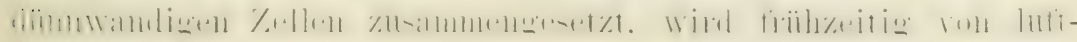

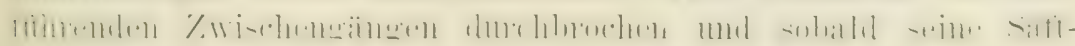
tiihlume anthört. fïllt es sich elsentalis mit Luft.

bils Holz wächst durch die 'Thätigkeit des Bildungsringes

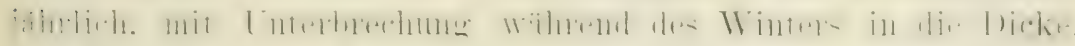
The Zuwaths jeden .Tahnes. Holz- oder Tahresting genannt. zeigt 


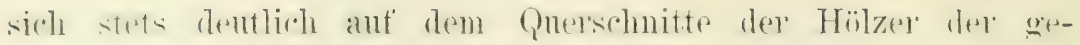
mäsigten und kalten Zone. nicht aber dex tropischen Zome. Hiex ist are cutweder vollständig unsichtbax oder zeigt nur sellwer zu unterscheidende Grenzen und kam keinesfalls zul Bestimmmog de Alters des Baumes dienen.

In den Hölzern aller \%onen unterscheidet sich der sulint oder das sattholz, als äusserer, lebensthätiger Teil. von dem Herzoder Kernholz, das rom ersterem durch hellere onler dunklere Farhe und innere Beschaffenheit (grössere Härte, höheres ( iewicht n. s. Ir) gleicham alogesondert ist. Bei einigen Bamalten ist ummittelhar nach der Fällumg kein angenscheinlicher Lntrschied zwischen Kernholz mo splint zu bemerken, die Luft erzengt jedoch bald einen Farbenalsticl. Bei älteren Bäumen weicher Holzarten ist das Kermholz häutig ganz oder teilweise rerwest, der Stamm wirl hohl, wächst abel weiter und kann noch lange leben. Das Tryhältnis zwischen Kernholz mo splint schwankt stark in den rer'schiedenen Arten, als Regel aber gilt. dass die jungen Bämme einer bestimmten Art rerhältnismässig mehr splint besitzen wie dir alten. Gewöhnlich ist der splint mintaglich zu Werk- und Batmholz, einige Arten bilden aber eine Ausnahme.

Dir Terrandlumg des Splints in Kernholz nimmt je nach oler Natur der Bamart und des Klimas 1 bis 20 . Jahre in Anspruth und selhst eine noch längere Zeit, wie bei einigen Eichenarten. Gewöhnlich erfolgt sie in gleichmässigem, ringfömigem Fortschreiten nach answirts, zuweilen macht sie aber auf del einen Seite de stammes grössere Fortschritte wie anf dor anderen. verursacht durch eine stärkere Einwirkung von Licht and Luft.

Die Markistrahlen bestehen ans verdichtetem Zellgewene mil obgleich sie meistens von der Markröhre hi: zum Bildungsinn laufen, so gibt es doch manehe. die als Vebemmarkstrahlen zu butrachten sind. sie stehen weder in Terbindmo mit der Markrïhre nuch mit den Hauptmarkstrahlen.

In den Nadelhölzern werden die Markstrahlen zu so feinen Linien zusammengedraingt. dass sie mit dem unberwaffneten Auge? nicht erkennbar sind.

Die Holzzellen siml nie anf den Tänden so rerdickt. dis.sich nicht im Imnern eine Höhlmng wahrnehmen liesse. je dick'r ihre Wände sind nnd je meln Zellen in einem lestimmten Raume sich gehänt haben. desto dirhter und schwerer ist das Holz. Larin 


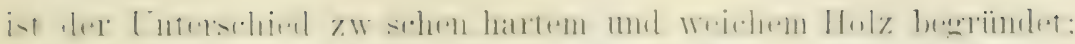

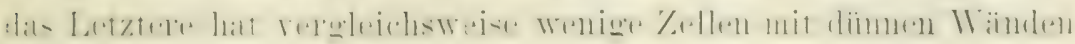
anf einem bestimmten Raume.

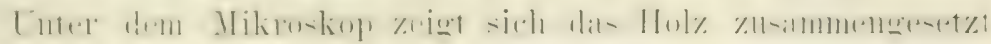

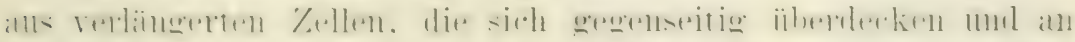

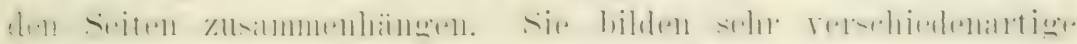

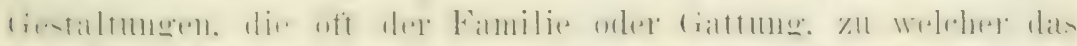

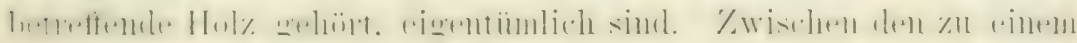

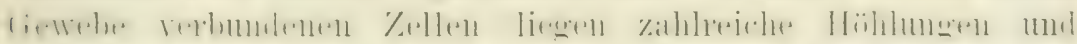

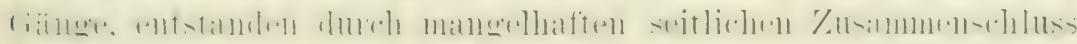
der Zellen. welche teils Lutt, teils Saft, Harz oder andere Ab-

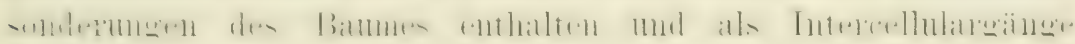
hereichnet werden.

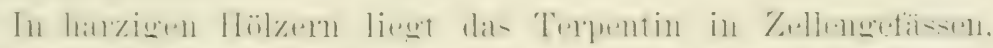

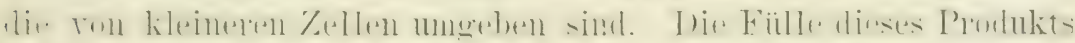

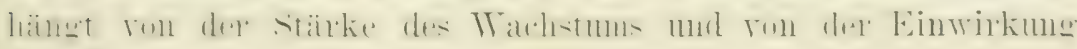
fles Lichts und (ler Luft ah).

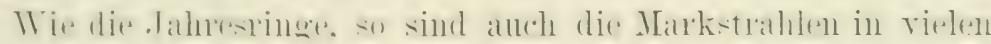

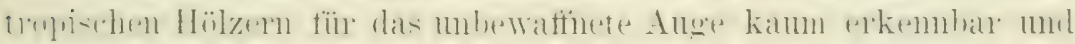

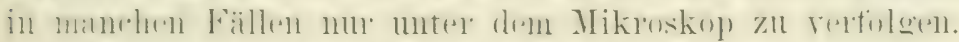

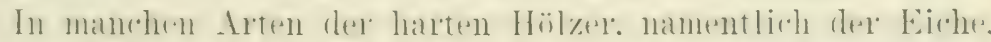

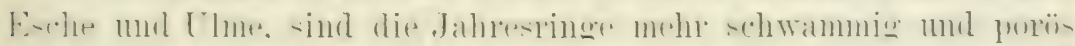

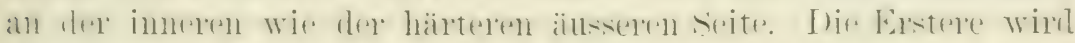

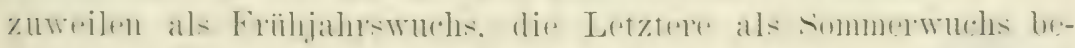

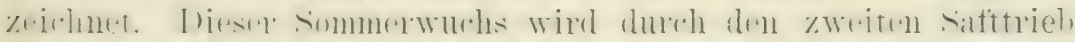

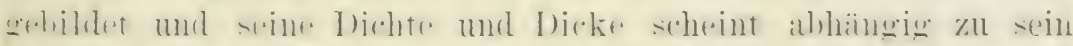

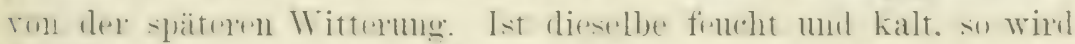

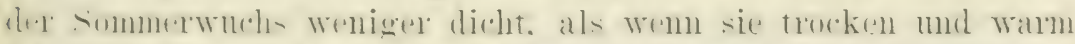

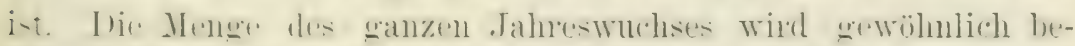
stimmt dureh die llittermeg im Fribjiah und Frïhsommer. und motex den Tropen durch dir. Witterung während der Reorenzeit.

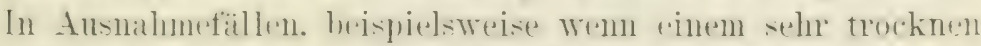

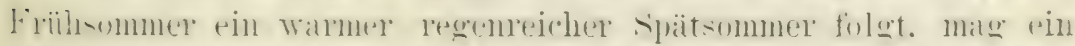
zWriter dahresw

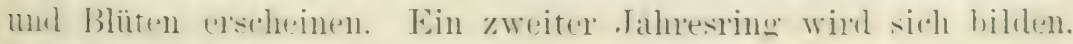

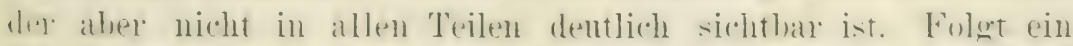
kilter Winter, dann schwehen die Bïmne in liefahr schwer geshaidigt zu werden. In der halbtropischen Zone i-t es aibrigens moth lieger wie Ansnahme. dass der Jahneswohs gewöhnlich aus 


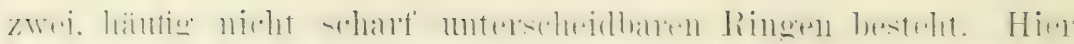

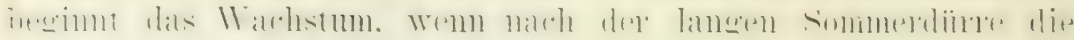

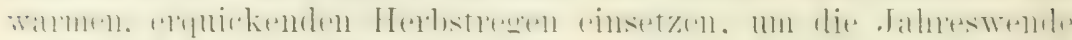
wird es anf kuze Zeit durch die kalte Witterung, die oft Eis

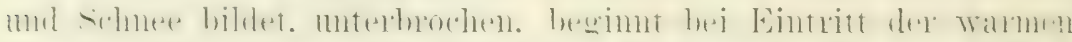

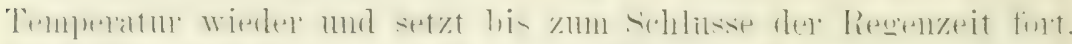

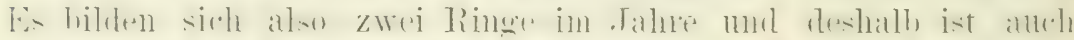

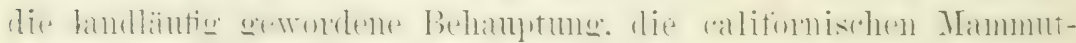
bäume seieni 4000 Jahre alt. Treil man 4000 Ringe auf einem

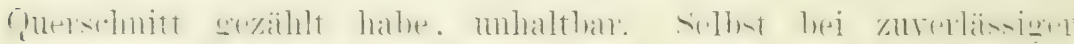

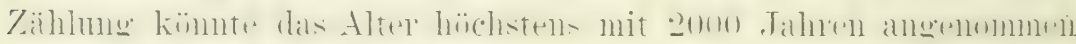

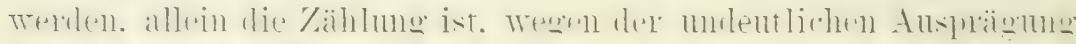

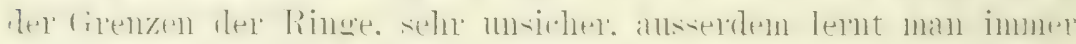

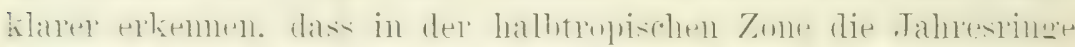

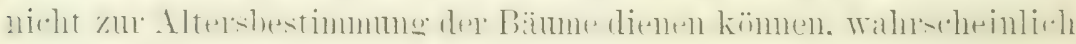
ans einem Zusammenwirken verschiedener Ursachen.

In solchen Höizern, welche deutlich unterscheidbare Jahres-

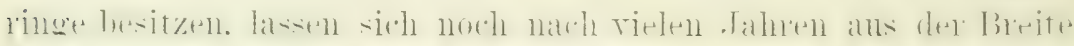

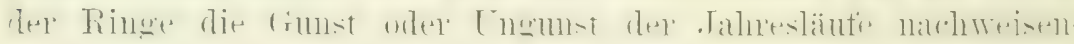
Beispielsweise mag jeder 3. oder 4. Ring sehr schmal sein. Er

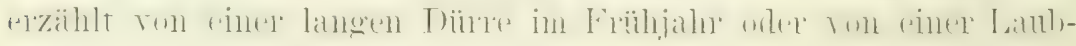
verheerung durch Raupen.

Als Regel sind die Jahre für das Wachstum des Holzes am

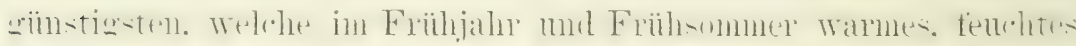

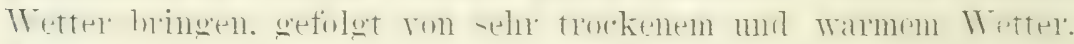

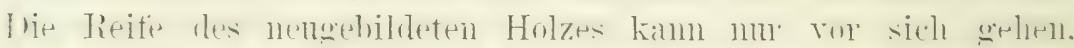

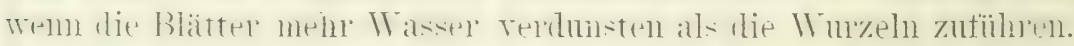

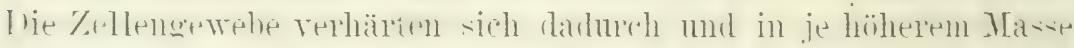

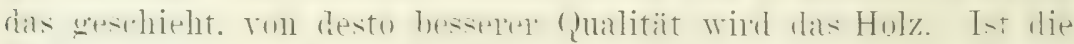

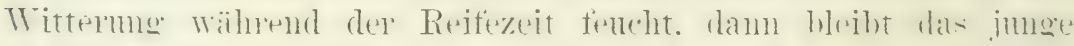
Holz weich und füllt dem Frost leicht zum Opfer.

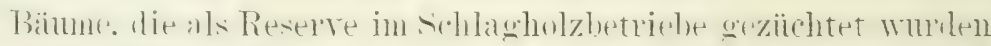
und während ihrel Entwickelung abwechselme fired standen und von anderen Bämun heschattet womlen. liefer'n härteres Holz. wie solche. dir munterbrohen in dichtem Bestande wodhsen. allein es ist in Folge rom zahloeicheren Ästen knotiger mold da diese Bämm

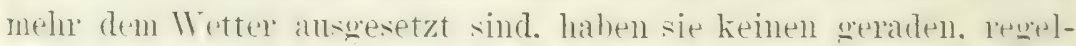
mässigen stamm, wachsen auch nicht so lorch. Wie Bämus in

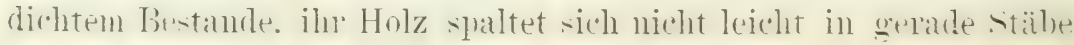




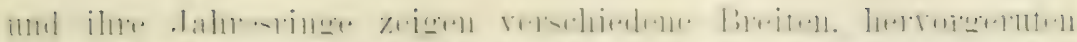

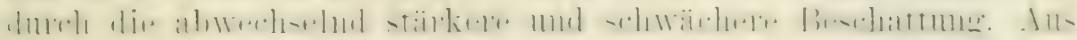
einem Querschnitte dieses Holzes kimm daher nicht ant den Cllarakter der .Taluesläute geschlossen werden.

Auch in der Rinde bilden sich filnestinge und in manchen Fiblen kïmen sie noch nach mehreven obluen dentlich nuter-

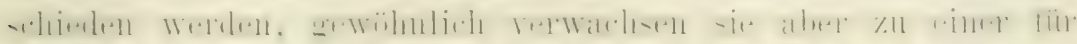

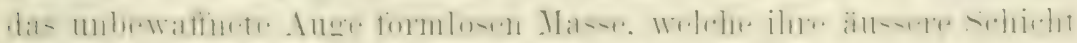

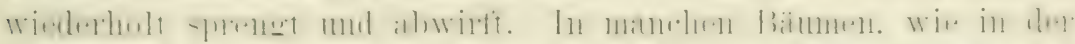

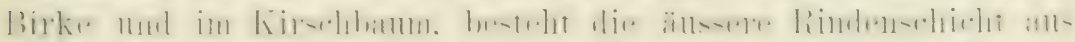

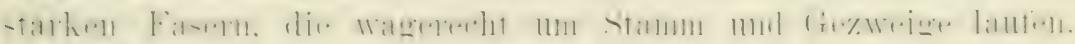

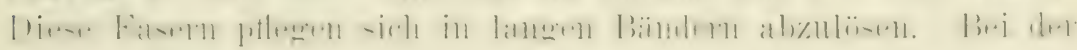
Platanc tïllt die änssere Śchicht in harten. grossen Stücken al) mud latsst eine frische ohentlibche. die zuerst meiss ist und damn

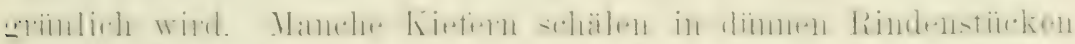

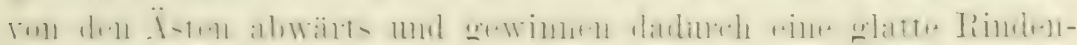
nberfläche.

Wemn die Rinde und das Holz eines Bammes relmumdet wird:

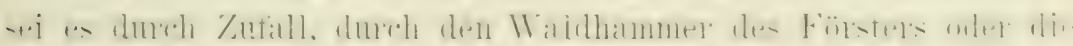

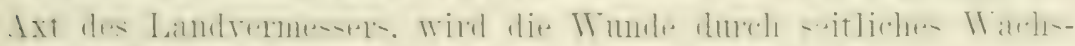

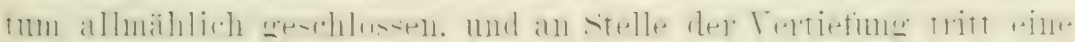

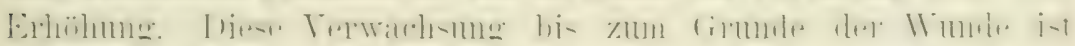

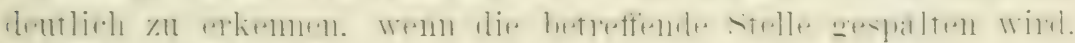

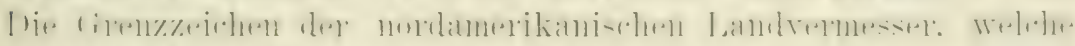

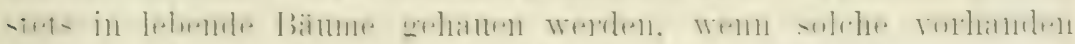

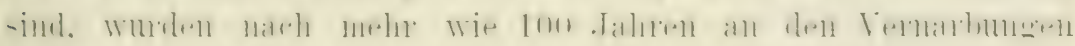
entdeckt.

Die Jahresringe legen sich mit grüsseler oder geringerel

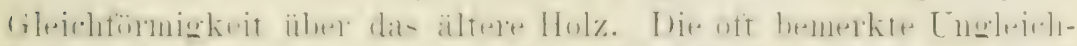

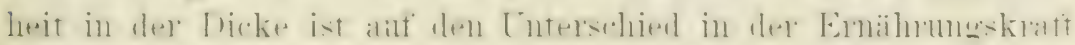

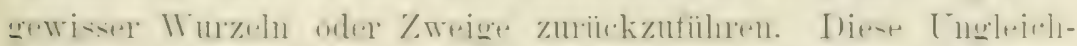

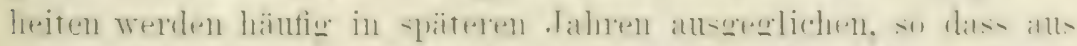

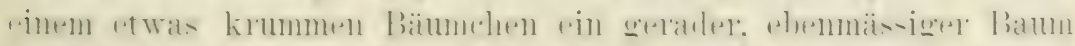

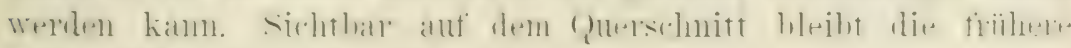
Unregelmässigkeit aber dauelnd.

Ein schiefer Banm hat seine Markiölue etwas von dem

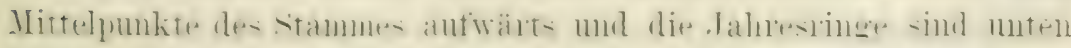

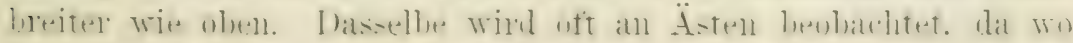




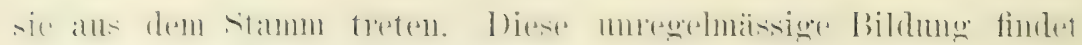
sich häntig in tropischen Hölzern.

In manchen Nadelhölzer'n, namentlich in den Kiefer'n und

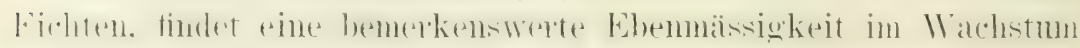

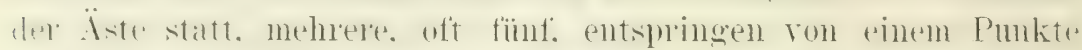

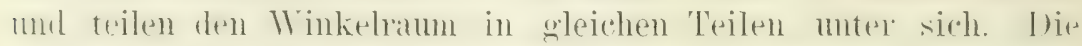

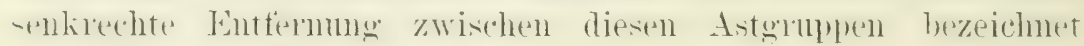

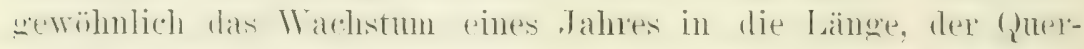

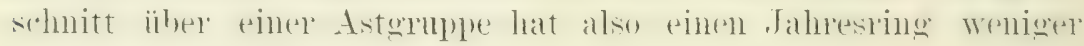
wie der: untere Querschnitt.

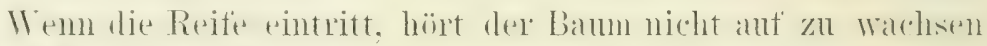

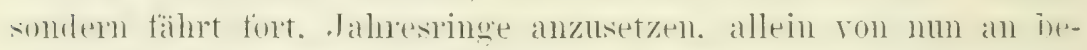

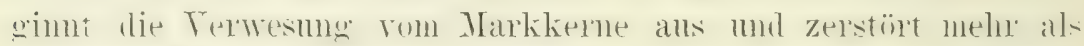
der nelle /uwachs beträgt. Daher die forstlole Regel, die Bäume zur \%eit der Reife, als im lö̈clsten Terte stelenul, zul fälen.

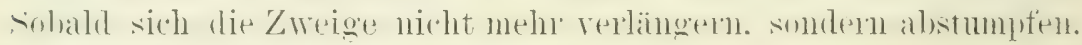
hat der Banm seine Reife ïberschritten.

Es ist bis in die neueste Zeit eine viel motrittene Frage

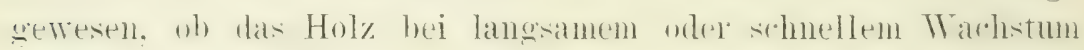
stärker und dauelhafter wiirde. Kein Zweifel kann obwalten.

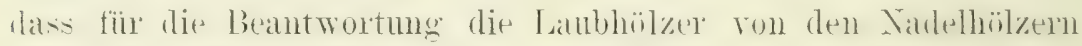

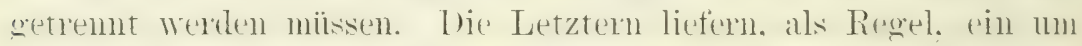

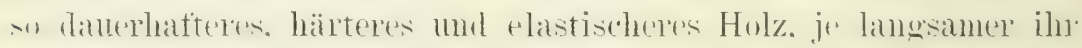

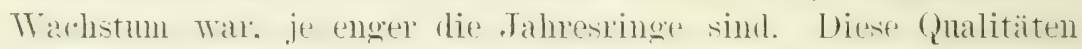

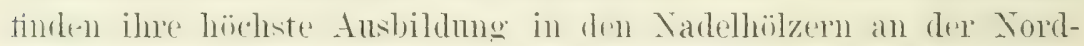

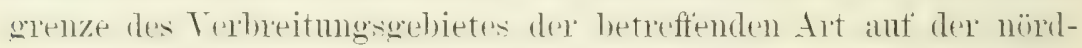
livluen Erelhältte und an der südgremze ant der siidlichen Frodhältte. Als Beispiele mögen dienen das Kiofernholz der russischen ()-Aeenovinzen. Fimmlands Fdeltannenholz, das sibirische Tärohen-

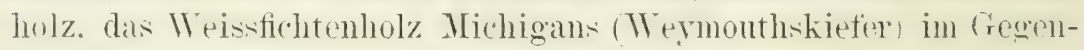
satz zu demjenigen Pennsylvaniens.

Bei vielen Laublëblzen ist das Gegenteil der Fall, doch muss rabei in Frimnerumeg gehalten werden, dass das durch einen ansnahmstreisen fetten und teuchten Boden bei sehr weschitzter Lago beschlemigte Wachstum eine reiche, poüse Holztextur bewirkt. weil die oben elklärte Holzreif nicht in ansegiebigen Masse stattfindet.

Bagneris, der sich eingehend mit bezïglichen Lntersuchungen beschätigte, bemerkt in Bezug auf die Holzbildung: dass in den 


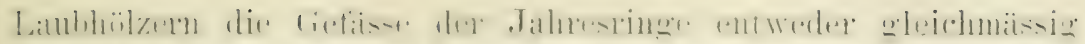

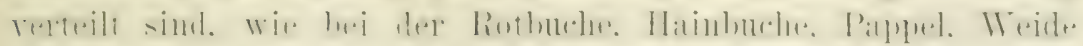

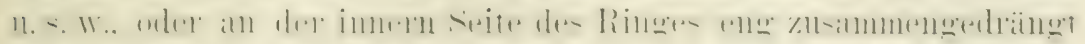

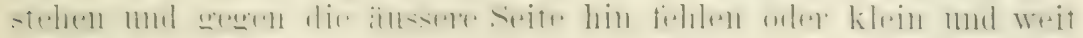

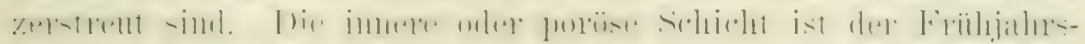

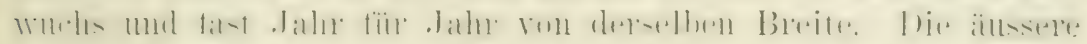

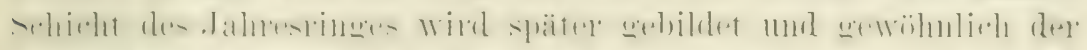
-

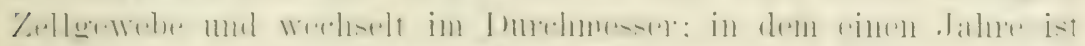

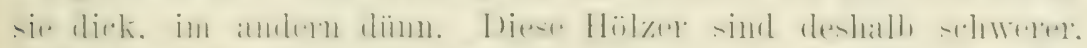

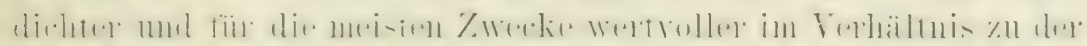

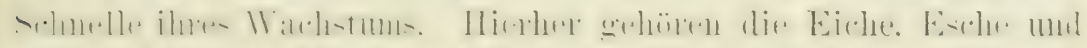

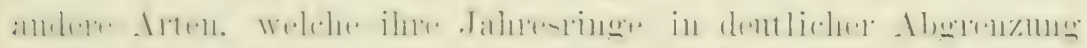
zeigen. Das Kernhol\% ist gewöhnlich anders gefärbt wie der

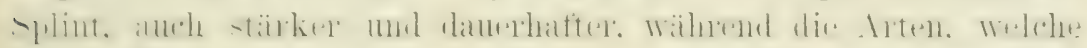

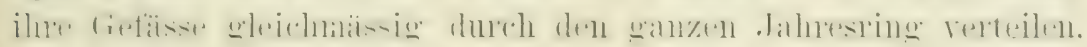

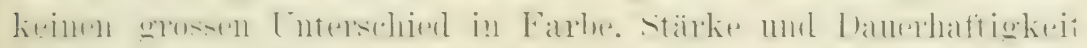

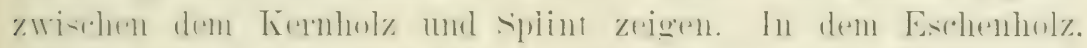

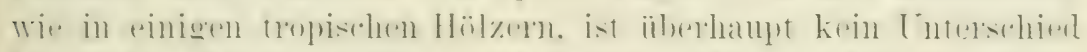

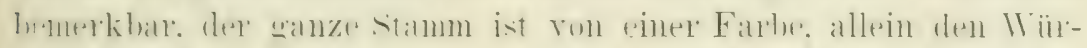

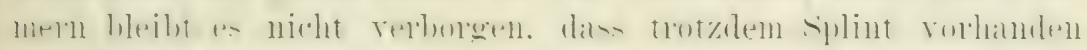

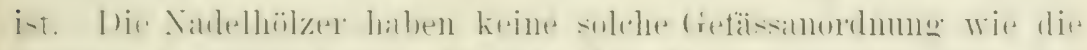

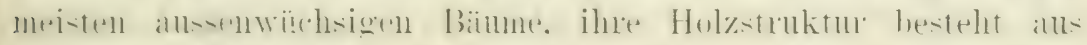

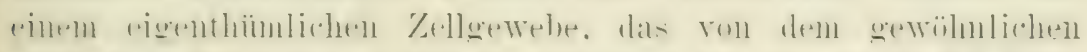

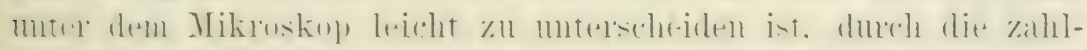

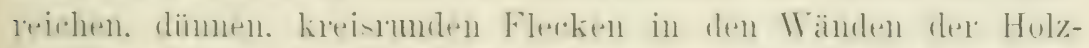

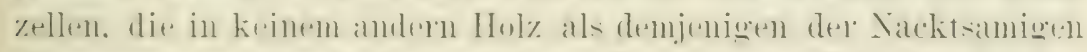

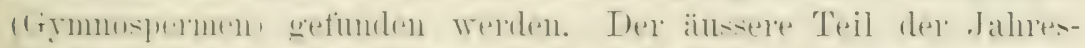

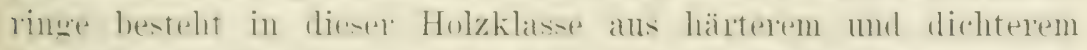

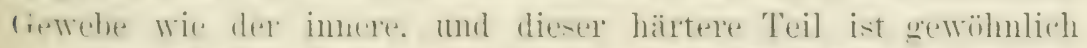

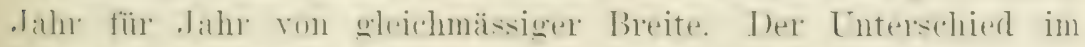

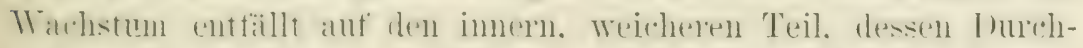

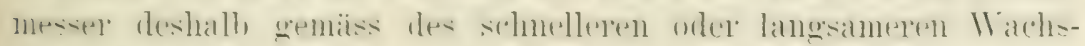

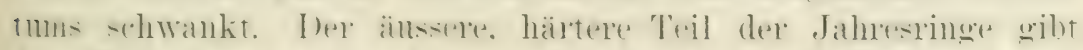

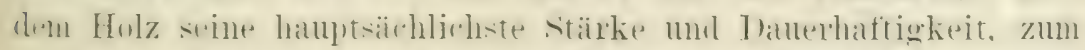

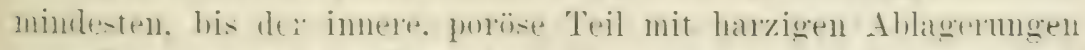

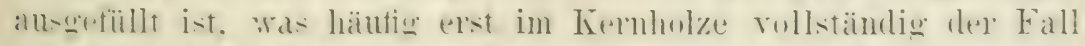

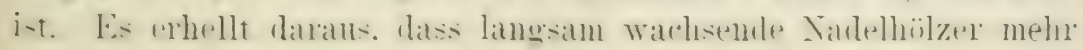




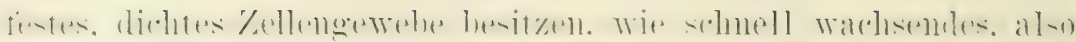
tein fïr die meisten Zwecke wertwolleres Holz liefern.

Professor Sargent, der die Kensusarbeiten ïber die nord-

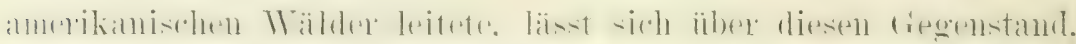

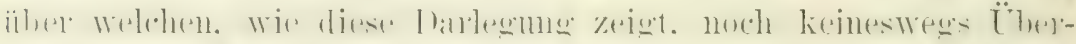

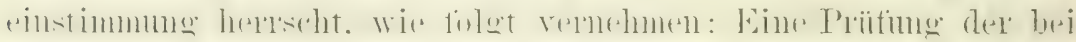

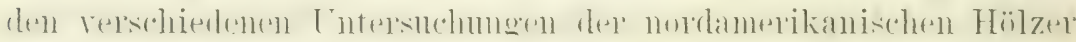

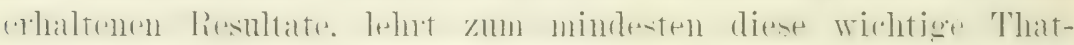

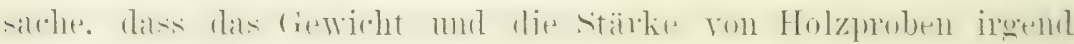
einer Art abhängig sind ron dem Rammanteil in den Jahres-

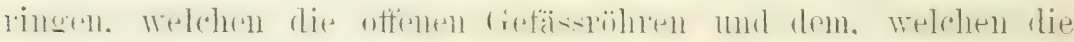

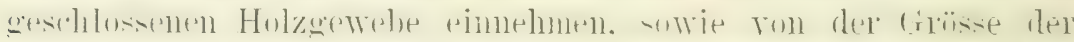

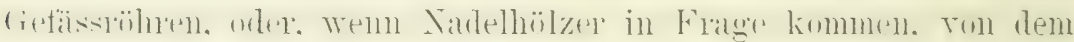

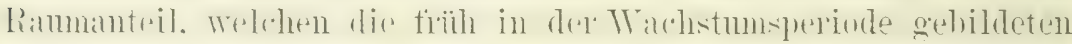

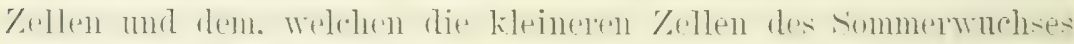

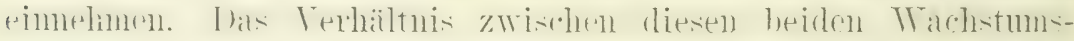

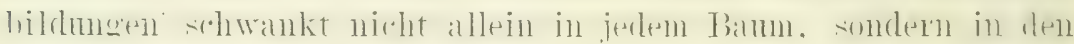

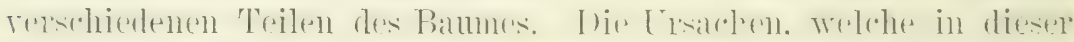

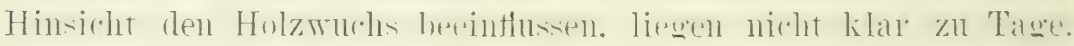

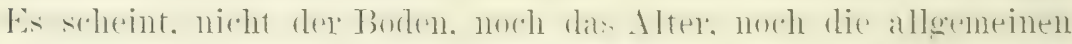

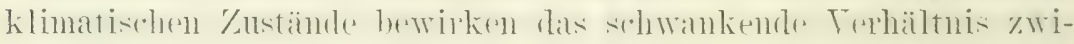

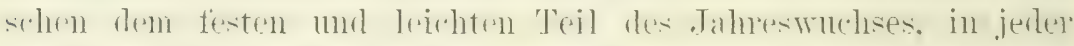
Art. denn in dem einzelnem banme schwankt dieses Terhälnis ron Jahr zu Jahr und zwar sehr unregelmässig: Nicht, wiè ge-

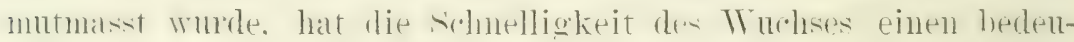

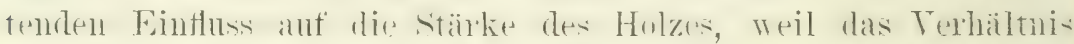

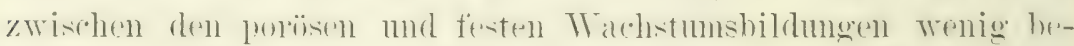

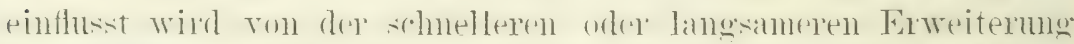
des lourhneseres der Bäune. Tn wie weit die jührlishen klima-

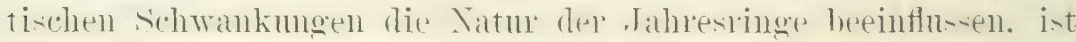
nir.ht nachgewiesen worden. doch ist es nirht mumöglieh. dass in

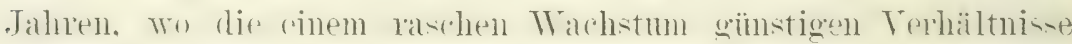
his spät in dor Wachstmmsperiode bestehen bleiben. die porïss.

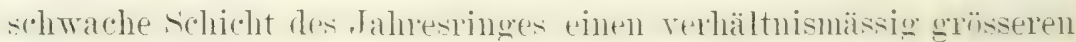
Ranm einnimmt. Wir in einem Jahr. Wo die dem raschen Trachstmm giinstige Zeit kuirzer ist.

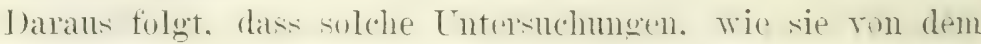
Zensubeanten ansgetuilnt wurlen. nothwendig sind. den rerhältnismäsigen wie Hüchstwert jeder Alt testzustellen; nachlem das gre- 


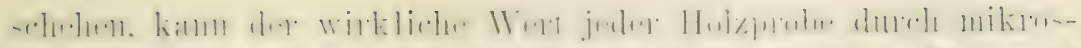

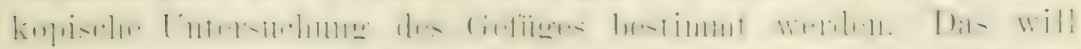
sagen: 2 Proben des Holzes cinel Art. welche von dem Zensus-

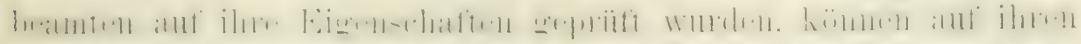

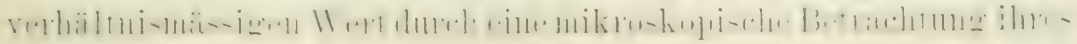
Gefüges ebenso gut oder bussex untersucht werlen. wie lurch rine muständliche Prifung:

Die Maser'n oder Figmen des Holzes werden meln von di+lo

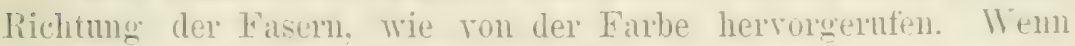

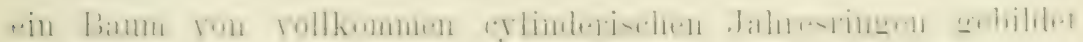

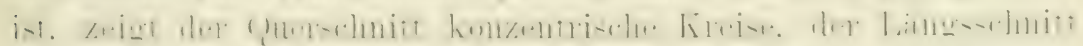

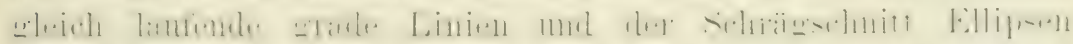

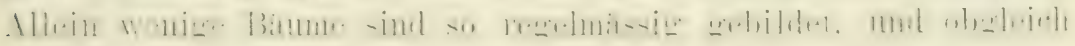

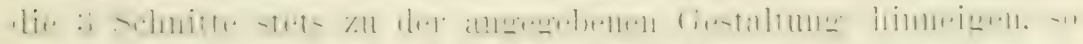

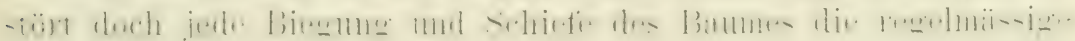
Anordnung der Fasern und hilft die Masern rermehren. Ein senkrechter Schnitt durch den Kel'u des Baumes zeigrt die ver-

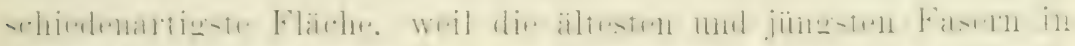

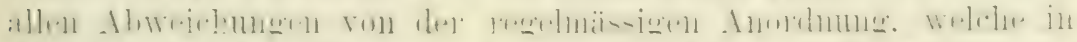

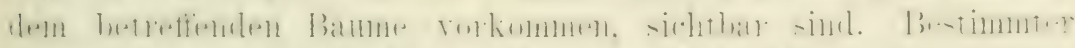

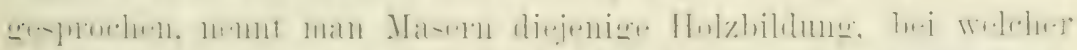

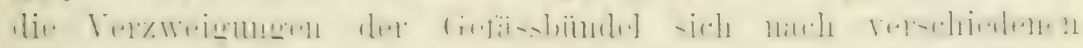

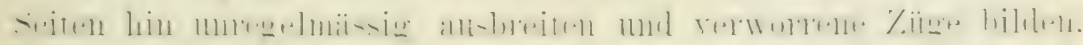

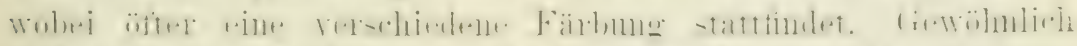

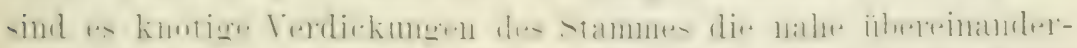

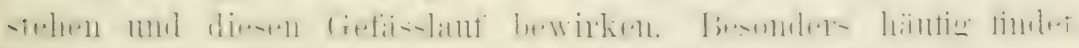

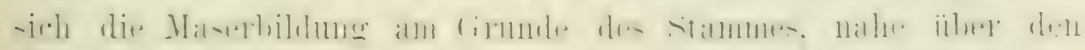
Murzeln: Durch öfteres Auslichten der Aeste kann die Maserbildung befürdert werden.

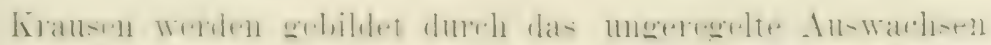

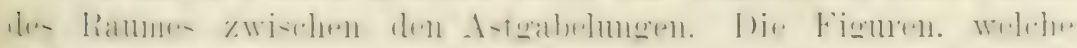

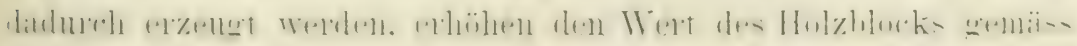
der '/ahl ilner Kransen.

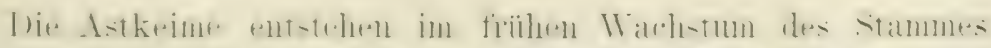

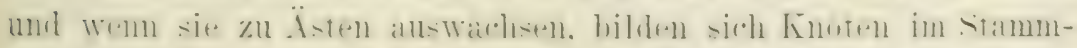

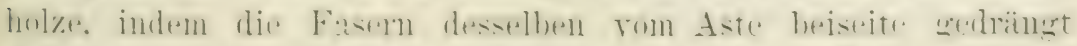

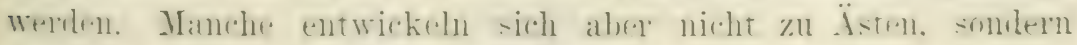
werden von späteren Jahresringen überdeckt. 
Solche ïberwachsenen Astkeime finden sich znweilen in

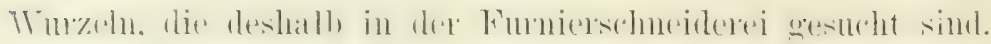

In manchen Hölzern. wie im Seiden- Ahorn- und Eschenhol\%.

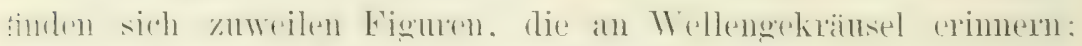

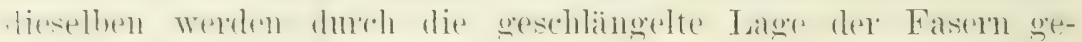
bildet.

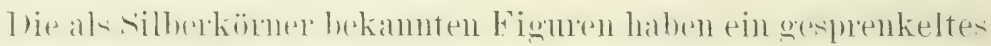
Answehen. wite as anlich elzengt wird, wem man reidentiden krenzt.

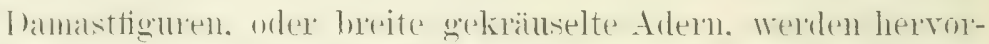

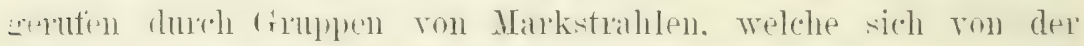

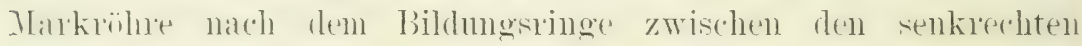
Fasern durchschlängeln, anstatt grad zu laufen.

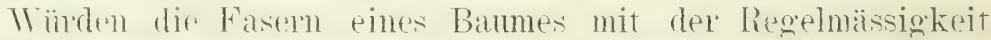

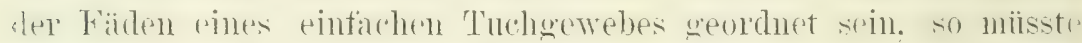
las Holz eine gledonässige Färbung zeigen. da abel die Fasern

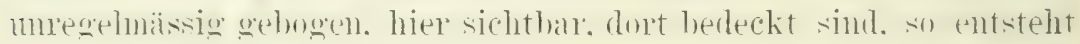
eine Abrechselung ron Figuren.

Nicht selten wird eine abweichende Färbung der'selben Holzant bemerkt. Welele anf andere Trsachen. wie die vorstehenden. zuxïckzuführdu sind. In manchen Faillen tritt cin Farbenwechsest hei Begimm der Terwesmo ein. noch ele die stärke notleidet. wir berspielswe be einigen Kiefermaten. Dem Fortscheiten

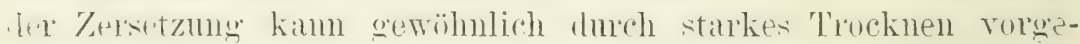
inngt werden. Ist in derselben Holzart. in gesmondem Zustand, ein

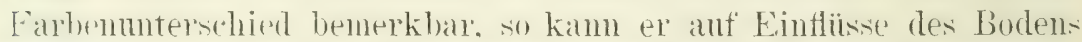
zurückgefïhrt werden. I)ie Lärche mul hiefer haben anf trockenem -henem. tiufsandigen Boden oft ein schwach rötliches Holz, während lasselhe anf anderen standorten wriss ist. Mahagoni mol andere tmpisehen Hölze zeigen hänfig in der einen Gegend eine tiefer Fär)me wie in dw anderen, was sich wahscheinlich nur durch Tuterschiede in der ahemischen Zusammensetzung des Bodens elkiären lässt.

Von den rersohiedenen Fehlern, welche in den Hölzen anttraten, sind die Kernuisse die weitaus häufigsten, ja, es wird sich kanm eine Holzart aufweisen lassen, die unter allen Lmstiuden thei ron ihmen bleibt. In gewissen Holzarten kommen sie aber al: Regel riel seltener mal in milderer Form vor wie in anderen. 


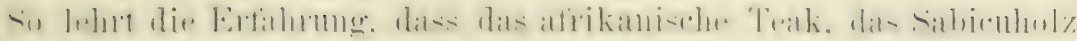

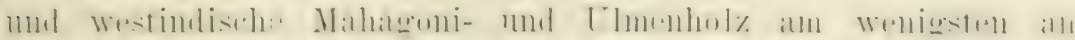
diesem Fehler leiden. wïhrend er das indische Teak und das

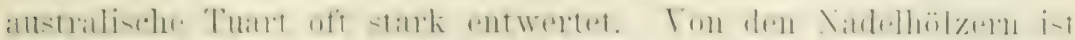

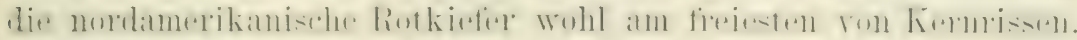

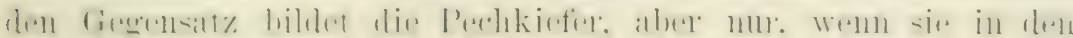
siidstaaten der Union rolkommt.

Nur das geübte Ange des Fachkenner's entdeckt die Kern-

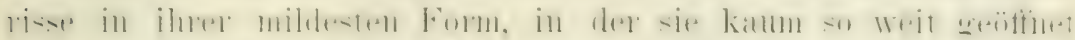

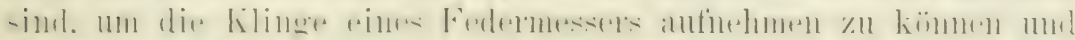

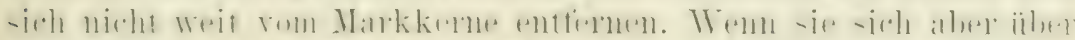

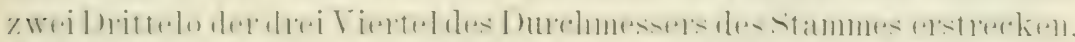

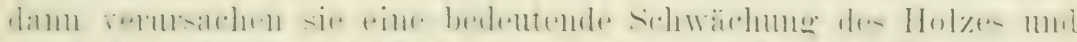

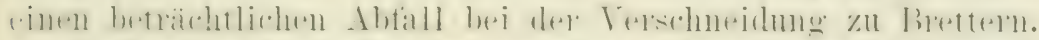

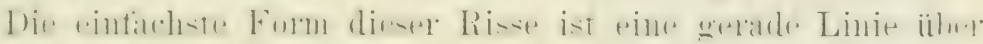

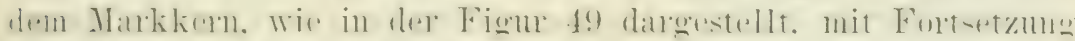

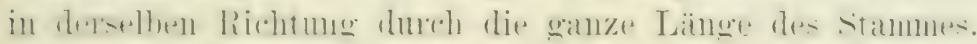

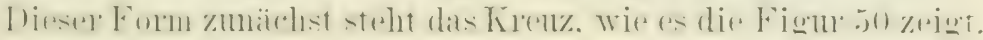

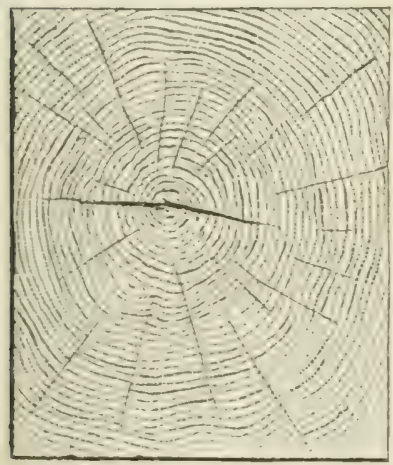

Fignx 49.

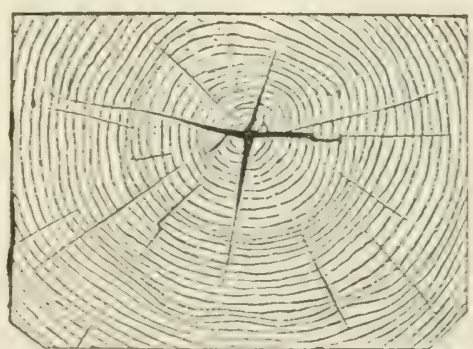

Fim 50.

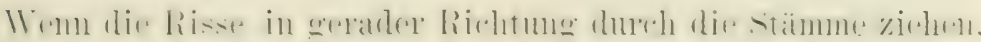

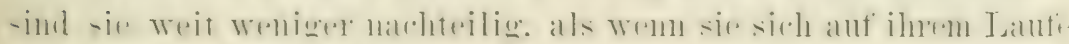

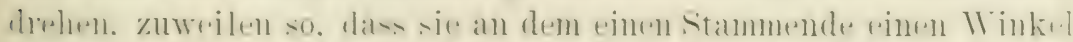

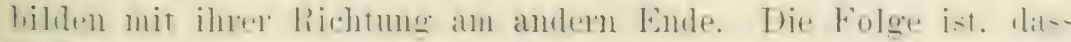

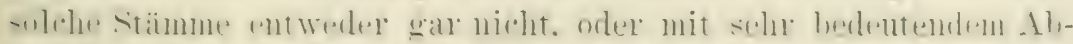

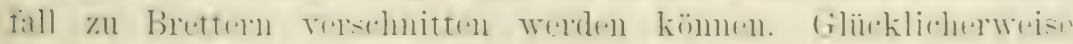

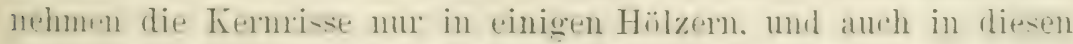
nicht oft, eine gewundene Richtung. 
Der zunachst wichtige Fehler ist der Stermiss, welcher in

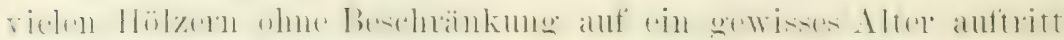

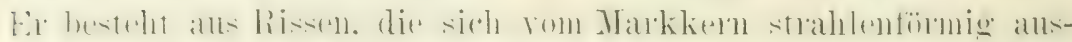

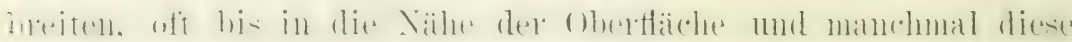

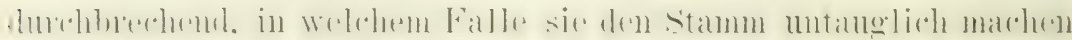

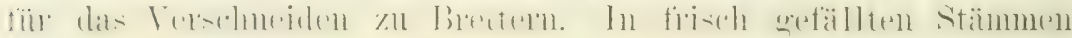

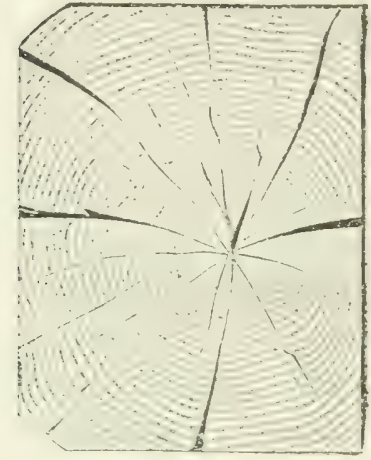

Fisu1 51. sind die Stermisse kamm bemerklich. sobald aber das Holz einigermassen trocken geworden ist, sind sie augenfällig: da die Kanten der Risse durch Beriührung mit der Luft dunkler und horniger werden, wie das übrige Holz. Die Figu 51 zeigt einen Sternriss der gewölnnlichen Form. Wenn er: in der schlimmsten For'm. die OberHäche des Stammes an mehreren Stellen durchbricht und dabei Längsiisse von $1 / 4$ bis 1 Meter bildet. kann er schon entdeckt werden. während der Baum steht.

Die Krreisrisse odel' 'Tasschisse. dargestellt in den Figuren 52 und 53. werden am hänfigsten an den nutern Stammenden gre-

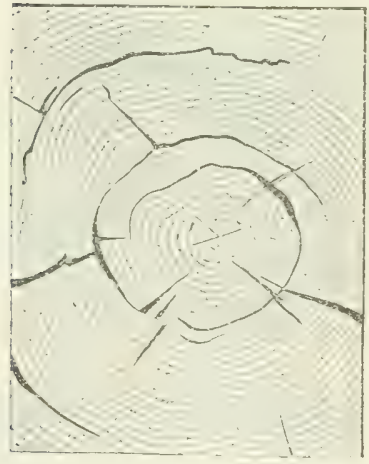

Figur 5:.

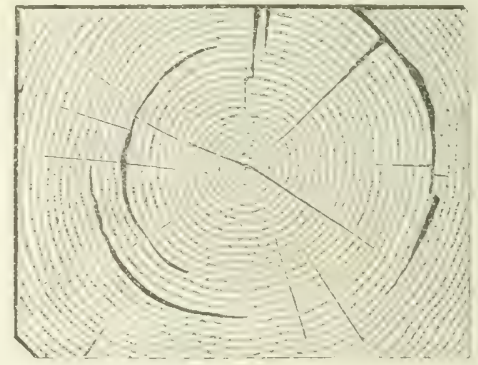

rigniv 53.

fimden, sie entstehen durch die 'Tremung zweicr Jahneszinge. Manchmal ist die kreisrmule Tremmug nicht rollständig, da an cinigen Stellen die Holzfasern ihre Bindekraft bewahren. manchmal haben sich mehrere Jahresringe an kleinen Teilstrecken gelïst. Tur wenn dieser Fehler in der schlimmsten 


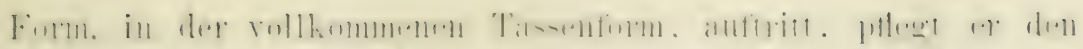

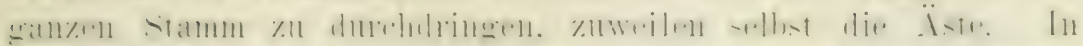

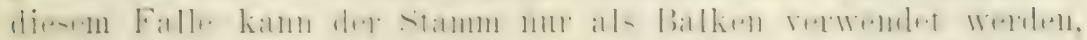

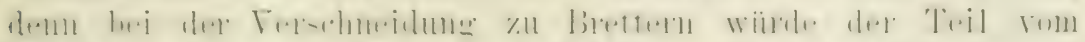

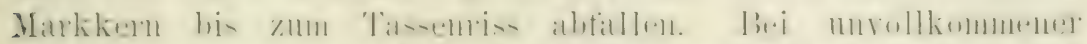

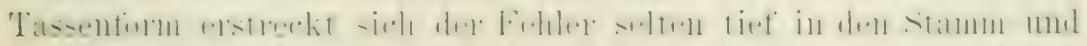

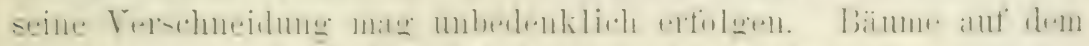

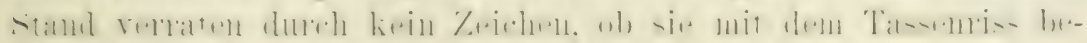
lattet sind.

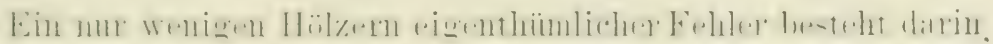

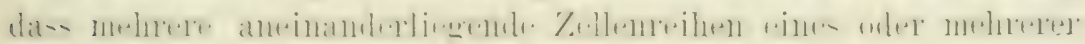

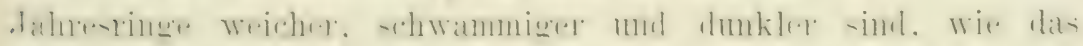
uibrige Holz. Diese am häutigsten in den nordamerikanischen Jimen antretende Missbildung beeintrăchtigt sowohl die Stäke. wie die Dauerhaftigkeit des Holzes; sie ist in der Figur 5t reranschanlicht. Es möge angefügt werden, dass jede Farbenabreichung in einem Jahresringe oder mehreren, auch bei ganz gleichförmigem Gefüge, eine Qualitätseinbusse andentet. Flecken, wem sie dem Holze

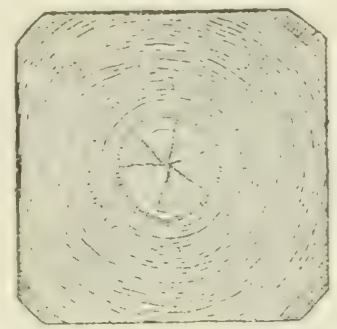

Figur :is.

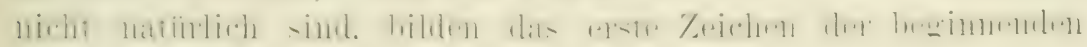
Telresumg:

Eine Anschwellung des Stammes dentet in der Regel einen

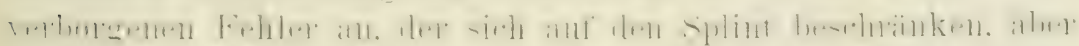

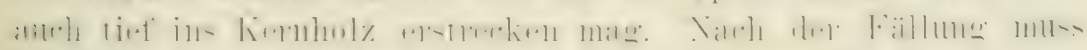

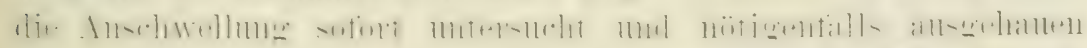
werden, dem es finden auch Ansuahmen ron der Regel statt.

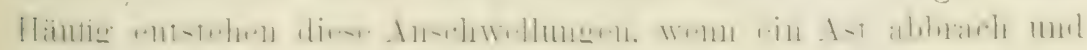
die Verwesung an der Bruchstelle einsetzte: hevor sie ron der

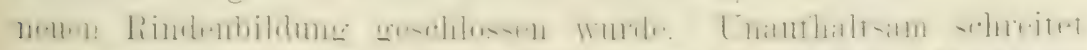

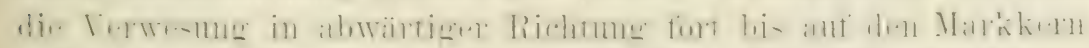

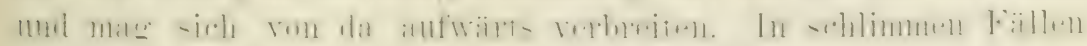
strömen die Faulstellen einen widerlichen Geruch aus. wenn sie geörinet werden.

Trirl ein Baum nicht tiefer bis zum sylint rerwundet,

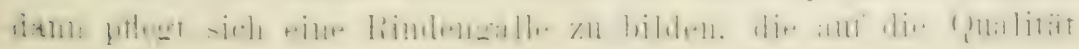




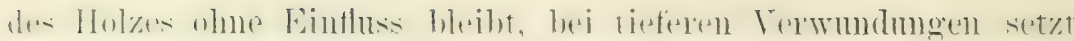

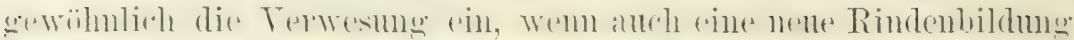

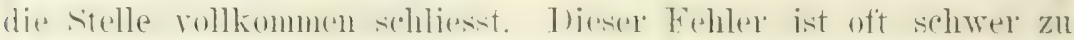

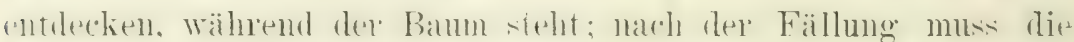

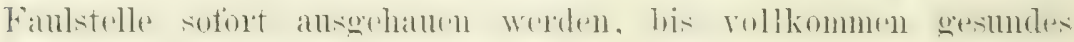
Holz zum Vorshein komme, da so mabliasig weiter um sich greift.

\section{Die Zeit der Holzfïllung.}

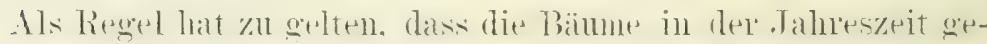
tiallt werden solfen. Wo ihne Lemensthitigkeit am schwächsten ist. weil damn ihr Holz diuterhafter ist und scheneler trocknet. als wem die Fällumg zur Zeit des statken satttlusses stattfindet. In des tropischen Zone wiol daher die Fällung vom del Ditte der Trockenzeit bis zum Beginn der Regenzeit stattzufinden haben, in den ïhrigen \%onen entweder im Mittwinter oder Mitt:sommer. Fs veldient ïbrigens herrorgeluben zu werden. dass in Fachkreisen ïbel diesen cregenstand noch abweichendes Ansichten herischen. so sagt rin nordamerikanischer siigneüller: die Erfalnumg meiner langjährigen Praxis hat mich geleht. dass die Monate Angust.

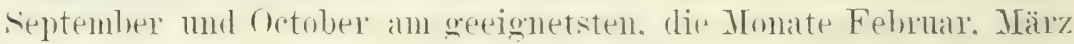
und April an mereignetsten für die Fällung sind. Ein roter Ahorn, im September getällt. bleilıt als stamm vollkommen treis: mul gesmul bis zum närbsten Angust, wird er dagegen im Mä̈\%

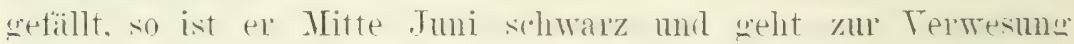
iiber. Eine im September gefällte gelle Birke bleibt in gutem Zu-

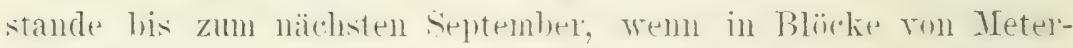
länge geschnitten; wird ie im März getaillt, so ist sie anfangs August schon wertlos.

Holz, das geschält werden soll. kamm nur im Friihsommer gefällt

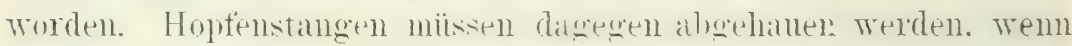
die Rinde an zähesten hänot. da sie duroly das Abfallen derselben wertloser werden.

Im östlichen Frankreich werden die Nadelhölzer seit voldenklicher Zeit in sommer getällt. hamptsächlich um des Torteils willen, sie leicht schälen zu kïmen. Durh die Abnahme der Rinde wird das Holz vor den Angriften der Insekten bewahrt mo rascher getrocknet. Es wird aber anch behamptet. das Nadelholz.

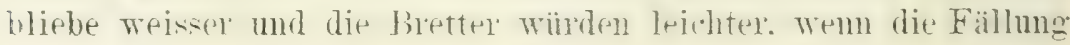




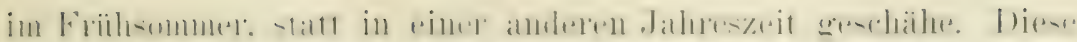

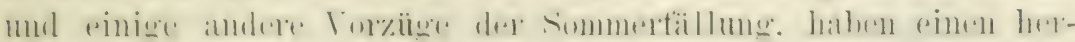

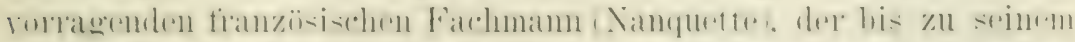

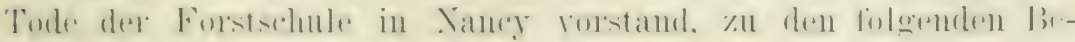

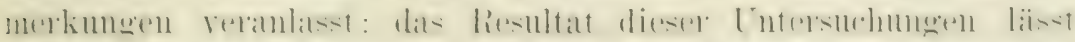

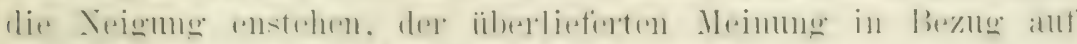

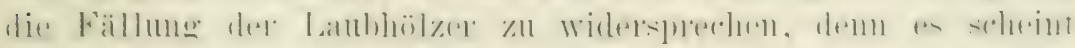

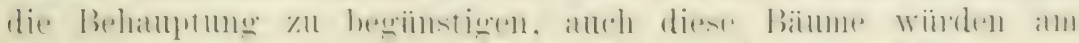

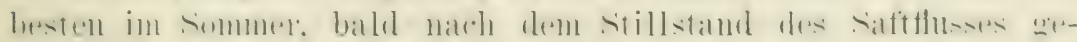

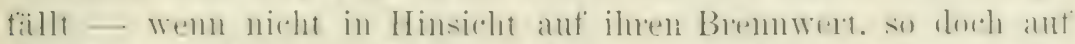

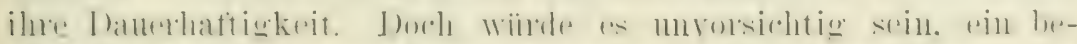

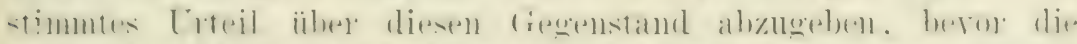

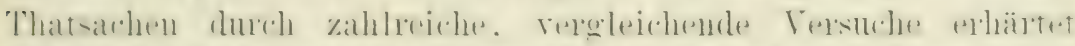

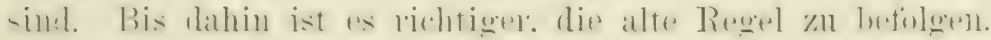

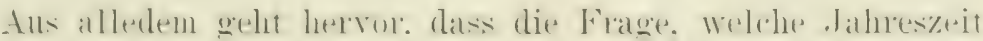

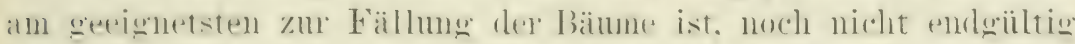

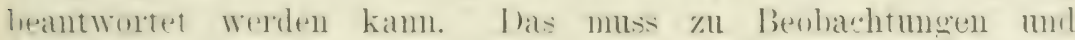

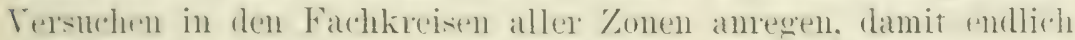

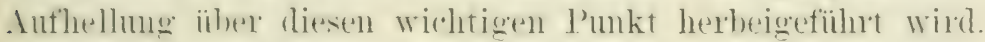

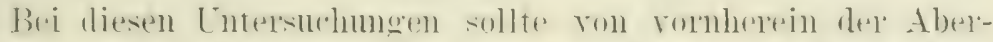

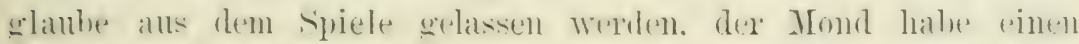

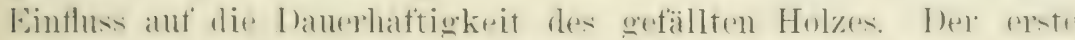

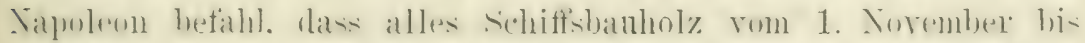

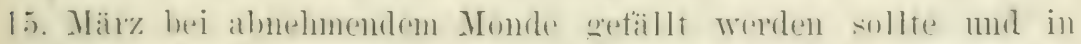

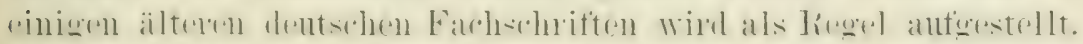

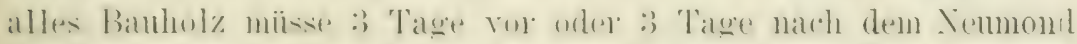

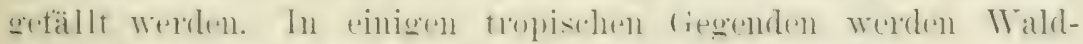

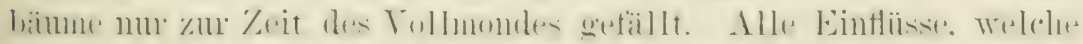

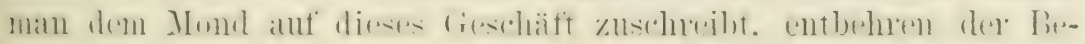
grïndung:

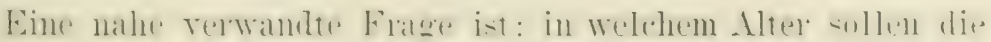

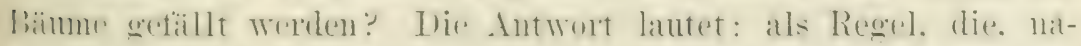

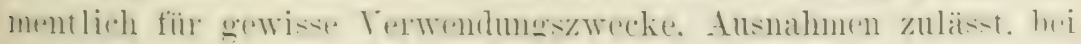

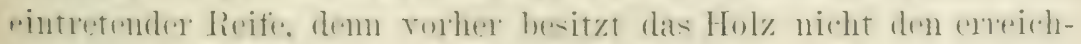

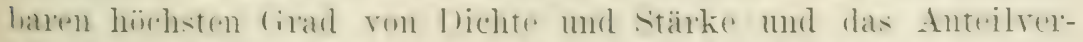

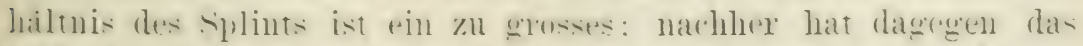

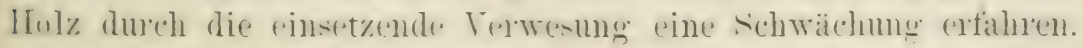

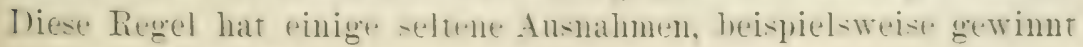




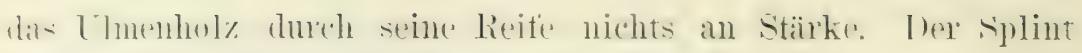
wird so branchbar betrachtet wie das Kernholz.

Da boden und Flima auf don Eintritt der Reife Einflus: Hiben. su kimn diesellhe für eine Bammat nicht mit bestimmten

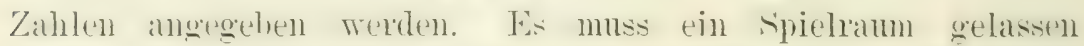
werden. wie: die Eichereift in 100 bis :00 Jahren. die Kiefer und Tanne in 70 bis 100 . Tahren. die Lärche. Esche und TTme in 50 bis 100 Jahren, die Pappel in 30 bis 50 Jahren.

Tn Buzun anf die Fällung selbst ist zu bemerken. dass sie tief am stamm anseführt mud der. (iegenschnitt so wemacht werden sollte. dass ..der stamm rom stmmpt springt". da el anderufalls im Fallen sualten könnte. Der stamm sollte unverzïglich geschält.

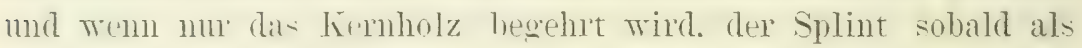
möglich abgehatlen wrelen. Zumeilen wird der Bam im Frühjaln ant dt'm ctande geschält ume das Fällen bis zum Herbst

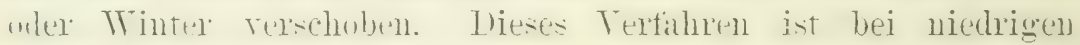

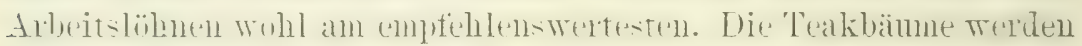

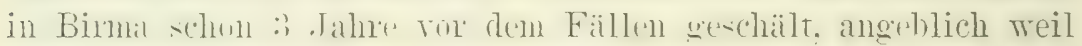

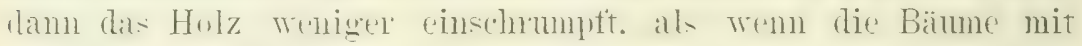

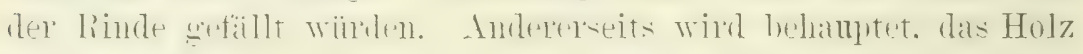
wïrde spröder - 3 Jahre sei zu lang; um den Stamm auf dem Stande zu trocknen.

\section{Das 'Trocknen des Holzes.}

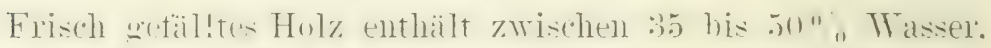

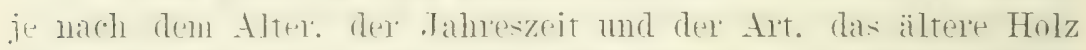

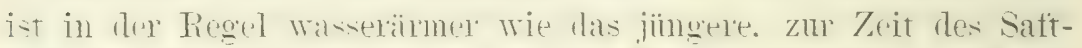

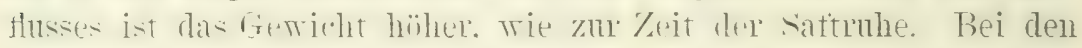

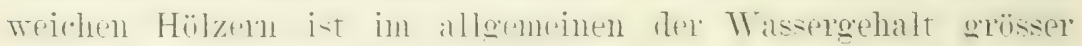
mie bei den harten.

Dieses Trasser ist nur teilweise chemisch mit dem Holze rerbunden und rerdunstet in sohwankemen Mengenrerhailtnissen. untel dem Fintluse dex Luft. Ist das Trucknen bis za rinem

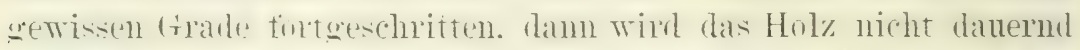

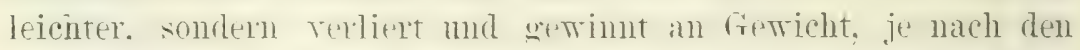
soluankungen in der Temperatur und dem Fenchtigkeitsgehalte dur Luft. Die folgende Tabelle zeight die Teränderungen nach firichtsprozenten. welche in winigen Hölzern. wälnend des Trocknens, ror sich gehen. 


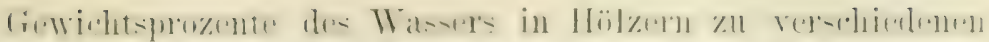
Zeitabschnitten nach dem Fällen.

Rundholz von Aesten.

$\begin{array}{lll}6 & 12 & 18\end{array}$

Monate Monate Monate Monate
Iiundholz von jungen Bïumen.

$\begin{array}{llll}6 & 12 & 18 & 24\end{array}$

Monate Monate Monate Monate

$\begin{array}{llll}30,44 & 23,46 & 18,60 & 19,95 \\ 32,71 & 26,74 & 23,35 & 20,28 \\ 27,19 & 23,08 & 2 \mathrm{C}, 60 & 18,59 \\ 39,72 & 29,01 & 22,73 & 19,52 \\ 40,45 & 26,22 & 17,77 & 17,92 \\ 33,78 & 16,87 & 15,21 & 18,09 \\ 41,49 & 18,67 & 15,63 & 17,42\end{array}$

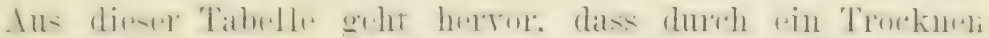

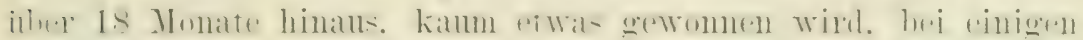

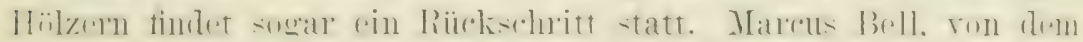

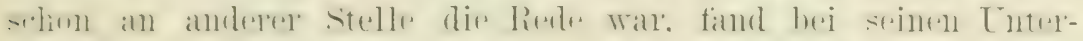

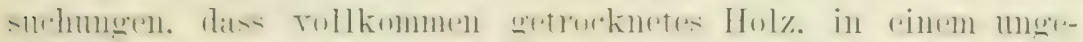

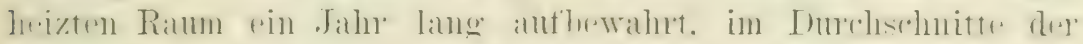

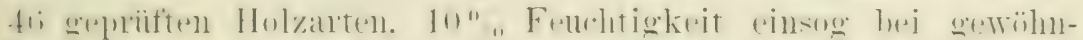

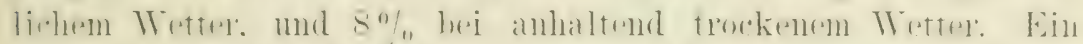

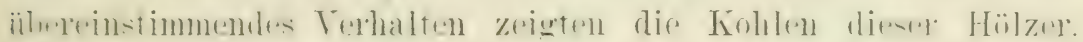

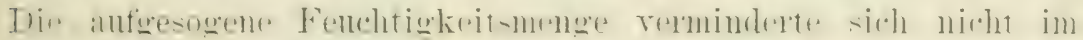

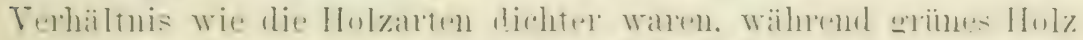

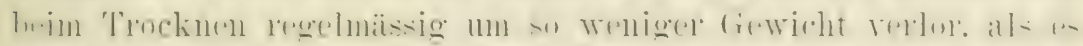

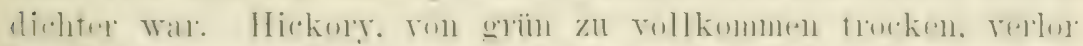

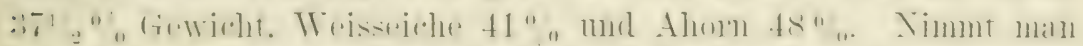

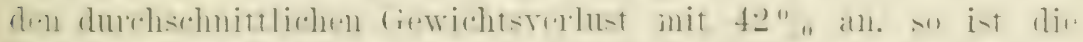

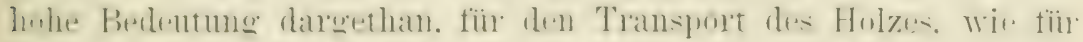

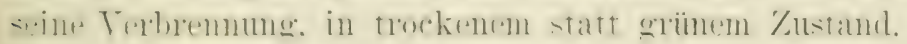

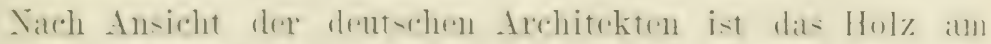

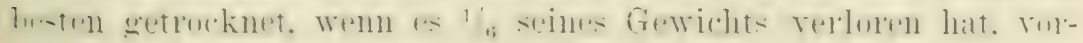
ausgesetzt, es wurde während der Saftruhe gefällt.

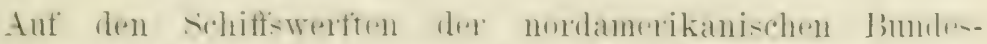

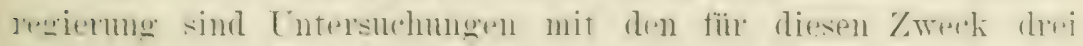

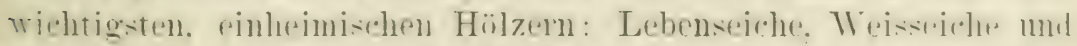

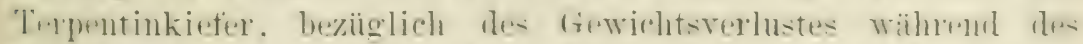

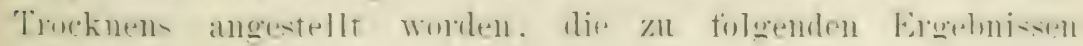
fiihnten : 
We isse i che.

12 behauene Stïcke, 90 Zentimeter lang, spezifisches Gewicht 1,069

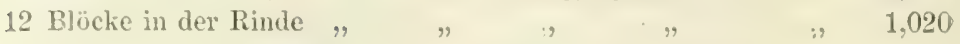

Gewichtsverlust im ersten . Tahre

Blöcke in der Rinde, gefüllt im Sommer $18 \%$

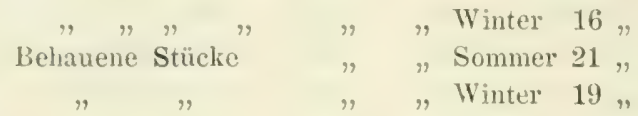

Gewichtsverlust nach vier Jahren.

Blïcke in der Rinde, gefïllt im Sommer $32 \%$

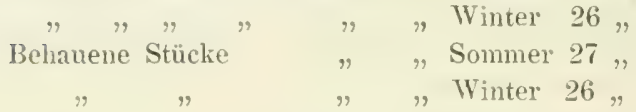

Lebenseiche.

12 behanene Stiicke, 90 Zentimeter lang, spezifisches Gewicht 1,259

12 Blöclie in der Rinde , , ",$\quad$, $\quad, \quad$, $\quad 1,191$

Gewichtsverlust im ersten Jahre.

Blöcke in der Rinde, gefällt im Sommer $5 \%$

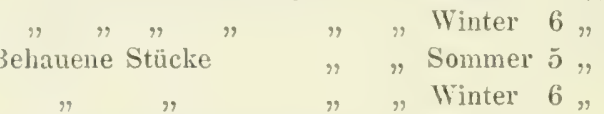

Gewichtsverlust nach vier Jahren.

Blöcke in der Rinde, gefällt im Sommer $23 \%$

$\begin{array}{ccc}\text { Behauene Stucke } & \text { " } & \text { Winter } 27, \\ " \text { " } & \text { "Sommer } 23 " \\ \text { Terpentinkiefer. } & \end{array}$

12 behauene Stücke, 90 Zentimeter lang, spezifisches Gewicht 0,637

12 Blöcke in der Rinde 90 Zentimeter lang, spezifisches Gewicht 0,781

Gewichtsverlust im ersten Jahre.

Blöcke in der Rinde, gefällt im Sommer $16 \%$

$\begin{array}{cccccc}\text { Behauene Stücke, } & \text { " } & \text { " Winter } 19 & \text {.. } \\ \text { " Gommer } & 11 & \ldots \\ \text { Gewichtsverlust nach vier Jahren. } & \end{array}$

Blöcke in der Rinde, gefällt im Sommer $27 \%$

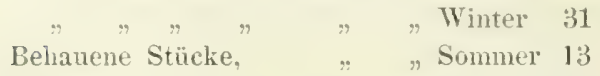

"Winter 16 ,

Es muss erwilhnt werden, dass die sämtlichen Tersuchshölzer aus Tordcarolina stammten, ein Staat, dessen K'lima eher halbtropisch wie gemässigt genannt werden muss; eine genaue Bestimmung ist nicht möglich, da der ansgeprägte Charakter fehlt. Trotzdem in diesem staate dex Winter nur zu einer kurzen. milden 


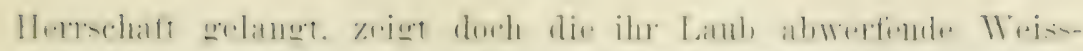

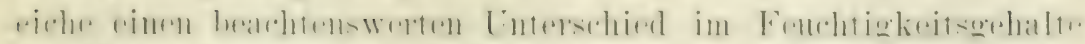

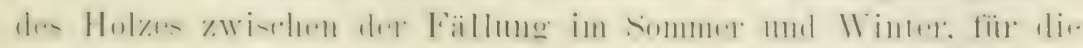

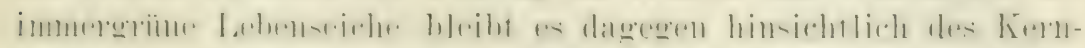

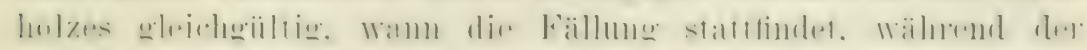

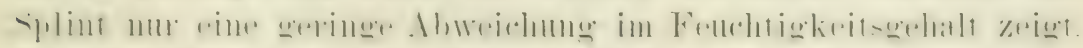

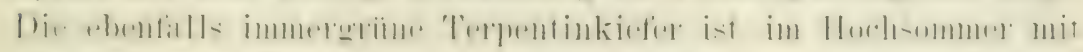

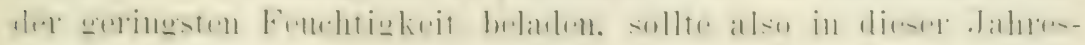
zeit getillt werden.

Grïnes Holz. anf weite Entfernmgen rersendet, kommt teil-

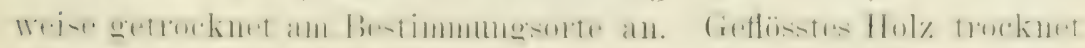

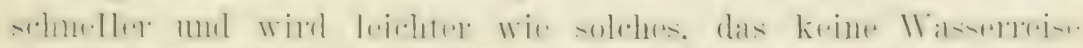

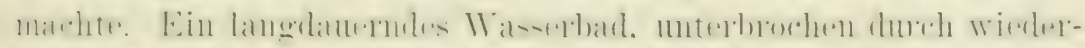

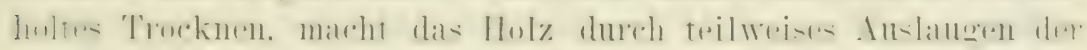

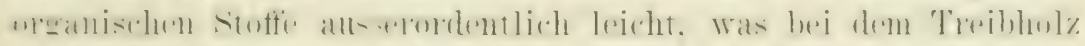

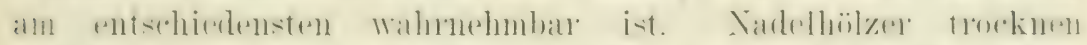

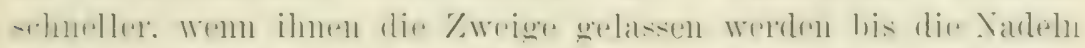

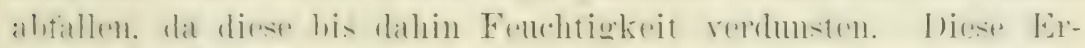

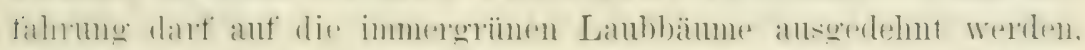

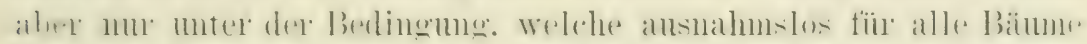

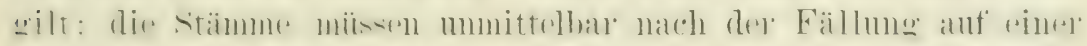

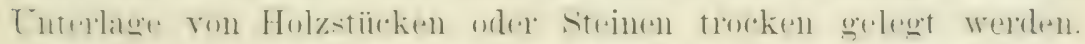

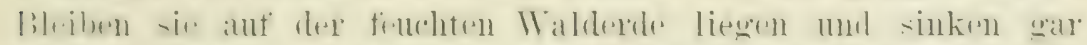

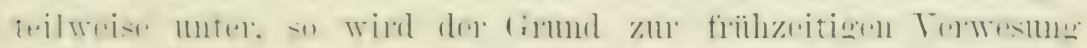
velegt.

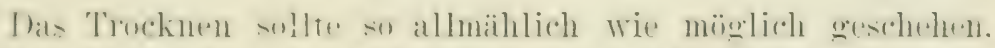

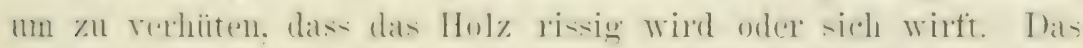

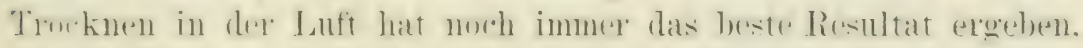

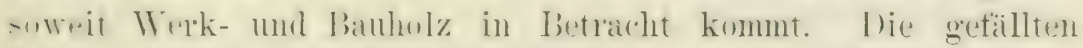
stimme sollen unter allen L'mstimslens so bald wie möglich be-

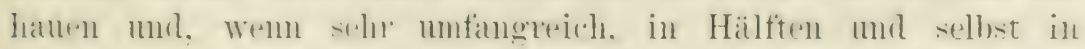

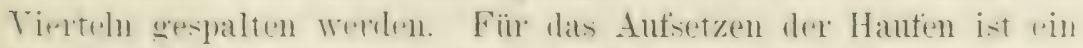

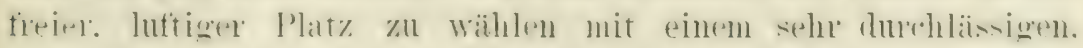

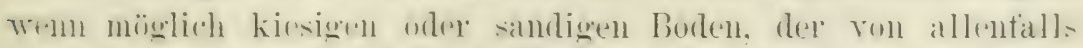

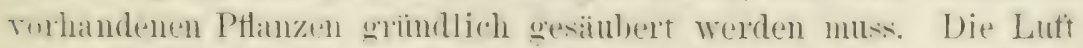

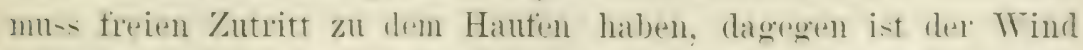

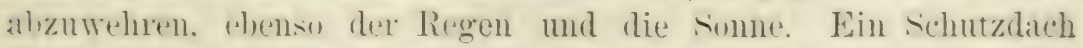
i-t mithin unerlässlich. magr es anch noch so loikht gebatut seiu 


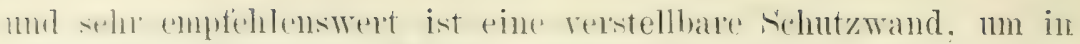

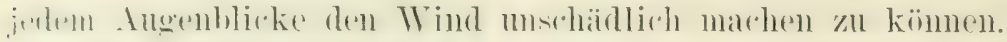

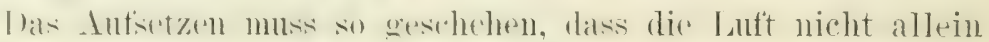

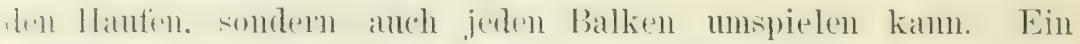

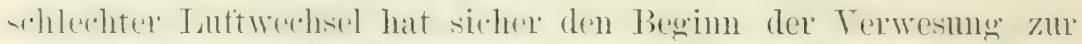

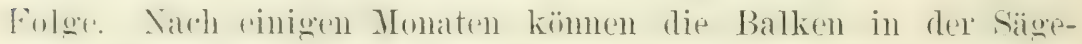
mïhle vershnitten werden, die Bretter. Latten oder I'fosten müssen

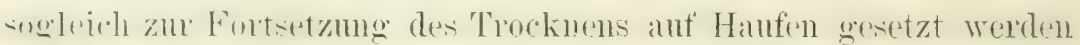
mud zwall mit so viel stiitzpunkten, dass sie sich nicht wertell kïmen. Wamit sie ganz gleichmässig aufliegen und sich nicht krïmmen këmuen. Werden sie nicht selten anf Lattengeriiste, stuckmerkweise ïhereinandergehant, gestapelt. Duch eine Balken-

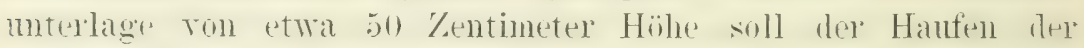
fenchten Fude entriickt werden und jerles stiick durch pinen Zwishenalun von mindestens : Z Zentimeter ron seinen Nachbarn unetrennt liegen. Was von schichte zu schichte dureh eine Latten-

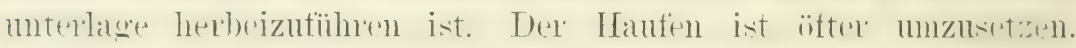

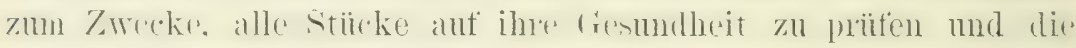
von dre Terresung ereriffenen zu entfemen. Bis dicht muter das Inach dart' der Hanten nicht shöht worden. Weil die whersten

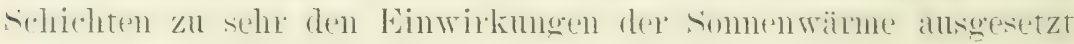
sein wiirdell.

Wie bereits an anderer Stelle geschildert, verfährt mani an der P'azitikkïste, wo die sägemiihlen. wie hervorgehoben zu werden

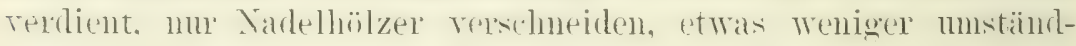
lich. Die Blöcke werden bald nach ihrer Ankunft aus dem

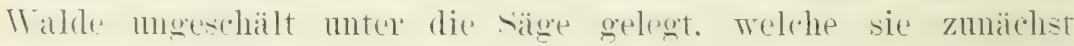
viereckt. Erst als Bretter orler Pfosten wird das Holz im Hofe zum Trocknen aufgesetzt.

Jaweilen wind ein abweichendes Torfahren seribt, num Eichenhulz zu trocknen. Lie in grïnem Zustande geschnittenen Balken werden nicht wagerecht gelegt, sondern senkrecht gestellt, ebentalls mit \%wischenämmen. Welche moghinderten Lutwechsel gestatten. Ant diese Treise soll das Eichenholz schon nach einem halben . Tahre hratuchbar für die Tischlerei getrocknet sein mad zwar schön weiss ohne die bekamnten ärorerlichen Lohflecken. Es ist der Prüfung wert. ob dieses Verfahren rorteilhaft auf andere schwer trocknende Hölzer ansgedehnt werden kamm. Die Wahrsolheinlichkeit spricht dafür. dem der saft des Holzes ist rouzugs- 


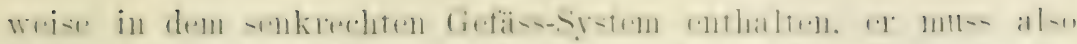

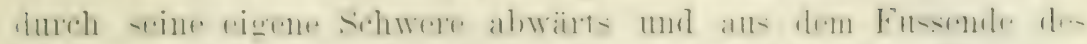

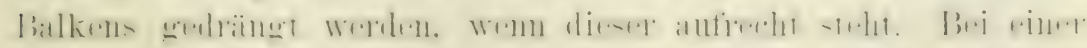

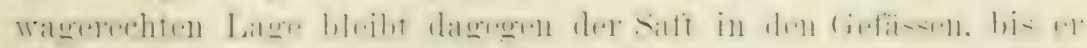

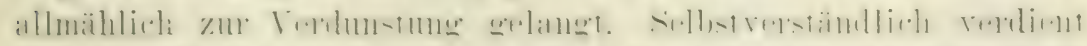

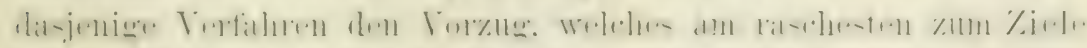

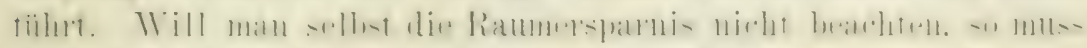

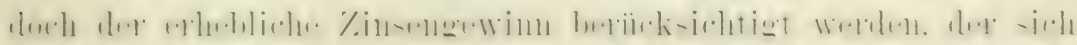

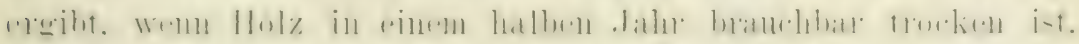

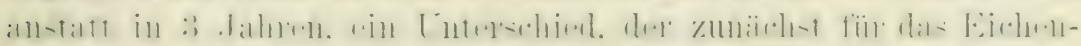
holz gilt, aber noch tïir andere Hölzer zutreffen wird.

ऽu zu Brenn\%wecken mag man unbehanene Stämme trock-

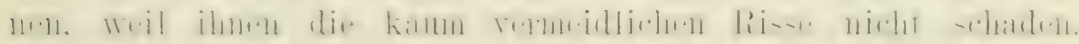

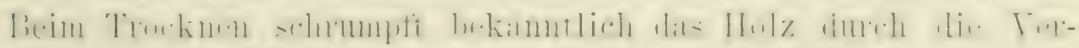

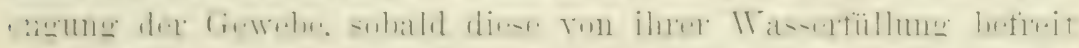

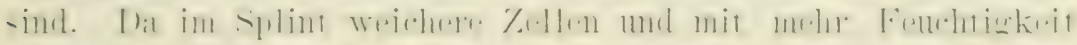

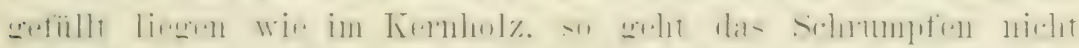

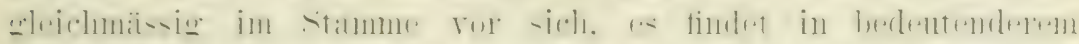

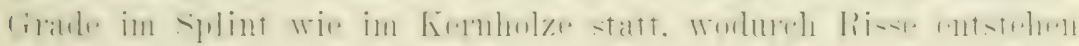
miissen.

Da die Stimenden der geschnittenen wie nngeschnittenen

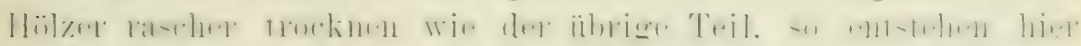

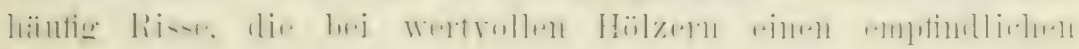
Verlust berleuten. Um denselben zu verhitten. beklelot man die

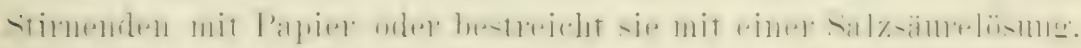
nentralisiert mit Kalk. Wenn kein besseres Sichutzmittel zul

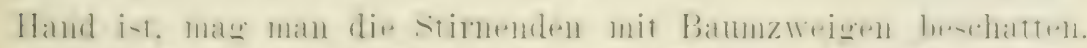

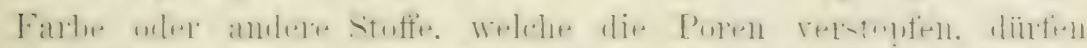

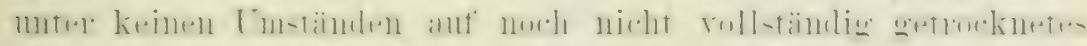

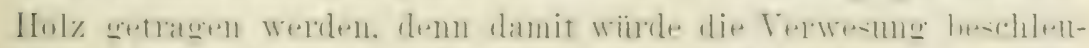

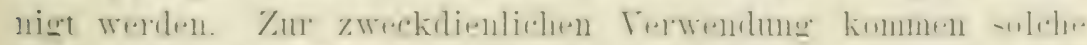

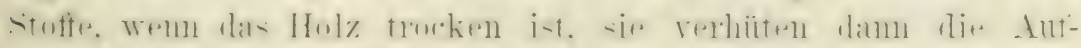
saugung von Feuchtigkeit.

Zuweilen zieht man es ror, den Saft des Holzes durch ein

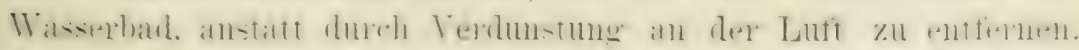

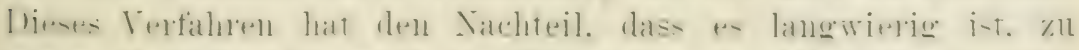

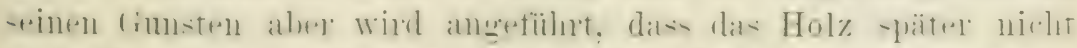

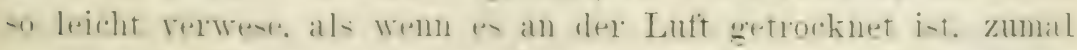

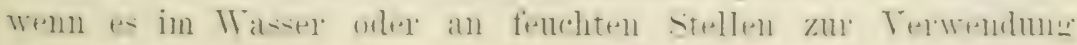




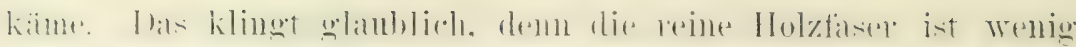

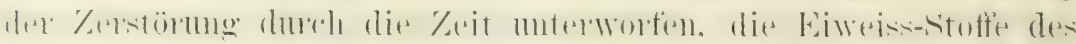

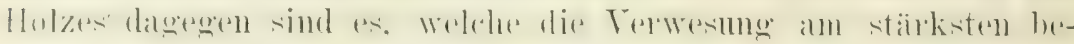

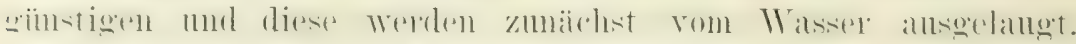

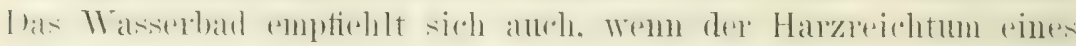

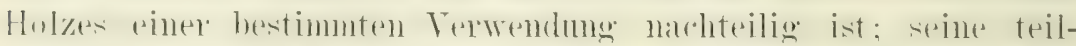

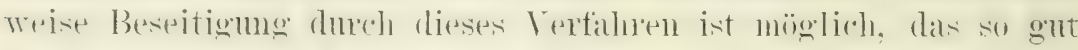

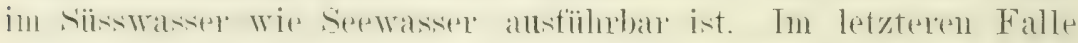

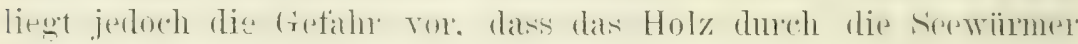

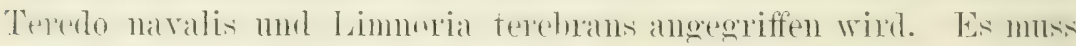
deshalb eine sorgfältige Überwachung stattfinden.

Ein zwei-bis dreiwönhiges Masserbad mag häntig als eine entur Torbereitume tür das Trocknen an der Luft befunden werden. dorh ist zu bearhten. dass, einerlei wie lange das bad dauert. las Holz entweder vollstandig untereretancht oder von zeit zu Zeit gewendet werden muss.

Als ein teilweises 'Trocknungsverfahren kann anch das Thimpten des Holzes betrathtet werden, das zur Anwendung kommen muss, monn grosen stücke gebogen werden sollen, was am häufigsten im Srliffban rorkommt. Die Regel ist, dass ant' je :; Zentimeter Iricke eine stunde gedämptt wird. Thas Terfahren ist zureilem der stäke des Holzes nachteilig, allein es schïtzt ror Verwesung. Werfen und Aufreissen und beschleunigt das Trocknen.

Zum Dämpfen wird ein Apparat benutzt, der aus einem Thamplkessel und dinem zum Einlegen des Holzes bestimmten sisernen Kasten. mit Zement oder Maner'rerk überkleidet, besteht. In den dicht rerschliesharen Kasten wird ein dauernder strom Trasserdampt geleitet. der, nachdem er sich zu Wasser verdichtot mol die Saftbestandteile anfgelöst hat. durch einen Hahn abgelassen wird. Dif ablantende Brihe ist stets dunkel. so brammot hei Mahagoni, schwarzhan bei Fichen u. s. W.. so bald sie hell Hiesst wird das Verfahren als beendet betrachtet. Die gedämpften Hölzer werden nach der bereits geschilderten Weise in der Luft oder der Trockenkammer getrocknet; ihr Gewichtsverlust durch das Dämpfen beträgt 5 bis $10 \%$

Die 'Temperatur des Dampfes darf' keinenfalls 100 " C. ïberseheeiten. da sonst die Holzfasern not leiden. etwa $80^{\circ}$ werden am geeignetsten erachtet. 


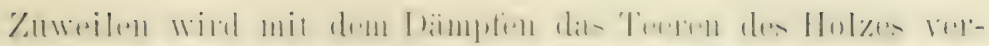

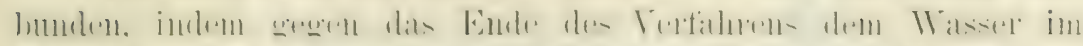

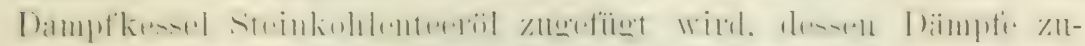
gleich mit deven des Wassers in das Holz dringen.

Das Trocknen mit kïnstlicher Wärme findet eine immer'

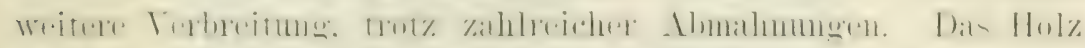

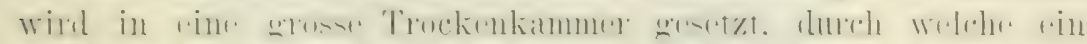

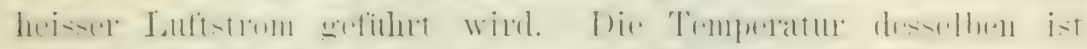

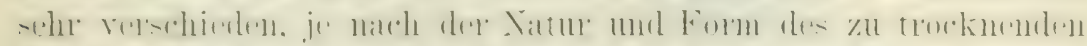

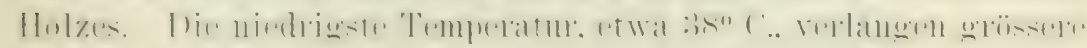

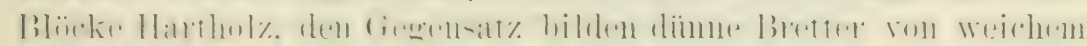

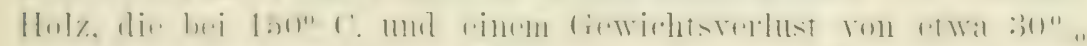

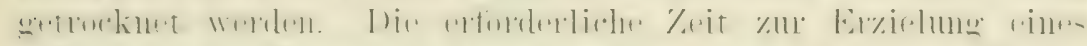

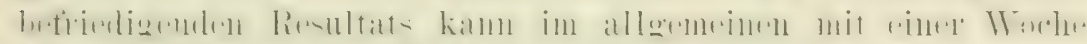

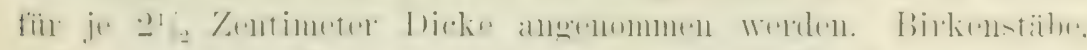

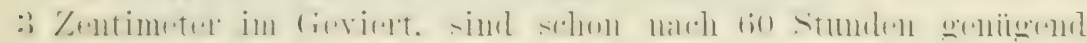

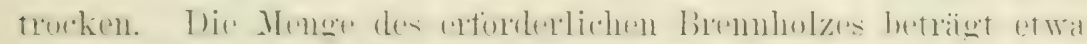

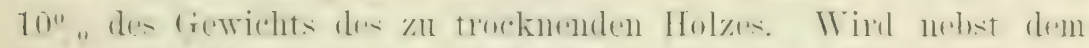

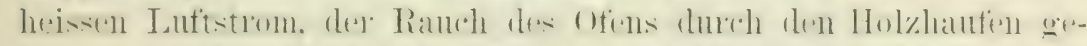

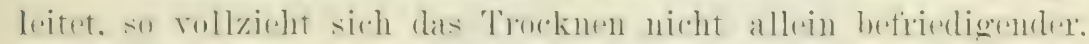

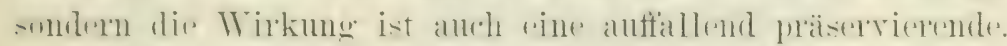

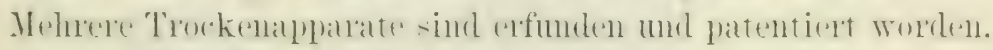
ron welchen in Nordamerika an rerbreitetsten der in den

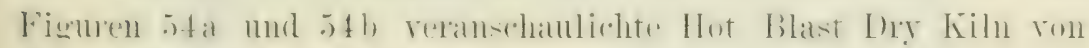
Huyett of Smith in Detroit, Michigan, ist.

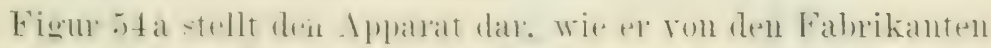

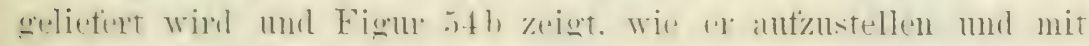

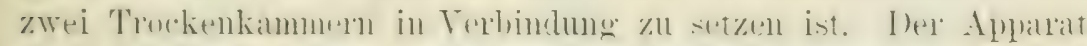

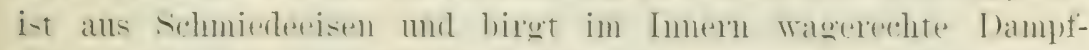

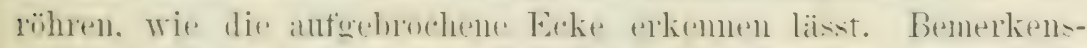

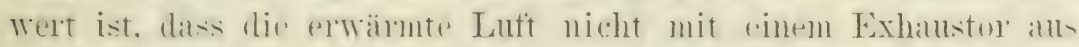

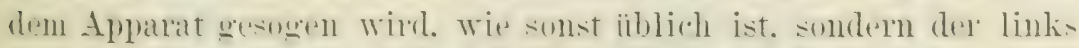

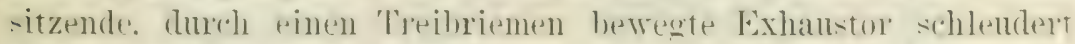

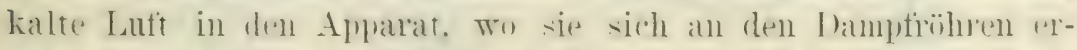

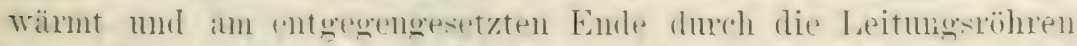
anstreten muss: wie sir in dir Truekenkammern steigt. zeigen dir

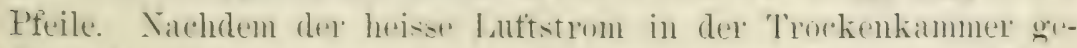

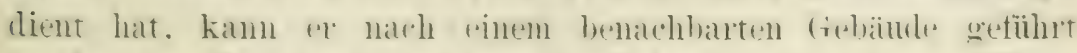

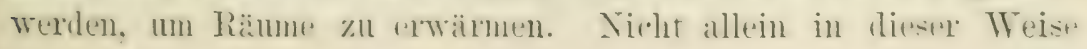




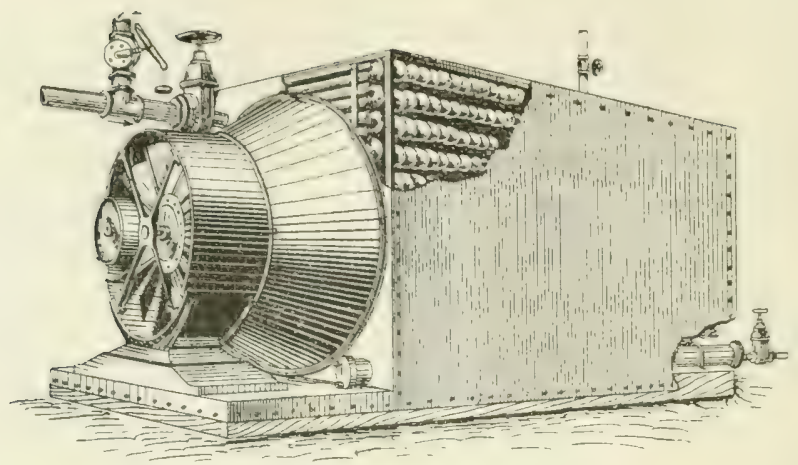

Fixur 54a.

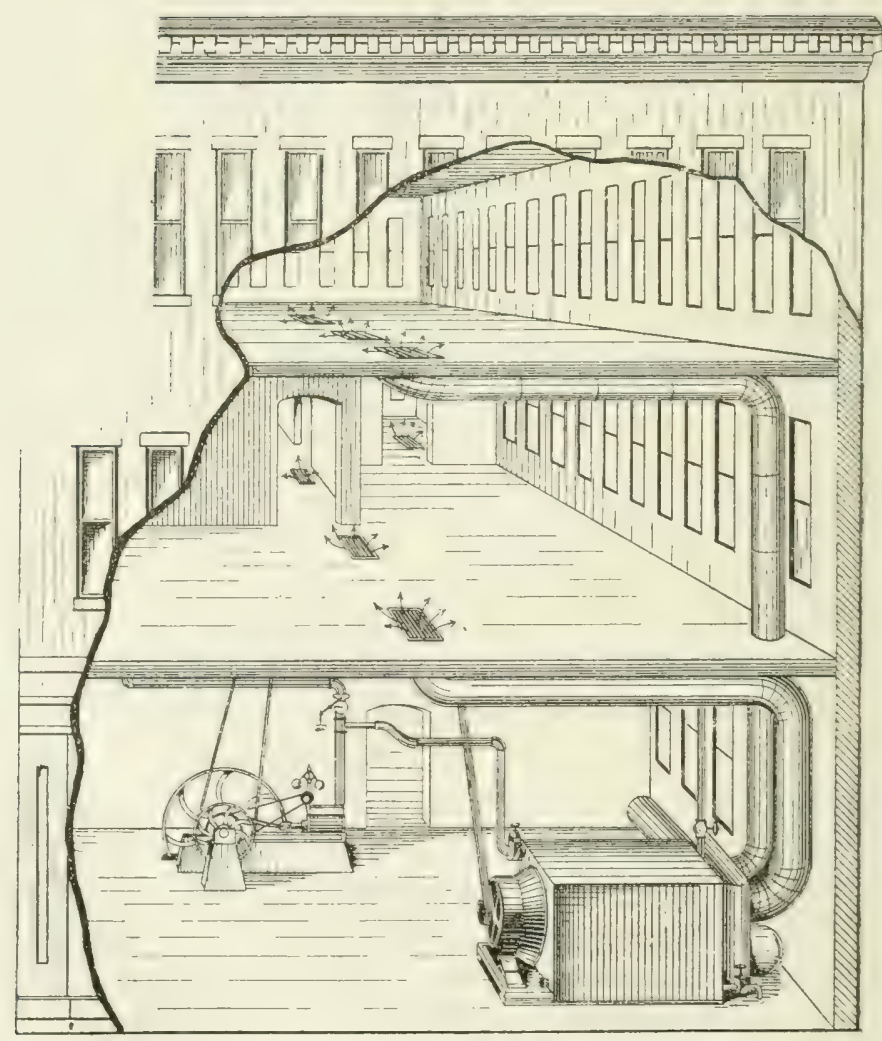

Figur jub. 


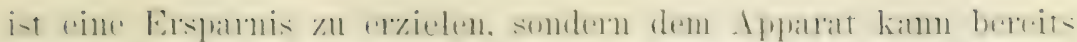

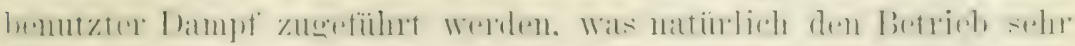

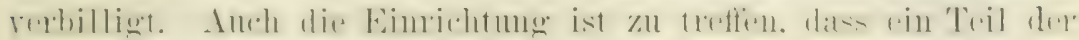

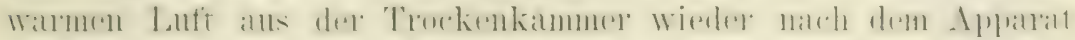
zuriickgefiihrt und damit Heizkraft erspart wird.

Die 'Trockenkammer wird entweder aus Holz oder Back-

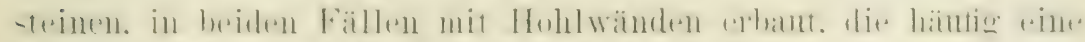

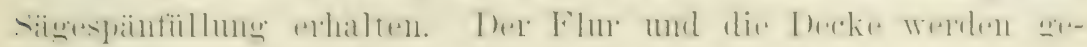
doppelt mit '/wischenlagen ron starkem Papier.

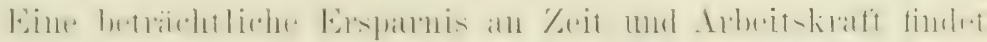

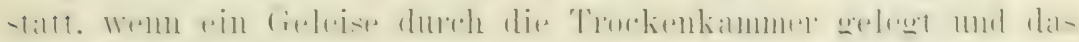

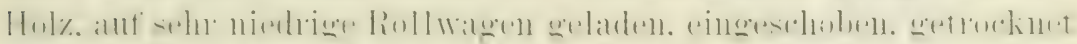

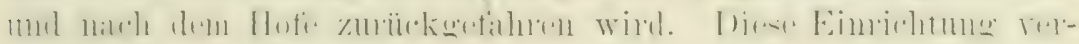
anschaulicht die Figur 55.

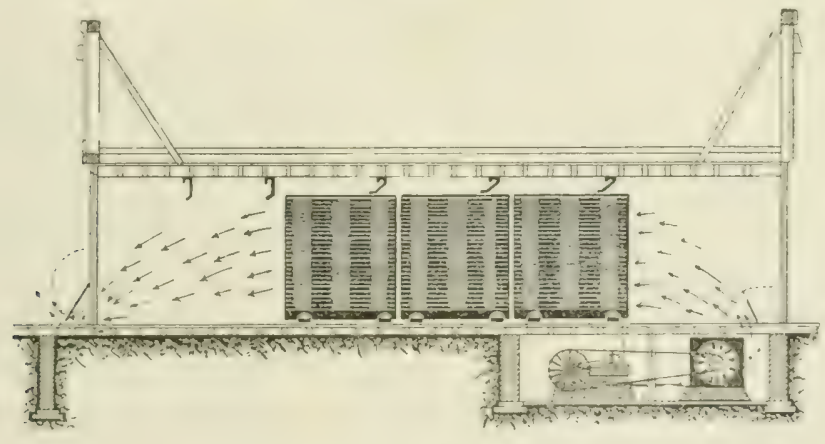

Figur 55.

Die Wagen treten bei A ein und bei B ans. Die notwendig.

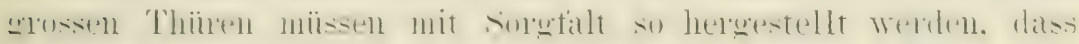

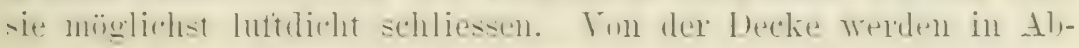
-tänden von 3 Meter Markisen ron segelturh ant die hedatenen

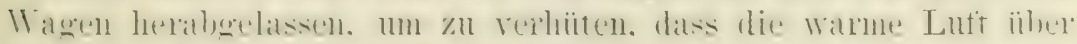

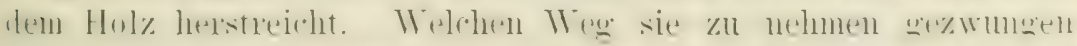
ist, deuten die Pfeile an.

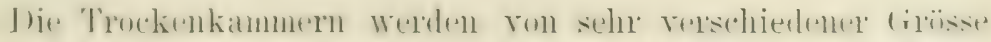

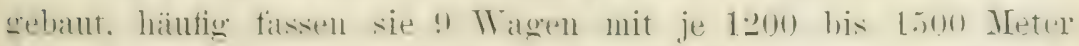

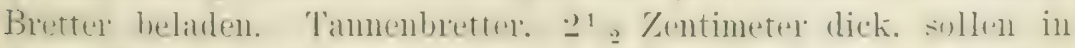
diestu houkenkammem schun nach jo lagen vollkommen trocken merden, ohne sich zu werfen oder Risse zu zeigen. 


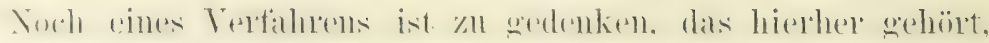

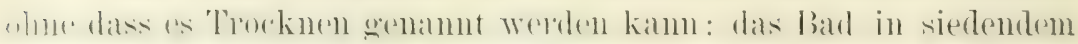

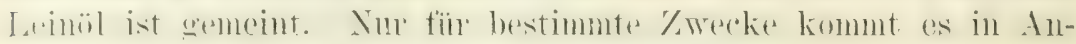

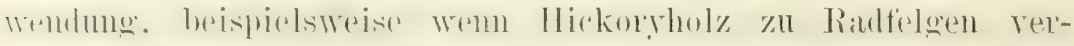

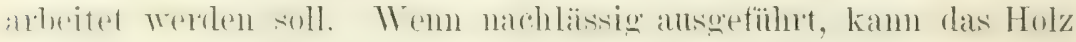

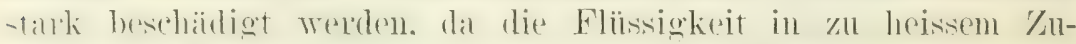

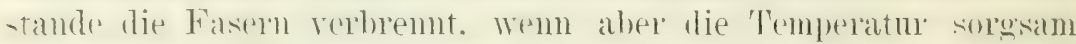

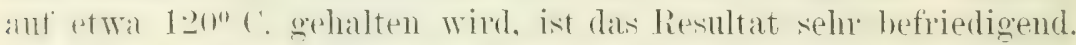

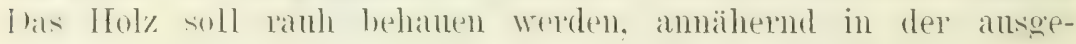
arbiteten ciestalt, es wind dam nicht allein gut und weichmässign truken werden. sundern anch bedentend an starke gewimen.

I nurch das loocknen im allgemeinen wird die stäkes des Holzes phöht. vorallsesetzt, dass sorgtailtig ansgetiiht worden ist. Der stäkegewinn selewankt indersen sehr. Fichtenholz gewimt etwa

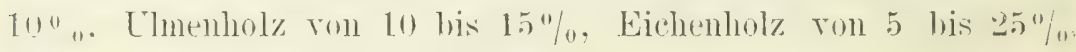
Eschen- und Buchenholz manchmal 40\%

has Holz whrumpft stets zu einem grösseren oder geringeren trate beim T'rokinen, in Folge der Entfernumg der Fenchtigkeit. rinige Hölzer werfen sich zugleivh sehr stark, währemd andere rissig und damit menfalls in ilnem Werte seln beeinträchtigt whden. Las Schrumpfen in der Länge ist gewöhnlich nicht sehn bemerkbar. dagegen findet das schrmmpen in der Breite oft in einem beträchtlichen (rade statt. In weichem Holze, wie Birke. heträgt ts bis 8" o. Da das Keruholz dichter und saftämer ist wie dor sulint, so besitzen Bretter; die ans diesem und jenem besthen. resschiedene (Qmalitäten mol werfen sich sicher beim Trocknen. Die einfache Prïfmo der Lage der Markstrahlen mor . Tahresinge in einem Strick grimen Holzes, befähigt zu beurteilen. rom welchem 'Teile des stammes es kommt und welche Formverändermg' das 'Trocknen herbeiführen wird.

\section{Die Charakteristik des Holzes.}

Im Holzgerchäfte spricht man von weichen und harten Ḧ̈lZern. Zu den Ersteren gehören die Nadelhölzer und einige Laulhölzer: wie Pappeln mo weisse Birken, alle übrigen Laubbäume genören zur zweiten Abteilung, die in 2 Klassen gesondert wird:

1. in diejenigen Hölzer, welche breite, stark ansgeprägte Markstrahlen besitzen;

2. in diejenigen mit undeutlichen Markstrahlen. 
Diese Kỉassen zerfallen in zwei Unterklassen:

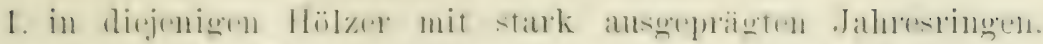
wie bei der Eiche in der ersten, und bei der Esche in der zweiten Klasse:

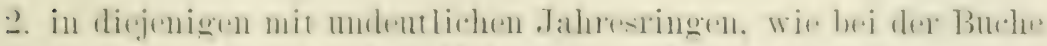
in der ersten, und dem Mahagoni in der zweiten Klasse.

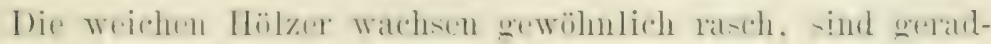

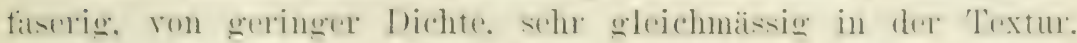

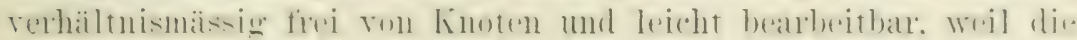

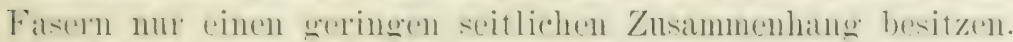

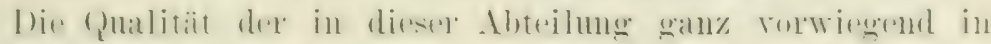

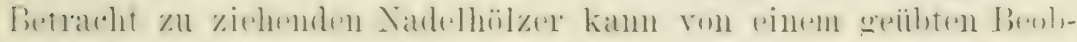

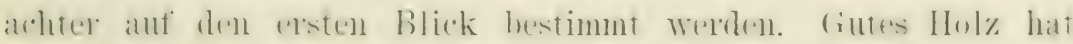

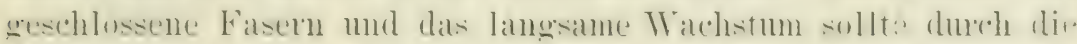

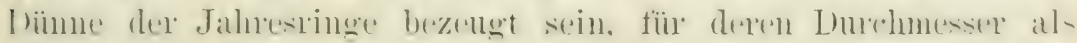
Höchstmass 25 Millimeter zu betrachten ist.

Die Jahresinge und folghich der ganze Stamm sollon durchans ebenmässig gebildet sein.

Dats beste Holz ist mit Harz durehtrinkt. Wolches guen Tuwesmes schiitzt. Stärke und Elastizität rerleiht: seine Gegenwart wirel durch starken Geruch angezeigt. Die Faserumg sollw

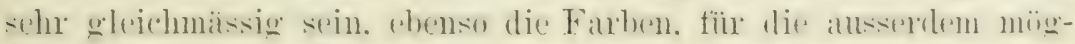
lichste Reinheit erwünscht ist.

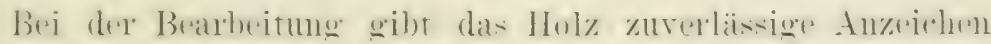

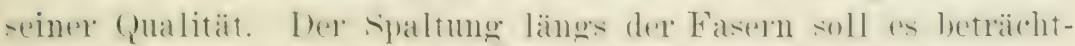

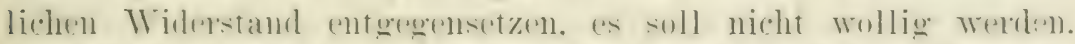

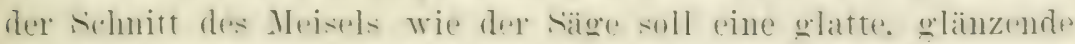
Fläche hinterlassen. I je Hobelsuäne sollen krätio mo elastisch

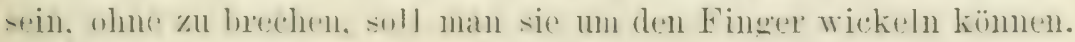

lie harten Hölzer sind dichter, schwerer. stärker und nicht

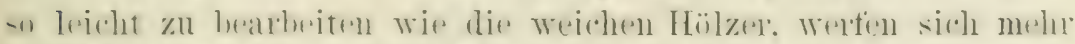

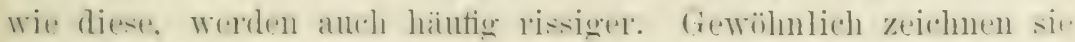
-ich durch Daturhattigheit ans. manche sind sehr zäh und elastisch.

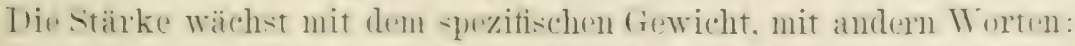
die schwersten Hälzer sind div stärksten. in den meisten Fällen anch die dautrhaftesten. Ehenso lässt sich die Regel autstellen. dass diejenigen harzlosen Hälzer am stärksten und dauerhaftesten sind. welche am wenigsten saft und Gummi enthalten. 
Die frische schnitflaiche soll fest, glatt mol seheinend, die Hobelsuäne soluen habburchsichtig sein. Ein ranhes, kreidenartiges Anselsen. sowohl der Schnittflache wie der Hobelspäne, ist das erste Anzeichen begimnender Terwesung. Keine losen Fasun dürfen sich hemmend vor dic arbeitende säige legen; die ganze Faserung muss fest zusammenhängen.

Dunkle Farbe ist im allgemeinen ein Zeichen von stirke und Daurhaftigkeit: je dunkler, desto stärker mol damerhafter.

Die Jahresringe sollen fest gepackt liegen. mol das Zellgenebe der Markstrahlen fest und dicht sein.

Ton einigen Fachlenten ist behauptet worden, dasjenige Nadelholz. welches den meisten splint und dasjenige Hartholz, welches den wenigsten splint habe. sei an danerhattesten. doch ist die Richtigkeit dieser Regel zweifelhaft.

Das Koplen an ein stimende sull einen klaren, sogenamnten gesumlen Klang herroruten. Die Tahresingr sollen ron ebenmässiger l)icke mul dir Fitsern gerad liegen. Frei soll das Holz von solchen Fehlern soin, wie tote Knoten. Risie. welche ron dex Marköhro austrahlen oder die ungekehte! Richtung pinnehmen. niter dinen Jahresing ron dem andern teilweise trennen. Fermer

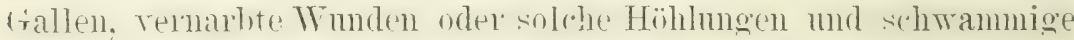
Stellen, welche die einsetzende Verwesung andeuten.

Blöcke sollen bei trockenem Wetter gepurift werden, da die Fenchtigkeit manche Fehler verdecht. Dit Farbe soll star und

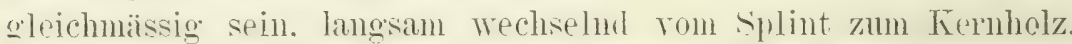
Trisse Flecken sollen nicht vorhanden suin: die trockene Fämle wird in ihrem Beginn durch gelbe Flecken angedeutet.

Bei Batu- mol ITerkholz soll der Splint als unbratrehbar ansgeschieden werden, mit Ansmahne ron Lanzen-hickory- Thnen und pinigen andern Hölzern, deren Splint so gut ist, wie das Kernholz, zuweilen sowar hesser. Der Mittelpunkt des Kermholzes reifer Bänme ist in der Regel ebenfalls anszuscheiden. da er zur baldigen Tertresung neigt. Unbranchbar ist das Holz ron Bämmen, welche nach ihrem ans irgend einer Trsalche erfolgten . Ibsterben gefïllt wurden.

Boden und Flima beeinflussen in hohem Grade den imneren Wert des Holzes. Als Regel wachsen die stärkisten mol schwersten Hölzer unter den Tropen. anf mässig fenchten Büden. 


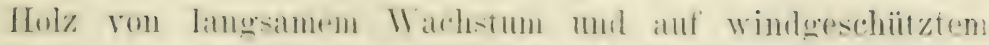

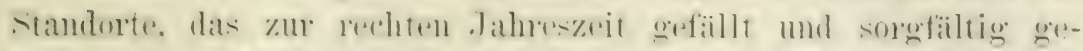
trocknet ist, bleibt frei ron Risisen und llählen. Risise. welche die

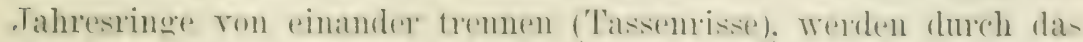

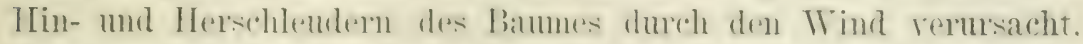
Längsrisse im stamme entstehen chenfalls durch den Wönd, häufiged jedoch dureh zu schmelles Trocknen. Im kalten Klima ruft der

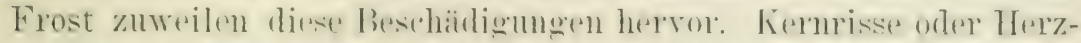

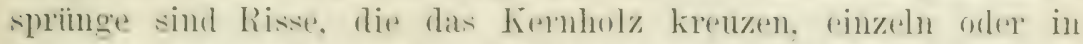
Gruplen: sie treten in allen IIolzanten anf. s. die betr. Figuren

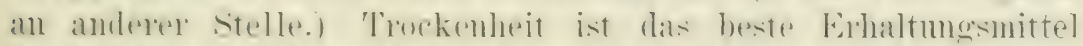

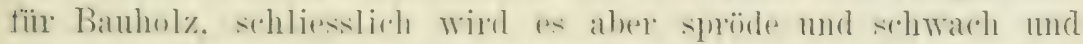
mag unter einer leichten Last zusammenbrechen.

IVasere hildet elonfalls ein Erhaltmesmitel. aher nur für

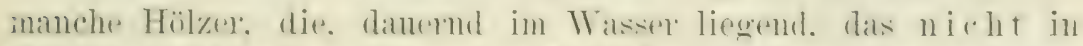

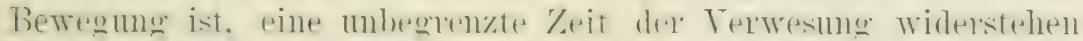
moigen. Die erste Wirkme des Wasiors ist die Anslangme de lïslichen stoffe. Wohei das holzige (xemehe unheschädigt bleibt. onder nur unbedentend angegriffen wird ron dem sauterstoff des.

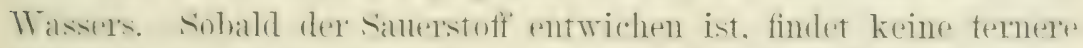

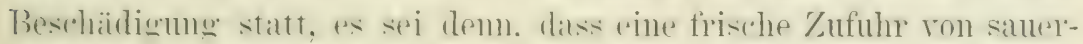

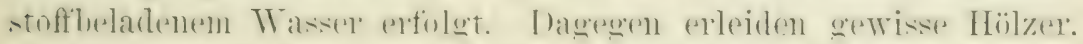
wic Birke. A-pe. Linde mol Weile, allmählich pine Verändepung im Wasser, die sie breiartig macht.

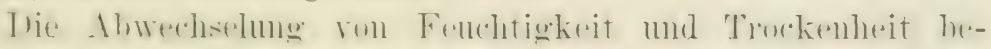

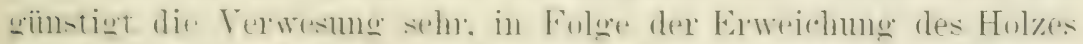

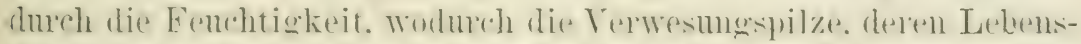

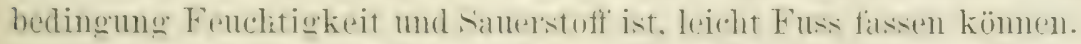

Eine damernde femelhte mul walme 'Temperatur luschlemiot lie Verwesung ebenfalls: am längsten widerstehen harzedehe Hölzer. weil der Harzenalt das Eindringen der Fenchtigheit rerhindert.

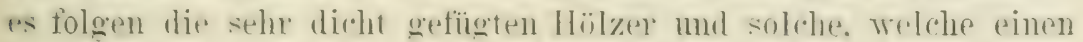
füulniswidrigen Stoff, wie Gerbsäure enthalten.

Ther splint ist leichter zur lerwesung gemeigt, wie das hernloolz, weil er mehr lösliche Stoffe enthält.

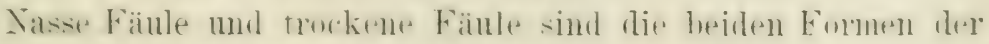
Terwesung.

Die nasse Fänle tritt in jedem Teile des Holzes anf, das

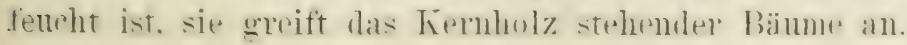




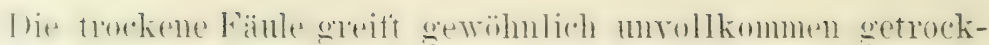
netes $\mathrm{Holz}$ an, das ron warmer Luft umgeben ist.

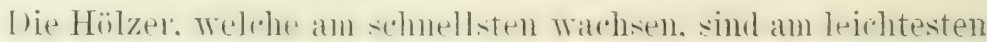

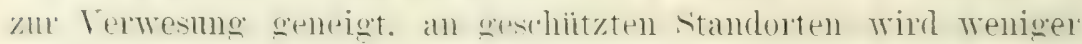
danerhaftes $\mathrm{Holz}$ erzengt, wie an ungeschïtzten.

Vicht erimdlich setrockntes Hol\%, mit Farbe hestrichen. wird bald ron der trockenten Fïnle angerriffen. weil die zuriekgebliebene Fenchtigkeit nicht verdunsten kann.

Cnter Fänle ist die Zexetzung dex ejweissähnlichen Stoffe der Saftbestandteile zu rerstehen. wobei sie die Holzfasern so stark rerändert. dass diese ihren Zusammenhang verlieren und zuletzt zu einer zerreiblichen Masse wroll. Dieser Torgang wird anch das Vermodern oder Verstocken des Holzes genannt.

Bei Torhandensein ron genügender Fenchtigkeit bildet sich ant der Oberfläche del sogenamnte sichwamm. Diese wohernden schwämme mul Pilze. von denen besonders der Hansschwamm 'Thetephora domestica). der Hansreisch (Boletus destructor) mo der Faltemreisch ("erulius rastator') auftreten. kündigen sich (nach Wagner's (hemischer Technologit) in ihrem Entstehen durch weisse. mehr und mehr sich rerorösermde. in tin graues Fasergeflecht ïbergelende Flecken an, die später in die tïr die einzelnen Arten. rharakteristische Massen ïbergehen; su lildet del Hansschwamm ästige, häntige Lagen. deren untere Seite aus rinem rioletten. tilzigen fiewehe besteht. Während der Rand ein fleckiges Ansehen hat. Ter Hansreisch mterscheidet sich durch einen mogleichen rmalichen und reissen Hut; ersoheint, oft weit verbreitet. das ganze Jahx hindureh an tenchten. solıdhatten stellen mol zwischen Batken: jung ist el weich und shimmelartig und schwitzt einen stark aber nicht mangenehm riechenden saft ans. Der Faltenreisch zeigt sich an abgestorlenen Banmstämmen, faulenden Balken und Brettern. Flach ansgebreitet wird er mehreve Fuss lang. schwammig Heischig. rostbram. ant dex unteren seite faserig und simmetähnlich: "r kriecht auf dem Holze fort und zerstört es nach mol nach vollständig. Meist wirkt er rersteckt. erscheint plötzlich. nuter den Dielen herrorlurechent. zerfrisst mal durchbricht sie. Ans den Diselen geht er in die Wände und greeift das Nanerwerk dergestalt an. dass el steine heht und zermalmt. In dieser Treise wird er zun Manerschwamm und entwickelt hier seine'n goführlichsten ('harakter. I)ie Lebenselemente des schwammes 


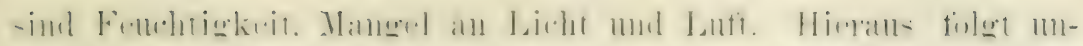

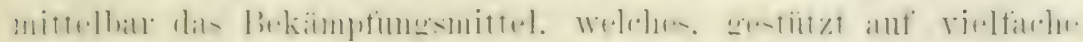

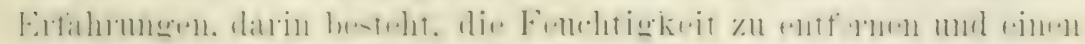
mum

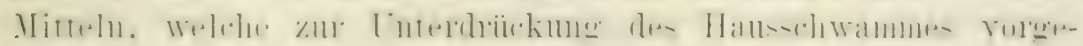

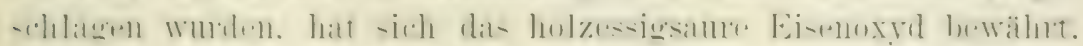

Fïr die zerstärenden Eintlïsse besitzen die verschiedenen

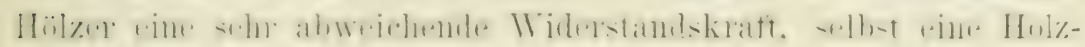

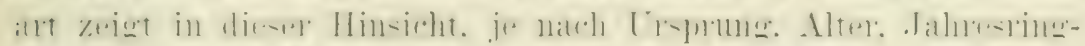

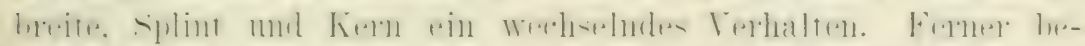

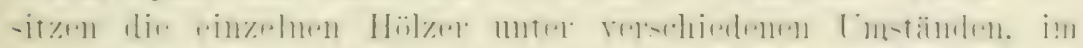

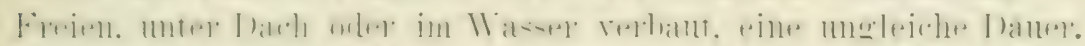

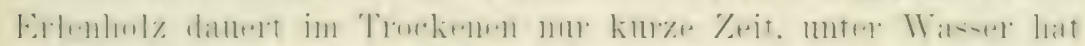

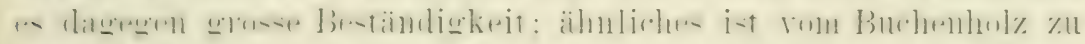

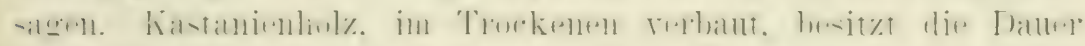
des Eichenholzes, nicht aber renn es im Trasser liegt.

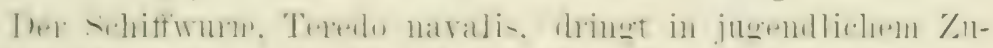

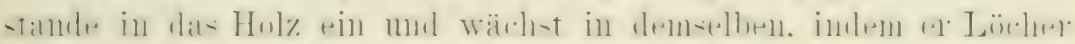

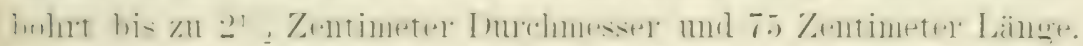

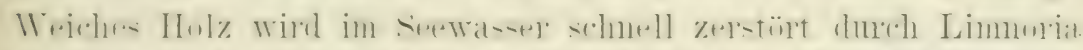

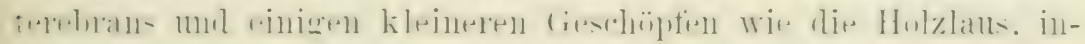
dem sie das Holz rundum der Jahresringe durchfiessen.

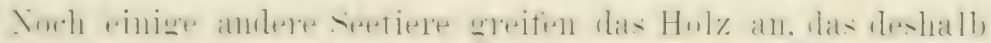

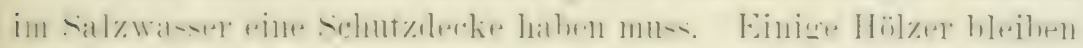

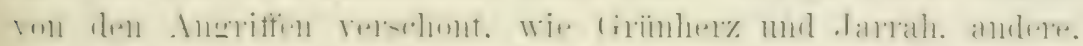

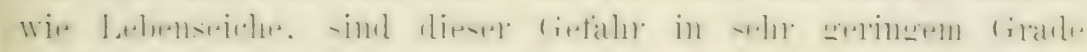
allsgesetzt.

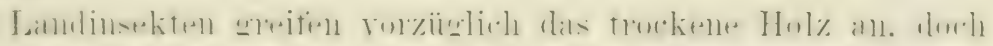

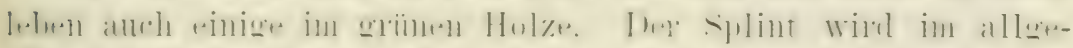

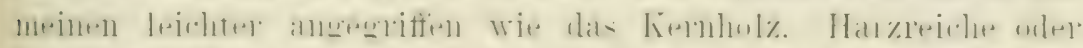

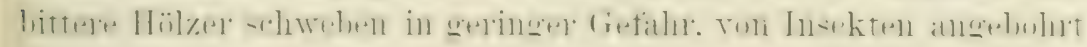
\%ir werden.

Ich komme num auf einen Gegenstand zu sprechen, ïber

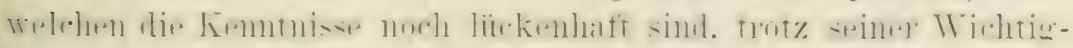

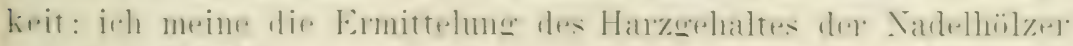

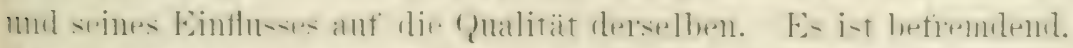

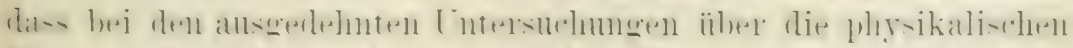

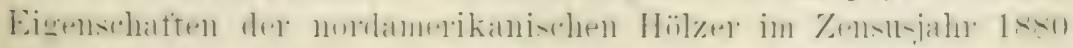

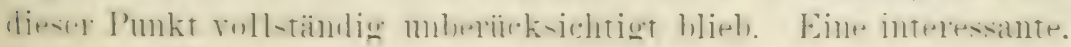




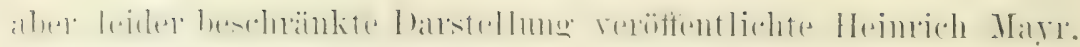
die ich hier tolgen lasse.

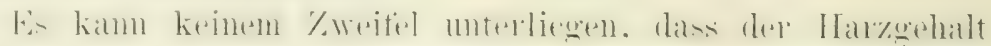

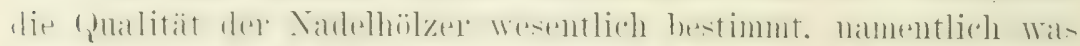

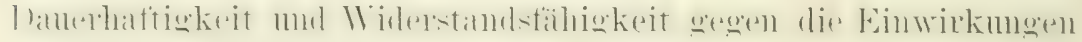

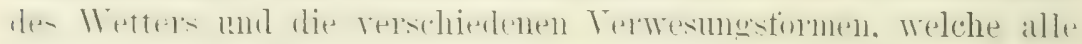
curch besondere Pilzarten entstehen. betrifft.

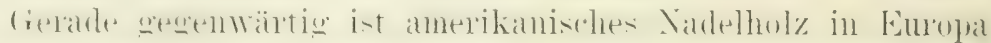

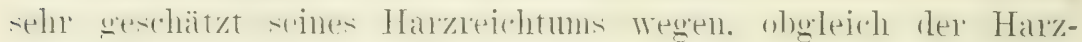

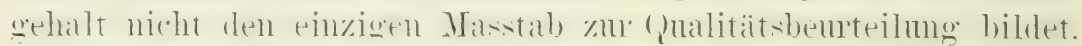
I as: Holz der Fdeltanme (Ahies pectinata). die weite Flächen in ent knltivierten Wablem bederkt. enthäl dar wenigste Harz von

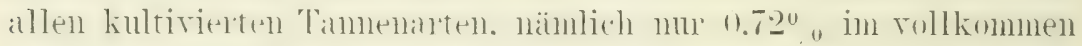

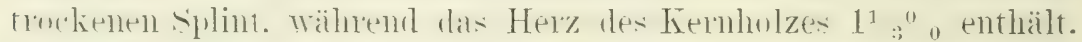

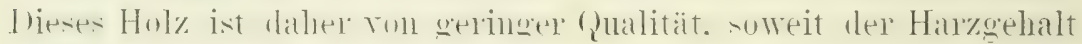

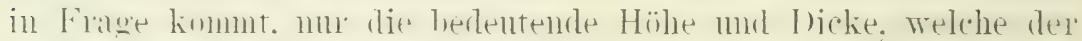

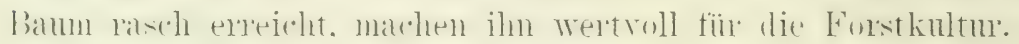

Die Fichte (Picea excelsa, Rottanne oder Schwarztanne),

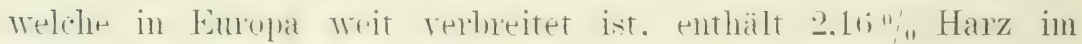

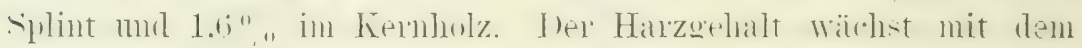
Alter des Baumes.

Ich fand als Resultat meiner Untersuchung: dass ein sehr

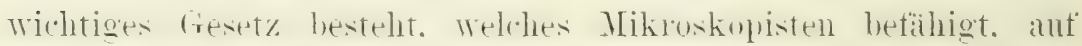
len ersten Bhick sulint vom Kernholz zu motercheiden. Nur das

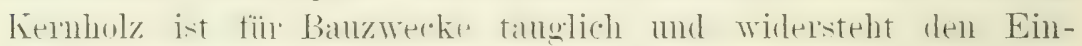

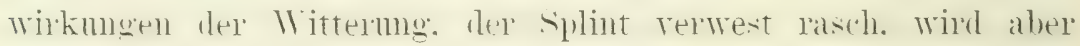

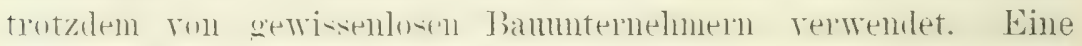

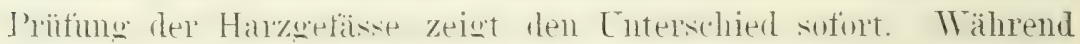

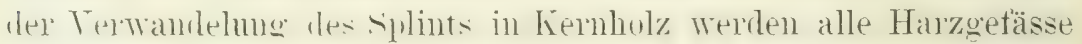

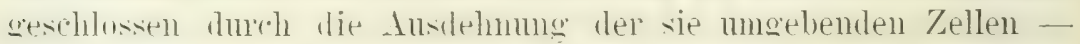
ein Forgang. Welcher selbst in den kleinsten Tadelholzstïcken zweifellos zal erkemnen ist: ein ähnlicher Torgang finclet im trachstum der Rinde statt.

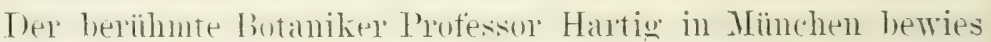
dureh sorgfältige lntersuchmgen das folgende Gesetz: Die Qualitat des Holzes aller Bimme erhöht sich so lange. als das jührliche Wachstmu pine steigermo Jahr tiir Jahr zeigt. Bis jetzt wurde welehrt. die Qualität des Nadelholzes sei mu so besser. je enger die Jahresinge liegen. das ist jedoch nur teilweise wahr. Je 


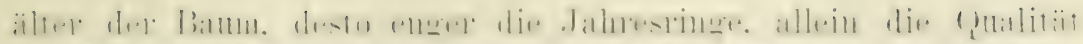

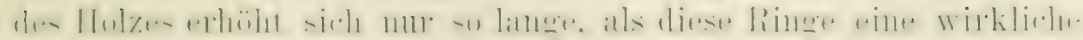

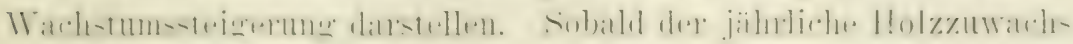

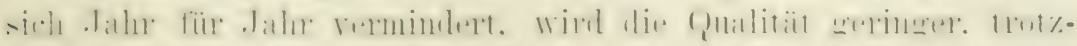

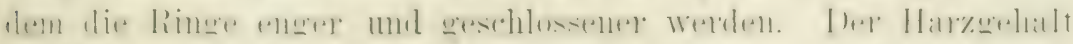

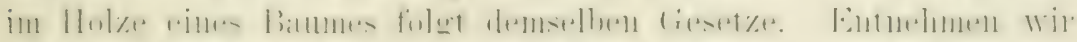

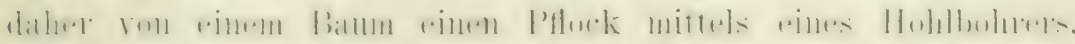

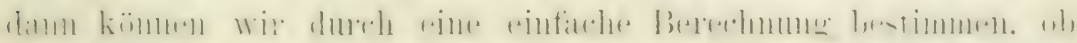

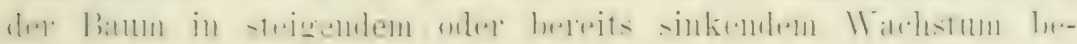
gniften ist. also an innerem Wert zu- oder abnimmt.

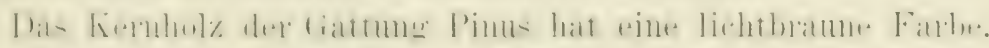

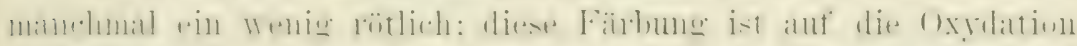

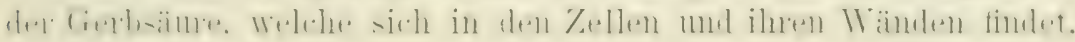
zmüickzutïilıen.

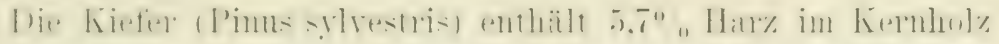

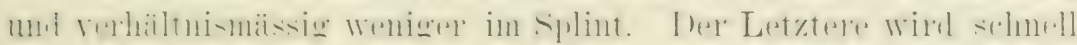

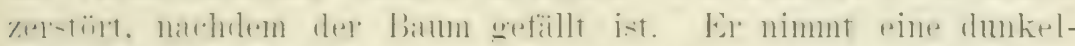

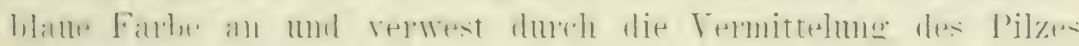
Ceratostoma piliferum.

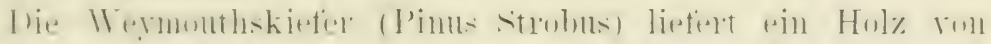

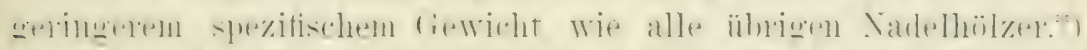

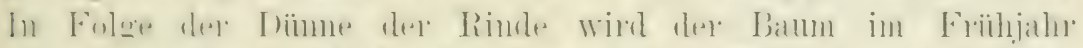

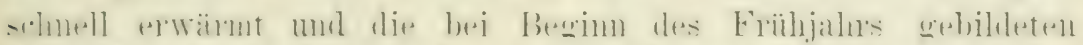

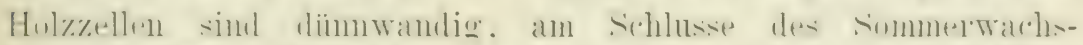

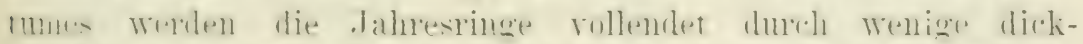

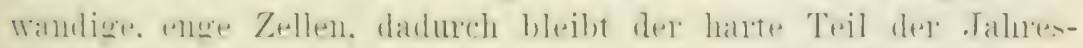

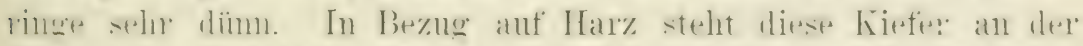

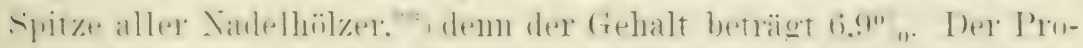

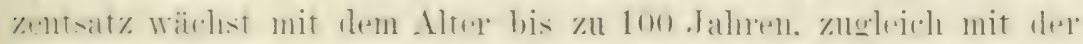

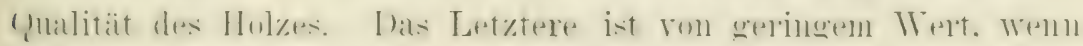
jung und der Feuchtigkeit ausgesetzt.

Irip Arr l'inus ('mubra). lo-inisch in den Alpen mul in

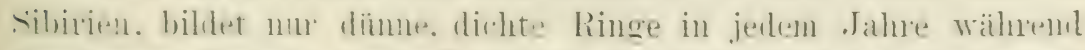

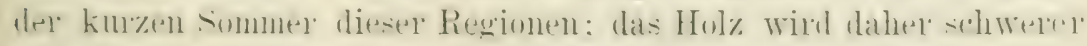
mul obgleich weniger harzreich, wertroller.

Die Lärche enthält $3.9 \%$ Harz.

\%) Das trifft nicht zu, wie aus einer unten folgenden Tabelle hervorgeht. Anm. d. V.

**) Dazu erlaube ich mir ein dickes Fragezeichen zu machen. $\mathbf{A n m}$. d. V. 
1)ie Domglastichle liefert rin Holz ron viel höherem spezi-

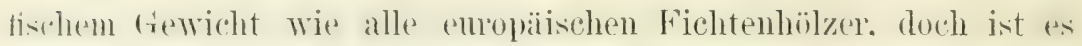
nidht so hoch. Wie dasjenige des Tänchenholzes; seine Qualitä wähst im Terhaltnis zur Breite seiner Jahrestinge - eine Thatsache. welche bis vor Kurzem als im Widerspruch mit den Erfahrungen mit emropäischen Nadelhölzen gehalten wurde.

Diese kurze Abhandlung zeigt. wie wichtig dieser tegenstand ist. aber anch wie viel noch zu seiner rollständigen Klatstellung zu thun ist.

\section{Einteilung des Bauholzes.}

Nach der ... Tentschen Banzeitmown wird das Bamholz eingeteilt wie folgt:

a. Ba $u$ holzstä $m \mathrm{me}$.

1. Extraordinästarke. ïber 14 Meter lang, mit mehr als 34 '/entimeter Zopfstärke.

2. Ordinarstarke, 12 bis 14 Meter lang, 29 bis 34 Zentimeter Zopfstärke.

8. Mittelban- oder Riegelholz, 9 bis 12.5 Meter lang; 21 bis 20; Zentimeter Zopfstärke.

4. Kleinbau- oder Spartholz. 9 bis 11 Meter lang. 15 bis 21 Zentimeter Zopfstärke.

5. Bohlstänme. 7 bis 9 Meter lang. 13 Zentineter Zoptstäre.

6. Lattstämme, 6 bis 7 Ieter lang, \& zentimeter Zopfistirle.

7. Schrammbanm- oler rindschäliges Holz. 9 his $12^{1}$ a Meter lang. 21 bis 26 Zentimeter Zopfstärke.

8. Sïgeblöcke (Abschnitte von Langhol\%). 5 bis s Meter lang, 36 bis 47 Zentimeter Zopfstärke.

Anmerkung: Zur Bestimmung des Holzgehaltes geschichteten Holzes rechnet man auf Zwischenräume 30 bis $40 \%$ des ganzen Schichthaufens und zwar setzt man 1 Kubikmeter des Schichthanfens bei :

Klobenholz gleich 0,7 Kúnikmeter Holz und 0,3 Inubilimeter (d. i. 30\%) Zwischenraum.)

Knüppelholz gleich 0,60 bis 0,65 Kubikmeter Holz und 0,40 bis 0,35 Kubikmeter (d. i. 40 bis $35 \%$ Zwischemraum.

$$
\text { b. Bearbeitetes Holz. }
$$

1. Terbandholz, eingeteilt in Ganz- Hall)- mo Kienzholz.

2. Schnitholz eingeteilt in:

Bohlen nicht unter 5 Zentimeter stark. 
13retter: ganze Spundbretter nicht unter halbe

Tischlerbretter

Schalbretter

Kistenbretter

Finuruir.

Latten: starke

schwache

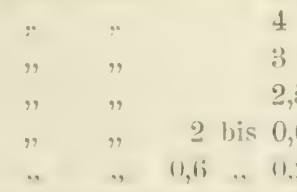

8 \%entimeter breit, 4 \%entimeter hoch.

$6, \overline{3} \quad, \quad, \quad 4,3$
45 \%entimeter stark.

4

3

$2,5 \quad$. $\quad, 9$

, ,

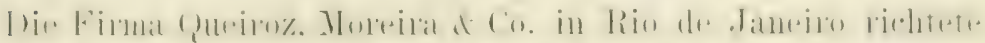

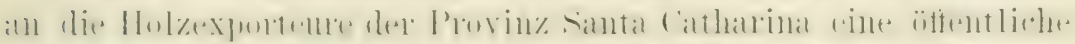

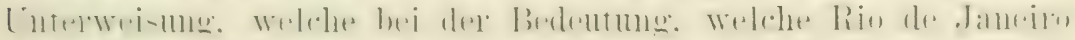

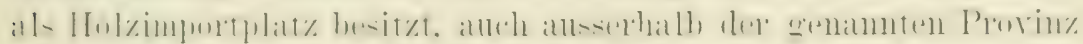

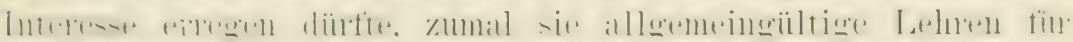

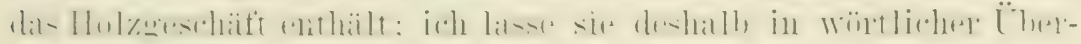
setzung folgen.

\section{Unterwe is un en}

iiber

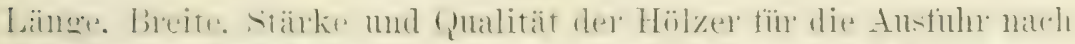

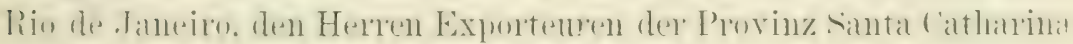
gewidmet ron

Q u e iroz, Noreia \& Co.

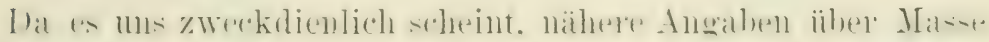

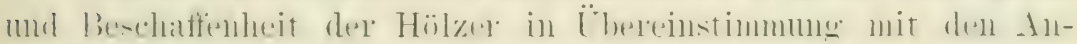

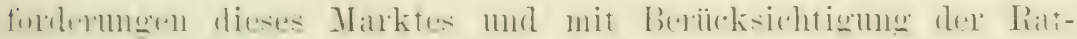

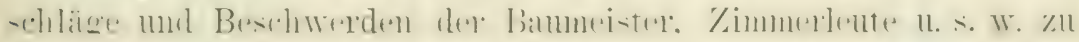

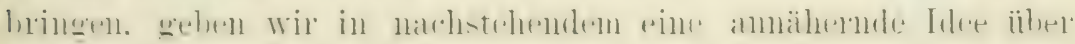
das tïir jede Sorte Zweckdienlichste.

Bretter

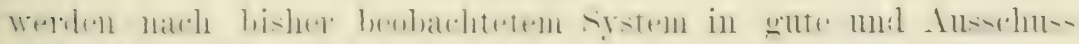

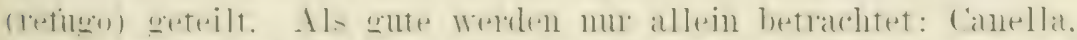

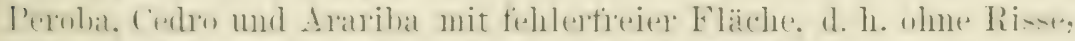

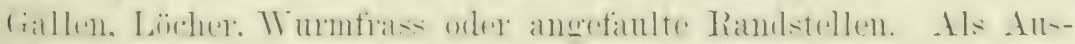

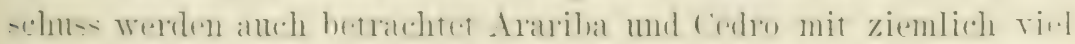

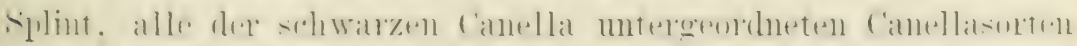

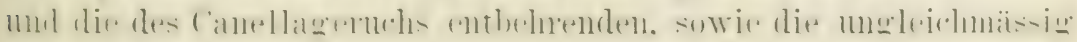
geschnittenen. zu dicken oder zu dimnen Bretter.

Das Brett, welches auf einer Seite fehlerfrei ist, aber auf

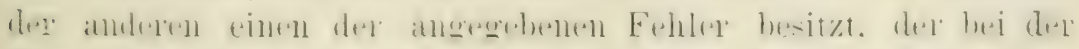

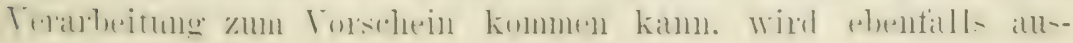
geschieden. 
Als Ausschuss werden alle Bretter von sogenamnten gesetzlichen Hölzern (madeiras de lei) und andere Sorten betrachtet, welche irgend einen Fehler besitzen, wemn sie nicht fanl, ron cinem Ende zum anderen gerissen oder sonst unbranchbar geworden sind.

Beim Schneiden ist das Abweichen der Säge zı rerhïten,

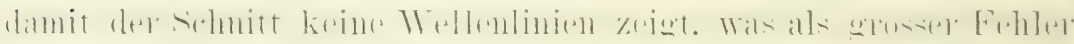
betrachtet wird.

Folglich ist die grösste Gleichmässigkeit md Genanigkeit die beste Empfehlumg für den erwälnten Artikel.

Breite Bretter.

Die geringste Länge ist 18 Palmos, bei 12 Zoll Breite und $1^{1 /}$ Zoll Stärke. Bei Cedro und Arariba ist $1^{1 / 2}$ Zoll vorteilhafter.

\section{Schmale Bretter.}

Der Unterschied zwischen breiten und schmalen Brettern besteht darin, das letztere nur 9 Zoll breit sind.

$$
\text { Paos (Terbandholz). }
$$

Geringste Länge 20 Palmos, bei 6 Zoll Breite und 4 Zoll

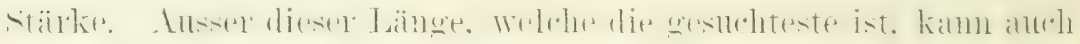
zu 22 und 25 Palmos, in kleinen Posten, geliefert werden.

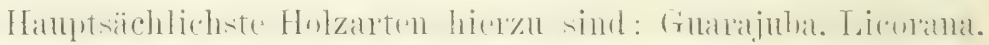

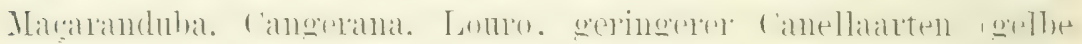
Capitão-mór, Burra n. s. w.). weisse Peroba und rote Oleo.

Die Blöcke ron schwarzer Canella und roter Peroba, welche

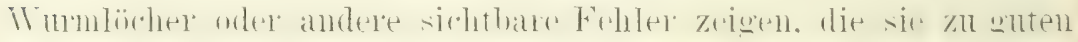

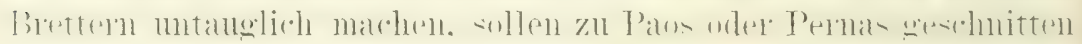
werden.

\section{Pernas (Verbandliolz).}

Über diese Holzsorte, für welche das ïber Paos Gesagte gilt.

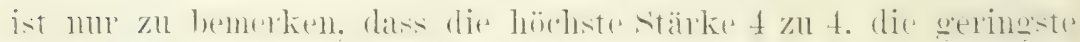
$3^{1}$ a zu 4 Zoll ist. Länge und Qualität sind wie die der Paos.

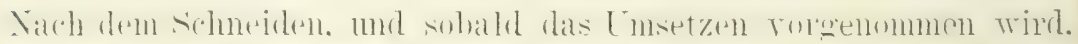

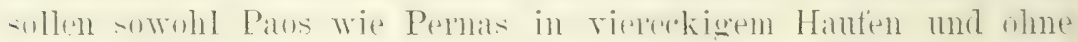

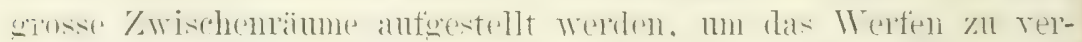

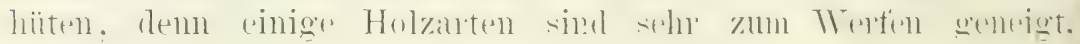
während sie trocknen. 
Boli le 11 .

Hiel ist ror allen l)ingen zu benerken, dass zu dieser boute mu wan\% fehlentieies Holy genommen werilen darf. weil sie zu

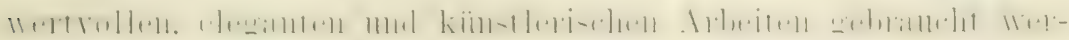
den; sie dan' ron C'ello. Alariba mud Cangerana sein.

Cedro revesso (wilerharig'). anch batata genannt. dart' nicht

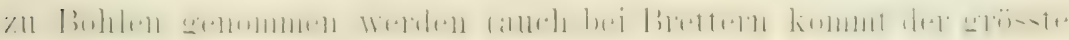
Teil zum Ausschussi. sondem es muss hierzu das beste Cedroholz.

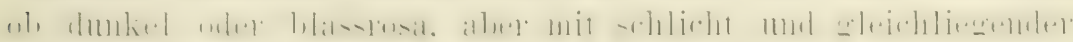
Faser. ansoewälilt werilen.

Arariba ron beilen sorten. rot und gell. olne sulint und

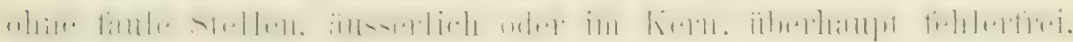
ist ein seln geschätztes Holz.

Cingelana wird zu verschiedenen \%wecken seln gescluät mul verablocitet als Paos, Pernas und Bohlen.

¿̈ber Linge, Breite und Stäke lnaben wir keinerlei Ändelungen zu erwähnen; es bleiben $3 \times 12>18$ die breiten. und $3>9>18$ die sehmalen wie bisher.

\section{Bemelkul gren:}

Alle Hölzer miissen rollkantig sein.

Das Mass nach Zoll bleibt wie bisher das portugiesische.

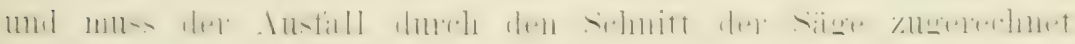
werlen. damit die Stärke genau bleibt.

Bei der Länge der Hölzer werlen Bruchteile ron weniger wie 2 Palmos nicht bericksichtigt. Wenn also ein Stïch $21^{1} / 2$ Palmos misst. wird es mu zu 20 Palmos herechnet.

$$
\text { šchlıs. }
$$

Die Nichtbeachtung dieser Torschriften lat Tiele. die sich

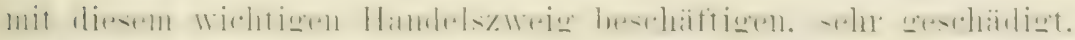

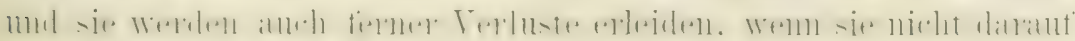

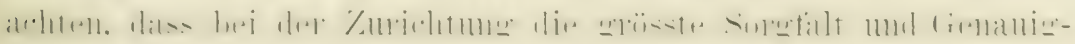
keit herrscht.

Die Bauten mehren sich; die sogenannten Corticos und alle

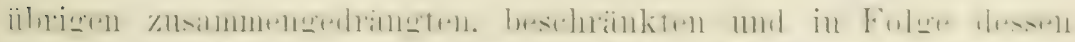

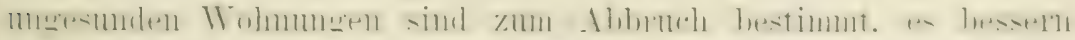

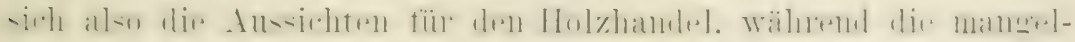

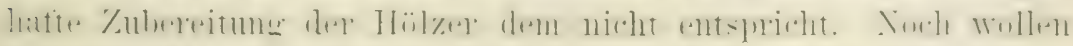

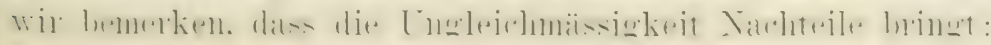




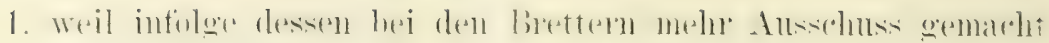
und der Wert dieser wie der Paos. Permas md Bohlen rermindert wixd;

2. weil sich dadurch der Verbrauch zum Vorteile des T'ammen-

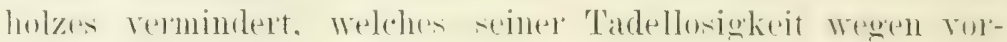
gezogen wird;

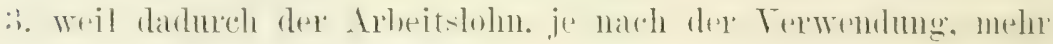
oder weniger erhöht wird.

Yon den oben angefiihrten Hölzern habe ich nur iiber die

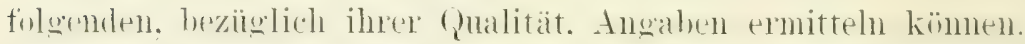

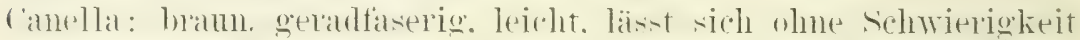

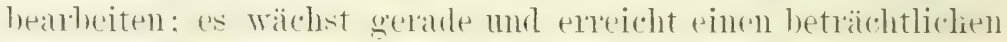
Lmange. Verwendung zu Zimmermannsabeiten und Doekplanken; wird nicht als dauerhaft betrachtet.

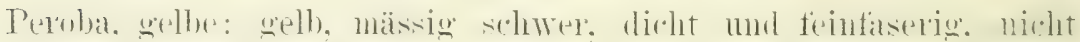

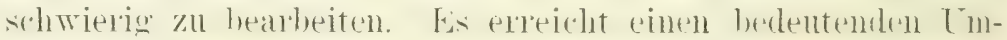
fang, dient zu Hausbanten und Möbehn und gilt als sehr

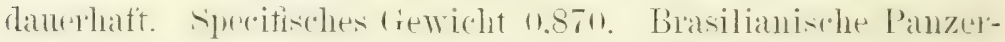
schiffe wurden ron diesem Holz erbant, da es sich gut mit Eisen verträgt.

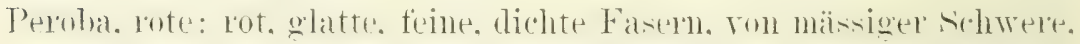
es hat eine entfernte Ähnlichkeit mit rotem Cedernholz.

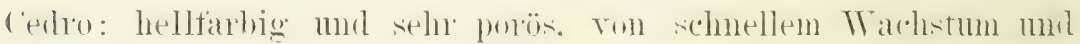
geringer Qualität.

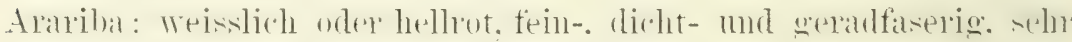
leicht, erreicht nur einen mässigen Umfang und wird in der Tischlerei verwendet.

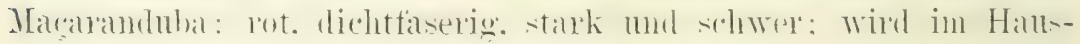
und Schiffbau gebrancht.

\section{Die Stiirke des Holzes.}

D) verschiedenen Nutzhölzer sehwanken answerordentlieh in ihreg stäre mul sellset in derselben Holzart kommen heträchtlicht

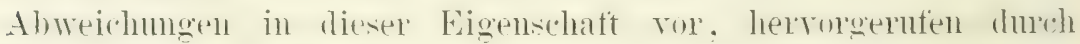
Tonterschiede in Alter. in den klimatischen und Bulenrerhilltnissen. wie ïberhant in allen ant die Entwickelung des Bammes sirh geltemd machenden Finfliisse: das meln wher minder soretailtien 


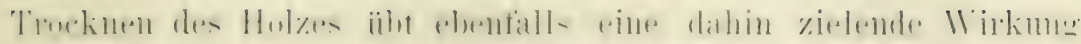

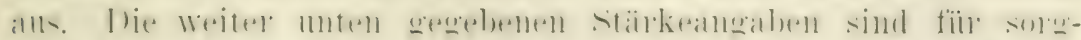

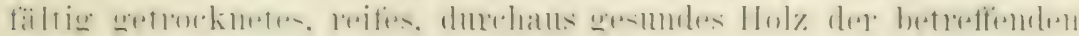
Bammat zu verstehen.

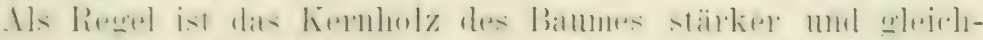

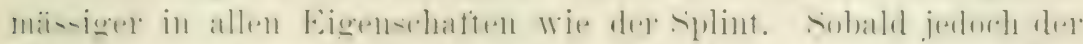

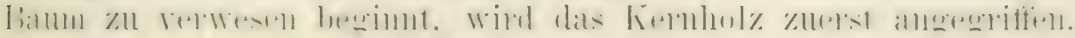

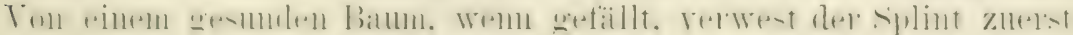
mol zwar viel schmeller wie das Kermholz.

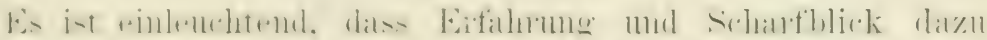

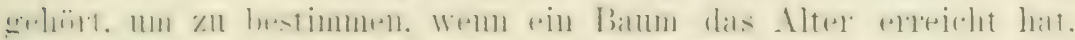

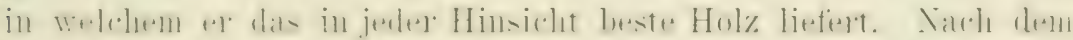

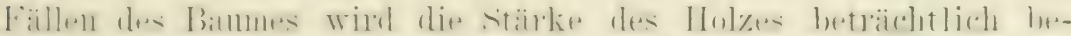

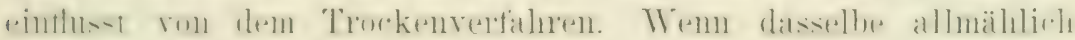

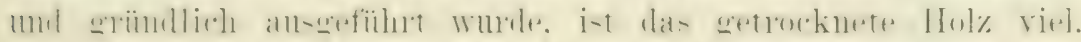
zuweilen un das doppelte stärker wie das griine.

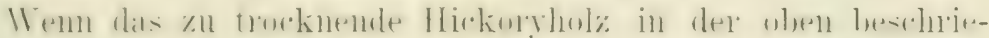

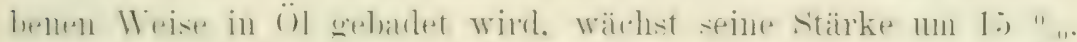

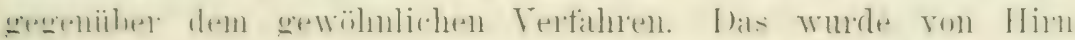

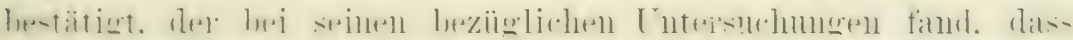

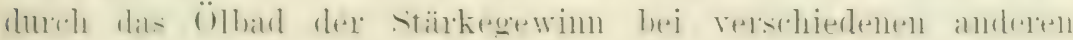
Hölzern 10 bis $20 \%$ betrug:

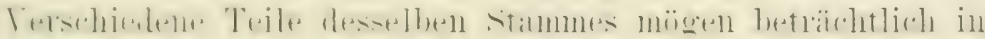

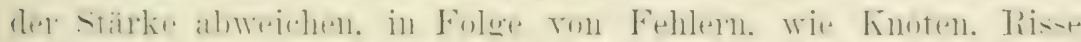

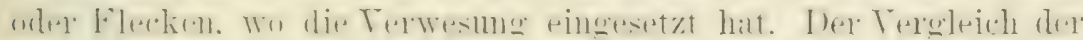

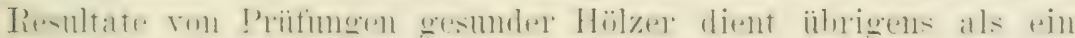

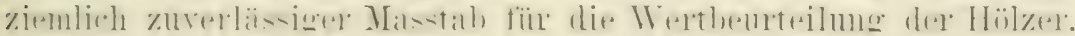
relche man zu benutzen beabsichtigt.

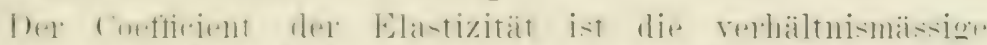

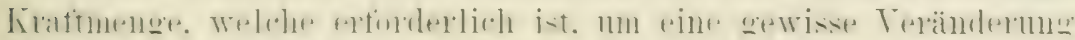

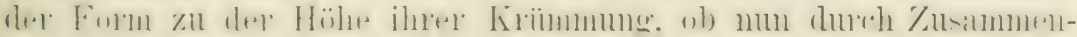

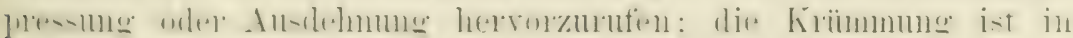
allen Fällen innerhall) der Grenzen der Elastizität.

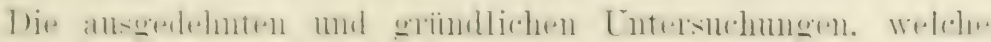

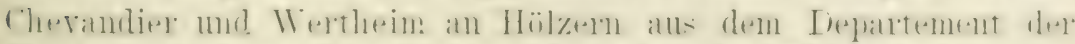

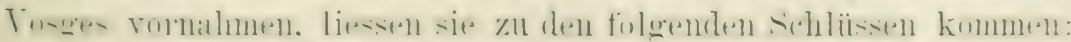

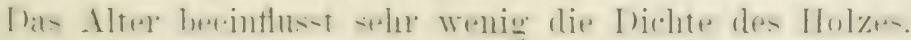

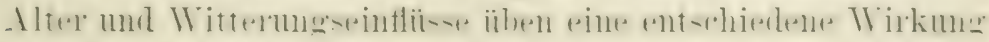
aif lie Terlbindungrestigkeit. 
1)as Alter vermindert den Coefficient der Elastizitiat, nachdem der baum die Reife ibersehniten hat.

biamme, welche and trockenem Boden, in latgen, often mach Norden. Nordosten mu Nordwesten wathsen. liefern Holy, welches den höchsten foeficionten hat. Nasser oder smmpfiger boden. in Lagen nach süden often, bringt Iloly hervor, das den niedrigsten conefticientem hat.

Die Jahnesteit, in welcher die Trallung stattand, hat keinen erkembatren Winfluss ant den Goofficionten.

To diumer in Nadelhölzern die Jahrestinge sind. desto höher

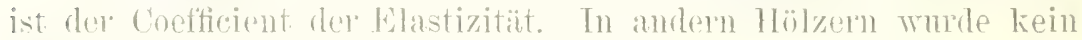
Eintersehied ans diser Ursiche entrleckt.

Holz hat keine lestimmte Grenze der Elastizität. Dieselbe

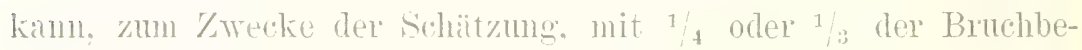
lastung angonommen werden.

Is folct num eine ans den Resultaten verschiedener T'ntelsuchungen zusammengestellte 'T'abelle, die melu' Wert besitzen wiirde. wem die L'riffer mehr sorefalt ant die genanere Bestimmmg der Hölzer rerwandt hätten. Beispielsweise: Fichte aus Ten-Fingland. Diese Stantengrupe besitzt mehrere Fichtenarten. Trelche ist gemeint? Ulme - welche Ulmenart? n. s. t.

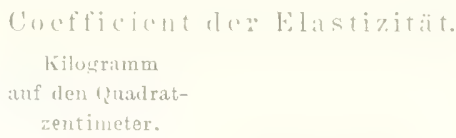

Kitoirianm anf den madratzentimeter.

Esclice $11 * .480$

biuchstrol\%

Katstanio

Ilune

Kiefer, bultiscle

Fichte ans Non Eisgland

Lïleche

Pockloly. $\left.12(i, 5) \frac{1}{2}\right)$

(1). 1.90

$1(1), 450$

$120,5 \pm 0$

$8 \pm, 3(i)$

(1), 4 : i)

70,300
Maluagui

Eiche (Quereus sessiliflom ) 119,510

Peehlitef'r"

hote kitere

133,570

$126,5 \pm 0$

Gelbkiefur

112,400

Wermouthskiofer" (I'inus Strobus)

Teak, indisches

11 eirle.
70,380

$1 \pm 7,030$

98,420 auf ileu Quadrat-
zentimeter.

() $S,+20$

Der Elastizitatscoefficient der nordamerikanischen Hölzer, wie ar im Zensusbericht niederoleot ist. wird weiter unten in rinor besonderen 'labelle gegeben.

Die '/ugfestigkeit ist von vielen Nutzhölzern sehr sorgtïltig. "mittelt worden, doch ist auch hier der obige Tor'murf zu wiederIolen. Der Modulus der Zugtestigkeit ron jedem Stoft ist die In dere Zugkratt in Kilogramm, welche exforderlich ist. um 
eine stange von einem Qubdratzentimeter Durchnesser an der Brubstelle anseinander zu reissen.

Die folgende 'labelle ist ans den Resultaten rerschiedener'

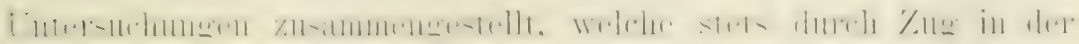

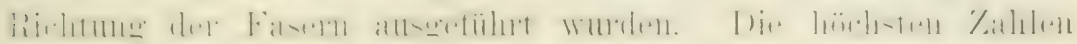
sind für reifis, sorgtältig getrocknetes Kemhol\% zu verstehen.

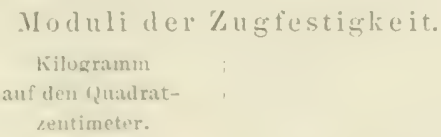
kilogramm atu? then quadrat- zentimpter.

lisclic

7(1) 3 bis 105 อั

Birlie, selıw:arze

4!) .. 703

finclue, amerikanische

5) 6 i2 .. $84 t$

buelisholz

$703 \quad . \quad 1055$

'l'anne, californische

$81 t$. $98 \pm$

Ceder von bermuda

281.527

Guadaloupe

İastanic

Rosshastanie

Cyplesse

Elmes

352,668

4!) . . 738

$562 . \quad 8 \pm t$

$281 \% \quad 422$

562 " $91 \pm$

Fichte aus Neu-England 352) "

liefer, biltische

¿5े. .. 879

422 .. 6333

lirüılı⿻上丨.

703 .. 10 อัว

Hicliory

Lanzenhol\%

Iairche

l'ockliolz

703 "98t

562.1055

12. : 703

$703: 84 t$
Akazie (Robinia I'seudnacacia)

703 bis 1650

Jahngoni vou Honduras 350 ..

bust. spanisch. 062 .. 1050

Ahorn

Lebenseiche, amerikan. 703

Weissciche,,$\quad 703$

Wintereiche $\quad 633$.. 841

Douslastanne $\quad(933), 984$

Biruholz $\quad 492,703$

I'echlicter \$ 562

liote Kiefer $\quad 352$ :

Weymouthsliefer" 362

Gelbliefer $\quad 352$. $84 t$

I'flaumenlioly $\quad 492 \quad$ : 703

Pappela $\quad$ ti?

'Teak 703 .. 1055

Walluussholz, schwarzes ö 6 ?

Weide 703

Guer den Faseru ist die Zugfestigkeit greringer, mun ${ }^{1 / 10}$ bis 1: vo fïr Nadelhölzer und $1 / 6$ bis $1 / 4$ füı harte Hülzer, wie die ge-

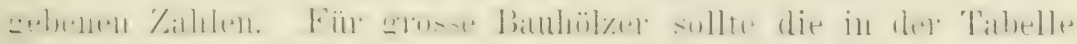

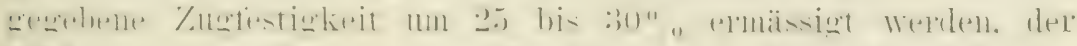

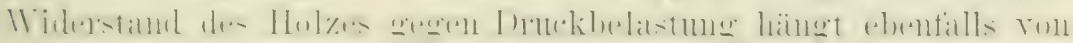

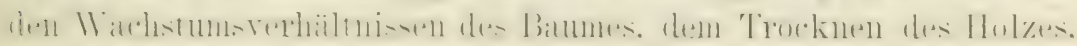
seiner Form und Grösse alb.

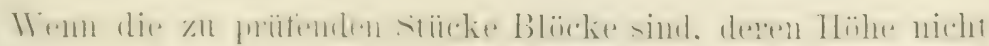

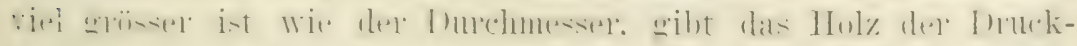

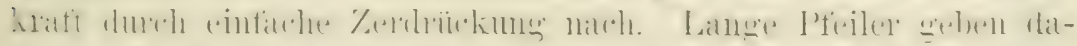

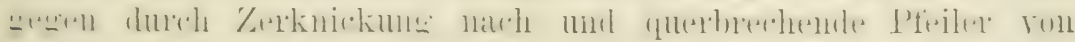

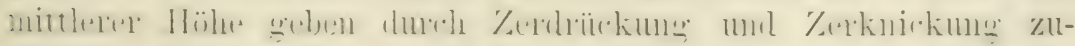
gleich nach. 


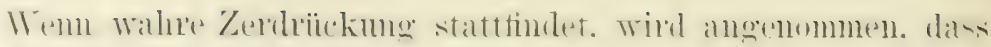

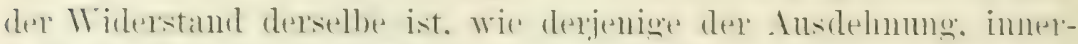

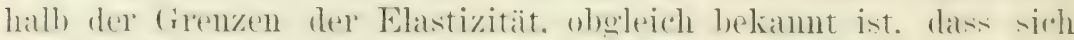

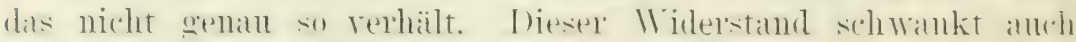
mit der Grösse des Durchmesser's.

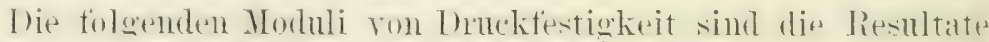

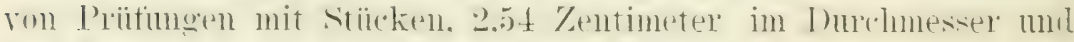

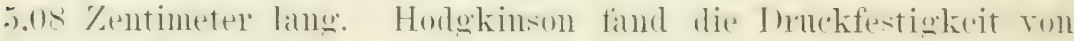
t'muchtem Holz lä̈utio weniger demn die Hälfte. wie ron trockenem.

Ioduli der Druckfestigkeit in gleicher Richtung mit den Fasern.

\begin{tabular}{|c|c|c|c|c|c|}
\hline & $\begin{array}{r}\text { Kil } \\
\text { auf der } \\
\text { zen }\end{array}$ & $\begin{array}{l}\text { gramm } \\
\text { Quadrat- } \\
\text { timeter. }\end{array}$ & & $\begin{array}{r}\text { Kilo } \\
\text { auf den } \\
\text { zent }\end{array}$ & $\begin{array}{l}\text { gramm } \\
\text { Quadrat } \\
\text { timeter. }\end{array}$ \\
\hline Erle & 422 & bis 492 & Ahorn & 352 & bis $42 \cdot 2$ \\
\hline Esche & 323 & . 562 & Mahagoni, sparisches & 492 & $\because . \quad 562$ \\
\hline Buche & อ̃ 62 & .. 633 & Wintereiche & 457 & .703 \\
\hline - Birke, amerikanische & 422 & $" 703$ & Lebenseiche, amerikan. & ว62 &.$\quad 703$ \\
\hline$" \quad$ europäische & 352 & . 457 & Weisseiche, & 587 &.$\quad 662$ \\
\hline Buchsholz & $56 ?$ & .703 & Birnholz & 537 & \\
\hline Ceder & 281 & .457 & Rote Kiefer & 422 & . 527 \\
\hline Kinschholz & 352 & $\therefore 457$ & Weymouthskiefer & 211 &..$\quad 422$ \\
\hline Kastanienholz & 281 &.$\quad 337$ & Gelbkiefer & 457 & .703 \\
\hline Ulme & 562 & .703 & Teak & 122 & $\therefore 70: 3$ \\
\hline Grünherz & 703 & .. 984 & Wallnussholz, schwarzes & 394 & " 492 \\
\hline Hickory & 562 & . 689 & weisses & 527 & r. 633 \\
\hline Lärche & 211 & : 387 & Weide & 211 & $\because \quad 422$ \\
\hline Aliazie, falsche & 527 & .. 668 & Douglasficlite & $6 \pm 7$ & .. 808 \\
\hline Pockholz & ธ62 & .. 675 & & & \\
\hline
\end{tabular}

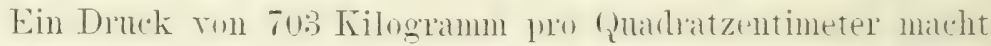

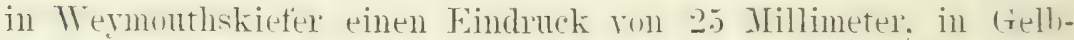
kieter ron 1 dillimeter mo in harte Hölzer zu einer katum bemerklichen 'Tiefe.

Die folgenden Moduli der Bruchtestigheit sind bei Prütumen von Hölzern in guter Beschaffenheit ermittelt worden.

\begin{tabular}{|c|c|c|c|}
\hline & $\begin{array}{l}\text { Kilogramm } \\
\text { auf den Quadrat- } \\
\text { zentimeter. }\end{array}$ & & $\begin{array}{l}\text { Rlogramm } \\
\text { den (2uadrat- } \\
\text { entimeter. }\end{array}$ \\
\hline Esche & 844 & Ceder, nordamerikanische & 562 \\
\hline Buche & 633 & Kastanienholz & 492 \\
\hline Birke, amerikanische & 668 & Ebenholz, westindisches & $105 \bar{~}$ \\
\hline Buchsholz & 598 & Ulme & ว์62 \\
\hline Ceder, westindische & 562 & Fichte ron Neu-England & 492 \\
\hline
\end{tabular}




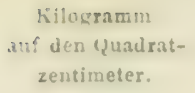

Fichte von liight

Sorwegen

(ivinher\%

Lanzenholz.

Lairche, curopaiische amerikanische

['ackilioly.

Sliazie, falsche

Mathasoni, spanisches von Hondur:us

Alorn

\section{2}

492

$70: 3$

1055

762

703

844

814

562

703

562 kilogramm

auf den (Quadratzentimeter.

Eicle von Canada

703

700

Lehenseiche, amerikanisclıe 844

Weisseiche, 773

Pechkiefer 562

liote Kiefer

Gelbkiefer $\quad 492$

'Teak 1050

Wallnussholz, schwarzes 844

Weide

492

Douglastichte

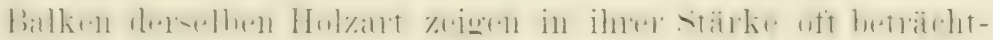

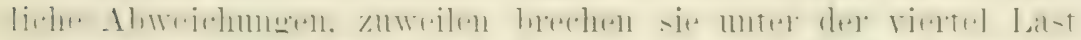

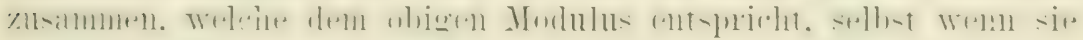
angenscheinlich gesund sind.

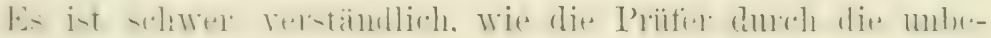

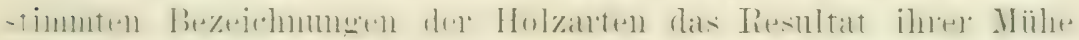

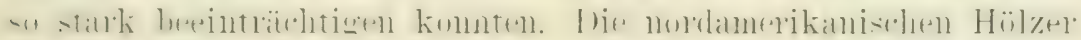

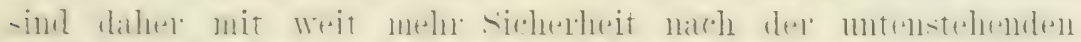

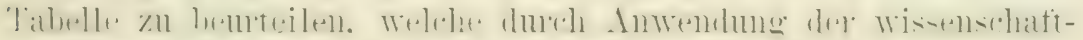

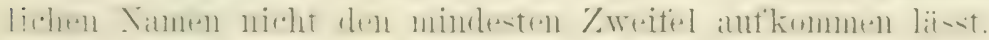

\section{tustralische Hölzer.}

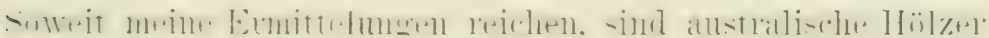

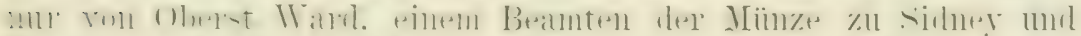

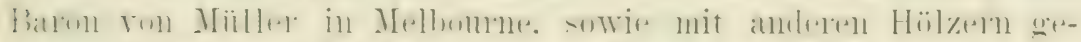

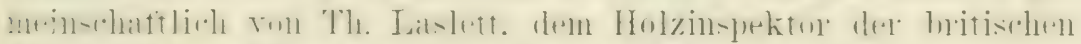

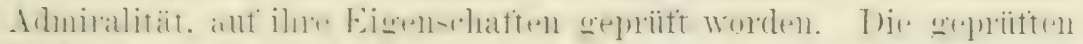

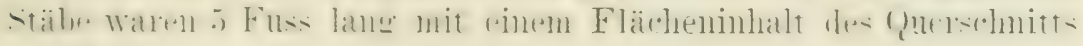
ron 2 Quadratzoll englisches Mass. 
Resultate des Oberst Ward.

\begin{tabular}{|c|c|c|c|c|c|c|}
\hline & & $\begin{array}{l}\text { Spezifisches } \\
\text { (iewicht. }\end{array}$ & $\begin{array}{c}\text { Hüchstmass } \\
\text { und der } \\
\text { wihrend die } \\
\text { unbecinträcl }\end{array}$ & $\begin{array}{l}\text { es Gewichts } \\
\text { iegung, } \\
\text { Elastizitiit } \\
\text { tigt blieb. }\end{array}$ & $\begin{array}{l}\text { Gewicht, } \\
\text { erforderlich } \\
\text { zum Bruch }\end{array}$ & $\begin{array}{l}\text { Beugung } \\
\text { and der } \\
\text { Elastizitäts- }\end{array}$ \\
\hline & & & $\begin{array}{l}\text { Gewisht } \\
\text { in } 1 \text { fund. }\end{array}$ & $\begin{array}{l}\text { Biegung } \\
\text { in } / \text { oll. }\end{array}$ & in Pfund. & in Zoll. \\
\hline Eucalyptus 1 & leucoxylon & 1,167 & 1605 & 1,33 & $203 \div$ & $1,4 \tilde{i}$ \\
\hline$"$ & cebra & 1,111 & 1456 & 1,07 & 1904 & 1,87 \\
\hline$"$ & capitelata & 0,922 & 925 & 1,15 & 1512 & 2,03 \\
\hline.. & virgata & 0,964 & 924 & 0,97 & $120 t$ & 1,97 \\
\hline$"$ & hemiphlora & 1,172 & 1400 & 1,09 & 1792 & 1,90 \\
\hline$"$ & saligna & 0,989 & 1232 & 1,05 & 1680 & 2,45 \\
\hline .. & hömastoma & 1,080 & 784 & 1,01 & 1204 & 2,03 \\
\hline .. & rostrata & 0,942 & 1106 & 1,16 & 1327 & 2,09 \\
\hline .. & pilularis & 0,990 & 980 & 1,35 & 1232 & 2,92 \\
\hline.. & longifolia & 1,078 & 924 & 1,25 & 1176 & 1,82 \\
\hline .. & sideropholia & 1,146 & 1251 & 1,02 & 1526 & $2,03^{3}$ \\
\hline .. & amygdalina & 1,085 & 896 & 1,09 & 1078 & 1,69 \\
\hline.. & piperita & 0,897 & 747 & 1,28 & 840 & 1,83 \\
\hline " & teretic ornis & 1,131 & 1139 & 0,98 & 1400 & 1,43 \\
\hline Doryphora s & sassafras & 0,659 & 686 & 0,09 & $85 \check{4}$ & 0,187 \\
\hline Eugenia mys & yrtifolia & 0,731 & 765 & 0,97 & 1064 & $2,0 \mathrm{~s}$ \\
\hline Acacia decu & urrens & 0,717 & 1269 & 1,04 & 1549 & 2,35 \\
\hline Cedreda aus & stralis & 0,444 & 560 & 1,14 & 728 & 1,97 \\
\hline Grevillea rol & obusta & 0,564 & 一 & - & 728 & - \\
\hline Tristania cor & onferta & 0,977 & 850 & 2,01 & 1064 & 3,00 \\
\hline Flindersia au & australis & 0,936 & 1022 & 1,14 & $1016^{\circ}$ & $2,2 \tilde{z}$ \\
\hline
\end{tabular}

Resultate des Baron von Müller und J. G. Lühmann. l)ie Stäbe waren 2 Fuss lang, mit 2 \%oll (quadratfläche. engliches Mass.

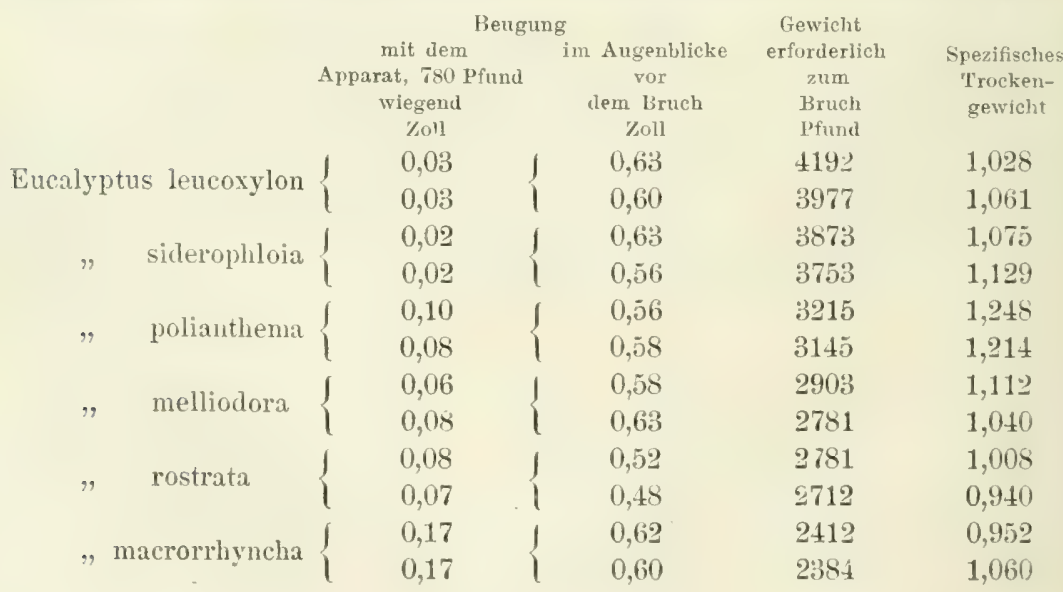




\begin{tabular}{|c|c|c|c|c|c|}
\hline & & $\begin{array}{l}\text { mit dem } \\
\text { Apparat, } 750 \text { Pfund } \\
\text { wiegend } \\
\text { \%oll }\end{array}$ & $\begin{array}{c}\text { gung } \\
\text { in Augenblicke } \\
\text { vor } \\
\text { dem liruch } \\
\text { Zisll }\end{array}$ & $\begin{array}{l}\text { Ciewfoht } \\
\text { erfurilerlich } \\
\text { zum Bruch } \\
\text { Ifund }\end{array}$ & $\begin{array}{l}\text { Spezifisches } \\
\text { T'rockengewicht }\end{array}$ \\
\hline \multirow{2}{*}{\multicolumn{2}{|c|}{ Eucalyptus Cimmuii }} & 0,12 & 0,75 & $23 \cdot 7$ & 0,950 \\
\hline & & 0,14 & 0,75 & 2268 & 1,021 \\
\hline \multirow[b]{2}{*}{ " } & \multirow{2}{*}{ Stuartianat } & 0,12 & 0,51 & 2425 & 1,010 \\
\hline & & 0,14 & $(0,5)$ & 2170 & 1,001 \\
\hline \multirow[b]{2}{*}{$"$} & \multirow{2}{*}{ vininalis } & $0,1 \geq$ & 0,63 & 2384 & $0,95+$ \\
\hline & & 0,12 & 0,70 & 2195 & 0,916 \\
\hline \multirow[b]{2}{*}{, } & \multirow{2}{*}{ gronioc:alyx } & 0,16 & 0,50 & 2209 & 0,948 \\
\hline & & 0,20 & $0, \overline{5} 8$ & 2050 & 0,937 \\
\hline \multirow[b]{2}{*}{$\because$} & \multirow{2}{*}{ amygdalina } & $(0,12$ & 0,65 & 2195 & 1,0 tう \\
\hline & & 0,12 & 0,70 & 2132 & 1,076 \\
\hline \multirow[b]{2}{*}{$"$} & \multirow{2}{*}{ obliqua } & 0,12 & 0,50 & 2053 & $1,04 \tilde{}$ \\
\hline & & 0,14 & 0,48 & 1776 & 0,935 \\
\hline
\end{tabular}

Nordamerika:

Carya, rerschicel, Arten

Quercus aliba

Australien:

deacia melanoxylon | $0,08 \quad$ I 0,50

$0,08 \quad\{0,5 \pm$

Iell-Seeland:

Dammara australis $\left\{\begin{array}{l}0,08 \\ 0,08\end{array} \quad\left\{\begin{array}{l}0,42 \\ 0,42\end{array}\right.\right.$

Eullopa:

Pints sylvestris

$$
\left\{\begin{array} { l } 
{ 0 , 1 7 } \\
{ \mathbf { 1 } }
\end{array} \quad \left\{, 21 \quad \begin{array}{l}
0,70 \\
0,48
\end{array}\right.\right.
$$

3579

0,785

0,808

0,716

0,669

2192

0,616

0,613

$2261 \quad 0,613$

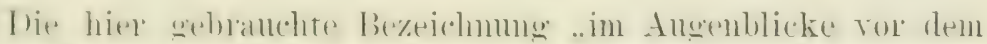

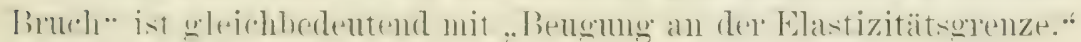

Neuseeländische $\mathrm{Hölzer.}$

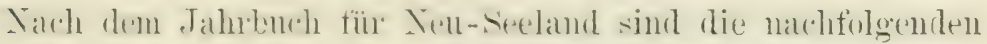

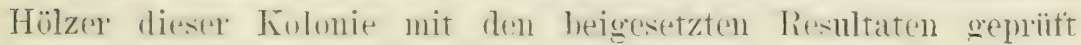
woriten.

lie Probestïcke hatten rine Länge voll 12 \%oll und rinte Quadratfläche ron 1 Zoll, englisches Mass. 
Volkstümliche Ximen

lin:n

Kahikatea

Kiluri

Kawakit

Kolrekohe

Kowhai

Black Maire

Marre-tawhake

Malio

llanoas

Hangi

Manulí

I:tpan

Mit tipo-tarata

MIatai

Miro

Puriri

Rata

liewarewa

Rimu

Taraire

Tawiri-kohukolnu

Titoli

Totarn

Tawai (red birsch)

Tawai (hlack birsch)

Whan

\section{Wissenschaftliche}

Samen:

Elacocarpus dentatus $\quad 0,562$

Podocarpus dacrydioides 0,488

1) ammarar australis $\quad 0,62: 3$

Libocedrus doniana 0,637

Drsoxcylum spectabile $\quad 0,678$

$\{$ Sophora tetrapter:a $\}$

Olea Cumninghmii $\quad 1,159$

Eugenia maire $\quad 0,790$

Aristotelia racomosa

Dacrydium colensoi

'etranthera calicaris

Leptospermum ericoides

Ayrsine urvillei

Pittosporum tenuifolimm

Potocarpus spicata

Podocarpus ferruminea

Vitex littoralis

Metrosideros lucida

linightia excelsa

Dacrydium eupressinmm

Nesodaphne tawa

Carpodotus serratus

Alectryon excelsum

Podocarpus totaria

Fagus menziesii

Fagus fusca

Entelea arborescens

0.593

0,788

0,6921

0,943

0,991

0,950

0,787

0,658

0,954

1,045

0,785

0.563

(), 761

(), 822

0,916

().5.59

(1),626

(), 780

Schwerstes

frewicht, welches

die Illastizitit unbeeintrichtigt Gewicht für liess

Pfund

94

57,9

97

75

92

98

193

106

62

200

109

115

92

125

133

103

175

93

93

92,8

142,4

80

116

77

73,6

108,8

13

Ërforde1 pfund 125 106 165,5 120 117,4 207,5

314.2 179,7 122 230 137,9 239 192,4 243 197.2 190 223 196 161 140,2 205.5 177,6 248 133,6 158 .? 202,5 0,187

Die Pröflungen ron 'l'homas Laslett.

Der Holzinspektor der britischen Admiralitä, hat die ilm sebotene vorzïgliche Gelegenheit benutzt, um eine Zahl Hölzer

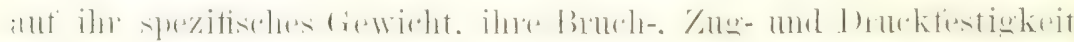
zu untersuchen. Die Durchschnittsergebnisse längerer Tersuchsreihen, sind in den mtenstehenden 'Tabellen niedergelegt, zu welchen Laslett die folgenden Fiäuterungen gibt. Das Bruchsewicht in allen meinen Untersuchungen wurde an staben $2^{\prime \prime} \times 2^{*} \times 84^{\prime \prime}=336$ Inbikzoll ermittelt. Teder Stab wrude auf Träger in genanem Abstand ron 6 Fuss gelegt und damn Wasser

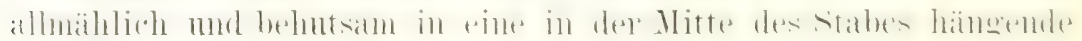




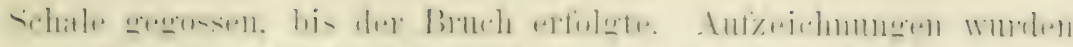

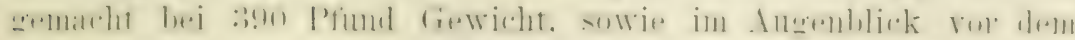

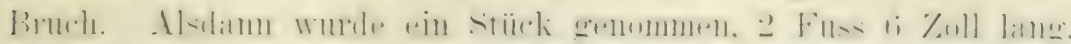

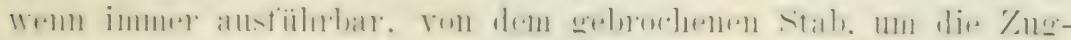

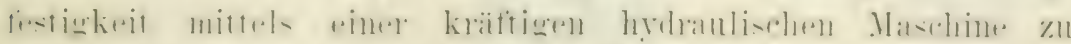

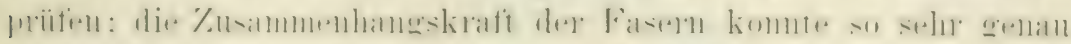

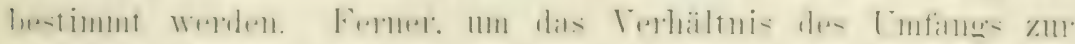
I.

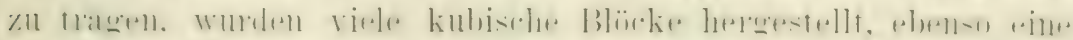

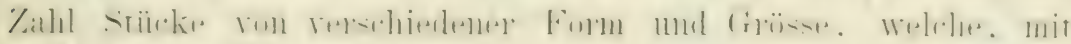

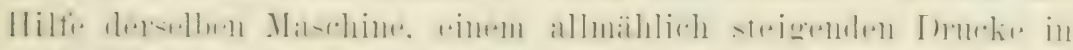

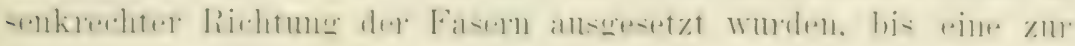
Zerknitterum hinreichende Kraft er'eicht murde.

Ein oben erhobener Vorwurt trifft auch Laslett: duch mu-

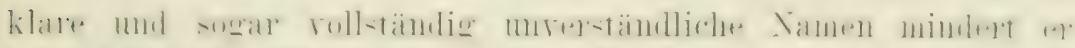

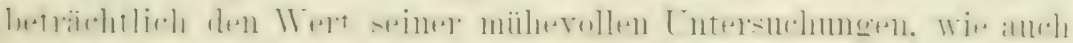

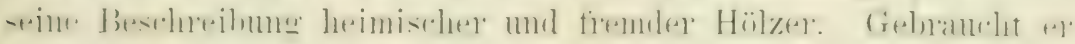

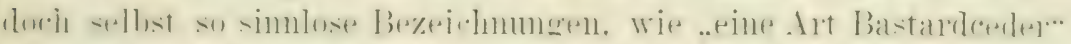

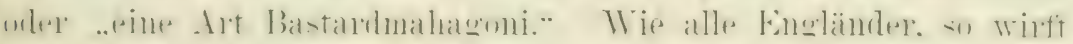

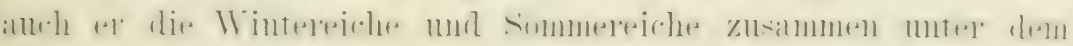

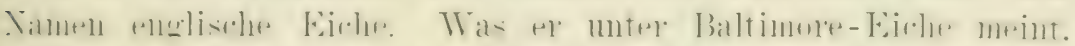

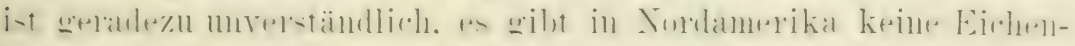

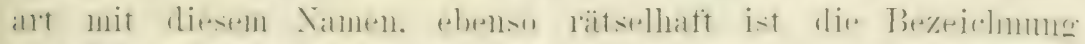

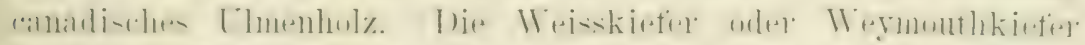

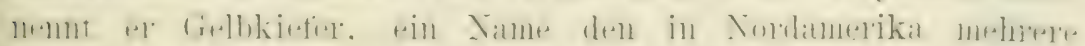

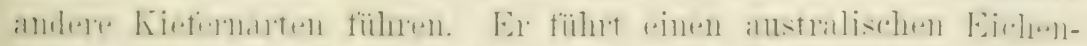

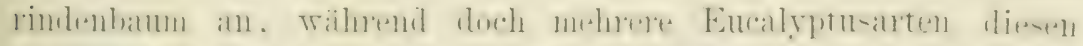

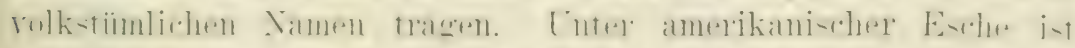

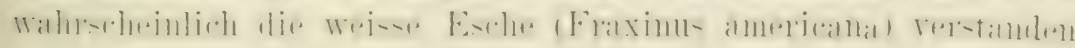
mond unter englischer Ulme. Ulmus campestris.

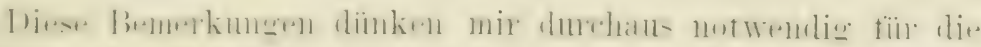

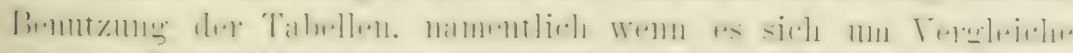

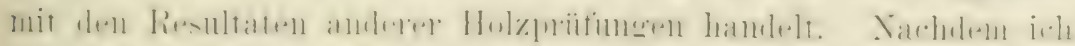

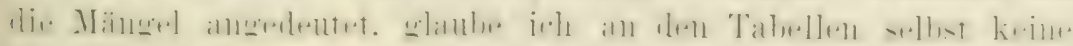

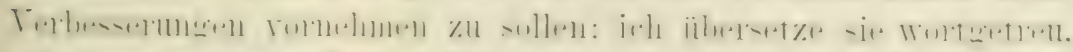

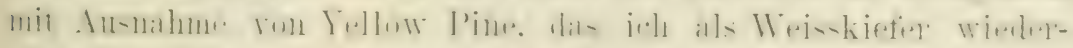

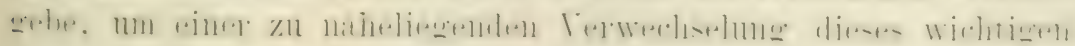
Holzes volzubeugen. 
1. Tabelle.

\begin{tabular}{|c|c|c|c|c|c|c|c|}
\hline \multirow[b]{3}{*}{ Afrikanischer Teak } & \multirow{3}{*}{$\begin{array}{c}\begin{array}{c}\text { Spezifi- } \\
\text { sehes } \\
\text { Gewicht. }\end{array} \\
0,993\end{array}$} & \multirow{3}{*}{$\begin{array}{l}\begin{array}{c}\text { J3ruch- } \\
\text { gewicht } \\
\text { pfund } \\
\text { und } \\
\text { Quadrat- } \\
\text { zoll. }\end{array} \\
\quad 277\end{array}$} & \multirow{3}{*}{$\begin{array}{c}\begin{array}{c}\text { Zug- } \\
\text { gevvicht } \\
\text { Pfund } \\
\text { und } \\
\text { Qualrat- } \\
\text { zoll. }\end{array} \\
7052\end{array}$} & \multirow{2}{*}{\multicolumn{4}{|c|}{$\begin{array}{c}\text { Druckgewicht } \\
1^{\mu} \times 1^{u} \times 1^{u}\left|2^{u} \times 2^{u} \times 2^{u}\right| 3^{u} \times 3^{u} \times 3^{u} \\
\text { Tons pro Quauratzoll }\end{array}$}} \\
\hline & & & & & & & \\
\hline & & & & 4,900 & 4,573 & 4,388 & \\
\hline Esche, englische & 0,736 & 216 & 3780 & - & 3,109 & - & \\
\hline " amerikanische & 0,480 & 160 & 5495 & - & 2,453 & - & \\
\hline Gummibaum, blauer & 1,029 & 178 & 6048 & - & 3,078 & - & \\
\hline Ceder von Cuba & 0,439 & 140 & 2870 & - & 2,000 & - & \\
\hline Chow von Borneo & 1,116 & 244 & 7199 & - & 5,621 & & \\
\hline Ulme, englische & 0,558 & 98 & 5460 & - & 2,583 & & \\
\hline , canadische & 0,748 & 230 & 9182 & 3,312 & 4,062 & 4,097 & 3,45 \\
\hline Kiefer von Danzig & 0,582 & 219 & 3231 & 3,146 & 3,172 & 3,097 & 2,99 \\
\hline$" \quad$, Riga & $0, \check{5}+1$ & 150 & 4051 & 3,312 & 2,109 & 1,770 & 2,17 \\
\hline Spruce-Fir (Picea excelsa) yon) & 0,484 & 168 & 3934 & - & 2,166 & - & 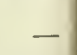 \\
\hline Grïnherz & 1,149 & 333 & 8820 & $6,7 \hat{0} 0$ & 6,819 & 6,368 & 5.81 \\
\hline Hainbuche, englische & - & - & 6405 & - & 3,711 & - & - \\
\hline Eisenrinde von Australien & 1,142 & 352 & 8377 & - & 4,601 & - & - \\
\hline Jarrah & 1,010 & 172 & 2940 & - & 3,168 & - & - \\
\hline Karri & 0,981 & 216 & 7070 & - & - & - & 5,14 \\
\hline Kapar von Borneo & 0,956 & 296 & 6790 & - & 5,300 & - & - \\
\hline Kauri von Neu-Seeland & 0,530 & $204^{\circ}$ & 4543 & 3,190 & 2,625 & 2,772 & 2.97 \\
\hline Kranji von Borneo & 1,029 & 371 & 10920 & - & - & - & -1 \\
\hline Lürche, russische & 0,646 & 157 & 4302 & 2,875 & 2,672 & 2,174 & 2,66 \\
\hline Mahagoni von Cuba & 0,769 & 214 & 3791 & 2,750 & 3,250 & 3,024 & $2,4:$ \\
\hline$" \quad$ " Honduras & 0,659 & 201 & 2998 & 2,806 & 2,750 & 3,044 & $2,8:$ \\
\hline " Mexiko & 0,678 & 196 & 3427 & 2,437 & $2,6: 33$ & 2,549 & $2,3 !$ \\
\hline Molave von den Philippinen & 1,013 & 311 & 7812 & - & - & - & - \\
\hline IIora von Trinidad & 1,087 & 332 & 9240 & - & 3,812 & - & -1 \\
\hline Eiche, Baltimore & 0,747 & 181 & 3832 & - & 2,630 & - & -1 \\
\hline$"$ englische & 0,735 & 194 & 7571 & 3,562 & $3,+11$ & 3,252 & 3,1 \\
\hline , & 0,862 & 121 & 3837 & - & - & - & - \\
\hline$"$ französische & 0,976 & 219 & 8102 & - & $3, \tilde{5} \pm 7$ & - & - \\
\hline$"$ ron Danzig & 0,835 & 118 & 4212 & 3,773 & 3,375 & 3,166 & 3,0 \\
\hline .. $\quad "$ Modena & 1,109 & 211 & - & - & - & - & -1 \\
\hline$\because \quad$ "Sardinien & 0,990 & 190 & - & - & 2,604 & - & -1 \\
\hline .. " "Toscana & 1,040 & 190 & - & - & 2,437 & - & - \\
\hline .. $\quad$ "Spanien & 1,042 & 141 & - & - & - & -- & \\
\hline .. vom Rhein & 1,026 & 165 & - & - & - & - & -1 \\
\hline$\because \quad$ weisse amerikanische & 0,983 & 201 & 7021 & 3,166 & 3,109 & 2,500 & 2.0 \\
\hline
\end{tabular}




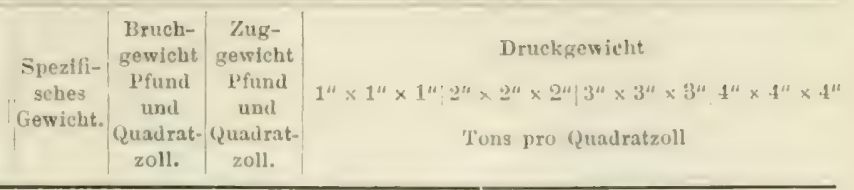

thicfer von Canada

eissticfer, amerikanische

chkicfer "
bicu vou Cuba
ak von Birma

lart vou Australicu

ngow von Borneo

engadu you Birma

\begin{tabular}{c|c|c|c|c|c|c}
0,552 & 163 & 2705 & 3,479 & 2,115 & 2,431 & 2,125 \\
0,435 & 157 & - & - & - & - & - \\
0,554 & 126 & 2027 & 2,521 & 1,863 & 1,750 & 1,375 \\
0,659 & 262 & 4666 & - & 2,885 & - & - \\
0,917 & 331 & 5558 & 3,082 & 3,961 & 4,140 & 3,922 \\
0,776 & 228 & 3301 & 2,416 & 2,838 & 2,640 & 2,343 \\
1,169 & 257 & 10284 & 4,469 & 4,195 & 3,931 & $4,10.2$ \\
0,747 & 318 & 6311 & - & 4,539 & - & - \\
1,176 & 324 & 9656 & -- & 5,208 & - & -
\end{tabular}

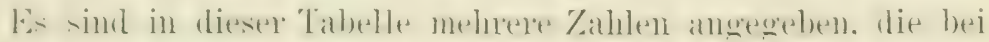

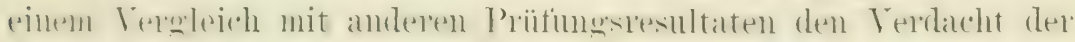

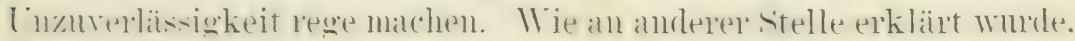

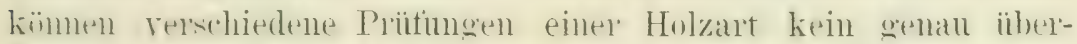

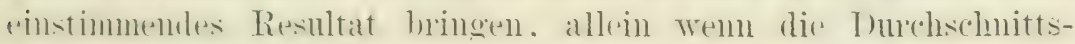

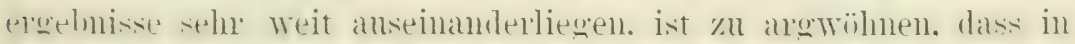

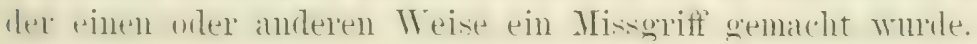

$$
\text { 2. 'Tabrile. }
$$

Coeffizienten der

Elastizität

I'fund pro Qua-

ùratzoil.

Kranji

Eisemriule

Grünherz

Mora

Sabicu

Pyengadu

P'ingow

Molave

Kiapol

Teali, afrikanisches

'luart

Chow

Ulme, cunadische

Pechkieter

T'eak von Birma

Kiefer von Danzig

\section{$150 \pm 910 \quad$ Kiarri}

960740 Esche, englische

463880

466570

972350

$10319 \pm 0$

1259690

823990

1463000

410430

776990

1013836

618.50

755240

5) 30970

579190

Kauri

Jarrah

Rothiefer
Coeffizienten der

Elastizität

Pfund pro Qua-

dratzoll.

930950

573100

771030

492550

846100

Eiche, weisse amerikanische 528650

Gummibaum, blauer

721380

778300

296810

588900

$3+3980$

$6 \pm 9130$

$752+20$

449710

621050

250 820 


$$
\therefore \text { 'Tallolle. }
$$

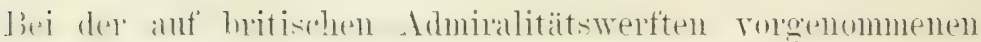
I'mwandlung ron 1413894 inbikfuss roh behanener blöcke velshierlenel Holzarten, wie sie in den Handel kommen. murde von dem Kubikfuss ein solcher Bruchteil Kinbikfuss Balken. Bohlen.

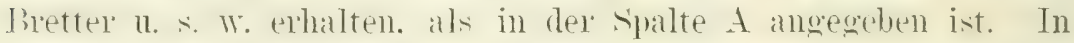
der spalta B ist der Abfall an suänen mol sägemehl in Buchteil Kinbikfuss angegeben.

\begin{tabular}{|c|c|c|}
\hline & A & $B$ \\
\hline Eiche, italienische & 0,649 & 0,351 \\
\hline " Baltimore & 0,648 & 0,352 \\
\hline$" \quad$ sardinische & $0,+146$ & 0,354 \\
\hline$"$ weisse amerikanische & $0,6+1$ & 0,359 \\
\hline$" \quad$ französische & 0,527 & 0,473 \\
\hline$"$ englische & 0,526 & 0,474 \\
\hline$" \quad$ spanische & 0,520 & 0,480 \\
\hline 'Tuart & 0,681 & 0,319 \\
\hline Sabicu & 0,674 & 0,326 \\
\hline Grünherz & 0,605 & 0,395 \\
\hline Mora & $0, \overline{7} 5 \tilde{5}$ & 0,445 \\
\hline Teak, afrikanisches & 0,519 & 0,481 \\
\hline Mahagoni von Mexilio & 0,721 & 0,279 \\
\hline$" \quad, \quad$ Cuba & 0,634 & 0,366 \\
\hline$"$ Honduras & 0,596 & 0,404 \\
\hline Ceder von Cuba & 0,726 & 0,274 \\
\hline Teak & 0,660 & $0,3 \pm 0$ \\
\hline Ulme, englische & 0,5331 & 0,469 \\
\hline$" \quad$ canadische & 0,687 & 0,313 \\
\hline Weisskiefer & 0,705 & $0,29 \bar{z}$ \\
\hline Kiefer von Danzig & 0,700 & 0,300 \\
\hline$" \quad, \quad$ Riga & 0,677 & 0,323 \\
\hline Rotkiefer, canadische & 0,650 & 0,350 \\
\hline Pechkief $\in$ r & $0,6 \pm 0$ & 0,360 \\
\hline Lärche, russische & 0,610 & 0,390 \\
\hline
\end{tabular}

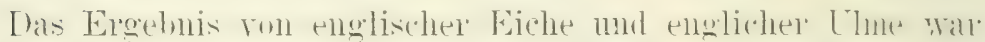
nicht ron viereckig behtuenen. sondern roh zugerichteten Blïchen rhalten. Gut geriereckte Blörke geben an den Kanten nur wenig Abfall und bringen etwa o.tis Kubikfus zugerinhteter Material. wie das Beispiel des Tuarts zeigt. rorefiltig weriereckte Blücke hringen etwas mehr. Wie dats mexikanische Mahageni. sehlecht geeviereckte bringen dagegen wenigrel. wie das atrikinicche Teak. 


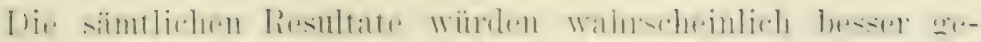

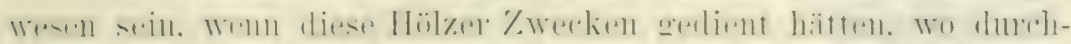

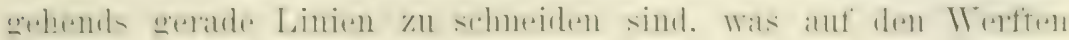
nicht del Fall ist.

Die Niitzlichkeit einer solchen 'Tabelle muss einlenchten: as

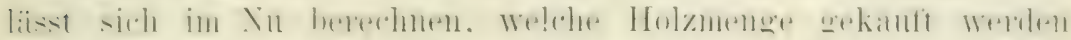
muss für eine bestimmte Nenge ron zugerichtem Holz.

Die nordamerikanischen Hözer.

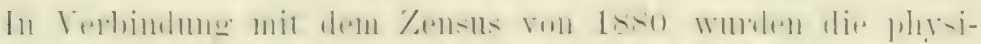

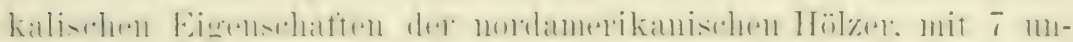

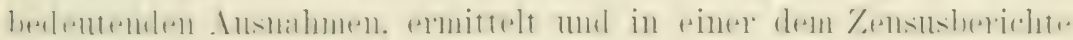
einverleibten Tabelle veröftentlicht.

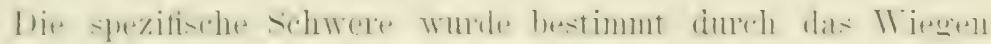

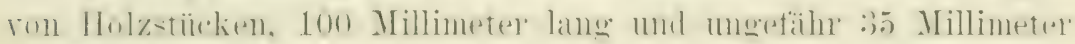

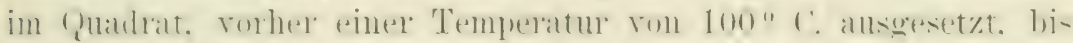

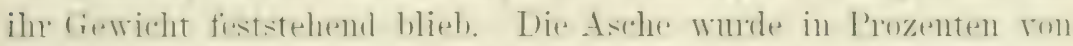
trocknem Holze hestimmt. in der Weise. dass kleine Holzstiicke in

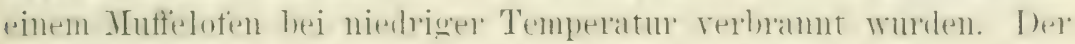

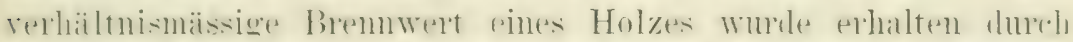

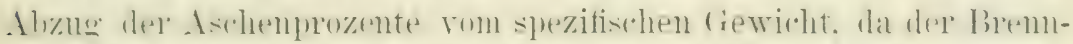

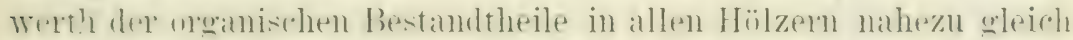

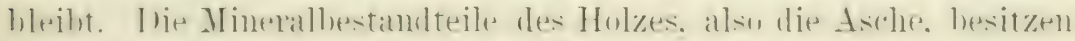

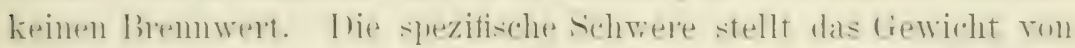

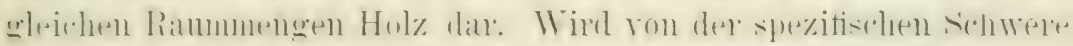

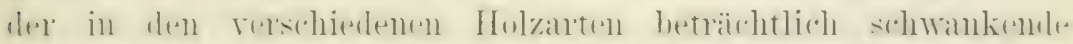

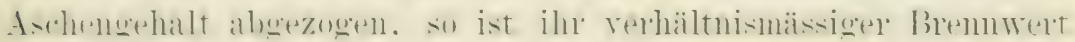
leperehnet. Fin rom Asche freese Holz. mit dem spezitischen tere wioht rom 1.000. wiirde daher die Einheit des Bremnwerts dal'-

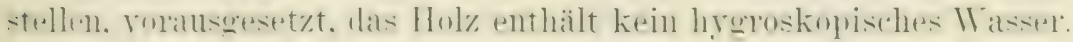

Wenn die so erhaltenen Zahlen mit 4000 vervielfacht

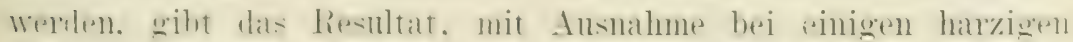

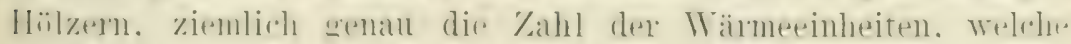

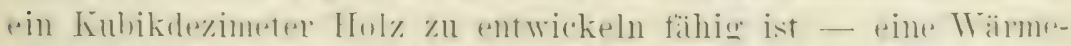

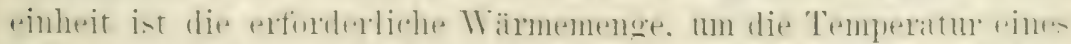

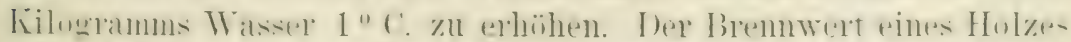

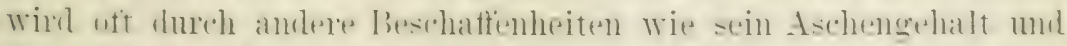

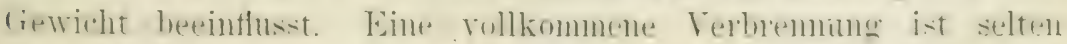

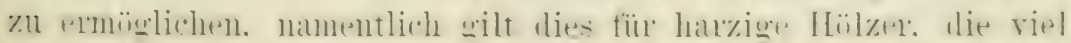




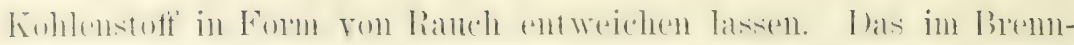

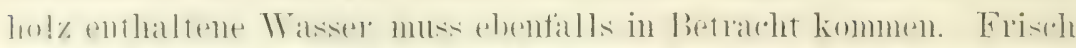

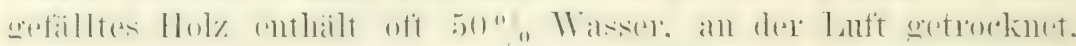

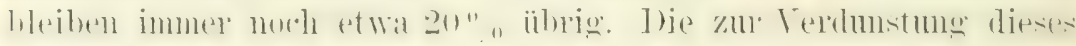

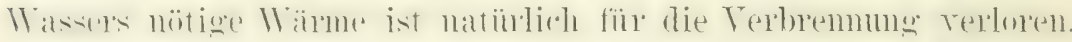

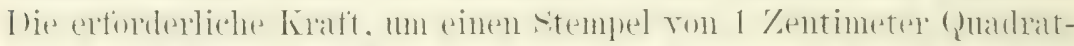

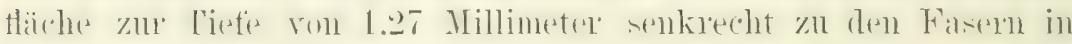

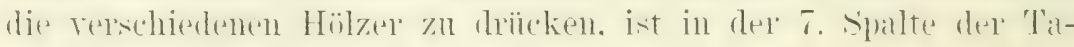
belle angegeben.

D) Elastizitä worle emittelt an Stäben mit einem Fläroleninhalt des Querschnitts ron 2 Zentimeter.

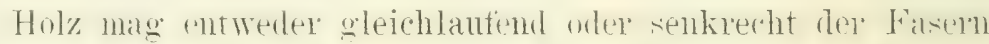
gepresst werden.

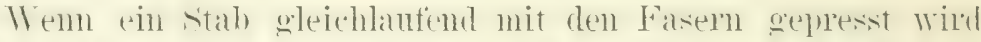

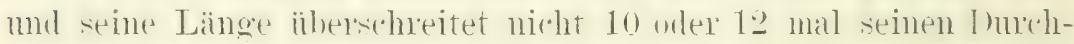
messer. wird el gewöhnlich nicht zerdrïckt. smolern zerknickit. und die erforderliche Kraft tür ein solches Zerknicken strut im Verhälntis zu dem Flachenmhalt des (fuerschnittes des stabes.

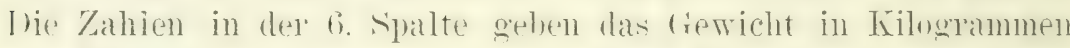

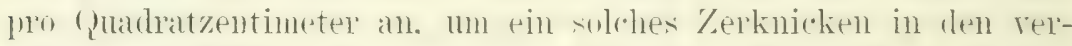
schiedenen Hölztron hervorzunten. I'm das liewicht zn timden. welchem irgend ein stab wirlerstehen kamn. sind die zahlen in der Siralte mit der Zahl der (Mandatzentimeter am Ende des stahes zı vervielfachen.

Wenn cin stab an beiden Enden aufugelegt nnd Gewicht an seinen Mittelpunkt gehänght wird, hiegt er sich im Verhältnis zu jerler Gewirhtserhöhmg bis zu einter gewisen Grenze, melche nivht ïbereinstimmend ist in den rerschiedenen Hölzern. Diss (irenze wird die Elastizitätsgrenze des Holzes genannt.

1)er Modulus der Brochtestigkeit ist in Kilogrammen pro (Yuadratzentimeter zn rerstehen. eleenso der ('vetfizient der Elastizitat.

In den meisten Fällen wurden die Proben dem unteren Endo des Stammes antnommen und waren frei von splint und hinoten, sie stellten daher das beste Holz dar. Welches von dem Bamme erhalten werden konnte.

Zum mindesten zwei Bestimmungen des speritischen Gerwichts wurden allsgefïhrt ron jeder zur P'rïfung gestellten Bammart und von solchen, welche wirtschattliche I'ichtigkeit besitzen. wurden Proben von mehreren Bämen genommen, die in weit anseinander 


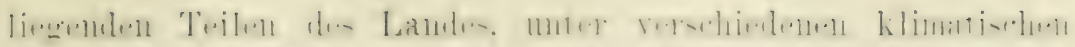

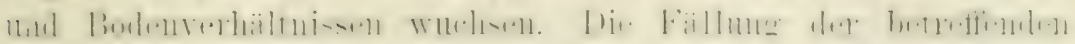
biimme geschah im IInter vor Mär" und die Proben wurden sorgfältig getrocknet.

Diejenigen Probestäbe, welche zur Feststellumg der Bruch-

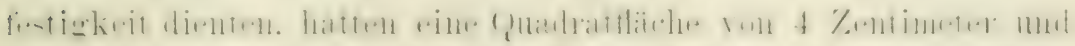

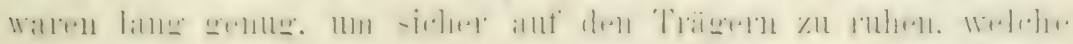

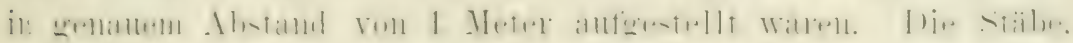

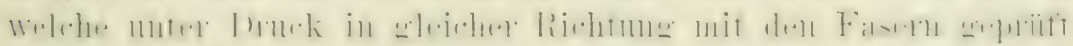

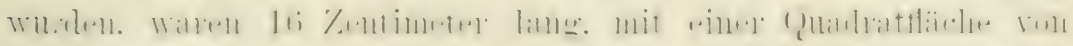

\section{Zentimeter.}

Eine Tergleidnung zeigt. dass die Stärke der verschiedenen

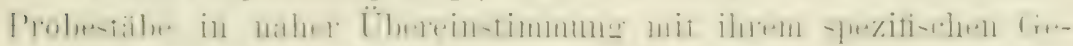
wicht steht, jedoch nicht in ansnahmsloser: Regel.

Ferner rerdient die Aufmerksamkeit auf' die 'Thatsache ge-

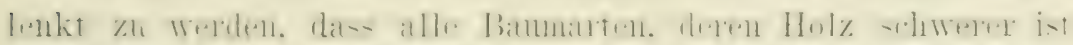

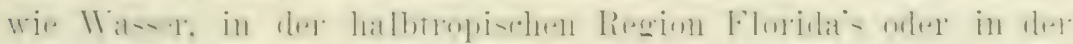

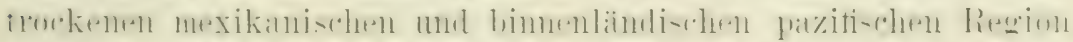

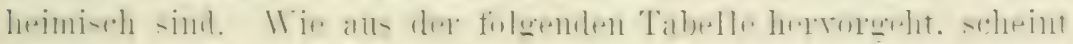

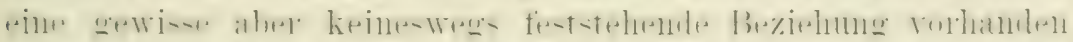

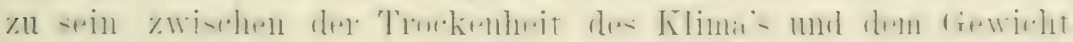

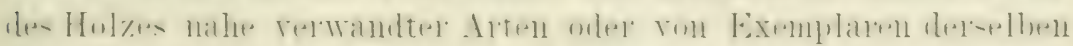

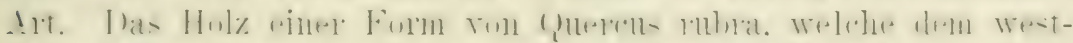

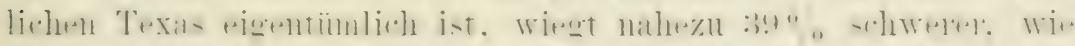

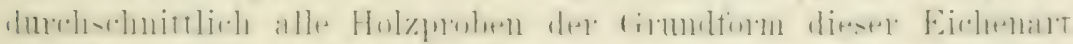

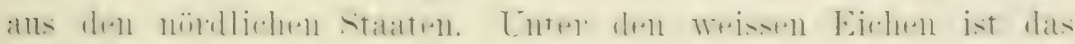

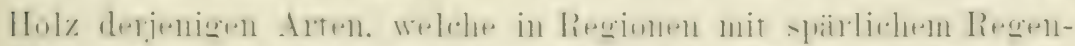

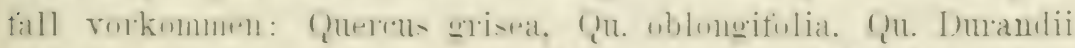

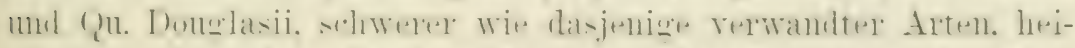

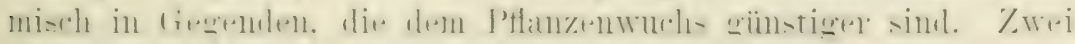

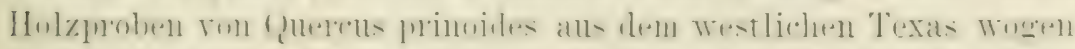

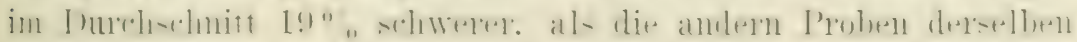
Art aus anderen Gegenden.

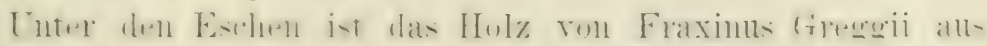

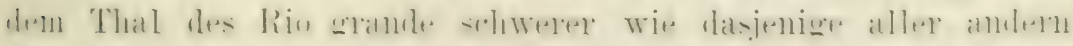

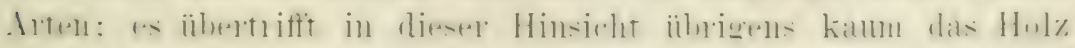

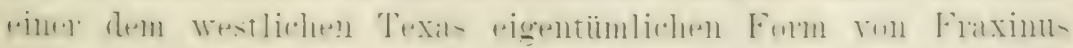

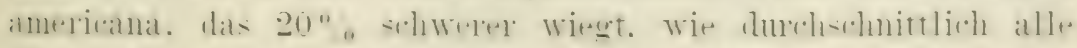

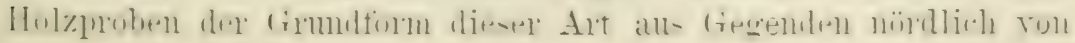


Texas. Andererseits ist das Holz der texanischen Form ron

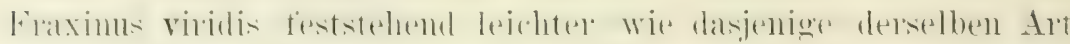

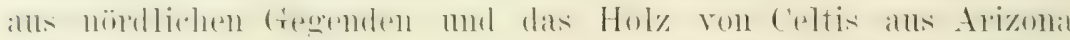
ist leichter wie die alle andern Proben derselben Art.

In der Gattung Juglans erzengt J. rupestris das schwerste Hol\%. eine Art. die in riner Region mit geringem Regentall lei-

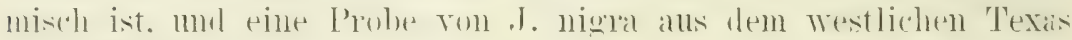

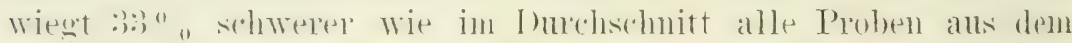

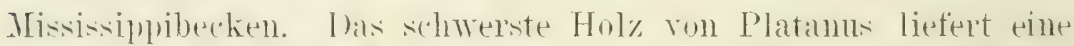

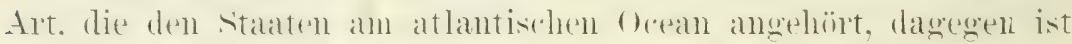
das Holz einer Art. die in dem rereledelsweisen fenchten Flima des sildwestlichen drizona's vorkommt. beträchtlich leichter. wit dasjenige einer Art. welche in dem trockeneren Kilima vïdlialiforniens heimisch ist.

Schliesslich sei noch bemerkt, dass die Rangordnung der

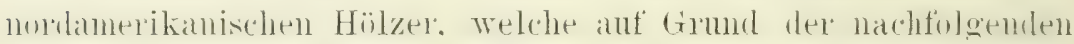

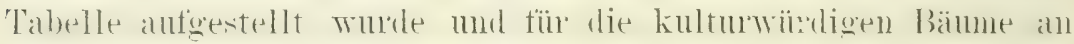
den betreftemden stellen angegeben ist. nicht als mabanderlich richtic betrachtet werden dart, dem die Einschaltimg einer drt oder melnerer muss selhstrerständlich eine Rangrerandermg aller Arten von geringeren Werten zor Folge hahen. Bereits ist die Zahl der bei dem Zensus rom 1880 gekamnten 412 Arten anf 480 Arten angeschwollen. Freilich sind die ne'l entdeckten Arten selten mul unwichtige und von melneren ist noch der Zweifel zu lissen. ob sie wirkliche Arten wher nur spielanten sind. das wiirde aber nicht hindern. dass die zensusheanten eine veränderte tabellarische Rangordnumg aufstellen mïsten. Wemn sie gegenwärtig ilne Arbeit in Angriff nähmen.

Ferner kömnte sich die Rangstellumg verändern. wemn eine

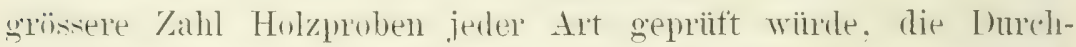
s-hnittsesultate mïchten dann vielleicht kleine Abweichungen zeigen. In anderen Worten: (irmpen ron 20 bis 30 Arten. welche sich in Range folgen. mïgen ihre Plätze mit einander wechseln. Ine Erklärmog liegt teilweise in dem Mangel an frleichmässigkeit des Holzes jeder Art. teilweise in der Thatsalde. dass. Wo su riele Priifungsesultate zwischen redhälnismässig enge tirenzen fallen. die Rangfolge sehr dem Zufalle ausgesetzt ist. 


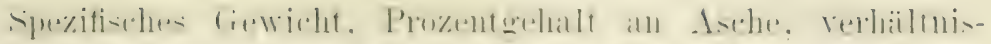

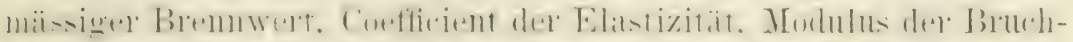

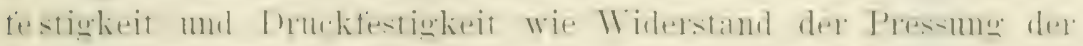
nordamerikanischen Hölzer.

\begin{tabular}{|c|c|c|c|c|c|c|c|}
\hline Art. & $\begin{array}{c}\text { Spezifi- } \\
\text { sches } \\
\text { Gowicht. }\end{array}$ & $\begin{array}{l}\text { Prozent } \\
\text { der } \\
\text { Asche. }\end{array}$ & $\begin{array}{c}\text { Ver- } \\
\text { hälthis- } \\
\text { mässiger } \\
\text { Brenn- } \\
\text { wert, }\end{array}$ & $\begin{array}{c}\text { Coeffi- } \\
\text { cient der } \\
\text { Elasti- } \\
\text { zitiit. }\end{array}$ & $\begin{array}{c}\text { Modulus } \\
\text { der } \\
\text { Bruchfe- } \\
\text { stigkeit. }\end{array}$ & $\begin{array}{c}\text { Bruchbe- } \\
\text { lastung } \\
\text { auf Zer- } \\
\text { knicken in } \\
\text { Jinings- } \\
\text { richtung. } \\
\text { (Druckfe- } \\
\text { stigkeit.) } \\
\end{array}$ & $\begin{array}{l}\text { Wider- } \\
\text { stand } \\
\text { gogen } \\
\text { den Fin- } \\
\text { druck. }\end{array}$ \\
\hline 1. Magnolia grandifolia & 0,6360 & 0,53 & 0,6326 & 90330 & 792 & $\$ 82$ & 197 \\
\hline glauea & 0,5035 & 0,47 & 0,5011 & 91299 & 736 & 424 & 102 \\
\hline$" \quad$ acuminat: & $0,+690$ & 0,29 & 0,4676 & 92817 & 671 & $41 \tilde{0}$ & 107 \\
\hline cordata & $0, \pm 139$ & 0,32 & 0,4126 & 94073 & 600 & $\$ 10$ & 89 \\
\hline macrophylla & $0, \overline{3} 309$ & 0,35 & 0,5290 & $|116854|$ & 696 & 189 & 130 \\
\hline * umbrelli & 0,4487 & 0,20 & $0,4 \pm 78$ & 74365 & 583 & 366 & $8 t$ \\
\hline Fraseri & 0,5003 & 0,28 & 0,4989 & 94162 & 707 & $\$ 18$ & 123 \\
\hline 8. Liriodendron tulipifera & 0,4230 & 0,23 & 0,4220 & 92667 & 657 & 372 & 82 \\
\hline 9. Isimina triloba & 0,3969 & 0,21 & 0,3961 & 48179 & 391 & 212 & 69 \\
\hline 10. Anona laurifolia & $0,505 \overline{3}$ & 4,86 & $0,+\$ 807$ & 50113 & 607 & 302 & 127 \\
\hline 11. Capparis jamaicensis & 0,6971 & 4,76 & 0,6639 & - & - & - & - \\
\hline 12. Canclla alba & 0,9593 & $1,7 \tilde{5}$ & 0,9720 & 111698 & 1026 & 782 & 573 \\
\hline 13. Clusia flora & 一 & - & - & - & - & 一 & - \\
\hline 14. Gordonia Lasianthus & 0,4728 & 0,76 & 0,4692 & 79414 & 670 & 387 & 99 \\
\hline pubescens & - & - & - & - & - & - & - \\
\hline 16. Fremontia californica & 0,7142 & 1,69 & 0,7021 & 一 & - & - & - \\
\hline 17. Tilia americana & $0, \pm 525$ & $0,2 \tilde{5}$ & $0, \pm 500$ & 81010 & 589 & 348 & 63 \\
\hline 18. " heterophylla & $0,4 \cdot 53$ & 0,62 & 0,4227 & $8 \pm 659$ & 577 & $39 t$ & 68 \\
\hline 19. Byrsoniama lucida & 0,58888 & 2,46 & $0,57+3)$ & 52503 & 424 & 391 & 210 \\
\hline 20. Guaicum sanctum & 1,1432 & 0,82 & $|1,1338|$ & $86: 321$ & 787 & 737 & 793 \\
\hline 21. Porliera angustifolia & $1,11 \cap 1$ & $0, \overline{1} 1$ & $|1,10 \pm 4|$ & - & - & - & - \\
\hline 22. Xanthoxylum americanum & $0,565 \bar{t}$ & 0,57 & $|0,5622|$ & - & - & 一 & - \\
\hline$" \quad$ Clava-Herculis & 0,5050 & 0,82 & 0,5015 & 72577 & 640 & $\$ 49$ & 159 \\
\hline$" \quad$ caribaeum & 0,9002 & 2,02 & 0,8820 & 86750 & 754 & $68 \overline{0}$ & 373 \\
\hline , pterota & $0,7 \pm 4 \pm$ & 0,78 & 0,7386 & - & - & - & - \\
\hline 26. Ptelea trifoliata & 0,8319 & 0,30 & 0,8994 & - & - & 一 & - \\
\hline 27. Canotia holacantlıa & 0,6885 & 5,33 & 0,6518 & - & - & - & - \\
\hline 28. Simaruba grlauea & 0,4136 & 0,93 & 0,4098 & 93217 & $56 t$ & \pm 26 & 86 \\
\hline 29. Bursera gummifera & 0,3003 & 2,04 & 0,2942 & 41694 & 148 & 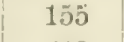 & \pm 7 \\
\hline 30. Amyris sylvatica & 1,0459 & $0, \overline{5} 9$ & 1,0397 & $108507 \mid$ & 1305 & $7 \pm 8$ & อ̄อิ0 \\
\hline 31. Swietenia mahazeni & $11.7 \cdot 3 \cdot 2$ & $1.1) ! !$ & $0.7201 \%$ & $106 i 272$ & 10113 & tititi & $3+1 !$ \\
\hline 32. Iimenia americana & 0,9196 & 0,73 & 0,9129 & - & - & - & - \\
\hline 33. Ilex opaca & 0,5818 & 0,76 & 0,5774 & $6 \pm 317$ & 686 & $\star 19$ & 176 \\
\hline 34. "dahoon & 0,4806 & 0,91 & $0, \pm 762$ & $6+192$ & 572 & 349 & 113 \\
\hline $35 . "$ cassine & 0,7270 & 0,87 & 0,7207 & - & 一 & - & 一 \\
\hline decidua & $0,7+20$ & 0,70 & 0,7368 & - & - & - & - \\
\hline
\end{tabular}




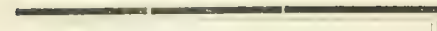

\section{Art.}

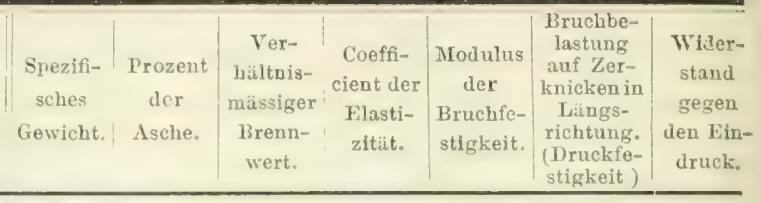

37. Cyrilla racemiflora
38. Cliftonia ligustrina
39. Eronymus atropurpureus
40. Myginda pallens
41. Schaefleria frutescens
42. Reynosia latifolia
43. Condalia ferrea
44. " obovata
45. Rhamnus caroliniana
46. " $"$ californica
47. Purshiana

48. Ceanothus thyrsiflorus

\section{$0,678 t$ \\ 0,6249}

0,6592

0,9048

0,7745

1,0715

1,3020

1,1999

0,5462

0,6000

0,5672

0,5750

0,8208

0,4552

0,4274

0,4980

0,6332

0.8126

0,8367

0,9533

0,9102

0,5299

0, อว330

0,4909

$0,+2$

0,42

0,58

3,42

$2, \overline{3} 4$

3,20

8,31

7,03

0,64

0,58

0,67

0,69

1,75

0,86

1,00

0,70

1,17

1,50

4,34

う6. Hypelate paniculata.

57. trifoliata

58. Acer pennsylvanicum

59. $"$ spicatum

60. ", macrophylium

61. " circinatum

62. " glabrum

63. " grandidentatum

6t. $"$ saccharatum

64a. "

$$
\text { val. }
$$$$
\text { nigrum }
$$

0,6660

10,6028

0,6902

1,25

1,38

0,36

0,43

0,54

0,39

0,30

$0,6 \pm$

0,6756

48828

$0,6223 \quad 78250$

314

0,6554

0,8739

0,7048

$\mid$\begin{tabular}{l|l|l|}
1,0372 & 105005
\end{tabular}

1,1938114316

1,1155

$0,5+27$

0,5965

$0,563 \pm$

0,5710

0,8064

0,4503

74084

0,4231

0,4945

0,6258

$(1,80)+83681$

0,8004

0,9414111144

0,8976

0,5280

0,5307

0,4882

0,6634

-

1190

526

-

371

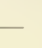

-

147$$
\begin{array}{l|l}
0,6912 & 0,51
\end{array}
$$

0,6915

0,71

0,5269

0,33

0,6010

0,68558

65. " dasycarpum

66. . rubrum

66 a. " " var. Drum-

$$
\text { mondii }
$$

67. Negundo aceroides

68.,$\quad$ californicum

69. Rhus cotinoides

70. " typhina

71. $"$ copallina

72. " venenata

73. " metopium

\section{0,6178}

0,37

0,5459

0,34

0,4328

1,07

0,4821

$0, \tilde{5} \pm$

0,6425

0,4357

0,50

0,5273

0,50

0,4382

0,60

0,64

0,7917

2,39 \begin{tabular}{|l|l|l|}
0,6875 & 146108 & 1149
\end{tabular}

619

\begin{tabular}{|l|l|l|}
\hline 0,5252 & 110973 & 1019
\end{tabular}

$0,6155|94284| 811$

\section{0,5440}

0,4282

$0, \pm 795$

58156

529

0,6393

0,4335

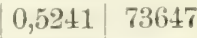

0,4354 \begin{tabular}{|l|r|}
94537 & 796
\end{tabular}

$\begin{array}{llll}0,7728 & 105007 & 656\end{array}$
ธ็อ

482

463

322

442

257

377

533
111

107

252

181

176

109

639

649

136

192

71

108

149

272

-

381

-

162

200

-

57
51
76

-

209 


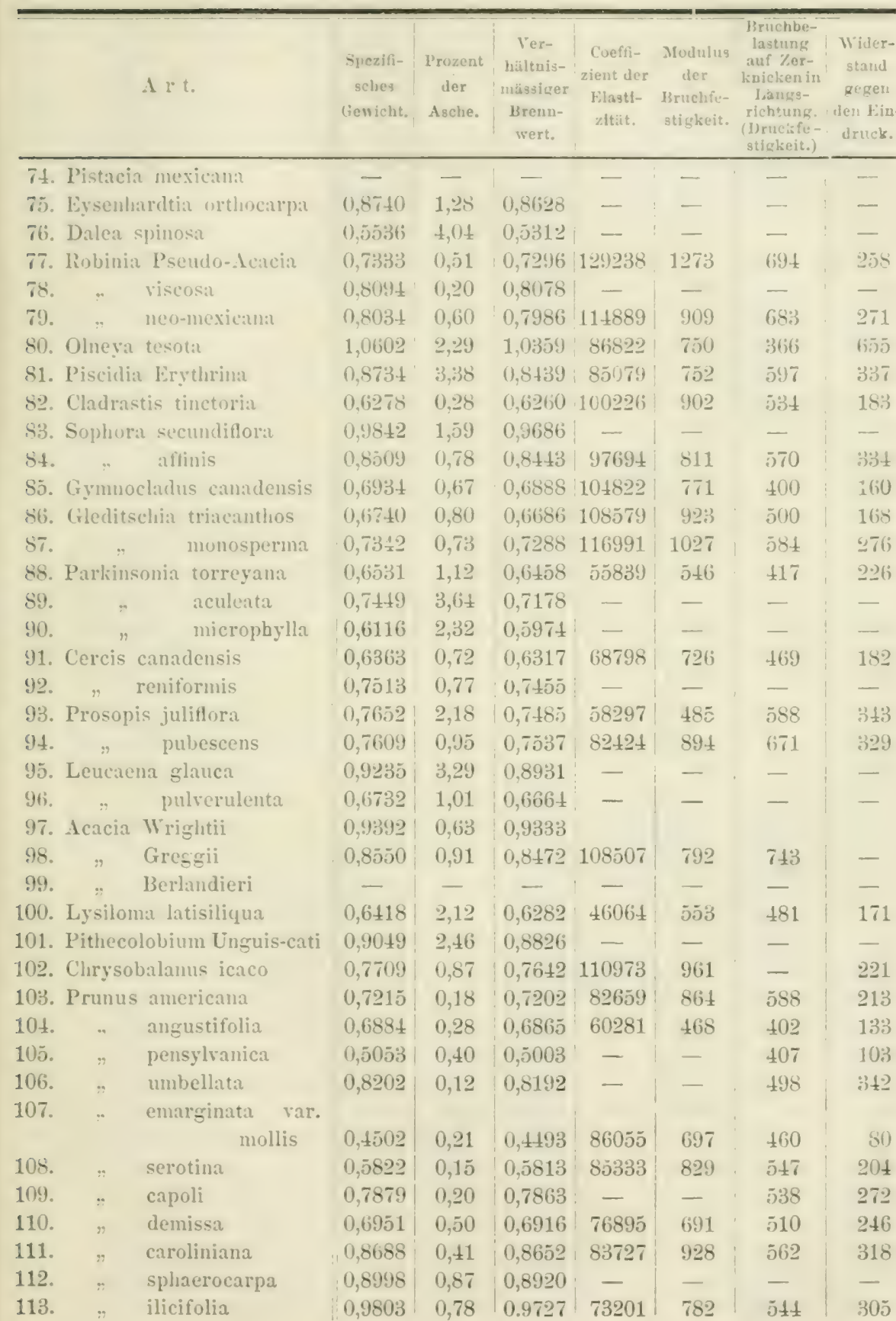




\begin{tabular}{|c|c|c|c|c|c|c|c|}
\hline$d r t$. & $\begin{array}{c}\text { Spezif- } \\
\text { sches } \\
\text { Gewicht. }\end{array}$ & $\begin{array}{l}\text { Prozent } \\
\text { der } \\
\text { Asche. }\end{array}$ & $\begin{array}{c}\text { Ver- } \\
\text { hilltnis- } \\
\text { missiger } \\
\text { Brenn- } \\
\text { wert. }\end{array}$ & $\begin{array}{c}\text { Coeffi- } \\
\text { cient der } \\
\text { Elasti- } \\
\text { zität. }\end{array}$ & $\begin{array}{c}\text { Modulus } \\
\text { der } \\
\text { Bruchfe- } \\
\text { stigkett. }\end{array}$ & $\begin{array}{c}\text { Bruch- } \\
\text { belastung } \\
\text { auf Zer- } \\
\text { knicken in } \\
\text { Längs- } \\
\text { richtung. } \\
\text { (Druckfe- } \\
\text { stigkeit.) } \\
\end{array}$ & $\begin{array}{l}\text { Wider- } \\
\text { stand } \\
\text { gegen } \\
\text { den Ein- } \\
\text { druck. }\end{array}$ \\
\hline 14. Vanquelinia Torreyi & 1,1374 & $1, \pm 5$ & 1,1209 & - & - & - & - \\
\hline 115. Cercocarpus ledifolius & 1,0731 & 1,04 & 1,0619 & - & - & 655 & 480 \\
\hline parvifolius & 0,9365 & $0, \pm 5$ & 0, & - & - & - & - \\
\hline 117. Pirus coronaria & $0,70+8$ & $0, \tilde{2} 2$ & 0,7011 & 64241 & 485 & 419 & 250 \\
\hline angustifolia & 0,6895 & 0,33 & 0,6872 & - & - & - & - \\
\hline rivularis & 0,8316 & 0,41 & 0,8282 & - & - & - & - \\
\hline americana & 0,5451 & 0,83 & $0, \check{\partial} \ddagger 06$ & - & - & 380 & 117 \\
\hline sambucifolia & 0,5928 & $0,3 \check{0}$ & 0,5908 & 62600 & 415 & 383 & 107 \\
\hline 122. Crataegus rivularis & 0,7703 & 0,35 & 0,7676 & - & - & - & 一 \\
\hline Douglasii & 0,6950 & 0,33 & 0,6927 & - & - & - & - \\
\hline brachyacantha & $0,6793 \mid$ & 0,42 & $0,676 t$ & - & - & - & - \\
\hline arborescens & $0,6491 \mid$ & 0,56 & 0,6 & 78837 & 621 & 498 & $18 t$ \\
\hline Crus & 0,7194 & 0,56 & 9,7154 & $66 \pm 36$ & 65 & 430 & 210 \\
\hline coccin & 0,8618 & 0,38 & 0,8585 & - & - & - & - \\
\hline subvillosa & 0,7953 & 0,69 & 0,7898 & 90023 & 738 & 538 & 263 \\
\hline tomentosa & 0,7585 & 0,52 & 0,7 & 73160 & 709 & 445 & 940 \\
\hline cordata & 0,7293 & 0,46 & 0,7 & - & - & - & - \\
\hline apiifolia & 0,7453 & 0,97 & 0,7381 & - & - & - & - \\
\hline spathulata & 0,7159 & 0,$66 ;$ & $(1,7112$ & 67349 & 506 & $45 i$ & 218 \\
\hline berberifolia & - & - & - & 一 & - & - & - \\
\hline aestivalis & 0,6564 & 0,57 & 0,6527 & 59185 & 712 & 140 & 224 \\
\hline flava & 0,7809 & 0,79 & 0,7747 & - & - & - & - \\
\hline 136. Heteromeles arbutifolia & 0,9326 & 0, & & - & - & - & - \\
\hline 137. Amelanchier canadensis & 0,7838 & 0,55 & 0,7795 & 119677 & 1132 & 670 & 280 \\
\hline 138. Hamamelis virginica & & 0,37 & 0,6831 & - & - & 一 & 一 \\
\hline 139. Liquidambar styraciflua & $0, \tilde{5} 909$ & 0,61 & 73 & 86388 & 651 & 466 & 132 \\
\hline 140. Rhizophora inangle & $1,16: 7$ & 1,82 & 1,1416 & 165557 & 1207 & 860 & 462 \\
\hline 141. Conocarpus erecta & & 0,32 & & 102411 & 9 & 599 & 370 \\
\hline 142. Lagun cularia racemosa & 0,7137 & 1,62 & $|0,7021|$ & 72396 & 518 & 449 & 149 \\
\hline 143. Calyptranthes chytraculia & 0,8992 & 3,32 & 0,8693 & - & - & - & - \\
\hline 14t. Eugenia buxifolia & 0,9360 & 1 , & 0, & 157510 & 1055 & 887 & 396 \\
\hline dichotoma & 0,8983 & 0,74 & 0,8917 & - & - & - & - \\
\hline monticola & 0,9156 & 1,89 & 0,8983 & 108507 & 1172 & 553 & 408 \\
\hline longipeles & 1,1235 & 3,48 & $1,08 \pm 4$ & - & - & - & - \\
\hline procera & 0,9453 & 2,62 & 0,9205 & $\mid 119111$ & 1176 & 672 & 444 \\
\hline 149. Cercus giganteus & 0,3188 & 3,45 & $0,3078 \mid$ & - & - & - & - \\
\hline 150. Coruus alternifolia & 0,6696 & 0,41 & 0,6669 & - & - & - & - \\
\hline florida & 0,8153 & 0,67 & 0,8098 & 82112 & $90 \pm$ & 534 & 305 \\
\hline Nuttallii & 0,7481 & 0,50 & 0,7444 & 103081 & 991 & 663 & 242 \\
\hline 15̋3. Nyssa capitata & & 0,34 & $0, \pm 597$ & 68083 & 682 & 431 & 155 \\
\hline 27 sylvatica & 0,6356 & $0, \tilde{5} 2$ & 0,6323 & 81832 & 830 & 468 & 196 \\
\hline
\end{tabular}




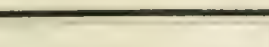

110 $\overline{155 . ~ N y s s a ~ u n i f l o r a t ~}$

156. Sambucus grlauca

15\%. " mexicana

158. Viburnum Lentago

159. " prunifolium

160. Exostema caribaeum

161. Pinclineya pubens

162. Genipa elusiaefolia

163. Guettarda elliptica

164. Vaccinium arboreum

165. Andromeda ferruginea

166. Arbutus Menziesii

167. $"$ xalapensis

168. $"$ texana

169. Oxydendrum arboreum

170. Kalmia latifolia

171. Iihodmenden maximum

172. Myrsine rapanea

173. Ardisia Pickeringia

174. Jacquinia armillaris

175. Chrysulfyllum wlivat forme

176. Sideroxylon mastichoden-

177. Dipholis salicifolia

178. Bumelia tenax

179. " lanuginosa

180. $"$ spinosa

181. " tycioides

182. " cumeata

18\%. Minmsu\} - vie!neri

184. Diospyros virginiana

185.

texana

186. Symplows tinctoria

187. Halesia diptera

188. " tetrapiera

189. Fraximus Greggii

190.

anomala

191.

pistaciaefolia

192.

americana dron

\section{,}

0,9316

0,7293

$0,65 \pm 4$

0,6693

0,7467

0,7959

1.11:3

0,7908

$0,8 \pm 60$

0,5325

0,5705

0,5628

$0,790 \pm$

0,6597

0,6810

$0,65+3$

var.
1,0109
0,7636

$0,70 \quad 0,5158$

$1,57 \quad 0,5007 \mid$

2,00

30517

0,99

0,4522

0,7282

$0, \tilde{2} 2$

$0,8989+90054$

0,23

$\begin{array}{ll}0,8289 & 90654 \quad 951\end{array}$

$0, \pm 1$

\begin{tabular}{ll|l|l|}
0,9289 & 119357 & 1005
\end{tabular}

$\mid$\begin{tabular}{l|l|l}
0,53328 & 68291 & 405
\end{tabular}

1,06

1,0207

1,05

0,39

$0,8250 \mid$

0,7080

$0, \pm 6$

(0,

0,7465

$0, \pm 0$

0,7

$0,7024 \quad 8383 \pm$

0,26

0,51

$0,7081 \quad 61577$

0.7462

0,37

0,7430 :

$0, \pm 1$

0,7131

88851

58481

11.36

11,62811

(iti)

0,81

$1,8 t$

3,45

1.2 .4

0,8271

$0,8+44$

0,6708

1.2.

5,14

(1, !. $244 \quad 11 \cdot 2+24$

\begin{tabular}{ll|l}
0,9589 & 109948
\end{tabular}

0,32

\begin{tabular}{|l|l|l|}
0,9286 & 133593
\end{tabular}

0,78

$0,7236 \quad 75120$

1,23

$0,6 \pm 6 \pm \quad 4833 t$

1,24

0,6521

0,81

0,7407

78125

-

1,90

0,7808

60281

$\therefore .111$

1.15)5 1102\%6

$$
\text { - }
$$

679

907

618

618

728

\section{9}

60:3

430

262

$1 ! 11$

(3)!

-

0,96

3,33

$10,7832: 7823 t$

-

0,68

0,8178

0,42

$0,5289 \quad 62202$

$-$

45

i)!

-
הin-
355
274
181
160
-

-
-
342
355
274
181
160
-

970

650

1148 730

-
הin-
355
274
181
160
-

673

452

-
-
342
355
274
181
160
-

387

362

-
-
342
355
274
181
160
-

562

489

220

วิ15

478

286

:3

321

879

50 3

159

197

0,40

\begin{tabular}{ll|l}
0,5681 & 68321
\end{tabular}

619

384

8507

$43 \pm$

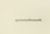

0,93

0,50605

0,7830

0,85

$0,65 \pm 1$

0,62

\begin{tabular}{|l|l|l}
0,6768 & 60119 & 622
\end{tabular}

622
861

385

210

171 texensis
$0, \pm 2$

$0,6516 \mid 101668$

1105

\section{1}

38

313

225

47

()1

\begin{tabular}{l|l|l|l|l}
0,70 & $0,7583 \cdot 10817 \pm$ & 1125 & $5 \pm 1$ & 198
\end{tabular}

81

(1)

11

20




\begin{tabular}{|c|c|c|c|c|c|c|c|}
\hline 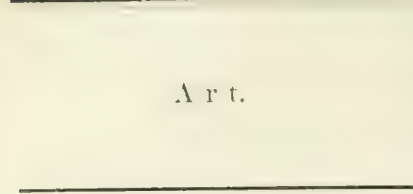 & $\begin{array}{c}\text { Spezifi- } \\
\text { sches } \\
\text { Gewicht. }\end{array}$ & $\begin{array}{c}\text { Prozent } \\
\text { der } \\
\text { Asche. }\end{array}$ & $\begin{array}{c}\text { Ver- } \\
\text { hültnis- } \\
\text { mässiger } \\
\text { Brenn- } \\
\text { wert. }\end{array}$ & $\begin{array}{c}\text { Coeffi- } \\
\text { cient der } \\
\text { Nlasti- } \\
\text { zität. }\end{array}$ & $\begin{array}{c}\text { Modulus } \\
\text { der } \\
\text { Bruchfe- } \\
\text { stigkeit. }\end{array}$ & $\begin{array}{c}\text { Bruch- } \\
\text { belastung } \\
\text { auf Zer- } \\
\text { knicken in } \\
\text { Längs- } \\
\text { richtung. } \\
\text { (Druckfe- } \\
\text { stigkeit.) }\end{array}$ & $\begin{array}{l}\text { Wider- } \\
\text { stand } \\
\text { gegen } \\
\text { den Ein- } \\
\text { druck. }\end{array}$ \\
\hline 193. Fraxinus pubescens & 0,6251 & 0,26 & 35 & 22 & 8 & 435 & 204 \\
\hline viridis & & & & & & & 220 \\
\hline platycarpa & & & 0,3515 & 47637 & 536 & 251 & 138 \\
\hline quadrangulata & $18 t$ & 0,78 & 0,7 & 39 & 811 & 499 & 222 \\
\hline oregrana & & & & 84818 & 665 & 520 & 166 \\
\hline sambucifolia & & & & 87185 & 806 & 423 & 194 \\
\hline 199. Forestiera acuminata & 0,6345 & 0,72 & 0,6 & 70282 & 717 & 401 & 170 \\
\hline 200. Chiomanthus virginica & & & & - & - & 一 & - \\
\hline 201. Osmanthus americanus & & & & 123133 & 1051 & 547 & 247 \\
\hline 202. Cordia sebestena & $|0,7108|$ & 4,22 & & & & & \\
\hline Boissieri & 690 & $\delta$, & & & & & \\
\hline 204. Boureria havanensis & 73 & & & 99649 & 944 & 575 & 294 \\
\hline 205. Ehretia elliptica & & & & & 721 & 7 & 229 \\
\hline 206. Catalpa bignonioides & 0,4474 & 0 , & & 68161 & 590 & 364 & 77 \\
\hline .. $\quad$ speciosa & & & & 82156 & 635 & 407 & 86 \\
\hline 2ris. Chilopsis saligna & & & & 54421 & 578 & 297 & 144 \\
\hline 2(1). Crescentia cucurbitina & 19 & 1 ; & 234 & - & - & - & - \\
\hline 211. Citharexylum villosum & 10 & 0,52 & & 125717 & 937 & 689 & 308 \\
\hline 211. Avicennia nitida & 38 & & 99 & - & - & - & - \\
\hline 212. Pisonia obtusata & 29 & & & 46503 & 297 & 310 & 108 \\
\hline 213. Coccoloba floridana & & & & 113538 & 918 & 1 & 394 \\
\hline 214 & 0 & & 3 & - & - & 258 & - \\
\hline 215. Persea carolinensis & 0 , & 0 , & 30 & 83900 & 902 & 573 & 199 \\
\hline 216. Nectandra Willdenowia & & & & 一 & - & - & - \\
\hline 217. Sassafras officinale & 0 & & 37 & 51910 & 602 & 382 & 134 \\
\hline 21ঙ. Umbellularia californica & 17 & & 92 & 106766 & 806 & 568 & 199 \\
\hline 219. Drypetes erocea & & & & 103 & 796 & 650 & 362 \\
\hline 221). Sebastiana lucida & 05 & 2 , & 1,0602 & - & - & - & 一 \\
\hline 2.21. Hippomane mancinella & 0,5772 & & & & & & \\
\hline 2.2. Ulmus crassifolia & 0 & & & 70 & 773 & 453 & 255 \\
\hline fulva & 0,6956 & 0,83 & 0,6898 & 95274 & 869 & 539 & 150 \\
\hline americana & & & & 74742 & 852 & 446 & 17 \\
\hline racemosa & & 0 , & 19 & 109628 & 1066 & 592 & 205 \\
\hline alata & 0,7491 & 0,99 & 0,7417 & 52323 & 724 & 449 & 25 \\
\hline 227. Planera aquatica & 0,5294 & 0,45 & 0,5270 & 55167 & 621 & 394 & 14 \\
\hline $22 \AA$. Celtis occidentalis & & & & 68527 & 789 & 421 & 217 \\
\hline 229. Ficus aurea & 0,2616 & 5,03 & 0,2484 & 25699 & 239 & 162 & 61 \\
\hline$\because \quad$ brevifolia & & 4,36 & 0,6119 & - & - & - & - \\
\hline 31. . pedunculati & & & & 40690 & 230 & 281 & 118 \\
\hline 232. Molus rubra & 0,5898 & 0,71 & 0,5856 & 82377 & 775 & 420 & 178 \\
\hline .. microphylla. & 0,7715 & 0,68 & 0,7663 & - & - & - & 一 \\
\hline
\end{tabular}




\begin{tabular}{|c|c|c|c|c|c|c|c|c|c|}
\hline & & $1 \mathrm{r}$ & $\begin{array}{c}\text { Spezifi- } \\
\text { sches } \\
\text { 'Gewicht. }\end{array}$ & $\begin{array}{c}\text { Prozent } \\
\text { der } \\
\text { Asche. }\end{array}$ & $\begin{array}{l}\text { Ver- } \\
\text { hiltnis- } \\
\text { mässiger } \\
\text { Brenn- } \\
\text { wert. }\end{array}$ & $\begin{array}{c}\text { roeffi- } \\
\text { cient der } \\
\text { Elasti- } \\
\text { zitiat. }\end{array}$ & $\begin{array}{l}\text { Mfodulus } \\
\text { der } \\
\text { Bruchfe- } \\
\text { stigkeit. }\end{array}$ & $\begin{array}{c}\text { 13ruch- } \\
\text { belastung } \\
\text { auf Zer- } \\
\text { knicken in } \\
\text { Längs- } \\
\text { richtung. } \\
\text { (Druckfe- } \\
\text { stigkeit.) } \\
\end{array}$ & $\begin{array}{l}\text { Wider- } \\
\text { stand } \\
\text { gegen } \\
\text { den Lin- } \\
\text { druck. }\end{array}$ \\
\hline 34. & Maclura : & aurantiaca & 0,7736 & 0,68 & 0,7683 & 94373 & 1131 & 809 & 363 \\
\hline 35. & Platamus & occidentalis & 0,5678 & 0,46 & 0,50652 & 86402 & $633 \overline{5}$ & $\$ 50$ & 165 \\
\hline 36. & $"$ & racemosa & 0,4880 & 1,11 & 0,4826 & 62401 & $5\left(i^{2}\right)$ & 4 & 93 \\
\hline 37. & $"$ & Wrightii & 0,4736 & 1,35 & 0,4672 & 45644 & $4 \cdot 3$ & 327 & 117 \\
\hline 38. & Juglans c & cineren & 0,4086 & 0,51 & 65 & 81 & 547 & & 90 \\
\hline 239. & $"$ & nigra & $0,(i 115$ & 0,79 & 0,6067 & 109200 & -5.56 & & 196 \\
\hline 40. & $\because$ & rupestris & 0,655 & 1,01 & $6 \pm 88$ & 726332 & (i) & & 182 \\
\hline 41. & Carya oli & livaeformis & 0,7180 & & 0,7099 & 666646 & 5 & & 232 \\
\hline t.. & all & lba & 0,8372 & 0,73 & 0,8311 & 13 & $12 \div 10$ & & 271 \\
\hline 43. & sul & ulcata & 8 & 0,90 & 0,803 & 34 & 11 & & 288 \\
\hline $4 t$. & to: & omentosa & 218 & 1, & 31 & 95 & 11 & & 277 \\
\hline 45. & po & orcina & 0,8217 & 0,99 & 0,8136 & 103300 & 11141 & 7 & 301 \\
\hline 46. & an & mara & 0,75ว2 | & 1,03 & 74 & 10 & 11111 & & 242 \\
\hline 47 & $\Rightarrow m$ & yristicaeformis & 0,8016 & 1,06 & & 84 & $1: ;$ & & 315 \\
\hline 248. & $\because \quad a q$ & quatica & 0,7407 & 1,27 & 0,7313 & 101261 & $x+4$ & 486 & $27 t$ \\
\hline 249. & Myrica $c$ & ceri & 337 & 0,51 & 0,5608 & 78 & 815 & & 144 \\
\hline .50. & $"$ & californica & 0,6703 & 0,33 & 0,6681 & 99161 & $1636 i$ & & 188 \\
\hline 251. & Quercus & alba & 0,7470 & 0,41 & 0,7439 & 97089 & ใหร̃ & 511 & 213 \\
\hline 52. & .. & lnhata & 0,7 & & & 4 & & & 188 \\
\hline 53. & $:$ & garryana & 0,7453 & 0,39 & 0,7424 & 81109 & หร?! & ว0อ̃ & 240 \\
\hline 54. & $:$ & abtusiloba & 0,8367 & 0,79 & 0,8301 & 83257 & $x ; 2$ & 487 & 276 \\
\hline$=$ & 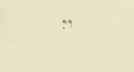 & $\begin{array}{c}\text { undulata var. } \\
\text { Gambellii }\end{array}$ & 0,8407 & 0,99 & & & $6 \times 0$ & 417 & 255 \\
\hline 56. & $n$ & macrocarpa & & & 100 & 29 & 140 & 491 & 233 \\
\hline 57. & 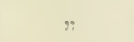 & lyrata & 0,8313 & 0,63 & 0,8259 & 133438 & 11125 & 4 & 252 \\
\hline 58. &.. & bicolor & 0,7662 & $0, \mathrm{\partial} 8$ & 0,7618 & 90636 & $!(19 !)$ & $\$ 90$ & 221 \\
\hline 59. & $n$ & & & & 03 & & 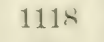 & & 233 \\
\hline 60 & .. & Prinus & 0,7499 & 0,77 & 41 & $125 \pm 73$ & $111: 31$ & & 230 \\
\hline 51. & , & prinoides & 0,8605 & 1,14 & 0,8507 & 112461 & 12:3i & 5 & 264 \\
\hline 62. &. & & & $0,8 t$ & & 66 & & & 374 \\
\hline 263. & $"$ & oblongifolia & 41 & 2,61 & 95 & 85739 i & $71 !$ & 434 & 439 \\
\hline 64 & $"$ & grisea & 92 & 1,82 & 0,9308 & 73982 & 937 & 479 & 364 \\
\hline 265. & ; & reticula & 0,9479 & $0, \tilde{5} 2$ & $0,9 \pm 30$ & - & 一 & - & - \\
\hline 266. & " & Durandii & $0,950 \overline{7}$ & 1,78 & 0,9338 & 83766 & $(1 ! 1: 3$ & รั34 & 308 \\
\hline 267. & $"$ & virens & 0,9501 & 1,14 & 0,9393 & 113627 & 1017 & 7 & 324 \\
\hline 268. & 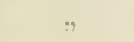 & chrysolepis & & 0,60 & 42 & 119 & $126 \pi$ & 545 & 317 \\
\hline 269. & $n$ & Emoryi & 0,9263 & 2,36 & $0,90+4$ & 63828 & 7113 & +22 & 415 \\
\hline 270. & $"$ & agrifolia & 0,8253 & 1,28 & 0,8147 & 95276 & $91: 35$ & 463 & 235 \\
\hline 271. & $"$ & Weslizeni & 0,78555 & 1,02 & 0,7775 & 860อ̄5 & 818 & 533 & 272 \\
\hline 272. & $n$ & rubra & $0,65 \pm 0$ & 0,26 & 0,6523 & 112798 & $\$ 931$ & 511 & 177 \\
\hline 273. & $"$ & coccinae & 0,7405 & 0,19 & 0,7391 & 108507 & 11154 & 504 & 202 \\
\hline
\end{tabular}




\begin{tabular}{|c|c|c|c|c|c|c|c|c|c|}
\hline & & $\mathrm{Ar} \mathrm{t}$. & $\begin{array}{l}\mid \text { Spezifi- } \\
\text { sches } \\
\mid \text { Gewicht. }\end{array}$ & $\begin{array}{l}\text { Prozent } \\
\text { der } \\
\text { Asche. }\end{array}$ & $\begin{array}{c}\text { Ver- } \\
\text { hältnis- } \\
\text { mässiger } \\
\text { Brenn- } \\
\text { wert. }\end{array}$ & \begin{tabular}{|c|} 
Coeffi- \\
cient der \\
Elasti- \\
zitiit.
\end{tabular} & $\begin{array}{l}\text { Modulus } \\
\text { der } \\
\text { Bruchfe- } \\
\text { stigkeit. }\end{array}$ & $\begin{array}{c}\text { Bruch- } \\
\text { belastung } \\
\text { suf Zer- } \\
\text { knieken in } \\
\text { Längs- } \\
\text { richtung. } \\
\text { (1)ruckfe- } \\
\text { stigkeit.) } \\
\end{array}$ & $\begin{array}{l}\text { Wider- } \\
\text { stand } \\
\text { gegen } \\
\text { den Fin- } \\
\text { druck. }\end{array}$ \\
\hline & 0,7045 & 0,28 & 0,7025 & $|103427|$ & 1041 & 501 & 202 \\
\hline \multicolumn{2}{|c|}{$\begin{array}{l}\text { 27t. Quercus tinctoria } \\
27 . \quad \text {.. Kelloggii }\end{array}$} & Kelloggii & 0.6435 & 0,26 & 0,418 & $|74488|$ & 768 & 449 & $17 t$ \\
\hline \multicolumn{3}{|l|}{276.} & 0,7324 & 1,16 & 0,7239 & 97656 & 1043 & 497 & 286 \\
\hline \multicolumn{3}{|l|}{$27 \%}$. & 0,6928 & 0,25 & 0,6911 & 140151 & 1193 & & 201 \\
\hline \multirow{2}{*}{$\begin{array}{l}276 . \\
279\end{array}$} & .. & Catesbaei & $0,729 t$ & 0,87 & 0,7231 & 103468 & 1046 & 457 & 228 \\
\hline & .. & palustris & 0,6938 & 0,81 & 0,6882 & 112296 & 1090 & 491 & 190 \\
\hline \multirow{2}{*}{$\begin{array}{l}280 . \\
281 .\end{array}$} & .* & aquatica & $0,724 \frac{1}{x}$ & 0,51 & 0,7207 & 122657 & 1052 & 501 & 198 \\
\hline & .. & laurifolia & 0,7673 & 0,82 & $|0,7610|$ & $\mid 125916$ & 1181 & 526 & 253 \\
\hline \multirow{2}{*}{$\begin{array}{l}282 . \\
2 \times 3 .\end{array}$} & .. & heterophylla & 34 & 0,17 & 22 & 122 & 1073 & 2 & 182 \\
\hline & . & cinerea & 0,6420 & 1,21 & $|0,6342|$ & 75120 & 993 & 448 & 201 \\
\hline $2 \pi 4$ & .. & hypoleuca & 0,8009 & 1,34 & 0,7902 & 94409 & 1113 & 293 & 272 \\
\hline \multirow{2}{*}{$\begin{array}{l}285 . \\
286 .\end{array}$} &. & imbricaria & 0,7529 & 0,43 & 0,7 & 119 & 1218 & 2 & $2 \cdot 26$ \\
\hline & .. & Phellos & 0,7472 & 0,50 & 0,7435 & 78440 & 989 & 390 & 216 \\
\hline \multirow{2}{*}{$\begin{array}{l}287 . \\
288 .\end{array}$} &.. & densiflora & 0,6827 & 1,49 & $|0,6725|$ & 96347 & 946 & $47 i$ & 224 \\
\hline & Castan & nopsis chrysophylla & $(1,5574$ & 0,35 & 4 & 101195 & 741 & 435 & 119 \\
\hline \multicolumn{3}{|c|}{ 289. Castanea pumila } & $(1.58877$ & 0,12 & $0,5880 \mid$ & 114108 & 991 & 495 & 118 \\
\hline \multirow[t]{2}{*}{290.} & $"$ & americana & 0,4504 & 0,18 & 0,4 & 85621 & 696 & 381 & 106 \\
\hline & Fagus & $s$ ferruginea & 883 & & 18 & 120996 & 1148 & 478 & 196 \\
\hline \multirow[t]{2}{*}{292.} & Ostrya & a virginica & 284 & 0,50 & 0,8243 & 137279 & 1134 & 542 & 231 \\
\hline & Carpin & nus caroliniana & 0,7286 & 0,83 & 0,7226 & 114881 & 1149 & 498 & 213 \\
\hline \multicolumn{3}{|c|}{$\begin{array}{l}\text { 294. Betula alba var. populi- } \\
\text { folia }\end{array}$} & $0, \tilde{5}$ & 0,29 & 43 & 72960 & 778 & 348 & 129 \\
\hline 995. & $"$ & papyrifera & & 0,25 & 40 & 130557 & 1065 & 487 & 126 \\
\hline 296. & .. & occidentalis & 0.6030 & 0,30 & 0,6012 & 92424 & 806 & 391 & 127 \\
\hline 297. & $"$ & lutea & 0,65533 & 0,31 & 0,6533 & 161723 & 1248 & 619 & 161 \\
\hline 298. & $"$ & nigra & & & & 111322 & 972 & 438 & 132 \\
\hline 299. & $"$ & lenta & 0,7617 & 0,26 & 0,7597 & 141398 & 1216 & $\$ 19$ & 226 \\
\hline 300. & Alnus & maritima & & 0,39 & 0,4977 & - & - & - & 129 \\
\hline 301. & $"$ & rubra & & & 0,4793 & 106046 & 811 & $41 j$ & 117 \\
\hline 302. & $n$ & rhombifolia & 0.4127 & 0,31 & $0,410 \pm$ & 84580 & 682 & 356 & 78 \\
\hline 303. & " & oblongifolia & 0,3981 & 0,42 & 0,3964 & 76937 & 686 & 278 & 74 \\
\hline 304. & " & serrulata & 0.4666 & 0,38 & 0,4648 & - & - & - & - \\
\hline 305. & $"$ & incana & 0,4607 & 0,42 & 0,4588 & 108507 & $8: 0$ & $2 \times 9$ & - \\
\hline 306. & Salix $n$ & nigra & 0,4456 & 0,70 & 0,4425 & 39026 & 424 & $21: 3$ & 93 \\
\hline 307. & $n$ & amygdaloides & 0,4509 & 0,92 & 0,4468 & 50144 & 5อ & 264 & 81 \\
\hline 308. & 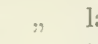 & laevigata & 0,4872 & $0, \check{8}$ & 0,4844 & 48828 & 644 & $: 319$ & 118 \\
\hline 309. & $"$ & lasiandra & 0.4756 & 0,60 & 0,4727 & - & -- & -- & - \\
\hline 310. & $"$ & longifolia & 0.4930 & 0.48 & 0,4906 & - & - & - & - \\
\hline 311. & .. & sessilifolia & 0,4397 & $0, \overline{0} 0$ & 0,4375 & - & - & - & - \\
\hline & .. & discolor & 0,4261 & 0,43 & 0,4243 & - & - & - & - \\
\hline 313. & .. & flavescens & 0.4969 & 0,61 & 0,4939 & 108507 & 408 & $4(1)$ & 98 \\
\hline
\end{tabular}




\begin{tabular}{|c|c|c|c|c|c|c|c|}
\hline A r t. & $\begin{array}{c}\text { Spe zifi- } \\
\text { sches } \\
\text { Gowicht. }\end{array}$ & $\begin{array}{l}\text { Prozent } \\
\text { der } \\
\text { Asche. }\end{array}$ & $\begin{array}{c}\text { Ver- } \\
\text { hältnis- } \\
\text { mässiger } \\
\text { Breun- } \\
\text { wert. }\end{array}$ & $\begin{array}{l}\text { Coeffi- } \\
\text { cient der } \\
\text { Elasti- } \\
\text { zitit. }\end{array}$ & $\begin{array}{c}\text { Modulus } \\
\text { der } \\
\text { Bruchfe- } \\
\text { Btigkeit. }\end{array}$ & \begin{tabular}{|c|} 
Bruch- \\
belastung \\
auf Zer- \\
knicken in \\
Liangs- \\
richtung. \\
(Druckfe- \\
stigkeit.) \\
\end{tabular} & $\begin{array}{l}\text { Wider- } \\
\text { stand } \\
\text { gegen } \\
\text { den Eirn- } \\
\text { druck. }\end{array}$ \\
\hline 14. Salix Hookeriana & 0,5350 & 0,32 & 0,5333 & - & - & 427 & 111 \\
\hline 310. $"$ cordata var. restita & 0,6069 & $0, \overline{6} 9$ & 0,6033 & - & - & 一 & - \\
\hline 316. " Jasiolepis & 0,5587 & 0,98 & 0,5532 & 88778 & 813 & 385 & 140 \\
\hline 317. " sitchensis & 0,5072 & 0,59 & $0, \% 0+2 \mid$ & - & - & - & - \\
\hline 318. Populus tremuloides & 0,4032 & $0,5 \overline{5}$ & $0,4010 \mid$ & $81+41$ & 677 & 330 & 80 \\
\hline grandidentata & 0,4632 & 0,45 & 0,4611 & 96327 & 721 & 358 & $6 i 2$ \\
\hline heterophylla & 0,4089 & 0,81 & 0,4056 & 72338 & 642 & $28: 3$ & $86 ;$ \\
\hline balsamifera & 0,3635 & 0,66 & $0,3611 \mid$ & 850 & 0 & 320 & 7i) \\
\hline angustifolia & 0,3912 & 0,79 & 0,3881 & $458+7$ & 400 & 271 & 76 \\
\hline trichocarpa & 0,3814 & 1,27 & 0,3766 & 111694 & 665 & 390 & 63 \\
\hline monilifera & 0,3889 & 0,96 & $|0,3852|$ & $99+17$ & 0 & 3 & 83 \\
\hline Fremontii & $0, \pm 914$ & 0,77 & 0,4876 & 105116 & 698 & 378 & 86 \\
\hline 326. Libocedrus decurrens & $0, \pm 017$ & 0,08 & 0,4014 & $8 \pm 729$ & 682 & 403 & 98 \\
\hline 327. Thuja occidentalis & 0,3164 & 0,37 & 0,3152 & 53311 & 512 & 306 & 60 \\
\hline 328. " gigantea & 0,3796 & 0,17 & $0,3790 \mid$ & 103372 & 749 & 450 & 70 \\
\hline $\begin{array}{l}\text { 329. Chamacyparis sphae- } \\
\text { roidea }\end{array}$ & 0,3323 & 0,93 & 0,3311 & 40410 & 456 & 259 & 67 \\
\hline nutkaensis & $0, \pm 782$ & 0,34 & 0,4766 & 102881 & 801 & 455 & 101 \\
\hline Lawsoniana & 0,4621 & 0,10 & & 121772 & 888 & 466 & 82 \\
\hline 332. Cupressus macrocarpa & 0,6261 & 0,57 & 0,6225 & 107327 & $10 \pm 5$ & - & 237 \\
\hline Goveniana & 0,4689 & 0,45 & $0,4668 \mid$ & 49941 & 539 & 359 & 178 \\
\hline Macnabiana & - & - & - & - & - & - & - \\
\hline " guadalupensis & 0,4843 & $0, \pm 4$ & 0,4822 & - & - & - & - \\
\hline 336. Juniperus californica & 0,6282 & 0,75 & 0,6235 & - & - & - & - \\
\hline pachyphloea & 0,5829 & 0,11 & 0,5823 & 61275 & $76 i 1$ & - & - \\
\hline occidentalis & 0,5765 & 0,12 & 0,5758 & - & - & - & - \\
\hline 339. " virginiana & 0,4926 & & 0,4920 & 66692 & 740 & 416 & 148 \\
\hline 340. Taxodium distichum & 0,4543 & 0,42 & 0,4524 & 103206 & 682 & 423 & 81 \\
\hline 341. Sequoia gigantea & 0,2882 & 0,500 & 0,2868 & 45146 & 459 & 388 & 68 \\
\hline 342. Sequoia sempervirens & 5,4208 & $0,1 \pm$ & 0,4202 & 67646 & 5 & 416 & 78 \\
\hline 343. Taxus brevifolia & 0,6391 . & 0,22 & 0,6377 & 76133 & 1078 & 483 & 264 \\
\hline 34t. " floridana & 0,6340 & 0,21 & 0,6327 & - & 一 & - & - \\
\hline 345. Toreya taxifolia & 0,5145 & 0,73 & 0,5107 & 82833 & 837 & $\$ 60$ & 158 \\
\hline $3 \pm 6 . \quad " \quad$ californica & 0,4760 & 1,34 & 0,4696 & 10146 & 583 & 351 & 122 \\
\hline 347. Pinus strobus & $0,385 \pm$ & 0,19 & $0,38 \pm 7$ & 85093 & 626 & 339 & it \\
\hline " monticola & 0,3908 & 0,23 & 0,3899 & 95068 & 609 & 334 & 67 \\
\hline " Lambertiana & 0,3684 & 0,22 & 0,3676 & 79375 & 597 & 336 & 78 \\
\hline flexilis & 0,43558 & 0,28 & $0,43 \pm 6$ & 67531 & 621 & 349 & 108 \\
\hline albicaulis & 0,4165 & 0,27 & $0,415 \pm$ & $381+7$ & 581 & 331 & 107 \\
\hline$"$ reflexa & $0, \pm 877$ & 0,26 & $0,486 \pm$ & 91287 & 770 & 489 & 128 \\
\hline " Parryana & 0,567 เ & $0, \bar{\jmath} t$ & $0,56 \pm 4$ & $3778:$ & 426 & 339 & 195 \\
\hline
\end{tabular}




\begin{tabular}{|c|c|c|c|c|c|c|c|c|c|}
\hline & & A r t. & \begin{tabular}{|c|} 
Spezifi- \\
sches \\
Gewicht.
\end{tabular} & $\begin{array}{c}\text { Prozont } \\
\text { der } \\
\text { Asche. }\end{array}$ & $\begin{array}{c}\text { Vor- } \\
\text { hältnis- } \\
\text { mässiger } \\
\text { Brenn- } \\
\text { wert. }\end{array}$ & $\begin{array}{c}\text { Coeffi- } \\
\text { cient der } \\
\text { Elasti- } \\
\text { zitiit. }\end{array}$ & $\begin{array}{c}\text { Modulus } \\
\text { der } \\
\text { Bruchfe- } \\
\text { stigkeit. }\end{array}$ & \begin{tabular}{|c|} 
Bruch- \\
belastung \\
suf Zer- \\
knicken in \\
Längs- \\
richtung. \\
(Druckfe- \\
stigkeit.) \\
\end{tabular} & $\begin{array}{l}\text { Wider- } \\
\text { stand } \\
\text { gegen } \\
\text { den fin- } \\
\text { druck. }\end{array}$ \\
\hline 354.1 & Pinus c & cembroides & 0,6512 & 0,90 & $|0,6453|$ & - & - & - & — \\
\hline $35 \%$ &. & edulis & 0,6388 & 0,62 & 0,6348 & 42094 & 447 & 349 & 212 \\
\hline $35 \check{6}$ &. & monophylla & 0,5658 & 0,68 & 0,5620 & 43488 & 288 & $27 t$ & 169 \\
\hline 357. &, & Balfouriana & 0,5434 & 0,40 & 0,5412 & 59386 & 424 & 337 & 147 \\
\hline 358. & , & resinosa & 0,4854 & 0,27 & 0,4841 & 113216 & 800 & 455 & 85 \\
\hline 359. &, & Torreyana & 0,4879 & 0,35 & 0,4862 & 54213 & 756 & 290 & 147 \\
\hline 360. & .. & arizonica & 0,5038 & 0,20 & 0,5028 & 82370 & 653 & 381 & $10 \tilde{5}$ \\
\hline 361. & ., & ponderosa & 0,4715 & 0,35 & 0,4698 & 88731 & 720 & 381 & 107 \\
\hline 362. & , & Jeffreyi & 0,5206 & 0,26 & 0,5192 & 92777 & 744 & 417 & 116 \\
\hline 363. &. & huana & 0,5457 & 0,39 & 0,5436 & 72575 & 832 & 337 & 154 \\
\hline 364. & ", & con & 315 & 0,19 & 0,5804 & 158533 & 993 & 554 & 149 \\
\hline 365. & , & Murrayana & 096 & 0,32 & 0,4083 & 77113 & 564 & 3 & 86 \\
\hline 366. & .. & Sabiniana & 0,4840 & 0,40 & 0,4821 & 58517 & 779 & 337 & 138 \\
\hline 367. & .. & $\mathrm{Co}$ & 0,4163 & 0,37 & 0,4118 & 114108 & 761 & 367 & 92 \\
\hline 368. &. & insignis & 574 & 0,30 & $0,4 う 60$ & 97850 & 740 & 417 & 105 \\
\hline 369. &. & tuberculata & 0,3499 & 0,33 & 0,3487 & 42870 & 409 & 263 & 86 \\
\hline 370. & .. & taeda & 0,5441 & 0,26 & 27 & 112 & $88: 3$ & 127 & 107 \\
\hline 371. & .. & rigi & 5151 & 0,23 & 0,5139 & 58127 & 7339 & & 133 \\
\hline 372. & .. & serotina & 942 & 0,17 & 0,7928 & 116957 & $116 t$ & 505 & 296 \\
\hline 373. &. & inops & & 0,30 & 0,5 & 54 & 658 & & 156 \\
\hline 374. & .. & cla & 0.5576 & 0,31 & 0,5559 & 54295 & 502 & 377 & 131 \\
\hline 375. &.. & pungens & 0,4935 & 0,27 & 0,4922 & 80330 & 726 & 354 & 115 \\
\hline 376. & .. & muricata & & 0,20 & 0,4929 & 119 & 1031 & & 122 \\
\hline $37 \pi$. & . & mitis & 0,6104 & 0,29 & 0,6086 & 137495 & 1038 & 477 & 129 \\
\hline 378 &.. & glabra & $|0,3931|$ & 0,45 & 0,3913 & 44750 & 496 & 288 & 106 \\
\hline 374. &. & Banksiana & 761 & 0,23 & 0,4750 & 94231 & 652 & 396 & 101 \\
\hline 380. & " & palustris & $|0,6999|$ & 0,25 & $\mid 0,6982$ & 148733 & 1152 & 629 & 153 \\
\hline :881. & .. $\quad \mathrm{c}$ & cubensis & 0,7504 & 0,26 & 0,7484 & 157747 & 1172 & 664 & 186 \\
\hline 382. I & Picea ni & nigra & $|0,4584|$ & 0,27 & 0,4572 & 109987 & 747 & 407 & 77 \\
\hline 383. & .. & alba & 0,4051 & 0,32 & 0,4038 & 102280 & $7 \pm 7$ & 343 & 74 \\
\hline 384. & ., & Engelmanni & 0,3449 & 0,32 & 0,3438 & 80791 & 574 & 267 & 76 \\
\hline 385. & .. & pungens & 0,3740 & 0,38 & 0,3726 & 55360 & 454 & 258 & 79 \\
\hline 386. & $" \quad \mathrm{~s}$ & sitchensis & $0, \pm 287$ & 0,17 & $0,4280 \mid$ & 99001 & 649 & 353 & 73 \\
\hline 387. ' & 'Tsuga c & canadensis & 0,4239 & 0,46 & 0,4220 & 89970 & 736 & 384 & $8 \cdot 2$ \\
\hline 388. &.. & caroliniana & 0,4275 & 0,40 & 0,4258 & 71282 & 461 & 403 & 125 \\
\hline 389. & , & Mertensiana & 0,5182 & 0,42 & 0,5160 & 137483 & $9(09)$ & 547 & 101 \\
\hline 390. & $"$, & Pattoniana & 0,4454 & 0,44 & 0,4434 & | 77524 & 719 & 379 & 104 \\
\hline \multirow{2}{*}{\multicolumn{3}{|c|}{$\begin{array}{l}\text { 391. Psendotsuga Douglasii } \\
\text { 391 a. " " Douglasii }\end{array}$}} & $\mid 0,5157$ & 0,08 & 0,5153 & 128297 & 881 & $5 \check{19}$ & 1011 \\
\hline & & & 0,4563 & 0,08 & 0,4559 & 105007 & 846 & 463 & 11) 2 \\
\hline
\end{tabular}




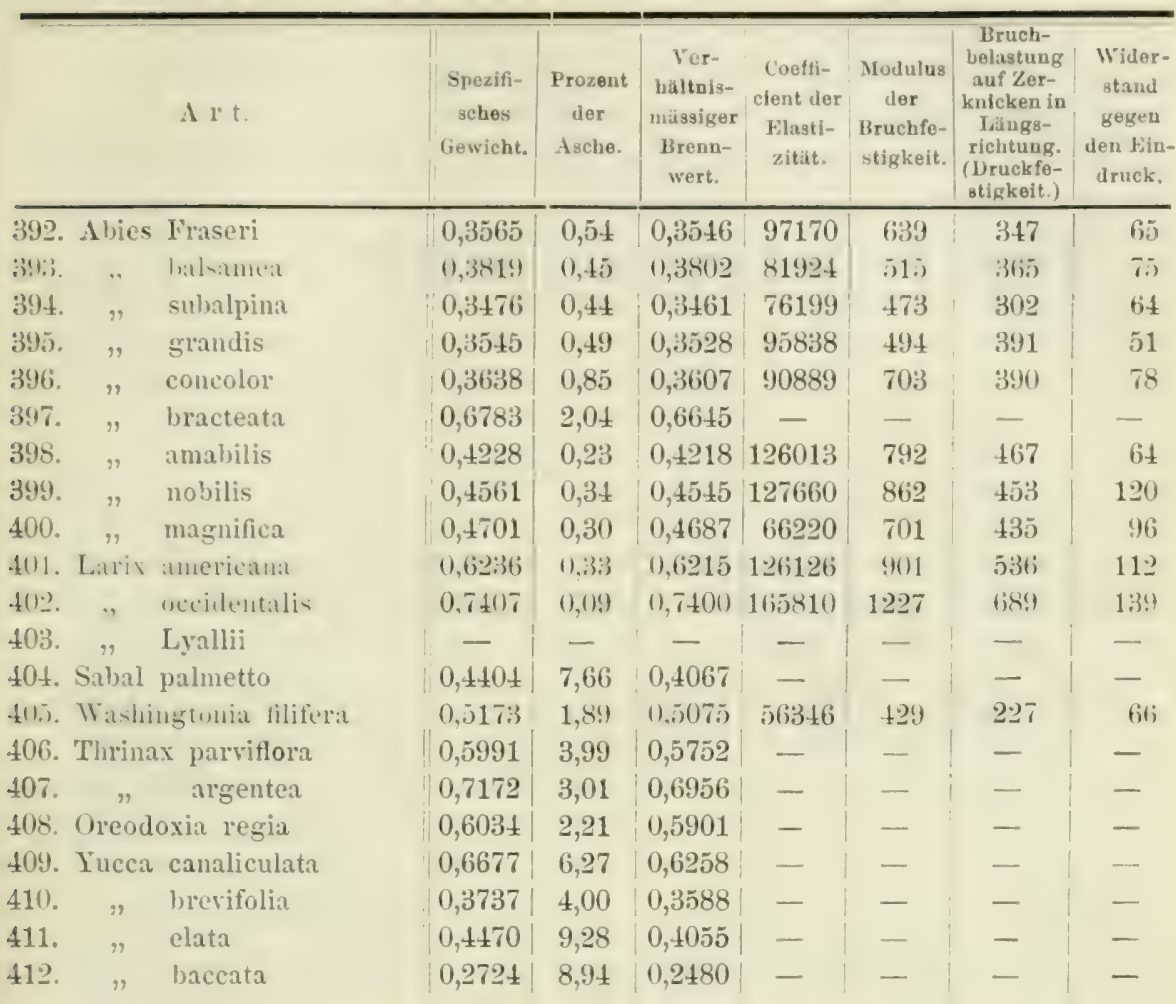

\section{Die Beurteilung der Farbhölzer.}

ln Jinglexs polytechnischem Jommal gah) Ir. R. ron Höhnel

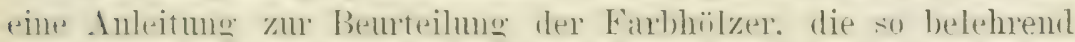

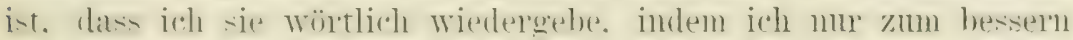

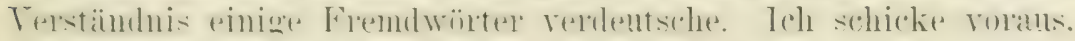

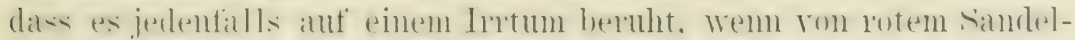

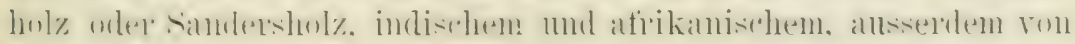

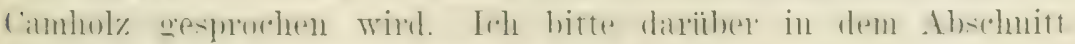
iiber die Farbhïlzer nachzulesen. 


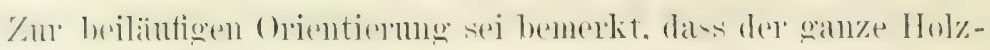

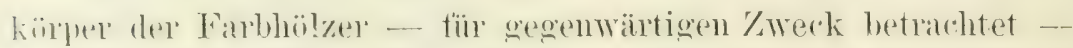

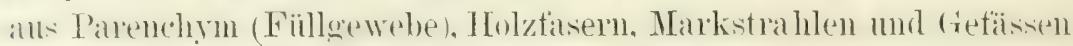
hestelit. Die Darkstrahlen erscheinen anf dem (Puersehnitt manchmal shom dem freien Ange. immer aber bei einer 4 bis 5 maligen Thuenveroüsermo als zarte, matte, gleichlatufende Linien, die in rintel meist dunkleren, festen Grundmasse, die ans Holzfasern zusammengesetzt ist, eingebettet sind. Die Richtung der Markstrahlen ist die radiale. Fin in dieser Richtmo gefïhter Längsischnitt heisst Radialschnitt. Senkrecht anf der radialen Richtumg tamgential - verlanfen auf dem Qnerschnitt andere teine. meist etwas wellige Linien, welche die Grenzen der , Tahrestinge darstellen. Der auf dem Radialschnitt senkrecht geführte Längsschnitt heisst Tangentialschnitt; ex durchschneidet alle Markstrahlen quer. während sie der Radialschnitt ihrer Länge nach bloslegt. I) Holzfasern und Gefässe erscheinen anf dem (querschnitte im senkrechten Durchschnitte. Erstere stellen gewissermassen die Grunctmasse des Holzes dar: sie bedingen die Festigkeit des Holzkörpers und erscheinen anf dem Querschnitt als dunklere, feste, geschlossene frewebemassen. in welche die meist hellen Parenchymmassen al; Flecken von rundlicher oder tangential quergestreckter Gestalt oder als zusammenhängende. tangentiale, schmale Bänder oder streifen eingebettet sind. In diese durch ihre Anordnung meist sehr charakteristischen Parenchymmassen sind num die Gefässe als hohle, der Länge des Holzkïrpers nach gerichtete Röhren eingelagert.

Hat man einen anch nur kleinen splitter des Holzes. su gelingt es mit Hilfe dex leicht herzustellenden Querschnittsfliche. mue weiteres genan orientierte Radialschnitte mol Tangentialschnitte zi führen, elsenso gerichtete spaltungsflädhen zu erzengen mnd sich so in den Besitz aller jener Kardinalansichten des Holzkiorpers zu versetzen. welche für die Ansführmg der folgenden Untersuchungen notwendig erscheinen.

schon eine vorläntige Tntersuchmg der (puerschnitte mit dor Lupe zeigt, dass sich die Farbe- und nächst rerwandten ähnlichen Hölzer in eine Anzahl von Gruppen teilen, die bezilinlich des Bantes s:harf rom einander getrement und zu unterscheiden sind. immerhalh welcher aber eine sichere T'ntersheidung mit gröseren schwierigkeiten verbunden ist. 
Diese Gruppen sind: 1. Blauholz; 2. die minderen Rotholz-

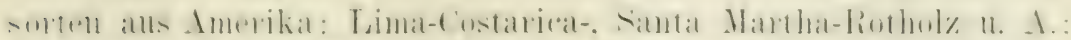

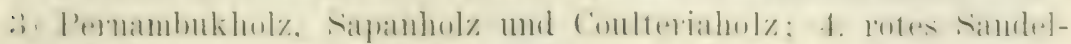

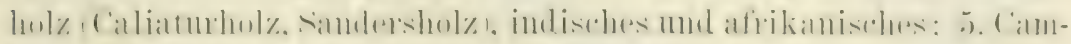
hol\%: 6. Fustik: 7. Sanerdorn; 8. Fisetholz.

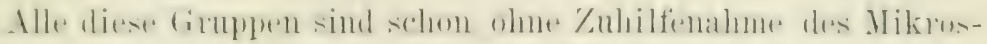

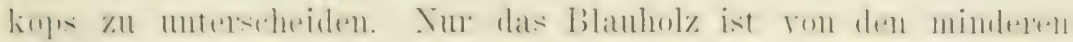

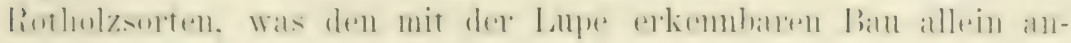
betrifft. manchmal nicht leicht zu tremen.

\section{Gill)}

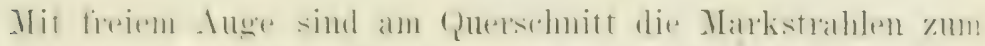

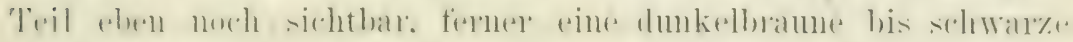

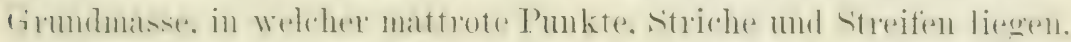

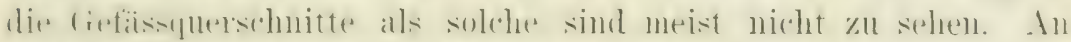

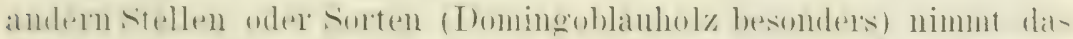

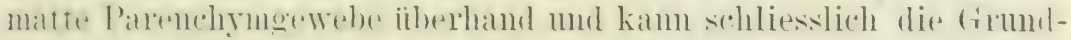

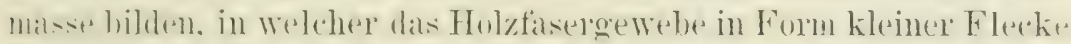

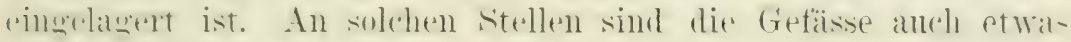
weiter und als Holzröhren dentlich zu sehen.

Anf dem Tangential- mol Radialschnitte sind die fietäsist

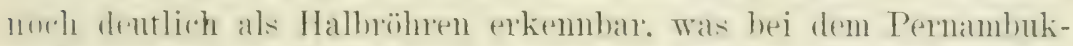
hul\% niellt mehr der Fall ist. Anf dem Tangentialschnitte ist rout

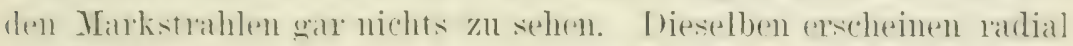

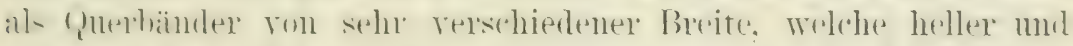

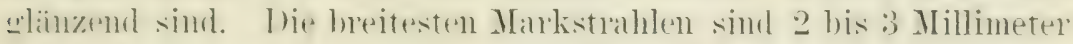

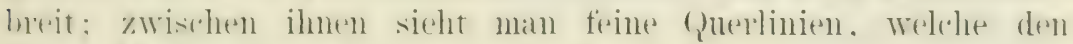

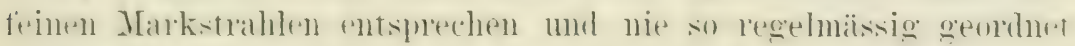
sind wie bei Pernambukholz.

\section{Gruppe.}

l) merinderen liotholzsolten schliessen sich im Ban ene an

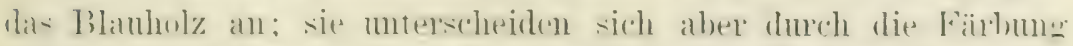

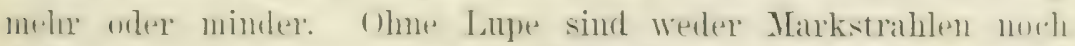

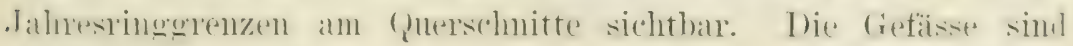

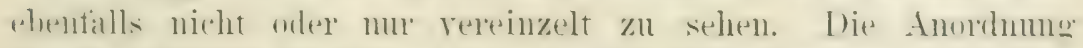

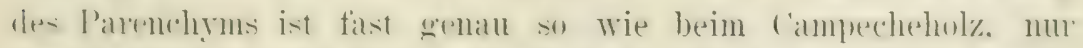

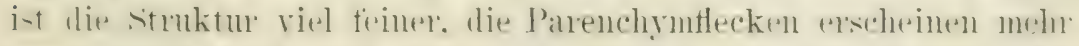

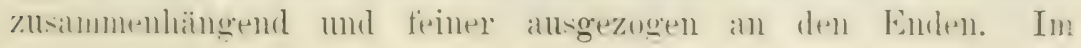


T'ancentialschnitt erscheinen die Gefässe nur als dumkle Linien und die Markstlahlen als sehr kurze und zarte dunkle Längsstreifen, die nicht, wie beim Pernambukholz zu wagrechten Reihen seordnet sind. Anf dem Radialschnitte zeigen sich die nur bis 0.3) Millimeter breiten Markstrahlen, welche beziiglich ilmer Breite in der Mitte zwischen dem des Pernambuk-Kapanholzes stehen.

\section{Grupe.}

I)as Pernambuk-, Sapan- und Coulteriaholz stimmen in den wesentlichen Eigentimlichkeiten des Banes ïberein, alle drei hesitzen nämlich fast gleichmässig zerstrente Gefässporen und rundliche. sehr charakteristische Parenchymflecken. Das Coulteriaholz vom Conlteria tinctoria hat unter den Rothölzern die feinste Struktur und der Querschnitt zeigt genau dieselbe Beschaffenheit wie beim Pernambukholz, nu sind die Jahresringorenzen deutlicher und das Holz ist mehr braun wie rot gefürbt. Auch Tangentialund Radialschnitte verhalten sich ganz so wie beim Pernambukholz. Das Letztere lässt beim Querschnitt eine rotbrame. larte. glänzenute Grundmasse erkennen, welche mit sehr zahlreichen. cinzelstehenden, mattroten Punkten bestreut erscheint, von welchen viele undentlich und wie rerschwommen sind. Markstrahlen und Jahresringgrenzen kömen ohne Lupe nicht erkamnt werden. Am Tangentialschnitte erscheinen die Gefässe nur als zarte. dunkle Längslinien. Tangentiale spaltungsflächen zeigen mgemein zarte, genäherte Querhinien, welche denselben ein feinwelliges Aussehen geben und ron den in Wagerechten Reihen geordneten Markstrahlen herrïhren. Ein ähnliches Aussehen besitzt auch der radiale Hauptschnitt. Die Markstrahlen sind alle schmal, 4 bis 5 gehen auf 1 Millineter. Das Sapanholz zeigt am Querschnitte grössere Parenchymflecken als das Pernambukholz. Die Gefüssquerschnitte sind schon mit freiem Auge als Löcher erkembar, die Jahresringrenzen sind deutlich. Dadurch, dass die Parenchymflecken am inneren Raude der Jahresringe dichter gestellt sind, entstehen charakteristische hellere und dunklere conzentrische Bänder. die Markstrahlen sind eben noch mit freiem Auge zu sehen, die radiale Ansicht zeigt keine Wellung, hingegen sind die Markstrahlen deutlicher wie beim Pernambukholz (0,25 bis 0.66 Millimeter). Ebenso wenig zeigt die tangentiale schnittfläche Wellung. Sthr deutlich er- 


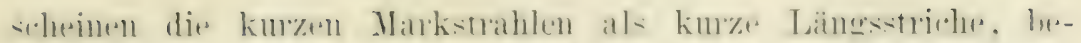

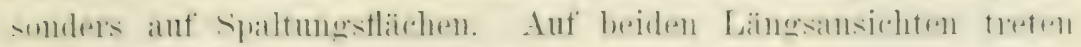
die Gefiisse als erkemubare Halbröhren ant.

\section{Gruppe.}

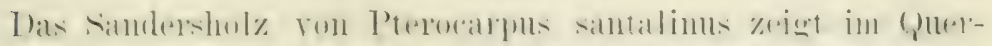

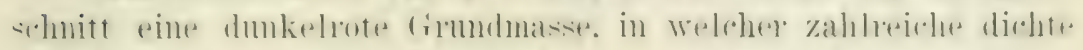

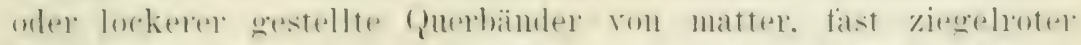

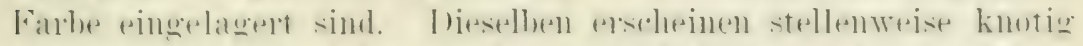

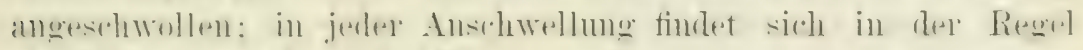

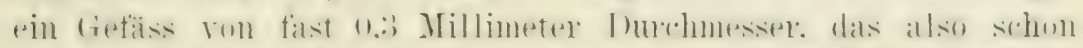

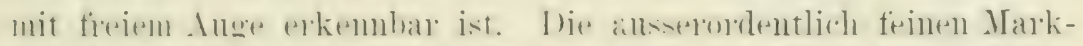

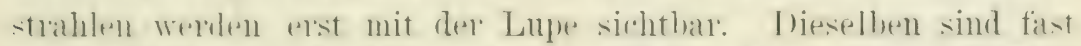

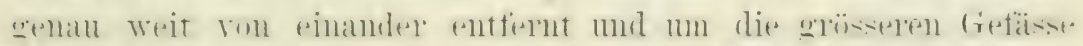

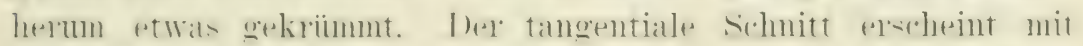
mulewaffneten Aluge mit ungemein zatrten. katum welligen Querlinien berleckt. Wolehe rom der regelmäisigen Anordnumg der

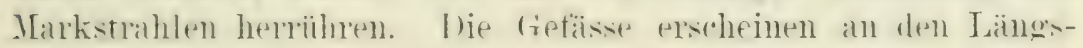
schniten meist als etwas krumm verlantende. dumkelluam. lebhatt glänzende Halloühren. Der Radialschnitt zeigt die schmalen mul

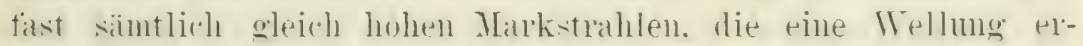
zengen. Anserden sieht man etwas vom einandey abstehemde.

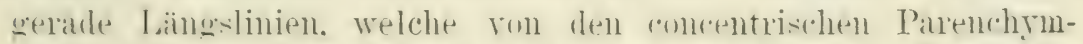

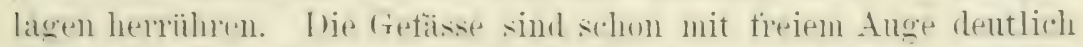

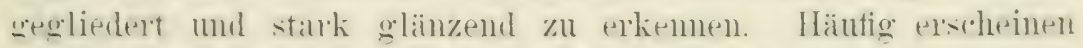
sie aut raulialen spaltungstlärhen als unverletzte Röhen.

Dats afrikanische sambersholz ist von dem asiatischen wedel makro- noch mikroskopisch zu untershodelen. Vach Vugl ist en

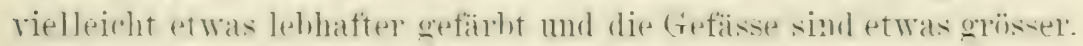

\section{Grupe.}

lats (amholy ist ansiefordentlich charakteristisch gehant.

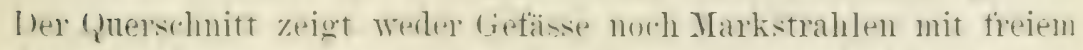

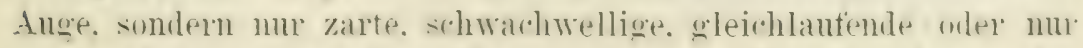

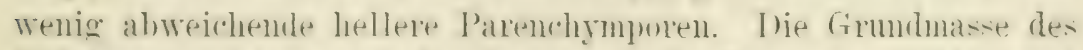

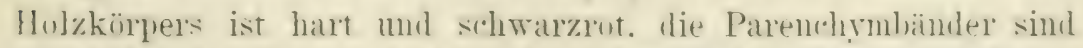
munterbrohen kirsehot. Suln charakteristisch sind an der radialen schnittlärche die von den Parenchymzonen herriihrende'n Läng:- 


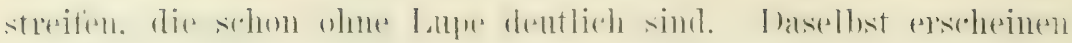

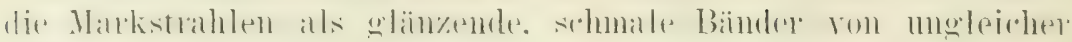
Breite.

\section{Gruploe.}

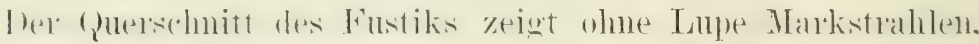

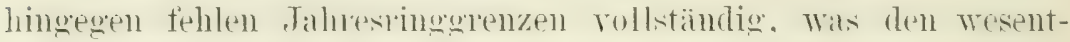

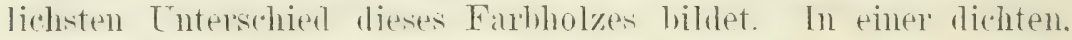

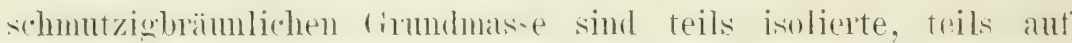

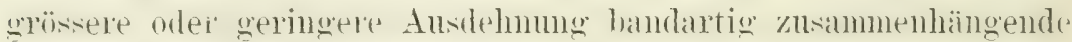
Parenchymflecken eingesprengt. Die Bander maheinen gezarkt. Die crefässe sind ganz mit Parenchym erfüllt, daher man die firsfassiffnungen anch nirht mit der Lupe sehen kann. Joer 'Tansentialschnitt zeigt in einer glämzenten Frmolmasse zahlreiche. gletrhmäsig zerstreute. dumkle, kuze Striche die Markstrahlen und meist "twas geboren. ockergelbe. riemlich breite streifen. relche ron dem Parenchrm erfïllten frefässe herrïhren. Am Tadialschnitte erscheineil dis Markstrahlen als matte. im Mittel 11,2 his 0,25 Millimeter breite (onerstreifen. die mit der Lupe (i) bis 20 zarte Linien zeigen. welche ron den einzelnen Zell-

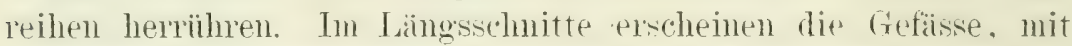
der Impe betrachtet, wie mit ockergelben, gämzenden schiipuchen

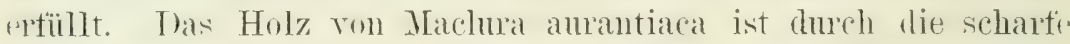
sondermon der dahresinge leicht von dem Fustik (Machua tinctoria) zu untessheiden, fernex durch die hell und nicht ockergelbe Fänbung der Parenchymmassen und die bedentend feinere struktur. Auch sind die Parenchymflecken mehr quergestreckt.

\section{Gruppe.}

Das samerdormlolz ( ITuzeln rou Berberis vulgaris) ist intensiv

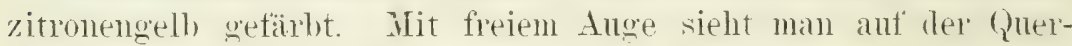
schnittläche gleichnaissig eingebettete Markstrahlen. Alle Markstrahlen sind deutlich. Die frefässe escheinen als kleine dunkle. l'mule Punkte, welche teils ant dem (querschnitt gleichmässig' zerstreut, teils in Quexbändern geordnet sind.

\section{Grup pe.}

Das Fisetholz lässt mit freiem Auge im Querschnitt cou-

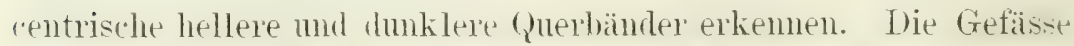
erscheinen als kleine Piuktchen und die Markstrahlen sind nur 


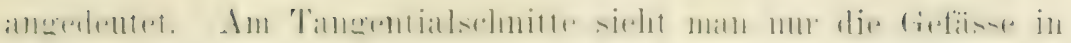

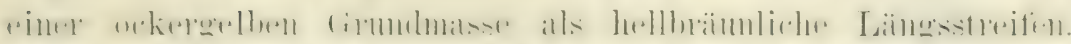

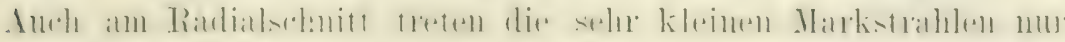

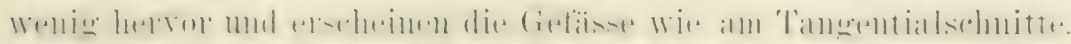

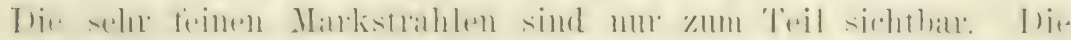

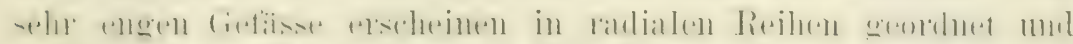

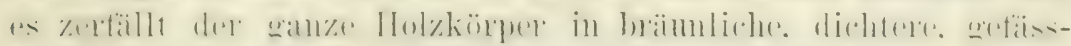

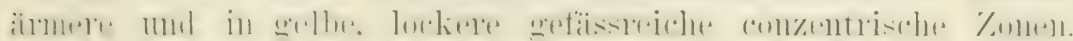

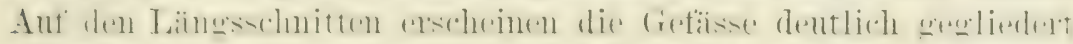

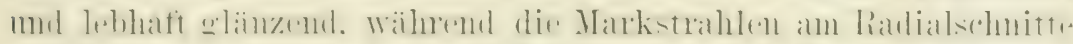

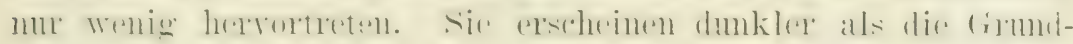

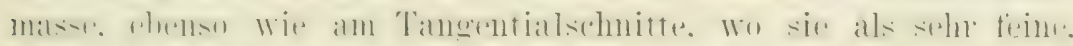
hellbäunliche Längsstrichelchen zu erkennen sind.

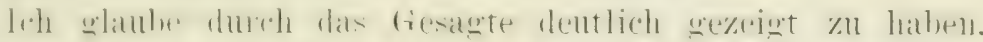

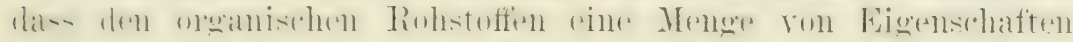

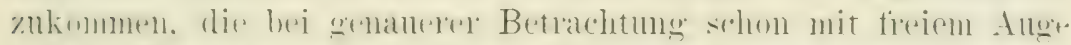

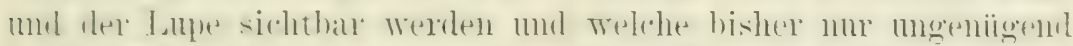

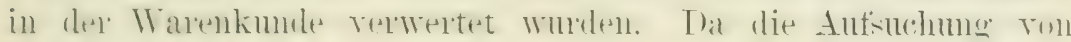

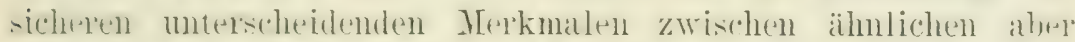

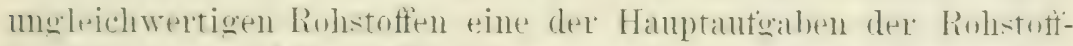

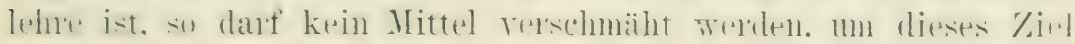
möglichst vollständig zu erreichen. 


\section{I)ie Nebenprodulte des Waldes.}

\section{Iíohlen.}

Wem Holz muter teilweisem Luftabschluss einer Wärme von tra 280 ( $C$. und höher ausgesetzt wird, rerfluchtigt sich ein Teil seiner Bestandteile, namentlich Masser. Kuhlensäure und Stickstoft, in Form von Dämpfen mo Gasen. und es bleiben Kohlen als Rïckstand.

Die Menge des Rückstandes schwankt. je nach der Holzart und de'n Baumteilen, gewöhnlich beträgt sie zwischen 40 und $70^{\circ}$ " des Raumes. und zwischen 18 md $25^{\circ}{ }_{0}$ des Gewichts. In Schlesien werden, einer Ermittelung zufolge. im Durchschnitt dem Ramme nach Kohlen elzielt: $52,6 \%$ ron stammholz, 42.70 : ron Asthol\%. und $39,5 \%$ ron Wurzelholz.

Mushet erhielt bei seinen Lntersuchungen als Resultate die fingenden Prozentsätze rom frewicht und Zusammensetzungen ron verschiedenen Holzarten:

$\begin{array}{lccc} & \text { flüchtige Stoffe. } & \text { Kohle. } & \text { Asche. } \\ \text { Eiche } & 76,895 & 22,682 & 0, \pm 23 \\ \text { Esche } & 81,260 & 17,972 & 0,768 \\ \text { Birke } & 80,717 & 17,491 & 1,792 \\ \text { Rothiefer } & 80,441 & 19,204 & 0,355 \\ \text { Mahagoni } & 73,528 & 25,492 & 0,980 \\ \text { Sykomore } & 79,20 & 19,734 & 1,066 \\ \text { Stechpalme } & 78,92 & 19,918 & 1,162 \\ \text { Kiefer } & 83,095 & 16,456 & 0,449 \\ \text { Buche } & 79,104 & 19,941 & 0,955 \\ \text { Ulme } & 79,655 & 19,574 & 0,761 \\ \text { Wallnuss } & 78,521 & 20,663 & 0,816 \\ \text { Zuckerahorn } & 79,331 & 19,901 & 0,768 \\ \text { Amerikanische Buche } & 77,512 & 21,445 & 1,033 \\ \text { Laburnum } & 74,234 & 24,586 & 1,180 \\ \text { Pockholz } & 72,643 & 26,857 & 0,500 \\ \text { Kastanie } & 76,304 & 23,280 & 0,416\end{array}$




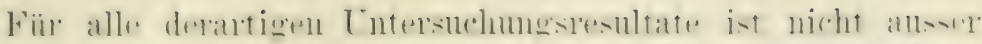

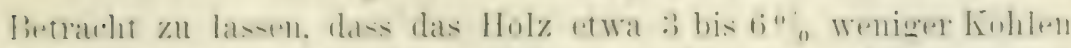

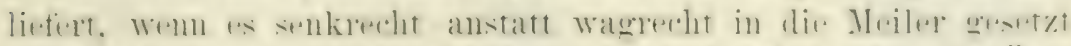

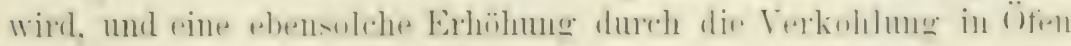
statt in Meilern erzielt wird.

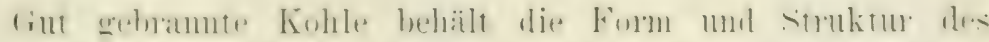

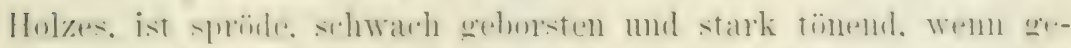

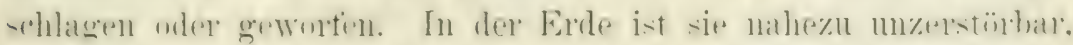

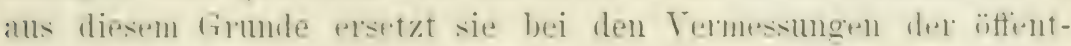

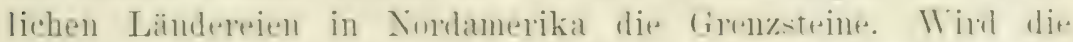

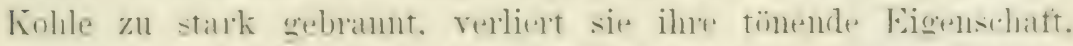

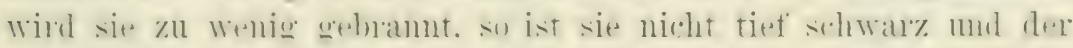

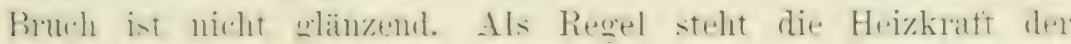

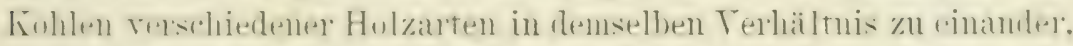
wie die Heizklati der betreffenden Holzarten. mol steht in lin-

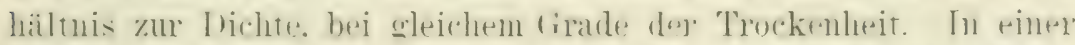

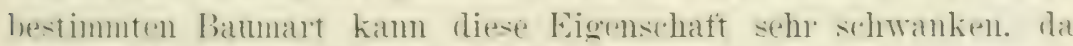

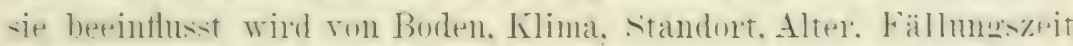

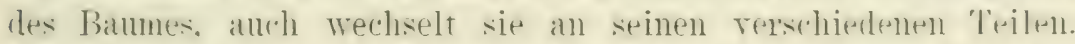
Die Zweige hahen weniger Heizkraft wie der stamm be-i den

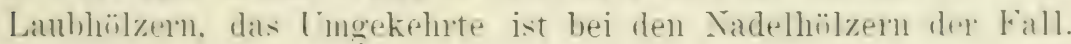

I)a sich also die Brenmqualität des Holzes auf die

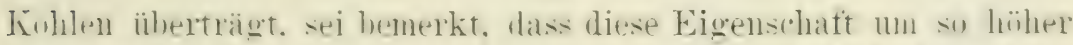

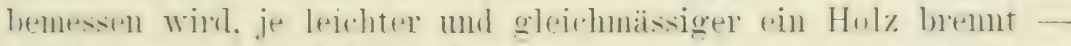

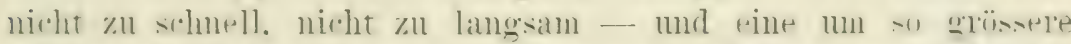
Wirmeentwickelung ron einer bestimnten Holzmalse stattfindur.

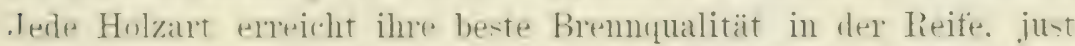
herur es sich zum Viedergange neigt. Das schlaghol\% gedangt

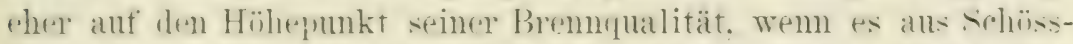
lingen. anstatt ans samen aufwärhst, und in ersteren Falle wher. wem w alten. anstatt jungen stiumpten entspringt. Wenm wir nu Bremnhulz prouluzieren wollen. ist der Vieder- und Yittelwaldhetriwh häutig vorteilhafter. Wie der Hochwaldsbetrieh. ologleich pine luestimnte Holzmenge zum Bremen mehr Wert hat. Wenn sie dem letzteren sistenn. statt dem crsteren entstammt. Zum Zwerke len Terkohlungr erredoht übrigens das Holz seine hüchste (Gualitait ror der Reife, etwa dam. wem der Entersehied semer liremunaliät bis zur Reife sehr gering ist. 
Holz, das langsam trocknet, brennt in der Regel langsam,

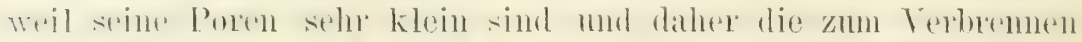

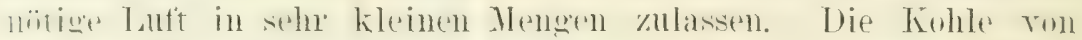
solehem Holze danert lange im Fener, gibt aber wenig Hitze. Hol\% das mul "inige Monate geteockmet ist mol 20 his 250"

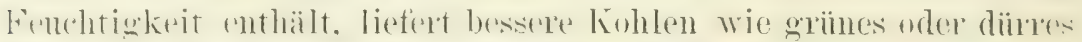

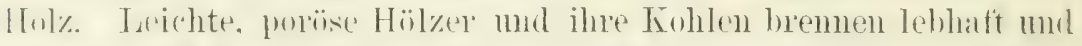

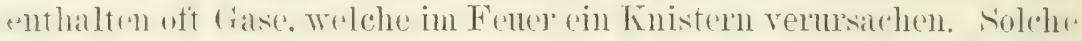
Kuhlen. hauptsächlich von Frlen, Birken. Haschuss mol Faubaum rignen sich zur Polverfabrikation. Bei ihrer Bereitmo ist Tol- irlot anzuwenden, dass sie nicht mit sand vermischt werden. Alls

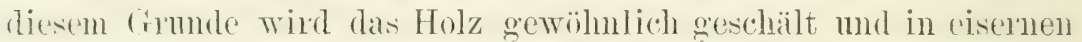
Jetorten mit äusserlicher Anwendung von Hitze verkohlt. Noell ein anderer Punkt kommt in Betracht.

Wemm das Holz bei der zulïsig niedrigsten Wärme, alsu zwischen 280 und $300^{\circ}$ ('. verkohlt wird, enthält es mehr IV asser'stoff. Samerstofi' und stickstoff, als wemn es bei höheren 'Temper-

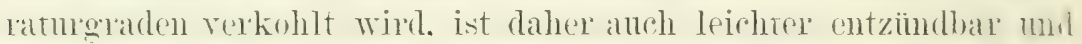
berise zul Pulvelfabrikation geeignet. Der (irad der Entziundharkeit wärchst mit dem Grade dex 'Temperatur. bei welcher dir Verkohlmng stattfand.

Fohlen. welche bei dem schmelzpunkte des Platins gebrannt wurden, entzïnden sich erst bei einer Wärme von $1250^{\circ} \mathrm{C}$.

(rebrannt be 290 bis 350$)^{0}$ entzïnden sice sich bei $3600^{\circ}$. wt-

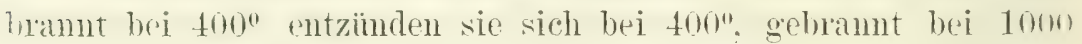
bis $1500^{\circ}$ entziunden sie sich bei 600 bis $800^{\circ}$.

Der Prozentsatz Kohle von demselben Holze schwankt quemäss seines Alter's und der Bereitungsweise: ob die Terkohlung -chnell oder langsam stattfand. Anfschlïsse dariber geben die folowenden Resultate, welche Karsten bei seinen Lntersuchmogn

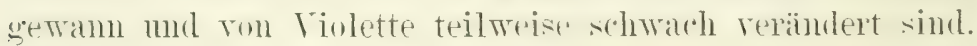


l'rozentwitze nach fiesicht: hei sclineller Verliolulung.

bei langsamer Verkoulumg.

Eiche, jung . alt

Buche, jung

., alt

Hainbuche, jung alt

Birlie, jung , alt

Weisstanue, jung alt

Erle, jung ., alt

Fichte, jung

:, alt

Linde

\subsection{4}

15,91

14,87

14,15

13,12

13,65

13,05

12.20

it, 25

14,05

14,45

15,30

15,52

13,75

13.33
25,60
25,71
25,87
26,15
25,22
26,45
25,05
24,70
25,25
25,00
25,65
25,6อั
26,07
25,95
$2+, 50$

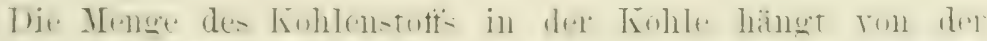

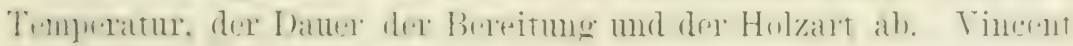

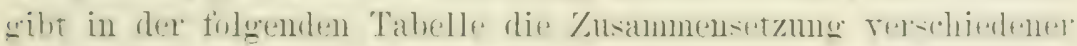
Fohlen, bereitet bei demselben Wänmegrad.

\begin{tabular}{|c|c|c|c|}
\hline Faulbaum & $\begin{array}{c}\text { Kohlenstoff. } \\
73,236\end{array}$ & $\begin{array}{c}\text { Wasserstoff. } \\
4,254\end{array}$ & $\begin{array}{l}\text { Sauerstoff und Stickstoff. } \\
\qquad 21,962\end{array}$ \\
\hline Birke & 71,133 & 4,552 & 23,554 \\
\hline Buchsbaum & 70,499 & 3,740 & 24,115 \\
\hline Esche & 70,395 & 4,039 & $2 \downarrow, 367$ \\
\hline Ahorn & 70,069 & 4,613 & 24,892 \\
\hline Cornelkirsche & 69,026 & $3,8+1$ & 26,490 \\
\hline Hainbuche & 68,835 & 4,142 & 26,382 \\
\hline Pappel & $68,7 \pm 1$ & 4,866 & $25,0 ็ 39$ \\
\hline Stechpalme & 68,521 & $4,7 \pm 1$ & 25,870 \\
\hline Aspe & 68,169 & 5, & 25,729 \\
\hline Eiclıe & 67,421 & $\downarrow, 099$ & 28,479 \\
\hline Clme & 66,862 & $\frac{1}{2,669}$ & 28,181 \\
\hline
\end{tabular}

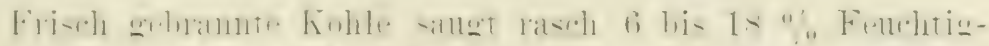

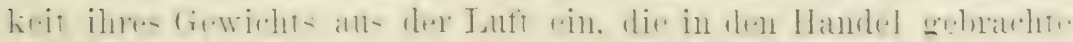

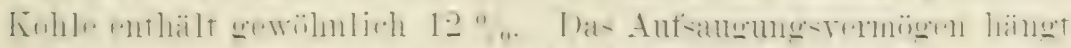

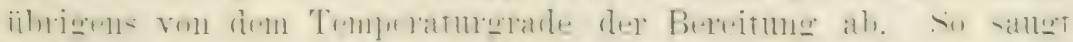

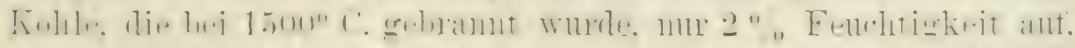

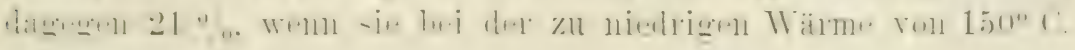
gebramint murde. 


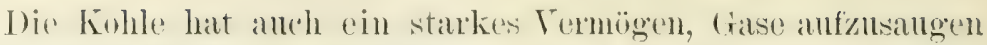
ma in ihren Poren zu verdichten, ohnes sich mit ihnen zu ver'hinden. Die dabei sich entwickelude Wärme ist hänfig die Ursathe von selbstentziindungen solcher kohlen gewesen, die zu bald nach ihn'e Bereitumg gehäuft wurden. Das Auf'augmgsvermögen ist nicht fïr alle Gare gleich, sondern tïr diejenigen am grössten, welehe am leichtesten in Wasser löslich sind. Die anfgesangten Gase werden in einem Tacumn (luftleeren Ramm) wieder abgegeben. Dnrch Benäsung verliert die Kohle ihr Anfsaugungsvermögen für Gase in starkem Masse.

Häutig wird dieses Aufsangungsvermögen benutzt, um Orte von schädlichen Gasen zu befreien oder Flüssigkeiten zu läntern. smmptiges Wasser. durch abwechselnde Schichten von Kohle und sand filtrirt, wird klar, trinkbar und bleibt es längere reit. I)ie Trastertäser der Schiffe, wenn sie im Innern angekohlt sind. beWahren das Wasser viel länger frisch, als wemn diese Massregel unterlassen wird. Die Kohle sangt auch Farbstoffe auf, indem sie mit manchen morganischen Köruem derselben müsliche Verlindmeen eingeht. Als Fanbe wird nur die Fohle ron gewissen Bammaten gebrancht, so als spanisch schwrizz ron Kork, als Kienruss von harzigen Nadelhölzern.

Einer der schlechtesten Wärmeleiter ist hohle mol als ein (tektrischer Leiter kanm sie kamm gelten, wenn sie boi der ïblichen T'emperatur ron $300^{\circ}$ C. oder gar noch riedriger gebramnt ist. IVird sie dagegern in einer Retorte bei einer Wäme rom $1500^{\circ}$ (? fobmunt. dam ist ihre Leitmosfahigkeit zwei Inittel so gross, wie diejenige des Eisen: und in dieser Buschaffenheit dient sie zur Anfertigung der Stifte für die elektrischen Lichter.

Wenn Kohle von der Luft abgeschlossen ist, verändert sie sich nicht. Wrmm sie der grösten Hitze ansgesetzt wird, dagegen bremnt sie bei Luftutritt lobhatt, ohne Flammen oder Rauch zu entwickeln.

Die entzinndetrn Kohlen bremnen eine reit, die um so kïrzer ist, je höher die 'Temperatur der Verkohlung war — die bei nitrigen Wärmegraten bereituten liohlen daucru also am längsten im Fener.

Das zur Verkohlung bestimmte Holz soll gut getrocknet wrerlen, was in etwa is Monaten zul erreichen ist. Nadelholz 
trocknet sehmeller. Wenn man ihm nach dem Fällen dir Zweigr se

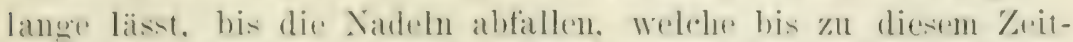

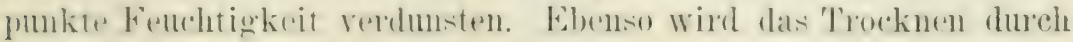

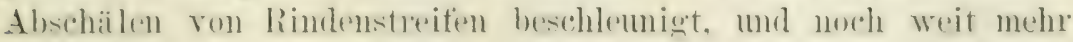

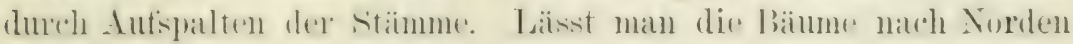

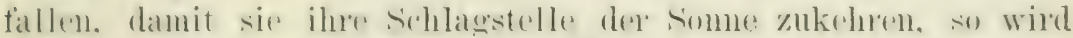

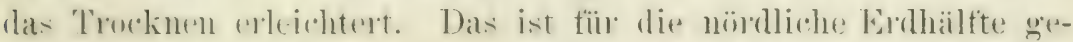
meint. allf der südliehen ist die mogekelete Latge zul bewirken.

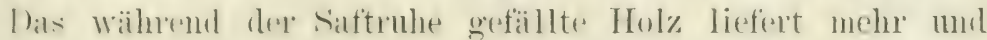

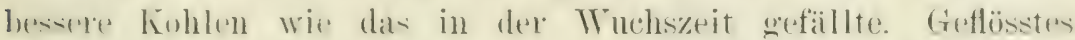

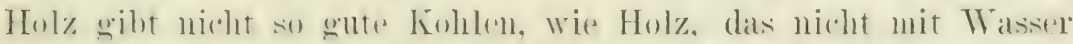

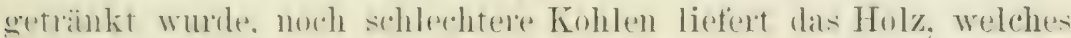
nath siner Fiallume so lange lagute. bis die Terwesme einsetzte.

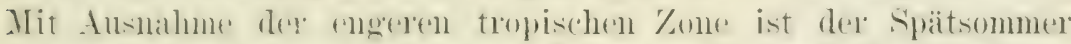
mul Fuihherbst als die geeponetste Zeit zum Kihlenbrennen zu hetrachten. das nïtige Holz ist in vorhergehenden schlatern und während des sommers zum Trocknen anfzustapeln.

Die Verkohlumg findet nach rerschiedenen Verfahren statt. ron welchen dasjenige in I[eilern das weitans üblichste geblieben ist. \%ur Anlager vines Meiler's wählt man rinen trockenen Platz.

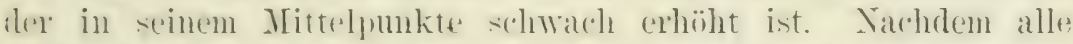

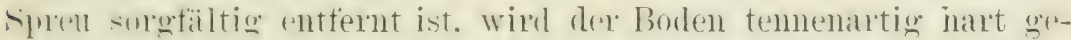

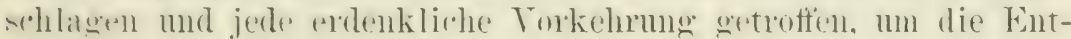

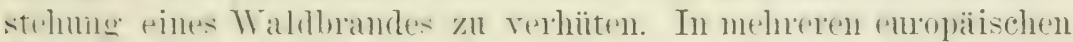

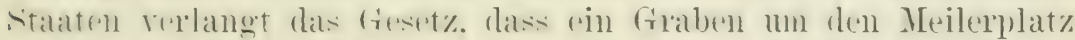

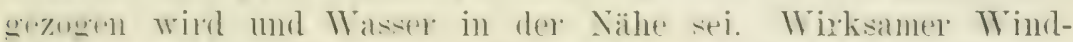
solut\% von allen re.iten und Bindigkeit des bodens, danit kein Luftzng von unten in den Meiler treten kilnn, sind weitere Besdingrungen fiir die Anlage.

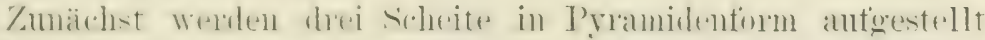

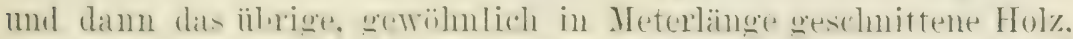

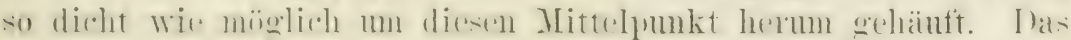

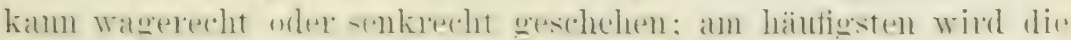

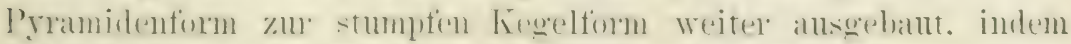

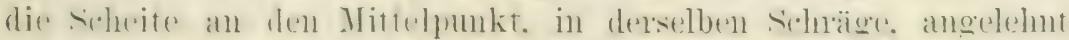

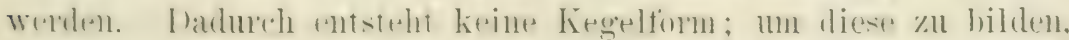

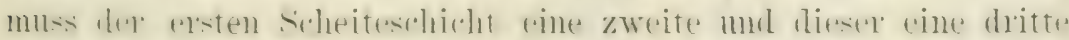

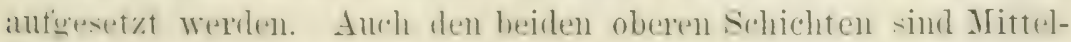

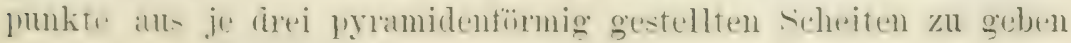




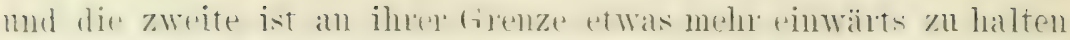
wie die erste mol die dritte dwas mehr wie die zweite damit

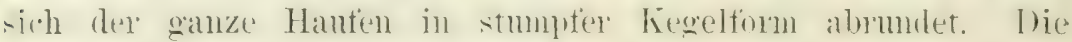

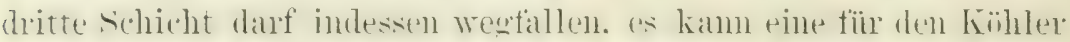
berpumere und dabei fehlerlas Form mit zwei schichten hergestellt werden. In allen Fiallen wird dir homische Holzmasse durch wagerecht gelegte scheite abgerundet: der in dieser Ireise entstehende Aufsatz heisst die Haube.

Der ganze Hanten ist dam zu hedecken, am hesten mit Raseln: t: kömnen aber anch stroh. Schilf. selbst düre Blätter dienten. Ferrollständigt wird die Decke durch eine sichicht bindiger Erde. die testgeschlagen wird zur Alsmehr der Luft. Welche nur an bestimmten und leicht kontrollierbaren stellen des Ifeilemantels Zutritt hahen soll. Nicht nötig: aher fürderlich für die Beantsichtigung und Arbeit ist es. wemn mm den Fuss des Meilers eine Erdbank ron etwa Meterhïhe gebant wird. von welcher der Meilersipted leicht mit der Hand zu erreichen ist. Bei dreischichtig sebanten Meilern wird man der ersten Erdhank eine zweite antstzen mïssen - einwärts gerïckt. gleich einer Treppenstufe. Ina die zweite Erdbank schmäler gebant werden muss wie di er:te. besitzt sie weniger Tragkraft und wird deshalb zweckmäsion mit schräg gegen den Boden gestellten stangen gestïtzt.

Dem Mantel gibt man eine überall gleiche Wicke ron 10 bis 15 \%entimeter. ansgenommen an der Haube. die stärker und dichter weschlagen sein mus. weil sie der Wirkung des Feners an meisten an-gesetzt ist. Wo Winde den Meiler nachteilig werden kiinnen. ist an der Windseite eine sichutzwand ans Brettern oder Stangen herzustellen.

Gewoinnlide wird del Brand von when in den Mittelpunkt de- Meiler's geworfen. zumeilen lässt der Köhler an der seite eine Höhle. mu das Fenter anzulegen. Es emptichlt sich, den Mreiler firih morgens in Brand zu stren und zwar hei trockenem Wetter, demn es ist shwierig mo erfordert riel Aufmerksunkit. das Fener zu rhalten. bis es chir närhstliegenden scheite escriften hat. Sobald dite Terkohlunger gut im Gamere i-t. wird das Luch de- Mantel: im Gipfel. dureh welehes der Brand pingerwerten

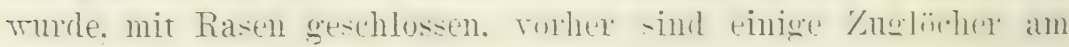
Fusse des Nantels zu öfinen. 
Von dem Fortgange der Verkohlung hängt es ab, ob die

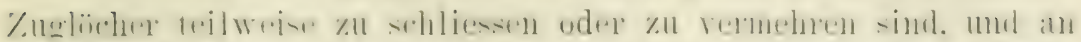

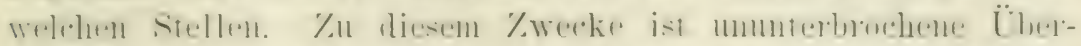

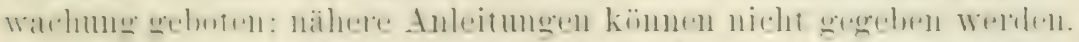

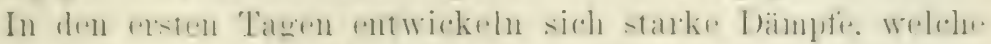

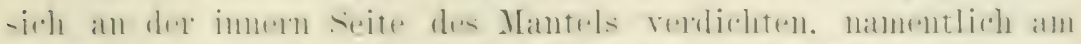

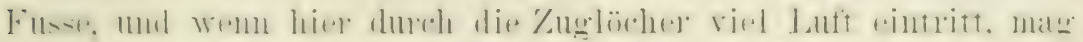

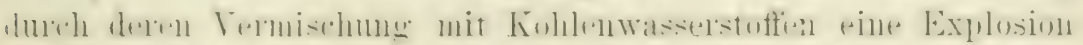

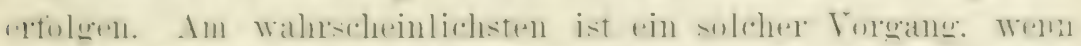

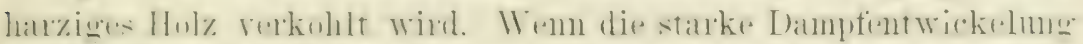

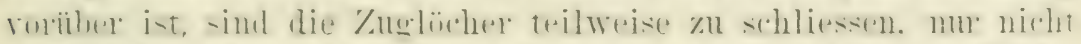

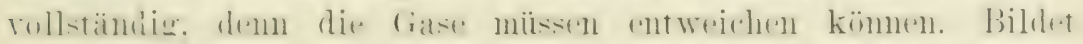

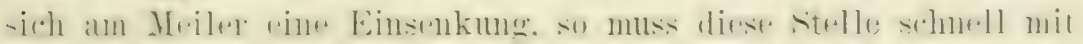

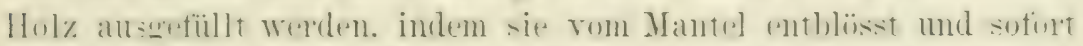

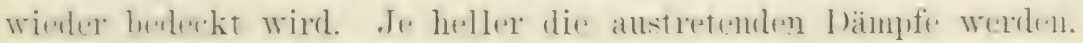

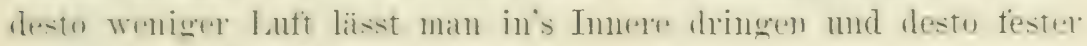
schlägt man den Mantel.

An dem rerschwindenden. zugleich hau mol hell werdemden liauche lässt sich erkemnell. Wann die Terkohlung bermetet int. Der Meiler wird dam so dicht wie möglich zugedeckt. $10 n$ di.

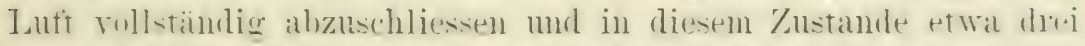
Tage gelassen. Die Kohlen sind nach dieser \%eit so meit ari-

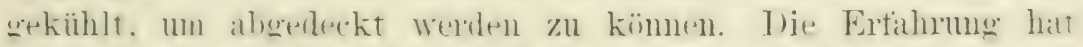

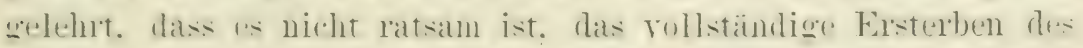
Folters alszuwarten, sondern die letzten glimmenden stellen des

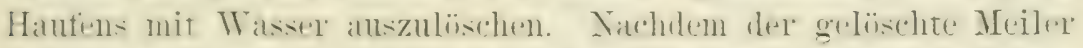

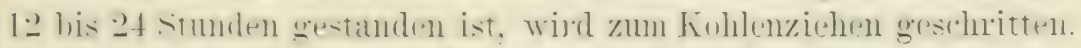

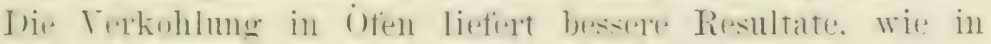

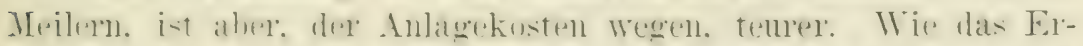

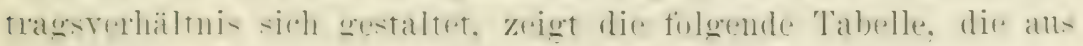

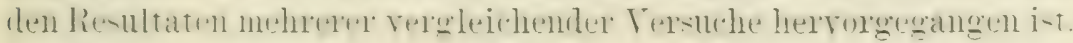

$$
\text { In üfen }
$$

Gewichtsprozente. llaumprozente.

Birlie, Stammholz

Buche u. Eiche, Stammh.

Fichte, Stammholz

Astholz

Tanne, Siammholz

Astinolz

Liirche, Stammholz

Weisstanne, Stammholz
20-21

$23-27$

$24-28$

$20-24$

$22-25$

18

24

$20-28$
$65-68$

$52-54$

$60-70$

$42-50$

$60-6 \pm$

57

75

$60-65$

In Meilern

Gewlchtsprozente. Raumprozente.

semler, Wald wirtschaft.

18

19

19

18

20

16

2)

19
53

$\pm 7$

58

53

ธำ

$+2$

60

52 
Lie (̈) wen werden gewöhnlicin ron Backsteinen in versthiedenter Form gebaut. In Nordamerika haben sie häufig eint Länge vom 15 Meter, eine Breite von 3,6 Meter und eine Höhe ron :3,6 Metex. I lie Bedachmo ist leicht gewölbt und das Manerwerk änsserlich durch ein hölzernes (rerippe, verbunden mit eisernen vitangen. gestiitzt. An der Front befindet sich eine eiserne Thiire, rie luftdicht verschliessbar ist, iiber derselben. nahe am I)ache, ist eine kleinere 'Thiure, un den oberen Teil des Innenrammes vollpacken zu künnen. An beiden Seiten sind Zunglöcher, die mit eisernen Schiebern beliebig weit rerschliessbar sind.

Andere Öfen sind ihrer Form den Meilern nachgeahmt. stimmen aber im Übrigen mit jenen ïberein. Welcher Form man den Torzug geben mag: ausser einer Inftdicht verschliessbaren Thïre müssen sie eine Anzahl Luftlöcher am Fusse wie in der. Tähe der Bedachmo haben, welche nach Bediurfnis geöffnet und grechlossen werden kïmen. Empfehlenswert ist es, den Ofen an einem Hange zu banen. einlegen und die Kohlen durch eine Thüre am Fusse der entserengestzten s'eite ausnehmen zu kömnen. Wenn bei grösserem Betriebe mehrere (i)ten nahe bei einander gestellt werden. erzielt man eine Ersparniss in der Überwachung.

In Erinnerung zu haltem ist, dass die mit dem Ranche rerdampfenden Gase der Kohlen anf den Kalk des Mörtels und aut Fìren anflösend wirken. Die Öfen mïssen mithin in dieser Beziehung beanfsichtigt werden. um Misserfolgen oder Unfällen vorzubengen.

In nenester Zeit hat die Verkohlung in Cylindern Terbreitmng wefunden. namentlich in Tordamerika, wo man diesen Verfahren navhrihhnt. es liefere $33^{1}, 3 \%$ mehr Kohlen wie die Meiler, eine Angabe, die ich vorlälifig dahin gestellt sein lasse.

I)iese Crlinder sind von Eisenblech mit einer Fassungskraft von 3 his ti Kubikmeter Holz. Gefiillt werden sie von oben durch eine Öffnung. die luftelicht verschliessar ist. Durchlöcherte Röhren treten von unten ein mil fïhnen die nötige erhitzte Luft herbei. Die Anordnung wird gewiihnlich so getroffen, dass eine Arbeitersmple mehrere cylinder bedient, einige werden gefïllt oder entleert. während die iibrigen in Thätigkeit sind. Die Entleerung creht leicht ron statten. dia diese Cylinder keine Böden haben. also nur anf die Seite gelegt zu werden branchen. 


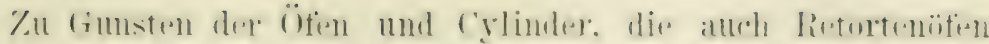

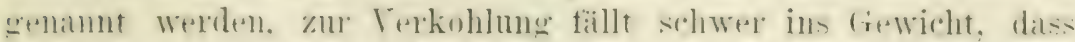

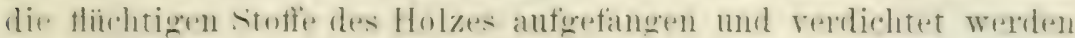

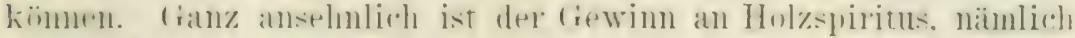

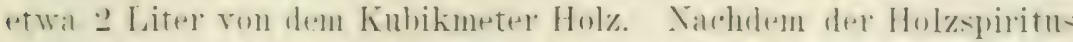

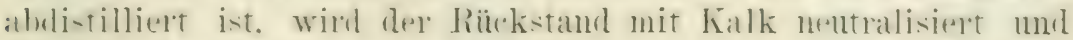
dient zur Fablikation von Bleiweiss.

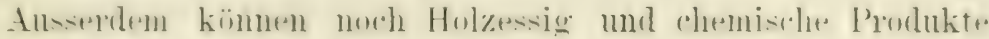

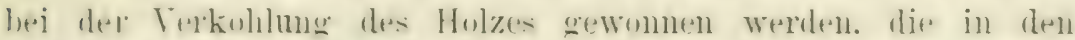

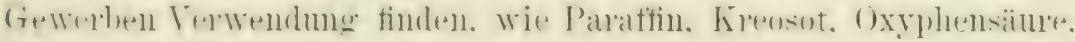
Plıenylsänue. Benzol u. A.

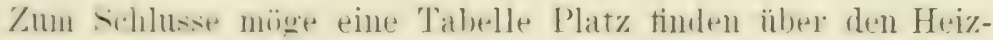

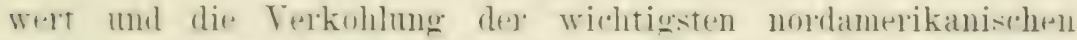

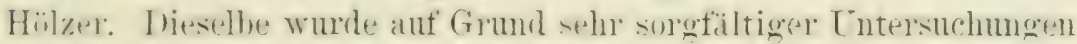
von Malens Bull in Philadelphia 1s-2ti zusammenge-tellt. und gilt leute noch als unübertroffen zuverlässig.

\begin{tabular}{|c|c|c|c|c|c|}
\hline $\begin{array}{c}\text { Volistumlicbe } \\
\text { Jamen. }\end{array}$ & $\begin{array}{l}\text { Wistenschaftliche } \\
\text { Namen. }\end{array}$ & $\begin{array}{l}\text { Spezifische } \\
\text { Schwere } \\
\text { des } \\
\text { trockenen } \\
\text { Holzes. }\end{array}$ & \begin{tabular}{|c|} 
Die \\
Verkohlung \\
ergibt \\
$\mid$ in Gewichts- \\
prozenten.
\end{tabular} & $\begin{array}{l}\text { Spezitizche } \\
\text { Schwere } \\
\text { der Kohle. }\end{array}$ & $\begin{array}{l}\text { Verhältni3- } \\
\text { masslger } \\
\text { Heizwert. } \\
\text { wenn } \\
\text { Hickory als } \\
\text { Grundlage } \\
=100 \text { gilt. }\end{array}$ \\
\hline Weisse Esche & Fraxinus americana & 0,772 & 25,74 & 0,547 & 77 \\
\hline Buche & Fagus ferruginea & 0,724 & 19,62 & 0,518 & 65 \\
\hline Scliwarze Birke & Betula lenta & 0,697 & 19,40 & 0,428 & 63 \\
\hline Weisse Birlie & $" \quad$ alba & 0,530 & 19,00 & $0,36 \pm$ & 48 \\
\hline Butternuss & Juglans cinerea & 0,567 & 20,79 & 0,237 & 51 \\
\hline Rote Ceder & Juniperus virginiana & 0,565 & $2 \pm, 72$ & 0,238 & 56 \\
\hline ILastanie & Castanea americana & 0,522 & 25,29 & 0,379 & 52 \\
\hline Wilde Kirsche & Cerasus virginiana & $0, \overline{097}$ & 21,70 & 0,411 & 55 \\
\hline Hartriegel & Cornus florida & 0,815 & 21,00 & 0,550 & 75 \\
\hline Ulme & Ulmus americana & 0, วั80 & 24,85 & 0,357 & 58 \\
\hline Weisser Hickory & Carya alba & 1,000 & 26,29 & 0,625 & 100 \\
\hline $\begin{array}{l}\text { Schweinenuss- } \\
\text { Hickory }\end{array}$ & $"$ porcina & 0,949 & 25,22 & 0,637 & 95 \\
\hline Stechpalme & Ilex opaca & 0,602 & 22,77 & $0,37 \pm$ & 57 \\
\hline Hornbaum & Carpinus americana & 0,720 & 19,00 & 0,455 & 65 \\
\hline Zuckerahorn & Acer saccharinum & 0,644 & 21,43 & 0,431 & 60 \\
\hline Iioter Ahorn & " rubrum & 0,597 & $20,6 t$ & 0,370 & $5 t$ \\
\hline $\begin{array}{c}\text { Immergrüne } \\
\text { Magnolia }\end{array}$ & Magnolia grandifolia & 0,605 & 21,59 & 0,406 & 56 \\
\hline & & & & & 26 \\
\hline
\end{tabular}




\begin{tabular}{|c|c|c|c|c|c|}
\hline $\begin{array}{l}\text { Vulkstümliche } \\
\text { Xamen. }\end{array}$ & $\begin{array}{c}\text { Wissenschaftliche } \\
\text { Namen. }\end{array}$ & $\begin{array}{l}\text { Spezifische } \\
\text { Schwere } \\
\text { des } \\
\text { trockenen } \\
\text { Holzes. }\end{array}$ & \begin{tabular}{|c|} 
Die \\
Verkohlung \\
ergibt \\
in Gewichts- \\
prozenten.
\end{tabular} & $\begin{array}{l}\text { Spezifische } \\
\text { Schwere } \\
\text { der Kohle. }\end{array}$ & $\begin{array}{c}\text { Verhälinis- } \\
\text { mässiger } \\
\text { Hoizwert, } \\
\text { wenn } \\
\text { Hickory als } \\
\text { Grundlage } \\
=100 \text { gilt. }\end{array}$ \\
\hline Weisse Eiche & Quercus alba & 0,855 & 21,62 & 0,401 & 81 \\
\hline Pfosteiche & " obtusiloba & 0,775 & 21,50 & 0,437 & 74 \\
\hline Dattelpflaume & $\begin{array}{l}\text { Diospyros virgi- } \\
\text { niana }\end{array}$ & 0,711 & 23,44 & 0,469 & 69 \\
\hline Gelbe Kiefer & Pinus palustris & 0,051 & 23,75 & 0,333 & 54 \\
\hline Pechkefer & $"$ rigida & 0,426 & 26,76 & 0,298 & 43 \\
\hline Weymouthskiefer & $"$ strobus & 0,418 & 24,35 & 0,293 & 42 \\
\hline Tulpenbaum & $\begin{array}{l}\text { Liriodendron } \\
\text { tulipifera }\end{array}$ & 0,563 & 21,81 & 0,383 & 52 \\
\hline $\begin{array}{l}\text { Pyramiden- } \\
\text { Pappel }\end{array}$ & Populus dilatata & 0,397 & $2 \tilde{5}, 00$ & 0,245 & 40 \\
\hline Sassafrás & Sassafras officinalis & 0,618 & 22,58 & 0,427 & 59 \\
\hline Bergahorn & Acer Pseudoplatanus & 0,535 & 23,60 & 0,374 & 52 \\
\hline $\begin{array}{l}\text { Schwarze Wall- } \\
\text { nuss }\end{array}$ & Juglans nigra & 0,681 & 22,56 & 0,418 & 65 \\
\hline
\end{tabular}

Han unterscheidet harte Kohlen (Kohlen von harten Hölzern) und weiche Kohlen (Kohlen von weichen Hölzerm). Ferner unterscheidet man zwischen der vollständig verkohlten Schwarzkohle und der unvollständig rerkohlten Rot-oder Röstkolıle.

Nach der Grösse teilt man die Holzkohlen in Mittelemopa in:

1. Stiick-, Grob-, Lese- oder Ziehkohlen, das sind die grössten und dichtesten Stücke;

2. Schmiedekohlen, dichte Stiicke von Faustgrösse;

3. Quandelkohlen, aus der Nähe des Quandels, das ist der Mittelpunkt des Meilers, kleine undichte Stiicke;

4. Kohlenklein. Kohlenlösche, kleine stücke und staul):

5. Brände, rohe oder rote Liohlen, mvollständig rerkohlte Stiicke.

Rot- oder Röstkohle hält die Mitte zwischen schwarzkohle mold gedorrtem Holz, sie ist sanerstoffreicher und wenigrer porös wie jene, leicht zerreiblich und locker. Aus diesen Gründen übertrifft sie an Brembarkeit und Flammbarkeit bei weitem dit schwarkohle; ihre Trwendmg findet hauptsächlich in schachtöfen zu metallurgischen Zwecken statt. 


\section{Die Gerbstofle.}

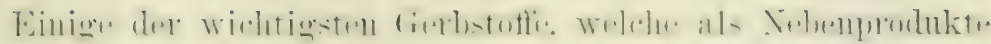

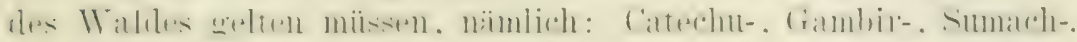

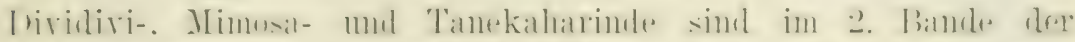

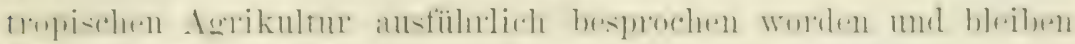

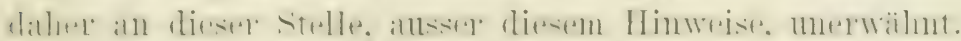

\section{G e r b e r ind e.}

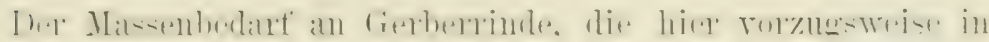

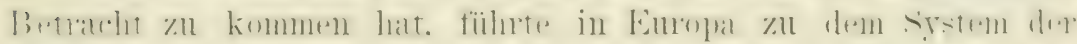

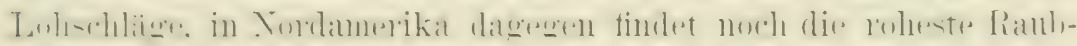

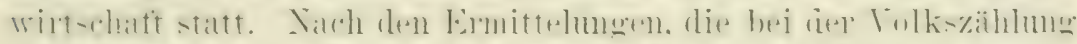

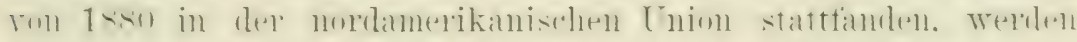

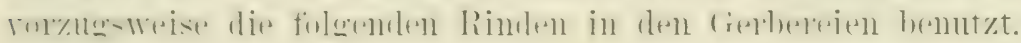

Iangrove

I.turusuche

TVeisse Eiche

Fürbereiche

Scharlacheiche

Rote Eiche

Westliche Kastanieneiche Östliche Krastanienciche

Iiastanie

Engelmann's Fichte

Hemlocktanne

Douglastanne
Rhizophora IIangle

Quereus virens

, alba

" tinctoria

, coccinea

, rubra

, densiflora

, prinus

Castanea americana

Picea Engelmanni

Tsuga canadensis

Pseudotsuga Douglasii

$31,4 \%$
$10,4 i "$,
$7,85 "$
$5,90 "$
$7,78 "$
$5,55 "$
$16,46 "$
$7,75 "$
$6,25 "$
$12,20 "$
$13,11 "$
$13,79 "$

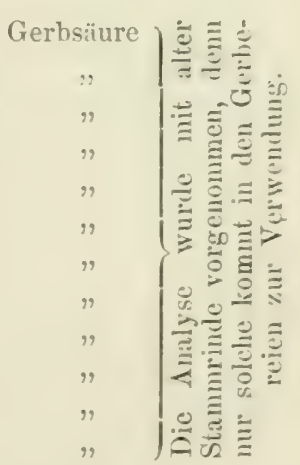

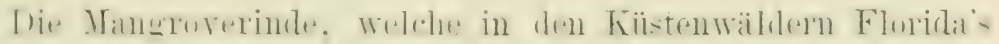

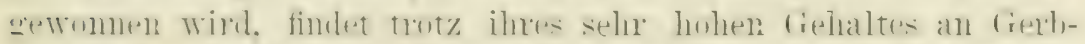

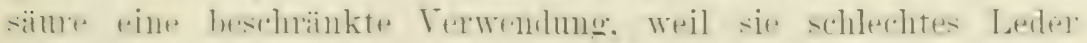

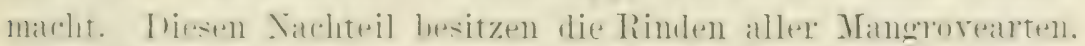

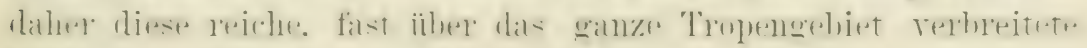
Gerbsäurequelle unbenutzt bleiben muss.

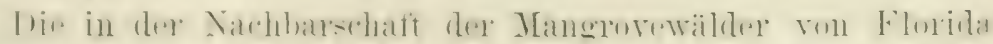

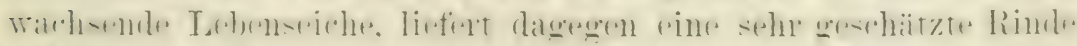

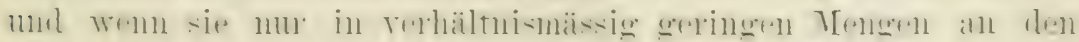

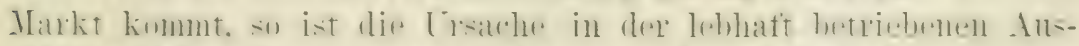

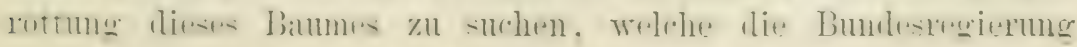


veranlasste. zur Nicherung des vorzinglichsten nordamerikanischen shoffshanholys fïir ihne Werften das wertvollste Waldrevier zu leservieren. Sidbstrerstandlich sind ron demselben nicht allein dies sïgemiiller. sondern anch die Rindenschäler ausgeschlossen. nü die Rinden der für die Bundeswerften gefällten Bämme wird absegeben. Von riner Forstkultur in diesem rescrvierten Revier ist. iibrigens keine Rede.

lie immergrüne Lebenseiche rerlangt ein warmes, firostfrubes Flima. Wo diese Bedingung gegeben ist mol die Produktion ron trerber'rinde geplant wird, nöge man diesem wertvollen Bame, der noch an riner anderen Stelle besprochen wird. Beachtung schenken.

Grössere Rindennengen liefert die weisse Eiche, die aber immer seltener, also fïr diesen Zweck unwichtiger wird. Ihre Rinde wird, nächst der Lebenseichenrinde, am höchsten geschätzt von den zahlreichen Eichentinden ïstlich der Felsengebirge. Die Rinde der Färbereiche ist weniger wichtig für die Gerbereien, gremahlen kommt sie als der bekannte Farbstoff Querzitrone in den Handel. Ausser der östlichen Kastanieneiche, der roten und scharlacheiche werden gelegentlich noch andere Eichenarten geschält, doch wird ihren Rinden keine Wichtigkeit beigelegt und über ihne Qualität scheint sich kein klares Urteil gebildet zu haben. Die Fichenrinde spielt überhaupt in den Staaten üstlich der Felsengebirge, Canada eingeschlossen, der Hemlockrinde gegenüber eine untergeordnete Rolle. Fachkenner behaupten, die jährlich zur Verarbeitung gelangende Gesamtmenge zerfalle in zwei Drittel Hemlockrinde und ein Drittel Eichenrinde.

Die Hemlockrinde spielt diese wichtige Rolle, weil die Hemlocktanne ausgedehnte, zusammenhängende Wälder bildet. die des geringwertigen Holzes wegen von den Sägemüllern rerschont werden ond den Rindenschälern überlassen bleiben. Dir trewimmung kam daher billig und in grossartigem Masstabe stattfinden. Ferner spricht zu Gunsten dieser Rinde der grosse Gerbsäuregehalt, dagegen ist zu ihrem Nachteil zu sagen, dass sie das Leder rot färbt und spröde macht. Die Hemlockrinde wandert teilweise als gemahlene Lohe in die Gerbereien, teilweise dient sie zur Bereitung eines Extrakts, der auch nach Europa exportiert wird. Die gemahlene Rinde wird durch heisses Wascer ausgelaugt und die Flüssigkeit in riner Vacumptamet 


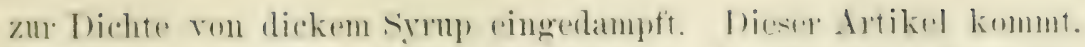
in Fissern verparkt, als Tambextrakt in don ilandel. Aurh dir

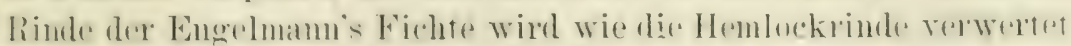

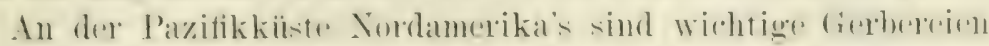

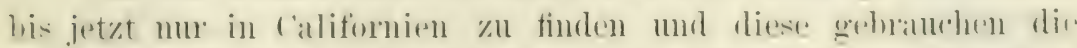

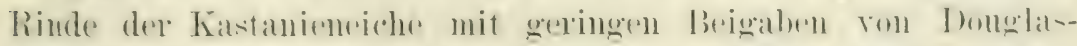

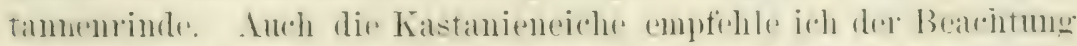

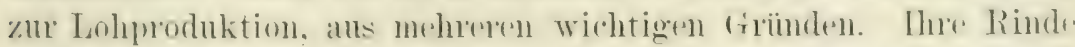

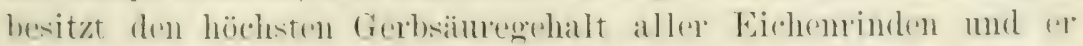

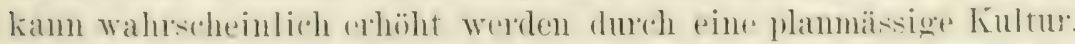

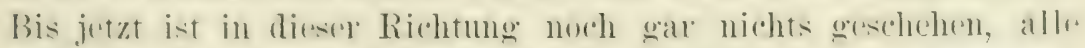

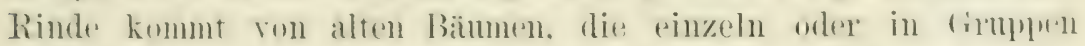

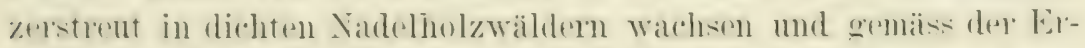

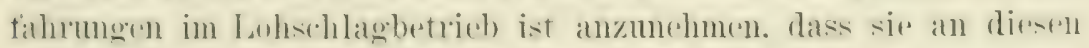

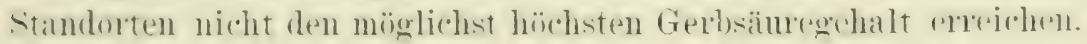

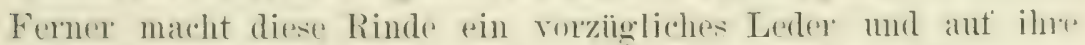
Ferwendung ist us zuriekzuführen. dass sich das califomische? Leder in dem ïstichen Nordamerika eines hohen Rutes erfient. Writer ist zu Gunsten der Kastanieneiche zu sagen. dass sip rasch wäldst und aus ihren stïmpten zahlreiche und kräftige schöinlinge treibt. ihe Holz aber ist in den Gewerben mbranchbar mol hat wenig Brennwert.

Die hastanieneiche ist, wie die Lebenstelche. immergrün.

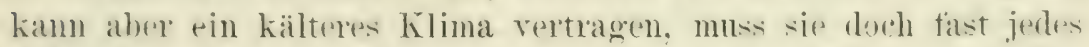

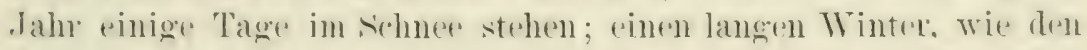
destschens, wird sir wahrsehemlich nicht überloben. Ihr Vurkommen ist ant das mittlere und nördliche californien beschränkt. wo sie anf tranit-. Basilt- und sandstemboden wächst mol his nahe an das Meer tritt.

Der Jame Kastanienerohe ist hezeichnend, demn dieser Banm nimmt aine Mittelstellung ein zwischen den Eichen und Katstanien und wenn ihn auch die Botaniker zu den erstern zahlen. \&o këmnen sie ihn doch keiner (iruppierme der Arten einfïgens.

leh sprach when ron winer rohen Raubwirtschatt und hahe das zu begründen. Ein Lohschlagbetrieb. wie er in Eureprat anscrobildet wurde, ist niemals in Nordamerika rersucht worden,

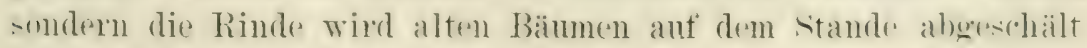
mod num wem das Hol\% wetroll ist. wie bei dey weisen und

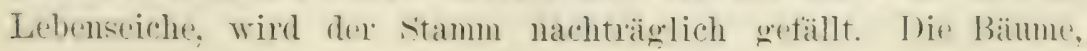




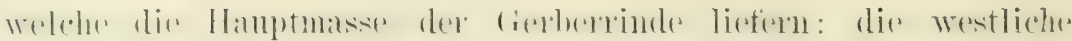

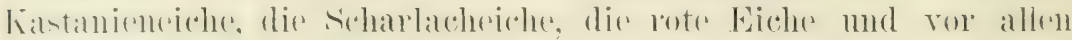

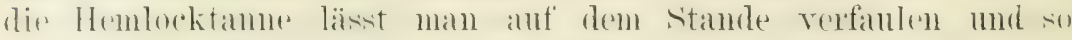

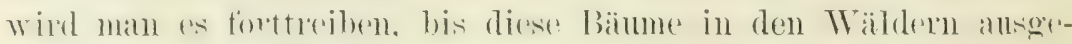
rottet sind.

In Europa wirl die Hauptmasse dex Gerberrinde im Lollselhlaghetrieb produziert. I) verhältnismissig mbedentenden

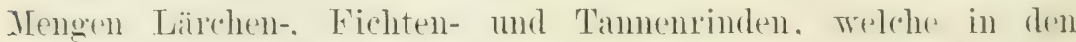
frerberejen zur Verwendung kommen. stammen ron Bäumen, die

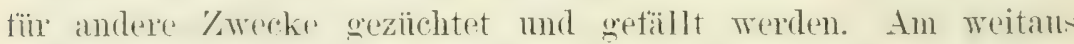

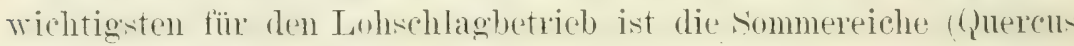
pedunculata). nur in beträchtlichen Frhebungen soll die Wiatereiche (() nerus sessiliflora) besser rentieren. In spanien wird dir Korkeiche zu diesem Zwecke angebaut, duch scheinen die Resultate nicht "mutigend zu sein. da die Zahl der Lohschläge beschrankt ist mol scheinbar bleibt. In Frankreich wird. allswer del sommereiche, dir Kastanie zn Lohsohlägen benutzt. freilich mit ahmeichender Verwendung dex Ernte. Das grüne Kastanimholz mit der Rinde wird unter ein Hobelwerk gebracht, welches die späne quer der Faserung schneidet. Die spane werlen in einem nexchlosinen Kessel einge Zeit eingeweicht, dam wird I)ampt zugefiihrt, der die Gerbsäme anszieht. Die verbleibende Flüssigkeit wird geseiht mol in einer Vacumptame eingedampft. Das Verfahren ist also demjenigen sehr ähnlich, welches oben füi die Bereitung ron Tamninextrakt angegoben worde. Del Kastanienholzextrakt wim in den seidenfärbereien mo zum Gerben leichter Ledersurten vermendet. In der Nachbarschatt von Lyon werden etwa 25 Gewichtspozent Extrakt rom Holz gewomen. Der Preis stellt sich durchschnittlich auf 14 Mark per 100 Kilogramm.

Fiir die Anlage eines Eichenlohechlages ist die Wahl des Budens mol Standortes ron Bederitmong. Windgeschützte. somnigw Hänge mit einem ans (rranit, Basilt odex Grünstein herrorgesangenen Borlen sind tïr diesen Zweck am seeignetsten. Eine starke Funchtigkeit im Borlen ist schädlich. namentlich wenn sie zum Sumpf allsiltret. alleh ein hoher Kalkgehalt ist nicht erwïnsht. demn wie jeder saure so ist der Kalk auch der Gerbsime schärlich. Damit sull nicht enesagt sein. das vollständige Fehlen des Kalks sei als ein Vurzug zu betrachten. demn die Eiche bedalt dieses Minerals zu ihrem Aufban. es muss daher rorhanden sein. 


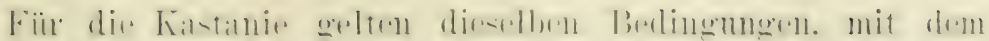

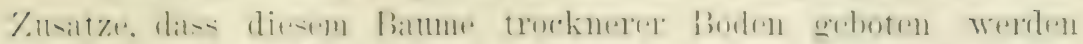

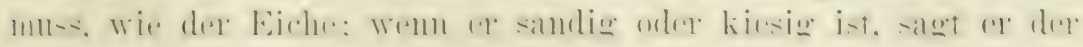
Kalstanie besonders zut.

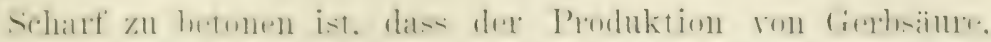

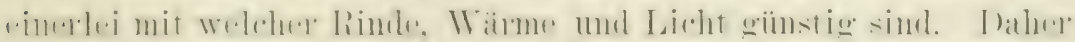

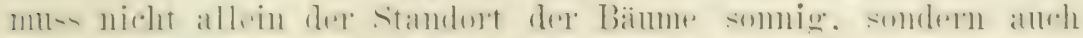

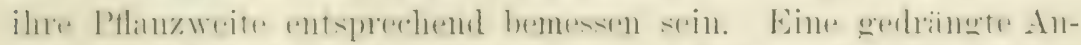

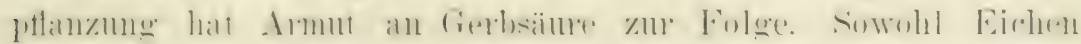

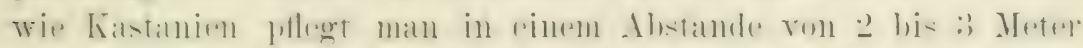

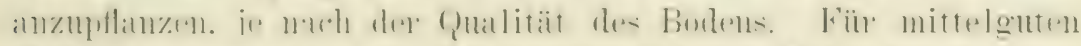

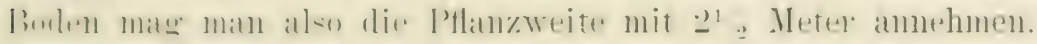

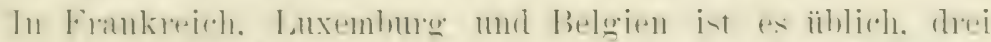

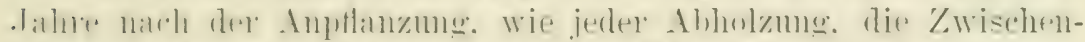

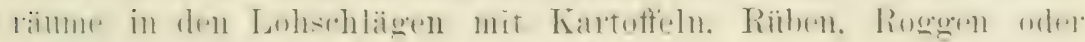

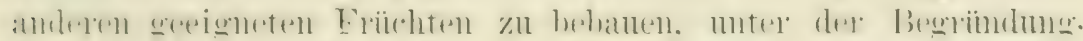

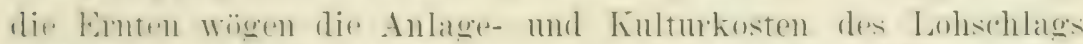

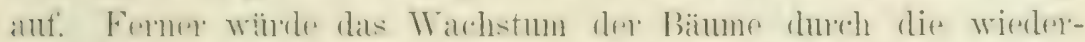

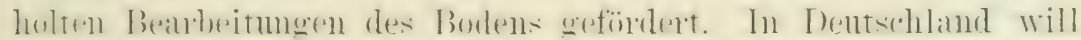

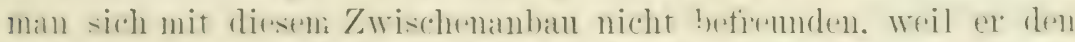

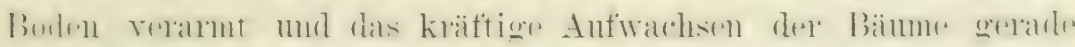

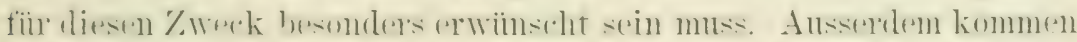

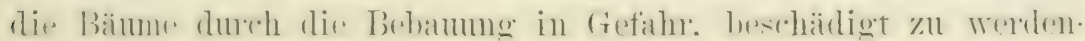

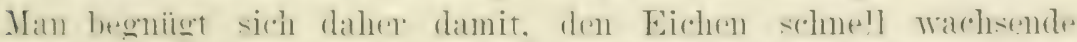

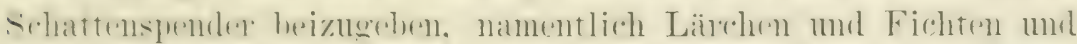

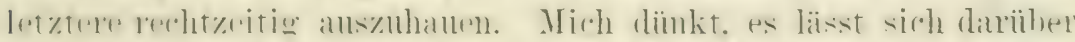

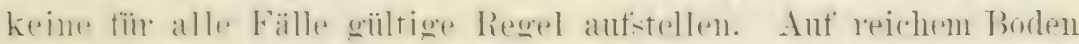

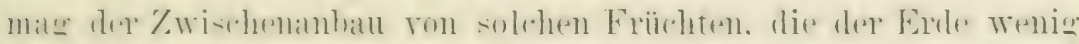

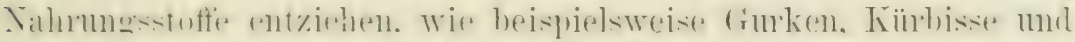

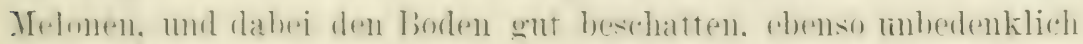

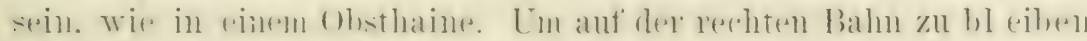

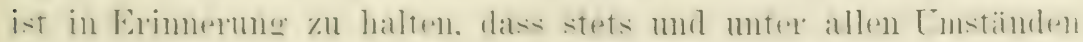
die höchste Bodenrente das anzustrebende Ziel ist.

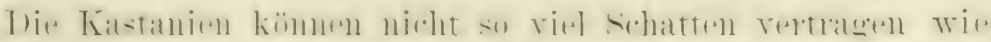

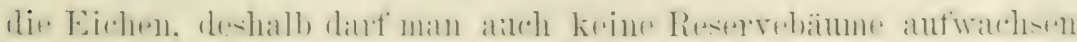

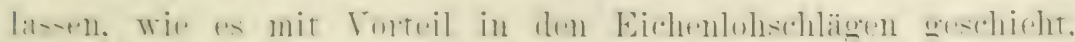

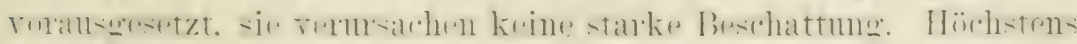

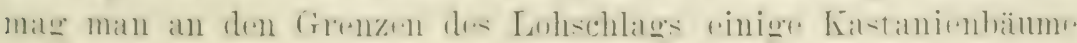


anfwateren lassen, wemn man starkes Holz und Fröichte zur Fortpflanzung wiinscht.

Wemn die Kastanienbäume einen Duchmesser von 5 his 7 Zentimeter erreicht haben, werden sie hart am Boden abgeschnitten; das näldıste Frühjahr schiessen zahlreiche Schösslinge anf, gribt (s doch wenige Waldbämme, deren stümpte so lobenszäh sind und so kräftige und schnell wachsende Schösslinge austreiben, wie die Kastanie. Nach 6 his 8 Jahren werden die Schösslinge so durchforstet, dass nur 2 bis 3 an jedem, stumpfe bleiben. die sich in Folge der vermehrten Nahmugsufuh so krättig entwickeln, dass sie nach 6 bis 7 . Tahren einen Duchmesser von 10 bis 15 \%entimeter haben. Nun wird in der Regel abgeholzt. zuweilen aber noch eimmal durchforstet und die verbleibenden schösslinge weitere 4 Jahre wachsen gelassen.

Alle durchforsteten Schösslinge haben Wert. Die Jüngsten werden zu groben Flechtwaren und zu Fassreifen benutzt, dit in siidenropäischen Weinländern wegen ihrer Danerhaftigkeit rehr beliebt sind, die ت̈lteren dienen zu Rebenpfählen, die abentalls sehr geschätzt sind, zu Hopfen- und Bohnenstangen. Zammiegeln und ähnlichen Zwecken. Die letzte Abholzung wird in der erwähnten Weise zu Tanninextrakt verarbeitet. In Frankreich behauptet man, ein Kastanienlohschlag würe einen höheren Gewimn ab. wie ein Eichenlohschlag, und könne bei sorgfältiger Behandlung 100 Jahre alt werden.

Auch im Eichenlohschlag lässt man die Bämme nach der Anptlanzung einen Durchmesser von 5 bis 7 Zentimeter erreichen, un sie damn hart über dem Boden abzuhanen. Empfehlenswert ist es. die Stümpfe so lange mit diurem Laub zu bedecken, bic die Trunden relnarbt und Schösslinge anszutreiben begimnen. Fortan wird der Lohschlag alle 16 bis 20 . Tahre abgeholzt. je nach seinem Wachstum. Unter ausnahmsweise güustigen Verhälmissen mag die Abholzung nach 15 . Tahren stattfinden; länger wie 20 Jahre soll sie nicht hinausgeschoben werden, selbst bei sehr langsamem Wachstum. Das Zuchtziel muss eine glatte. glänzende, saftige Rinde sein, dem diese enthält die meiste Gerbsämre, und die wenigste ist in einer alten, geborstenen, bemoosten Rinde zu finden. Es wird num klar sein, warum man das Wachstum der Bäume durch die Wahl des Standortes und Bodens, wie durch die Bearbeitung des Letzteren zu fördern sucht, und die Abholzung nicht iuber das 


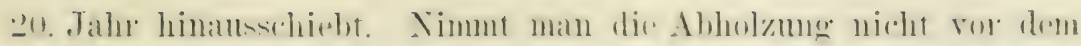

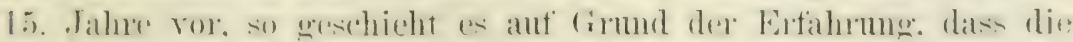

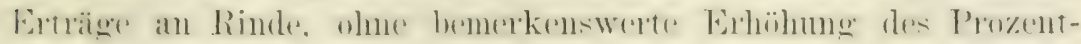
satzes an Gerbsïme, einbüssen wïrden.

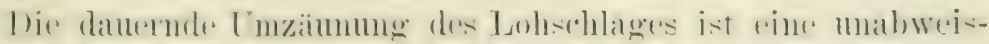

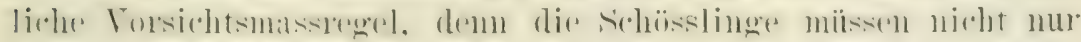

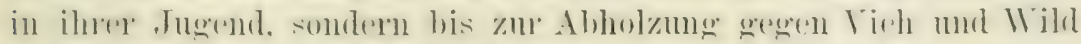

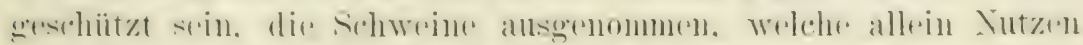
statt sehaden im Lohsehlag stiften. Lambfressende 'Tiere wïrden die schösslinge in ihrer Jugend his zur Wretlosightit verstimmeln. in ihrem späteren Altre ihr Wachstum hemmen und dir Entwiekr-

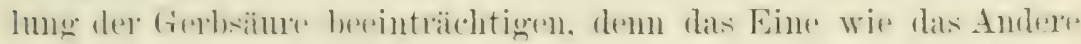
steht im Abhängigkeitsverhältnis zur Belaubung.

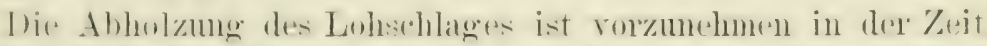

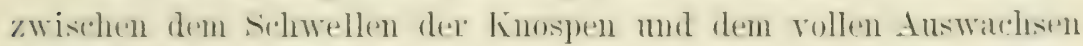
We Blätter. im Frühjahr also. do sie anch stattinden miisste, wemn immergrïne Eichen angebant wïnden. Denn die Lebenswholn wie Kastanieneichen werden nur nach der winterlichern saftruhe geschaili. im engeren Tropengürtel. wo die saftruhe, dies

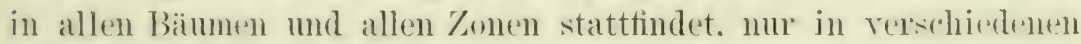
Abstufungen. in die 'Trockenzeit fällt, ist die Rindenschälume. narlo den Erfahrumgen in der. ('hinchonakultur. bald nach dem Fintritt

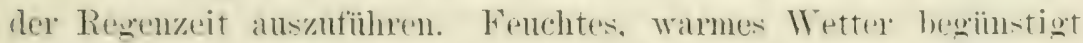

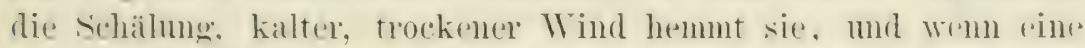
Reihe kalter 'Tage das Warehstum zum storken loringt. muss dies Arbeit eingestellt werden.

I) Berguemlichkeit weren eneschieht das Abschälon anf dem stande. soweit der Arbeiter in die Höhe reichen kann. fiewöhnlich zieht ex rom Stmmpt aufwirts zwei Rindenringe, je 75 Zentimeter lang. ah. indem er mit einem kräftigen. scharfen X[rserer hart ïber dem Stumpl rine'n Rundschnitt in dir Rinde macht. damn rinen zweiten in der Hoilhe von 75 Zentimeter. und einen dritten in sleichex Entfermung von dem Letzteren anfwïts. Dann schlitzt or dic Rinde der Länge nach vom obersten his zum untersten Ringe anf und schailt sie ab. Die Zweige sind leichter zoll schallen wie dir Äste, vorausgesetzt, es geschieht längstens an zwriten

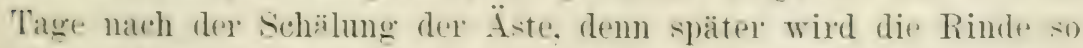
zäh anhängend. das: sie schwierig zu lïsen ist. Es empfuehlt sich

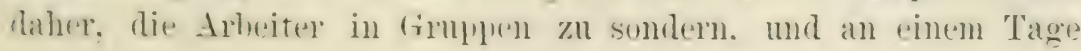




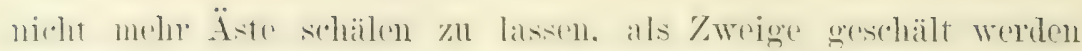

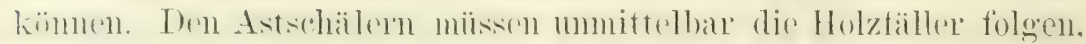

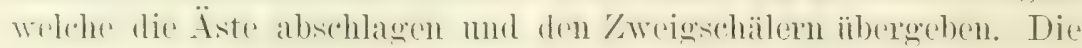

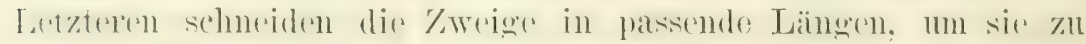
rhälon. Dabei diuten sie sich keiner Tresshwendung schuldig mathen. indem sir diune Zweige überogehen, denn diese entha!ten die meiste Grrbsäure. Teder '/sweig, der schälbar ist, muss seine Timble herquben. selbst wenn er mit einem Messerstiel oder hïlmenen Hammer geklopft werden mus, ähnlich wie die Kuaben verfahren, wenn sie Weidenpfeifen machen.

Die geschälte Rinde wird ant einem stangengerïst getrocknet.

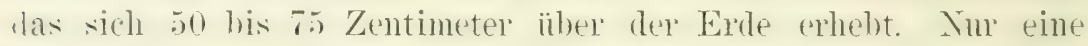
kmzr Zeit wird ihre imnere seite der some ausgesetzt, dam -rhichtet man sie 50 Zentimeter hoch, mit der imneren seite abwärts mul legt die grössten Stiicke obenanf als schutz gegen den Regen. welcher der trocknenden Rinde sehr getährlich ist. Nach $\therefore$ vder + Tagen werden die Schichten anseinandergelegt nud umgesetzt, um die Entstehumg ron Moder zu rerhïten. Bei sehx gimstigem Wetter ist das Trocknen in 8 Tagen rollendet. es mag anch 2 bis 3 Wochen beanspruchen.

Nach Wimsch getrocknete Rinde ist vom heller Rahmtarbe und bricht leicht. vom Wetter beschärigt ist sie bram — ein Zeichen, lass sie einen Teil ihrer Gerlosiure rerloren hat. Wem griundich getrocknet. wird sie unter Dach gebracht. zerbrochen mol in sacke gepackt. Die Auflemahrung sollte in einem dunkeln. kïhlen Raume geschehen, demu Licht mol Trame wirken zersetzend anf die Gerbsäne. Ein Terlust an derselben läst sich ïhrigens bei de'r besten Lagermg nicht remeiden, daher ist e: rorteilhaft, die Rinde möglichst bald zu verwenủen.

Eis wird angenommen. dass die Äste und 7weige etwa s." " inres trewichts Rinde liefern. und ar Letztere bein Trocknen ein Drittel ihres Gewichts verliert.

Das geschälte Holz kann zum Verbrennen und Terkohlen dienen.

Der Nachteil des oben geschilderten Terfahrens. dass es an eine Jahreweit gebunden ist. mo der Landbau dringend Arbeitskrätte hegehrt. mun die Abholzumg den Stämpfen an schädlichsten i-t. latt in Frankreich zur Erfindmo des ... Tomaison Procés. yeteiihrt. Welche die schälumg das ganze Taht gestattet. Dieser. 


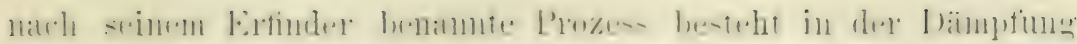

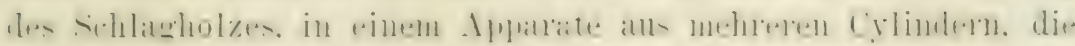

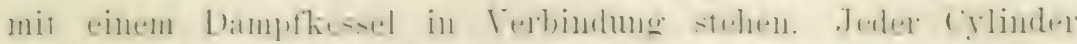

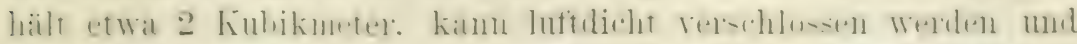

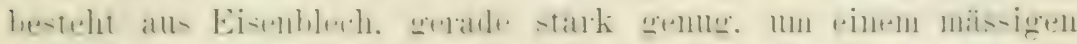

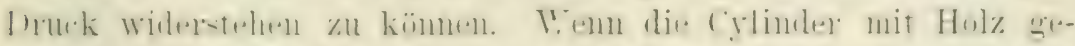

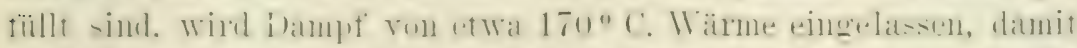

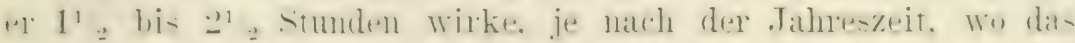

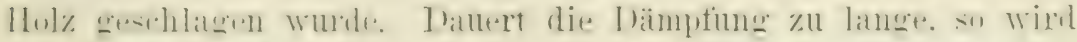

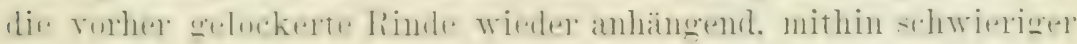
zil schälen.

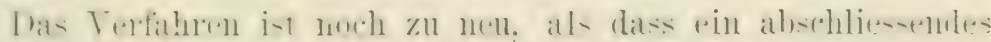

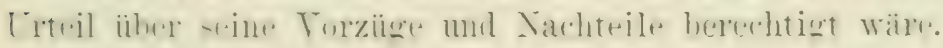

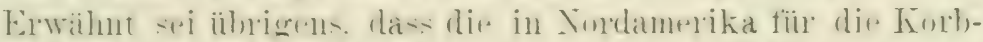

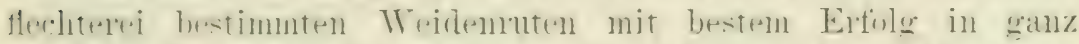

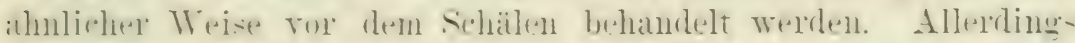
ist in diesm Falle krine Riuchsicht ant die Gerbsinne zu nehmen. dem die wichtigste Frage bei dem Tomalomprozess ist: welehen Einfluss übt der Dampf auf die Gerbsäure?

Narh In. E. Wolff finden sich durchschnittlich in der Rinde: der Sommereiche folgende Mengen Gerbsäme:

\section{Alter der Stämme.}

\begin{tabular}{|c|c|c|c|c|c|c|}
\hline & der rauhen Rinde mit Borke & $10,86 \%$ & $\$ 1$ & bis & 53 & Jahre \\
\hline & " Bastschicht der alten Rinde & 14,43, & 41 & $"$ & 53 & $"$ \\
\hline & Glanzrinde & 13,23, & $\$ 1$ &. & 53 & $"$ \\
\hline & rauhen Rinde und Glanzrinde & 11,69, & 41 & " & & \\
\hline & "Bastschicht und Glanzrinde & 13,92, & 41 & 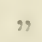 & 5 & \\
\hline & ., Glanzrinde & $13.95 \ldots$ & 14 & $\therefore$ & & .. \\
\hline & $"$ & 15,83, & 2 & $"$ & & $n$ \\
\hline
\end{tabular}

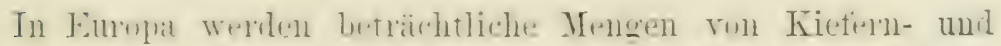
Tammenrinden. geschailt von Banhulz. zur Gerberei benutzt: si.

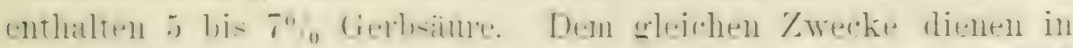

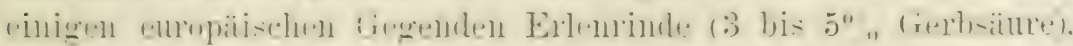

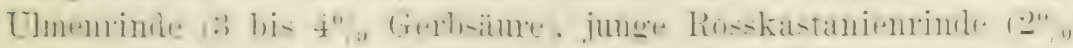
Gerbsäure), Buchemrinde (2\% Gerbsäure).

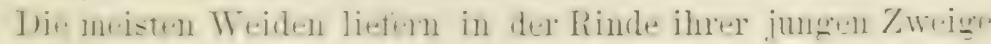

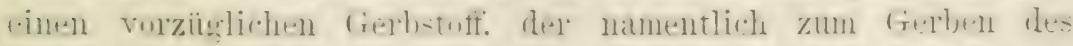

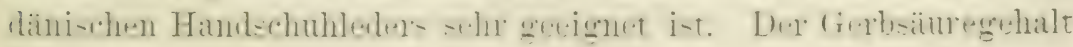
beträgt 3 bis $5 \%$. 
In Fen-Serdand dienen die folgenden Rinden zur Gerberei. teilweise auch zur Fïrberei:

Wissenschaftliche Namen.

Phyllocladus trichomanoides

Elaeocarpus dentatus

Metrosideros robusta

Coriaria ruscifolia

Eugenia maire

Weinmaunia racemosa

Elaeocarpus hookerianus

Fuchsia excorticata

$\left.\begin{array}{lc|}\text { Volkstüliche Namen. } & \text { Prozent Gerbsäure. } \\ \text { Tanekaha } & 23,2 \\ \text { Hinau } & 21,8 \\ \text { Rata } & 18,6 \\ \text { Tutu } & 16,8 \\ \text { Whawhako } & 16,7 \\ \text { Tawhero } & 12,7 \\ \text { Pokaka } & 9,8 \\ \text { Kotutuku } & 5,3\end{array}\right\}$

Die beiden, an der spitze stehenden Rinäen nehmen anch in Bezng anf Qualität den ersten Rang ein. Die Hinaminde kam nicht allein zum Gerben. sondern auch zum Schwarzfärben benutzt werdell. Durch einen Zusatz von Eisenoxyd wird eine vorzïgliche Tinte hrorgestellt. welche die Federn nicht angreift. Der aut heiden Inseln rorkommende Baum wird 15 Meter hoch, sein Hol\% ist gelbbraun, dicht und sehr dauerhaft.

\section{Vallonea.}

Enter diesem Namen werden verstanden die Fruchtbecher (Eichelkelche) einiger in Griechenland, Kleinasien und Syrien rorkommenden Eichenarten. von welchen die weitaus wichtigste puereus aegilops ist. Die Vallonea macht ein ebenso gutes Teder wie die beste Eichenlohe, behauptet wird sogar ein härteres und Trasserdichteres. answerdem gibt sie dem Leder einen reichen Hanch. der seine Terkäuflichkeit hebt. Griechenland, namentlich Morea. int die wichtigste Bezugsum lle dieses Artikrols. Man unterscheidet dort:

1. Die reife Vallonea, das sind die von stibst von den Bämen fallenden Frnchtbecher, welche ron Ende Juni bis Ende Tuli gesammelt werden. Dieselbe bildet die beste Qualität und wird getremnt in Chamada: grosse stïcke. mit nach oben gekehrten schuppen, welche dir Eichel rollständig einschliesen und thamadina: kleine Stïcke von der Grösse einer Nuss, mit meist verkriippelten Eicheln. dir gleichfalls rollständig nou den schnppen eingeschlossen sind. 
2. Dir unreife Vallonea, Welehe matn von den Bämmen ab)-

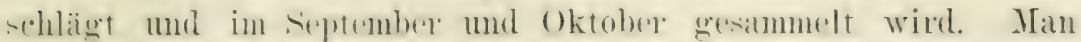
muter-cheidet: Rabdistal (stah), der heleh ist fred, die schuppen sind nach oben gekehrt und (homdra (grob): der Kelch ist geleich-

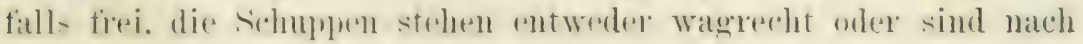
unten gekehrt.

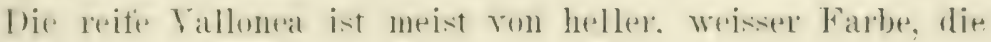
mueife ist gewölnulich dunkelbram.

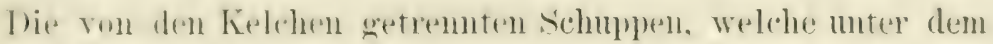
Simen (millat in den Handel kommen. sind gerbstoftereher als dite helohe. So regah die chemische Analyse einer Vallonea aus

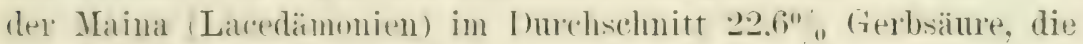
Schuppen enthielten $36,6 \%$.

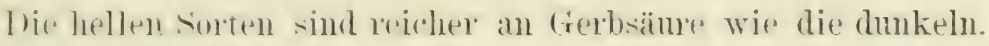

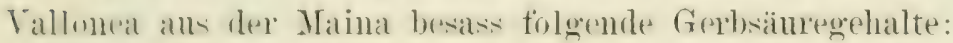

$\begin{array}{lcc} & \text { hell. } & \text { dunkel. } \\ \text { Chamada } & 33,482 \% & 24,51 \% \\ \text { Chamadina } & 35,450 \% & 25,10 " \\ \text { Rabdista } & 30,080, & - \\ \text { Chondra } & 27,027, & 22,26,\end{array}$

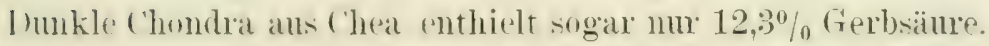
Vallonea. von smyma exportiert, ergal bei einer Cntersuchumg :34,78\% Gerbsäure.

\section{Galläptel.}

Von den krankhaften Alswïchsen an Pthanzene, welche Gallen

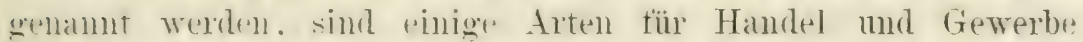

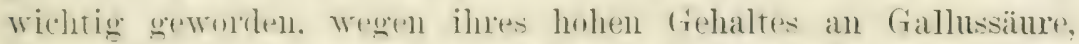

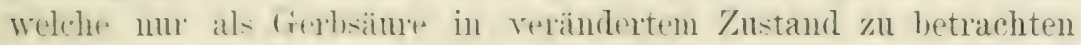
i-t. Hir Gallus äure ist ledith ansuscheiden in der Form ron

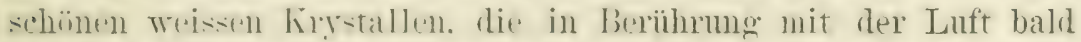
fialogelh werden und rine'n Handelsatikel bilden. seit Gallussäure rin Fixiernittel tïr photographische Bilder wurde. Beror dieser berlate zu decken war. dienten die fialläptel nur fiast alsshlieslich in der Farberei und Tintentabrikation. wo sir noch hente kaum zu entiohen sind. 
As die besten Galliaptel gelten die tiukischen, welcher etwat die Grösere einer Muskatmuss besitzen. von Constantinopel und smyona expontiert werden und in die schwarze mol weisse Qmalität zerfallen. Die Erstere, dio eriunlicheran bis tiefolivenfarbig ist, wird gesammelt, während das Insekt noch in den Galläpfeln molint und ist schwerer und weitans wertvoller wie die Letztere, welche nicht weiss, sondern brämlicherb ist und ein Loch besitzt, durch welches das Insekt anskroch. An manchen Handelsplätz'n wirl noch eine griune Qualitat unterschieden, die mit der selıwarzen fiast gleichwertig ist; wie diese das Insekt noch enthält, nur etwas heller gefärbt ist. Alle Qualitäten sind geruchlos und haben einen ekelerregenden, bitteren, ausserordentlich zusammenziehenden Geschmack. I)ie Gestalt ist nahezu kugehrund, die Oberflache ist mehr oder minder warzig, der Bruch ist kieselig.

Diese Galläpfel werden erzengt durch den Stich einer Gallwespenart (Cynips quercus-galli) an den Zweigen der Galläptelriche (Quercus infectoria), heimisch in Vorderasier, vom Marmorameer bis syrien und vom griechischen Archipei bis zur persischen Grenze. Im Handel werden rerschiedene Sorten unterschieden, ron welchen diejenigen von Aleppo und Mosul den ersten Rang. fimehmen, sowohl was Menge wie Gïte betrifft. Mosul, das 10 'Tagereisen von Aleppo entfernt ist, exportiert über' diesen Platz seine Galläpfel, welche die besten sind, doch wird es, dieser 'ngen Handelsbeziehung wegen, mit der Sonderbenemmg nicht genan genommen. Teniger bekamnt sind die Galläpfel ron Tripoli und 'Taraplus.

Eine andere Gattmo Galläptel sind die Corianther-oder kleinen Aleppogalläpfel, die gewöhnlich von der Grösse einer Ertse und stets durchlöchert mul leer sind. Die Farbe ist bräunlich-gelb, die Gestalt ist 1mud, ant der foberflache sitzen. kleine stumrfe Stacheln.

Eine dritte (iattung: die Bassora- oder Mekkagallen, welche auch unter dem Jimmen Sodomäptel gekannt sind, werden ebenfalls an der (ralläpteleiche, aber von ciner anderen trallwespenat (Cynips insana) erzeugt; sie kommen nur in kleinen Pöstchen in den Handel. IDiese Galläptel zeichnen sich durch ihne Grösse ans, welche derjenigen einer Pflame gleichkommt. Tie Oberflache ist grlatt, mit Ausnahme eines shwarhen ringartigen Answelses. 


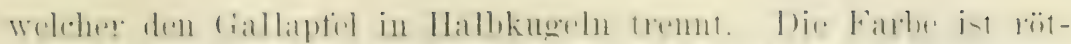

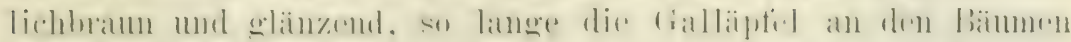

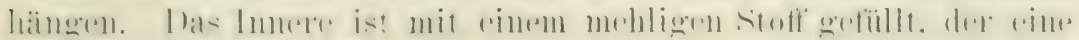
gewisse Ähnlichleit mit Asche besitzt.

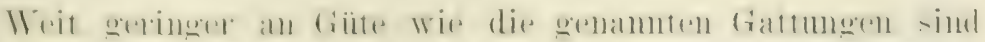

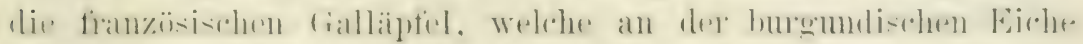

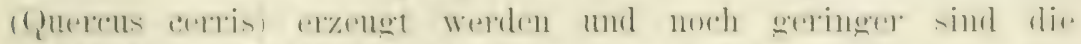

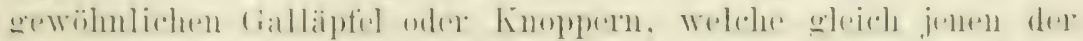

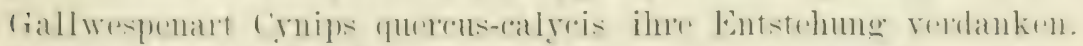

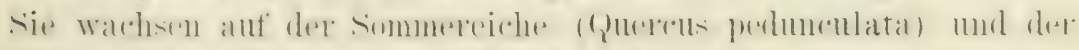

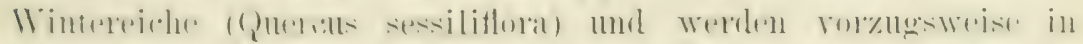

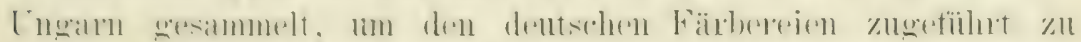

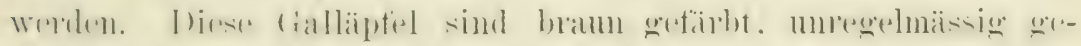

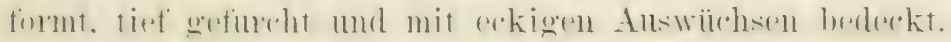

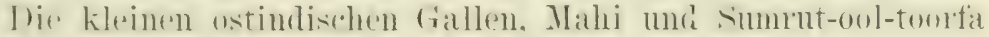
in Indien wenannt. Werden von dor 'Tamariske framarix indirat

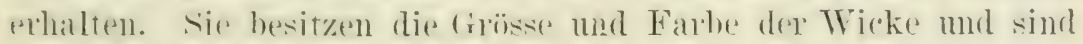

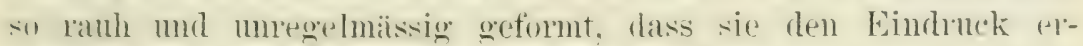

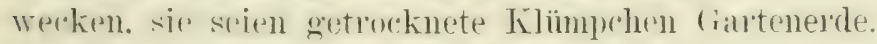

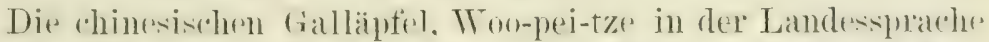

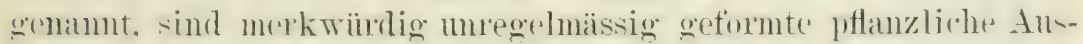

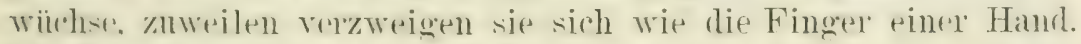

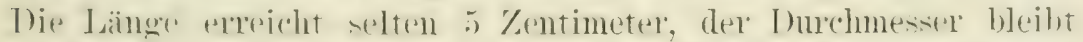

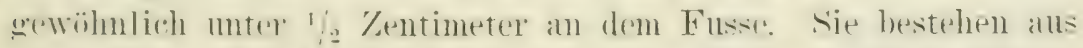

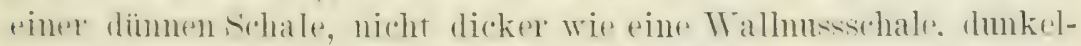

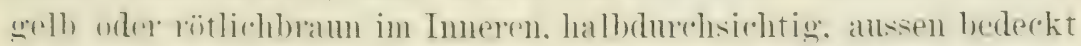

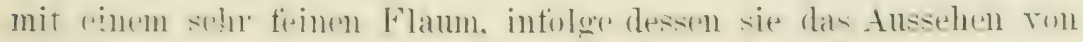
just ausbrechenden Hirschhörnern besitzen.

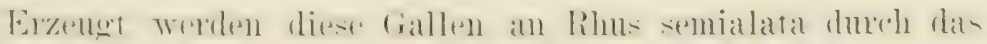
Instit Aphis rhinensis. liesmmmelt morden sio vol Eintritt de

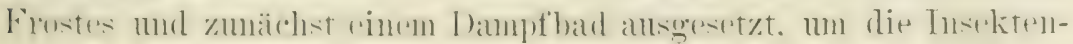
bewolnel zu töten.

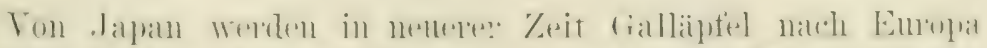

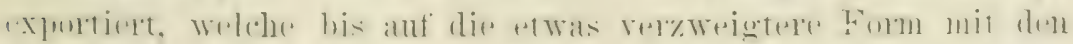

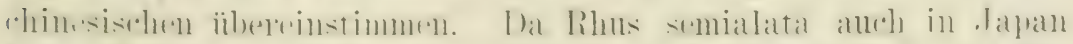

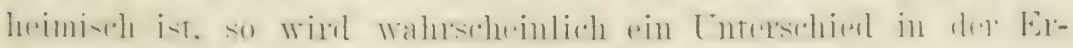

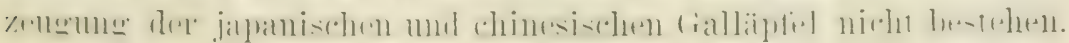




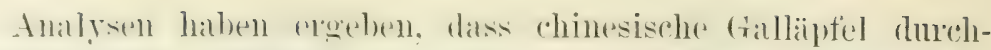
-romittleh 7.

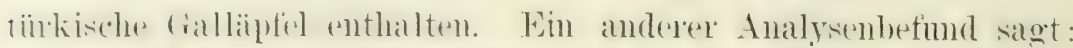

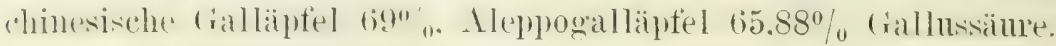

In dem Markthericht dex Hamburger Warenbërse rom März 1887 wurden notirt:

$\left.\begin{array}{llllll}\text { schwarze Galläpfel } & 60 & \text { bis } & 70 & \text { Mark } \\ \text { grüne } & " & 62 & , & 65 & , \\ \text { chinesische } & " & 61 & , & 62 & ,\end{array}\right\}$ pro 50 Kilogramm.

4. Myrabolane.

I) Arten der Gattmo Terminalia. Familie Combretaceae, welche in den Gebirgen Indiens heimisch sind. Die Blüten dieser Bäumchen nnd sträucher haben einen abfallenden, glockenförmigen Kelch und keine Blumenbläter. sit werden ron etwa olivengrossen, saftlosen Frïchten gefolgt. T. Belerica, mit eiförmigen ganzen Blättern an langen stielen ist die weitans wichtigste Art, streng genommen sollten nu ihre Früchte als Myrabolane gelten, indessen kommen die Frïchte anderer Arten anstandslos mnter diesem Namen in den Hamble Nur das etwa ${ }^{1}$ a Zentimeter dicke, ausserordentlich zusammenziehende Fruchtfleisch ist wertvoll. getrennt vou der Frucht dient es in den Färbereien und Gerbereien. zuweilen auch als tunischer Mittel in der Heilkunst. Mit Eisen erzengt es eine vorziïliche schwarz. mul mit Alaun eine danerhatte. reiche, bramgelbe Farbe.

In der Gepherei madhen die Mrrabolane ein weiches. gelbes Ledex mit weng tewicht. Ihr Gerbsänegehalt schwankt zwischen 20 ind $25 \%$.

In den beiden letzten . Tahozehnten hat die Nachfiage nach diesen Artikel ant den eurnäischen Märkten hententend zugenommen. Was dex indischen Forstrerwaltung Teranlassung hot. Mrrabolane zu einem ihrer wirhtigstem Tebenjodukte zu machen. Naw:h dem Marktheridhte der Hamburger Warenbärse rom März 1887

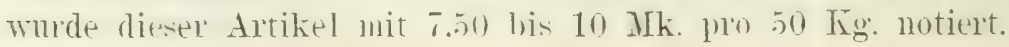




\section{Pottasche.}

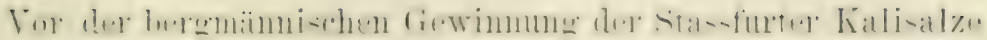

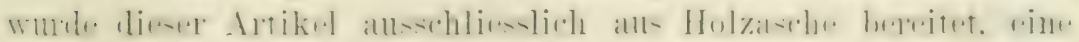

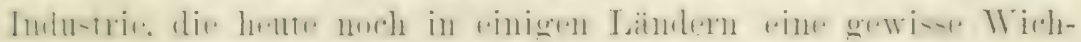

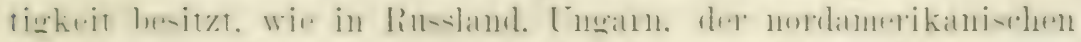

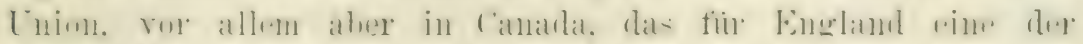

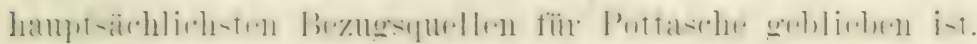

Fïr ein ackerbantreibendes Land ist es sicher eine kur\%-

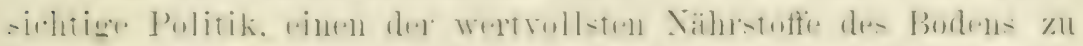

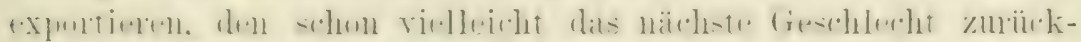

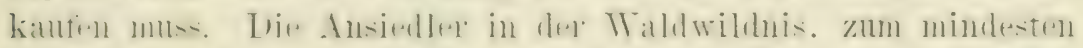

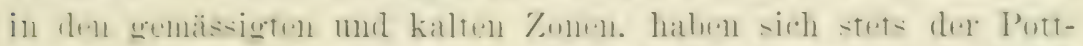

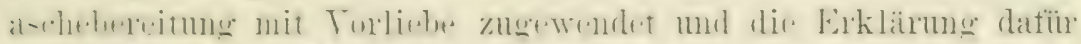

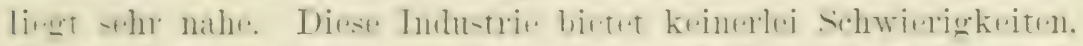

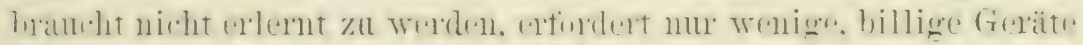

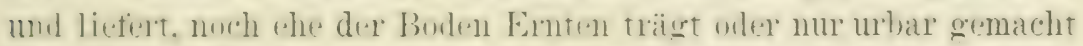
i-t. Nittel \%ur Cuterhaltung der Fanilie oder zur Ausbildumg

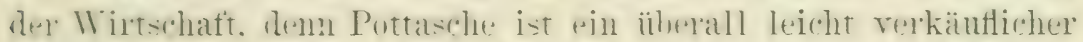
Artikel. Inese Vorzinge fallen fïr die Ansiedlex schwer ins frewicht

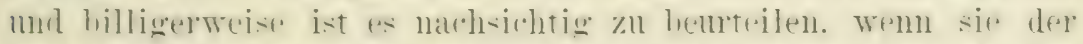

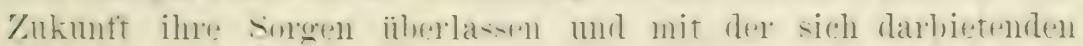
Hilfe die bergehohen schwierigheiten des liegenwalt zu iiberwältigen suchen.

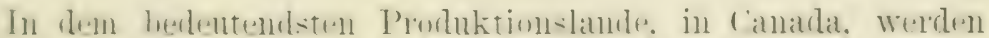

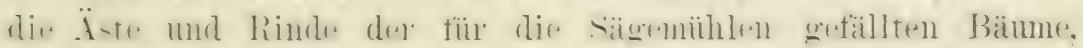

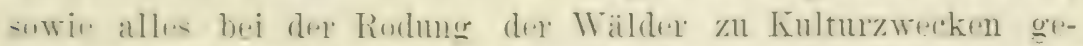

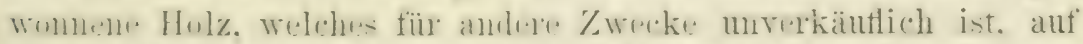

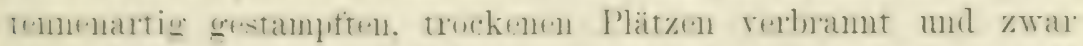

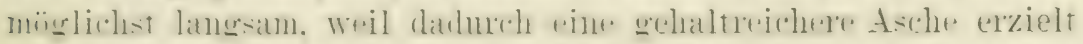

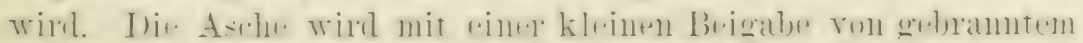

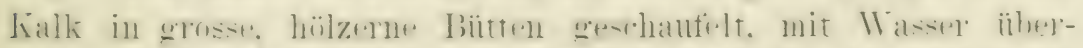

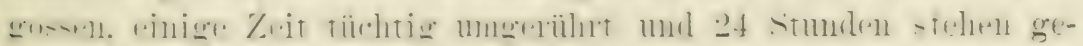

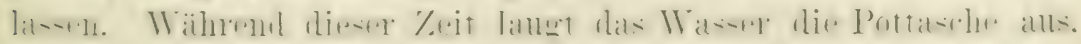

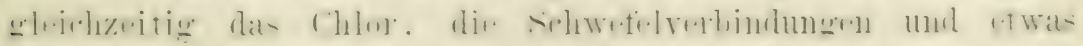

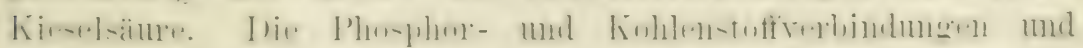

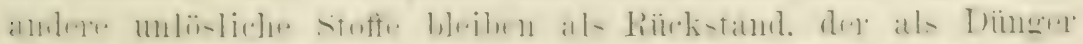

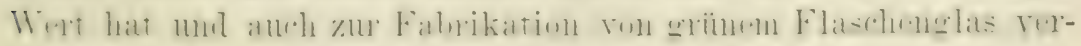

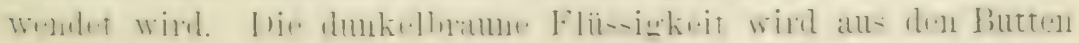




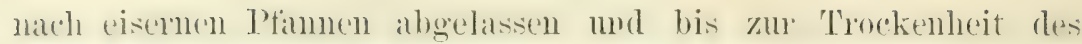

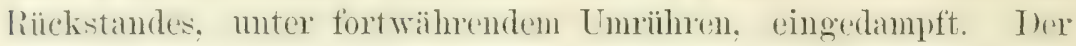
letztere wirl in Giuhhitze versetzt, um die feinen Kohlenteilehen und halbverbamnten organischen Stoffe vollständig zu verbrenn+n. 1)ieses Calcinieren exschah frïher ausschliesslich in eiserne'n Töpfen, die auch hente noch ron unbemittelten Ansiedlern gebratucht werden, daher der Name Pottasche. ('Topf $=$ Pot dex Engländer.) Wo die Bereitumg in grösserem Masstabe stattfindet. benutzt man hesonders für diesen Zweck konstruierte Öfen. Dannt. ist die gewöhnliche Pottasche des Handels fertig. Alssen ist sie grat, im Bruch zeigt sie einen rötlichen Schein. Da sie stur leicht zerfliessbar ist, muss sie in möglichst dichten Fäs-iern rexpackt werden.

Die Zusammensetzung der calcinierten Pottasche wechselt sehr' ihr allein wertvoller Bestandteil, das kohlensaure Kali, beregt sich zwischen 40 bis $80 \%$.

Eine Analyse zahlreicher nordamerikanischer Pottaschproben, calciniert im Ofen, ergab im Durchschnitt das folgende Resultat

kohlensaures Kali
schwefelsaures Kali
Chlorkali
Wasser
unlösliche Stoffe
Verlust

$\begin{array}{r}71,4 \% \\ 2,3 \% \\ 14,4, \\ 3,6, \\ 4,5 \% \\ 2,7 \% \\ 1,1 \% \\ \hline 100,0 \%\end{array}$

Gewöhnliche Pottasche wird zur Fabrikation ron filas und. nachdem sie kaustiziert ist, von S'eife benntzt. Fïr fast alle übrigen Terwendungen ist sie zu mrein mol mus erst time Reinigung durchmachen, durch welche sie zur Perlasche wird. Zu diesem Zwecke wird sie in kleine Stiicke gobrochen mol in einer Bütte mit durchïchertem Boden, der mit Stroh bedeckt ist, in der möglichst geringsten Wassermenge aufgelïst. Die Flüssigkeit seiht durch das Stroh. in welchem die moelösten. hamptsächlich ans schwefelverbindungen bestehenden 'Teile hängen bleiben, in eine tlache. eiserne Pfamme, in welcher sie cingedampft wirt. Wenn der Rückstand nahezu trocken ist. wird er mit eisemen stangen numgerïhrt, $u m$ ihn in rundliche Brocken zu zerbrechen. 


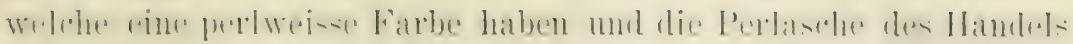
bilden.

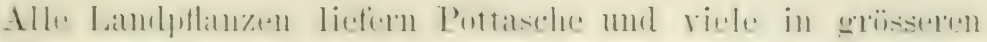

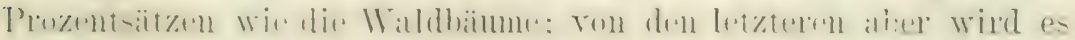

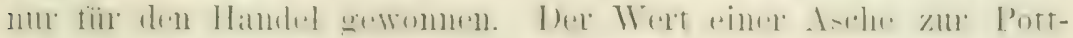

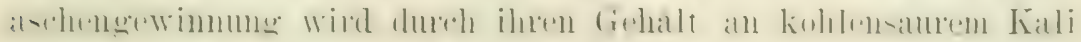
bestimmt. Nach Hïss liefern 1000 'Teile:

$\begin{array}{lcc} & \text { Asche, } & \text { Pottasche. } \\ \text { Fichtenholz } & 3,40 & 0,45 \\ \text { Buchenholz } & 5,8 & 1,27 \\ \text { Eschenholz } & 12,2 & 0,74 \\ \text { Eichenholz } & 13,5 & 1,50 \\ \text { Limenholz } & 25,5 & 3,90 \\ \text { Weidenholz } & 28,0 & 2,85\end{array}$

\section{'Teer.}

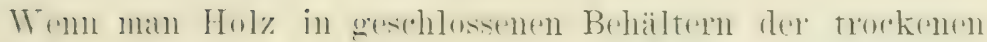
Ine-tillation aussetzt, erhält man rerschiedene gasformige und

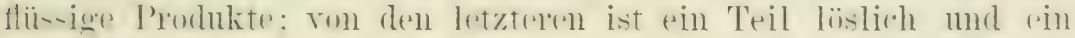

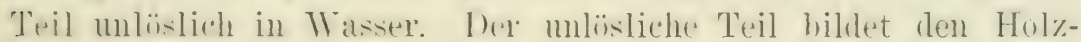

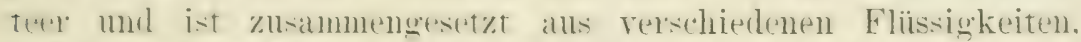

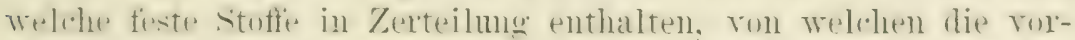

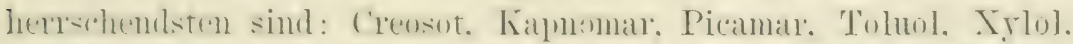

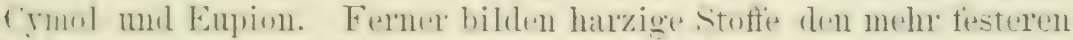

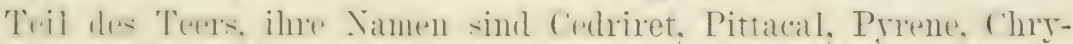
sene und Pyroxanthin.

Der Holzteer ist eine bräunlich schwarze, dicke, zähe

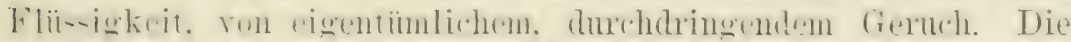

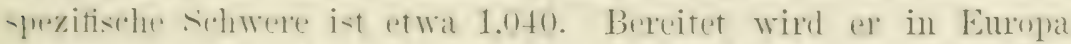

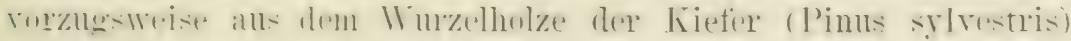

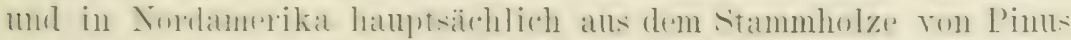

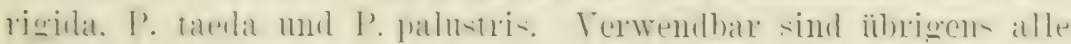
harzigen Nadelhölzer.

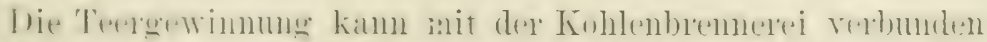

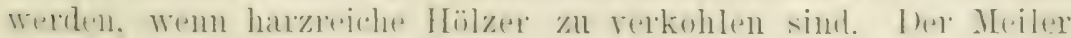

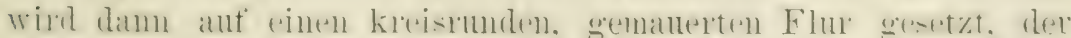

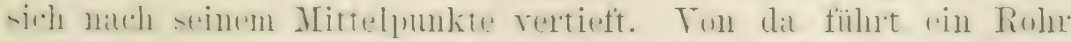

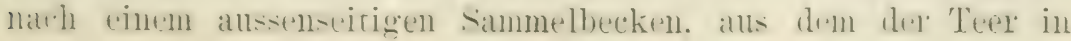




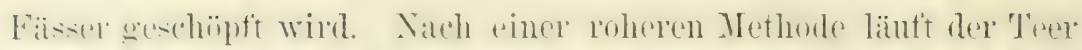

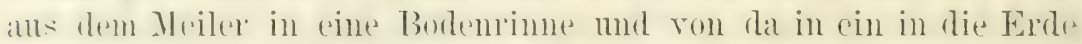

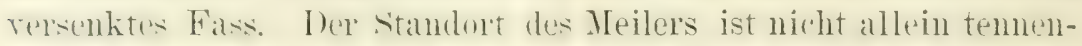

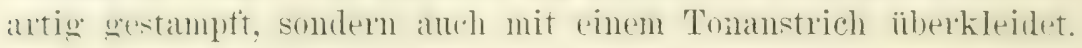

In Inentshland wird läutig rine Lehmsteinhüte im Walde errichtet. die im Wesen mit den oben geschilderten (̈̈ten tü̈ die Kohlenbremerei übereinstimmt. Tn diesen Hütten findet dir Verkohlung statt und der auf dem Boden in einer Tertictung sich sammehnde 'terer fliesst durch ein Rohr nach einem Behälter im Freien.

Die fortgeschrittenste Methode hesteht darin. dass das Holz. anch die Rückstände bei rer Terpentinbereitung, in einen gros-en eisemen Cylinder gebracht werden, der so eingemantert ist. dias 'l' an seinem Fusse äuserlich ron Fener umgeben werden kimn. Ein Rohr am Boden des Cylinders tührt den Teer nach dem sammelbecken, ein anderes Rohr am Teckel leitet die gasfïmigen Produkte nach einem Apparate. der sie rerdichtef wie bei der gewöhnlichen Destillation.

Pech ist einfach Teer, eingerlamptt zu einem Grarle. dass er beim Erkalten fest wird.

\section{Kienruss.}

Harzige Hölzer werden bei geringem Inttutritt rerbramnt und die entsteigenden Russmassen durch einen Kanal geleitet. del mit einem Tuchsiehe verschlossen ist. Dasselbe lässt die Gase durch stine engen Naschen entweichen. nicht aber den Rus-. der ron Zeit zu Zeit ausgenommen wird.

\section{Harze.}

Trit diesem Namen werlen Bestandteile des Ptlanzenreichs: bezeichnet. dip ans Kohlenstoft. Wasserstofi und Sauerstoff. stets ohne Beimengungr von Stickstoft bestehen; sie sind nahe rerwandt mit den ätherischen ()len. welche sowohl gemeinschaftlich mit ihnen rorkommen, als anch durch Oxydation in Harze ïbergehen kümmen. Der Luft allogestzte ätherische Öle rerden allmählich dickflii-sing und erstarren schliesslich zu harzähnlichen Massen. Die vom den Pflanzen anseschiedenen Harze sind niemals rein, sondern hänfig

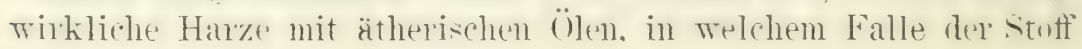




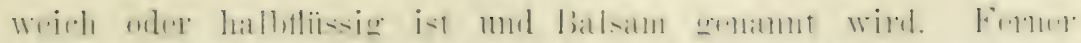

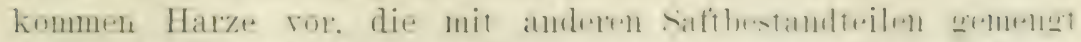

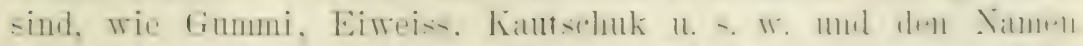

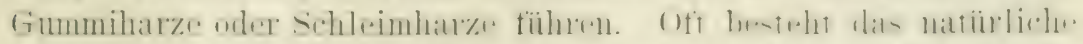

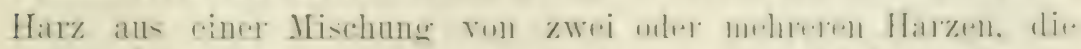

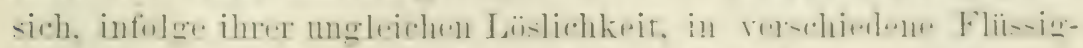

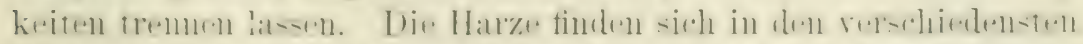

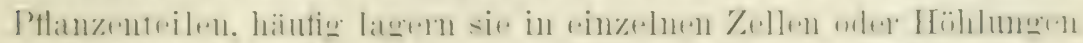

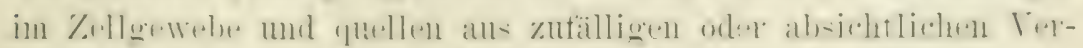

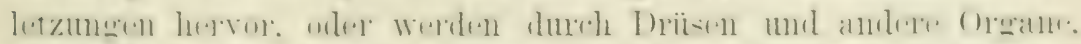

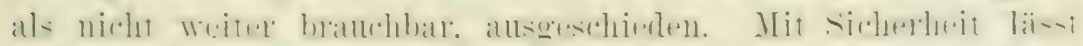

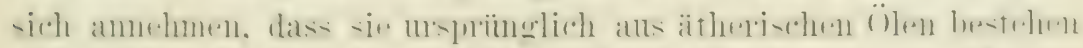

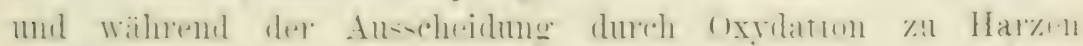
werden.

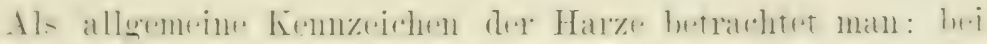

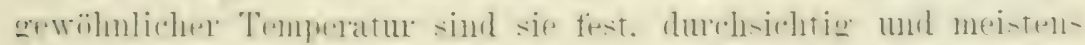

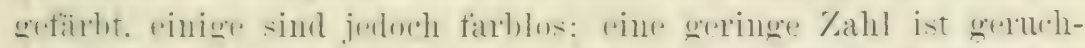

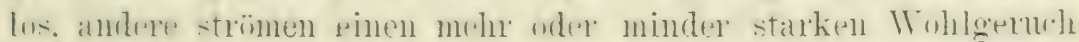

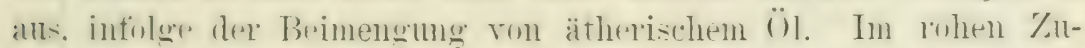

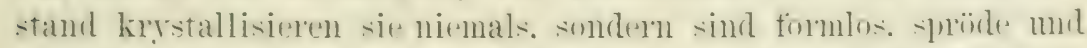
brechen mit einem musheliern Bruch. In reinem Zustanke

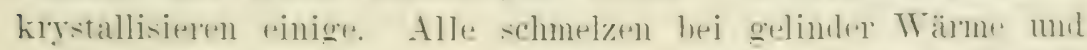

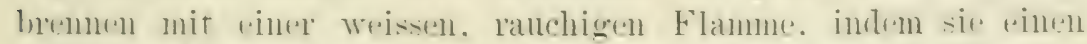

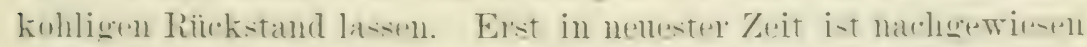

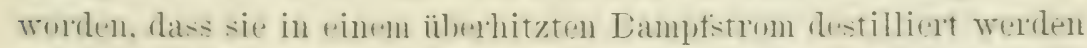

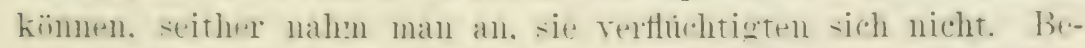

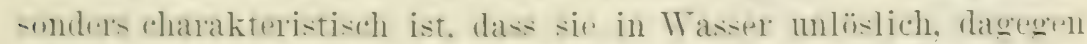
löslirh sind in Alkohol. Äther. ätherischen und fetten (i)len. All. sind Nirhtheitex dex El+ktrizität und werden durch Reiben negativ clektricch. Einige besitzth rine Beimengme ron säme. ilne

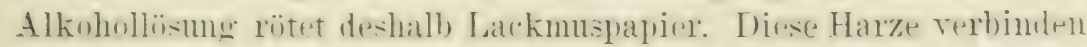
sich mit Alkalien und bilden, in alkalinisehe Latuen gedmacht.

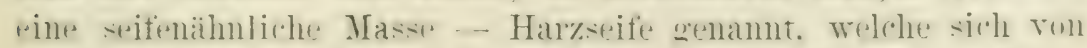

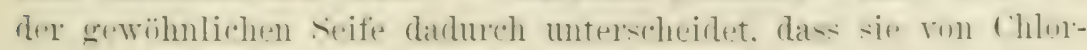
natron nicht gefällt wircl.

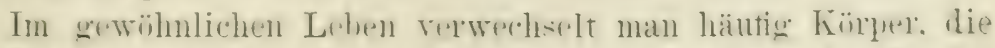

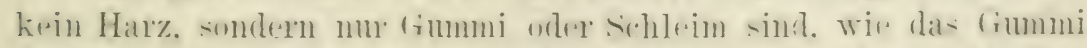

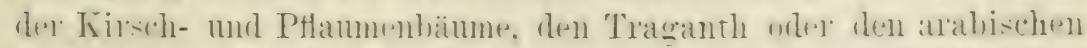
Gummi mit Har\%. Gan\% frei von Harz sime wenige Pflanzen. 


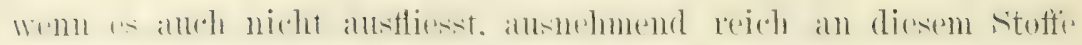

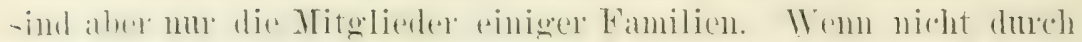

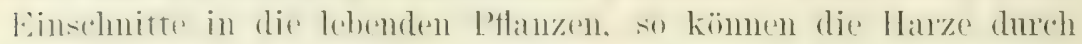

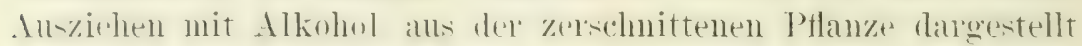

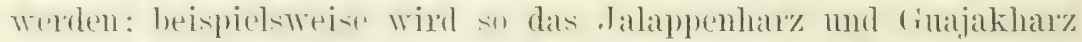

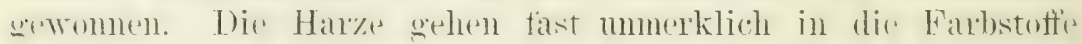

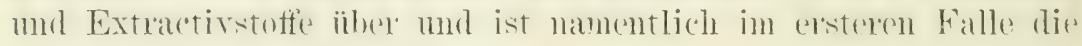
Unterscheidung oft schwierig.

Trie schon argerlentet, zerfallen die Harze in droi Klaksen: in die harten Hallor, die weiche'n Harze oder Balsane und die Gimmihare'. I)ie harten Harze sind bei gewöhilicher 'T'emperatu' latrt und spröde, sie lassen sich leicht pulverisieren und chthalten wenig oler kein atherisches (i). Zu dieser Klasse gehören Kopal. Dammar, Gummilatek. Mastix, Sandarak. Benzoin. Jalappen- mol Guajakharz.

Die weichen Harze kïmnen mit der Hand geforment werdell.

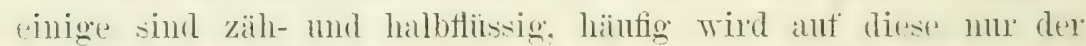
Same Balsam angewendet. Alle bestehen ans einer Mischung von harten Harzen und äthexischen (i)en, oxyclieren an der Lutt und werden allmïhlich zu harten Harzen. Elemi. 'Terpentin, storax. copatrabalsam. Balsam von canada. P'e'u und Tolu gethören zu rieser Klasse.

Die Gummiharze sind die an der Luft verhärteten Milchsätte gewisser Pflanzen und hestehen ans einer Mischung von Harz. itherischem (i) und Gummi. Wem in Masser zerrieben. machen -ir dasselbe triib und milchion, weil sich das Gummi antlöst.

Wie sich die Gummiharze nur teilweise in Wasser, so lösen sie sich auch nur teilweise in Alkohol ant, denn dieser bleiht dem frummi grentiuber wirkungslus. Einige Mitglieder dieser Klasse, wie Ammoniacum. Arafoetida. Euphubium. Galbanm. frummigut, Mrrrlue. Olibanum oder Weihrauch werden als Heilmittel geschazt. während andere, wie Kantsehn mol fintapereha. ron grossem Werte für die Gewerbe sind.

Aluch mehrer weiche Harze spielen eine berlentende Rolle in rler Heilkmst. Während die harten eine ansegedehnte Terwentung

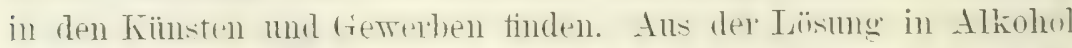
mer atherischen (ipstalt eines glitten. durhscheinenden. glänzenden Ïherzngs an- 


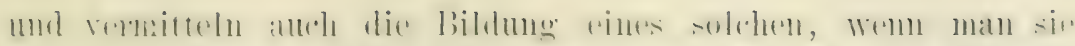

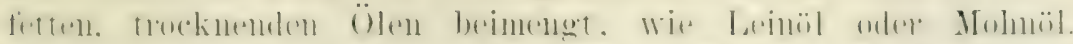

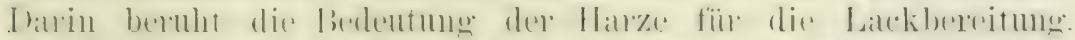

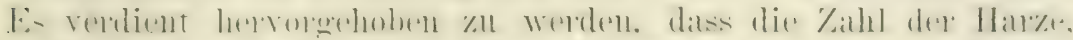

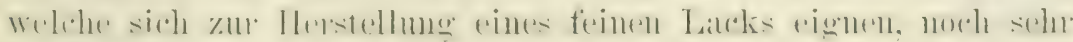
beschrinkt ist.

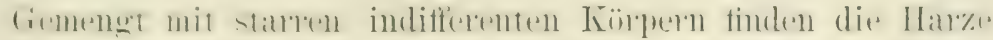

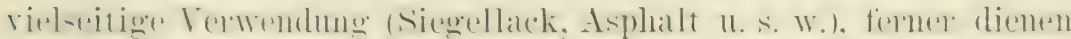
sie als lindemittel. indem man sie ferin sepuldert zwischen die.

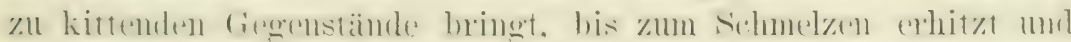

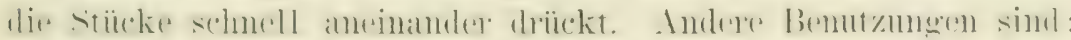
z. Seife, kïnstlichem Licht und Malerfarben.

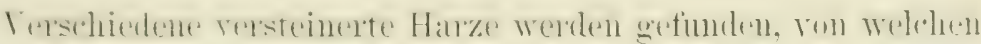

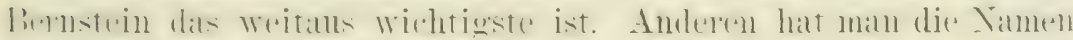

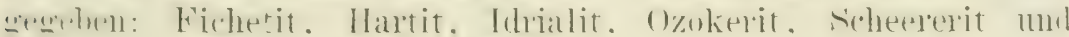
Xyloretin.

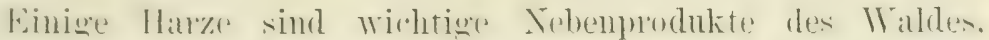

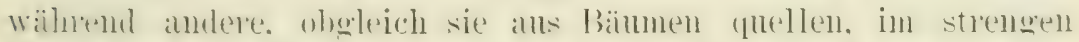

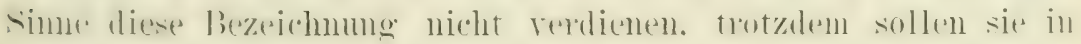

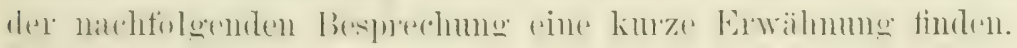

\section{Ko pa l.}

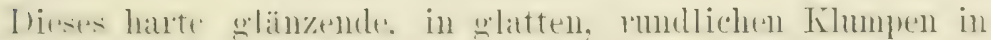

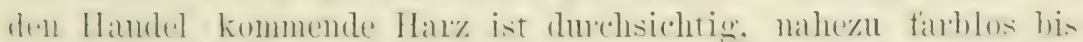

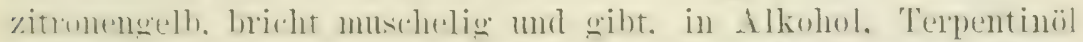

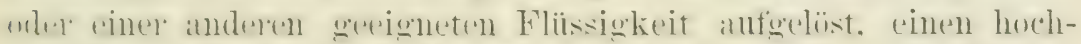

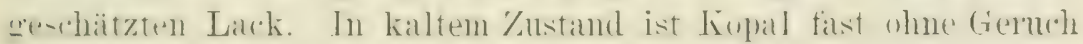

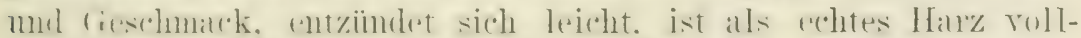

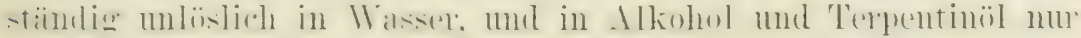

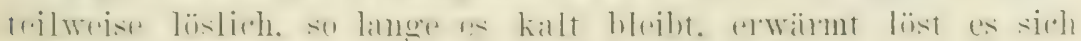
dagegegen leicht auf.

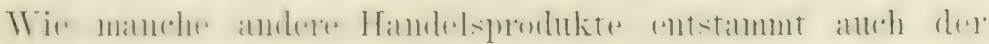

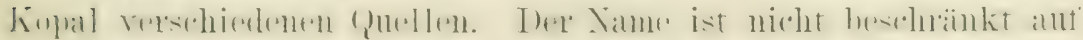

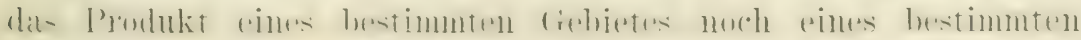

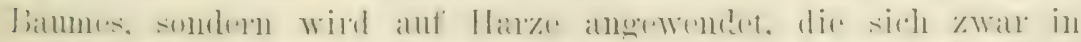

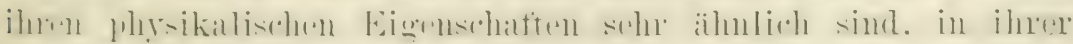

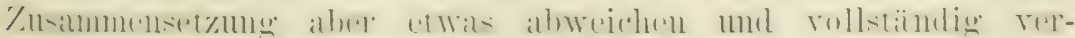

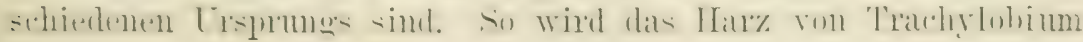


Hen'nemamnianmm im Handel simsibarkopal, nach cinem renalteten

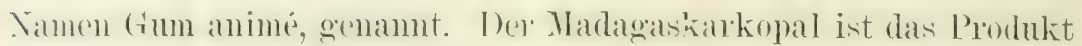
rom Trachylobiun reprucosum. Von Guibourtia copallifera stammt der Kopal von sierat Leone, fin duderer Kopal wird an der samzen tiopischen Westküste Afrikas in ressteinertem Zustande nefunden: "r ist wahrscheinlich das Produkt eines ansuestorbenen Bammes. In Brasilien nut anderen südamerikanischtsln Ländex'n wird Kopal gewonnen ron Trachylubium Martianum und verschiedenen Arten der (tattung Hymenaea, Familie Leguminusa, rouzugstreise ron H. ('ourbaril. Die Quelle des mexikanischen Kopals, des ersten, den die Europäer kemen lernten - stammt dorll der Name Kopal aus Mexiko, wo el auf Harz im allgemeinen ansewendet wird - ist noch nicht zweifellos festgestellt, wahrscheinlich ist sie eine Art der Gattming Hymenaea. Mit dem mexikanischen Kopal ist zuweilen ein anderes Harz verwechselt worden, das in Mexiko hänfig zur Lackbereitung dient, aber anderen Crsprungs ist. Der Name dieses Harzes ist 'Tescalana, es stammt von Ficle nymphaefolia.

Das mexikanische wie südamerikanische Kopal wird halbversteinert am Fusse der produzierenden Bäume gefunden.

I)as indische Dammarharz ron Vateria indica wird zuweilen indischer Kopal genannt, weil es den ührigen Fopalsorten ähnlich ist.

Ton allen Kopalsorten ist für den Handel am weitans wichtigsten der ostafrikanische oder Sansibarkopal, das Produkt ron Trachylobium Hornemannianum. Dasselbe wird in zwei rerschiedenen Zuständen gefunden, nämlich: roh oder jung, von den Küstenbewohnern Sandarusiza miti oder Chakazi genannt: der letztere Tame wurde von den englischen Kanflenten zu Sansibar in Jackasscopal verstummelt; sodam der reife oder echte Kopal, der sandarusi inti der Eingeborenen.

Der rohe Kopal, der direkt ron den Bämmen erhalten wird. bei deren Wruzeln oder nahe der Oberfläche der Bamscheiben en sich findet, wird ron den Eingeborenen nicht hoch geschätzt und kommt nicht in den europäischen Handel. Die sanze Alsbeute geht nach Indien und ('hina. wo sie zur bereitung eines groben Lacks dient.

Der echte Kopal wird anf einer weiten strecke in Dentschcotafika in der Erde gefunden, an Orten, wo jetzt kein Balum 


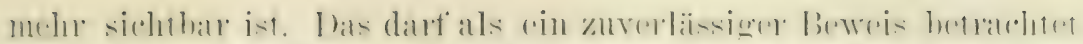

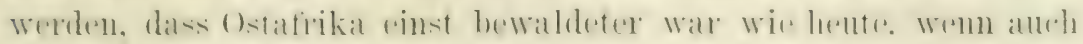

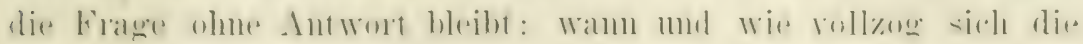
Wäldelverwiistmug?

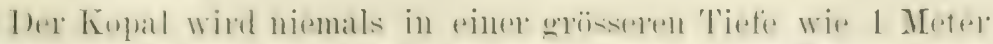

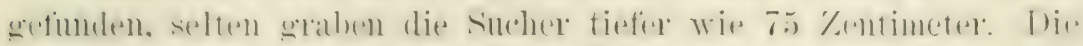

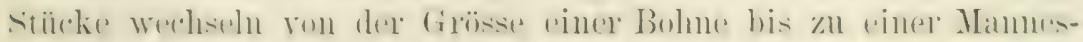

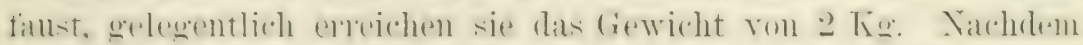

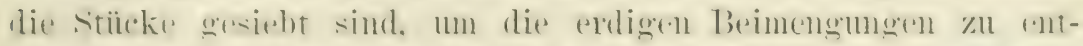

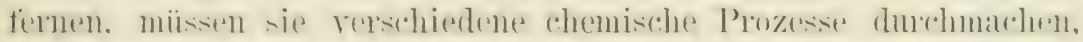
damit sie vom der ... Giansehant" befient werden - rin Xame. Wel-

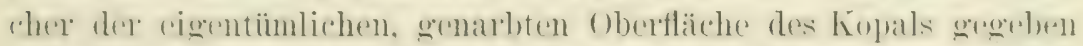
wirl. Friiles wurde angenommen. die tränsehant wiilde verul-

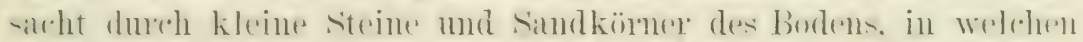

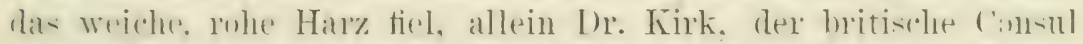
in sansibar, versichert. der hopal bexitze keine syur rom dianse-

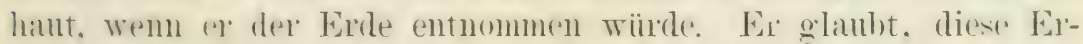
scheinume sei die Folge der (Oxydation dex oberfläche bis zu einel gewiscen Tiefe, nach der Berïhrung des Kopals mit der Luft. orler

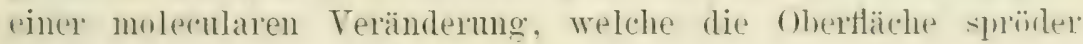
mache wie die innere Masse.

las hopalsuchen wird von den Eingeborenen in soldelonel. whertliahlicher Weise betrieben und der Handel in diesem Artikel ist mit manchen sỏnwerigheitén rerbunden, eine schattenseite. welche dem fiechät mit allen rohen Tolksstämmen anhaftet. Es wird behauptet. die Kopalvorräthe in Deutsch-( stathika seien un-

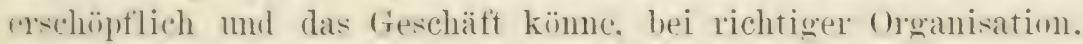
die Wuhlstandsquelle piner zahheicheren Berölkerung werden, als jetzt die Konalregion bewohnt. Eim beträchtlicher Teil dex Kopalausbente goht über Bumbay nach Europa, allein anselmliche Mengen werden von Sansihar direkt nach Famburg und London rexschifft. her gresante Export dieses, nul ab sansibar verschifften Artikrls. hält sich in der Xäle ron 500000 Kg. im . Tahre. Lie Resultatr

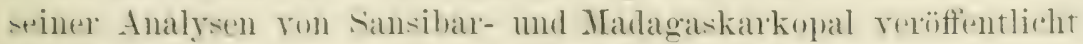
Filhot wie folgt:

$\begin{array}{lcc} & \text { Sansibarkopal. } & \text { Madagaskarkopal. } \\ \text { Kohlenstof } & 79,70 \% & 79,80 \% \\ \text { Wasserstof } & 10,40 \% & 9,42 \% \\ \text { Sauerstoff } & 9,90 \% & 10,78 \% \\ & 100,00 \% & 100,00 \%\end{array}$


Simsibarkopal wird in Hambure mit 4 his 8 Mark pro her. notilet.

\section{D a m m ar.}

(ileich Tópa! wird auch dieser Name auf Harze verschiedenen Trymungs angewendet. doch verstelit man monter dem echten Dammar das Produkt ron I)ammara orientalis, ein grosser, auf den bergen von Java, Sumatra, Borneo und den Molnkken wachsenHer Banm, von welchem der Name stammt, der auf die Gattumo. ïbertragen wurle. Dieselbe gehört zu der Ordumg der Tadelhïlzer mol zeichnet sich ron allen ïlnigen Gattmogn dieser Ordnung durch lanzettiche, lederantige Blätter mit zahlveichen, gleichlautenden Adern aus, wie durch Samen. der nicht an den Enden. sondern an den Seiten geflügelt ist. Der Dammarbaum (D. orientalis) wächst zu einer beträchtlichen Höhe und erreicht manchmal pinen Inuchmesser von 2,7 Meter. Der untere Teil des Stammer ist gewöhnlich mit Knoten besetzt, so dick wie Mannsköpfe. Das Holz ist weich mud geringwertig, der Wert des Bammes besteht hauptäichlich in reinem Harzporodukt. das in bedentenden Mengen in einem meichen, zähfliissigen Zustand alsfliesst, einen starken Tohlgernch rerbreitend, der sich mit der zunchmenden Terlä̈rtung verliert. Die Letzter' erlangt schon in wenigen Tagen ihren Abschluss mod das Harz ist damn spröde, durchsichtig. strohgelb und geruchlos.

Hänfig begnügen sich die Hawzsucht'l nicht mit den freiwilligen Auspmellungen, sondern verwunden die Bämme, namentlich in ine Knoter, wodurch Ansflüsse stattfunden. die wie fusslange ma handbreite Eiszapfen rom Baume hängen. I)ie Terwundungen wrorden ibrigons nu in gewissen Monaten gemacht, denn nicht das ganze Jahr hindureh ist das Hawz von gleicher frïte: in der einen Jahreszeit ist es heller wie in der andern.

f)as in den Handel gebrachte Dammax enthält nur spuren vom ätherischem Oel, ist leicht, spröde, brïthig. leicht löslicis in

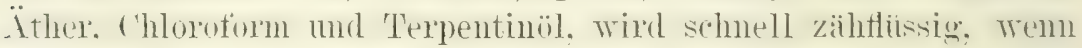

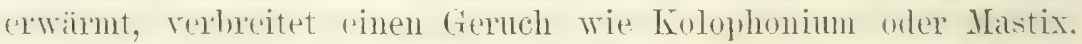

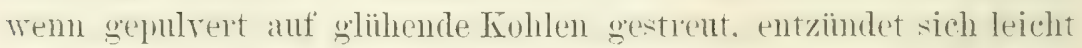

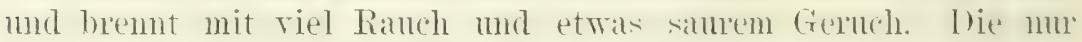
teilweise löslichkeit in Alkohol beweist, dass es nicht ats reintm Hal'z besteht. 


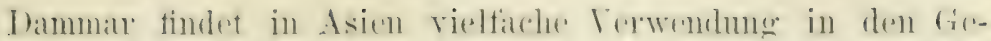

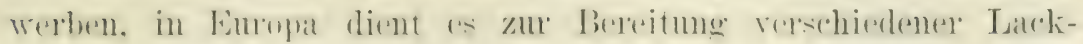

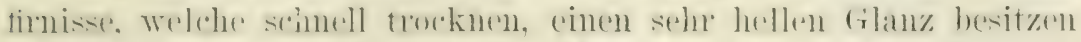

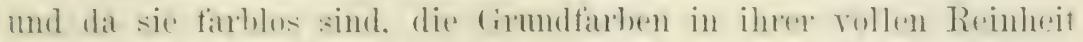

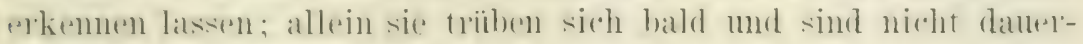

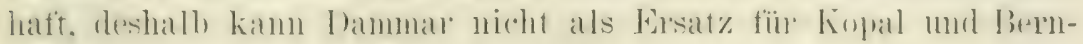
stein gelten.

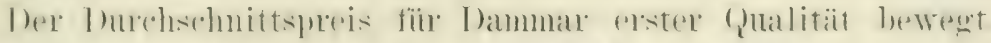
sich in Hamburg zwischen 1,75 bis 1,90 Mark pro Kg:

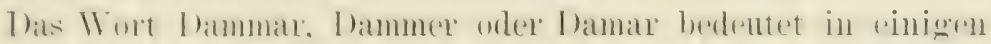
indisehen sprathen Hatz, und wird mit einer moterscheidenden

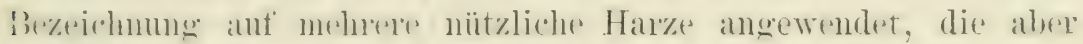

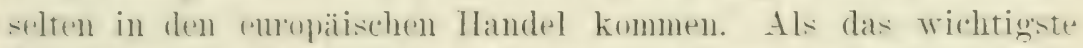
derselhen gilt das schwarge I)ammar. Welches nach Einigen das P'rudukt von Marignia acutifolia, nach Andern ron Canarium strictum ist. Kala-damar ist der Name für dieses Harz in Hindostan und Cantrium strictum ist in Indien heimisch. während Marignia acutifolia auf den Molukken rorkommt. Mahrscheinlich licfern die beiden bäume ein ganz ähnliches Produkt. Sichwarzes J)ammar ist ein sehr weiches, stark riechendes Har, das in 'Trocknen pine tief dunkle Farbe amimnt. É wird anstatt Pech gebraucht. liefert auch eine Art Terpentinöl. welche durch Destillation ansgeschieden wird. Ein den Copaivabalsam ähnliches Harz. einfach Damar genamnt, wird durch Einschnitte in den Stamm ron dem auf dem malarischen Arehipel heimischen canarium microcarym gewonnen. Fs ist ein zähthissiger, wohlriechender, gelh)licher stoff. der auf den schiffswerften zum Kalfatern bentzt wird. Termischt mit etwas Kreide oder Schilfrinde, wird el so hart wie Stein.

Ganz verschieden ron dem schwarzen ist das weisse Dammar (Sufod damar in Hindostan). zuweilen indischer Lóngal. Animé oder Piney damar genamnt, das Prodnkt von Tateria indica, ein glosiser zur Familie loipterateate gehörender Batm. Gewoment wird es durch Finschnitte in den Stamm. dom es klar, wohlofechend mol

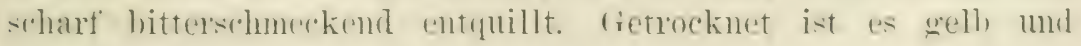
glasartig spröde.

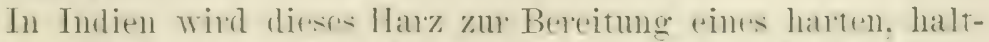

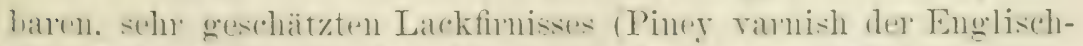
Indier) benutzt, aussoldem dient es in Malabar zur Fertigung ron 
Keryen, wethe ein klantes Licht mit weniw Ratuch geben und einen angenehmen Geruch verbreiten.

Sal-dammar wird in Indien ron dem seines Holzes wegen encechätzten rialbaum (shorea robusta) gewonnen. Das Felsendammar (Dammer batu der Malayen) stammt ron Hopea micranthat. Das ron Hopteil odorata, heimisch in IBima und Pegn, gewonnene Har\% wirl ebentalls Felsendammat genamnt. Einige wenige bekamnte Harze, die rorzugsweise im schiffbau rerwendet und ebenfalls Dammar oder I ammer genamnt werden, entstammen rerschiedenen Arten der Gattung Shorea.

\section{K a $11 \mathrm{ri}$.}

Dieser Harz ist dem echten Dammar nahe verwandt, sowohl hinsichtlich der Eigenschaften wie der botanischen Qnelle, wird es doch auf Grund dieser Ähnlichkeit zuweilen neuseeländisches Dammar genannt. Produziert wird es von der Kaurifichte (Dammara anstralis) die in Neuseeland, und nur auf der Tordinsel, heimisch ist, wo sie wegen ihres, besonder's für den Schiffbau geeigneten Holzes sehr geschätzt wird.

Dieser schüne Banm erreicht eine Höhe ron 40 Meter, seine in Wirteln stehenden Zweige sterben am untern Stamme ab, wie ('s bei der Rotfichte der Fall ist. Das Holz ist weiss, dicht. damerhaft und elastisch, für Masten steht es in den Augen der englischen Schiffsbaner merreicht da. Anf den Fidschis, den Hebriden und in Anstralien kommen andere Arten der Gattung I)ammara ror, deren Holz als Kamifichtenholz in den Handel kommt, dem newseeländischen an (Qualität aber nachsteht.

Alle diese Arten haben eine dunkele. dichte Belanbung und alle lieferm ein Harz, das Kamriharz, australischer Kopal und anstralisches oder neuseeländisches Dammar genant wird; loch wie das beste Holz. so produziert die neuseeländische Kamrifichte anch das beste IIar\%. Dasselbe bildet anch den weitalls grössten 'Teil des in den Handel kommenden Kauri.

Das nenserbindische Kanni kommt unter ähnlichen Verhältniscon Tor: wie dex ehte Kopal. Es wind nalse an den Wuzehn lebender Bämme getunden, ist damn weisslich mud wenig geschätzt. Ton viel höherem Werte ist das halbversteinerte Kami, welches in einer Tiete ron $1 / 2$ his 1 Iteter an Orten ansegraben wirl. wo friiher Kantitichten wucheen und zwar häutig in so grosesen 


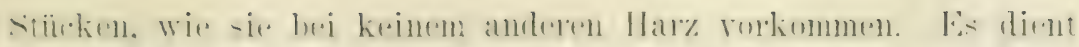

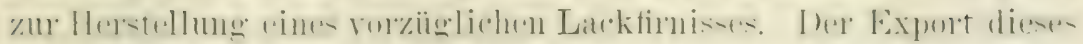

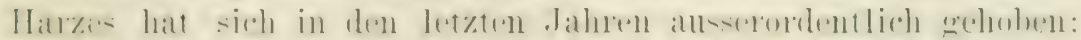
18.5) hetrog e. Werte ron 6400000 Mark.

\section{Mastix.}

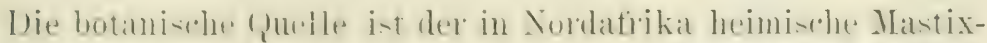

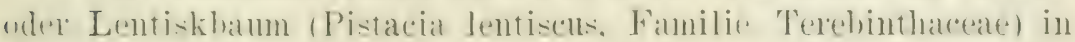

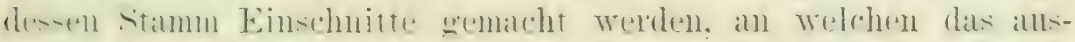

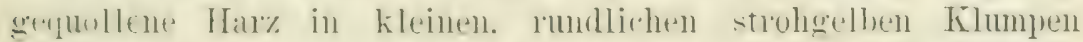

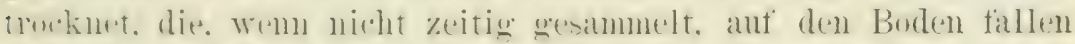

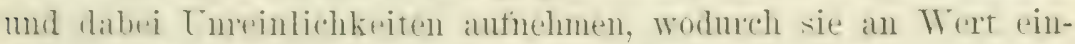
hiir-al. I) haluptsälohlichste Verwendumg dieses Harzes ist für

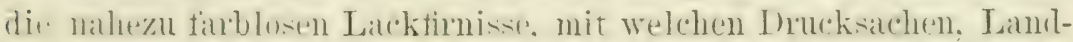
kilrten, \%eichnungen u. \&. w. ïberstrichen werden. Zuweilen benut\%'n es die Zahnärzte zum Füllen ron hohlen Zähnen.

ber erösste Teeil des in den Handel kommenden Mastix wird an der Kïiste von Marokko gesammelt.

\section{ว. Storax.}

Diespes von dene alten Römern als styrax geschätzte Harz futstammt dem im Morgenland heinischen. vorzugsweise anf der lusel ('hios kultivierten. 5 his o Meter hohen Storaxbaum istrax ufticinaliss. II ird die Rinde verwundet. quillt das Hayz alls und velhibtur an der Lutt. In zwei Formen wird es in den Handel

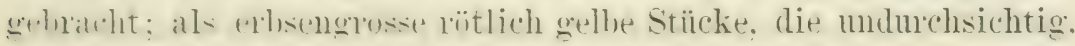

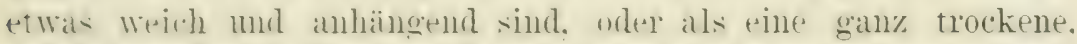

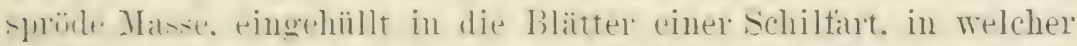

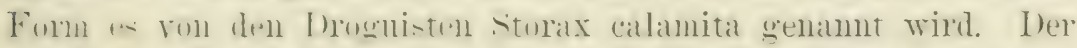
Sturax duftet angenehne schmerkt aromatisch. wirkt amegend

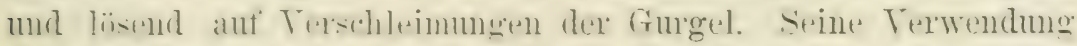

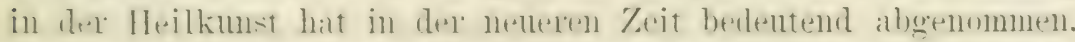

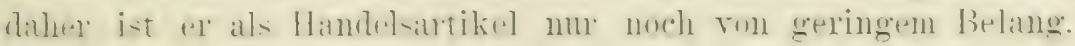

\section{1). St a ll d a ra k.}

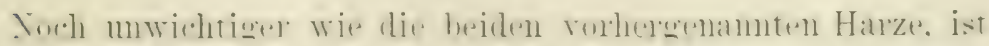

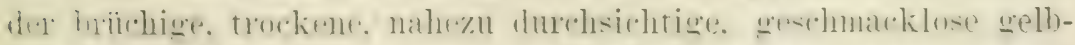

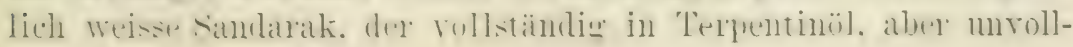




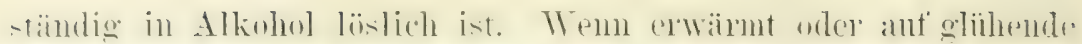
kohlen gestrent. strönt ex einen angenehmen balsamisehen fieluch

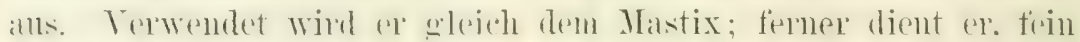
julverisirt. zum Bestrenen radierter Stellen in Briefen mol Büchern, anf welche dam wieder geschieben werden kam. Nordatrika rxportiert wong Sandarak, was wohl nicht allein dureh die

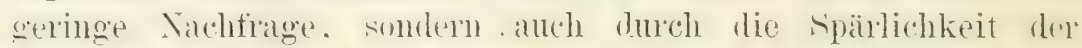
Jutanischen Quelle zu eklären ist. Dex zu den Nadelhölzerlu gehörende sandarakbaum (callitris quadrivalvis) liefert nämlich ein stark wohlriechendes. ansseroudentlich danerhaftes. wertrolles Hol\%, daher lassen ihn die an Mälderverwüstung gewöhnten Finscoborenen nicht zahlreich werden. In Gegenden. wo das Kilina dem nordafrikanischen ähnlich ist, diufte sich der Sandarakbaun. aboesehen ron seiner Harzproduktion. als eine wertrolle Einfiilhrung für die Forstkultur erweisen.

\section{Benzoin.}

Renjamingummi ist ein im englischen Handel häutio wohranchter Name für dieses mohlriechende Harz, dessen botanische (unelle Styrax benzoin oder Lithocarpus benzoin. Familie Styracear. ist. Dieser in Siam, Borneo, Jara, Sumatra und anderen malarirchen Inseln heimische Baum erreicht eine betrïchtliche Grös-e. reine jungen 7 weige sind mit einem weisslich-lostigen Flaum bedeckt, ebenso die unteren seiten seiner länglich und zugespitzten Blätter.

Fs gab eine Zeit, no irrtïmlich angenommen wurde. Benzoin -ei das Produkt ron Benzoin odoriferum. friiher Laums benzoin. Familie Lantacea, ein in Tirginien heimischer 3 bis 4 ILeter Inher strauch mit grossen, etwas keilfürmigen Blätterm, der noch jetzt in Sordamerika Benzoin- oder Benjaminbamm, anch Crewiirzund Fieberstrauch, genannt wird. seine sehr aromatiche Rinde wirkt tonisch. gleiche Eigenschaften hesitzen die Beeren und beide Werden eregen das Wechelfieber angervendet. Eine Abkochung der Zweige gilt als. Wurmmittel.

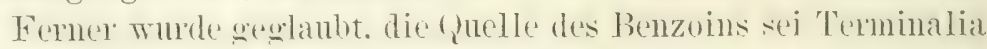
henzoin, Familie combetaceac. heimisch in Mauritins. Iler milehige Saft diens Banmes trocknet zu Hallz ein, dats wohl dem Benzoin ahnlich ist. es aber nicht esotzen kam. In den Firchen jener Insel dient es als Weihranch. 


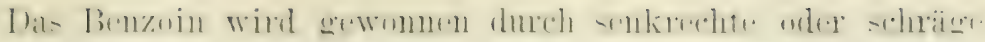

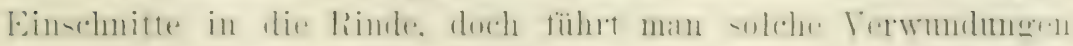

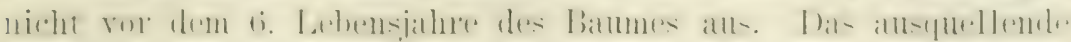

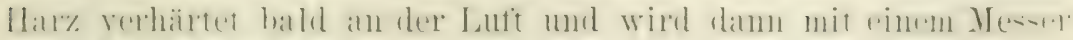

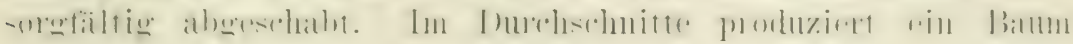
jïhlich $1^{1 /}$. Kölogramm benzoin fül 10 bis 12 . Tahre.

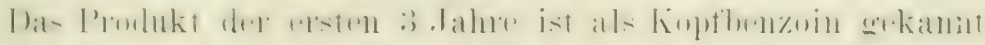

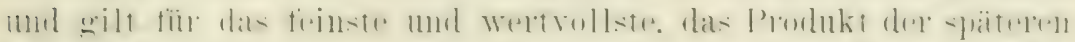

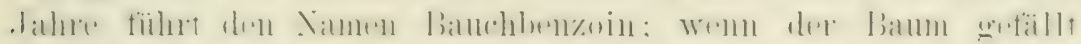

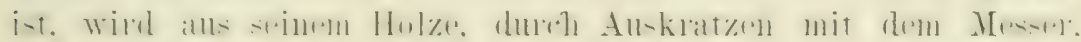

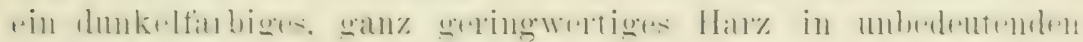
Mengen gewonnen, das Fussbenzoin genannt wird.

Im Handel wird Siam- und Sumatrabenzoin mnterschieden

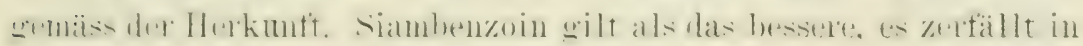

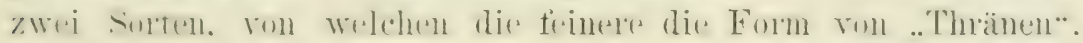

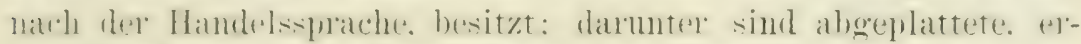

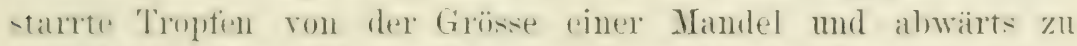

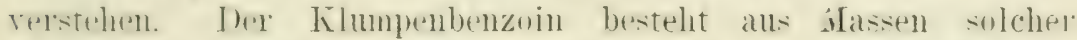

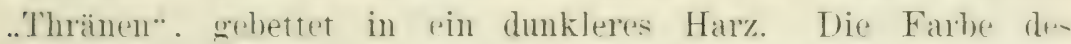

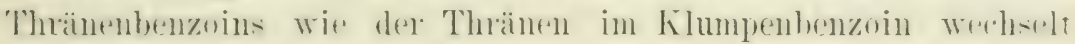
von hellgelb zu rotbraun.

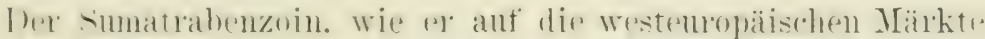

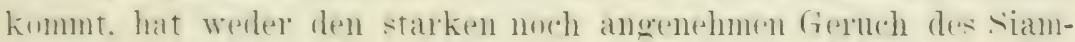

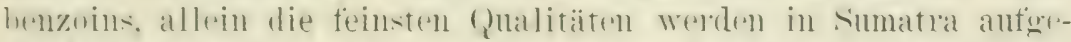

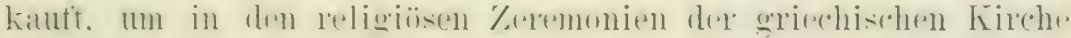

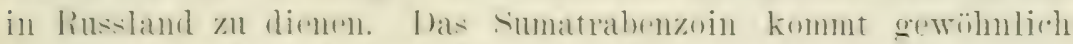

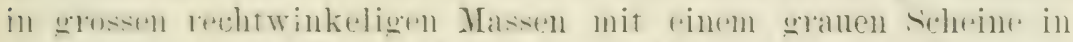

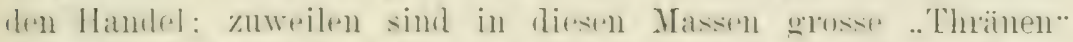

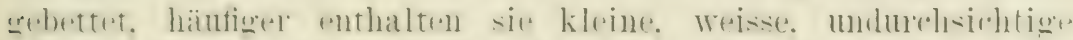

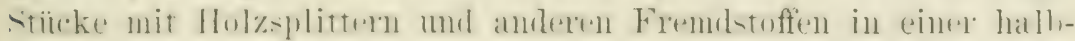
durchsichtigen Hülle.

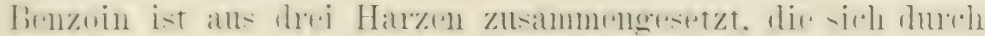

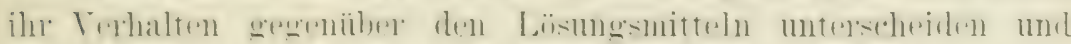

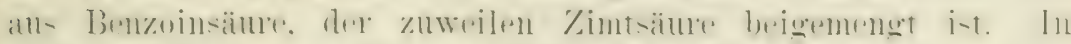

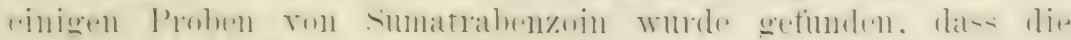

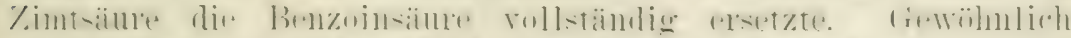

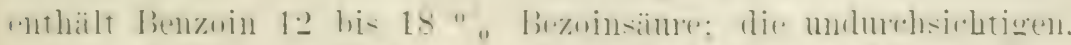

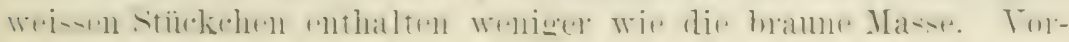


handen sind anch spuren ron sehr aromatischen ätherisehen (̈)en. mamentlich von struol. das anch dem Storax seinen Wohlgeruch rerleiht.

Sumatral exportiert in Enuchichnitt 800000 Kilogramm Benzoin jührlich. Siam nur 22500 Kilogramm. doch ist in Betracht zu ziehen. dass ganz hedentende Jengen dieses Artikels bei den religiösen Zetemonien im sïllichen und üsthehen Asien verbrancht werden. vomustweise zu demselben Zwecke wird er nach Europat exportiert. In rer Heilkmst findet Benzoin selten Terwendung. ansgenommen zum Exweichen ron Geschwïren und zum luftdichten Vershluss als Firnisiiberzug ron zusammengehefteten Tunden. Tiesm Zwecke dient es gewöhnlich unter dem Namen Wundhal-am. Jünchsbalsam oder .Tesuitentropfen - ein Heilmittel, einfach bereitet, indem Benzoin 2 Tochen in gereinigtem spiritus ringereicht wird. Tie alsdam durchgeseihte Lösung bildet den genamnten Balsam.

\section{Guajak.}

Ler in Zentralamelika und Testindien heimische dumke]belaubte. immeroühe Batm. der am bekamtesten monter den Namen Pockholzham mo Lignm vitae ist mol an einer anderen Stelle diests Buches pingehmolere Erwähnumg findet, produziert ein Holz. das so stark mit Halrz (lurrhtränkt ist (etwa 26" ${ }_{0}$ ). dass es weder Ira-ele now (i) ammimmt und in mabsehbarer Zeit nicht rerwest. Dex splint ist harzfiei und gelblich. das Herzholz grünlichshwarhamm: das Letztere ist das schwerste aller bekamnten Hoil\%t. das speritioche Gewicht beträgt 1.33:3. Es ist so ausserordentlich hart. das- es kaum zu spalten ist. es bricht auseinander wite Glax oder stein. Lie Rinde ist hart und spröde. aus ihr "puillt fieiwillig das Harz in sehr reinen ,Thränen." Es wird

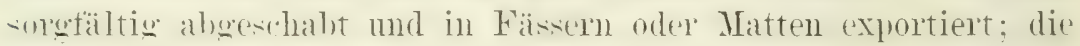
"lsteren halten zwischen 50 his 200 Kiloglamm. die letzteren in der Regel nicht mehr wie 50 Kilogramm.

Tn der Farhe werhselt dieses Harz beträchtlich. teils ist es brämlich. teils rötlich oder griulich. stets aber wird es grün. wemn es im Freien dem Licht ausgesetzt ist. Es besitzt einen grewisen Grad ron Durchsichtigkeit und bricht mit einem glasartigen Bruch. Wenn gepulvert. strömt es einen angenehmen bal- 


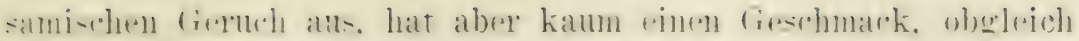

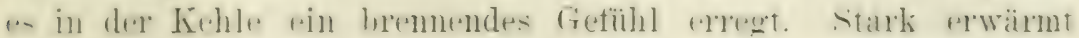

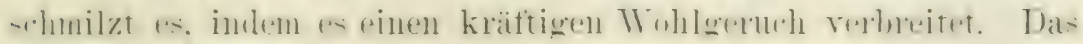
spezifische Gewicht ist 1,229.

In Form ron lonlrer. Pillon mul 'linkturen wird diest: Hatr. in der Hrilkunst gegen schleichende. Hautkrankheiten. Rhema-

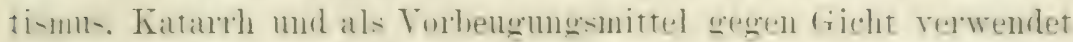

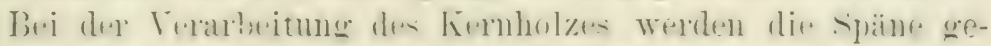

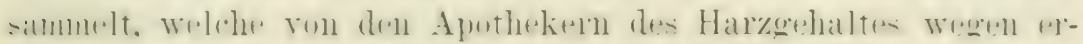
worken werden.

\section{Gllmmilack.}

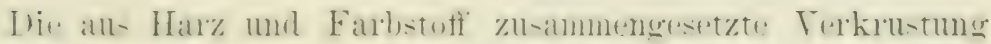

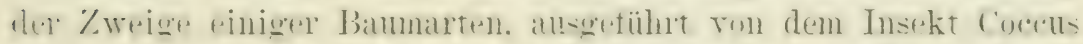
litwa, wird in Indien Lakh (Lakicha in Samskrit. Lakh im Hindu-tani, gethannt. eine Bezeichnung. welche mit dem Zahlwort

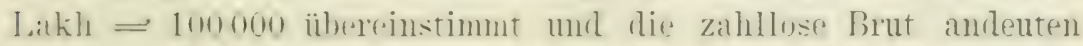
-ull. welche jede feneration diese ln-ekt- hinterlaset.

coceus lated ist nahe rewandt mit dem Cochenilleinsekt

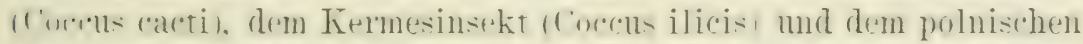

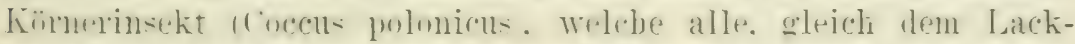

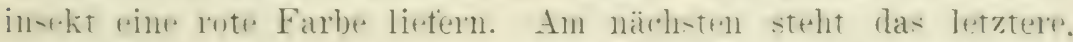

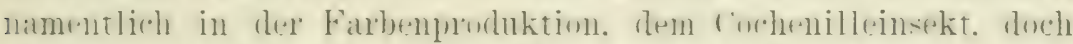

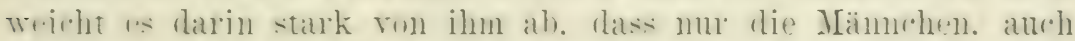

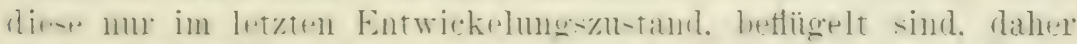

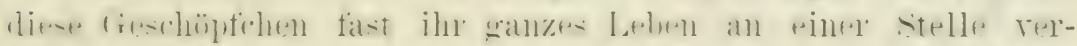

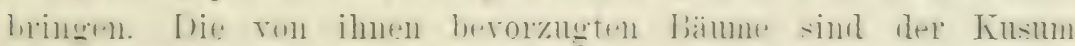

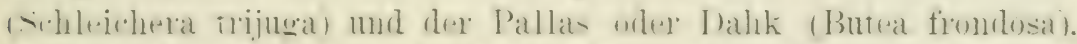

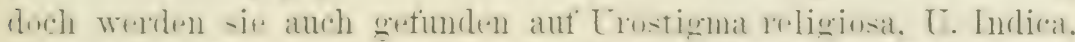

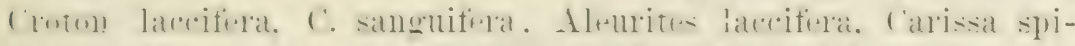

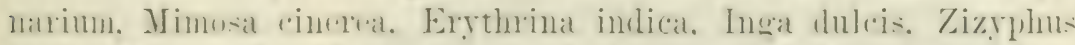

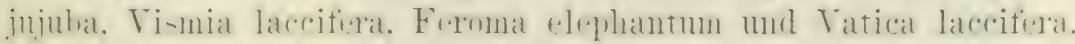

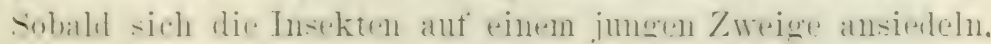

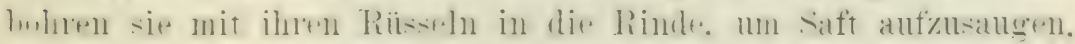

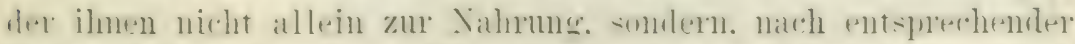

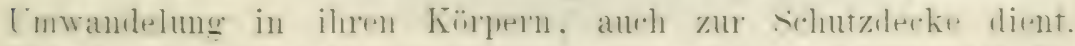

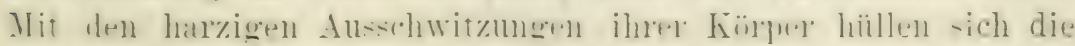

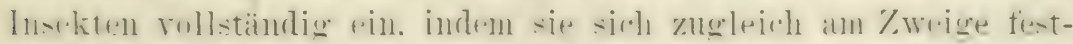

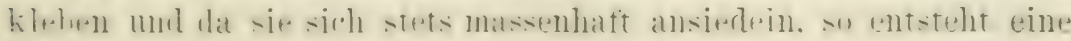


dicke, latute Kinste ans zusammenhängenden Zellen. Ans diesent selbstgeschaffenen (ivabe entweichen die Weibchen niemals. Jirselben machen die Masse der Ansiedelung, denn anf etwa somo

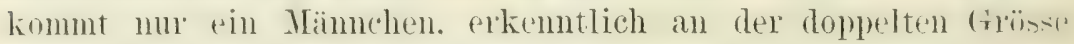
und an den Flügeln, wenn sein Lebensende naht.

Zwei Generationen rrscheinen jährlich, anfangs .Juli und anfangs Dezember. Etwa :) Monate nach der Ansiedelung tindet die Begattung statt. nach welcher sich die Mänmchen befieien. während die Weibchen eine Gestalt ammehmen, die in einem länglichen. glatten, glänzenden, cammoisinroten Sack besteht. allwelchem ein Riissel hervorragt, der in die Rincle fühn't. Wrm die Teibchen Eier gelegt haben, sterben sie, in kurzer Zeit tritt die junge Brut ins Leben und frisst sich durch die Zellen einen Ausweg ins Freie. Ausserordentlich klein und zahllos wif sit ist, hat sie bei ihrem Ausschwärmen den Anschein von blutrotem Staub. Emsig snchen die jungen Tierchen nach weichen Zweigen. um sich in der erwähnten Teise für die Daner ihres Leben: anzusiedeln.

Wie ihre Terwandten, die Cochenilleinsekten, werden auch die Lackinsekten einer Zucht unterworfen, die allerdings sehr einfach ist. Kurz ror der Ausbrïtung der Eier wird eine Ansiedelung mit dem Zweige abgeschnitten und als sogenannter Samen in die Krone eines anderen Bammes gebunden, welchen die junge Brut willig als ihre Wohnung betrachtet. Ausserdem erstrerkt sich die Kultur daranf, dass nicht alle Ansiedelungen ror dem Ausschliipfen der Brut geerntet rerden. Seit die indische For'stverwaltung ins Leben trat, hat sie der Lackinsektenkultur eine eingehende Anfmerksamkeit zugewendet. gewäht inr diesclbe dow recht ansehnliche Einkünfte.

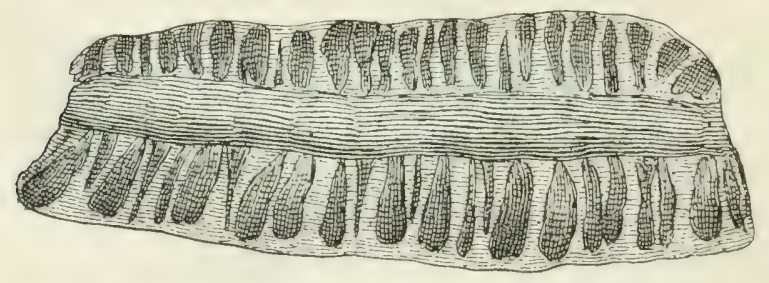

Figur 56 a.

Die Fig'uren 56 a und $56 \mathrm{~b}$ helfen die Wohnung und die Erscheinmo des Lackinsekts rerständlichmachen. Figur a zeigt den Längsschnitt eines Stiicks Stocklack in natürlicher Gröse. Tir. ersichtlich. ist die Verkmstung mit länglichen Zwlen gefüllt. 


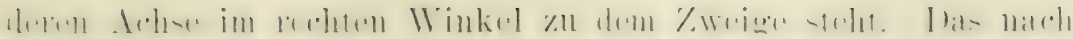

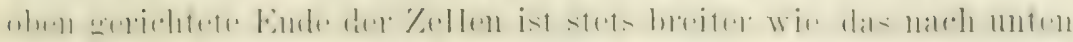

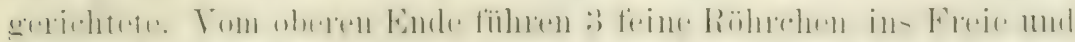

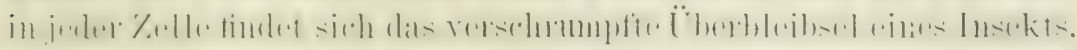

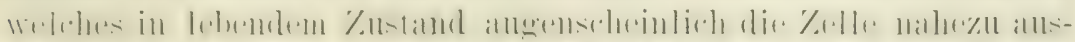

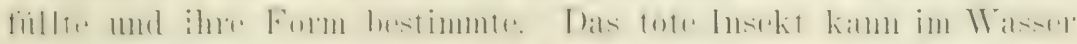
zum grestellt werden; so wird es in Figm b, etwas rergrössert, reranschanlicht. Fïsse sind nicht vorhanden: am hinteren Kör'perende sind auf dem Bilde mu 2 hervorragende Drüsen sichtbar, in Wirklichkeit sind :' rorhanden. Die grö̈sste derselben bildet gewissermassen cinen Schwanzstumpf, sie ist mit 10 Haaren besetzt und vieltich durchlöchert, wahrscheinlich dient sie zum Atmen,

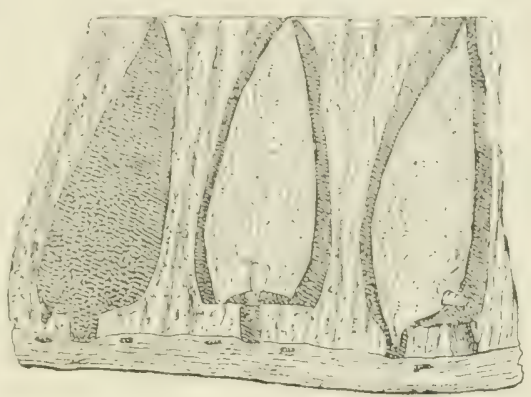

Figrur $56 \mathrm{~h}$.

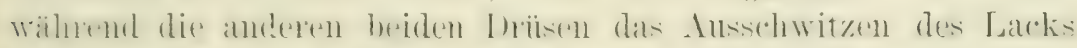

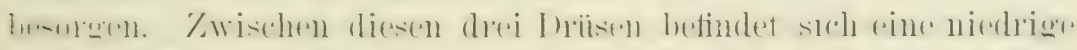

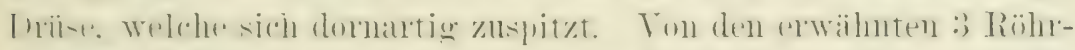

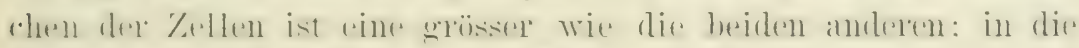

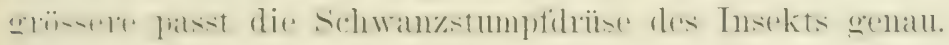

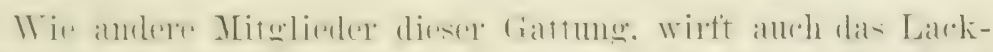

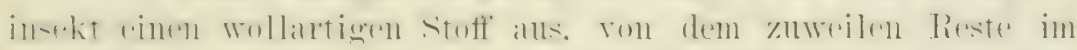

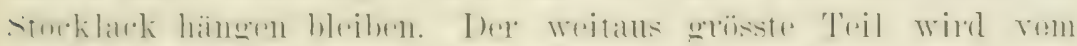
Tinde weggerveht.

Einfach wie die Zucht, ist auch die Emte. Die Zweige mit

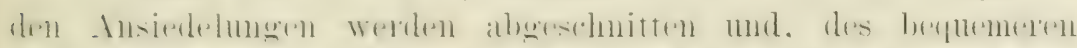

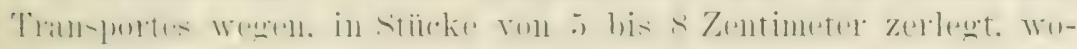
durch ïbrigens Verlust durch Abfall entstehen soll.

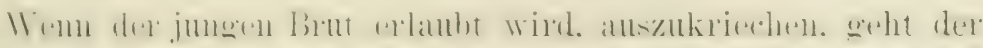

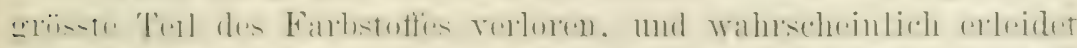

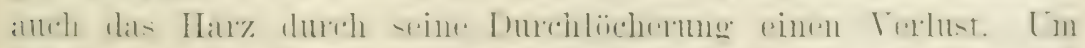

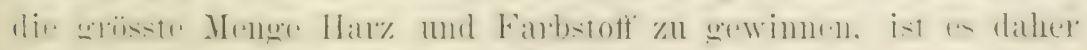

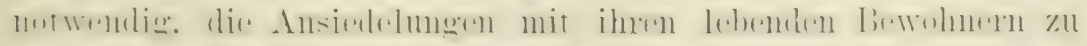
ernten; das geschieht im Juni und Tovember. 
1)ie Finte, wie sie von den Bämen kommt, wind stocklack grenamut. Im Durehsehnitt enthailt sie 68\%" Harz, 10\% Farbstoff (Late dye) und $6^{0 /}$ "eines wachsigen Stoftes. Das Harz ist ein zusammengesetzter Körper. dessen Bestandteile sich den Lüsmg:mitteln gegenuiber verschieden verhalten.

Die Güte des Stocklacks wird nach seiner Dicke beurteilt. zuweilen bildet er eine $1^{1 / 4}$ \%entimeter dicke Firuste rund um der Zweig, und nach seiner Farbe, die tiefrot sein und gegen das Licht gehalten. lebhaft lenchten soll. Wem er nach dem Ausschliipten dex Brut gesammelt wurde, ist er löcherig und tahl, der Farhstoffgehalt ist unbedeutend.

Die Preise dieses Artikels bewegten sich anfangs 1857 ant dem Hamburger Markte zrischen 77 und 80 Pfg. pro Kö.

Stocklack kommt in geringen Mengen zum Export, der gräiste Teil wird in Indien zu Schellack umgewandelt. Das geschieht von Fabrikanten, welche das Rohmaterial ron der Forstverwaltung oder ron den in den Waldgebieten unherreisenden Händlern aufkaufen. Der Stocklack geht zunächst durch zwei kräftige Walzen, welche durch eine einfache Vorrichtung enger und weiter gestellt werden können. Der zorknirschte stoff wird gesiebt, um den Lack von dem Holz zu trennen. I) Erstere wird in grosse. mit Wasser halbgefüllte Bütten gehracht, wo er von Mämnern und Franen gewaschen wird. Dieselben stehen in der Bütte, halten sich mit ihren Händen an еiner äber ihnen herlanfenden stange und stampfen abwechselnd mit Zehen und Fersen, bis nach mehrmaligen Wasserwechsel die Flïssigkeit klar hleibt. Die rorher abgelassenen Wassermengen werden geseiht und in ein grosses Fass gebracht, um einige Zeit ruhig zu stehen. Tnterdessen setzt sich der Tiederschlag anf den Boden: sobald sich dieser Torgang vollzogen hat. wird die Flïssigkeit abgelassen und der Viederschlag noch einigemal mit klarem Wasser an-gewaschen und, wenn halbtrocken, unter eine Presse gebracht. Im zu kleinen, viereckigen, haten, dunkelpurpurroten Kuchen mit der Handelsmarke des Fabrikanten geformt zu werden. Diese Kuchen kommen als Ladclye (Lackfarbe) in den Handel. Der Fartstotio, welcher durch diese Answaschmgen gewommen wird, sollen rle Körper der Insekten. nicht besondere Aussehwitzungen sein.

Die Auswaschung des Stocklacks kann in kaltem odel warmem Wasser, anch in einer schwachen alkalinischen Lüsung 


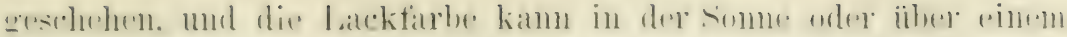

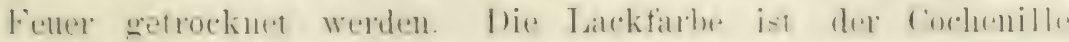

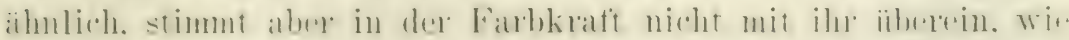

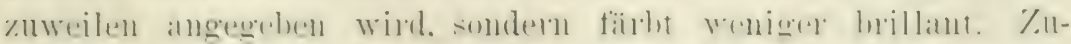

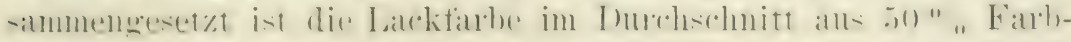

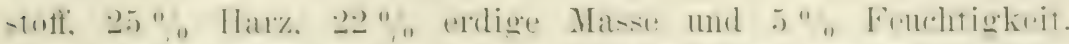

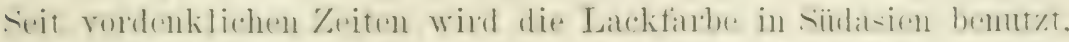

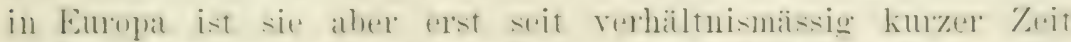

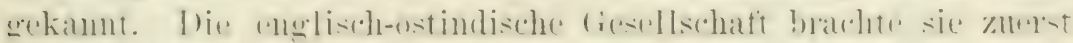
als Ersat\% für die cochenille ant die enropäischen Mäkte.

In nevester Zeit lat die Lackfarbe eine sehr geringe Be-

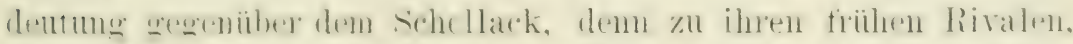

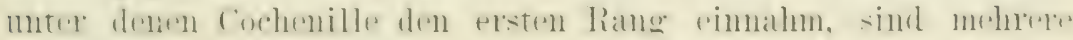

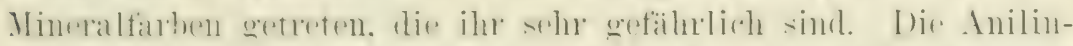

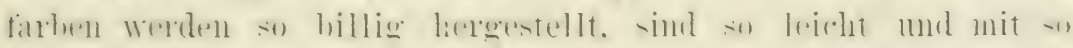

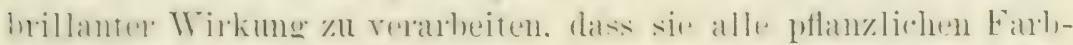

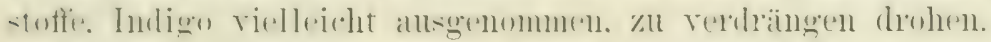

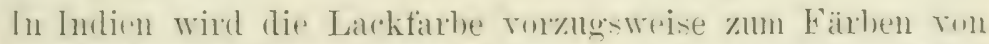

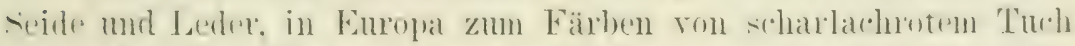

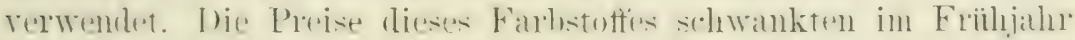
1857 anf dem Hamburerer Markt zwischen 0.5) und 1 Mark

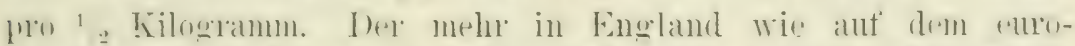

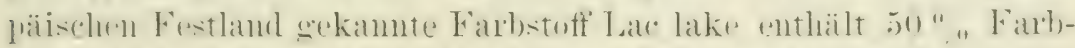

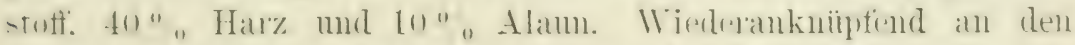

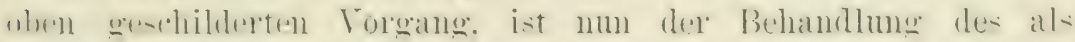

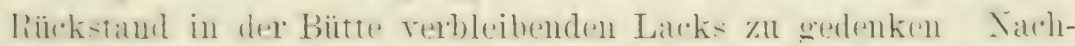
dem dereelhe obertlathlich getrocknet ist. wird er in crlinderische

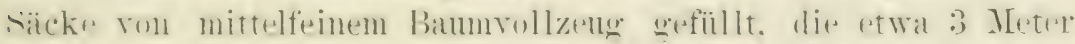

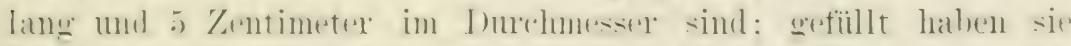

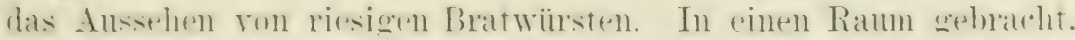

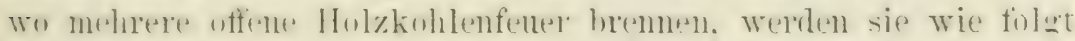

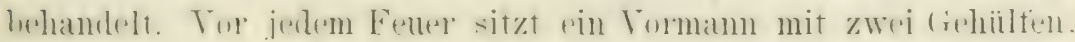

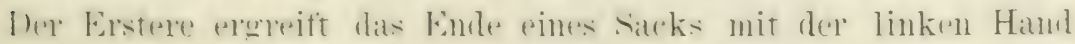
und dreht es langsam in nächster Nähe des Feners. zu

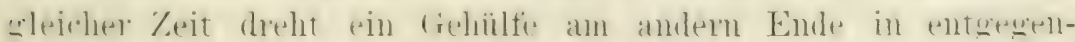

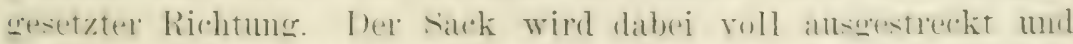

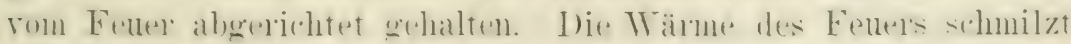

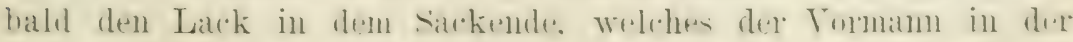




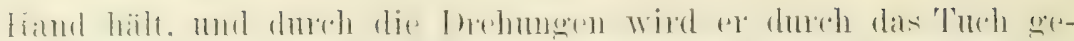

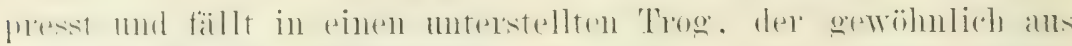
r.inem blatte dere amerikanischen deave Agare americanal besteht

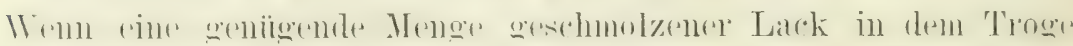

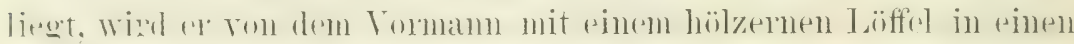

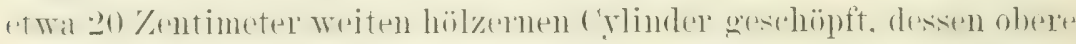

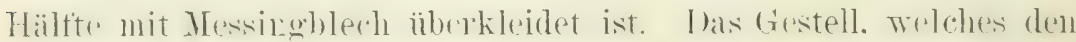

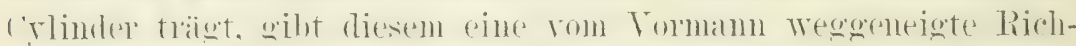

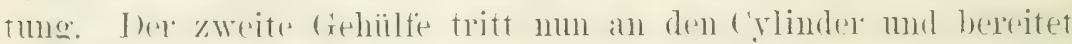

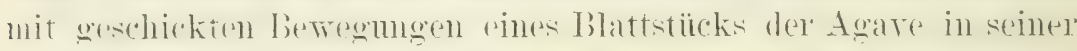

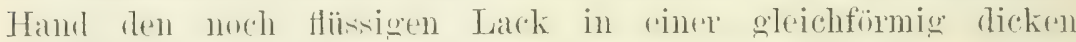

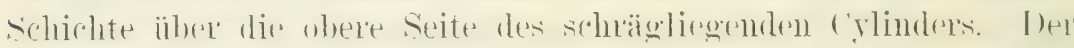

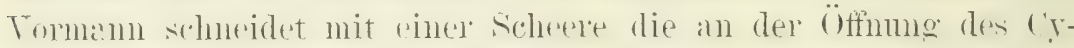

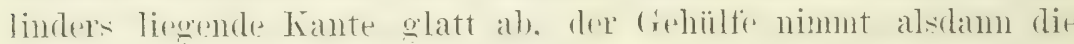
schicht mit bediln Hänlen anf. schwenkt sie einige Angenhlicke

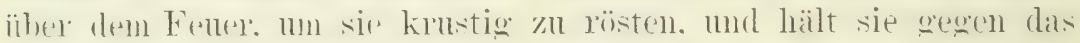

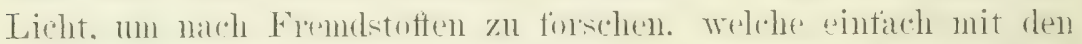

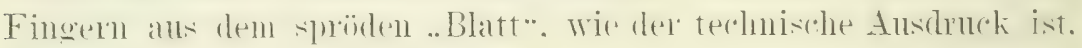

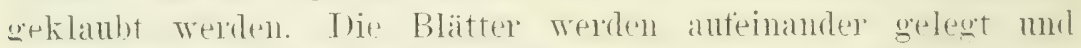

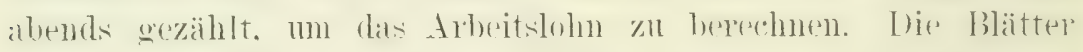
werden in Kisten gepackt. in werehen sit in riele Bruchetïcke: zerfallen. Weln sie starken Presumgen oder Erschïttelungen alls-

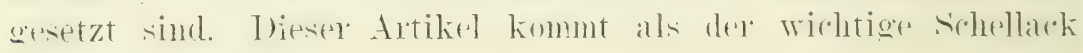
anf dell Markt.

Nicht immer fällt der durch die Säcke gepresste Lack aut'

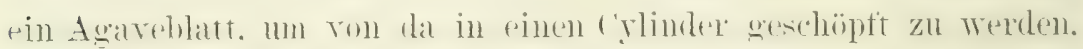

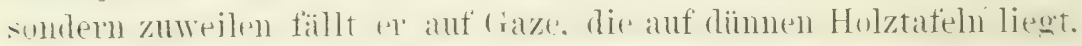

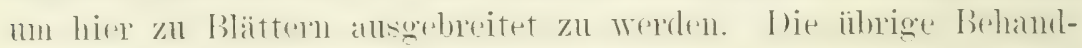
lung ist nicht abweichend.

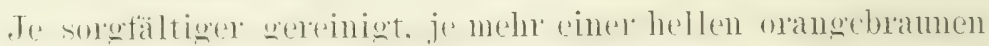

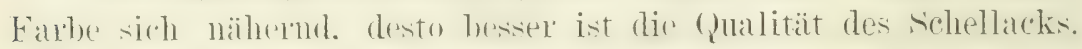

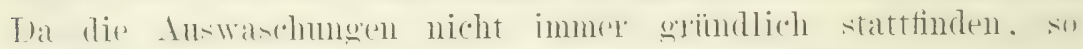
Kommen verschiedene Farbensehattierungen ant den Markt. dir.

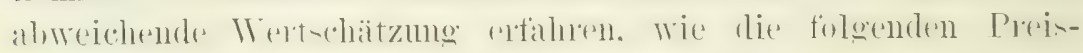

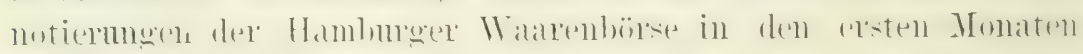
von 1887 zeigen :

Schellack, blut-, kirschroth und rubin 1 bis 1,12 Mark pro Külogramm.

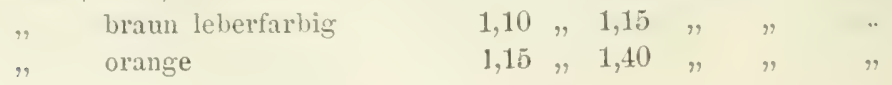




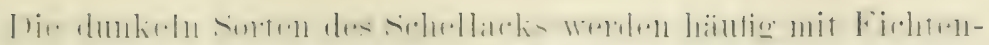

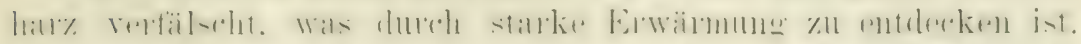

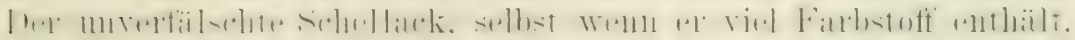

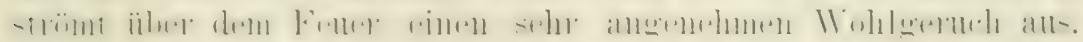
nicht so rer mit Fichtenhar\% verfälschte.

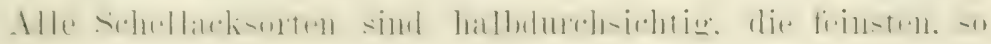
diimn wie schreilpapier, sind sogar durchsichtig.

Der Schellack kamn gebleicht werden, indem man ihn in

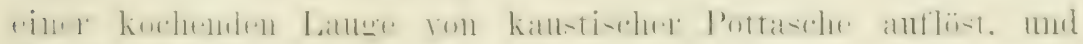

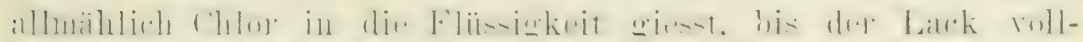

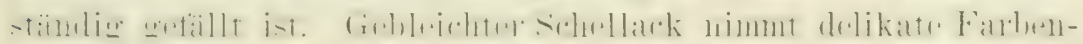

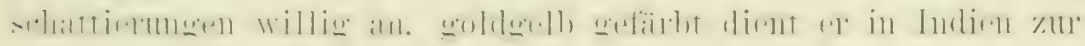
Anfertigung ron Schmucksachen verschiedener Art.

In Eniopa und Tordamerika dient der Schellack rorzugs-

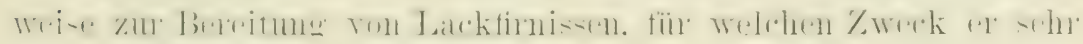
wertroll ist, weil el sich leicht lüst und einen glatten, harten

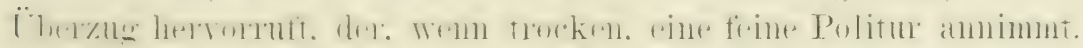

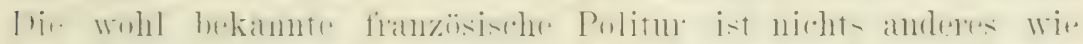

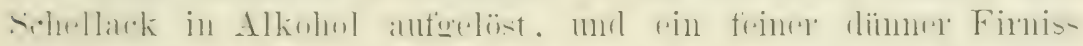

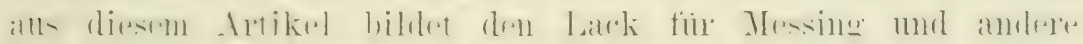

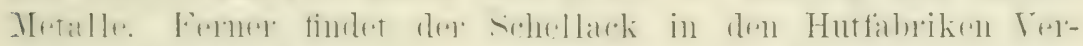

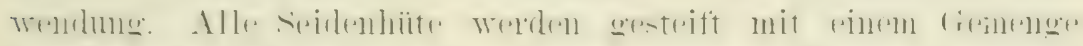

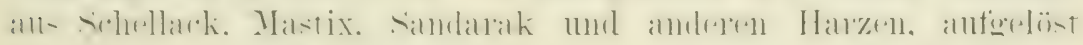
in Alkohol oder Japhtha. Der Rand wird stets mit diesem

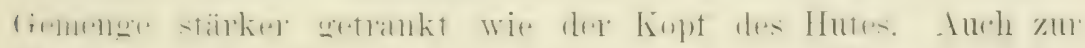

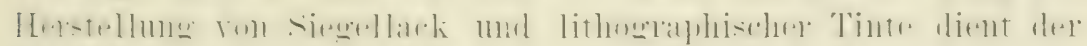
schellack.

Nicht im deutschen, aber im englischen Handel wird ron

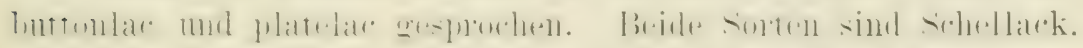

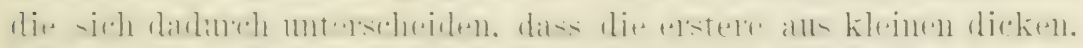

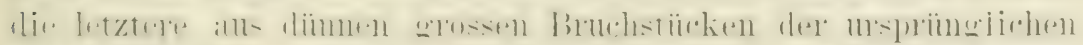

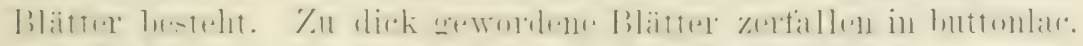

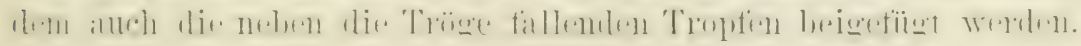

Samenlack, ron dem selten im Handel die Rede ist, wird

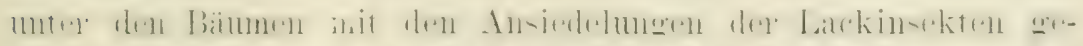

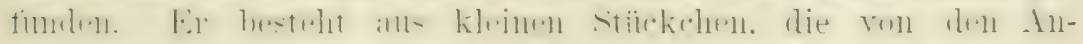

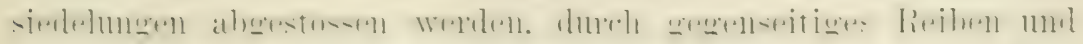
Schlagen der Äste während eines Windes. 
Die wichtigsten Prouluktomsgentete des Latcks simd L-sam. liengalen und die Zentralprovinzen von Tndien. Die nordwestlichen Provinzen spielen in dieser Hinsicht eine mbedentendo Lolle. Madras. Bombay. Sind mod das P'mjab lioferon ms mäsiget Jengen. Einige tegenden in Birma sind anserordentlich reich an diesem Produkt. ('hina. Sian. Ceylon mol singe Inseln des malavischen Archipels bringen ebenfalls Lack in den Handel. rehr geschätzt ist der Lack rom riam. Als der beste indische Lack gilt der ron Assam und Birma.

Nicht in allen Produktionsländern wird der Ansbente gleiche Anfmerksamkeit geschenkt. In Hinterindien befinden sich Mïlder mit reichen Iackrorräten, die unberiihrt bleiben. weil die Fumrurte schwer zugänglich und der 'Transport nach den Handelsplätzen zu kostspielig ist.

Fast der ganze Lackexport Indiens geht iiber (alcutta. Ilie Produktion, soweit sie nicht dem heimischen Terhature dient, creht nach, jenem Hafen, 10 zum weitaus grössten Teile nach Fugland und Noldamerika verschiftt zu werden. In nellester 7. it hat sich Birma ron ('alcutta mabhängige zu machen gestleht mur dilekt exportiert.

Die Ansfuhr des indischen Reiches an den rerschiedenen Lacksorten beträgt geconwärtig ewa 1500000 Kilogramm und an Lackfarbe 410000 Kilogramm. Der Ausuhrwert der beiden Artikel beträgt zwischen 10 un- 12 Millionen Mark.

\section{E $l+m$ i}

Dieser nentere Name ist wahrschemlin.h. sleich dem iilteren: Animé ron Enhaemon herzuleiten. der Bezeichnmg dines Hнilmittels, von dem Plinius sagt. es enthalte Thränen und schwitze ans dem Olivenbaum Arabiens.

Enter Elemi, ohne unterscheidenden Zunamen, wird las Harz verstanden. welches anch Einschnitte in die Rinde einer auf den Philippinen heimisehen Art der Gattung Canarium gewomen wird. ron weldher Flïckiger und Hanbury meinen. sie wi wahrscheinlich ïbereinstimmend mit Boswellia frereana, ein Baum. welcher in der Xähe ron Bunder Marayali, Westlich vom Kalp Gardafin, vorkommt.

Elemi ist ein weiches. halbdurchsichtiges. klfhendes Har\% ron körniger Beschaftenheit und fenchelähnlichem fieruch. In 


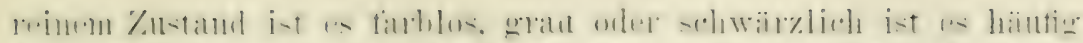

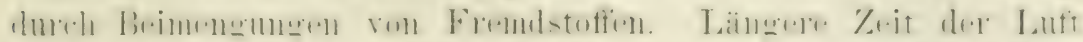

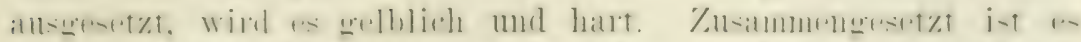

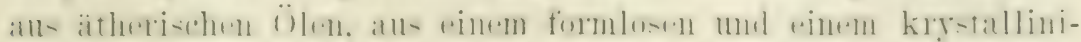

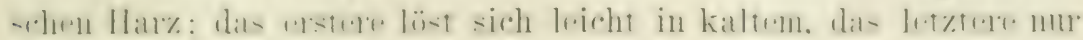
in warmem Alkohol.

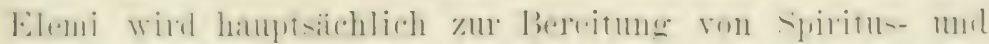

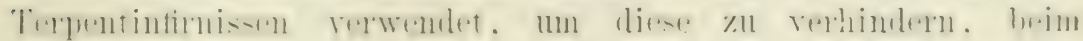
'llockmen rissig zu werden. Ais amegende salbe hat es im

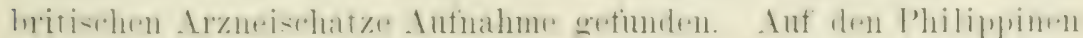

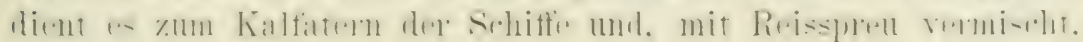
zil Fackeln.

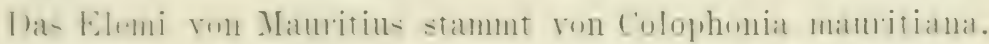

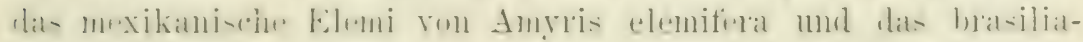
nische Elemi ron verschiedenen Arten der Gattung Icica.

\section{Ba lsa me.}

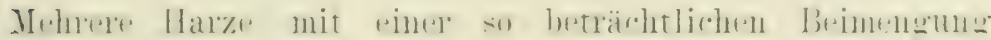

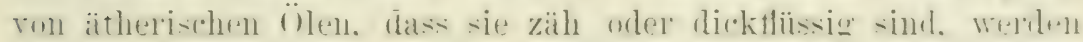

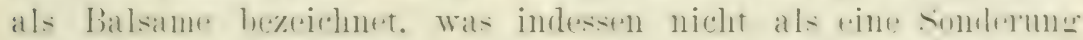

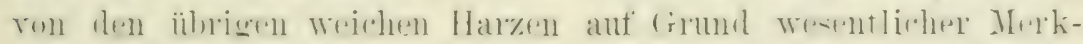

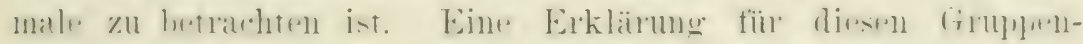

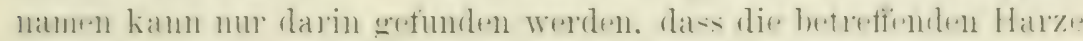
mehr wie andere in der Heilkunst Verwendung finden.

Dem Balsam von Peru pflegt man den elsten Rang in

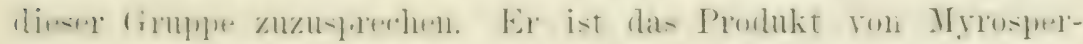

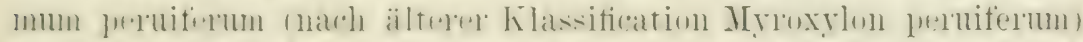

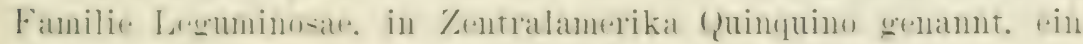

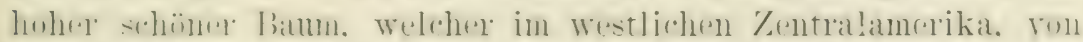

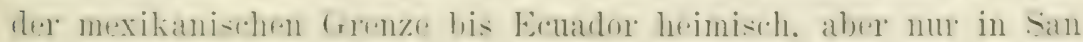

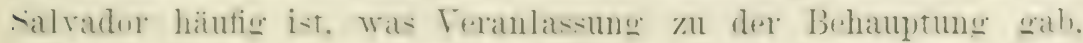

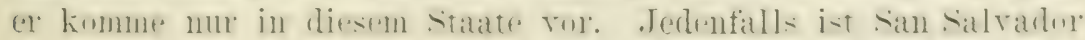

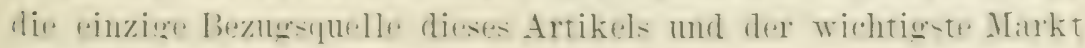
ist der Kïistenplatz Sonsonate.

Im Handel wird weisser und schwarzer Balsam von Peru

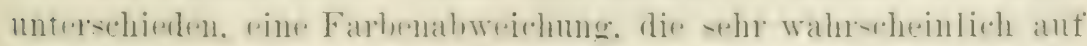

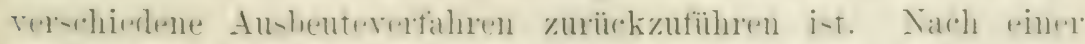

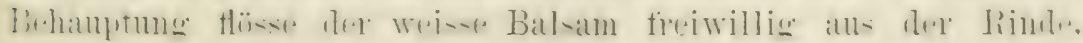




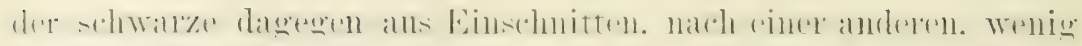

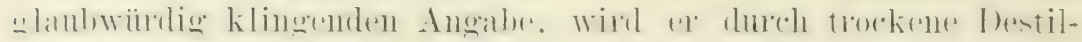
lation und dureh Abkochung des Holzes gewonnen. Es ist

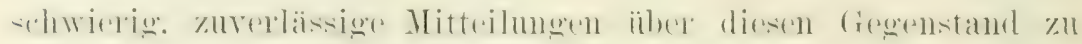

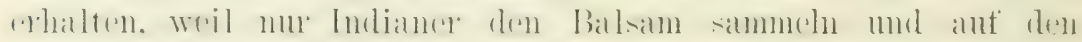

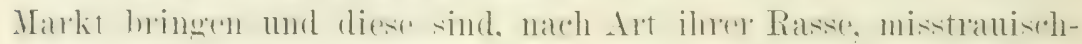

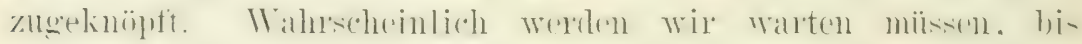

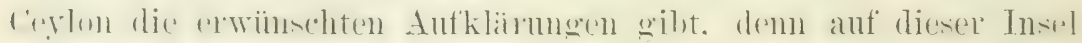

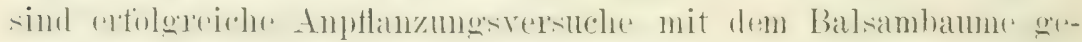

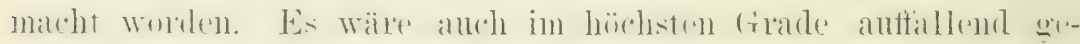

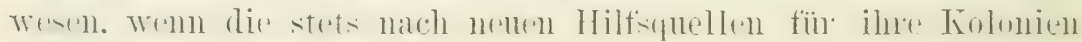

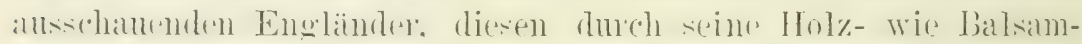

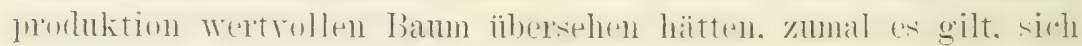
ton einem IIonopol mnabhängig zu machen.

Der weisse Balsam von Peru ist anfänglich von der Dichte

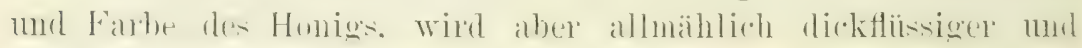
geht ins Gelbbrame über.

Der schwarze Balsam von Peru ist rötlich- bis schwärzlich-

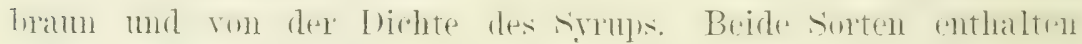
Zimtsäure bis zul $46 \%$. Harz 30 bis $35 \%$ und ein öl, das

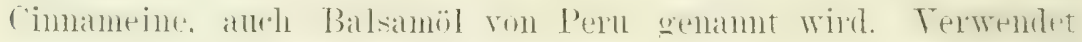
wird dieser Balsam zam Parfürmieren vom Comditorwatren und in dep Heilkunst imnerlich und ätsstrlich als anregendes Mittel.

Der Balsam ron 'Toln entstammt einer anderen Art der

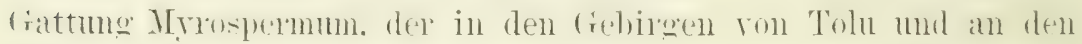

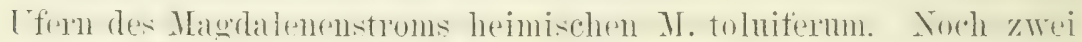
Arten: M. punctatum und M. pebuscens sollen diesen Artikel liefern. duch sind dariiber noch zuverläsigere Mitteilumgen abzu-

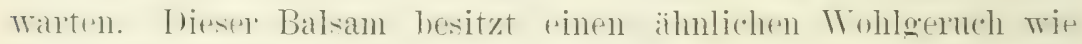

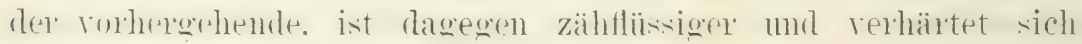

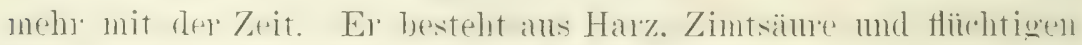

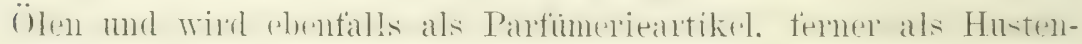
syrup verwendet.

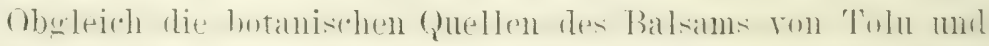

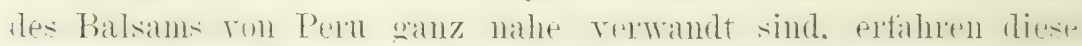
heiden Artikel doch eine sehr abweichende Wextechitzung. Wi.

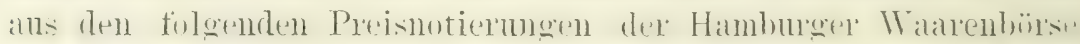

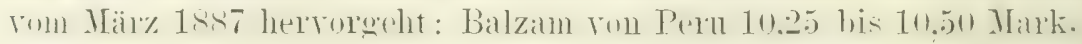
Balsam von Tolu 3,20 bis 3,40 Mark pro Kilogramm. 


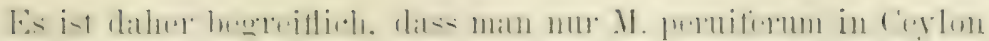

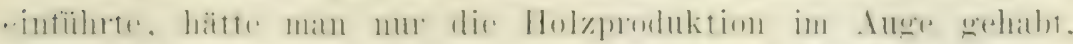

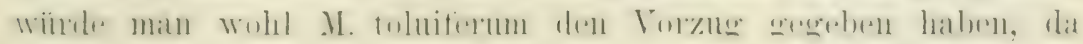

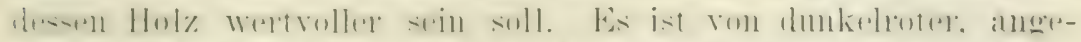

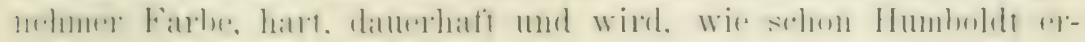
wiilnt. in Columbia vielfach zu Banzwecken verwendet.

Liquidambarbalsam stammt von dem in Kileinasien hei-

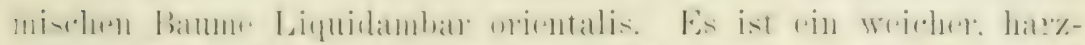

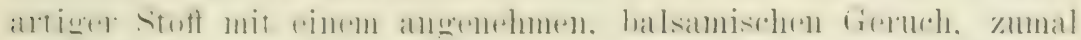

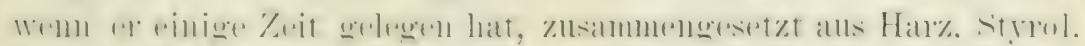
strlatein. Kom:

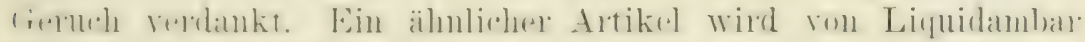

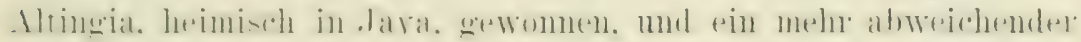

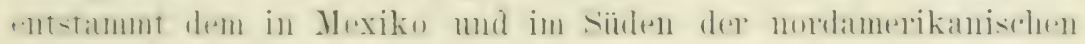
Union heimischen Baume Liquidambar styraciflua.

Gileadbalsam oder Mekkabalsam ist das Produkt ron

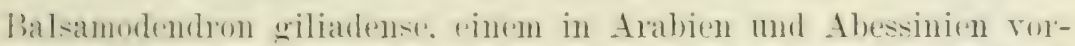
kemmenden baume. Woun es als den Rinden quilt. ist ess rom triblet weisser Farbe, der Dichte des Honizss einem durehdringen-

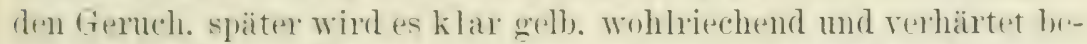
träichtirh. Inieser Balsam wurde ron den Völkern des Altertunlonch geschätzt und steht herte norh bei den Bewolneren des siid-

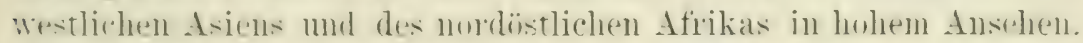

(1)ubalsaln entstammt einem nahen Verwandten des rorlesl-

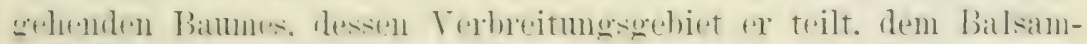

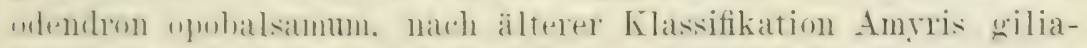
densis. Dieser Artikel ist fahlgell, klar, durchsichtig, ron der

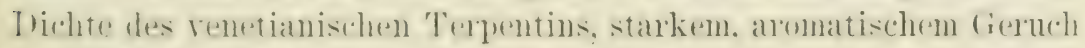

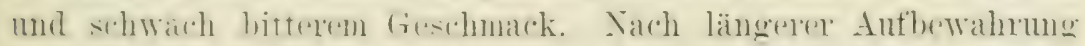

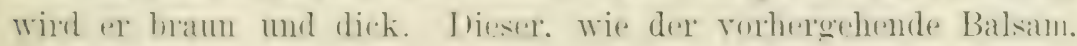
haben nu in dem genamnten Gebiete Bedeutung.

Imiribalsam -tammt ron Humirium floribmudum. rinem in

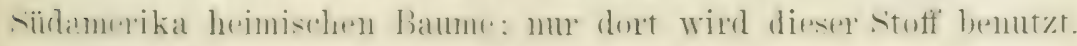

Canadabalsam ist das Produkt ron Abies balsamea,

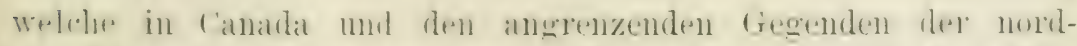

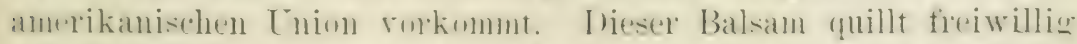

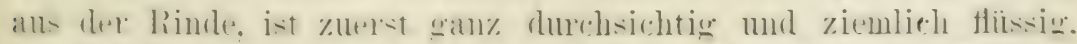

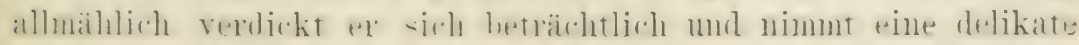




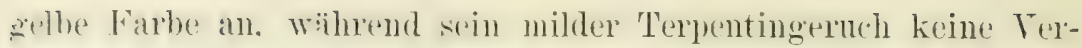
änderme erfährt. Seine wesentlichstrn Bestandteile sind: 24" " itherische ()̈le und 60\% Hax\%. löslich in Alkohol. Gelegentlich ist dieser Balsam. der in Fässern von etwa 50 Kilogramm Gewicht in den Handel celnacht wird, als Ersatz für Copairabalsam rerwendut worden. allein seine hauptsächlichste Benutzmo war mo ist zur Bereitung von Firnissen und zum Aufkleben ron fiegenständen. Welche mter das Mikroskop gelegt werden sollen. Streng genommen ist der lanadabalsam als eine 'Terpentinsorte zu betrarhten. dasselbe quilt rom dem ungarischen Balsan, der von Pinus Pumilio und dem kitrpathischen Balsam, der ron Pinus Pinea stammt.

Copalyabalsam ist, närdhst dem Balsam ron P'eru, jedenfalls das wichtigste Heilmittel dieser Harzgruple. In der Hauptsache besteht a als Copaivaharz und dem fliidhtigen copaivä̈l. sein lieschmack ist herhe und sein eigentimlicher fieruch nicht mangenehn. In kleinen Gaben wirkt es harntreibend, in grossen ahbiihrend. seine geschätzteste Eigenschaft besteht in seiner kiäftigen Wirkung auf die Schleimhäute.

Thie botanische Onelle dieses Balsams bilden melnere fiederhatterige Arten der Catmog Copaitera. Familir Legminosae. die im Amazmenthal wie in den Mädlem ron tiniana. Tenezuela mol rolumbia rorkommen. Die Art. Welche die geschätzteste sinte, den weisen (opaivabalsam. liefert. findet sich in der hrasilianischen Provinz P’ara. von wo jährlich beträchtliche Mtengen rerschifft werlen. rorzugsweise nach Frankreich. Diesur Baum wird infolge des Ansbentererfahrens immer seltenter. und die sammler sind jetzt schon serwmeren, nach langen Kahnfahrten tief in die Mälder zn dringen. Wemn sie einen Bam gefunden haben. der. Wenn ant gutem Boden stehend. am Fuse dinen stammumfang von 2 bis $2^{1} / 2$ Meter und einen astfreien Stamm von 27 Meter mit einer Hachen. dichten hrone haben mag; schlagen sie ein tietes Loch in den Stamm. Das exforkert Geschicklichkeit, demn das Loch soll nicht viel hreitex we die Axt. somdern mur so gerämig sein. dass seine Riehtung nach dem Fermholz hin so geändert werden kamn. dass der sammler nicht rerfehlt. Was er die Ader nemnt. die sewöhnlich am Rande rom liernholze getumden wird and den Balsam ansquellen lässt. l)ie mutele Wand des lorhes muss sorgtaltig glatt und in sanft abwiats geneigter Rich- 


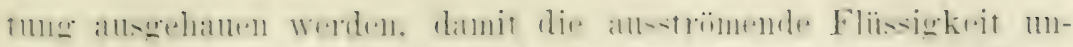

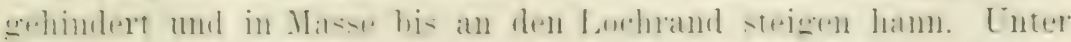

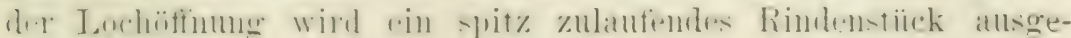

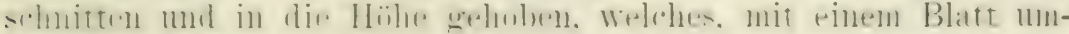

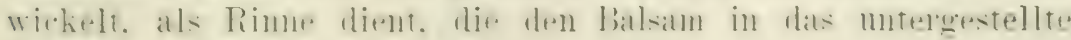
Zinngefäss leitet.

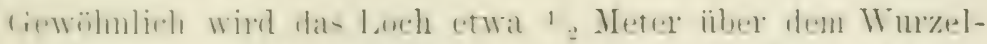

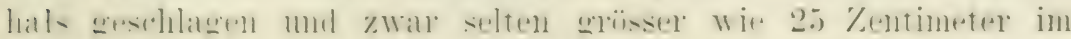
Geviert. Der weisse Splint ist etwa 10 bis 12 Zentimeter

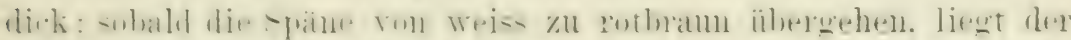

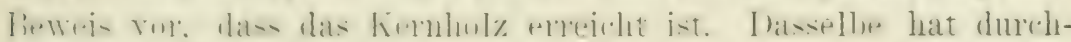

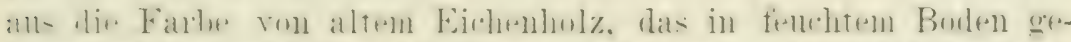

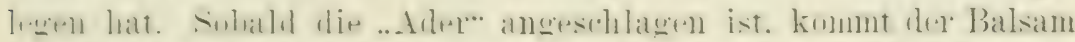

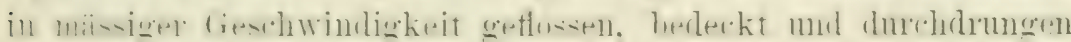

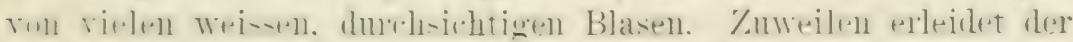

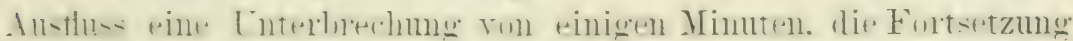

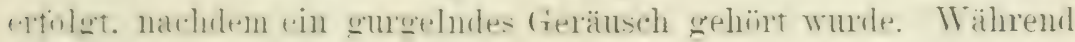

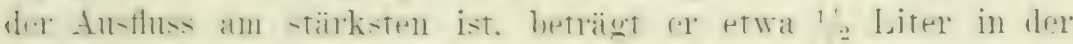
Minute.

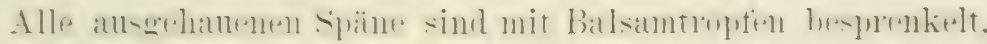

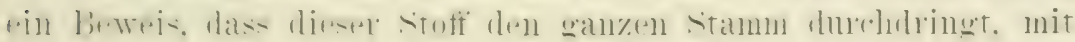

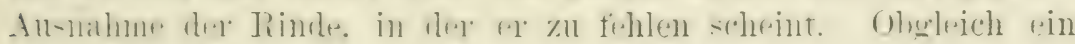

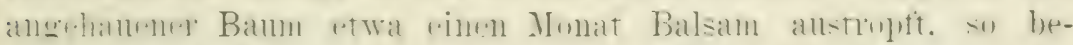

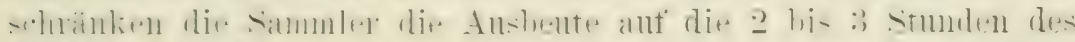

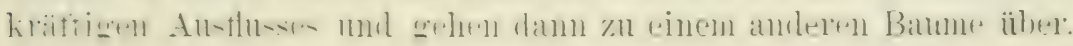

Sehr grosse Bäume liefern zuweilen eine Ausbente ron

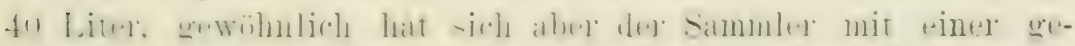
ringeren Menge zu begnitgen.

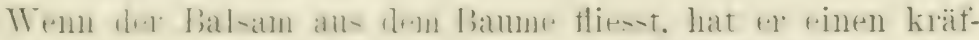

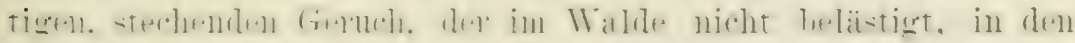

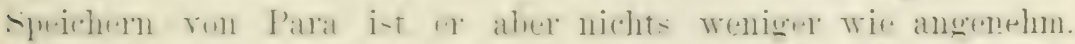

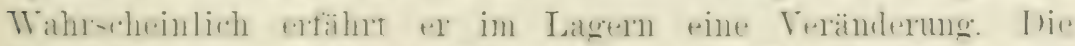

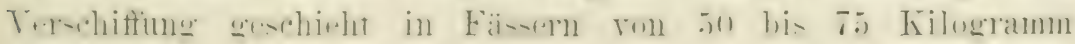
Gericht.

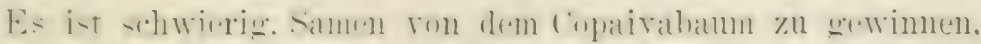

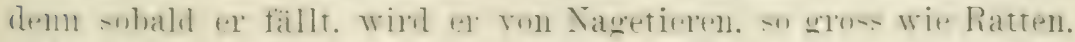

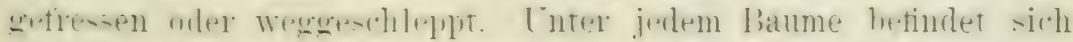

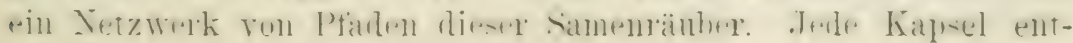




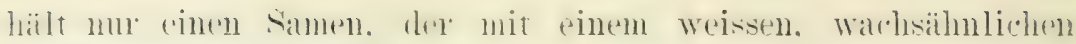
Stofter ron delikatem Geruch ïherzogen ist. Der same selhst ist schwarz und von der Grösse und Form der Feldbohne.

(1) Anbauversuche mit dem copaivabam gemacht wordm -ind. babes idh nirht exfahren kïmnen, jedenfalls liegt die Tor-nchumg dazn weniger nahe wie mit dem Guinguino, denn fopaivabalsam besitzt nur etwa den dritten 'Teil des Wertes wie der Balsam von Peru; im März 1887 wurde el in Hamburg mit 3,50 bis 3,60 Mark pro Kilogramm notiert.

In Indien mod dem malayischen Archipel glatuls man in dem Gujumbalsam einen Ersatz für den copairabalsam zu besitzen, selbst englische Ärzte verwenden ihn in den indischen Hospitälern als Heilmittel. Ansserdem dient er zur Bereitung eines Firnisses, der gegen die Termiten schützt. (tewonnen wird dieser Stoff rom mehreren Arten der dattung Lipterocarpus, hauptsächlich ron I). turbinatus: im fieruch und dem bitterlichen, ekelerregenden Geschmack ist er dem Copaivabalsam sehr ähnlich.

Dex dunkelrote Balsam, den Hardwickia pimmata. Familir Leguminosae liefert, wird ebentalls als Ersatz iür Copaivabalsi m betrachtet.

\section{Terpentin.}

Yur in warmen Klimaten ist die fewinnme dieses dickHlïsigen Harzes lohnend. in der halbtropischen Zone bietet sit die weitgehendsten Torteile. Fnd an eimem zegebenen orte ist die Ausbente reichlicher in einem feuchten und warmen. wie in einem trockenen nnd kühlen . Tahrgang. Bäume, der Luft und Sonne allsgesetzt. sind ergiebiger wie solche, die gedrängt und im Schatten stehen: eine stark sutwickelte. dichtbelaubte Krone ist ein Wahreichen starker Terpentinproduktion.

bas ist allgemeingiultig tiir die terpentinhaltigen Bäume. deren Zahl nicht gering ist. duch gehören sie vorzugsweise den Nadelhölzern an. Tom den letzteren besitzt nur die Gattung Taxus keine harzführenden (iefisse. Wähend die Gattme Pinuan reichlichsten damit resulen ist. Zwischen diesen beiden Extremen stehen abgestutt die Gattmgen Larix. Psendolarix. ledrus, Abies. Picea. Thuja. cupresus. Biota. Tsuga, Psembotsugat. Araucaria und Chamaecyparis. 


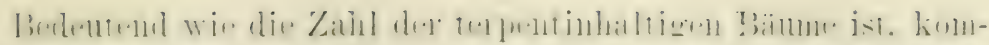

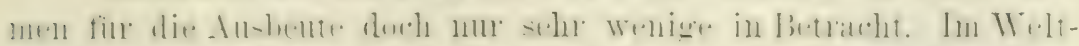

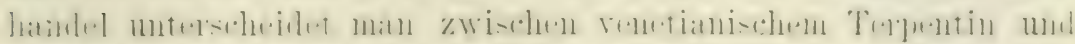

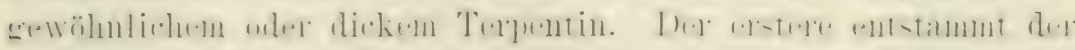

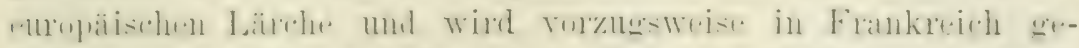

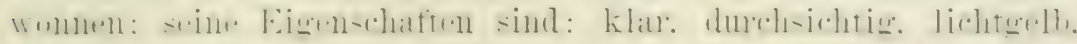

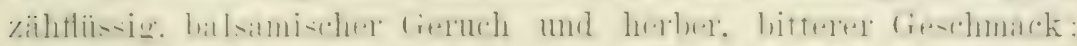

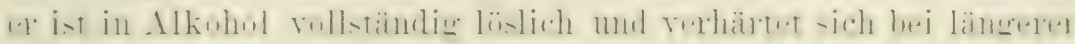
Beriihlumg mit der Luft.

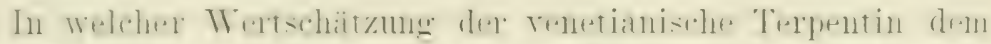

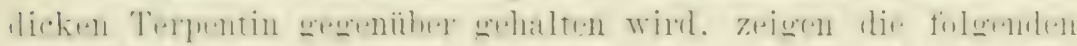

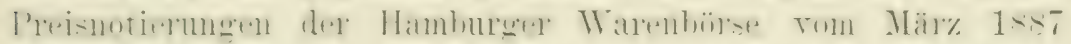

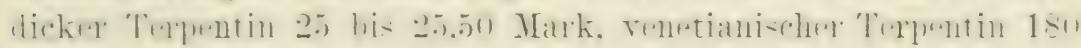
bis 190 Mark pro 100 Kilogramm.

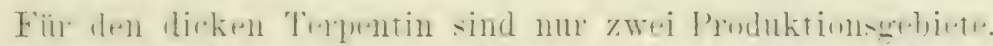
mit je einer hiefirnat. ron bedentung: Cordearolina und an-

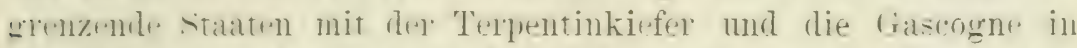
Frankreich mit ler strandkiefer. Was sunst noch in Europal run

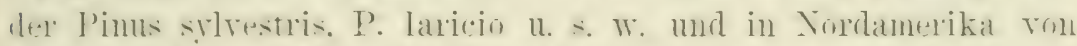

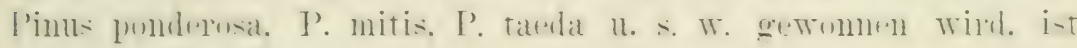
kaum der Rede wert.

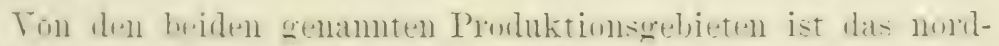

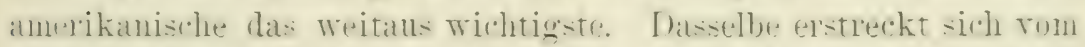

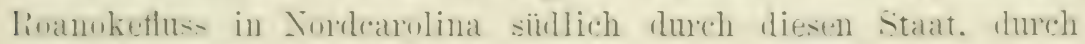

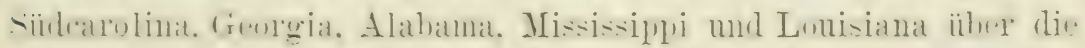

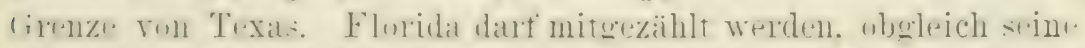
Jerpentinkirfern niche mit dem grwsen IValde im Znsammenhange

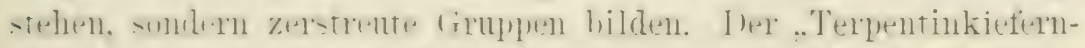

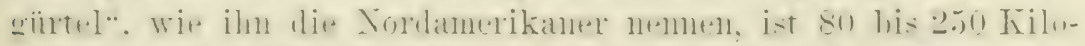

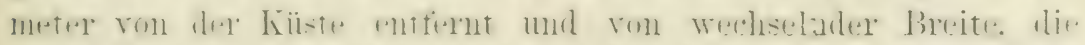

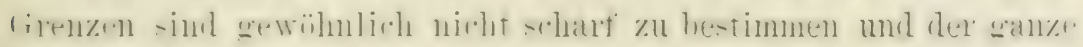

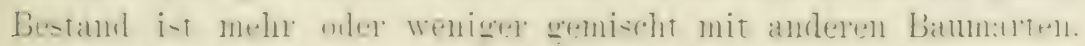

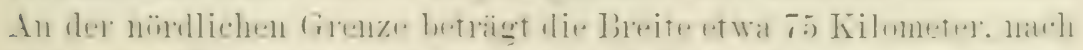

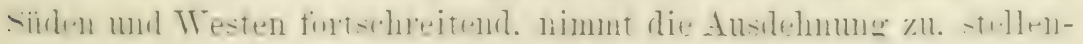

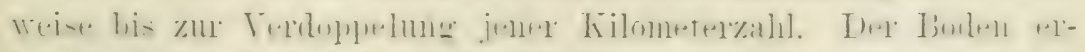

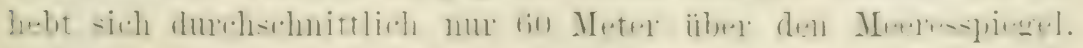

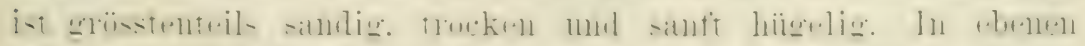

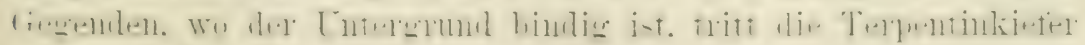




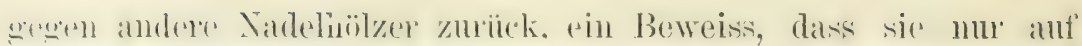
rintm mäsige femehten, durehans lockeren boden fiendig gedeiht.

Frïher worden andh Pinus taeda, I’. mitis und I'. rigida zur 'lerpentingewinnmg herangegengen, für die Gegenwart aber darf bohanptet werden, dass nu' die 'Terpentinkiefer diesem '/aweckr dient. Lilnghlittrige Fiefer, ostliche Gelbkicfer und harte (relbkieter sind andere rolkstïmliche Namen fïr diesen Banm, den Miller l'ints palustris nannte: Michaux führte ihn als P. anstralis an. Carriere hat wieder zu dem alten botanischen Namen zuriickgegretforn, der in Folge dessen in den nordamerikanischen wissenshaftlichen Kroisen allgemein gebränchlich geworiten ist.

Dir Terpentinamshente erfolgt teils durch die Figentümer der Waldstrerken, teils durch Piichter, in beiden Fällen mit Verwendung ron tarbigen Arbeitern, "Terpentimnigger" genannt. Lis Texpachtung weschicht selten anf eine längere Zeit, 2 bis $\therefore$ Jahre ist die Regel. Das Revier, welches der Eigentiumer oder der Pächter ausbentet, gilt als Terpentinfarm.

1)ie Arbeit beginnt in November mit dem Aushauen ron 'Taptlïchern. etwa 30 Zentimeter ïber dem Fusse der Bäume. Die Tircher sind :30 bis to Zentimeter lang. 10 bis 15 Zentimeter tief und rïckmärts halbmondfürmig ausgehauen, an der breitesten Stelle 8 Zentimeter messend.

Die Füllung der Lörder mit 'Terpentin beginnt etwa Mitte Mä̈\%, zunächst lang'sam, dann steigend bis zum Mittsommex, von da al) zuriuckgehend, um bei Fintritt dex Külte abzubrechen. Zum wstemmal Ende März, später noch einigemal werden die Löcher reroxissert, indem zunächst an beiden Ecken, just iiber dem hinteren Rande ein siran und dam gerade über dem Loch eine Vtörnige stelle anscehanen wird. Ton diesen Stellen wird wiichentlich eimmal mit pinen pigentümlich geformten Messer Holz abeschabt, elst mem dieses Mittel nicht mehr fruchten will. findet pine weitere Tergrösserung mit dem Beil statt. Mit anderen Torten, das streben ist daranf gerichtet, dem Bamme eine frische Wunde zu erhalten.

Die Entlersum aler Löcher weschieht eimmal monatlich mit ticten Lïfteln in Wimer. dies wenn gefïllt, nach dem Lagerplatz sertagen mol in Fäsor ansegensen werden. Das bereits rerhärtete Terentin wird mit einem schabeisen ansgekratzt und in hesondere Eimer gebracht. 


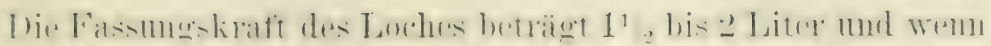

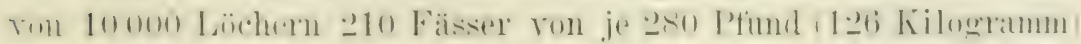

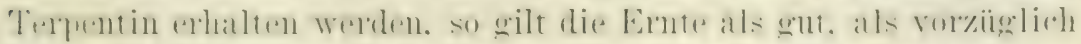

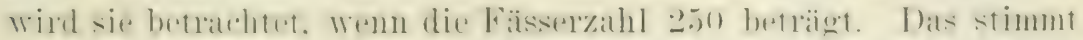

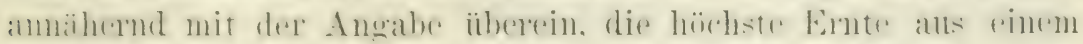

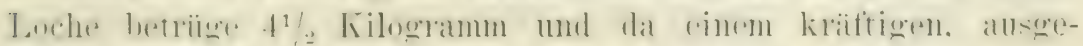

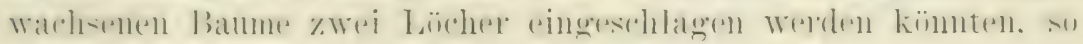
produziere er im Jahre 9 Kilogramm 'lerpentin.

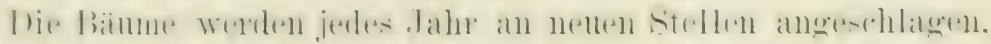

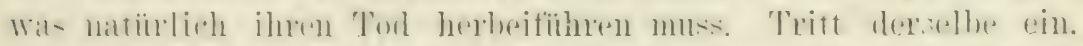

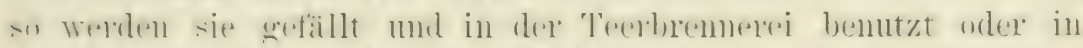

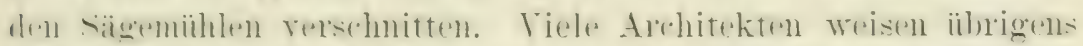

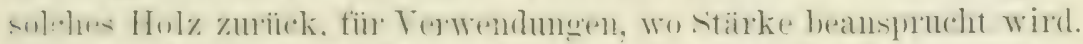

In den meisten , Terpentinstalaten" muss das Terpentinfass

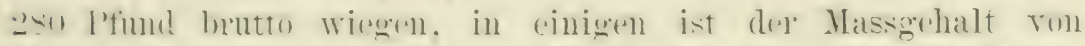

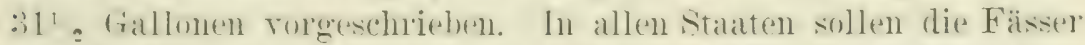
Branlzedeleen tragen und zwar ioberall $V$ für Virginturpentine. In Sordearolina und reorgia ist s̀ für soft und H füx hard einzuhremen. In Florida soll is reiner serape. I) gelloe (pualitiot bezeichnen.

Zur Öherwathung dieser Bestimmungen sind in allen staten 'lerpentininspektoren angestellt.

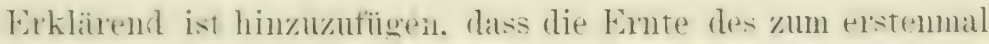

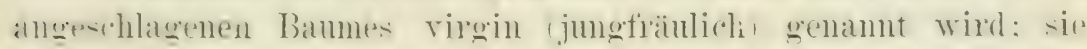

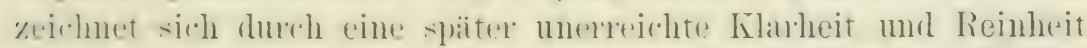
all- Das fulgende Jalle wirl die Ernte yealling (Jährling genamut. in allen folgenden Jahnen int sie old stuff (alter stoff').

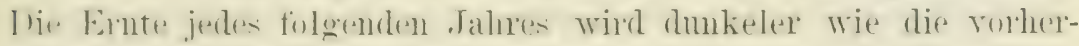
gehende: ron farblos zu gelb, von gelb zu bram.

E: komme ïhrigens mehr und mehr in Aufiahme. das rohe Terpentin an Lroduktionsont duch Destillation in colophonium

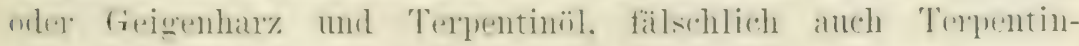

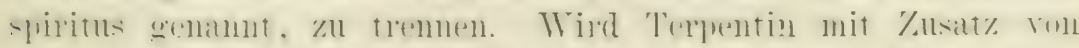

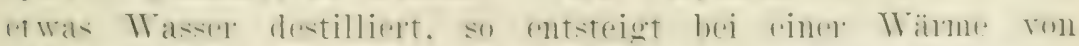

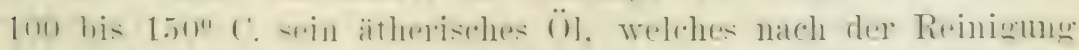

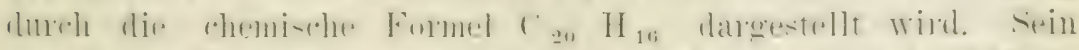

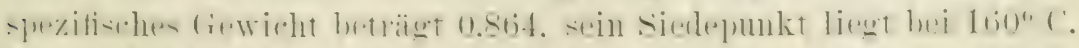

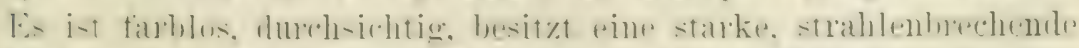

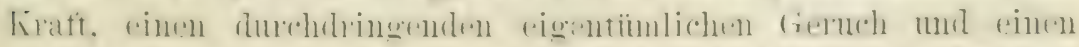

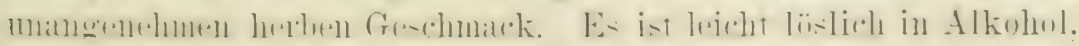


Äther. Hüchtigen und fotten Ölen, aber nicht in Wasser, anf dem as soluwimmt. Für manche stoffe gilt es als gutes Lïsemittel, wie sichwefel, Phosphor, Kautschuk und resschiedene Harze. In manchen Gewerben findet es ansgedehnte Terwendung, won allen (i)farben bildet es einen Bestandteil.

l)as in der Destillierblase zurickbleibende Har\% wird durch rine Budenklappe abgelassen. geseiht und nach einer Bütte geteluitet. aus der es in Fässer geschöpft wird und damit marktfähig ist. Die Farbe des Harzes zeigt starke Abweichung'n. je nach der oben gekennzeichneten stufenfolge der Terpentinernten und der bei der Destillation angewendeten Wärme. Das in den ersten Monaten geschöpfte jungfränliche Teruentin liefert, wenn nicht in der Blase verbrannt, ein schönes, durchsichtiges Harz, das im Handel als waterwhite (wasserweiss) bezeichnet wird und die Marke W. W. trägt. Das in späteren Monaten geschöpfte jungfräuliche Terpentin liefert ein etwas trüberes Harz, das als Windowglas (Fensterglas) bezeichnet wird und die Marke $\mathbb{T}^{*}$. G. trägt. Die ïbrigen Qualitäten, in Farbenabstufungen von hellgelb bis nahezu pechschwarz. werden nach ihrer Gradierung mit den Buchstaben A. bis N. gemarkt, wobei J. übergangen wird. A. bezeichnet die dunkelste Qualität, N. die hellste.

IVenn ron dieser Reihenfolge der Durchschnitt gezogen wird, so stellt sich der Preis um zwei Drittel niedriger, wie derjenige, welcher für .. wasserweiss" bezahlt wird. Beispielsweise wude im März 1887 in Hamburg braunes amerikanisches Harz mit 7 Mark, das beste helle amerikanische Harz aber mit 23 Nark pro 100 Kilogramm notiert.

Geigenharz, im deutschen Grosshandel einfach Harz genamnt. ist ein sehr sprüdes, brüchiges Harz mit einem schwachen Kieferngeruch, das bei einer Tärme von $80^{\prime \prime}$ C. erweicht und bei einer 'Temperatur ron $100^{\circ} \mathrm{C}$. und höher vollständig schmilzt. Es ist leicht löslich in Äther. Belizol und chloroform und nur teilweise löslich in Alkohol und fetten (i)len. Es findet eine ausgedehnte dnwendung: zur Bereitumg von Harzseifen und ordinären Firnissen. zu C'ement und Schusterwachs. ferner dient es zum Verpechen der Lagerbiertässer, zum Bestreichen der Bogen musikalischer Instrumente und zu zahlreichen mwichtigeren Z Zecken. Im Arzneischatze bildet es einen Bestandteil mehrerer Salben und Pflaster. Beträchtliche Mengen werdesi durch trockene Destillation zu einen äligen 


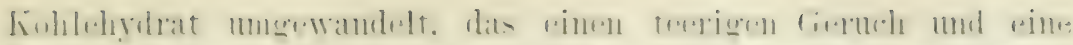

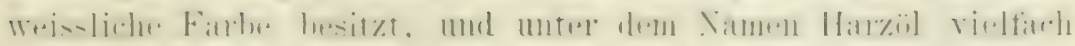

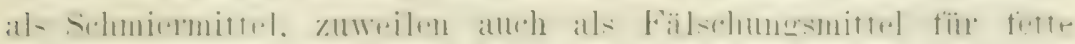
(i) verwendet wird.

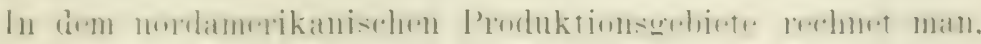

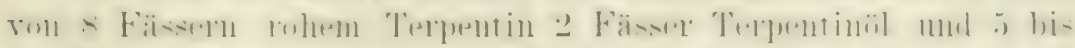

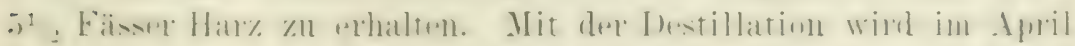

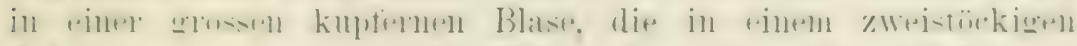

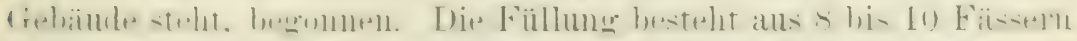

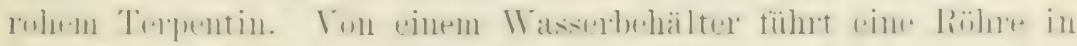

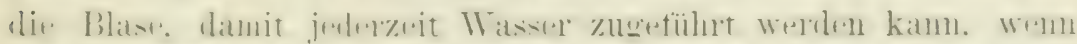

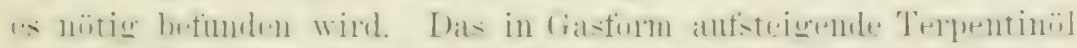

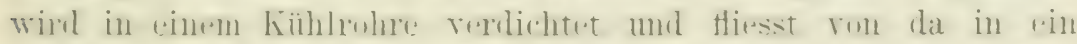

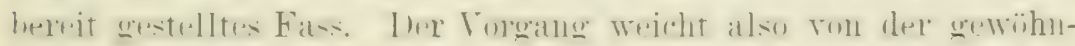

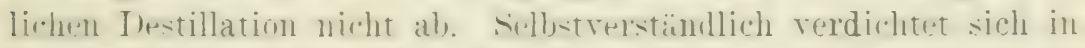

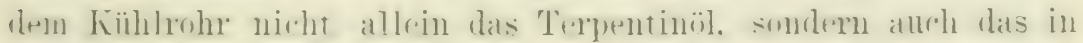

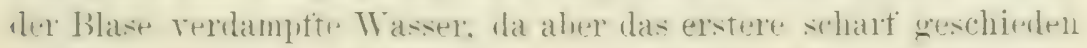
aut dem letzteren shwimmt. so ist die Tremume leicht allszutïihren.

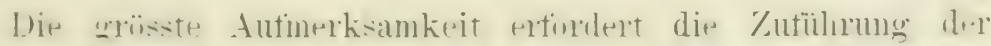

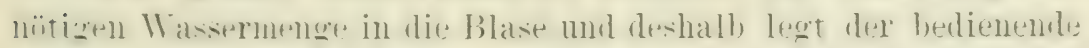

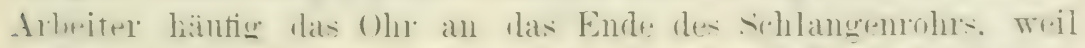

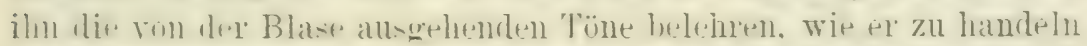

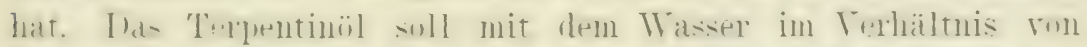

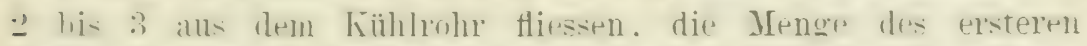

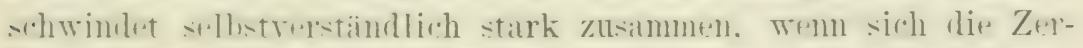
s.tzung in dor Blase dem Ende zuneigt. Wem dir Sarhfiage: fïr Harz stäker ist wir fïr Terpentinoil. wird die Destillation

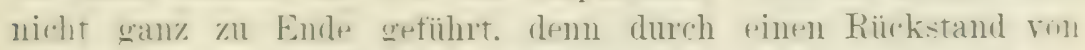
Timpentiniil wiml das Har\% rerbesert. jedentalls in der Mengr

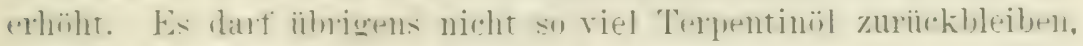

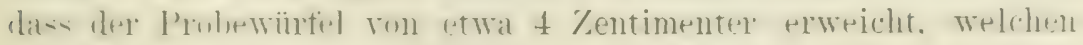

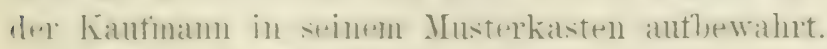

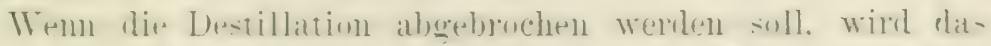

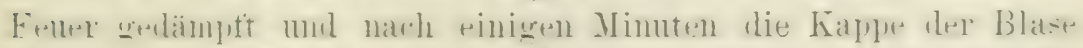

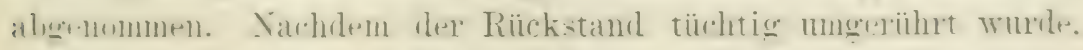
wirl ex - immer noch kochemd leeis - durch rine Klalpe: am

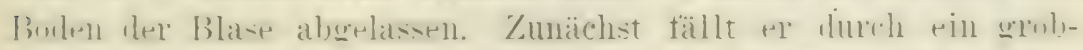
mathiges Lraht-ieh). ant welchem die Rimlenstilche und andert 


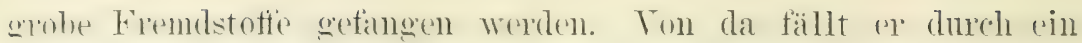
teimmatchiges Thahtriel) mod dam duch ein grobmaschiges Thahtsich), das aber mit Watte bedeckt ist. Wem die flïsige Masios dnch diese drei iiberemanderstehende siebe gelanfen ist, werden diese entfernt. Sun wird das noch ganz heisse, dicke Harz mit cinem schöpfer aus der Blase in bereitstehende Fässer getracht, in welchen es ungestirt bleibt, bis es so hart ist. dass nur mit Miihe ein Stock eingestossen werden kann.

Das durcheseihte Harz gibt die teinste Qualitait und wirl in Handel gereinigt oder raffiniert genamt. Wird. wie oben "rwähnt, die Destillation nicht rollständig zu kinde gefühnt. damm heibt der weitaus grösste Teil des Rückstandes so flïssig, daks el geseilit werden kamn, der Terlust an Terpentinöl wird auforwogen durch die entsprechend höheren Preise des gereinigten Harzes. Weml das Harz hart zu werden beginnt, wind es mit Handschanfeln ans de'n Sammelfässorn gestochen und in Tersandtäsier ans Tammen- oder Kiefernholz rerparkt. Sehr dicht gemalchte Eichenfässer, mit inseiti@ rerleimten Xähten, dienen zur Anfuihme des T'erpentimöls.

Beide Produkte werden rom den ..Terpentinfarmen" narch den Terschiffungshafen Wilmington. Charleston. Savamah mul Brunswick rersendet. Saramuah gilt für den berlentendsten Terpentimmarkt der Welt.

Dere jährliche Export der nordamerikanischen l'nion stellt sich im Durchschnitt wie tolgt: rohes Terpentin und Har\% 1 oum (n) Fässer in Werte ron 10100000 Mark. Terpentinöl 252mum Liter, Wert 9650000 Mark.

Während man in Nordamerika noch im Lnklaren darïher ist, in welchem Alter die Terpentinkiefer ohne Nachteil für ihre terneres Fntwickelung nud Produktion angezapft werden darf, hat man in Frankreich ermittelt, für die Strandkiefor träte dieser Zeitpunkt etwa im 25. Jahre ein. I)a aber das Wachstum nicht iiberall weich ist, worden als zurerlässigere Merkmale angegehen: in Irrterhöhe ïber den Boden soll der Stamm 1 Meter im Lmfang haben, fermer soll ex 5 Meter hinant astfrei sein. Bäume mit rerhälnismässig kurzen, dicken stämmen mol stark entwickelten Kronen

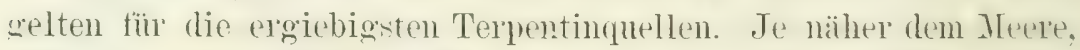
desto langsiamer ist das Wachstum. dagegen ist die 'Terpentin- 


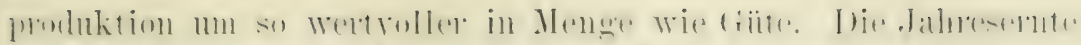

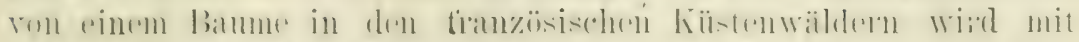

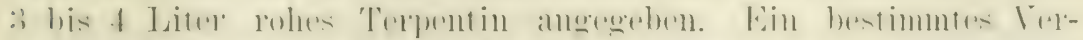

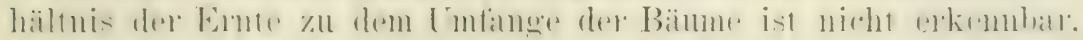

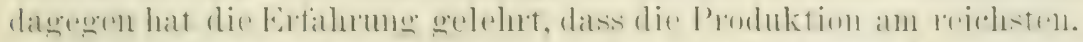

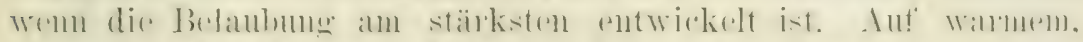

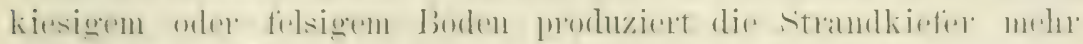

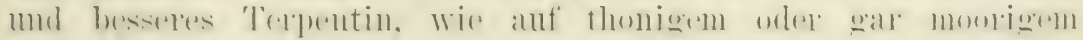
Boden.

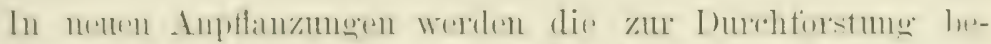

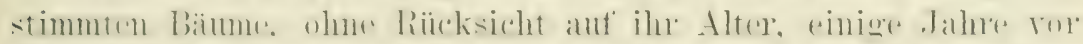

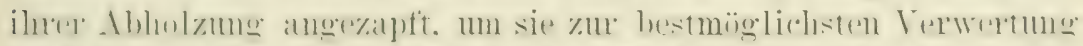

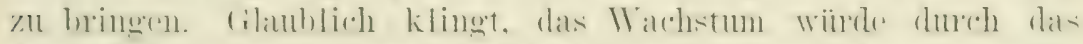

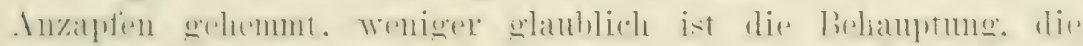

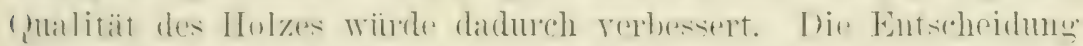

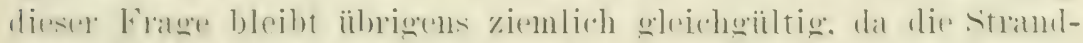
kiefer unter allen Cmstinden oin Holz liefere, das nur als erering-

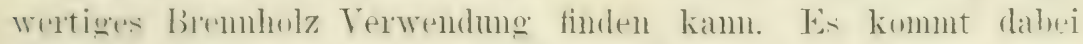

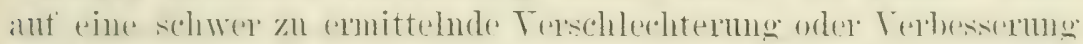
nicht an. Würde sich die stranclkiefere nicht so rorzüglich

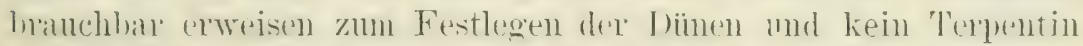

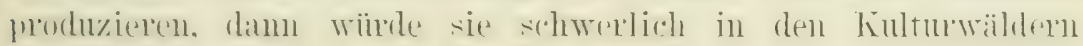
Anfinalime finden.

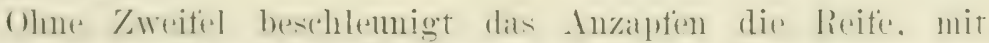

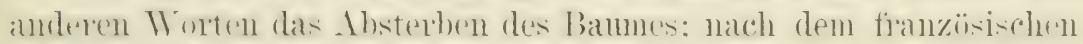

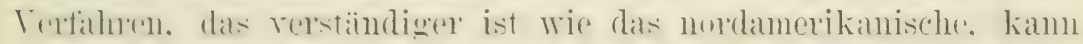

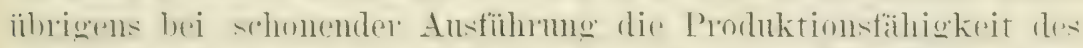

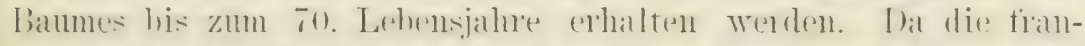

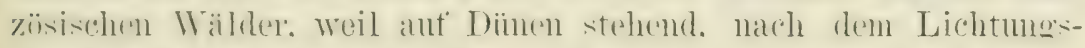

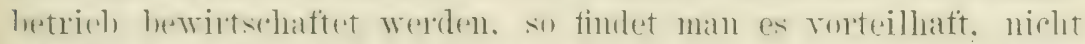

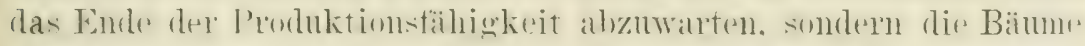

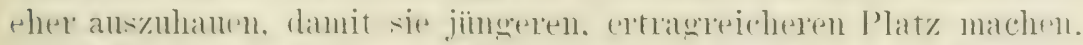

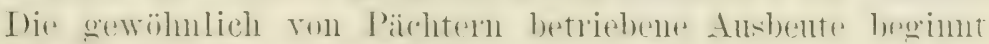

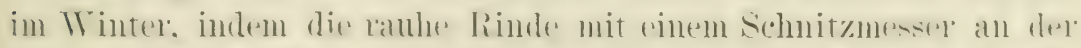

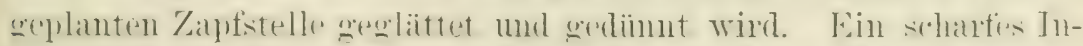
strument mit einem convexen Rand dient anfangs Mär\% dazn. an

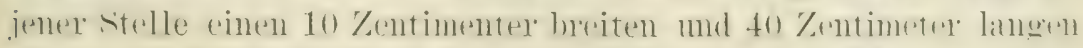

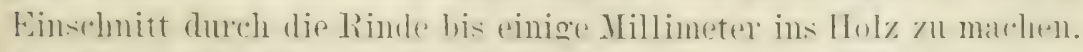

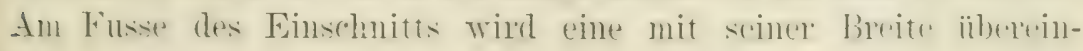




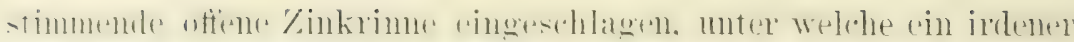

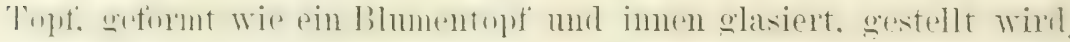

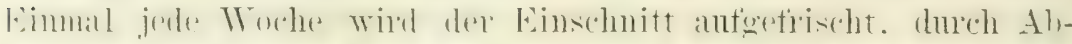

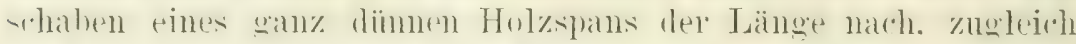
wirl dere Einschnitt un 2 his :) Zentimeter nach oben rerlängert. te nateh der I)iche des Bames werden zwei wher mehr solcher Finsehnitte gemacht. niemals aber wird die angegehene Breit. ïherschriten. Jahr für .Jahn werden die Finschnitte vertireft mol rerlängert. sie mögen sohliesslich bis zur Höhe fon 4 his 5 Jetex reichen. allein niemals wird von den Eurstheanten gestattet, dasdie Einschnitte näher aneinander gelegt werden. als ihre rigen Breite beträgt. Das monter der Rindenbedeckmg wachsende Holz schliest allmählig die Finschnitte ron beiden reiten nnd lässt schliesslich nur tiefe spalten ührig. Das ibberwachsende Holz wird ebenfalls in langen spanstreifen abgeschnitten. un die Texpentinguelle zu rerjüngen: so setzt sich das Terfalneen fort bis zum Fällen des Baumes.

.Te höher die Einschnitte gefiihnt. desto höher werten die Töpte gehängt, dern Entleerme in regelmässigen \%eitabschnitten -tattfindet. Wem Mitte Oktuher der Terpentinfluss anthört. wirl die weisslivhe moluchsichtige Kunste ats den Töpten geshaht: die Letateren bleiben mugestiuzt am Fusse der Bäme ïher Wiuter stehen.

Die Destillation findet wie geschildert statt, mit der Verhessermg. dass das Terpentin ror der Eintiillung in die Blase wo*hmolzen mol gespiht wird mol die Blase mit einer Wasserleitme verbunden ist. die ihr munterbrochen genan so viel Wasser zutiihnt als sie rerdamptt. Da das rohe Turpentin geserint wurde. $\therefore$ läut der Destillationsrïckstand nicht durch 3 siehe. wie in Tordamerika. sondern nur durch 2. T)ie dunkelsten Harzqualitäten werden entwoder mit 'leer zu Pech eingekocht wher einer trockenen Lestillation muterworfen. un den when erwihnten äloharzigen

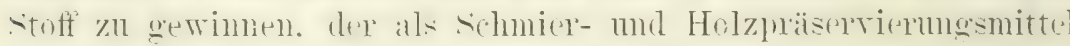
wie zur Bereitung ron Druckerschwärze dient.

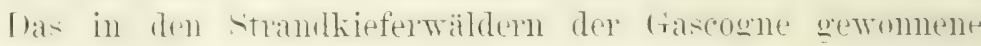
T'erpentin goht zumärhst nach Bordeaux. Weshalh ps im Hamblel häufig Bordeauxterpentin genannt wird.

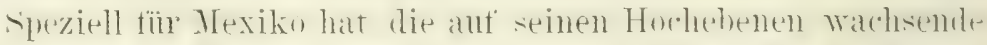
T'inus tencote als Terpentinumelle Berlentung. Dals Prorlukt wirt 


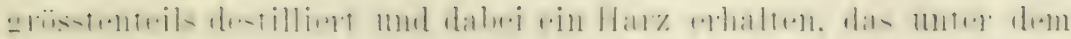
Xamen Brea zur Fahrikgtion ron Seife mo manchen anderen

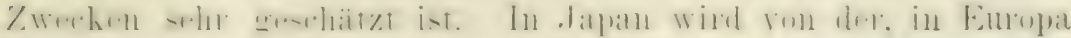

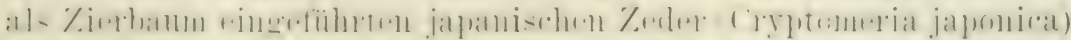

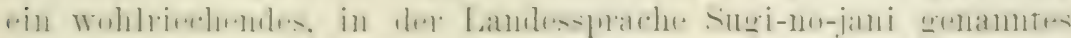

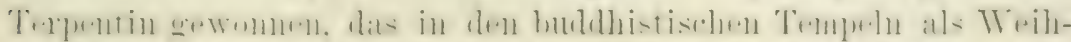

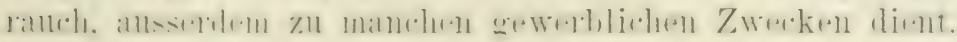

Khasraterpentin ist ein Produkt ron Assam und wird von

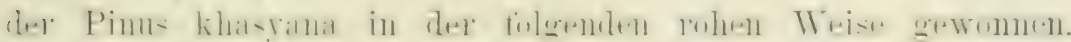

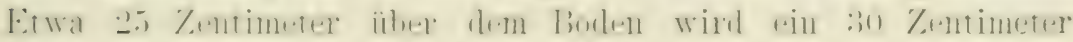

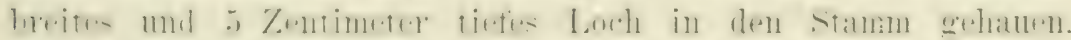

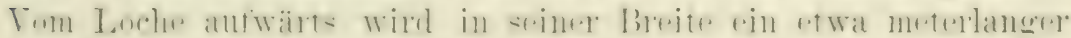

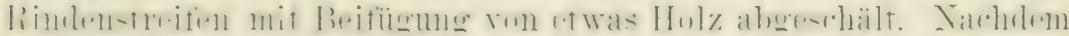

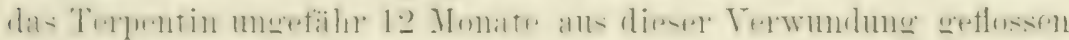

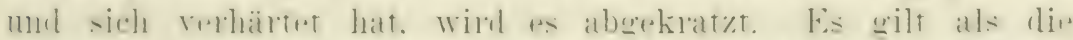

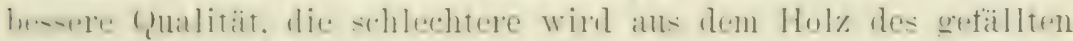
batumes destilliert. \%u diesem \%wecke werten die 5 his 1:2 Zenti-

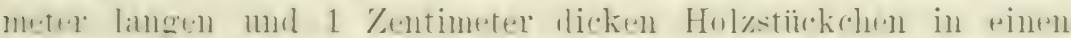

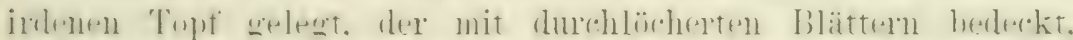

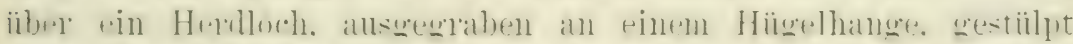

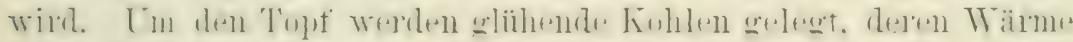

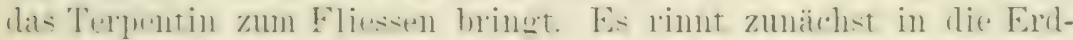

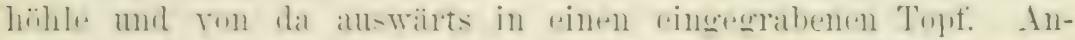

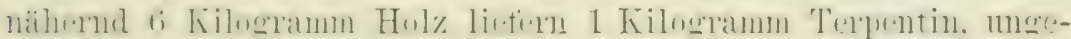
rechnet des Verlustes.

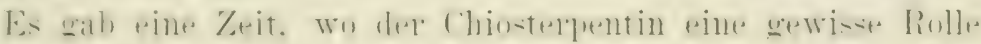

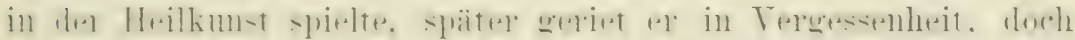

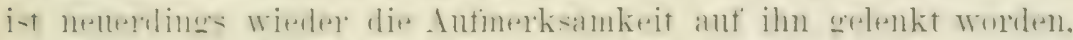

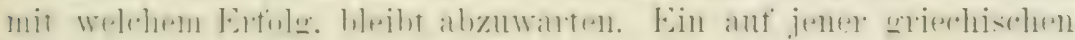

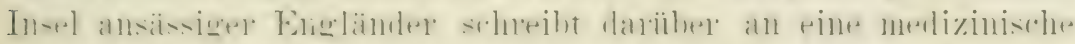

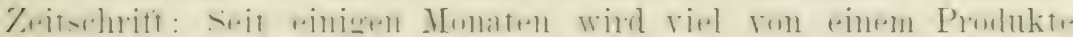

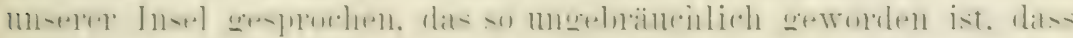

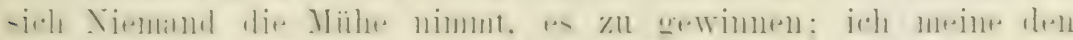

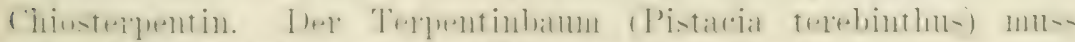

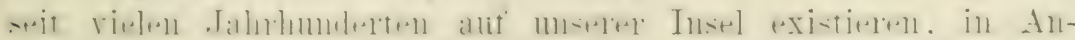

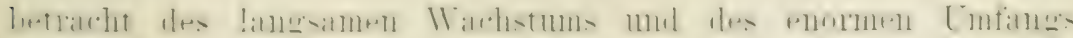

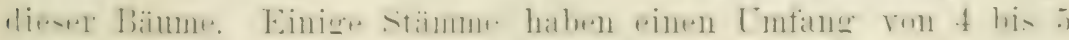

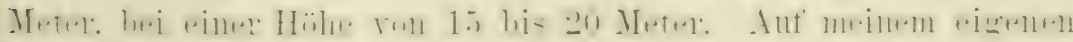

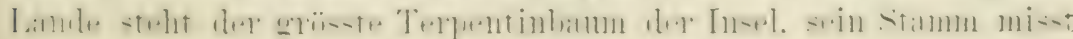




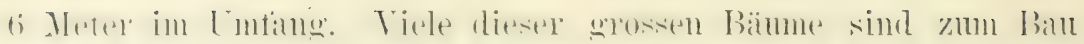

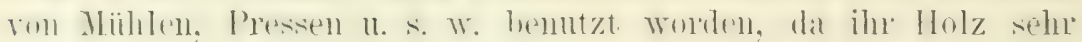
hart ist. In der Nähe der Stadt und drei oder vier Dörferm werden diese bämue nur noch getumden. ilure Zahl mag. nach sorg-

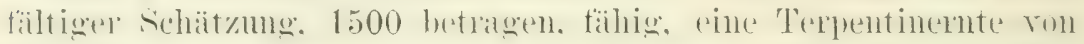

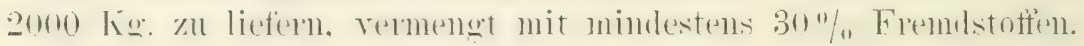

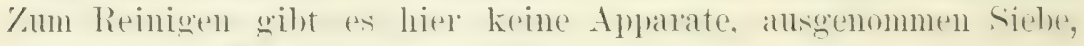

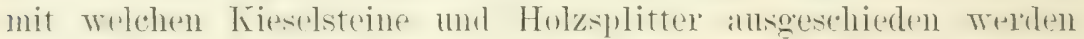
kömen. 'Zur liewinnmg des Terpentins werden im .Juni Einschnitte in die stammminde gemacht, und die Anspuellungen hänfig mit einem heeiten Mresere abgeschaht. Der Gertald dieses Terpentins erimert an Malstix, seine Farbe wirl im Teluarten allmählich weiss.

\section{Gum migutt.}

Ine botanische Herkmft weniger Handelsartikel wall su schwierig festzutellen, wie diejenige dieses Gummihares, oboleich dasselbe schon am Anfange des siehzehnten . Taluhunderts in Funna als ein kräftiges Abführmittel gekamnt war. Tnfolge seiner stark angreifenden Trirkme ist es ans dem Alyneischatze fast aller emopäischen Länder rerbannt worden, dageneren ist es ereschätzt

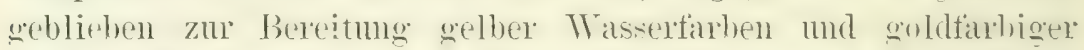
Firnisse für Messingwaren. Gelegentlich findet es anch als Holzpolitur Verwendung.

Alle drten der Familie Guttiferae quellen, wemn verwundet. fimmiharz ans, allein ss sind nu wenige Arten, deren Produkt als Gummigutt in den Handel kommt. Üeber die Benemung dieser Arten sind die Botaniker. wie iblich, meinig. Garcinia ficctoria oder lambogia pictoria kommt in Indien, zumal in

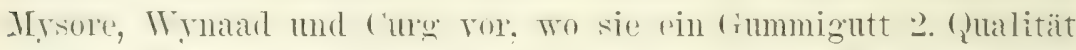
liefert. Ton anderen Botanikern wird dieser Baum Xanthochỵmus pictorius genamnt, muter welchem Vamen er in nenester Zeit in die französischen frewärchshäuser eingeführt worden ist. Geschätzt wird an ihm besonders, dass ar, als der cinzige seiner Familie, im Geтächshatse Früchte zur Reife bringt. Dieselben haben die frösse und Farbe ron grossen Aprikosen und schmecken sïss mit einem schwachen sänerlichen heigescimack. Als rste Qualität kämen diese Frïchte uibrigens nicht gelten. Der Baum macht mit seinen langen gegenständigen Blättem. von schöner grïner 


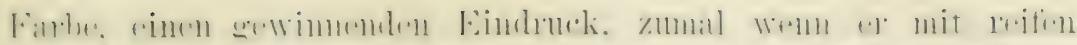
Friichten behangen ist.

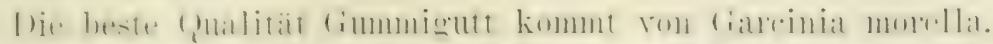

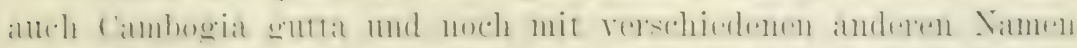

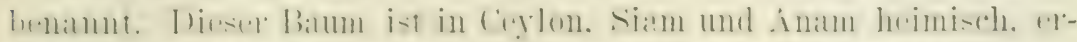

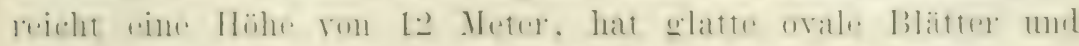

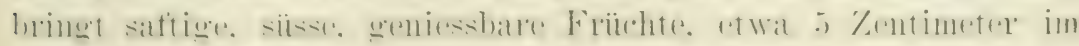
Durchmesser, hervor.

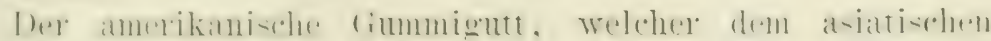

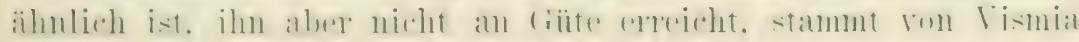

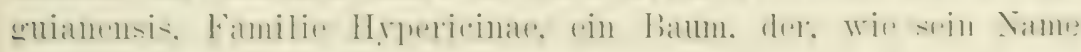
sagt, in Guiana heimisch ist.

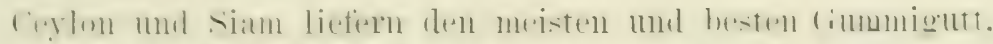

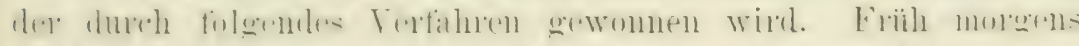

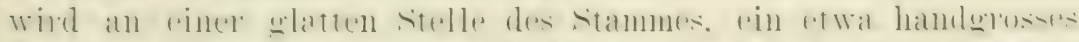

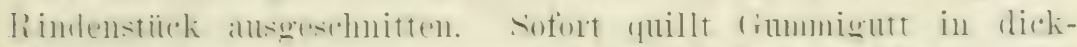

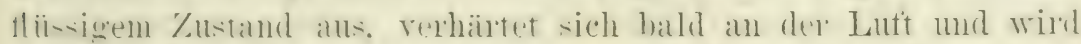

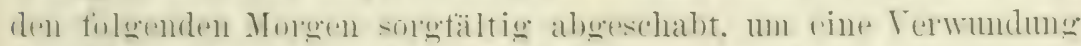

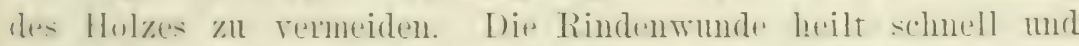

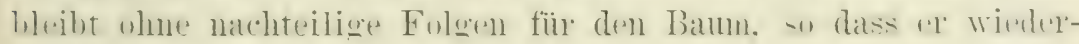
holt angezapft werden kamn.

In drei Formen kommt der Gummigutt in den Handel. 1. Pfeifengumnignt: Cylinder ron etwa $4 \%$ entimeter Inrehnesere

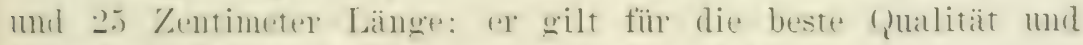

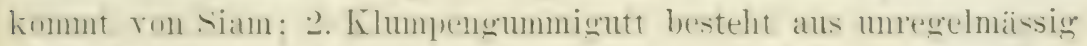

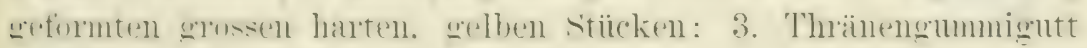
besteht aus kleinen rundlichen Stïcken.

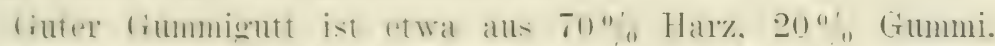
10" "Fendetigheit und Fremdstoften zusammengesetzt. Fr hat einen

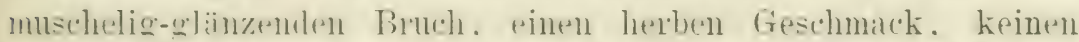

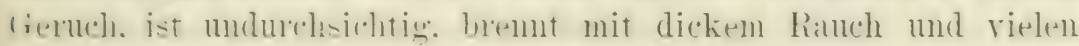

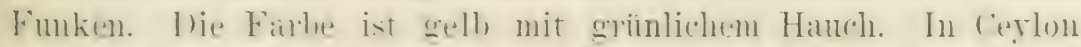

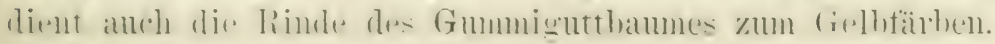

\section{Myrrhen.}

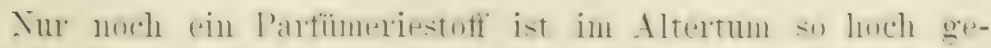

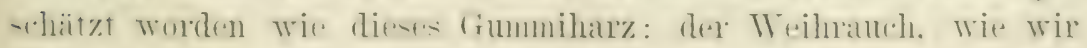

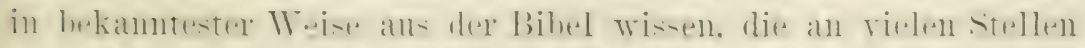

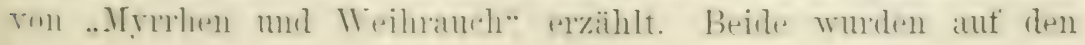




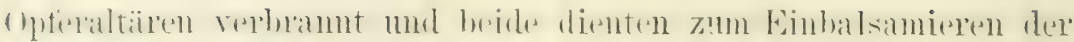
Leichen.

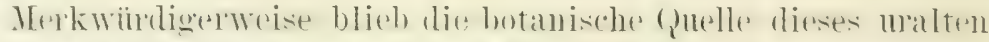
Itambelsartikels bis zum zwriten Viertel diesess Jahrhunderts in

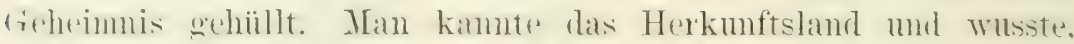
das: der Xame Myrthen anf dats arabische Wort Morr zuriickzutühron ist, darïher hinats reirhten die Kenntnisse nicht. Erst

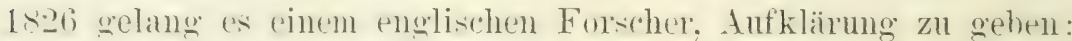
:m somign Hängen des saratgebirges, in Erhebungen von 4511 1)is 1000 Meter, entdeckte er den Mrrrhenstranch, dem el den wissenschattlichen Namen Balsamortendron myriha gaab. Xicht höher mie :) bis + Meter wird dieser Strauch, der mit seiner hellsranten Rinde mit seinen dornigen Zweigen eine gewisse Aehnlichheit mit dem Weisidorn besitzt. Die Blätter sind glatt, langoral. sezahnt und dreispaltig. Die beiden Seitenblätter sind klein in Verluältnis zum Mittelblatt. Die Frucht ist oval, etwas eingedrïckt mul becitzt die Grösse einer Frbse. Dex Strauch wächst gewöhnlich im (remenge mit tkazien mol Euphorbieli in niedrigem (iebüsch.

We'mu das Mrrohen auscruillt, ist es von öliger, etwas spätel von butteriger Beschattenheit mol gelblich weiser Farbe. Allmählich rexhärtet es sich. indem es einen rötlichen Schein annimmt. Torzngsweise wird dieses Crmmiharz im Somaliland und in der Nachbarschaft ron Harar $\left(9^{\circ} 20^{\prime}\right.$ n. Br., $42^{\circ} 17^{\prime}$ o. L. $)$ im Juli und August gesammelt und auf die grose Y[ese von Berbera gebracht. die in November. I)ezember und Jamuar stattfindet. Ton da wirh es zmächst math Aden mul damm nach Bombay verschifft, wo dit sortierme vorgenommen wird. Die exeringeren () nalitäten werden rorzunswe nach China, die feineren nach Europa rersendet. bie: indischen Mrrrhenkauflente pflegen Agenten in Makallah und Aden zu latten. Welche die Mresse von Berbera besuchen mol englische mol indische Waren gegen Mrrrhen mod Weihratch tamschen

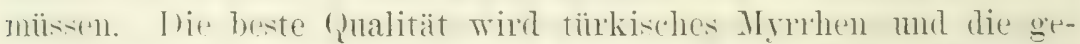
ringte ostindisches Myrrhen genamnt, entsprechend dem Cmwegte.

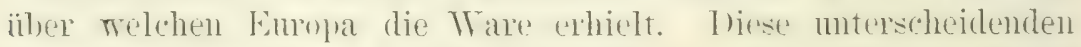
Bezeirhnugen haben ïbrigens jetzt keme. Berechtignng mehr. dem das Myrrhen. welches nicht über Bombay geht. wird vom Alen direkt mach Enropal exportiert. Cirade jetzt rollzieht sirh

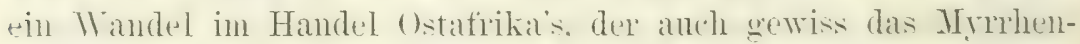

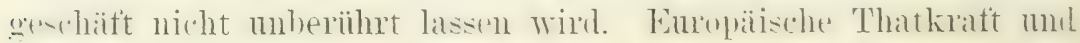




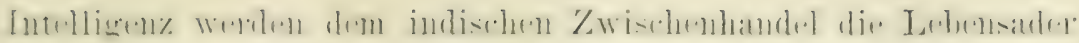
unterbinden.

Die Somalis setzen anch nach der arabischen Küste über.

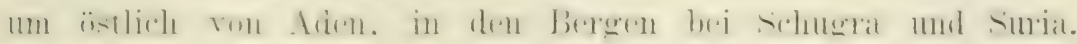

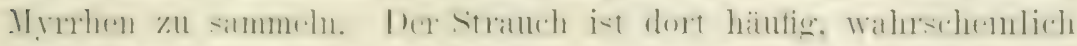

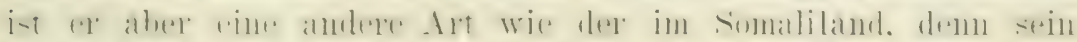

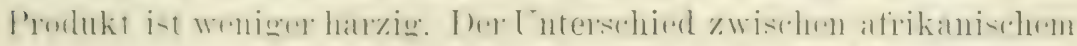

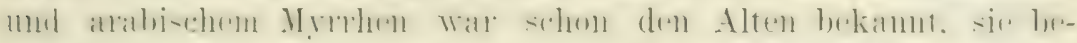
vorzugten das erstere, wie es noch heute die Krauflente ron Bombay thum.

Myrhen wird gerröhnlich in Kisten von 50 bis 100 Kiln-

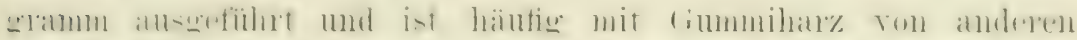

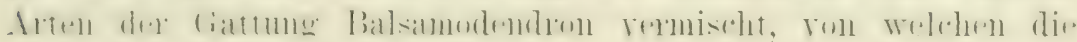
folgenden am wichtigsten sind:

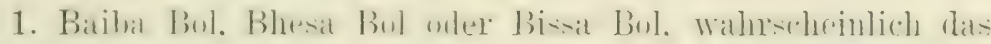

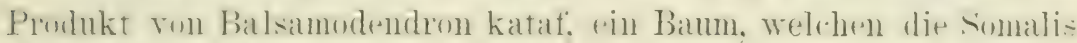

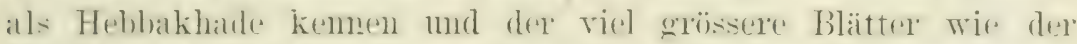
Mrrohenstraudh hat. Dieses fimmiharz ist dem Mrrrhen ä̈lserlich ähnlich, hat aber cinen bitterlichen, mangenehmen liechnack.

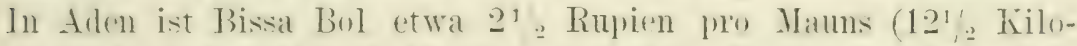
eramm wert. wähnend Mrrrhem nit $91 / 2$ Rupien bezahlt wird.

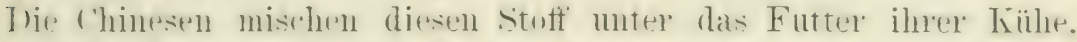

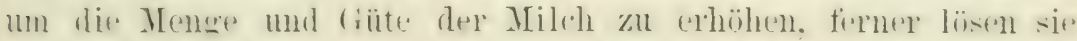
ihn in Kalkwasire. Wenn sie einen Anstrich Glan\% geben wollen.

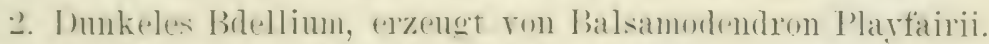

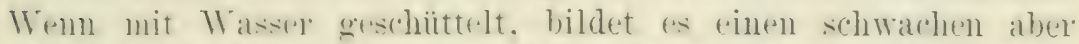

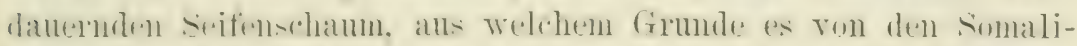

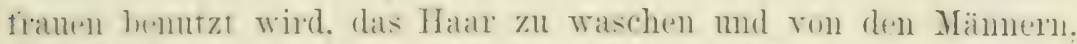

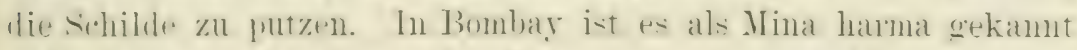

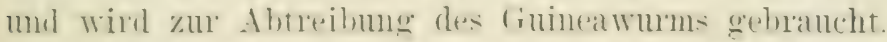

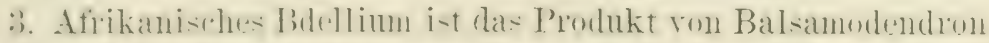

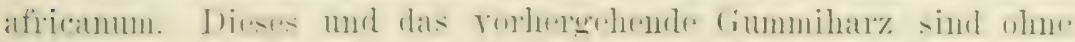

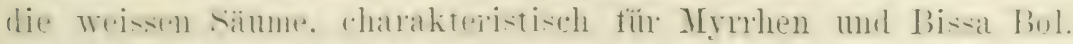

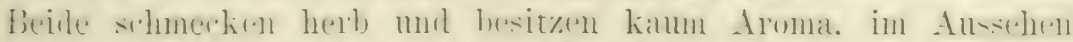

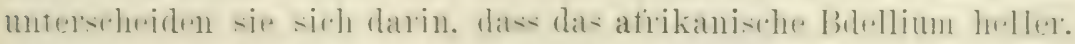
klarer und harziger ist, wie das dunkle Bdellium.

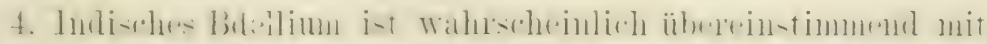

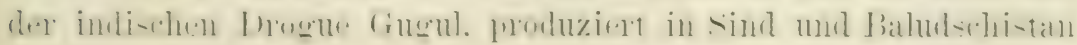




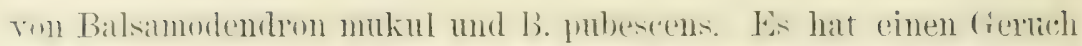

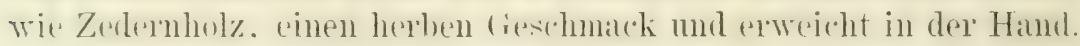

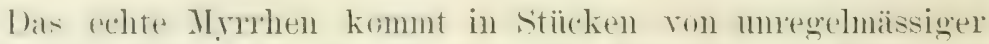
fiestalt mol firosse in den Handel, ihr Inrohmesser sehwankt zwischen 1 und 7 Zentimeter. die Farbe ist stets rötlich braun.

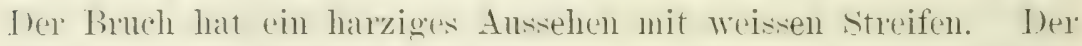
ferehmack ist hitter-aromatisch und der Geruch charateristisch. Fs besteht ank einex Mischung ron Har\%, Glummi und ätherischen (̈) len. in schwankenden Anteilen. Inas ätherische öl ist von "3 bis

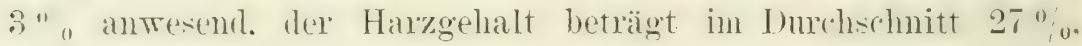
etwas höher stellt sich der Anteil des Gummis. Das Harz scheint ein zusammengesetzter Körper zu sein, dem es ist teilweise löslich in Äther. trilweise in Schwefelkohlenstoft. Das trummi ist löslich in Wasser und bildet einen kräftigen Klebestoff.

Mvrrhen wird in dex Heilkunst gebrantht, teils um die Wirkung anderer Arzneien zu stärken oder zu schwäichen, teils als Aluetiterreger nnd um die inneren Organe zu erwärmen. Als Parfimerio wird es zwar nichl meln so viel gebrancht wie fiuher.

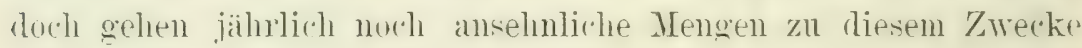
in Rauch auf.

Nim sirh die Besitzvexhältnisse an der ostafrikanischen Kö̈ste qeändert und ansogdehnte Gebiete teils nuter deutsche Herrschaft. teils unter deutschen Eintlus gestellt sind. ist dif Frage zeitgemäss: sollte es sich nicht lohnen, den Mrrmhenstranch der Trildniss zn entreissen? Tenn sich die Engländer betrogen fanden. den I'rubalsambaum in ('eylon einzuführen. um ihn zu kultivieren. muss sich da nicht der (iedanke antdrängen. es rei erfolgrer-prechenter den im eigenen Lande heimischen Myrrhenstranch anzulbanen, dessen Produlit ebenfalls hoch geschibitzt ist und stete Nachfrage findet!

\section{We ihranch.}

()ibanum ist cin anderer. im Drognengeschäft gehnändhlicher Name für dieses frummilary, desen Verwendung als Ränchermittel. bis ins Altertum zurïckreichend. hereits erwïhnt wade. Nach de'n

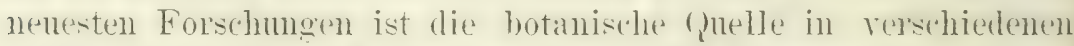
Arten der liattung Boswellia, Familie Burseraceac, za suchen. Die Mitgliteder dieser Gattmug hesitzen die folgenden gemeinsamen 


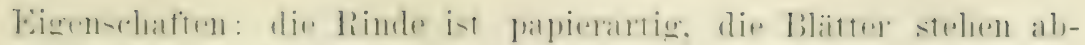

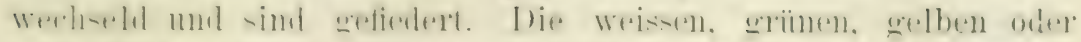

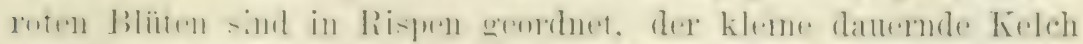

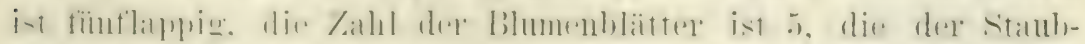

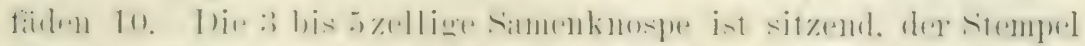

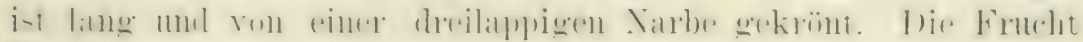
ist dreickig, dex Same platt.

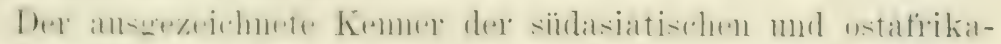

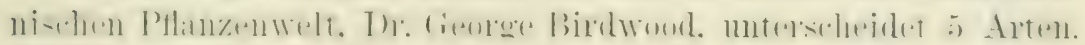

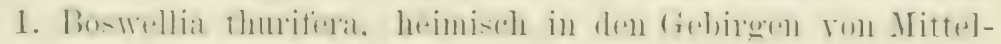
indien und der Koromandelkïste;

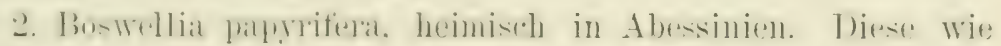

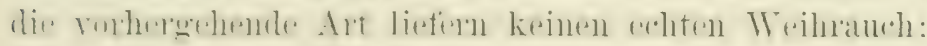

3. Boswellia Frereana:

t. Boswellia Bhan-Dajiana;

5. Bu-wellia Carterii sind die in smaliland als Yegatr.

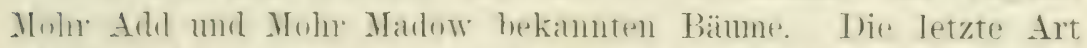

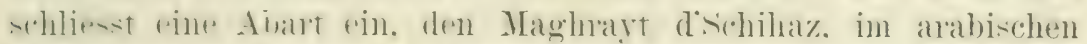

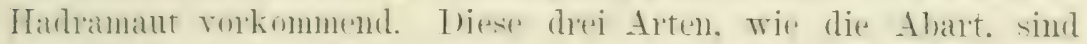
Quellen des echten Weihrauchs.

Die Bäume an der Küste ron Adel werden von Kapitän

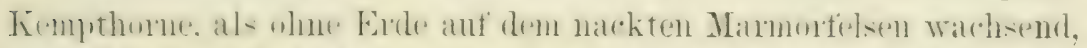

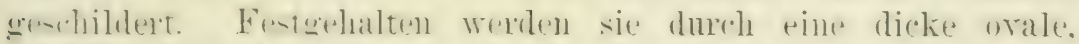

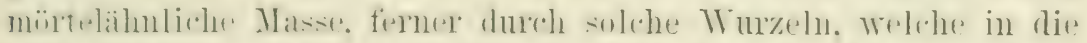

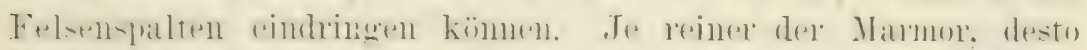

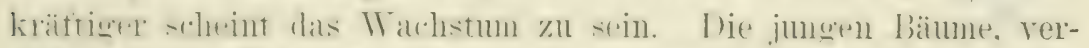

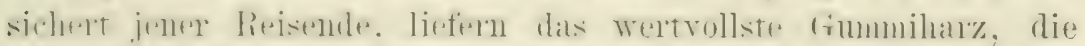

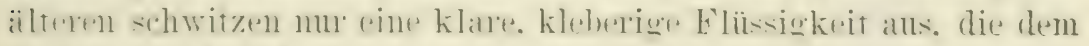
Kopallack ähnlich ist.

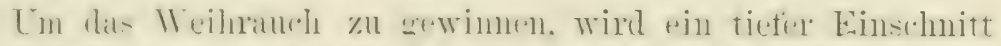

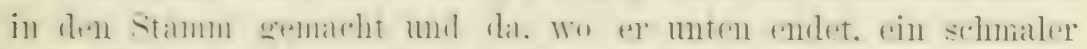

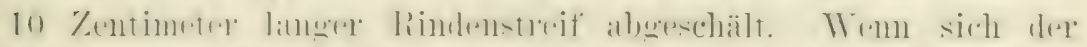

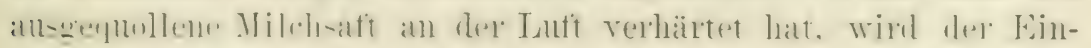

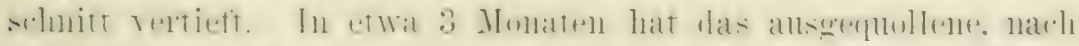

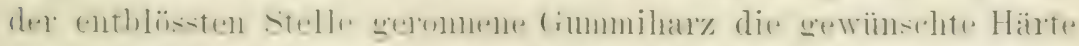

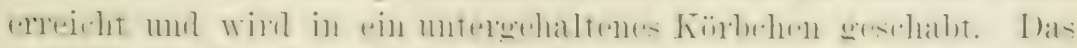

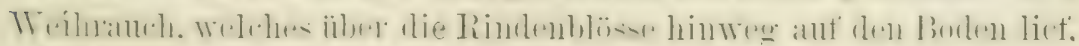

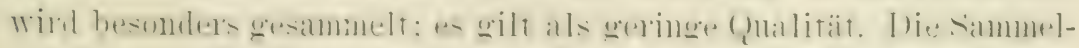

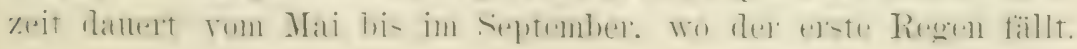




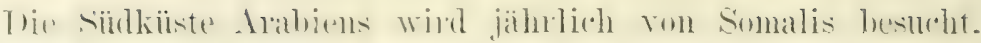

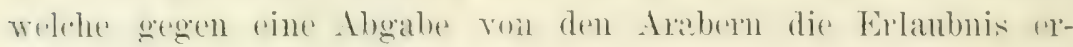
werben. Weihrauch zu ernten.

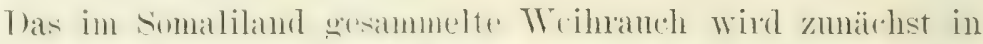
verschiedenen ()etsohatten anf Hauten gelagert und damn im fie-

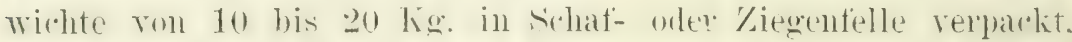
un nach der Mesise von Berbera transportiert an worden. Von da findet die Versehiffung nach Aden mol Makallah orler mit Termeidung dieses Umwerese direkt nach Bombay statt. An diesem Platze findet die Sortiermo mol Tiederanstuhr nach Europal. China und andern Ländern statt. Die immer wieder anfgefrischte Ansabe. das Weihnuch sei ein indisches Erzengnis, ist wahrocheinlich durch die Thatsache zu erklären, dass Bombay den Zwischenhandel an sich gerissen hat mol damit zur Terteilungsstelle dieses Artikels geworden ist. Terstäkt ist diese läuschmg wohl geworden durch das Produkt von Buswellia thurifera. von dem behauptet wurde. es sei echtes Weihranch, während es sich ron demselben dadurch miterscheidet. dasis es weich ist mol, auf Hanfen gelagert. eine Veigung zum sichmelzen zeigt. In den Dorfbazaren ron Thandeisch in Indien wird es unter dem Namen Dup-salai. d. i. Weihranch rom Salaibaum. verkautt, und in kleinen Pïstchen wird es nach China ansgeführt. wo es als wohlriechendes Ränchermittel dient.

Das exhte Weilnauch erscheint im Handel als halbdurchsichtige, ovale oder langrunde Körmer vder als umegelmässige Klumpen, welche mit einem weissen Staub redeckt sind, als Resultat der gegenseitigen Reibung auf dem Transporte. Die immere struktur ist formlos. der Bruch ist matt und die Farhe gellhich bis gelbbraun. Die besten Qualitäten sind nahezu farblos und besitzen einen grünlichen Hanch. einen etwas bitter aromatischen fipschmate und einen balsanischen Geruch, der bei Erwärmung klätiger wird. Treihnatuch enthält etwa $72 \%$ eines in Alkohol lissirhen Harzes, dinen beträtchtlichene Prozentsatz wasserlösliches Gummi, das angensheinlich mit arabischem Gummi ïbereinstimmt. und eine kleine Mengr farbloses. entziundliches ätherisches (i). Weihratuch bronnt mit einex hellen. Weisisen Flamme und hinterlässt eine Asche. dic rotzugsileise ans kohlensaurem halk besteht. Der hest wird gebildet ron phosphor-

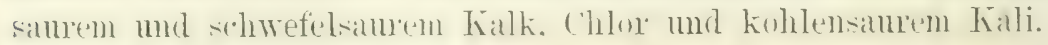


Ahwedhumgen. laksen sich aber in ihrem Verhalten zum Wasser in zwei Hauptabteilumgen trement T)ie der eines Abtrilumg

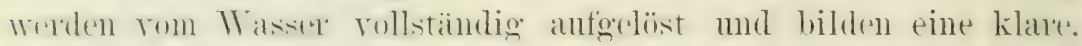

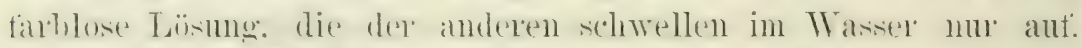

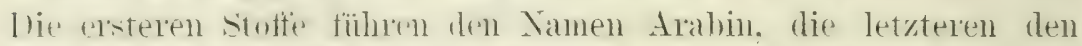
Xamen Basorin. Mit sialutersäme behandelt, liefern die Tüsungen

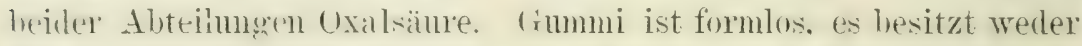
die säckchenähnliche Bildung der stärke, noch hrystallisiert es gleich Zurker. The freiwilligen Ausquellungen des Gummis deuten ant einen klankhaften Zustand der Bänme. zum mindesten ist das bestimnt utesen tïn die Akazien und die ganze Rosenfamilie. The Trasche liegt in der Üherfïlle ron saft in den jungen Geweben. Wodurch dieselben erweicht und schliesslich gesprengt werden. Ine dadurch getormten Höhlungen füllen sich mit saftigen Ansschwitzungeren. die an der Luft verhärten und das Gummi biluten. Es ist ïbrigens wahrocheinlich, dass nicht immer eine Z̈berfülle rom saft vorhanden zu sein braucht. um diese Errheimung herrorzuruten. ist es doch allen Baumzüchtern der warmen Länder wohlbekamut, dass jeder dex somne schutzlos preis-

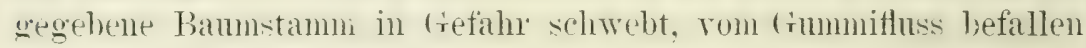
zu werden und zwar um so mehr, je juinger er ist.

Auch heiste. anstroknendr Winde kännen diess Krankheit durch Bersten des Rinde herromenten. Eine Bestätigng dieser Antïhnmgen liegt in der 'Thatsache. dass alles in den Handel kommende Gummi in warmen Ländern produziert wird.

In der roinsten Form wird Gummi ron verschiedenen Akazienarten erzengt. muter welchen Acaria arabica und A. Ehrenbergii den ersten Rang einnchmen. Minder wichtig sind Acacia rela, A. tortilis und A. specinsa. Iniese Alten kommen im nordöstlichen Atrikil unc? anf dem Festlande des siidlichen Asiens ror. Thr Produkt, das meter dem Namen arabicches Gummi in den Handel kommt. Wurte seither zum weitans grösten 'Teile aus dem Sudan

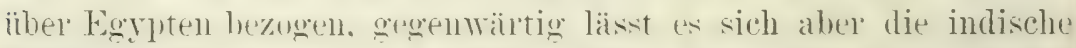
Forstrerwaltume angelegen sein. steigend an der loekmo des Berlarfs teilzunelmene. Sie betreibt die Anptlanzung von Acacia atahica, Weil diese Alt, altsiser dem stets hegehrten Gummi, eine (ierberrinde liefelt. Welche in Indien wuter dem Xamen Babulrinde sehr geschätzt ist. 


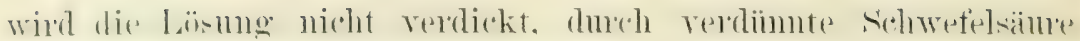
wird sie in Dextro-Glukose verwandelt.

berbereigummi stammt vou der in Nordafrika beimisclent Anacia enumbitera. We ist dunkelfarbig und wird in der Feinbäckerei benutzt.

Geddagummi ist rine geringere (qualitait des Berbereigummis.

Ints anstralisehe Gummi wird ron den Gerberakazien (Avaria decourens, a. mollissima und a. dealbata) produziert, deren Kultur in 2. Bande der tropischen Agrikultur eingehend geschildert ist. Es ist geringwertiger wie die vorhergenannten Gummisurten und kommt nu in den Tebereien mol Kattundruckereien zur Verwendumg. Das gleiche ist von dem siidafrikanischen Gummi zu sagen. welches von Acacia karru stammt.

Das ostindische Gummi ist von verschiedener (Pualitat. T)as Beste wird über Bombay exportiert. Bengalen erzengt eine mittelsute und Oomrarattae eine geringe Qualität. Alles ostindische frummi ist dlumkelfarbig und geringwertiger wie das arabische trummi, wird aber trotzdem bereits in Mengen ron 250 onou Kilogramm jährlich ausgeführt.

Traganth wird ein Gummi genamnt, das aus dem viamme und den Ästen des dornigen Strauches. Astragalus tragacantha, quillt, welcher in Torderasien heimisch ist. Friher wurden nu fieiwillige Ausquellungen gesammelt, die häufig brämlich war’n. segenwärtig macht man ïber dem Wruzelhalse Einschnitte und gewinnt dadurch die feine, weisse, Hockige Qualität, welche sn hoch im Handel geschätzt wird. Die Ansquellung findet vorzugsweise nachts statt und wird beginstigt durch trockenes, heisses Tretter: Die Verschiffung geschieht hanptsächlich über smrrua. futes Traganth erscheint in hoinigen. biegsamen und doch ziihen. diunnen, gedrehten Flocken ron mattweisser Farbe. Es ist halbdurchsichtig. gertuchlos und schmerkt schwah bitter. indem es im Munde zerfliesst.

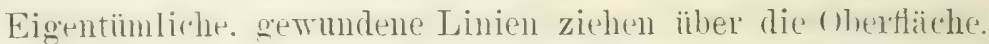
Temn bei 100" C. extrocknet. verliert es etwa 14" "Wasser und

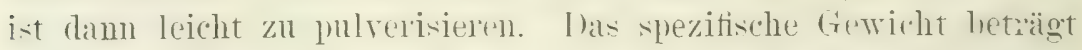
1.384. In Wasel schwillt es anf mol selbst mit 50 (imwichtsteilen dieer Flüssigkeit vermischt. bildet es noch einen dicken schleim. Nur trilweise ist as in Wasser lïslich, wis anch seine 


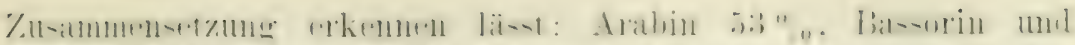

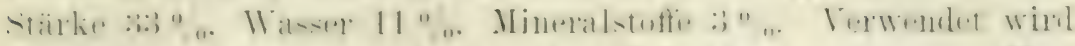

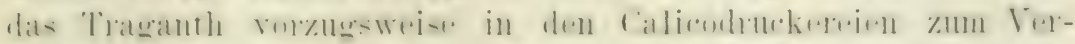

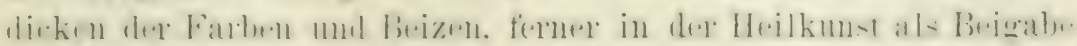

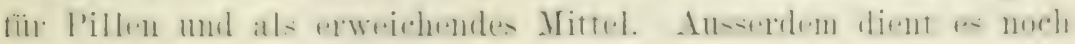

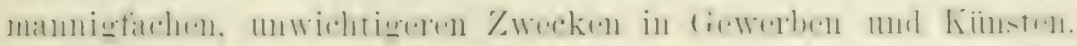

kuthagummi is änsorlich dem Traganth ähnlirh. alwer

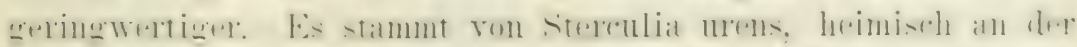

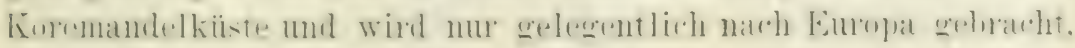
um als Ersatz des 'Traganths zu dienen.

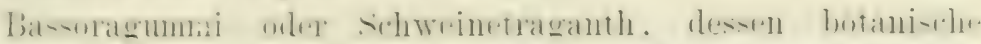

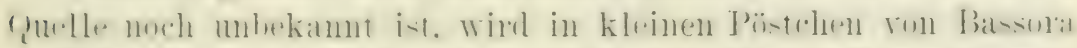

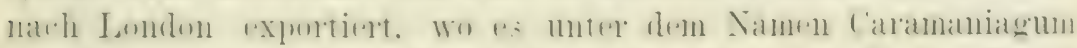

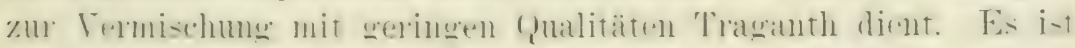

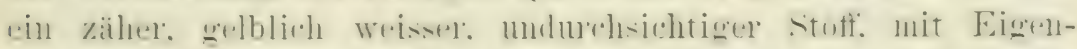

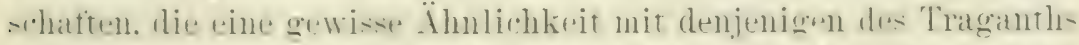

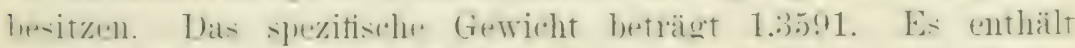

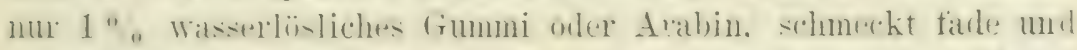

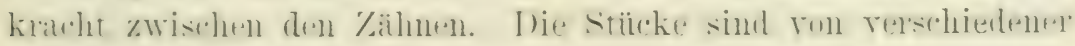
Grösse und Form.

Itep afrikanishe Traganth stammt fon stereulia tragantha.

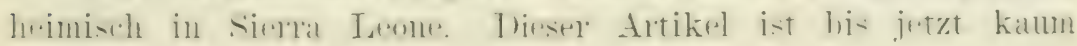
gekannt.

\section{Ahornzucker.}

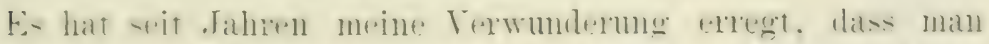

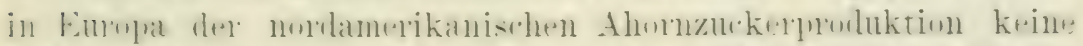

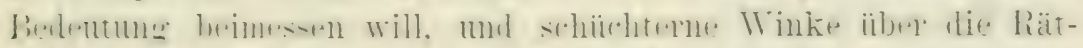

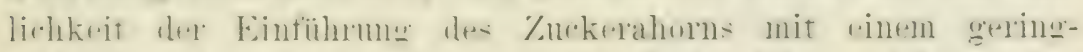

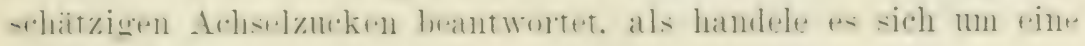
unklare 'Träumerei.

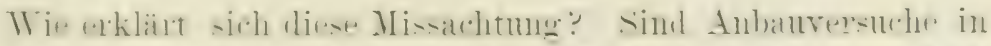

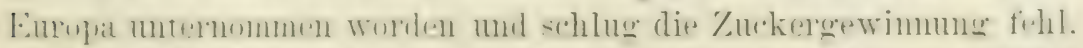

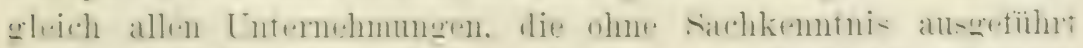

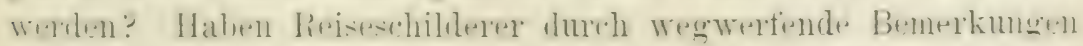

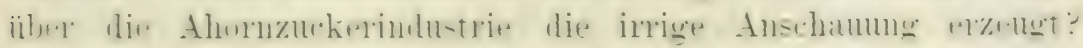

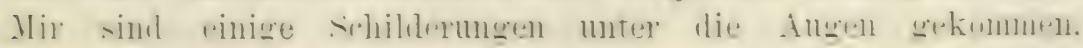

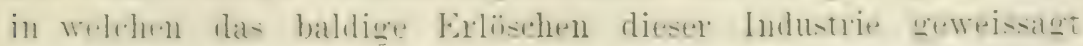

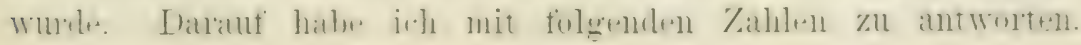




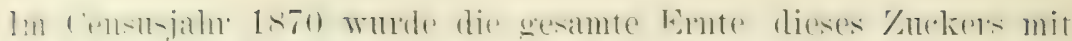

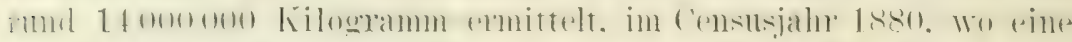

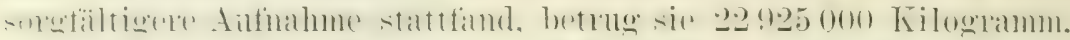

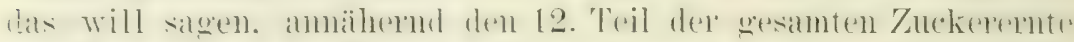

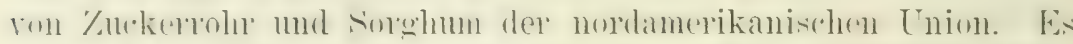

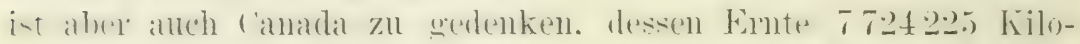

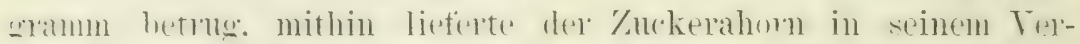

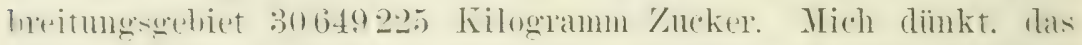

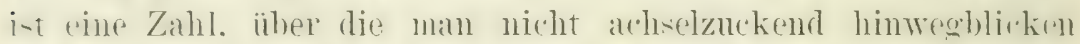

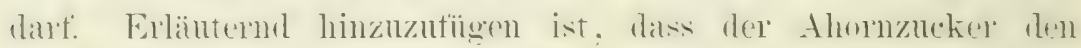
vollen IVert von Rohzucker besitzt mul dass nicht die wanze

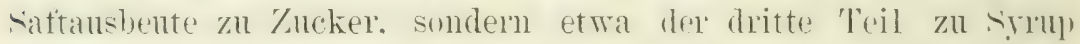

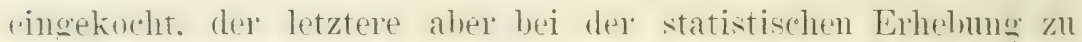
Zurker mugererhnet wurde. Alomzurker wird niemals rattinist.

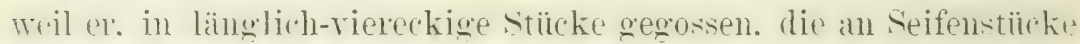

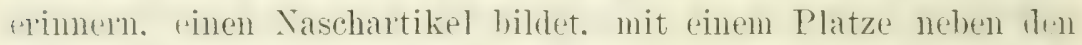

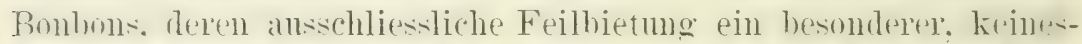

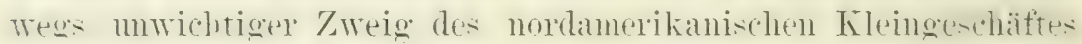

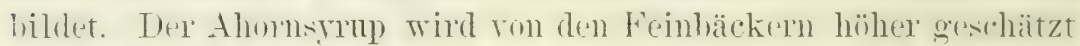

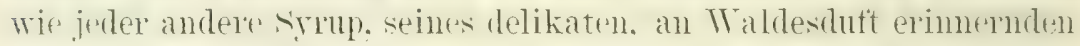
Aromas wegen. Torzugsweise bringt inn dor Stant Tormont in geschmackvollen Verpackungen in den Handel.

/um richtigen Bemteilumg dieser Tudustrie ist noch hervolzuheben. dass der Zuckerahorn (Acer saccharinum) in ganz Nurdamerika, istlich vom Missouri und nörllich bis fixst zur Jordertuze der Provinz puebec rorkommt und eines der geschätztesten Werknud Bremnhölzer liefert. dahei nimmt er einen hohen Rang as Allet- mol Zierbanm ein. Al. Maldbaum wird ex noch an einel anderen Stelle dieses Buches besprochen.

Wind er nicht rol seinem 20. Lebensiahne angezaptit. und finden dir Anzanfungen mit richtiger Bescheänkmo mud nachträglicher Terstopfung der Zaptlöcher statt. dann becintriuchtigt die

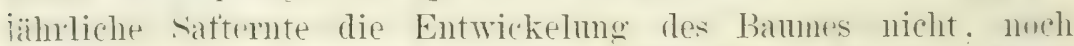
kiirzt sie sein Iaben ab. das sich anf 200 . Tahe erstrectien hann. Die fiäte des Holzes loidet weniw nut. eigentlich nul in Bezug ant stärke. denn die Zapflioher verheilen in 2 Jahlen und lassen um eine Sarbe zurick. Tle safternte findet in einer Jalueseit -tatt. Wodie landwirtschaftlichen Arbuten tast vollständig l'uhen. Den

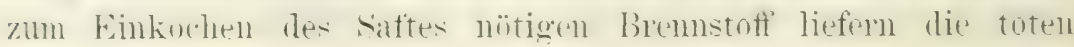




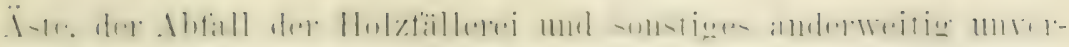

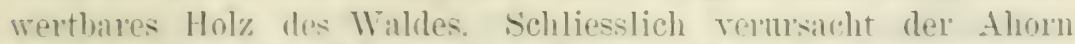

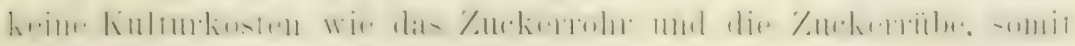
ist die \%uckerernte nahezu als reiner Tebuewinn der liultur eines wertwollen Waldbanmes zu betrachten. Fïge ich hinzu.

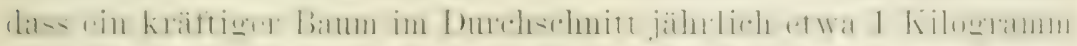

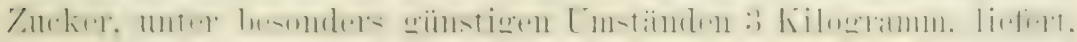

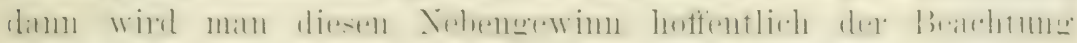
wert halten. Wenn auch eine bis zu 15 hilogramm colhende

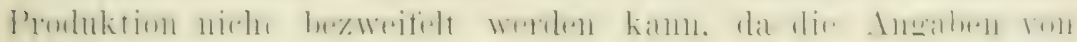

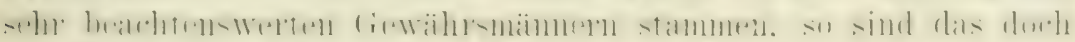

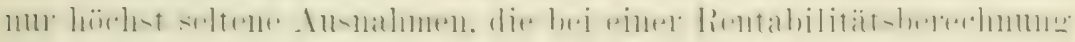
nicht in Betracht gezogen werden diurfen.

Voch sind nicht alle Vortheile dieser. Industric genamnt.

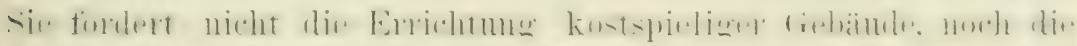

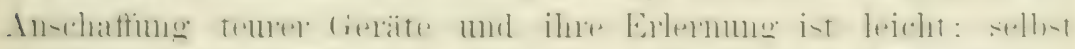

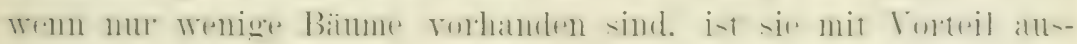
fïhrbar:

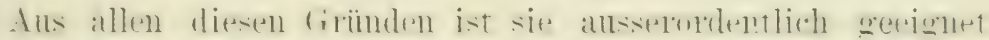

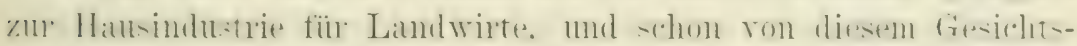

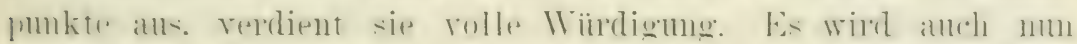

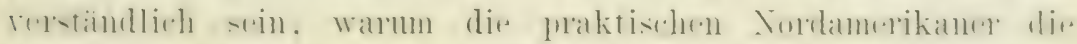

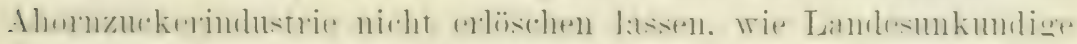

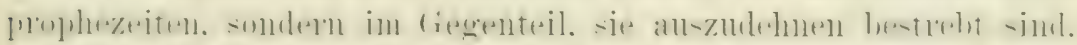

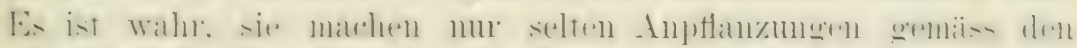

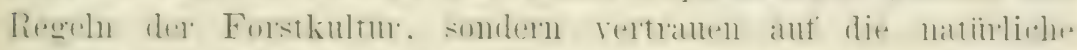

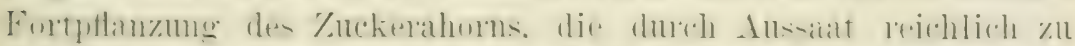

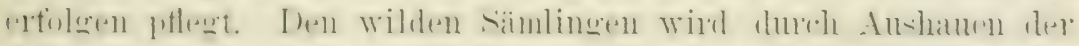

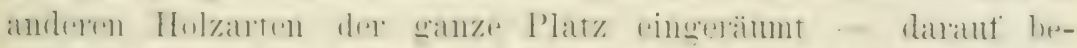

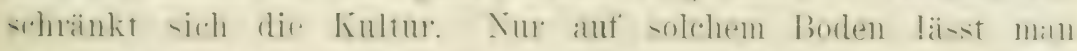

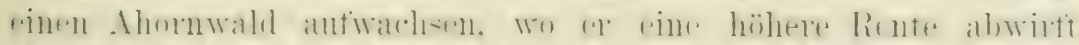

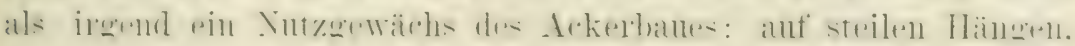
steinigen Bergrücken, kiesigem Ufergelïnde u. s. w.

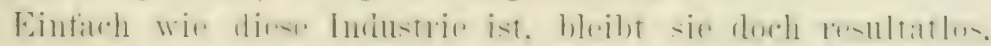

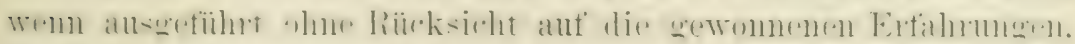
die hier in gedrängter Kïirze folgen.

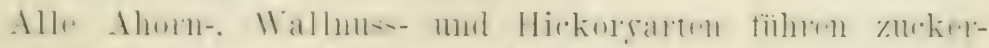

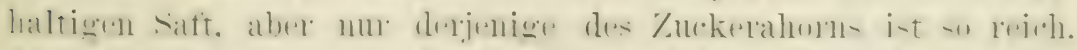

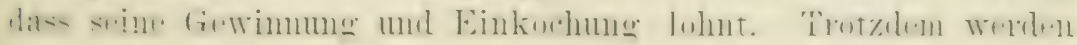


von einigen anderen Ahomaten quingfitgige \%uckermengen in

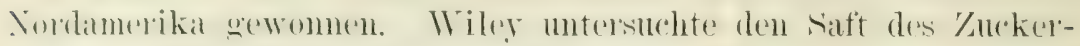

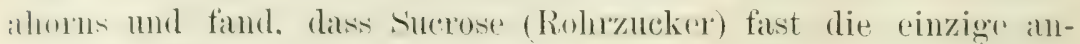

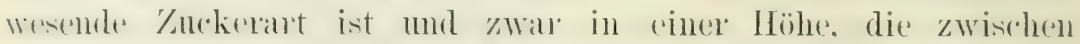
1.95 his $3.5 \%$ schwankt. Eis sind fermer anwesend 0,0088 bi: $0.0113 \%$ Eiweissstofte, keine stäke, 0,00005 bis 0,0050"Apfel-

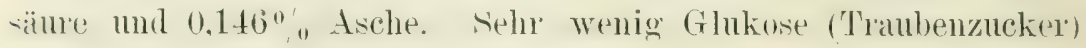
fand sich gegen Ende der Erntezeit vor.

Anf dem fenchten Boden ron Niedermgen liefert der Znckerahorn einen so wässerigen Saft, dass sich dessen Einkochung nicht lohnt. Anf trockenen Berghängen ist der geeignete und bevorzugte standort dieses Bammes, wie auch darans hervorgeht, das"r in mehreren Gegenden Felsenahorn genamnt wird. Der Boden -oll nicht zu seicht sein, kiesig und kalkreich ist erwünscht, ein starker Kaligehalt aber eine Bedingme. Tie ans der Aschenanalyse des Holzes herrorgeht. hat der Zuckerahorn ein so starkes Talibediufnis wie die Buche. was wohl zu beachten. wurde doin frïher vier Fünftel der exportierten Pottasche aus dem Holze des Zuckerahorns gewomnen.

Eine glatte Rinde ist das Wahreichen starker Saftproduktion. an kesselfürmigen standorten ist der saftfuss reicher wie an knollenförmigen.

Bämme. die auf südlichen Hängen stehen, liefern einen l'elheren Saft. wie solche auf nördlichen Hängen mol viel reicher ist dex saft der Räume, die am Rande des Waldes. uiberhaupt der vollen Einwirkung von Licht und Luft ausgesetzt sind. wit derjenigen, die gedrängt und schattig stehen. Eine befriedigende Zuckerernte darf daher nur von lichten Wäldern auf somnigen Hängen oder ron einzeIstehenden Gruppen, eine noch bessere ron Freilandsbäumen erwartet werden. Tch lenke die Aufmerksamkeit anf die Besiumung der Gebirgswege mit /nckerahornen, die jedenfalls ein nützlicherer Exsatz für die Obstbämme sind, wie dir Pappeln, Ebereschen mo ähnliche Bämme. die man zu diesem Zwecke bevorzugt.

Eine Bedingung ist ron gröister Wichtigkeit: zur 'Zucker'hildung ist Frost nötig - wo kein Frost auftritt, gibt es keinen Ahormzucker. Im Zuckerrohr und der Zuckerribe besurgt die some die Tomwandelung der in den Zellengefïssen antgespeicherten stärke. im Zuckerahom aber der Frost. Zunichst dadurch. dam 


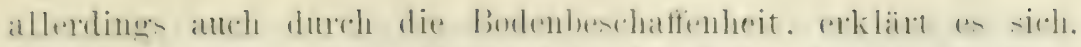

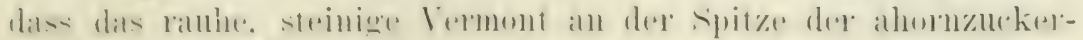

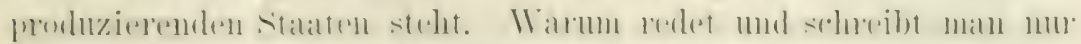

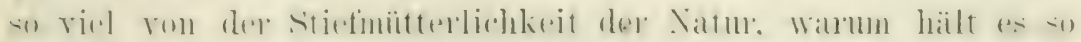

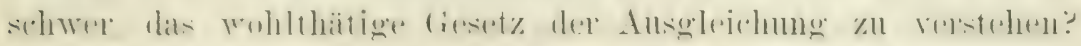

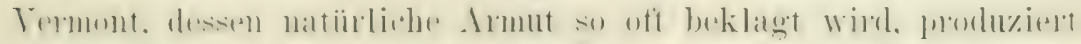

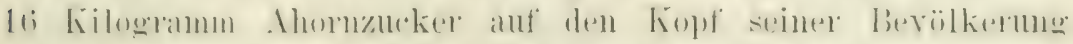

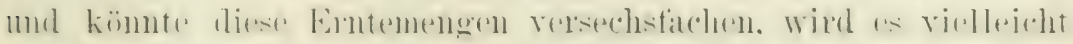

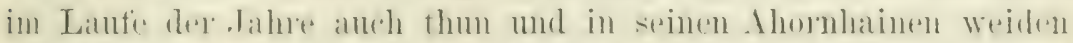

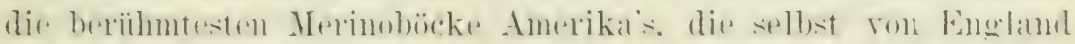
und Australien gekauft werden.

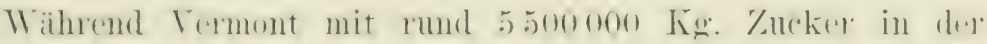
statistischen Talmelle ver\%elehnet steht. sind die sïdstaten wo

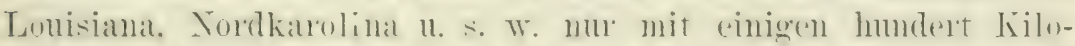

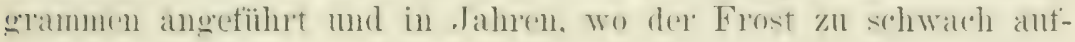
tritt, findet iiberhaupt keine Ernte statt.

Lie Erfahrung leht: je kialter und trockenex der vorhergehende Winter war, desto ertragreicher sind die Ahornbäums.

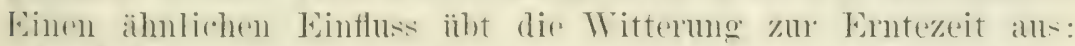
schofte 'Temperaturwechsel wirken giunstig. Wem anf einf kalte

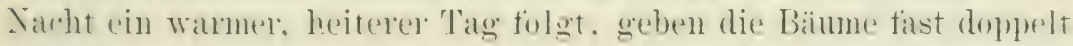

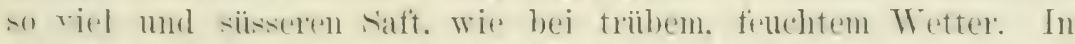

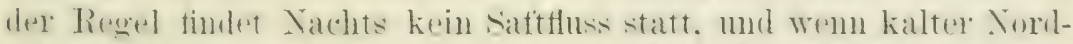

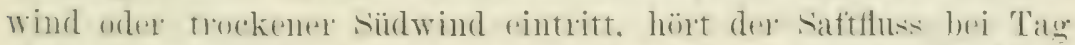

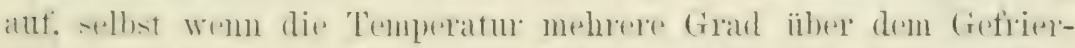

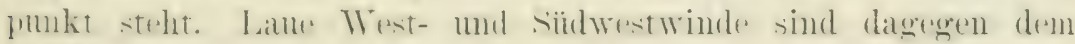
Saftthuss sehr gimstig.

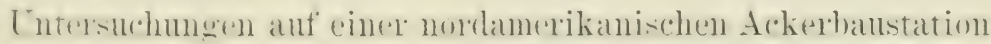

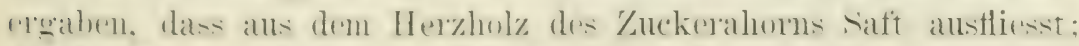

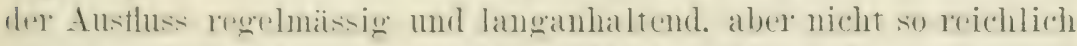
wie rom splint ist: ans rimbenenthlïsten stellen fliesst der sitt

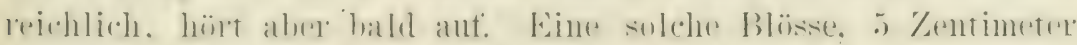

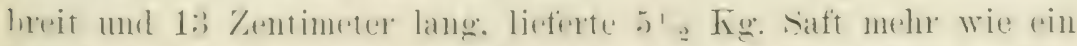

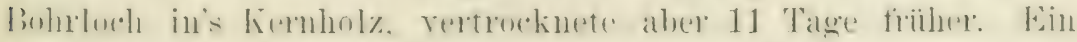

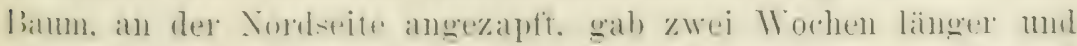

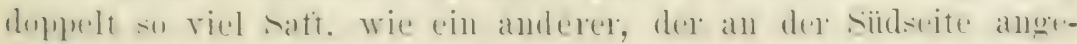

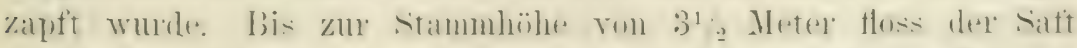

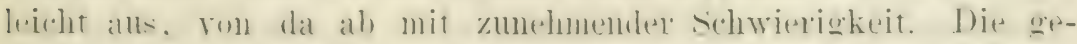

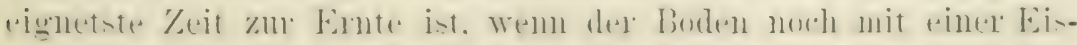




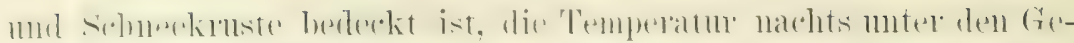

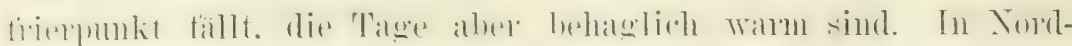

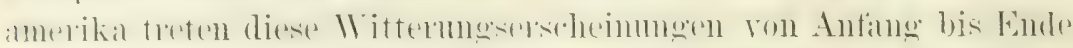

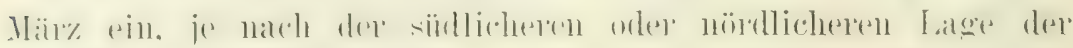
Produktionsdistrikte.

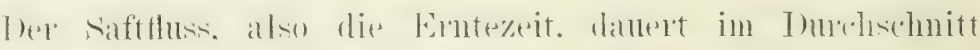

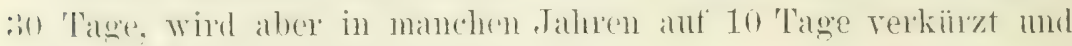
in anderen auf 45 Tage verlängert.

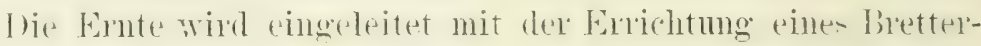

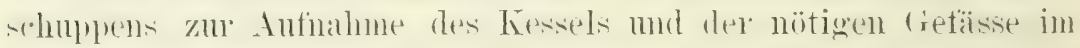
Tralde. dem eine wesenthelo Bedingung der ertolgreichen Zuckersedered ist die möglichst lasche Eindampfung des sattex. Dersethe muss mrermedllich einge Zeit in den Zapteimern bleiben, dals Silmmeln in grösseren fefäsen nimmt ebenfalls reit in Anspruch, fände damm noch der Transport nach dem entfernten Wrirts-haftsombäule statt, würde inzwischen die Gïhrung nud damit der Vuderb einsetzen. Dahley ist en motwendig. dass die Finkochmng im Walde geschieht.

Fine nicht minder wichtige Bedingune ist peinliche Reinhaltung aller zur: Verwendung kommenden Geräte. Dal Holzgefäse minheroll rein zu hialten sind mo bei der seringsten Ternachlässigung in dieser Beziehmo Giarpilze in ilne Poren autnehmen. $\therefore$ ist nan fast allgemein zum (rebratuche von Zinngefässen uibergegangell.

Etwa 50 bis 75 Zentimeter über dem Boden rerden mit einen Bohrer von $1^{1}$. Zentimeter Durchmeser die Zapflöcher gehohrt. Die Frfahrumg hat gelehrt, dass es, sehr starke Bämue ansqenommen, keinen Torteil lietet. cinen Bam an mehr wie tiner stelle anzuhohren. demu das Ernteresultat wird durch die Vermelnumg der Zapflöcher nicht erhöht, wohl aber merden dem

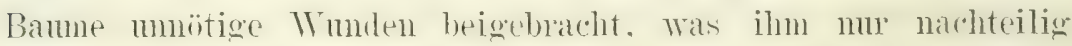
sein kamn. Dem Zalutloch sibt man cine aufwärts ecelichtete schwache Schräge. damit rew saft leicht abfliessen kamu, hohrt es nicht tiefer wie $2^{1 / 2}$ \%entimetor in den splint mol niemals an dex

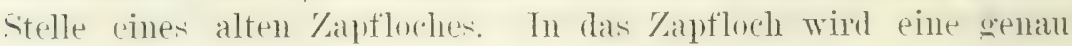

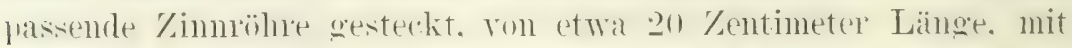
einem metallenen Hakell. an welchen der kleine Zinneimer ge-

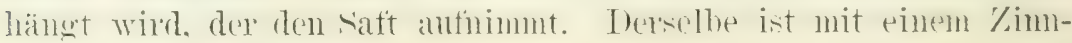




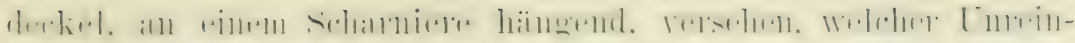

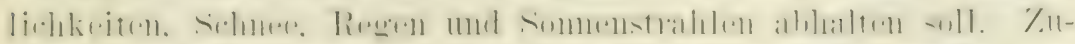

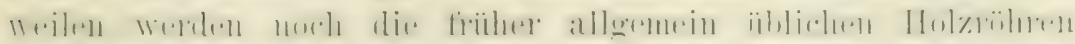

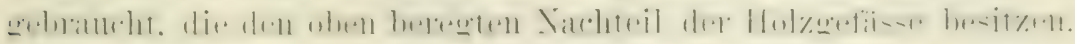
Die (iefahr, dass sie Gïrpilze beherbergen, ist so gross, un gor-

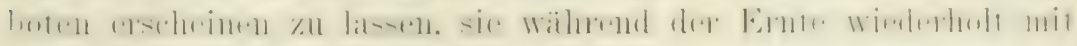

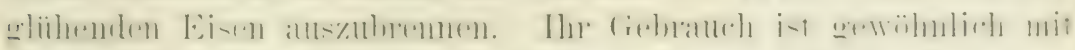

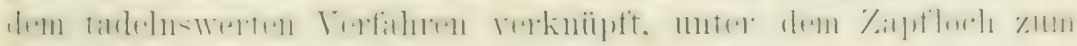

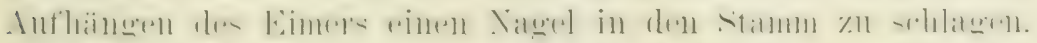

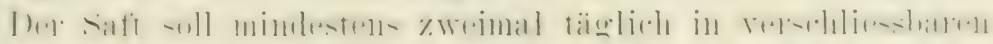

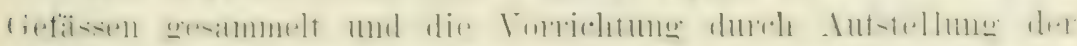

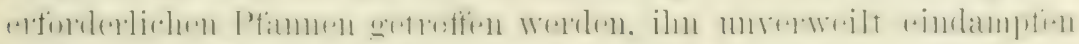

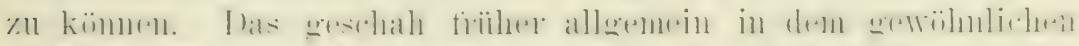

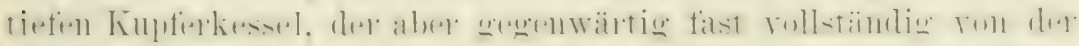

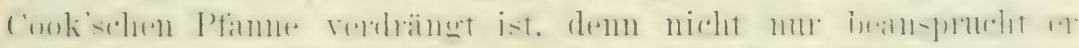

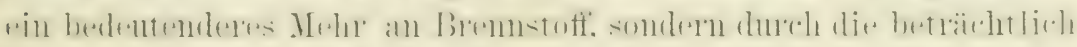

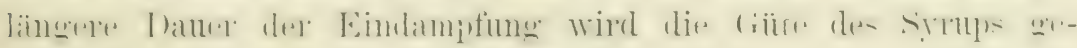

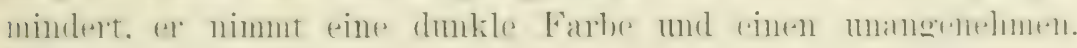
brenzeligen Geschmack an.

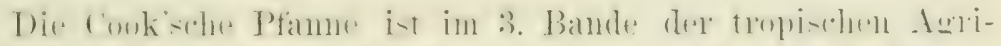

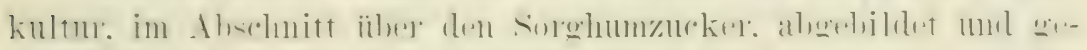

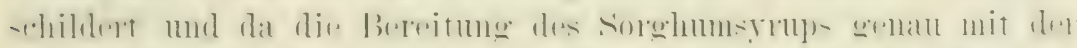

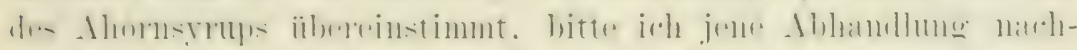

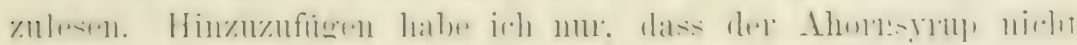

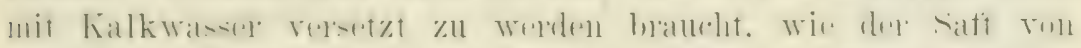

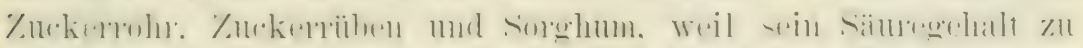

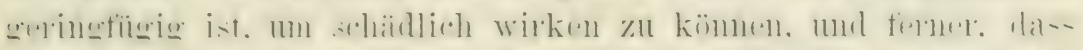

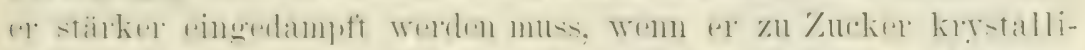

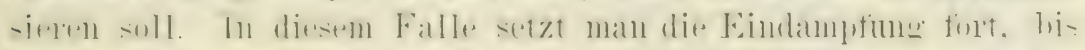

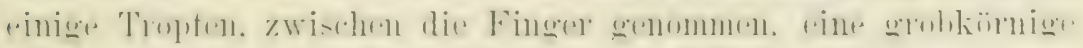

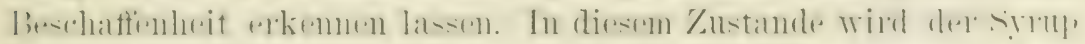

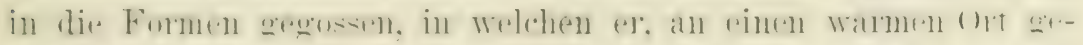

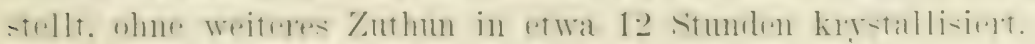

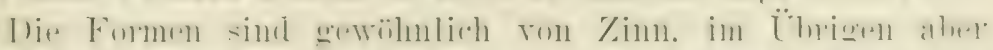
nivht

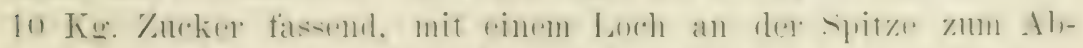

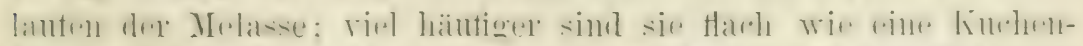

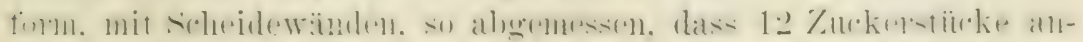

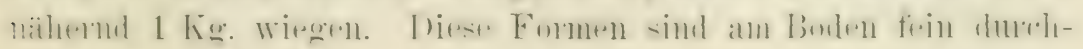




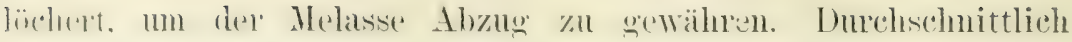
wird $1 \mathrm{Kg}$. Zucker von 48 bis 56 Liter Saft gewonnen.

Wo dex thormancker nicht bereits eingeburgert ist. rate irh « hei der bereitume von syrul bewenden zul lassen, fü den es nirgends an Abnehmern fehlen wird. In Termont wird der Ahornsyrup in demijohnförmigen Messingkamen rerpackt, die genan 1 tiallone (3,1 Liter) und ${ }^{1}{ }_{2}$ (iallone fassen und eine geschmackvolle Etikette tragen mit dem Nimen des Produzenten. Hochfeiner Syrup wird in zierliche Messingflaschen gefiillt, die ein Quart (1).9 Liter) fassen und zu je ${ }^{\circ}$ oder 12 in eine Kiste rerpackt werden. In allen Fällen mïssen die Flaschen sorgfailtig gelïthet und rersiegelt sein, um den srrup ror dem teilweisen Krystallisitelen zu bewahren. Der durchschnittliche Preis, welcher seit 1880 den Produzenten für sirup bezalilt wurde, betrug 3.36 Mrark pro Gallone.

\section{Querzitron.}

Dieser, stets in lebhafter Nachtrage stehende Artikel ist das Lrodukt der Färbereiche (quercus tinctoria), welche in der nordamerikanischen Tnion, östlich ron Missomi, von Ten-England im Sorden bis Georgia im Süden, obgleich hier nm in beträchtlichen Erhebungen. verbreitet ist. Sie ist einer der stattlichsten Bäumt der Tälder. nicht selten erreicht sie eine Höhe ron 30 Meter, bei rinem stammdurchmesser ron 1 Meter. Del Stanm ist mit einer ziemlich dicken, tiefgefurchten, dunkelbrannen, fast schwarzen Rinde bekleidet. Was Teranlassung zu dem Namen schwarze Eiche in manchen fiegenden gegeben hat. Nach dem Abfallen del Blätter. bietet die Rindenfarbe ein anffallendes. sicheres Erkemmungzeichen für diese Eichenart.

Die Blätter sind gross, fünflappig. tief eingeschnitten, doch nicht so tief wie die der nahverwandten Scharlacheiche, ath sind sie weniger glänzend grïn, und ihre (oberflächen sind mit einer Mrenge kleiner Höcker bedeckt. Die Blütezeit ist im Mai; jeder zweite Tahr trägt dieser Bam auf dicken, schmppigen. tlaubenartig beisammenstehenden. kurgestielten Techerchen rumbliche. zur Hailfte ron den Bechem bedeckte Ficheln. Anssertem ist der Banm merkwiirdig. Wegen der zalhlreichen, ron Insektenstichen herrührenden Galläpfel. 


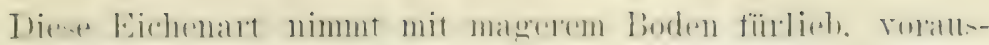

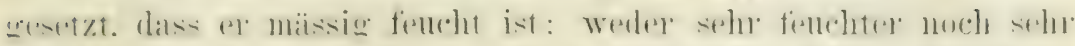

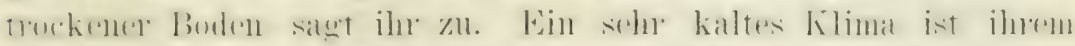

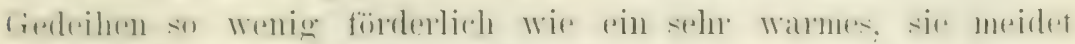
also, im Klima wie im Boden, die Gegensiatze.

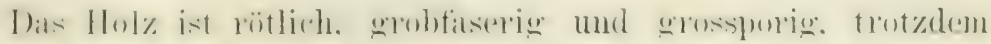

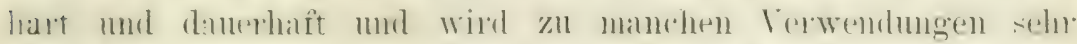

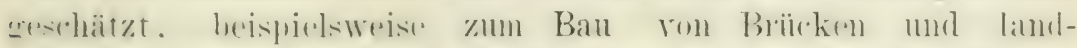

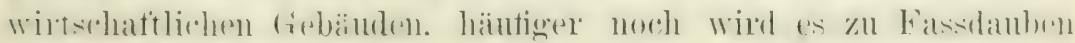

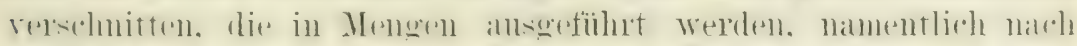
Ilestindien. Wu maln sie zu Zuckerfisisern zusammentïgt. Anch als Bremnholz ist es vorzïglich.

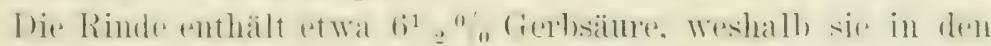

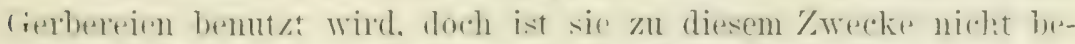

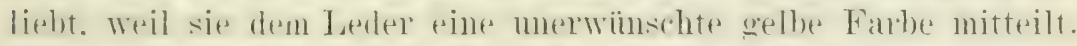

Sie thut das vermöge pines farkstoffes, der rolzugrweise im batst. aber alloh in den allschliessenden T'eilen der Borke enthalten

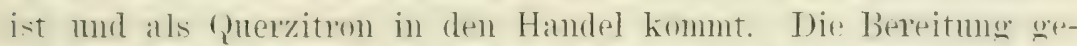

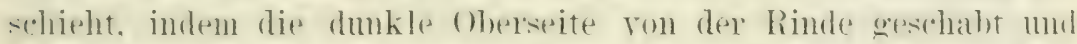

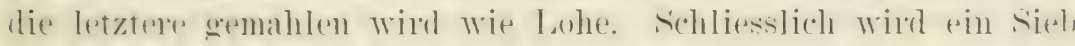

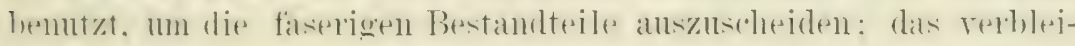
bende grobe Pulver ist das Querzitron.

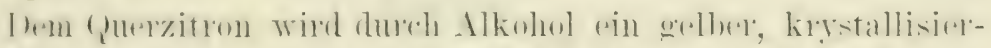

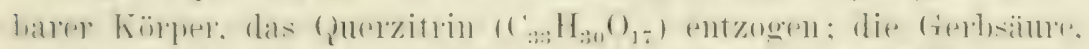

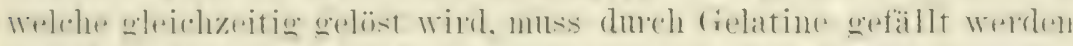

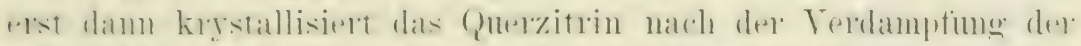

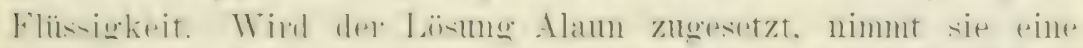

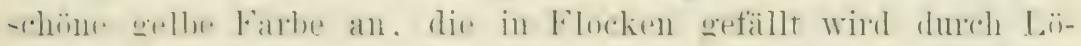

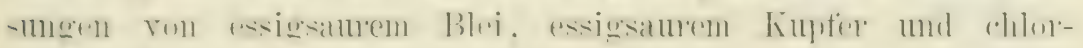
satuem $/ /$ inn.

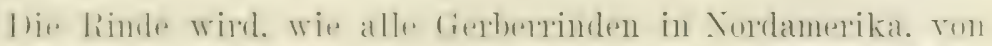

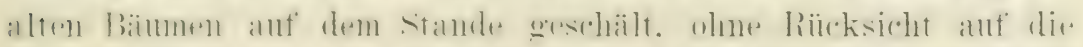

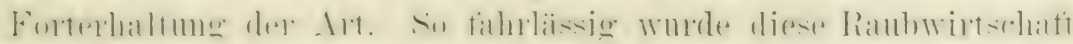

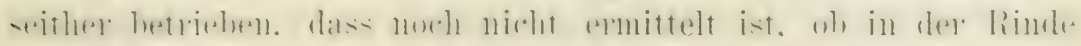

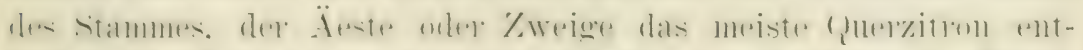

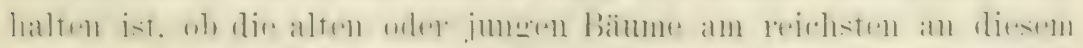

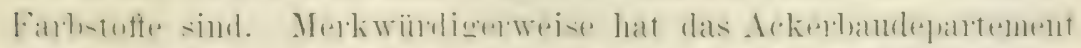

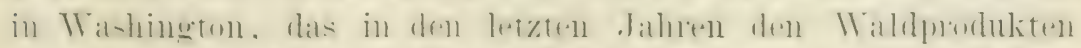

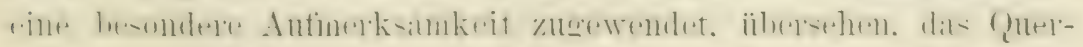




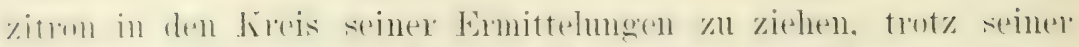

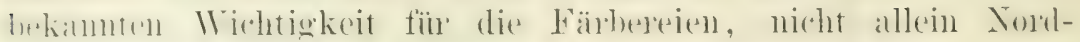
amerika's, sondern anch Europa's.

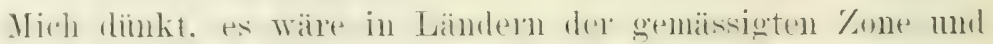

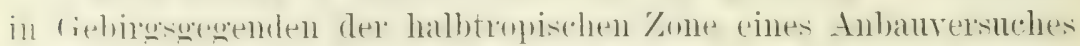

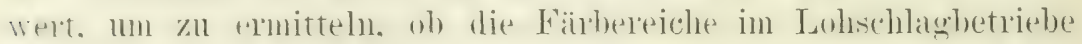

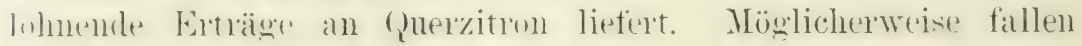

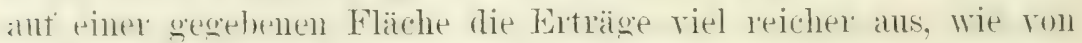
Ieiten bämmen. mönglich ist es selbst. dass sich der Lohlosehlag-

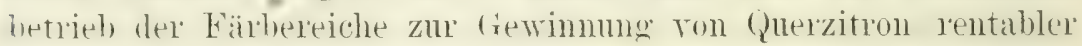
sweist. wit derjenige der Sommer- oder Wintereiche zur Ge-

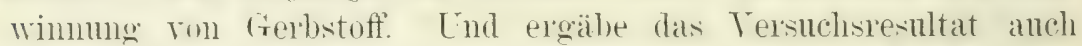
mu eine gleich hohe Rentabilität. wïrde die Färbereiche doch die Einfïgung in die Forstkultur verdienen.

In Frankreich ..soll“" ein Anbanrersuch mit dieser Eichenart motemommen worden sein. doch sind die französischen Fachschrifteu daribler so solnweigsam. dass ich an der Wahrheit zweifele. End

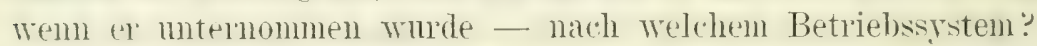

Querzitron wurde im März 1887 in Hamburg wie folgt notiert: Philadelphiagualitäten 6.25 bis 6.50 Mark, Baltimorequalitäten s bis 7 Mark pro 50 Kilogramm.

\section{Kermes.}

Fin anderer Farbstoff. der als Tebenprodukt des Vialdes selten kann. aber eine viel geringere Bedentung wie das Querzitron besitzt. wird zuweilen Scharlachbeeren. häntiger jedoch Lémes genamnt. Seit rordenklichen /eiten wird er zun Rotfärben

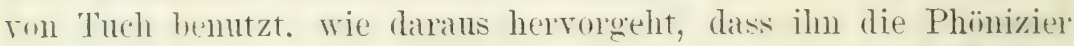
als 'Tholat. die tiriechen als focous und die Araber als Kémes kannten. Fhe die corhenille in Europa hekannt wurde. spiclte (") in der Färbesei eine wichtige Rolle; seitdem ist el durch diese

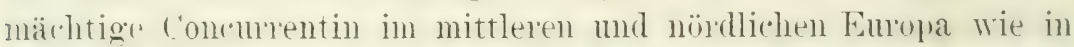
Sordamerika vorlö̈ngt worden. bis anf eine geelegentlich muter-

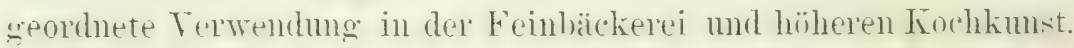
In sïdemopa findet noch eine mässige Benutzung der Kermes in

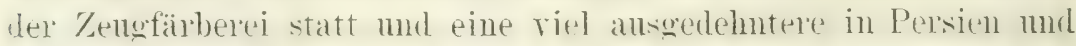
Indien, wo dieser Farbstoff hänfig ist.

liermes besteht aus den getioteten Insekten coccus itiois.

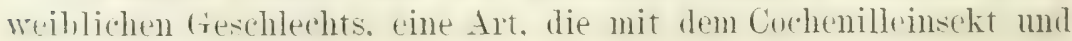




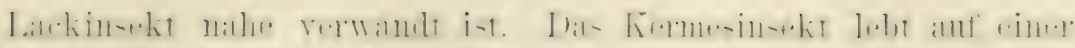

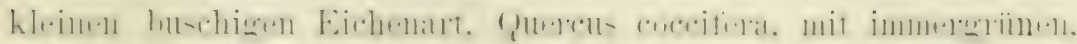

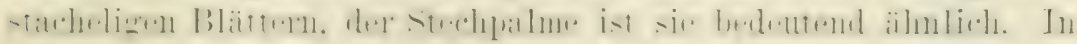

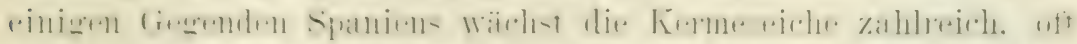

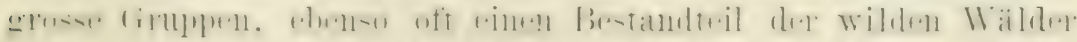

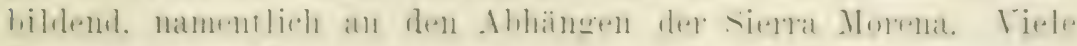

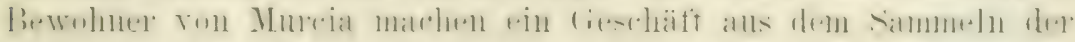

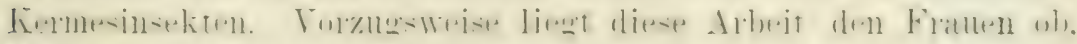

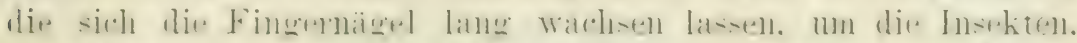

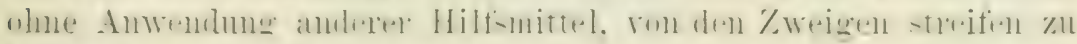
kömmen.

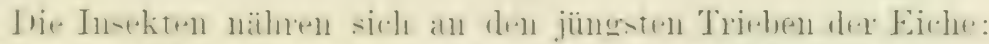

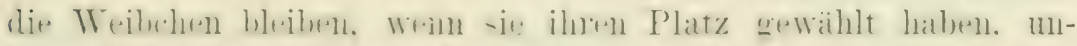

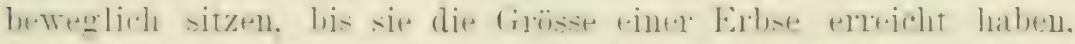

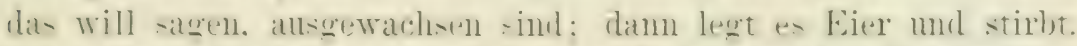

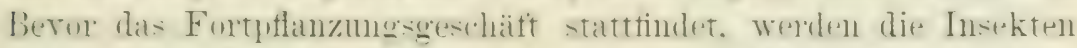

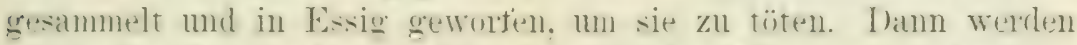

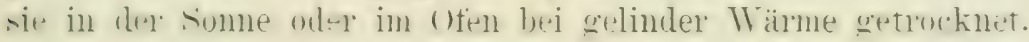

ln Europa ist nath spanien friechenland dats wirhtigete Produktionsgebiet.

Thotzlem dieser Farbstofi in Eurna gewommen wird. ist seine Herkmutt ron der genanuten Insektenalt erst in tutane

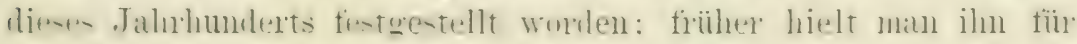
die Samenkörner einer Pflanze.

\section{Kino.}

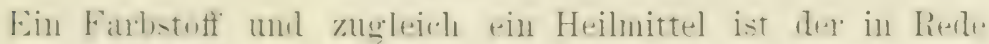

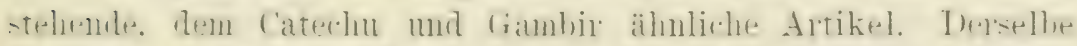

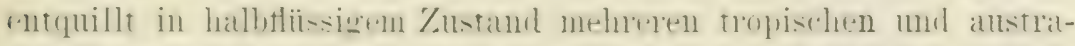

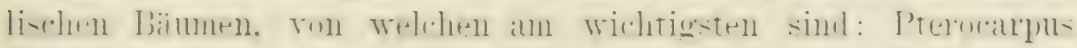

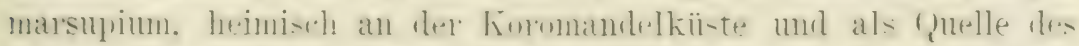

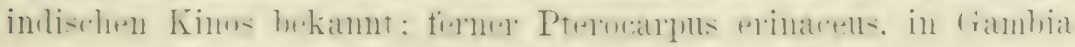

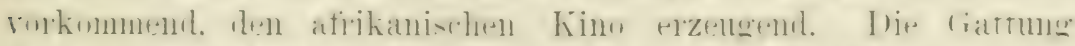

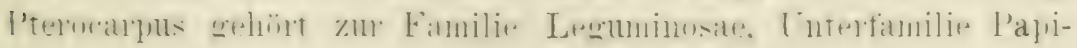
lionaceae.

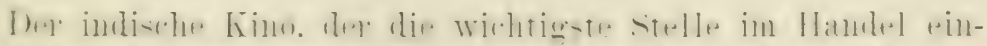

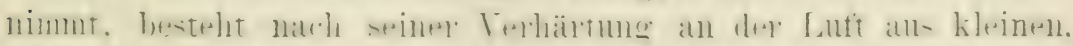

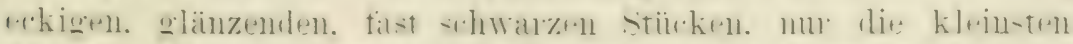

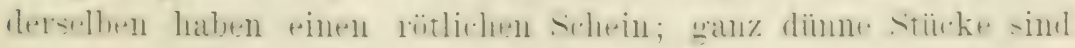




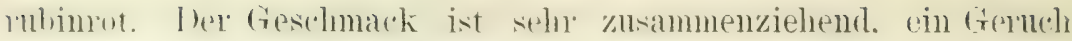
ist nicht bemerkbar, die stiicke sind spö̈d und lassen sich leicht pulverisienem. Bengalkino ist ein ämlicher Artikel, erzengt ron Butea fiondosa.

Das dunkelrote. formlose Botanybaikino ist das Produkt ron Encalyptus resinifera; noch eine Anzall anderer Encalyptusaten 'nthalten diesen Stoff. wie des Xäheren in der sichildermo dieser Artengrupe in einem anderen Alschnitt dargethan wird. Gerbsïnre und (atechusäne geben dem Kino die zosammenziehende Eigenschatt. rermöge welcher die Terwendung in der Heilkunst. stattfindet, vorzugsweise gegen hartuärokigen Durchfall und rexwandte Krankheiten.

In Indien wird Kino anscedehnt in der Fïrberei angewendet, num Banmwollstoffen die gelblichlraune Farbe zu geben. welche als .Nanking gekannt ist.

Das Butanyluakino winl ron den anstralischen tierbern anderen (ienhstoffen beigenischt. Wenn sie ant die helle Farbe des Leder's kein (rewicht legen. denn das Kino gibt, moemischt angewendet. dem Leder eine unerwïnscht dunkle Farbe. 


\section{Die Farbhölzer.}

\section{Blatuhol\%.}

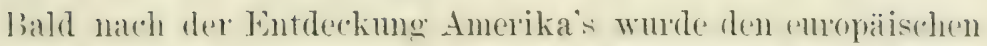
Märkten aus mexikanisehen Häten ein dunkeluotes Falbholz zugefiiht. mit einel Anpreismo zum Blaufärben. Eine fremdliche Anfiahme fand dieser Artikel zunächst nicht, weil die mit ihm ryengten Farben sehr unbestandig waren, ging man doch in England so woit, den Gebratuh während des langen Zeitranus voll 1581 his 1662 erestzlich zu verbieten. Als aber die Färbu danerhatte Farben mit diesem Holze hervorzurufen lernten, in Folge einer besseren Kemntnis seiner Eigenschaften wie durch die Eutderkung geeignetro Beizen, wich der anf ihm lastende Bann mond eselangte zu eines Verwendbarkeit, wis nur norh wenige andere Farbstofte, in der Wollenfärberei steht es in dieser Hinsicht sogar unerreicht da.

Dieser Artikel ist das Produkt von Hemaloxylon camferhianmm, Famile Legeminosar, cines in Mexiko, Zentralamerika. ('uba, sim Inmingo. Janaica und pinigen kleineren westindischen Inseln vorkonmenden Bammes, der niemals höher wie 12 Metrer wächst, gewöhnlich aber nur eine Höhe rom li bis \& Meter rereicht. Die Blätter sind pararier getiodert, die blïten sind in Thanben geordnet und äbrlagen die Bläter. 1)er helch ist ror

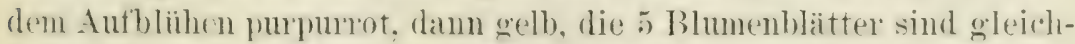
falls gelb. T)ie lanzettlichen Hülsen springen nicht an den Vïhten, sondern in der Mitte der Klappen der Länge nach ant. Der splint ist erelblich, er wird mit der linde als nutzlos rom dem

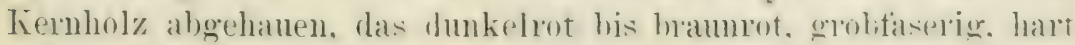




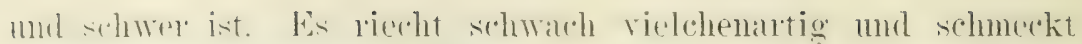

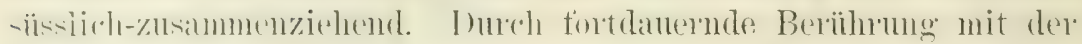
Inft verlunkelt die Farbe allmählich und wird schliesslich

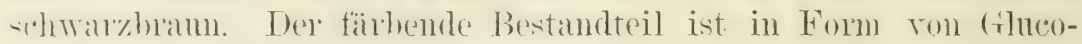
-ide sexenwärig. die durch Gährmo in das farblose Haematoxylin

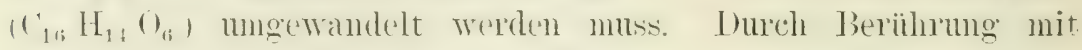
der Luft findet die oxydation des Hatmatoxylins statt, das dadurch zul dem Färbenittel Haematë̈n ( $\left.{ }_{16} \mathrm{H}_{12} \mathrm{O}_{63}\right)$ wird. Es rerdient Bearhtung, dass hier ein Terhältnis vorliegt. wie zwischen dem weissen und blanen Indien, nämlich der Lnterschied von 2 Atomen Masserstoft. Diese Lmwandelung wurde ron Cherrenl nachgewiesen.

Haemateün ist also das Färbemittel, weldhes dem vorbereiteten Holze die rote Farbe und den angefenchteten mol damn getrockneten spänen den grünlichen schillex gibt, wie ihn die Flügel mancher Käfor besitzen. Die Thatsache, dass es ganz vorwiegenrt mit Beigabe von Alkalien zum Blaufärben dient, erklärt den Tamen Blauholz. werden statt Alkalien dem Bade Säuren zugesert, entstehen rote schattiexungen. Mit Eisen- nud Kupferbeizen färbt es braun und schwarz.

I)meh die Einwirkmg ron Wasserstoft und rehwefelsäure wird Haemateïn leicht zu Hatmatoxylon zurïckverwandelt, ein Kïryer, der ein empfindliches Reagens abgibt fiur Alkalien und viele Metalle.

Das Kiernholz gelangt in der Regel in Blöcken ron der Länge tines Meter's und ron sehr umregelmässigen Formen zur Terschiffung: je dicker sie sind, desto wertwoller gelten sie. In dun Bestinmmosländern werden die Blöcke zum Gebranch für die Färbereien verarbeitet: 1. in Suäne, 2. in Holzmehl, 3. in einen fisten ofler halbfliusigen Extrakt. Das Färbemittel Haemateün wird entwickelt dur ${ }^{2}$ Befenchtung der späne oder des Holzmehls mit Wasser, dais frei ron Eisen und verwesenden Pflanzenstoffen stin muss und durch tiährmg der gebildeten Haufen, mit strenger Bewachung, mm eine zn weit gehende Gährmng zu rerhindern.

Das Blauholz zeigt beträchtliche Abweichmgen in seiner pualitä, hervorgutufen duch die verschiedenen klimatischen mol Bodenverhältnisse de’ Produktionsländer. Die allgemein anerkimut beste (pualität kommt ron der Campechebai in MLexiko. woher aber die Zufuhren hedentend abgenommen haben. in Folge 


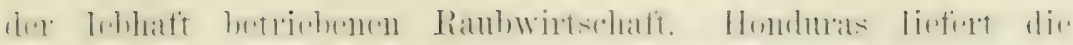

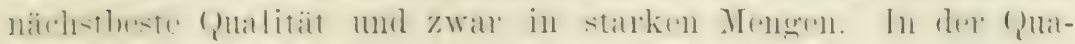

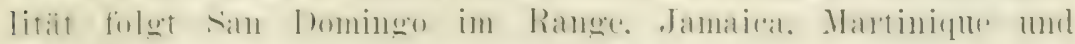
Guadaloupe erzengen die geringsten Qualitäten.

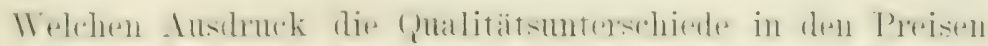

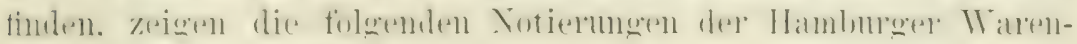
biirse rom Mär\% 1887:

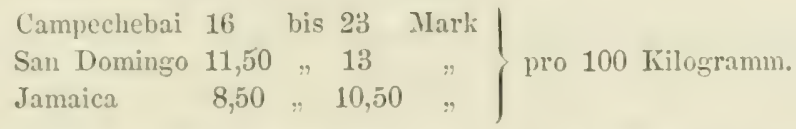

Verepolich habe ich geforsht. oh die hultur diesses wertvollen balumes versucht worden ist. Felbst da, wo man es an

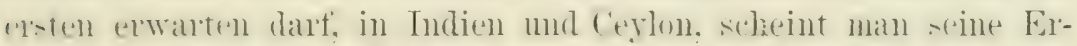
werhumg nuch nicht in Angriff genommen zu haberil. Ich muss mitel daher anf dir Anführung beschränken. dass der Blauholzhaum ein luffeuchtes, tropisches Kilima rerlangt und auf feuchtem. etwat thonigem Boden am besten gedeiht. Die Behauptmg. er kïme bereits rom 10. Tahne ab gefällt werden. ist. so lange er dem Anbau entrïckt bleibt, nicht als zweifellos zu betrachten.

\section{Brasilienholz.}

Ibas ist win Gattumgsmame für verschiedne sorten Rothölzer. iiben deren hotanische (quellen wir noch wenig unteirichtet sind.

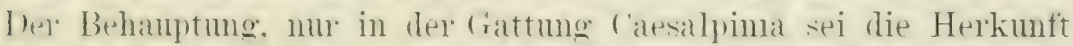
zu - mehem. steht die andere gexpenibler, anch die Gattmog PeltoJhomm sei an dore Produktion leteiligt. Es ist doch gewiss höchst

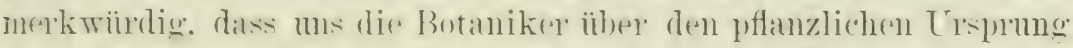
wichtigere Handelsartikel jahrhmulertelang im Thukeln lassen.

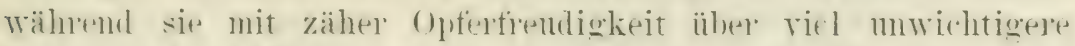

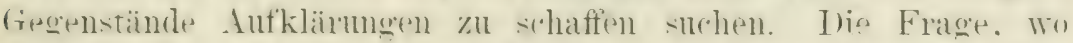

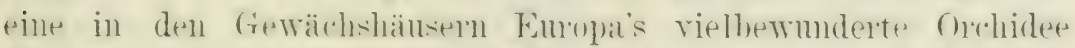

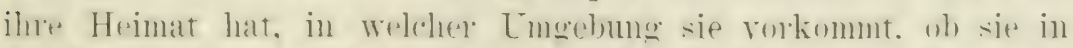

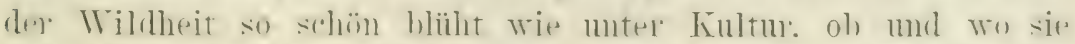

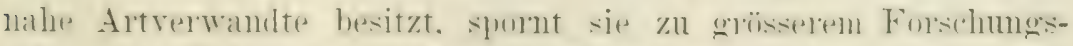

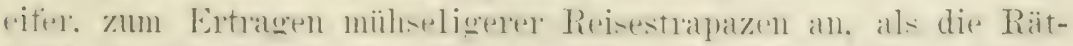

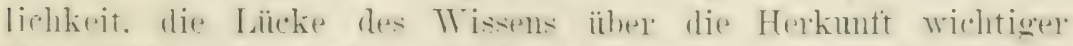

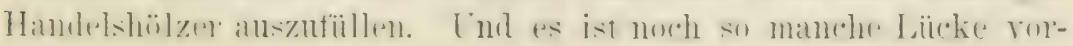


handen. wite ich an verschiedenen stellen dieves Buches zeige. Heisst ss dem die Wissenschatt entweihen. wenn man mit ihrer Hilfe dic wirtschaftliche Wntwickehmg der Völker muterstiitat? Ist die II issenschatt um ihrep selbst willen da? Xicht ans allen. aber doch ans vielen Werken wissenschattlicher Reisenden slaubt man pine bejahende Antwort heransesen zu kömen. Mit erkembarer sehen oder (ieringschitzung suchen sie allem ans dem Wege zu gehen. Was das nïchtern- rschäftliche Interesse des Kantmanns. Fabrikanten und Landmanns erregen kann. Die Nutzgewachse

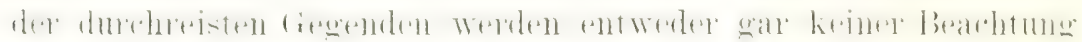

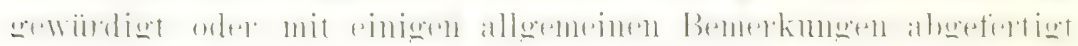
und keine wilde Pflanze wird anf die Wahrscheinlichkeit untersucht, ob in Anbau lohnend sein kömne. Das einseitige Streben ist daranf gerichtet, Pflanzen zu entdecken, von welchen noch kein Botaniker gehört hat und ihre nene Namen dem langen botanischen Terzeichnis beizufïgen. Nach der Heimkehr wird lebhafter Anteil genommen an dem endosen verwirrenden Streit über die Klassifikation, just als ob die Klassifikation das Wesen

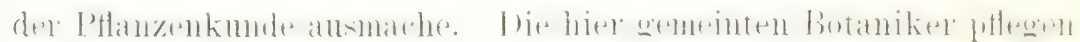
viel von den idealen Zielen der Wissenschaft zu reden. Darf das

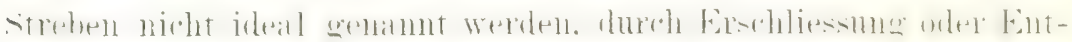

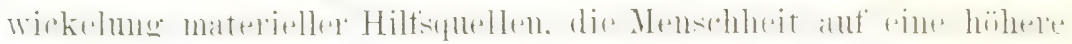
Stufe der Kultur und Gesittung zu heben?

In absehbarer Zukunft wird der Anbau der Farbholzbäume eine Hilfsquelle der tropischen Länder werden, schon aus dem

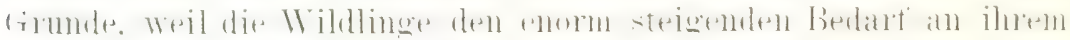
Kernholze nicht decken kömnen. Tem diese Anfgabe in Angrift cenommen werden soll, wird sich das Tersäumnis der botanischen Forschumg fïhlbar machen.

Das Brasilienholz zerfällt in die Sorten: Permambuco oder Fernambuk. St. Martha, Nicaragua- odex Ptirsichholz und Limaholz. Pernambuco gilt als die weitaus beste sorte; in welcher Wertschätzmg sie den anderen sorten gegeniibersteht. zeigen die folgenden Preisnotisungen der Hamburger Warenbörse rom Nä1\% 1887 :

$\left.\begin{array}{lllll}\text { Pernambuco } & 40 & \text { bis } & 50 & \text { Mark } \\ \text { St. Nartha } & 16 & . & 18 & . . \\ \text { Nicaragua und Lima } & 14 & . & 17 & . .\end{array}\right\}$ pro 100 Kilogramm.




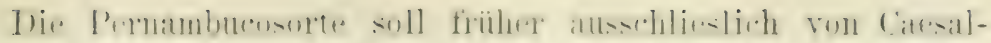

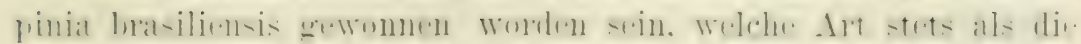

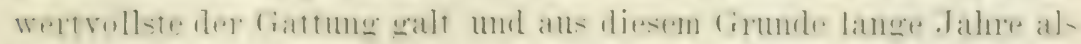

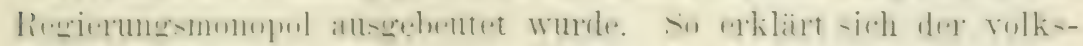

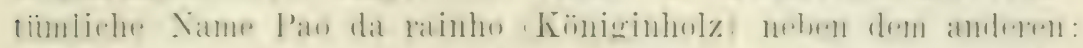

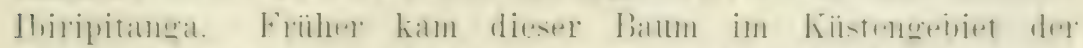

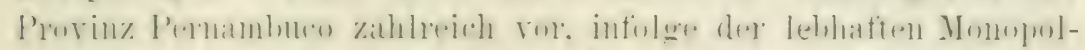

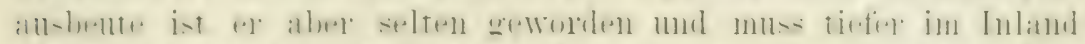

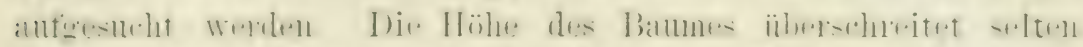

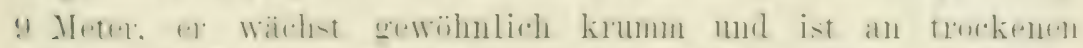

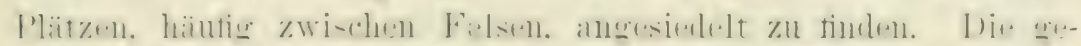

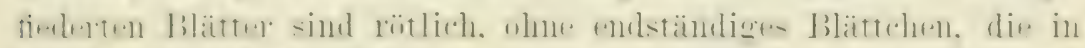

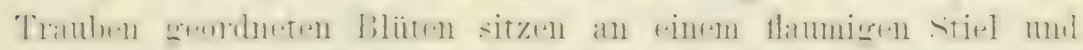

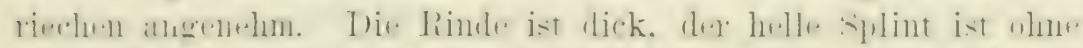

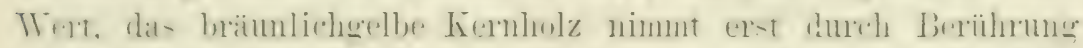

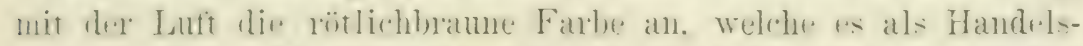

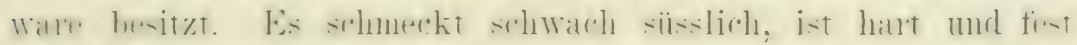
und nimmt eine schöne Politur an.

Seit dieser Batm selten ereworden ist. Wird rin] ['ernambutInlz von latesalpinia rehinatal gewomnen. einem dornigen Banm

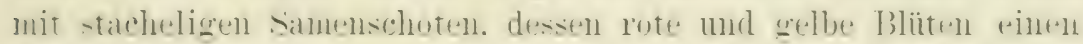

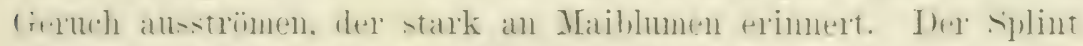

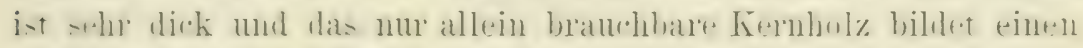
geringen 'Teil des Stammdurchmessers.

Welche Art das Limaholz liefert. i-t norch unauferelärt.

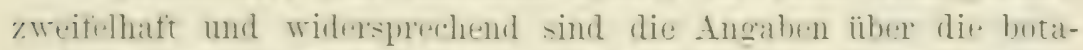

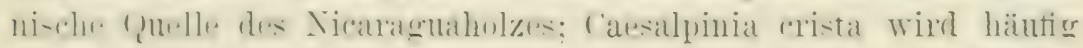

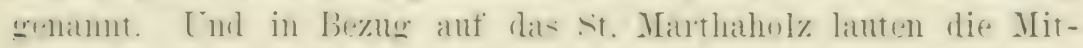
teilungen nicht bestimmter.

Alle dies. nur ans hernhnly lustedenden sorten werden in

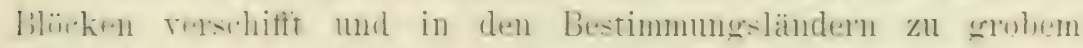

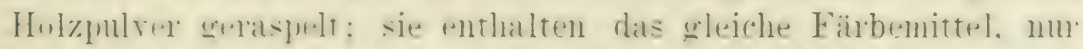

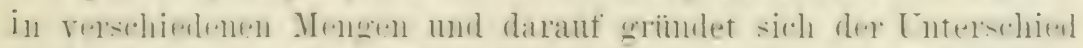

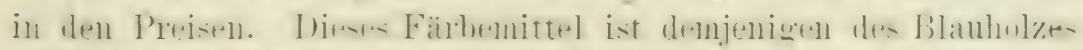

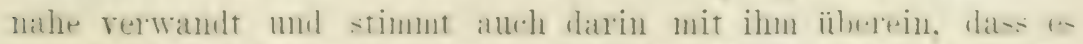
r. Net dum oxplation zu einem wirklichen Fäbmittel wiml. In

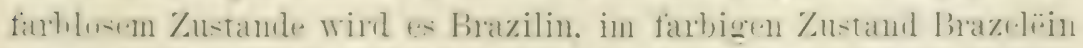

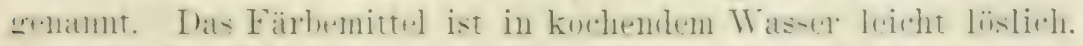

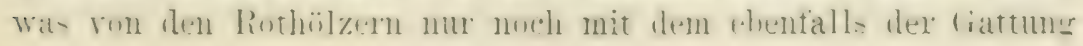


Cassalpinia entstammenden Sapanholz der Fall ist. Die ribrigen hothiilzer des Handels: Camhol\% und Caliatur sind nahezu nulöslich in kochendem Wasser.

Das Brazilin whorde zuerst rom cherreul nachgewiesen. es kinn in nadelformigen Krystallen ansezogen werden, die nalrezu tanblos sind. ainen bittersïssen ficschmack besitzen und lösich in Mrasel und Alkohol sind. Duxch Berithrung mit der Lutt werden die Krystalle rot, indem sie dieselhe Lmwandelung erfahren. wio del weisse Indigo, der blan und das Haematoxylin, wem es Haemateïn wird. nämlich durch die Abgabe ron 2 Atomen Wasserstoft. Wie die folgende Formel verdentlicht:

$$
\begin{array}{ll}
\text { Brazilin } & \text { Brazelein } \\
\mathrm{C}_{22} \mathrm{H}_{18} \mathrm{O}_{7} & \mathrm{C}_{22} \mathrm{H}_{16} \mathrm{O}_{7}
\end{array}
$$

Die rerschicdenen sorten Brasilienholz geben lebhatte abel nicht daterhafte Farben, deshalb werden sie gewöhnlioh in Ter-

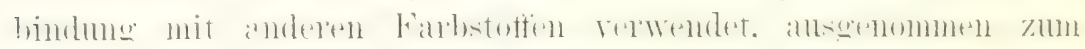
Färben ron Lackfirnissen, welche in der Papier- und Tapeten-

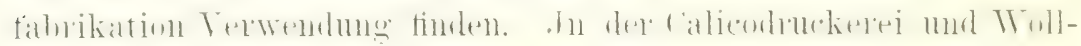
färberei wird Brasilienholz nu gebratucht, un gewissen Farben einen stich ins Pupmrote zu geben.

\section{Sapanholz.}

Caesalpinia Sapan, Familie Leguminosate, ein schwachwiich-

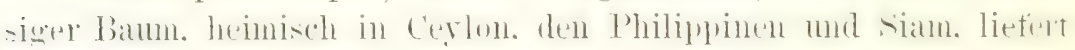

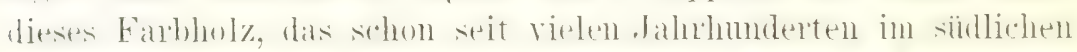

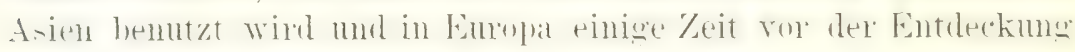

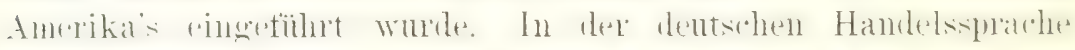

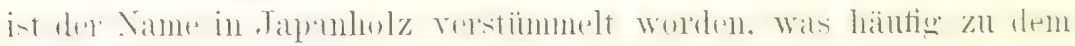
Irrtum Veranlassung gibt, dieses Produkt stamme aus Japan.

Sapanholz findet dieselbe Telwendung wie das iahe rer-

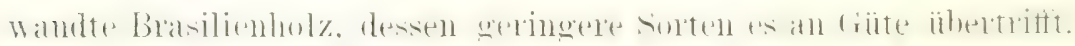

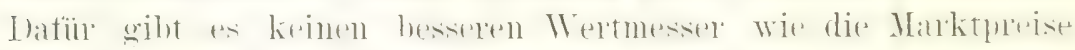

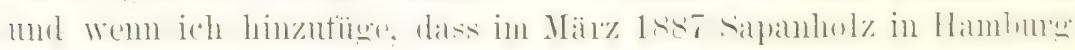
mit 25 bis 30 Mark po 100 Kilogramm notint wurde, so zeigt

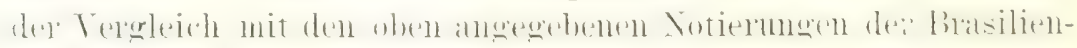
hölzer, dass nur die Sorte Pernambuk höhere Preise erzielt. Sapanholz ist etwas heller wie die besseren Sorten Brasilienholz, sein farbender Stoft ist ebenfalls Brazilin. 
Zur wichtigsten Bezngsquelle des Supanholzes ist Ceylon

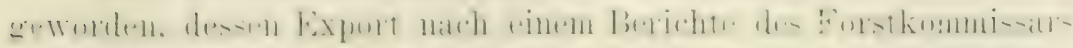

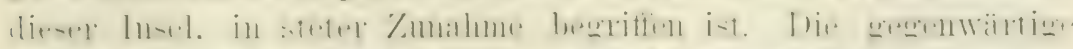

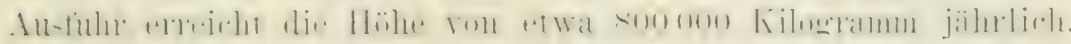

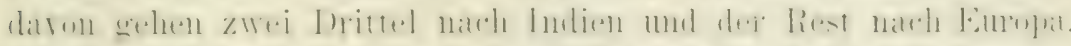

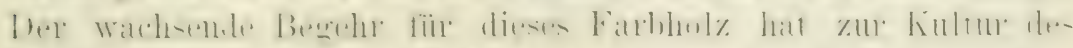

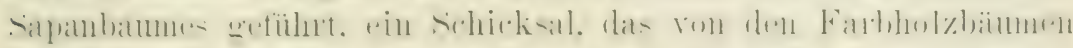

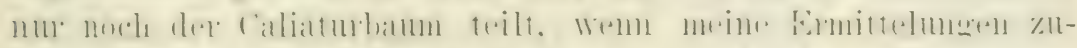

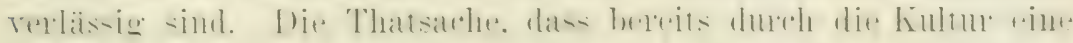

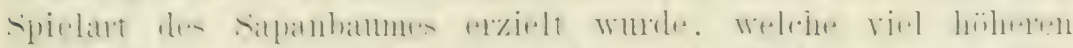

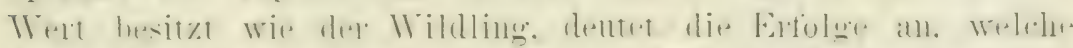

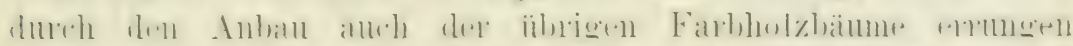

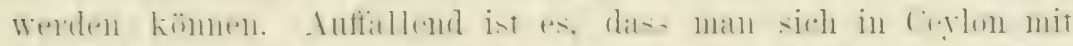

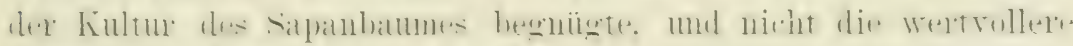

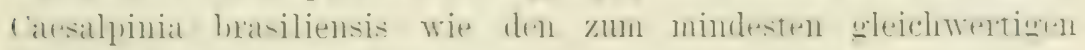
Blauholzbaum hinzugefügt hat.

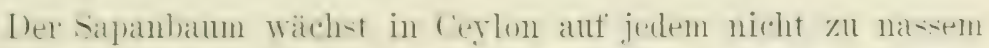

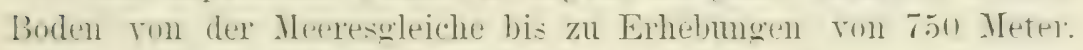
Ilie in der Balumschule gezildhteten Pflänzlinge werden in Alstande

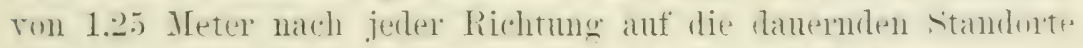

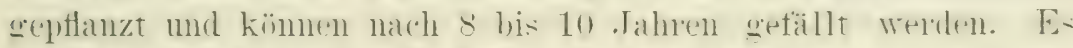
ist much zul bewrisen. ob es nicht rorteilhaftex ist. die bämune

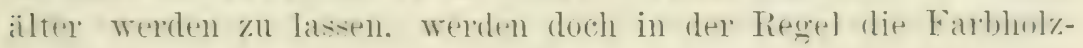
blöcke un so besser bezahlt, je dicker sie sind.

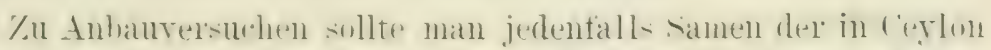
kultivierten spielart benutzen. Dir. Firma .I. P'. Willian at Bro

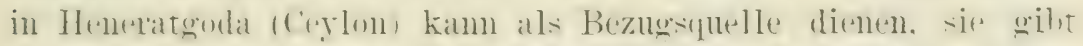

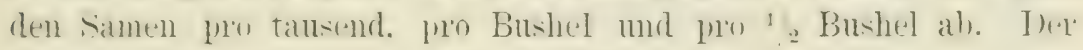
Bushel (36,35 Liter) hält etwa 40000 Samen.

\section{Caliaturhol\%.}

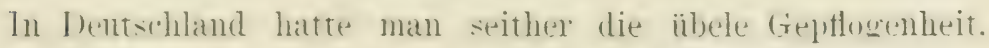

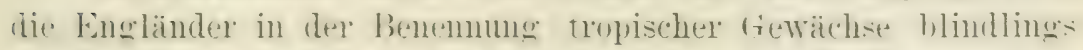

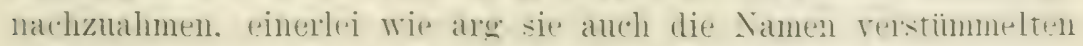

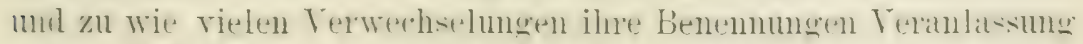
salben. Weil die Engländer ans dem santalholz sindelhol\% milehten.

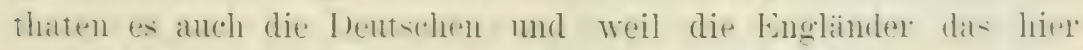

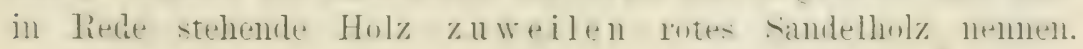




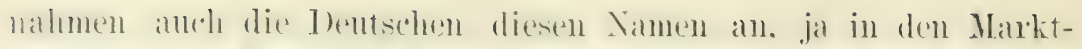

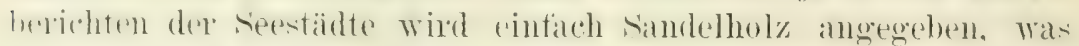

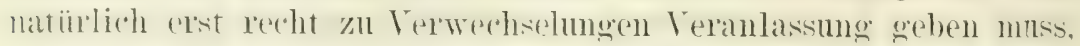
deme das sindelhol\%. richtiger sautaholz, entstammt anderen Bäumen und dient anderen Zwecken.

Es ist eine beklatgenswerte Thatsalche, dass in den dentschen seretidlen. zamal in den Hansestaidten, Marktberichte veröttentlicht werden. die rom Fehlan wimmeln. sowohl bezüglich der liechtschreibung, der Benemmeng we der Gruppierung, moldas schlimmste ist. dass im Bimnenlande diese Haklerschöpfungen als Born del' Belehrung betrachtet werden, denn ...in den serestädten muss man doch zurerlissig wissen, wo die Waren herkommen, wie ihr richtiger Name ist und welcher Natur sie sind."

Mit Terlatuh! Aus eigener geschäftlicher Erfahrung in den Hansestadten meiss ich, dass die Makler, welche die Marktherichte rerfissen, gewöhnlich federleicht an ihren geographischen Kenntnissen tragen, in der Rechtschreibmg eine bedenkliche Unsicherheit verraten und ron den Waren nicht mehr wisten, als was zu ilner älsseren Beruteilume gehört. So kommt es, dass sie in den Marktberichten Harze als frummi antühren, noch immer Terra japonica notieren, sellost der T'usim 'Terra catechn kommt ror. Sapanhulz scheiben sie .Tapanholz, Fisetholz Tisetholz, Raycras Ryegras und st. Marthaholz st. Martensholz. Tor der Übersetzung fremder Xamen scheinen sie manchunal ratlos dazustehen. Es ist ihnen bis jetzt entgangen, dass Arrowrot Pfeilwurz im Dentschen heisst mol Pitch pine mit Pechfichte, Barrel mit Fass ïbersetzt werden kamm. Seit getrocknete anerikanische Äptel in Dentschland eingrefühnt werden. ist den Makilern eine Nuss zwischen die Zähne sesteckt worden. die sie nimmer knacken können. Die in Dörrapparaten getrockneten Äpfel werden von solchen Amerikanern. die nicht schwer an ihrem Schnlsack zu tragen haben und dazu gehören die Makler nud Fommissionäre, ..evaporated” genamnt fin sprachlicher Tnsinn. dem dieses Mort heisst in trener Ïbersutzung .. verdamptt". Man kam Wasser und Alkohol rerdampten. abel keine $\ddot{A}$ fel. und wäre es möglich, damn könnte man ganz gewiss kine rerdampten ت̈ptel ant den Markt bringen. Wird diese sinachsiunde ans dem Englischen ins Dentsche heriibergenommen. mu zur Bildung von dem Kanderwelsch zu dienen: Aepfel eraporated . . so heisst das den blödsimn auf die Spitze treiben. 


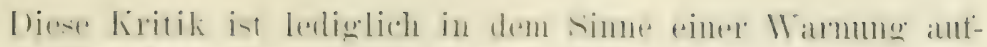

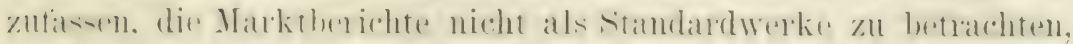

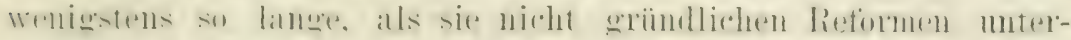

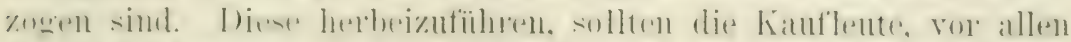

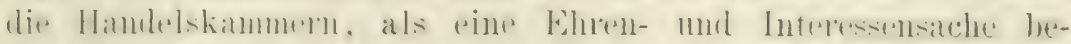

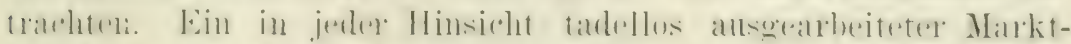

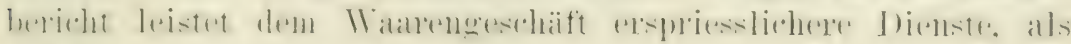
aut den ersten Blick scheinen mag:

Mïssen wir, wie im rorliegenden Fall, einen englischen

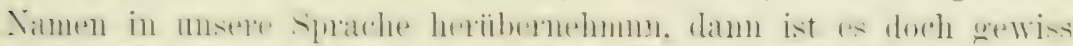

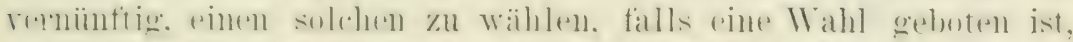

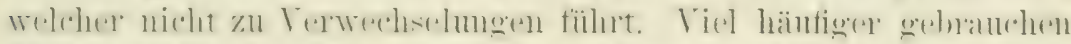

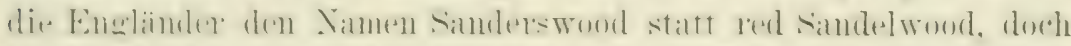

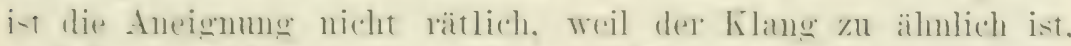

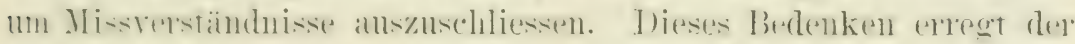

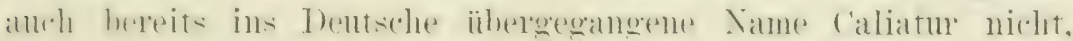

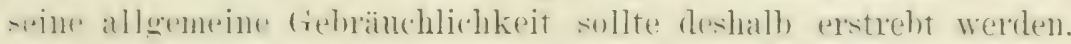

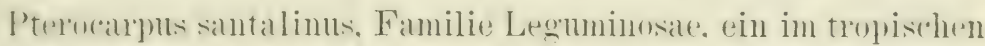
Axien heimis.her, am häufigsten in den ciebirgen siudindiens und

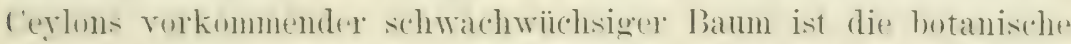

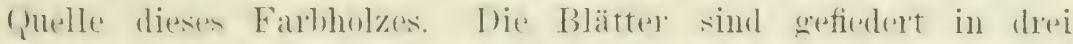
Blattrlede. die in Trauben geondneten Bliiten treten alls den Blattwinkeln. Wie bei andern Farbholzbämmen ist anch bei diesem

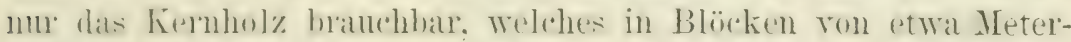

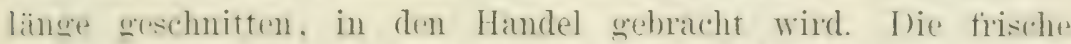
s.hnittlache des Holyes hat wine reiche, tiefirote Farbe, welche durch den Einfluss dere Luft allmählidh dunkelbram wird. Das Holy ist su schwer, dass es im Wasser sinkt, dicht, aut dem Bruche splitterig. riecht schwarh aromatisch. schmeckt of was zusammenziehend und nimmt eine schöne Politur an.

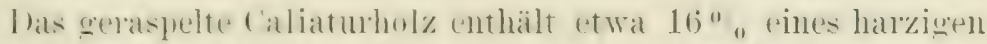
Kuirpers, der durele Alkwhol. Ammoniak, starker Esigsoilme und

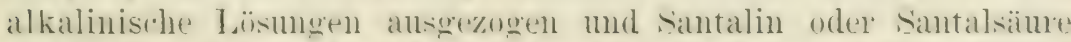

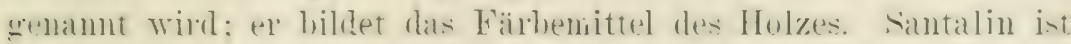
vollständige unlioslich in kaltem Wassere as neutralisiert Alkalien

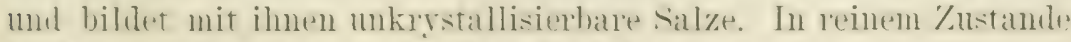

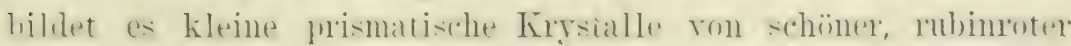

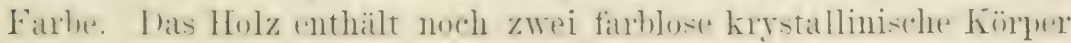




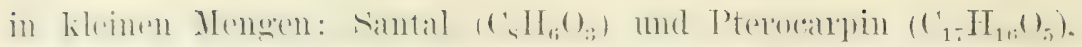
fermer einen formlosen Körper $\left(\mathrm{C}_{17} \mathrm{~A}_{16} \mathrm{O}_{6}\right)$.

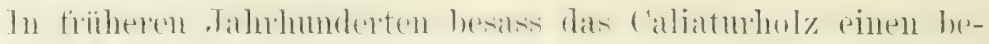

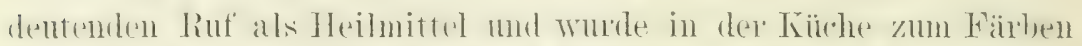

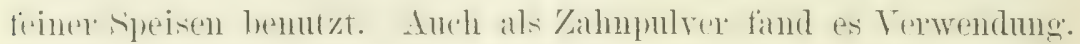

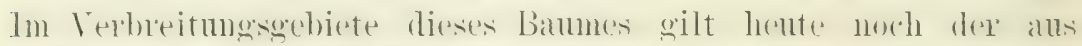
Finschnitten des stammes hervorergunllente rote. dicke saft ron zusammenziehendem Geschmack. als ein gutes Mittel für manche Kranklesten. Gegenwiirtien wird Caliaturhol\% in den Kulturländern nur als Fanstoff verwonlet, der in der Calicodruckerei, mehr noch in der Wollfäberei. eine beträchtliche Wichtigkeit besitzt, weil ('l sehr danexhafte Farben liefert. Selten wird caliaturholz allein verwendet, in welchem Falle es rot oder rotbram färbt, je nach der Beize; gewöhnlich wird se als Grond für Indigo oder in Terbindumg mit anderen Farbstoffen benutzt, mn den gewiuschten Farben einen rötlichen Stich zi: geben.

Die Präsidentschaft Madras bildet die vorzüglichste Bezuls-squelle für Caliaturholz. hier wird anch der Bam kultiviert, namentlich seit es eine indische Folstrerwaltung gibt. Angespornt dureh den steigenden Begehr erweitert diese Behörde die Trultur des Caliaturbaumes, was zur Nachahmmng anspornen sollte. Der samen wird wohl an besten aus der Stadt Madras bezogen. Für den Anbau gilt das von dem Sapanbaum Gesagte.

Für Tinlturpläne darf iubrigens nicht unbeachtet bleiben, dass Caliaturholz billigel ist wie Sapanholz. In März 1887 wurde es in Hamburg mit 13 bis 14 Nark pro 100 Kilogramm notiert.

Ein naher Terwandter des Caliaturbaumes ist Pterocarpus indicus, sein Holz wird ebenfalls unter dem Namen Sanderstrood oder c'aliatur ron Indien exportiert - zwei Namen, die geröhnlich unterschiedslos gebraucht werden.

Indien besitzt norh eimen andern Rotholzbaum, den Rukta(hundun (Adenanthera paronina. Familie Leguminosae), dessen Holz zuweilen gleichfalls als Sandersholz orler ('aliaturholz ausgefuihrt wird, jedoch stets nur in kleinen Pöstchen. In Indien findet es dagegen eine ansedehnte Verwendmo in den Färbereien. 


\section{Cambolz.}

Barholz ist ein anderer Name fïr dieses Rotholz, was erst

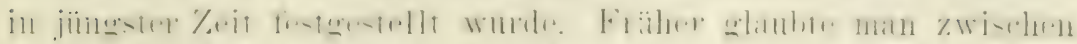

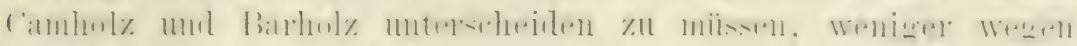

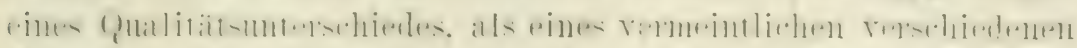

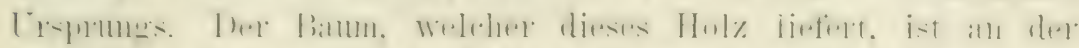

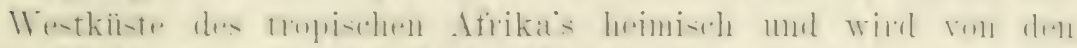

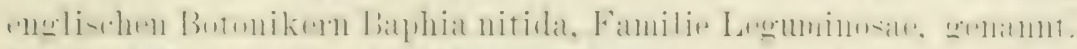

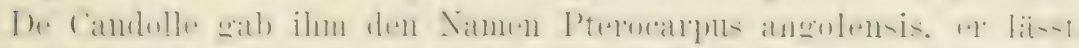

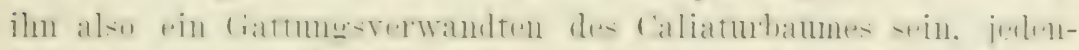

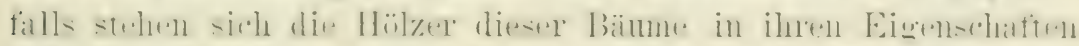

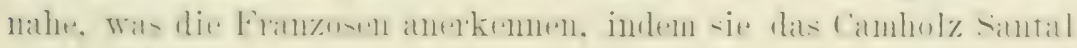
rouge d'Atrique nennen.

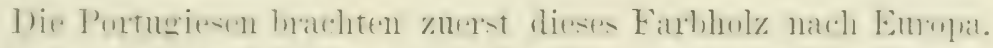

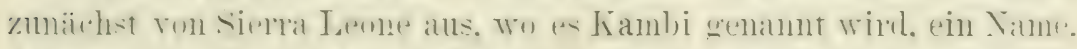

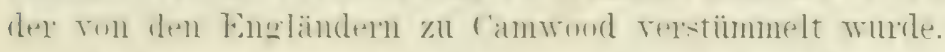

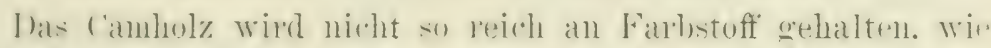

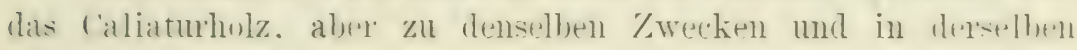
Weise verwendet.

\section{Fustik.}

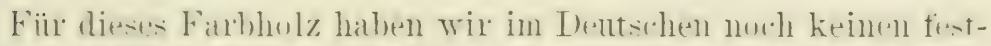

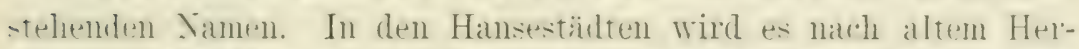
kommen lielbholz. von den Importreuren gelegentlich anch Fustik genant. ein Vame, dex nicht selten im Binmenlande gebrancht wird. In terhnischen schriften finde irh häutig die englische Bezeichnung alter Fustik gehrablent. in fiegensatz nämlich zum jungen Fustik. der richtiger Fisethol\% genamnt wird. Seit meln wie ein gelhes Farbholz in den Handel kommt. ist der Jame Gelhholz für eine-

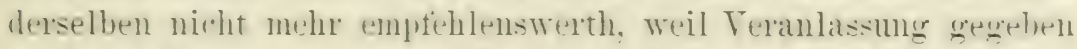
wird zu Terwedhelungen. Lur uewiss i-t es nicht rätlich. in Sachohmmg der Engländer ron alten und jungem Fustik zu

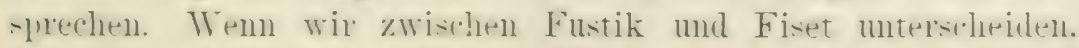
laben wir deutliche. zu keinem Missverständnis fühnende Xanten tïr die zwei in Betrateht kommenden Farbhölzer. Mich diunkt. . hamm nur zur Emptehlung meines Vorschlags gevedolen. dass Fustik

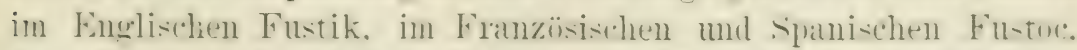
lat- Fiser im spanischen Fustete. in Franziosischen und Portu- 


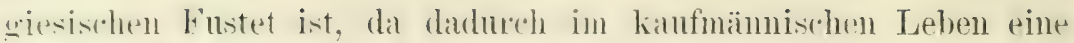
Enösere sicherheit in der Erkemmung des gemeinten Finbholzes gegeben wird.

Fustik ist das Produkt ron Matchua tinetoria. Fandie Mroraceate. rin im tropischen Amerika heimischer groser Bamm mit langrumden, zugevitzten Blättern und geniessbaren, aber nicht besonder's greschätzten Frübhten. J)as HoIz ist brämlichgelb, wird aber. durch den Einfluss der Luft fast bram. Zuweilen wird es zu Funieren und Ineherabeiten benutzt, seine hauptsächlichste Texwrudung ist jedoch in der Färberei. Wie andere Fambhölzer wird auch Fustik in B!̈̈cken verschifft und in den Bestimmungsaländern zum Gebramche fïr die Färbereien geraspelt. Ier färbende Stoft des Fustiks wird Iloritansäure genamnt. ex hat diese Zusammensetzung: ( ${ }_{26 ;} \mathrm{H}_{16 ;}()_{20}$. und kamm durch Abdampfung der wässerigen Lö:mng in Krystallen ausgeschieden werden. Fustik färbt sehr damerhatt. aher etwas dumpf, und wird daher rorzugsweise in Terbindung mit anderen Farben rerwendet.

Die Herkunft des Fustiks bedingt Qualitätsmuterschiede. die in den Preisen Ausdruck finden, wie die folgenden Hamburorer Notierungen vom März 1887 zeigen:

$\left.\begin{array}{lrrrr}\text { Cuba } & 12 & \text { bis } & 14 & \text { Mark } \\ \text { Campeche-Tampico } & 9,50 & , & 10,50 & \\ \text { Maracaibo } & 8,50 & , & 9,50 & \ldots\end{array}\right\}$ pro 100 Ǩilogramm.

Die in Nordamerika heimische Osage Orange (Machura aurantiaca) ist mit dem Fustikbam nahe rerwandt, ilu Holz färbt ebentalls gelb und dient zuweilen als Ersatz fiir Fustik.

\section{Fiset.}

Rhus cotinus, Familie Anacardiaceae. im gewöhnlichen Leben Perïckensumach oder renetianischer Sumach genannt, liefert dieses Farbholz, das schön orangegelb und, wemn mit richtigen Beizen vorgearbeitet, anch danerhaft färbt. Dieser etwa 2 ILeter hohe Stranch ist im siidlichen Europa und in Vorderasien heimisch: die ronzïglichsten Bezugsquellen seines Produktes sind die jonischen Inseln und Morea. Der Strauch ist sommergrün, die Blätter sind verkehrt eiförmig. steif. glatt, ganz. am Grunde gerundet und sitzen an langen stilen. Die kleinen, langgestielten Blïten sind grünlich weiss und in lockeren Rispen geordnet, nach dem Terwelken tiallen die meisten Blüten ab. ihre stiele rerlängern sich 


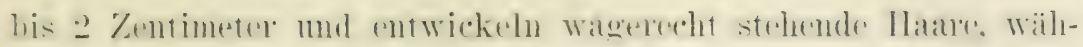

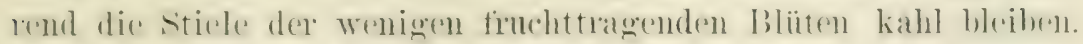

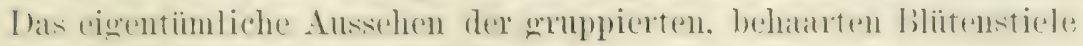

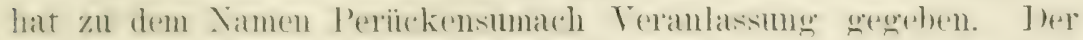
Safte ist reiftig. Das seidenartige Hol\% dient nidht allein zum Firben, sondern auch zu Furnieren.

\section{Quebrachohol\%.}

Seit rinigendahren wird dieser Altikel rom Harre mol rinigente

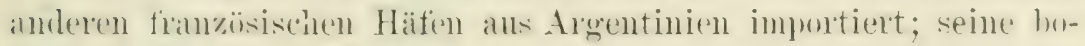
tanische Quelle ist Loxopterygum Lorentzii.

(queloracho colorado. schlechtweg Quebracho genamt, lat ein spezitisches Gewideht rom 1.11 bis 1.137. ist sehr hart und anf dem (jueschnitt hell bis dmkelbrammot. Es enthält 18 bis 20 "'n rines (ierbstoftes. welcher nicht mit dem der Fichemrinde und de: Kitstanienholzes übereinstimmt, ansserdem 2,8" "einer anderen znsammenziehenden Säme. welche ron tierischer Hant nicht fixiert wird und sich gegen Reagentien wie Gallussäure verhält, fermer rinen Farbstoff. mit dem sich schön gelb tärben lässt. Dir wässerige Abkochumg des Holzes ist schwach samer, von rötlich selber Farbe, trïbt sich. wem konzentriert. heim Erkalten unter Abscheidung eines rotbraunen Körpers.

Konzentrierte schwefelsüne, in geringen Mengen zugesetzt.

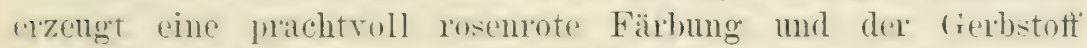
rchlägt sidh fleischfarbig nieder. Komzentrierte salzsiume bewirkt Fällumg ohm. liosafïrbung. konzentrierte salpetersäme erzengt rinen gelloramen. kmmentrierte Phosphorsäme einen fleischfarhigen Yiedrrschlag. Beim hochen mit rerdünnter schwefelsäure spaltet dir (Qnebrachogerlosiure keine Gallussïme ab.

Quebuacho soll sich unter ['mständen so) gut wie Sumach zul Fabrikation ron saffianleder eignen. namentlich für solches. die dunkele Farben haben sollen. Mit einem angeblichen trerhstoftwethalt von 20 " wird er in Have zum Preis ron 21 Mark pon 100 Kilogramm geliefert.

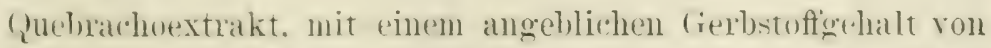
(1) bis 75" "ist in Hamburg mo bremen bereits ein ganglatrel 


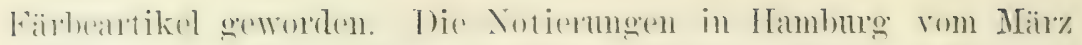

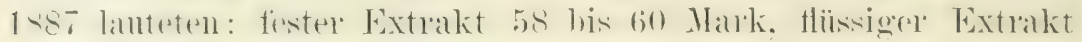
14 bis 46 Mark pro 100 Kilogramm.

\section{Grïmes Ebenhol\%.}

Nur Fngland importiert dieses Farblonz in ansehnlichen Jengen als dem tropischen südamerika. I)ie botanische Quelle ist Jacarandia oralifolia, Familie Bignoniaceae, ein stattlicher Bamm mit prangenden. in 'Trauben geordneten Blüten. Das Holz ist olivengrün und hart, es wird gewöhnlich in Blöcken ron 7.5 Zentimeter Länge rerschifft und zureilen zu 'Tischler- und Dreherartikeln verarbeitet.

Es fürbt olivengriun, bram und gelb, je nach den angewendeten Beizen. 


\section{I) wohlriechenden Hölzer.}

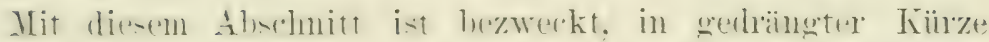

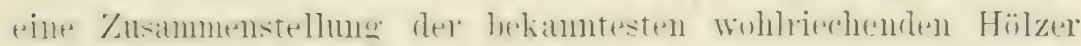

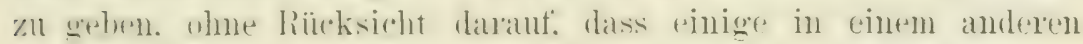
Teile dieses Burhes allstïhrlicher bespuchen sind. Ohgleich Wohlererithe selur weit im Pflanzenreiche rerbreitet sind. finden sir sich duch nicht oft in dem Holze der Bänme und Sträucher. Am bä̈ntigsten sind sie den Blüten eigen und in ganz besonderer Fülle sind sie in manchen blattern enthalten. wie in denjenigen des Zitronemglases, der Fasamorchidee (Angraecum fiagrans). ron Eualyptu- eitriodoral mol F. odorata. Manchmal sind die samen

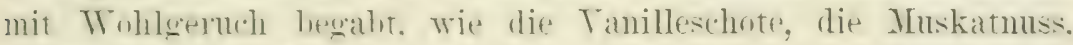

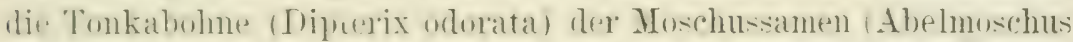

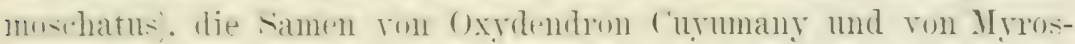

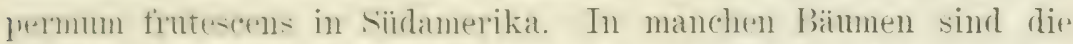
aronatiolhen Bestandteile an stäksten in ler Rinde entwickelt. we im \%imt nnd lasiabaun. in sasatias von 'lasmanien (Atheros-

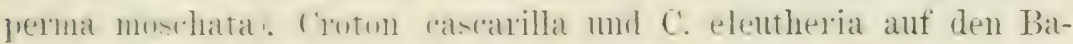
hamals. Von mehrepes derselben werden ätherische (i) gewomente

7n anderen Zwerken poflegt man die Heilzer gemös ihrer

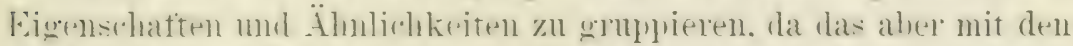

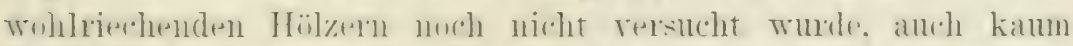

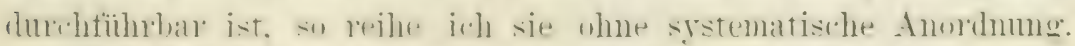

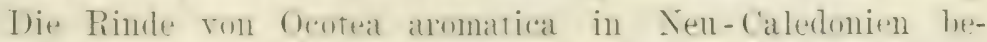

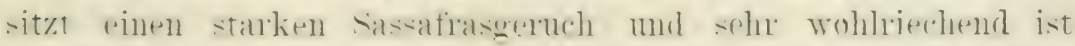

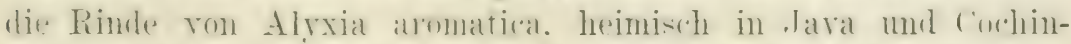

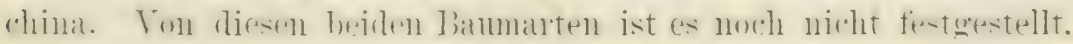
ob nur die Rinde oder anch das Holz wohlriechend ist. 
Tahiti hesitzt in lxora odorata ein festes mol wohlriechendes Holz.

In Tasmanien und Australien findet sich der Moschusbamm (Eurybia argophylla), dessen Holz einen angenehmien Geruch und eine schön gefleckte Farbe hat: es ist recht bràchbar zu Möbeln. Treherarbeiten und Parfümeriezwecken. D)as anstralische Buchsholy (Bursaria spinosa) hat ebenfalls einen angenehmen aber rergänglichen Geruch. Das Riechholz von Tasmanien (Alyxia buxifolia) besitzt einen Gertch, der an die Tonkabohnen erimnert. Es ist ein krakeliger, an der Küste rachsender stranch, mit einem stamme von höchstens 12 Zentimeter Durchmesser. Er produziert sonach kein dickes vielfach relwendbares Holz, was zu bedanern ist, da es fein und festfaserig und ron schönem lichtbraunem geflecktem Anssehen ist. Ob die Kultur ans dem Strauche einen wertvollen Nutzbaum machen könnte?

Die Kolonie Westaustralien ist stolz anf ihren himber'duftenden Baum (Acacia acuminata), der diesen Namen empfing;, weil sein Holz ähnlich wie Himbeeren, richtiger wie Himbeerrallerte riecht. Es ist ein schönes $\mathrm{Holz}$, sehr geeignet für die Tischlerei. Ostanstralien besitzt den wohlriechenden Myall (Acacia homalophylla), der ein sehr hartes, wehweres Holz liefert. welches finen starken, köstlichen Teilchengeruch ausströmt. Es ist dunkel und schön markirt, wodurch es viel rerwendbar in der Tischlerei und Dreherei ist. Leider wächst der Stamm selten über 30 Zentimeter im Durchmesser, trotzdem wird er zuweilen in der Fournierschneiderei benutzt. Anf der Londoner Weltausstellung von 1862 wurden von Queensland. wo der Baum am häufigsten vorkommt, Luxusartikel aus diesem Holze zur Schau gebracht, dessen bemerkenswerte Eigenschaften seitdem allgemein bekannt wurden und Veranlassung zu einer danernden Nachfrage in Europa gab, zur Fabrikation ron Kästchen tïr Handschuhe, Briefpapier u. s. w.

So lange das Myallholz mpoliert bleibt. bewahrt es seinen eigentimlichen Veilchengertuch. Was in solcher Tollkommenheit bei keinem anderen bekannten Holze der Fall ist.

In der Nähe des Murrayfluses wächst die Wüstensandarakfichte (('allitris verutcosa), ein mittelgrosser Baum. dessen Stamm selten mehr wie 45 Zentimeter Durchmesser hat. Das Holz besitzt einen, wie man sagt. die lnsekten rertreibenden Geruch, der 


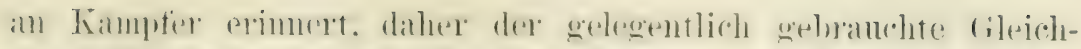

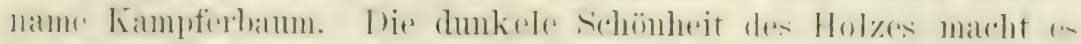

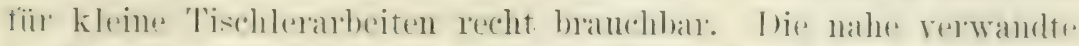

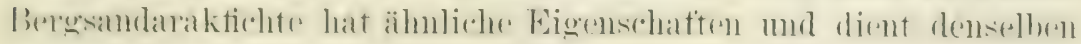
/weckell.

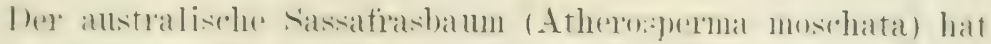

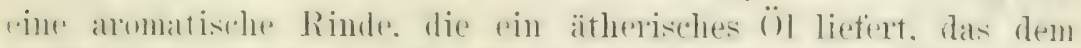

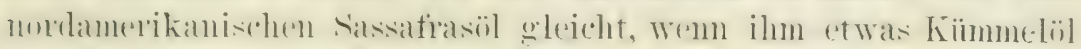

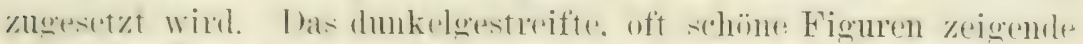

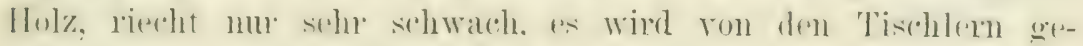
schätzt. weil es eine schöne Politur annimmt.

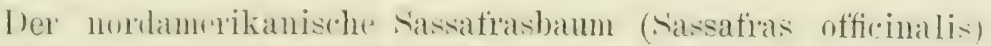

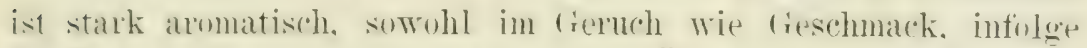

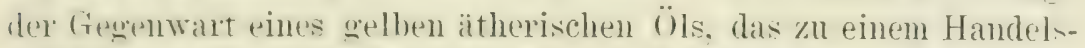
artikel enworden ist. Tha dex tieruch dir Insenten vertreibt, bemutzt man in Indien das Sassafrasholz zum Auskleiden von Koftern. Kommoden, Kisten u. S. W:

Der sumptisassafrasbaum (Magnolia glanca) ist ebentalls in Sordamerika heimisch. seiner wohlriechenden Rinde streben die Biber leegerig mach. daher der rieichname Biberbaum.

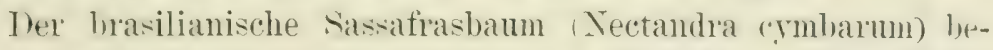
sitzt eine aromatische Rinde. Während das Holz kamm pinen IVohlgeruch bemerken lassen soll.

Das rantalholz ist das Produkt verschiedener Arten dre frattung silntalum. Von welchen s. album die gösste Wichtigkeit besitzt. Ina e ein hartes, dichtes. schönes Holz ist, dient es zu vershiedenen Vrowendmugen in der 'Tischlerei nut Holzschnitzerei.

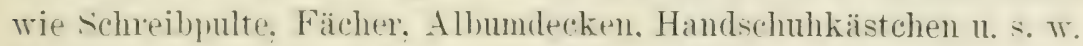
I be bemerkenswerteste Eigenschaft dieses Holzes besteht aber in seinem rigentiimlichen fieluch, ron einem ätherischen ïle hel1.ïhnend, das in Indien vieltach zu Parfümerieznecken revwendet

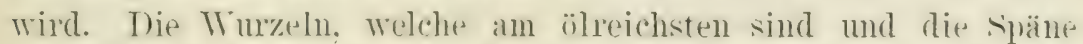

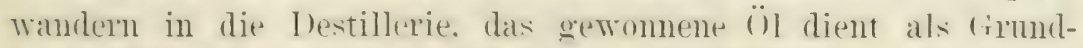
hustandteil von manchen Partïmülen. dient anch manchmal zum Aromatisieren rom gewöihnlichem Holz. um ex als siantalholz zul verkatutin. T)ie wohlhabenden Hindus zeigen ihn'm Reichtum und

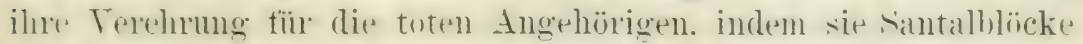

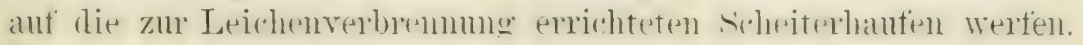




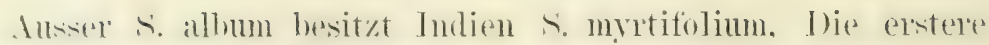

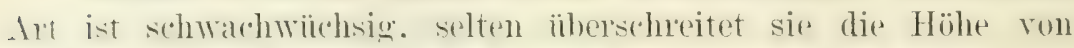
s Mroter. Des Export ihres Holzes von Madras ist beträichtlich. naneentlich nach Bombay. Bengalen. Pegu und dem persisehen Golt.

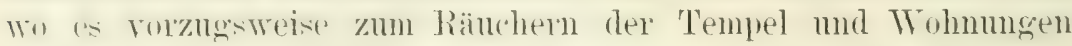
der Reichen dient. Zn gleiohen Zwecken importieren die Chinesen nicht allein beträchtliche Mengen Santalholz. sondern anch Santalsïesuane. die sie zn kleinen Kuchen formen, um sie zu verbremnen. ott werden sie anch. in niedliche Sächehen getïllt, von den Framen als Gegenzauber getragen.

Anstralien bringt rin geringwertiges Santalholz in den Handel. das ron Santalum lanceolatum. S. oblongatum, S. obtusifolium und S. venosum produziext wird - Bäume. Welche in Queensland und Testanstralien vorkommen. Die letztere Colonie verschiffte seither jïhnlich etwa 7oog Tomnen dieses Holzes. doch beginnt dir Anstulır zu fallen, weil die Torräte in den bewohnten Gegenden nahezu erschöpt sind und der Transport ans entfernten Inlandsorten sehr kostspielig ist.

Mehrere santalarten sind ïher einen 'Teil der siidserinsehn

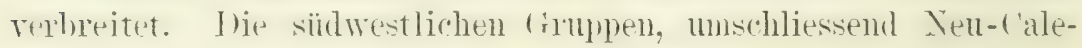
donien. die Loyalitätsinseln, die Yel-Hebriden. Fsprrito-santo und einige Andere. sind an reichsten hedacht. Die Fidschis, welche in den letzten 30 . Tahren mehrere tausend 'Tomnen santalholz verschifften, besitzen nux noch dürftige Vorräte.

santalum anstro-caledonicum in Vent'aledonien liefert eine

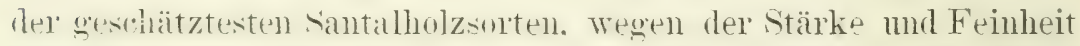
dea freruches. Dierel Baum wurde in rücksichtslosester Weise filst allsgerottet. ist aber in der nenesten Zeit unter Kultur gebracht worden. [bas ans rem Holze destillierte (i) wird in Frankreich mit 140 Mark fro Kiloglamm bezahlt. Wite bei anderen - rantalhölzern. hat anch bei diesem nur das Keruholz Wert. Der stamm um die dickelen Äste werden in Längen ron 0.75 bis 1.50 Meter zerlegt mul der sulint nebst der Rinde mit der Axt abgehanen. eine Hantiermeg die Reinigen genamnt wird. Dadurch

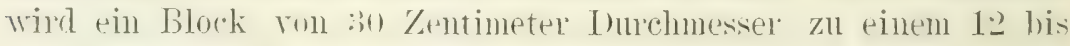
15 Zentimeter dicken Scheit.

Ant den sandwichinsehn kommen ror: Santalum ellipticum mal s. Freveinetianmon. die letztere Art wird anch in Tahiti ap- 


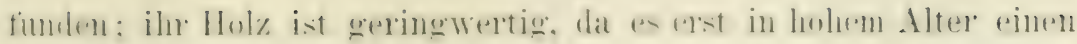
schwachen Geruch amimmt.

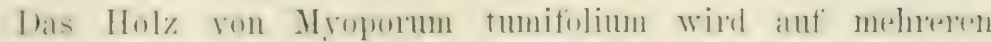

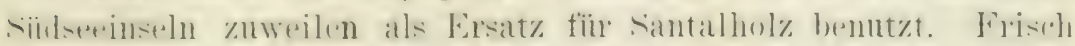

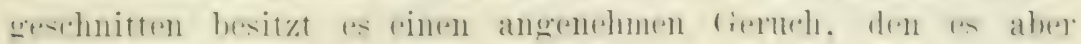
hald verliert.

las Batardsantalhol\% rom Australien (Fimophila Mitrhelii)

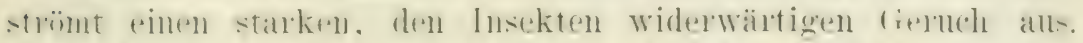
lis ist hart. hram, shoun markiert mol daher emptehlemswert zu Furnieren.

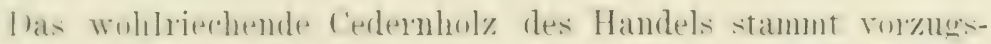

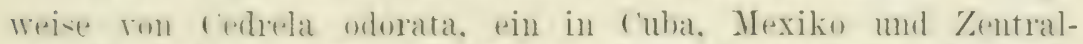
antrika heinischer Baun. Jen geleiden Namen fïhnt das Hol\%

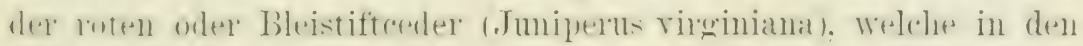
sïl-talaten der nordanerikanischen L'nion rorkomnt und in Baiern einerefiilnt wurles, un das zur Bleistiftabrikation nötige Holz im rigenen Limule zu erzengern. Als diesem Holze wird dis wohlriechende öl Cedrine destilliert.

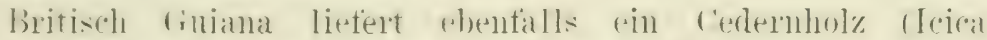
alti--imal), das einen st starken aromatischen Geroch he:itzt, dass « dir. Insekten veltreibt: es ist brallehbal in der Thischlerei.

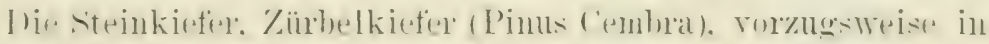

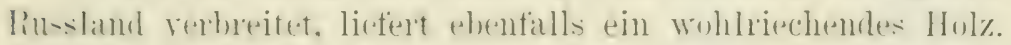

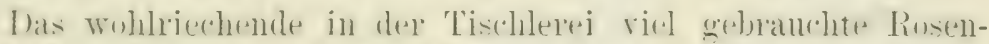

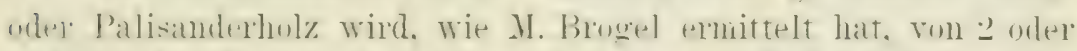

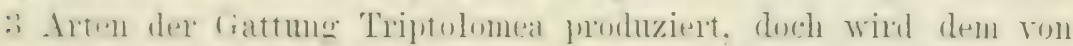

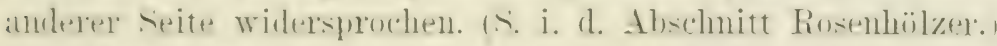

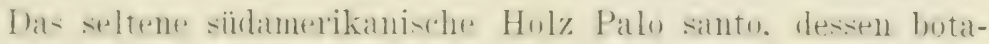

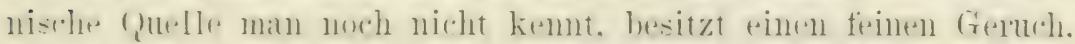

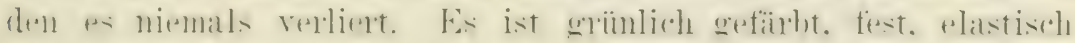

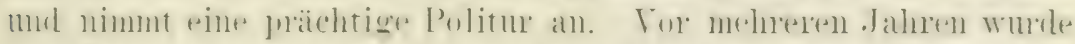

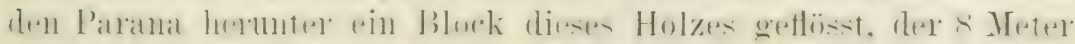

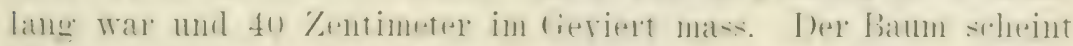

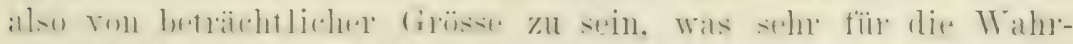

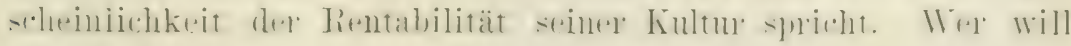
sein Torkommen und sein Wesen erforschen:

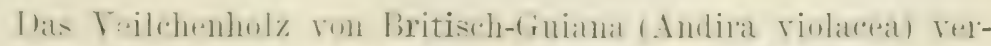

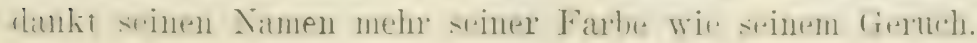


llas ans dem östlichen Asien stammende Kamplextolz ist wohlbekamnt als ein gutes Schutzmittel gegen die Motten; es sutstammt dem japanischen Kampterbaum (('amphora officinarum). Sumatra und Borneo besitzen einen anderen Kampferbaum, mit dem wissenschaftlichen Namen Dryobalanops aromatica. Nicht allein Holz und Rinde, sondern anch Blätter und Früichte dieses Bammes riechen nach Kampfer. In Sumatra wird dieser Baum hänfig an der Westküste gefunden. gewöhnlich in ansgedehnten Irwäldern, aber niemals in höheren Erhebungen wie 300 Meter. Ex ist von ungewöhnlicher (rrösse, der grade Stamm hat zuweilen einen Umfang von 6 Meter und die gigantische Krone ibberragt die benachbarten Waldbäume oft 30 Meter. Selten liefert ein Bamm mehr wie ein $1 /$ \& Kilogramm Kampfer und dieser geringen Ausbeute muss er zum Opfer fallen. Stamm und Wurzeln werden in kleine Splitter gehauen, un die in den Höhlungen, namentlich an den Astauswüchsen, versteckten Kampferkörner zu finden. Aus den Holzspänen quillt ein ätherisches Öl, das zuweilen gesammelt. wird, doch soll diese Arbeit nicht lohnen. I)as Holz wird als zäh, dauerhaft und geeignet zum Schiffbau geschildert, da es ron den in dem indischen Ozean so gefährlichen Seewürmern seines treruches wegen nicht angegriffen wird. Da es ölig ist, rosten die eingeschlagenen Nägel und Klammern nicht.

Französisch Guiana exportiert ein Bois de rose femelle genamntes Holz, wahrscheinlich von dem Baume Licaria odorata, das einen köstlichen, an Bergamotöl erinnernden Geruch besitzt, der aber so ausserordentlich flüchtig ist, dass das $\mathrm{Holz}$ erst ummittelbar vor der Füllung der Destillierblase pulverisiert werden darf. Das (i) wird seit neuerer Zeit von den pariser Parfumeriefabriken verwendet. Das Holz ist gelb und grobfaserig und kanm zu einem anderen Zwecke benutzbar als dem vorstehenden.

Keine wohlriechenden Hölzer werden ron den Südasiaten höher geschätzt wie die, welche die Handelsnamen Lignum aloer, Garoe, Calambak oder Adlerholz führen. Noch ist nicht zurerlässig festgestellt, ron welchen Bäumen sie produziert werden. Das beste Aloe- oder Adlerholz soll von Aleoxylon agallochum, Familie Legrminosae heimisch in ('ochinchina, stammen. Aduilaria ovata und $A$. agallocha, Familie Aquilariaceae, die in anderen Teilen des tropischen Asiens vorkommen, sollen geringere Sorten Aloe- orler Adlerholz liefern. Alle sind stark wohlriechend und 


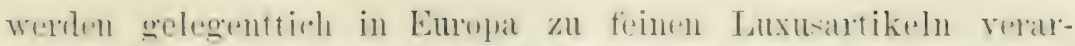

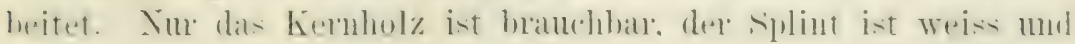
geruchlos.

Ayulariat agallochat ist ein mittelhoher Batum. der am Golt ron sian in den fiehirgen ron Borneo, sumatra und la val wirehst.

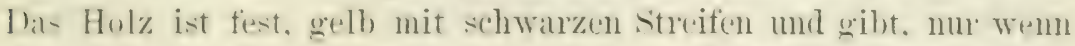
e gerieben oder gespalten wird, einen Rhabarbergeruch ab. deter rinem dunkelfarhigen Harze entstammt, wie bei allem Holzr ron gleichem Namen.

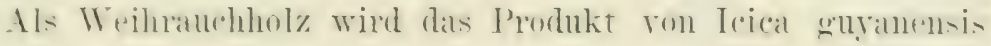
lieimisch in Guiana, bezeichnet.

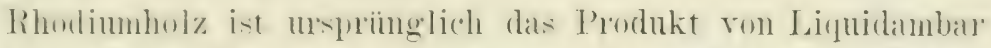
mientale. ein in Vorderasien heimischer. kleiner Batum. siäter worrle dieser vame ïbertragen auf das Holz von convolvolus theridus. l'. sonparius. zwei anf den canarischen Inseln rorkommend" stribleler. wie anf Amyris balsanifera, ein kleiner Batm Tamaicar. Alle diese Quellen liefern ein Holz, das angenehm rosenalnulich duftet. Wemn es gerieben wird und welches in der Inestillierblast das ätherische, wohlriechende Rhodiumöl abgibt.

Inere californischen staatsmiversitä wurde von dem Depalrtrenelnt wf Agriculture de commeree in Cawpore. Indien. ein Girshenk von samen verschiedener indischer Bäume äbermittelt. Wrgleitet rom rimem Briefe des Assistant Directors in l'awnore. der si heleherend ist. dass ich glaube, seinen weentlichen Inladt mitteilen zu sollen :

Der I hak (Butea frondosa) kommt im ganzen nordwestlichen Indien zahleeich for; wildwachsend auf dem unbebanten (ielände der Ehenen. Inis Holz wird zu Brunnenrïhren rerwendet. rorzugsweise aber zum Brennen, für welchen Zweck es rorzüglich ist. Mit Ausnahme des Babul (Acacia arabica) ist es der einzige Baum. der anf wiistenartigem Boden fireudig gerleiht, selhst anf sulchem. der whatch mit Alkalien durchsetzt ist. In den Ebenen kommt +r häufig über die strauhhöhe nicht hinaus, allein auf den Torhiugeln dex Gebinge elitwickelt er sich zu einem richtigen Batume.

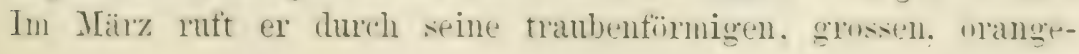


roten Blïten aine ansserordentliche Winkung hervor, die oft mit

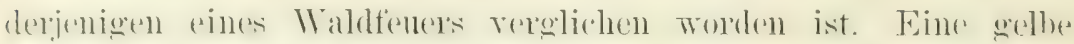
Farbe wird ans den Bliiten gewomen. welche einigen Handelswert

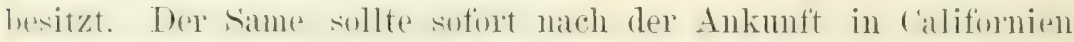
sersät werden, ohne ihn ans den sichoten zu nehmen und zwar ant die danernden Standorte, da die Bämmchen das Terptlanzen nicht vertragen.*)

Der schisoham (I)albergia sissu) ist ein grosser banm mit lichtgrüner. delikater Belanbung und kleinen. gelhlichwoisen Blïten. Er kommt in den unteren Himalayawädern ror mul zwar nux auf leichten Böden. Am ïppigsten gedeiht er anf niedriw liegendem, leichtem. sandigem Schwemmland. Das kelnholz ist dumkelbraun und in der. Tischlerei sehr geschätzt, vielleicht mur wie ein anderes in Indien produzierte Holz. Mahagoni answenommen. Die jungen Blätter mol Zweige werden als Viehfutter. auch als Arzenei benutzt.

Lie Fortphtanzmg kam duch samen und auch selu Iricht dur.h Sterklinge geschehen. die 30 Zentimeter lang sin sollen. I)ie Pflanzwrite auf den daueluden Standorten muss ! Metre hetragen. Ter sime muss in den Hülsen gosät werlen. was aut rin Beet der Bammschule geschehen mag. Bes Bexinn der nächsten Regenzeit kann die Verpflanzung der Sämlinge stattfinden.

The indische Tamarinde ('Tamarindus indicus) ist ein grosserer, uft 25 Neter hoher baum, der in ganz Indien kultiviert wird. Ther Stamm ist kurz. dick mol trägt eine prichtige. breite mol lohe Krone. Die Blätter sind gefiedert, den gelben. in lusen Tramben geordneten Blïten folgen Samenschoten. die ein sänelliches, häufig mäserviertes Mark enthalten: es ist cin mschät\%bares Mittel gegen skorbut. Der Baum wächst alsserordentlich langsan. Der Same wird im April in die Bamschnle gesiit. l) sämlinge miissen während des kalteli Wetters beschiitzt mol im Februar oder wälnend der Regenzeit rerpflanzt werden. Ilie Bäume sollten an Wegen in Abständen von 12 Meter stehen. Thas Holz ist fïr keinen anderen rweck wie zum Bremen lnauclibar. The Nimi (Melia indica) ist ein grosser, in ganz Indien rexIneiteter Baum, cer anf jedem Boden wärdst. I) Re Rinde ist glan

*) Anm. d. V. Dieser Baum bildet eine bevorzugte Wolnung des Lackinsekts und ist die Quelle des Bengalkinos. 


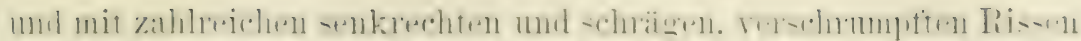

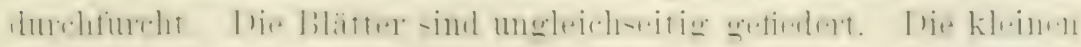

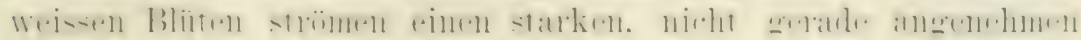

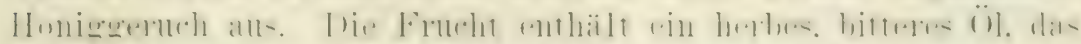

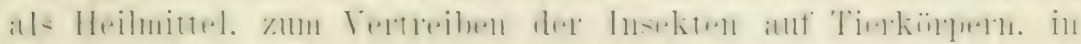

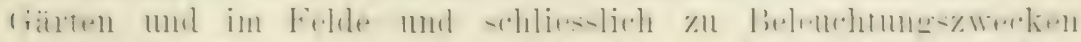

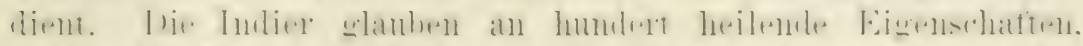

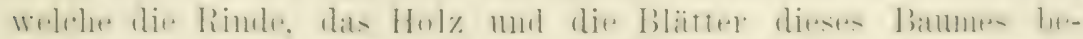

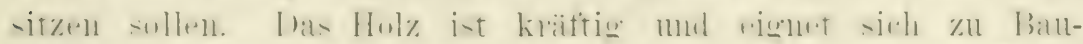
zwecken. Der Same kam in die Baumschule oder aut die

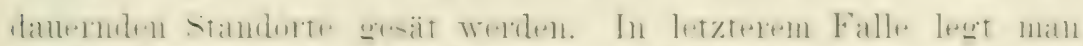

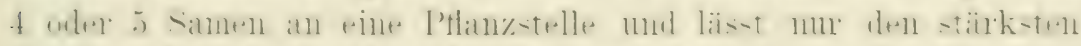

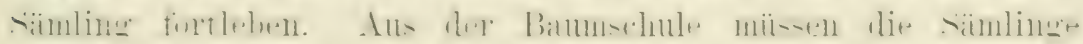

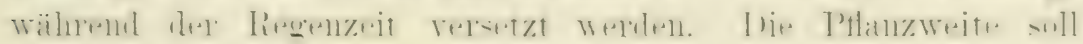
12 Meter betragen.

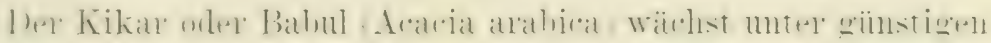

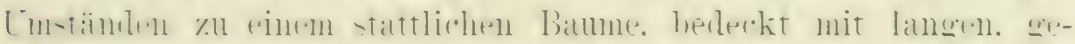

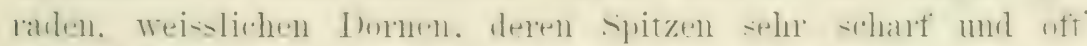

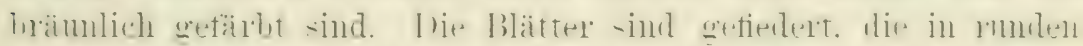

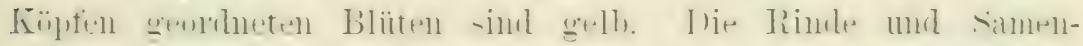

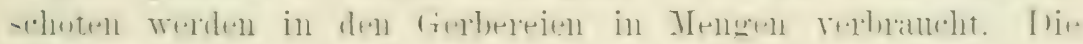

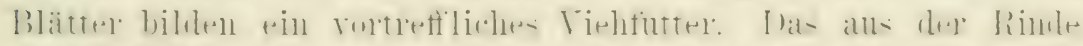

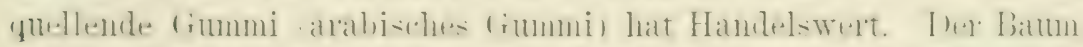

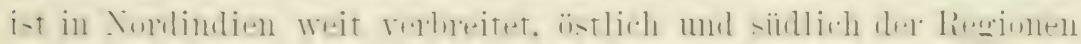

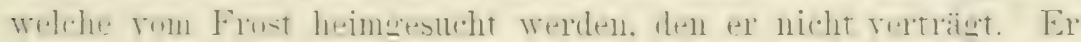

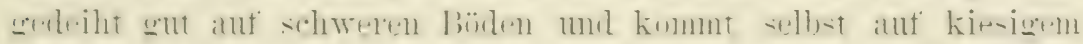

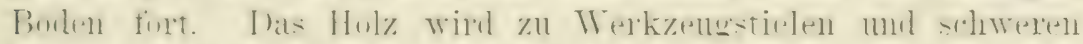

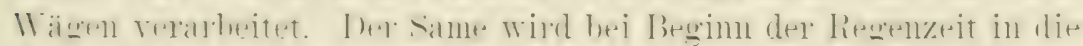

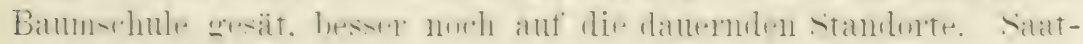

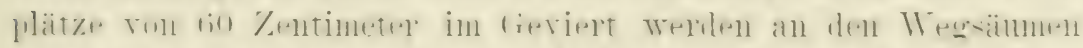

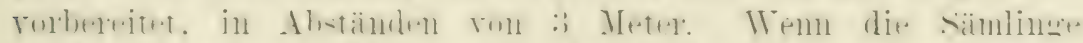

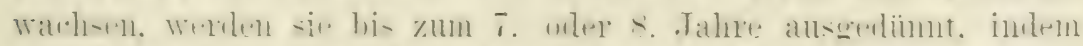

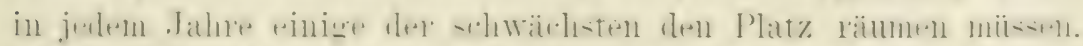

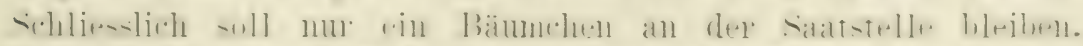

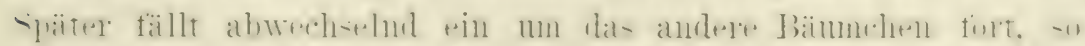

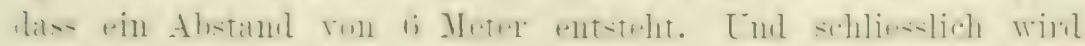
rer Abstand auf 12 Meter durch Abhol\%ung er'meitert. 
Der Remyal (Aracia meophea) mud ('hamikar (Prosopis spicyon) -ind zwei biame, welche wir der Kikin zu behandeln sind. Ni Watchsen ant jedem Boden, aber seln langsam und dürfen nivht verpflanzt werden.

Ich marhe darauf antmerksam, dass diese Anleitung nur tïr die Beptlanzme ron Strassen zu verstehen ist. In der Forstkultur sind diese Bäıme dicht zu pflanzen nud allmählich zu durchforsten. 


\section{I)ie kulturwürdigen Hölzer.}

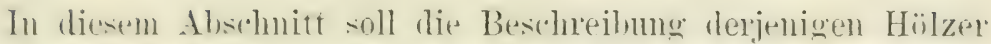

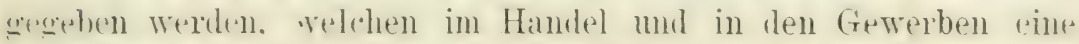

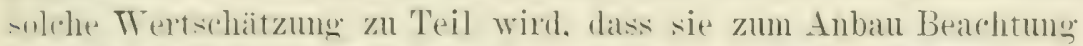

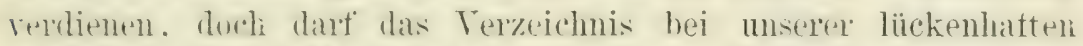
Kemtnis der tropischen Tralder nicht als abgeschlossen betrachtet. werden. Sehr nahe liegt die Wahrscheinlichkeit der Entleckung mopischer Hölzer, die sich den grekamnten besten an die seite stellen, mithin ebenfalls kulturwïrdig sind.

I ter Tadel wird seine Stimme erheben, warum ich nicht eine Gruppierung auf botanischer oder geographischer Grundlage rorEnommen labe. Ireine linwiderung lautet: von einigen Hölzern wiscen wir überhaupt noch nicht die botanische Quelle, von anderen ist sie zweitelhaft und ïber mehrere streiten sich die Gelehrten, wellher Gattung und Familie sie beazuzählen sind. Da ich kein wi-enschattliches, sondern ein für den praktischen Gebrauch bestimmtes Buch schreibe, so muss ich mich an die vurhandenen Handelsnamen haltria und diese sind in nicht wenigen Fällen quelchlautend fiir mehrere Hölzer ohne botanische Terwandtschaft mal ron relsidiedener geographischer Herkunft. Türde ich solche gledelmamigen Hölzer trennen, behuf: (iruppierung auf botanischer mele geographischer Grundlage, dam verlöre dieser Abschnitt an Übersichtlichkeit fiir den Mann der Praxis.

Fiir die nordamerikanischen Hölzer treften diese Berlenken nicht zu, sit sind simtlich botanisch festgestellt und seit in den Burichten über den Zensus und dir geologischen Termessung:arbeiten die wissenschaftlichen Samen der Bäume in Ïbereinstimmung mit bentham und Hooker für die Laubhölzer und mit carrierm tïr die Sardchlölzer angeführt. also gewissermassen ofticiell wurden.

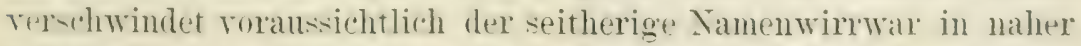
Yukuntt. wodurch volle Klarheit auf diesem Gebicte herrschen wird. Ibiese officiellen wisienschattlichen Samen sind atloh in 


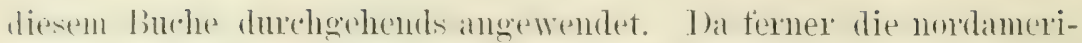
kanischen Hölzex keine enleichlautende Handelsnamen mit Hölzern anderer geographiseher Herkunft führen, so kömen sie unbedenklich zu piner Gruppe behuf. Erhöhnng der Übersichtlichkeit diesel Darlegmg zusammengestellt werden. Dasselbe gilt für die kleine Gruppe der europäischen Hölzer:*')

\section{Die nordamerikanischen Hölzer.;)}

\section{Fichen hol $\mathrm{z}$.}

Die zur Familie ('apuliterae gehörende Gattung (Quercus (Eiche) zerfällt in etwa 250 Arten, welche rolzugsweise in der gemässigten Zone der nördlichen Erdhälfte heimisch sind; einige ñommen in den Gebirgen des engeren Tropengürtels, in Sürdamerika und dem malayischen Archipel ror, un sehr tenige finden sich in der kalten Zone; Australien besitzt nicht eine Art. Anf Vordamerika entfallen 40 Arten, welche auf (rrund der Rindenfarbe in weisse mol schwarze Eichen getrennt werden. Die Ersteren wachsen langsamer wie die Letzteren und liefern ein in jeder Hinsicht rorzilglicheres Holz. Die schwarzen Eichen haben durchgehends eine ramhe, dunkle Rinde. ihr Holz ist spröd und porïs und der Tnterschied zwischen Splint und Kernholz weniger dentlich wie bei den weissen Eichen.

Von dieser stattlichen Artenzahl können nur die wenigen, unten angeführten. zur Ku!tur tür die Holzproduktion empfohlen werden. Fiir die Rindenproduktion sind bereits an anderer Stelle zwei Arten als beachtenswert bezeichnet worden: die Kastanieneiche der Pazifikkïste (Qnercus densiflora), welche nicht mit der Kastanieneiche der atlantischen Staaten (1)uercus prinus): relwechselt werden darf, deren Rinde iibrigens ebenfalls in den

*) Anmerkung: Die botanischen Namen der Nadelhölzer wurden nach den Beschlüssen des Dresdener Kongresses der deutschen Coniferen-Kenner und Züichter von 1887 eingetragen.

**) Anmerkung: Über die in Zahlen ausdrückbaren physikalischen Eigenschaften ist die betreffende Tabelle im Abschnitte über die Holzkunde nachzulesen. Die nachfolgend angeführten physikalischen Eigenschaften sind zum grösseren Teile dem Zensusbericht von 1880 entlebnt; obgleich derselbe als Standvermerk gilt, nahm ich doch $\mathrm{Abänderungen} \mathrm{und} \mathrm{Ergänzungen} \mathrm{vor,} \mathrm{die} \mathrm{sich}$ auf beste fachmännische Urteile stützen. 


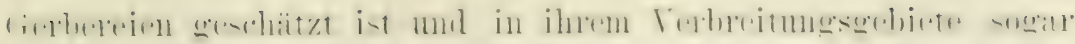
der Rinde jeder andern weissen Eiche vorgezogen wird.

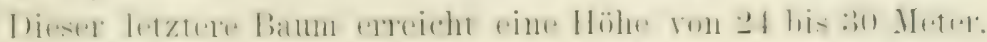

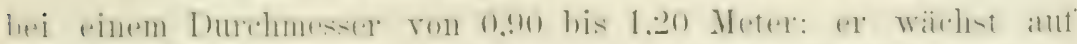

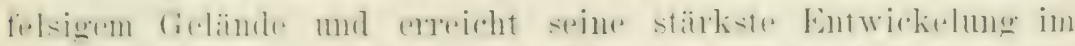

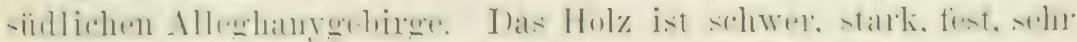

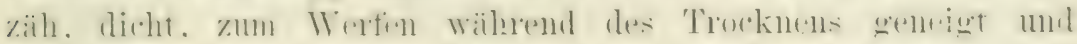

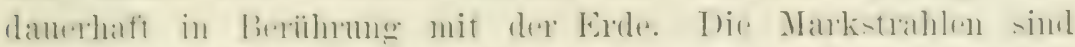

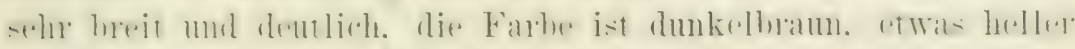

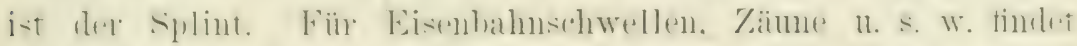
dieses Holz ausgedehnte Verrendumg.

Fener die Färbereiche (Quercus tinctoria), die zwal' in

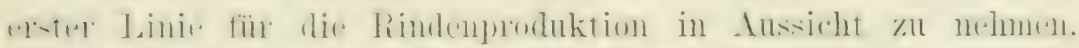

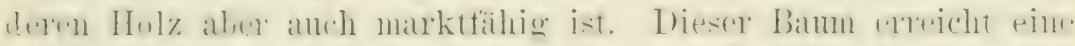

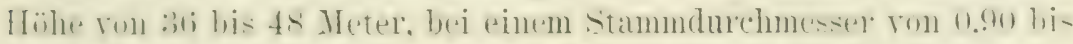

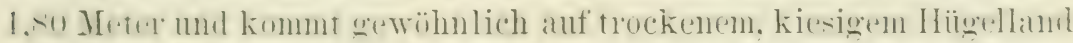

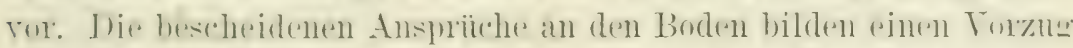

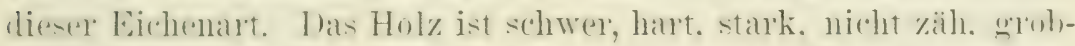

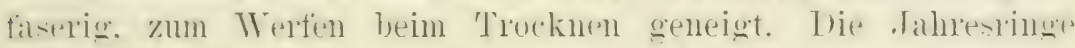

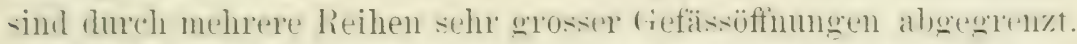

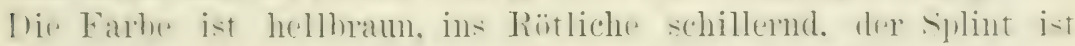

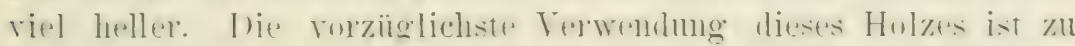

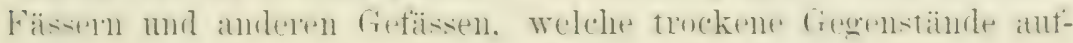
nehmen sollen; auch als Brennstoff ist es geschätzt.

\section{a. Weisseiche (Quelcus alba).}

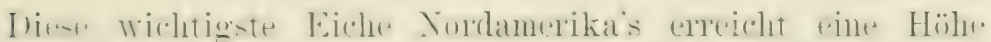

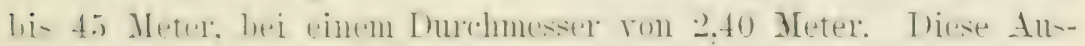

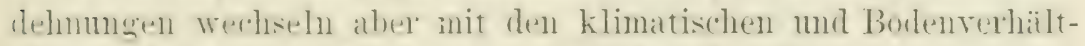

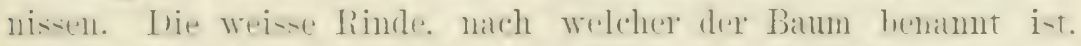

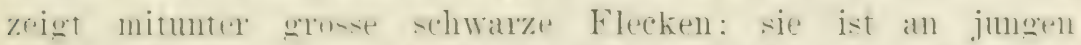

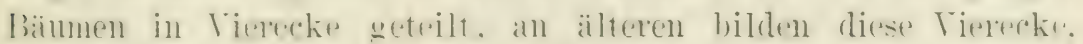

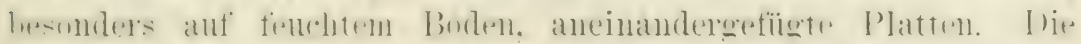

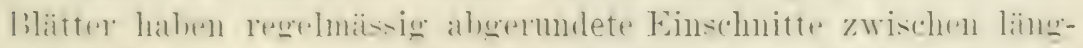

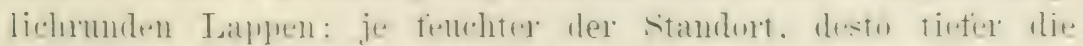

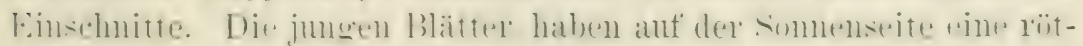

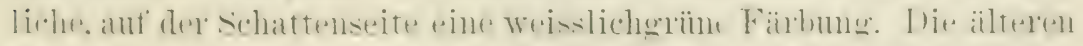

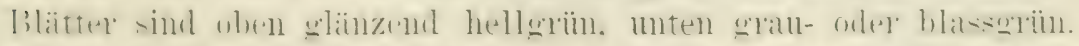

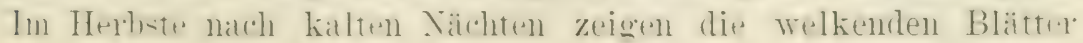


blïulichn. violette, mit rotbram mul röthohgesb abwechselnde Schatticrungen. Nur diese Eichenart behält, in ihrem Terbreitungscebiet, das Laub den Winter hindurch bis zum nächsten Frïhjahr mol zeidhnet sich dadurch, wie durch ihre ausnehmend weisse Rinde. vor den ïbrigen Eichenarten wïhrend des Winters aus. T)ie Blïte erscheint gewöhnlich im Mai; damn entwickehn sich die granbranen, bisweilen gräulichblanen Eicheln in rauhen. wenig vertieften, grauschuppigen Bechern; sic stehen an 2 bis $\therefore$ Zentimeter langen Stielen bald parrweise, bald einzelli und find ziemlich gross, länglich rund und von siisslichem Geschmack. I)ie Bäume tragen gewöhnlich sehr schwach, oft kam mall anf weiten Strecken kaum einige Hände voll Eicheln auflesen.

Ton canada bis Texas wächst diese Kichenart; im Norden mnd Sïden spärlicher, auch nicht häufig in den überaus firuchtbaren Marschländern an den Ufern der grossen Ströme des Westens. am zahlreichsten tritt sie anf und erreicht ihre höchste Entwickelung an den westlichen Abhängen des Alleghanygebirges und im Thale des Ohio, wo sie oft einen groswen Bestandteil der Wälder bildet.

Ias Holz wird ron Sachkemern folgendermassen charakterisiert: hellbran mit einem Stich ins Rötliche, der Splint ist lichtbraun bis strohgelb, stark. schwer, dicht. sehr zäh, elastisch, danerhaft in Beriilırung mit der Erde.

Die Jahrestinge sind scharf abgegrenzt durch mehrere Reihen grosser, offener Gefässröhren; die Markstrahlen sind breit und sehr deutlich. Wem nicht rorsichtig getrocknet, wirt es sich stark. schrumpft und reisst, daher hat es wenig Wert zur Bretterrerschneidung. Das Schrumpfen beträgt etwa ${ }^{1} / 32$ der anfänglichen Ansdehnung. Versuche zeigten: 1. dass behanenes Holz 10\% in einem Jahr und $5 \%$ in 4 Jahren mehr an Gewicht rerlor. wenn die Fällung in der warmen statt der kalten Jahreszeit stattfand; 2. dass Blöcke in der Rinde $8 \%$ in einem Jahre mo 17 ". in 4 Jahren mehr an Gewicht verloren. wem die Fällumg im Sommer statt im Winter erfolgte.

Das spezifische Gewicht bewegt sich zwischen 0,7 und 1,1. Ein Kinbikmeter wiegt durchschnittlich 705 Kilogramm in trockenem und 1121 Kilogramm in grünem Zustand. 


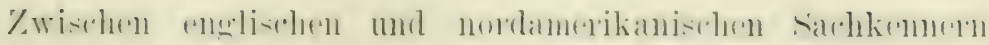

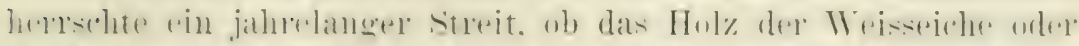

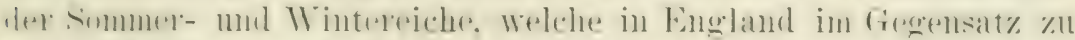

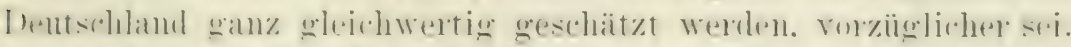

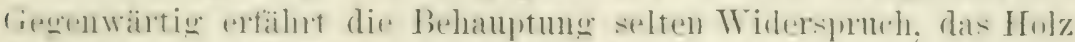

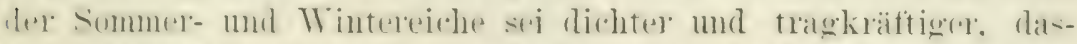

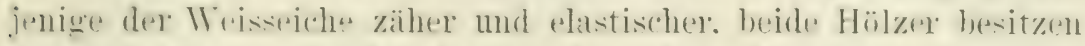

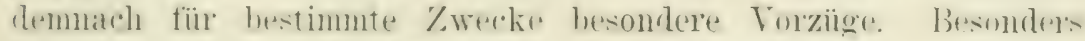

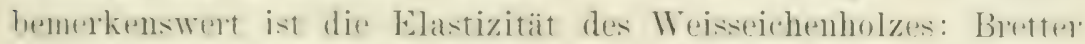

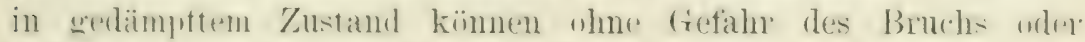

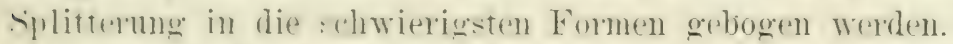

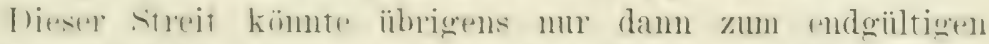

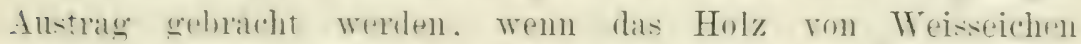

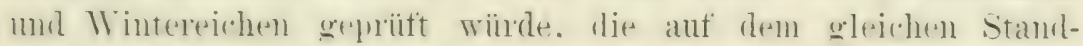

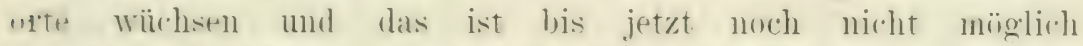
getwertll. Allhekamnt ist, dass das Holz der Weisseiche heträroh-

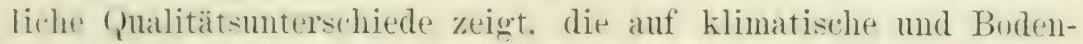
rerhältnisse zurïchzuführen sind. Ant dem ziemlich häufig: getundenen standorte, welcher in Fribleahr ïberschwemmt, in Reste des Jahres aber trocken bleibt. ist der Friihjahrswurhlocker und porös. Während der sommermuchs hart und dicht ist. volules Holz ist weder stark noch dauerhaft. dageren besitzt es infulge sinel relschiedenen Faserung ein selng getalliges Auscellen mnd wird daher in der Tischlerei geschätzt. Auf finem somnigen standonte mit pirem, das ganze . Jahr hindureh mässio fenchten L.thmburlen wird das Holz su divht, stark und lallerhaft. dass sir.l

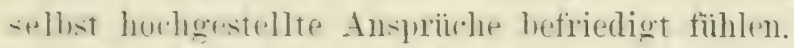

l)is Holy wird spröde und hrïrhig. sobald die Bämme ihre lieife ereicht halen: ann zialesten und krätigsten ist es bei einem Alter von so bis 100 . Tahren. Das Holz der granz jungen sitamm. ist spinel anserorlentlichen Flastizitat mol grenamen Teilbalkeit wegen zu Fasserifon. T'eitschenstelen und mancherlei Flerht-

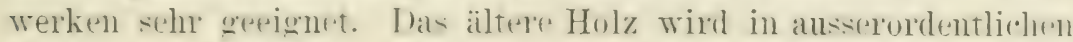

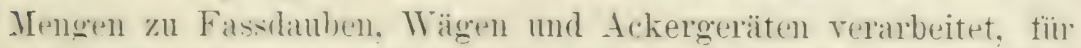

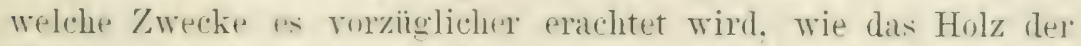

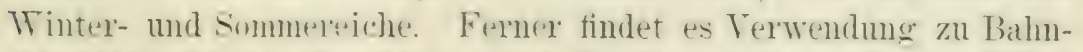

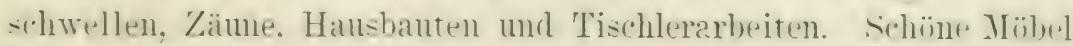

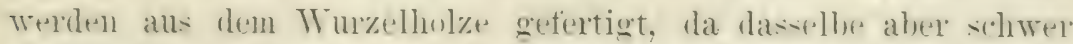

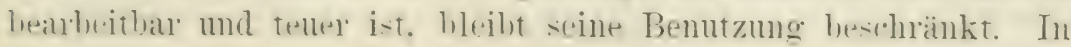


hohes Arhtmo strht Weisseichenhol\% bei den nordamerikanischem

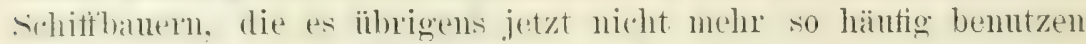
wie fiuhler, weil gute Qualitäten stark im P'reise gestiegen sind. mod dis Holz ïberhant von Eisen und Stabl im schiffbau mehr mul mehr verdrängt wirl. I) englischen Schiffbaner haben stets dats Holz der Wrintereiche bevorzugt nnd wohl mit Recht.

In Bezug anf spezifische schwere nimmt das Weisseichenholz muter den nordamerikanischen Fölzer'n den 124. Rang, auf verhältni-mässigen Bremwert den 63. Rang; ant den Coeffizienten de Elastizitat den 12. Rang, anf Bruchfestigkeit den 89. Rang. aut Thuckfestigkeit den 89. Rang und auf Eindrukfestigkeit den 109. Rang ein. Das Holz anderer Eichenaten steht bald in dem einen, bald in dem andern hang höher, doch ist daran zu erinnern. dass die Tertschätzung eines Holzes anch nach seiner Grad- und J)ichstämmigkeit und Astfreiheit zu beurteilen ist. und in dieser Hinsicht gebührt der Treisseiche der erste Rang unter den nordanerikanischen Eichen. Während sie der Sommer- und Tintereiche vollständig gleich steht.

In der zu befolgenden Anbaumethode schliest sich die Treisseiche eng an die Sommereiche an. Zwar wird sie auf vielen Budenarten gefunden. allein ilne höchste Entwickelung erreicht $\therefore$ ie aut mässig feuchtem, kalkhaltigem Lehmboden, der tiefgriundig sin mus. da die IVeisseiche eine I'fahlwurel bis zur Tiefe ron $1^{1}$ : Meter treibt. In Folge desen üht auch der Tntelgrund einen entschiedenen Einfluss auf das Machstmm und die Qualität des Holzes ans. Mässig geklüftetes Kalkgestein, die milden Thonshlefter. die reicheren sandsteine, Mergel, Granit. Basalt, Grünstein und thoniger Porphyr werden als gimstiger Tnterorund betrarhtet, da sie kein frmulwasser halten und doch danemel frisch bleiben.

Die Weisseiche beronzugt, gleich del sommereiche, warme Thäller und somige Torberge. Freistehend ist sie geneigt, sich tief zu verïsteln. allein wem sie steht gemäss der forstlichen Regel: mit freier Frone. beschattetem stamme und bedecktem Fus.

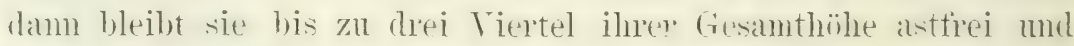
bildet einen schönen, geraden, dicken Stamm.

IVie ambere Eichem. ist anch die Weisseiche von Xatur nicht

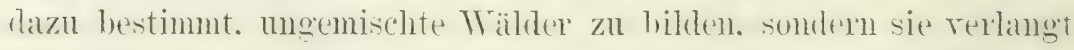
sir. Hilti. von whattenspendenden und bodenverbeserenden Bäumen. 


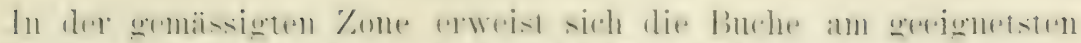

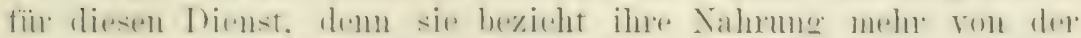

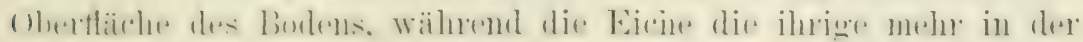

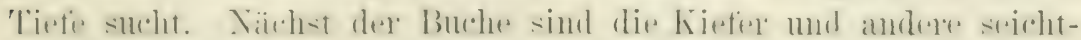

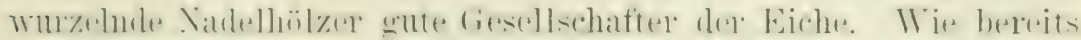

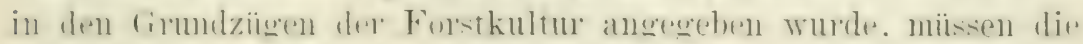

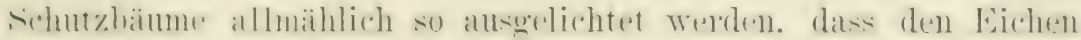

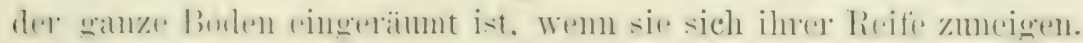

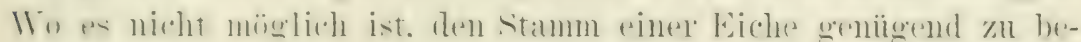

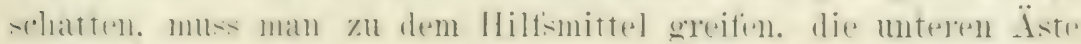

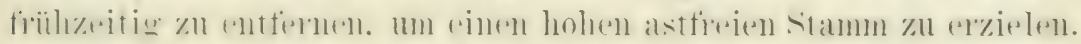

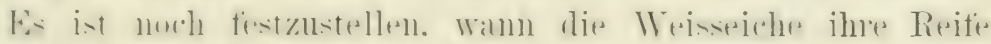

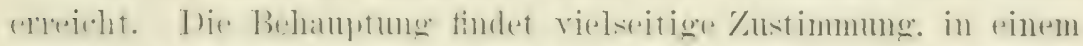

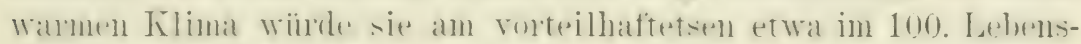

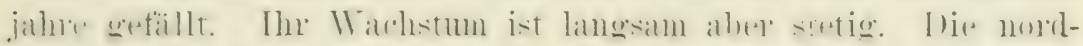

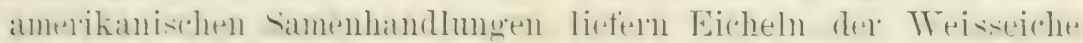

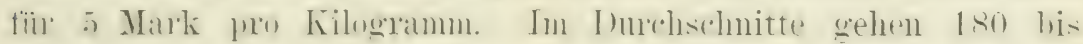
200 Eicheln auf das Kilogramm.

b) Posteiche, Eiseneiche (Quercus obtusiloba).*)

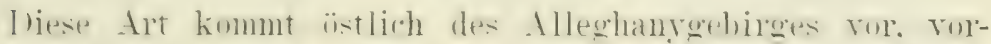

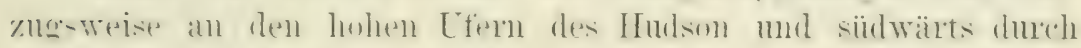

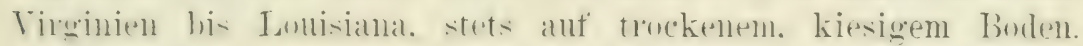

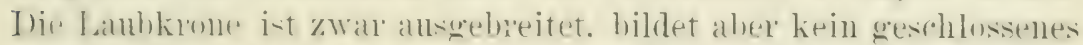

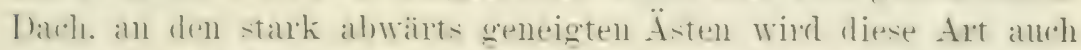

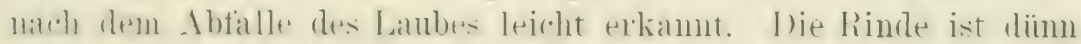

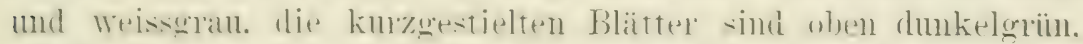

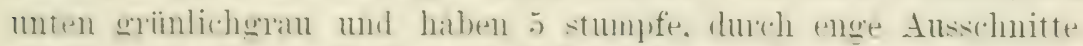

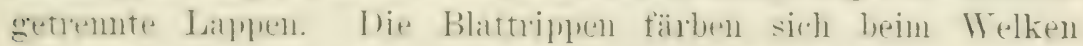

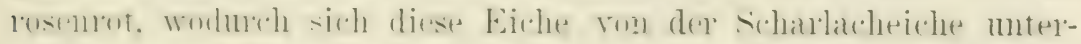

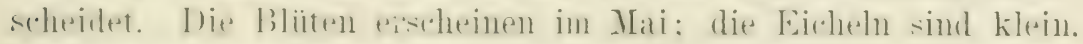
länglich und von angenehm siisslichen Geschmack.

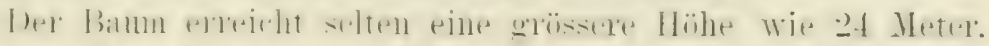

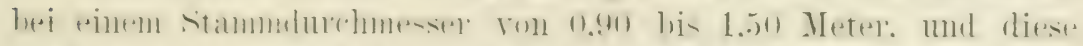

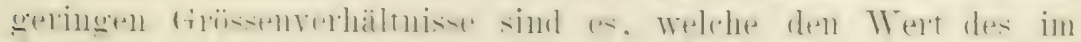

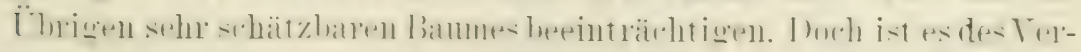

\% Ammerkung: Die Bezeichnung, „Posteiche" ist in der deutschen Dendrologie kaum oder gar nicht bekannt; daher unser entsprechender Zusatz: Eiseneiche.

H. $H$. 
suches wert, ob durch die hultur. rou welcher bisher abgesehon wurde, eine befriedigerende Stammdicke zu erzielen ist. zumal dabei ein Boden in Betracht kommt, so mager und trocken, dass el für eine andere unter Kultur befindliche Eichenart untanglich ist.

Das Holz ist s'ilwer, hart, dicht und damerhafter, stärker und feinfaseriger wie das Teisseichenholz, dem es nur in Bezug auf Elastizitat nachsteht. I le Farbe ist hellbram bis gelb, der Splint ist hellgelb, die Jahrestinge sind durch 1 bis 3 Reihen nicht grosser; offener Giefässröhren begrenzt. Die Markstrahlen sind zahheich und deutlich. Torsicht ist im Trockenen geboten, da sich sonst das Holz stark wirft.

In Berïhrung mit der Erde ist dieses Holz sehr dauerhaft, daher es für Bahnschwellen und Banzwecke stark begehrt ist. Zu Pfählen und Fassdauben wird es dem Weisseichenholz vorgezogen und im schiffbau ihm gleichgestellt. liefert aber seines geringen Umfanges wegen fast nur Kniee, selten Planken. Auch zu Ackergeräten und im Wagenbau findet es vieltache Verwendunw.

L'nter den nordanerikanischen Hölzern nimmt dieses Holz den 66. Ratng in spezifischer Schwere, in verhältnismässigen Brenıwert den 64. Rang, im roefficienten der Elastizität den 175. Rang, in der Bruchfestigkeit den 104. Rang, in der Druckfestigkeit den 104. Rang und in der Eindruckfestigkeit den 104. Rang ein.

Bei dieser Rangeinteilung darf nu nicht ïbersehen werden, dass sie erfolgte auf Grund der Ermittelung der I)urchschnittsqualität einer beschünkten Anzahl Siäbe. Wem ich oben sigte. das Posteichenholz sei stärker wie das Weisseichenholz, so stiitzte ich mich anf das Urteil erfahrener Architekten und wenn das mit der hiex angeführten Rangeinteilung nicht ganz übereinstimmt, so ist das durch die Qualitätsmuterschiede zu erklären, welche jedes Holz anfweist.

Die nordamerikanischen samenhandlungen fïhren keine Eicheln der Posteiche, besorgen sie aber auf Wunsch ohre Schwierigkeit.

\section{c) Lebenseiche (Quercus virens).}

Dies: bereits an anderer stelle erwähnte immergrïne Eichenart. kommt rom sürdlichen Virginien der Küste entlang bis zur Mïndung des Mississippi vor, vom da verbreitet sie sich bis zum westlichen Texas mol nach dem nördlichen Mrexiko, wo sie bis zu 


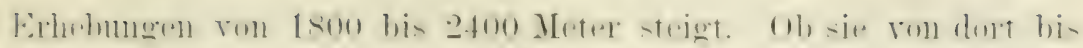

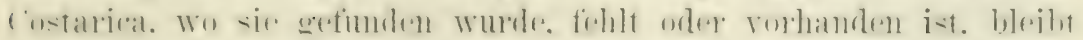
der Forschumg rorbehalten.

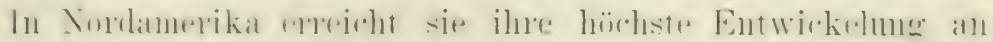

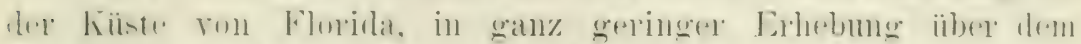

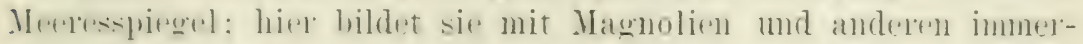

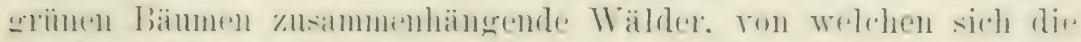

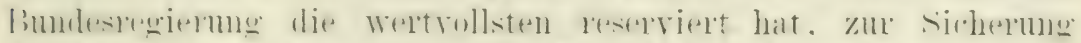

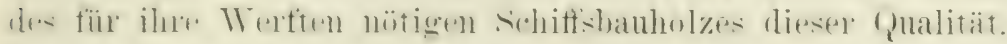

Das Holz ist sehr schwer, hart, stark, zäh, sehr dicht.

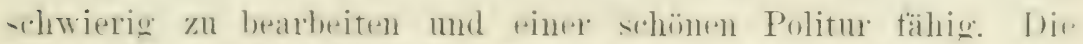

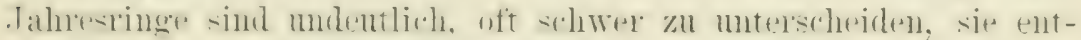

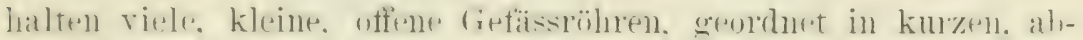

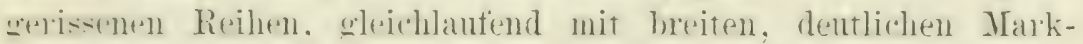
-trahlen. Ilie Farles ist liehtbram orler gelb. der splint is

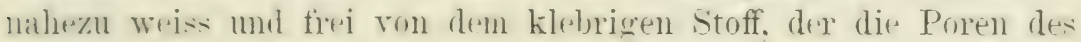
dirhtren Kermholzes retiillt and es dautehatter macht. Trotzdem

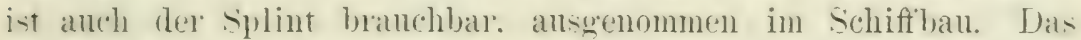
Holz wirtt sich stark. Weme es während des Trocknens den somnen- trahlen oder dom Winde ansogesetzt ist. Bei sorertaltiger Behand-

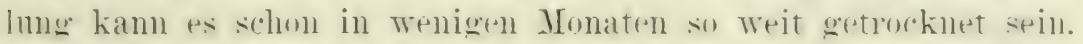
rlass es im Schiffbau verwendbar ist.

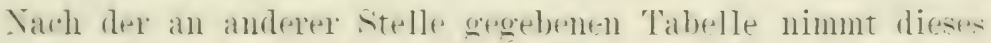

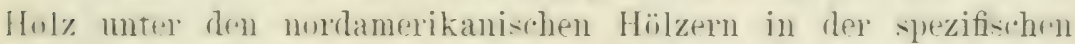

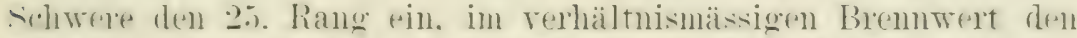

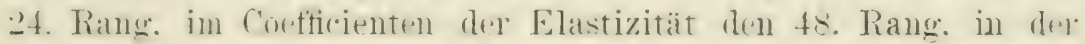

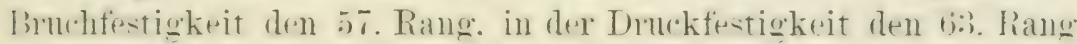
mnd in der Eindrucksfestigkeit den 33. Rang.

Ter Baum wächst 15 his 18 Metre horh. hei trinem vitammdurchmessel ron 1,50 bis 2,10 Meter.

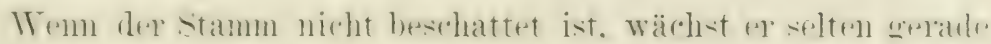

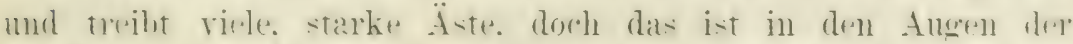

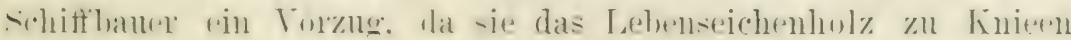

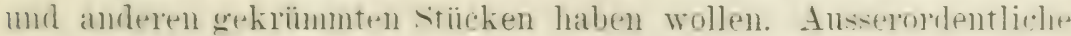

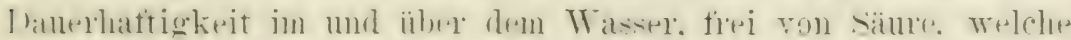

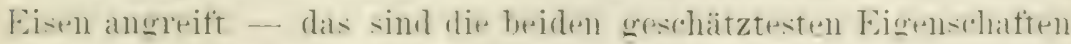

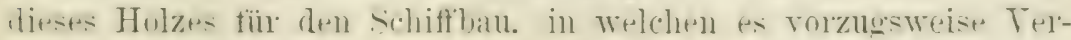

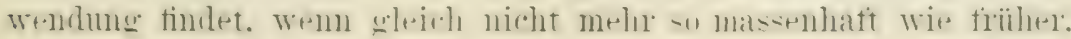




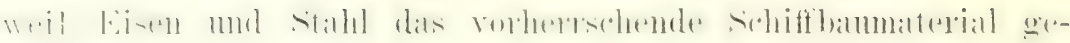
worlen sind.

Eine andere Terwendung ist als Werkhol\%, namentlich zu IVaneralbeiten und landrirtschaftlichen Maschinen.

An Auforderungen, diesen nuitzlichen Baun unter Kultur zu

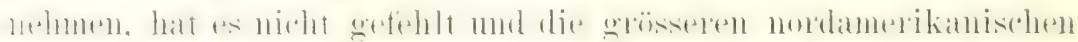

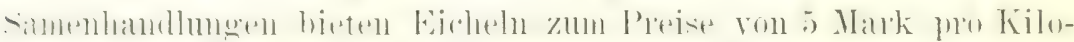

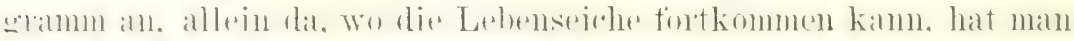

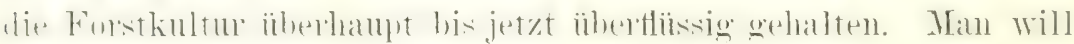

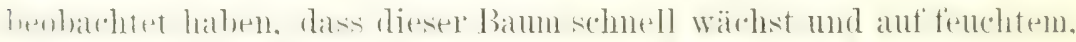

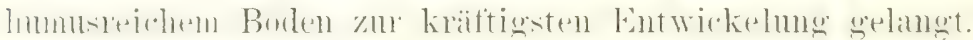

\section{d) Burreiche (Quercus macrocarpa).}

Diese schöne dichtbelaubte Art erreicht eine Höbe bis zu

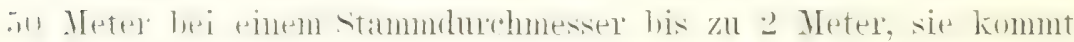
ron Nova Ścotia im Norden bis T'exas im siiden vor. und verbreitet

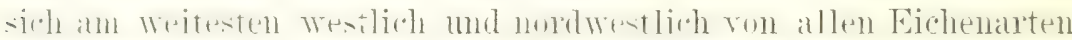

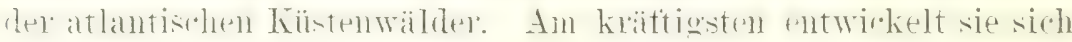
anf Prärie- und Schmemmboden. Die Blätter sind bisweilen :n \%

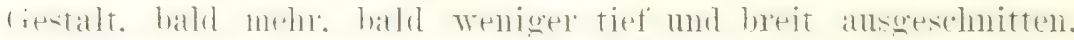

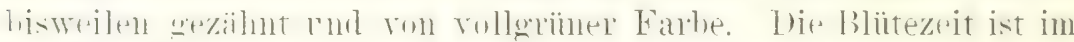

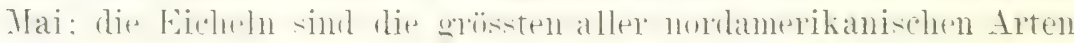

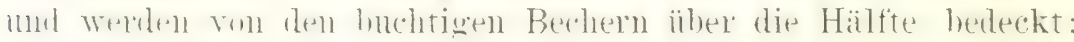
die Ränder der dicken. ramhen Becher sind dicht behart; an

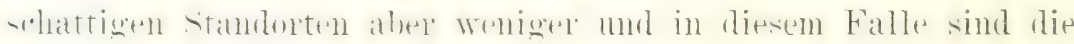
Ränder einnärts gebogen.

Das Holz ist schwer, stark, hart, zäh. dicht, danerhafter in

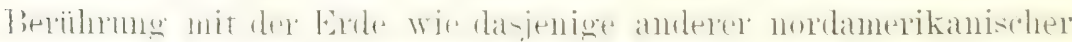

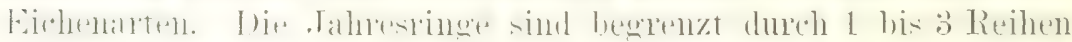

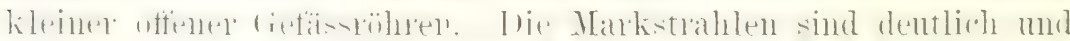
oft breit. Die Farbe ist dunkel- oder reichhellbraun, der Splint ist viel heller.

Rangstellumg mor den nordamerikanischen Hölzern die 128. in spezifischer Schwere, die 129. im verhältnismässigen Brennwert, die 128. im Coefficienten der Elastizität. die 68. in

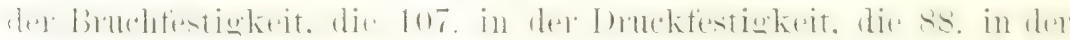
Findrucksfestigkeit. 


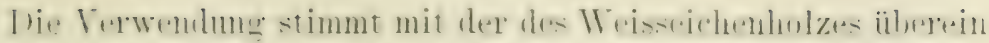

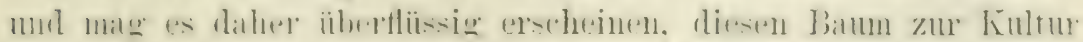

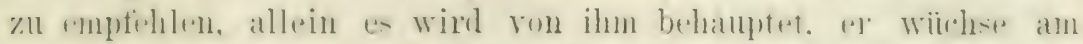

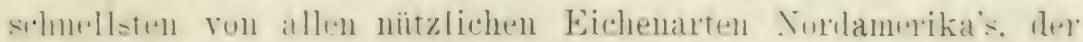

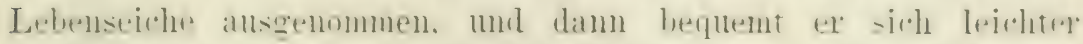

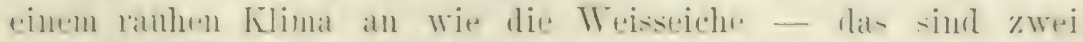

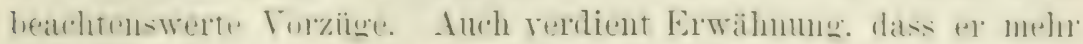

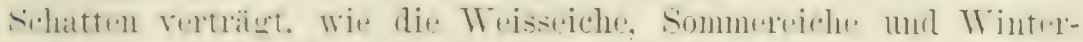

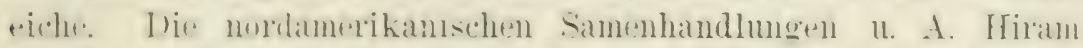

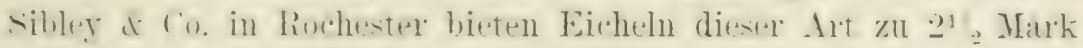
pro Kilogramm an.

\section{e) Korbeiche (Queicus Michauxii).}

Von delaware sïdlich bis zum nördlichen Florida, in den tioltstatton, Arkansas, Kenturky, dem sürlirhen Inlinois unr Indiana ist diese. von allen weisen Eichen der Coltstaaten niitzlichste Art, verbreitet. Ier Baun erreicht eine Höhe ron 2y his

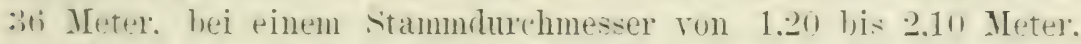
mul kommt rorzugsweise an Flussufer'n und anf häutig iibersehwemntem Gelände ror: seine kräftigste Entwickelung erreicht rl' auf tiefem schwermboden in Lunisiana und Arkansas.

I as Holz ist schwer. hart, sehr stark, zäh, dicht, sidn dauterlate in Berihhrung mit der Erdes und leicht spaltbar. Die Tahreslinge sind begrenzt durcll wenige, grosse, oftene frefïssriohrent. Ilie Markotrahlen sind dentlich und breit. Dit: Farlue ist licht-

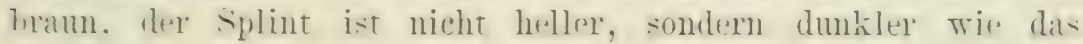
Kernholz.

Iliess Holz findet eine ans gerlehnte Verwendung zul Arker-

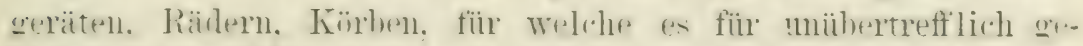

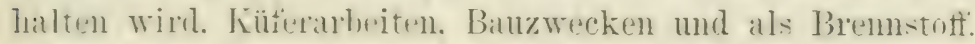

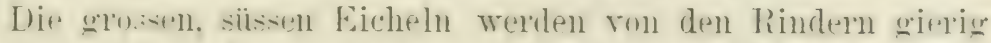

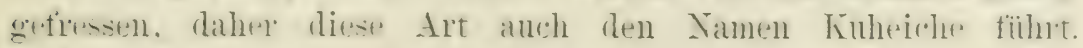
Andere Tiere riaschen die Eicheln ebenfalls gerne.

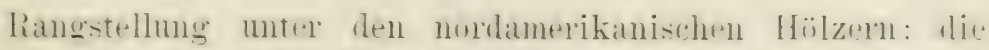

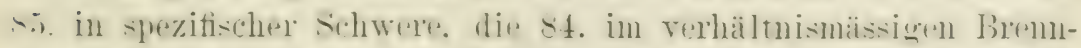

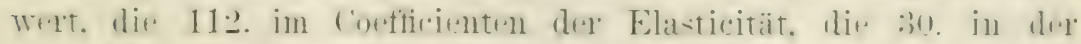

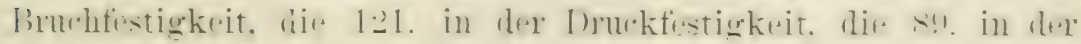
Eindruckstestigkeit. 
I ie nurdanerikanischen Sannenhand lungen fuhnen diese Eivhehn nicht, besorgen sie aber.

\section{B й he $12 \mathrm{~h} 0 \mathrm{I}$.}

Die Familie ('upuliferae besteht nur ans den 6 Gattmenen (Mnerens. Fagus, Castanea. Ostrya. ('atstanopsis und ('alpinus, spielt aber trotzdem eine wichtige Rolle in der Zusammensetzung der Tälder der Erde. Die Gattung Fagus / Buches zerfaillt in etwa ¿5 Arten, von walchen eine in Europa, eine in Nordamerika. die übrigen in Japan, Südamerika, Anstralien und Nenseeland lieimisch sind.

Nordamerikanische Buche (Fagus ferruginea).

Diese der emopäischen Buche (Fagus sylratica) ähmliche Art. erreicht eine Höhe ron 25 Meter bei einem Stammdurchmesser ron 1 bi: 1,20 Mreter und kommt rorzugsteise in Kentucky: Temmessee und an den Ufern des Ohio vor. wo sie den rorher'rschenden Bestandteil ausgedehnter Wäder bildet. Die Rinde des Stammes ist dick, grau und selbst an den ältesten Bänmen ohne Furchen und Risse. Die Blätter sind länglich eiförmig, zugespitzt gezahnt. glänzend grün und während des Frïhjahrs mit feinen, weichen Härchen eingefasst, die sich allmählich rerlieren. Die kleinen grünlichen Blüten erscheinen im Mai und sind in rundlichen, hängenden Büscheln geordnet. Die Früchte sind längliche. nussähnliche, mit weichen, biegsamen Stacheln besetzte Kapseln, welche sich zur Zeit der Reife ron selbst öthen und 2 dreieckige Samen enthalten.

Das Holz ist sehr hart. stark, zäh, sehr dicht, nicht dauerhaft. wenn abwechsehnd der Sässe und Trockenheit ansgesetzt. aber selur dauerhaft. Wenn beständig unter Wasser. zum Werfen während des Trocknens geneigt. fühig. eine schöne Politur anzumehmen. Die Markstrahlen sind breit und selu deutlich. die Farbe wechselt sehr, gemäss dem Boden und Standort. ron dunkelrotbraun bis zn einem lichten Rot. der Sylint ist nahezu weiss. Fs findet eine ausgedehnte Verarbeitung zu Stiilılen. Scluhleisten. Mangelwalzen, Sipulen. Trasserbanten. Kisten u. s. W. In del Fohlenbremerei wird es hoch geschätzt. und gilt als eines der besten Brennhölzer. 


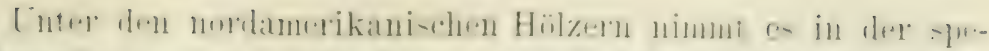

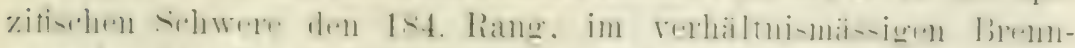

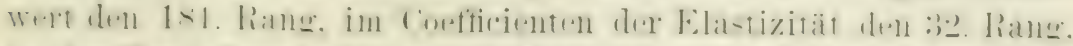

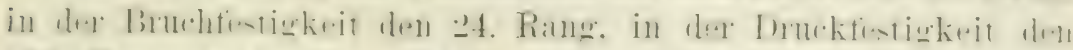

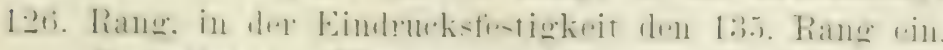

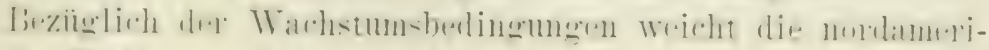

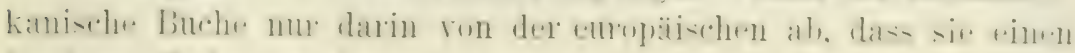

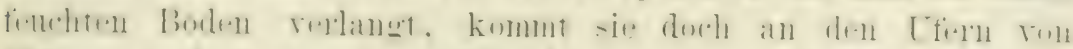

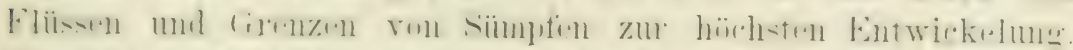

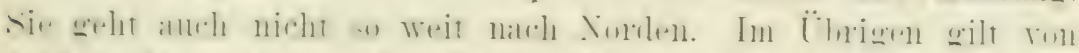

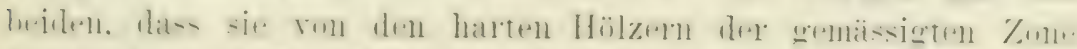

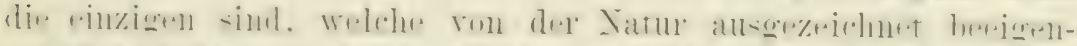

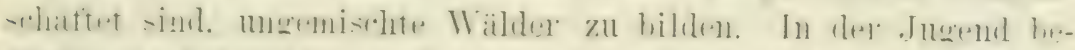

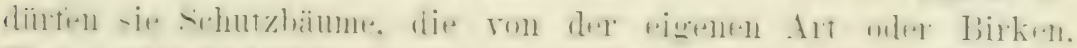

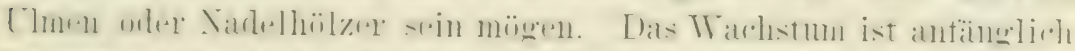

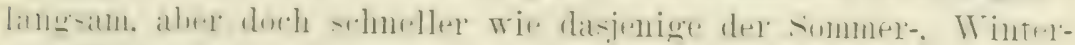
und Treisseiche.

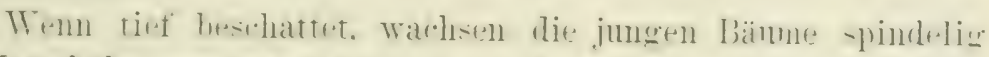

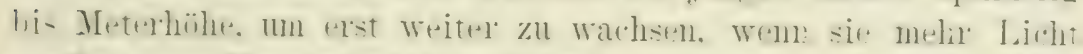

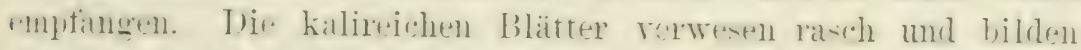

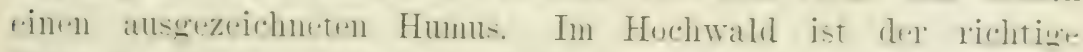

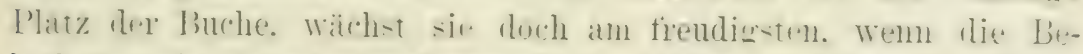

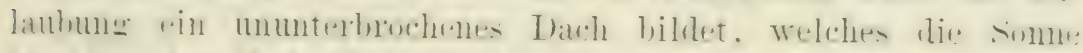

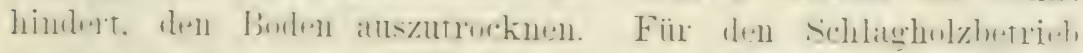

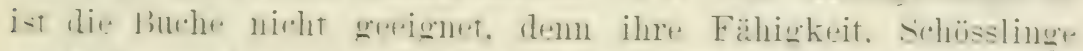

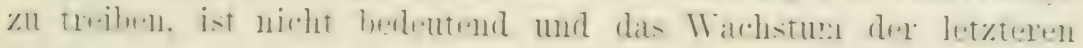
ist langsam.

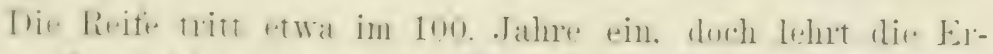

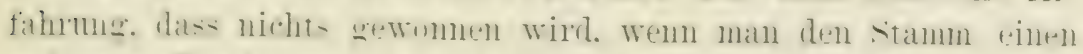

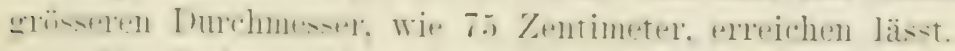

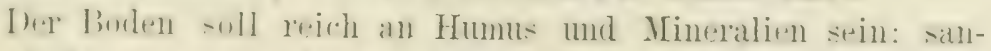

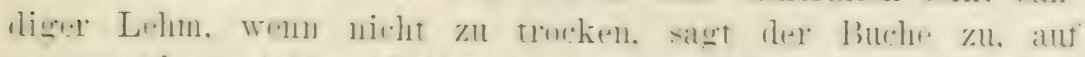

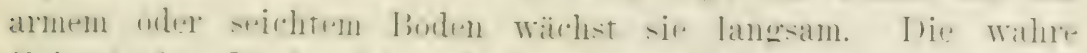

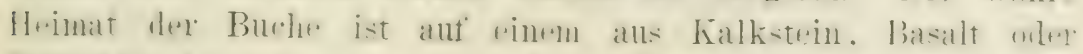

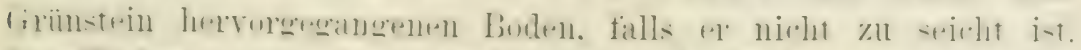

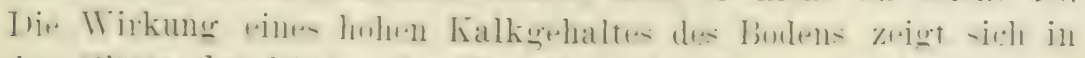

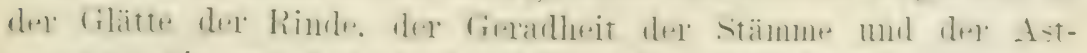

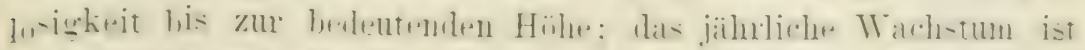

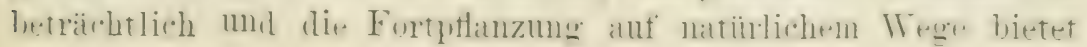


ke'me s.hwierigkeit. Anf geschützten standorten mit kalkreichem Bulen begrinnt die Buche etwa im -0. Tahre Samen zu tragen und tahnt damit in Fiille fort, in Lnterbrechungen von 3 his 5 Jahren.

Ihe nordamerikanischen Simenhandlungen bieten samen ron Fagls ferruginea zum Preise rom 15 Mark pro Kilogramm an. \%wischen 2500 his $\$ 000$ samen gehen auf das Kilogramm.

\section{Kastanie nholz.}

Tordamerikar besitzt 2 Kastanienarten. ron welchen die eine (1'astanca pumila) zwar ein dichteres, feinfaseriges und dauerhafteres Holz liefert. wie iroend eine andere Kastanienart. zum Anbau aber nicht empfohlen werden kann. weil ihr Stamm ron so geringer Ausdehnung ist, dass er nur eine beschränkte Terwendumg zulä-st.

Nordamerikanische Kastanie (Castanea vulgaris var. americana) fiüher Castanea americana.

Ein groserer Baum, bis 30 Meter hoch, bei einem stammdurchmener von 1 bis 4 Meter. Die etwa 15 Zentimeter langen mol 3 Zentimeter breiten, länglichen, scharf gezahnten Blätter haben eine schöns, glänzend grïne Farbe und anf der untern seite hrrorstehende Rippen. Die weisichen, mangenehm riechenden Blïten erscheinen im Mai und stehen an 10 bis 12 Zentimeter langen Stielen haufenweise wie bei der Roskastanie. Die kugeltörmigen. mit feinen stacheln besetzten Früchte enthalten zwei, an der einen Seite abgeplattete, etwa $2^{1}$ a Zentimeter lange, brame. an unteren Ende weissliche Nïsse. Welche sïsser sind wie die Edelkastanien.

Dieser Bam erreicht seine höchste Entwickelung an ler mittleren und westlichen Abdachung des Alleghanygebirges, nürdlich wie siidlich. ron oda wird ex seltener gefunden. Der Niagara bildet die nördliche Verbreitungsgrenze.

Das Holz ist in seiner Jugend sehr elastisch, im Alter wird es spöde; muter der Belastung beugt es sich zuerst beträchtlich und bricht damn plïtzlich. Es ist leicht, weich. grobfaserig und ausserordentlich dauerhaft, sowohl unter Wasser. wie auch. wenn es abtrechselnd der Nässe und Trockenheit ansgesetzt ist, ebenso in Beriihrung mit der Erde. Ferner ist es leicht spaltbar mo nimmt eine schöne Politur an. Wenn nicht rorsichtig behandelt. wirtt es sich beim 'Thoknen. Die Tahresringe sind durch mehrere 


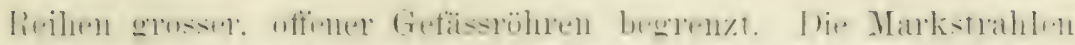

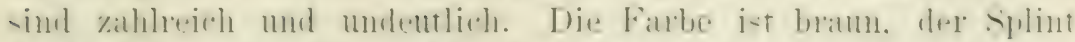

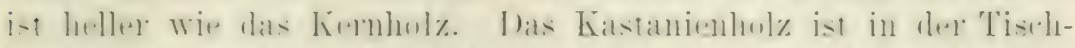

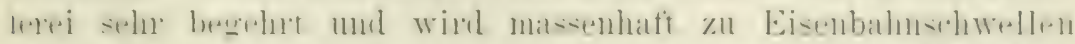

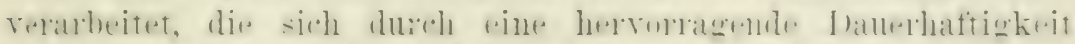

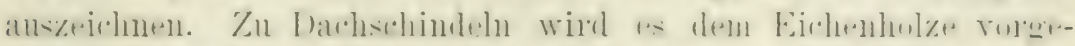

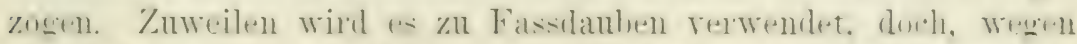

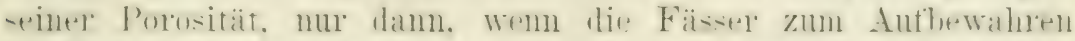

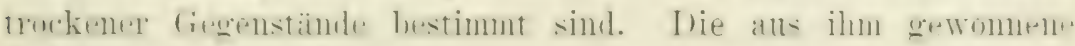
Kohle ist ausgezeichnet.

Rane-tellumg unter den nordamerikanischen Hölzern: den

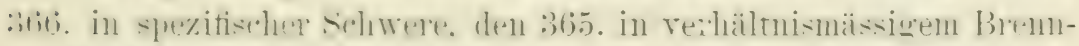

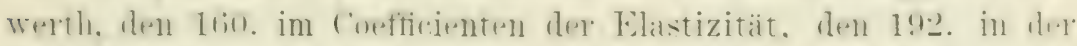

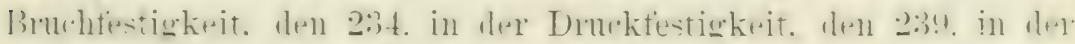
Eindruckfestigkeit.

Ther hastanuenhaum verlangt pinen leichten, kiexigen Burlen: -1. levorzugt einen solehen. der ans der. Terwitterung von Granit.

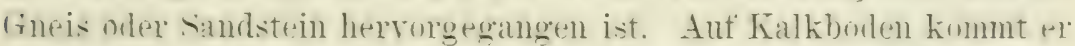

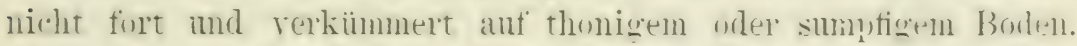
Mäsigr lohe Berghänge sind seine Lieblingstandurte durh diurtell sie dem Mreere nicht zu nale liegen. Tha sich die sianlinge niolnt leicht verpflanzen lassen. sollte die Alswalt auf dir dallelmelen

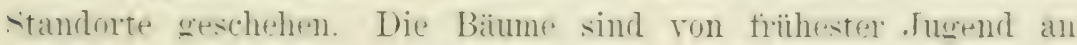
lebensaih und entwiokeln sich krätig. voransgestzt. sie stehen nicht im schatten, den sie nicht rertragen kijmen. Die Wurzeln

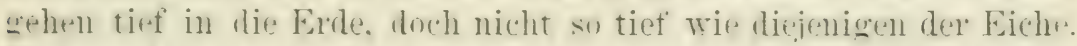
ISis zun 60. wder 70. Jahre wachsen sif sehr schnell, dam langsiun mol leben nach ihrer Reje lange fort. Es bietet aber heinen Torteil. den Kastanienhatum alter wie etwa 80 . Tahre worden zu

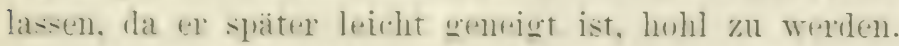

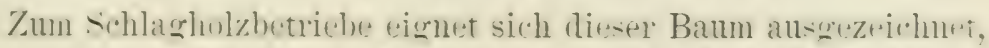

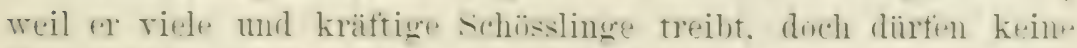

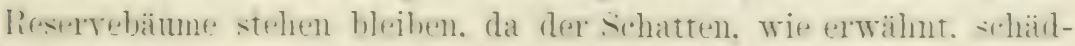
lich wirkt.

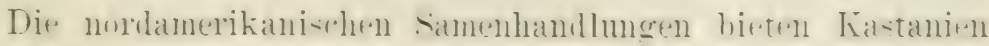
zu 4 Mark pro Kilogramm an. 


\section{B irkenholz.}

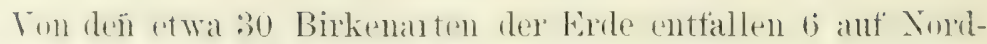
annerikil. von welchen die beiden folgenden wine besondere Beachtume zu Anbaturestuchen in andern Ländern verdienen. sowohl ihres guinstigen Wudhes, wie ihres wertrollen Holzes wegen. Anf die luhe Rangstellume des Letzteren unter den nordanerikanischen Heilzern. beziiglich der physikalischen Eigenschaften mache ich besonders aufmerksam.

Tie alle lirkenarten. können aurh diese num im Mischwaln angeptlanzt werden, wobei zu berïcksichtigen ist, dass ihre Kronen keine starke Beschattung vertragen.

a. Gelbe Birke. (Betula lntea, Familie Betulaceae) Gleichname: graue Birke.

Das ist die grösste aller Birkenarten, sie erreicht oft eine Höhe ron 25 his 29 Meter, bei einem stanmdurchmester ron 0.90 his 1,20 Meter, wähst und reitt schnell. Terbreitet is sip rom mittleren canada, sudlich dem Alleghangebirge entlang. bizu den hörhsten Erhehungen von Nordarolina und Temnesse.

Die Rinde ist gelblich oder silhergran und löst sich in whe diimmen schichten ab. Die Blätter sind schwach herztörmig, oft lassen sie diese Form nicht erkemen mol verengen sich dam gegen den Grund; oben sind sie dunklergrün wie unten. gewöhnlich sind ihre Rippen an der untern Seite flaumig:

r)as Holz ist schwer, sehr stark und hart, sehr dicht, seidenartig und nimmt eine schöne Politur an. I) Markstrahlen sind 7ahlreich und molentlich. Die Farbe ist hellbram. ins hötliche schimmernd, der schwere Splint ist nahezu weiss.

Die Verwondung findet statt zu Mïbeln. Radnaben. Dreherarbeiten, Bürsten. spulen, schuhstiften. spielwaren und Kisten. ferner als Brennstoff.

Rangstellung unter den nordamerikanischen Hölzern: I)ie 201. im spezitischen Gewicht, die 200. im verhältnismässigen Bremwert. die 10. im c'vefticienten der Elastizität. die 10. in der Bruchestigkeit. dir 34. in der Inuckestigkeit, die 97. in der Eindrucksfestigkeit.

Dieser grösste Laubholzhanm der nördlichen, atlantischen Kï̈stenstaaten nud ciner der nützlichsten. wird anf feuchten. 


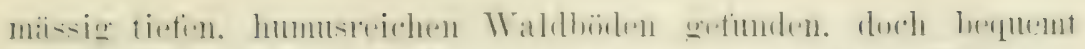

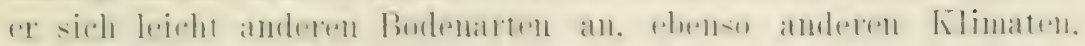

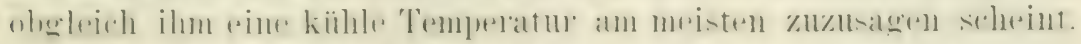

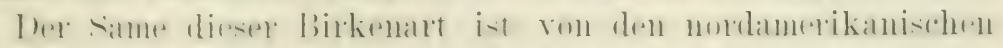

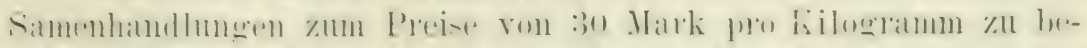

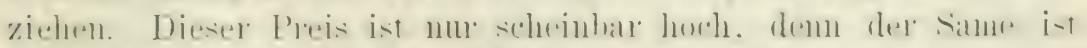

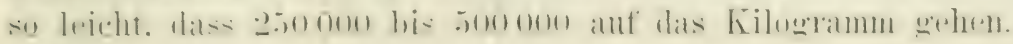

\section{b) Schwarze Birke (Betula lenta).}

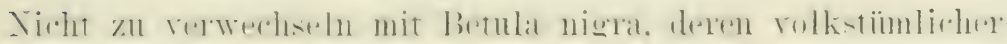
Name rote Birke ist.

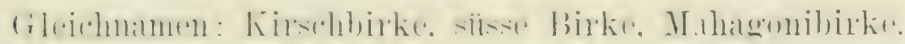

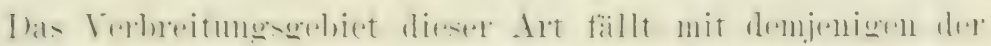

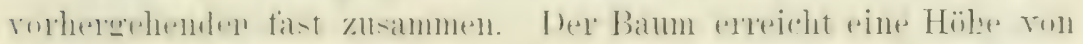
Is his at Metel bei einem stammolutelmmestel voll 0.90 his

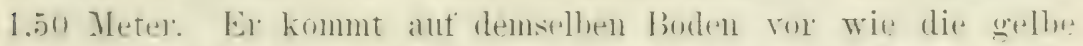

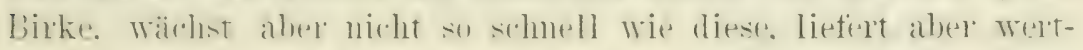

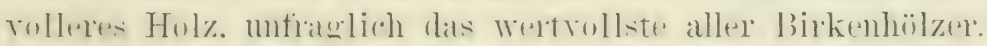

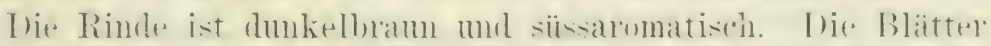

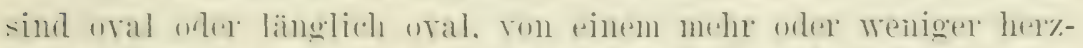

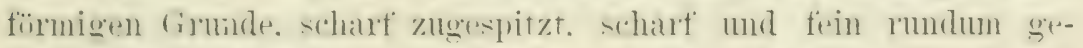

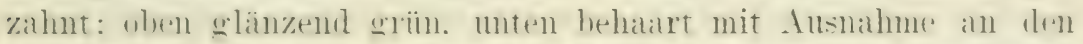

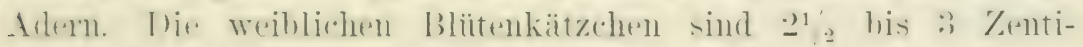

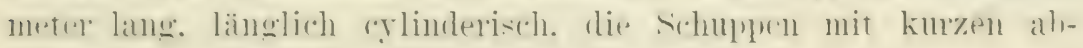
schweifenden Lappen.

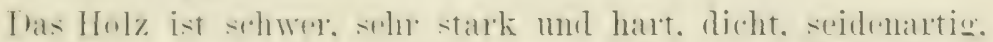

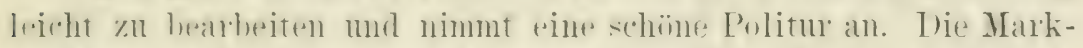

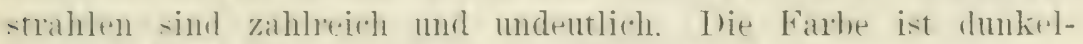

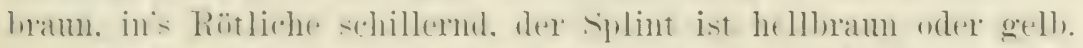

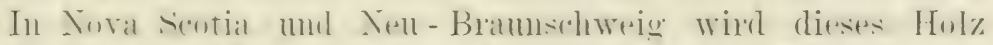

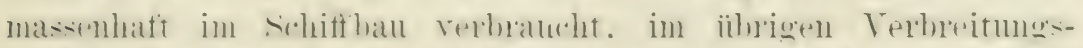

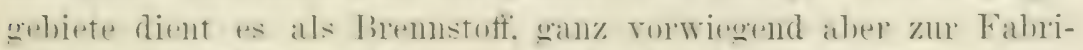

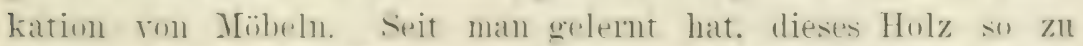

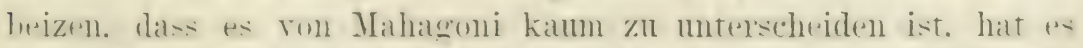

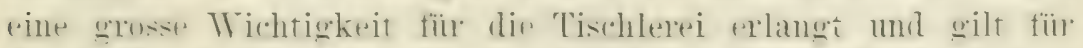

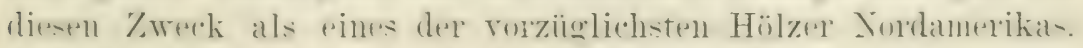

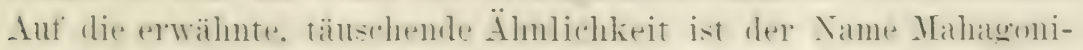

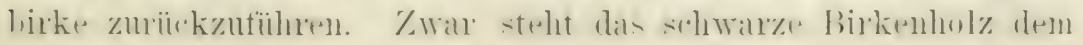


Mahagoni nicht gleich, allein es ist so schön mol dabei vergleichsweise so billig, dass seine hohe Beliebtheit leicht begreiflich ist. Anch fiir die imnere Auskleidung der Hänser findet 's Verwendung mol bietet hier. wenn farbig poliert, ein wahrhaft reiches Auswehen. Voch ist seiner Figenschatt zu gerlenken, dass es. wemn sorgfältig getrocknet, später niemals schumpft noch sich wirft. Bis zum Markkerne ist das Holz gewöhnlich gesund und weun Herzrisse anftreten, sind sie klein, bei seiner Terarbeitumg kam also nur ein geringer Abfall stattfinden. England importiert dieses Holz in beträchtlichen Mrengen. in behanenen Blöcken ron 1.8 bis 6 Meter Länge und 30 bis 75 Zentimeter Durchmesser.

Rangstellung unter den nordamerikanischen Hölzern: die 110. im spezifischen Gewicht, die 108. im verhältnismässigen Bremwert, die 3. im Coefficienten der Elastizität, die 5. ir der Bruchfestigkeit. die 33. in der Druckfestigkeit, die 169. in der Eindruckfestigkeit.

In Bezug auf Samen mo Bodenanspriiche gilt das von rev gelben Birke Gesagte.

5. Magnolienholz.

Fon den 7 in Nordamerika rorkommenden Magnolienarten ist nur die folgende zum Anbau behut's der Holzproduktion zu empfehlen.

\section{Grossblütige Magnolie}

(Magnoliagrandiflora, Familie Nagnoliaceae.)

Gleichnamen: Big Laurel; Bull Bay.

Dieser prächtige, immergrïne Bam erreicht seine grüsste Entwickelung am istlichen Mississippiufer zwischen Ticksburg und Natehez und im westlichen Louisiana; ex kommt in ganz Florida ror. an der Kïiste der (tolfstaaten und im siidwestlichen Arkansas; im Nississippithal geht er nördlich bis $32^{\circ} 30^{\circ}$. Tnter grimstigen Verhältnissen erreicht er eine Höhe ron 24 Meter bei einem Stammdurchmesser von 0,60 bis 1,20 Meter.

Die Krone bildet häufig einen rollkommenen Kegel, auf finem graden astfreien stamm thronend, der einer schönen säule wleicht. Die Truzeln sind meit rerzweigt. aber spärich mit Faserwurzeln besetzt. Die Rinde ist glatt. gränlicil mol schmeckt 


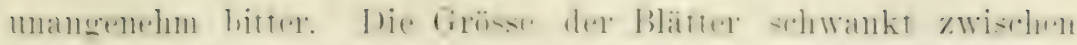

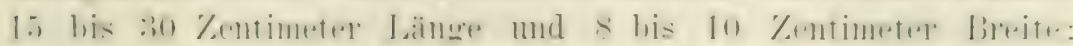

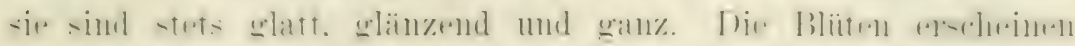

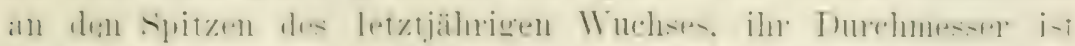

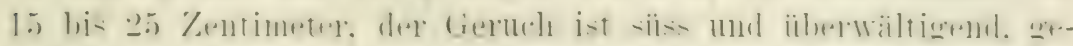

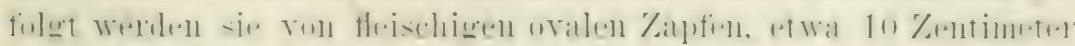

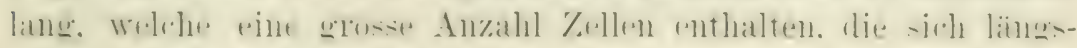

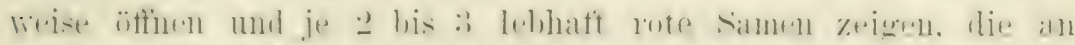

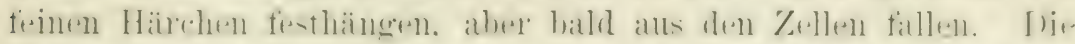

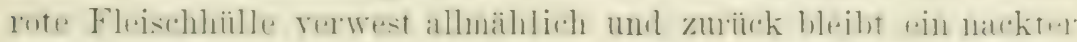
stein mit einem milchigen Kern.

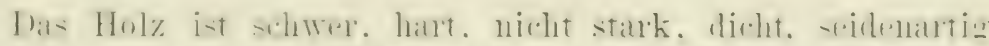

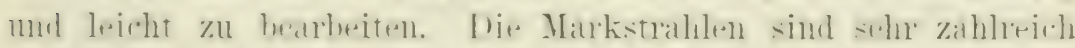

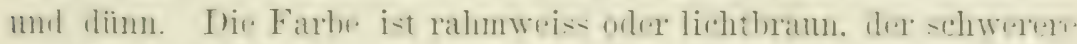
splint ist nahezu weiss. frewiss ist es bearhtenswelt. dats rin

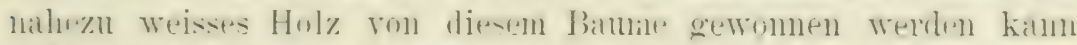
unul linzuzutïgren ist: ro nimmt rine schüne Politur an.

Rangstellung unter den nordanerikanischen Hölzern: di.

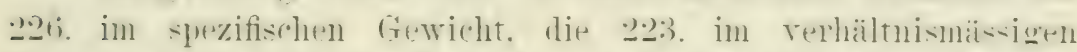

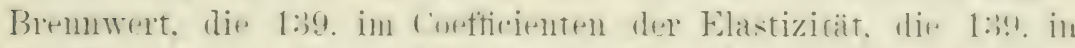

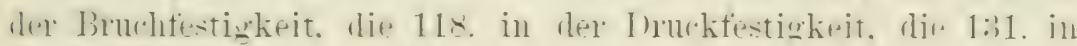
der Eindruckfestigkeit.

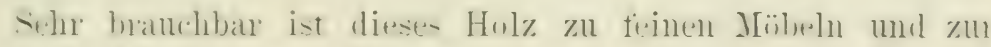
imeren Auskleidung ron Häusern.

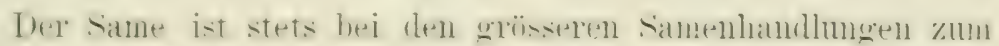

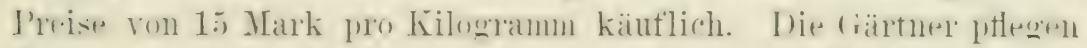

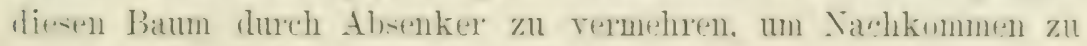
erziehen, die früher blïhen wie Sämlinge.

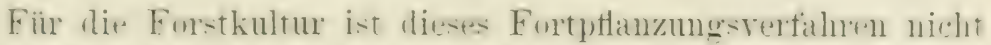

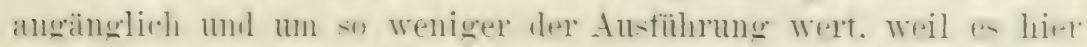

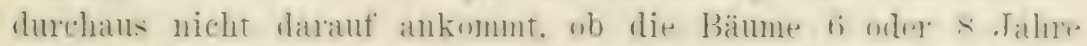
frïher hiihen wler nicht. Sïmlinge treiben stäkere mul rerzWeitere Wurzeln wie Ab-enker. sie sind langlebiger. p kalln

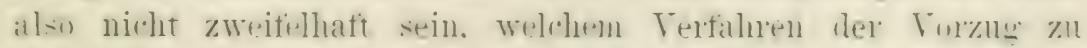

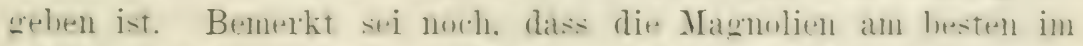
schatten anderer Bämne gedeihen und tireten. lockitren Humu--

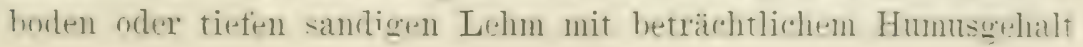




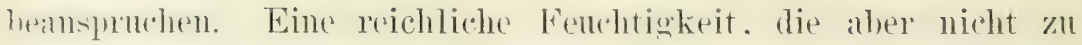

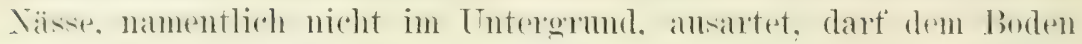
nicht fehlen.

\section{6. 'T'ulpenholz.}

Tulpenbaum (Liriodendron tulipitera, Familie Magnoliaceae).

$$
\text { Gleichnamen: gelbe Pappel, Weissholz. }
$$

Diese Art, die einzige der Gattung Liriodendron, ist in Enropa schon längst eingeführt, aber nur als Zierbaum. Lnter allen Labhölzeru Tordamerikas erreicht der Tulpenbaum die berentendste Höhe mal [Dicke. Gewöhnlich wird er 50 bis 40 Doter hoch bei einem Stammdnchmesser ron 2 bis :3 Meter, allein in wiuntigen Lagen sind die Bäume ron 50 bis 60 Meter Höhe, bei einem Stammdurchmesser von 4 Meter nicht selten.

Die aschgrane Rinde der jungen Bämme ist weich und glatt. begimnt jedoch bald rissig zu werden mul die Tiefe der Furchen steht im Terhältnis zum Alter des Bammes. I) 15 bis 20 Zentimeter breiten, dreilappigen, etwas fleischigen, hellgrimen Blïttex' stehen an langen Stielen wechselweise und kommen im Frühijahr bei den ersten warmen Wetter zum Vorschein. Die tulpenförmigen Blïten zeigen sich in südlichen ( regenden im April, in nördlichen erst in Juni mol sind von verschiedener Farbe aber stets geruchlos; au hüufigsten sind sie grimlichgelb, zuveilen orangefarbig oder woldgelb. Die Früchte sind ans zahlreichen Schmpen zusammengesetzt. $\bar{y}$ bis \& Zentimeter lang und enthalten 70 bis so Samen.

Terbreitet ist der Tulpenbaum vom siidwestlichen Vermont im Vorden durch das westliche Nell-England südwärts bis zum Torden ron Florida; westlich durch den staat New-Tork bis zum Vichigansee und ron da südwärts dem ästichen T'fer des Mississippi entlang bis zum 31. Breitegrad. In den beiden Virginien erreicht 'M seine höchste Entwickelung: Das Holz ist leicht, weich. nicht -tark. spröde, sehr dicht, gradfaserig und leicht zu bearbeiten. I) Markstrahlen sind zahlheich und nicht deutlich. Die Farbe ist hellgelb, zuweilen ins Bräunliche schimmernd, der splint ist nahezu weiss. 


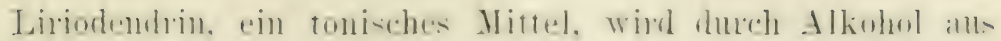

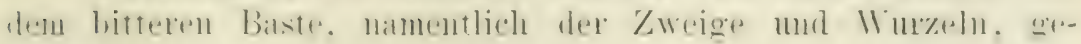
womllen.

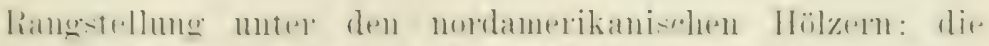

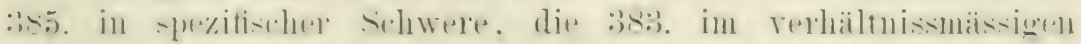
Bremwert. die 131. im cuefficienten der Elastizitat. dir 2-15. in

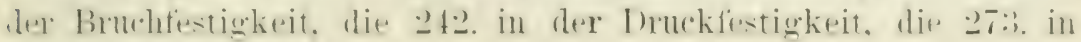
der Eindruckestigkeit.

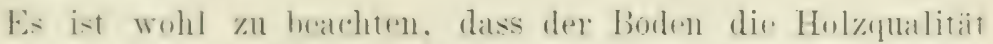

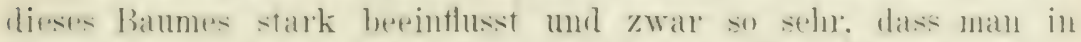

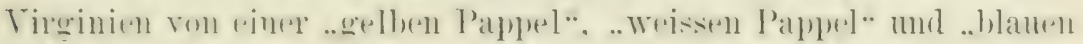

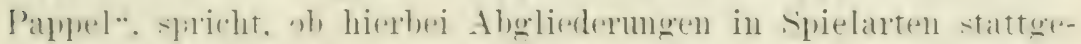

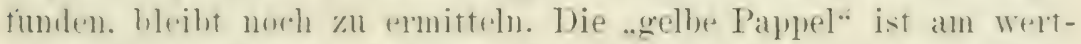

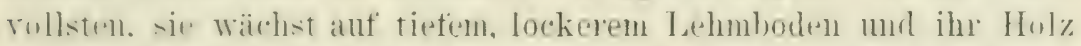
ist es. welches ohen charakterisiert wurde und von wethem now

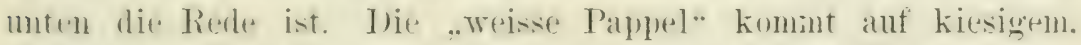

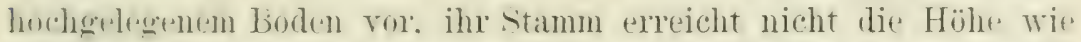
der vorberyehende und ilu Holz ist grobfaseriger und weniger daurerhaft. Fon der ..blanen Papuel" ist in allgemeinen dassellue zu sagen.

Anf diree Abweichumgen sollte bei samenbezïgen zu Anbanzwecken Rïcksicht genommen werden.

Dats Tulpenholz dient. weil es weich und leicht hearbeithat in. häufig als Elsatz des liefermbolzes zur inneren Anskleilume der Hainser und da es zugleich eine schëne Politur annimmt, int

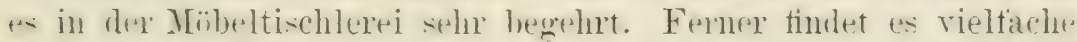
Terwendung zu kleinen Holzwaren. auch zu Pumpen. selindelu. Thüren $11 . \therefore$ W.. doch muss es in diesen wie in allen Fällen. wo « der Wittrumg answestot ist. mit einem Anstrich geschelitzt werden. dat es sonst nicht daterhaft i-t. Als Grund zul Fomrnieren wird es ebenfalls geschätzt.

In Holzgerchätte des ötlidhen Nordamerika's hat dieses Holz

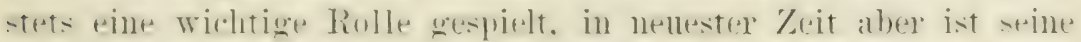

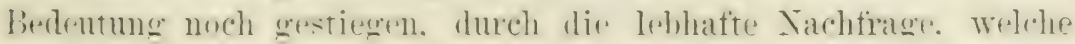
es in Grossbritannien findet.

In diesem Lande ist es unter dem Namen Kanarienholz

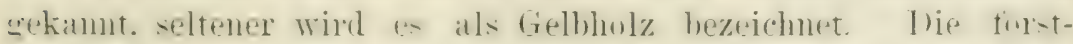

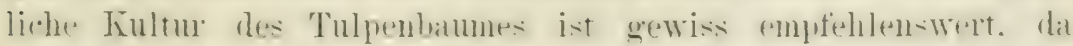

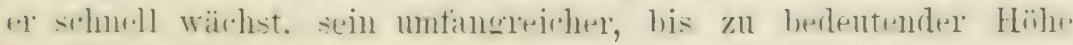


attherer stamm vorteilhaft versehneidbate ist and das Holz einen jeclerzeit offenen Markt findet.

Die Fortpflanzung dureh simen ist sehr leicht. derselbe -nllte in feine Lamberde gesit und mu schwach bedeckt werden. Die Verptlanzmg ist etwas schwierig, da die sämlinge eine -tanke Pfahlwurel und wenige Faserwuzeln treiben. Es empfiehlt sich die Anshebung mit dem Ballen und die Kürzung der Pfihlwhrel mit einem scharfen Messer.

Ein windgeschiitzter: somniger standort verdient in allen Klimaten den Torzug. T'ieforiundiger; nicht zu trockener Lehmvider Schwemmboden ist dem Wachstum und der Holzqualität an giunstigsten. Die Krone des Baumes verlangt viel Ticht, zum mindesten so riel wie diejenige der Eiche. Da die Stiumpfe viele mul kräftige Schösslinge treiben, ist der 'Tulpenbaum zum Schlagholzbetrieb geeignet.

Zwischen 25000 bis 50000 Samen gehen auf das Kilogramm. für welches die nordamerikanischen Samenhandlungen 4 Mark notieren. Da ein beträchtlicher Prozentsatz des Samens nicht keimt, empfiehlt es sich beim Bezuge wie bei der Aussat darauf Riicksicht zu nelmen.

\section{Stech palmen holz.}

Nordamerikanische Stechpalme (Ilex opara. Familie Ilicineae).

Das Terbreitungsgebiet dieses schönen, immergrinen Bammes herinnt nördlich im mittleren Massachusetts und dehnt sich südwärts bis tief nach Florida hinein, wendet sirh durch die Golfstaaten und zieht sich dem Missisiplpithal hinant his ins südliche Indiana.

Unter günstigen Terhältnissen erreichtt ex eine Höhe ron 15 Meter, bei einem Stammdurchmesser ron 0,50 bis 1,20 Meter.

Die Rinde der alten Bämme ist glatt und reisslich grau, an jüngerem Wuchse ist sie dagegen grïn und glänzend. I)ie Blätter sind oval, scharf zugespitzt, stachelig an den Rändern, glänzend und ron lichtgrïner Farbe; die im Mai oder Juni anstreibenden weisslichen Blïten sind mscheinbar und werden zefolgt ron uhönen, runden, scharlachoten Beeren, die lange an den Zweigen hängen, oft während des ganzen Winters. 


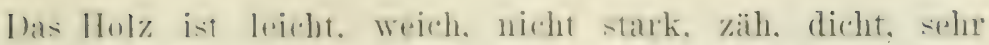

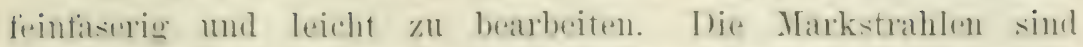

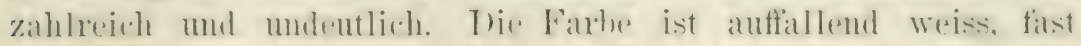

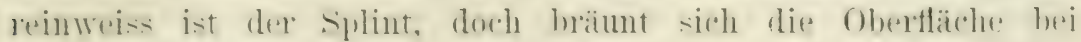
längerer Beriihrumg mit der Luft.

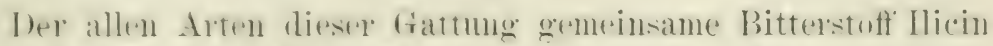
ist alls den Fridehten dirses Balumes gewomlen worden.

Rangstellung unter den nordamerikinnischen Hölzeln: die 261. in speritischer sohwere, die 261. in verhältnismäsigem bremewert. die 250 . in loveticienten des Fiastizität. die 195. in der

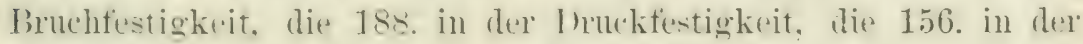
Eindruckfestigkeit.

Ditres Holz, dats sich leicht beizen lässt und rinte schöne Politur annimmt, int zur Anfertigmo ron Yrïheln und zur imeren Anskleidung der Häustr vorzitglich geeignet. Ferner wird es zu feinen Drechslerabeiten, mathematischen Instrumenten und zu Schnitzereien gebraucht. Üblich ist es in der nellesten Zeit geworden. ant' dieses Holz zu malen. Dasselbe hat nur den einen stïrenden Nachteil, dass es sich während des Trocknens stark wirft. Als das beste Verfahren diesem Öhel rorzubengen. wird empfohlen. die Blöche. beror sie zu Brettern versägt werden. längere Zeit in einem feuchten folupuren und selbst ins Freie zu legen. Das schliesst nicht ans. dias das Trocknen mit griisster Torsicht durchgefiihrt werden muss.

Die stedupalme verlangt einen greschiitzten standort und einen kiesigen. humuserehen, etwas feuchten Boden. Denentsprechend wird sie am häutigsten in Mälderm, an Cfern ron Wascreläufen gefunden. Zwar kommt sie auch auf trockenem. sandigam Lehmboden vor. ereicht hier aber nicht ilne kräftigste Entwickelumg.

The same wird ron den nordamerikanischen samenhandumgern zu 10 Jark pro Kilogramm angeboten.

\section{A hor nllol z.}

Fon den etwa ju Ahornarten der Erde enttallen a ant Norrlamerika. ron welchen ich nur eine zum Anbau enptehlen kann. oheleich Acer macrephyllum u. A. rubrum liäufig ebenfalls als 
kulturwürdig bezeichnet werden. Da se sich nur mu die Auswahl des Besten handelt. muss die Beschünkung anfrecht erhalten bleiben anf den

Zuckerahorn (Acer sachlarinum. Familie Sapindaceate).

Welcher nicht mu einer der nützlichsten, sondern anch der frächtigsten Bämme Nordamerika's ist. Kan den niitzlichsten miïste er zählen, selbst wem er nicht zu der an anderer Stelle an führlich besprochenen Zuckergewinnmg diente. Es ist ein die wirmste Emptehlung verdienender Wald-, Zier- und Alleebaum.

Unter giunstigen Verhältnissen erreicht er eine Höhe ron s6) Meter bei einem stammdurchmesser ron 1,20) Meter. Gewöhnlich wird er aber nur 24 Meter hoch. bei einem Stammdurchmesser ron 0,70 bis 0,80 Meter. Der Stamm ist gerade ohne irgend eine Friummung, und zeigt hier und da rorspringende finorren und Auswïchse. Die Rinde ist von so heller Farbe, dass sie ein leichtes Erkemmugszeichen für diesen Baum bildet. An freien standorten, mo er sich nach allen seiten entfalten kann, zeichmet er sich durch die ansserordentliche Schönlıeit der dicht belaubten. regehmässigen Krone aus. Die handförmigen, fümflappigen Blätter sind bei rerschiedener Länge gewöhnlich 8 bis 12 Zentimeter breit; sie stehen an langen Stielen par'weise entgegengesetzt und sind oben antänglich glänzend, suäter matt hellgrün, unten weisslich. anfänglich mit einem weissen Flaum iuberzogen. später glatt. Im Herbste färben sir sich in allen Schattierungen, von dem hellsten Gelb lis zum tiefsten Carmoisimot - eine Pracht. die alle empfindenden Menschen hoch entzückt. Wer eine farbenschimmernde Herbstlandschaft liebt, wessen tuge sich nicht allein an der erwachenden, somdern anch an dex arsterbenden Natur weiden will, der pflanze den /uckerahorn. Freilich, seine reichste Farbenpracht ('ntfaltet er mur da, wo der echte. dharaktervolle Winter anftritt.

Die grünlichgelben Blüten erscheinen in April und Mai, sie hängen an dïnnen Stielchen mol werden von nussähnlichen. geflïgelten Samen gefolgt, die anfangs Oktober reifen.

Der Zuckerahorn kommt ror im sildlichen Veufundland. an der st. Lorenzobai, längs der nördlichen Tfer der grossen Seen. von da siidlich dem Alleghanygebirge entlang bis zum nürdlichen Alabana mol westlichen Florida, bis zum östlichen Kansas und ïstlichen 'Texas. Seine grösste Fntwickelung ere'elcht er in der 


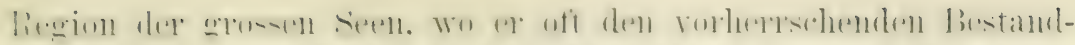

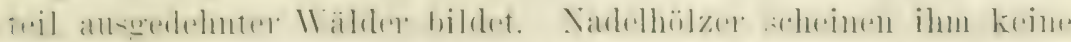

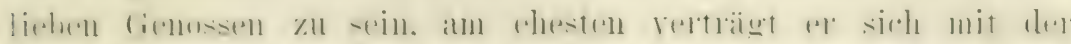

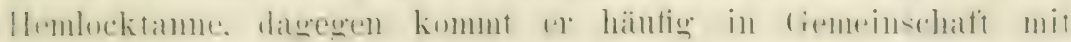

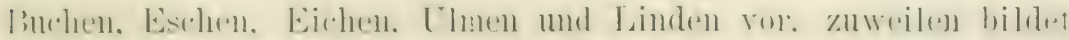

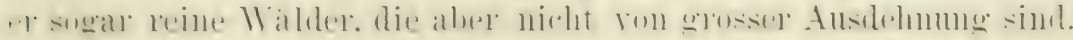

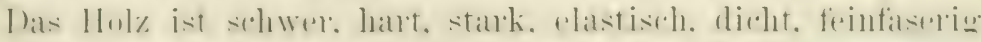

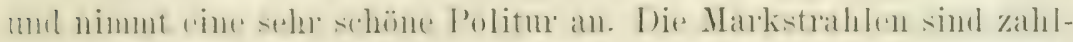

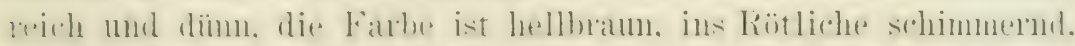

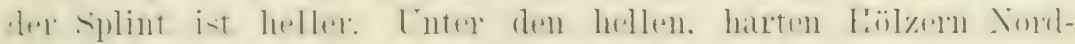

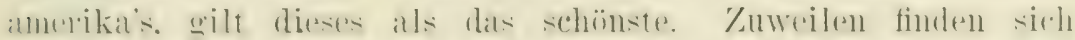

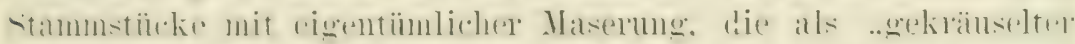

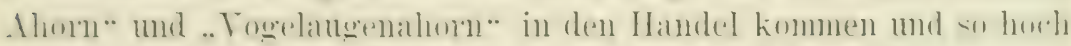

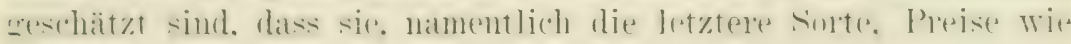
Mahagoni bringen.

Das Ahornhol\% ist nicht so danerhaft wie das Holz der

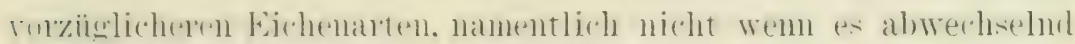

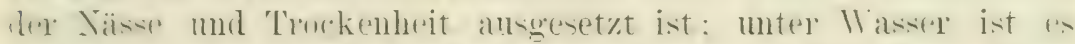

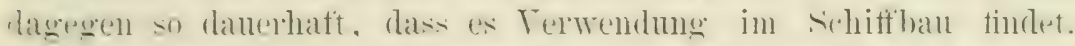

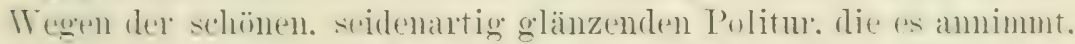

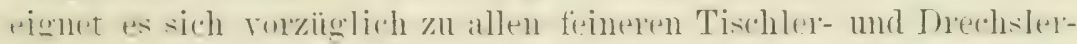

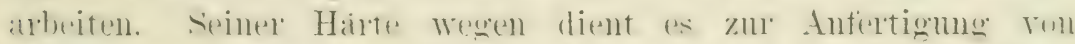

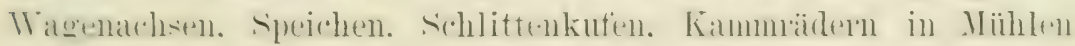

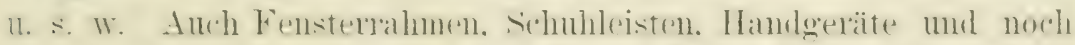

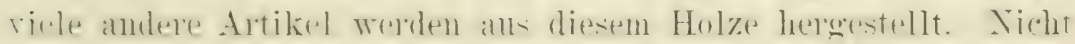

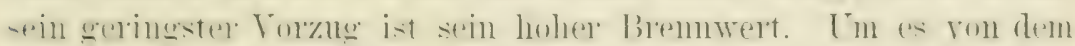

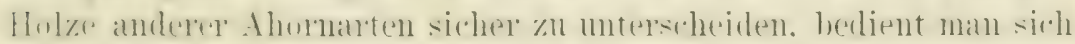

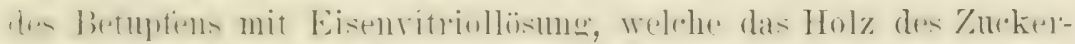

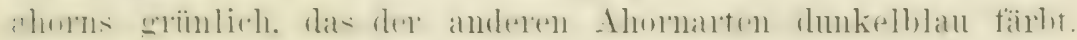

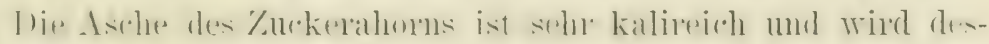
halb häufig zur Pottaschebereitumg benutzt.

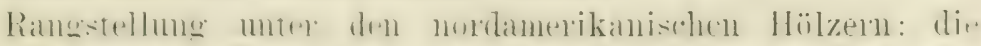

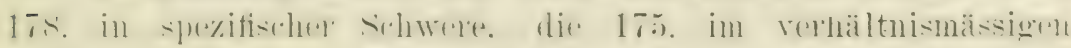

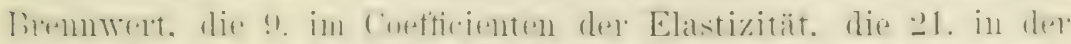

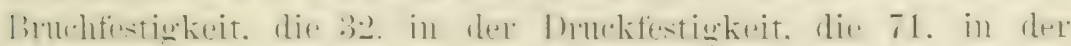
Eindrucksfestigkeit.

Es sei noch bemerkt, dass rom westlichen Termont bis siid-

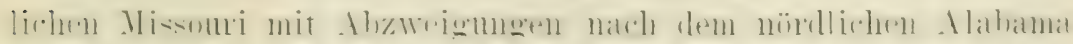

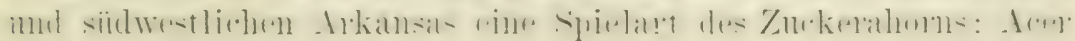




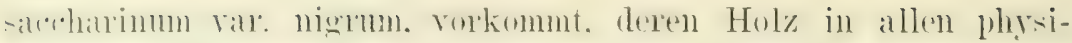
kalischen Eigenshaten demjenigen der frundform nachsteht. lnsheich der letzteren zieht sio einen feuchten. tettbodigen stand-

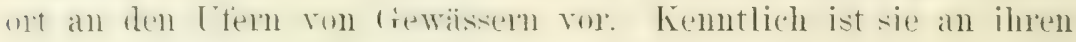
breiter gelappten, unten oft Haumigen Blättern.

Der Zurkrahorn bevorzugt einen frischen. kraiftigen, mineralleidhen Buden. der ans verwittertem Kalkstein. Basalt. Grünstein, 'Thmochiefer onler tranit hervorgegangen ist. also ähnlich. wie ihm die Buche beansurucht. duch kam er nicht so viel Fenchtigkeit wie dies vertragen. Fredeiht nicht in tiefem sandboden. noch in stritem Thon und anch nicht ant danemd nassem Gelände, daher wird er nicht in Gesellschatt mit Bäumen sefunden, denen ein - mpmptiger standont zusat. Lieber wohnt er im Gebirge, in dem er ziemlich horh steigt. wie aut der Ehene. Aloch hommt er auf der letzteren recht sut fort. Wem el pinen zusagenden Boden findet.

7wishen sum! his 12000 sanele gehen auf das hilogramm. las ron rem nurdanerikanischen samenhandlungen mit 15 Mark notiert wird. Der in lorkere Lauberde gesäte same keimt leicht mul die sambinge -ind lebenszäh. wie schom darans herrorgeht

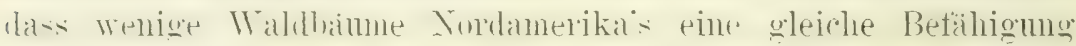

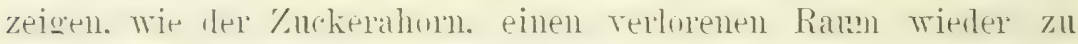
gewinnell. II rin ans liesem Bam hestehender Wald, teilweise

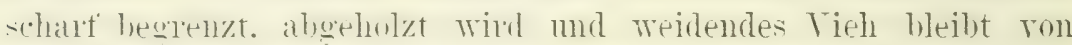

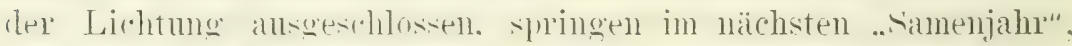

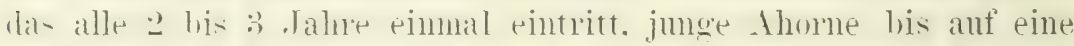

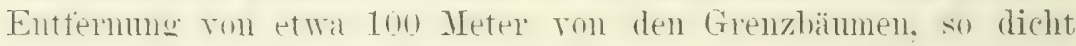
wie schilf alt. In den tolgenden samenjahren rïckt das junge

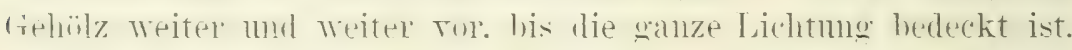

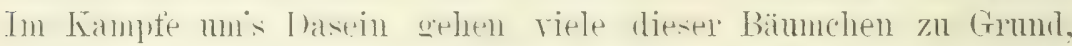

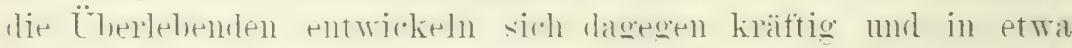
10. Jahren haben die stäkeren einell stammolurehnesser von

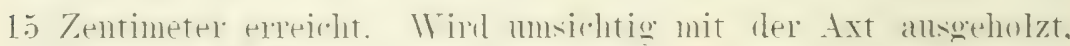
lann stehen die bälune in 20. Tahre zur Zuchurgewimmo bereit.

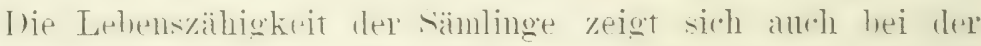
Terptlanzung, lie niemals thhlshlägt. Wenn sie num nit einiger Tin-icht gesthieht. terner kïnnen sie in der Beschneidnng seradezu mi-handelt werdent. whe ihr Leben zur rernichten. Diese Eigen-

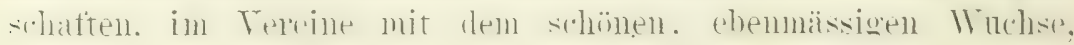




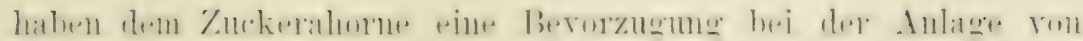

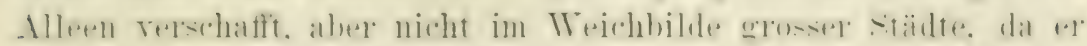

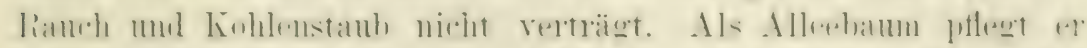

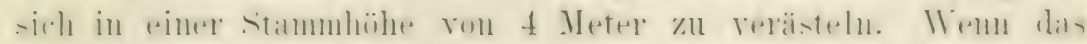

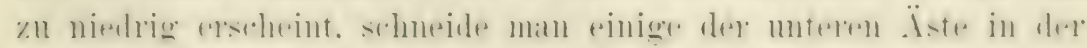

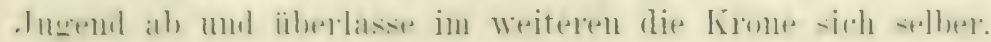

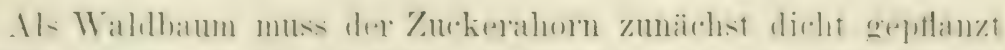

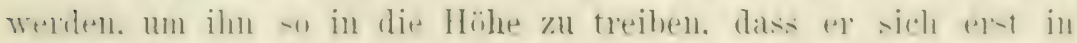

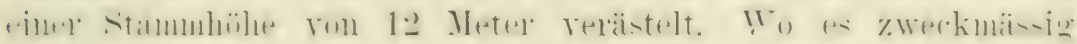

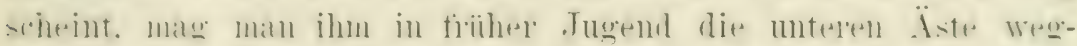
schneiden.

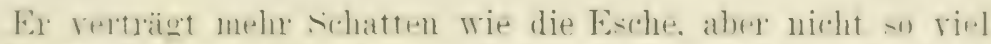

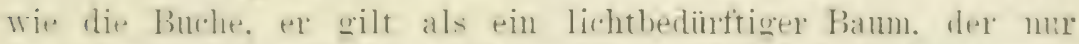
lanm im sirken schatten forthommt. Wem der Boden seln grim-tig

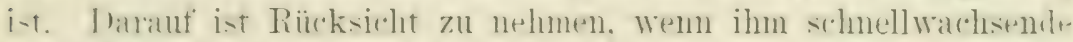

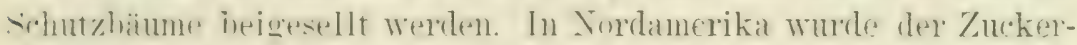

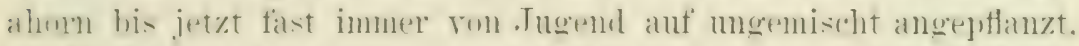

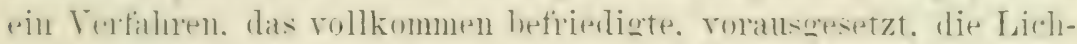
tung erfolgte nach forstlichen Regehn.

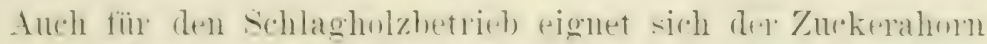

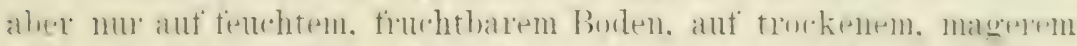

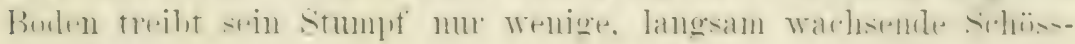
linge ans.

\section{A kazienhol\%.}

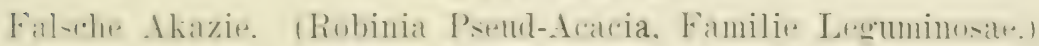

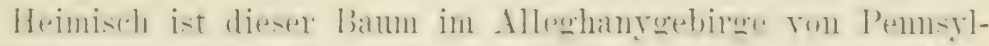

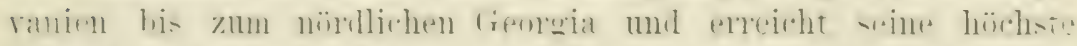

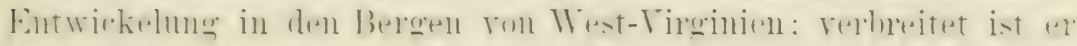

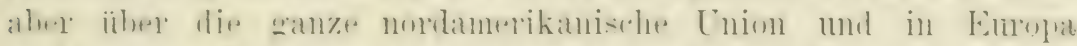

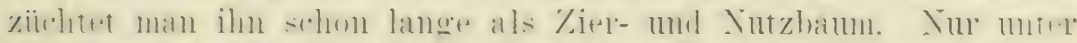

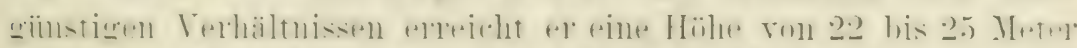

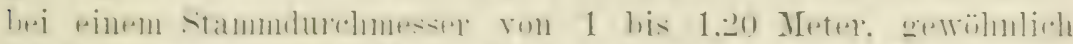

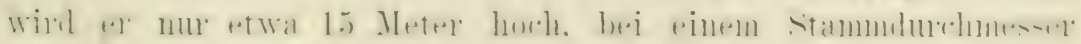
Yon 0.60 bis 0,90 Meter.

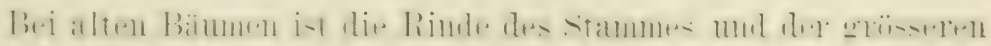

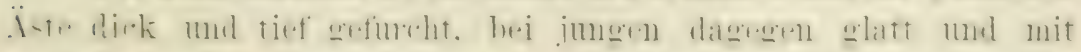

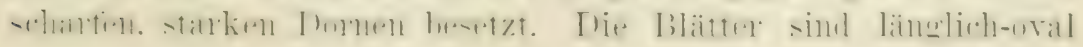




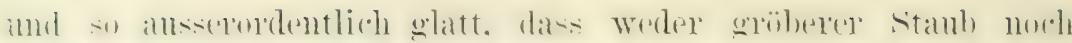

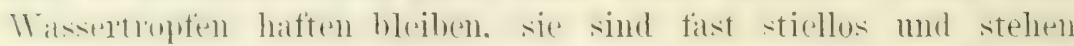

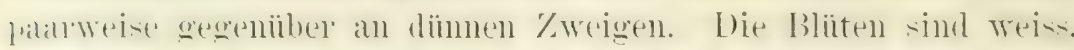

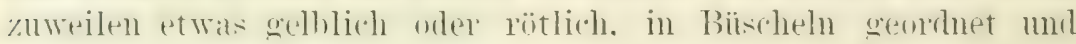
rerbreiten einen starken angenehmen Geruch.

Die dunkelbramen oder schwärzlichen samen sind zu j. 5) uler t: in gelblichweisen. 5) bis \& Zentimeter langen mul etwa 1 Zentineter breiten schoten enthalten. I)ie Wurzeln kriechen zom 'Teil an und anf der Erdoberfäche fort und zeigen eine stark" Veigung, schöslinge zu treiben. Seit er kultivient wird. hat sich dieser Bam in viele spielarten gegliedert: mit grlben mol roten Blïten. mit oder onne Dornen, mit schmäleren oder hreiterer Blättern It. S. w.

Das Holz ist schwer, ausserordentlich hart und stark. dirlit. s+lur

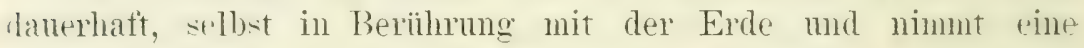
schöne Politur an. Die .Tahresringe sind deutlich abgegrenzt durch 2 oder 3 Reihen grosser offener Gefïssühren. Markstrahlen sind nicht sichthar. weder ist ein Geruch noch ein Geschmack hemerklich. Ant der Drehbank ist es leicht. anderweitig ahor schwer zu bearbeiten. Die Farbe wechselt in Folge des Einflusies des Bodens, am häufigsten ist sie grünlichgelb. zuweilen fram. gelb oder weisslich, der Splint ist stets heller. In nordamerikitnischen Holzhandel wird die brame Farbe an höchsten geschätzt. zunal wem sie ins Rötliche schimmert, es folgt die griunlichgellye und shliesslich die weissliche. welche als ein Zeichen geringer Danerhaftigkeit betrachtet wird.

Rangstellumg unter den nordamerikanischen Hölze?n: die 138. in spezifischer Schwere, die 137. in rerhältnismäsigen Bremwert. die 19. im d'oeffizienten der Elastizität. die :3. in der Brushtestigkeit, dir 15). in der Thurktestigkeit, die 70. in der Eindruckisfestigkeit.

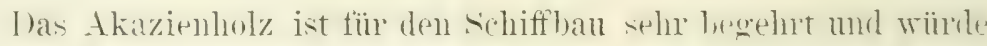
eine ritel ansedehntere Terwendung in dieser Indnstrite finderln.

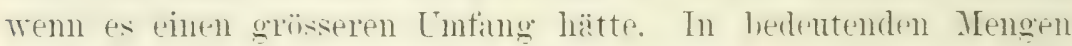
wird es zu Bahnsehwellen und Banten henutzt. Eanz hesonders ist « zu Werkholz und Irechslerabeiten geeignet. Xur wenigr. Hölzer werden ron den Wagnem gleich hoch oder höher greschätzt. The Ertahrung lehrt. dass der Akazienbanm in seinem fo. his so. Tahre dar beste Holz liefert - ein rerhaltnismä-sig kurzer 


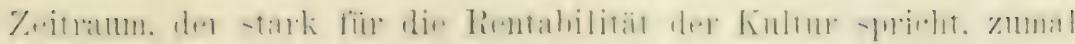
wenn man das schnelle Wachstum in's Inge filsst.

Die Rinde der Wuzel wirkt tonisch, in grösseren Gaben abfithrend mol erbrechent.

Fribher wurle die falsche Akazie in Nololamerika als Nutz-

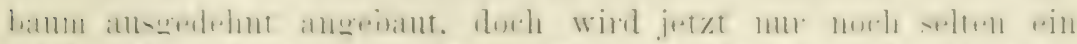

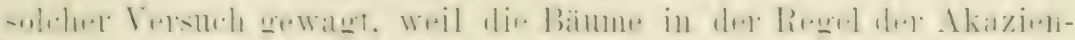

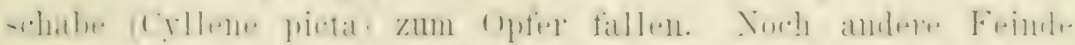

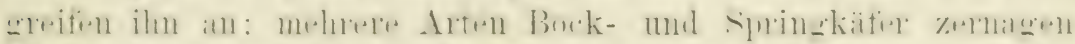

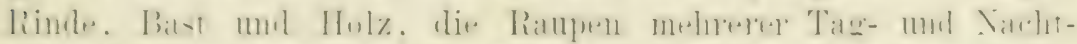

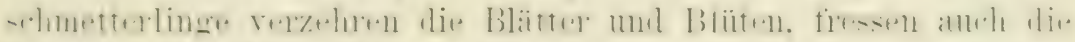
Schoten an und zerstiren den Samen.

Die falsche Akazie gedeiht am besten aut lockerem. naln-

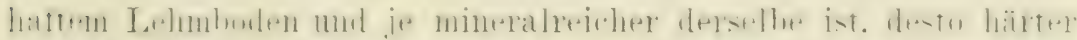

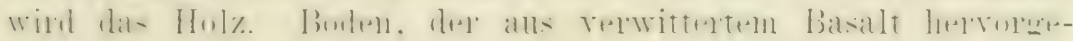

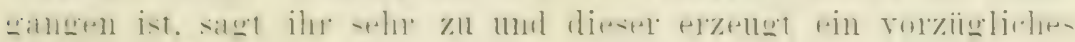

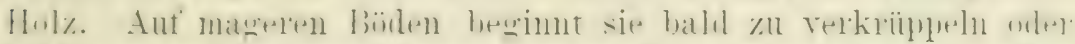

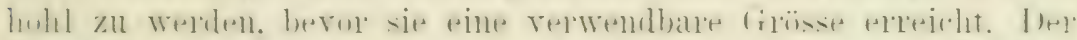

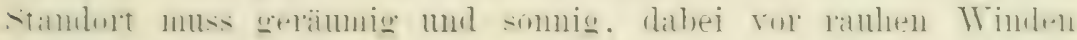
greschüitzt sein.

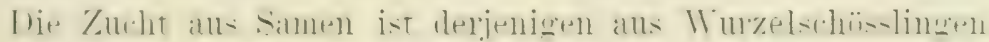

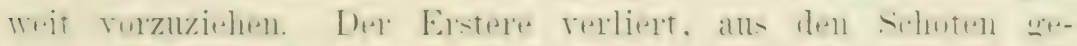

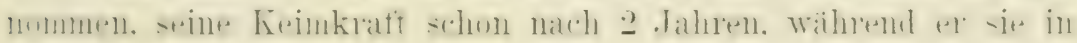
den schoten 5 bis 6 . Tahre bewahrt.

Man legt die Samen ror der Aussat in laumarmes, abel

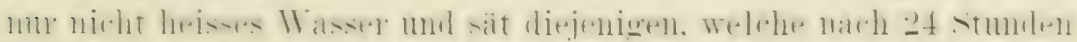

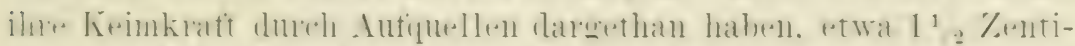

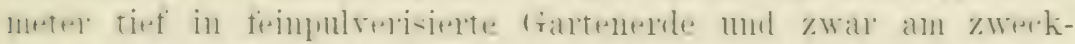

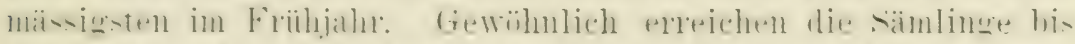

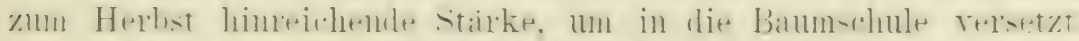

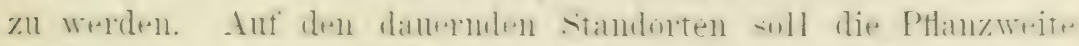

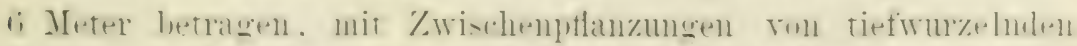

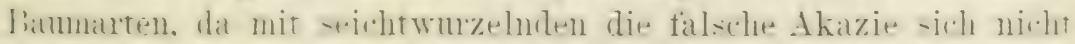

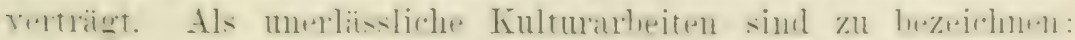

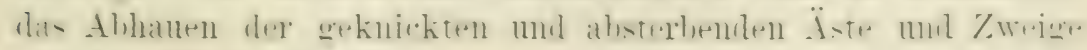
wie del IInzelschösslinge. 
11. II

Mesquit (Prosopis juliflora, Familie Leguminosae).

Gleichnamen: Algaroba, Honey Locust, Honey Pod.

Liscer, der falschen Akazie in der Erscheinmo ähnliche Banm. ist im nördlichen Mexiko. in sïdcalifomien, Arizona, Nen-Mexikn und im westlichen 'Texas rerbreitet. Anf ginnstigem Borlen erreicht a eine Höhe von 9 bis 15 Meter, bei einem Stanmdurchmesser ron $0 . \overline{70}$ ) his 0.90 Meter; auf fèlsigem Cielände rerkümmert er zu einem liusch. An den Säumen von Wüstenflüssen bildet "r oft Tälder. im Thale des Santa ('ruz in Arizona erreicht cr seine höchste Entwickelung immerhalb der nordanerikanischen Enion. Im westlichen Texas erreicht er in Folge der jährlichen Präriehrände nur Meterhöhe. während sich die Wurzeln ausserordentlich "ntwickehn, oft wiegen sie 100 bis $200 \mathrm{Kg}$. Die Texaner sprechen daher' von Lntergrundwäldern. Im westlichen 'T'exas liefern dieselben das billigste und rorziiglichste Brennholz. Ton seinem Trelte spricht, dass es muerkohlt in den Schmiedeessen zur Terwendung kommt. In anderen Gegenden des Terbreitungsgebietes, bildet das Stammholz das rorziiglichste und of einzige Bremholz; es bremnt langsan mit klarer Flamme und liefert vorzïgliche Kohlen. die aber zur Lampterzeugung unbrauchbar sind, da sie zerstörend aut die Fesiel wirken. Das Holz ist schwer, sehr hart, nicht stark. dicht, schwierig zu bearbeiten, fast unzerstörbar in Berïhrumg mit der Erde und enthält viele. gleichnässig verteilte. grosse. offene Gefässiöhren. Die Markstrahlen sind zahlreich und dentlich. T)ie Farbe ist reich dunkelbraun oder rot. ler Splint klargelb.

Rangstellung unter den nordamerikanischen Hölzes'n: Die 108. in spezifischer schwere, die 115 . im verhältnismässigen Bremwert, die 260. im Coefficienten der Elasticität, die 281. in der Bruchfestigkeit, die 42. in der Inrukfestigkeit, die 27. in der Eindruckfestigkeit.

Terwendumg findet dieses Holz zu Hausbaten, Drechslerarbeiten, Ralfelgen, und. Weil es eine sehr schöne Politur amnimmt, zи Möbeln. Berlentende Mtengen werden za Kohlen gebrannt. die Arster Qualität sind. In dinigen texanischen städten hat es zur Holzpflasterung sehr befriedigt.

Aus dem stamme quillt ein dem arabischen ähnliches (rummi. das Handelswet besitzt; die undeifen markigen Fruchtschoten 


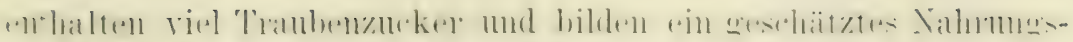
mittel fïl' Menschen und 'Tiere.

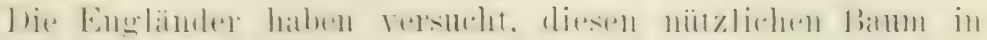

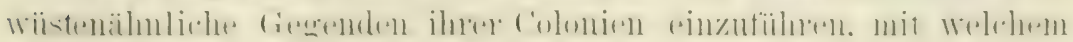

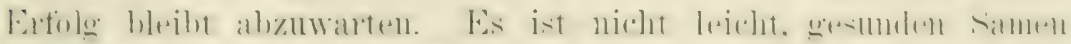

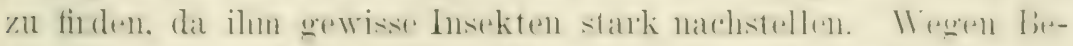

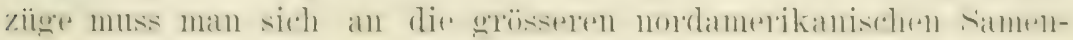
liandlumøen wenden.

\section{Ki r sell hol z.}

Ton den etwa 80 Arten der Gattung Prunus sind 11 in

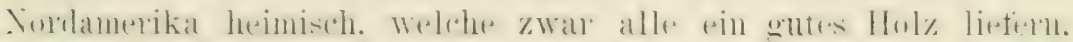
doch ist nur die folgende anbanwiurdig.

Schwarzer Kirschbaum I'rumus serotina. Familiv Rusitreate).

Gleichname: Rumkirschbaum.

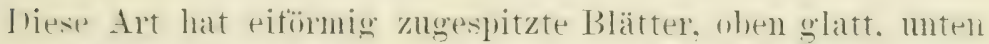

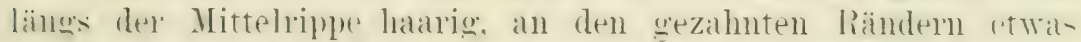

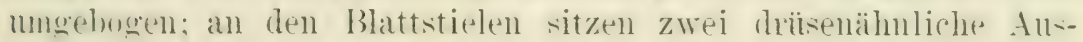

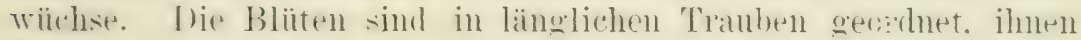

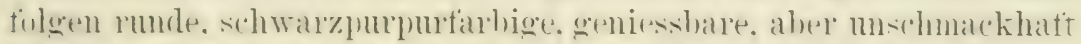

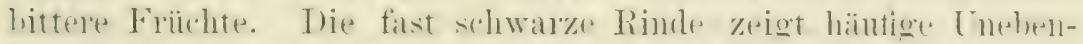

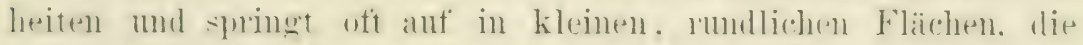
sich allmählich ablösen.

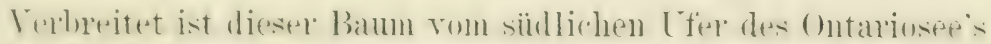
his tief nalch Florida hinein. Westlich bis zum Miscoure und his zum

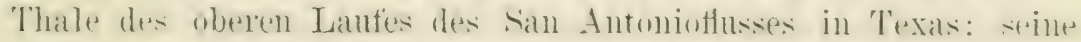

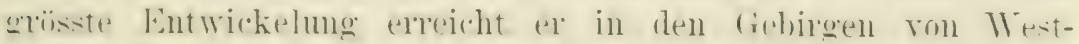

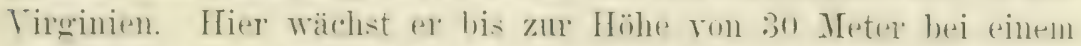

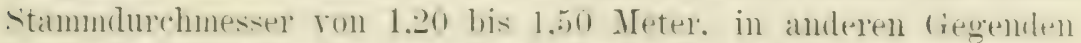

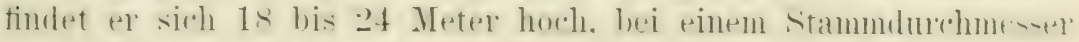
roul 0,75 bis 1.10 Meter.

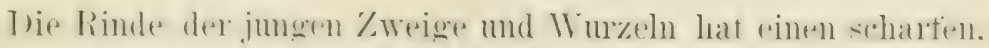

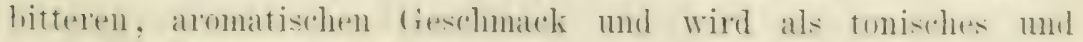

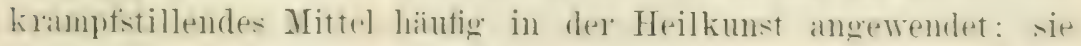
enthailt einen kleinen Prozentsatz Blausånre.

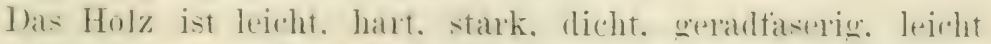

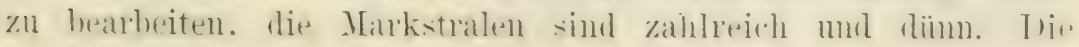




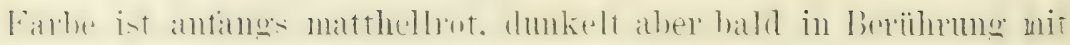
der Luft; der diume Splint ist gelb.

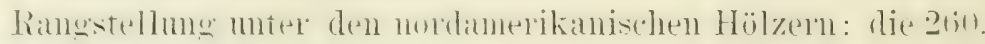

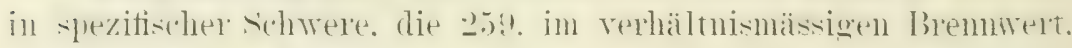
die 15\%. in coefficienten dey Elastivitat, die 119. in der Butch-

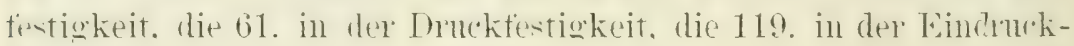
festigkeit.

Dieses Holz ist in der Mröbeltischlerei. nicht allein Nord-

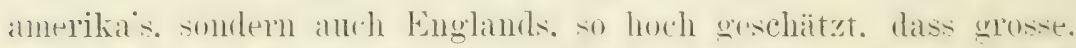

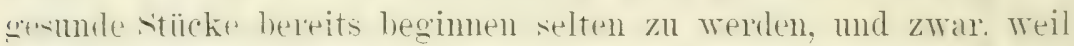
es sich nicht wirft. nachdem es getrocknet ist. eine schöne Politul amnimmt und durh Beizung dem Rosenholz. Nahagoni und Ebenlon\% im Answehen selnr nahe gebracht werden kann. Seine schönheit nimmt mit dem Alter zu und es kommt eine Zeit, wo es kamun ron dem Mahagoni zu unterscheiden ist. Fermer ist das

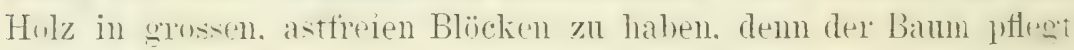
sich erst in einer Höhe von 18 bis 20 Neter zu verästeln. mul die Blörke zeigen höchstens ganz schrache Risice an Kern. falls sie rorsichtig getrocknet warden. Kanke Stellen kommen selur selten vol, das Holz kam also mit wenig Abfall reparbeitet werden.

Der schwaze Kirschbaun ist nicht wählerisch his rer Bodenart. am besten gedeilht ex ührigens anf nicht zu fenchlem. sandigem s.hwemmhoden. Zur Anptlanzmo anf der Prärie hat er sich recht yeeignet erwiesen. Anch bedart er einigen Windschntzes in der . Tugent. Wem er gerad wachsen soll. Keinenfalls rant er als Ansnalume ron der Regel gelten. dass er mit dichter Anptlanzmo mul allmählicher Auslichtung aufwarhsen muss. da er sonst in Bezug anf die astireie Höhe des Stammes zu wïnschen ührig lasst. Er wächst schnell unter einigermassen gimstigen Cmständen. rerträit sich gut mit anderen Bämmen und kamn auf einem ziemlich stark beschatteten Standort stehen.

Der Same ist in den nordamerikanischen samenhamblungen tïr 10 Mark uro Kilogramm kïuflich. Zwischen :3non nud somm Kerme gehen auf ras Kilogramm. 


\section{Hartiegelhol\%.}

Hartriegel (Cormus Horida. Familic ('olnaceae).

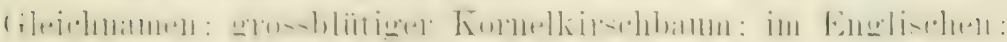
tiowering dogwood.

Fon allen Hartriegelarten ist die grossbliitige bei weitem

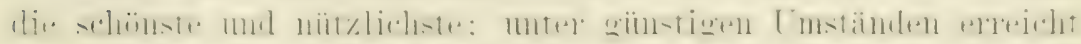

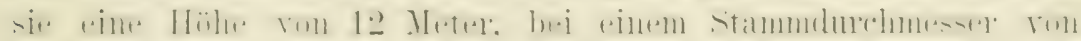
0.45 Meter. doch wächst sie im I)urchschnitt nicht höher wie

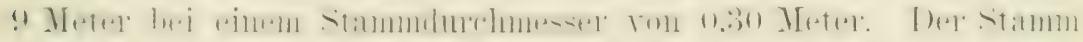

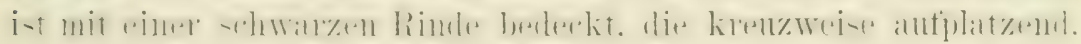

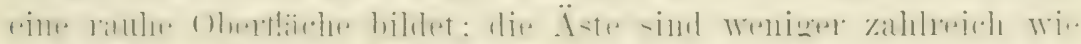

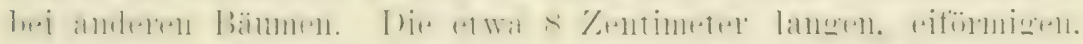

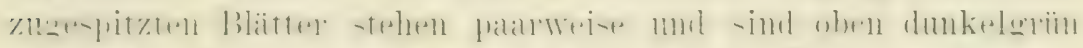

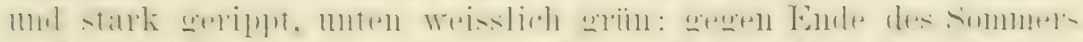

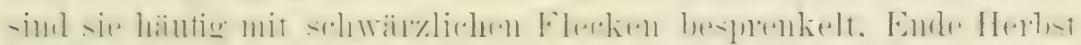

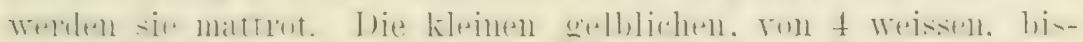

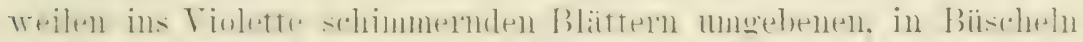

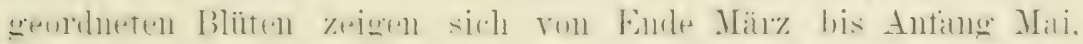

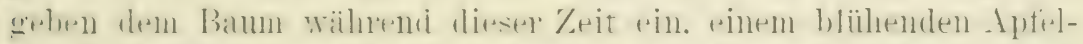

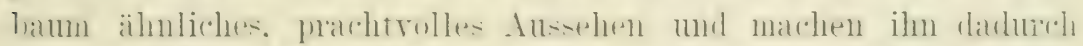

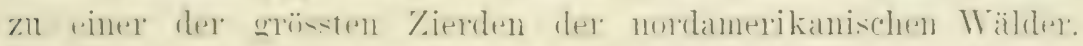

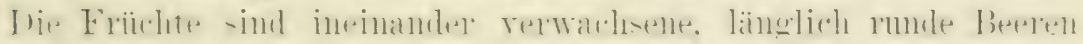

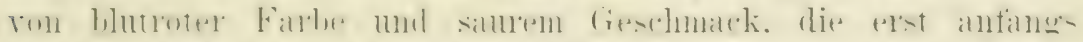

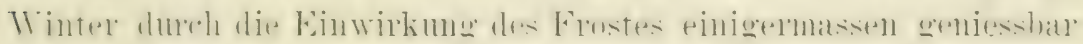
werdell.

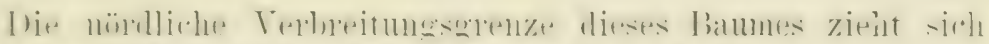

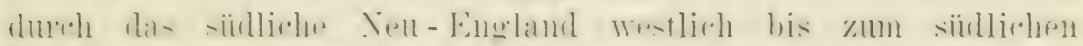

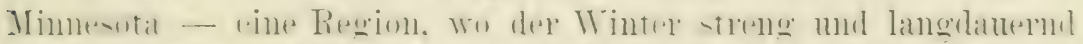

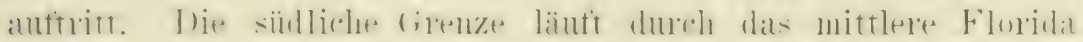
nach dem 'Thale des Brazosflusses in 'Texas.

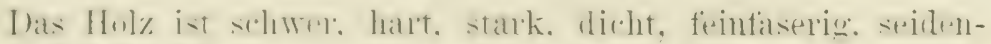

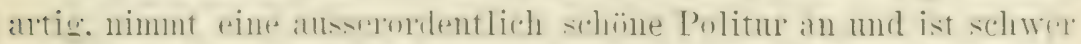

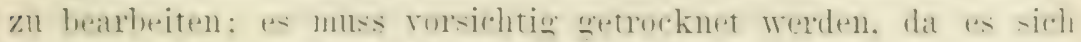

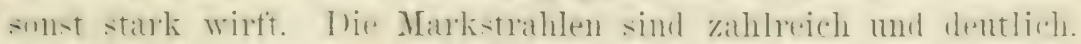

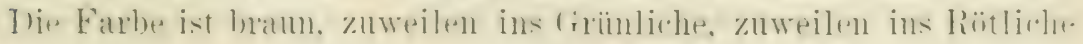
schimmernd, der Splint weisslich.

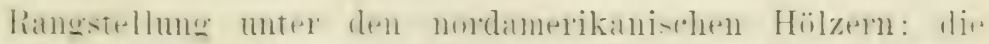

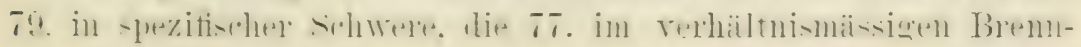




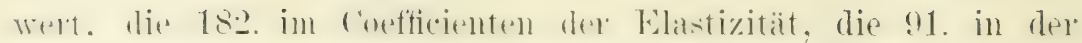

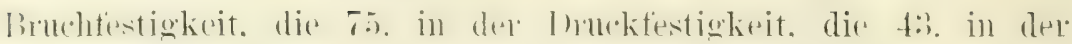
Eindruckfestigkeit.

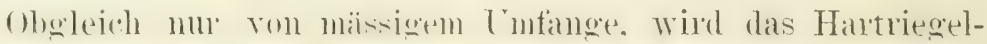
hol: doch sehr geschätzt. mamentich zu Drechslerarbeiten. Schnitzwriken. Radnaben, sichlittenkufen, Trerkzenstielen, Hansceräten,

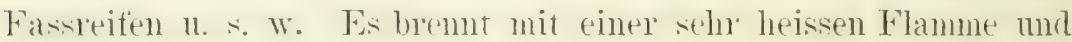
hinterlässt eine auffallend weisse Asche.

Die Rinde, namentlich diejenige der Wuzeln, besitzt bittere. tonische Eigenschatten und wird häutig anstatt ('hinin gegen Malaria angowendet: anserdem dient sie zur Tintenfabrikation. Auc der Rinde der Fasermureln wissen die Indianer eine scharlachote Farbe zu gewimnen. Eine Abkochung der Blüten wird als Mittel gregen das Wechselfieber und der safi der Früchte als krampfstillend empfohlen.

Der Hartriegel gedeilut an besten ant kiesigem, humusreichem. feuchtem Buden. somie er luäufig in der Xähe ron Flïssen mon Bächen gefunden wird; der standort muss geschiitzt sein.

lie nordamerikanischen samenhandlungen pflegen den samen des Hartriegels nicht zn tïhren. hesorgen ihn abes whne Schwierigkeit.

\section{1.). Thpelohol $\%$.}

Tupelobaum (Nyassa sylvatica, Familie Cornaceae).

Gleichnamen: Sour Gum, Black Gum, Pepperidge.

Gewöhnlich erreicht dieser Bamn eine Höhe von etwa 15 Ileter hei einem stammdurehmesser von 0,60 bis 0,75 Mfeter; unter besonders grimstigen Lmständen gewimnt er den doplelten Umfang. Die Rinde ist dick, tief gefurcht und häufig in regelmässige sechsecke stetheilt. Die 8 bis 10 Zentimeter langen Blätter sind länglich wal, auf der muteren Seite biunlich gran mo stehen wechselweise, an den Enden der Schösslinge häutig in Wirteln. I)ie kleinen, mscheinbaren Blüten ersheinen im April und Mai, die zahlreichen, faarweise an einem etma 5 Kentimeter langen stiele sitzenden. Elbsengrossen. dunkelblanen Frïchte reifen im oktoher und bleiben noch einige Zeit nach dem Abfall des Laubes anf den Bäumen.

Das Holz ist schwer, weich, stark, sehr zäl, schwierig zu hearbeiten, zum Werfen geneigt. Wem nieht sorgtiltig getroknet, 


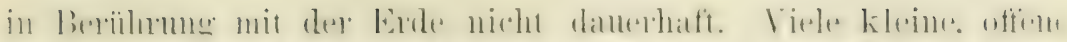

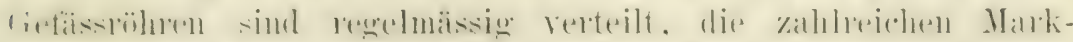

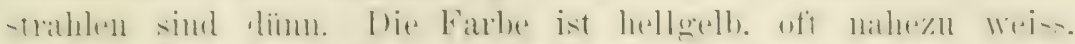

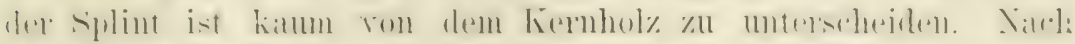

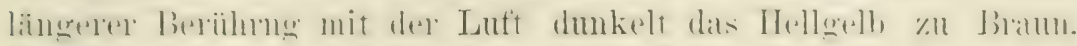
hisweilen ins Rütliche schimmernd.

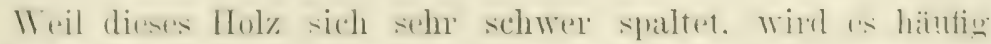

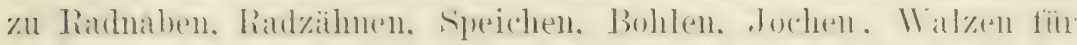

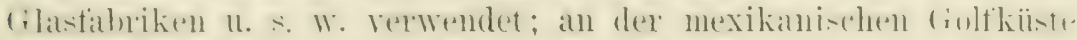

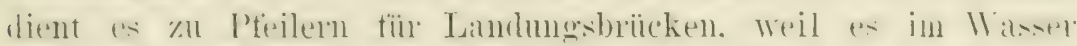

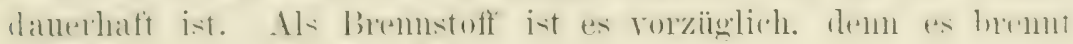
langsam und mit heisser Flamme.

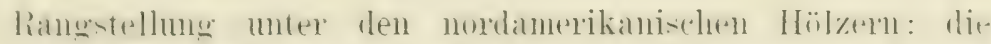

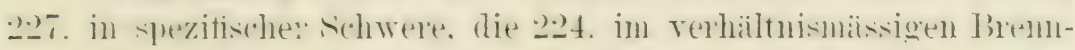

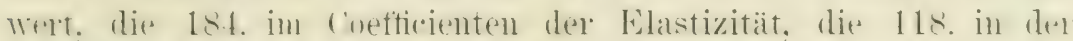

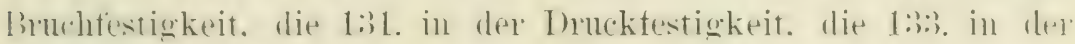
bindrutektigkeit.

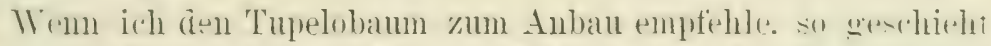

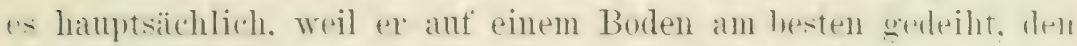
man entweder nubenutgt lässt. Wenn man ihn nicht zul landwirt-

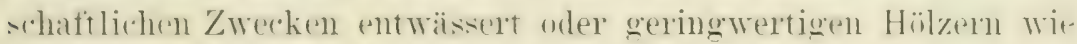

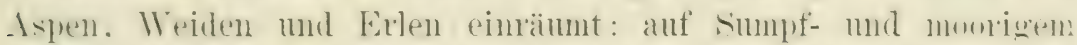

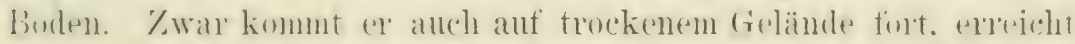

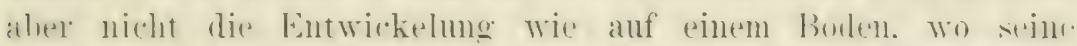

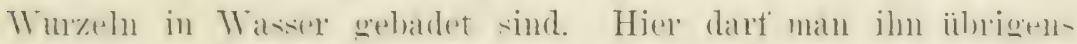

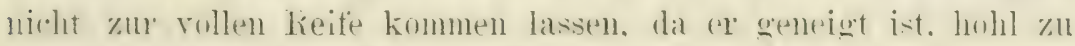
werden, sobald er aufhört, kräftig zu wachsen.

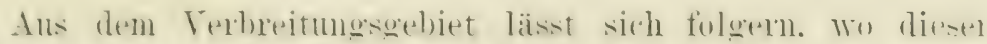

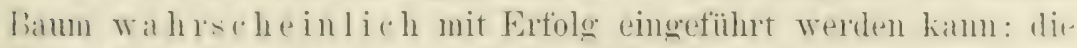

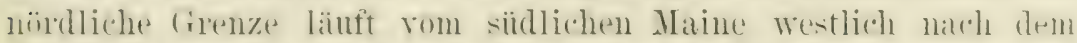
mitlemen Michigan. die südliche zieht sich von der Tampahat in Florida nach dem Brazosflusse in T'exas.

Fiir den simenbezug grilt was ron dem vorhergehenden bainm bemerkt wurde. 
14. Virginisches Dattelpfla umenholz.

Virginische Dattelpflaume (1)iospros virminth. Fanilin. Ebenaceate). Gleichname: Persimmon.

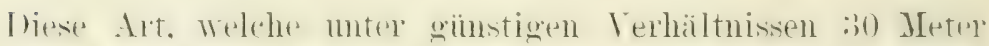
Hïhe und 19.60 Deter Stammesdicke erteicht. gewöhnlich aber nu halb so hoch und dick wird, ist von der sïdemopäischen Ihattel-

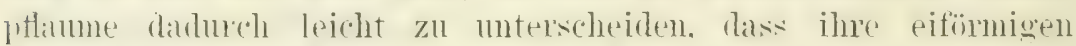
Blätter hellgrim ant heiden veiten. 15 Zentineter lang und 10 \%entimeter breit sind. Die blassgelben. zumeilen etwas griulichen liliiten erscheinen im Juni ma Juli. ihnen folgen gelbe rundliche Frïchte. getüllt mit einem fleischigen Mark. Welches 7 his \& halbtirmule. harte. dunkelpumpurne Kerne enthält. Erst der Frost macht die Frucht eniesslar, kimn ihr übrigens nicht den herben. zusammenziehenden Geschmack nehmen: ron vielen zahmen und wilden Tieren wird sie gern gefressen.

Verbreitet ist dieser Banm rom mittleren Connecticut bis zmm Caloosathus in Florida, westlich bis zum östlichen Kansats

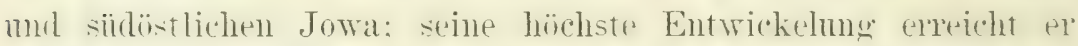
anf dem fruchtbaren schwemmboden des unteren Ohiothales. In den sïdstaten hat er oft verlassene Felder vollständig eingremommen.

Das Holz ist schwer, hart, stark, sehr dicht, nimmt eine anserordentlich schöne Politur an. enthält einige zerstrent stehende offene ciefïssühren: ein oder mehrere Reihen ähnlicher Gefässröhren hegrenzen die Jahresringe. The Markstrahlen sind zahlreich und deutlich. Die Farbe ist dunkelbram. oft nahezu schwarz. der ricke sulint ist lichtbram und enthält oft zahloteiche. dunkle Fleckell.

Rangstellung unter den nordamerikanischen Hölzern: die 9:3. in slezifischer schwere, die 92. im rerhältnismässigen Bremwert. die 198. im Coefficienten der Elastizitat. die 102. in der Bruchtrstigkeit, die 14. in der Druckfestigkeit. die 33. in der Eindruckfestigkeit.

Diese- Holz ist besonders gesucht zu feinen Drechslerarbeiten nuld wird hoch bezahlt, wemn es nahezu schwarz ist - eine Farbs. dio sich nur in den alten Stämmen findet. Solche Holzstiick Werden tief schwarz geheizt mo dienen als Ersatz tïr Ebenholz. mit dem es botanisch rerwandt ist. Ferner wird dis Dattel- 


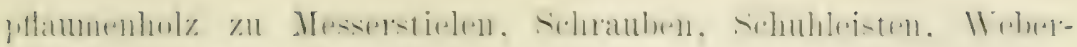
schiftchen u. S. w. verarbeitet.

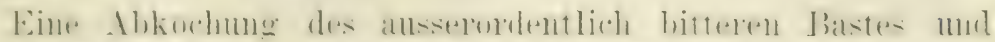

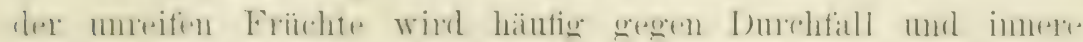

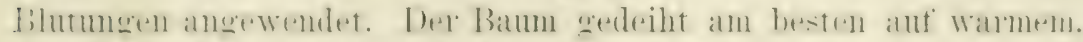

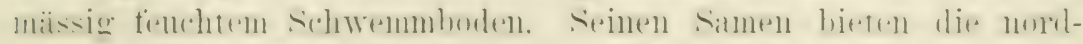

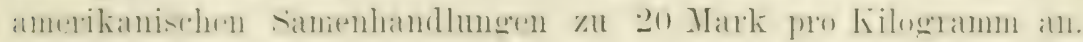

\section{Schwarzes Dattelpfla me n holz.}

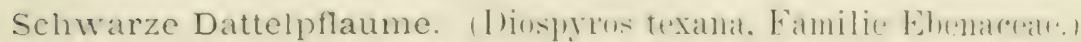

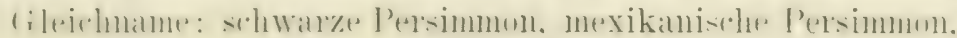

Chapote.

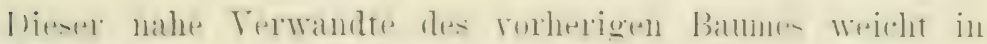

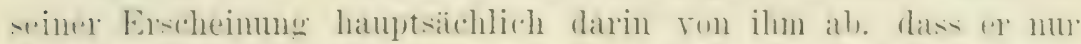

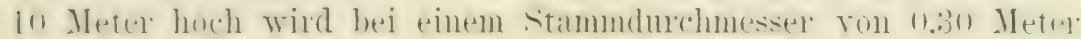

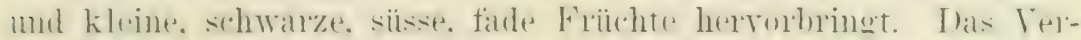

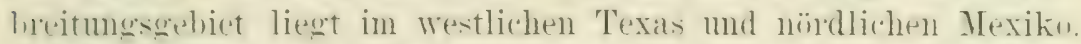

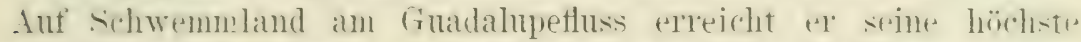

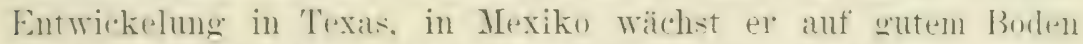

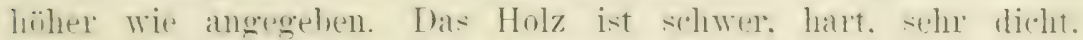

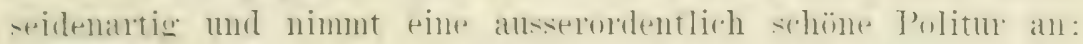

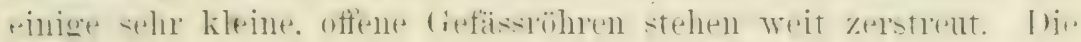

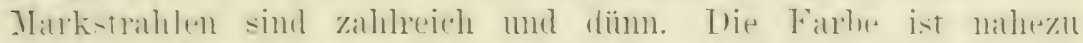

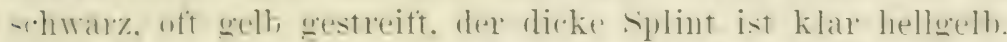

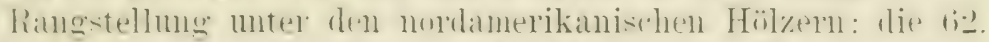

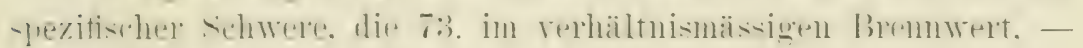
andere Eigenschatten nicht untersucht.

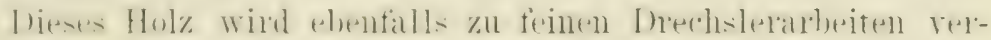

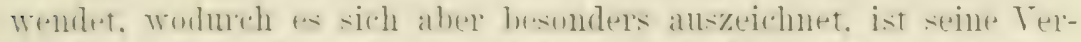

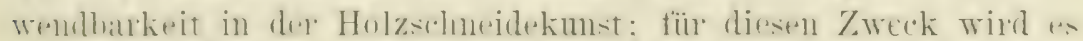

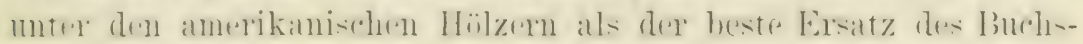
holzes betrachtet.

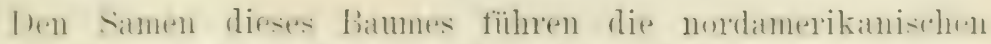

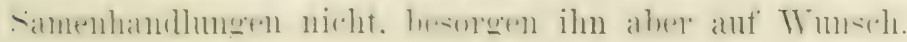

\section{Eschenholz.}

Fon den etwa 20 Eschenarten der Erde, die alle in der

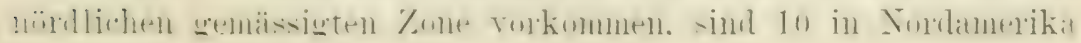


heimish. von welchen aber nur eine zum Anbau empfehlenswert ist. da die übrigen teils entschieden geringeres Holz liefern. teils nimdriger im Tuchs bleiben, ohne bes eres Holz zu erzengen.

\section{Weisse Esche (Fraxinus americana, Familie Oleaceate)}

Wegeir der vorziiglichen Eigenschaften ihres Holzes, der schmelligkeit ihres Wuchses und der Schönheit ihrer Erscheinumg sehört die weisse Fsche zu den hervorragendsten Waldbäumen Tordamerikils. Ihre durchschnittliche Höhe ist 21 bis 25 Meter, hei einem Stammdurhmesser ron 0.80 bis 1,20 Meter, in sehr soltenen Fällen ist eine Höhe ron 42 Meter, bei einem Stammdurchmesser ron 1.80 Meter beobachtet worden. Die Rinde des stammes spaltet sich in tiefe Furchen; die Äste gehen in regelmässigen kntfernungen allmählich dümner und kürze: rom stamme in doplelter Krïmmung ab und bilden eine sehr gleichmässige Krone; die Zweige sind dick mol endigen in siner grossen Endknospe. Die jüngeren Triebe sind blänlichgran mol glatt: die Endknospen blassbram und änserst bitter. Wodurch diese frt ron der emopäischen Esche leicht zu unterscheiden ist.

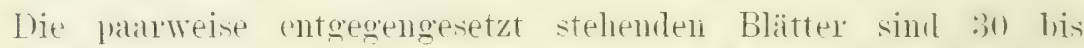

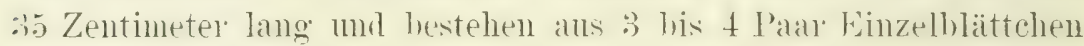
mit einem Endblättrhen. Diese Blätchen sind s lis 10 Zentimeter lang. 5 Zentimeter breit. eifürmig, zugespitzt, zart mul stehen an wanz kurzen stief(lon: im Frïlling sind sie nit eincm zarten Flamm bederkt, lex suäter verschwindet, im sommer glatt. oben hellgriun. unten weisslichgün. I le letlgrünen Blïten elscheinen groühnlich im Mai. die 4 Zentimeter langen. in dex Tähe des stiels walzentürmigen, damm abgeflachten Flügelfiüchte revifen frïh

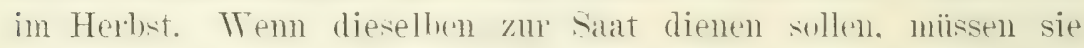
sofort bei ilner Reife gresammelt. dium zum Trocknen ansobreitet mu in cinem groben sack an einem kïhlen ort anthewaht werden.

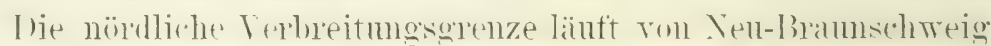
nach dem süden ron ontario mul dem nördlichen Mimnesota. die - iirlliche zieht rom nürdlichen Florida dureh das mittlere Alabama

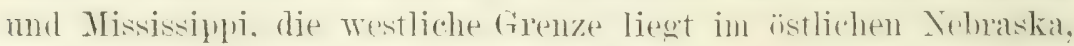
Kansas nud Indianerteritorium. Die stälkste Futwickelung elreicht dieser Baum ant dem sohwemmborlen des interen (1hiothales. In westlichen 'lexas tritt aine kleinere syicelart (var. texensis) 


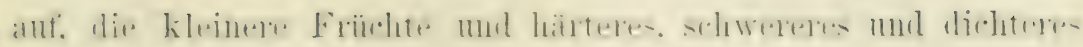
Holz erzeugt.

Das Holz ist mitssig schwer, hart, stark, gerad- und grob-

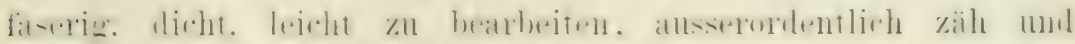

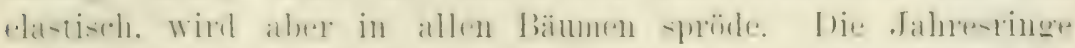

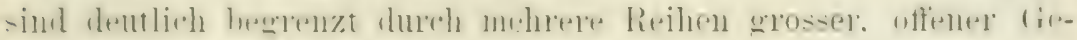

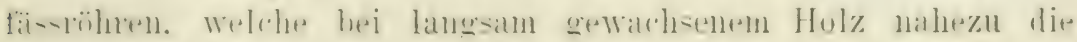

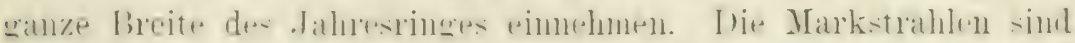

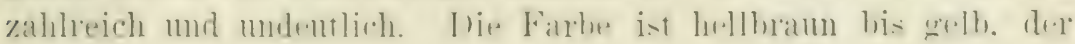
diime Splint ist heller, oft nahezu weiss.

liang-teblung moter den moldanedikanischen Hoilzern: die

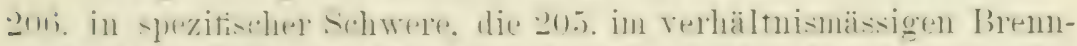

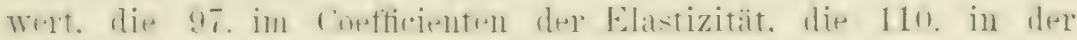

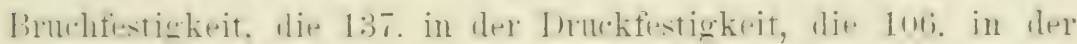
Eindruckfestigkeit.

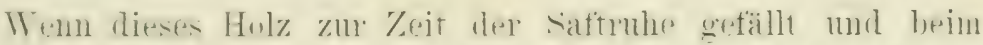
Trurken soretiltig behandelt wirt, ist es sehr dauerhaft. andemfalls rewest as rach. namentlich. Wemn die Bliacke lange move-

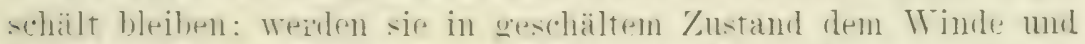

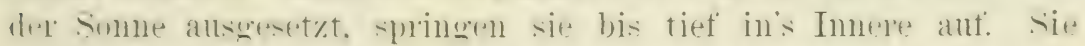

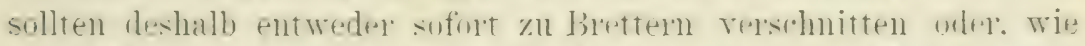

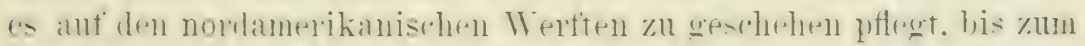
Gebrauche unter Wasser gehalten werden.

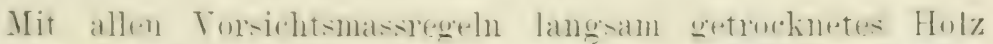

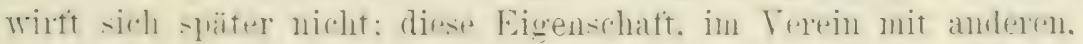

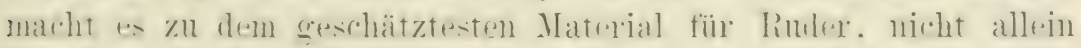

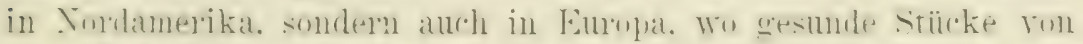

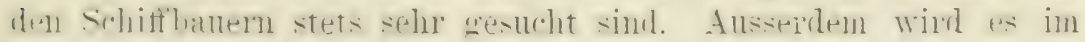

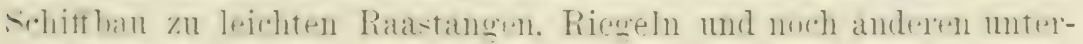
geordneten Zwecken ver'wendet.

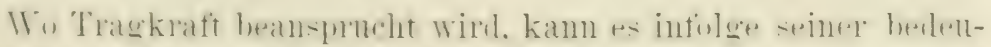

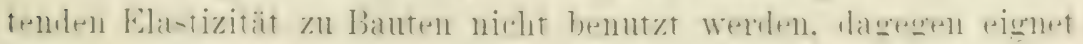

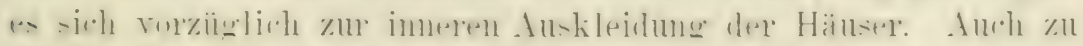

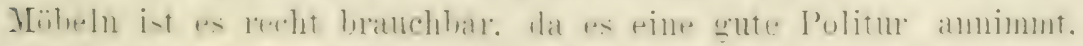

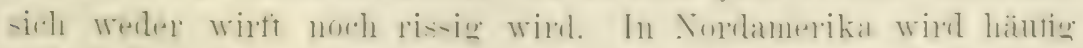

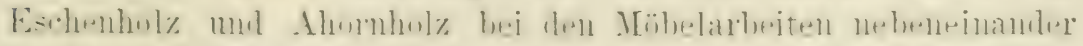

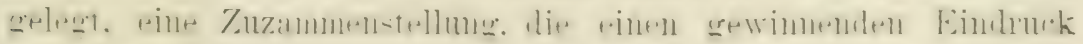
macht. 


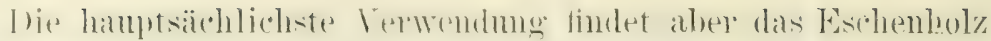
im 1 agemban mol in der Fabrikation landwirtschaftlicher Gerate, tem in diesen tiewerben ist minersetzlich, weil es siols in gedimptem Zastand in jode form biegen lässt, whe Beschädigung der Fasem. Freilich kommen dahei srine anderen goten Eigens-haften: Abwesenheit ron Linonem und Astlöchern, Kähigheit, banerhattigkeit mo festes stehen in der Form ebenfalls in Betracht. Werkzengstiele und manche andere kleine Artikel werden masenhaft ans Eschenholz gefertigt, ebenso Fassdanben. die denjenigen aus Eichenholz rorgezogen werden, wemn die Fäser zum Autbewahren von Mrohl mol gerükeltem Fleisch dienen sollen.

Tie Eache eignet sich rorzïglich zum sichlagholzbetrieb, weil der Stumpf riele krättige Schönslinge treibt. llieselben werden in Pausen ron 4 bis ; Jahren abgeholzt, wem site zu groben Flechtwaren. spazierstïcken und Peitschenstielen dienen sollen mul in Pansen von 8 bis 9 Jahren, wenn die Anfertigma ron Lanzenschäften, Fassreifen, Angelruten oder kleinen Drechslerabeiten in: Ange gefasst ist, fermel wemn Bremstoff zum Ränchern von Heringen gewünscht wird. zu welchem \% wecke das junge Eschenholz unibertrefflich gilt.

Nordamerika exportiert heträchtliche Mengen Eschenholz als Panken oder in teilweise rerabeitetem Zustande nach Europa. wo es frihher einen ausgezeichneten Ruf renoss. in nenerer Zeit aber häutig abfällig beurteilt wird. Die Erklärung ist nicht schwer zu finden. Infolge des enormen Begehrs wird Eschemholz n'ster Qualität immer seltener. Während die Holzhändler golank»n, zweite und dritte Qualität als Ersatz bieten zu kïmen. Thol an solchen geringen (pmalitïten fehlt es nicht. weil die Tordamerikaner ibberreite Bäume tällen. es mit der Fällungseit nicht genau nehmen und das schälen dem Fälen nicht immer ummittelbar folgen lassen. so kommt es, dass viel Eschemholz im Handel elscheint. das rote mol gelbe Flecken und streifen aufweist - die ersten Zeichen der Tepwesung. Bein Ankante ist daher genan daranf zu achten. dass das Holz eine reine hellbrame Farbe frei von gelben oder roten Flecken aufweist.

Tnter "amerikanisches Eschenholz" soll das Holz der weissen

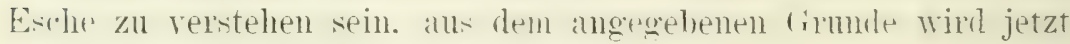
das Holz anderex Eschenarten mutershoben. An hïinfusten dient 


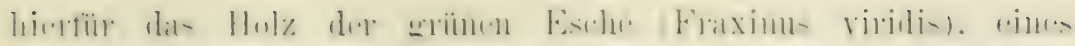

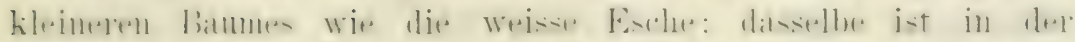

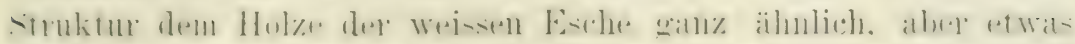
dunkler gefärbt und spröder:

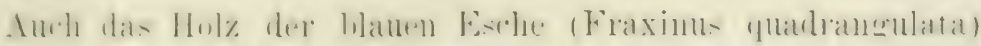

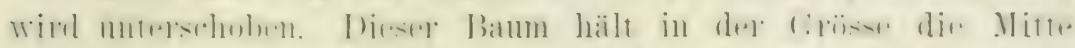

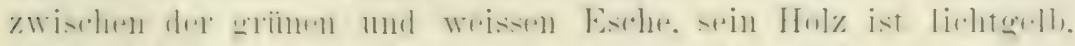

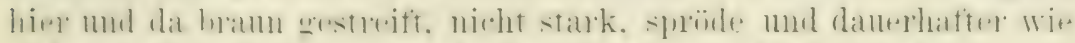

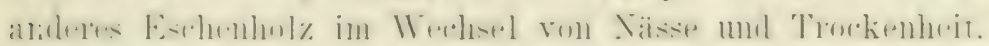

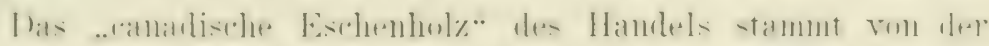

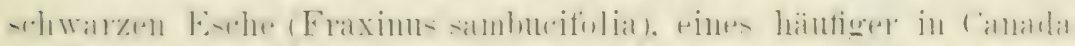

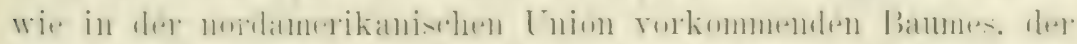

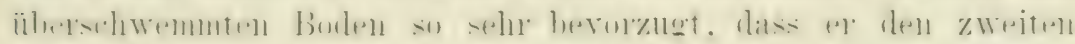

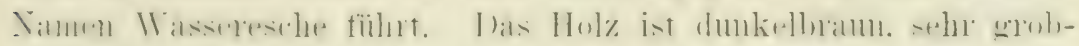

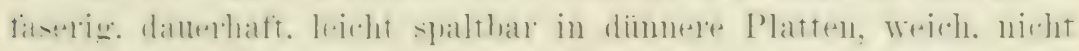

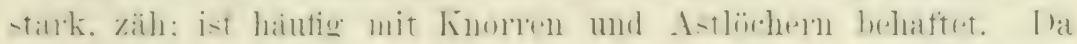

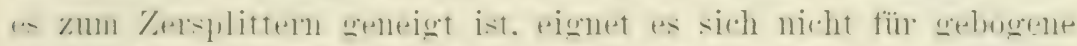

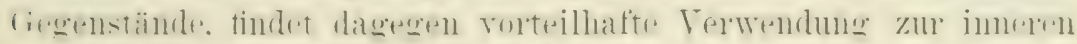

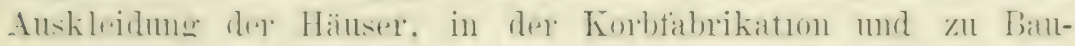
zwecken, wo geringe 'Tragkraft beansprucht wird.

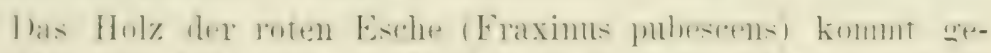

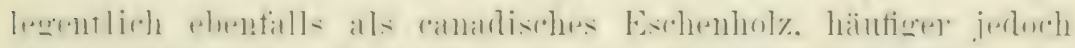

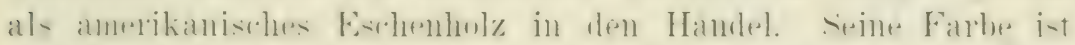

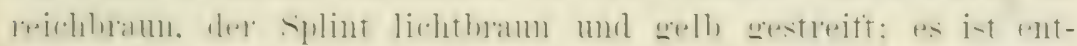

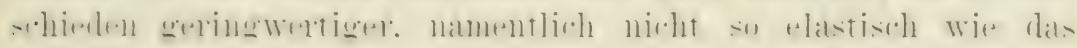
Hol\% del' Weissen Esche.

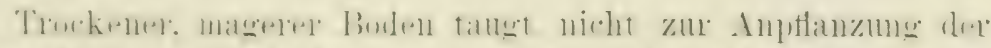

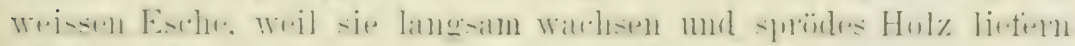

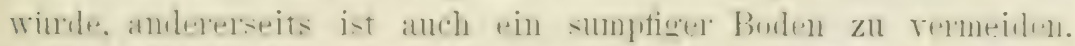

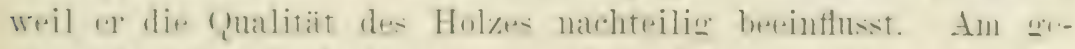

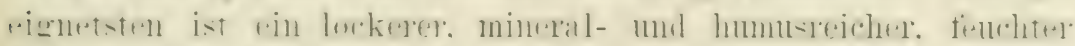

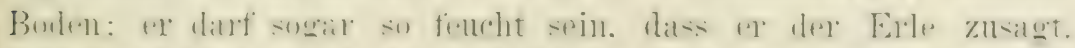

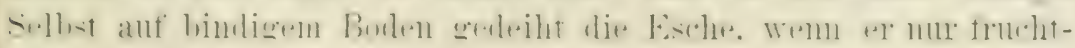
har ist.

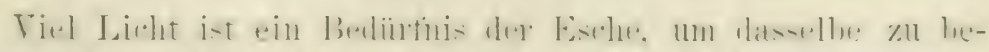

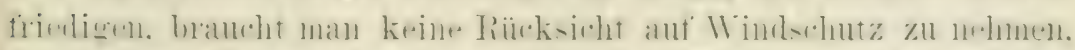

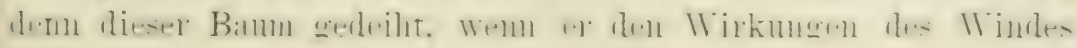
rollständig alsigesetzt ist. 


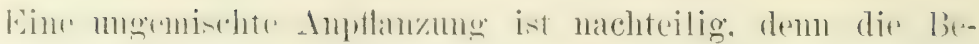

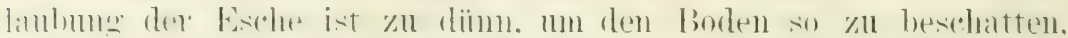

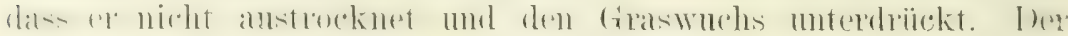

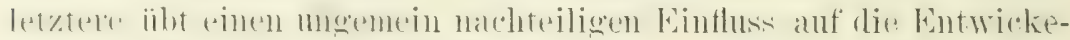

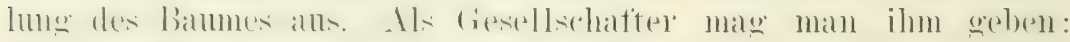

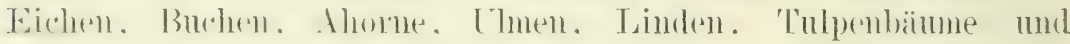

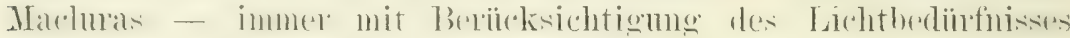
der Esche.

So hoch wie die Buche steigt die Esche in's Gebirge. Die

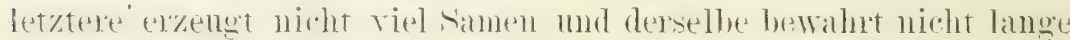
seine Keimkraft.

1 ter Same mins seidht. krinestalls tiefer wie 2 \%entimeter in

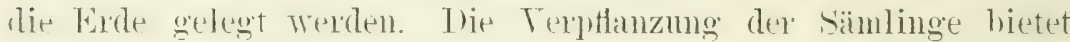
nicht die geringste Schwierigkeit.

Zwishene 25000 und 50000 , samen gehen anf das Kilogramm. welehes von den mordamerikanischen samenhandlungen mit 1.s Mark notiert wirt.

\section{1 a a a l l a h hol\%}

Westlicher Catalpa. (l'atalpa speriosil. Familie Bigmoniacean.) Gleichname: harter Catalpa.

Mit Betommer muls daranf anfmerkisan gemacht werden, dass

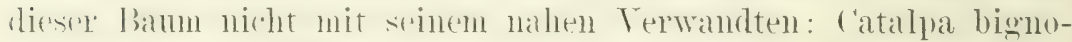
nubides repwechselt werden dart. Wolcher schom seit geranmer Zeit

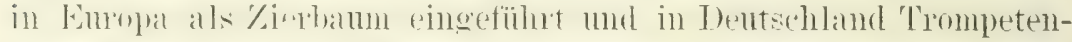

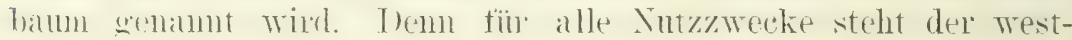

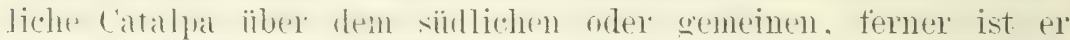
viel klimahärter, was sich auch schon aus den Verbreitungs-

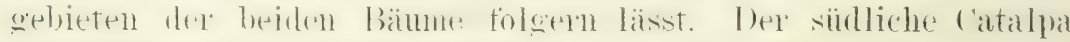
ist heinisch im weslichen Flonila. im sïdwestlichen Grergia. im mittlepen nul sïllichen Alahanta und Mississippi; der westliche

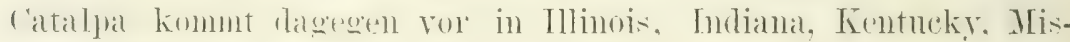
somri und Arkansas.

Der westliche Catalpa ist grösser wie der siidliche, demn

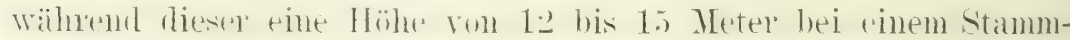

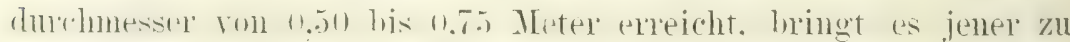

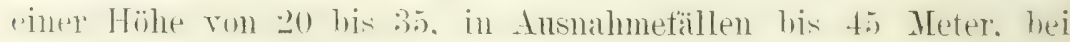
einem Stammdurchmesser von 1 bis 2 Meter. 
Die likinde des westlichen Catalpas ist graubram und mit

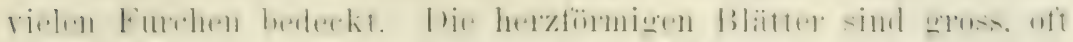

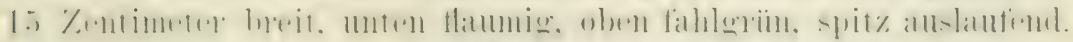

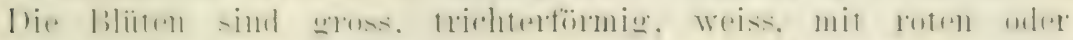

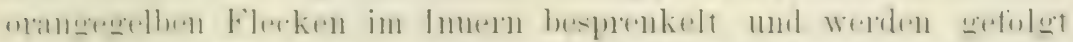

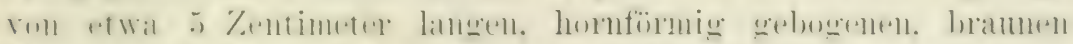

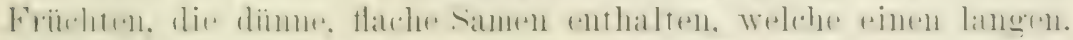

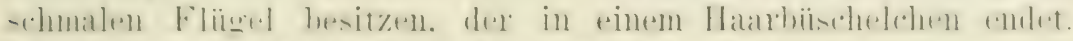

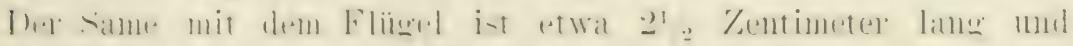
2.5 Millimeter breit.

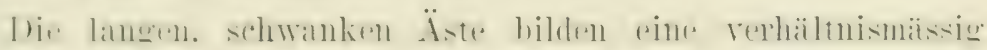
sehr breite Krone.

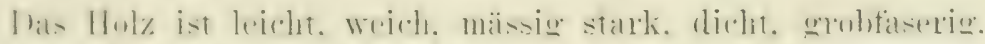

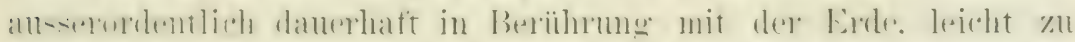

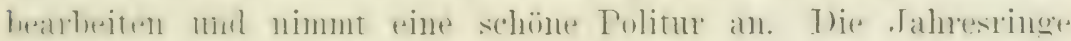

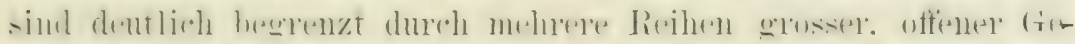

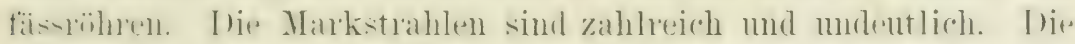

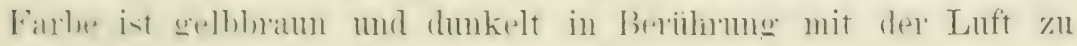
bram. Der dimme Splint ist heller.

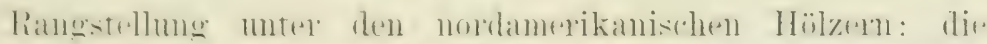

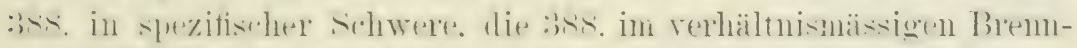

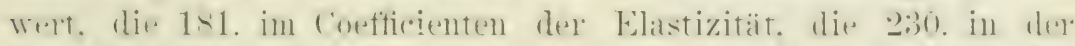

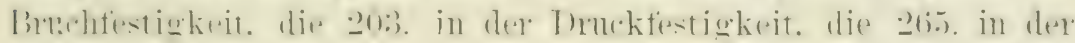
Findruckfestigkeit.

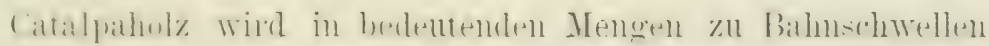
verarbeitet. weil es in der Erde nahezu unzerstörbar ist. Das

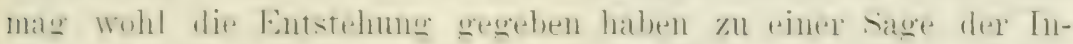

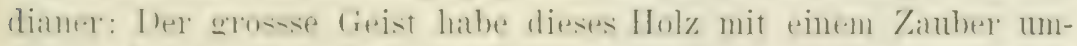

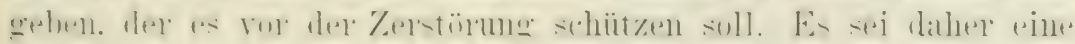

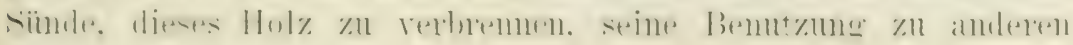
ZTrecken sei dageģen ellaubt.

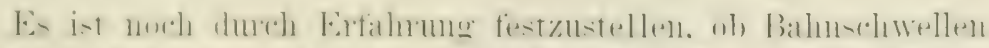

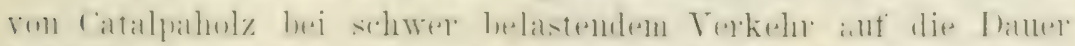

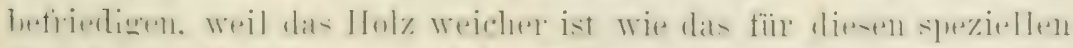

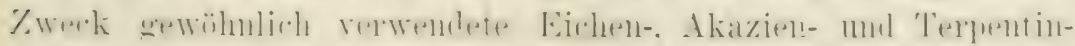

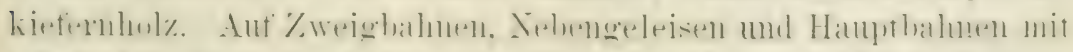

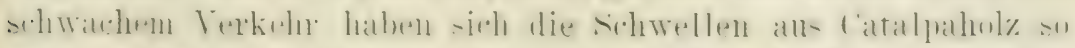

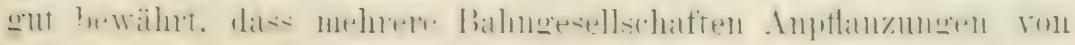


('athlpabüumen anstiihnen liessen zur leckumg ilnes bezüglichen Bedlarfes.

rehr geeignet ist das ('atalpaholz zon Telegraphenstangen, לämen. Schindeln. Rebptählen. Hopfenstangen, Gefässen, särgen, immerer Auskleidung der Häuser und Banzwecken, wo keine starke Tragkratt beansprucht wird. T) es sich nicht wirft mol nicht rissig wird. wenn sorgfältig getrocknet, schön gemasert und leicht zu bearbeiten ist, findet es eine steigende Verwendung zu Möbehn und zur inneren Auskleidung der Eisenbahnwagen.

Ansser der Vielverwendbarkeit des Holzes sprechen noch andere Grïnde zu Gunsten der Kultur dieses Baumes. Zunächst passt er sich leicht dem verschiedenartigsten Klima an. Er übersteht die sibirischen Winter ron Minesota und Jowa, gedeiht an ciolfe ron Mexiko, ist in dem heissen Südindien. in Anstralien. Tasmanien und südafrika eingeführt worden; ex besitzt eine grosse Widerstandsfühigkeit gegen die I)ïrre. wächst frendig auf der windgepeitschten steple und ist einer der wenigen Bäume. dic an Seestrande fortkommen. Trem er eimmal festen Fuss gefasst hat. erträgt or die schwersten Misshandlungen; smmer und immer wieder. treibt er s'chösslinge aus seinem Stumpfe, niemals dagegen aus seinen Wurzeln.

Ein fernerer Torzug ist das ansserordentlich rasche Wachstum dieses Baumes. Ter Ailanthus oder chinesische Götterbaum gilt mit Recht als einer der schnellwachsendsten Bäume. In einer grösseren Anptlanzung, welche die Kansas ('ity Fort Scott \& Gulf Raihroad Company auf ihrem Gelände mit catalpa- und Gö̈terbäumen Seite an Seite ausführen liess. wurde nach 6 . Tahren das durchschnittliche Wachstum ermittelt, mit diesem Resultat: ('atalpabäume 5,4 bis 6.3 Meter Höhe, 0,30 bis 0,45 Meter Durchmesser:

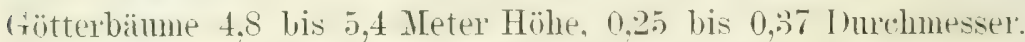

Der Catalpa ist nicht wahlerisch im Boden; er entwickelt sich aber am ïppigsten auf feuchtem. fruchtbarem sichwemmboden. während er auf trockenem Boden verkiuppelt. Inrch stecklinge lïsst er sich leicht fortptlanzen. ebenso durch siat. die riel empfehlenswerter ist. Der Same darf nicht tiefer wie 1 Zentimeter mit feiner Frde bedeckt werden. Thas satbeet ist selu snrofiltig ron Lnkraut rein zu halten. MVhrere Zürchter haben mofohlen, den Wuchs des ersten .Jahres bis nahe üher dem Boden zmüükznschneiden. (s entwickele sich dadurch im zweiten Tahre 


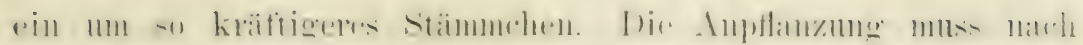

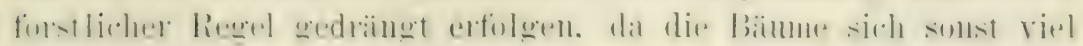

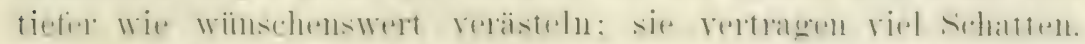

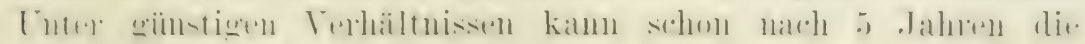
erste Auslichtung stattfinden.

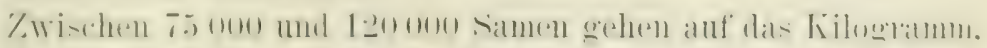

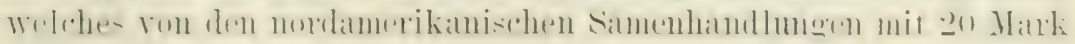
notiert wirl.

\section{Sassafiashol\%.}

Sassafras (Sassafias officinalis, Familie Lamaceae).

Gewöhnlich erreicht dieser Baum eine Höhe ron 12 bis

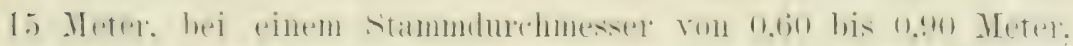

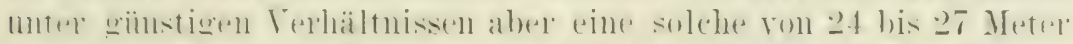

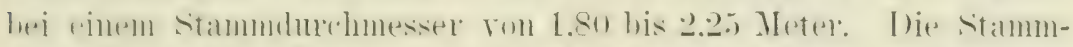

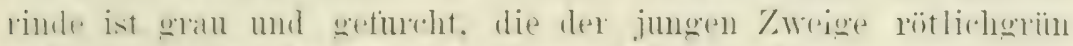

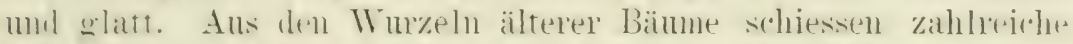

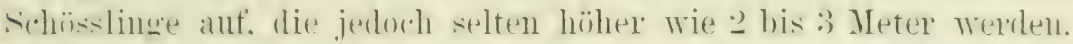
loie 10 bis 12 Zentimeter langen Blätter stehen abwechselnd mol siml anfang: wollig und zalt. Werden aber nach kuryer Zeit glatt mol staker. bemerkenswert ist die rerschiedeme Form der Bliatter

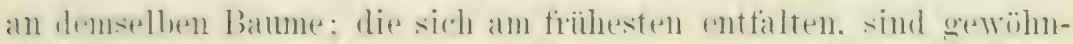

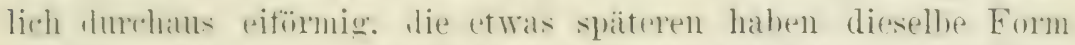
mit einem Lalplen an der seite mo die letoten haben regehmässin

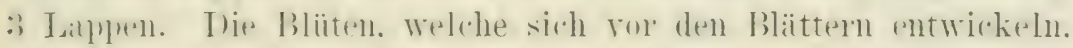

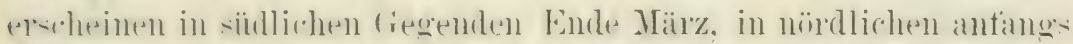

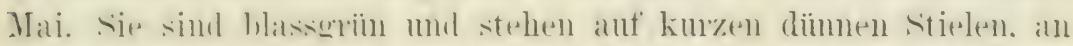

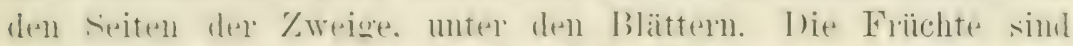

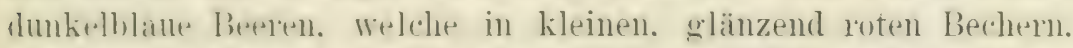

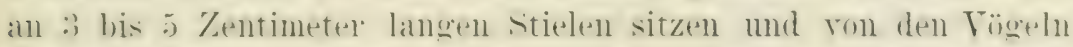
gerne gefressen werden.

Die nörlliche Grenze des Terbreitungevebietes dieses banmes

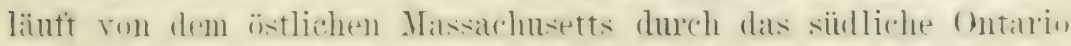

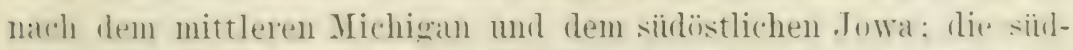
liche zieldt ron dem mittleren Florida nach dem 'Thale des Brazuflusses in 'T'exas.

l)as Hol\% ist leicht. Weich. nicht stark. spröde, grobfiaserig. sehr datlerhaft in berihlume mit der Erde. schwath aromatisch. 


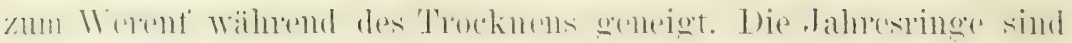

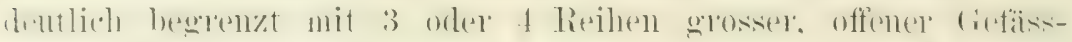

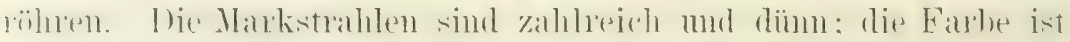
dumpf orangebram, der dïme Splint lichtgelb.

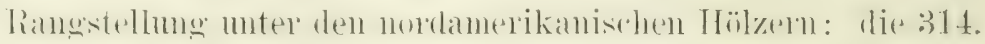
in suezifischer selowere, die :312. in reshältnismässigen Bremwert.

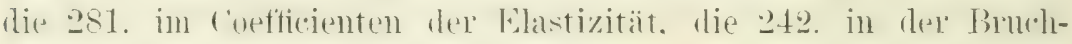

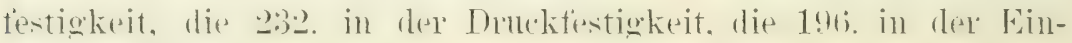
diruckfestigkeit.

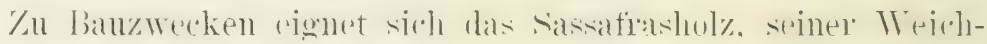
heit wegen. pigentlich nicht, da aher die Erfahrmegeleht. dass er. rom der Rinde befreit. der Verwesme sehr lange widersteht und seines eigentïmlichen (ieluches megen ron Insekten nicht ancescriffen wirl. so benutzt man es germe zu sichwellen und Pfosten bei leichten ländlichen Gebäuden. tirnel wird es. un dieser Eigenschatten willen. maswenhatt zu Bettstellen. Kisten. Fommonlen. Gefässen und Zäunen verarbeitet.

In neulerer Zeit wird das sassafiasloglz nach tropischen Iänder'n exportiert zur inneren Anskleidung rom Koftern und anderen Bebälterm. welehe nebst ihrem Inhalt ror Insektrnfiass geschiitzt werden sollen.

Der Sassafras ist von Wichtigkeit für die Heilkunst. Aus dron Wuzehn, zuweilen anch aus dem weniger aromatischen stammhol\%. Nird das bekamnte Sassatrasöl destilliert - ein seln kräftiges, anregendes mo shweisstreihendes Nittel. Der ans der Rinde mon dem Mark der jungen Zweige gepresste saft gilt als schleimlïsend, der ans den frischen Blïten bereitete Thee als magenstärkend.

In Lomisiana werden die Bläter. spinatähnlich zubereitet. gregessen und im ganzen Terbreitungsgebiete des Banmes wird ans den jungen schössingen und der Wurtelrinde ein wohlschmeckendes, unter dem Namen Rootbeer bekanntes Getränk bereitet. desien Genuss sehr zuträglich ist.

Der Sassatias nimmt mit jerlem lockerem Boden fürlieb, zumal wemn er fencht ist. 1)ie Fortptlanzung geschieht am besten durch samen, der aber oft 2 Jahre im Boden liegt bis er keimt. Stecklinge bewuzeln sich leicht, müssen aber in den ersten . Tahren ror rauhen Winden und starker Besommg geschït Werden. 


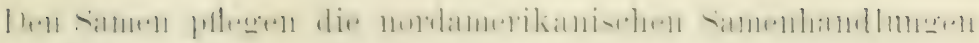
aicht zu fiihren. besorgen ihn abel.

14. Californisches Lorbeerhol\%.

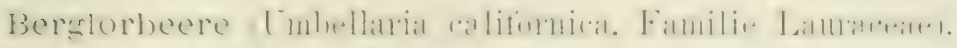

(rleichnamen: Gewiuzbatun. Baybaum.

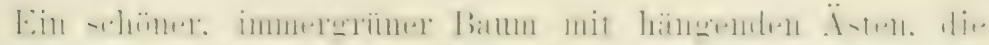

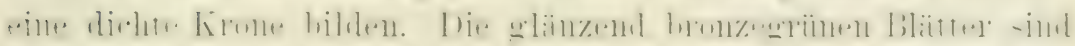

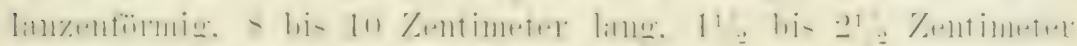

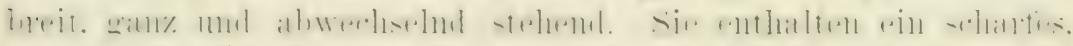

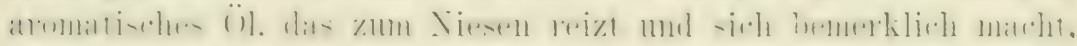

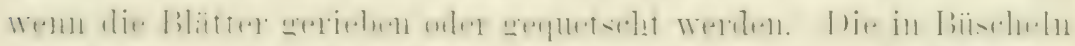

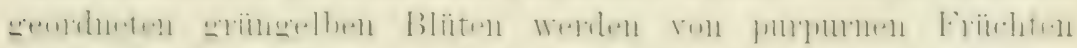

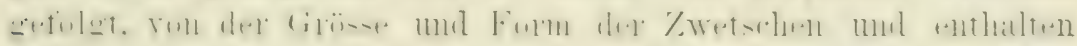

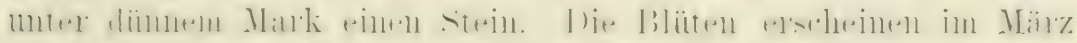

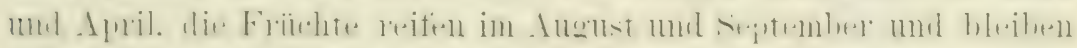

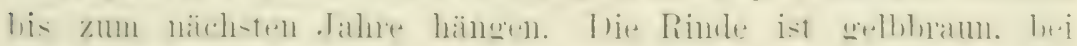
jungen Bämmen olatt. bei ältereren etras rissig:

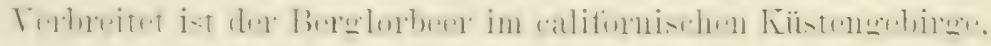

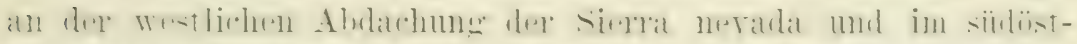

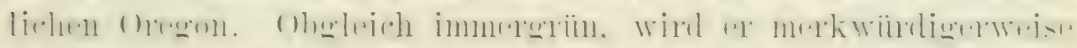

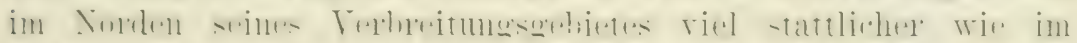

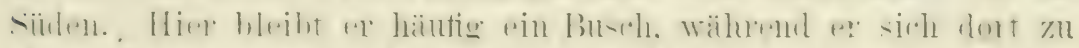

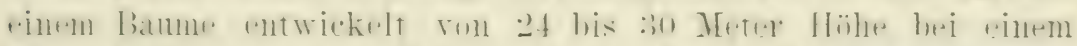

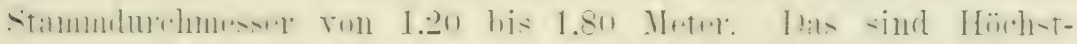

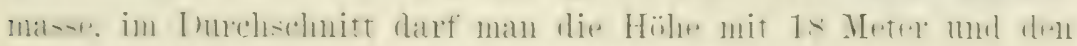
Stammdurchmesser mit 0,80 Meter amnehmen.

Das Holz ist schrer, hart, stark, dicht, nimmt eine aus-

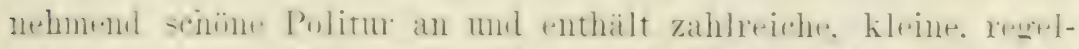

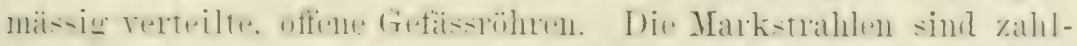

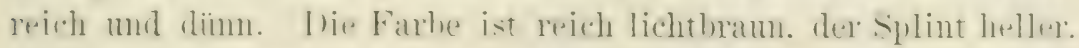

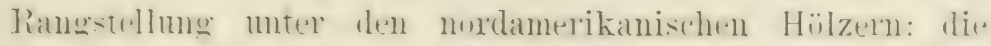

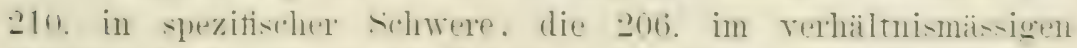

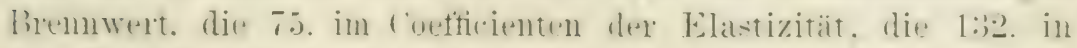

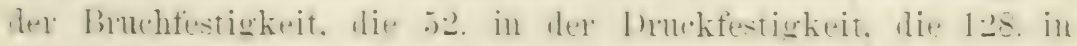
del Eindruckfestigkeit. 
An der ganz'n nordamerikanischen Pazitikkiiste gibt es

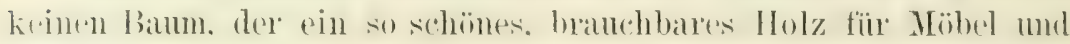
die immere Auskleddung der lläuser liefert wie der Berelorberer. seine Bedentme wird daduch beschränkt, dass el im grö̈sten teile seines Terbreitungsgebietes nur von mässigem oder gar schmaitchtigem stammmutange rorkommt. der nur ein Terschneiden zu Fumieren zulässt. Möbel, ganz ans diesen Holze, bieten ein wahrhaft reiches Aussehen; sie gewähen die weiteren Torteile. dass sie sich nicht werfen. nicht rissig und nicht ron Insekten angegriften werden.

In Oregon wmode dieses Holz germe im Schiffban rerwendet, allein die Preise sind allmählich so sehr gestiegen. dass es jetzt selten diese Verwendung findet.

I)ieser schöne. nützliche Baum ist untraglich wiirdig, unter Fultur genommen zu werden; wemn das bis jetzt noch nicht an der Pazifikküste geschah, so dürfen daraus keine gegenteiligen schluisse gezogen werden, dem hier betasst man sich iberhaupt nuch nicht mit der Forstkultur. Der Berolorbeer wird am hänfigsten an den kiesigen Ufern der Gebirgsbäche gefunden. otfenbar sagt ihm Bolenfenchtigkeit sehr zu, doch salh ich ihn nicht selten auf ganz trockenen, aber fruchtbaren Standorten kräftig gedeihen. Da wo er zur kraftigsten Entwickelung kommt. in den Thälern des siidöstlichen Oregons, herrscht ein Kilima, das mit demjenigen von siidtyrol recht gut veroleichbar ist.

Jen Samen notieren die califomischen Samenhandlumgen mit 20 Mark pro Kilogramm.

\section{Ulmenholz.}

Ton den 16 Uhmenarten der Erde. die rolzug'sweise in der nördlichen gemässigten Zone rorkommen, entfallen 5 auf Nordamerika, die alle ein gutes Holz liefern, von welchen ich aber doch nur eine zum Anbau empfehlen kamn. Zwar ist die weisse oder amerikanische Ulme (Llmus americana) die grösste dieser Gruppe und liefert das meiste $\mathrm{Holz}$ in den Handel, doch iibergehe ich sie, weil in Fachkreisen ibbereinstimmend anerkannt wird, das Holz der enropäischen U'Ime (Ulmus (ampestris) sei härter und dauerhafter, während der Baum gleiche Grössenverhültnisse zeige. 
Felsenulme (Ulmus racemosa, Familie Urticaceac).

Gleichnamen: Korkulme, Hickoryulme, Kílippenulme.

liese Alt erreicht pine Höhe ron 20 his 30 Meter bei einem

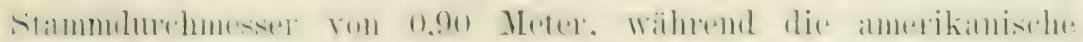

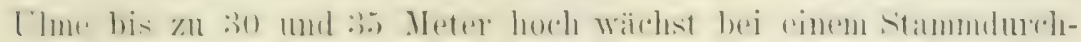

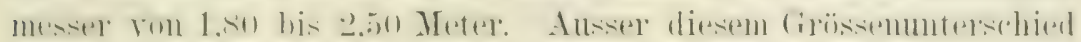

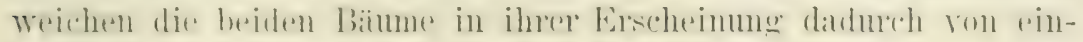

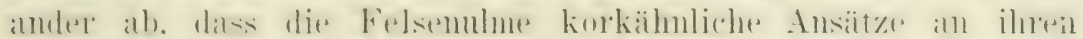

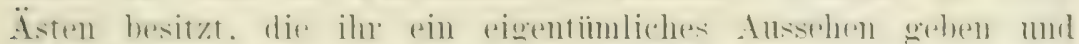

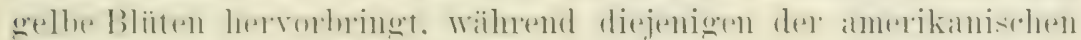

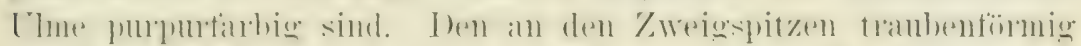

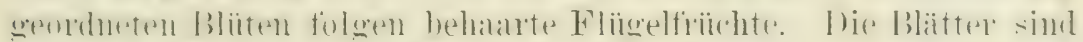

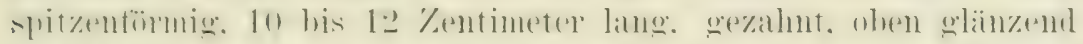

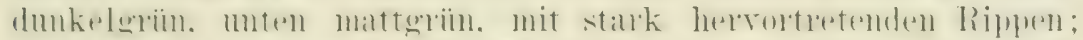

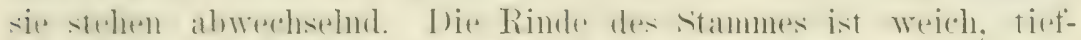

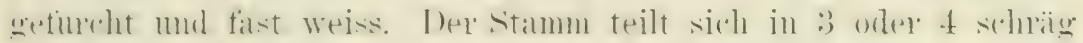

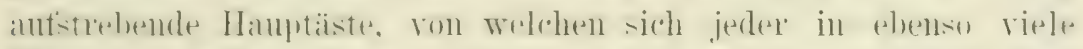

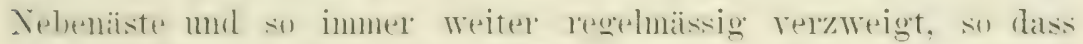

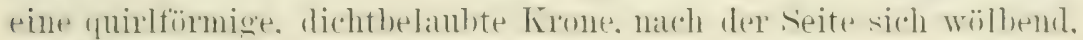
gebildet wird.

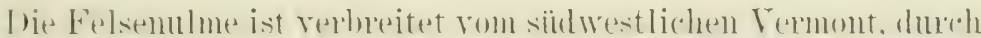

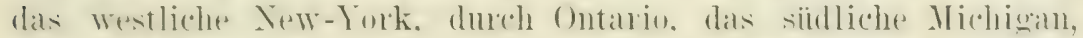

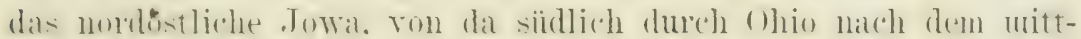
lemen Kentucky. Die amerikanische [lone hat ein weiteres Ver-

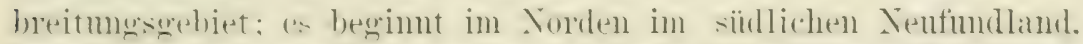

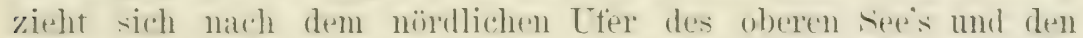
ïstlichen Abhïngen des Felsengehinges: sïdlich dehnt es sich his zum Cap Canareral in Florida mo dem Thate des comboflusses in T'exas.

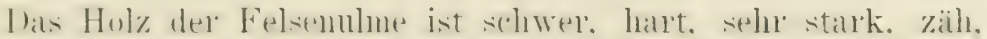

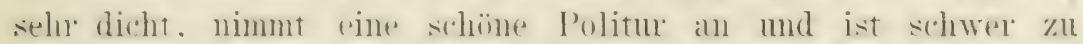
bearbeiten. Lie Tahresinge sind mit 1 oder 2 Reihen kleiner.

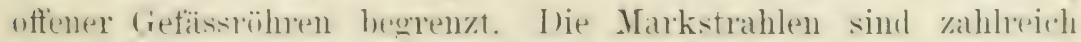
und meleutlieh. Die Farbe ist licht klathlann, oft ins Raitliche schimmernd, dex dickt splint ist viel heller, matnchmal nahe7ll weiss.

Rangstellung unter den nordamerikanischen Hölzern: dir 149. in spezifischer schwere, die 145. im rerhältnisnlïsigen Brenn- 
wert. die 64. im Coefficienten der Elastizitit, die 37. in der

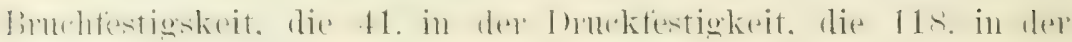
Eindruckfestigkeit.

Das Holz der amerikanischen UIme unterscheidet sich vou

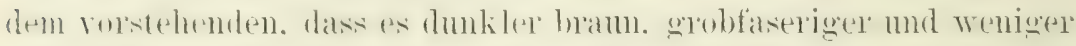

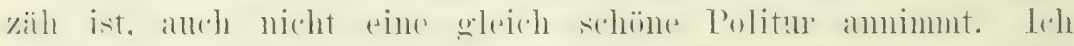

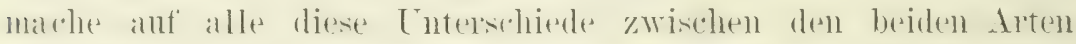
antmerksam, weil sie ron Xichtkemern gewöhnlich für ïbereinstimmend wehalten. und ihr Holz moterschiedslos entwerler als

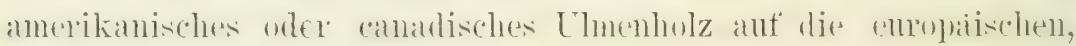
zumal auf' die englischen Märkte kommt.

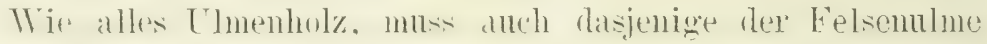

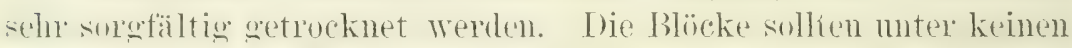
Cunstinden länger wie vine Woche dex somne oder dem Winde schutzlos luersegeben bleiben. Können sir nicht sotort verschnitten werden odel sind sie zu Balken bestimmt, damn lässt man beim sichälen die Bastbedeckmg zurïck. his die Bläclie ins Tasiser gelegt werden kömnen, wo sie bis zun Bedart zu bleiben haben. Werden sie zu Brettern rerschnitten. so sind diese an einem rollstindig winderechïtzten ()nte zu trocknen; (mpfehlenstrert ist, ihne stimenden mit einer Mischung ans Talg und Har\% zu bestreichen. Alle diese Torsichtsmassregeln sind nötion. Weil das Chnenholz leicht geneigt ist. im Trocknen tiefrissig zu werden, wodurch natülich sein Wert stark beeinträchtigt wird.

Das Holz der Felsemulme kommt gewöhnlich astfrei mal gesund anf den Markt, gelegentlich zeigt es Kermisse, aber ron milder Form und noch seltener ist ilnn ein Eehler eigen. der dem aus einigen tregenden stammende Holze der amerikanischen Clme ziemlich häufig anhaftet: unige hei einander liegende Tahresringe sind weicher und poröser wie die ïbrigen und leicht zu erkennen an ihrer dunkleren Farbe. Selbstrerständlich beeinträchtigen sie die Qualität und es ist daher beim Ankauf des Holzes darauf zu achten, dass es von durchaus gleichmässiger Farbe ist.

I ieses Holz ist sehr daurhaft unter Wasser. ebenso wem trocken gehalten. dagegen verwest es bald. wenn abwechsehnd des Nässe und Trockenheit anseretzt - eine Figenschaft. die es mit allem L'menholz gemein hat. Lie Terwendung ist eine ansserordentlich vielfache: es wird im Schiffbau benutzt, zu Planken die morer Trasser bleiben, Drechsler und Möbeltischler gebranchen 


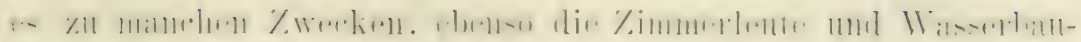

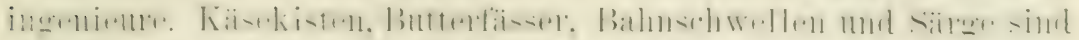

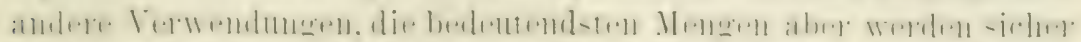

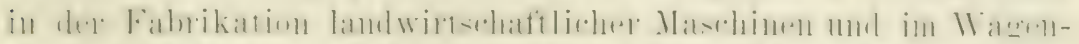

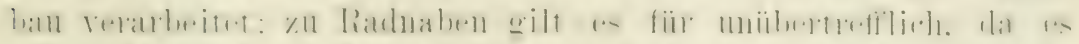

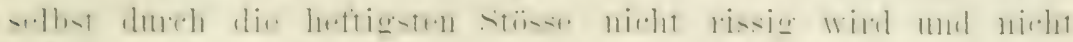
aut'sprinurt, wemn Vägel eingeschlagen werden.

Mährend die amerikanische nud emopäische Unmen eincn

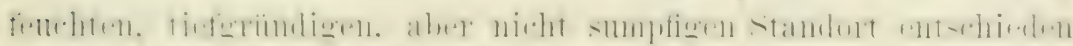

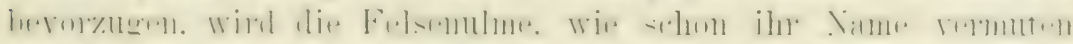

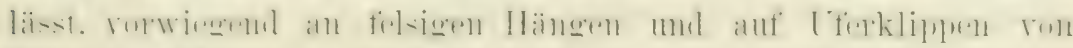
Elissen gefunden. Doch kommt sie auch auf tiefliegenden.

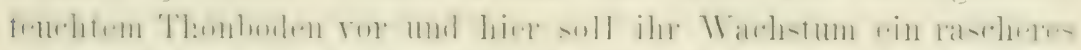

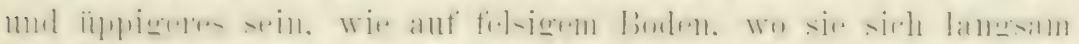

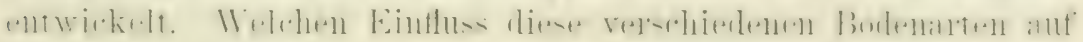
die Qualitït des Holzes iiben. bleibt noch festzustellen.

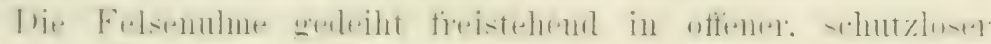

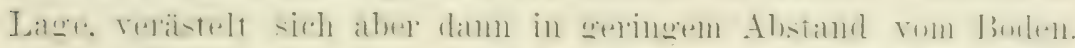

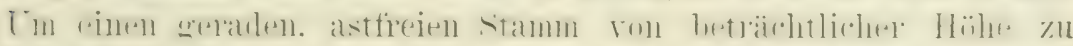

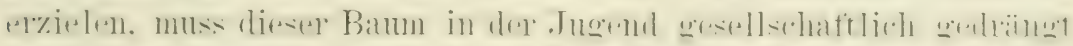

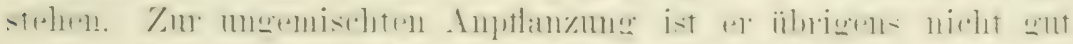

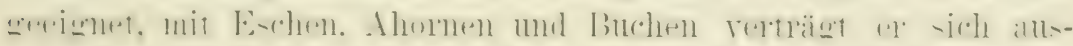

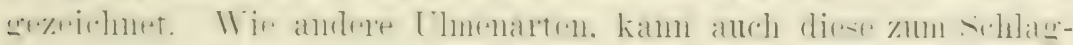

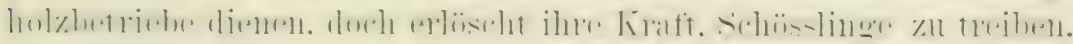
in verhältnismässig kurzer Zeit.

Der Same verliert bald seine Keimklaft. el sollte đaher

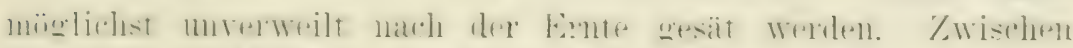

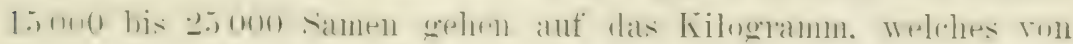

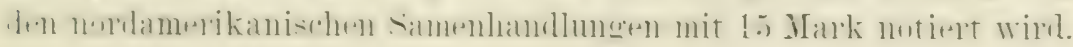

\section{Ma cluraholz.}

Maclura. (Maclula amantiaca, Familie Urticaceae.)

Gleichnamen: Osage Orange. Bois d'Arc.

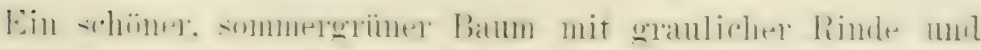

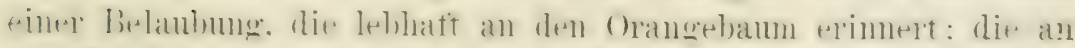

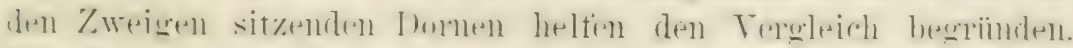

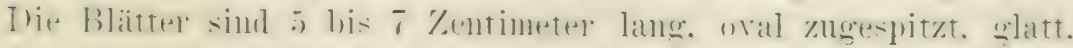

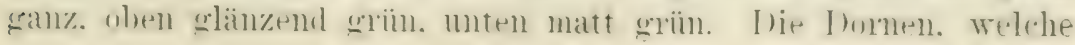


all- den wheren Blattwinkeln treten. sind rinfach. sohr stark und

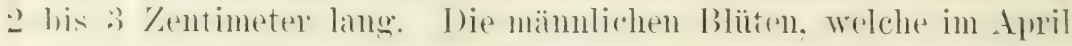

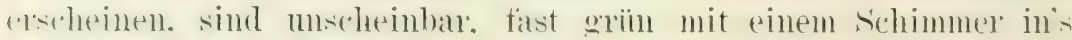
dielbe und sind in kleinen. hängenden bïscheln geordnet. Dit Weihlichen blïten sind rund. von der (rö̈se einer Kirsche. Die im september reifende Frucht hat die (xö̈se einer bitteren oxange mor enthält zahlreiche. langovale, abgeplattete samen. ron der Hrïse eine: Orangekerns. terner eine sïsliche Flüssigkeit, die an der Lutt gerimt wie Milch. Da diese einzige Art ihrer (rattumg zw wo beide Geschlechter nachbarlich wachsen.

Heimisch ist dieser Bam im siddwestlichen Arkansals. im siddistlichen Indianerterritorim, wo ex im 'Thate des roten Flusses die gröste Entwirkelung erreicht und im nördlichen Texas, rerhreitet ist er aber. mit Ausnahme der nördlichen staaten. über die canze Cnion. teils als Heckenptlanze. teils als Walcabam. Auf den Prärien und in den sïdlichen Gegenden der Pazitikküiste giht es keine beliebtere Heckenptlanze wite den Alarlura. \%u diestn Zwecke kam er leicht in einer Höhe vom $1^{1}$. Meter gूehalten werden. als Waldbaum, anf gutem Boden gezüchtet. Wïchst ex bis zu 15 und 18 Meter hoch. bei einem stammdurchmester von 0,60 bis 0,80 Neter.

Das Holz ist schwer, ausserordentlich hart, sehr stark, clastisch. dicht. sehr danerhaft in Beriihrung mit der Erole unl dem Tretter ansqesetzt. seidenartig, nimmt eine schöne Politur an. schnumptt wenig beim Trocknen und enthält zahlreiche, kleint, offene (refässröhren. I)ie Jahresringe sind durch breite Bänder grosiser Gefiissöhren dentlich begrenzt. Die Markstrahlen sind dium. zahheich. deutlich. Die Farbe ist anfänglich hell orange. bräunt sich aber durch Berïhrmg mit der Luft, der splint ist lichtgelb.

Rangstellung unter den nordamerikanischen Hölzern: die 100. in spezitischer Schwere, die 99. im rerhältnismässigen Brennwert. die 12.2. im ('oefticienten der Elastizitait. die 27 . in del Bruchestigkeit, die t. in der Drucktestigkeit, die 24. in der Findruckfestigkeit.

Das Macluraholz findet eine ausgedehnte Terwendung zu Furtieren, Ackergeräten, Bahnsehwellen, Radspeichen, Strassenphlister. Zaumpfosten und ähnlichen Artikeln. fïr welche Härte, 


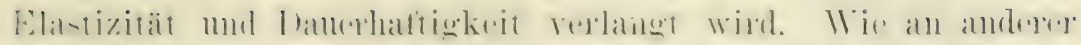

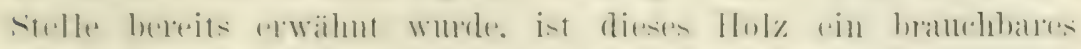
Färbemittel.

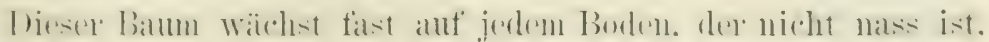

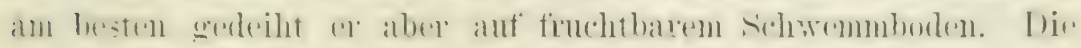

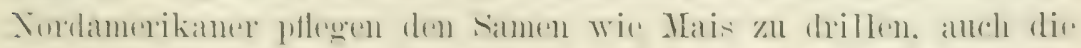

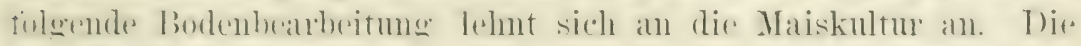
simlinger worlen in rinem Alstand ron :30 is is :35 \%entimetex in

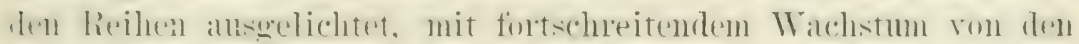

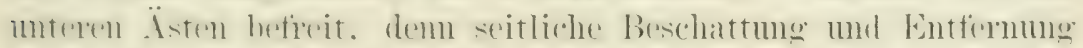

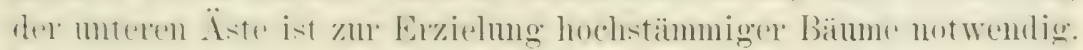

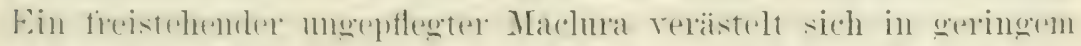

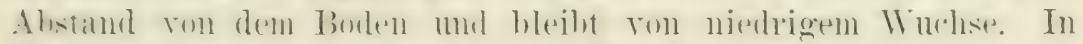

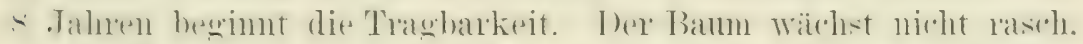

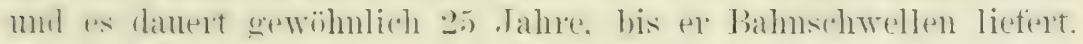

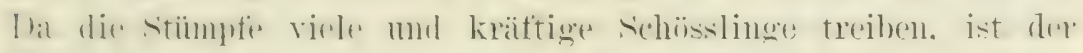
Maclura anch zum Niederwaldbetrieb geeignet.

Zwischen 8000 bis 120010 samen gehen ant das Kilngramm. tiij welehes die nordamerikanischen somenhandlungen 7 his \& Mark notieren.

\section{Wa 1 I n us sho I $z$.}

Lie Lattunge Juglans wird ron manchen Botanikeln in i.

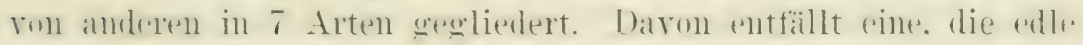

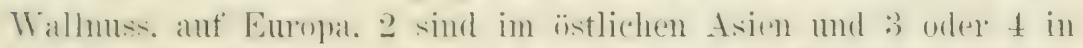

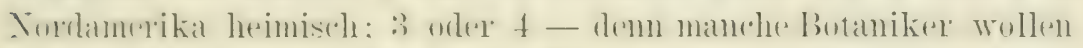

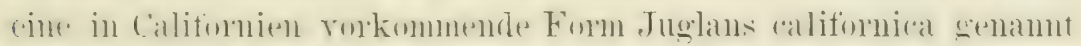
mul nirht mit Juglans run stris ïbereinstimmend gehalten wissen.

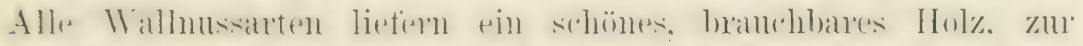
Forstkultur kam ich aber m empfehlen den

schwarzen Wallnussbaum Tuelams nigla, Familie Juglanditerar.

l)iese schöne. stattliche Art erreicht eine Höhe ron 24 bis

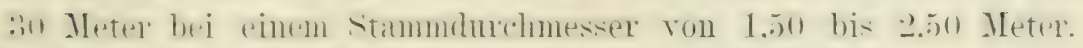

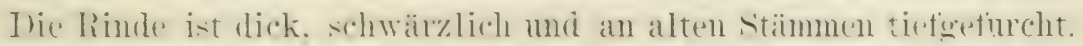
lice spitzlanzettö̈migen. evzahnten, bisweilen leicht heharten

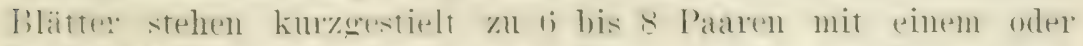

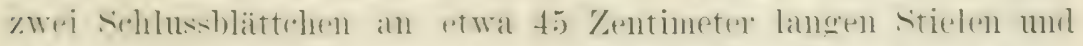

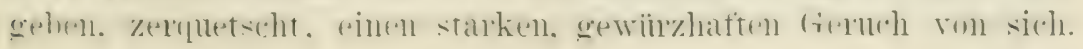




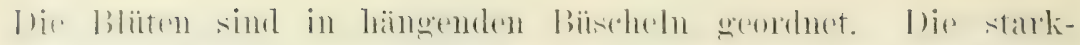

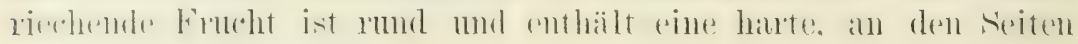

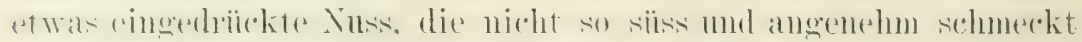

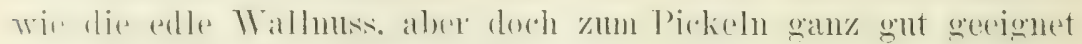

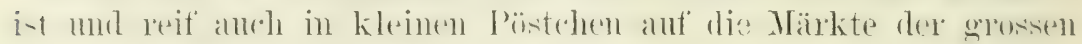
Stidte kommt.

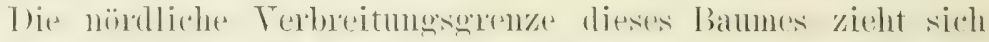
ron dem westlichen Massalchusetts natch dem siidlichen Ifer des Erieseres, durch das siidliche Vichigan und limmesota nach dem ästlichen Nehlaska; die sïdliche läuft rom westlichen Florida narh dem mitteren Alabama und Mississippi his zum Thale des san Antonioflusses in Texis. Seine grösste Entwickelung erreicht er an den westlichen Abhängen des sïdlichen Alleghangagbirges.

Das Holz ist schwer, hart, stark, dicht, etwas grobfaserig. leivht zn bearbeiten. damerhaft. Wenn dem Wetter allsgesetzt und in Berïhrung nit der Erde, nimmt eine sehr soüne Politur an, wirft sich in Tracknen. wenn nicht sorgfaltig behandelt und ent-

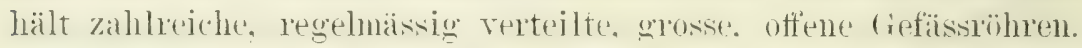

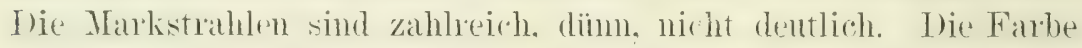
ist gewöhnlich reich dunkelbram, zuweilen sehokoladebram oder ins Rötliche schimmernd. Der dimme splint ist vel heller. manchmal weisslich.

Rangstellung moter den nordamerikanisehen Hölzern: die 24:2. in suezifischer schwere. die 242. im verhälnismässigen Bremuwert, die 65. im Coefficienten der Elastizität, die 113. in der

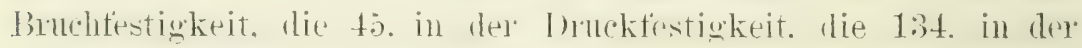
Eindruckfestigkeit.

In Nondanerika wird von allen einhreinischen Hölzern dieses

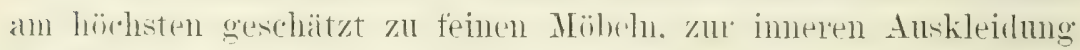
der Häuser. ̈iberhampt als Luxushol\%, ja rs wird in der diesem

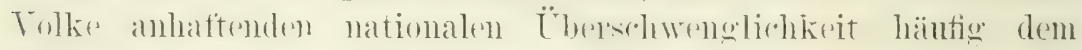
Tahagoni gleichwertig an die seite gestellt. Wak aber als eine

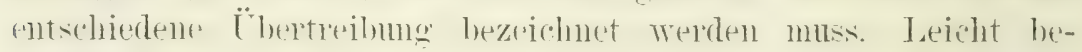

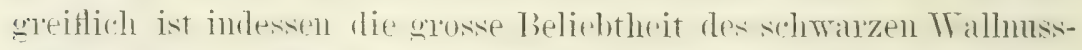
holzes. die es nilcht allein in ganz Nordannerika. sondem in nenerer Zeit anch in Englanre chlangt hat. mo obgleich diese feschmacksrichtme als eine Mole zu betradehten ist. die wie auf allen Gehivten. so aluch auf diesen sich mbeständig zeigen wird, so ist doch mit Gewissheit anzmehmen, dass das chwarze Ifallnussholz. 


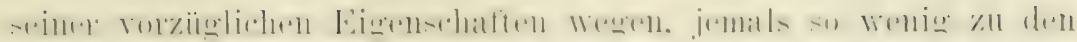
veloessenen Hölzern gohören wird. Wie das Mahagoni.

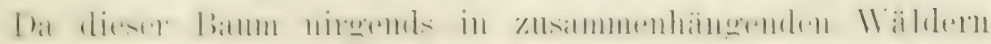

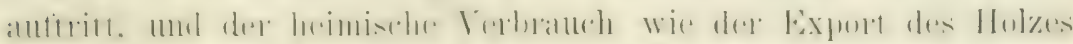

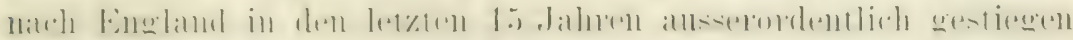

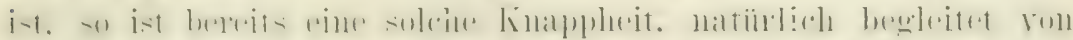

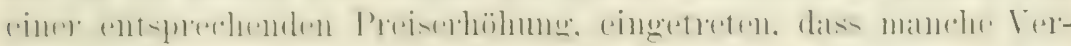

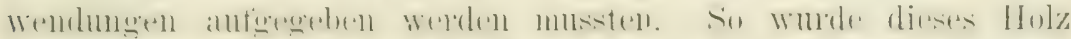

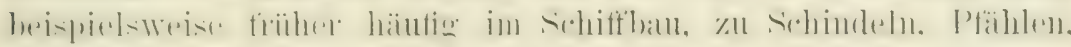

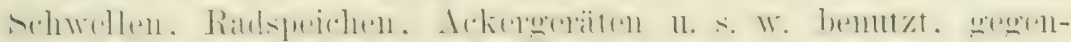

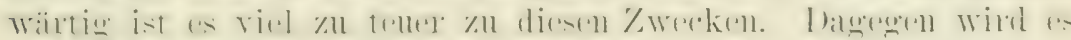

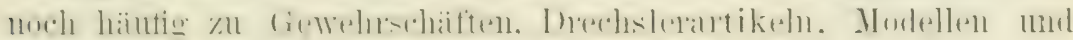
kleinen Luxusholzwalen verarbeitet.

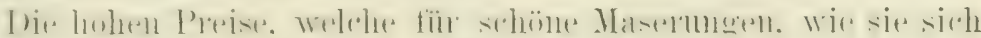

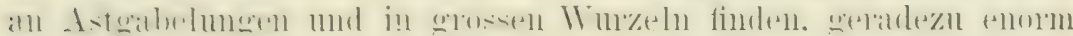

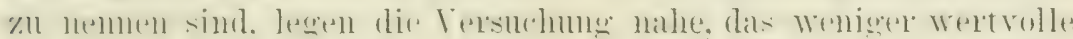

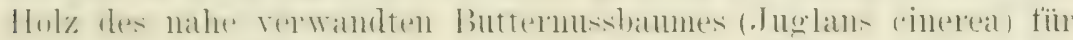

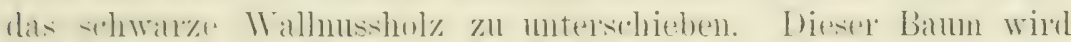

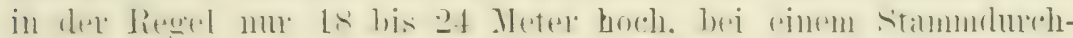

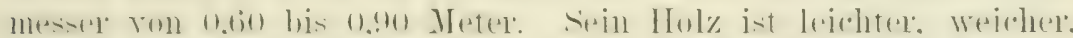

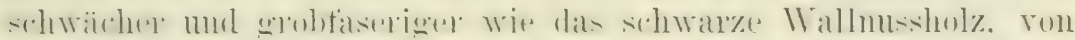

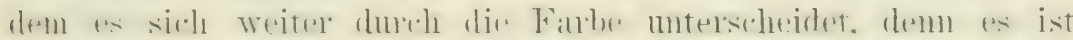

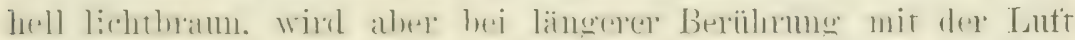

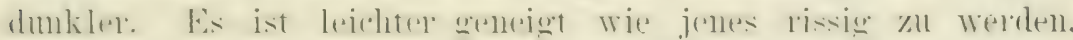

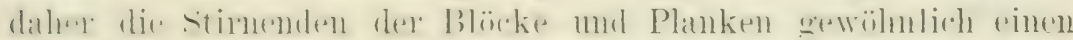

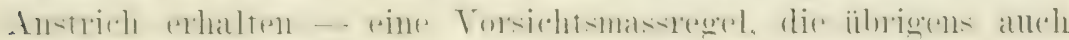

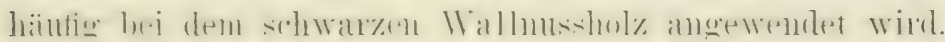

In neuerer '/eit haben die Noldamerikaner der Kultur des

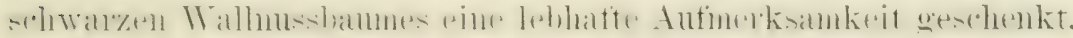

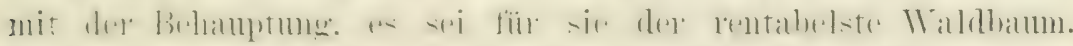

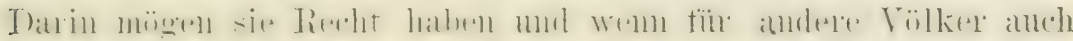

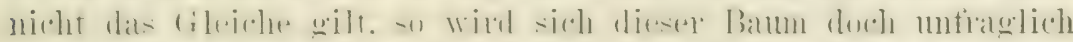

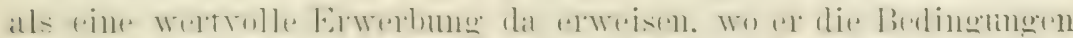

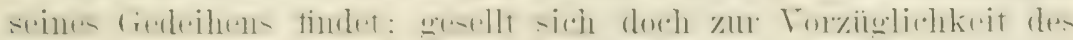
Holzes der Vorteil eines ziemlich raschen Wachstums.

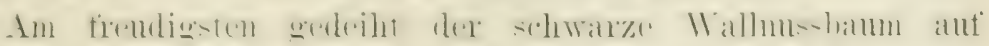

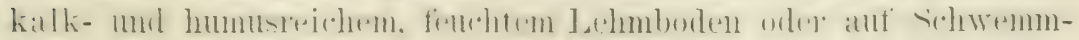

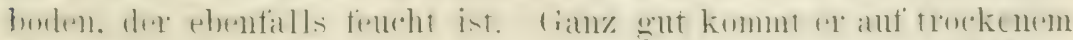

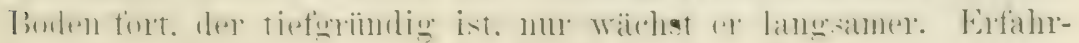




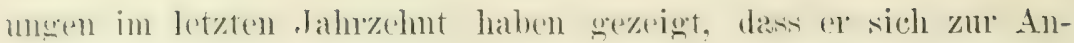

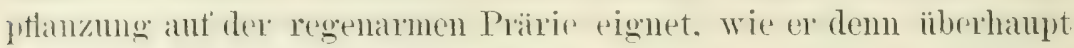
als klimahärter zu betrachten ist. wie der edle oder känigliche Trallnussbaum (Juglans regia).

I'm garade. bis zur bedentenden Höhe astfieie Stämme zu (rzielen. muss der schwarze Wallnusbanm in Gesellschaft anderer bäime angepflanzt werden. die seinen Stamm beschatten mol ihn vor den Irinden sehiityen. Die Eicrenkultur bietet das treffendste Vorbild.

Da die jungen Bäume sehr leicht durch die Terpflanzmo leiden, so empfiohlt sich die saat anf die danernden Standorte.

I) Holzqualitat steht etwa im 100. Lebensjah des Bames auf ihrem Höhepunkt.

sichwarze Wallnïse sind bei jeder nordamerikanischen samenhandlung. häufig auch anf offenem Markte, käuflich. Der Preis beträgt etwa 9 Mark pro Bushel (rund 36 Liter).

\section{Hickoryholz.}

Die Gattung Carya, welche die neneren Botaniker von der (rattung Juglans ansschieden, zertallt in \& Arten, die sämtlich in Nordanerika heimisch sind. Wie bei den Wallnussbämmen, sind die Blüten der Hickoryäume, das ist der rolkstümliche Name

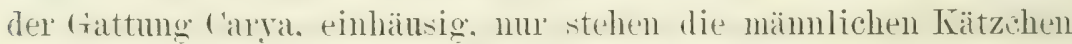
nicht einzeln. sonder'n zu drei auf einem gemeinschaftlichen stiele. Die Früchte bestehen nicht. Wie bei den Wallnussbäunen. aus zwei Hälften. sondern sind vierklappig. und dic grüme Fruchthiille iöst sich gleichtalls entweder ganz oder bis zur Mitte in 4 Klappen. Ein bequemes C'nterscheidungsmerkmal zwischen Walnussbämen und Hickorybaumen bildet das Mark der Zweige. Bei den Ersteren ist dasselbe durch Lamellen in trepuenartige Fächer greteilt. bei den Letzteren ist es fest, ans einer gleichartigen Masse bestehend. Ine Hickorybäme sind von schönem, schlankem

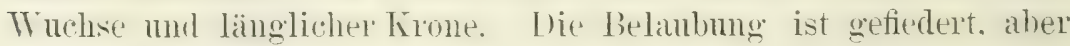
nicht so gross, wie die der Wallnusshame. I)ie Rinde ist ron weissgraner Farbe, antangs glatt. bed alteren Bämen rissig. diem jenige des jungen Wuchses ist von solcher Zähigkeit. dass sie als Bindematerial benutzt werden kann. 
Fon den 8 Arten halte ich nur die folgenden fïr kultur-

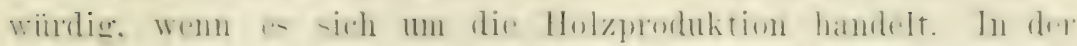

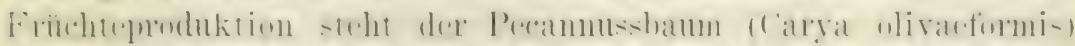

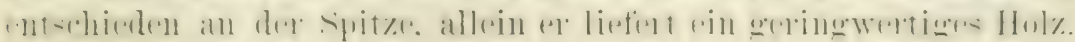

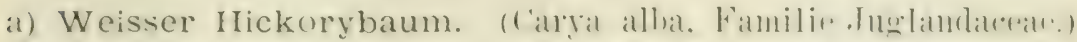
Gleichamen: Shellbarkhickory, Shagbarkhickory.

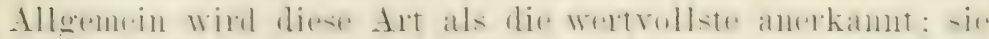

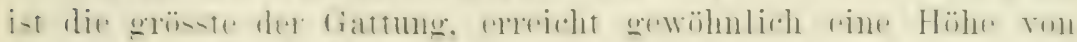
24 bis 30 Meter. bei einem Stammdurchmesser von 0.90 bis

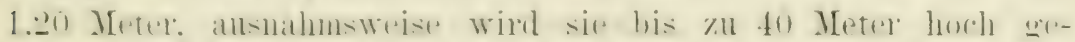

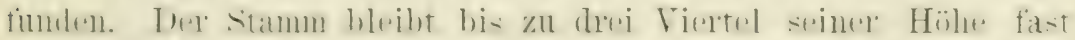

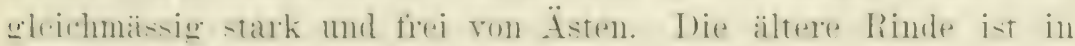

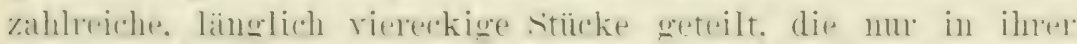

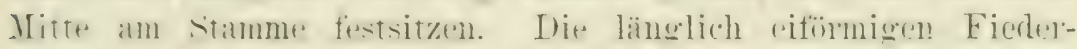

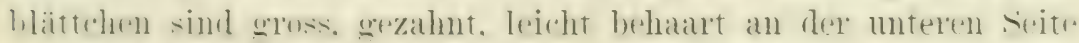
mul stehen zn zwei Paaren mit einem Endblättrhen an einem 2.; bis fll Zentineter langen stiele; sie haben einen gewiuzigen fielnch. Eledeh den Wallnusblättern. I)ies Blöten erscheinen im Iai: die gendesbaren. einen berdentenden Handrlsatikel bildenden Niisse reifen im Oktober.

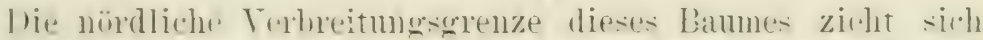

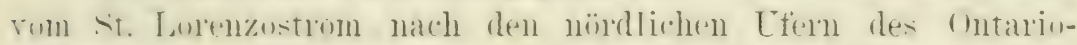

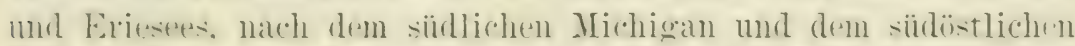

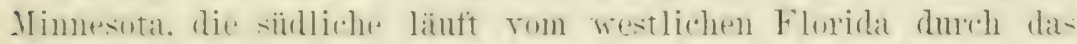

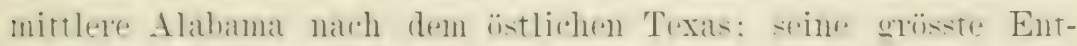

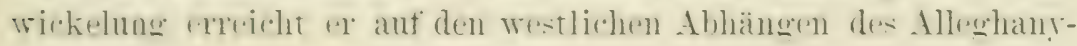
grebirges.

Diese Art bedarf zu ihrem Gedeihen eines frischen. aber

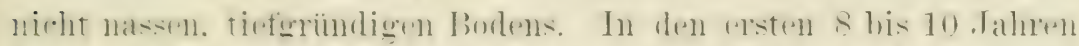

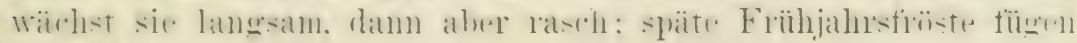
ihr Sicharten zu.

Das Holz ist schmer; selur hart und stark, zäh, elastisch.

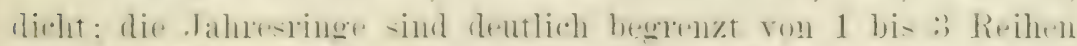

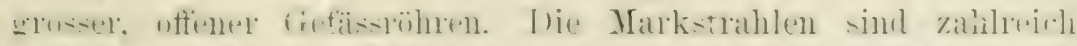

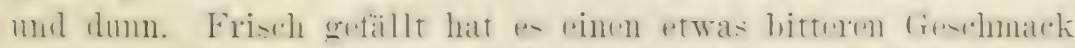

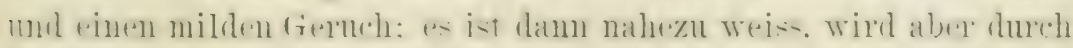

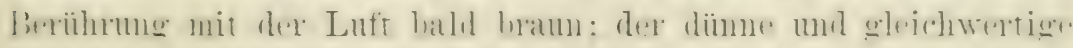

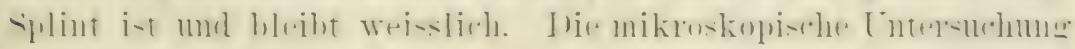
semler, Waldwirtsehait. 


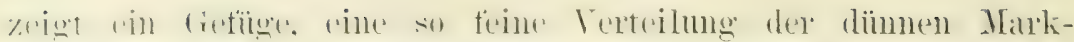

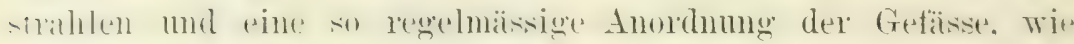

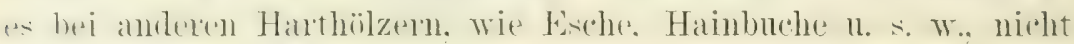
der Fall ist.

Raingsthmeg moter den nordamerikanischen Hölzern: die i4. in spezifischer schwere. die (i). im rerhältnismässigen Bremnwert. die 12. im C'nefficientes der Elastizität, die 12. in der Bruch-

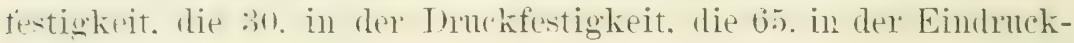
festigkeit.

\section{b) Spötternussbaum. (Carya tomentosa.)}

(iloichnamen: schwarzer Hickory, Teissherzhickory, grosser

Knospenhickory, Bullennuss, Königsnuss.

Ine nördliche Terbreitungsarenze dieser Art zieht sich rom st. Idorenzostrom nach dex nördlichen Ltern des ontario- und Eriesee bis zum iostlichen Nebraska. die stidliche geht ron dex Tampabai in Florida ans mol länft nach dem thale des Brazosflusses in Texas. Der Baum erreicht eine Höhe von 24 bis

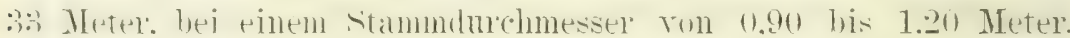

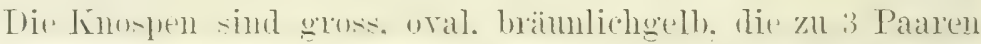
mit einem Endhlätchen sitzenden Fiedexblätter simb mngekehrt eitürmig. gezahnt. menten behaart. Die Frocht ist mittelgross.

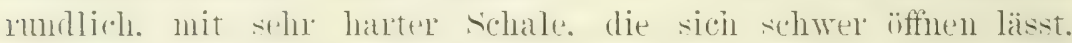
daranf bezieht sich der Name Spötternuss.

Hervorzuheben ist, dass diese Art die einzige der Gattung

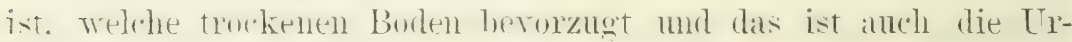
-alche. Wartm ich sie hier als kulturwiunlig anfülne: selbst aut

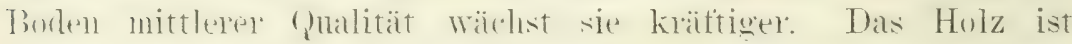

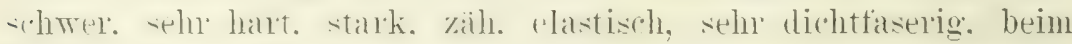

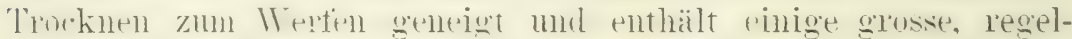

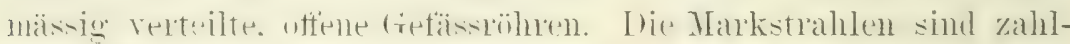

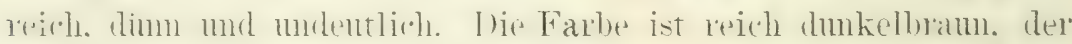
dicke branchbare Splint mahez? weiss.

Rangstellunge unter den nerdamerikanischen Hölzen: die

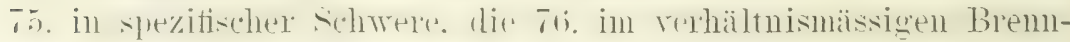

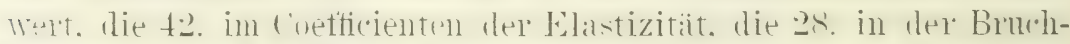

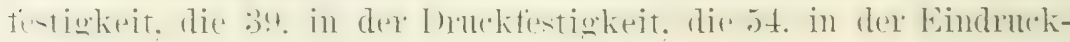
testigkeit. 


\section{c. Muskatmusshickorybaum (lillat myri-tiratrolmi-).}

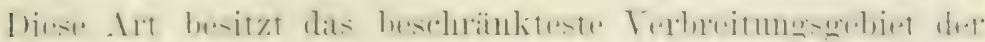

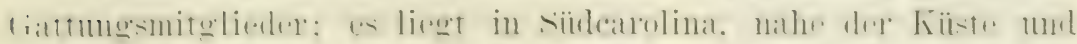

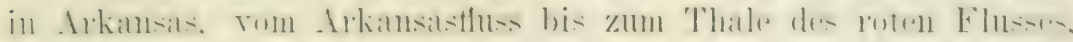

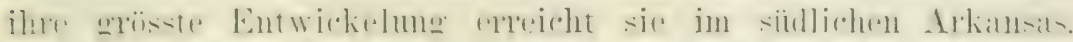

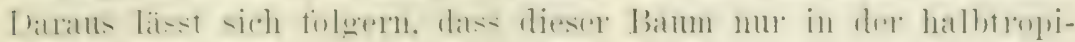

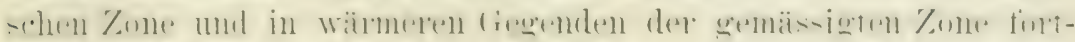

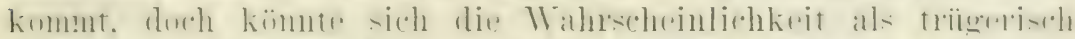

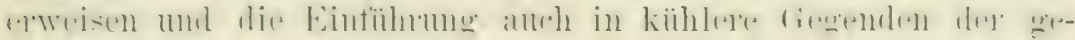
missigten Zone erfolgreich sein.

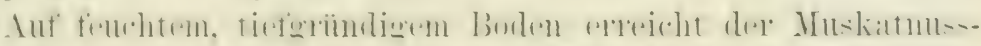

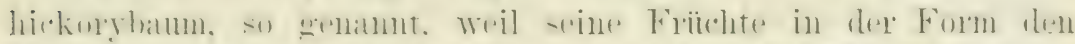

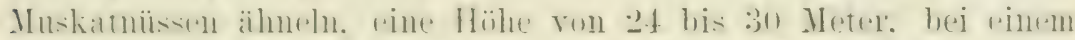

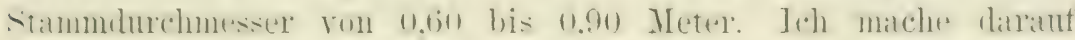

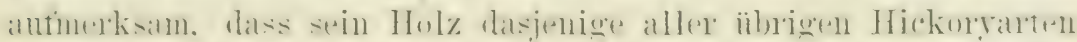

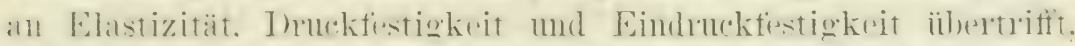

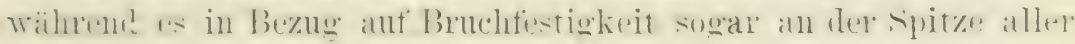
nordamerikanischen Hölzer steht.

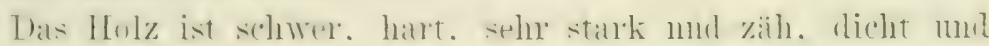

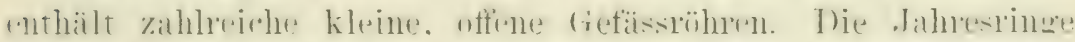

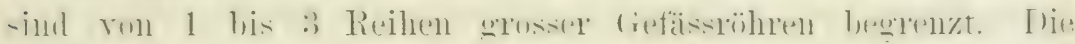

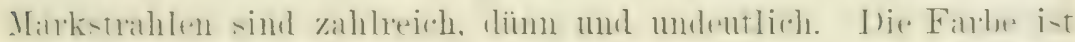
lichtbraun. der Splint heller:

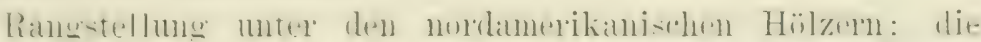

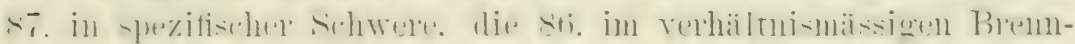

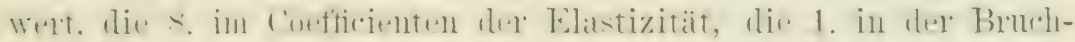

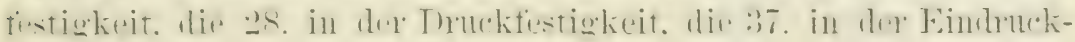
festigkeit.

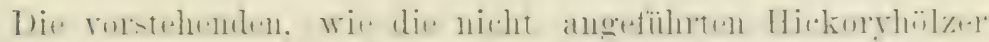

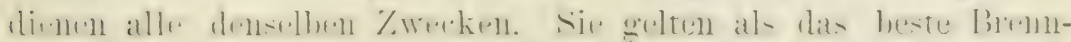

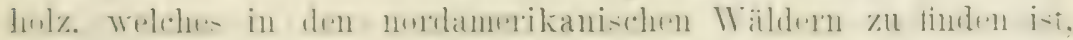

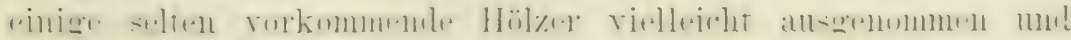

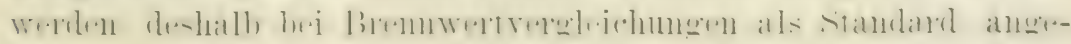
n!nmen: in

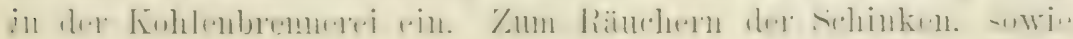




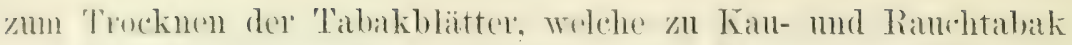

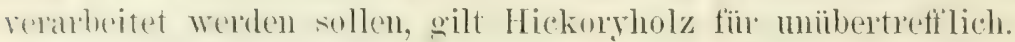

Junge Hickorybämmes geben vorzïgliche Fasseden. Peitschen-

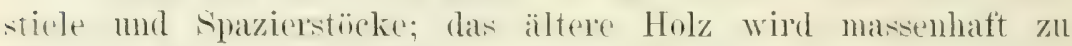

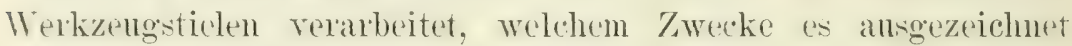
mutspricht. I)ie bedentendste Terwendung findet es aber im IV agenbau und in der Fabrikation landwirtschaftlicher Maschinen, und seine hohe Bramehbatkeit hierfür ist es nanentlich. Was inm cinen Teltweiten Ruf rexschafft hat. Bei fabrikmässiger Herstellung der Räder wird in Yordamerika fast stets diese Zusammensetzung ringehalten: die Felgen aus Hickoryholz, die Npeichen ans IIeiseichenholz, die Naben aus Tlmenholz. Alle Fremden. Welche Nordamerikit betreten, erstaunen iiber die nur 2 Zentimeter breiten Räder dex unter den Samen Bugries bekannten leichten offenen Luxuswagen. Diese Räder haben nm zwei Felgen mol wïrden nicht herstellbar sein ohne das Hickoryholz.

Indessen dürten auch die Schattenseiten dieses ausgezeichnetrn Holzes nicht verschwiegen werden: abwechselnd der Yässe und Trockenheit ansgesetzt, zumal wenn die Nässe mit Wärme begleitet ist. zeigt es geringe Dauerhaftigkeit, furner greift es der Holzwrum germe an. Neniger Bedentung hat, dass os nach einre Reihe von Gebrauchsjahren spröde wird; denn welches $\mathrm{Holz}$ verliert nicht mit der Zeit seine Elastizität?

I)iese nicht zu leugnenden Schattenseiten tühren im Auslande ifters zu einer iber das gerechtfertigte Mass himausgehenden mgiumstigen Beurteilung, ja Verurteilung des Hickoryholzes. Su ersehe ich aus Fachschriften, dass in neuerer Zeit dentsche Tagenfabrikanten ihre stimmen gegen das importierte Hickorvholz erheben, es als wumstichig, spöid mud in allen seinen Figenschaften als aufgepufte bezeichn'n; sie raten dem besseren Akazienholz den Vorzug zu geben. das man seither nur nicht gewiurdiot labe. weil es ein Produkt der eigenen Erde sei.

Patriotische Vurschläge finden bei mir stets cine hremdlichu Anfinalnme; allein in diesen Falle muss ich kïhl daranf verweisen. dass die fialsche Akazie dieselbe Heimat wie the Hickorybämme hat. mnd wer sich die Estere aneignet, kamn mud sollte sich aurh die Lrotere aneignen … dex Anfang damit ist ja bereits in Deutschland gemacht. Fermer mus ich scharf betomen: rem schon eine Bammat Holz von resschiedener (pmalität liefert. wit 


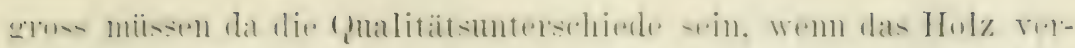

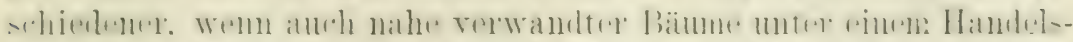

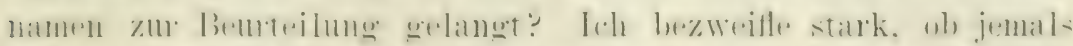

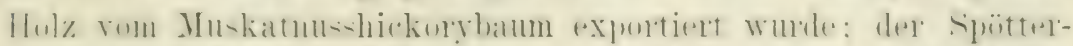

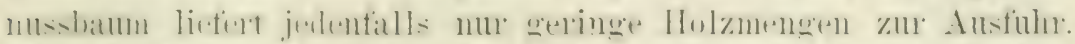

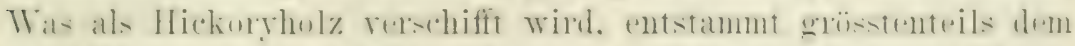

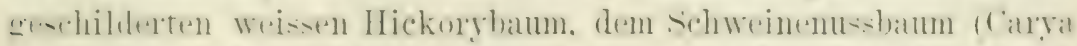

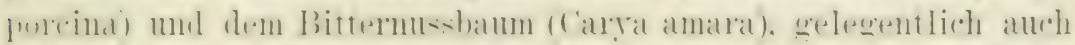

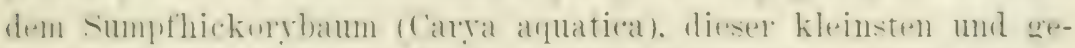

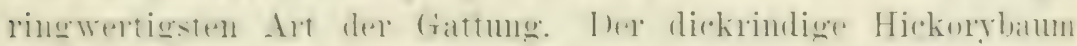

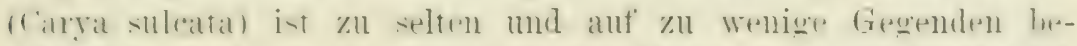

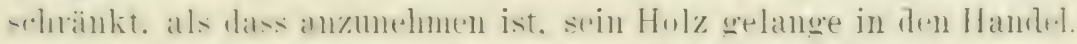

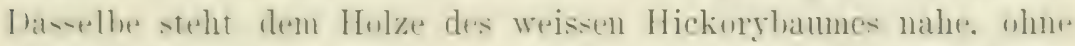

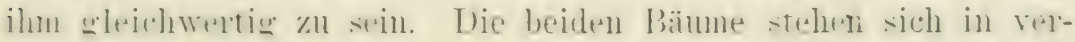

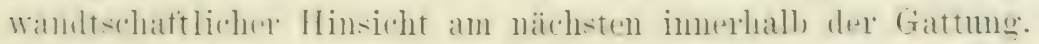

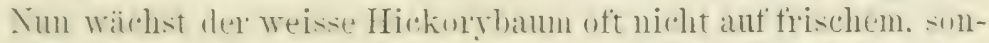

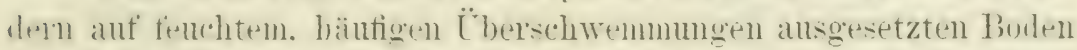
- ant einem Standorte also. der verwerflich ist zur Produlition rom Werkholz. Die anderen wrihhnten Arten. welche sellst damm geringwertiges Holz wie der weise Hickorybam lietern. wem -ite an seiner teite auf frischem Boden wachsen, werden ganz

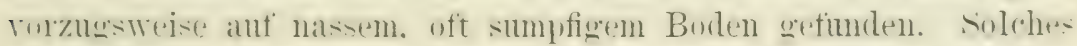
Hulz ist rergledehsweise poriis. wenig damerhatt mul wird. Wem anch antanes plastisch. sehr bald spröl. Das Holz des sumpt-

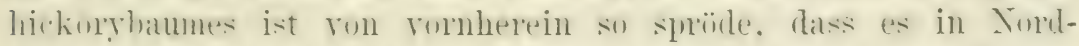

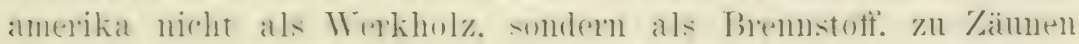
u. s. w. benutzt wird.

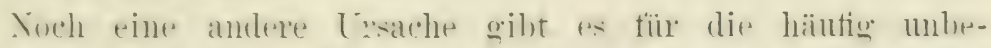

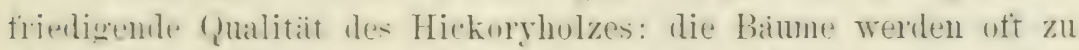
einer Zeit geffillt. Wo es ein Forstmam nie und nimmer gestatten

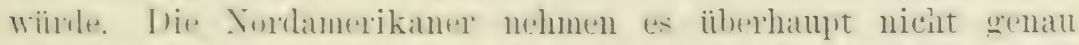

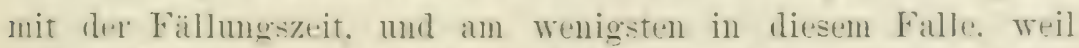
sich auf dem natsen standorte der Hickorybäume wähemd dor

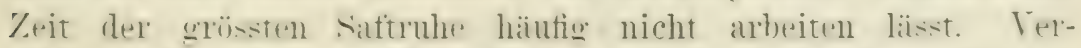

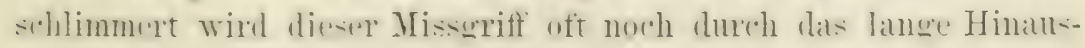
schieben der Schälung der Blöcke.

Dieser 'Tadel ist nicht auf die cranze Hirkoryholzprorluktion an-zudehnen. Fs kummen ron diesem Holze qute Qualitätru in

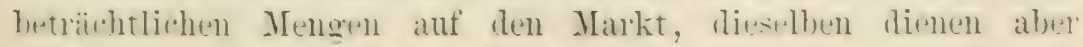




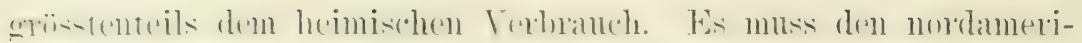

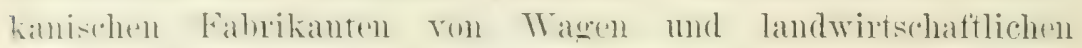

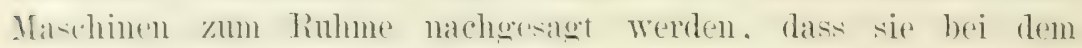
Ankant ihres Hol\%hedartes mit feinlicher sorgefalt verfahren und sich durch holue Preise füm gute (smalitioten nicht abschrecken lasisen. Anderntalls wibden sie die Cherlegenheit ihrer Fabrikate ant dem Trelmarkte nicht erungen haben. Das Beste bleilot. alse im Lande. das wenig Bescere schwimmt ïber de'n ()zean nach Enropa.

Selbst das beste Hickoryholz wird in Tordamerika noch. duch ein Barl in heissem Leinïl verbessert. um die oben bezeichmoten schattenseiten abzuschwächen. Es ist nicht zu viel behauptet, dass ans keinex Fabrik ein Rad herrorgeht, das nicht ror dem Beschlagen in cinem hessel mit siedendem Leinöl eine halbe Stunde langsam umgedreht wurde.

Die Kultur der Hickorybäume schliest sich eng an diejenige der Walhussäume an. Welcher Boden zu wählen ist. Wurde hereits bemerkt. Die Saatniisse sind aus denselben (puellen und zu amähernd denselben Preisen zu beziehn. wie schwarze Wallniisse. dnch emptehle ich in Anbetracht der weiten Terbreitungscrebiete des weissen Hickorybams und spöttermussbaums, die Torsicht tïr Finführungstersuche in kältere Gegenden der gemässigten Zone. Saatgut aus dem Norden der Verbreitungsgebiete stammend, zu beziehen. Dasselbe gilt in verstärktem Masse ron Pflünzlingen, die in Baumschulen. welche sich der Züchtung von Taldbämmen widmen. beispielsweise W. Wr. Tohnson in. Snowflake in Michigan. bereits eimmal verpflanzt, für 20 Mark pro 100 Stiick käuflich sind. Es gribt übrigens auch in Deutschland einige Baumschulen. welche Hickntybäumchen liefern. T'm den samen les Muskatumshickorybaumes zu beziehen. muss man die Termittelung einer grösseren Samenhandlung in Tordamerika in An-puch nehmen. Pflänlinge dieser drt sind meines Wissens in keiner Baumschule zı haben.

I) Saat der Nüsse geschieht wie liejenige der Wallniisse. Tha dir Sibulinge starke Pfahlwuzeln treiben. wird häufig das 


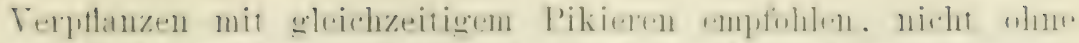

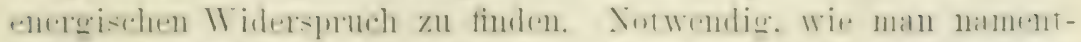

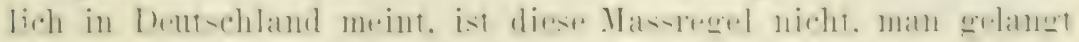

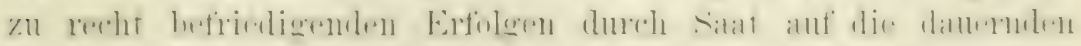

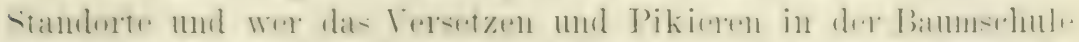

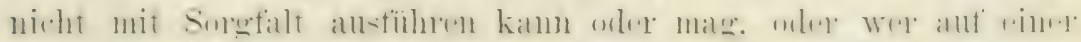

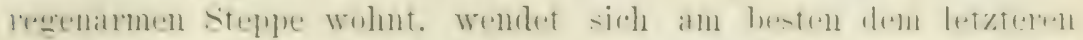

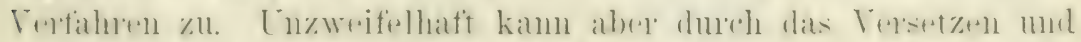

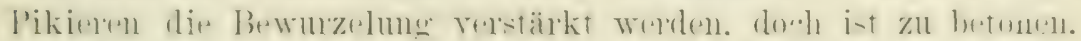

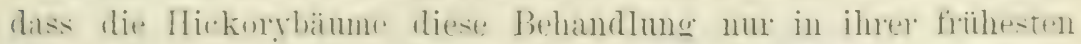

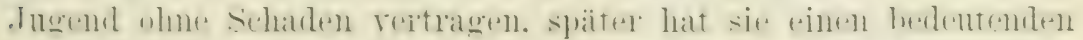

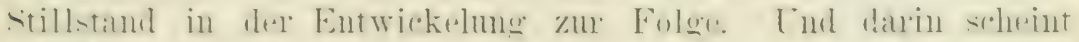

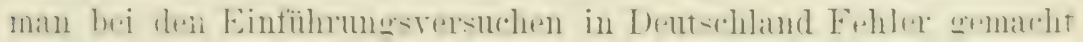

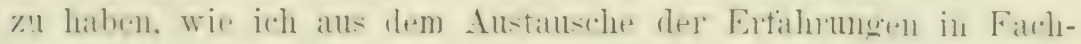

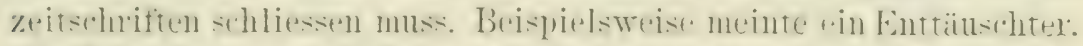

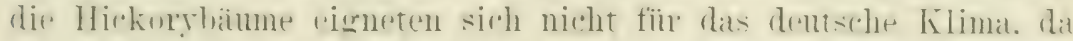

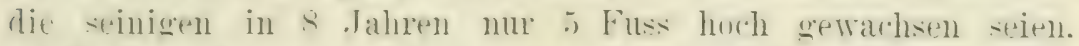

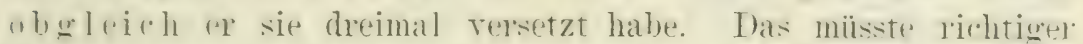

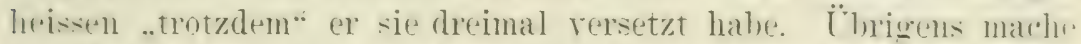

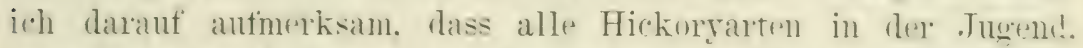
twa bis zum 10. Tahue. langsam wachsen. Was nicht rntmutigen hart. dem von da ah ist die Entwichelung un sn krättiger.

Als die vorteilhafteste behamblung erscheint das Pikieren

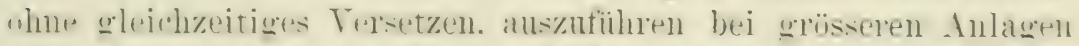
mit dem an anderer stelle geschiblerten Batmoraberpthe. Wi -irh descen Anschaffung nicht lohnt. mage man das zuwrilen vent

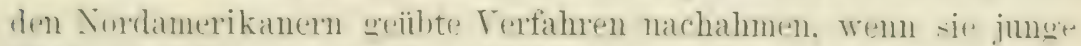

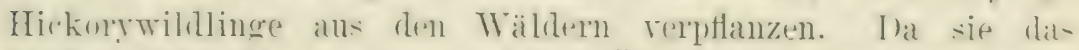

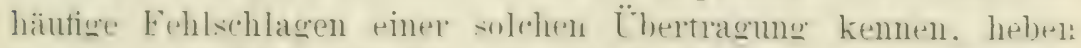
se an einer seite der Wuzchn pin Lacin aus und stussen mit einem scharten Thstrument ein stïck her Ptahlwumel ah. lomm tïllen sie dik Loch wirder ans und lassen das Büumehen his zum nitehstell Jahne stehell. wo ex getahrlos verpflanzt werden kann.

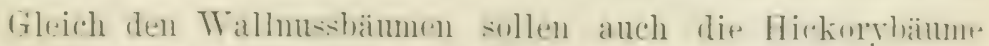

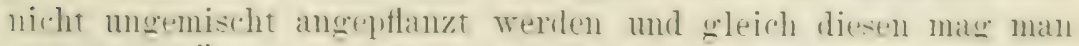

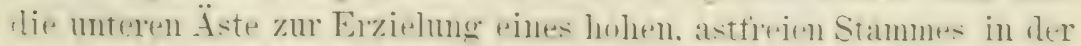

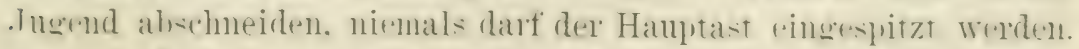

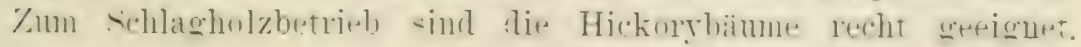


dem ihre stimmete treiben kräftige sehösslinge ans. die rine vielsedige Verwendme finden kïmen, wie ans obigen Angaben ersichtlich ist.

\section{Oregoncedernholz.}

Lawsonceder ('hamaecylaris Latsoniana, Familie ('oniferat).

Gleichnamen: Port Oxfordceder,

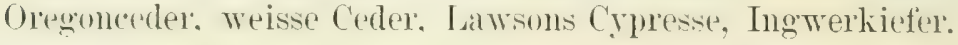

Die Gattme ('hamaecyaris besteht nur ans 7 Arten, von welchen eine in astlichen, zwei im westlichen Nordamerika und vier im: östlichen Asien heimisch sind.

Die Lawsonceder ist ein anch in Europa bekannter prächtiger Zierbaum, der als solcher selbst an der Pazitikkiiste, wo man. wie üburall auf der Erde, den Propheten des eigenen Lander nicht zu achten ptlegt, die rerdiente Wiirdigung gefunden hat. Hirr, in seiner Heimat, ist er aber anch ron hoher wirtschaftlicher Bedeutung. In Californien kommt dieser Baum selten ror. srin eigentliches Terbreitungsgebiet ist die Küste von Oregon in einer Breite ron etwa 50 Kilometer. Fr erreicht eine Höhe von 45 bis 60 Meter bei einem Stammdurchmesser ron 1,80 his 4 Meter. The schlanken Äste stehen entweder wagerecht odex sanft geneigt. die Zweige hreiten sich fächerartig und sind ammutig mit der spitze anfwarts gebogen. Die Nadeln sind klein, zugespitzt, tiefgrün, mehr oder weniger mit Drüsen besetzt. Unter jeder Schupe der Zapfenfrucht liegen 2 bis 4 Samen.

I)as Holz ist leicht, hart, stark, sehr dichtfaserig, leicht zu bearbeiten. sehr dauerhaft in Berührung mit der Erde, von wohlriechendem Har\% durchdrungen, seidenartig, nimmt eine schöns Politur an. Die Schichten der kleinen Sommerzellen sind dïmn. hie Markstrahlen sind zahlreich und sehr undentlich. Die Farbe ist rahmgelb oder nahezu weiss, der düme Splint ist kaum rom Kernholz zu unterscheiden.

Rangstellung unter den nordamerikanischen Hölzern: die 3..2. in spezifischer Schrere, die 350. im rerhältnismïssigen Bremmert, die 31. im coefficienten der Elastizität, die 97. in der Bruhfestigkeit, die 135. in ler Druckfestigkeit, die 275. in der Eindruckfestigkeit. 


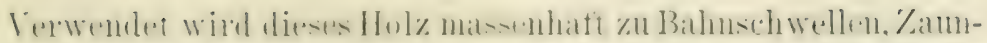

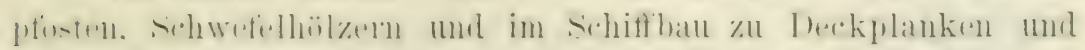

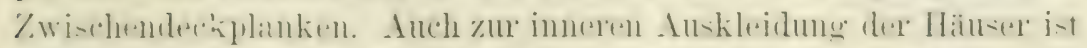

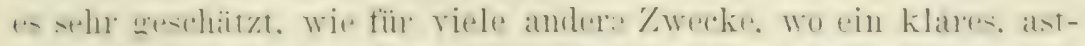

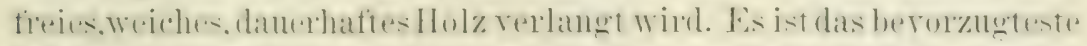

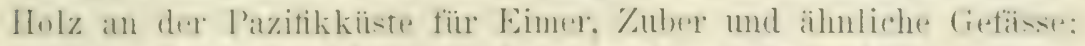

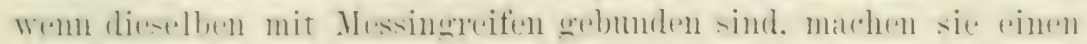
sehr gefälligen Eindruck, dabei sind sie dauerhaft.

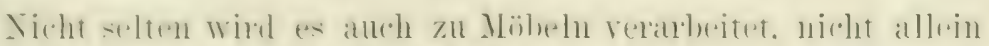

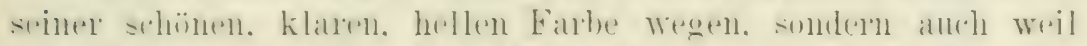

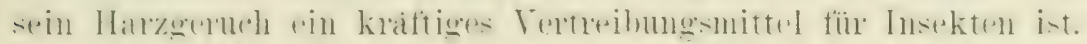

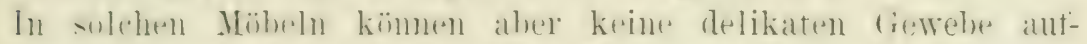

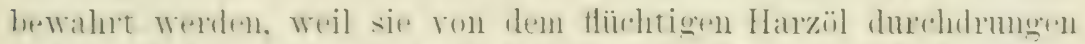

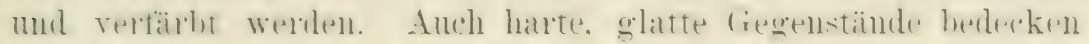
sich bald mit einem harzigen Überzug.

leer same ist rom allen californischen somenhamblumeren

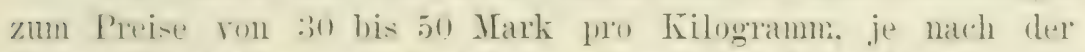
Gröse des Auftrags. zu berichen. Derselbe darf bei der satat nur mit sehr wenig Erde bedeckt werden.

Die Law-onceder ist nicht wällerisch in Buden. doch muss

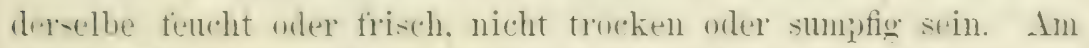

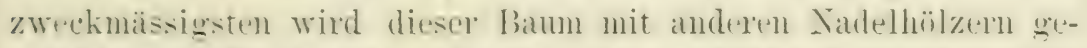
mischt angegflanzt: wie sthe ilnm eine seitliche Beschattmo not thut. geht datraus hervor, dass er. als Zierlnam freistehend. sich ganz tief reäistelt, währencl er als Waldham einen ast- mul

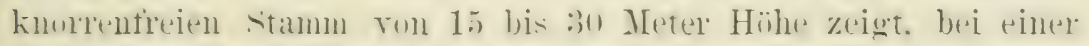
Gesamthöhe ron 45 bis 60 Meter.

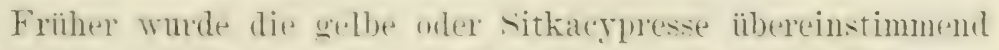
mit der Lawsonceder gehalten: Carriere aber hat sie als chamatecyparis nukatensis getrennt: sie unterscheidet sich ron der Lawnon-

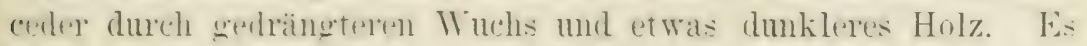
ist der wichtigste Maldhaum Alaskat's mol wohl wert. in andere

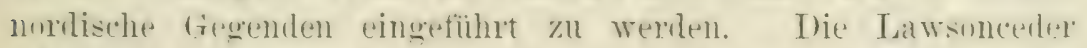

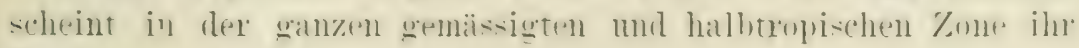
Fortkommen zu finden. 
25. Weisses Cedernholz.

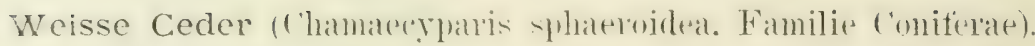

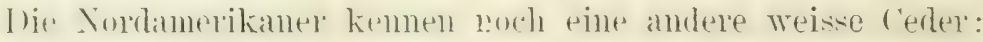

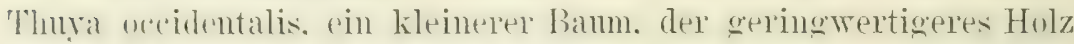

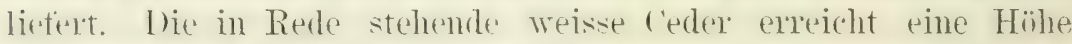
vom 24 his 27 Meter, bei rimem stammdurehmesser von 0,60 bis 1.:0 Meter. Die Bläter sind sthr klein, schuppenförmig, tahl, säluzend griun mol sitzen in + heihen. Die blüten sind einhäusig nut sitzen an den Enden reschiedener /weige. Die weiblichen Tïtzollen sind rund, obenso die Früchte. Wolche. fest geschlossen, sich bei der Reite äftuen. Die scluppen sind dick. spitz und berlecken an ihrem Grunde die wenigen samen. Terbreitet ist dieser Bam vom sïdlichen Maine his nörllichen Florida und dev Golfküste entlang.

Das Holz ist selur leicht und weich. nicht stark. dichtfaserigr, leicht zu beabeiten, whhliechend. selu danerhaft mter Wasser, in Berïhrumg mit der Fide und dem Wetter ansgesetzt. Die schichten der kleinen Sommerzellen sind düm, dunkelfarbig mnd deutlich. Die Markstrahlen sind zahleteh und undentlich. Die Farbe ist lichtbram ins Rötliche schimmerus, dumkelt nach in Berïhrung mit der Luft; der Splint ist heller.

Rangstellung untel den nordamerikanischen Hölzern: die 42:). in spezifischer Gchwere. dic 124. in verhälnismässigem Bremnwert, die 302 . im (oufficienten der Elastizität, die 289. in der Bruchfestigkeit, die 309. in der Druckfestigkeit. die 301 . in der Eindruckfestigkeit.

Diese: Holz findet eine massenhafte Terwendung zu Schindeln, Zämuen, Tolegaphenstangen. Bahnschwellen. ॠo leichter Terkehr stattfindet. billigen Möbeln, zur immeren Anskleidung der Häuser mol im Bootban. Ganz besonders geeignet aber ist es zur Helstellung von spielwaren. Gefïsen und jenen kleinen Holzwaren, mit welchen sich die Sordanerikaner einen weltweiten Markt erobert haben. I)ie Iónhle wird von den Pulverfabriktn gekauft. Als rouzüglich gilt auch der diesem Holze entstammende Kiemuss.

Auf diesen nïtzlichen Bamm mache ich deshall mit Betonung antinerk-am. weil er sich zur beptlanzung rim sumpten eignet. die

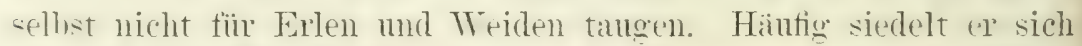
in so tiefen siimpten an. das seine Wurteln keinen klätigen 


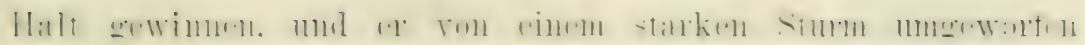

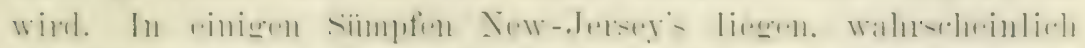

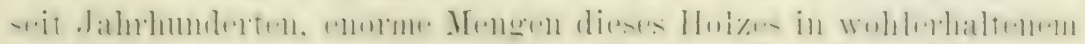

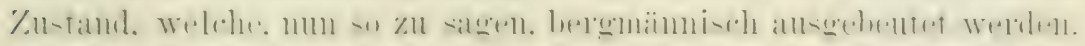

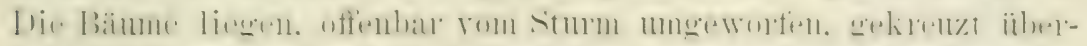

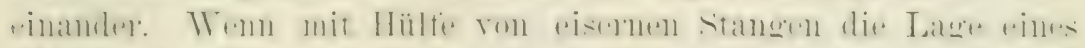

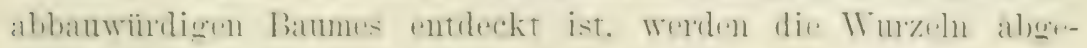

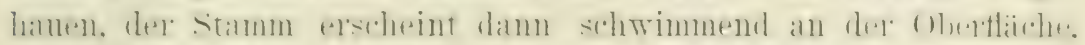

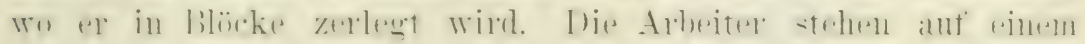
Floss.

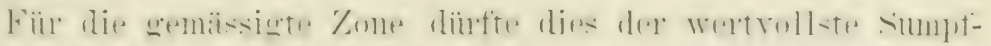

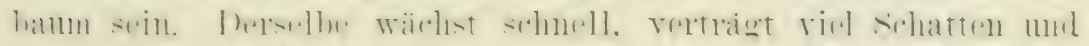

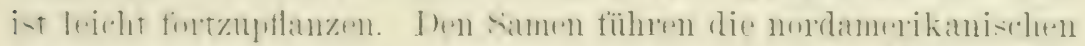

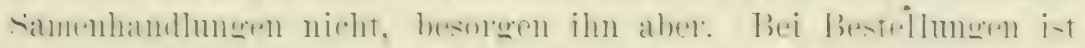

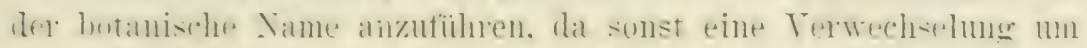

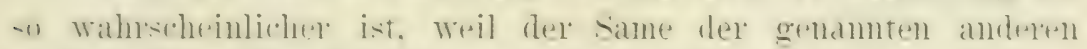
weissen Ceder gewöhnlich rorrätig gehalten wird.

\section{Rotes Cedernholz.}

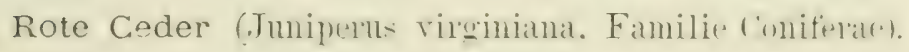

Gleichmamen: Bleistiftceder, Savin.

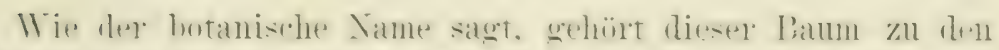

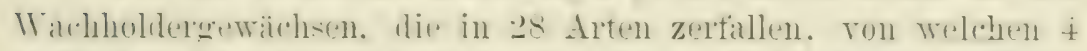

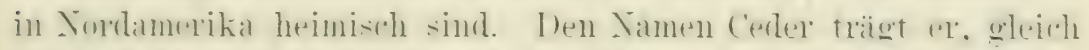

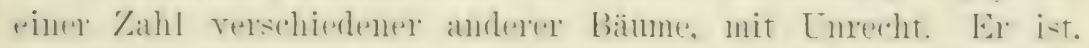

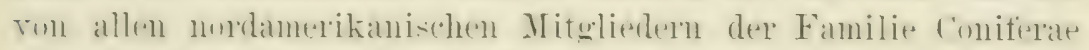

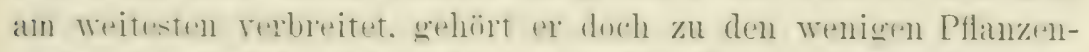

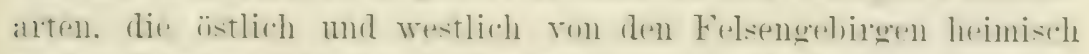

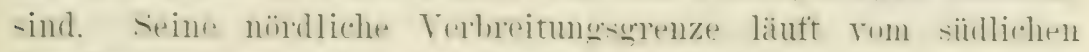

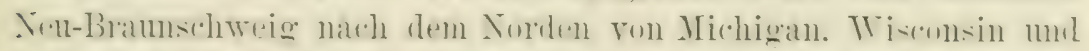

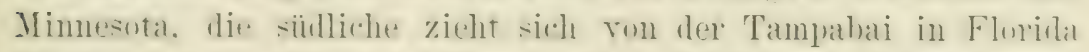

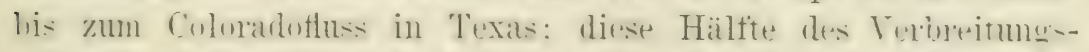

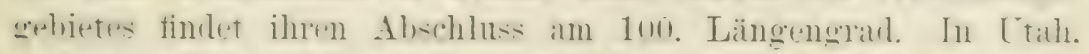

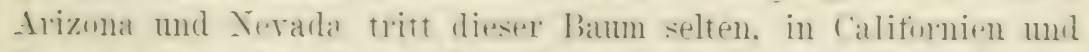

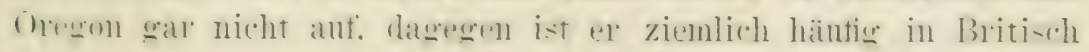
Columbia.

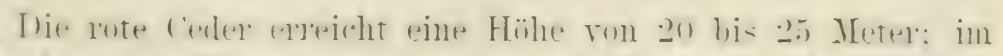
Thale des roten Fluswes in Texas. wo el -ich am kraiftiesten ent- 
wickilt. Kommen Exemplare von 30 Metep Höhe vol: zum Busche: wird er an seiner nördlichen Verbreitungsgrenze.

Die Blätter sind klein, schuppenartig, zugespitzt mol stehen entgexpmesetzt. Die sehr kleinen Kätzchenblüten sind zweihäusig. zureilen einhäusig und werden ron kleinen, beerenartigen, harzigen. aufrechtstehenden Frïchten gefolgt.

Das Holz ist leicht, weich, nicht stark, spröd, sehr tein-. dicht- und geradfaserig; wohlriechend, ron bitterem Geschmack. der gegen die Angriffe der Insekten schützt, leicht zu bearbeiten und schr danerhaft in Berührung mit der Erde. Die Schichte der kleinen sommerzellen ist breit und dentlich. Die Markstrahlen sind zahlreich und sehr undeutlich. Die Farbe ist dumpfrot. der. diinne Splint nahezu weiss.

Grimes Holz wiegt 512 Kilogramm pro Kubikmeter, trockenes 148 Kilogramm.

Beim Trocknen findet also ein vergleichsweise geringer (trwichtsverlust statt, deshalh rollzieht sich dieser Torgang schnell.

Rangstellung unter den nordamerikanischen Hölzern: die 825. in spezifischer Schwere, die 324. im verhältnismässigen Brennnert. die 244. im (oefficienten der Elastizitä, die 165. in der Bruchfestigkeit, die 195. in der Druckfestigkeit, die 183. in der Eindruckfestigkeit.

Benutzt wird dieses Holz zu Bahnschwellen, Zampfählen, M[ïbehn. Schachbrettern. Linealen. Gefïssen, Hohlmassen und zur immeren Auskleidmg der Hänser. seine bekamnteste Verwendung aber findet es zu Bleistiften, behaupten doch Sachkemner. es sei las einzige Holz, welches $z \pi$ diesem Zwecke vollstündig befriedige. Thas war auch die Crsache, warum die bayerische Regierung schon vol Tahren diesen Baum in ihre Wälder einführte und wie wohl sie daran that, zeigt die in der Gegenwart mehr und mehr zu Tage tretende Finaplpheit an diesem Holze, denn für dasselbe ist der Begehr steigend, nicht allein im Inlande, sondern auch im Auslande. wohin es in runden wie behauenen Blöcken exportiert wird, während die Forterhaltung des langsam wachsenden Baumes der Natur iiberlassen bleibt.

Eine Abkochung der Frïhte dient als harntreibendes Mittel.

I)ie rote Ceder wird am häufigsten auf trockenen. kiesigen Hängen, von hart am Heeresstrande bis zu bedeutenden wr- 


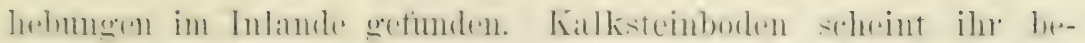

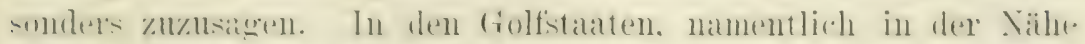

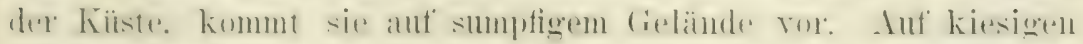

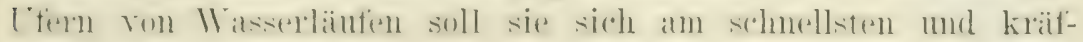
tigsten entwickeln.

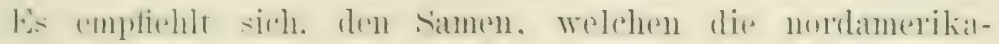

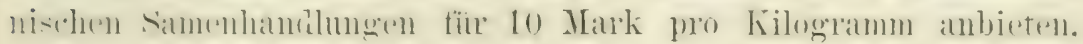

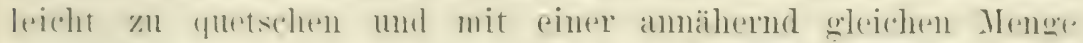
masier Holzastele zu vermengen. In etwa 3 Wochen haben dis Al-

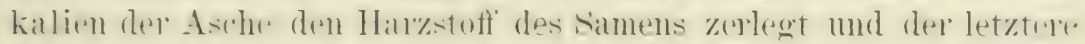
kamm nun pein gewatchen und in feine. mit Sand vermischte Liulh-

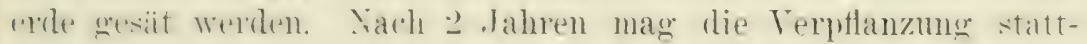
finden.

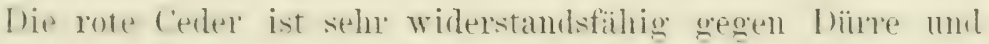
verträgt eine ziemlich starke Beschattung.

\section{Schwarzes Cypressenholz.}

Schwarze Cypresse. Taxodium distichum. Fanilie ('oniferat. (rleidnamen: kable Crpresse, sommergrime Cypresse. lote Cypresse, weisse Cypresse.

Es ist kamm nötig. daranf hinzuweisen. dass die rolkstimlichen Vamen der nordamerikanischen Bämme teilweise in Wider-

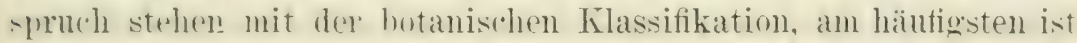

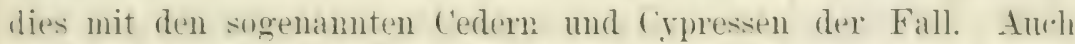
der in Rede stehende Baum ist keine cynesse. sondern gehourt einer liattung an. die in Nordanerika nur durch eine Art vertroten und den Eiben fGattung Taxus) nahe verwandt ist. Ex ist sommereriun. was an ihn. den milderen fegenden angehörigen Sadelholzham hervorzhelen ist. Seine nördliche Terbleitumg:grenze lïuft rom sïdlichen Delaware nach dem sïdlichen Illinois, die siblliche zocht sioh rom lap homano in Florida, mit Lm-

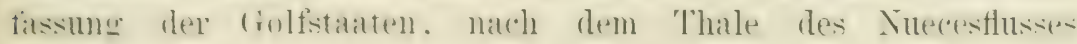
in 'lexas.

lie Blüten sind einhbiltsig und sitzen an demselben Zwoige :

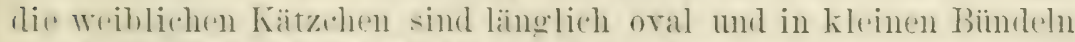

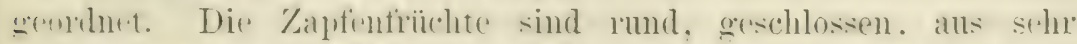

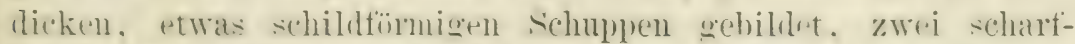

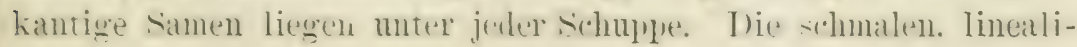




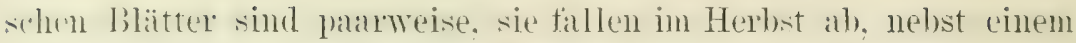
Teile der dümen. laubartigen rweige vom letzten Wuehse.

Die Höhe dieses stattlichen Banmes beweat sich zwischen

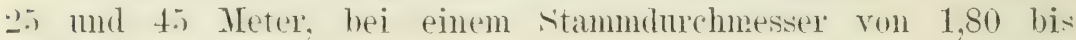
4 Meter.

I)as Holz ist leicht, weich, dicht- mol geradfaserig, nicht stark. leicht zn bearbeiten, sehr danerhaft in Beriihrung mit der Frde und nuter Wasser fast mzerstïrbar. Die Sichichten der kleinen sommerzellen sind breit. dentlich und harzig. Die Markstrahlen sind zahlreich und sehr undentlich. Die Farbe ist dunkelluam bis hellbram, der splint nahezu weiss. Im Holzgeschäfte wird zwischen schwarzem und weissem (in Wahrheit dmkelhatunem und hellbramem) ('ypressenholz von derselben Bammart muterschieden und ist noch festzustellen, ob diese Farbenabweichung ant Einfliisse des Bodens zurickzutïhren ist oder ob sich der Bam in zwei spielarten gegliedert hat; wahrscheinlicher ist das erstere.

Diese Holz findet in seinem Verbreitungsgebiet eine massenliafte Verwendung. rorzugsweise zu schindeln. '/ämnen. Gefässen und kleinten Holzwaren, zm inneren Auskleidung der Hänser und zu Bahnschwellen. die sich sher nur tür leichten Terkehr bewähren; für schweren Verkehr ist das Holz zu weich.

Die schwarze Cypresse bedarf viel Licht und eines sehr finchten his nassen Bodens. sie wird ant tictgründigen. lummsreichen Flusintern. häufiger in wasserreichen simpfen gefunden, wo clie Wurzeln der älteren Bämme oft teilweise entblöst und eigentïmlich kniefürmig gebogen sind. Der untere stammteil ist zuweilen hohl. Inas beste Holz soll sie anf feuchtem sandboden. der kein stehendes Wasser hält, liefern.

Die Fortpflanzung durch Samen soll leicht sein, wie behauptet wird, keinenfalls auf tirund zahheicher Tersuche, dem dieser Baum wurde noch nicht forstlich angeptlanzt und dient auch nicht als Ziexhatun. Die nordamerikanischen samenhandlumgen führen den Samen nicht, besorgen ihn aber.

\section{Rothol z.}

Rotholzbaum s'requoia sempervirens. Familie ('oniferac).

Fin Californien eigentïmlicher Batm: seine nördliche Ter'-

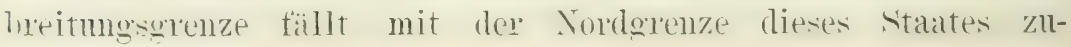




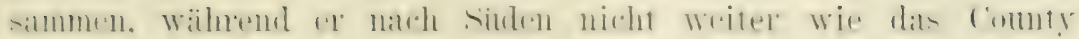

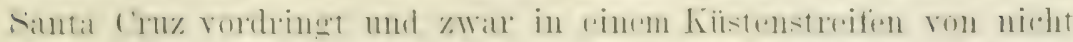

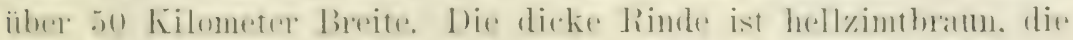

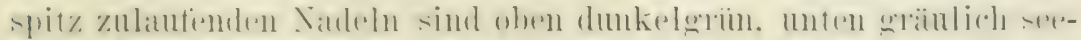

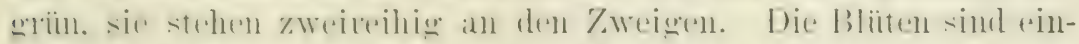

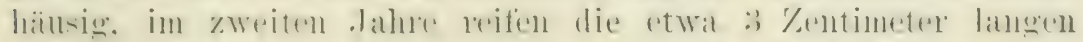

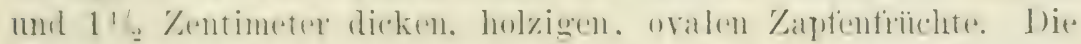

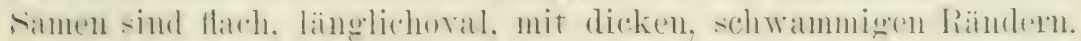

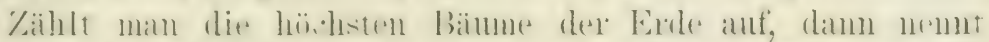

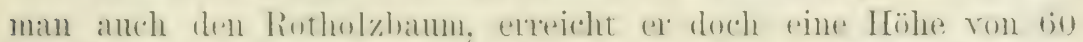

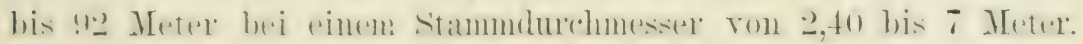

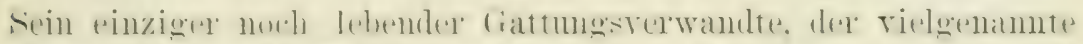

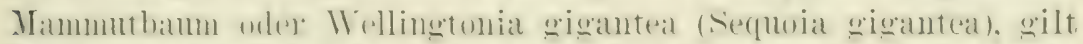

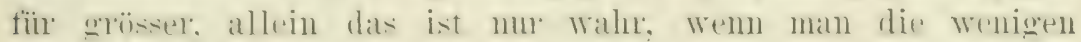

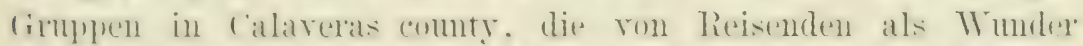

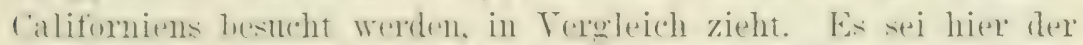

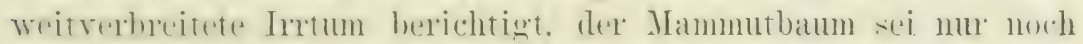

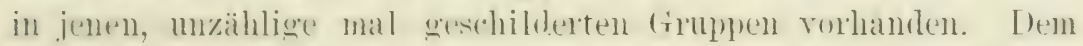

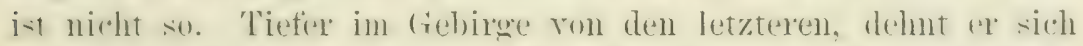

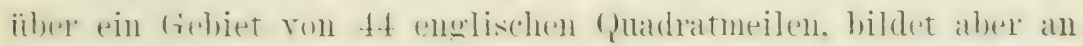

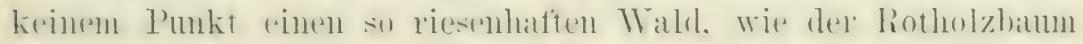

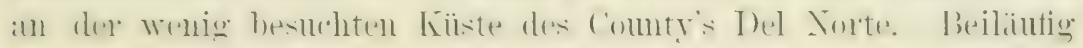

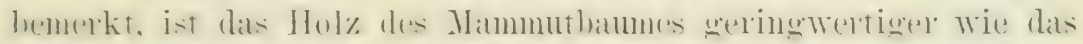

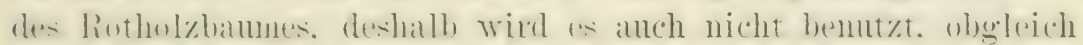

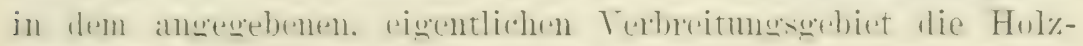
gewimumng nicht verboten ist.

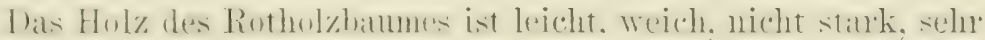

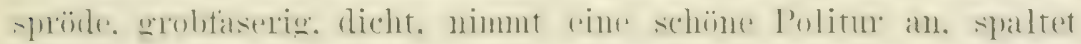

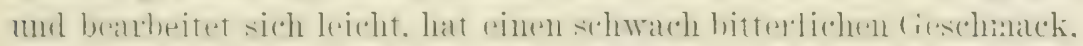

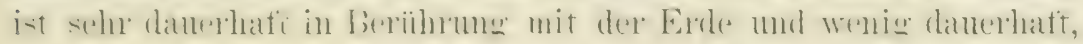

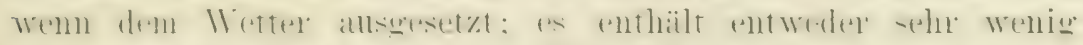

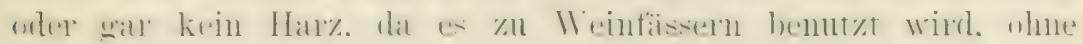

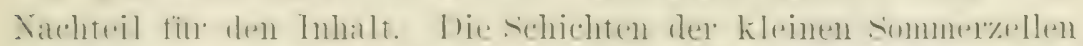

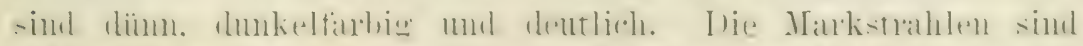

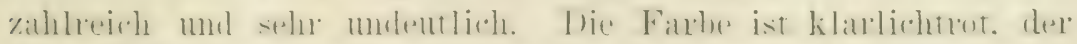
dimne Splint nahezu weiss.

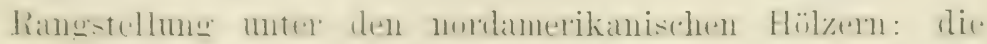
:

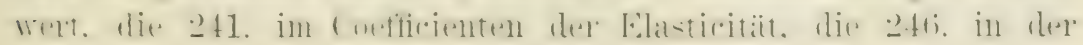




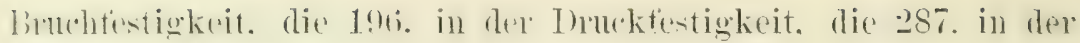
Eindruckfestigkeit.

So ist das wichtigste Nutzhol\% ('alitonniens beschaffen -- das

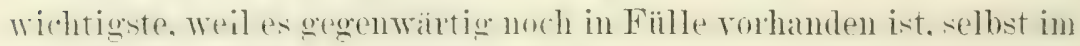
Tergleiche zu dem grossatigen bedarfe, sowie in einem fielicte steht. wo die Gewinnmg an leichtesten und billigsten im Staate ist und rine riclseitige Terwendbakeit zuläst. Wemn es in ralifornien auch. nach der landexiblichen Bauweise. zur äusseren Bekleidmg der. Hänse', zu schindeln mud Zäunen benutzt wird, so darf das in Bezug aut seine Wetterfestigkeit nicht irre führen. Was auch ron Seite Derer gesagt wird. die an dem Aufpuffen dieses Holzes ein Interesse haben oder es als eine patriotische Pflicht erachten, dasselbe hervolzuheben - die Haltharkeit des Rotholzes ist ron geringer Dauer. wemn dem Wetter ansesetzt, und wemn dies schon in rem trockenen Kilima ('aliforniens zu beobachten ist, um wie riel auffälliger muss es in einem regenreichen oder nur luftenchtem Kilima sein?! In Californien lebt man der Gegenwart, ohne berechnenden Blick in die Zukunft, so erklärt sich die Terwendung des massenhatt auf den Markt kommenden billigen Rotholzes zu den angegebenen ungeeigneten Zwecken. I a dasselbe seit cinigen Jahren in steigenden Mergen ausgeführt wird. so schien mir diese Darlegung geboten zu sein.

Dagegen ist das Rotholz muweifelhaft recht gut geeignet zur imeren Anskleidung der Hänser, ebenso zu billigen ínbeln. 7/n diesen Zwecken empfiehlt es sich durch seine angenelume Farbe, seine klare Faserung, leichte Bearbeitung und "festes Stehen". C̈ber den letzteren Vorzug ist erklärend hinzuzufïgen. dass das Rotholz leicht trocknet mit geringer Neigung zum Werfen. trotzdem darf es nur gut getrocknet verarbeitet werden, da es die Eigentiunlichkeit besitzt. mehr wie andere Hölzer in der Lïngenrichtung zu schrumpfen.

Zuweilen finden sich im Rotholz ähnliche Maserungen wie in Zuckerahornholz. dbenfalls Togelangen genamnt. die als urächtiges Luxusholz in der Möheltischlerei hochgeschätzt und entsprechend bezahlt werden.

Seiner Farbe und leichten spaltbarkeit wegen ist dals Rotholz zu Cigarrenkistchen sehr branchbar. ferner ist seine Benutzung emplehlenswert füi Lohfasser, sïrge, Modelle, Bahnschwellen und Kisten, namentlich leichte Obstkisten. 
Der Brennwert ist gering, wohl bremnt es leicht und mit

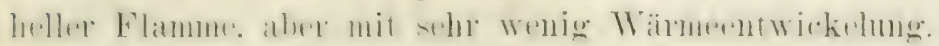

Das Rothol\% kommt selten und nur in milder Form mit

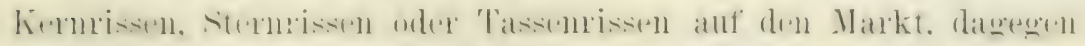

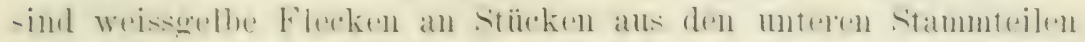

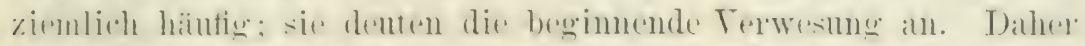

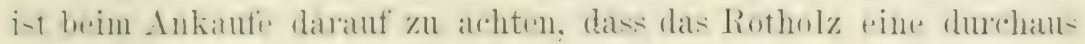
klare, Heckenlose, lichtrote Farbe besitzt.

Fïr den Rotholgham seheinen die seenebel wine deben--

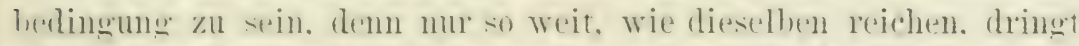

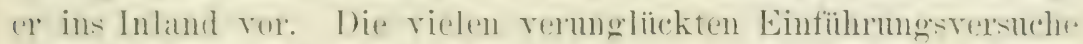

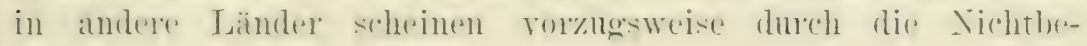
achtumg dieser 'Thatsache rerschuldet zu sein.

In seiner Heimat kommt dieser Bamm ant einem Borlen vor. ller ans sand-tein und batsalt hervolgegangen ist, we anf sehwemm-

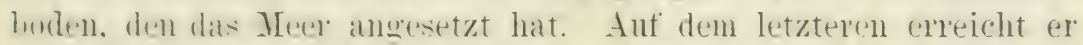

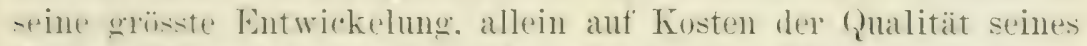
Hulzes. Pemerkenswert ist, dass da. wo im Verbreitumgrgebiet inselartige Kalkstein aufritt. der Rotholzhaum fehlt. Feuchtigkeit des Bodens ist eine Wachstumshedingmg. aut trockenem, seichtem Buden findet sich dieser Baum entweder gar nicht oder rerkriupreht.

Wril zan den Xadelhölzern gehörend, ist es vine anfiallende

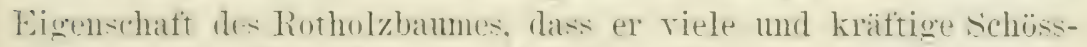
linge ats dem stumpt treibt. Auf diese Iroise ermellern sich die abgeholzten Rotholzwälder.

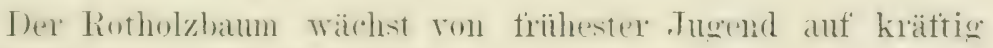
und verträgt ziemlich viel Schatten.

Indn Samen dieses baumes bieten dir califonnischen samenhandlungen mit 30 Jark pro Kilogramm an.

29. Weymouthskiefernholz.

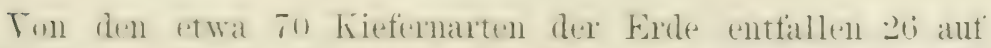

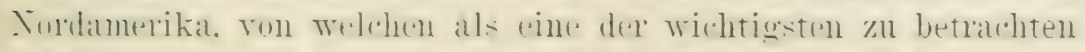
ist rie

Weymouthskiefer (l'inus rtwhlus. Familie (mitura).

Gleichname: White Pine.

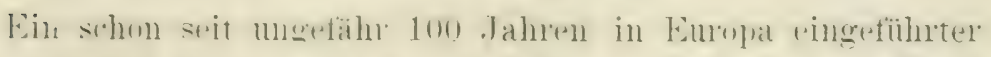

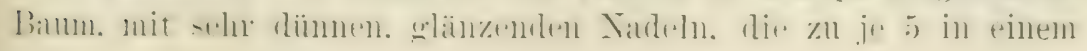




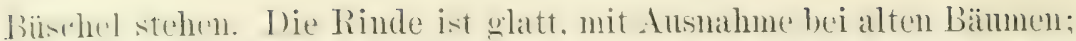
die Fruchtzapten sind dium. cylindrisch, oft etwas gebogen, 10 bis 1.2 \%entimeter lang; die schuppen sitzen ziemlich lose; der sime ist glatt.

Dir Höhe des bammes bewegt sich zwischen 24 und 52 Meter: bei einem stammdurchmescer ron 1.20 bis 3,50 Meter. Das Terhreitumgsgebiet unfasst Teufundland. ant dem Festlande zitht die nïrdliche firenze von der nürdlichen Kïste der st. Lorenzobai nach dem Nipigonsere und dem 'Thale des Wimnipegflusses, die sïdliche lianft von Pemnsylvanien nath dem südufer des Michigansees, mit einel Abzweigung längs des Alleghanygebirges bis zum nördlichen (reorgia. I)ie höchste Entwickelung erreicht dieser Baum in der

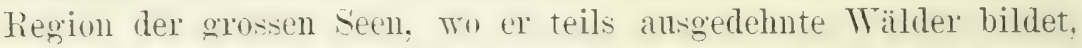
teils in Gruppen in den Laubholzwäldern auftritt. Nördlich rom 47. Breitegrarl, sïdlich rom Pemsylvanien, im mittleren Yichigan und Minnesota kommt er seltener ror, ist kleiner und liefert gering*rertigeres Holz.

Las Holz ist weich. leicht, nicht stark, sehr dicht- und gerarlfaserig; leicht zn bearbeiten und nimmt eine schöne Politur an.

Iie schichten der kleinen Sommerzellen sind diimn. nicht dentlich, die Harzgefäse sind klein, weder zahloeich noch deutlich. Die Farbe ist fahloelb. zuweilen ins brämliche oder rötliche schimmernd.

Ich glanbe hier aut folgenden Tiderspruch antmerksam machen zu sollen: in manchen nordamerikanischen Fachscinriften wird das Weymonthskiefernholz harztied erklärt. während es Heimrich Tarre an die Spitze der harzigen Yadelhölzer stellt, wie in einem anderen Abrohnitte dargethan wurde. Jedentalls liegt die Wahrheit in der Mitte.

liangstellung mutel den nordanerikanischen Hölze'ns: die 498. in suezifischer schwere, die 409. im rerhältnismässigen Bremwert. die 161. in Coefticienten der Elastizitä, die 22:2. in der Bruchestigkeit. die -271. in der Inruktestigkeit. die -29:) in der Eindrucktestimleit.

Als Xachteile dieses Holzes sind zu bezeichnen: es ist nur in trockener Luft danerhaft, quillt und schumpft stark, wenn sich in Fenchtigkeitsgehalte der Luft bedeutende Schwankmgen rollziehen, für manche TerTendungen ist seine Teichleit ein ernstlirhes Hindernis, es ist Kermissen und Kreisrissen ansgesetzt, und 


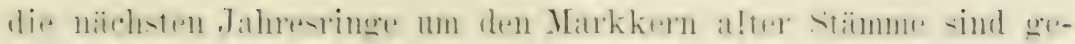

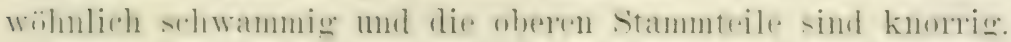

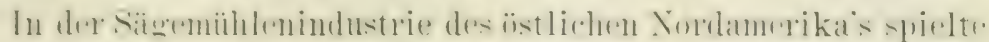

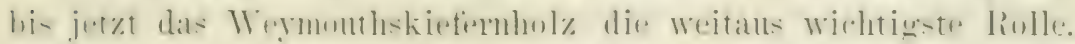
durt wirl kein anderes Hol\% in annähernden Mengen zu birttern.

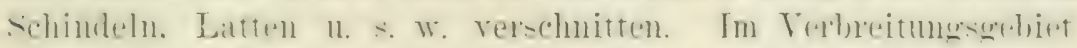

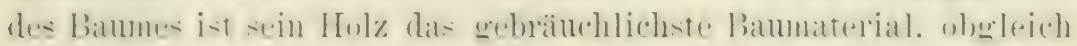

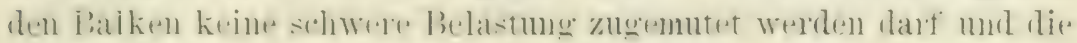

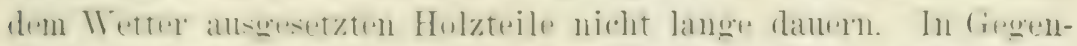
dent. Wohin das Holz in Form von Brettern exportiert wird. dient

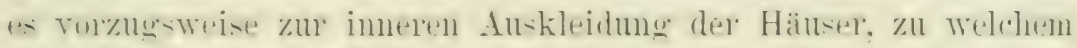
\%werke es hei den Tischlem seln helieht ist. Weil as sirh leicht mul shön bearlecitet. Fermer dient es zur Anfertigung ron

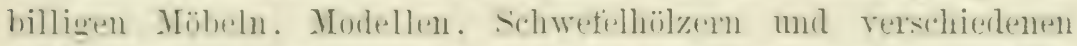
Holzwaren. Als Bremetoft hat es katum Wert. Im silhiffbatu

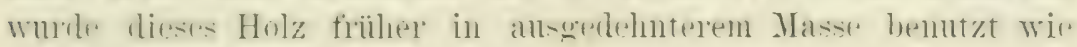

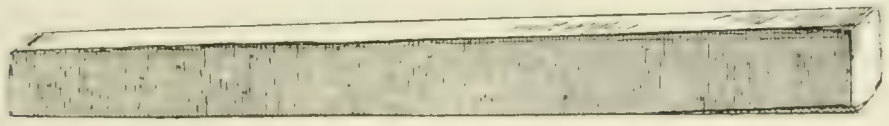

Figur 5ั.

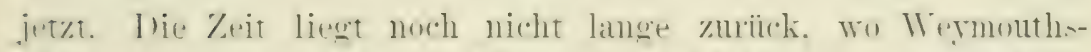
kiefermasten als alleresten Ranges betrachtet worden. gegonwätig

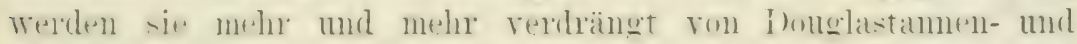

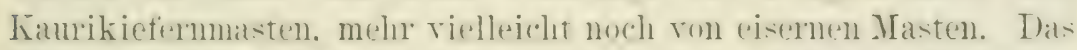

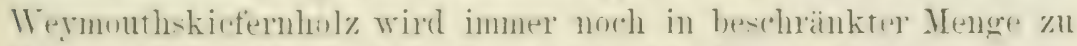

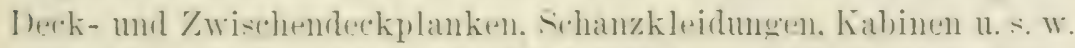

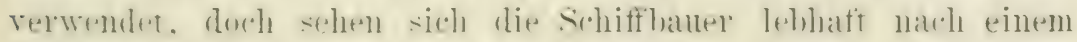
Eratye um. da sie sehr wohl wisterle dass die Vurläte dieses

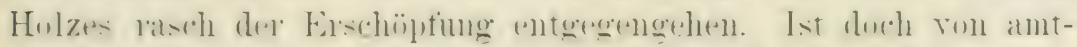

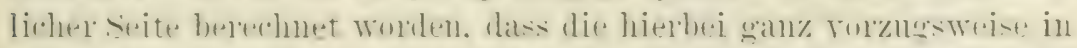

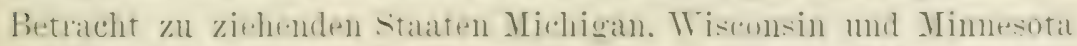

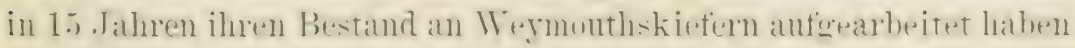

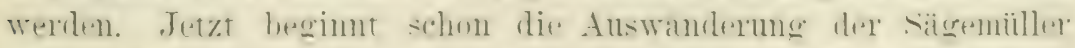

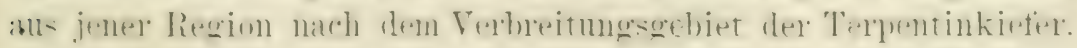

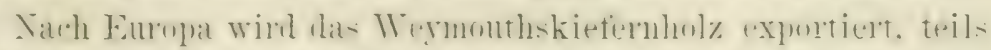

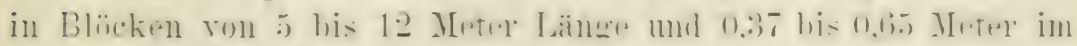

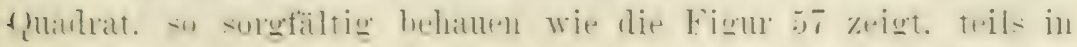


Brettern von :3 bis 6 Metex Länge, von verschiedener Breite und Dicke. Die Letzteren werden in 3 Qualititen sortiert und mit pinem Rötelstein I. II. und III. markiert. In den Fakturen und

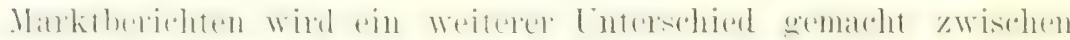

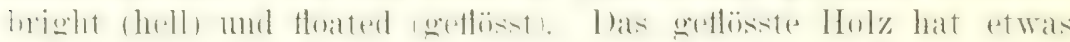

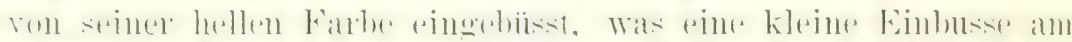
Preise, gegeniiber dem nicht geflössten Holze, zur Folge hat.

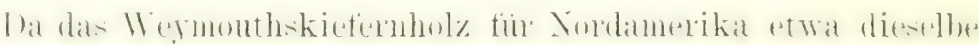

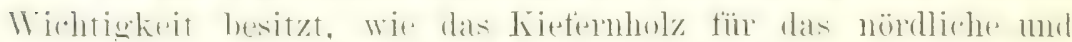

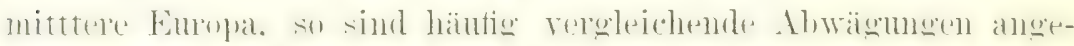

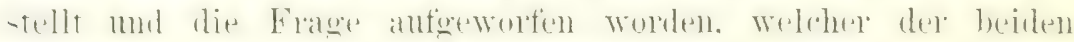
Bäume der wertvollere sei. Meines Erachtens schwebt ein Ter-

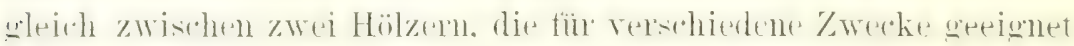
sind, in der Luft. Kein Sachkenner wird dem Weymouthskiefermholz ditselbe Traglast zumuten wie dem Holz rom Pinus

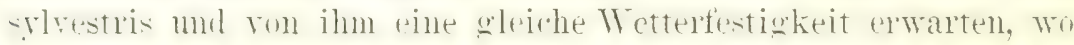

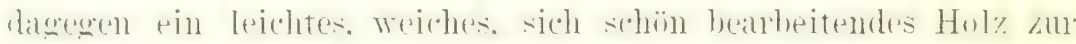

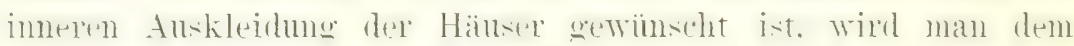
Weymouthskiefernholz den Vorzug geben.

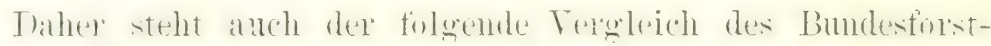

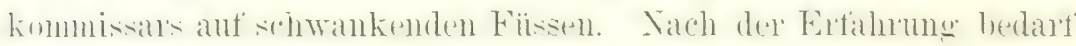
die Weymonthskieter in Nordamerika dine go jährigen Wathstum.

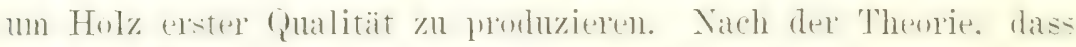

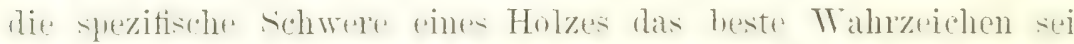

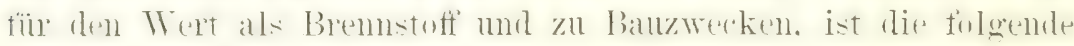

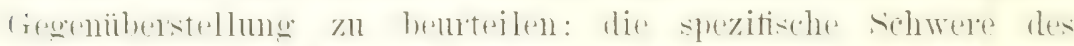

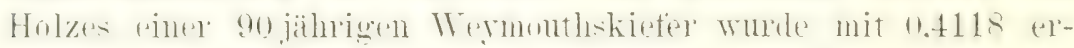

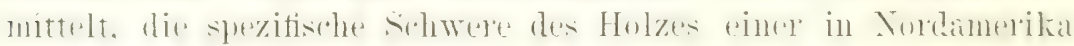
gewachsenen 75 Jahre alten Kiefer (Pinus sylrestris) dagegen mit 0,491 .

Darans kann höchstens gefolgert werden, die Kiefer liefere

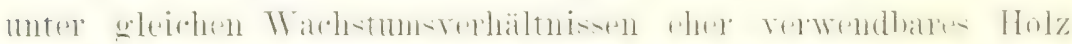

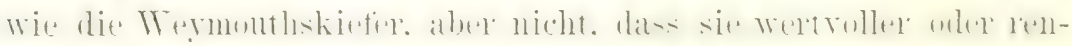
tabeler sei wie diese, denu die Holzpreise sprechen dabei mit.

Es war nur natülich, dass ein so wichtiger Baum wie die

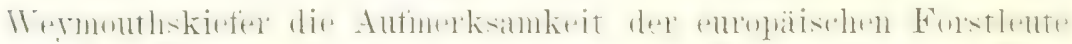

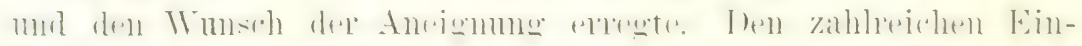

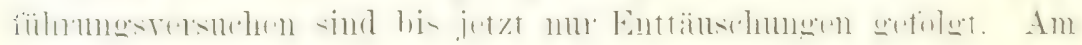




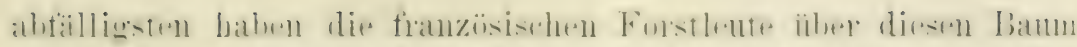

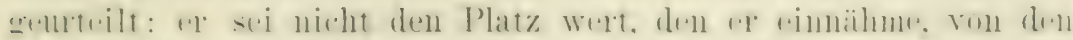

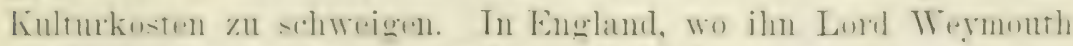

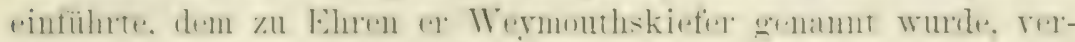

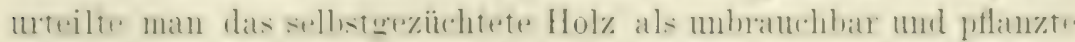

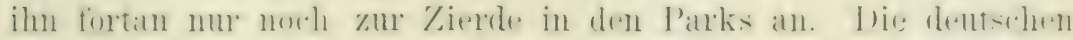

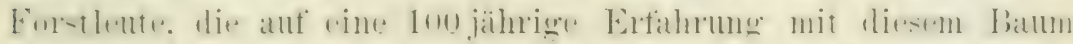

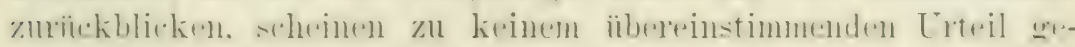

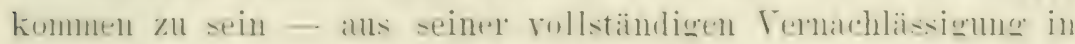

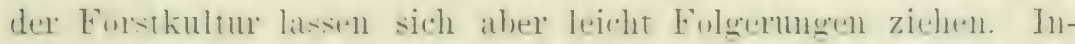

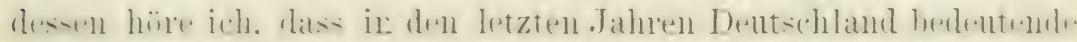

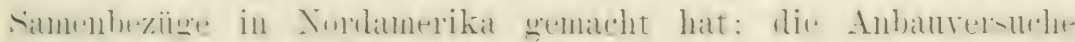
sollen also jedenfalls wiederholt werden.

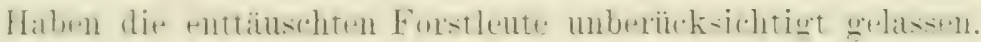

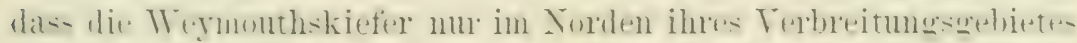
wertvolles Holz lietert, also in einem Klima mit langen. strengen "Wintern und kurz begrenzter jährlicher Warchstumseit? Für Frankreich und England muss diese Frage mohl bejaht werden. Ist das 909 bis 100 jährige Warhstum der Weymouthskiefer abgewartet worden. his das Holz auf seinen Wert gepriift wurde? Zum mindesten haben die franzïsischen Forstlente zu hastig geturteilt. Tielledeht sind atuch Misogrifte bei dex Wahl des Bondens gemacht worlen. Auf halksteinboden kommt die Weymouthekiefer katum fort, ant wichtem. felsigen Gelände liefert sie ein werthos Hulz.

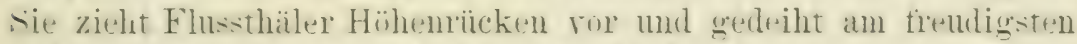

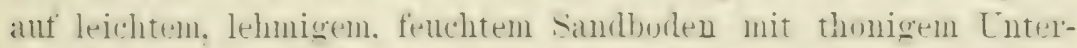
wruml. schwemmborlen sagt ihr elonfalls zu: jedenfialls ist sie nur auf einem tieforindigen, meln fenchtem wie trockenem Boden erfolgreich anzubauen. da sir sich emptimellich gegen dürren zeirt. lie: Weymouthskiefer wächst rasch. rertrïgt nirht riel schatten und winl am hesten unit Laubhölzern gemischt angeptlanzt.

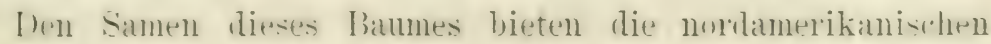
samenhandlungen mit 15 Mark por Kilogramm an. Aut das Kilogramm gehen zwischen 15000 und 25000 Samen. 
30. Zuckerkiefern holz.

Zuckerkiefer (Pinns Lambertiana, Familie Conifiace.

Ton diesem Baum wird gresagt, er sei die grösste Kriefernart der Errle und wenn sich darüber anch streiten lässt, so ist er doch unzweifelhaft eine der grössten Kiefernarten. Seine Höhe bewegt sich zwischen 40 und 92 Meter bei einem Stammdurchmesser ron a bis 7 Meter. Die Rinde ist lichtbraum, glatt und löst sich beim Torgange der Ermenerung in kleinen Stïcken ab. Die Nadeln sind S bis 12 Zentimeter lang, an den Rändern kaum bemerklich gezahnt, blangrün, im Alter etwas gedreht und in Büscheln zu 5 geordnet. Die Samenzapfen reifen im zweiten Jahr, sie sind von hellbraner Farbe, cylindrisch, 25 bis 40 Zentimeter lang, 8 bis 10 Zentimeter im Durchmesser und sitzen an 7 Zentimeter langen Stielen. Die Schnppen überklappen sich lose. sie bedecken den glatten, schmarzen, walen, etwas geflachten samen mit Flügeln, die nicht ganz zweimal so lang wie breit sind.

Terbreitet ist dieser Baum in Oregon, im Küsten- und Cascadtegebirge, ron den (quellen des Mackenzieflusses und dem Thale des Rogueflusses siidwärts bis zur californischen Grenze; in Californien an der westlichen Abdachung der Sierra nevada, dem Tïistengebirge entlang bis zu den Santa Luciabergen, in den San Bernardino- und Cuyamacabergen.

Seine grösste Entwickelung erreicht er in der Sierra neradia des mittleren Californiens, in Erhebungen ron 1200 bis 1800 Meter. Manche irrige Folgerungen in Bezug auf die klimatischen Anspriiche dieses Bammes sind aus der Thatsache gezogen worden, dass er in den angegebenen Erhebungen das freudigste Gedeihen zeige. Die Erklärung ist im Boden zu suchen. Die Sierra nevada besteht ans Granit, bedeckt mit jügerem, rulkanischem Gestein. Tun verschwundene Gletscher haben auf dem etwa 3000 Meter hohen Kamm des Gebirges die rulkanische Decke bis anf die granitne Unterlage durchschnitten und die Geschiebe in der Erhebung ron 1200 bis 1800 Meter als Moränen abgelagert.

Es wird nun begreiflich sein. warum in dieser Höhenlage nicht allein die Zuckerkiefern, sondern alle Waldbäume dieses (rubirgs zur höchsten Entwickelung gelangt sind. In keiner 


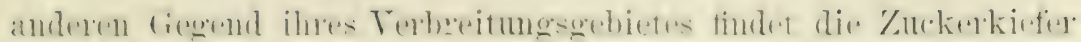

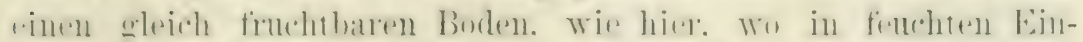

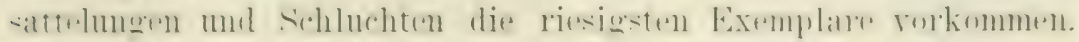

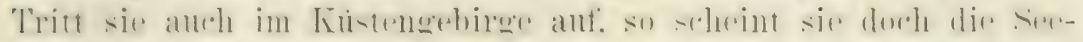

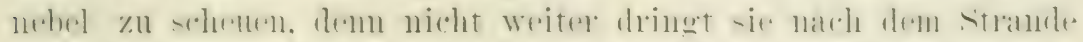

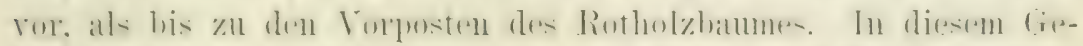

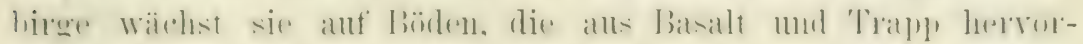

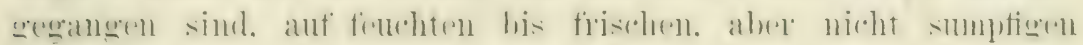
standorten.

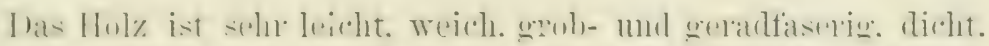

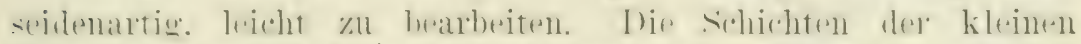

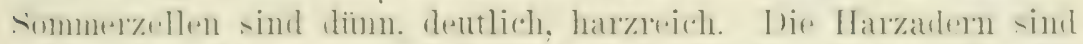

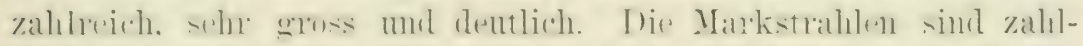

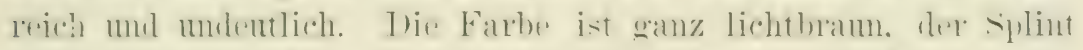
nahezu weiss. Der Geruch ist schwach aromatisch, der Geschmack siisslich.

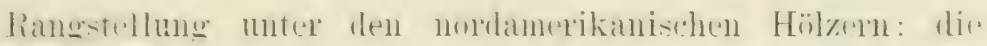

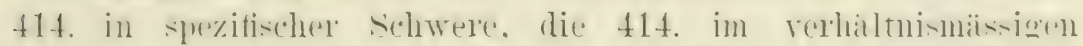
Bremwert, die 247. im cofficienten der Elastizitat. die 297. in

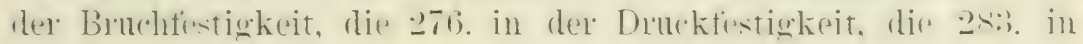
ler Eindruckfestigkeit.

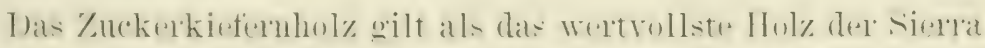

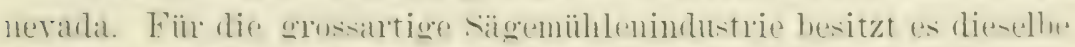

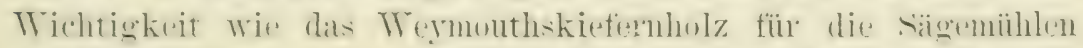

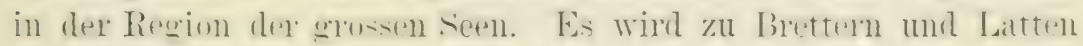
rerschnitten. dic zur inneren Anskleidung der Häuser. zu Fenster-

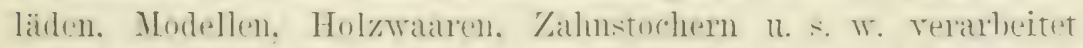
werden. Inen langiälerigen streit, wh das Zncherkicternlong mit den nahe verwanden, fist denselleen Zwerken dienenden 11 ermouths-

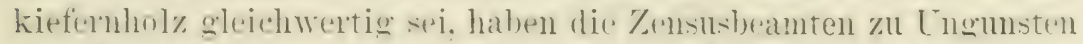
des Eisteren entochiestent. allein die californischen Arohitekten

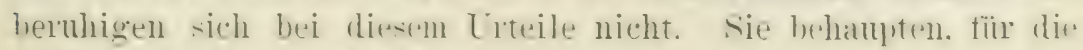
in Betracht kommenden Verwendungen sei es glepheriiltig. ob das

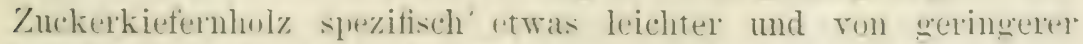
Bruchfestigkeit sei wit das Tremouth kiefernhol\%. dies'm gegenüber sei es nur dureh seinen gröisereen Reichtum an Harz im Nachteil. das nach der Terarbeitmo oft dureh die Politur oder den Anstrich dringe. Diesem lebelstande kömue indessen durch pin 


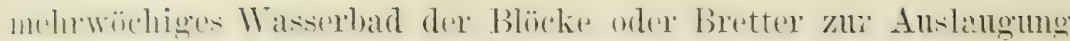

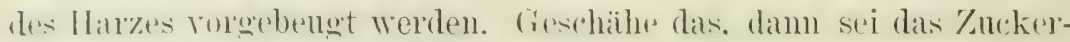

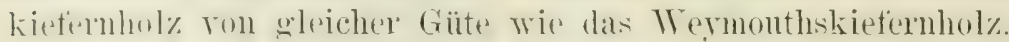

(1) diese Behauptmg. voll begründet ist oder nicht, jedenfalls ist die Zunkerkiefer eines Einführungsversuche's wert da, wo das telingen wahrscheinlich ist, dem sie besitzt Eigenschaften, welche -ie dem Forstmanne empfehlen. Derselbe wird es zu wiindigen wissen, dass die $\ddot{A}$ ste und ZWrige so schlank und elastisch sind, dass sie weder Wind- noch sehnepbruch zulassen. Während eines stumes in dex sicra nevada kamn eine dichterische Phantasir eine'n Tergleich finden zwischen den flatternden Haaren ron Riesenweibern und den wehenden Kronen der Zuckerkiefern. so sehr -chmiegen sich dieselben der Luftströmmng an. Der gerade, umfimgreiche, bis zu bedentender Höhe astfreie Stamm spricht ebenfalls zu Gunsten der Zuckerkiefer, ebenso ihre Lebenszähigkeit. Tielleicht befriedigen Einführungrersuche da. wo solche mit der Weymouthskiefer zu Enttäuschungen führten.

Aus den stammwunden der Zuckerkiefer quillt ein silsslicher Stoff. dessen richtige Bezeichnung wahrscheinlich (rmmmiharz ist. und der von Indianern und Berglenten zuweilen als Abfïhrmittel benutzt wirl. Diesem Stoffe rerdankt die Zuckerkiefer ihren Tamen: dieselbe als Zuckerquelle in Anssicht zu nehmen, wie es geschehen ist, klingt über die Massen lächerlich.

Den Santen dieses Baumes liefern die californischen Samenhandlungen zu 30 Mark pro Kilogramm.

\section{Rotkiefernholz.}

Rote oder harzige Kiefer. (Pinus resinosa. Familie C'oniferae.) Gleichname: Red Pine.

Ein in Teufundland. ron der nördlicnen Kï̈ste der St. Lolenzobai bis zum Thale des Trimnipegflusses und nach siden bis zum mittleren Michigan und Minmesota und zum nördlichen Pemısylranien heimischer Baum. Seine Höhe beregt sich zwischen 2t und to Meter bei einem Stammdurchmesser von 0.60 bis 1,40 Meter; die grösste Entwickelung erreicht er im nördlichen Trisconsin und Mimnesota, auf leichtem. sandigem Lehmboden oder trockenen, felsigen Hügelrücken. 


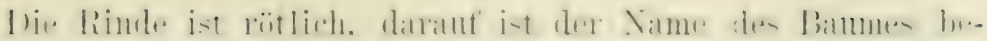

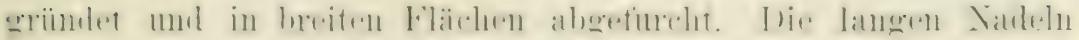

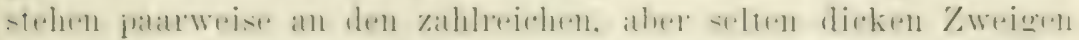

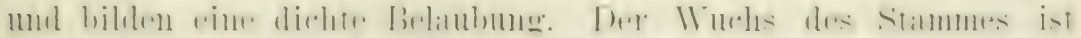

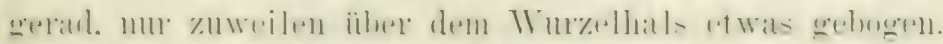

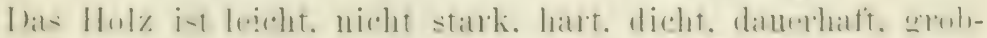

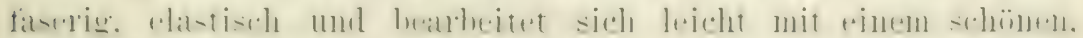

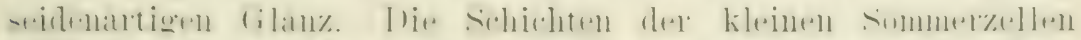

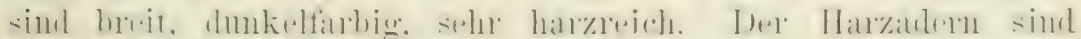

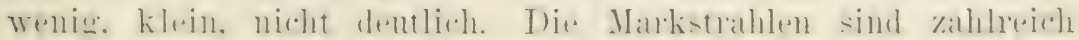

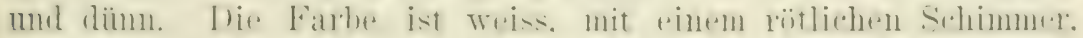

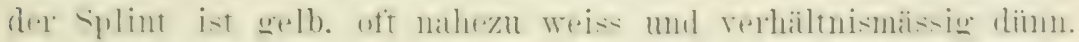

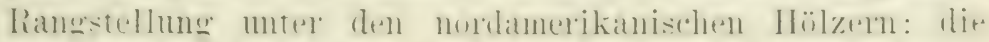

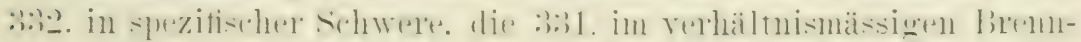

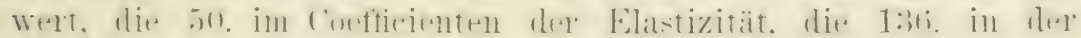

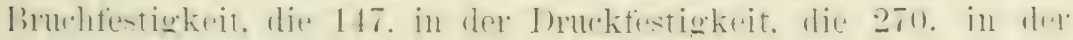
Eindruckfestigkeit.

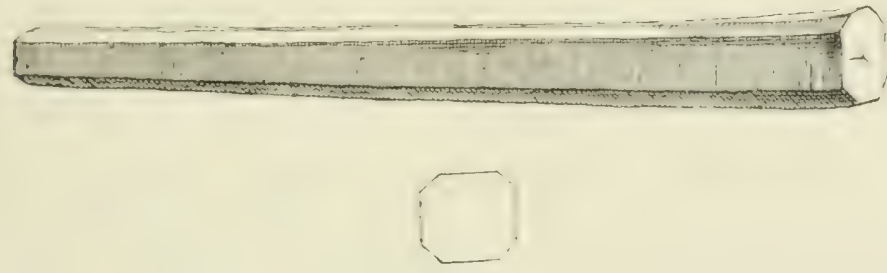

Figur 59.

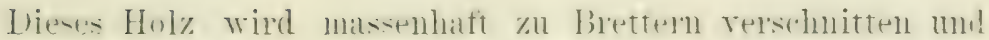
als Balken zu leichteren Batuten verwemdet. Bei den Zimmerlenten und Tischlem ist es selir helieht. Weil es heim 'Truckllen

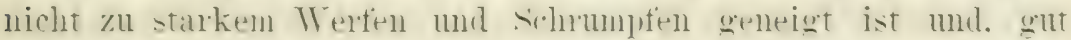

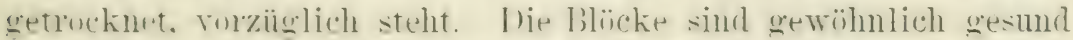
und test bis auf den Markhirle und der splint ist dimn: es eriht also wenig Abfall bei der Bearbeitung:

Die Bretter kommen hauptöichlich zur imneren Aliskledilung dex Hänsix und in rer Tischlerei zur Verwendung. In schifflan findet dieses Holz eine starke Penutzmo zu I)eck- mol Zwischendeckplanken wie zu Raastangen.

Canada macht ein lehhaftes Exportgeschät in diesem Holz.

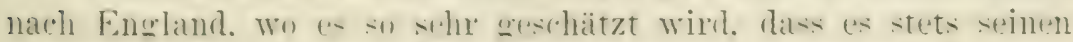


richtigen Xamen fïhnt und nicht, wie die ribrigen Xardelhölzer

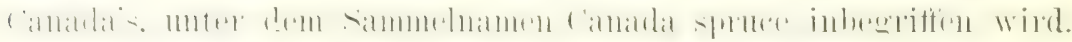
Die zur Ansfuh gelangenden Blöcke haben die in der Figur 58 reranschanlichte Form; sie sind im engen Anschluss an die stark veriünt zulaufende form des stammes behanen.

Die Rotkiefer ist wiederholt der Anfmerksamkeit der Forstlente ompfohlen worden. weil sie rasch wächst und ein grosses dnbequemminsrermögen an Boden und Klima zeigt. Sie trotzt

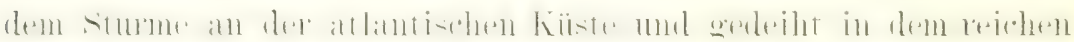

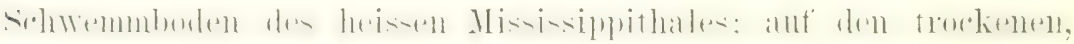
sandigen Ebenen des westlichen Kansas hat sie sich eingewöhnt und die sibirischen Winter ron Wisconsin und Mimnesota vermögen ihr keinen schaden zu thun. Auf trockenem, armem Boden entwickelt sie sich rascher, wie irgend ein anderer, ebenso nützlicher Nadelbaum Nordamerika's.

Der Same wird aus mir unbekannten Grimden von den nord-

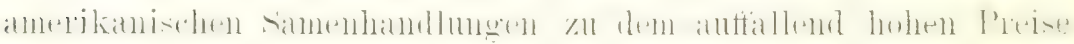
ron 80 Hark pro Kilogramm notiert.

\section{Pechkiefernholz.}

Pechkiefer. (Pints rigida, Familie Coniferae.)

Die nördliche Terbreitungsgrenze dieses Baumes zieht sich

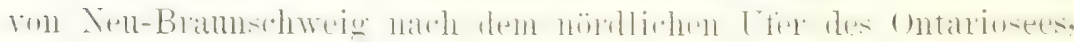
die siidliche länft durch das nördliche Georoia nach den westlichen Abhängen des Alleghanygebirges bis Kentucky. Er erreicht eine Höhe ron 12 bis 24 ileter bei einem Stammiurchmesser ron 0,60 bis 0,90 Meter. Der Wuchs ist rollkommen gerad, die 10 bis 12 Zentimeter langen, dunkelgrünen Nadeln stehen zu drei, die 3 bis \& Zentimeter langen Fruchtzapfen sind oval bis langoval, hïngen oft in Bündeln. die scharfkantigen

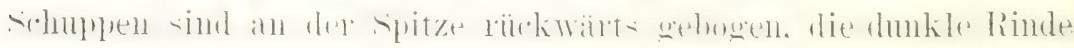
ist sehr raul. Die Bliiten erscheinen im Frïhjahr, die Fruchtzapfen reifen erst in Herbst des nächsten Jahres.

Das Holz ist schwer, hart, gerad- und grobfaserig, elastisch, stark, sehr dauerhaft, harzreich und im Vergleiche zu anderen Tadelhölzern etwas schwer zu bearbeiten. Die Schichten der

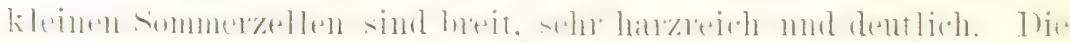




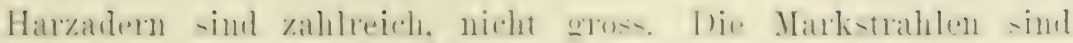

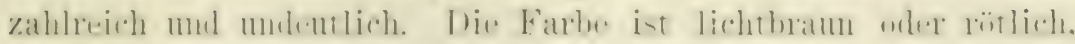
der splint ist gelb, oft nahezu weiss.

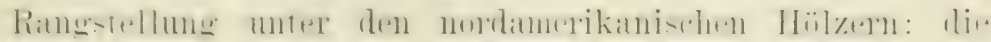

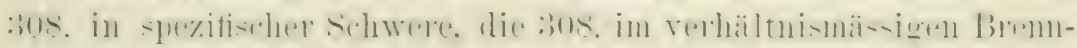

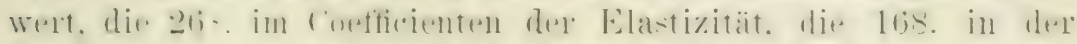

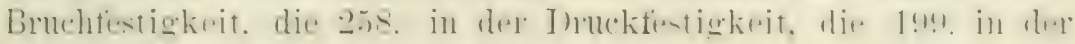
Eindrucktestigkeit.

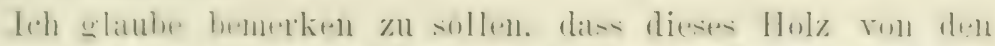

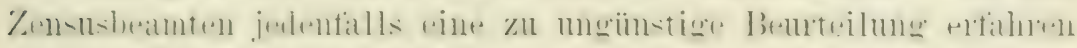

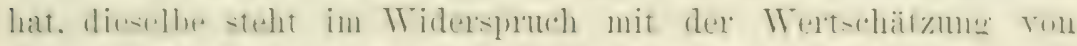

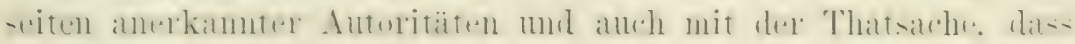

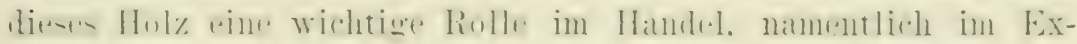

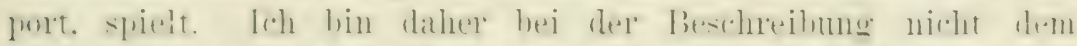

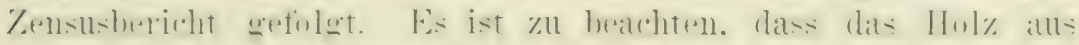

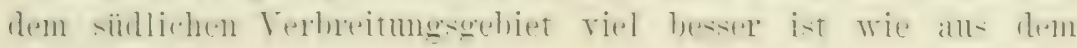
nördlichen.

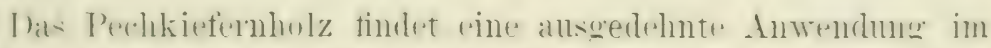

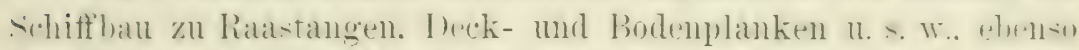
bei Hanthauten als Guenhalken. seltener als Traghalken. \%u

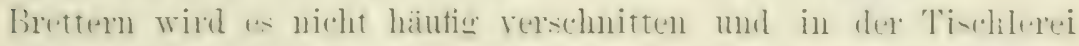

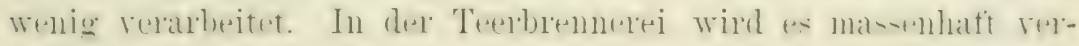
braucht; als Bremnstoff ist es sehr geschätzt.

Expertiort wirl dieses Holz nach englischen mol anderent

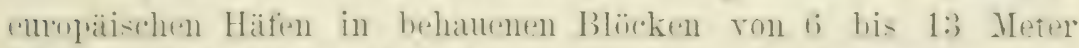

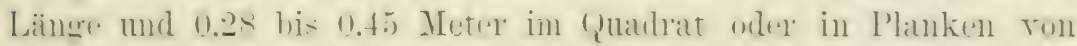

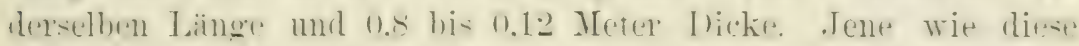

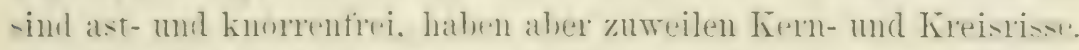

Dic Perlakiefer kommt in der liegel ant trockenem. sandigem mler felsigem sie nimnt also nit armen boden fürliel). Herrorzuhehen ist. tas:

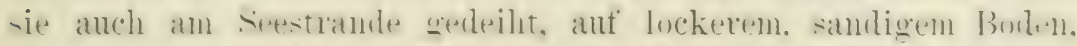
wenn er nur nicht ans Flugand besteht. Die Wurelu dingen

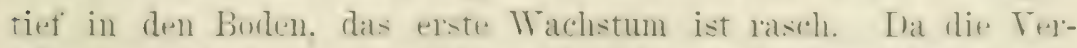

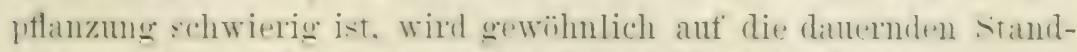
mte gesiat. - I leser Banun repträgt nicht viel schatten.

Ten samen dieses banmes bieten die nordamerikani-chen camenhandlungen mit :3 Mark pro Kilogramm an. 
33. Wiesenkieternhol $\mathrm{k}$.

Wiesenkiefer (Pinms cubensis, Hamilie Coniterae).

Gleichnamen: Smmpticter. Bastardkiefer.

Das Terbreitungsgebiet dieses bammes dehnt sich ron sidGandina in Norden bis tief nach Westindien im siiden. stets als Kïstenstreiten von nicht über 100 Kilometer Breite. Er erreicht pine Höhe ron 24 bis 30 Meter bei einem Stammdurchmesser von

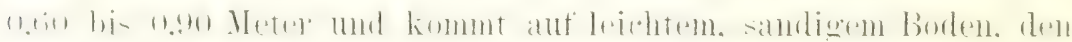

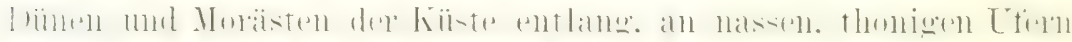

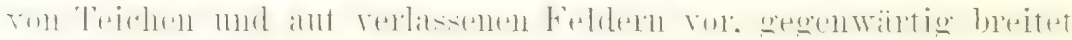
er sich rasch über das Gelände aus. auf welehem die 'Terpentinlieter abgeholzt wurde.

Das Holz ist schyer, ausserordentlich hart, sehr stark, zäl. crobtaserig. dicht. dauerhaft. Die Schichten der kleinen Sommerzellen sind sehr breit. harzreich und dentlich. Die renigen Harzadern sind nicht gross. Die Markstrahlen sind zahlreich mnd dentlich. Die Farbe ist reich dunkelorangegelb; der Splint heller. oft nahezu weiss.

Rangstellung meter den nordamerikanischen Hölzeru: die 117. in spezitischer Schwere, die 116, im verhältnismäissigen Brennwert. die 5. im Coefficienten der Elastizität. die 18. in der Bruchtestigkeit, die 23. in der Drucktestigkeit. die 145. in der Findrucktestigkeit.

Ein Vergleich zeigt, dass dieses Holz eine noch etwas hïhere Rangstellung einnimmt. wie das nahe rentwandte hoch-

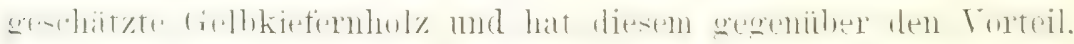
dass der Bamm megen der grösseren Fruchtbarkeit leichter fortzuptlanzen ist, wie die Gelb- oder Terpentinkiefer. In FIorida

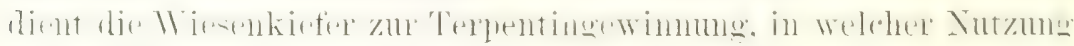
sie der 'Terpentinkiefer' nicht nachstehen soll. Die Wiesenkiefer' wächst rasch, ist leicht fortzupflanzen. trägt fiüh samen und ist lichtbediuttig.

Den Samen der Wiesenkiefer fïhren die nordamerikanischen Samenhandlungen nicht, besorgen ihn aber. 


\section{Gelbkiefiernolz.}

Terpentinkiefer. (l'inus palu-tris. Fanilit. (imbifirate)

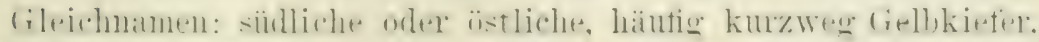

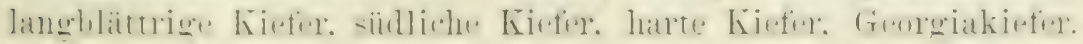

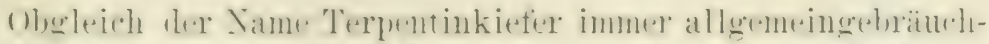

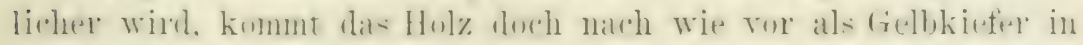
den Handel. trotzlem dimbeh Verwedsolungen beginstigt werden.

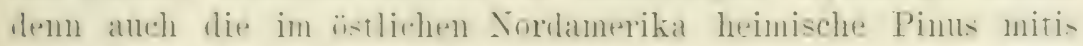

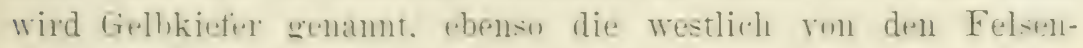
gebirgen rorkommende Pinus ponderosa.

schwn bei der schilderung der Terpentinbereinung wurk.

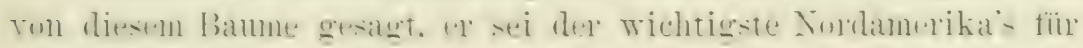

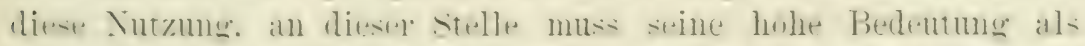

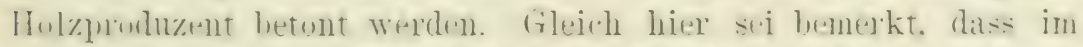
molianerikanischen Holzhandel das Peclukiefermbolz und tielikiefermholz. nidht solten rerwerhselt werden. heide gehen oft. umi

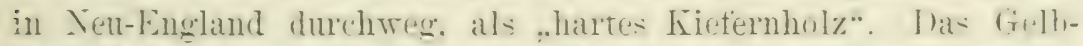
kieternholz reldient ührigens entechieden den Torzug.

Ine Terpentinkiefer gehört zu den wenigen Bäunen Vorrl-

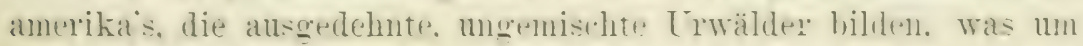

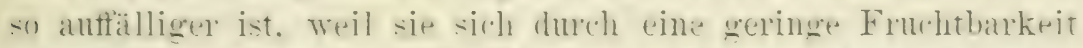

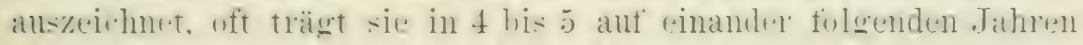
nicht. Dadurch erkliart es silh leicht. warum iilscrall, wo sie al,-

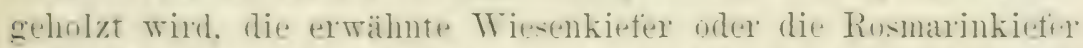
(Pinus Taeda) in ihre stelle tritt. Freilich bildet sie nicht iiherall

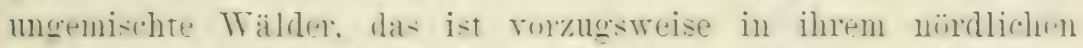
Terlneimngegeriet der Fall, wolches im südiistlichen Tirginien begimnt und in Vordcarolina seinen schwerpunkt findet. In - viiden des fa-t bis zur nexikanischen Grenze reichenden Ter-

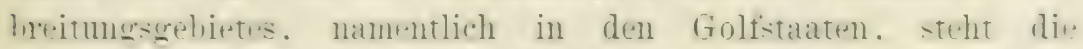

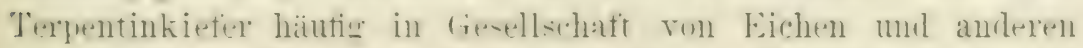

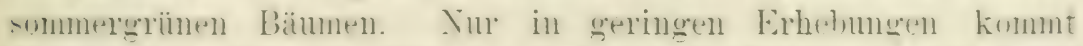

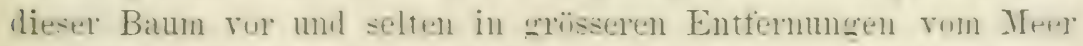

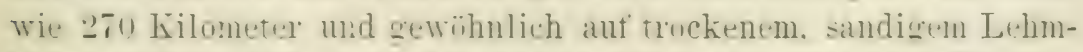
bulen. selten wirn er an den nasen Lfern ron niendigen siumpten

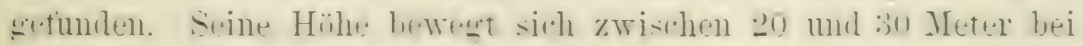
einem Stammdurchmesser ron 0,60 bis $\mathbf{1 . 2 0}$ Meter. 
l)it: Holy ist schwer: answerordentlich hart, sehr stark, zäh,

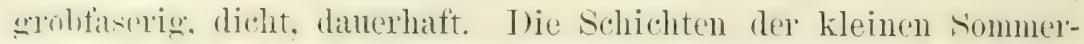
zellen sind hreit, seh" harzeich, Anukelfarbig. Die wenigen Harzadren sind nicht dentlich. Die Markstrahlen sind zahlreich und deutlich. Lie Farbe ist lichtrot oder orangegelb, der düme Splint ist nahezn weiss.

Rangstellung mer den nordanerikanischen Hölzern: Die 168. in spezifischer sichwere, die 167. im rerhältnismässigen Brennwrt. die 7. im coefficienten der Elastizität, die 20. in der Bruchfestigkeit. die 29. in der Drucktestigkeit, die 178. in der Eindruckfestigkeit.

Die nordamerikanischen Fachlente behaupten: das Gelbkiefernholz ist das allgemein nützlichste Nadelholz unserer Wälder. und wemln man die Bewegungen des Holzhandels beobachtet, kamn man ihnen nicht wider'prechen. Die Behamptung ist aber jedenfalls zu weitgehend: das Gelbkiefernholz wiùde vollständig an Stelle des Weymouthskiefermholzes treten, wom dessen Torräte erschöpft scien. Dem steht entgegen. dass das Teymouthskieferuholz für gewisse Zwecke scinel hellen Farbe, Leichtigkeit und leichten, schönen Bearbitung wegen beliebt murde, das (fellhiefernholz aber viel schwerer, dunkler, harzeicher und schwieriger zu bearbeiten ist. To diese Eigunschaften nicht stören. findet es dieselbe Termendung wie Weymouthskieteruholz oder anderes dirhteres Nadelholz. als Beweis rafïr kïmnen dit bedeutenden und in jedem Jahre steigenden Brettermengen dienten. welche von der grostartigen sagemiülenindustrie in den Terpentinkiefernwäldern anf den Markt gebracht werden. Für Banzwecke nimmt das rolbkiefernholz unter allen nordamerikanischen Nadelhöizern den ersten Rang ein: wetteifert é doch in der Tragkraft mit dem Weisseichenholz und lässt seine Danerhaftigheit in Folge des Harzreichtums wenig zu wünschen übrig. Im sichiffban findet (s schon seit vielen Jahrzehnten eine alscedehnte Terwendmg zu I)eck- md Zwischendeckplanken. Riegeln. Raastangen ul. $\therefore$ w. Wo ein leichteres Holz wie Eichenholz. bei nur wenig geringer 'Tragkaft und Festigkeit. gewünscht wird. ptlegen Architekten und Ingenieure dem Gelbkiefernholz den Tomgrg gu geben. Dasselbe hat sich anch zu Bahnschmellen und 'Telenraphenstangen sehr bewährt. ferner wird es zu Zäunen, Prmpen, Tastrleitungen und vielen sich der Aufzählung entziehenden Znecken benutzt. 


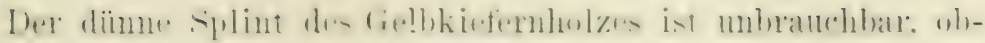

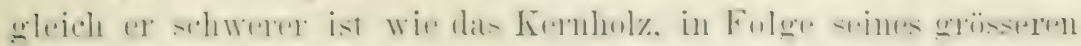

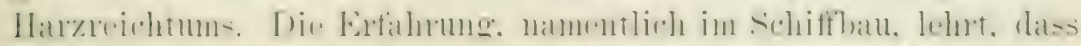

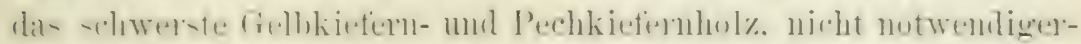

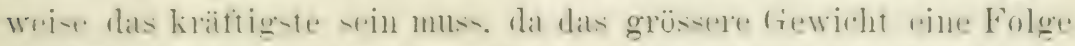

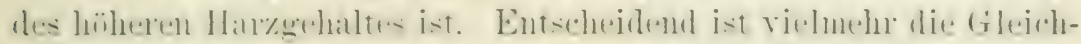

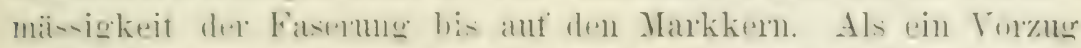

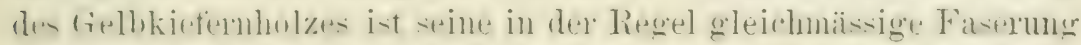

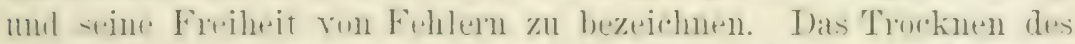

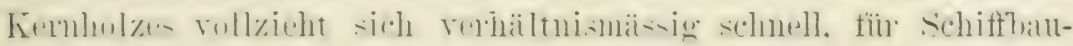
zwecke geniigen wenige Monate.

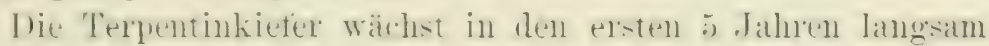

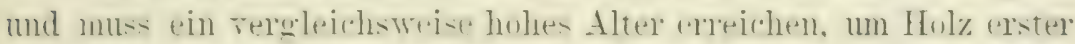
Qualität zu liefern. Zur krättigen Entwirkelung rerlangt sie pin luttendhes Kilina mol viel Lieht - ron allen nordamerikanischen Kiefer'n verträgt sie an wenigsten Schatten.

Den somen diens Banmen führen die nordanerikanischen simenhanklungen nicht. wemn sie iln besurgen, wird es zu hohen

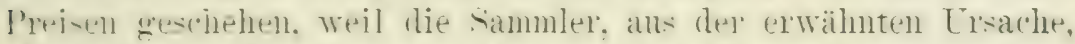

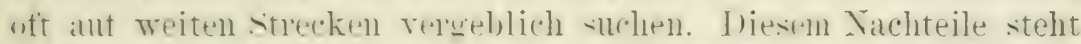

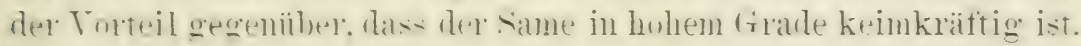

\section{Westliches Gelbkiefernholz.}

Westliche Gelbkiefer. I'imm puntero-a. Familir Comitura.) Gleichname: Bullkiefer.

Da wo die Zuckerkiefer rorkommt, hat sie zur Gesell-

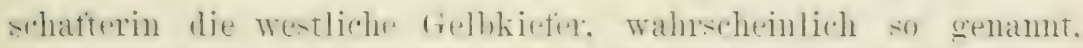

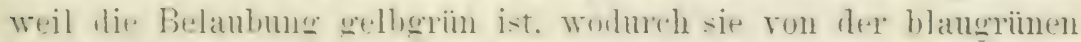

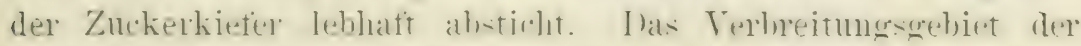

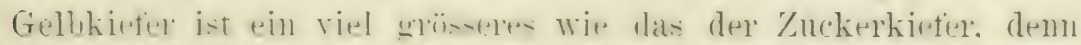

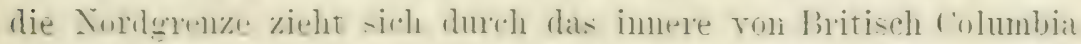

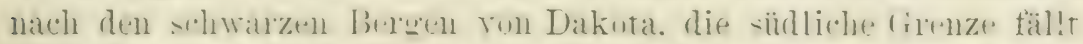

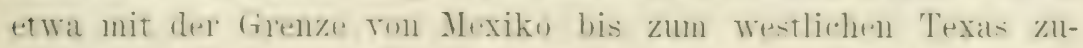

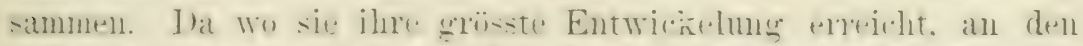

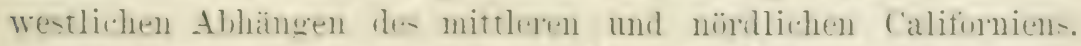

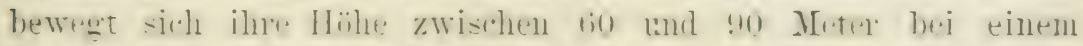

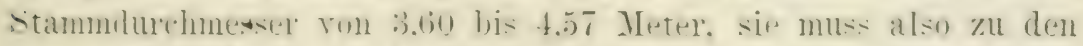

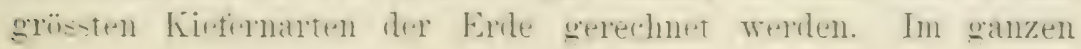




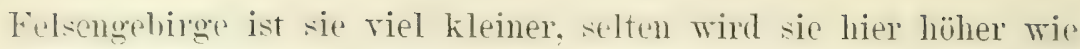
(3) Meter gefundon. Nächst der Donglascanne ist dieser Baum der riobreitetste und wichtigste in den Wäldern westlich der Felsenswbirge, im östlichen Washington und Oregon. im westlichen Montana und Idaho, in den schwarzen Bergen Dakotas, in Arizona. Vell-Mexikn und Testtexas deckt el rorzugsteise den Holzbedarf der Sägemiihlen und in Californien kommt sein Holz häufig unter dem Namen und als Ersatz des Zuckerkiefernholzes anf den Markt.

Die Rinde der Gelbkiefer ist sehr dick und auffallend hellrotlram, tief gefurcht, wodurch grosse. glatte Flächen begrenzt werden. die sich durch den Torgang der Ernemerung allmählich ablïsen. Die ovalen Fruchtzapten sind etwa 10 Zentimeter lang. bei "inem Durchmesser ron 4 bis 5 Zentimeter; oft in Bündeln ron 3 bis 5 geordnet.

I as Holz wechselt sehr in der Qualität, das bessere ist schwer. lart. stark. sprörte. dicht, mässig feinfaserig. nicht wetterfest. Die Schichten der kleinen Sommerzellen sind breit oder eng. deutlich mnd sehr harzreich. Die wenigen Harzadern sind dün. Die Markstrahlen sind zahlreich und mdeutlich. Die Farbe ist weissrot oder lichtbraun, der dicke Splint ist nahezu weiss.

Rangstellung unter den nordamerikanischen Hölzern: (die 345. in spezifischer Schwere, die 342. im verhältnismässigen Bremnert. die 146. im Coefficienten dex Elastizitat, die 179. in der Bruchfestigkeit. die 236. in der Îruckestigkeit. die 237. in der Eindruckfestigkeit.

Grösstenteils wird dieses Hol\% in den Sägemïhlen zu Brettern mul Latten rerschnitten, ein Toil dient zu Bahnschwellen, Zamriegeln und ähnlichen Verwendungen.

Die Gelbkiefer kommt in der Regel auf trockenen, felsigen Bergriïcken oder Ebenen vor. selten wird sie in sumpfigem Boden frefunden. Sie ist ein exhter Gebirgshanm und auf diese Eigenshaft hin mag sie bei den Forstleuten Beachtung finden. In der Sierra nevada steigt sie bis zu Erhebungen ron 3000 Meter und mltwickelt sich bis zu 2500 Meter zn einem grosen. stattlichen Baum. Doch ist sie lange nicht so sturmfest wie die Zuckerkiefer. was bei der Anpflanzung in Berïcksichtigme zu ziehen ist. Zu iluren Gunsten ist noch zu sagen. lass sie sich schnell und kräftig entwickelt. 


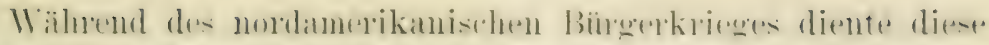

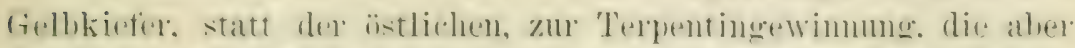

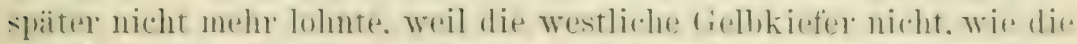

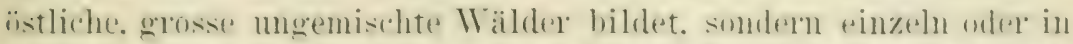

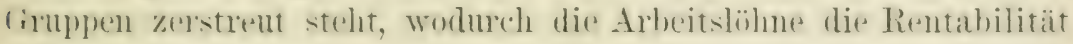
ummöglich machen.

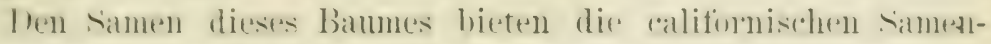
handlungen mit 15 Mark pro Kilogramm an.

36. Seluwarzichtenhol\%.

Schwarzfichte (Picea nigra, Familie Coniferae).

Lie crattumg Picea zertailt in 20 Alten, won welchen 7 in Nordamerika rorkommen.

Die schwartichte ist ein schöner, zuwrilen in den Parks

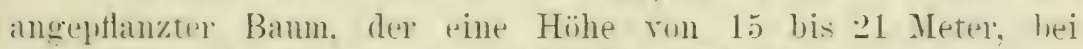
(inem stammlurehmesser von 10,60 bis 0,90 Meter erreicht und seine'n Namen den dunkeln Zaphen rerdankt. Das Verbreitung:grebiet ist Yeufundland, auf dem Festlande ron dex Hudsomshay nath der Mründumg des Mackenzieflussess. den ästlichen Abhängen des Felsengebirges entlang, das mittlere Michigan, Wisconsin und Jimmesota und dem Alleghanygebirge entlang his zu den hörhstem Gipfeln ron Tordcarolina.

Er gedeiht am besten auf' leichtem, felsigrem, trockenm Bomlen, auf sumpfigem Gelände rerkrüppelt er.

I as Holz ist weich, leicht, elastisch, nicht stark, dicht- mol geradtaserig. sedenähnlich. Die schichten dex kleinen Summerzellen sind dium und hatrereich. Die wenigen Harzadern sind klein und die wenigen Markstrahlen sind deutlich. 1)ie Farbe ist weissrot, oft nahezu weiss, der Splint ist heller.

Rangstellung merer den nordanerikanischen Hölzern: die 357. in spezifisches schwere, die 855. im verhältnismäsigen Bremwert, die 62. im Coufticienten der Elastizitiat, die 162. in der Bruch-

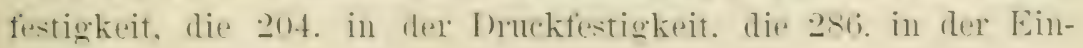
druckfestigkeit.

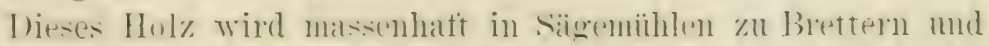
Latten verschnitten, die unter dem Samen sintue in den Hamdel

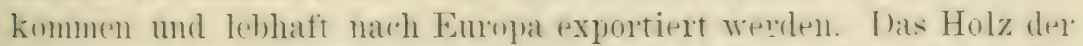

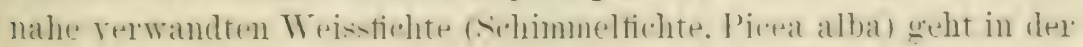


mordamerikamischen L"nion stets ebenfalls unter dem Namen Spruce, wibluend man es in Camada gewöhnlich als White spruce gesondert hält und nur die ïbrigen Fichtenhölzer einfach als spruce verkautt. Der Grund ist schwer ersichtlich. Die Weissfichte ist wohl der weitaus häufigste Baum in Britisch Nordamerika und wïrhst etwats grössel wie die Schwarzfichte, allein ihr Holz ist ni.ht gleichwertig; es zeigt geringere Zahlen in der spezifischen Silhwere, Elastizitat, Bruchfestigkeit, Druckfestigkeit und Eindruckfestigkeit.

Der änsserliche Unterschied ist allerding's gering. Das Weissfichtenholz hat mehr Markstrahlen wie das schwarzfichtenholz und schimmert in's Gelbe, während das letztere in's Rötliche srhimmert. Die Bretter der beiden Hölzer kommen in 3 Qualitäten in den Handel, ron welchen die dritte sehr knorrig zu sein pflegt.

Den Samen der Schwarz- wie Weissfichte liefern die nordamerikanischen Samenhandlungen zu 10 Mark pro Kilogramm. Beide Bäume wachsen schnell und rertragen nur eine mässige Beschattung.

37. Strandfichtenh $01 \mathrm{z}$.

Strandfichte, Sitcha-Fichte (Picea sitchensis, Familie ('oniferate). T'ideland Spruce in Californien.

Ein stattlicher Baum ron grosser, industrieller. Wichtigkeit, der eine Höhe von t5 bis 60 Meter, bei einem stammdurchmesser von 2.40 bis 5,20 Meter, erreicht. Der stamm wächst prramidal mul ist mit einer schuppigen, dicken. rotbramen Rinde bedeckt. Die Nareln sind flach, zngespitzt, etwa 2--3 Zentimeter lang. Die Fruchtzapfen sind cylinderish oral, \& Zentineter lang. fahlgelb, der Same ist dium und hängt an einem dreimal längeren Flügel.

Der Bamm wird, ob mit Recht wher Emecht sei dahin gestellt. die riesigste aller Fichten genamnt. Er wädost, wie sein Name andentert. an strand, selten dringt er tiefer wie 100 líilometer in's Inland vor. Meistens wird ex anf fenchtem Boden gefinden,

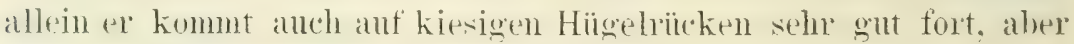
nicht anf Dünensand.

Das Terbreitmesgentet diestes Bammes liegt ron Alaskia im Vorden. der Kïste entang bis zum Comty Mendocino in Cali- 


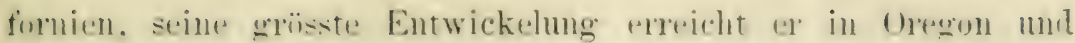

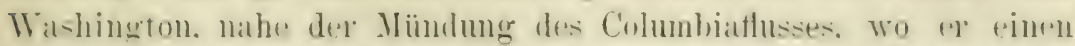
15 his 75 hilometer hreiter. fiast munterbrohenen Wa!dgiotel bildet.

Las Hol\% ist leicht, weich, nicht stark, dicht- mol geraulfartrig. seidenartig. Die Schichten der kleinen sommerzellen sint eng. dibht deutlich. die wenigen Harzadern sind undentlich. Die Markstrahlen sind zahlreich und hervortretend. Jie Farbe int lichthram ins Röhliche schimmernd, dex splint ist nahezu wei-s.

Rangstellung unter den nordamerikanisohen Hoilzern: die :379. in spezitischer sichwere, die:378. im verhältnismässigen Brennwert, die 105. in Coefticienten dex Elastizitä, die 22:3. in der

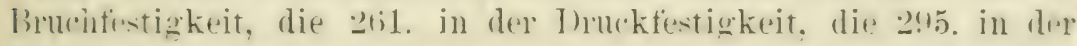
Eindruckfestigkeit.

Tnter dem einfarhen Namen spruce spielt dieses Holz winte wirhtige Rolle im Hamblel der Pazitikiöste. im Anslande wird is

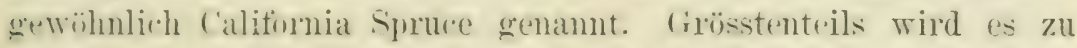
Brettexn rerschnitten, die zur imeren Auskleidumg der Hänstrer zu Holzwaren und Küferarbeiten und in schiffbau zu Zwischenderk- ma Bodemplanken dienen. Ler kleinere 'Tril wird zu leichteren Bauten, Zäunen u. s. w. verwendet.

Da die \%ahl dex am reestrande credeihenden Sutzbaume aroring ist. sollte dieser schnellwahlsende, wertrolle Baum der Be-

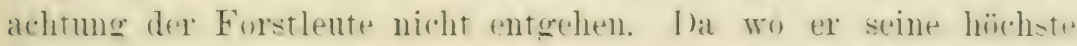

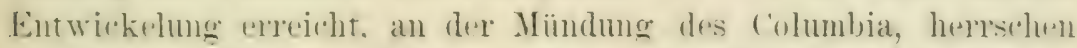
den grüssten 'Teil des . Jahres raulue, kalte Winde. die häufig zu stïmen ïbergehen. Dicke libel sind dort eine gewohnte Wittrrungserscheinung; strenge Winter treten nicht auf.

Len sitmen der strandfichte fïhren die californischen simen-

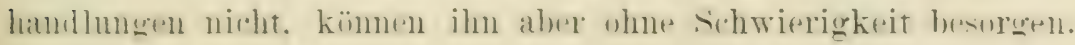

\section{Douglasfichtenholz.}

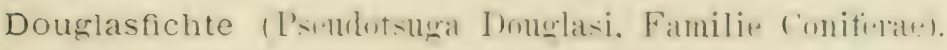

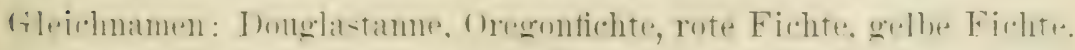

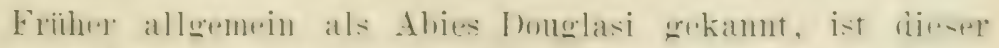

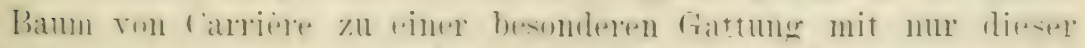

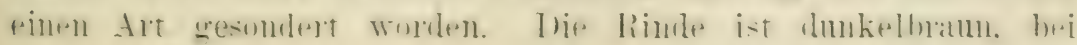


iilteren Bäumen sehr dick und tief gefurcht. Die Nadeln sind etwa 21: Zentimeter lang, linealisch, mit glatten Rändern, deutlich gestieit, oben leicht gefurcht, unten mit einem schwach bläulichen Schimmer. Die Bliiten treten ans den Winkeln der letztjährigen Blätter, die im ersten Jahre reifenden Fruchtzapfen sind längend, länglich eiförmig, zugespitzt, 8 bis 12 Zentimeter lang, $2^{1} / 2$ bis 5 Zentimeter im Durchmesser. Ilie verhältnismässig wenigen Schuppen sind gross und lose geordnet.

Verbreitet ist dieser Baum im Küstengebirge und auf den inneren Hochebenen ron Britisch ('olumbia, südlich vom 55. Breitegrad und östlich bis zu den östlichen Abhängen des Felsengebirges, wo der 51. Breitegrad die nördliche Grenze bildet. Femer in den Gebirgen ron Washington, Oregon, im californischen Küistengebirge und an der westlichen Abdachung der Sierra nevada, in den Gebirgszügen ron Idaho und rom westlichen Montana, Wyoming und colorado. im Guadalupegebirge von T'exas, in Wahsatch- und Uintahgebirge, in den Gebirgszïgen des nördlichen und östlichen Arizona's und im nördlichen Mexiko. Dieses Gebiet lässt eine Lïcke zwischen der Sierra nevada und dem Wahsatchgebirge, südlich von den blauen Bergen Oregons und nördlich von Arizona, wo bis jetzt dieser Bamm noch nicht entdeckt wurde, der als der weitverbreitetste und wichtigste Waldbaum der Pazifikregion gelten muss.

Er erreicht eine Höhe von 60 bis 92 Meter bei einem Stammdurchmesser ron 0,80 bis 3,65 Neter: in den Felsengebirgen bleibt er jedoch bedentend kleiner, hier wächst er selten bis zu 30 Meter Höhe. Eine Form nit grösseren Fruchtzapfen und schmäleren, spitzeren Nadeln (var. macrocarpa, Engelmamn) kommt in den San Bernardino- und Cuyamacabergen in siidcalifornien vor - ein kleiner Baum mit dunklerem, leichterem und geringwertigerem Holz wie die Grundform.

Das Holz ist hart. stark. danerhaft, dicht. zälı und elastisch. gerad- und regelnässig gefasert und schwieriger zu bearbeiten wie viele andere Nadelhölzer. Durch eine Fülle ron spiraligen Holzzellen unterscheidet es sich von allen anderen Nadelhölzern. Die s.hichten der kleinen Sommerzellen sind breit, sie nehmen die volle Hälfte der Breite der Jahresringe ein, sind dunkelfarbig; deutlich und werden bald so hart, dass sie schwierig zu durch- 
schurden sind. Die Markstrahlen sind zahloreh und undentlich. Jie Farbe wochest rom hellow zo geelb, der diume splint ist nahezu weiss.

Rangstellung unter den nordamerikanischen Hailzern: dir 307. in spezifischer schwere, die soti. im verhältnismäsimen Bremwert. die 20. im coefticienten der Elastizitä, die 101. in der Bruchtestigkeit. die 81. in der Irukfestigkeit, die 252. in der Eindruckfestigkeit.

Bei der Anfmerksamkeit. Welche man in der Nenzeit dissem Batume im Auslande. zumal in l entschland, geschenkt hat, glaube ich scharf betonen zu sollen, dass sein Holz ungewöhnlich grosse Ahweichmeren in der Qualitit zeigt. Von einem Bamme, der, wite die Thuglastichte, ron der Meeresgleiche his zu Erhembugen von filst :3000 Ileter rorkommt. der sich dem fouchten Kïstenklima anberatemte mod die bitterstrengen Winter im Felsengebirge überdimert. der in heissen, regenamen Arizona und im sprüchwärtlich regenteichen Oregon wohnt, wird man kein Holz gleicher (qualitat (rwarten, aber auftallend ist die Erscheinung, dass da. wo die Houglastichte ihre grösste Entwickelung erreicht, im westlichen Wa inington, namentlich in der Lmgebung des Pugetsundes, wo sir grosse, zusammenhängende Wälder bildet, bedentende Qualitaitsabweichmeen beobachtet werden. Die sägemiuller muterscheiden hier zwischen der ., roten und gelben Fichte." I)ie Erstere liefert dunkeleres und grobfiaseriges, als geringwertiger erachtetes Holz wie die Letztere. Manche glauben diesen Untersehied durch filiederungen in spielarten, also durch Abweichungen von der Grundform, sklären zu hönmen. allein gewiegte Botaniker haben diese Annahme verworfen und die Termutung ausgesprochen Altersunterschiedr böten die Erklärung, die sägemiiller aber schiitteln dazu die Köpfe.

Wiu now so vieles im Wesen der nordamerikanischen Waldbïume zu erklären ist, so auch diese Erscheinmog, welche im Auge zu behalten man im Auslande wohl thum wird, damit man hei Einfiihrungsversuchen diesen Bamm nicht voreilig veruteilt.

Wohin man auch die Inuglasfichte überträgt. man wird erforschen miissen. anf welchem Boden sie das beste Holz liefert. In ihrer Heinat heunemt sie sich, allsere dem Sumpfe, jedem Borlen an. allein es ist noch festzustellen. anf welchem das Holz erster 
( ) nalitat wird. In dem erwïhnten Gebiete am Pugetsund ist der Buden aus Basalt und noch jüngerem, vulkanischem Gestein hervingegangen. Nebel, Regen und Winde sind häufig, der Winter aber tritt milde auf. Hier will man ein im Vergleiche mit anderen Nadelhïlzern schnelles Wachstum der Douglasfichte beobachtet haben.

Auf' die Thatsache glanbe ich aufmerksam machen zu sollen, dass man schon vor vielen Jahren im östlichen Nordamerika - diesen Baum einzuführen suchte und zu diesem Zwecke Samen ron der Pazifikkiiste bezog. Die mehrmals wiederholten Tersuche schlugen vollständig fehl, man sah darin eine weitere Bestätigung der Erfahrung, dass die Bäume der Pazifikwälder östlich des Felsengebirges nicht gedeihen. Terhältnismässig spät wurde die Donglasfichte im Felsengebirge entdeckt, anfänglich aber, wegen inres schwächeren Wuchses, für eine Abart gehalten. Botaniker stellten jedoch die Übereinstimmung mit der Grundform fest. und nun wurden jene Einführungsversuche mit Samen von den am weitesten nach Osten vorgeschobenen Bämmen erneuert, diesmal mit vollem Erfolge. Gleiche Bestrebmgen, mit gleichen Enttäuschungen und Erfolgen haben bezïglich der westlichen Gelbkiefer (Pinus ponderosa) stattgefunden.

Die nordamerikanischen Samenhandlungen bieten den Samen der Douglasfichte mit 75 Mark pro Kilogramm ohne Angabe des Herkunftsortes an: der Besteller darf es aber nicht unterlassen, sich dariiber zu unterrichten.

Das Holz der Douglasfichte geniesst als Oregonpine *) einen weltweiten Ruf. rorzugsweise wird es ron den Sägemühlen am Pougetsunde und im nordwestlichen Oregon in deri Handel gebracht. Es dient als Balken zu Haus- und Brïckenbanten, als Bretter zur inneren Auskleidung der Häuser, zı Tischlerarbeiten und Holzwaaren, auch als Brennstoft und zu Bahnschwelien ist es heliebt. Schiffsmasten ans diesem Holze sind sehr geschätzt, doch vertragen sie nicht so viel Reibung wie die ans Kamikiefernhol\%.

Zur besonderen Empfehlung dient dem Douglasfichtenholz, dass es auffallend frei von Kinorren und unregelmässigen Faserungen ist. In sägemühlen werden oft Stämme ron 2t Meter Länge

*) Anm. Richtiger wäre Oregon Spruce oder Oregon Fir; denn Pine ist Kiefer, Spruce: Fichte und Fir: Tanne. 


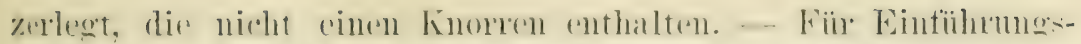

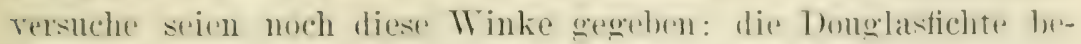

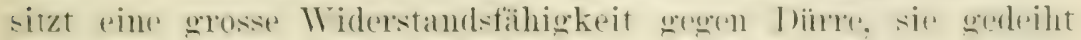
ant windigen standenten und verträgt riemlich viel sehatten.

39. Ed e l t a n n e n ho $1 \%$

Edeltanne"). Edelweisstante (Abies nobili.: Fam. (onifirar). dileidhame in Amerika: Rote 'Tamne. In Inentschland: Silhertame.

Die Gattmong Abies zerfaillt in ot Arten, die alle ant der nördlichen Erdhältte heimisch sind, 9 derselben kommen in Nordamerika vor.

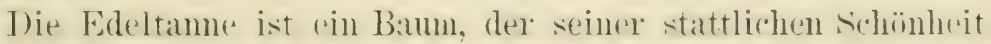

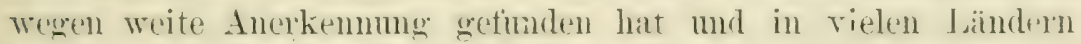

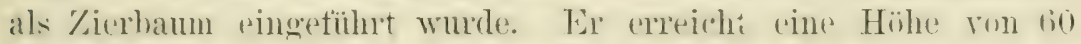
bis 9.2 Meter. bei rinem Stammdurchmesser ron 2.41 bis 3 Meter. Dir dicke Rinde ist ausien zimtham, innen rot. I)ie Nadeln sind steif. otwas aufwäts gebogen, gespitzt, glänzend. etwa $2^{1}:$ Z Zentimeter lang und bedecken die obere Seite der Zweige. 1)ie Fruchtzapten sind cylinderisch, anfrecht, 15 bis 20 Zentimetel lang. stumpt zugespitzt. die sichuppen sind rexhältnismässig schmal, die dinnen samen haben Flïgel, die breiter wie lang sind.

Inas Terbreitmosgebiet zieht sich rom columbiafluss dem Cascarlegehirge südlich entlang bis nach dem nördlichen Calitornien, in einzelnen, aber in den kräftigst entwickelten Exemplaren. tritt er im Küstengebirge von Oregon auf.

I)as Holz ist leicht. hart, stark. sehr dichttaserig. Ilie Schichten dex kleinen sommerzellen sind breit. deutlich. harzig, dunkelfarbig.

Die Markstrablen sind diunn und kamm zu erkennen. Die Farhe ist linhtham. ins rötliche shommernd, der splint ist otwats dunkler.

Rangstellung unter den nurdantrikanischen Heilzern: die

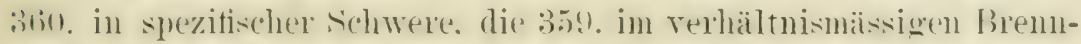

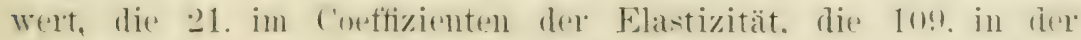

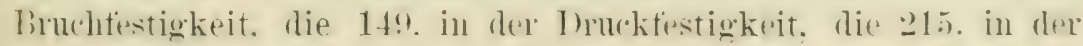
Eindruchfestigheit.

*) Anm. Nicht zu verwechseln mit der deutschen "Edeltanne" $=$ Weiss-

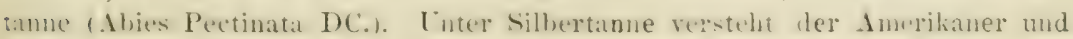
Englïnder sämtliche echten "Tannen" Abies. 
Von den ! nordamerikinischen Arten der Gattmng Abies liefert die Edeltanne das vorzilglichste Holz, und wenn es bis jetzt wenig benutzt wurde, so liegt die Erklärung in der Unzug:inglirhkeit der Wïlder, die in Gebirgsgegenden liegen, wohin keinr IIasserstrasse führt und bis jetzt noch keine Eisenbahn gebaut ist. Zu bezweifeln aber ist nicht, dass die Edeltanne als Waldbaum eine Zukunft lat. Danit ihm diese wird, ist es wichtig. dass ihm Terwechselungen mit seinen Artgenossen erspart bleiben. Im Cascadegebirge bildet er gemeinschaftlich mit der Abies amabilis mn im nördlichen ('alifornien mit der Abies magnifica, die ebenfalls rote 'l'ame (Fir) genannt wird, ansgedehnte Wälder. Diese beiden Arten liefern aber ein beträchtlich geringwertigeres $\mathrm{H}_{\mathrm{n}} \mathrm{l}$ \% wie die Edeltanne.

Die Letztere scheint sich mach den Erfahrungen, welche als Zierbaum mit ihr gemacht wurden, jedem Boden anzubequemen. der nicht nass ist. In ihrer Heimat kommt sie vorzugsweise aut Bïden ror, die aus Granit, Basalt, Lava und Sandstein hervorgegangen sind.

Den Samen dieses Bammes liefern die californischen Samenhandlungen für 60 Mark pro Kilogramm.*)

\section{T a marackhol z.}

Tamarack (Larix occidentalis, Familie Coniferae).

Wie der botanische Name erkemnen lässt, ist dieser Batm ein Gattungsgenosse der emopäischen Lärche, zwei andere besitzt Nordamerika noch, die aber entschieden geringwertigeres $\mathrm{Holz}$ liefern. Das Holz der vorzugsweise auf sumpfigem Gelände ron Teufundland bis Pennsylvanien vorkommenden Larix americana, gewöhnlich Hackmatack, seltener ebenfalls Tamarack genamnt, wird zwar häufig zu Bahnschwellen, Telegraphenstangen und auf den nordamerikanischen Schiffswerften verwendet, allein man hat erkamnt, dass es von geringerer Güte ist, wie das Holz der emopaiischen Lärche, was Teranlassung gegeben hat, die Letztere in Nordamerika einzuführen, wo sie recht gut gedeiht.

*) Anm. Es verdient hervorgehoben zu werden, dass die californischen Samensammier äusserst unzuverlässig in Bezug auf die Benennung der Bäume sind. Wer sicher gehen will, informire sich genau nach guten amerikanischen Werken, z. B. "The woods of the United States" von Prof. C. S. Sargent. 
Anders rerhailt es sich mit dex 'Tamallatek, die ein rorzitgliohes

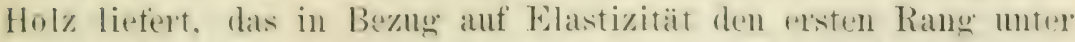
den nordanerikanischen Hökern einnimmt. Heimisch ist dirier

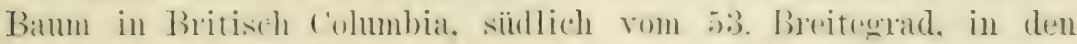
Gehirgen rom Malshington und voll da istlich bis zu den westlichen Abhängen des Felsengebirges in Montana; sibdlich vom Culumbia kommt er nur in den blatuen Bergen von oregon vor.

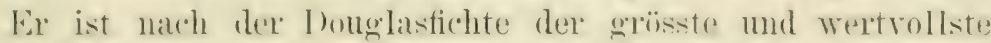
Baum des columbiabeckens. Soine Höhe bewegt sich zwischen :30 und to Jeter bei rinem stammdurchmesser rom 0,90 bis 1,50) Metex. Die kuzen, schwanken Äste sind hängend, und da sie sich nicht rerzweinen, bietet der Batm ein kahles Anssehen. Die Nadeln sind lang. sehr dïm und bläulicherïn. I) Fe Fruchtzapfen haben dies

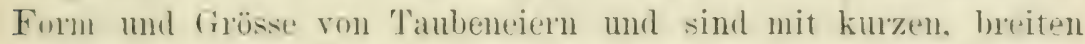
Schuppen bedeckt. Der Stamm wäthst vollkommen gerade.

Die 'lamarack ist ein Gebirgshatum, sie kommt in Erhehmoen von ion his 1500 Meter ror, hamptsächlich an den Efern ron GeWïsselm. doch diuf daraus nicht geschlossen werden, sie sei. gleich der Hackmatack, ein Sumpthaun. Die Tamarack liebt einen feuchten, durchlatsenden Boden, in dem sich niemals frumdwasser sammelt, fernex viel Sommenlicht und Luft. Nirgends bildet sie monemischte Täder. stets steht sie zerstrent zwischen anderen Taldbämmen, wie wir es anch bei der emropäischen Lärche zu sehen gewohnt sind.

lits Holy ist schwer, alsserordentlich stark und hart, aicht grobfaserig, seidenartig, nimmt eine schöne Politur an und ist sehr dantrhaft in Berïhrmg mit dex Erde. Die sehiehten der kleinen sommerzellen sind hreit, sehr harzereh, dunkelfarbig. Die wenigen Harzadern sind undeutlich. Die Markstrahlen sind zahlreich und dium. Die Farbe ist licht helhot, der diume splint ist nahezu weiss.

Rangstellung unter den nordamerikanischen Hölzern: die 135. in spezitischer sichwere. die 130. in rerhältnismässigen Brennwert, die 1. im roefficienten dex Elastizitit, die 7 . in der Bruchfestigkeit, die 15. in der Intuktestigheit. die 191. in der Findruckfestigkeit.

Jur gelegentlich wird dieses $\mathrm{H}_{0} \mathrm{l} z$ zu Brettern verschnitten. vorzugweise wird es zu Bahnschwellen. Telegraphenstangen. Pfosten, Balken. im schiftbau. ̈̈berhaupt zu den Zwecken gelnrancht, für welche man das eurupäische Lä̈rhenholz zu verwenden ptlegt. 
Iten samen dieses Bammes tïhren die nordamerikanischen Famenhandlungen nicht: um ihn zu beziehen, setzt man sich am hesten mit den californischen Samenhandlungen in Verbindumg.

(Siche Anm. auf Seite 616.)

\section{Verschielene Hölzer.}

\section{A k a z i enhö $\mathrm{lz}$ er.}

Die aus Bäumen und Stränchern bestehende Gattung Acacia gehört zur Familie Leguminosae und zur Unterfamilie Mimoseae. Ihre etwa 420 Arten sind weit zerstreut über die warme Region der Frde, doch entfällt die ïberwiegende Mehrheit auf Australien und Afrika. während Europa leer ausgeht. Da im gewöhnlichen Leben nicht selten Akazien und Mimosen verwechselt werden, sei bemerkt, dass sich die Gattungen Acacia und Mimosa imnerhalb ihrer Familie am nächsten stehen, aber doch folgende leicht erkenntlichen Lnterscheidnngsmerkmale besitzen: die Blïten der Ersteren laben mehr Stanbfaden wie die Letzteren, und den zweiklappigen Fruchtschoten fehlen die Querabteilungen der Mimosenschoten.

Die Blüten der Akazien sind klein und in rundlichen oder läuglichen Büscheln geordnet. Die Blätter sind im allgemeinen gefieciert, bei einigen, grösstenteils in Anstralien heimischen Arten sind die Blattstiele geflacht und dienen als Blätter. Diese Arten werden deshalb blätterlose Akazien genannt; bei mehreren stehen die Ränder der Blattstiele gegen Himmel und Erde, weshalb die Kronen keinen vollkommenen Schatten werfen kïmen.

Eine beträchtliche Zahl der Arten besitzt eine mehr wder minder hervorragende Wichtigkeit für Handel und Industrie, wenige aber nur bezïglich ihres Holzes. Acacia arabica, A. vera, A. Ehrenbergii. A. speciosa und A. tortilis liefern arabisches Gummi, ron A. verek, A. seyal, A. nilotica und A. Andansonii wird das Senegalgummi, von A. gummifera das Berbereigummi gewomnen. Ein ähnliches. aber geringwertigeres Gummi wzengen die in Anstralien heimischen A. decurens, A. mollissima, A dealbata mod A. affinis, sowie die in Südafrika rorkommende A. Karru. Der catechu ist cin Produkt ron A. catechu. die Fruchtschoten ron A. concinna hilden in Indien einen Handelsartikel, da die Samen die Stelle der Seife rertreten kännen. In Nordafrika werden die Fruchtschoten ron A. nilotica unter dem Namen Yeb-neb als Gerbstoff 


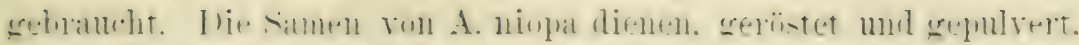

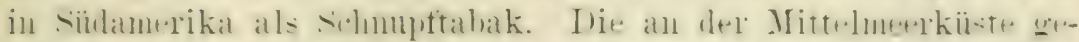

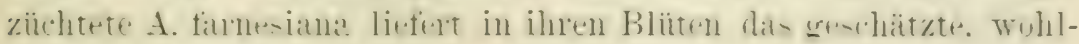
riechende Cassiäil.

Fine steigende Wirhtigheit al: lierbstoff besitmt dir hind,

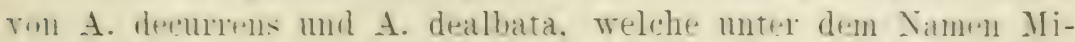
mu-arinde ron Anstralien in den Handel grebracht wird. Ine Gultur diesel Bämue zum Zwereke der Rindengewimnung ist in dem 2. Bande der tropischen Agrikultur ausfïhrlich egechildert. Ebentall- zum (repten dient dir Rinde ron A. arabica. volzugsweise in Indien. wo sie den Namen Babulrinde führt.

Zwar findet das Hol\% mehreler der erenamuten Arten Texwemlung. namentlich von $\mathcal{A}$. decurens und $\mathrm{A}$. acaria, allein es

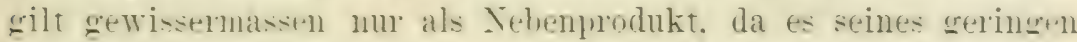
Lnfangs wegren nur eine beschränkte Terwendung finden kann Verabeitet wid es volusweise zu Fasseifen. Rarlspeichell. Rarl-

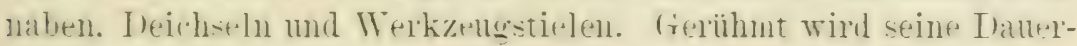
haftigkeit und Härte.

Zun ansichliessichen Zwecke der Hulzproduktion hathen his jetzi nu die folgenden wenigrn Alten Beachtung grefunden. virl-

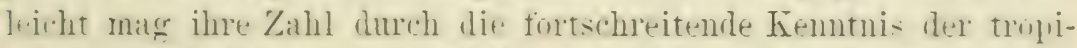

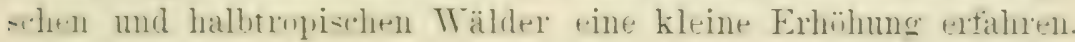

\section{a) Myallholz.}

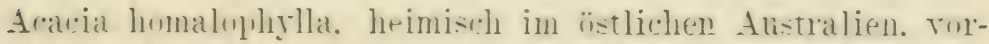

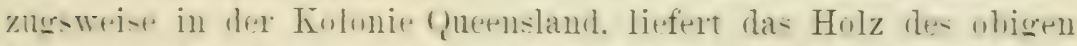
Namens. Der baum ist solhwarhwïchsig. der stammdurchneser

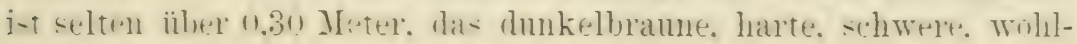
riwhende Holz rlaher nur von nüs-igem Lmfange. Was natürlir.lt sine Verwendbarkeit berchänkt. Torzugswelse dient $\cdots$ zu

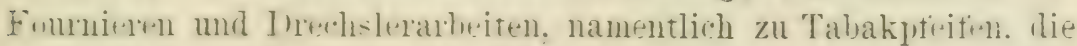
in Australien sehr beliebt sind.

So langr das Holz unpolient heibt. bewahnt es seinen rigentiimlichen Veilchengeruch.

ler same dimer Art. wite der fulgenden. kann von jeder

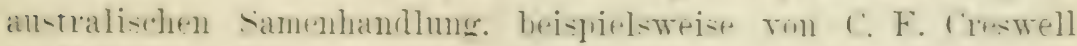
in Melbourne, bezogen werden. 


\section{b) Schwarzholz.}

Blackwood wird in Alstralien sowohl der Batm Acacia melanoxylon wie sein Holz genamt. Das ist einc der grössten Akazien. sie rreicht eine Höhe von 24 Meter bei einem stammdmolnmesser von 0.60 bis 0.90 Meter. Heimisch ist sie im istJichen Anstralien und in Tasmanien, wo sie in tiefgründigen Binden. vorzugsweise in fenchten 'Thätern und an Flussufern rorkommt.

Das Holz steht in dem genamnten Verbreitungsgebiet in hoher "Tertschätoung: es ist dunkelbraun, hart. dauerhaft und nimmt eine so schönt Politur an wie Wallnussholz. Verarbeitet wird es zu feinen Möbehn, Eisenbahnwagen, Billardtischen, Fomrnieren und im Schiffhau. In gedämpftem Zustand biegt es sich leicht olne Beschädig'ung der Fasern.

C̈ber die Bruchfestigkeit und Elastizität sind Zahlen im Abschnitte ïber die Holzkunde zu finden.

\section{c) Himbeerduftendes Holz.}

Acacia acuminata, heimisch in Westanstralien, liefert dieses wie Himbeergallerte duftende Holz. ron dem in seinem Terbreitungsgebiet mit hoher Anerkennmg beziiglich seiner Brauchbarkeit zu feinen Mäbelı und ähnlichen Gegenständen gesprochen wird, anch in Engiand haben die wenigen dahin exportierten Püstchen recht gut gefallen. Indessen haben Ansländer noch zu wenig Gelegenheit zur Beurteilung gehabt, als dass eine abgeschlossente Charakteristik gegeben werden kömnte.

\section{d) Sabicuholz.}

Ein schon lange in Europa gewürdigtes Holz, das der in Tiestindien heinischen Acacia formosa entstammt. Am hänfigsten kommt der Baum in ('uba ror und fast nur von dort findet der Export des Holzes statt. Der Stamm wächst häufig nicht ganz gerarte und erreicht nur eine astfreie Höhe von 6 bis 12 Meter, bei einem Durchmesser von 0, 40 bis 0.80 IIeter, doch wird dieser Narhteil in hohem (riade aufgewogen durch die fast rollständige Fehlertreiheit und den sehr dimnen Splint, sowie das unbedentende Schrumpfen während des Trocknens. Bei der Bearbeitung gibt es also wenig Abfall, zumal Kermrisse. Stermrisse und Kreisrisse 
nul seln selten und immel nur in der mildesten Form anfureten:

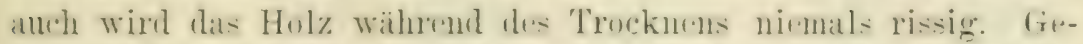

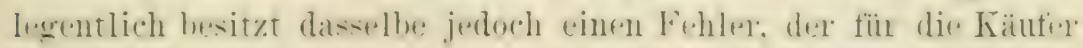

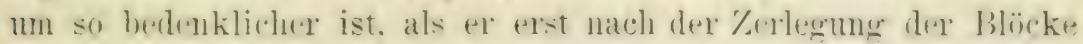
entleckt werden kamn. Fr bestrht in zerrisenen Fastrm in dere Vähe des Markkerns, dariert also selur wahrselueinlich alls dere Jugend und mag durch starke schwankungen de- Stammes unter der Gewalt von Stïrmen entstehen.

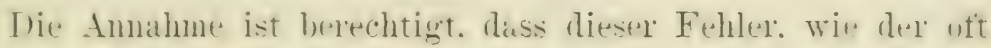

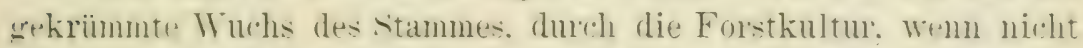

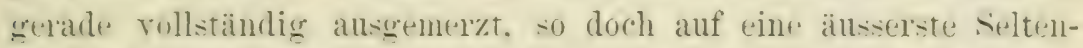
leeit herabgedritckt werden kinn. Eine forstliche Behandlung hat dieser Bam bis jetzt nicht erfahren. am wenigsten in Cubal. wo dir. Wiader einer Raubwirtschaft den rohesten art meterworfen sind.

Thas Sabiculolz ist von dunkelkastanienbauner Farbe. hart, s.hrer. stark. dichtfaserig. nimnt eine sehr schöne Politur an und ist ausserordentlich dauterhaft, selbst wenn es whe Anstrich wder Lack dem Wetter ausgesetzt ist. Häntig ist es prächtig dunkel gemasert, solche stïche bezahlen die Mröheltischler mit sehr hohen Preisen.

I)anit ist eine Torwendung dieses Holzes angedentet: in der Möbeltischlerei. Im weiteren sinne ist es ein luxushol\% muss es doroh häutig Rosen- mol . Iacarandaholz esetzen. Former wird es

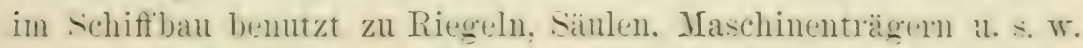
- sim bedentendes spezifisches Gewicht, das in Durchschnitt 0.916 beträgt, verhindert steine anserelente Anwendung bei Hausbanten.

Ther die in Zahlen antriithbaren phrsikalischen Eign-

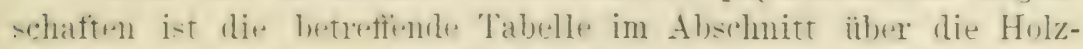
kumbr nachzusehen. Fin Vergleich zeigt. dass dats sabicuholz einen hohen Range eimnimnt in Bezug anf Bruchfestigheit. Drucktestigheit. Zugfestigheit und Elastizität. Jur mit wenigen Hälzexn teilt das sihicuhol\% die Eigensohatt. dass es eine hohe Belastung trägt wher Anzelehen des Bruches. Wird aber dir Belastung

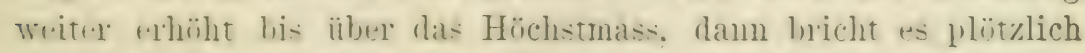

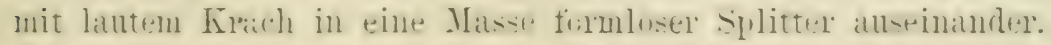




\section{Angeliqueholz.}

Seit Anfang der siebziger Jahre hat sich franziosisch Gulana bemïht, dieses Holz in Europa einzuführen, bis jetzt aber nur mit Erfolg in Frankreich. Es entstammt dem mässig grossen Batume Inicorenia paraensis, der einen astfreien Block bis zli 15 Meter Länge bei einem 1)urchmesser ron 0.80 bis 1 Meter liefert. Auch in Holländisch Guiana soll er rorkommen, aber in geringerer Zahl.

Das Holz ist rötlichbram, mässig hart, stark, zäh, elastisch und nicht schwierig zu bearbeiten, obgleich es sich nicht leicht spaltet. Gewöhnlich liegen die Fasern dicht und grad, nu selten sind sie gemasert. Der Splint ist sehr düm. Andere Fehler. wie gelegentliche Kernrisse in milder Form, besitzt dieses Holz in der Regel nicht. Es ist frei von Knorren und, mit der exwähnten Ansnahme, gesund bis anf den Markkern. Bei der V'erarbeitung gibt es mithin sehr wenig Abfall.

Das Holz soll sehr dauerhaft im Wasser sein und ron manchen Insekten rerschont bleiben. die andere Hölzer angreifen, weil es pinen unangenehmen Geruch ansströmt, der sich allerdings nach und nach verliert. Das ist ein Torteil und zugleich ein Nachteil, weil dadurch die Verwendbarkeit beschränkt wird.

Die Franzosen rerwendeten bis jetzt dieses Holz rorzug:weise im Schiffbau, empfehlen es aber für Banzwecke im allgemeinen. Die wenigen gemaserten Stiucke mögen sich türr die Möbeltischlerei eignen.

Die srezifische schwert wird mit $770 \mathrm{inis} 820$ angegehen.

\section{A raukarien hö I zer.}

Ibe Gattumg Arancaria, zur Familie Coniferae gehörond, besteht aus hohen Bämmen, die auf der sïdlichen Erdhälfte heimisch sind und als gemeinsames Merkmal zweihäusige Blïten besitz'n; die Stanbfäden der männlichen Blüten sind in 10 bis 12 Kitpseln fnthalten. welche an der spitze jeder schmple hängen. die weiblichen Bliiten sitzen zu zwei unter den schuppen, jede hat dine Samenknospe. 
Alle Arten sind immergrim. ihre Blatter sind breiter wie

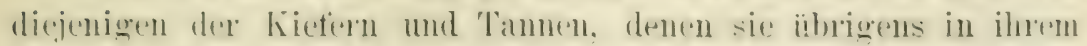
Gesamtaussehen gleichen.

A. imbricata, zuweilen ('hilitichte gernatunt, komment in den Andes ron chili vor, an deren westlichen Abhängen sie ansegedehnte Wïlder bildet, aber nicht nürdlicher wie Santiago gedeilht, da sie ein mäsig fellehtes Klima beansprucht. Lnter giinstiquen

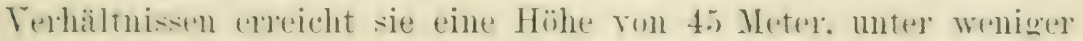

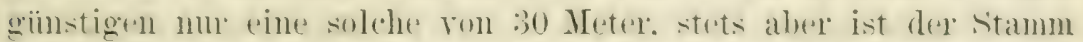
schnurgeral und knotenfiet. Die Rinde dex jungen Bälume int

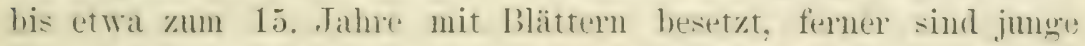
Bämue fast rom Grunde ans verästelt, alte Bämme tragen dagegen eine Krone aluf hohem, astfreiem stamm. Lie Fruchtzaptem sind rundlichoral, 20 bis 25 Zentimeter im l)uchmescer, die sechuppen emrlen in einer langen alntärmigen syitze, die samen sind keilfiiming mol tast 3 Zentimeter lang. Ile Rinde ansgewachsener Bülume ist 10 his 15 Zentimeter dick. die borke hesitzt pine korkartige 'Textur, der Bast ist schmammig-porös.

Alls allen Teilen des Baumes tuillt Harz ans und zwar in

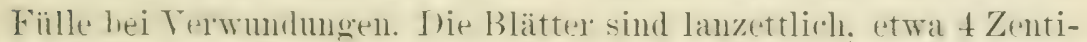
meter lanes. 1: Zentimeter am Grunde breit mol spitz zulatufend.

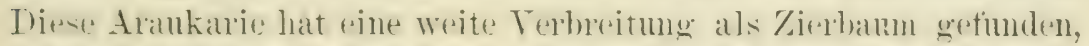

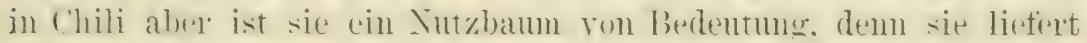

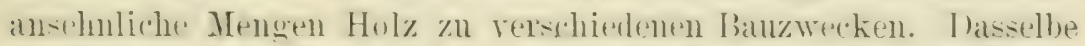

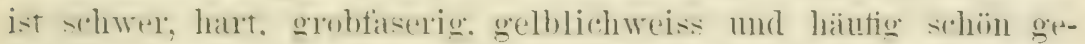

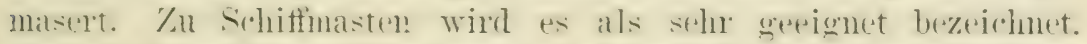
Thls Hal\% ist weiss. besitgt pinen nicht mangenthmen lieschmack und einem Geruch, der an Weihrauch erinnert. Es dient als Pflaster

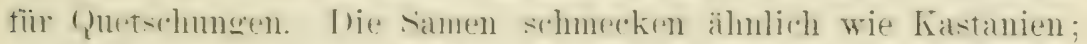
sir bilden ein wiehtiges Sahrmesmittel der Indianer, welche sie

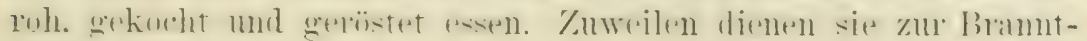
weindestillation.

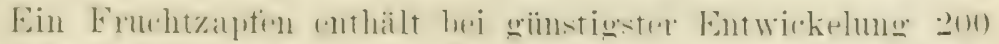

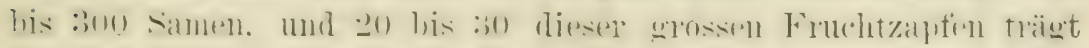
ein in rollex Lebenskraft stehender Baum.

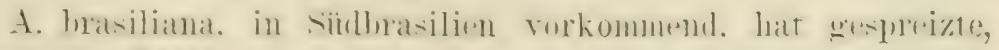

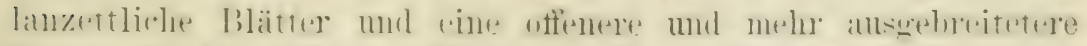

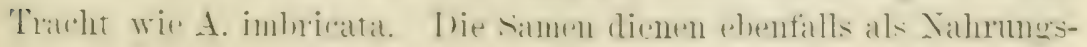


mittel, in welcher Fülle sie wahsen, zeigt, dass sie anf dem Markte ron Rio de Janeiro regelmässig rerkautt werden. Das weissliche, grobtiserige Holz wird in Nïdbrasilien vielfach zu Banzwecken verwendet, fïr die es sich lecht geeignet exweist, nur wird seine gringe Dauerhaftigkeit im Wechsel von Nässe und Trockenheit beklagt. I)as Harz wird mit Wachs rermischt zu Kerzen rerarbeitet.

A. excelsa führt den rolkstïmlichen Namen Nortolkfichte; sie ist auf der Norfolkinsel heimisch und wohl die grösste der Arankarien, erreicht sie doch eine Höhe ron 48 bis 60 Meter, mit einem Stamm von 2,50 bis 3 Meter Turchnesser und ist 24 bis 30 Neter hoch astfrei. Dit Blätter der jungen Bäume sind linealisch, diejenigen der alten Bämme länglichoval und dicht verwor'en. Die länglichovalen Fruchtzapfen haben eine Länge von 10 bis 12 Zentimeter.

Las Holz ist weisslich, zäh, dicht und schwer, lässt sich aber trotzdem ziemlich leicht bearbeiten. Es dient zu rerschiedenen Bauzwecken, ist jedoch dem Wetter ansgesetzt nicht dauerhaft.

Diese Araukarie ist, nächst der A. imbricata, als Zierbaum am bekanntesten geworden, in dor Ungebung ron Sidney spielt sie für diesen Zweck eine wichtigere Rolle wie andere Bäume, dort erregt sie durch ihre stattliche, anmutige Erscheinumg sofort die Aufmerksamkeit der Reisenden. Aber nur soweit wie die Seeluft inre Wirkung ansiibt, findet sich diese Arankarie; tiefer landeinwärts hat sich ihre Zucht noch immer erfolglos erwiesen. Bemerkenswert ist. das: in der Tingebung von Santiago in Chili die heimische A. imbricata des trockenen Klima's wegen schlecht fortkommt, während hier A. excelsa freudig gedeiht.

Ier same besitzt mehrere Eigentümlichkeiten, die interessant zu wissen sind. zumal sie schon mehrfach die Ursache zu gerichtlichen Prozessen zwischen Baumschulenbesitzern und Samenverkäufern geworden sind. I)a, wie bei der ganzen Gattung. so anch bei dieser Art die Blüten zreihäusig sind, kann eine Befruchtung nur erwartet werden. wo mämnliche mod weibliche Bämne nahe beisammen stehen. In diesem Falle reift eine Ernte in jedem 3. Jahre. Die Samen in dem mittleren Ringen der Fruchtzapten sind am krättigsten entwickelt. hesitzen also die stärkste Teimkraft, während diejenigen in den beiden Enden nahezu werthlos sind. Trenn der gesante samen eines Zapfens zu $50 \%$ " keimt, 


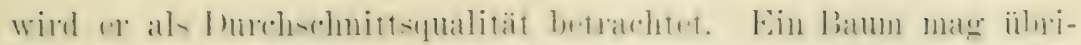

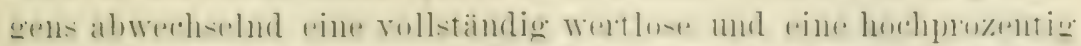

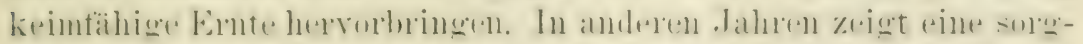

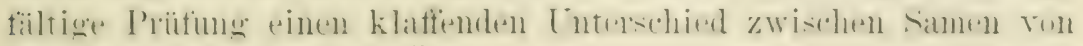
den oberen und unteren Ästen.

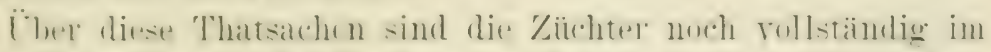

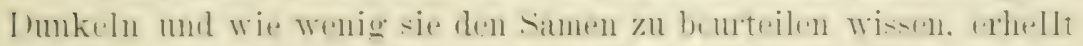

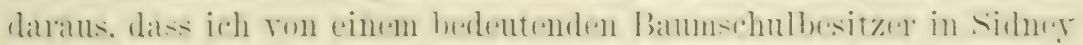

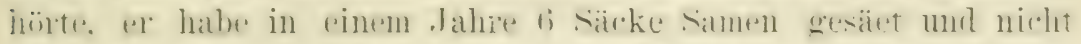

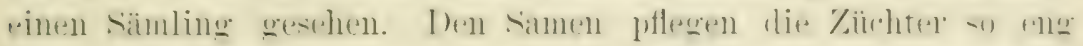
wie möglich zu säen.

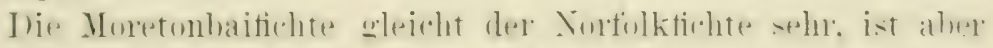

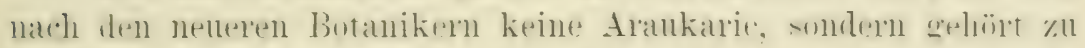

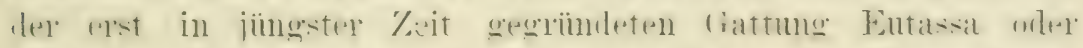

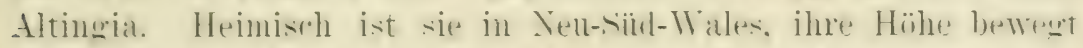

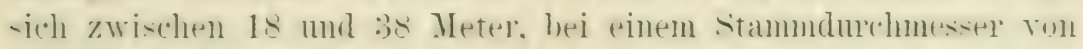

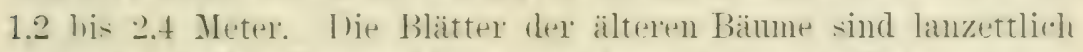

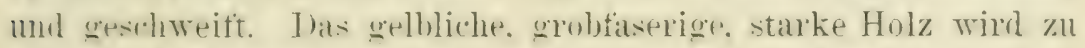

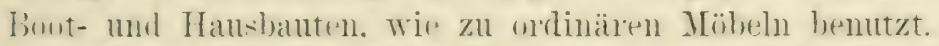

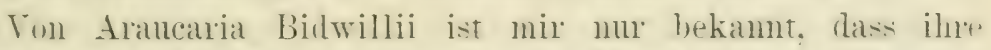

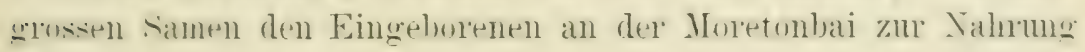
dienen.

\section{Buchsta be n hol z.}

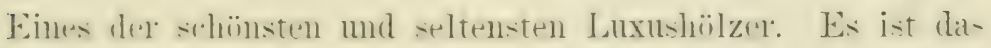

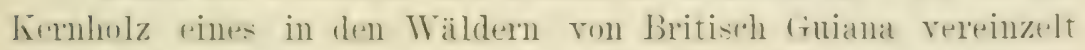

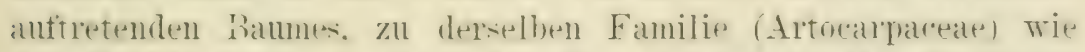

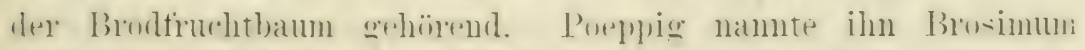

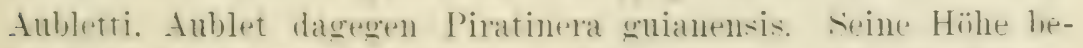

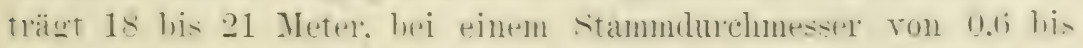

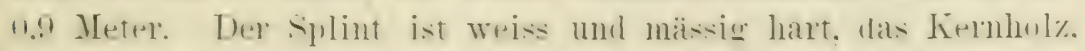
welches selten einen wässelun Durchmesser wie 200 Zuntinnter

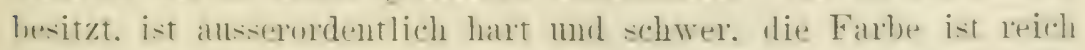

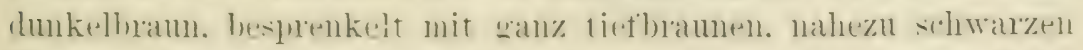

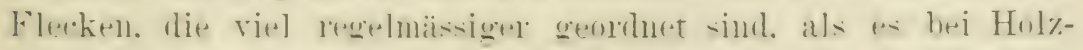

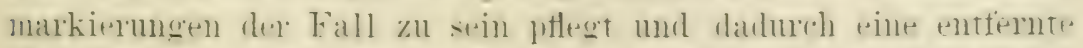

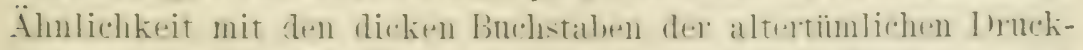

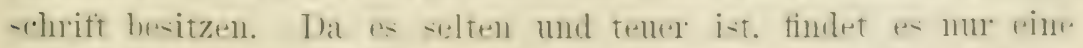

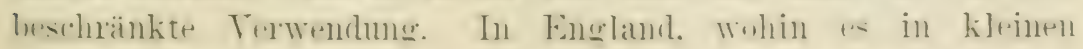


Pöstchen exportiert wird, dient es zu feinen fournieren und ein-

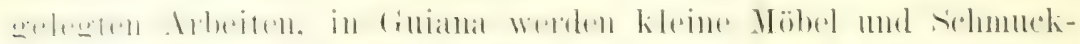

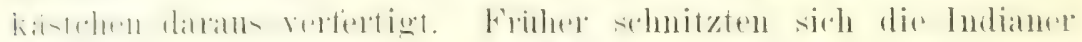

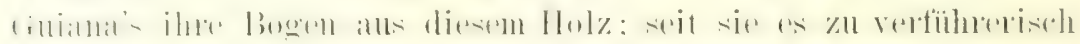
tenteren Preisen rexkanten kömnen, begniigen sie sich, geringwertigere Hölzer zи diesem '/wecke zu verwenden.

$$
\text { 5. } 13110 \mathrm{~h}=\mathrm{h} \| 1 \%
$$

Die Gattung Buxus, zur Familie Euphorbiaceae gehörend,

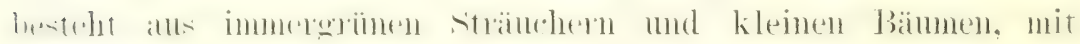

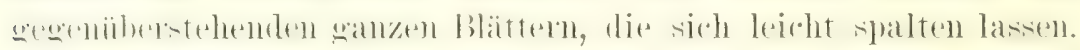

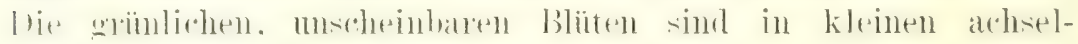

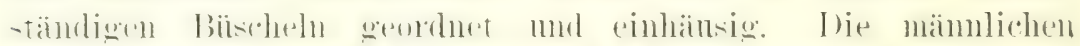

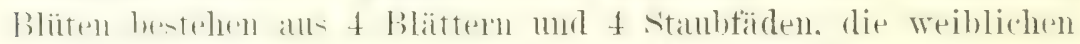

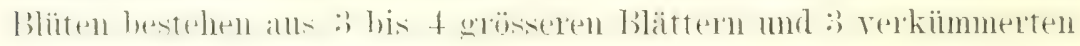

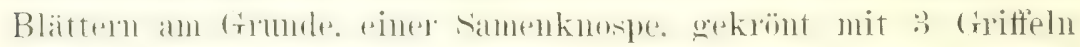

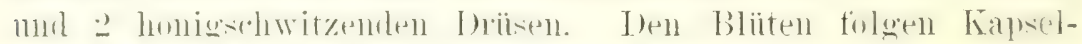

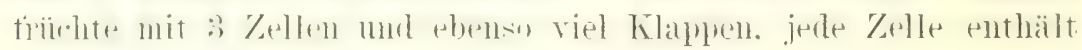
2 bis : schwarze Samen.

Die wichtigste trt ist der gemeine Buchsbaum (B. semperrirens). Welcher in südlichen Europa und vorderen Asien heimisch ist. In Europa kennt man ihn nur als Zierstrauch, in KRleinasien und in Kankasus aber hilft er Wälder bilden, encicht aber auch hier nur eine Höhe von 7,5 Meter, bei

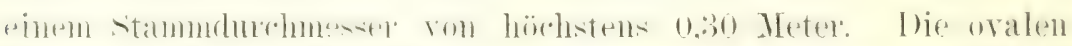

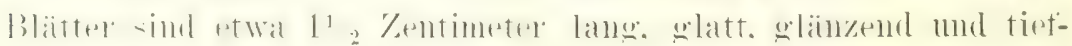
griin. Die Äste stehen gedrängt und verwachsen in einander, dalurch entsteht pine ansserordentlich dichte Krone. Mehrere

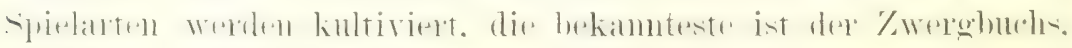
melcher zu Gartenbeeteinfassungen dient.

Die Blätter haben einen mangenehmen, bitteren Geschmack

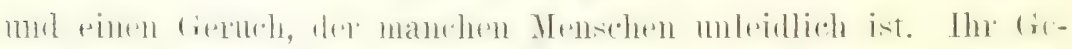
nuss remusicht staken Durchtall.

Das Holz ist schwerer wie ein anderes, das in Europa wächst, mol das einzige emropaicche, relches im Wasser sinkt; die spezi-

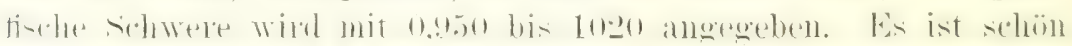

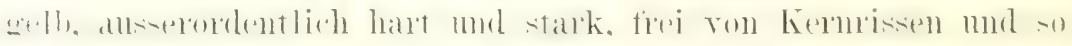
fest und dicht am Markkern wie kein anderes Holz. Seine 'Textur ist fein, regehmässig and geschlossen, es nimmt eine sehr schöno 


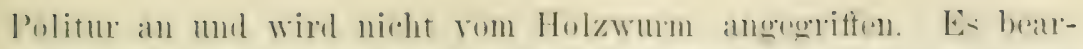
beitet sich glatt und mit stidenartigem Glanze. spaltet sirhe rom

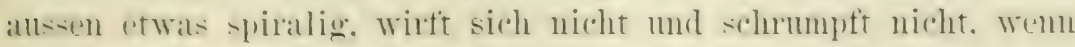
es gut getrocknet ist.

Spanien und Portugal nahmen früher bedentenden Anteil an del l'roduktion dieses Holzes. gexgenwärtig kommen sir als Bezugequelle nur wenig in Betracht, als solche haben nur noch llichtigkeit die: Wähler am sïdlichen Abhange des Kankasus, dorh gehen auch hiex die Vorräte so stark anf die Neige dass die Torsicht gethot. nath einem Ersatz zul surhen, doreh hat mall rinen roll hefrierligenden bis jetzt nicht getumlen, olggleich man dit Angen

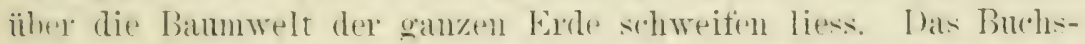
holz ron Abassia gilt gegenwärtig für das beste.

lows kaukasische Buchsholz kemmt über dies Häten des

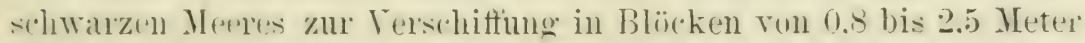
Liange mnd einem Lurehmesiser von 0.08 bis 0.30 Meter, welche now die diumse, golatte, grante Rinde der stämme tragen. Der cylliat ist nicht erkemntlich. Es wird nach fiewirht rerkanft mul zи [nerhslerabeiten. Flöten und andern Blasinstrumenten, Holzschnitzereien mud mathematischen Instrumenten verwendet, uniibertroffen aher ist es für die Hol\%schneidekmst. demn es grestattet einen so scharten. feinen Ausstich wie Metall. währenc? es die Thsche hesiry amnimmt. In spanien und Portugal wird aus den spainten

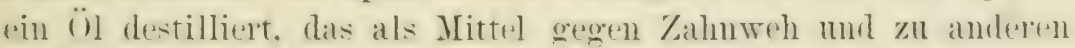
Heilzwecken benutzt wird.

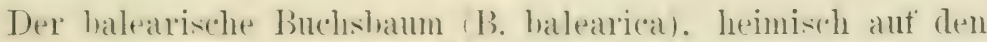

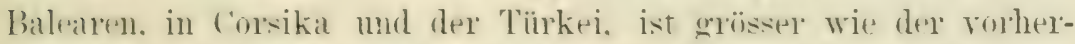

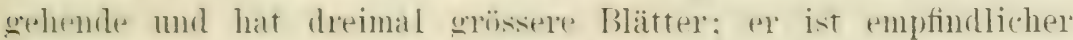
geren den Frost wie jener. Das Hol\% ist rom geringerel Gibte wie das exhte Buchsholz. wird aber trotzdem in Mengen iiber

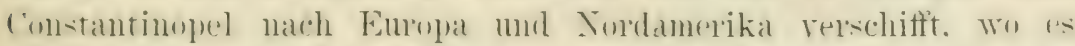

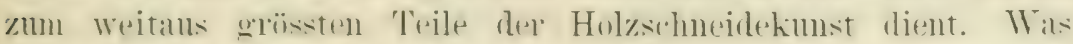

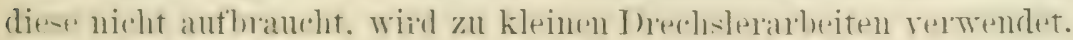

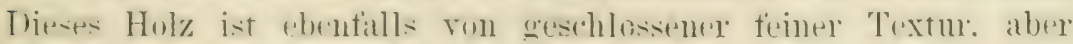

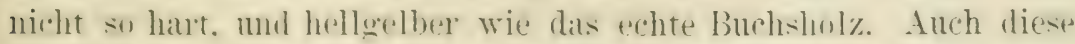
Blieke tragen die diunne. erane Rinde der stamms. die nitht glatt. sonderen mit vielen kleinen finoten besetzt ist. Zuwrilen hat

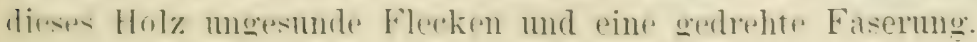




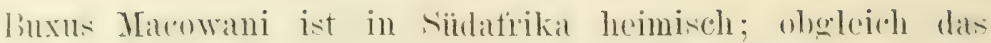

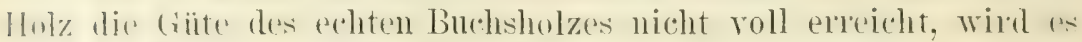
doch als Ersatz desselben ron England importiert.

I) anstralische Buchsbaum ist nicht mit den vorheroghenden biumen verwandt. Wie sein wissenschaftlicher Name Pittu-pormm molulatum ancientest. I)as Holz besitzt eine starke Ähnlichkeit mit dem ahten Buchsholz mol ist deshalb mit Ertolo zu seinem. Ersatz empfohlen worden.

Eine steigende Wichtigkeit als Ersatz des echten Buchsholzes cewinnt das westindische Buchsholz. das iibrigens nicht von Trestindien, sondern ron T'enezuela kommt. Über Plierto c'abello finden legelmässige Telschiffungen mach Hamburg statt. Die botanische (Juelle ist noch nicht sicher festgestellt. Die verschiedenen sorten tïhlen die Narken I, A, ('-H. G. Die Marke I (Naraujillo) ist am meisten geschätzt, doch kamn sie nicht als vollständiger Ersatz des echten Buchsholzes betrachtet werden. Neben ihr hat sich nu noch die Marke A (Atata) Bedeutung erringen können. Tn Venrzula heisst dieses Holz Amarilla yema de huero (d. i. dottergelb). es sull ron Aspidosperma Targasii stammen. Die anatomische Tntersuchung' des westindischen Buchsholzes schliesst jeden Zweifel a!r, dass (puebracho blanco sein nächster Terwandter sei. daher chenfalls von Aspidosperma-Arten abstammen miisse. falls vorstehende Behauptung richtig ist.

Das westindische Buchsholz hat eine gleichmässig hell dottergelbe Farbe: auf Sehnenschnitten ist ein leichter Flader eben erkemntlich, hervorgerufen durch cine äusserst zarte jahrringähnliche Schichtung des Holzes. Auf dem geglätteten (querschnitte sieht man schon mit mberaftnetem Auge dicht gedrängte, feine, geradläutige Markstrahlen mud mit der Lupe iiberdies zahlreiche, megehnässig zerstreute. helle Pünktchen. Das Holz ist mäsiç hart, leicht spaltbar und hat 1.39 spezifishes Gewicht.

Das Holz ist ïberaus reich an Gefassen. welche somohl vereinzelt wie in mmegelmässigen Grmppen ancinamder gelagert rolkommen. Sie sind über die ganze Breite des Querschnits zerstrent. meist $0.4 \mathrm{~mm}$ weit mul fast kreistund. Die Gefässwand ist ansehnlich verdicht und von zahleeichen Poren durchzogen. Sitoptzellen fehlen. Irie meisten Markstrahlen bestehen ans :3 Reilen in ansstrahlender Richtmng stark gestreckter, diimmantiger. ron

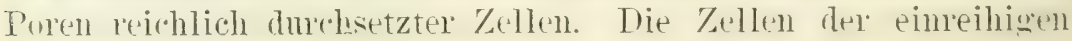




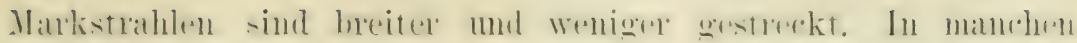

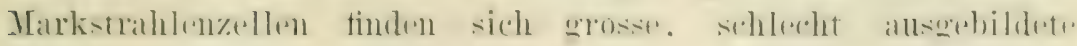
lirystalle.

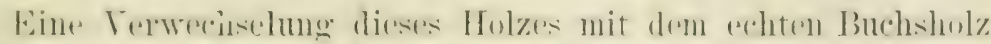

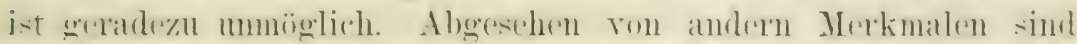

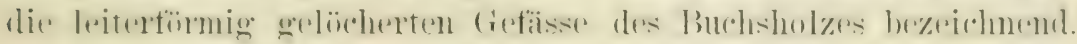

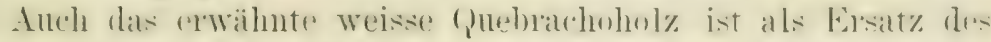

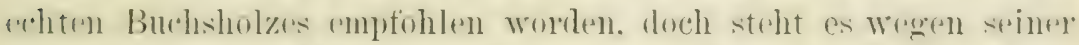

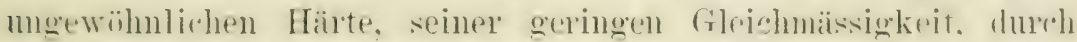
die geringer Zahl weiter Gefiisse und die breiten Markstrahlen weit hinter dem westindischen Buchshol\% zuriick. Von seiner Tin-

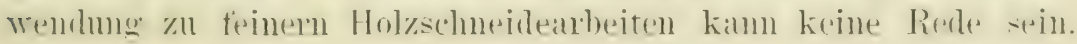

\section{Calamanderhol\%.}

Fin Vime. der wahrseheinlich eine Verstimmelung von finomandel ist: finden doch wahrscheinlich alls diesem Gebiete dir er-tru Anstuhren dieses Holzes statt. Dasselbe gilt als hochtrin. os gleicht dem Rosenholz, übertrifti es aber an sichünheit mul Danerhattigkeit. Der Bamm. welcher es poduziert, wird ron der Wiscenschatt Diospryos hirsuta, nach anderen Botanikern I). quar-ita genamnt. er gehört also derselben Gattme wie dio Eleenholzhäme an. Er hat längliche. ahgestumplte Blätter. die untern Hamnig sind. die stirllosen Blïten sitzen in Ähren engereängt. Heini-xh ist or im südlichen Indien mol in Ceylon. hier namentlich in denl Nialdern am Fusse des Pik Adam. Doch haben

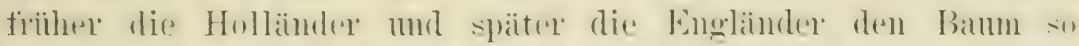

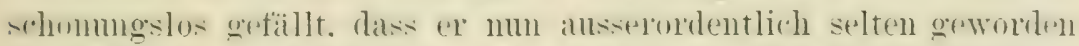

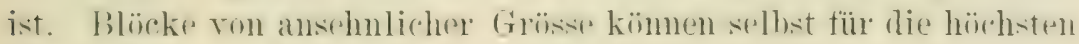
Preise kaum noch beschafft weriten.

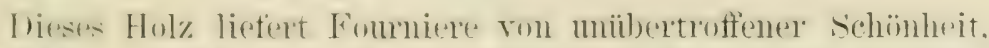

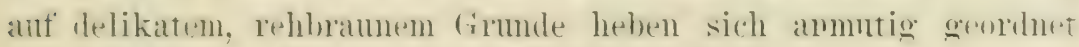
nahezu schwarze Flecken und Wellenlinien ab.

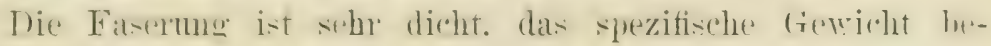
trägtt 0,980 .

\section{Casuarinahölzer.}

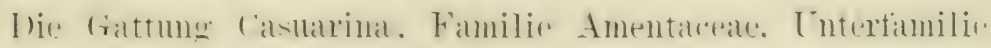

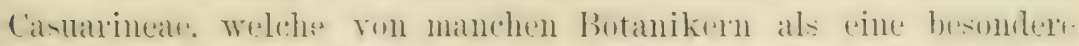
Familie betiachtet wirl. besteht alls Bälunen, die filst allscohlieso 
lich in Anstralien heimisch sind. Nur eine Art. C. equisetifolia,

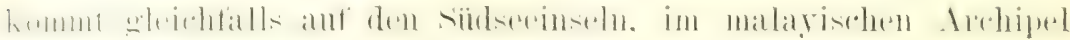
mnd an der Ostkïste dex Bai von Bengalen. nördlich bis Arracan vor. Einige Arten haben mehr strauch- wie Baunform, andere sind stattliche Bäume, alle aber haben ein eigentimliches Aus-

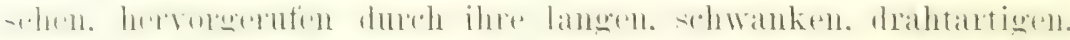

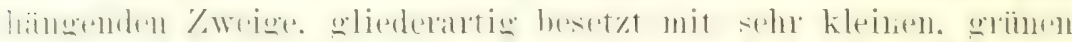

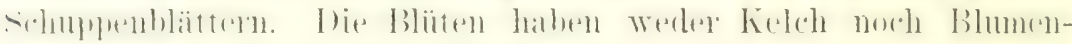

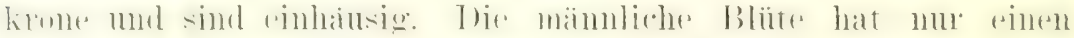

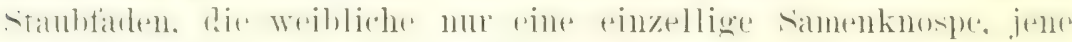

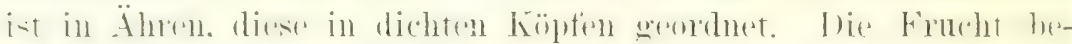

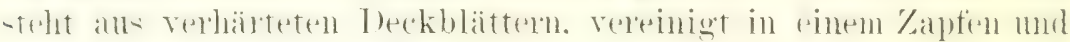
umschliessend kleine beflügelte Samen.

Etwas mehr wie 20 Arten dieser Gattung sind bekannt, daron

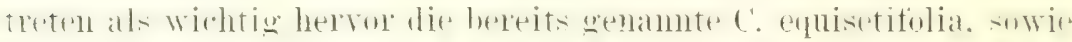

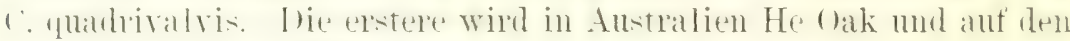

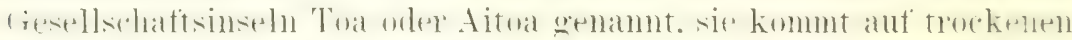

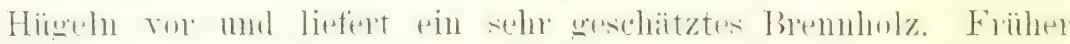

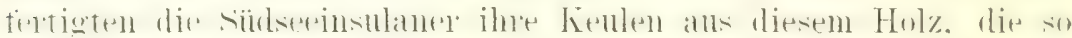
hart und dauerhaft waren, dass die ersten, jene Inselwelt be-

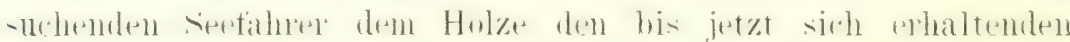
Tamen Eisenholz gaben.

C. quadrivalvis wird in Australien She Oak oder Beefwood gremannt. der letztere Same bezieht sich anf die Heischrote Fathe

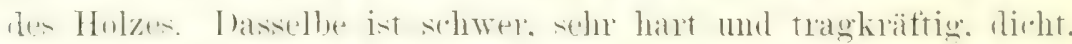
amsererdentlich dancehatt. Mamentlich moter Wassel nud nimmt

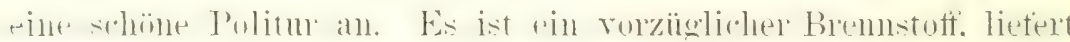

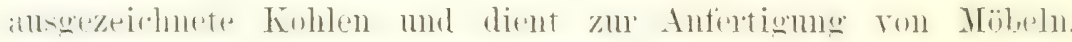

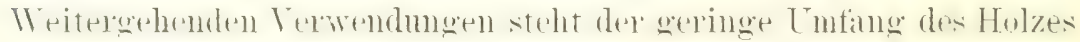

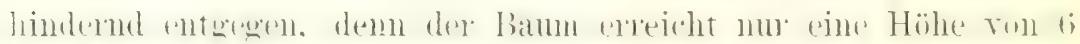

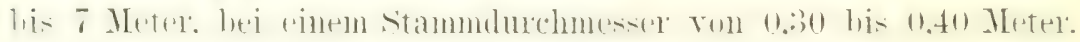
Diese Art hat sich ron ihrer engeren Heimat Nen-Süd-TTales

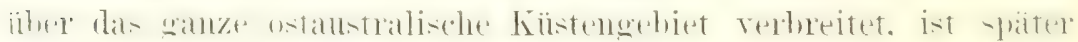

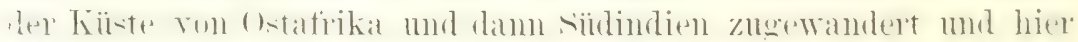

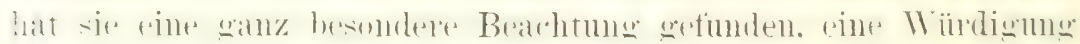

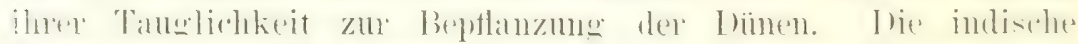

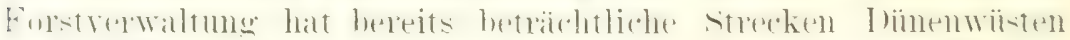

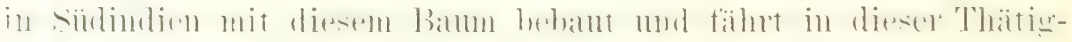
keit eifrig tort. 


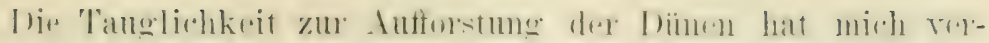

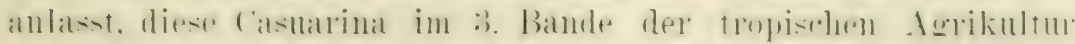

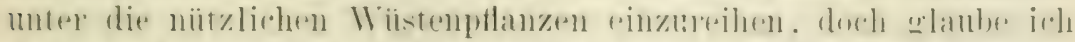

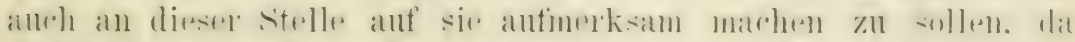

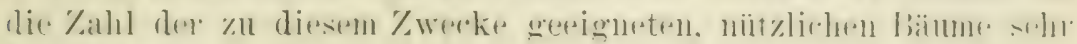
beschrïnt ist.

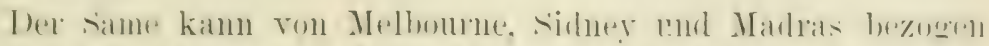

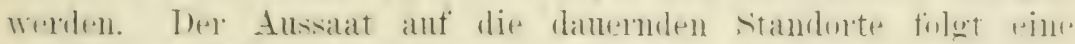

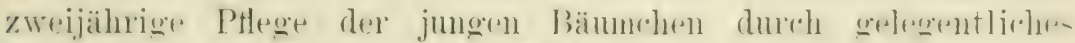

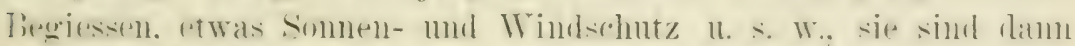

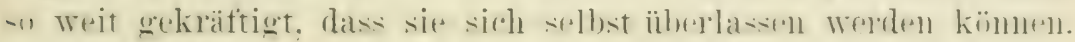

Cedern holz (siehe Seite 715-719.)

\section{Chittagonyholz.}

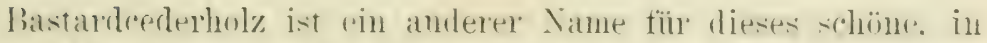

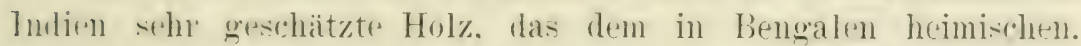
-tattlichen Bamme Chickrassia tabulens. Familie Cedrelaceaf. ent-tammt. Fes dient für allo \%wecke wie das Mahagoni. dem w ahnlich ist. duch wirft es sich leichter und besitzt anch nirlit

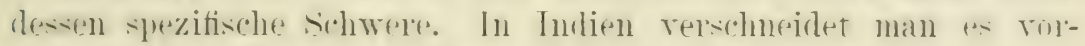

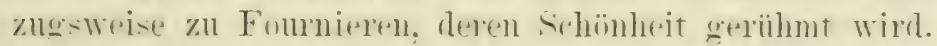

\section{Fbenhölzex.}

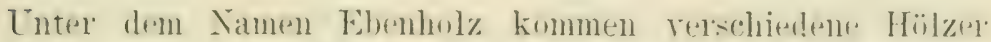
menter besonderen Sortemamen in den Handel, rom welchen jerles piner andoren botanischen Quelle entstammt. Ton gutem Elbenholz

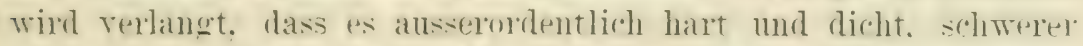
wie Wasere ferinfaserig. tirfichwarz sei und eine sehöne Politur

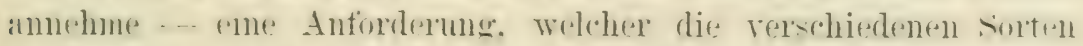

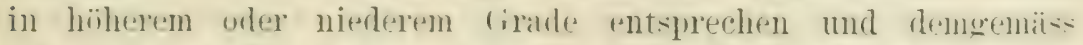
wechselt ilne Treatschätzung. Terwendet wird das Ebenholy zu Jäbeln. finen. vingelegten Aribeiten und Trechsterartikeln. iibre-

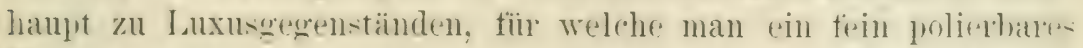
Holz wïnscht, das nicht im mindesten schrumpte sich nicht wirft

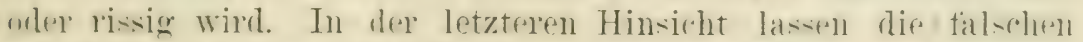

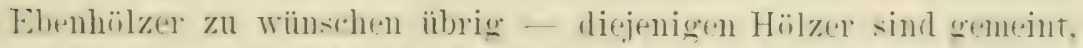
welche eine natioliche. domkle. abee dorele nicht schwarge Farbe 


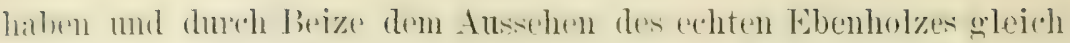

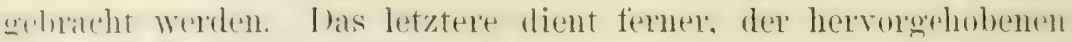
Figenschatten wegen, den Maschinenterhnikern zur Anfertigme newisser Modellwerke.

bie besten Ebenhölzer entstammen der Gattumg I)ios-

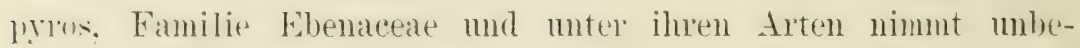
stritten D. Henum den ersten Rang ein. Dieser Batum ist in ('ylon heimisch. wo ex trïher ant einigen 'Tiefebenen zahhreich mo in so stattlichen Exemplaren vorkam, dass Blöcke von 1.60 Ireter Jurchmesser, gewöhnlich in der Länge von :) bis 4 Meter in den Handel gebracht werden komnten. Durch schonmes:lose Abholzung ist der Baum selten geworden und kaum geling't « noch, einen Block ron 0,25 MLeter Durchmesser zu beschaffen.

Lrsprimglich wurde nur das Holz dieses Bammes Ebenholz. gemannt. erst als die Europäer zu kolonisieren anfingen, wurde die-er Name auf andere schwarze oder nahezn schwa"ze Hölzer ïhertragen. die für den Handel $10 n$ so wichtiger wurden, als die Toräte ron jenen stark zusammenschmolzen. D. ebenum hat eine -chwarze Rinde, unter der ein vollständig weisser Splint liegt. welcher in ein so gleichmässiges, tiefschwarzes Kernholz ïbergeht. wie es kein anderer sogenamnter Ebenholzbam besitzt. Einer der'selbon (I). ebenastel') ist ebenfalls in ('erlon heimisch. wo el' ron den singhalesen laduberia genamnt wird: ansserdem kommt « in südindien vor. Das Holz ist schwarz, schön gelbbram gestreift. aber weder so dicht noch danerhaft wie das echte Ebenholz. Wem in den Ansfuhrlisten Ceylons für das Fiskaljahr 1 scis Ebenholz mit 7500 Tomnen angegeben ist. so darf mit sicherheit angenommen werden. dass der weitaus grösste 'Teil das Produkt von D. ebenaster war.

D. melanoxylon ist der Ebenholzbanm ron Koromandel. "' liefiert dem Hamblel beträchtliche Mengen sehr guten Ebenholzes. Las mag whl der cröste Baum seiner Gattmo sein, dem sein stamm yerimnt einen Tmfang ron 2.4 lis 3 Meter. Die Rinde ist. wie bei den meisten, wenn nicht allen Arten von Diosprros. gerbsïmelaltig. Ihie steifen Äste wachsen unregelmässig. die langovalen Blätter sind ganz, die weissen Bliiten haben einen fïnflapigen kelch und werden ron kleinen, rumden, fleischigen Becrenfiüchten mit 20 bis 8 simen gefolgt. Dieser Baum wird in 


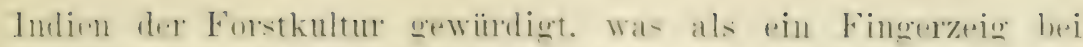

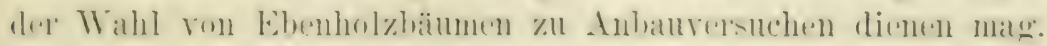

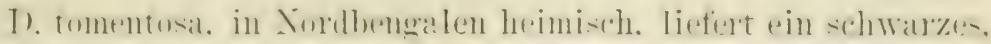

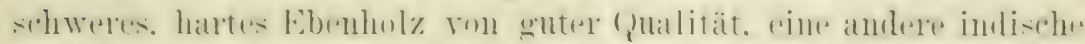

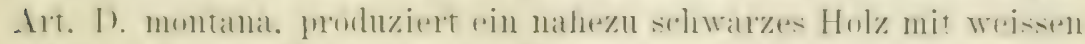

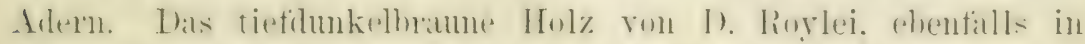
Indien heimisch, fiihrt auch den Tamen Ebenholz.

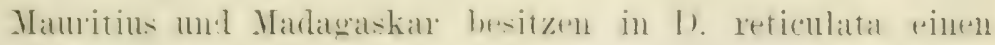
Ebenholzbamm, der ein vorziigliches Produkt liefert.

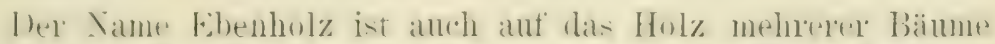

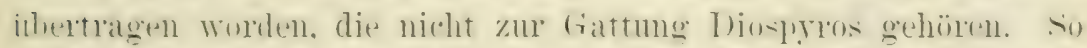

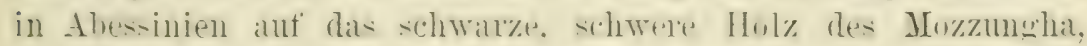

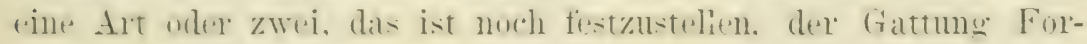
nasinia, Familie Leguminosae.

Thas we-tindische Ebenholz ist ein Anstuhrartikel ron winigem

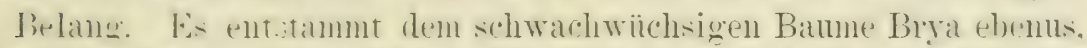

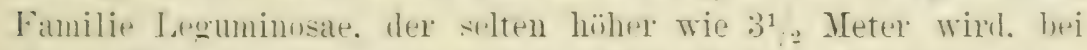

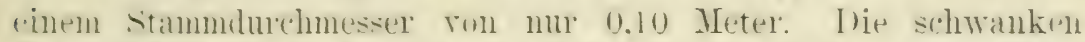

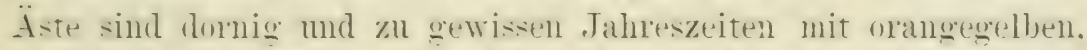

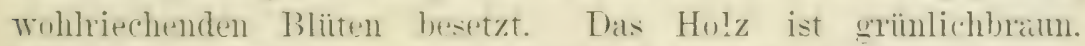
schwerer wie Wascer. allscerordentlich hat uml nimmt eine solöne J'ulitur an. Es wirl hatutsächlich rom musikaliselen Instrument+almachern begehrt.

Las mittlew wie siidliche Afrikil besitzen Ebenholzhäumr. die wahrseheinlich der Gattung loispyros angehören, was fextzustellen späteren Forschungen vorbehalten bleibt.

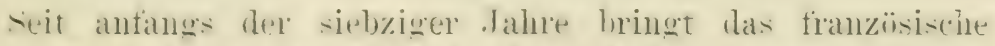
Gilana Ehenholz in den Handel. das offenbar mehreren Bammartels elltstanmt. Was and durch Forschungen autzuhellen bleibt.

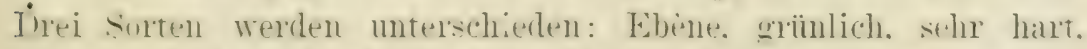

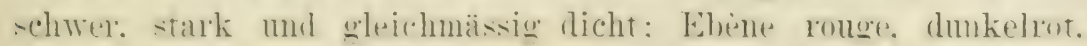

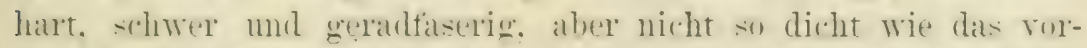
hergehende: Ebene verte. dunkelgrül. selne lart, schwer. dicht.

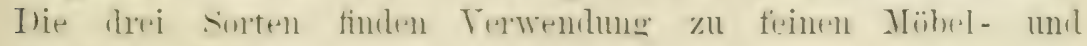
Drechslerarbeiten.

Alle Ebenholzsorten werlen anf den emonuiti:chen Märkten nach dem Gewicht rerkauft. 


\section{E i $=1 \times$ h hi $l \%$ er.}

Wimen ihner ansserordentlichen Härte mat sehwere emplingen in rerschiedenen Ländern Häl\%er, die in keiner verwandtschaftlichen Beziehung zu einander stehen. den Xamen Eisenholz.

In sïdlichen und östlichen Asien geniesst die Sorte Eisenlniz den besten Rut, weshalb sie zuweilen echtes Eisenholz genamnt wird, welche ron Metrosideros vera, Familie Mrrtaceae, stammt, ein im malayischen Archipel heimischer Baum. mit oral lanzettlichen. kurzgestielten. glatten Blättern. Dieses Hol\% ist ron Malayen, Chinesen und Japanern zur Herstellung ron Ruderu sehr weschätzt, zuweilen machen sie für kleine Fahrzeuge auch Anker daraus. Kleine Pöstchen werden dam und wamn nach England rerschiftt. Die Rinde gilt in Japan als ein Heilmittel fiir hartnäckigen Durchfall.

Bima besitzt in Muba buxifolia. Familie Ebenaceae, einen Eisenholztuaum.

In Indien und cerlon wind das Holz ron Meslla ferrea. Familie Guttiferae, Eisenholz genannt, ein Bam der häufig nahe den buddhistischen Tempeln gepflanzt wird, seiner wohlriechenden Blïten wegen. mit welchen die Gützenbilder geschmï̀kt werden. Ilie Blüten gleichen kleinen weissen Rosen und stechen auffallend ab ron den tief carmoisinroten Knospen und Trieben. Das $\mathrm{Holz}$ ist selur hart, so ist auch dasjenige ron MLesua speciosa. ein dem rorigen inahe rerwandter und in seinem Terbreitungsgebiete rorkommender Baum. der ebenfalls, aber nicht allgemein üblich, Eisenholzbaum genannt wird.

Das Holz ron Repris undulata. Familie Hiosmaceate. ist in siidatrika als weisses Eisenholz gekannt. Es ist sehr ziih und hart und wird hauptsïchlich zu Achsen. Pflügen und anderen Ackerbaugeräten gebraucht. Das schwarze Eisenholz desselben rebietes ist das Produkt von Olea laurifolia. Familie Oleaceae. und findet dieselbe Terwendung wie das weisse Eisenholz, anserdem zn Mröbeln.

Mauritius besitzt ein weisses Eistnholz, dont hois de fer blanc senamnt. das von Sideroxylon cinereum. Familie Sapotaceat. stammt. I as gewïnliche Eisenholz dieser Insel ist das Produkt ron Stadmamia sideroxylon. Familie sapindaceae. ein früher luäufiger, jetzt aber sehr seltener Baum. 


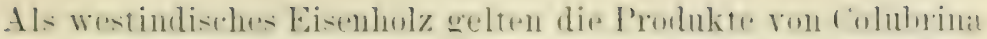

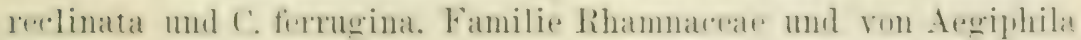

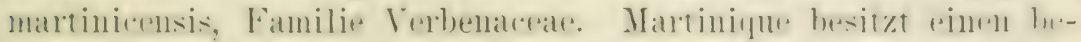

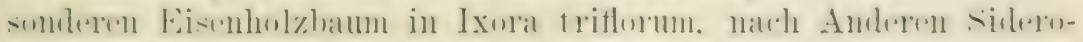

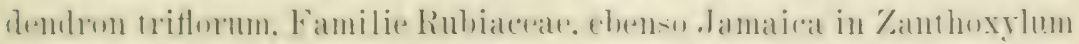

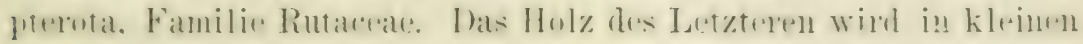

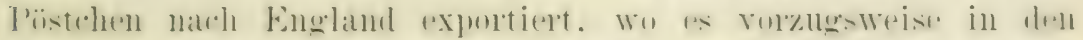

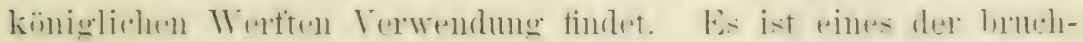

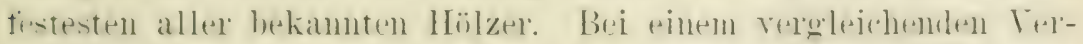

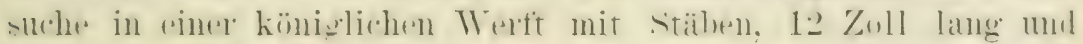

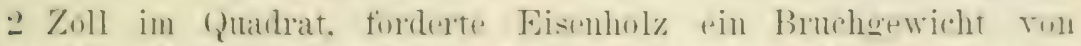

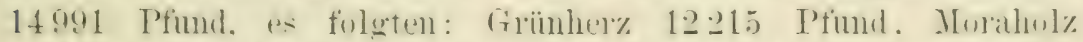

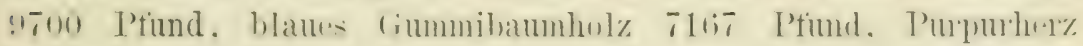
6393 Pfiund.

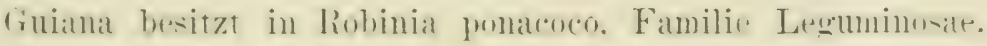
einen Eisenholzhaum.

Apuleia terrea und latealpina ferreal Familie Lexuminmate. -ind zwei hrasiliansole Arten. die Fisenholz lieferm.

In Mittelamerika stammt ein Eisenholz ron Cocoloba Erandifolia und C. pulescens. Familie Polrgonaceate. Seln wahlscheinlich ist es dieses Holz. Welches in betrichtlirhen Mrengen

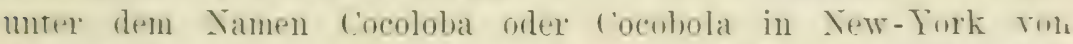
Aspinwall mol anderen mittelanerikanischen Häfen eingefïhnt winl.

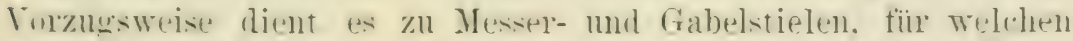

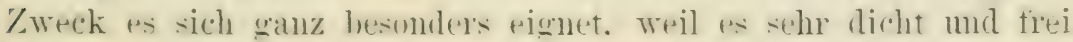
ron Knoten ist und keine Veigmeg zum Reissen besitzt. Thi greichen Eigenschaften machen es wertwoll für dite Fabrikanten rom Blasinstrumenten. In der Tischlerei wird es selten benutzt. weil es sich nicht grat leint. Es kommt in Blïcken ron lon lide :300 Kilogramm Gewicht zur Verschiffung.

Tasmanien bexitzt ein Fisenholz. Weldepes ron votelate

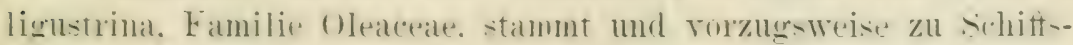
blöcken rerwendet wird.

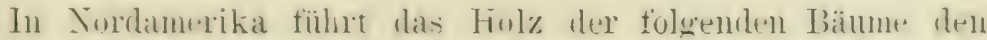

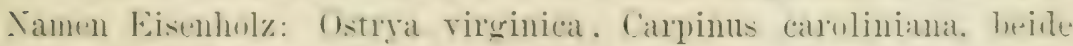

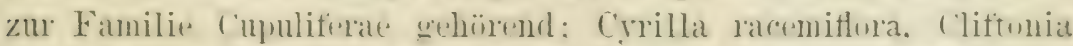

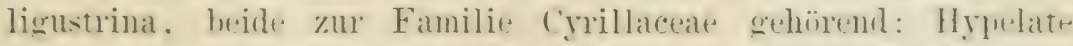

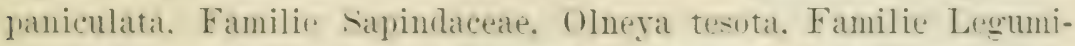

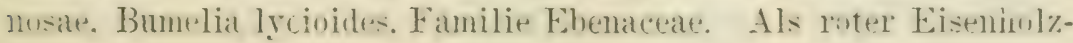


hanm wind heynosia latifolia, Familie Rhammaceate, bezeichnet, als Wriser Eisenlolzbaum Hypelate trifoliato, Familie Sapinlarear mols alswarzer Fisenholzham condalia ferrea, Famili Rhammaceae.

Fiscuhol\%, in Munde der Europièer. Welche sich anf den siidseeinseln aufhalten, ist das Produkt von Castarina equisetifolia, Familie Amentaceae.

Trem die Ven-Seeländer von Eisenholz sprechen, meinen sic den Rata der Eingeborenen. der Wissenschaft als Metrosideros Incida bekannt.

\section{Eucalyptushölzer.}

Bis jetzt ke'mut man etwa 400 Arten der ( 'attung Eucalyptus, Familie Mrrtacear, die bis auf wenige Ansmahmen, die auf XenGrinea. 'Timor' und die Molukken entfallen. in Anstralien und Tasmanien heimisch sind. In Anstralien werden die Eucalyptushämme in der Regel Gummibäume genamnt. eine Bezeichnumg die, wie der beste Kemmer der australischen Pflanzenwelt, Baron ron Miïler. mit Recht bemerkt, missleitend ist. denn jene Bämme prodnzieren kein Gummi. sondern einen Kino genannten Stoff. Bewriundeter Wrise kïmnten die Gerberakazien (Acacia decurens ect. fimmibäune genamnt werden, da sie ein wirkliches, dem arabisclien ähnliches Gummi ansschwitzen. Fs ist iibrigens ein anssicht-lose: Tnterfangen. diesen Sprachgebrauch zu bekämpfen. zumal er dis Encalyptusbämme auf ihrer Wandermo über die Erde begleitet hat. Dite Anstralier scheiden zwei (ruppen dieser Bäume audie eine nennen sie Ironbarktrees (Eisenrindenbäume) die ander Stringrbarktrees (Faserrindenbäume), jene habell glatte, feste. diese offene faserige Rinden.

Gemeinschaftliche Merkmale der Eucalyptusbänme sind: immergrüne. lederige Blätter. die, in mehreren Fällen. nur in der .Tugrnd ausgenommen. entweder schräge oder senkrecht hängen um mit Drüsen besptzt sind. welche ein wohlriechendes, flüchtiges ö enthalten. das eine nahe Ähnlichkeit mit dem Cajeputöl besitzt. Ibie Blïten sind olne Blumenblïtter und gleichen denjenigen der Mrrte. Die Knospen sind duxch eine Klappe geschlossen. welch zuriukspringt, wenn sich die Bhiite entfaltet. In dem sich rerhïrtenden Kielch, welcher die Frucht bildet. liegen zahlociche, 


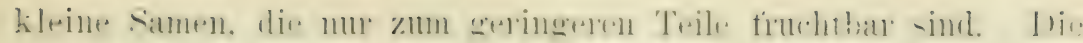

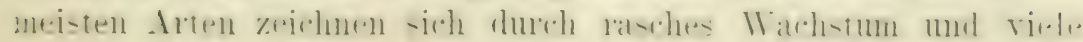

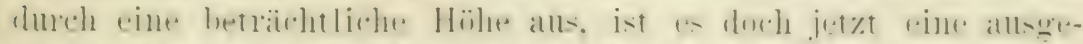

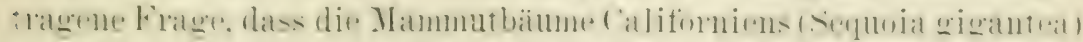

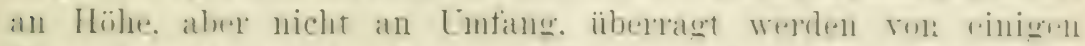

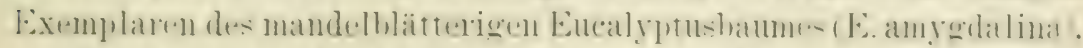

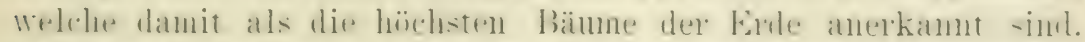

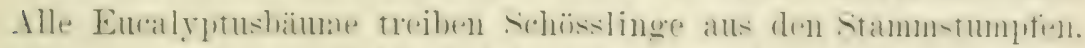

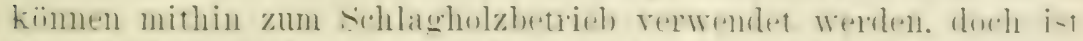

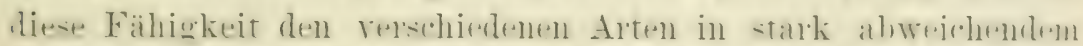

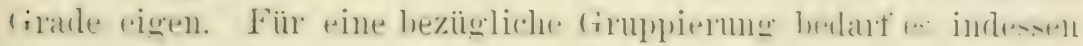
noch weiterer Erfahumgen.

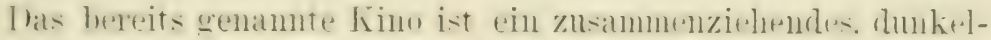

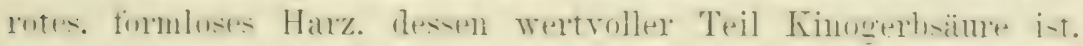
mud welches durrh Finselnitte in den stamm in hallfliissigem Znstand gewomnen wirk. Es ist in den Rinden mul den Holze enthalten und zwar in den rerschiedenen Arten, in stark abweichen-

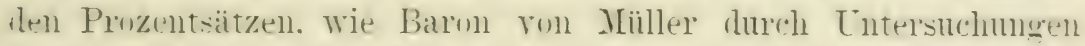
erezeigt hat, dexen Resultate er in der folgenden Tabelle nirderlegte.

In 100 'Teilen frischer Rinde waren enthalten:

\begin{tabular}{|c|c|c|c|}
\hline & & Kinogerb̀säure & Wasser \\
\hline Eucalyptus & leucoxylon & $21,9 \pm \%$ & je $1,13^{\circ} \mathrm{ic}$ \\
\hline$\Rightarrow$ & globulus & $4,8 \pm$ & 51,5 \\
\hline$\cdot$ & rostrata & 8,22 & $\vdots 1,16$ \\
\hline 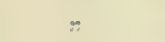 & Gunnii & $3,4 \pm$ & $5 \leftarrow, 09$ \\
\hline . & polyanthema & 3,97 & $\$ 6,66$ \\
\hline . & melliodora & 4,03 & 54,94 \\
\hline- & obliqua & 2,50 & 36,81 \\
\hline$=$ & 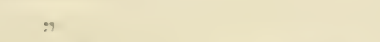 &, \pm 19 & j1, \\
\hline$\because$ & amygdalina | & 3,40 & 43,25 \\
\hline$:$ & $n \quad f$ liture linde & 3,22 & 39,63 \\
\hline$\because$ & goniocalyx & 4,12 & $\pm 5,50$ \\
\hline$:-$ & macrorrhyncha & 11,12 & 35ั,91 \\
\hline. & $"$ & 13,41 & 39,56 \\
\hline . & viminalis, glatte Rinde & 4,88 & 52,88 \\
\hline 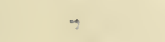 & $\because$ rauke $"$ & 5,03 & 54,10 \\
\hline$\because$ &.$\quad$ junge. & 5,97 & $\dot{5} 5,03$ \\
\hline
\end{tabular}

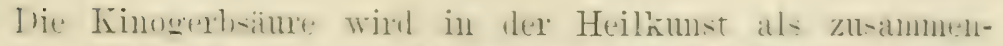

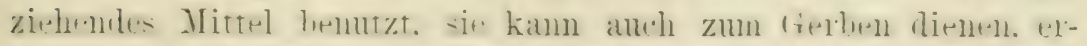

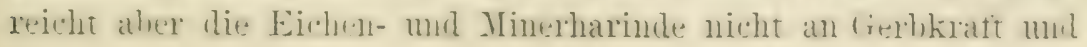


whih dem Luder cine dumkle Farbe. The anstralischen Gerber gemanthen sie als beimischung zu anderen terbstoften, in Fiallen. wo se ant rine helle Farbe des Leders kein fiewicht legen.

Jie bläter und junge Rinde von E. mannifera und E. vininalis "ryengen das anstralische Nanna, ein harter, undurchsintiger. sïsser stotf. der Melituse enthält. Bremnende Encalyptusbiitter bilden ein Hausmittel zur Erleichtermo des Asthma's und de- Kenchhustens. firische Blätter werden zim Verbinden von Trunden sebratucht, ausserdem dienen sie zur Bereitung eincr 'Tinktur, welcher' von den Är\%ten Heilwirkmgen auf den Blasenkitarh. auf Asthma und noch andere Krankheiten zugeschrieben wird. Auch von Wirkungen gegen die Malaria wurde frïher viel geverochen, allein sie werden gegenwärtig in Frage gestellt. jedentalls sind sie viel mbedentender wie diejenigen des Chinins.

Ten nacholgenden sichilderungen einer Gruppe von Encalyptusbämmen habe ich rorauszuschicken, dass ich Baron von Müller's klas-isches Trerk ïher die Eucalyuti als Führer benutzte. bei meiner Auswall aber anch die nenern Erfahrungen ïber den Wert der hetreffenden Hölzer, namentlich die Benteilung. Welche sie in Anslande erfuhren. herücksichtigte. Trie in allen sogenamuten nenen Ländern. lat man sich auch in Australien nach Kräften bemiiht. die natiulichen Hilfsquellen ins hellste Licht zu stellen. Wozu die Weltalsotellungsmanie die rortrefflichste Gelegenheit bot; zuthenher wurde durch Resle und schrift gewirkt. Sicharf in den Torderorum wuden die Eucalyptusbäme gestellt. alle erdenklichen gntrin Eigenschaften sullten sie besitzen. sollten wahle Wunderrroheimungen sein. Welche die ganze übrige Ptlanzenwelt iiberstrahlten. I) ie Bewundermo der ganzen Gattung worde zur Mode in allen Kulturländern und schliesslich artete sie in ein Encalyptusfieber alls. gergen das sich sellyst sonst kïhl und klar denkende Männer nicht grewalpnet reigten. I tem Ransche ist. wif immer. die Entnïchtrung gefolgt: es wird 11 zugestanden. dass schatten-eiten ïbersehen mol Lichtseiten zu hell belenchtet wurden. Wenu die Australier inse Encalyptushïlzer priesen und durch rielfache Verwendung ihren Worten Rücklat liehen. Wie musste das in del Auffasmong rles Teroleichs mit anderen anstralischen Hölzern entgrestengemmen werden. Eine gleiche Bemteilung auf dem Teltmakte. Wo dit Encalyptnshïzer mit den besten Hölzern ans allen Jänklem in Wetthewerl zu treten haben. war kaum zu erwaten. 


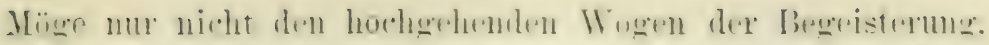

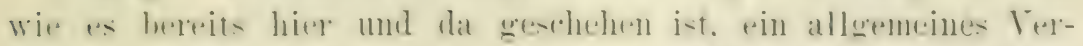

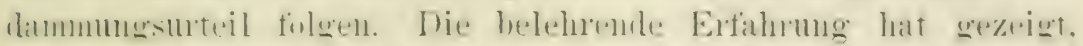

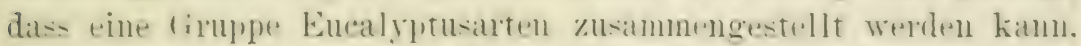

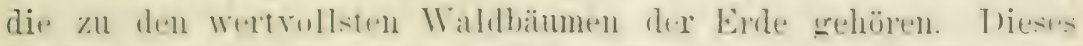

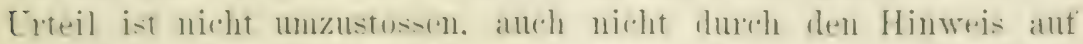

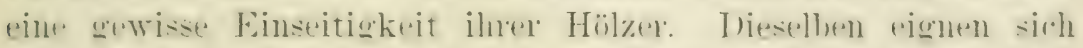

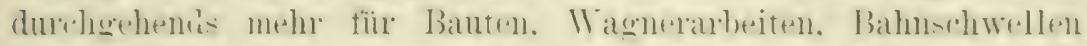

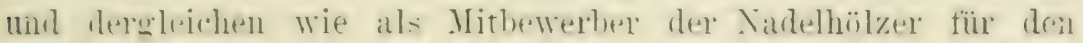

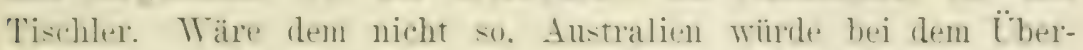

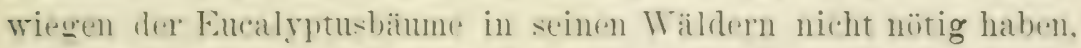
jährlich betentende. Mengen Vabelhol\% ans Xomamerika zu importieren.

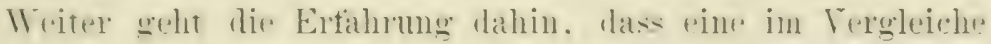
zum Reichtum der Arten geringe Zahl. stets den Rang als Zierpthanzen hehaupten wirl. Obgled he sich auf die Letzteren meine

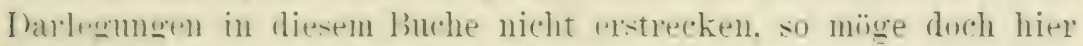
kurz lemerkt soin. dass die folgenden Eucalyptusarten zur Ter-

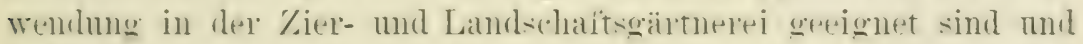
befiedigen werden:

E. riminalis ans Sïnlathstatien und 'Tasmanien. ein klima-

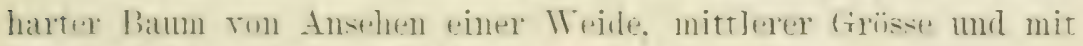

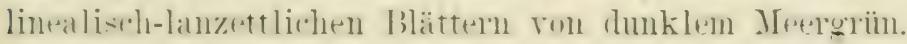

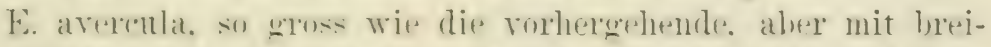
teren Bätron ron dunkeleriuner Fatre. Thi härteste und allgezeichnetste Art aus Tasmanien.

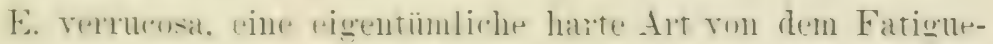

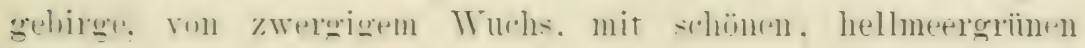
Blättel'1.

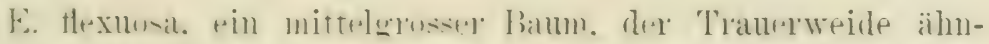

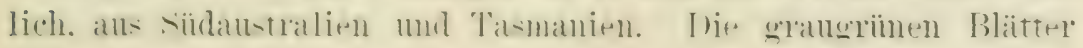
sind linealisch-lanzettlich.

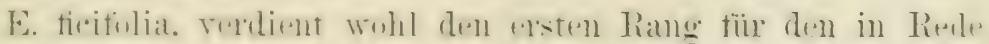
strelenden \%weck. Iniwe Art ist schwarhwïchsier. ziemlirh klima-

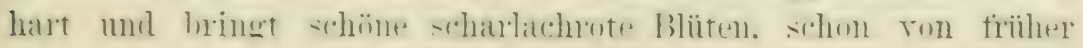
Jugend an, herrol:

F. corlata, ein kleiuer batum. am Huontlus-s und an iter

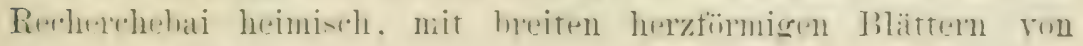
weisslicher Farbe. 


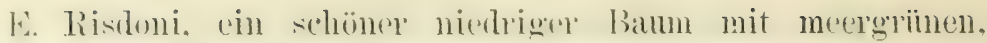
lanzethluxä̈mmigen Blättern von den Tfern des Dervent.

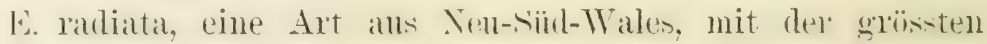
Teränderlichkeit des Laubes.

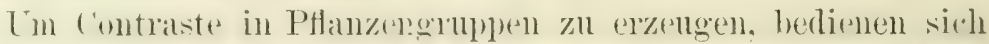

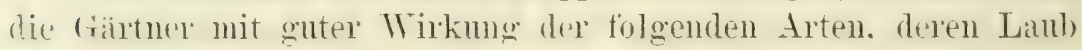
mol \%weige wie mit einem genderten Stoff bestreut erscheinen: E. pulverulenta. E. hemisphoia. E. melanophoia, E. pendula, E. stricta. E. piperita. E. longifolia und E. botryoides - alles stattliche Bäume, die aber niedrio gehalten werden kïnnen. Non noch einige allgemeine Bemerkungen über die Kultur der Eucalyptusbäune, deren Fortpflanzung. wie hervorgehoben zu werden verdient, nicht die geringsten Schwierigkeiten bietet.

Der Same mehrerer Arten ist in indien, Europa. Nordamerikia und Argentinien käuflich, bei einer beabsichtigten Amptlanzuny. der unten geschilderten Waldbäume ist aber Australien die sicherste Bezugsquelle. Railton of Co. in Melbourne, G. Brumning of Fons in St. Filda bei Melbourne und Anderson \& Co. in Sidney werden cut bedienen. Pflänzlinge aus weiter Entfernung zu beziehen ist nicht ratsam, weil sie. als immergrïne Bäume, eine längere Trennmg vom Boden nicht vertragen.

Die Fortpflanzung kamn auch durch Stecklinge geschehen. ein Terfahren. das sich aber nicht fiur die Forstkultur. sondern nur für die Gärtnerei emptiehlt. Junge Seitenschösslinge des rsten .Tahres. welche reif genug fiul diesen Zweck sind, werden in der Länge von 10 bis 15 Zentimeter in kalte. oder wem es die Jahreszeit erfordert, in mässig warme Beete gesteckt. Wo sit nach 2 oder 3 Wochen Wrzeln schlagen. Schon nach weiteren 3 oder 4 Wochen kionnen die bewmzelten Stecklinge an eine g'trreschützte Stelle der Baumschule versetzt werden. wo die jungen Bäume -2 Jahre lang bleiben mögen, um damn auf die danernden Standorte iibertragen zu werden.

Fïr die saat des Samens bereitet man sich Beete ans mäsig finchtbarer. fein pulverisierter Gartenerde. Den in 15 \%entimeter von einander entfernten Reihen gelegten samen bedeckt man mic

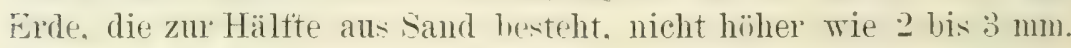
Wem das Wretter wam und die Luft trocken ist. mïssen die beete täglich mittels einer feinen brance begussen merden. In \& bis 14 'Tagen keimt der same: wemn derselbe krättig ist. Wachsen dit? 


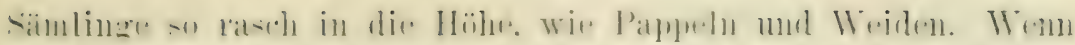

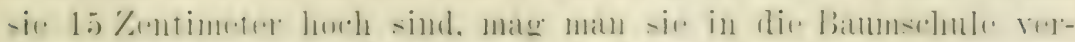

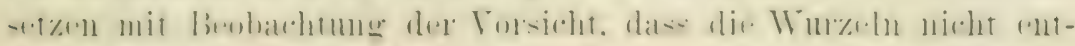

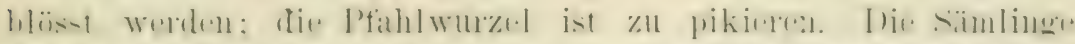

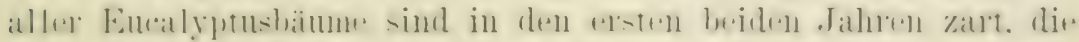

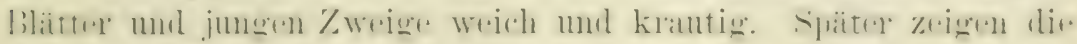

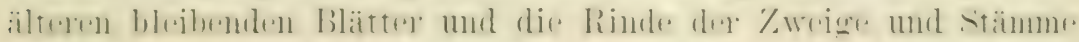

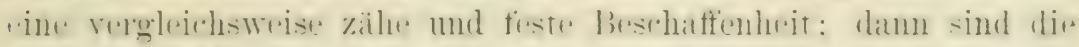

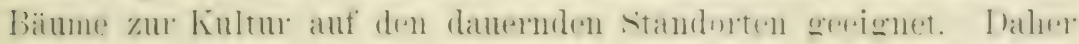

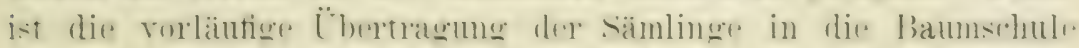

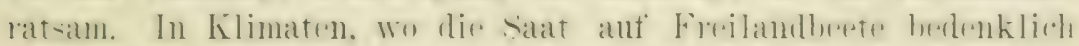
meleint. sind Kistehen emptehlenswert. tin \%entineter lane. 40 \% zul Entwässerung in len bäblen. Diese Kistrhen füllt man his mahe an den Rand mit diartenerde. salt wie in rin Freilandhent und setzt sie in ein haltheret, desien Fenster durh Muscelin zu leerhatten sind. Fin grëiltes Leinwandrach kamm als Ersat\% dele Fonster dienen. I) tägliche Bewäsierung darf nicht rexsämnt werden. Wenn dir sämlinge s Zentimeter hoch sind, muss ihre Abhärtung durch das öffinen des lialtbeetes in steigenden Zeitlängen beginnen. Ile weitere Behandlung unterscheidet sich nicht ron der bereits angegebenen.

In Indien pftegt man den Euralyptusamen in Bambustüpti. zu särn - ein Verfahren. das in den trundzügen der Fursthultur geschildert ist.

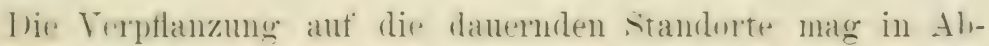

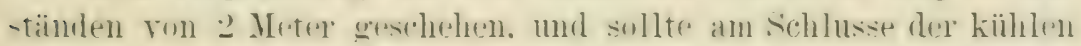

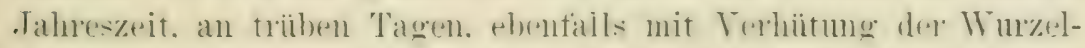
enthlissung vorgenomnen werden. In den heiden folgenden Jahren ist der Buden wiederhult mit dem Kuliltivator zu lockern und zu jäten: die Bäunchen werden von da ab) den Borden su stark beschatten

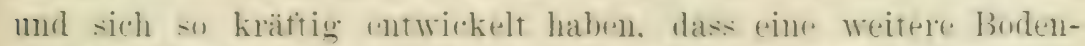
hearbeitung niche neitio ist. Inei Jahne nath dev Anpthanzunge

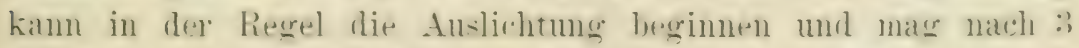

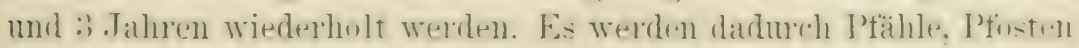
u. s. w. gewommen.

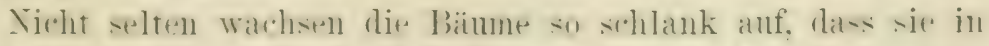

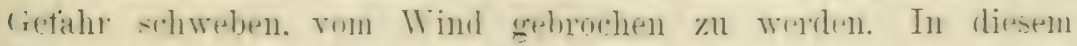

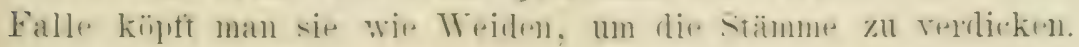


bej rinem solvhen Wachstum in die Höhe. wie es diese Bämme zajextr. muss das Aufästen, worunter der Forstmamn das Absägen der interen Äste versteht. unterbleiben. Welche Ansprïche die miten eseshidderten Arten an den Boden stellen, ist ans den Bemerkungen ïber ihr Vorkommen zn schliessen, bezäglich der klimatischen Anfordermgen kann ron allen gelten, dass sie keinen stäkeren Frost wie - 5 bis $7^{\circ}$ ('.. je nach dem Standort und auch nur anf kurze Daner, vertragen könmen. Nur einige schwachwïhsige und zwergige Eucalyptusarten vertragen höhere Kältegrade. Ans den angegebenen Verbreitungsgebiet für jede Art "rhellen am besten die klimatischen Bedingmaen des Gedeihens.

Iremn ich in den folgenden Einzelschildermugen die wissenschattlichen Tamen an die Spitze stelle, und die volkstiimlichen Benemungen stark zuritcktreten lasse, so geschieht es, weil in den letzteren eine kunterbunte Verwirming herrscht und auch, weil sie grösstenteils zu unpassend sind, als dass ihre Beibehaltung, vitel weniger noch ilne C̈bertragung nach anderen Ländern emiftehlenswert wäre. Wiederholt habe ich in der ..tropischen Agriknltur." darauf anfmerksam gemacht, wie unglücklich und ungeschickt die Engländer und ihre colonialen Nachkömmlinge sind. we'm sir fremden Dingen cinen Namen geben; hier verleugnen sie, wie so oft. ihren viel bewunderten maktischen sim. I'm bei den Taldbämmen zu hleiben: wie phantasiearm zeigen sich die Nordamerikaner in den betreftenden Benemungen. welches Durcheinander herrsht in der Ainwendung desselben Tamens für verschiedene Arten. wie unpassend im Hinblick anf die Eigenschaften der Bäume sind oft die gewählten Bezeichnmgen. Iras in dieser Beziehmo die Nordamerikaner Lnverständiges geleistet haben, wird von dell dustraliern weit ibertroffen. Fs scheint, dass in dem zuletzt entdeckten Erdteil dio Fähigkeit der Fngländer zu Benemung nener liegenstande auf den Gefrierpunkt herabgesmken sei. Hier haben sie nicht allein unverständige, sondern sogar alherne Tamen gewählt. mul sie hätten es doch so leicht gehabt, das Armutszenguis fïl ihre Phantasie zn umgehen, wem sie sich dir fast durchgehends kuren und wohlklingenden Samen der Eingreburenen angetignet hïtten! Anch Baron ron Miiller beklagt liv mverständigen Benemungen, so sagt er bezïglich Eucalyptus botryoides: es ist zu bedanem, dass ein so simnloser Vame wit Bastardmahagoni in ansgedehntem Masse Eingang in die sprache 


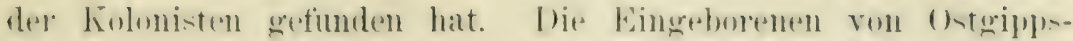
land nemnen diesen Baum Bimnak und diejenigen bee Port Jackison Bangalay.

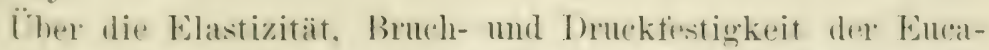
lyntushilger, suweit sie exmittelt sind. gehen die 'Tabellen im Abschnitt iiber die Holzkunde Auskunft.

\section{a) Eucalyptus rostrata.}

Der rote (iummibaum. Die zerstreut stehemden Blätter sind lanzettlich-sichelformig und gleichfarbig auf beiden seiten: die Zweigadern sind sehr fein, die (̈)drüsen spärlich oder rerborgen. Die schirmblïten achselständig oder seitlich answachsend, einzelstehend atn dïmen Stielen, mit 4 his $1+$ Bliiten besetzt. Die Frucht ist nicht gross. rundlich, 3-. ifters t-. selten 5-zellig, die kleinen Samesl sind alle ohme Flügel, die unfruchtbaren sind sehr schmal.

Verbreitet ist diese Art filst ibber das ganze australische Frotland. all:cenommen nur im siidwesten an einigen Kïstenstrertien: in 'Tasmanien fehlt sie vollständigr. Virgends steigt sie hoch in's trebirge, noch entfernt sie sich von den feuchten ()asen der Wö̈stemegionen. Thre hörhste Fntwickelumg errechol sies an den I"fern ron Wasserlänfen oder auf dem schwemmboden rom Thatsohlen.

lieser Bamm kamm als der allgemein nützlichste Fucalygtus. als die wichtigste Art der ganzen Gattung betrachtet werden. (b)-

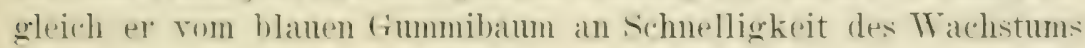
iibertroften wird, überragt er diesen dorh an Wert wegen seines

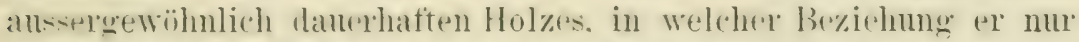
im . Tarahbaum (F. marginata) einen Wetthewerber hat, dem gregeniiber er aher den Torteil schnelleren Wachstums mol des grö̈seren Anherquemungrevermögens an Boden und Klima besityt; selbst in sumpigen und schwach alkalinischen bïden konnmt er fort und an su windgerpeitschten standorten. wo der blane fimmibanm bald brechen

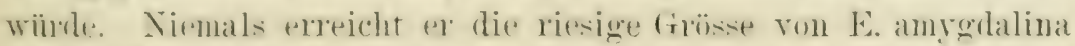
und E. diversionlur: allein er wächst doch \%ur stattlichen Grö-se

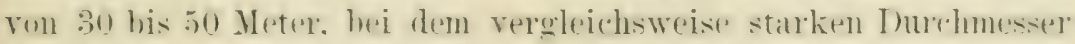
ron 3 bis 4 Meter, liefert also massiges Hol\%.

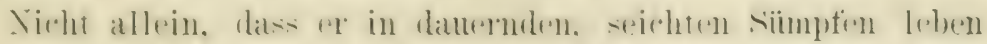

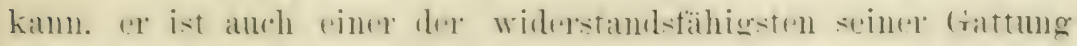
gegen tropische Hitze. 
Then Samen roter Gimmibanm ampfing diese Alt von der dumkelrälich brament Fabe des Holzes und nicht von der Rindenfalthe die nur gelexentlich sehwach rötlich bräunlich, gewöhnliels aber glatt ascheran oder weisslich ist. Die Eingeborenen am unteren Murrumbiảgee nennen diesen Baum Biall.

has Holz ist sehr dicht mo ausserordentlich daurerhaft, nimentlich im Boden, beim Trocknen schrumpft es in der Längenrichtung kaum benerklich und widersteht einem enormen Truck. Es nimmt eine schöne Politur an, doch ist es so schwierig zu bearbeiten, dass es selten zu Möbeln benutzt wird. Dieser Verwendung ist auch sein Gewicht hinderlich, beträgt doch die spezifische Schwere 0.858 bis 1,005 . Gebraucht wird dieses Holz hauptsächlich im schiffban für Planken und Riegel, für Wagnerarbeiten, namentlich als Felgen, für Zäune, Pfosten, Brïcken- und Hausbauten, fïr Telegraphenstangen und Bahnschwellen. Beachtımg rerdient, dass die Regierung der Kolonie Viktoria auf Grund ihrer Erfahrungen nur noch dieses Holz zu Bahnschwellen und Brïckenbanten verwenden lässt. Wenn Baron von Müller sagt, dieses Holz widerstände den Angriffen des Teredo und anderer Seetiere, so ist diese Behauptung von der Erfahrung unbestätigt greblieben. Wohl bleibt es im süssen wie salzigen Wasser lange Zeit frei von Verwesung. und es mag auch kein beliebter Angriftsgegenstand fïr die kleinen Seetiere sein, allein verschont bleibt es nicht, wofür unter anderen Beweisen die Zerstörmg einer ansehnlichen Zahl Pfeiler der Schiffslände im Hafen von San Franzisco vorliegt.

Mit diesen Pfeilern aus rotem Gummibaumholz wurde ein grösserer Versuch unternommen, um ihre Teredofestigkeit zu erproben, allein der Erfolg befriedigte nicht. Der IV ert dieser Erfahrung kamn nicht daduch beeinträchtigt werden, dass der Teredo in auffallend starker Zahl im Hafen ron San Franzisco auftritt. Die Hölzer aller anderen, in Californien eingeführten Gummibäume wurden ebenfalls versucht, doch mit schlechterem Resultat. Darunter befanden sich weder der Karri noch Jarralı und num hat die Hafenbehörde beschlossen, einen Versuch mit dem Holze des Ersteren zu machen. weil ihm das Zeugnis zur Seite steht, es habe im Hafen ron Melbourne bereits 25 . Tahre del. Verwesung und dem Teredo widerstanden. Dem Jarrahholze wurde seither eine grö̈ssere li iderstandsfähigkeit nachgerühmt, daraus: 


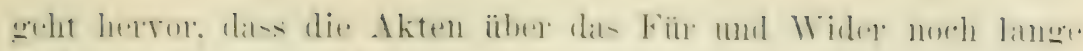
nicht geschlossen sind.

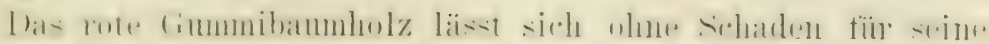

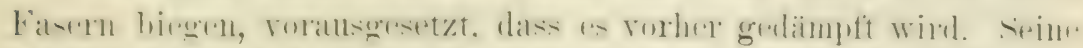

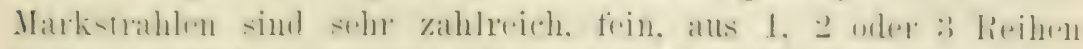

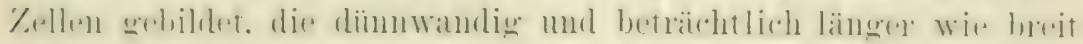

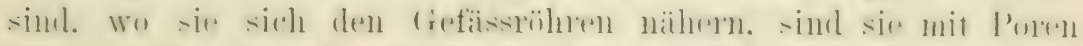

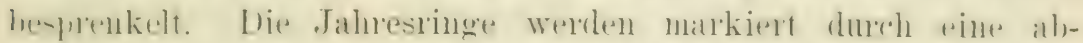

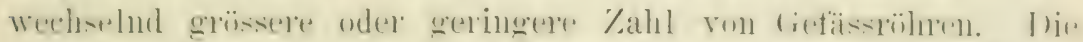

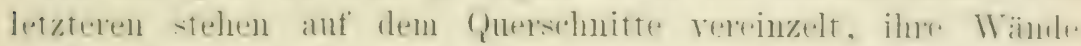

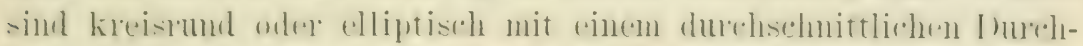

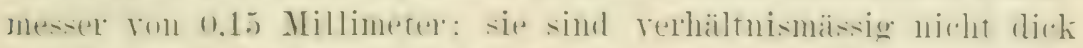
und rethalten oft dïmwandige Zellen mit einem rothaumen stuft:

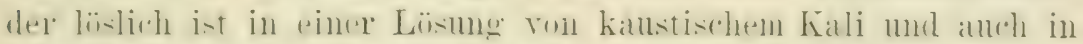

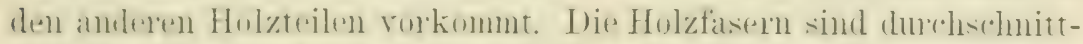

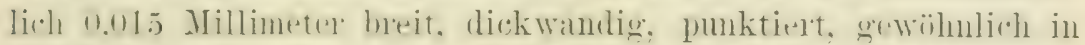

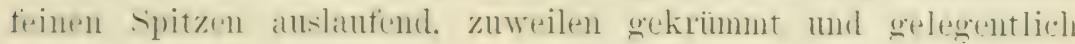
velzweigt.

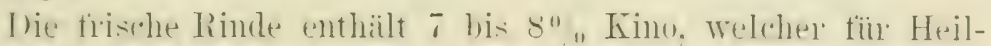

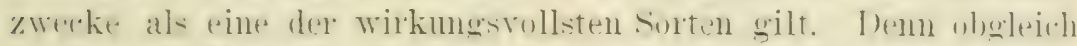

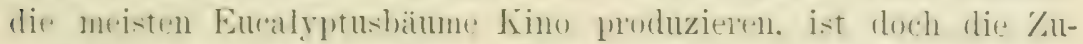

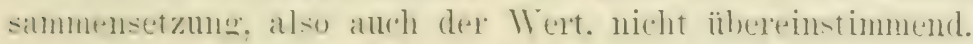

Dits luftrockene Hol\% enthält nateh den Lntersuchungen des

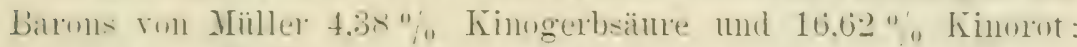
der letztere stoft ist liislirhe in Alkohol, abel nicht in Masser.

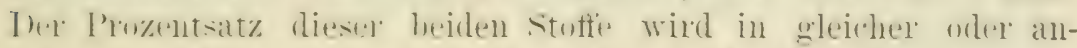

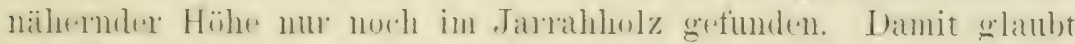

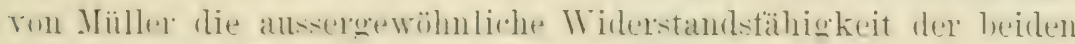

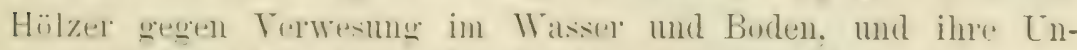

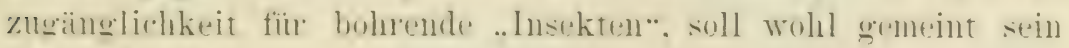
bohrende Kileintiere, erklïren zu kömnen.

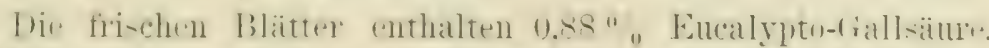

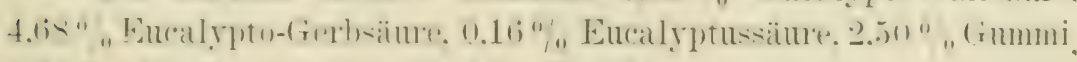
$0.72 \%$ Eucalyptin und 10,42\% Fruchtzucker.

\section{b) Eucalyptus pilularis.}

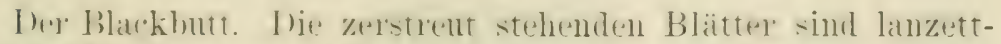

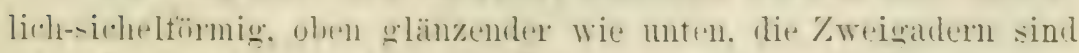

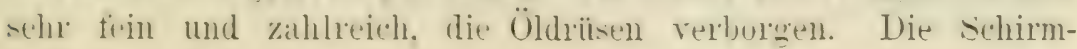


hlien meistens atchselstandig, cinzelstelend. alls 4 bis 16 Bliiten zusammengesutgt. Die halbovale Fucht ist 3 - oder t-, selten

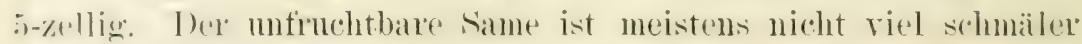
wie der firchtbare, alle sind ohne Flingel.

bieser Baum kommt vor in bewaldeten fexenden von Ustgippland bis siidyeensland, stets anf das Kiistengebiet beschränkt. linter giunstigen Linständen ereicht er eine Höhe von 90 Meter. bei vinen stammdurchmesser von 12 bis 14 Meter. allein in der Rexel ist er beträchtlich kleiner, 60 Meter darf als die durchs.hnittliche Höhe betrachtet werden. Die etwas faserige Rinde ist aussen schwarzgrau, imnen brämlich und von Querfaser'n durchzugen. Die Rinde der Äste und Zweige ist glatt, gran oder weisslich.

Das Holz refrent sich eines ansgezeichneten Rufes für Banzwecke. in Form von Balken und Brettern, Telegraphenstangen, Bahnschwellen, schindeln und Raastangen; wird dagegen als Bremnstoff geringwertig betrachtet, liefert indessen gute Kollen.

l)as spezifische ( fewicht beträgt etwa 0,897. Im Laboraturium des Barons von Müller wurde ein Stab dieses Holzes. 4 Fuss lang mol 2 Zoll im (puadrat, in der Mitte mit einem Fewicht ron 980 Pfund belastet: die Beugung betrug 1,35 Zoll, während die Elastizität unbeeinträchtigt bliel). I as schliessliche Bruchgewicht betrug 1232 Pfund.

Die Sämlinge haben glatte, langrunde Blätter, gran an der unteren Seite und auffallend besprenkelt mit durchsichtigen Öldrïsen.

\section{c) Eucalyptus botryoides}

Der Bastardmahagoni der australischen Colonisten. der Bangalay und Binnak der Eingeborenen.

Die zerstrent stehenden Blätter sind lanzettlich-sichelfürmig: blen dunkelgrïner und glänzender, unten fahler und dumpfgriuner; die feinen Seidenadern breiten sich fast quer aus, die Öldrïsen liegen sehr verborgen. Die an breiten, zusammengedriickten Stielen stehenden Schirmblïten sind achselständig. einzelstehend, aus 4 bis a Blüten zusammengesetzt. I)ie Frucht bis halboval, $\therefore$ his 5 zellig. die mufruchtbaren samen sind viel schmäler wie die fruchtbaren, diese wie jene haben keine Flügel. 


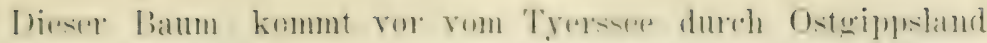

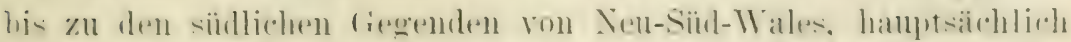

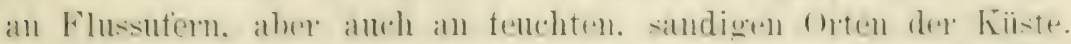

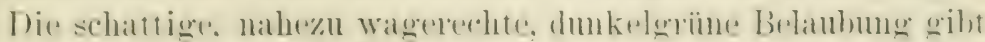

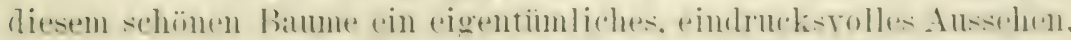

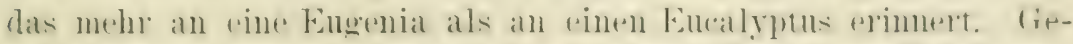

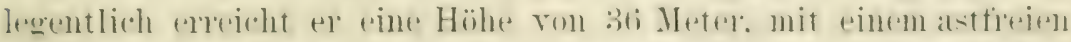

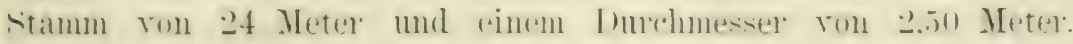

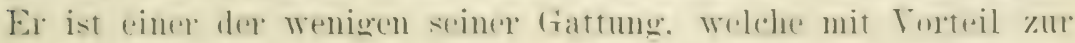

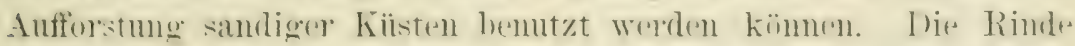
i-t dunkel. otwas gefiucht und nicht abfiallemel am stamme und den Hauptästen.

Das Holz ist lichtbratu. Es wird. wenn anf fruchtbarem Boden an Flusifern gewachsen. als rines der hesten unter den

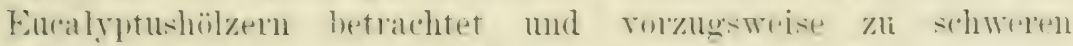
Wagnerarbeiten, nanentlich Felgen. verwendet. siohdeln alls

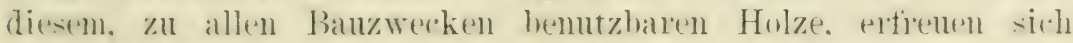
eines besonders guten Rufes.

Tem! der Baum im Küstensand wächst. ist der stamm uft knorrig. aber gexund bis auf dem Markkirn und branchbar zu Brettern und Zaunpfosten.

\section{d) Eucalyptus gomphocephala.}

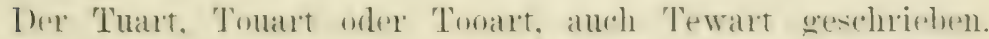
Lite an langen stielen zetrotrent sitzenden Blatter sind lanzettlicll-

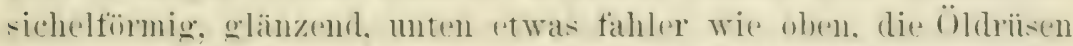
lienen verboreren. Dir sohirmblïten sind achselständigr. einzel-

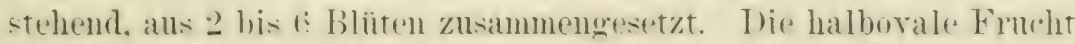

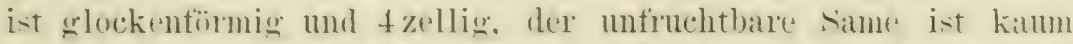
kleiner wie der fruchthare, beide haben keine Flïgel.

Tieser Bam ist in Westanstralien heimisch. Wo er anf die Sähe des Oceans bescheankt ist und zwar auf kalkecichem Boden. ïberlagert mit Treiband. Er erreicht eine Höhe ron sti Meter mit einem astfreien stamme von 15 Meter. Iter Belaubung ist fïr

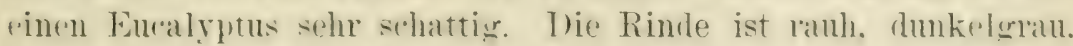
an jungen Bäumen glatt.

Lhas Holz ist hellgelly, auftallend hart und stark. sehr selhwer. dicht mol gerheht faserior. wodurch is sich sehr schwierigr spalten lässt. Lond was muter den Eucalyutushölzern als eine besonders 


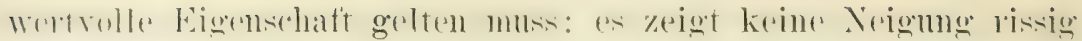
zir werden.

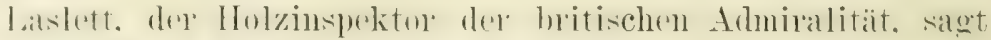

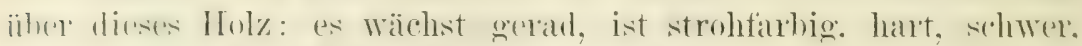

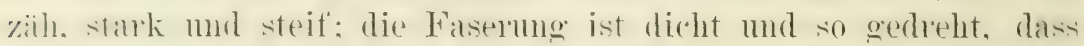

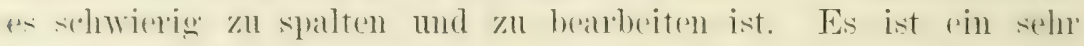

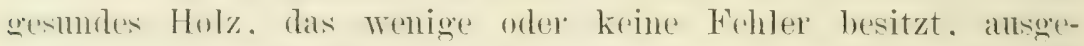

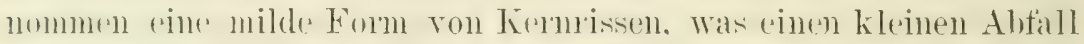

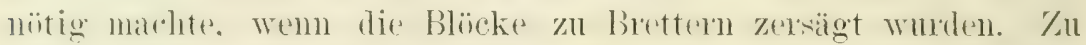
grossen Jalken benutzt, wird man es als ein sehr wertrolles Hol\% erkennesl, namentlich wonn bedentende stärke beansprucht

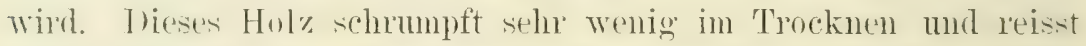
nicht withremel dieses Torganges. C'harakteristisch fü̈ dieses Holz ist anch. dass es lange Zeit den Einwirkmgen der Witterunw widersteht. Ich reiss, dass es rolle 10 Jahre diesen Ein-

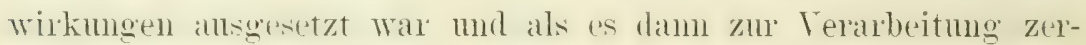
legt wurle. salı « immen so frisch aus wie nell gefälltes Hulz. trewiss kam kein hoserer Beweis fïr seine I)anerhattigkeit "l-

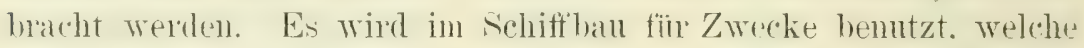

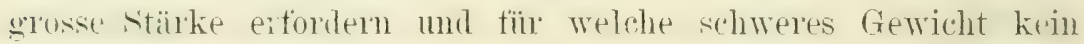
Hindernis ist. Fiur Banten ist ex kamn in diesem Lande fGrosimitammions gokimut, obgleich es mancho vorteilhatte Terwendung finclen kïnnte. wie zu Pfrilerue tïr l'iers und Brïcken und zu Dorkishlensen, da es im Masser widerstandstähig wegen die VerWesmen mol eines der stäksten der bekannten Hölzer ist. '/am

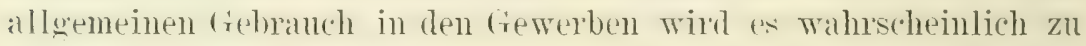
schwer befunden werden.

spezitische sichwere 1.147 his 1,194, im Inuchschnitt 1,169.

Baron von Miiller gibt folgende Empfehlung: wo in einem milden Klima tin kalkreicher Boden in der Nahe des Meeres beWaldet Werden soll, verdient unter den Hartholzbämmen der Tuat die gröste beachtung. Er wude zuelst in botanischen Gartril vou Nelbourne vor vielen Jahren unter Kultur genommen.

\section{e) Eucalyptus leucoxylon.}

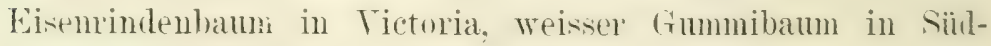
australien; der Yerrick der Eingeborenen.

Jie zerstreut stehenden bläter sind schmal lanzettlich. otwas sichelfümig. solten langrund lanzettlich.. entweder s'aulich oder 


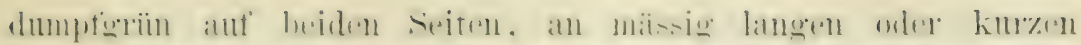
Stielen. Die Adern sind weder zahlreich. noch breiten sie sirh woit alls: die durch-irhtigen

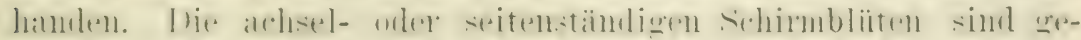

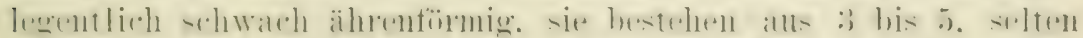

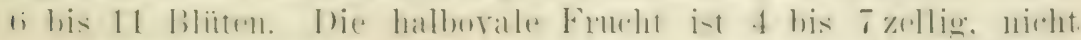

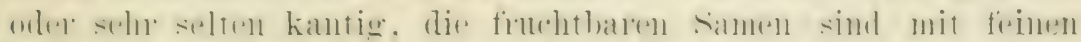

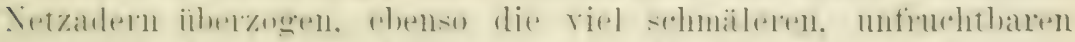

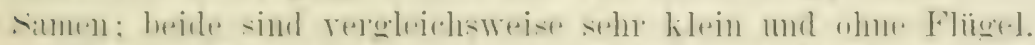

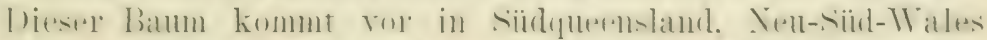

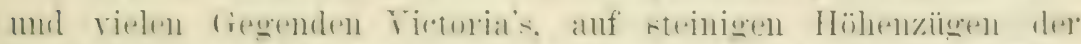

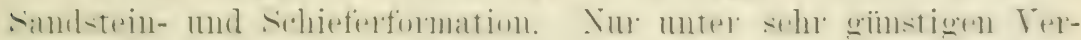

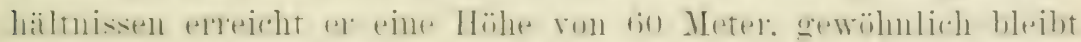
er beträchtlich riedriger.

life ganze limele bleibt atn dem stamm mol wird deshalh

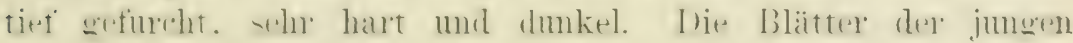
Bämme sind lanzettlich-oval, gegenständig und g'latt.

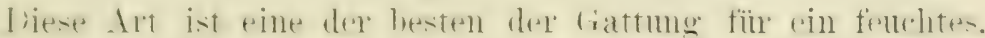

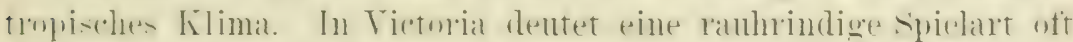

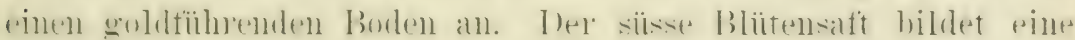
beliebte Bienentreide.

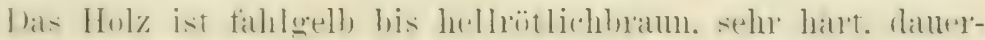

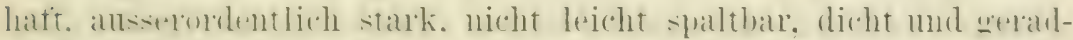

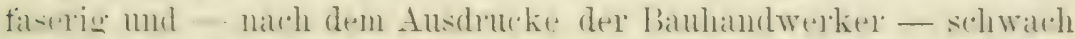

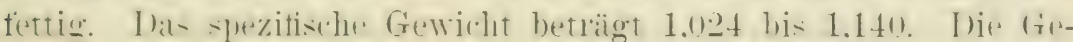

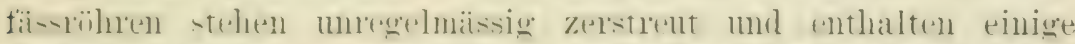
zellige stofte. derere Wände punktielt sind. Die Markstrahlen

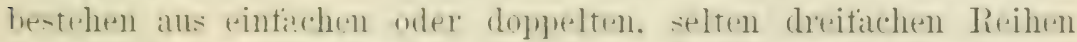

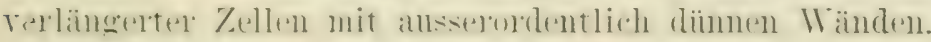

Die Terwemdung ist diojenige der anderen besseren Eucalyutushölzer: tön liahnshwellen. Telegraphenstangen. Wagnerarheien.

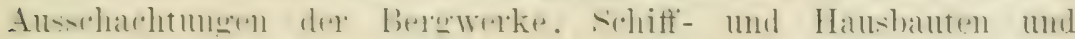
fierite, die ans starkens. selowerem Holz zu fertigen zwerkmaissig sind.

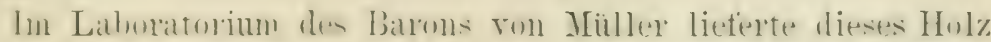

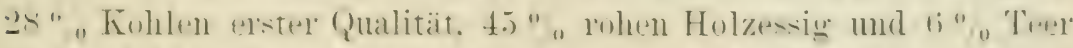
- P'rodukte. die sellstrestaindlirh ron allen Eucalyntushiolzerm mol vielen anderen Hoilzern gewommen werden kïmens. allein in

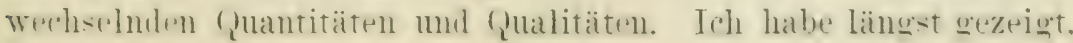


Sarrt barm vom Mïller. dass ans den imneren schichten dieser Rinde. wic aller Encalyptusrinden. Packpapier bereitet werden kamm. T) B Bätter enthalten in der Regel etwas mehr wie $1 \%$ Hiichtiges (i). Verhältnismässig reich an Kino ist dieser Baum, 2.2 " sind in meinem Laboratorium nachgewiesen worden. Dieses Kino ist leicht lïslich im Wasser, von schwacher, samer Reaction, trïbt sich durch Erwärmung, klärt sich aber wieder.

Trenn Baron von Müller wiederholt darauf hinweist, aus der Rinde der Encalyptusbäume könne Papier bereitet werden, darf an der 'Thatsache selbst nicht gezweifelt werden. Es drängen sich aber die Fragen in den Vordergrund: gestatten die Fabrikationskosten die Herstellung? Und ron welcher Qualitat wird das Papier? Dir die Papierfaürikanten gegenwärtig die ganze Pflanzendecke der Erde cifrig nach geeigneten Rohstoffen für ihren Gebrauch durchforschen und die ihrer Beachtung empfohlene Eucalyptusrinde unberiicksichtigt gelassen haben, so ist anzunehmen. dass die Antworten auf jene Fragen unbefriedigend ansgefallen sind.

\section{f) Eucalyptus Raveretiana.}

Der graue Gummibaum oder Eisengummibaum. Die zerstrent stehenden 8 bis 12 Zentimeter langen, 2 bis 3 Zentimeter breiten Blätter sind dïmn, oval oder länglich-lanzettlich, schwach sichelförmig, reichlich mit durchsichtigen öldrïsen besprenkelt, heller unten wie oben, mit sehr feinen, etwas entfernt stehenden Adern. Die Bliiten sind ausserordentlich klein, wenige bilden eine etwas zugespitzte schirmblïte. Die Frucht ist sehr klein. 3- selten 4zellig; die samen sind ohne Flügel, die unfruchtbaren sind kleiner aber kaum kürzer wie die fruchtbaren.

Dieser Baum, der eine Höhe von 90 Meter, bei einem Stammdurchmesser von 3 Meter, erreicht, kommt ror im istlichen Australien in feuchten Waldthälern, an den Ufern von Flüssen und Simpfen.

Die Rinde stïsst ihre äusseren Schichten ab, zum mindesten an den Ästen, welche dadurch gran und glatt erscheinen. am Stamme geschieht es oft nicht. Die Belaubung fallt zeitweilim fast vollständig ab.

Das Holz ist dunkelfarbig, dauerhaft. sehr hart, wertroll zu muterirdischen 'Tragbalken, Bahmschwellen und ähnlichen Z $/$ recken. Es widersteht den härtesten Stössen. 


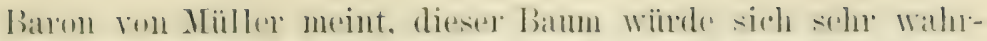

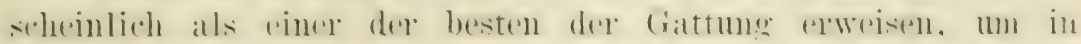

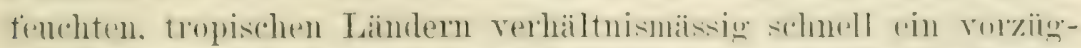

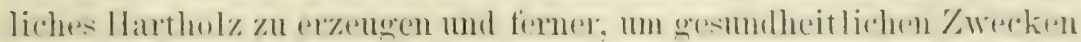
zil dienen.

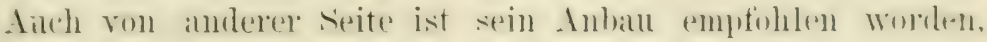
smohl im Hinhlick anf das allsicerordentlich feste Hol\%, als ant

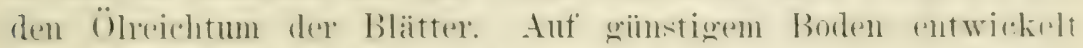

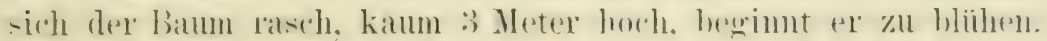

\section{g) Eucalyptus resinifera.}

ley pote Mahagoni orler Maldmahagoni. Die zerstrent sthernden Blïtter sind länglich oder schmal-banzettlich, etwas gekrümmt, heller unten wit oben, die feinen, zahlreichen \%weigadern hreiten

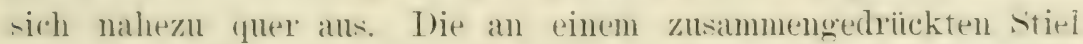
stehenden schirmhlüten sind achsedständig und ans o his 11. sutener alls 3 bis 5 Bliiten zusammeneretzt. Die Frucht ist halloval, shockenförmig, 3- bis 5-zellig, nicht orler selten kimtip. die finchtbaren samen sind viel breiter wie die unfuchtharen und sehr kantig: heide sind ohne Flügel. Die Rinde ist rauh. am Stamme bleibend, an den Ästen abschälend.

Verheret ist dieser, fo bis 50 Mreter horhwerdende batum in Cuernsland und Xen-siid-Wales. dringt aber nicht tiet in dat Inland.

Das Köno, welehes er liefert, gilt für Heilzwerke als dan beste der crattung. lat es doch alloh zuerst die Aufmerkiamkeit der Ärte anf diesen Stoft resenkt. In. White benutzte ('s bald nach Grüdung der Botanybaiansiedelung mit answezeichnetem Erfoleg gegen Inrehfall und berichtete, dass das Fino dieses Bammes sirh

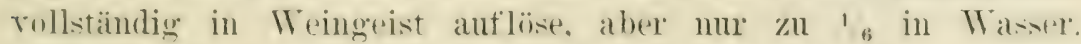
Heisses Iraser löst mehr wie die Hälfte anf, Alkohol mehr wh zwei lrittel, Äther ungetähr ein Zwanzigstel. Einschnitte in die Rinde besthlemigen und exhöhen den Fluss des Kinosattes.

C̈ber das Holz sagrt Laslett, der Holzinspektor der hritis.lwh Admiralität : 's ist tieffot. sehr hart, schwer. stark. atusererordentlinh steif und sehr shwierigr zu bearbeiten. Es hat einfiche. quelads Fasem und die sehr kleinen Poren sind mit diner weissen. hatten spröiden Aussonderung gefüllt. Her Baum ist im allgemeinen gesund, allein Herz- und sternrissen unterworfen und daher gewïhn- 


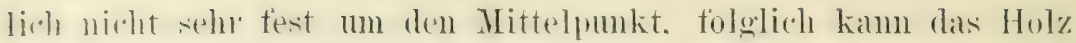
nivit rorteilhatt rerwendet werden, allsgenommen zu dicken Planken mul staken Balken. In Australien wird as ansedehnt im sidhitthalli mul zu Ingeniemwerken benutzt. in diesem Lande (ripossmitamienl wird es zum Ban rom Kanffahrteischiften gehrancht. wa vill schweres Material nicht beanstandet wird. Für Hanshatuten und die diewerbe wird es wahsoheinlich nicht stark verlangt werden. die alsserordentliche Härte und das schwere fiewicht schliessen es rom allgemeinen Gebranche aus.

Durchschnittliches spezifisches Gewicht 1,150.

In Australien hat man Einwände gegen dieses Lrteil erhoben mul wem man sich anch stets erimnern muss, dass dort ein hochwarliger Patriotismus. wie alle Naturschätze des Landes, so anch die Euralyptushölzer; in das glämzendste Licht zu stellen sucht. $\therefore$ mag doch in diesem Falle eine Erklärmeg in der folgenden Bemerkung des Barons ron Miiller zu finden sein: E. resinifera zeigt heträlchtliche Abweichungen in der Form, was nicht äherlar-hell kann, wenn wir berlenken. uiber welches weite Gebiet sich dieser Bamm rerbreitet. so nehmen in der fenchten, heiswen Region dex Rockinghambai die Bläter eine breite, fast ovalw Form an, nalrezu gleichfarbig anf beiden seiten und ron dicker Iexchaftenheit. Ich füge hinzu: wo so viele Formverändermgen anftreten. sollten da anch nicht beträchtliche (qualitätsmenterschiede im Holze zu erkemen sein? Wie dem anch sei, das Holz dieses Banmes erfient sich eines sehr guten Rufes in Australien, entsnerehend seine' ansgedehnten Terwendung, namentlich wird die Danerhaftigkeit gerühmt.

Baron von Müller hält diesen Baum sehr wertvoll für feuchte. tropische Länder:

\section{h) Eucalyptus corynocalyx.}

Der zuckerige Eucalyptus. Die zerstreut stehenden Blätter sind hroit odere äfter länglich-lanzettlich. schwach gekrümmt. spärlich ordex nicht mit (̈)driisen besetzt. mit einem öligen tilanz ant beiden seiten, etwas heller unten wie oben, die zahlreichen Adern hreiten sich mässig aus. Die seitlichen oder achselständigen Shormblitten, an fast "ylinderischen Ntelgeln sitzend, sind hïntig muter den Blättern zusammengedrängt und aus 4 bis 16 Blüten 


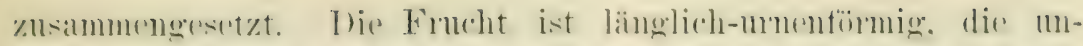

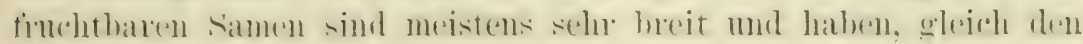
f'uchtbaren, keine Flïgel.

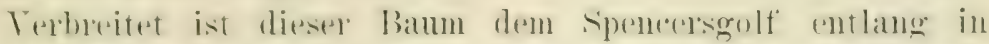
westlicher Ridhtme bis zur streakybai. an stringen Hängen de-

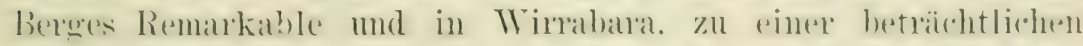

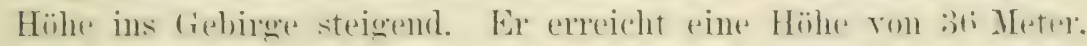
bei einem Stammdurchmesser von 1,5 bis 1,8 Meter.

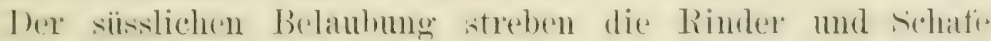

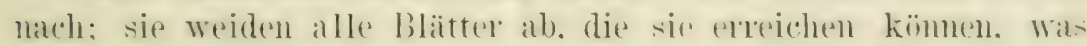
sie bei keinem andern Eucalyptusbaum thun.

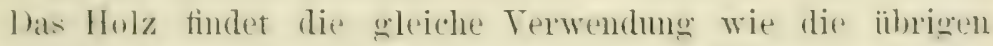
besceren Fucalyptushöler. Ton unterirdischen Ptosten wird berichtet. dass sie noch nath 15 Jahren frei von Zeichen der Verwesung waren.

Dex bexonderen Beachtung empfehle ich, was Baron von Mäller iiber diesen Baum sagt: Fiar eine Wüstenregion ist er einer der vorzïglichsten von den nüt\%lichen Eucalyptusbäumen. Ans dierin Grunde wählte ich diese Art zur Einfiihrung in das trockene. Hinterland ron Algier. Unter den nützlichen Encalyptusbäumen. welche im stande sind. die langen Dürren wie die ansserordentliche. Hitze der Wïstemregion zu ertragen. mögen für schnelle Holzprorluktion erwilhnt werden: E. polyanthema, E. bicolor. E. saluhris. E. ochophloia, E. salmomophloia und vielleicht E. terminalis. (1)qulcich E. rostrata rbenfalls fähig ist, eine ausserordentliehe trockene Hitze zu ertragen und wegen seines massigen, seln dantrhaften Holzes alle genannten Wiistenbäume an Wert weit iibrelagt. kommt er doch nur an Orten fort, wo der thonige Lntergrund stets etwas fencht bleibt, daher findet er sich bloss in Oasen

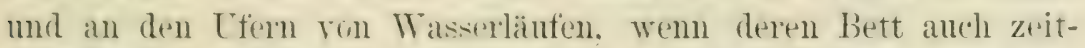
weilig lange trocken bleibt. An einer andern stelle empfiphlt derselbe Antor auch E. mirotheca als Wüstenbaum.

IT enn es sich in finer Wïste nur un die schnelle Produlktion ron Bremnlol\% handelt. mag noch E. pachyphỵlla in Betracht kommen. Diese Art wichst mehr stranchartig wie baumartigr d die an langenstielen stehenden Blätter sind dick, lederartig. wal und fein geadert: sit: kommt in den Wüsten Mittelaustraliens. vom sturts- mo Hookerbach his zum see Amarlens vor, wo sie die heissesten I)ürren überdaurt. Die Wärme, welche diese und andere 
mnitelathstalischen PHanzen ertragen, mag ansmahmsweise im Shatten auf $50^{\circ} \mathrm{C}^{\circ}$. und in der some auf 730, oder selbst aut $55^{\circ} \mathrm{C}$. im Schatten und $76^{\circ}$ in der Somne steigen.

\section{i) Eucalyptus siderophloia.}

Eisenrindenbanm in Nen-sïd-Wales. Die länglichen oder shmal-lanzettlichen Blätter sind schwach gekrümmt, fast von vrleich Farbe ant beiden Seiten. mit stark verborgenen öldrüsen. I) achselständigen Schirmbliiten sind ans etwa einem Dutzend Bliten zusammengesetzt. Die Frucht ist nahezu halboval, am Grunde etwas zugespitzt, kaum kantig. Die stmen sind alle ohme Fliigel mul die mfruchtbaren nicht sehr schmal. Die Rinde löst -irll nicht ah; sie ist tief gefurcht, die Furchen sind gelblich oder dunkelbraun.

Terbreitet ist diese Art ron den siidästlichen Inistrikten Greensiands bis zu Port .Tackson; sie erreicht eine Höhe von 15 Meter, bei einem Stammdurchmesser von 1.2 Meter.

Dals ist der hauptsächlichste Eisemindenbaum von Neusiud-Wales; er liefert für das Holzgeschät dieser Colonie den iiberwiegenden Teil des .Eisenrindenholzes", an dessen Produktion - irh ansserdem die 4 Arten beteiligen: F. crebra. E. melanophloia. E. paniculata. E. leucoxylom. Das Eisemindenholz von E. sideroIhluia wind aber besonders geschätzt: deshalb gehen auch die Vorräte der Erschöpfung entgegen.

Dieses Holz ist hellfarbig. schwel, stark, dauedhaft, wegen siner ansirordentlichen Härte schwierig zn bearbeiten. Terwendet wird es zu Bahnschwellen. Telegraphenstangen, Tragbalken ind allen \%werken. wo bedeutende stäne und Dauerhattigkeit gefordert werden. Für Speichen zieht man es in Australien allen anderen Eucalyptuhïlzen vor. ebenso für Radzapfen in Mïhlenwerken. Als Bremmolz ist es erster Qualität.

\section{k) Eucalyptus cornuta.}

lex Yate. Die zerstrent stehenden Blätter sind gewöhnlich schmal-lanzettluh, schwach sichelförmig. von dicker Beschaftenheit. ta-t wleichtarbig anf beiden seiten, die Adern breiten sich mässig. ans. die Öldrüsen liegen sehr verborgen. Die seitenständigen Bliatenstiele tragen :े und mehr Bliiten. Die gedrängt sitzenden 


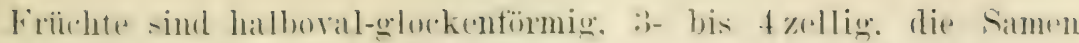
sind whne Flïgel. die untruehtharen nicht sehr schmal.

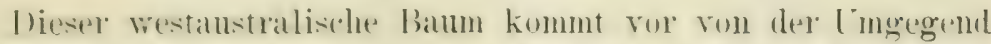

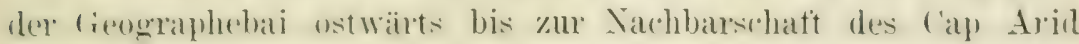
bi eignet sich tïr almen boden. der alls verwittertem Kalkstein hervorgenangen sein madr, doch zicht er pinen fenchten standent vor und gedeiht andh in einem feudhten, tropischen Klima. Betont zu werden rerdient, dass er in Lagen angeptlanzt werden kamm. Welche dem 1 inde schutzlos preisgegeben sind. Tntex giustigen Verhältrisien entwickelt ex sich sehr rasch. ist dorhe win Wahstum ron :3 Meter im . Tahre beobarhtet worden, doch

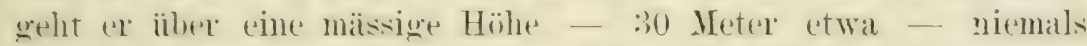
hinaus. Fehon in jugendlichen. huschigen Zustande beginnt er zu blïhen und Frïchte zu tragen. The Bläter der saimlinge sind gregenständig, oval, gestielt.

Ballon von Mäller salgt: das harte, elastisches Holz des Tate ist gesucht tiir Wagendeichel, landwirtschaftliche trerite und Bontrippen, wotür es sich in Werte der „englischen Esche" nähert. Fs ist ein schweres Holz. das. selbst wem grïndlich getroknet, im Wassel sinkt. die spezitische showere ist mit 1,235) ermittelt worden. Dats ist wahroheinlich am grosen Teile der Dicke der Holzzollenwinde und deren enger Höhlmng beizumessen.

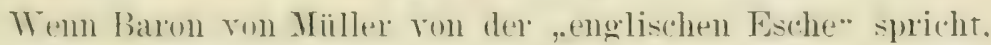
wird er damit Fraxinus exoelsor, die emopäische Esche meinen, dren diese wind gewöhnlidh vonden Briten und ihre kolonialen thkömmlingen als englisch. seltener als britisch bezeichnet. Weitere molïckliche vom sprachgeblateh in das schriftum ïbergegangene Leistungen anf diesem fehiet sind: die emglische Eiche. worunter

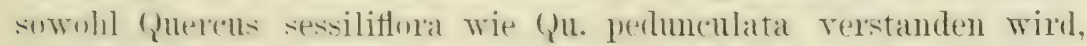
die "ngliselue Llme (Llmus "ampestrist, die englische Linde ITilia

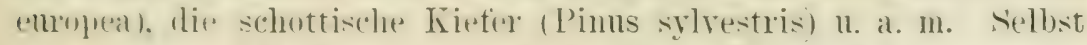
der gemeine Hagedorn ist zum englischen Hagedorn gistempelt worden.

II at iibrigens den Vureleich des Yateholzes nit dem kischenholze betrift. \&n hinkt ('I jedenfalls, schom allein wegen des bedeutenden Interschieds in Gewicht der beiden Hölzer. Es ist zu bedauern. dass iber viele Eucalyptushölzer bis jetzt norh keine Trteile nichtaustralischer Fachkenner vorliegen. 


\section{1) Eucalyptus goniocalyx.}

Iherefleckte (immuibamn in Viktoria. In andern fiegenden fiilnt er die Namen: dex blanweisos fimmibaum. der grane oder Batstardbuchs, selbst einen so allocrnen wie Bergesche.

Die zerstrent stehenden Biäter sind länglich oder sicheifïrmig-lanzettlich, gleichfarbig auf beiden Seiten, nicht stark glänzend. Die öldrüsen liegren verborgen oder sind durchsichtig. die diumen Adern breiten sich nur mässig ams. Die achselständigen, einzelstehenden Blïtenstengel tragen 4 bis 7 Blüten. selten weniger. Inie halbovale Frucht ist 3- oder 4-zellig, besäumt mit. 2 bis $t$ mehr oder weniger deutlichen Kanten. Die Samen sind ohne Flïgel, die unfruchtbaren meistens schmäler wie die fruchtbaren.

Ineser Baum kommt vor in der T'mgegend ron Portlandbai und ron Wimmera ostwärts bis zu len Flüssen Gellibrand. Orens und Hume. und siidlich durch Gippsland bis in die Nähe ron Braidwood in Neu-Siid-Wales. anf Tiefebenen bis zu Erhebungen von 900 Meter. In fruchtbaren Thälern erreicht er eine Höhe von 90 Meter, bei einem Stanmdurchmesser von 1.8 bis ausnahmsweise 3 Meter.

l)ie sämlinge haben herzförmige oder ovalrunde. gegenständige, sitzende Blätter, oft viel heller oben wie unten. die Stiele sind nicht viereckig.

Das Holz ist hellgelb bis braun. hart. zäh und gewïhnlich firei von Kinoadern. anserordentlich danerhaft. namentlich in der Erde. Es wirft sich nicht und in Folge seiner verfluchtenen Holzfasern ist es beinahe so schwierig zn spalten, wie das Holz von E. rostrata. Es ist sehr geschätzt von den Wagenbanem, die es hauptsächlich zu sueirhen verwenden, ferner wird es benutzt in schiffbau und zu Bahnschwellen: es gilt als ein gutes Bremnholz.

Die durchsehnittliche Weite der Gefässö̈hen ist 0,12 Millimeter. ihre Wände sind diun und die Holzfasern sind etwas geflacht. mässig dick und bis zn 0.02 Millimeter hreit. Ile sehr zahleichen Darkstrahlen bestehen ans 1 bis 2 Reihen kurer Zellen. 


\section{m) Eucalyptus amygdalina.}

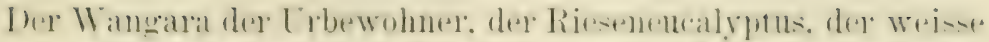

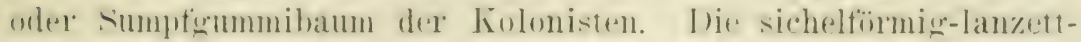
liehen blatter, meistens tieferün und etwas gränzend anf beiden

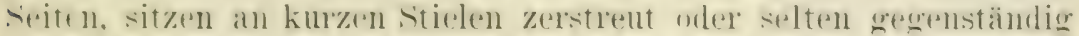
an sehlankin \%woigen. Die (̈)drïsen sind sehe zahlreich und

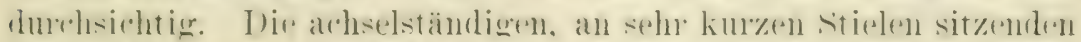

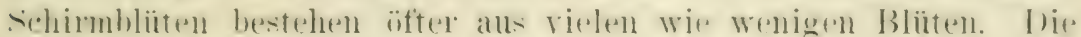
kleine Frucht ist halbural, 3 his 5 zellig. dir fruchtharen wir.

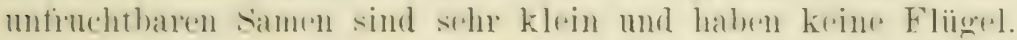

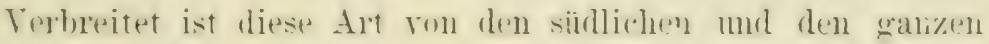

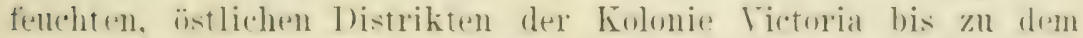
blaten Gebirge und dem Küstengehiet ron Vent-riid-llates. In Tasmanten ist sie häntig: hise wie ant den anstralischen Forland steigt sie bis zu brhebungen von 1200) Meter. Cnter den grusien Eucalybtusarten gilt sie für eine der klimahärtesten.

Thir when schon bemerkt wurde, muss dieser Bamm als der. hïhste der Erde gelten und in steiner battung nimmt er einen resten Rang ein. boüglich der schellen Produktion von hartem Holz. Jund pr liefiert pin Holz, das zu den besseren Euralyptushiil\%ern zählt: in dex (̈)gewimnung aus seiner reichen belaubung wird er nicht äbertroften und wahrscheinlioh nivht erreicht von irgend einem Baume der Erde.

Für Länder, wo werler strenge Kälte noch starke, fenclits IÖ̈me anftritt. ist dieser Banm jedenfalls eine wertrolle Erwerbungr. Unter versehiedenten klinatiochen und Budenverhailtnitsen nimmt er weelswelnde Formen an. So gewinnt er in be-

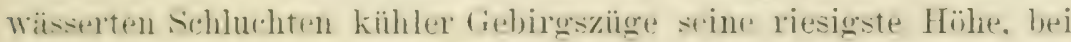
einem rollkommen geralen stamme. der glatt und fast weiss exsheint. Weil sich die aluseren Rindensehichten vollständig ahlïsen: unter dieser Wachstumsermst hat er, in Bezug anf Hëhe. mur den Karri (E. diversionlur) als einzigen Wettbewerber. An uffenten und trockeneren standonten bleibt, jener Batm vied

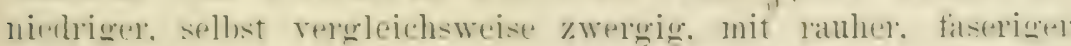
Rinde. Lnter soldhen L'mständen wird er in Virturia l'feffer-

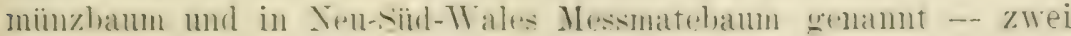
lamen, wele] werden. 
Also nur unter besonders zusagenden Wachstumsrerhältnissen wird $\mathrm{k}$. amygualina riesig, worunter man eine Höhe von 120 Meter hei pinem stammdurhmesser ron 7.5 Meter und einem astfreien stamme rom 88 Meter rerstehem muss, obgleich einige wenige Fixmplare ammïhernd 150 Meter hoch gefunden wurden.

las Holz ist im Vergleiche zu anderen Encalyptushölzern nicht schwer, schwimmt es doch im Wasser; in der Erde ist es nicht dauterhatt und ist auch kein Brennstoff erster (qualitait, allein es ist hauchbar zu vielen Banzwecken und Hausgeräten. Es lässt sich leicht spalten and wirft sich beim Trocknen nicht. Aus Baron ron Müllers Bemerkung: der Stanm. wenn gefällt, verwest. rascher wie derjenige vieler anderer Eucalyptusbäume. lässt sich schliessen, dass das Holz nicht wetterfest ist.

Betreff: der Ölgewinnung kamn für E. amygdalina kein besseres Zeugnis: ansgestellt rerden. als es in der folgenden Tabelle geschehen ist. Baron ron Viiller erhielt ans 1000 Pfim? frischen Blättern mit Stielen und Zweigen von:

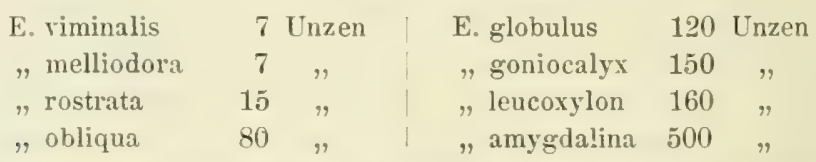

Dieses durchschnittliche Ergebnis mehrerer Lutersuchungen shrankt in den verschiedenen Jahreszeiten; während der kühlen Monate ist es bemerklich geringer wie im Sommer.

Das (̈) ron E. amygdalina ist hellgelb, diimn. von stechendem cajeputähnlichem Geruch, ron erst kühlendem. damn bitterem Geschmack und vom 0.881 spezifischer sichwere. Es siedet bei 165 his $185^{\circ}$ C. und scheidet bei niedriger 'Temperatur Stearopton aus.

Alle Eincalyptusöle lösen Guttapercha rasch anf: sie können, wleich Petrolem. zu Leuchtzwecken. ferner zur Lackbereitung und als Heilmittel dienen. In nenerer Zeit werden sie viel zu Parfïmerien gebrancht. fïr welchen Zweck wahrscheinlich das (i) ron E. Staigeriana eine besondere Bedentumg gewimen wird. Liese, noch nicht lange entleckte trt, fince ich nicht in dem berihmten Treke des Barons ron Müller beschrieben; sie ist in Queensland heimisch, wo sie del zitronenduftende Eisemindenbaum genamnt wird. I) Be Blätter besitzen einen feruch ganz ähnlich wie das Terbenenöl des Handels, das aber nicht ron der bekannten Verbenenblume, sondern ron dem indischen lirase Andropopogom 
ritratus stammt. Die getrockneten Blatter jontes baumes lieferen

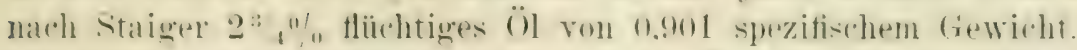

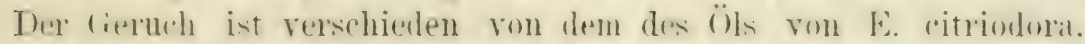

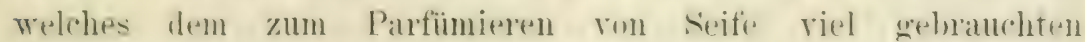
Limettenöl ähnelt. Da die Xachthage für Verbenenöl bedeutend ist - werden dowh allein von ceylon jährlich zwischen 13000 und

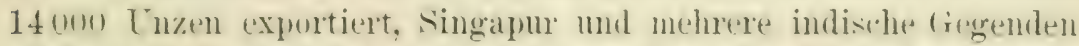
beteiligen sich ebenfalls an der Produktion - so verdient F. Staigeriana Beadlotung zum Anbau in geeigneten Ländern.

Alls den Blättern ron F. amygdalina hamn noch ein zweiter

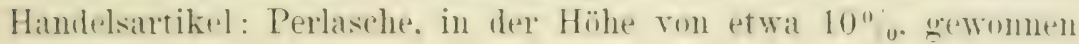
werden.

\section{n) Eucalyptus diversicolor.}

Der Karri. Die zerstrent stehenden Blätter sind breit-oder linglirhlanzettlich, leicht gekrümmt, anffällig heller unten wie when. die öldriisen sind unregehnässigr verteilt und liegren stark rerborgen. Lie achselständigen schirmblitten stehen einzeln an langen, schwanken stielen und tragen 3 his a Bliten. Dor Frucht ist ahgestumpt oral. 3 bis 4 zellig. die samen sind ungeflïgelt. dir fiuchtbaren schwar\%. nahezu wal. die untruchtharen viel zahlecicher. beträchtlich kleiner. hellbram und ron ineegelmăssiger Form.

Dieser westanstralisehe Baum komm: ror auf feuchtem.

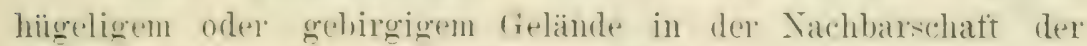
Flii-ses Walpeles. Frankland, Shammon. Warten und Inmolly. hauptsäldhlich gegen die Küste hin: lyei dem berge Iranylueak kommt er ebenfall- aher spärlich vor. Er gehört zu ilen grössten

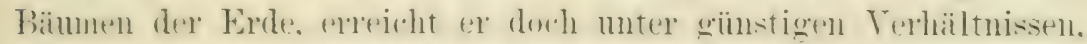
1. h. in fenchten. bewalleten Thälerm. rine Höhe von 124 Meter:

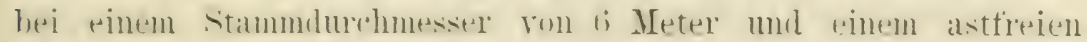
Stanm von gu Jeterle. In dichtem IValdbestand wärhst dieser

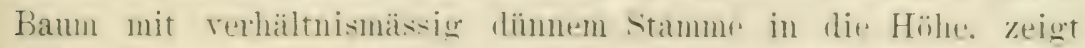

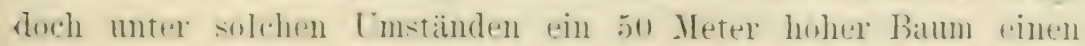

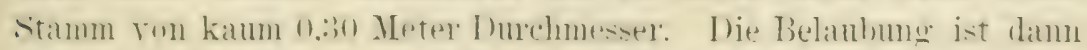
diirttig entwiekelt. Lie Rinde ist stets glatt mol wors.

lats Warhstum ist reroletehsweise rasch. selbst aut diurftigom Theden. Vahe Xelbourne erreirhte ant einem armen sandboden ein

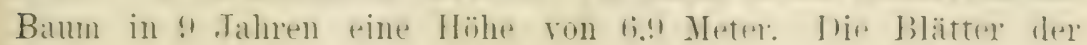


Sïnlinge sind breiter und ovaler, wie es bei vielen anderen Eucalyptusarten der Fall ist. Rei den ganz jungen Sämlingen sind die Bläter bereits dentlich gestielt.

l)ats Holz ist hellarbig, biegt sich leicht, wenn gedïmplt. ist geradfaserig, zäh und wird hauptsächlich begehrt für grosse Planken. Speichen, Felgen, Riegel und für den Schiftban.

Zur Unterstiitzung eines Tergleichs dieses Holzes mit anderen Eucalyptushölzern, nahm Baron ron Müller Messungen vor, deren Resultate hier folgen. Es lässt sich aus diesen Tabellen eine Idee ïber die rerhältnismässige Dichte des Gefüges der betreftenden Hölzer gewinnen.

Alle Messungen fanden auf dem Querschnitt statt.

1. Der gefundene grösste Durchmesser der Zellen in englischen Zoll.

E. marginata, hart
$", \quad$ leicht, dicht
" diversicolor
$"$ longicornis
" calophylla
"loxophleba

0,00082
0,00082
0,00082
0,00129
0,00070
0,00101
0,00063

E. salubris

0,00055

" cornuta

0,00082

, rostrata

0,00082

, globulus

0,00082

„Stuartiana

0,00082

"Bayleyana

0,0010 五

" loxophleba

"Doratoxylon, jung

0,00072

2. Dicke der Zellwände in englischen Zoll.

\begin{tabular}{ll|ll} 
E. marginata, hart & 0,00019 & E. salubris & 0,00023 \\
$" \quad$ leicht, dicht & 0,00024 & " cornuta & 0,00037 \\
$"$ weich & 0,00030 & "rostrata & 0,00020 \\
" diversicolor & 0,00058 & "globulus & 0,00020 \\
" longicornis & 0,00029 & "Stuartiana & 0,00015 \\
" calophylla & 0,00033 & "Bayleyana & 0,00025 \\
" loxophleba & 0,00023 & ", Doratoxylon, jung & 0,00022
\end{tabular}

3. Zahl der Markstrahlen auf einen Zoll.

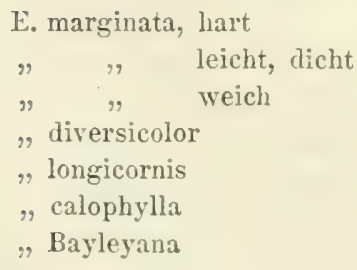

E. marginata, lart

$"$ leicht, dicht

$"$ weich

2, diversicolor

"longicornis

"Bayleyana
E. salubris

cormuta

, Stuartiana

"Bayleyana

0,00022

\begin{tabular}{l|ll}
390 & E. loxophleba & 330 \\
260 & "salubris & 470 \\
330 & " cornuta & 670 \\
170 & "rostrata & 390 \\
290 & " globulus & 310 \\
180 & "Stuartiana & 180 \\
315 & "Doratoxylon, jung & 330
\end{tabular}


4. Kahl der Gefässröhren auf' 1 Quadratzoll.

I. marginata, hart

",$\quad$ leicht, licht

$"$ weich

" diversicolor

"longicornis

, calophylla

Bayleyana

3500
2700
5100
4900
9300
3300
10000

E. loxophleba

„salubris

" cornuta

"rostrata

"globulus

,Stuartiana

"Doratoxylon, jungr

25000

42000

10000

อั700

3600

6300

32000

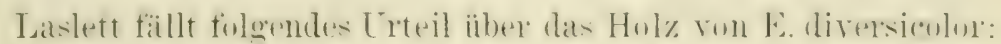

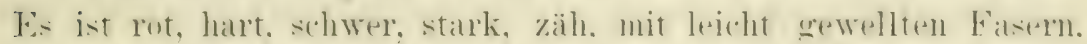
allein es ist nieht so gemasert, dats es tïr die Tishlhlerei mutehlens-

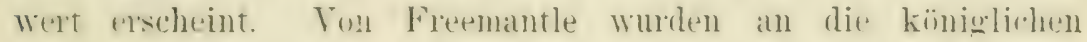

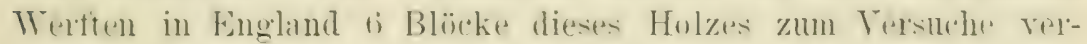

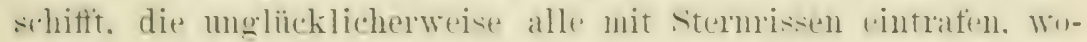

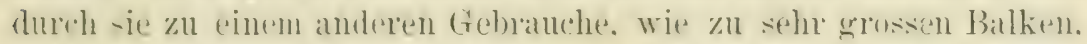

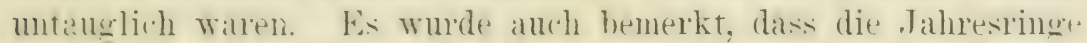
dieses Holzes das eigentimliohe, blasige Alssehen wie im .Tarahllulz hatten. folglich kamn es nicht zu Arbeicen bratuchbar brtialdetet werden, welehe rinen feinen Anfjut\% verlangen, duch ist

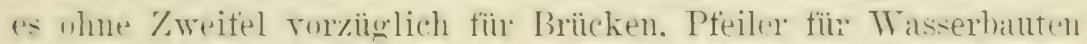
und deroleidhen geeignet. wie im allgemeinen fïr schwere Bauten. wo Erose Balkin und eine hedentende stäke verlangt werden.

Lilzu ist zu bemerken. dass man in Australien inzwischen feltent hat, das Holz besser zu trocknem, su dass weniger hern-

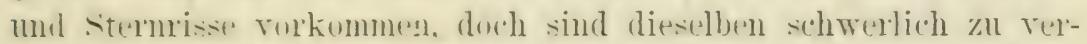
hiiten. wemn das Holz ant dem Transpute dir tropische Zone. krellzen muss.

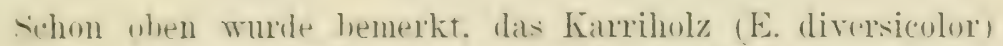
set nedurding in den Rut gekommen. widerstandstahig gegen den "lerenlu navalis zu sein. Was aber vorerst noch bezweifelt werden! mus: Dagegen stwht die Thatsache fest, dass es sich hei australi-chen Hafenhanten unter dem Wasserspiegel ganz allswerordentlich dauthaft erwiecen hat. Viel geringer soll seine Danterhattigkeit sein, wenn es dem Wetter ausgesetzt ist.

\section{o) Eucalyptus globulus.}

Der blatue timmibatun der Kolonisten. der Balluk der Crbewolner. 
Die zerstrent stehenden Bläter sind lanzettlich-sichelföringer, alck. wlelchtabig und etwas glänzend auf beiden seiten, die öldriisen liegen meistens verborgen. D)ie achselständigen Blüten sind slos.s. einzelstehend. Die etwas grosse Frucht nähert sich der Fugelrundung. I) Samen sind alle ohne Fliigel, die unfruchtbaren viel schmäler wie die fruchtbaren.

Die Rinde ist glatt. graulich oder bläulichweiss. E. globulus kimn sofort von seinen zahlreichen Verwandten unterschieden werden - E. alpina ausgenommen - durch die warzigen Blïtenkelche, bedeckt durch einen kronenförmigen Deckel, ausserdem ist ilım die Form der nahezu oder ganz sitzenden Frucht ausschliesslich eigen. Die: sämlinge sind hänlichweiss, wie mit einem wachsigen Pnder bestreut. haben scharf riereckige und sitzende, herzförmige oder breitwrale Blätter. I)ie bläulichweisse, damn bläulichgrüne Belaubung danert mehrere Jahre. sie hat Veranlassung zu dem Namen blaner Frummibaum gegeben. Mit der sichelform nehmen die Blätter auch eine tifforiule Farbe an, und während sie früher schräg sassen. hängen sie nun an stielen senkrecht. Diese Art kommt ror in Thälern wie an Berghängen der feuchteren Regionen rom sïlöstlichen Tiktoria. den südlichen Teilen von Veu-Süd-Trales und in manchen fiegenden 'Tasmaniens, gewöhnlich einzelstehend, zuweilen in Gruppen. nirgends zu alpinischen Erhebungen steigend. Ihre Aurchschnittliche Höhe kam mit 60 Meter, bei einem Stammdurchmesser ron 2 Meter, angenommen werden, obgleich einige 90 Meter hohe Exemplare entdeckt worden sind.

Ineissig Gramm gesiebten Samen ron F. globulus enthalten etwa 10000 truchtbare Samen, welche ihre Keimkraft jedenfalls + Jahre, wahrscheinlich aber länger, bewahren. Thie kleineren samen von E. amygdalina keimen noch nach 6 Jahren, während lie rerhältnismässig grossen samen ron E. miniata. Wie Tersuche im botanischen Garten von Melbourne gezeigt haben, ihre Keimkraft volle 13 Jahre bewahren.

Diese Art ist es hauptsächlich, welche den Anstoss gab zu lem bereits erwähnten Encalyptusfieber. Baron ron Miiller hat in hester, ehrenhaftester Absicht unablässig für ihre Terbreitung, nicht allein in Wort und Schrift, sondern anch durch samenrers'ndungen gewirkt, allein die Erfahrung hat gelehrt. dass er ihr rin etwas zn rosatarbiges Zengnis mit auf die Tanderschatt gegreben hat. Tnd der Meister wurde überboten ron seimen Jüngern: 


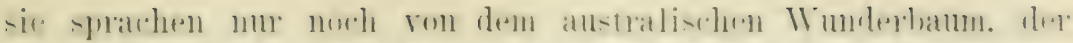

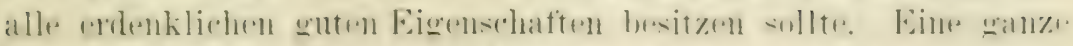

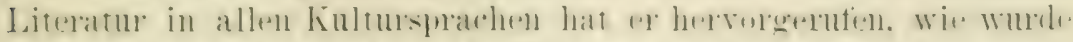

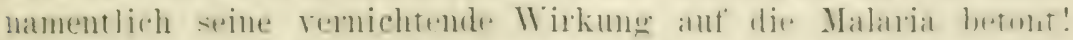

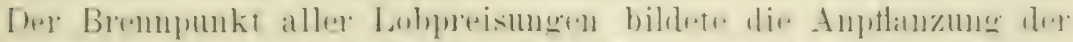
Trapistenmönche zu Tre Fontane luei Rom - nath wenigen Jahnell

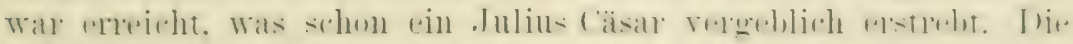

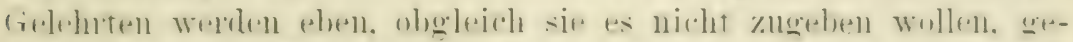

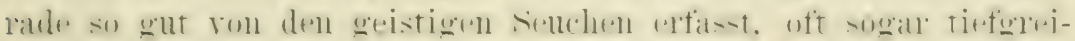

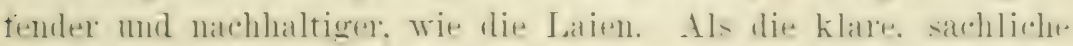

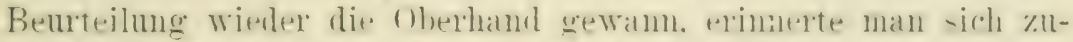
mächst des Nathweises, dass in der Heimat des banem Gummi-

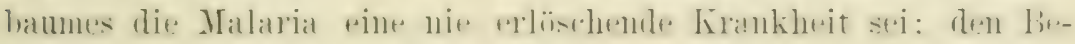

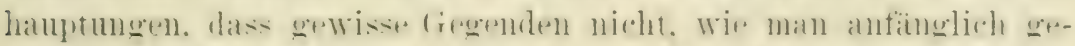

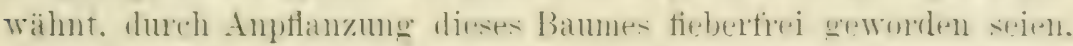

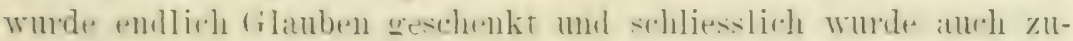
gestanden. dass man in bezng ant Tre Fontant zu vorplig genrteilt babe - das Fieher herrscht dort nach wir vor. Man hat

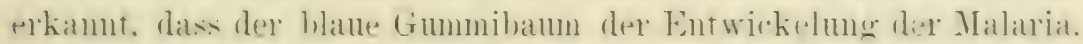

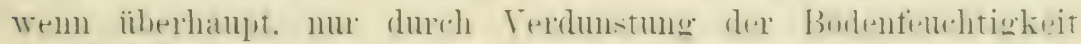

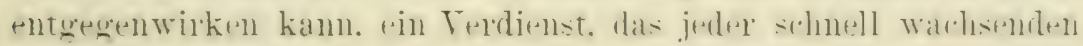
Pflanze zuzusprechen ist.

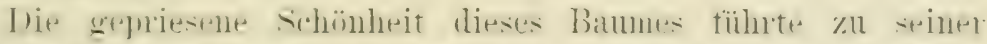

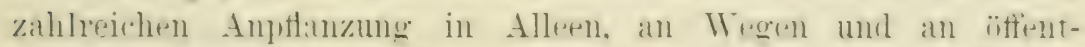
lichen Plätzen. Jetzt gretelet nan zn. dass man sich einer live

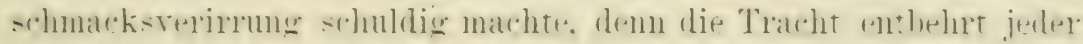

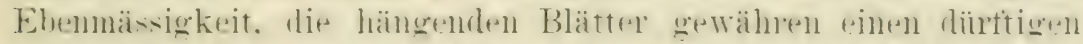

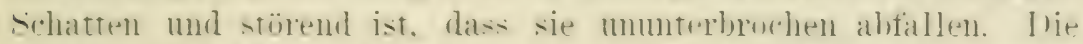
wämste Emblthlung begleitere ihn als shotzhaum, allein el ist

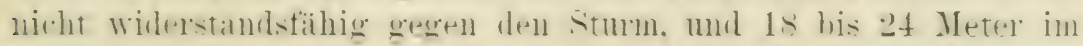

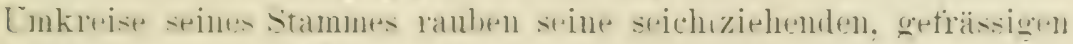
Turzeln anderen Pflanzen die Jahrung.

Was num die Hanptfage betrift, möge zunäbhst Barm von

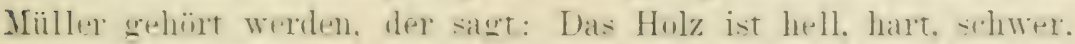
stark, danerhatt. Das swezitische fewicht schwankt zwischen

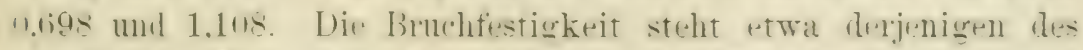

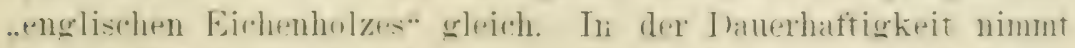
es eine Mittelstellung unter seinen Torwandten ein: es ist dau+1-

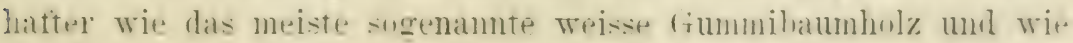


alles Falserdindenbaumholz. dagegen errededt es in dieser Hinsicht

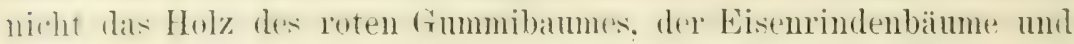

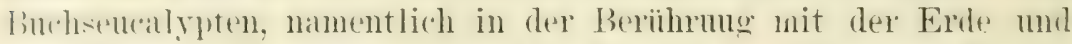

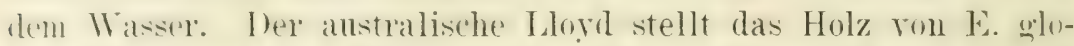
lunk in die zweite Kasse der heimischen Hölzer, dasjenige von F. rostrata. F. Iencoxylon und F. marginata bildet die erste Klasse. Trmm die rersohiedenen Teile eines schiffes ans einem der drei letztgenamnten Hölzer gebaut sind, wird das Fahrzeng fuir 12 Jahre als A klassitiziert. Das Holz des blanen timmmibaumes wird fermer zu Wagon. A(kerbangeraten, Telegraphenstangen. Bahnschwellen und Briickenplanken verwendet

Lalslett fällt folgendes Trteil: Es ist charakteristisch tür dir

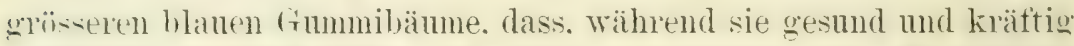
ercheinen und in Höhe und Lmfang zmehmen. der Stammkern nahe den Wurchn rerwest mol, wemn grefült, werden sie oft bis zu tiner betriahtlichen Entfermumg rom stanmende hohl gefunden. 1) Ler Lmfing der brauchbaren Blïcke. welche dieser Baum lieftert. hängt daher : ehı von seiner (iesundheit ab. Enfraglich kïmuen aber selnr grosse Balken rom ihm erhalten werden. Das Holz ist fahl strohgell, hart, schwer, mässig stark, zäh mol mit geedrehter Fasermug. Im Trockenen bilden sich an der ()berfläche tiete Risse und es schrmmptt und wirtt sich beträchtlich. Ich erimnere mich. auf küniglichen Werften einige ansserordentlich breite und lange Planken von diesem Holze gesehen zu haben. welche augenscheinlich ans hohlen Bämnen. wie sie oben erwähnt wurden. geschnitten waren. Sachdem dieselben eine Zeitlang getrocknet hatten, waren sie zu eintm solvhen crade geworfen und rissig geworden. dass es mmöglich wal. sie iromdwie als Planken zu verwenden. In Folge dieser Fehler wurde es nötig befunden. die Planken in ganz kurze stiicke zu zerlegen. un sie iblerhaupt benutzen zu kömnen, und so dienten sie ganz untergeordneten Zwechen. Vom einem zngesendeten Probehluck wurde eine if Zoll dicke Planke geschnitten. welche sich schnell 2 Zoll warf und bei $: 3^{1}$. Zoll stehen blieb. Rei der Prüimg erowb sich. dass sie voll tiefer, feiner Risse war. in C̈hrigen sich aber nicht viel revändert hatte wähend der achtjänigen Lagumo. kein Zeichen der Verwesung war bemerkbar. ohgleich sie lange Zeit dem Wetter ansgresetzt War. Es scheint. daher ein datlerhaftes Holz zu sein. Ibit spezifische schwerr schwankt zwischen 0,924 und 1,108 . 


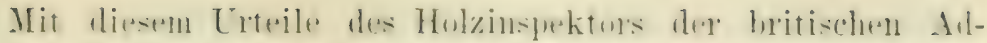

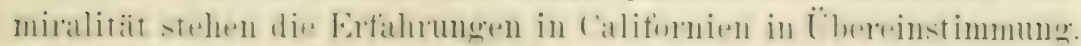
Tohl in keinen lamde ansielhath Anstraliens sind so viele blane

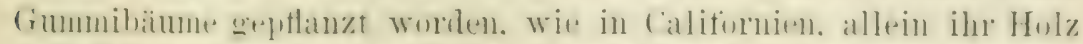
ist kein liandelsatikel geworden. obgledeh es hise an Hartholz rollstindig fohlt. Man beklatgt. dass es sirh stark wirtt. whe

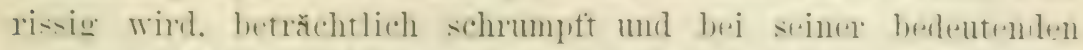

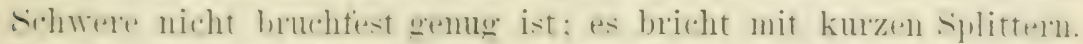

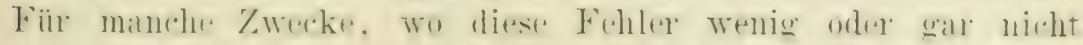
stïrend sind, wird seine solwere als Sarhteil betrarehtet: mant

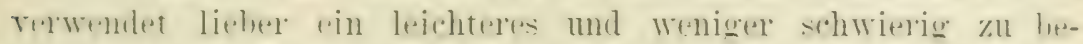

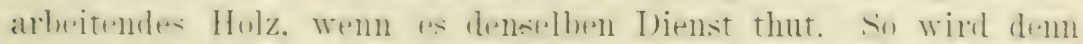
dat Holz des batuen dimmibames nur zu Telegraphenstangen.

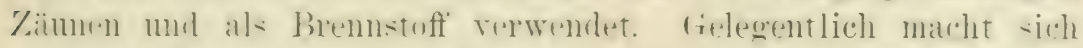
anch ein Farmer ein Gerät daraus.

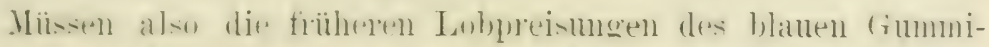
hatumes hetrablhtich helabgestimmt werdell. su hleibt er doch am

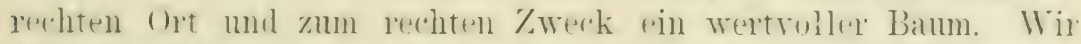

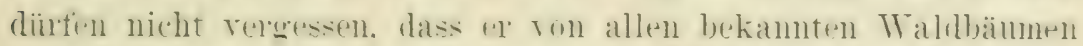
am whellsten wähst. nach baron ron Miiller wird er darin fon

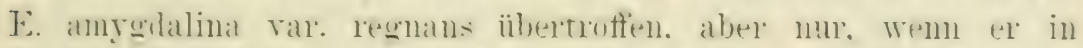

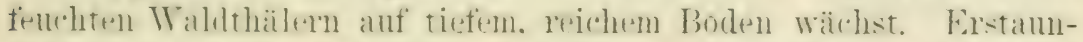

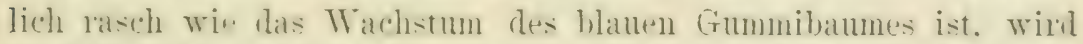

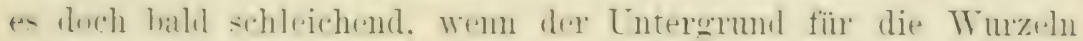
mulurhdringhar ist. Ferner ist ron diesem Baume zu riihmen.

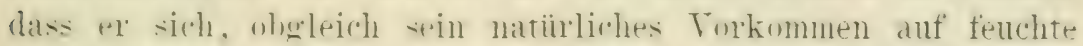
Gehirgshäler mol tiefer liegende. Waldoriund: beschränkt ist. sehr

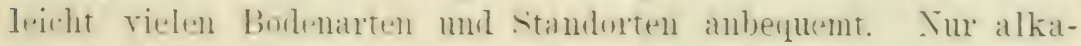

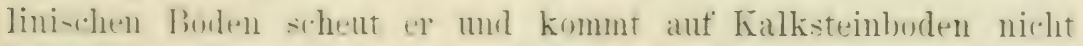
grut fint. An'h seine Lebenszäle i-t hervorzuheben: er iblexdantert

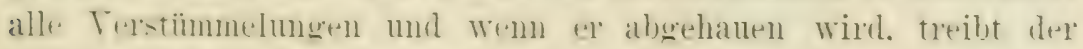

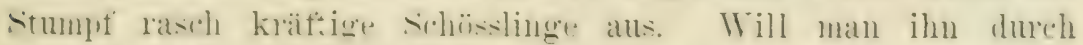
Ringeln töten. mus: man rundum his in den splint hinein abschailene dal sumst der Bildungsing wieder zusimmenwatehsen wiirte.

Alls alledem ist zu folgern. dass sirh dere blatle Gummibaum sehr selützhar erweisen wird. Wenn es gilt, in einer waldlosen fregend shnell Hol\% für das Bediurtinis der Rerölherunz zu produzieren: er mag da der Vorliuter langsamer warhsender Bäun+. stin. die erwinsthteres Holz liefern. Ferner ist diexper Eatun am 
Platze. Wrum mam in der Schaftung eines Waldgintels zum Schutze sexen Sindwehen, Überschwemmmuen oder Präriebrände rasch zum Ziule kommen oder wemn man die Dämme ron Flïsisen und simmelbeken durch Anptlanzungen befestigen will.

\section{p) Eucalyptus marginata.}

Der Jarrah der Urbewohner, welcher Name mehr und mehr allgemein rolkstümlich wird. der Mahagoni der Kolonisten.

I) ie zerstreut stehenden Blätter sind oval- bis schmallanzettlich. leicht gekrümmt, unten nicht glänzend und etwas heller wie oben. die in Fülle rorhandenen durchsichtigen Öldriisen liegen mehr odler weniger verborgen. Die seitenständigen, einzelstehenden Schimblitten bestehen ans 3 bis 12 Blïten. Die Frucht ist oralrund. die samen sind alle kantig und ohne Flügel, die unfruchtbaren meistens nicht schmäler aber kleiner wie die etwas grussen fruchtbaren; jene sind hellbrann, diese schwarz, etwas glänzeni und weit weniger zahlreich.

Dieser mestaustralische Baum kommt ror auf einer 550 Kilometer langen Küstenstrecke rom King Georgesund bis zum Kap Leeuwin und dem Moorefluss, stets in der Nähe des Oceans bleibend. Er bildet die hauptsächlichsten Wälder im sïdwestlichen Australien und erreicht gewöhnlich eine Höhte ron 30 und nur ausnahmsweise eine solche ron 45 Meter. bei einem Stammumfange ron 10 Meter. In seiner fenchten Heimat scheint er gleichgültiger regen Boden und Standort zu sein, wie die meisten anderen Eucalyptusbäume, allein er schent heisse, trockene Gegenden. Nur sorreit die seebrise fühlbar ist, gedeiht er freudig, womit aber kein schnelles Wachstum gemeint, das ihm nicht eigen ist. Er steigt bis zu 900 Meter in's Gebirge, wird aber schliesslich strauchartig. I)as rorziiglichste Holz wächst auf Granit- und Eisensteinboden.

In den letzten Jahren ist kein anderes anstralisches Holz so warm der Anfmerksamkeit des Anslandes, namentlich England's, empohlen worden wie das Jarrahholz und da die Trteile nicht iibereinstimmend lauten. finde ich es geboten. die beachtenswertesten an einander zu reihen.

Baron von Müller sagt: Es ist eines der am sehwersten entzündbaren Hölzer. eine Eigenschaft ron grosser Michtigkeit 


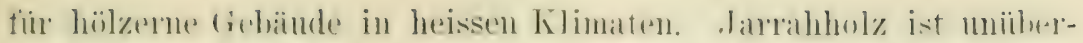
trotion dallerhatt. es ist leichter zu bearbeiten wie die moi-tell

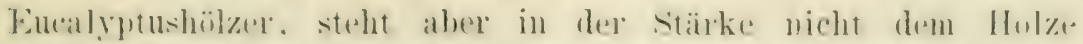
mancher sebine lerwanden greich. Dits Hol\% des rotell cimmi-

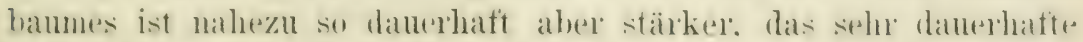
Hulz von k. lencoxylon ist mehr wie zweimal su stalk. llat luft-

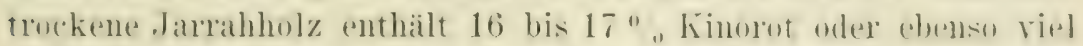
wie das Holz ron E. rostrata. Lis ist eines der hesten Hölzer fü̈

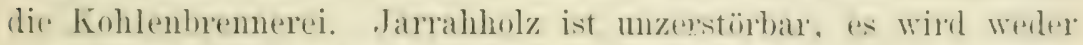
rom C'heluats, Teredos noch Termiten angegriften und ist deshalh

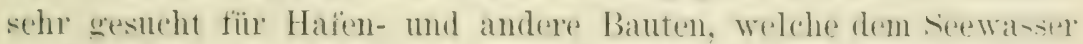
ausgesertzt sind. Sichifte, aus diesem Holze (r)baut. Warrll im

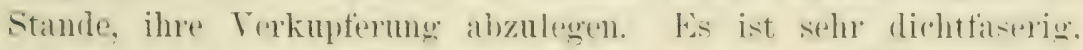

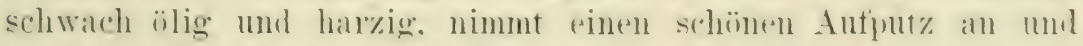
wird von schiftbautern in Melbume vorzüglicher pachter. wir.

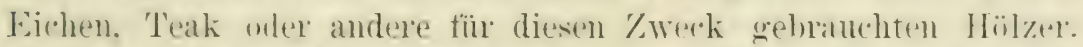
I)as comite des Lopyd beschloss, dieses Holz in die Linit :3 Tafel A der sitzumgen der ciesellsehaft einzutragen. Es steht

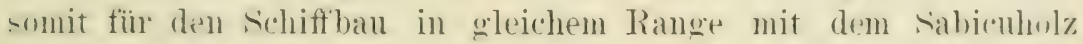
ron ('uba und dem Bleistiftedernholz. I) Verwendungen fïr das Tarrahholz sind mzählhar: es ist brauchbar. wo Teak mul sal sowohl verwendbar wie nicht rerwendbar sind.

Ther Almanach ron Westanstralien, desen Tupartuilichkeit allerdings nicht über allen Zweifel erhaben ist. lisst sich wie filgrt vernehmen: hipine unserer schwesterkolonien luesitzt ähnliches Holz wie das darrahhol\%. Wenn es in der Jahrezeit der grö̈sten Saftruhe gefälit wird. ist es das dauthlafteste afler Hölzer. Tnter dieser Bedingung widersteht es der Verwesung. dem Zahn der \%eit. dem Wetter mul Wasser, den Termiten und seewiirmern.

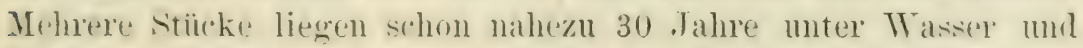
sind noch gresumd. Pfosten sind im sand rereraben worden. wo die Trmiten in wenigen Worhen alles andere Holz zerstiaren. Tun dieser loigentimlichkeit willen wird das Jarrahholz jetzt stark fiir Indien zu T'elexpaphenstangen und Bahnschwellen he-

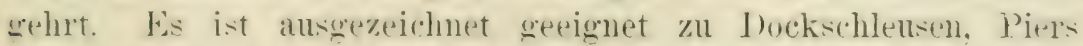
und ähnlichen \%wecken. ferner tür hielstücke und andere schwere

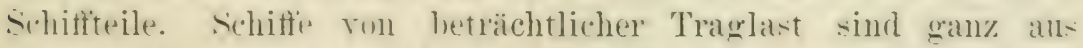

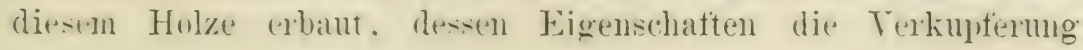


ïhertliissig machen, obgheich der seewurm sehr zahlecich in diesen Ocean ist.

Der beamte der öffentlichen Arbeiten in Freemantle. Westan-malien, drängt die Meinmgen der Schiffbanter mol anderer Saldrerständigen in folgendem Bericht zusammen. loas gesunde Tartahholz widersteht den Angriffen des Teredo navalis und der weisen Aneise ('Termite) Eine Analyse ron Professor Abel zeidete, dass es eine scharfe Sänre enthält, wolche lebenszerstörend wirkt. Dieser stoff wurde aher nicht in den ungesunden Teilen grefunden. Grosse Sorgfalt ist dalier im Zerlegen der Blöcke nötiщ. damit alle fehlerhaften 'Teile aus dem Kern ausgeschnitten mul mur vollkommen gesundes Holz benutzt wird. Die beistehende

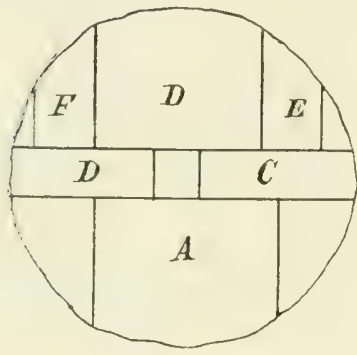

Figur 59 Figur 59 dentet das richtige Verfahren der Zerlegung an, um das gesunde Holz in allen verlangten Grössen zu jedem praktischen Gebrauch zu gewinnen. A B C D E F sind Balken.

Sehṛ viel ist daruiber gesagt worden, dass das Jarrahholz reisse, wenn es in Blöcken nach England oder Indien exportiert würde. Es ist daran zu erimmern, dass es in Folge seiner Dirhte sehr langsam trocknet und die imneren Teile der grossen Bäume in Zustande der Terwesung sind, selbst wenn die äusseren Teile in rolier Kratt stehen. Wenn ein Stamm unter diesen Verhältnissen : die inneren Teile vergleichsweise trocken und die änsseren voll von saft, sofort nach einem heissen Klima, wie dasjenige ron Indien, orler nach einem so veränderlichen, wie dasjenige von England, ver'schifft wird, muss es ganz natülicher W'eise durch das mgleiche schrumpfen rissig werden. Um diesen Nachteil zu vermeiden. möge man den Bam zur Zeit des schwächsten Sattflusses fillen und ihn nach der angegebenen Weise zerlegen.

Laslett, der Holzinspektor der britischen Admiralität, lässt sirch wie folgt rermehmen: Der Jarrah ist von geradem Wuchs und sehr grossem Tmange, ungliicklicher Weise ist er zum frïhen Verwesen im Kerne geneigt. I)ie gesunden Bämme liefern grosst und branchbare Balken, ; bis 12 Meter lang und 0,28 bis 0,60 Yeter im (puadrat, während diejeniggen mit faulem Kern nur 


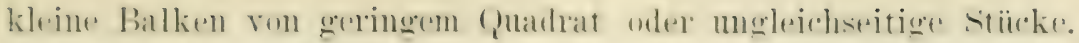
speckseiten genannt, lieferm.

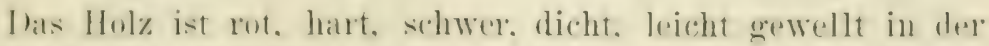

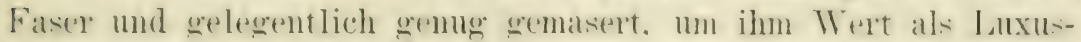
hol\% zu geben: es hearbeitet sich ganz glatt und nimmt pine gute Pulitur an. Die T'ischler mögen rs deshalh mbedenklich fiir

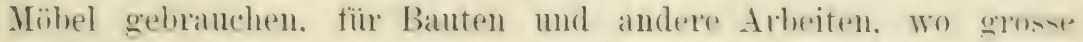
stäke gefordert wird. sollte es mit Vursidht verwendet werden. da Versuche gezeigt haben, dass es etwas spröde ist.

Vor einigen dahren wurde ein Pöstehen dieses Holyes der. Wert ron Woolwieh zur Lntersuhung seiner Qualitat zugesendet, allein die Proben befriedigten nicht. in Folge mangelhafter sorgfalt bei inrer Auswahl in del Colonie. Die Verschiftier schickten nur solche kleine viereckige Balken. Welche von läng-weise areschnittenten oder arevierteilten Blöcken erhalten sein mochten, wodurch in jedem Falle eine scinwache Fante bliel,. anstatt in voller Grösse den viereckigen, den wanzen Wuchs des Baumes darstellenden Block zu senden. Es ist übrigens möglich. dass das unvermeidlich war. demn aus der Art der Zerleguner komnte geschlossan werden, dass die betreffenden Bäume im lierne zu rerwesen begannen und hohl wurden. lange beror sie ihr. Reife elangten. I a dieser bemerkenswerte Fehler charakteristisch ist fülr den Tarrahbaum, so folgt, dass kein solider viererkigere Block über Mittelgrösse ans dem vollerwachsenen Bamm erhalten werden kamn und die Zerlegmg der fehlerhaften Stämme aut den Imfang ron speckseiten. mit Zuriicklassmog des Mittelkernes. heschränkt bleiben muss.

I) Eigentïnlichkeit wude in den ewähnten Proben hemerkt, dass ringe Höhlungen oder Blasen hatten. von 221 bis mehr Zentimeter lang in der längenrichtung der Fasern. und sirh ron $2^{1}=$ bis 8 \%entimeter enzentrisch ausbreitend. und zwar. wleich den Kreisrissen, in versiliedenen Entfornungen rom Mark-

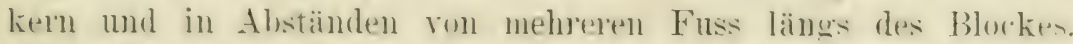
liese Höhlungen waren trilweise getfïlt mit einer harten. harzigen wher gummiartigen Ansidhwitzma. Welche bis zu einem gewisim cirarle die Dichte wieder herstellte. allein die stäke nicht ersetzte. weldhe durch den mangehden \%osammenschluss der Jahresinge verluren geht. I ieser eigentümliche Fehler wird in rersohieden Fucalyptushölzern und gelegentlich in Kirferm und Tammen getunden. 
Aus dem Vorstehenden ist leicht zu schliessen. dass die Be-

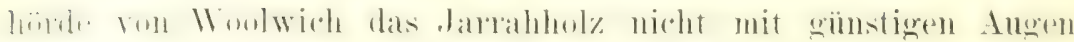

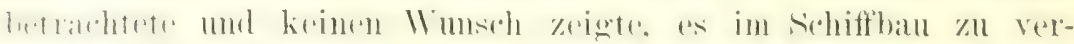

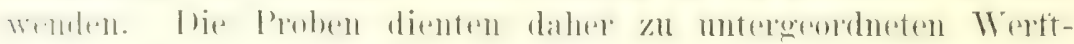
zwecken und während sie rerarbeitet wurden, benutzte ich

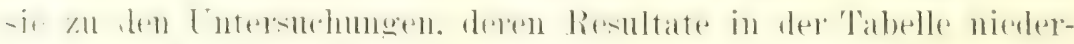

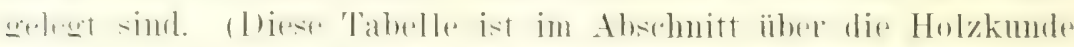

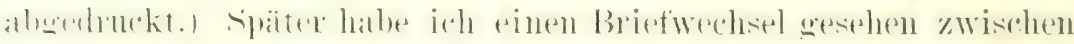

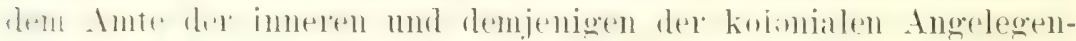

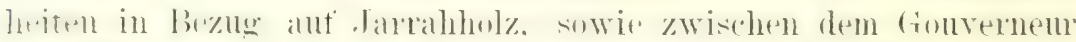

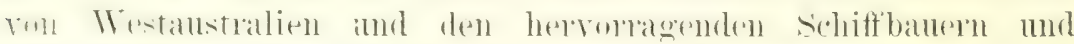
Rhedern, einschliesslich Lloyd's Agent in Freemantle.

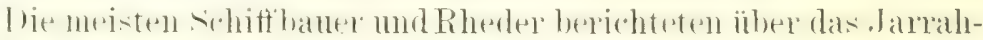

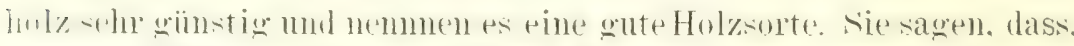
wrmm mit Eisen rerklammert. kein Jaterial das andere beschädigo

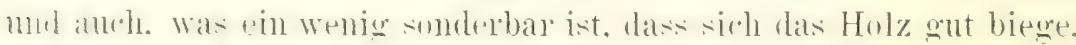

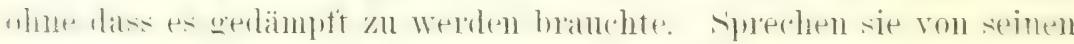
Vorziigen, dam geschieht es fast von allen mit eimem gewissen

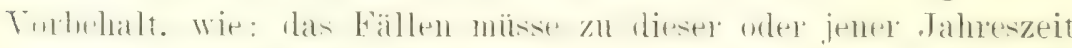

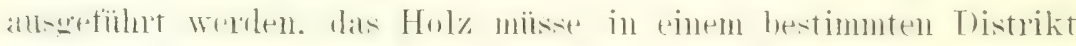
getrachsen sein and so fort. Lloyd's Agent berichtet weniger yiunstig. er sagt muter anderem: Ich betrachte das Jarrahholy Trertroll zum Verplanken so hoch wie die Wales und ich halte es anch besonders rorziglich fir kleine Fahrzenge, die nicht rerkmptert werden sollen. dem es widersteht dem Seewurm besser wie fast alle anderen Hölzer und ist weniger zum Terwesen ge-

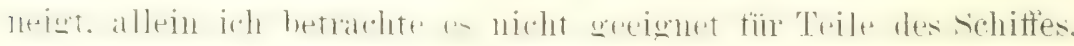

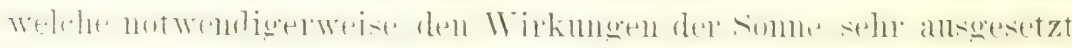
sincl. denn an solchen Stellen ist es mehr wie gewöhnlich dem s.hrumptem mul Wertin unterwaten: und a ist etwas mangelhatt in der Zähigkeit der Fasern. so dass es da nicht vorteilhaft zu

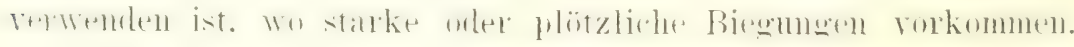

In einem Briefe ans Westaustralien sah ich erwähnen. dass eine Probe Jarrahholz ron Professor Frankland chemisch unter-

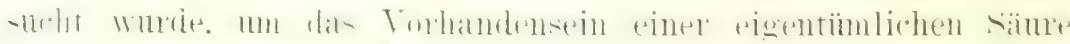

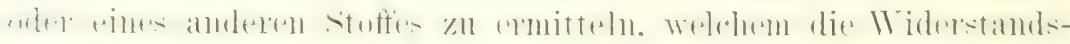

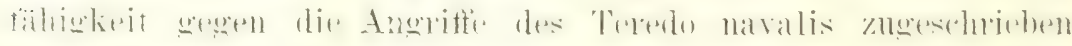
werden kömnte. Es scheint aber, dass nichts gefunden wurde. dem diese Wirkung beizumessen war. Der Professor glaubt, das 


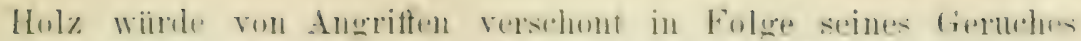

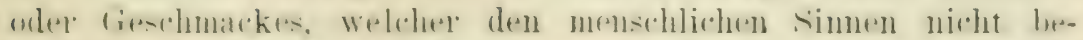

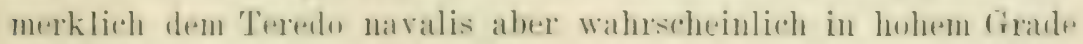
widerwärtig ist.

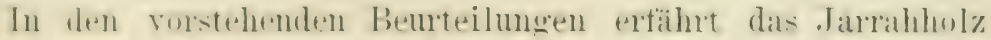

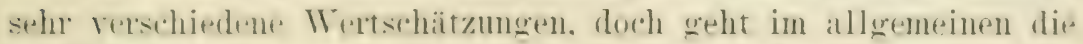

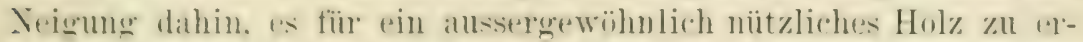

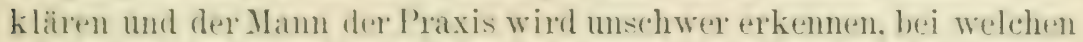

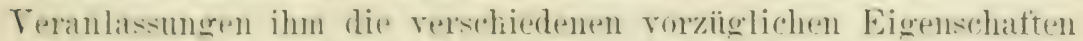

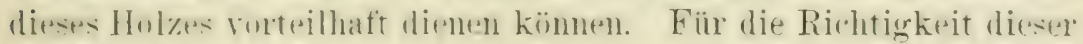

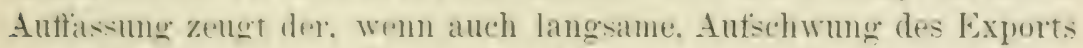

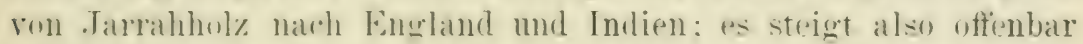

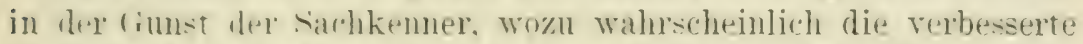

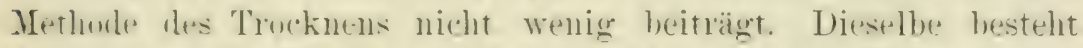

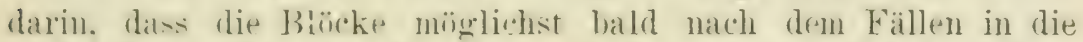

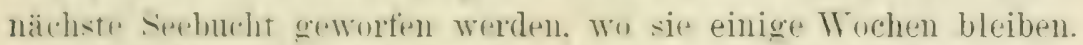

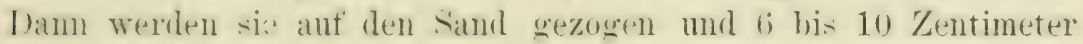
lirk mit sertang herterkt, wobei soretaitig darauf geachtet wird. dass die stimenden den sommenstrahlen mzuganglich sind. Nach-

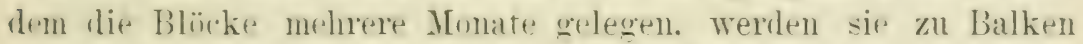

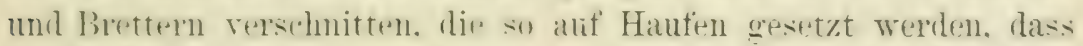

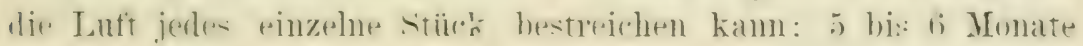
spätel findet die Verschiffung statt.

F. s-heint, das- nicht allein rem Jarrahhulz. sondern allen

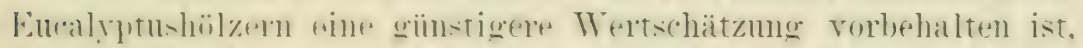

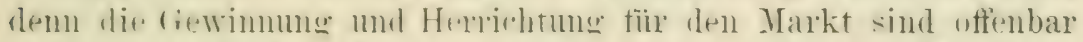

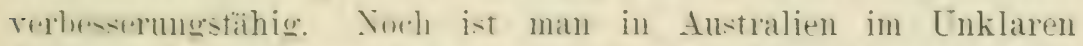

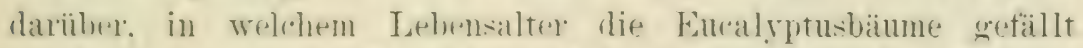

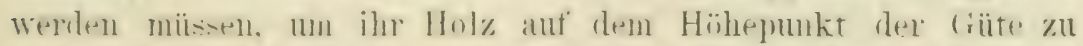

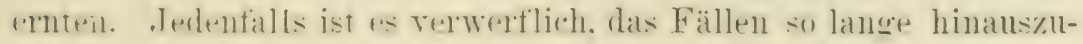

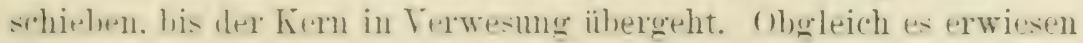

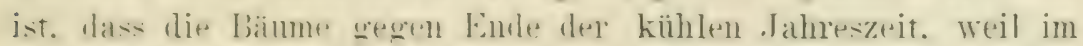

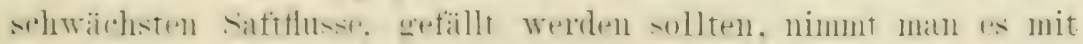

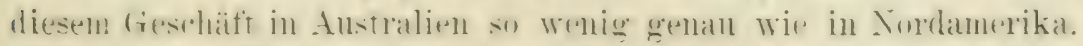

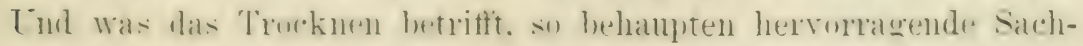

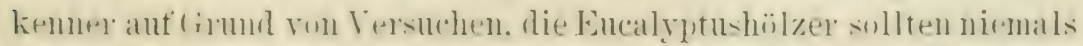
in Bliveken esetroneknet. sondern sotort nach dem Fällen in Balken,

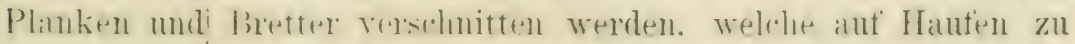


setzen und mit Sägemehl zu bestrenen sind, damit die Oberfläche milht viel rascher trockne wie das Imnere; gleichzeitig sind die stirnenden mit I'apier oder einem Anstrich zu bedecken. So sullten die Eucalyptushözer behandelt werden. es geschieht aber in den weitaus meisten Fällen nicht.

\section{Grit in herz.}

Sio wird das Holz genannt von Vectandra Rodiaei. Familie Lamaceae, einer der wertvollsten Bämne, wenn nicht der wertvollste Guiana's, denn ansser einem sehr geschätzten Holze liefert er eine Rinde, die Verwendung in der Heilkunst findet. Bibiru, Bibiri, Spiri und Sipeira sind die Tamen, welche die Rinde in rerschiedenen Gegenden führt. das Alkaloid. dem sie ihre Wirkung verdankt, wird rom der Wissenschaft Bibirin genamnt. Die Rinde ist hart. schwer und spröde, mit einem Bruch. der dem des Sandsteins gleicht. sie ist hellzimtbram. bedeckt mit einer weissen Oberhant. Ihr Geschmack ist sehr bitter. etwas zusammenziehend. ihre Wirkung ist fieberwidrig. ähnlich derienigen des Chinins und wem sie demselben auch an Kraft nicht gleichkommt, steht ihr doch der Torzug zur Seite, dass ihr Gennss hein Kopfweh verursacht. Gewöhnlich wird den Kranken nicht die Rinde selbst, sondern schwefelsaures Bibirin verabreicht.

Der Grünherzbam kommt rorzugsweise in Britisch Guiana vor und erreicht seine kräftigste Entwickehung auf den niedrigen Hügeln. welche sich den Flussthäler'n anschliessen. Hier erreicht er eine Höhe von 20; bis 28 Meter, bei einem Stammdurchmesser ron 0.9 bis 1.2 Meter und mit einem astfreien Stamme ron 12 bis 15) Meter. Der ganze Stanm witchst rollkommen gerade und schwach verjüngt nach der Spitze.

Tie der Yame andentet. ist das Holz grün-dunkelgrium. häufig in's Brame. selbst ins schwarze übergehend. Je dumkler die Schattierung, desto härter und daurrhatter gilt das Holz. Die Jahresringe sind selten zu trkennen und der Splint zeigt eine haum bemerklich hellere rchattierme wie das Fermbolz. Dieser Tustand gibt nicht selten zu der Behauptumg Veranlassmo. das Grünherz besässe keinen splint und der ganze Stamm sei ron durchgehends gleicher Qualität. 


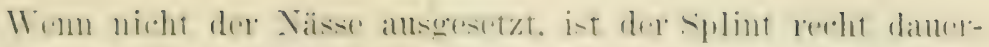

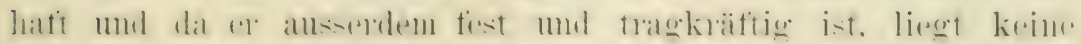

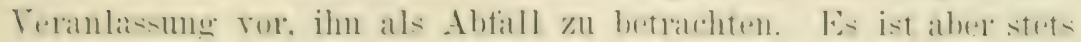

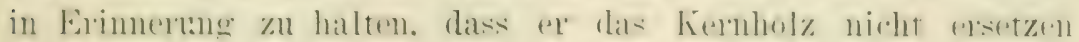

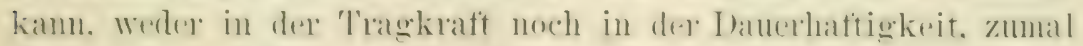

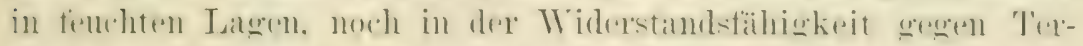

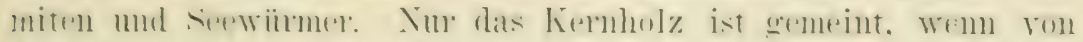

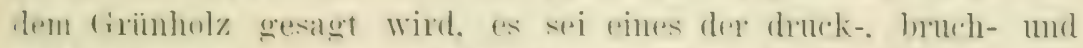

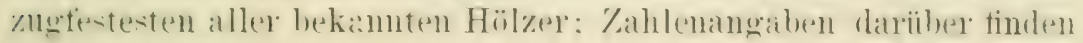

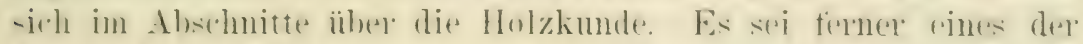

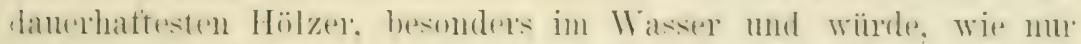

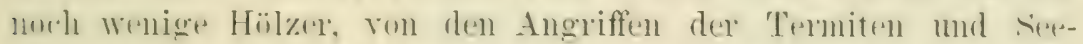

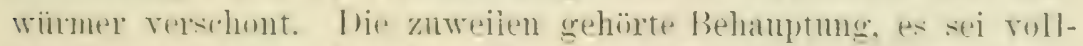
-tändig sicher rol den Angriften dieser sehädlinge. ist zul weitarehemit es wird von densellen nur selten, wie es sheint widerwillig in Ermangelung whes anderen Holzes angehohrt, allein das

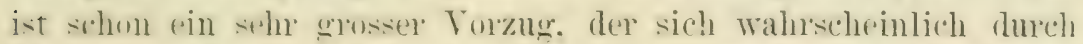
die anserondentliche Härte erklären lässt. So hart ist das Kernlılz. dass es den Holzfällern häufig die Äxte schartio macht. Es ist das wahrochemlich die I'rsache. Warum man sich in tinianat nicht die Nïhe gilst, die zur Terschiffung bestimmten liä̈ch" sharfkantig mol rein zu behaurn. wie ss mit anderen Handel--

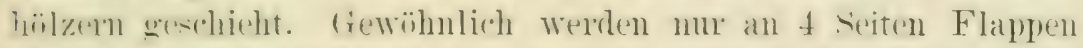

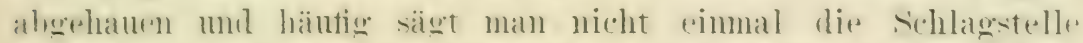

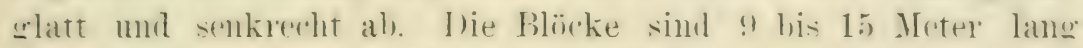
und durchsehnittlich 0,6 Meter im Quadrat.

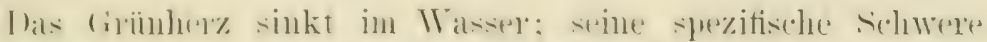

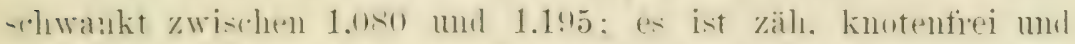

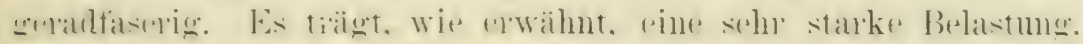

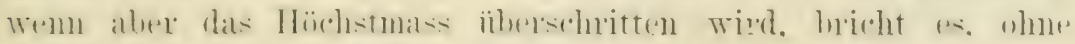

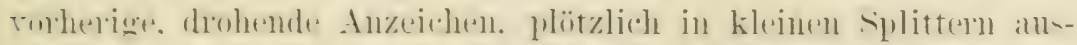

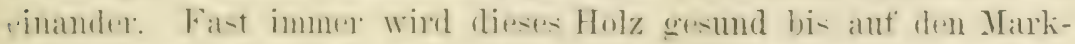

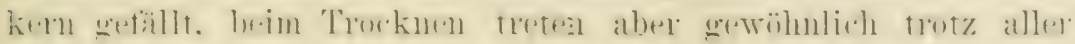

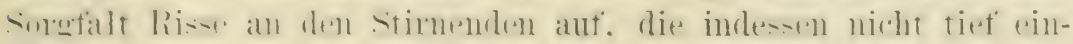

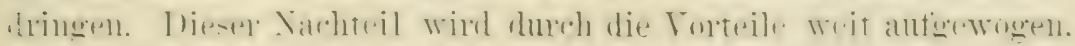

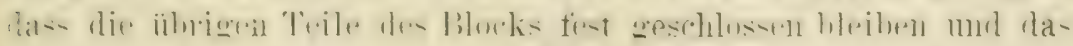
snt getrocknete, rerarbeitete $\mathrm{Holz}$ sich niemals wirtt, nicht schumptit und rissig wird. 
l)at: (irünher\% wird mit wenigen Ausnahmen über Demerarar liall lingland exportieri. wo cs eines der geschätztesten schiffbauhïlzel ist. Fs dient zu Balken, Riegohn. Maschinenträgern 11. - W. \%a Hansbatem hat es bis jetzt noch keine Verwendung entumben. Wohl abur zu Wasserbanten als Pfeiler, Schlensen, Pier's u. s. W.

Wat nicht tïr die vorstehenden Zwecke anfgearbeitet wird, mhmen die Drechsler als Ersatz für Pockholz, das dem Grünherz shlu ähnlich ist. ()hgleich das Letztere eine recht schöne Politur annimnt. wird es doch in der 'Tischlerei. seiner bedeutenden schwere wegen, nicht benutzt.

C̈her die Druch- und Zugfestigkeit u. s. w. sind Kablenangaben in Abschnitte ïber die Holzkunde zn finden.

\section{Halmalilleholz.}

Dieser Name ist in Ceylon üblich, während in Madras dieses Holz als Trincomali gekannt ist. Die botanische Quelle ist Irelrya amonilla, Familie 'Tiliaceae, ein der europäischen Linde nalle rerwandter und ähnlicher. aber grösserer in Ceylon heimischer baum. Das Holz ist auf dieser Insel sehr gescliätzt zu Haushautrn. Fässel'n und fieräten rerschiedener Art. ebenson zum Boothan. Wril es die Eisenterklammerungen rostfiei hält und, wie hehamptet wird. ron den Angriften der seewürmer verschont 1) leibt. Dies Behanptung ist übrigens stark in Zweifel zn ziehen. demn wäre cic begrïndet. wiuden die englischen Schiffbater dieses Holz ganz gewisi ihen Rohmaterialien zugefïgt haben. Bis jetzt ist es nach Madras mol Bumbay exportiert worden. Ife Boote, wellhe an der südindiachen hüste die gefährliche Brandung

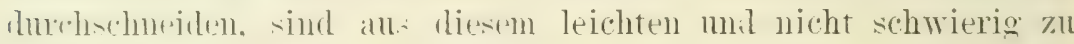
bearbeitenden Holze.

\section{Huonficlitenholz.}

Von dem Mrete der Maldhämne Tasmaniens wissen wir bis jetzt nuch wenig. allein die Bewohner dieser Insel stellen be.

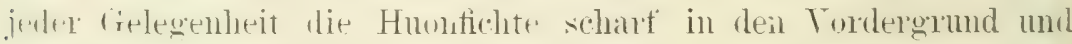
da anch Australiex und Furpläer. Welche in der Lage waren, sich in Tamanien rin Trteil zn bilden, beiptlichten. so muss di. Huntichte einere der wertrollsten Bäume. Wemn nicht der wertrollste: dieser Kolonie sein. 


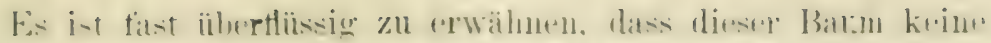

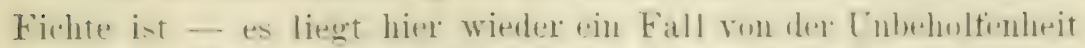

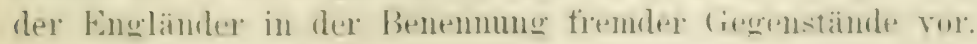

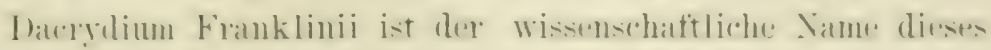

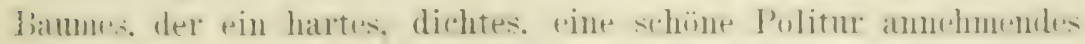

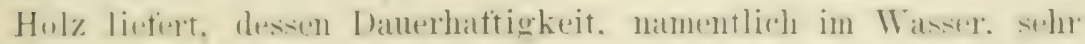

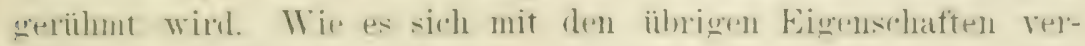

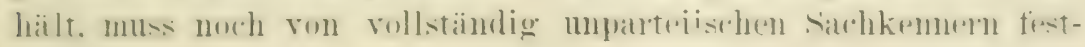
gestellt werden.

Als der Huntichtes unter den Waldhäunen 'Talsmantens zunäch-t-tehend. wird dire immergrüne, stattliche Buche Fatells l 'un-

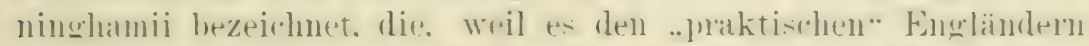
num rimmal niclit gexeben ist. zutreftende Xamen zu wählen. Mirte Enenannt wird. Für die Deutschen in den dentschen holonien

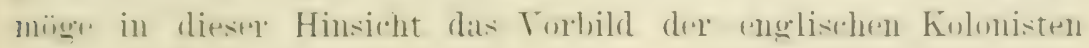
abschreckend wirken.

\section{Jacarandaholz.}

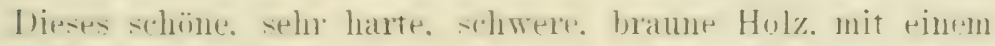

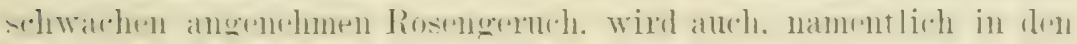

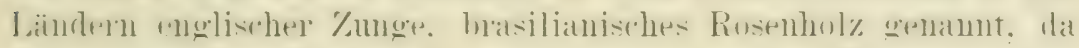

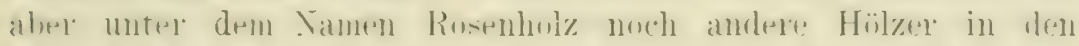

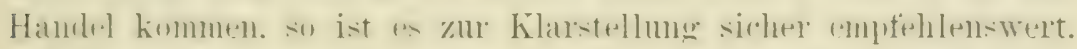

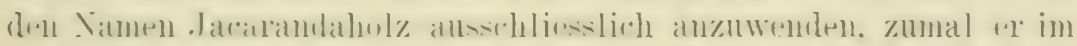
Herkunftsland Brasilien allein üblich ist.

Zutulge uine amtlichen. brasilianisehen Veröftentlidhung, die

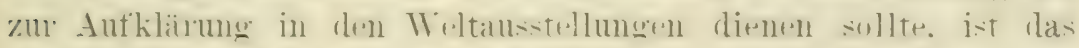

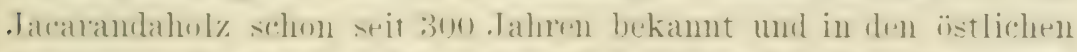

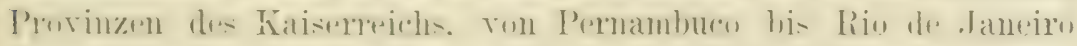

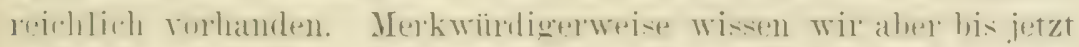

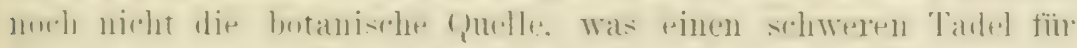

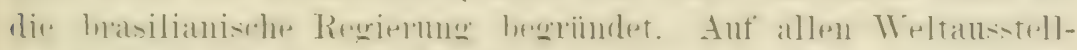

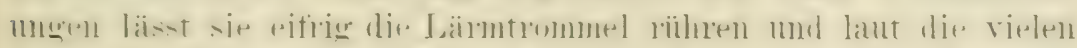

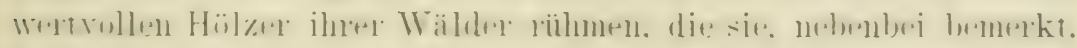

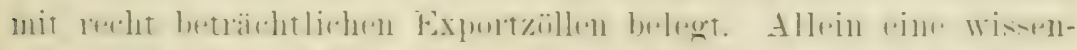

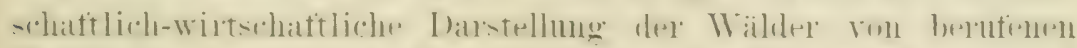

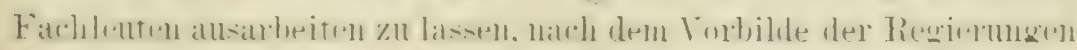

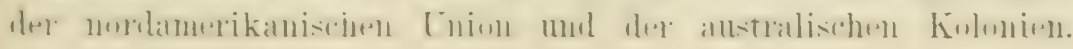




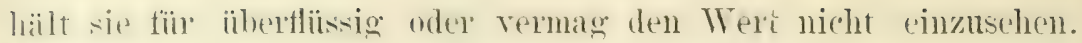
flas ist um so mehr zu bedanern. Weil die brasilianischen IVilder unfraglich ausserordentlich reich an Hölzern von vielsatigen rorzidglichen Eigenschaften sind - ein Reichtum. der norh zum grossen Teile der Aufmerksankeit der industriellen und Handelswelt entriickt ist.

Die Brasilianer sprechen ron einem Jacarandabaum, allein die Wissenschaft bat verschiedene Arten der (iattung .Jacaranda nachgewiesen, die zur Familie Bignoniaceae gehört: eine schwarze, jurpune, violette, weisse und dornige, ansserdem die Rosenjacaranda, die. wie es scheint, noch botanisch festzustellen ist. In Kataloge des Kew-Museums, wo man gut unterrichtete Angaben anzutreften pHlegt, ist die Termutung ausgesprochen, das Jacarandaholz stamme ron einer Art oder mehreren der Gattung Dalbergia. Derselben gehören 3 ostindische Arten zu: D. latifolia, D. sisu und D. cultrata. welche schweres, dunkles Holz liefern. das dem brasilianischen Jacarandaholz wohl ähnlich ist, es aber an sechönheit nicht errercht. Schon lange kennt man das Holz von D. latifolia als ostindisches Rosenholz.

Es ist übrigens fast mit Sicherheit anzunehmen. dass das Jacarandaholz einer Art der Gattung Jacaranda entstammt, sehr wahrscheinlich der J. mimosaefolia. Allein mit Bestimmtheit ist bis jetzt noch nicht die botanische Quelle dieses Holzes zu bezeichnen.

Der Export desselben hat sich in den letzten 50 Jahren rerzehnfacht, sein jährlicher Wert beträgt jetzt 22 Millionen Mark. l he Terwendung des Jacarandaholzes in der Luxustischlerei und Pianofortefabrikation ist zu bekamnt, nm einte Erklärung zu bediirfen.

\section{Kassoul-Khayéholz.}

Thlaya senegalensis. Familie Cedrelatceate ist rine der häutiosten Waldbämme im Flussebiete des Senegal. Er erreitht pint Hühe rom 2t bis : 31 Yetel und liefert ein in Handel zumeilen

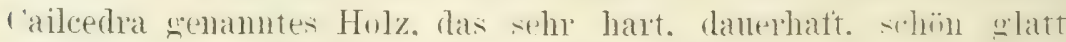
urefasert und rötlich ist. Die Rinde enthält ein eigentiimliches

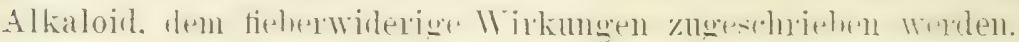


17. Kianifichtenhol\%.

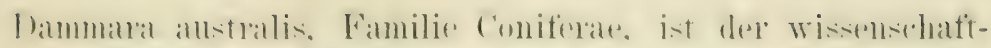

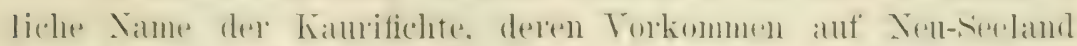

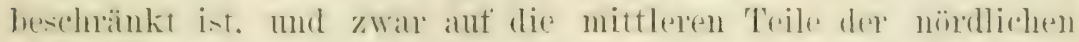

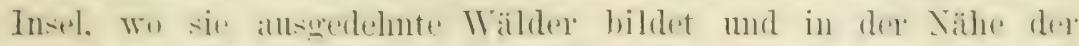

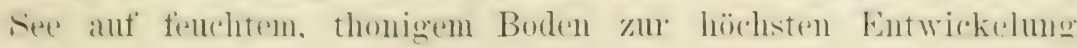
gelangt.

Aut den Fidschis, den Hebriden und in Anstralien kommen

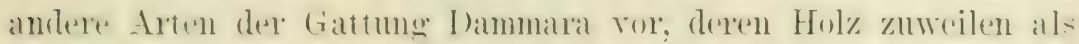

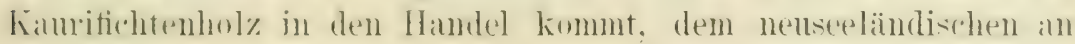
Qualität abex machsteht.

Dir haturifehte ist ein schöner geradwachsender batum, dere vine Höhe ron fo Meter. bei einem stammunfang ron 4.5 Mreter

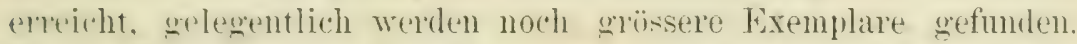
bie in Wirteln stehenden Zweige sterthen am untern Stamme alb. wie es hei der Rottamne der Fall ist. Der Stamm laitut nach when wanz schwarh verjüngt zu, die Zweige sind mit dunklen. ledrigen, sitzenden Blättern besetzt, die 2 bis $22^{1}$. Zentimeter lang sind. Ter Frublyaufen ist rund, misst etwa s zentimuter im

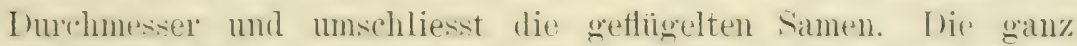
whatte Rinle ist 2- his 21/2 Zentimeter dick. Ton dem Harze. welderes dem stanme entunillt. ist an anderer stelle die Redie.

Itex \& lis 12 Zentimeter dicke splint zeichnet sich schart ron dem Kernholz al), das weisslich bis strohfarbig. mïssig hart. dicht. fein- und geradfanerig. dallerlatt molelastisch ist. Wem \& hearheitut wird. duftet es angenehm; es hobelt sich leicht mit Hinterlassung eines seidenartigen filanzes und nimmt eine schöne P'olitur an. Es sohrumptt wenig beim Trocknen und ist nicht zum

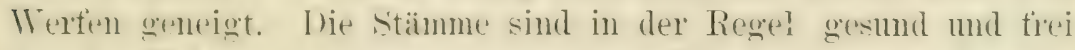
ron den Fehlern. welche vielen anderen Hölzern eigen sind. Nu solten treten Kermiso in milder form anf. stern- und fireisisise sind selbst in alten Bäumen selten.

Aus allerlem geht hervor. dass das Kamuitichtenholz eines der besten Hölzer ist. desen sich dex Zimmermann und Tischler bedienen kamn, und hegreiflieh wird es sein, warm sirh eine bedell-

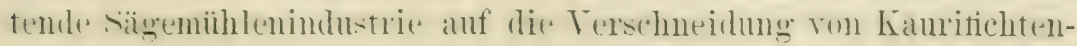
lolz gründet. 
Fïl Masten und Raastangen wird Fanrifichtenholy unïbertrofien gehalten, da es nicht allein die erforderliche Grösse, Leichtiokeit, Ntärke und Elastizitait besitzt, sondern anch damerhatter ist. wie andere für diesen Tweck gebrauchten Nadelhölzer. Auch zu leckplanken wird es rerwendet. namentlich weun anf ein schönes Äussere des schiffes gesehen wird, denn das Kamrifichtenholy ist regelmässig gefasert, knotenfrei und nutzt sich gleichmässig ab, so lass es nicht von Zeit zu Zeit abgehobelt zu werden braucht, wie es bei anderen Hölzern geschehen muss.

¿̈ber' die '/ug- und Bruchfestigkeit u. s. w. finden sich Kahlenangaben im Abschnitt über die Holzkunde.

\section{Ko kra hol z.}

('ocusholz ist ein anderer. seltener gebrauchter Name für das Holz des indischen Batumes Lepidostachys Roxburghii, der zu der sehr kleinen Familie Scepaceae gehört, die in bemerkenswerter Teise den Familien Euphorbiaceae und Amentaceae zugleich nahe steht. Das sehr harte, reich tiefbrame Kernholz dieses Bammes wird in Blöcken von 15 bis 20 Zentimeter Tomohmesser nach England exportiert, wo es zu Flöten und anderen musikalischen Instrumenten verarbeitet wird.

Der Kokrabaum erreicht nur eine mässige Höhe, mit ententsprechendem Umfang und hat gegenständige lederige Blätter.

\section{L a n z en hol z.}

Nectandra IVilldenowiana, Familie Laturaceae, also ein ( iattungsverwandter des Grümherzbammes, ist die botanische Quelle dieses Holzes. Der Baum wächst ausserordentiich gerad, erreicht aber nur eine Höhe von 9 bis 15 Meter, bei einem Stammdurchmesser ron 0,15 bis 0,20 Meter. Er kommt in Westindien, Mittelamerika, Mexiko und im äussersten siiden von Florida vor, exportiert wird sein Holz aber nur ron Westindien, namentlich ron Jamaica mol nur, wemn ich recht berichtet bin, nach England und Nordamerika.

Der Splint ist hellgelb, das Kernholz reich dunkelbram, schwer, hart, dicht, stark, elastisch, zum Werfen während des Trocknems geneigt. Auf dem (Querschnitt zeigen sich viele regelmässig rerteilte offene Gefässröhren mol zahlreiche dümne Markstrahlen.

Die übrigen Eigenschaften sind im Abschnitt über die Holzkunde in Zahlen ausgedriickt. 


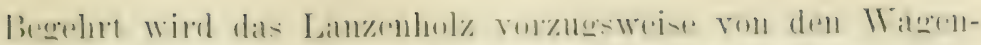

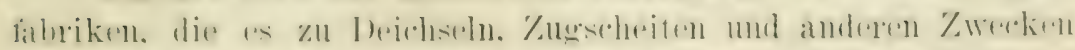

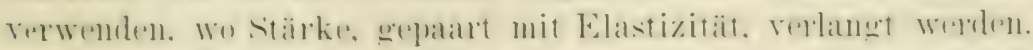

\section{If a hag a $\mathrm{n}$ i ho $0 \mathrm{l}$.}

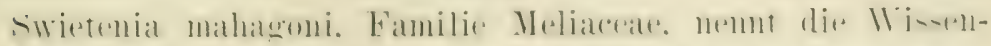

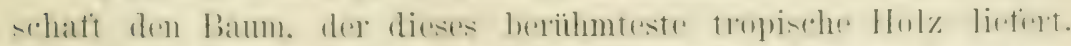

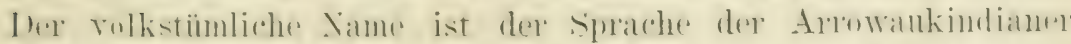

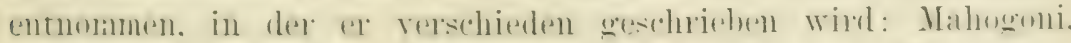
Mahagoni mol Mahomi. Heimish ist diecere Banm in Wistumlem.

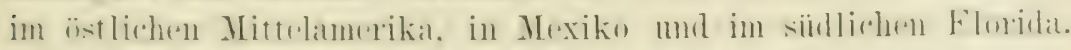

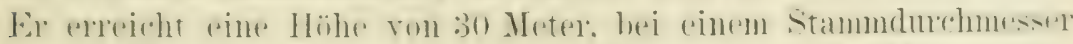

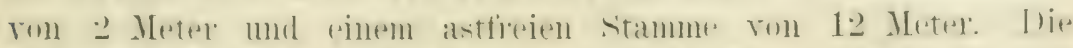

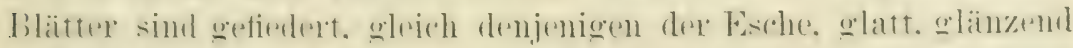

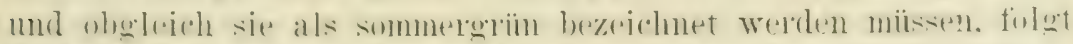

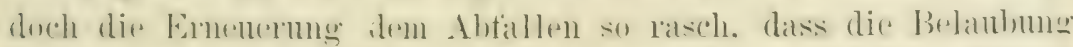

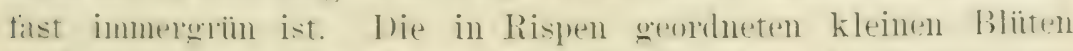

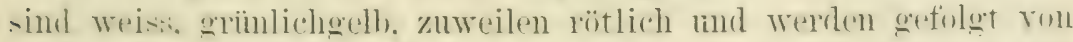
walen, holzigen Kapselfrüchten. so gross wie ein Truthuhnei mul nit 5 Zellen. die sinh bei der lieite äthen. un die vielen. kleinten

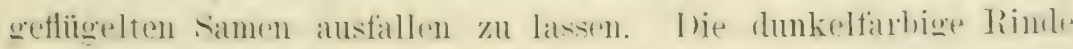

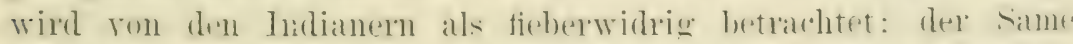

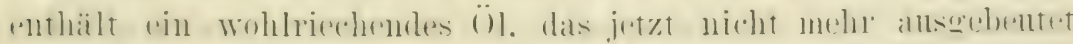
wird, bei den Azteken aber in hohem Ansehen stand.

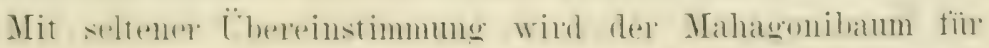

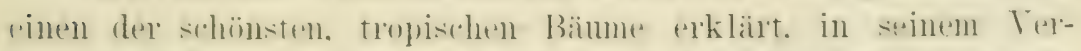

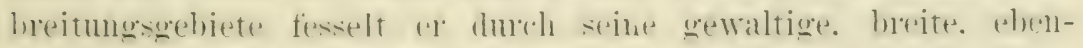

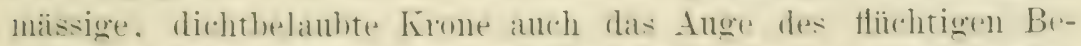

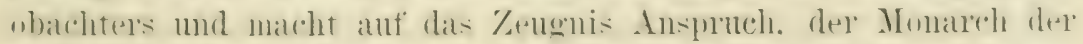

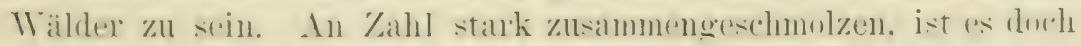

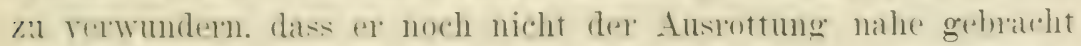

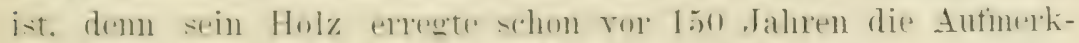

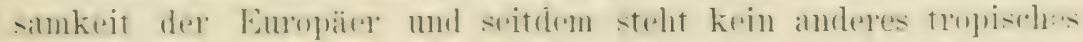

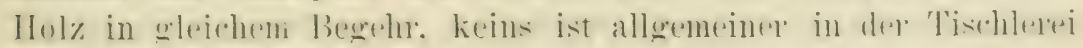

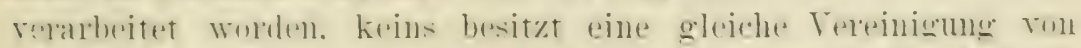

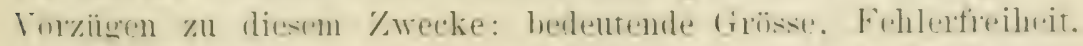

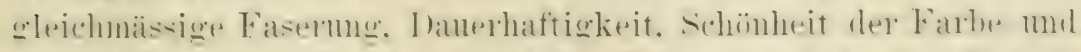

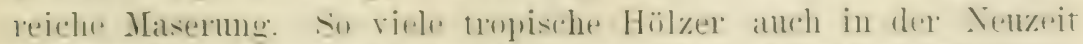

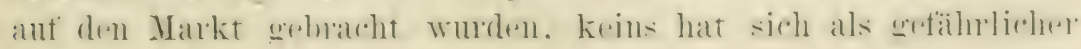




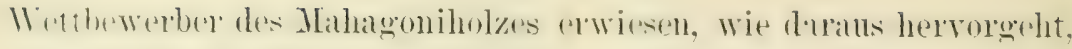

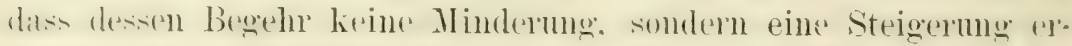

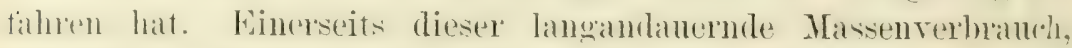

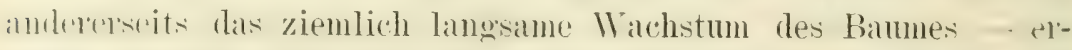
lamet derselbe doch ror dem 100. Tahre nicht die Reife zur Fiallumg - darauf stüzt sich das Erstamen, dass dieser, der lianbwirtschaft biberlassene baum noch immer in einer Zahl vorhanden ist, welche den Bedarf deckt.

Die ersten Europäex, welche auf das Malagoniholz aufmerksam wurden, waren englische Schiffzimmerlente, welche $15 ! 7$ zu Trinidad einige schiffe sir Walter Raleigh's ausbesselten; sie hrwunderten die schöne Maserung und die Härte des Holzes. allein in jener Zeit des Trammes ron Eldorado wude nach wertrolleren l)ingen wie Holz gesucht. Der erste Tersuch der Einführung des Malangoniholzes in Europa wurde von dem englischen Kapitan (iibbons gemacht, der einige Planken seinem Bruder D. Gibbons in London solickte. Derselbe ïbergab sie den Zimmerlenten, wreldr im Begriffe waren, ein Haus für ihn zu batuen, die sie aber als zu hart zuriekwiesen. Ein Tischler, der nun beauftragt wurle. einige Kerzenkïstchen ans den Planken zu fertigen, beklagte sich zwar auch ïber die Härte des Holzes, stellte aber doch dir Kästchen her, die sofort ein fiegenstand allgemeiner Bewmolerung wurden. Damit war die Bahn für das Mahagoniholz gebrochen. der Begehr; zmäehst in England, dann auch auf dem europäischen Festland, stieg ron Jahr zu Jahr und zwar blieb Jamaica die Bezuespuelle bis zur rollen Erschöpfung des Vorrats. Der Höhejunkt des Exports dieser Insel soll 1753 mit 521:300 Fuss erweicht worden sein. Es wurden alsdann die anderen westindischen Inseln stark in Anspruch genommen und später Honduras, das jotzt, was Menge anbetrifft, den ersten Rang einnimmt.

In dem letzteren (rebiete, die Republik gleichen Namens umi die britische Besitzung umfassend, findet die Fällung in zwei Jahneszeiten statt: gleich nach Teujahr, das ist das Ende der Regenzeit und anfangs Angust. Wo die hauptsächlichste Ausbente stattfindet. die bis zum Eintritte der Regenzeit fortgesetzt wird. Dis rom Fehruar bis September gefällte $\mathrm{Holz}$ ist sehr geneigt. beim Trocknen zu reissen. Was nur rermieden werden kann durch Anfbewahrung der Blöcke im Masser bis zur Terschiffung. Indessen wird in diesen Mronaten nur ganz ansnahusweise Hol\% 


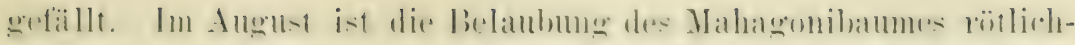

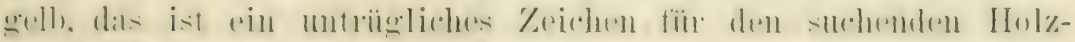

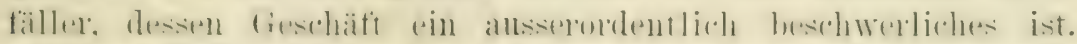

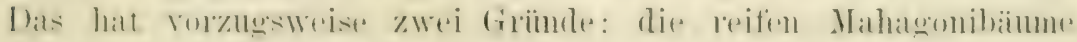

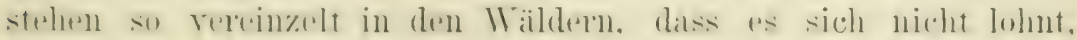

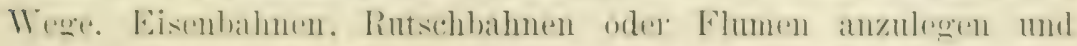

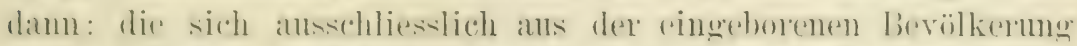
rekruteremen Hobtabler arbeiten immer noch mit ilnen alt-

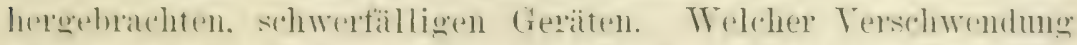
sie - ieh schuldig mathen. erhellt daraus, datsis sie eine Plattform

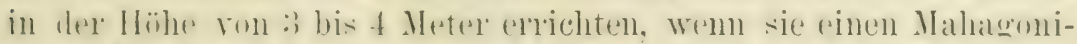

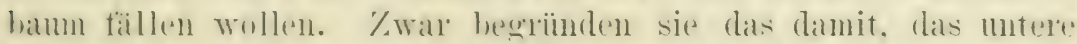

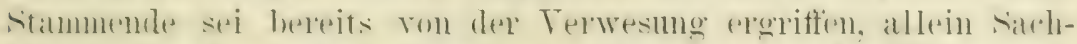

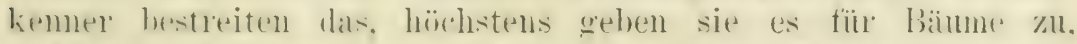

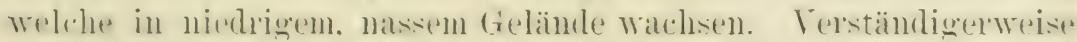

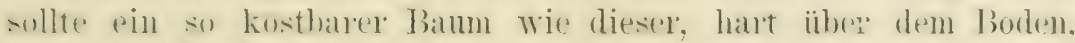

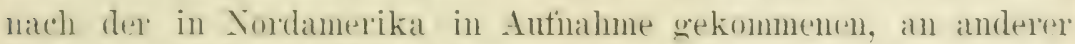
stelle geschilderten Mfethode. abgesiegt werden. Zeigt das mentere

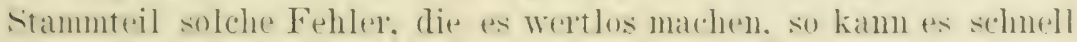
mal leicht mit cine sïgematshine abgeschnitten werden.

Der stamm ist in Folge seiner Massigktit an wertrollsten,

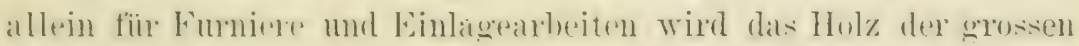

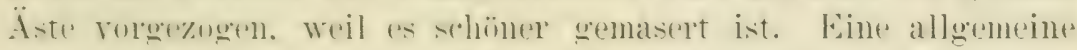
Charakteristik muss sich anf folgende Bemoxkungen beschäinken: Das Mahagoniholz ist schwer, ansisendentlich hart. sehe stark, spröile, sehr dicht mol nimmt rine schöne Politur an. Der verhältnismäsige diume splint ist gelb, das Kermhol\% ist rotbram in versohiestenten schattierungern. manchmal gelbhraun. oft in den-

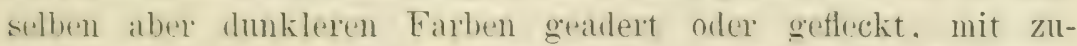
nerhmentem Alter nimmt die Färbung an Trefe zu. Die zahlrobhen Matrkstrahlen sind dium und katum erkemntlich. die

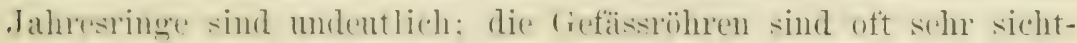
bar und bei dron in Westindien wathenden Holze mit dinem

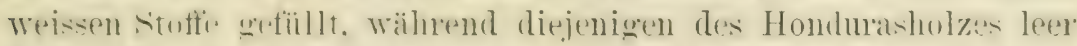

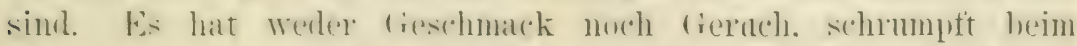

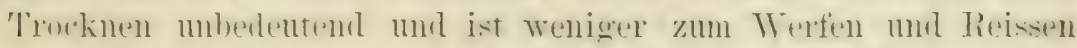

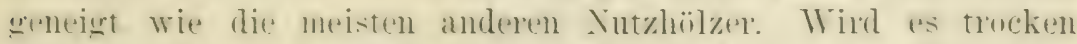

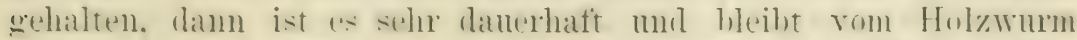

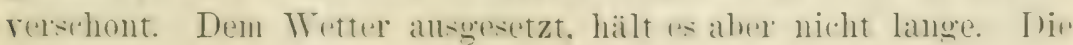


Terwendmo tindet vorzugsweise in der Tischlerei mol Inechslerei, in geringerem Masse in der Holzschnitzerei und im schiffban statt. In Lloyd's Liste der Schiffbanhölzer ist Mahagoniholz in der zweiten Klasse eingetragen.

Bezilglich der iibrigen Figenschaften sind Zahlenangaben im Abschnitte ïber die Holzkunde zu finden.

I) a das Mahagoniholz in seinen (qualitäten, je nach seinel' Herkunft, wechselt. ist die Beurteilung geboten, gemäss der im Handel iiblichen Klassifikation.

In diese zжеi Hanptgruppen findet die Einteilung statt: in das spanische Nahagoni und das Hondurasmahagoni. Das Erstere umschliesst die reichfarbigen. dichten, schweren Sorten, die einer sehr feinen Politur fähig sind mud hämfig eine schöne gewellte Maserung zeigen, in welchem Falle das Holz eine ausserordentliche Preissteigerung erfährt und nur zu Fomnieren rerschnitten wird. Dem Hondurasmahagoni werden die leichteren, weniger dichteren, einfarbigeren Sorten zugezählt, die den Leim hesser halten wie jene und geschätzt sind für die endlosen Zwecke. wo gesundes gerarles Holz, frei von aller Neigung zum Terfen. verlangt wird.

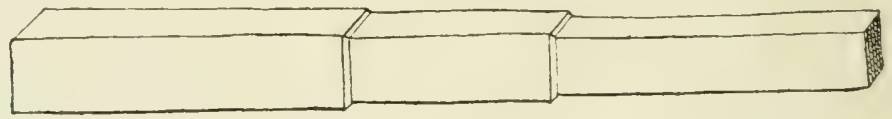

Figux 60.

Das spanische Mahagoni kommt gegenwärtig zum grössten Teile von ('uba, in Blïcken von 4 bis 10 Meter Länge und 0,25 bis 0.60 Meter im Quadrat. Dieselben sind scharfkantig gehanen, mit zwei oder drei Absätzen, wie die Figur 60 rerdentlicht. was geschieht, um Holz zu sparen. Diese Sorte ist sehr dicht, hart. schwer. nicht gerade häufig gemasert, reich rotbraun. Zuweilen treten Kermrisse auf. aber nur in sehr milder Form. Diese Sorte ist im Sichiffbau am berorzugtesten; sie dient als Ersatz des Eichenholzes für Balken, Planken u. s. w. Indessen wim sie ihres hohen Preises wegen, sowohl im schiffbau wie zu anderen Bauzwecken, immer seltener gebraucht.

Ursprünglich kam das spanische Mahagoni nur ron san Domingo, der Fxport dieser Insel ist aber sehr zurückgegangen. bei gleichzeitigor Verkleinerung der Blöcke. Dieselben sind sulten 


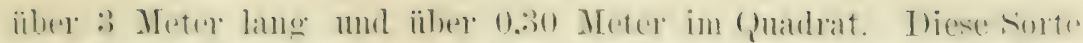

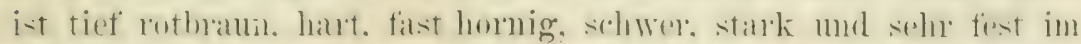

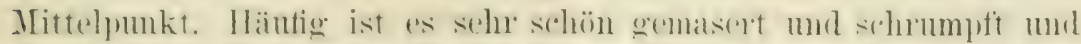

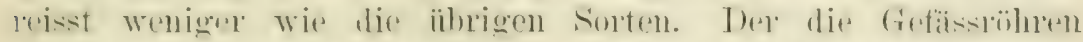
tïllende weisse stoff trift oft so stark allf, dass das IHol\% anl-sieht. als sei es mit Kreide gerieben worden.

Madeiraholz oder anch Nas:all-Mahatgoni wird in Furland

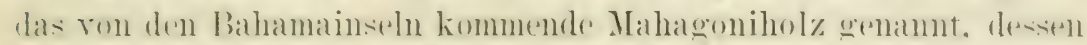

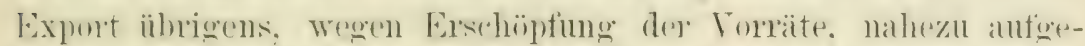

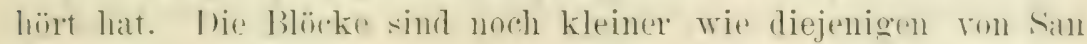

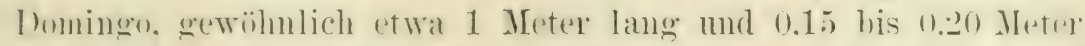
im Guadrat. Dieses Hol\% ist tiefrot. horrig, sehr dicht. fest mul zodolnet sioh dadurch alls. dass es reicher gemasert ist. wir alle?

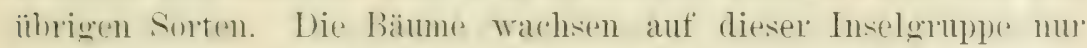

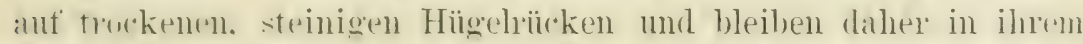
Wudse zwergig bei starker Terästelung. Damit ist die Erklärmug tïr dir hrowerehohenen Figenshatten dieser Mahagonisorte gegehen.

Jamaica bringet nur noch wenig Mahagonihol\% in den Handel. ma diestes wenige ist hollfarbig, porois und geringwertiger wip alle anderen Sorten.

Das Hondurasmahagoni komme in grössteren Blïreken wie das spanische Mahagoni in den Handel. geröhnlich haben sie eine Länge rom a bis 12 Meter und cin (Quarlrat rom 11,30 his 11.60 Jeter. Dats Holz ist rotbraun, elastisch in grünem. speridte in trockenem Zustand. selten gemasert. sondern gewöhnlich gerart-

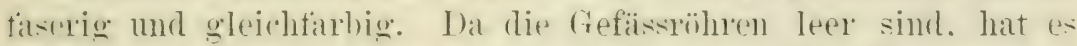
rin puröses Ausivelhe'll, anf welches ïbrigens der Standort des baumes grossen Finfluss hat. An der sïdlichen Küste von Hondura wächst der Baum gewöhnlieh auf niedrigem, fenchtem s.hwemmbenden und das Hol\%. welches gewöhnlich als Baiholz in den Handel komment. ist sehr jurios. fast schwammig. also geringwertig. An der nördlirhen Kïste kommt der Baum auf trockenem Högelgelände ror: hier ist das Holz dichter. fester. allein die (ivfässröhren bleiben unausgefiillt.

has Hondurasmahagoni reisst während des Trocknens an den seiterle tief aluf. Wenn dieser Torgang schmell erfolgt. Ist es sorerfiltig getrocknet, dam harbeitet es sich glatt und shön. wirtt sich nicht und schrumpft nicht. 
lats mexikanische Mahagoni gehört zur (iruple des Homdurasmahagoni: a wird in Blöcken ron 5 his 9 Meter Länge und ron

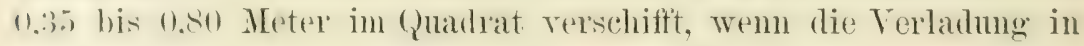
rinem guten Haten erfolgt. MLuss das sidhift auf ciner Rhede ankern. damn werden die Blörke in kuze Stïcke geschnitten, um die Verladung zin erleichtern.

lex Mahagonibam erreicht in Mexiko dieselbe (ipösce wis in Honduras, weiter nördlich, in Florida. ist er sehr schwachwïlhsig. in Westindien hält er die Mitte zwischen diesen beiden (iegensätzen.

Dat mexikanische Mahagoni ist im al?gemeinen weicher am Markkern wie das homdurasische und ist öfter mit langen Kernund sternisisen behaftet wie eine andere Sorte, ansgenommen dasjenige von 'Tabasco, welches für das beste gilt. das anf dem amerikanischen Festlande wächst. I)asselbe wird höher bezahlt wie jede andere sorte der Gruppe Hondurasmahagoni; ist es doch auch häufiger gemasert.

Das mexikanische Mahagoni bringt nahezu dieselben Preise wie das hondurasische, als dessen brauchbarer Ersatz es gilt. min je mehr descen Torräte zusammenschmelzen. desto mehr findet jenes Beachtung.

Die hohen Preise des Mahagoniholzes gebieten, mit der grässten Torsicht beim Ankanf zu verfahren. Wenn die Blöcke Kern-oder Stermisse besitzen oder am Markkern schrammig sind, so entleckt ein flüchtiger Blick diese Fehler. Nicht selten werden aber übcrreife Bämne gefällt, deren Kermholz ron der Terwesung ergriffen ist, an Stellen, die änsserlich nicht sichtbar werden bis nach Zurichtumg der Blöcke. Bleibt dieser Fehler mentdeckt, dam bringt er dem Käufer bedeutenden Schaden. Zur Termeidung deselben werden die Blöcke häufig angebohnt. Ein anderes emlffehlenswerteres Mittel ist: eine Person hält das Ohr dicht an dits eine stirnende des Blockes, während eine zweite Person dats entgegengesetzte stirnende mit einer Nadel leicht knatzt. Ist der Block durchans gestund, dam pflanzt sich der durch die Nadel liervorgerufente 'Ton bis zum entgegengesetzten Stirnende fort, andernfalls erstickt er unterwegs.

Das atrikanische Mahagoni wird unter dem häufiger angewendeten Tamen afrikanisches Teak an anderer stelle besprochen. Ton der ganz hervorragenden Wichtigkeit des Mahagonibames 


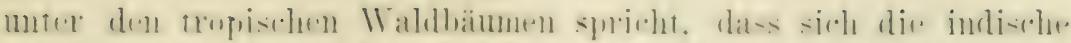

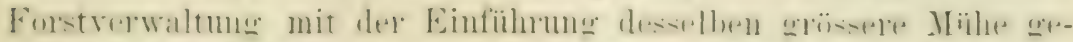

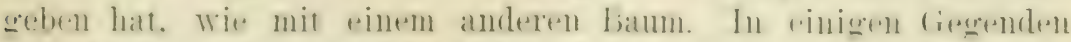

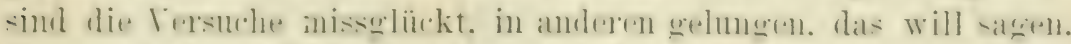

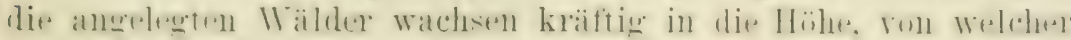

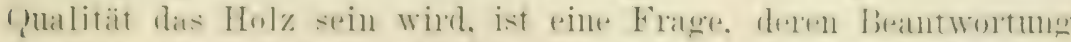

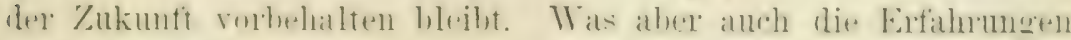

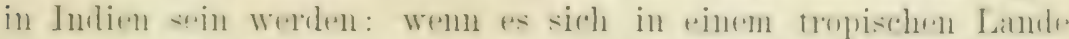

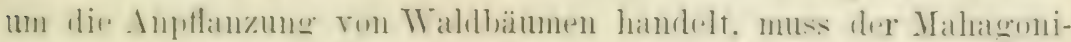

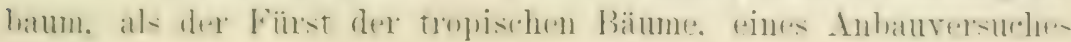
unterzogen werden.

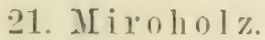

Puduatrus ferruginea ist dex wistenshaftliehe Sanne dwe in

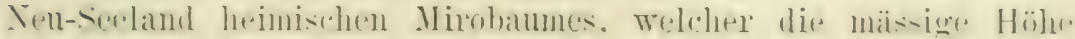

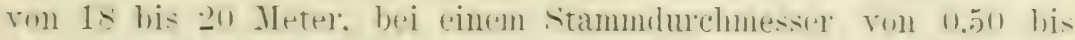

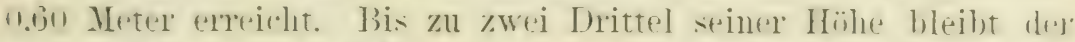
tets gerate tamm astfrei. von da ab breitet siche dir hrone in

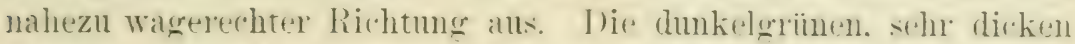
Blätter sind உِ his:) Zentineter lang und retwa 4 Millimeter hreit. [he Frumt ist eine rote Beere mit hatem stein. rin Liebling:futter der wilden 'Tauben.

Das Holz ist he-ll- his dunkelhraun. dirht, mäs-ign. hatet und

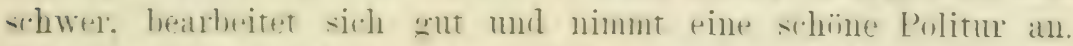

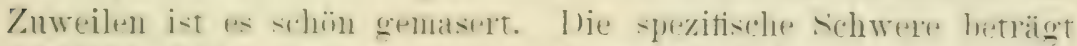

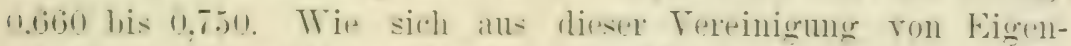

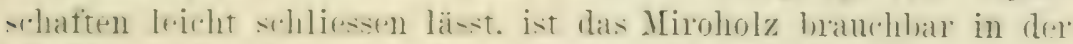

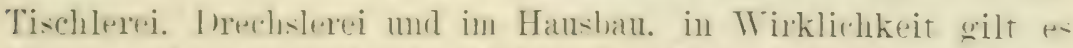

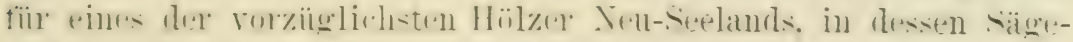
miihlenindustrie es eine wichtige Rolle spielt.

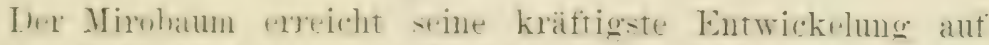

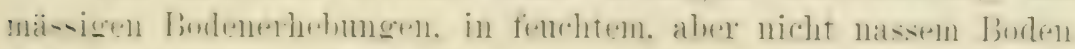
und in geschiitzten Lagen.

\section{If o I a veholz.}

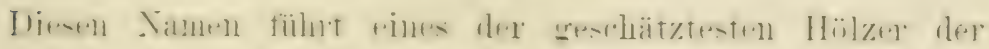

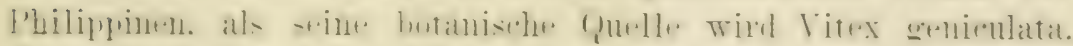

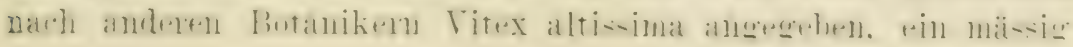


holner Bamm, der, wie Blanco in seiner Flora der Philippinen herichtet, sehr oft krumm wächst.

Das Holz ist strohgelb, schwerer wie Wasser, hart, stark. dicht. zeigt oft gewellte Masem, die an das Seidenholz erimnern und nimmt eine sehr schöne Politur an. Während des Trocknens schrumptt es wenig und reisst selten. es ist sehr dauchaft, selbst wenn dem Wetter ausgesetzt.

Über weitere Eigenschaften finden sich Zahlenangaben im Abschnitte ïber die Holzkunde.

\section{IL 0 ra hol $\mathrm{z}$.}

Mora excelsa. Familie Leguminosae, Unterfamilie l'atsalpincase, wurde von schomburgk entdeckt, der ihn als einen der majestätischsten Bänme Gnianals schildert. Bis jetzt besteht die Gattung Mora nur aus dieser einen Art.

Nächst dem Grimherz ist das Moraholz das wichtigste mul in Europa an bekamntesten gewordene Holz Guiana's, zum mindesten von Britisch Guiana, das über soinen Hafen Demeraral diese beiden Hölzer lebhaft exportiert.

Das Moraholz kommt in Bläcken ron 5 bis 10 Meter Lünge mor 0.30 bis 0,50 Meter im (quadrat in den Handel. I) Fa Farbe erimert an das Mahagemiholz. doch ist sie in der Regel dunkler. das will sagen kastanienbram. Es ist hart, schwer, zäh, stark. gewribnlich geradfaserig. zuweilen zeigt es aber eine sehr schöne Nasedung: Wodureh natïrlich der Wert der betreftenden Blïcke hedentemel exhöht wiol. Da es eme gute Pulitur amimmt. dient es in der 'Tischlorei und lorechsterei als Ersat\% für Mahagoni und Rosenholz.

In schiftbau enilt es als ein vorziiglicher Exsatz für Fichent-

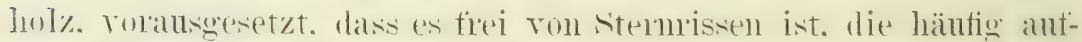
treten. Bbïrke die mit diesen Fohler behatted sind, kïmnen nicht vorteilhatt zu P'lanken und Brettern rexschnitten werden, dagegoen

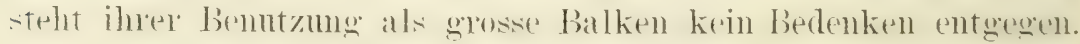

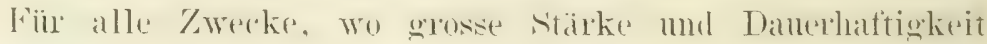

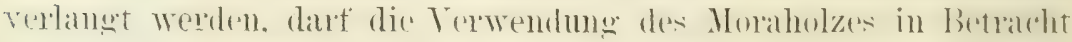
kommen. 
Seine hedentemele Danerhattigkeit in allem Lagen mag es wohl einer kleberigen Flïssigheit rerdanken, welche sirh in seinen Gefïssröhren findet.

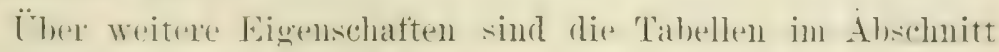
ïber die Holzkunde nachzusehen.

\section{Ni es s li $01 \mathrm{z}$.}

Waldarm wie das südliche Atrika ist, besitzt es dorhe einige

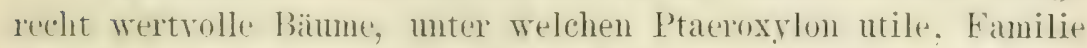
Silpindaceat. einen hervoragenden hang eimnimmt. Dieser Baum tritt am Zahlleichsten in den istlichen Distrikten der Kilpkolonit ant. Das Holz kommt an Schönheit dem Mahagoni nahe; es nimmt eine feine Politur an, ist sehr fest. stark und dauterhaft. Den Namen Niesholz empfing es, weil das sägemehl eine reizente Wirkung anf die Geruchsuerven ausiibt. Was ber der Terarbeitung belästigt.

Bei dem herrschenden Holzmangel in sürlafikat kann selhstrextändlich. trotz seiner Torzüglichkeit. dieses Holz nicht expor-

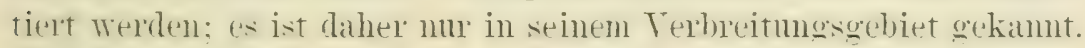

\section{Pocklol z.}

finjakhol\%. Franzosenholz mol im Apothekerlatein Lignum vitat - eine: Bezeichnmg. die. nebenbei bentert. allschliesslich ron den Engländron gebratudet wird - sind andere Vamen für

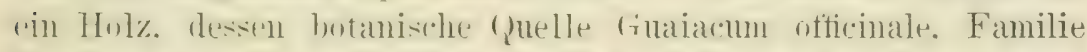

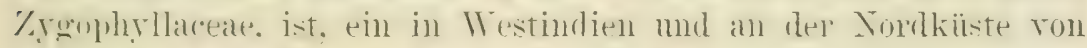

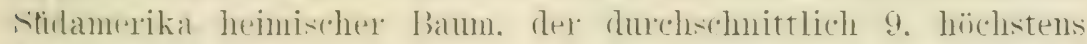

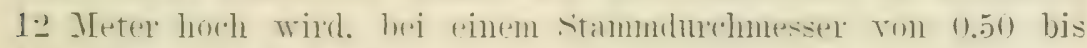

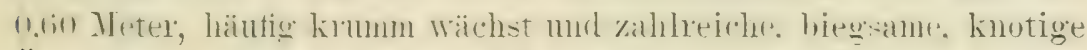

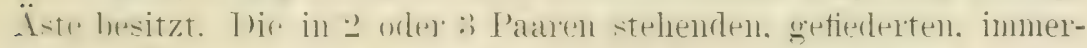

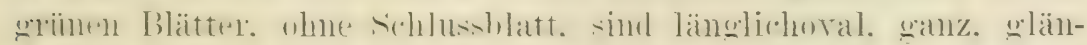

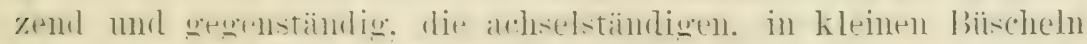

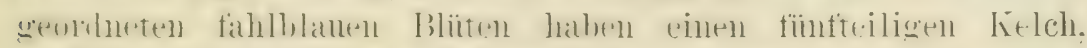

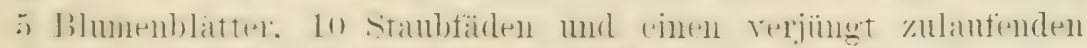

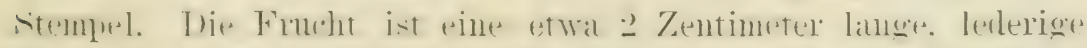

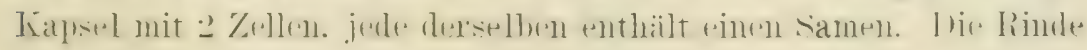
ist gefurcht, hart und spröde.

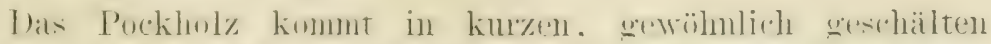

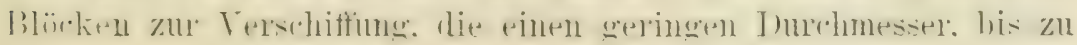


25 Zentimster etra und eine Länge ron 1,8 bis 3.6 Metel habsu, während die dickeren nur halb so lang sind. Der Terkanf findet nach Gewicht statt. Der 2 bis : Zentimeter dicke splint ist leelgelb, fiei ron Harz und lrauchbar; wenn er auch nicht dif: Härte des Kermholzes besitzt. Wird das letztere in Scheibenform rerarbeite und ihm eine dimne sichicht des splints gelassen. so bleibt es ror Rissen bewahrt. Das Kernholz ist dunkelgrünlichbram. sehr hart, stark und dicht, die spezifische Schwere schwankt zwischen 1:2 40 und 1,340. I)ie Jahresringe sind kaum zu erkemen. der ILarkkern ist nur in spuren verhanden. Jit einem Tergrïsserungsglas kïnnen die in gleichen Abständen lantenden, Zahlieichen Markstrahlen benbachtet werden. Es enthält 2060' Guajakharz. das an anderer stelle als Tebemprodukt des Waldes angeführt ist. Del Geschmack des Holzes ist beissend und aromatisch; wenn es gerieben oder erwärmt wird. gibt es einen schwachen, unangenehmen Geruch ab.

Eine bemerkensmerte Eigenschaft dieses Holzes ist. dass die Fasern sich schichtenweise. abwechsehnd in schräger Richtung kreuzen, wodurch es sehr schwierig zu spalten ist, buchstäblich grenommen kamn es nicht gespalten. sondern nur zerbröckelt werden. Gerade diese Faseranordnung verleiht ihm für die Zwocke. welchen es dient. rinen hohen Wert. der gesteigert wird durch eine beispiellose Thanerhaftigkeli. die fast his zur Enverweslichleit geht und wahrscheinlich nur dem bedentenden Gehalt an dem cigentïmlichen Harz zu verdanken ist. dere anch Insekten und Würmes

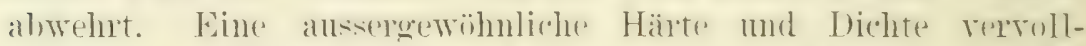
ständigen die Vowägo des Porkhol\%es. Als Mängerl sind dir

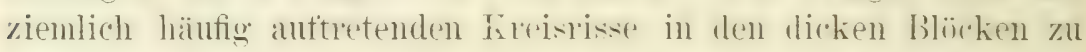

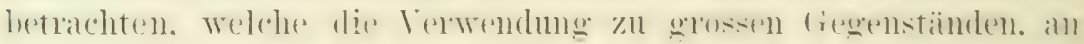

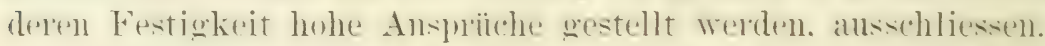

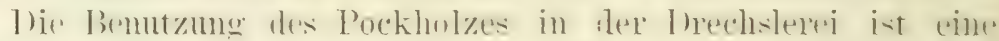

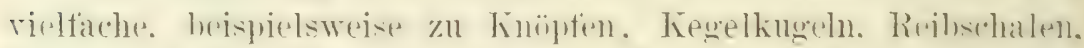

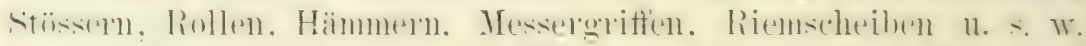

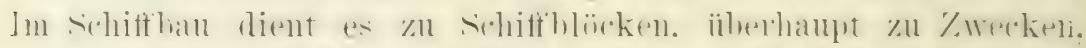

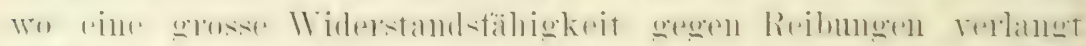

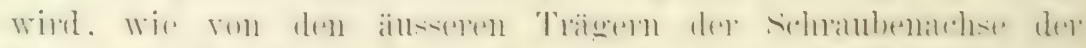

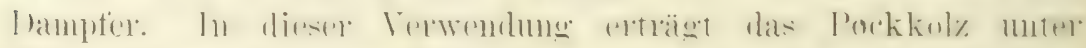
Wasser einen enormen Drucks. ohne sich abzunutzen orler zu erwärmen; es bewäht sich hierfür besser wie irgend ein Metall. 


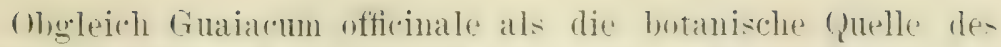
T'rckholzes grilt, so komnt nicht selten untrel diesem Samen dasthe ähnliche Holz von (sualacum sanctum in den Handel. Dies. - Art ist in c'uba, den Bahamas und siidfloridal heimisch und muterscheidet sirh ron jener durch kïrzere und schmälere Blätter. welche in 4 oder 5 Parren stehen, durch einen kürzeren mol glänzenden helch und eine tünfzellige Frucht. Ileser Baum wächst ebenfalls häufig krumm und mit knotigen Ästen, seine Hähe übersteigt selten \& Meter. bei einem stammdurchmeser von (1.30 Meter. Das Holz ist allsserordentlich schwer. sehr hart. stark. dicht, schwierig zu bearbeiten, bröckelt heim sualten nud enthält viele. gleichmässig rerteilte Harzadern. Die zahlreichen Markstrahlen sind sehr undentlich. ebenso die Tahn singe. In sylint ist hellgelb. das Kernholz tief gelbhraun. in älteren Bänmen nahezu schwarz.

Die Benutzung ist diejenige des echten Pockholzes. Thas Harz ist ein Handelsartikel und führt ebenfalls den Namen Guajakharz.

Eine dritte Art. Guaiacum aiboremm. kommt im Thal de: Magdalena ror. wo sie his zu Erhebungen ron 800 Meter steigt. Über ihre Nützlichkeit lauten die Berichte noch widersprechend. Im Gegensatz zu den beideli anderen Arten erreicht sie eine stattliche Grösse. I)as Holz ist grelb), in's (rrünliche schillernd und hricht fast pulvertïmig. Die Blüten sind gross und gelb. die Früchte besitzen 4 Zelleu. Lie beste (qualität res echten Pockholzes kommt ron San Lomingo. Die anderen wichtigeren Bezugstuellen sind Tamaica und die Bahamas. Da der Begehr nach riesem Artikel stets lebhatt ist mol die Vachfrage für grosse; behlertieie Blïcke oft nicht befriedigt werden kaln. so musi G. otficinale als antuahmewiindig in den tropicchen Kulturwald rscheinen.

\section{Porkupnienholz.}

Lnter diesem somderbaren Vamen kommt seit nenerer Zeit lias Holz der cucuspalme cous nucifera) in den Handel. rorzugstreise zum Fxport nach England. Im 1. Bande der tropischen Agrikultur ist diese Palmf und ihr Anbau eingehend geschildert. es ist dnet auch gesagt. dass sie immenwüchsig. ihr Holz daher erst rerwembar sti. nach ihrem natiurlichen Alsterluen. da- 
heshergatulut winde durch die sich mehr und mehr verdichtenden saftcrefïsse in dem von. Tugend auf fest begrenzten Stamm. Fs tritt buchstäblich ein Erstickungstod ein.

Dat: Porkupnienholz ist dunkelbraum. hart, dicht und nimmt pine sehn schöne Politur an - eine Vereinigung ron Eigenschatten, welche seine Einführung in die englische Tischlerei burikte. In ceylon und einigen anderen tropischen Länder'n. Wo ler Anban der Cocospalne von Bedeutung ist, dient iln Holz zum Hausbau und zur Fertigung von mancherlei Geräten.

Tn 1. Bande der tropischen Agrikultur; Abteilung: D)ie nïtzlichen Palmen, ist ausgeführt. dass noch andere Palmen wertvolles Holz nach dem Abschlusse ihrer Lebensthätigkeit lieferm, doch sheint bis jetzt keins zu einem Ausfuhrartikel geworden zu sein.

\section{Puririholz.}

Censetändisches Teak ist ein anderer aber nicht emptehlenswerter Vame für dieses Holz. dessen botanische Quelle Titex littulalis ist. ein in fast allen Wäldern der Tordinsel Nen-Feelands rorkommender Banm. der mer giunstigen Verhältnissen. das will sagen anf fenchten mol geschiitzten standorten. eine Höhs von 1ii lis 18 Meter. bei einem stammdurchmesser ron 0.9 bis 1.j Ireter ereicht. Die Rinde ist dium. glatt, gramweiss, die immerọinen Blätter sind ganz. hellgrün. \& Zentimeter lang; इ Znutimete hreit und stark gerippt. Den roten. glockenförmigen Bliiten tolgen kirschengrosere Beerentiüchte. die ein Lieblingsfintter vieler rägel bilden. In mgeschiitzten Lagen wächst der Stamm liälutig krtumm wher schief, eine rereinigte Wirkmor des Tindes und der schweren. breiten Krone.

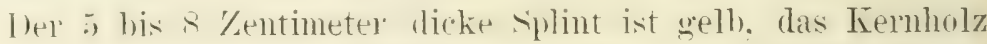
ist dunkelbram. ansecrordentlich hart, dicht. annïhemd 1.00 schwer. gewaihnlich fehlerfied und ansmehmend dantehatt. Im schifthan tindet es an vtelle des Teakholzes Verwendumg in Fisllen. wo es

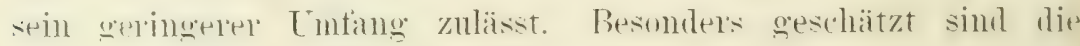
krtummoewachsenen Stiicke als Kniee.

In Xell-sereland wird diesem Holz der erste Ramy pingeräumt fiir Bahnschwellen, Pfosten und 'Tragpfeiler. 


\section{Purpurhol\%.}

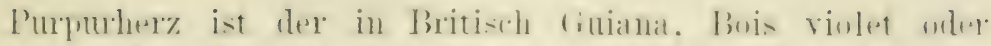

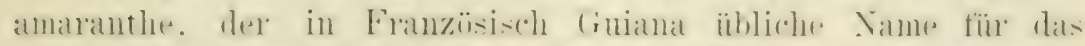

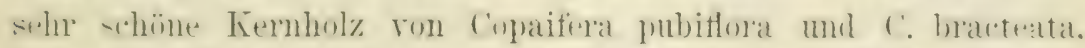

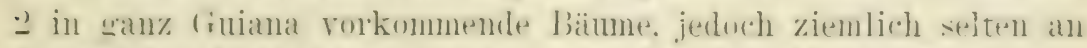

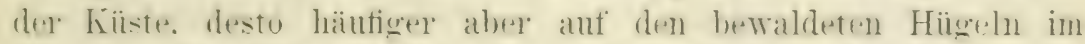

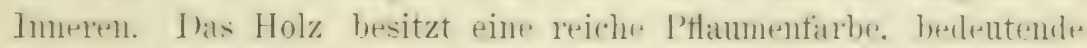
Härte. Schwere, I ichte mol Tragklaft. Bis jetzt hat es null

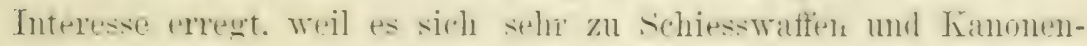
wagen eignet: es soll. hesser vie ein anderes Holly dir be-im schiesen erzengten Rückstioss ertragen. England impurtiert dieses, ron dem Lrbewnhnem des Britischen Gnianats Mariwayanat genamunte Holz. schon seit pines heihe von . Taln'en in kleinen

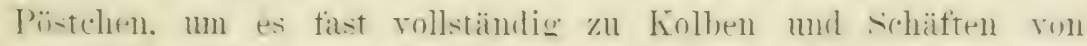
dewehen zu relarbeiten. Die Blïcke haben eine länge von 6 his 7 Meter und mesicen im Quadrat 10.2.5 his 0.35 Meter. Jas schüne. watt Alswehen und die Fïhigkeit. eine feine Politil anzunehmen. bereclitigen dieses Holz anch zur Aufmerksankeit in der TischLerei mad Drerlsslerei. Sobald ihm in diesen Gewerluen die Bahn

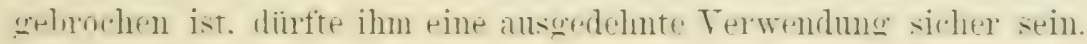

\section{P y e $n$ g a d u hol $\mathrm{z}$.}

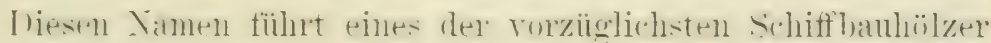

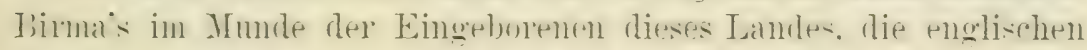

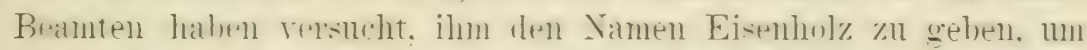

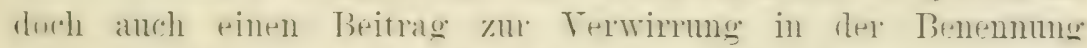

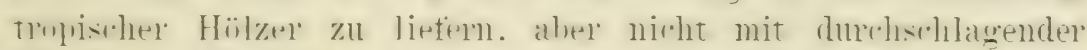

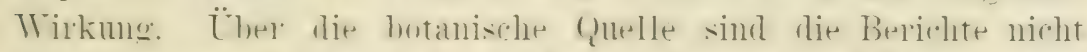

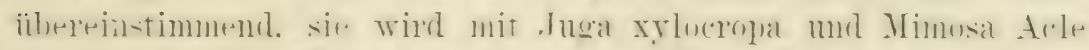

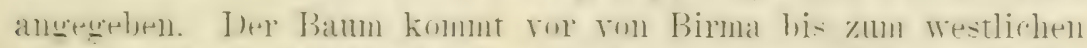

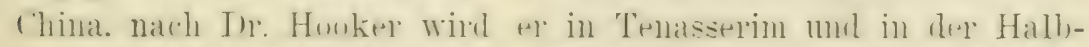

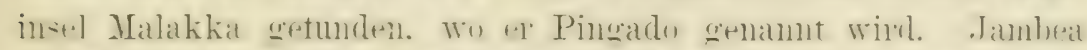

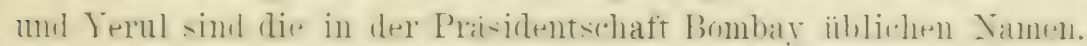

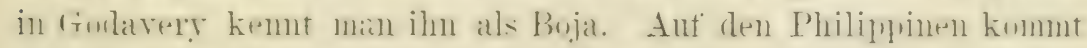

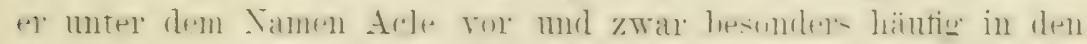
Wäldern ron Hloila und Négros.

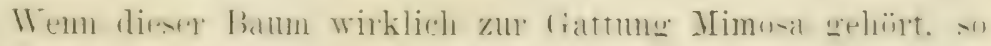

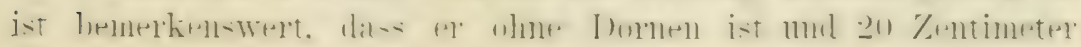


lange und \& Zentimeter breite Blätter hesilzt. Er erreicht eine Hiihe von :30 Meter. mit einem celaden, astfreien stamm ron 21 bis 24 Meter.

Dals Holz ist rotbraun. hart, schwer: stark, zäh und häufig ytmasert. Wem der gefälle Stamm behanen wird, tritt ein ̈̈liger. klebriger Stoff aus den Gefässö̈hen. dem wahrscheinlich das Holz seine ansserordentliche Danerhaftigkeit rerdankt. Er ist lästig. so lange das Holz nicht gründlich trocken ist, weil er rorher von der oberfläche nicht beseitigt werden kann. Die Termiten greifen dieses Holz nicht an und das Gleiche wird ron: dem 'Teredo gesagt, doch ist diese Behauptung his zul besseren Beweisfithrung mit Vorsicht entgegenzunehmen.

Nicht allein in Schiffban wird dieses Holz verwendet. sondern zu allen Zwecken, wo Stäke und Danerhaftigkeit verlangt werden, namentlich ist es für Hausbauten vorzüglich geeignet, selbst wenn es dem Wetter ausgesetzt bleibt. Zuweilen auftretende Kermisse bilden wohl den einzigen Fehler.

In dem Abschnitte über die Holzkunde sind über antere Eigenschaften Zahlenangaben zu finden.

\section{Ratahol\%.}

In Neu-Seeland werden zwei nahe verwandte Arten als Ratabaum bezeichnet: Metrosideros robusta und M. Incida. Tene erreicht eine Höhe ron 24 bis 30 Meter. bei einem Stammdurchmester ron 2 bis 3.5 Meter. diese eine Höhe ron 1101 1.5 bis 18 Mter, bei einem Stammdurchmesser rom 0.5 bis 1.5 Meter. In ausserdem M. robusta das wertrollere Holz liefert, so ist auf diesen Unterschied, namentlich bei Anbanversuchen. wohl zu achten.

M. robusta kommt in dichten Wäldern der beiden Tnseln ant fiuchtbarem, mäsig feuchtem Borlen zur kräftioten Entwickelung. hier treibt sie einen 10 his 12 Meter hohen. astfreien Stamm und finte breite. ans starken Ästen mo Zweigen gebildete Finne.

lie hellgrünen Blättel sind etra + \%entimeter lang und 1 his $1^{1}$ a Zentimeter breit. die dunkelnatume Rinde ist je nach dem Alter mehr oder minder zertetzt. Tm Dezember und fambar ist

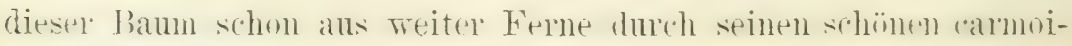
sinroten Bliitenschmuck kenntlich. 


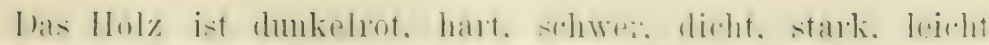

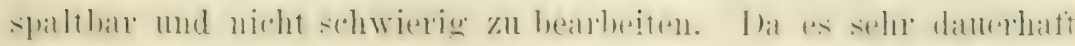

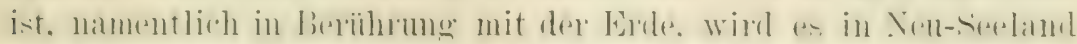

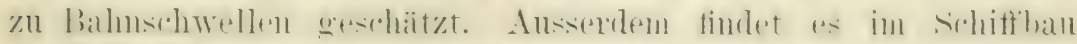

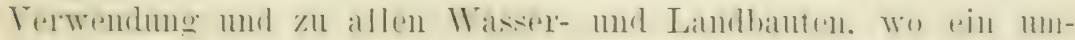

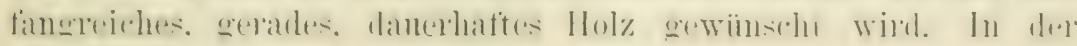
Tischlerei geniesst es einen guten Ruf.

Seine spezifische Schwere beträgt 0,780 bis 0,800 .

\section{Reb h uh h h o l \%}

Unter diesem Namen kommt ein sehr schönes. liartes Holz.

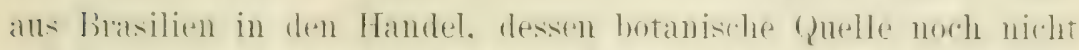

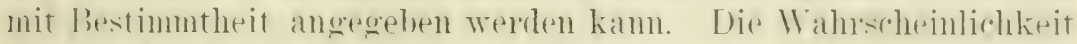

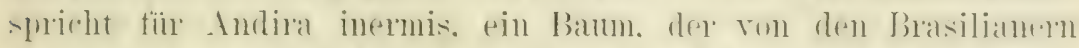

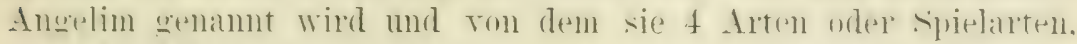

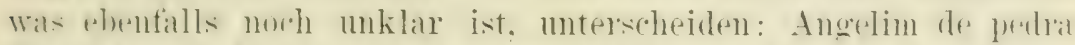
(xtein-Angelimı. Angelim amargoso bitterer Angelims. Angelim remelho (roter Angelim), Angelim valuea sultivierter Angelims.

Die hotanische Quelle zuverlässig nachzuweisent, bleiht also dery \%uknft vorbehalten. Das Holz ist rotbram in verschientemen

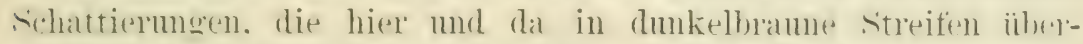
gehen. In manchen stïcken liegren diese streifen so greringent ïher rinander: dass sie Rebhuhnfedern gleidhen. Zeigen sie dabri pinen ungewïhnlichen Farbenabstich, so werlen die betreftementen Stiicke als Fasanenholz bezeichnet.

Wemn ich recht berichtet wurde, wird das einfach getïrhte. Holz in Brasilien zum sihiffbau rerwendet und nur die shoü malrkierten stïcke werden zum Expont nach England ansgelexin. wo sie als Partridgewoud und Jheasantwoud in der Mäbeltischlerei zur Verwendung kommen.

\section{:i:. Ii hod i $u$ m h h}

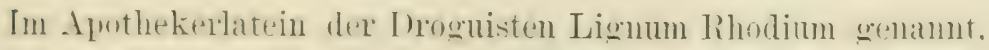

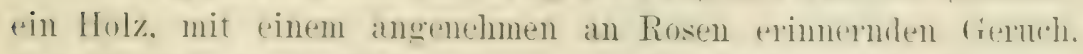
das in dicken. ziemlich schweren, cylindris hen aber knotiun Stïrken in den Handel kommt. Selten sind sie gespalten. erowïhnleh bedeckt sie rine rissige, grane Rinde. Der culint ist gelblich, narhe dem Markkerne zu wird das Holz zuntehment 
poitlich. lols Letztere hat einen aromatisch-bitteren fieschmack: \|enn es gerieben wird. duttet es angenehm rosenartig.

bieses Holz ist das Produkt rom zwei anfrechtwachsenden

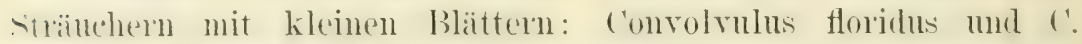
-roparius. heimisch auf den Camarischen Insehn. Es besteht ans den Wuzeln und dem stamme. I as Letztere ist geringwertiger, weil ärmer an dem ätherischen Rhodiumöl. Dasselbe wird durch Hestillation gewommen und als Beigabe zu salben und Eimreibmitteln, häufig auch zur Vorfälschumg des Rosenöls benutzt. In Nordamerika dient es ansserdem als Lockmittel bei der Vergiftumeschädlicher Nagetiere.

Ansser diesem Rhodiumholz gibt es eine amerikanische Sorte. die ebenfalls einen Handelsartikel bildet, das von Amyris balsamifera, heimisch in Jamaica. produziert wird und ein (i) liefert, wolches dem vorhergeheuden sehr ähnlich ist.

Im strengsten Sinne ist Rhodiumholz das Produkt ron Lipuidambar orientale, ein kleiner in Vorderasien rorkommender Batum. Trieser echte Artikel kommt jetzt kaum noch in den Handel, sein Nane ist anf die genamnten Sorten iibertragen worden, als man sie brauchbar zum Ersatze erkannte.

\section{Rimulolz.}

Ein bis zu 30 Meter hochwachsender Baum, mit einem geraden his 15 Meter astfreien Stamm, dessen Durchnesser 0.60) his 0,80 Meter ist, heimisch in Neu-Seeland, von der Wissenschaft Iacrydium cupressinum genannt, produziert dieses Holz.

Der Baum zieht fruchtbaren Boden und niedrige. geschiitzte standorte hohen trockenen Lagen vor. I)ie langen Äste haben eine sanft hängende Form, sie verlaufen in zahlreichen diumen Zweigen. welche nit kurzen. hellgriunen. fadenähnlichen Narteln hevetzt sind. Auch Zweige und Tadeln hängen; es ist daher leicht verständlich, dass D. cupressinum nicht allein ein Nutzbaum, sondern auch ein sehr geschätzter Zierbaum ist.

Das Holz ist am IIarkkern kastanienbram. nach dem splinte zu wird es heller, ins Rötliche schimmernd, mit schömen abmerh- hnden schattiermenen mol gelegentlichen Masemugen. Da es mässig hart ist, muter dem Hobel glatt wird, und eine schöne Politur amnimmt, so ist geningend dargethan, dass es in der Mö̈beltischlerei Bearhtung verdient. In Nen-Seeland wird s zum Hans- 


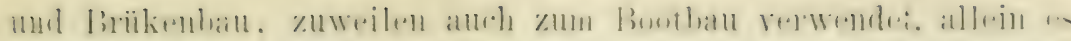

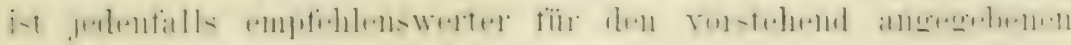
Zweck.

Die spezifische Schwere beträgt 0,670 bis 0.700 .

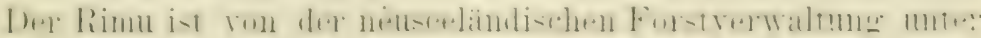
die Kulturbäume aufgenommen worden.

\section{Rosen hol z.}

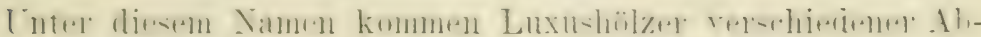

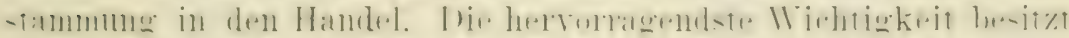

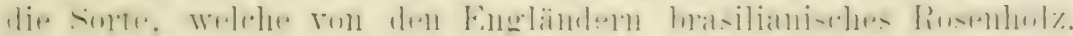

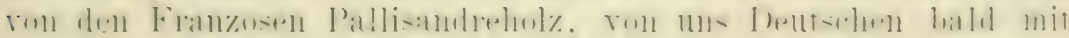

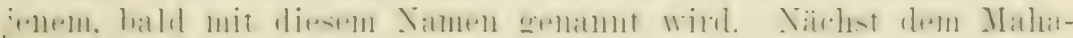

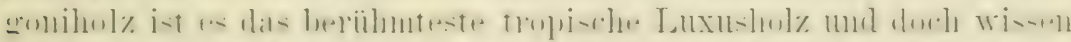

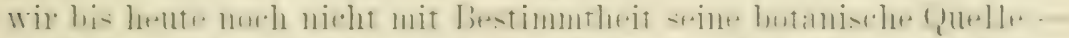

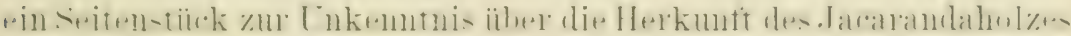

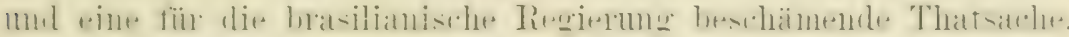

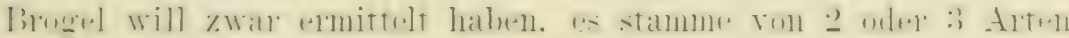

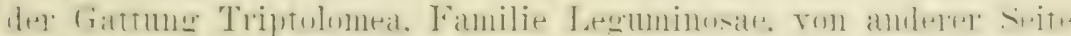

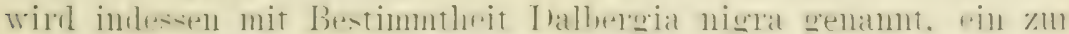

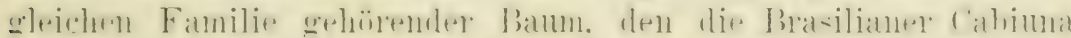

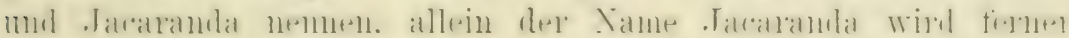

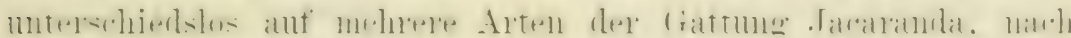

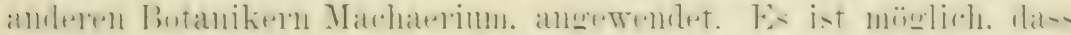

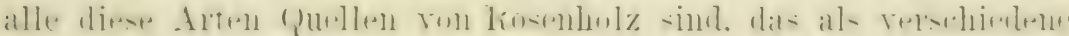

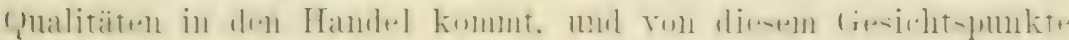

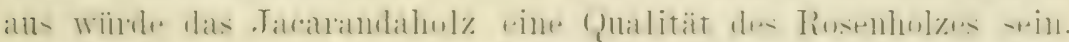

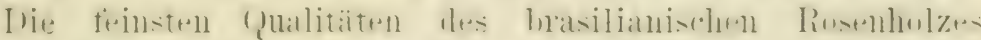

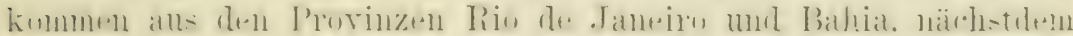

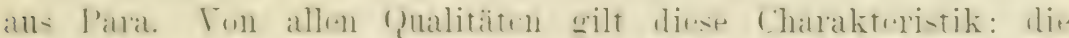

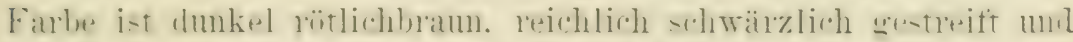

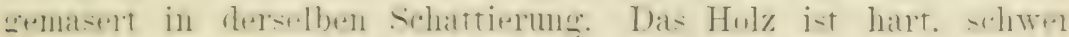

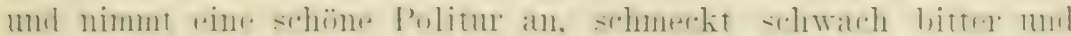

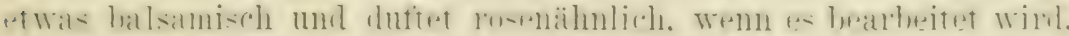

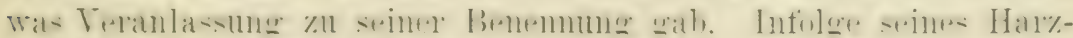

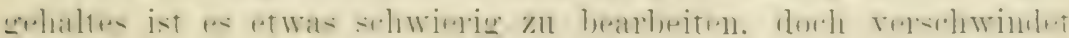

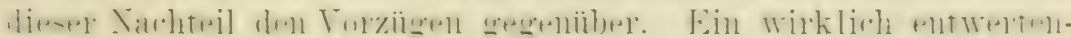

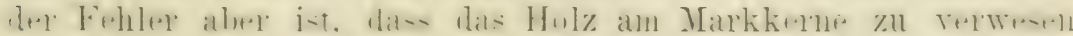

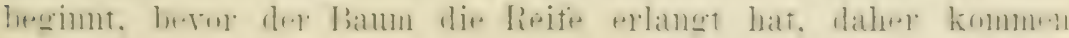


nimals viereckige libüke oder meite Planken an den Markt. s.llhst runde. gesunde Blöcke mittlerer Grösse sind selten. Gewöhnlich werden die Stämme in der Längenrichtung halbiert, in der Weise, dass schwarten, :3 bis :3,5 Meter lang und 0,15 bis 0,30 Meter dirk, entstehen. Zugleich wird das faule Holz ansgehamen. die shwarten zeigen daher auf der imeren seite keine ebene Flächr. sundern sind. entsprechend dem fanlen Kern, mehs oder minder ringrebancht. Thre mregehnässige Form nötigt zum Verkinte nach (iewicht: die Preise schwanken zwischen weiten Grenzen. gemäs: Rey Farbenschattierung und der Maserang. auch die Grösse des stiickes ist ron Einfluss bei der Bewertung. .Te schärfer dir Schattiermng'n ron denn (iruude abstechen. je muregelmässiger dir Maserung läuft, desto höher steigen die Preise.

(b)en murde Amyris balsamifera als (quelle des amerikanische? Rhodiumholzes genaunt. Wemn das stammholz so dick und grerade ist. dass es in der Tischlerei rerwendet werden kann. wird ihm der Name Rosenholz beigelegt. auf den es seines Geruchs wegen anch Anspruch erheben darf. Fs ist iibrigens heller wie dar hrasilianische Rosenholz und nicht so schön schattiert. Als westindisches oder Jamaicarosenholz kennt man es im Handel.

Um seiner Farbe willen wird in Brasilien das $\mathrm{Holz}$ ron Phrsocalymma floribunda Pan de rosa-Rosenholz genamnt. Dis Portugiesen bezeichnen es mit demselhen Namen. tür die Franzosen ist ex das Bois de rose. Während sie das obige Holz Pallisandre nemnen, wie bereits erwähnt. Was für die Engländer Rosenholz. ist für die Franzosen Pallisandreholz. md was für die Franzosen Rosenholz. ist fiur die Engländer 'Tulpenholz, für die Nordamerikamer aber ist Tulpenholz das Produkt ron Liriodendron tulipifera. Es fehlt also an Veranlassungen zur Verwimung nicht.

Das indische Rosenholz, von den Englälidern zuweilen Blackwour genamnt. i-t das Produkt ron Dalhergia latifolia. Familie Leguminosae, ein hauptsächlich in Malabar vorkommender Barm. les einen branchbaren Stamm ron etwa 15 Meter Länge mol pinem Inuchmesser des gewöhnlich gesunden Kernholzes bis zu 1 Meter liefert. Das Holz ist dmkelbram, fast schwarz schattiert und häutig schön gemasert. Es wird so hoch geschätzt und steht in so lchhaftem Begehr, dass sich die indische Forstrerwaltmer relanlasst sah, ansogedehte Anptlanzungen dieses Bammes ansz- 


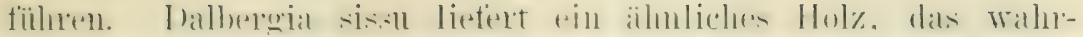

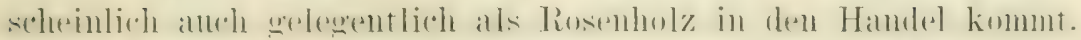

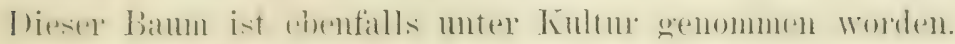

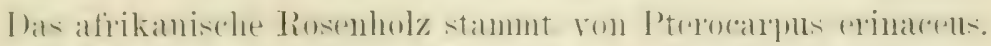

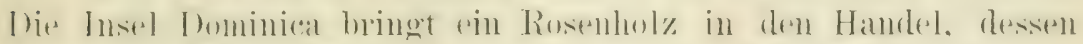

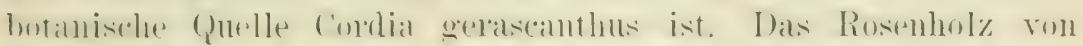

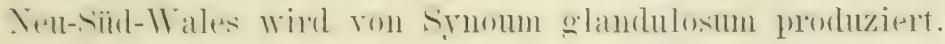

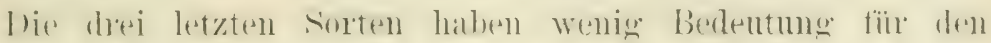
Hamelel mud sind anf vielen Därkten sar nicht gekame. Rosen-

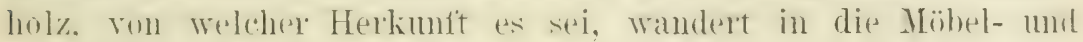
Pianofortefahriken: die am schünsten schattierten mol gemaserten Stiicke werden zu Fournieren rerschnitten.

Dir Franzosen haben sich in dex Teuzeit bemïht. ans ihrer Kolonie Ginana tin Holz in Enropa einzuführen. dem sie den Samen bois de rose femelle. Weibliches Rosenholz. gaben mul wahroheinlich das Produkt ron Licaria monata ist. Es besitzt vinen an Beramottïl erimernden fieruch. der aber so flüchtig ist, dats das Holz zur crewinnumg des atherischen (Gels erst mmittelbar ror Füllung der Destillierbiase gerasuelt werden darf. Eime andere Terwendung kam datsellor. grohtaserige, werig daterhafte Holz nicht finden.

Gleichzeitig tïhrten sie ein Bois de lose nales mämnliches Ronhlol\%, ein, das ebentalls gell, mäsig hat und grobfaserig ist. Es kamn nur eine untergenrdnete Vurendung finden, ein Luxusholz ist es ganz gewiss nicht.

\section{S a f r a n h o l $z$.}

Gelbholy ist ein anderer Name tür das Produkt ron Elatedendron roceum, Familie ('elastraceate. heimisch in südafrikia. E. ist. Wie sein Same andeutet. safrangelb, feinfaserig. hart, zäh mol nimnt eine schöne Politur an: verwendet wird es im Hausban, meln noch in der Mäheltischlerei. Wie ich schon an anderex stelle erklärte. ist das waldanme siidafrika nicht in der Lagte Hol\% an das Auslann abgeben zu kïmnen. allein es besitzt einige Bäume. welche tïr die Forstkultur die ernsteste Beachtung rer-

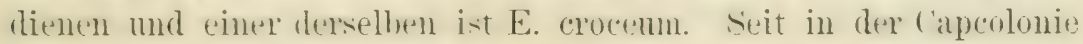

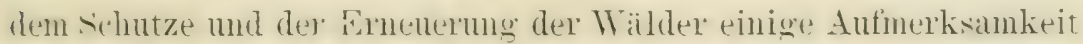

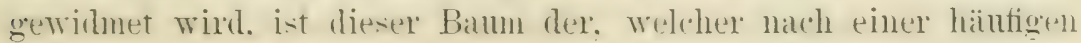


Geptlogenheit der Engländer denselben Namen trägt wic sein Hol\%, nämlich saffronwood. angeptlanzt worien, sowohl von dem Forstaufseher wie von Privatgrundbesitzern.

\section{Salholz.}

Shorea robusta, nach einer äleren Benemmeg Vateria robusta, Familie Dipteraceae, gilt für einen der wertrollsten Waldbäame Indiens. Am siidlichen Fusse des Himalaya, wo ex ausgedehnte Tälder bildet, führt er den rolkstïmlichen Namen sal, derselbe ist in die Antssprache der englisch-indischen. Terwaltumgsbehïrde libergegangen. Wie bereits in der Rundschau über die Wïlder der Erde herrorgehoben wurde, ist der Sal einer der wenigen indischen Bämme, welcher ron der Forstrerwaltung dieses Colonialreiches zur Anptlanzung ron Wäldern hemutzt und da, wo ex bereits Wäder bildet. nach den Regeln der Forstkultur behandelt wird. Da die sämtlichen Salwälder im Norden Indiens liegen. su rerbicten die 'Transportkosten den Export des Holzes, dessen Eigenschatten man mithin im Auslande nicht in die Lage kommt, zu prïfen. T'ir sind deshalb auf das Zeugnis der Britisch-Indier angewiesen, welches lantet: schwer, hart, sehr danerhaft, bratuchbar zu Banzwecken, Bahnschwellen und Wagnerarbeiten.

\section{St. Martinhol\%.}

In Guiana, rolzugstreise in der französischen Besitzung, kommt Rubinia panacoco. Familie Leguminosae, ror. ein mässig. hoher Bamm, dessen Holz als st. Martinholz gekannt ist. Dasselbe ist rötlich, hart, schwer, dicht, geradtaserig und nimmt eine schöne Politur an. Terwendet wird es im schiff- unl Hansban, wic in der Möbeltischlerei.

Der kxport geht fast nur nach Frankreich, in Blïcken ron 6 bis 8 Meter lang und 0,40 bis 0,50 Meter im Quadrat.

\section{Sall ta 1 ho $01 \mathrm{z}$.}

Der Handel mit diesem wohlriechenden Holz besass schom Wichtigkeit, als die geschichtliche Zeit zu dämmern begamm. und wird sie selbst nicht verlieren. Wem die Gätzendiener so rollstïndig amsgestorben sein werden, wie der Moa und Dodo. Die er'ste rohiftliche Erwähnung findet das santalholz in der sanskitsurarhe als Chandana in der Nirukta. der ätesten existierenden 


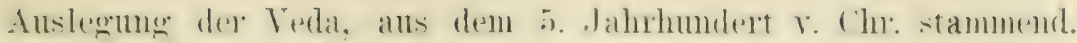

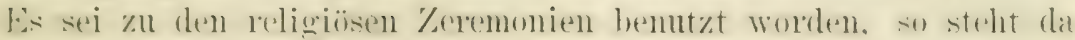

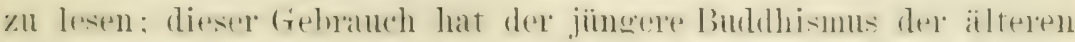

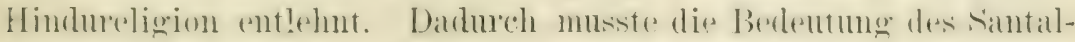

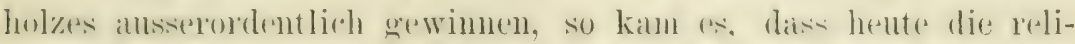

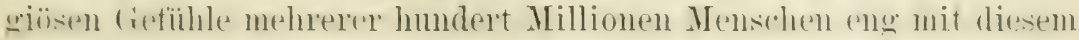
Hol\% verknijptt sind. Wem sich sein Ranch himmelwärts krïlselt,

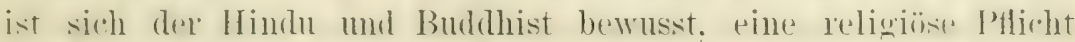

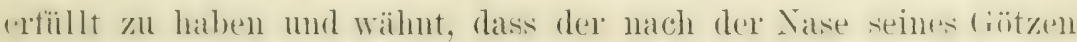

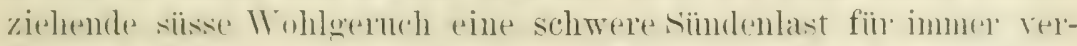

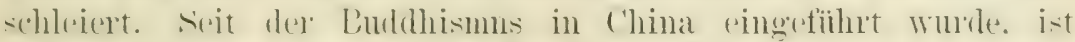

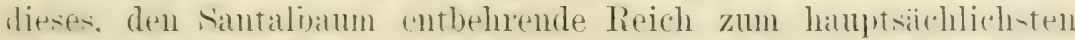
Markite jenes Holzes gerrorden. Stïcke ron 10 bis $15 \%$ \%entineter Thurehmesser werden als das angenehmste Optex hetrathtet, welches femand seinem trempelgatzen mathen kamm, freilich ist dats num reichen Lente'n möglich, die anch nu bei besonderen Teranlasinngen diese teure Gabe darbringen.

bas Sintallsolz entstammt mehreren Arten der diattungen Santalum und Fusanus, beide zur Familie Santalaceare gehörend. Ilie lrattung Santalum besitzt die weitaus grössere Ẅichtigkit: sir besteht alls etwa -o Arten, die über Asien. Anstralien und Poly-

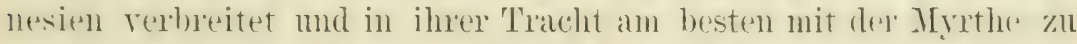
vereledehen sind. Die iestlichste Art ist s. insulare: fie kommt ant den Marefuesasinseln und T'ahiti rol, wo sie Eai genamnt wird.

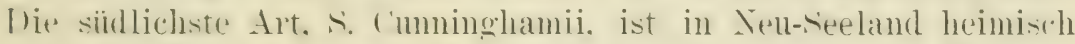
und wird Mairi genannt. Die beiden nördlichsten Arten. S. pirrularium und $x$. Freveinetiamm. kommen unter dem geeneinsanen Camen Lall ala auf den randwichinseln vor. I)ie westlichste Alt ist S. album, heimisch in Vorderindien.

In. Sexman entdeckte auf den Fidschis einen wertvollen

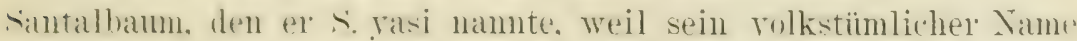

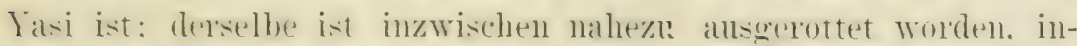

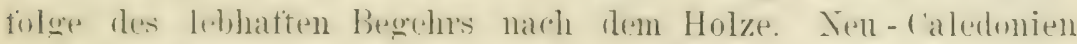

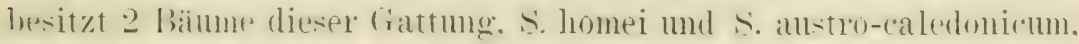

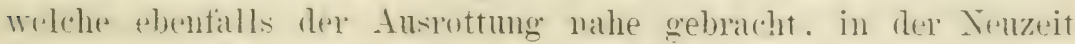

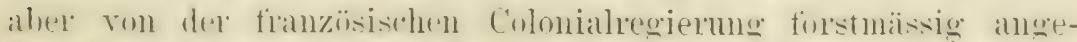

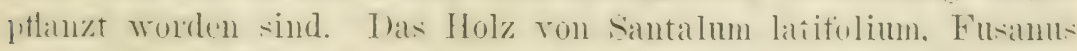

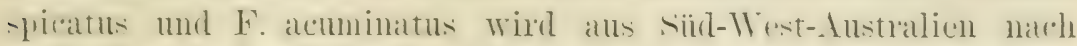

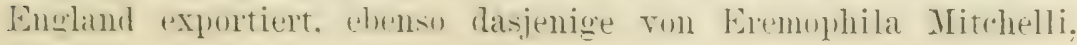




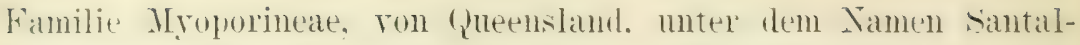
lul\%: allein diese sorten besitzen wenig Geruch und werden num

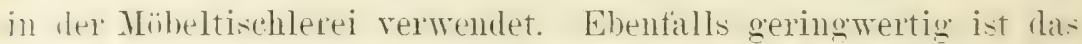
Elutz von $x$. myrtifolium, heimisch in Jara und Foromandel.

C̈her Sansibar kommt ein Santalholz in kleinen Pöstehen in den Handel. das ron Xossi-Bé kommen soll, die botanische (puelle ist $\therefore$ wenig bekannt. wie diejenige eines angeblichen Santalholzes. das ron Venezuela nach Deutschland ausgefiihrt wurde.

Bis zur Mitte des 18. Jahrhunderts war Indien die einzige bezugsplelle für Santalholz, die als damn erfolgende Entdeckmong dieses Artikels auf den Inseln des stillen Ozeans tïhnte zu einem beträchtlichen Handel ron etwas seeräuberischer Situl. Alle schwierigkeiten zwischen den europüischen Kantfahrem nur dan Eingeborenen wurden im Kampfe zum Austrag gebracht. In Menschenverluste in diesem Geschäte waren zu einer Zeit gröser wie in Walfischfang. mit dem es in einem Range als abententerlicher Beruf stand. Der Terkanf bereicherte nur die Hämptlinge: rom Kamehamea, dem Känig ron Hawaii (Sandwichinseln). wird behauptet. er habe un das Jahr 1810 atwa 1 Million Wark jährlich für Santalholz eingenommen. Gegenwärtig sind ant allen hekannteren Inseln des stillen Oceans die Torräte an diesen Artikel nahezu erschïptt. Anstralien machte sich Hoftumg. als Bezugsumelle an die stelle dieser Inselwelt treten zu kïmnen umi 18st stieg der Export sogar anf 2020 Tonnen, hatutsächlich ron Fu-anus acluninatis stammend; allein die Pleise enttänschten. sit

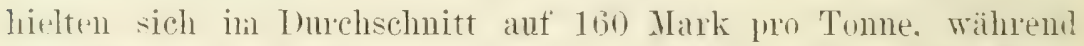
dit besseren Qualitäten Santalholz in China 2 fo his solo Mark die Tonne bringen.

Nicht alles rantalholz wird ror den crötzen rerbrannt. heträblitiche Mrengen werden in den Gewerben rerarbeitet und daraut triindet sich die when ausgesprochene Behauptung. der Handel mit diesem Artikel wiurde wichtig bleiben. anch nitch dem Anssterben der Giitzendiener. In Europa und Toldamerika dient dieses Holz zn Lnxuskästchen, Pultfä̈chern und Rahmen für Insektensammlnngen. in Indien wird es ebenfalls zu Luxuskästchen, ferner zu Fächern mol eingelegten Arbeiten rerwendet. Lnd das santalöl findet eine ancgerlehnte Benutzung als Parfüm: ron seiner Beimischung bleiben nur wenige indische Partümartikel tru. In Form ron Pulver wirs 


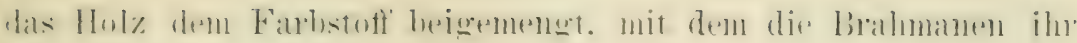
Tastenzeichen herstellen.

In der Nenzeit hat das Santalöl in Europa den Copaira-

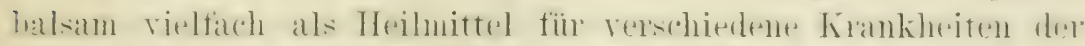

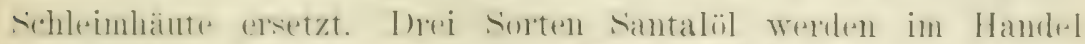

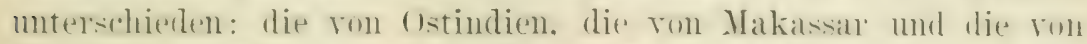

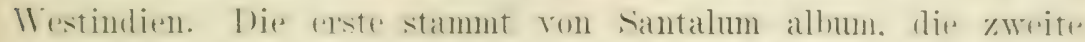

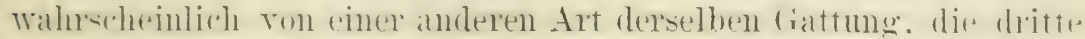

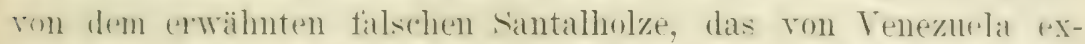

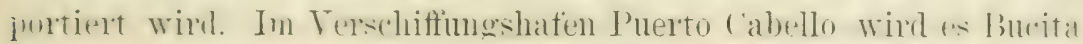
aupitala genannt: der (ieruch des Holzes wie des (ïls ist rollstandig verschieden ron denienigen des echten Santalholzes.

Inat: atherische (i). Welches schwerer ist wie Massel. verleiht mur allein dem sitntallolz seinen Geruch. Es hat siment vitz vorzugsweise im Kornholz und in den grösseren Wurzeln. der splint dere ältereren Bämme und das ganze Holz jungere Bämme i-t

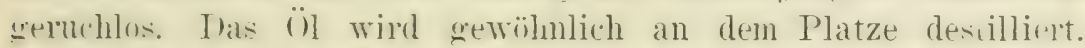
wo dit bänme gefällt werden und zwar alls den spänen mul Wurzeln.

Die indische Forstrerwaltung rechnet ron 1 P'fumd Hol\%

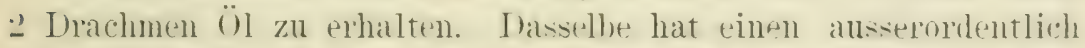
-tarken. durchdringenden Geruch und lässt sich leicht ans dem Holz destillieren. Bombay ist der weitaus wichrigste Ferschiffumg--

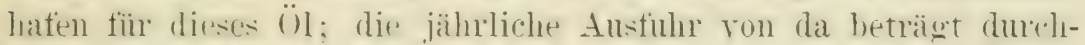

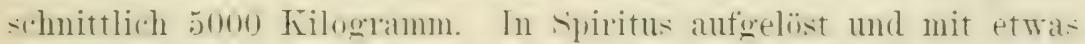
Rosenöl rersetzt. hildet das santaliil das Taschentuchpartiom Extrait de buis de santal. Weil ws sich willig mit Rosenuil vermischt. wird es of zur Fälschung diess kostbaren Artikels benutzt.

Wie in alten Zeiten, ist anch jeizt wieder Indien das writall: wiohtigste Produktionsogebiet des santalholzes und damit ist die hervorlagende Berlentung des weisen santalbaume-

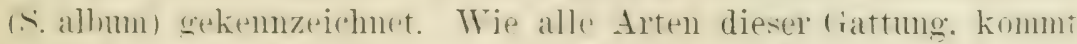

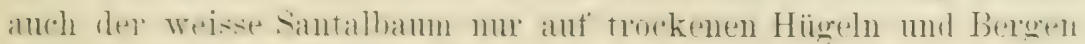

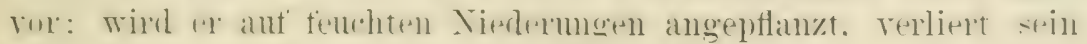
Holz fast jeden Wert.

Geröhnlich erreicht el eine Höhe ron 7 bis 8 Mreter. bei

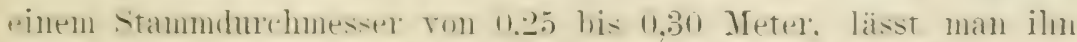

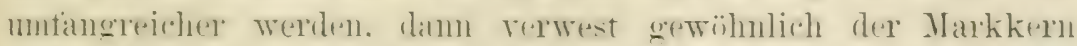

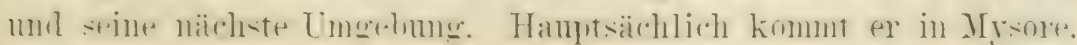


('oimbatore, nïrdlich mul nordwestlich von den Nilgiri, anch weiter instlich in den Distrikten Salem und Arcot ror. wo er ron der Meerescleiche lis zu Erhebungen von 900 Meter wächst. In malarischen Archipel kommt der Batm nur vereinzelt vor.

In Mysure bildet das Santalholz ein Regierungsmonopol. in $\therefore$ fo fern nur bestinmte Beamte Santalbämme fällen und verkanten diurfen. Diese Gerechtsame wurde 1770 von Hyder Ali durch einen Vertrag ant die englisch-ostindische Handelsgesellschaft iibertragen und ist reitdem beibehalten worden. Das Santalholz dieses Distrikts wird über Nangalone in der jährlichen Hö̉ie ron 700 Tonnen. Wert 540000 Mark. verschifft. In der Präsidentschaft Madras besteht kein Monopol in diesem Artikel, allein die Forstverwaltung. gewimnt bei sorgtältiger Schonmg der Torräte eine jührliche Ausbente von 500 bis 600 Tomnen.

Die Fortptlanzung des Santalbaumes kann nur durch Saat auf die daneruden Standorte erfolgen. da die Sämlinge die Terpthanzung nicht rertragen. wahrscheinlich. weil sie ihre Nahrung mittels knotiges Anschwellungen von den Wuzehn anderer Pflanzen s:hmarotzen. (iefiult werden die Bäume wenn sie 20 bis 25 Jahre alt sind. dem um diese Zeit erreichen sie ihre Reife. In Indien findet das Fällen gegen Ende des . Tahres statt. Ine Rinde wiril sofort abgeschält und der Stamm in Blöcke ron etwa 60 Zentimeter Länge gehanen, die für mehrere Monate in die Frde gehettet werden. Inir 'Termiten fressen inzwischen den splint vollständı@ al). lassen aber das wohluiechende Keruholz unberïhrt. Die Blïcke werden num mit dex Axt etwas zugestutzt und in rexchlossmen siedchern der Forstrerwaltumg einige Wochen langsam qetrocknt. es findet dabei eine Germchserfeinermge statt und der Neigme des Holzes zum Reisspn wird vorgebengt. Der Terkanf geschieht auf jährlichen Auktionen, zu der sich Kanfleute ans allen 'Teilen Indiens einfinden. Tor'ler' findet eine sortiestung der Bläkte statt. Je tiefer die Farbe. desto stärker dex (iteruch. mithin un so wertvoller das Holz. T)aher surtieren die

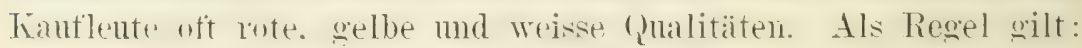
je nälex den Wurzehn. desto tiefer die Farbe und stärker der Germeh. Thaher wird beim Fiallen die Erde vom stamme entfernt.

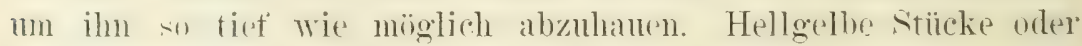
solvhe. Welden noch der weisse splint anhängt, haben weniw Wert. Thiefintll, muss die Farbe sein, besser" noch sie spielt in's 


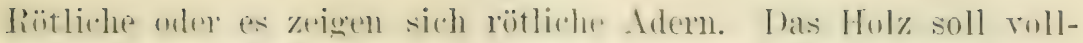

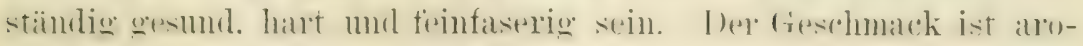
matischbitter, angenehm scharf.

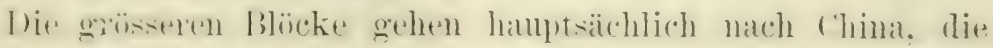
kleineren nach Arabien, die mittleren bleiben in Indien. ('hina

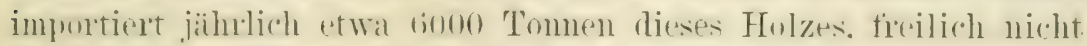

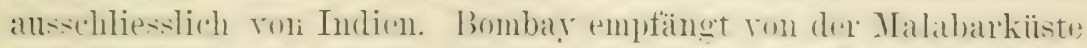
durchschnittlich Fon Tommen dieves Holzes, von walchen es t50 wieder austiihnt.

1). Hunter wies ror mehreren . Jahren nach. dass das simtalholz -ich zum Ersatz des Buchsholzes für die Holzchneidekmst. rigne. Einige Blörke lieferten über 20000 Abrrïrke. whe abgemutzt zu sein. Als das beste Holz für diesen \%werk bezeichnet er dunkelfarliges. etwa 1:2 Zentimeter im Ilurehmestes. das auf felsigem Boden gerrachsen ist.

Zum Schluss sei noch hemerkt. dass im Dentechen meistens

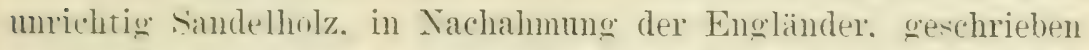
wird. Santal ist der arabische Same tür dieses Holz. a ist. wie when gezeigt wurle. in die sprache der Wissenschatt übergegangen. An der Malabarkinste lebt noch der alte Sanskritname fort: ('han-

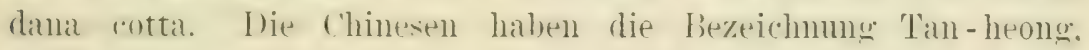
wohlriechendes Holz.

\section{Seiden holz.}

Ënter diesem Yamen kommen zwei schöne luxushüilzer in den Handel. ein westindisches und ein ostindisches. Tha Erstere wird fïr wertroller hetrallet. als seine butani-rhe quelle wird Ferolia guianensis und Maba guimensis angegehen. oftenbar ist man ïhne diesen Plunlt nuh nirht vollständig klar. Vun dem

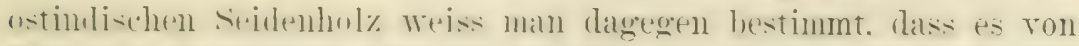

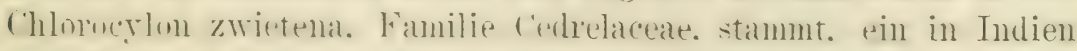

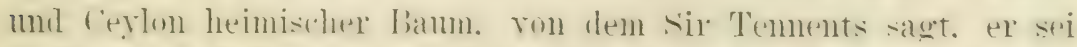

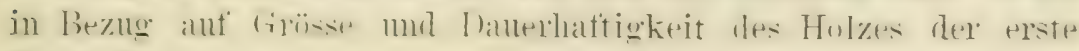
Baum Ceylons.

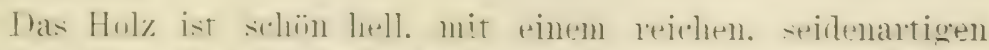
dilanze. manchnal dunkel befleckt oder betupte. Ende des 1s. Tahr-

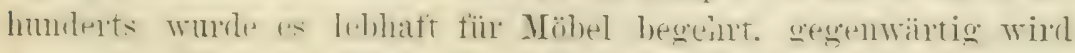

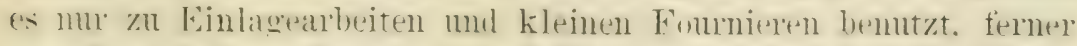

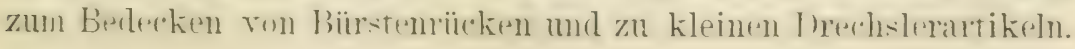


sir l'ements sat in seinem Wreke ïber l'erlon: die reichgetärbten und markierten Blöclie werden zu Mäbeln rerarbeitet, während die gewähnlichen Banzecken dienen. Die Balken and Flure aller. Hätser in den ästlichen Provinzen bestehen ans Seidenholz.

40. 'T'acam a hacaholz.

Die Gattung ('alophyllum. Familie Guttiferae. enthält melnere Alten, welche einen in südasien als Tacamahaca bekannten. hawzigen stoff' liefern, der zum Ränchern dient. Das echte indische Tacamahaca stammt von C. inophyllum. ein sehr grosser; schüner Batum. der oft als ichattenbaum und 1 m seiner weissen. wolnriechenden, tranbenförmigen Blïten willen angeptlanzt wird. Die Blätter sind länglich. stmunf zulanfend: die Frucht ist eine runde Steinfucht rom der Grösse einer Tralmuss und enthält ein fettes Öl. welches benutzt wird.

Diese Art nimmt unter den nuitzlichen VTaldbäumen des malayischen Archipels und der südsecinseln einen hohen Rang ein. Was sehr dauerhatte Holz gleicht in der Textur dem Mahagoni, ist. aber heller.

C. angustifolium. ron den Britisch-Lndiern Pineybaum genannt, kommt auf Penang und den Insehn nahe dex Ostkïste der Bai ron Bengalen ror. Er liefert sehr geschätzte. schöne, crerare Raastangen.

C. calaba, ist der Calababaum Mestindien's, oleichalls ein heliebter schattenbaum. mit weisen. Wuhlriechenden Blüten. Inas Holz wird zu Fässern verarbeitet.

\section{Tanekahaholz.}

I)ie Gattung Phillocladus besteht ans sogemannten selleriebätrigen Fichten. die zu derselhen Abteilung der Coniferen gehören. wie der bekannte europäische Fihenbaum, obgleich ihr Ansehen mo ihre Wohnorte ganz rershieden sind. Bis jetzt kemnt man mu 5 Arten dieser Gattmg. 3 in Nen-seeland. 1 in Tasmanien und 1 in den Gebirgen von Borneo.

Eine wirtschattliche Wichtigkeit lesitzt nur dir nelserelandische Art I'hillocladns trichmmannides. mit den volkstiumlichen Tamen Tanekaha. Dieser Bamn komme nur anf der nördlichen

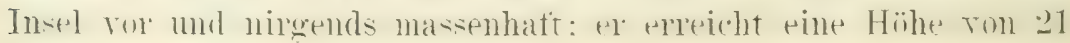




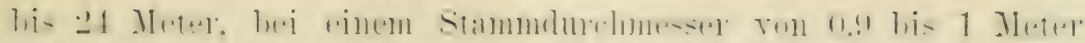

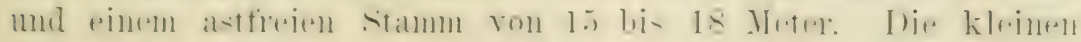

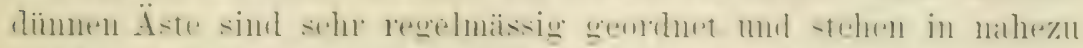

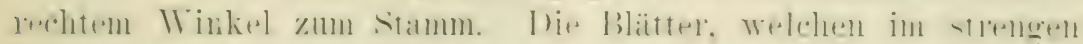

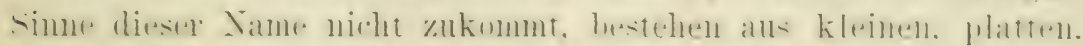

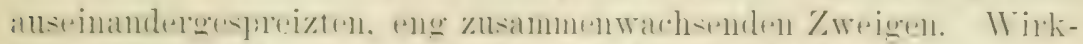

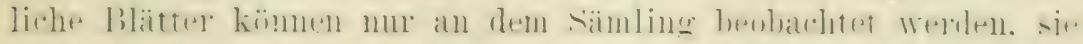

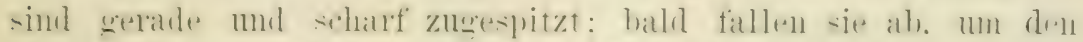

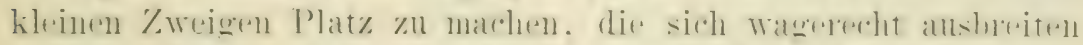

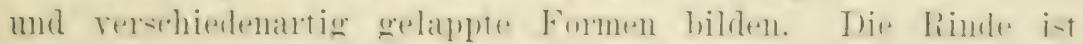
dick, glatt, dunkelbraun.

Das dauerhafte $\mathrm{Holz}$ ist so stark und zäh. dass die Urbe-

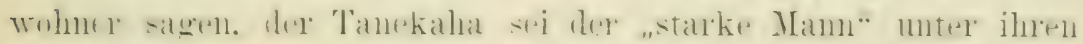

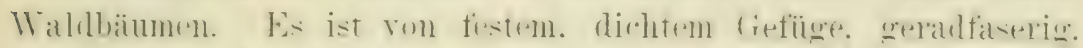

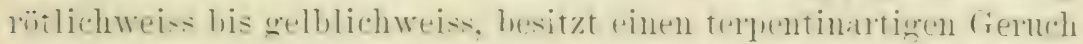

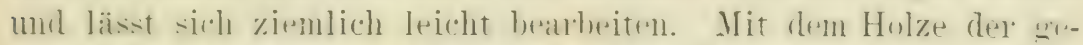

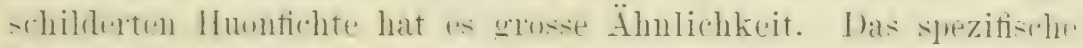

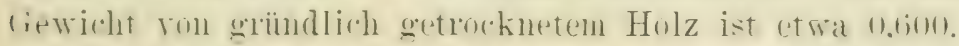

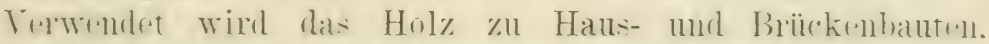

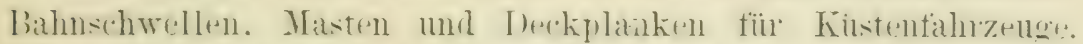

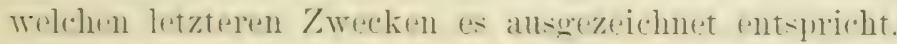

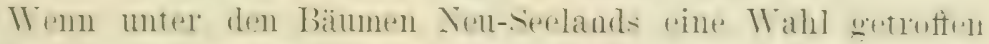

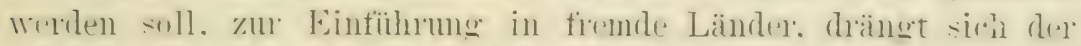

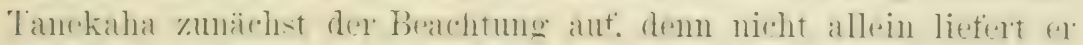

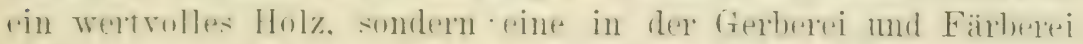

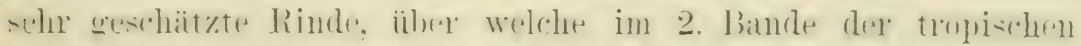

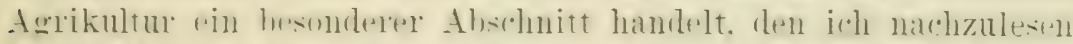

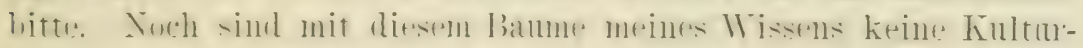

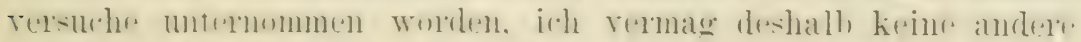

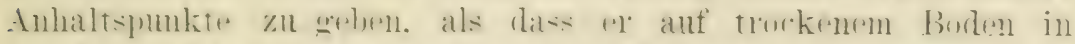

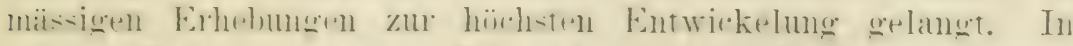

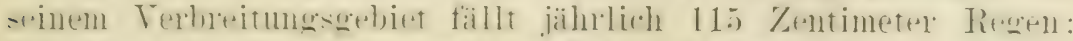

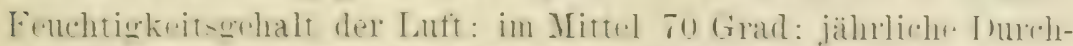

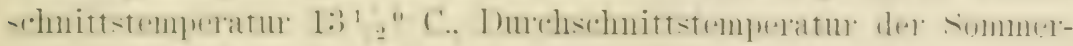
monate $18^{1 / 2}{ }^{\circ} \mathrm{C}$, der 11 intermonate $10^{\circ} \mathrm{C}$.

\section{2. 'T'e a k hol $\mathrm{z}$.}

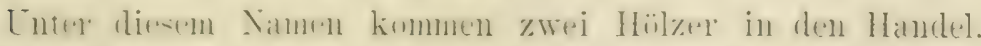

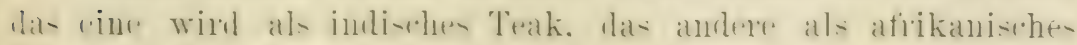
semlor, Wald wirtsobatt. 
Teak beredhet. Das Erstere ist das weitans wichtigere. reine hotanischt (quelle ist Tectona grandis, Familie Terbenacea, rin schuiner stattlicher Baum ron 24 bis 30 Meter, in seltenen Fällen his t5 Neter Höhe. bei einem stammdurchmesser ron 0.80 his 1.20) M[etre. Die sommerorünen Bläter sind oral, im Duchschnitt s) Zentimcter lang. mit rauhen Irüsen besetzt: den weissen. in wlusen Rispen geordneten Blüten folgen 4 zellige Früchte von der Grösse einer Haselmuss.

Das Terbreitmosgebiet dehnt sich rom 8. Grad siidlicher Breite in . Tava bis etwa zum 2:3. (rrad nördlicher Breite in Indien mol Birma. die westliche Grenze liegt mgefähr bei dem $72^{\circ}$ östlicher Länge, unermittelt ist bis jetzt noch die üstliche Grenze, wahrsheinlich liegt sie der Grenze Chinas nahe. Torzugsweise kommt dieser Baum in Erhebungen von boo bis 900 Meter ror, selten wird er tiefer wie 600 Meter angetroffen und wenn er in seinem nördlichsten Tordringen. im Bundelemd. 1200 Meter über den Meeresspiegel steigt. so kommt er ïber ein zwergiges Trachstum nicht hinans. Gewöhnlich tritt er in Gruplen anf. was der Ansbente sehr förderlich ist.

In . Tava hat die Colonialregierung eine rorzugswesse mit 'leakbämmen bestandene Waldtläche von etwa 700 Hektar monter Fontrolle genommen und das Fällen und Vermessen der Bäume sorefiltign geregelt. Ansserdem hat sie für die Amplanzung ron 'Thakwäldern Sorge getragen. In Indien umfassen die reservierten Tälder wirhtige Bestände dieses Bammes. die ausgedehnt zu vermehren. sich die Forstrerwaltung seit ihrem Bestehen angelegen sein liess. Am Beyporiflus in Malabar hat sie pinen Teakwald angelegt. del bereits über 2 Millionen Bämme umfasst und den sie jedes Jahr un etwa 40 Hektar vergrössem lässt.

In riam ist in nenerer Zeit rin beträchtlicher Reichtum an Teakholz recht wuter (Qualität nachgewiesen worden. allein die whohtigste Bozugsulelle ist und bleibt jedentalls ant lange Zeit Birna. zumal das Königreich dieses Samens num unter die Heresohate der indischen coloniahregiermo oebracht ist, die mit allen

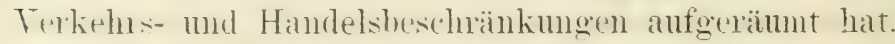

Lier Ansbente der birmanischen 'Teakbestande ist das garosartige Flussnet\% des Landes sehr förderlich, die wichtigsten Trasserwege tï̈ dieses (ieschät sind der Irrawaddy. Salwin mul 'Thongyin. 


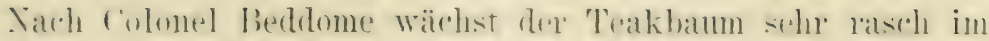
Vereledehe mit der kiche. Dieser Gewihrsmam behauptet, in den

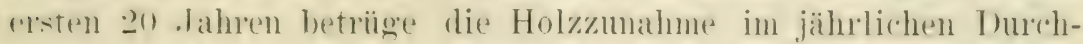

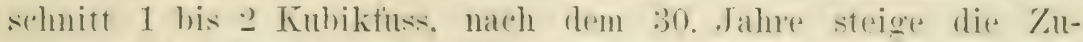

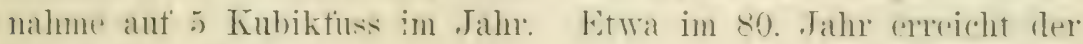
Baum seine Reife.

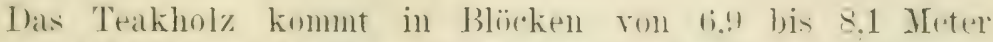

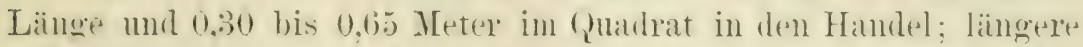
Blärke sind selten. obeleich sie unverhältnismäsige temer boahlt

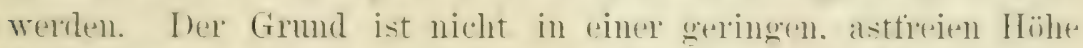
der Baime zu suchen. sondern in der Alneigmg dex birmanischen

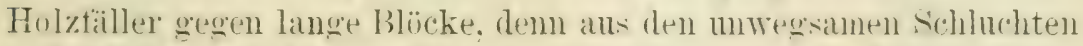
mol Thälern wird das Holz ron Elephanten nadh dem nächsten Tastrlauf geschleift. Es ist klar, dass dieser urwähosige 'Transjort der Bbïcke um so schwieriger ist, je länger die Iblïche sind mol dirses Verhältnis gestaltet sich nicht viel hesser in der Fliis-sed atf den gewundenen. in natiorlichem Zustand rerbliebenen Tasserläufen.

In Birma, Cochin. Travancone mod einigen anderen ciegenden werken die Teakhäume :) Jahre vor dem Fällen bis anf das Kermholz geringelt, um sie zu tiiten. eine Absicht, die schon natch wenigen Tagen erreicht ist. Iner stamm trocknet also anf dem

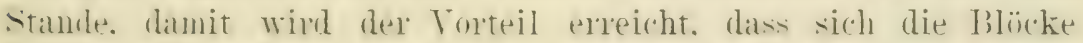
leichter fortechleifen lasicen und in Wasser schwimment. demn frisch gefält. hat dis Hol\% eine sperifische sichweres vol mindestens

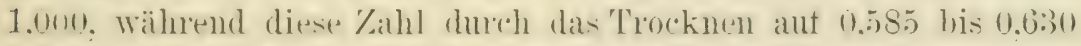
sinkt. Liess Gepflogenheit enthehrt demmach nicht guter Begrimdnng. trotzdem wird sie vom Fachkemern als verwertich Jereichnet. Las Holz trockene zu schmell. dahed die häufigen

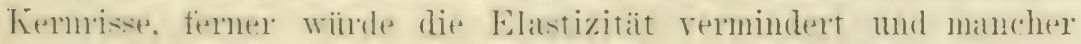
Wertrolle Batum zersplittere heim Fallen. In den Wäldern von

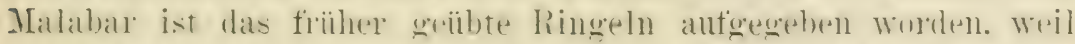

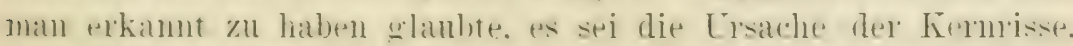

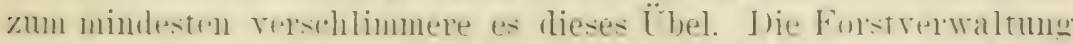

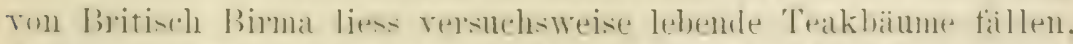

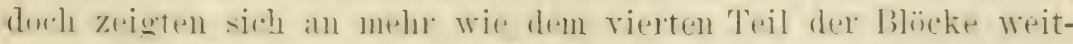

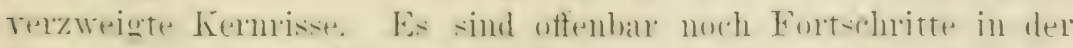
Behandlung des Teakholzes zu machen. 


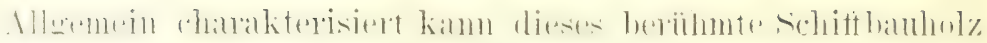
folgendermassen werden: seine Farbe wechselt ron strohgelb zu

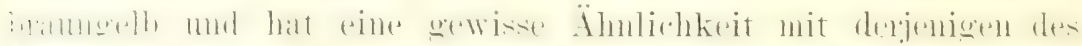

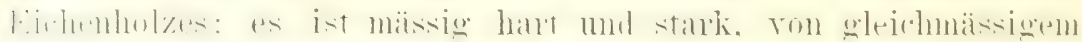

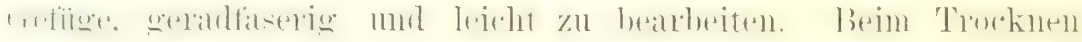
schrumptt es sehr we nig und reisst nicht von aussen nach innen. Dagegen reisst es, wenn beim Einschlagen ron Bolzen keine

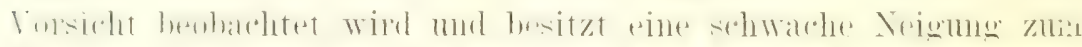

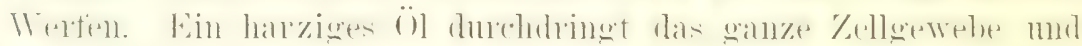
-ickert oft in die Kermrisse, wo es sich so rerhärtet, dass es kein

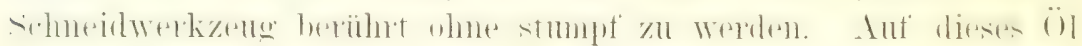

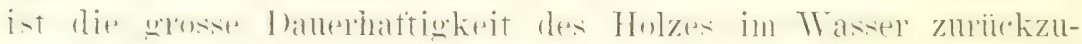
fïhren, ebenso die Verhiitung des Rostes von Eisen. welches in

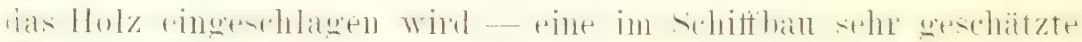

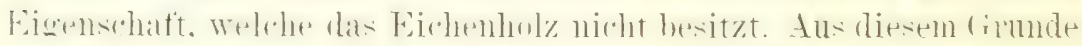
spielt das 'Teakholz eine so bedentende Rolle im Ban ron Panzerschiffen.

Hören wir, was ein dentscher Forstmann, Forstrat Nörd-

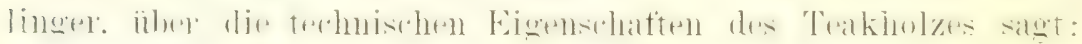

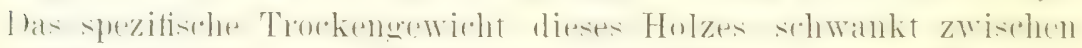

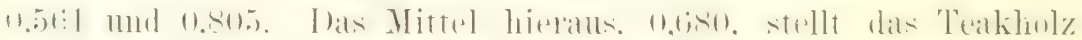

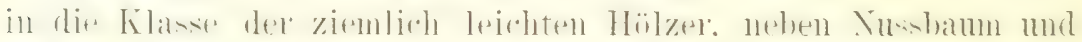

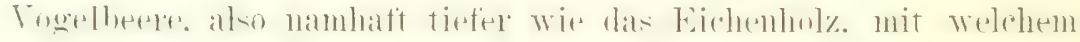
es in Bezug auf seine Vermendbarkeit wetteifert. Die an einer

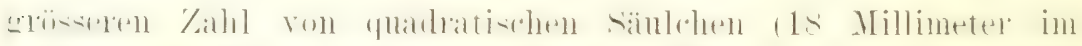

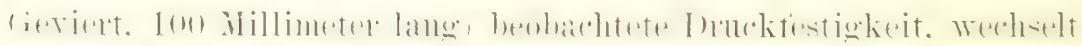
ron 4.47 bis 7,16 Kilogramm auf 1 (Quadratmillimeter, beträgt also im Mittel 5,81 Kilogramm, welche Ziffer sich als Durchschnittszahl einer grösseren Tersuchsreihe auf 5.87 Kilogramm indert. Die Zugfestigkeit konnte mu an 2 stibchen beobachtet werden, von denen nur eins tadellos mo zwar von gelber Farbe, mit glänzendem, fast kalkfreiem Porenimnern war. Dasselbe riss

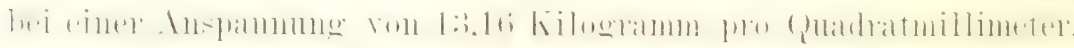
l)ie ziemlich ausführlichen Druckproben weisen das Steigen der

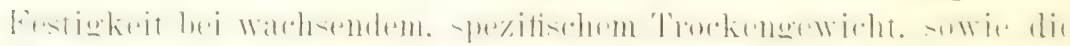

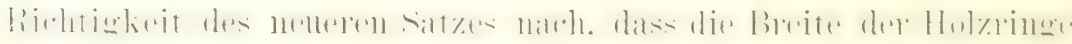

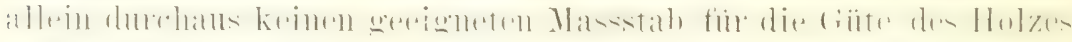
bildet. Yach dem beobachteren Quellen des Holzes und unter der Torausetzung, dass das schumpfen diesem gleich sei. reit Nörd- 


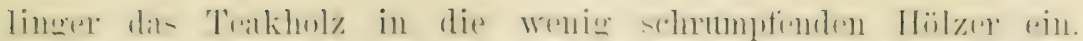

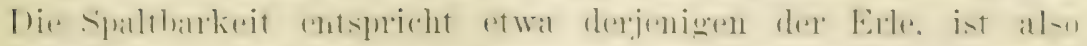

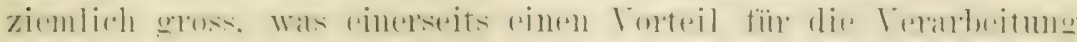

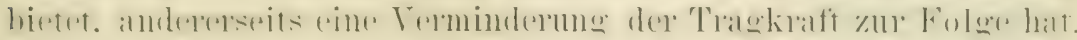

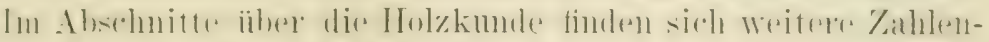

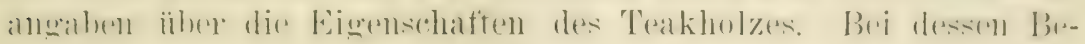

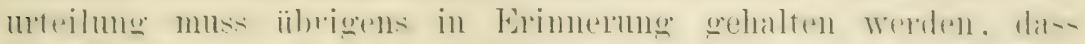

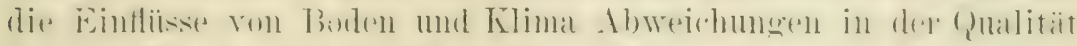

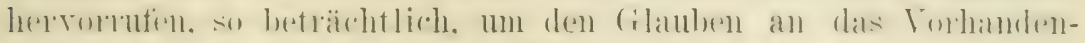

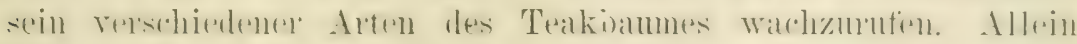
his jetzt haben die Butaniker nur eine Alt natehweisen kïmen.

In widhtigsten l'roduktionsland. in Birmal. wirl dats Holy.

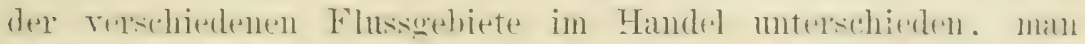
spricht ron Thongyin-, Salwin-, Karani-, Attaran-, Latinghur- mul Irrawablyteak. Alle weichell etwas in Farbes. firfïger mul Schrere ab.

Jis Thongrin- mol sillwinholz ist gelhlichbram, von gleichl-

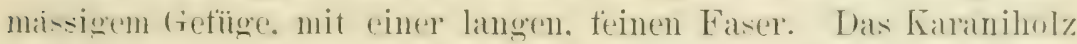

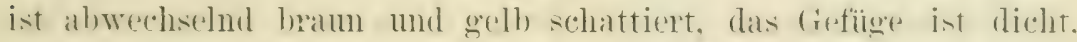

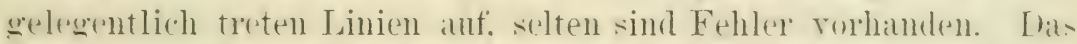
Attananteak kommt in kïrzeren, aber ebenso dicken Bläcken wite dir ïhrigen surten ror: das Holz ist hrämlirh. hatrt und geleirlet

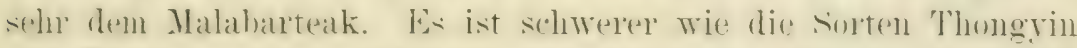

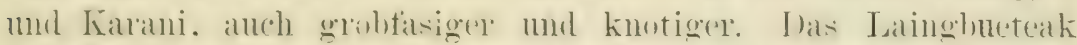

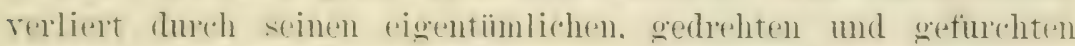
Wuchs sehn an Wert. In Folge dieser Bildung kam alls einem dicken stamm nu ein dïmer, gerader Block wehaucen worden, der ïbredies geringwertig ist. weil es nötig war, die Faserm zu

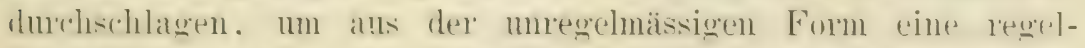

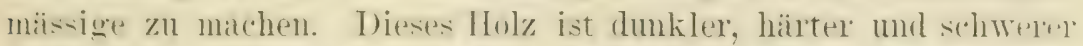

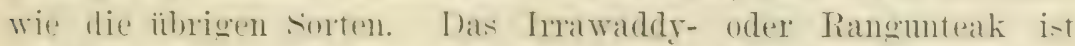

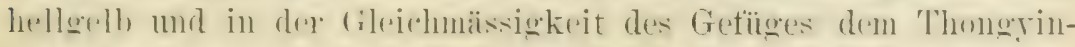

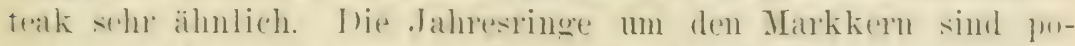

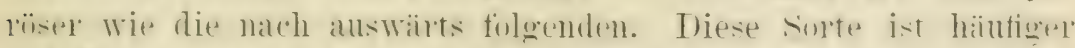

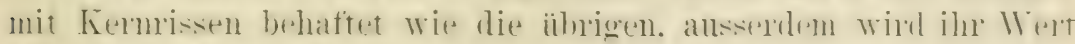

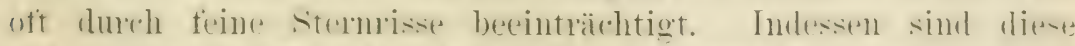

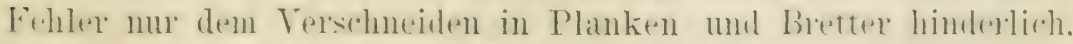

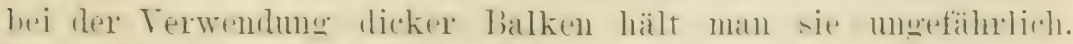

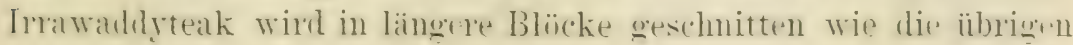




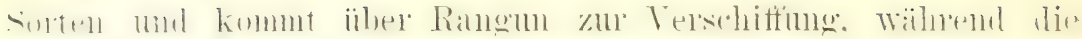
letzteren iiber Julmein zur Ausfuhr kommen.

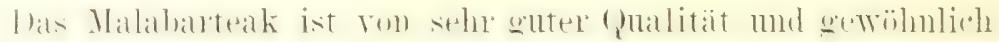
dunkler, dichter, schwerer, öreicher und etwas stärker wie das Birmateak.

Eine Schattenseite der ersteren Sorte bilden die häufigen. langen Kelnrisse, denen vielleicht durch ein besseres Trocken-

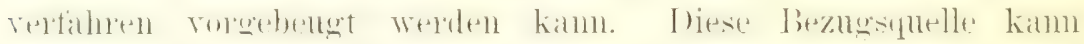
iibrigens so lange als erschöpft gelten, bis die jungen Wälder anterearehen sind, bavateak steht dem Malabarteak nahe: es int

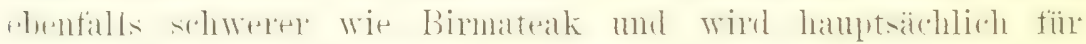
Planken geeignet gehalten wie für die Schiffteile unter dem Tasserspiegel.

Es wird so riel rom Ruhme und so wenig von den Fehlern des 'Teakholzes gesprochen! Tenig bekannt ist und der scharf'

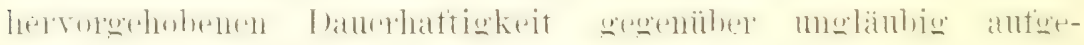
nommen wird, dass die Teakbảume häufig vor ihrer Reife am Markkern hohl zu werden beginnen; die Zahl der mit diesem Fehler behafteten Blöcke, welche die Flösser nach den Ver-

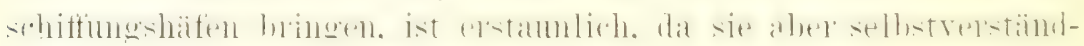

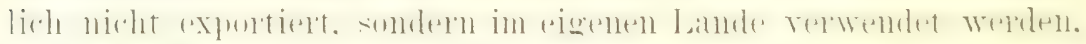

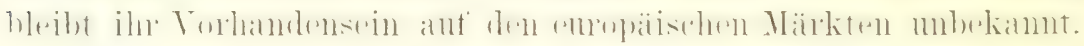

Wie schon exwähnt, treten Kermisse im 'Teakholz aller Sorten riemlich hänfig auf, sie hindern allerdings nicht die

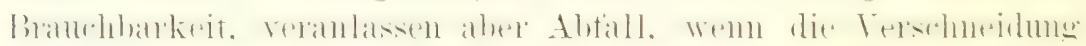
zn Planken stattfindet oder' sie schwächen die 'Tragkraft der Balken, welche aus den betreffenden Blöcken hervorgehen.

Manche 'Teakblöcke sind auf der Oberfläche wumstichig mach allen Richtungen hin. ein Zustand, der sich auf den ersten Blick durch ein mattes. mürbes Aussehen oftenbart. Das Holz ist in der Regel durchaus brỉchig, es ist deshalb nur zu unter-

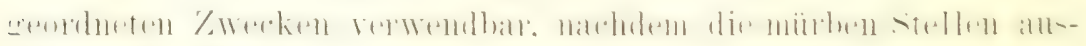
gehanen wurden.

Trotz dieser Fehler gilt 'Teakholz als das beste Schiff'banholz

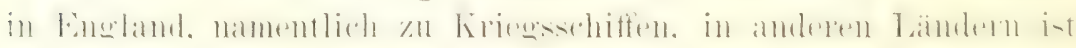
man zurückhaltender mit der Anerkemmug oder doch mit der

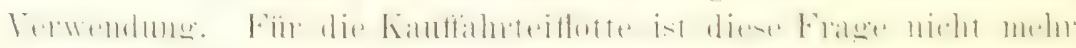

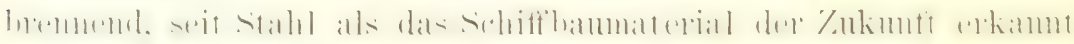
ist, dagegen ist sic vorläufig noch ron hohem Interesse für den 


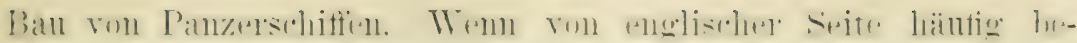

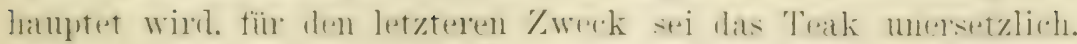

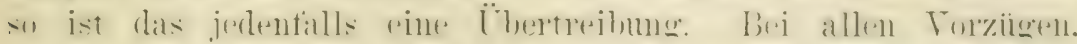

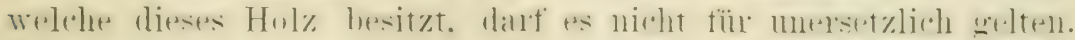

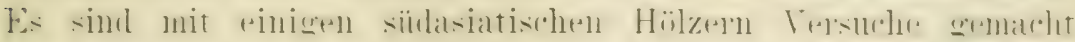

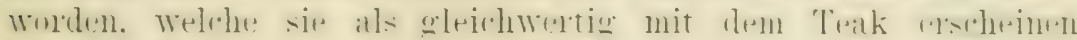

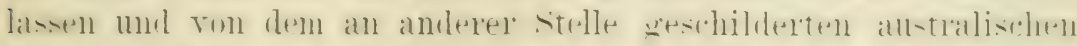

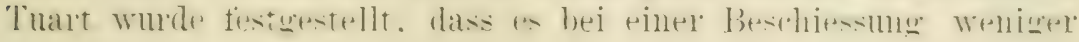
zersplittert wie Teak.

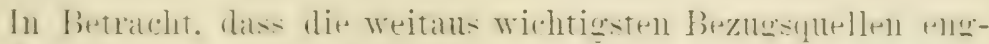

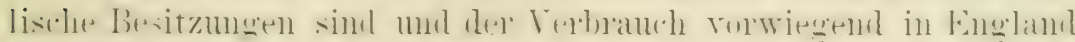

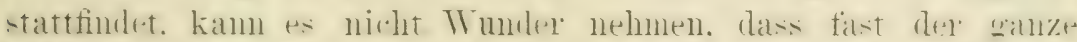

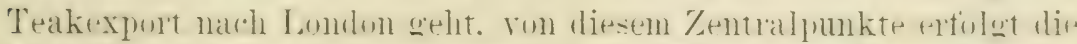

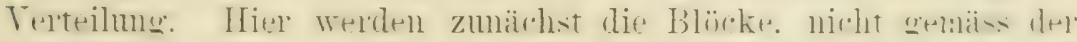

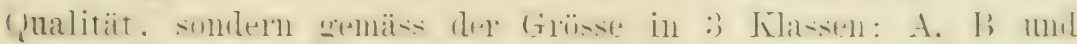

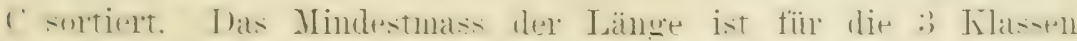

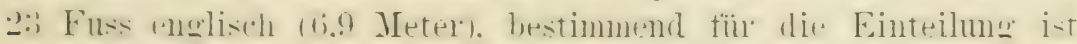

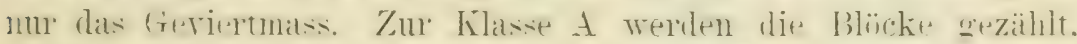

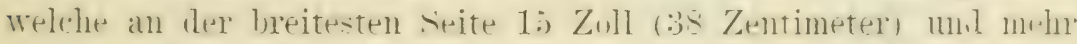

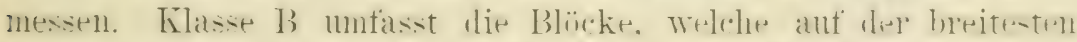

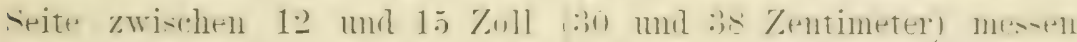

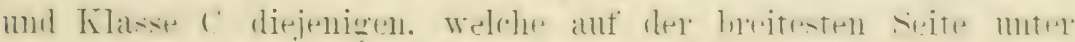
12 Zoll (30 Zentimeter) messen.

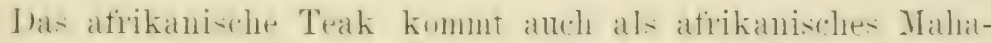

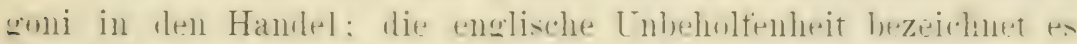

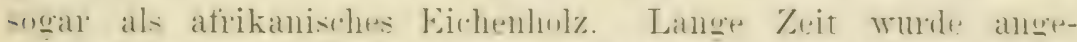

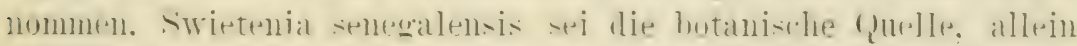
eregenwartig wird mit bestimmtiest loldteldia africand. Fanilie

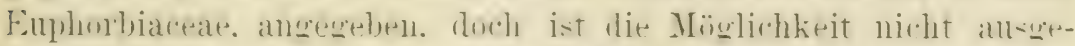

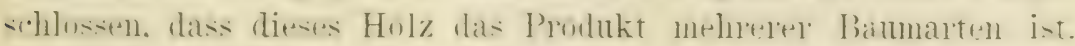

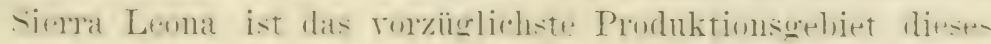

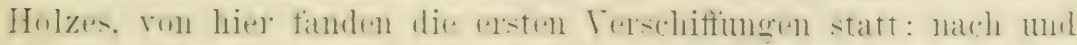

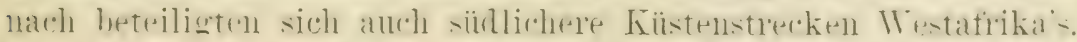

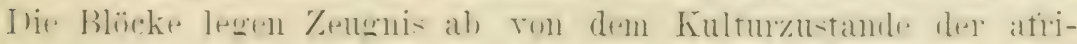

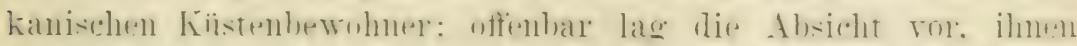

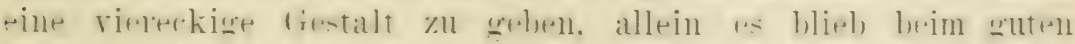

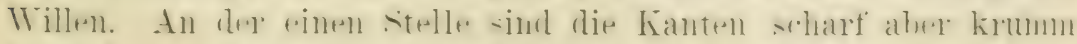

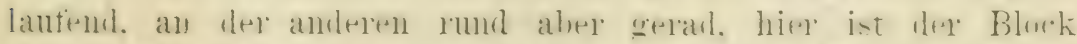

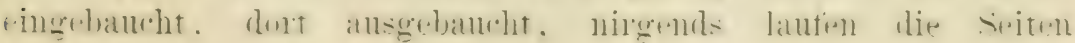




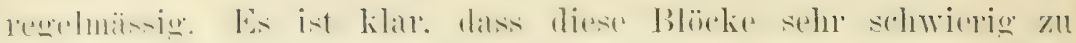

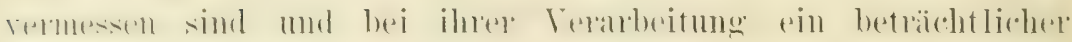

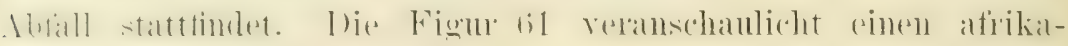
nischen 'l'eakblock.

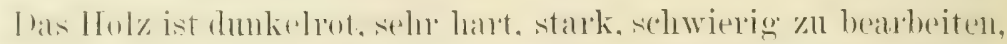
nanentlich zu sualten. Es ist fein- und dichtfaserig nut he-

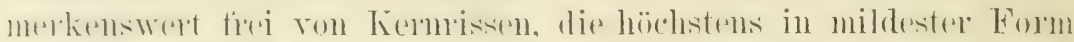
anftreten. Der Markkern ist kamm arkemntlich, die ihn $1 \mathrm{~m}$

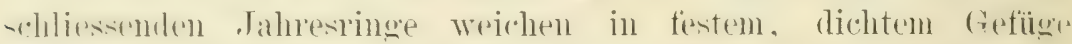

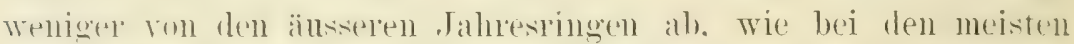

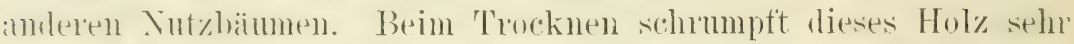
wenig. wirft sich selten und ist sehr danerhaft, selbst dem Wetter

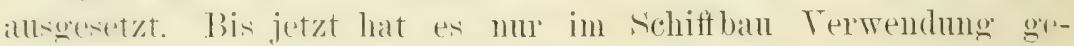
funden. ob es anch für andere $/$ werke vorteilhaft bemutzt werden kann, bleibt eine offene Frage.

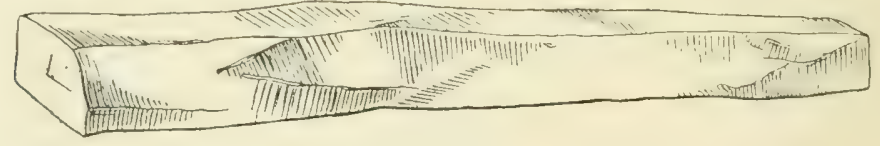

Figur 61.

Thore andere Eigenschatten sind in den 'Tabellen in Alschnitt ïber die Holzkunde Zahlenangaben zu finden.

43. 'I' 0 o n h o l z.

Thitkado und rotes Cedernholz sind Gleichnamen dieses indischen Holzes, dessen botanische Quelle Cedrela toona ist. Es ist hellrötlich. guradfaserig, mïssig hart md leicht zu bearbeiten. Fïr Ifodelle ist es nicht weich genum, allein für andere Zwech kann es als Ersatz des westindischen Cedernholzes dienen. Dir Blöcke sind 4 bis 12 Meter lang und messen 0.25 bis 0,60 Meter im Geviert: nirht selten sind sie mit Kermissen behaftet umb wem sie nicht rorsichtig getrocknet wurden, ist ihre Obertläche mit vielen kleinen Rissen bedeckt.

Iats Toomholz ist mehrfach in kleinen Versuchssendungen in Eurona cingetüht worden, scheint aber keinen rechten Anklane gefunden zu haben. Die indische Forstrerwaltung hat ïbrigen, den 'Tombanm in die Kulturwälder anfgrenommen. muss also ron dem Werte seines Holzes eine gute Meinung haben. 


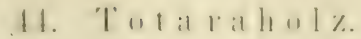

In der nördlichen Insel Veu-scelands kommt in mässiger

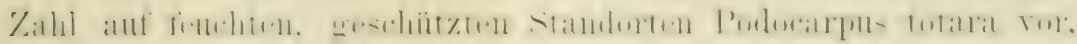

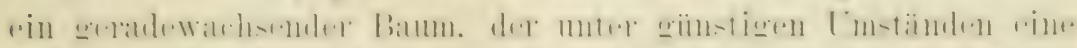

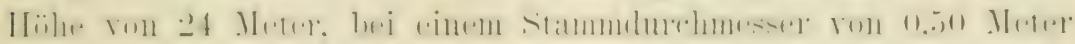

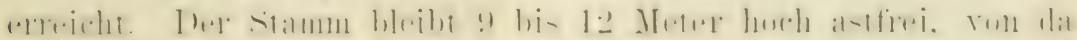
ab breiten sich die Äste nahezu wagerecht ans. Die dunkel-

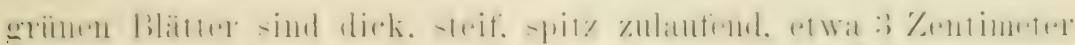
lang und $1 / 2$ Zentimeter breit. Die Rinde ist rot, faserig mor lüst sich in langen Streifen ab.

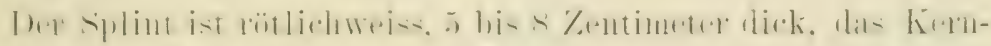
hol\% hat eine entschieden rote Farbe. es ist dicht. fein- und

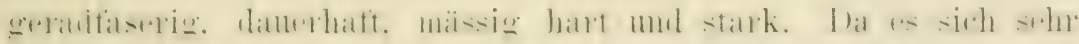

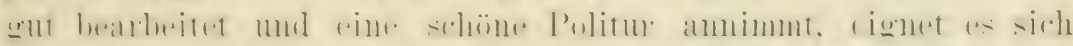

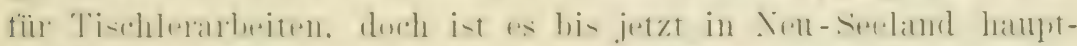

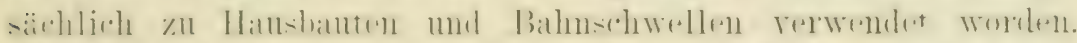

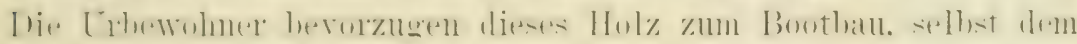
Kamiholz gegenïber.

Das spezifische 'Trockengewicht ist ungefahr 0,600 .

$$
\text { fi. } 11 \text { a } 11 \text { a l a } 11+1 \%
$$

Enter den in der Nenzeit ron Guiana nach Europa rer-

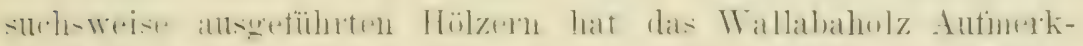

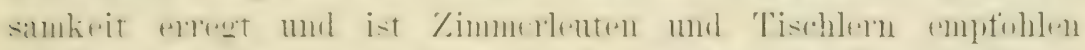

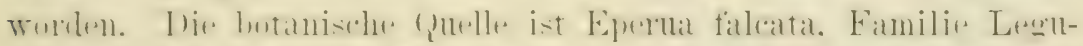

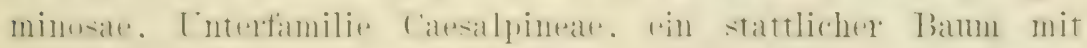

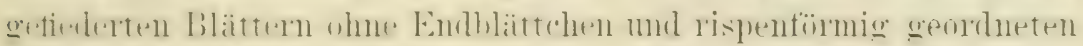

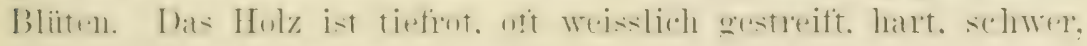
glämzend, harzig und sehr danerhaft.

\section{6. $\%$ e b r a ho $1 \%$}

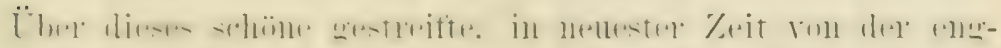

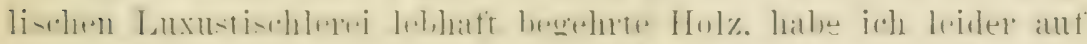

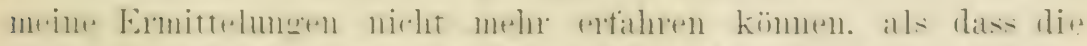

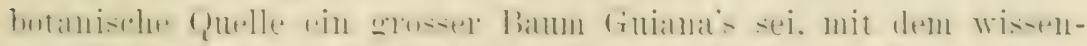

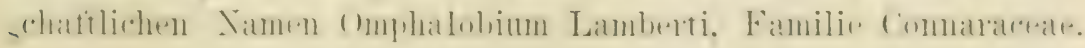




\section{Zedrach hol $\mathrm{z}$.}

Inter vielen rolkstïmlichen Namen ist in tropischen und halbtropischen Ländern ein Zier- und sutzbaum rerbreitet. den die Wissenschaft Melia azederach, Familie Meliaceae. nemnt, el ist also ein Familiengenosse des Mahagonibames. Melia namuten die alten Griechen die Esche, Azederach ist ein arabischer Tame, daraus lässt sich seine Heimat folgern: das siddöstliche Asien. Manche wollen sie nach Florida verlegen, weil der Banm dort. wild vorkommt. allein er ist jedenfalls nur rerwildert. In Flurida fiihrt er den Namen Pride of India, in englischen Sprachgebiet Thestindiens wird er Beadtree. Holytree. Chinabeny mol False sycamore. in einigen Gegenden des spanischen Amerika's Arbor sancta genannt.

Selten wird er höher wie 15 Meter. bei einem Stammdurchmesser ron 0.50 Meter. Terhälnismässig sehr breit ist seine dichte, schön belanbte Krone, die ihn zu einem beliebten schattenbaume macht. Die Blätter sind gross, dunkelgrim. doppeltgefiedcrt, bestehend ans glatten, spitzen, gezahnten Blätchen. Es nird begreiflich sein, dass sie ein anmutiges, elegantes Kronendach bilden. Wem der Winter naht, wechseln sie die Farbe und fallen ab. sobld nur der leichteste Frost anftritt. Die blanen sehr mohlriechenden Blüten erinnern in ihrer Gestalt stark an die Zirenen: sie werden von rtuden. gelblichen, kirschengrossen Beerenfïichten gefolgt. Das Mark ist süsslich und bildet ein Leckerbissen für viele Tögel. der Steinkern enthält rinen samen in jeder seiner 5 Zellen.

I) Thüchln gelten als ein gutes Wrummittel und der ganze Baum hat den Ruf den Insekten widerwätig zu sein; er wird deshalb oft in die Xähe ron ställen geptlanzt, un die Fliegen abzuhalten und gleichzeitig damit die Pferde die abgefallenen Früchte fressen kömnen, Telche, gleich den Wuzeln. die Eingeweidewiumer vertreiben sollen. Fruchtbäume, abwechselnd mit Zedrachbäumen gepflanzt. lleiben von schädlichen Insekten verschont, wie behauptet wird. Ferner sollen die Tnsekten getrocknetu Früchte nicht angreifen, wenn einige Zedrachbläter mit rerpackt werden. Die Fruchtsteine werden im spanischen Amerikia zu Rosenkränzen henutz. daher der Name Arbor sancta. heiliger Bamm. I) samen enthalten ein (i). das ansgepresst zur Beleuchtung und anderen Zwecken verwendet werden kam. 


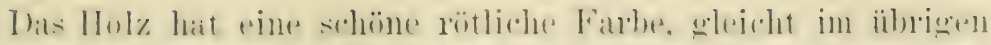

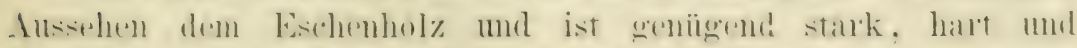

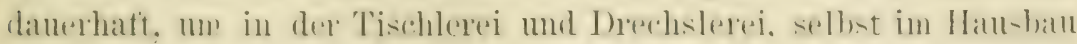

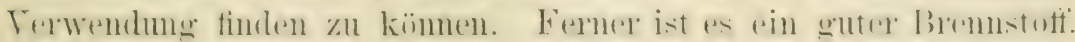

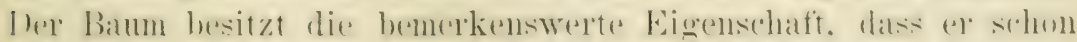
in frïher Jugend den Splint in Kernholz verwandelt.

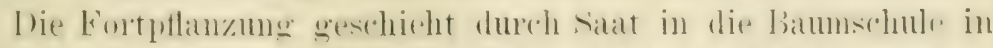

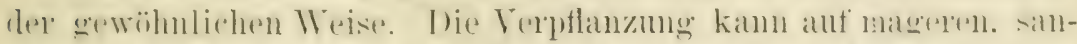

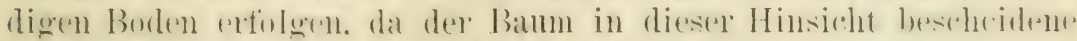

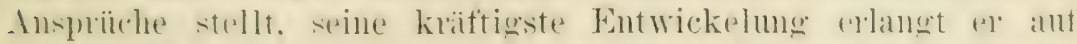

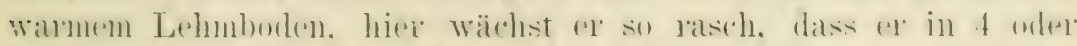
5 Jahren eine Höhe ron 4 bis 4,5 Meter ereicht.

\section{Ced e r n h ̈̈ lzer.}

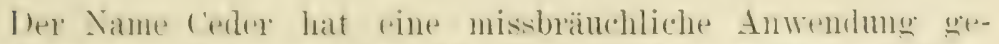

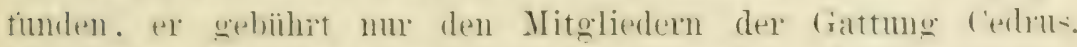
Familie coniferae: wahrscheinlich entstamme ex dem arahishen Kedr $=$ Wert oder Kedrat $=$ stark.

Die berühnteste, gregenwärtig aber keineswens wirtschatilials wiehtigste Art, ist ledrus Libani. die ceder des Libanmon. Welde

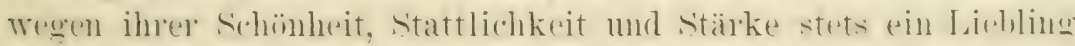

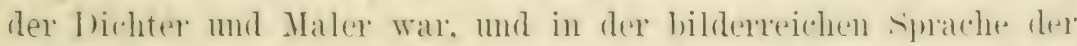
Bibel oft als Simubild der Starke und Langlebigkeit angeführt

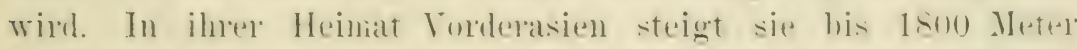
ins Gebirge, aber nirgends wird sie höher wie 2.) Meter atefmilen.

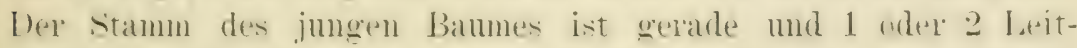
zweige ragen iiber das andere frezweige hinalls. In spaterent Alter Watchen dir wheren Äste durcheinander. wodureh die home klumpig wird.

Zahlreiche $\ddot{A}$ ste breiten sirh waterecht rom stammer alls.

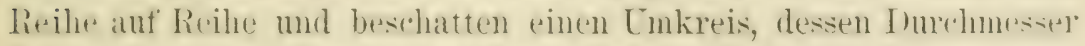

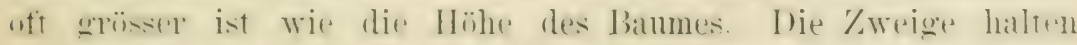
dieselle Richtung ein wie die Äste und die Belaubung steht sthe

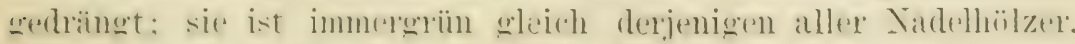
die Läredie atlsgenommen. Die Blätter werden in ferlem Frïhjahn Prnemert. sir fallen aher sn allmählich ab. dasi die belaubung

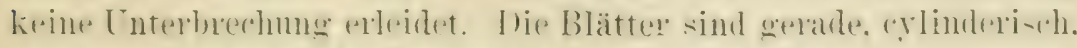

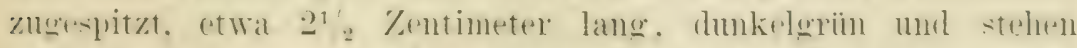

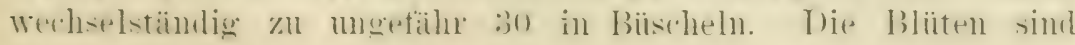


rinhä̈nis. die Fruchtzapfen sitzen an den oberen Seiten der Zweigr. -ir sind cefladit an den Enden, 10 bis 12 Zentimeter lang und 5 Zentimeter dick; sie reifen im zweiten Jahre und schwitzen inzwishen riel Harz aus. Die schuplen sind rötlich und fest anfrindnder gepresst, die Samen hesitzen lange Flügel. Die ITnzel ist sehr stark und rerzweigt sich im weiten Umkreise.

In sandigen Lehmboden erreicht diese c'mler; wie die ganze Gattung, ihre höchste Entwickelung:

Die friiheren bedentenden Cedernwaldungen des Libanon sind bis ant Reste verohwunden. von welchen die bekamteste Gruppe unter -taitlichen schutz gestellt wurde. Dieselhe befindet sich in einer Finsattelung anf dem Jebel-el-Arz, wtwa 25 Kilometer von del sere mud hesteht alls 12 alten Bämmen. inmitten tog jungen. Tip $\therefore$ dicksten haben einen Tmfang ron 18.9: 14.7 und 12.6 Meter.

Las Holz ist wohlriechend, duftet aber nicht so stark wit: ras rote Cedernholz rom Nordamerika. Es ist rötlichweiss. Ieicht.

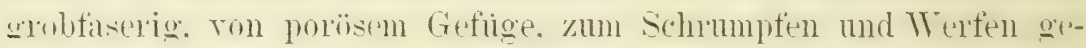
neigt. Als Bremnstoff ist es sehr geringmertig. es rerbremnt rasch mit wenig Wämeentwirkelung. Das Holz ans den ciebirgen ist twas dichter ma teines wie dasjenige ans den Ebenen, allein wine vorteilhafte Terwendharkeit ist ihm nicht ratchzurihmen. Dat ist die Crsache. Wartum diese Ceelel nu als Zierbanm angephlanzt wird. und das geschieht wohl nur wegen ihrer ans dem Altertum herrïhrenden Berïhmtheit.

End dise Berïhntheit steht ant sohwachen Füssen. Voncedernlwolz ist zwar scholl alls sehr frïher Zeit in der Bibel die Rede, allein diecol Xame a alt so wenig dem Holze eines bestimmten Batumes wir linte. Beispielsweise bezeichnen die Araber mit Alz (Eres ist

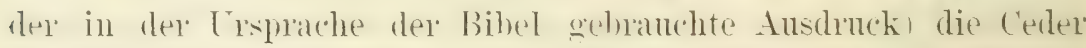
de: Libanon. die Fichte mod den Wathhohterherstrauch. I'linius

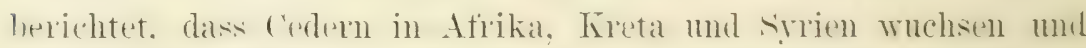
iln Holz muzerstimbar war. Weshalb es zur Herstellung rom Götzen-

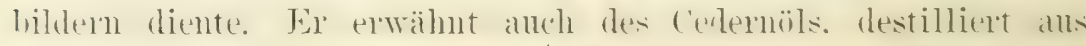

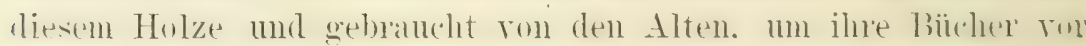
Juttell und sehimmel zu bewahren. Papyrtsiollen, mit diesem (i) ringerieben. wurden Cedrati libri gemannt. Ans diesen Angahen

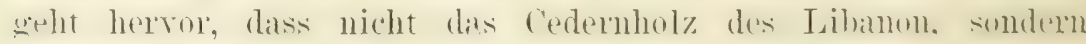
Wahrseheinlich das Holz rom Warhholderbäument gement war. 


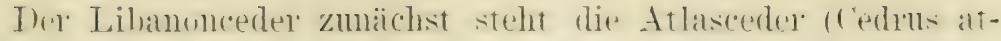

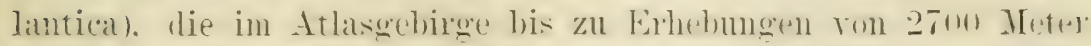
rorkomme; ihre Bläter sind kïrzer und stehen dicher wie dirjenigen der Ersteren; ihr Holz soll härter sein. Anch dieste trt hat die Weltwandermen als Zierbanm angetreten, in wirtechattlicher Hinsicht besitzt sie nur eine beschnänkte ärliche Bedlemtung immerhalh ihres Terbreitmosgebietes. Für die tropisolete Forstkultur von Wichtigkeit ist nur die dritte Art: Cerdens Dendoral.

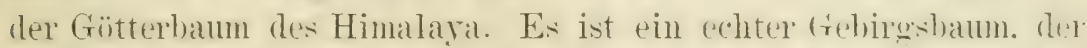
seine kraftigste Entwickelung ron Xepal his Kaschnir in Firhelumgen ron 1600 bis 2400 Meter elreicht mol selbst bis :3bu Meter steigt. Er erreicht eine Höhe vom 30 Meter. bei einem astfreien stamm ron 18 his 21 Meter. Die Blätter sind sraulirhgriin und diunn. die Zweige sind schlanker wie diejenigen der beiden anderen Arten.

Nicht allein als Zierbam hat die Deodora eine lebhatte Ibrachturge gefunden, schon ans dem Grunde. weil sie klimaluäter i-t wie ihre beiden schwesterarten. sondern auch als Tildbaum. Tin der indischen Forstrerwaltung wird sie als eine der wertrollsten Bämme Nordindiens betrachtet, und spielt in Folge desien pint

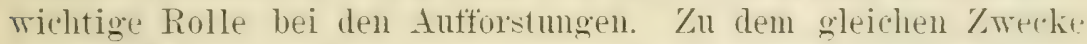
ist er in Anstralien eingefüht worden, mit welchem Erfolge. heiht abzuwarten. Das Holz ist rötlichweiss, dicht. langfaserig. mäsigg hart und schwer. wohlriechend. harzreich, sehr danerhatt. namentlich im Nasser. mol lässt sich ziemlich leicht bearbeiten. Es ist. oh mit Recht odel Lurecht, sei dahin gestellt. das Teakholz duHimalaya genamnt worden. Terwendmo tindet es im Hans- mol Brïckenbau, zu Wagnelarbeit:n und Bahnschwellen: seine Bremqualitait wird gelobt. Auch in der Tischlerei wird es benutzt. in Fällen, wo sein Harzreichtum kein Hindernis bietet. In schul,fachern alls diesem Holze werden Pelze und Wollenstoffe anflu-

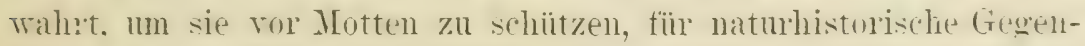

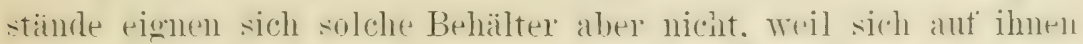
nach und nach eine Kinste aus dem in steter Verdumstung bleibenden harzigen Öle bilden wiirde.

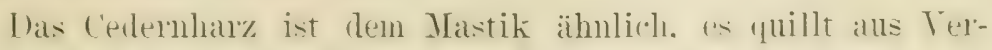

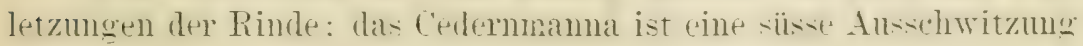
der Zweige. 
IIir oben angedentet, ist der Name ceder anf Bäume übertracen worden, denen er nicht gebührt. In Nordamerika werden jed. Thuya, jeder Wachholder. sowie drei Arten Chamaecyparis. rine Art Libocedrus und verschiedene Cypressen Ceder genamnt. Init wirtschattlich wichtigen dieser Bäme sind an anderer Stelle geschildert.

Die japanische Ceder (Cryptomeria japonica) steht den (yfresere sehr nahe; ihx Holz gilt fïr sehr danerhaft. In Spanien werden Juniperus thurifera und J. oxycedrus, also zwei Wachholderarten. ('eder genannt. Ans dem Holze der Letzteren schnitzten die alten Griechen Götzenhilder, das ans ihm destillierte (j) (Cadeöl) wilt als ein Heilmittel für Hautkrankheiten und als ein Abrehnmittel tïr Insekten. Icica altissima, Familie Amyridaceae, ist die ceder von tillana, ihr Holz dient den Crbewohnern zum Bootbau. In Australien führt Cedrela toona, Familie ('edrelaceae, den Namen rote ceder. Nectandra Pisí. Familie Lamineate, wird in Franzïsisch Guiana schwarze Ceder genannt.

Lie Bermudazeder ist ein Wachholder (Juniperus bermudiana). heimisch auf der Bermulagruppe. Das Holz dieses kleinen Bammes gleicht im Ansiehen und deruch demjenigen der roten Cerler (Juniperus virginiana), ist aber härter mol schwerer. Sorgfältig getrokket ist es sehe danerhatt. Wirtt sich nicht und wird nicht rissig. Es dient denselben $/$ wecken wie das rote Cedernholz. nämlich für Bleistifte. schubtärders. Kleiderschünke. Kirchenmöbel und zum Bart kleinerer Schiffe.

I)ar westindische ('edernholz, anch mexikanisches und ('ubarerteruholz. in Dentshland gewöhnlidh Cigarrenkisten-Cedernholz

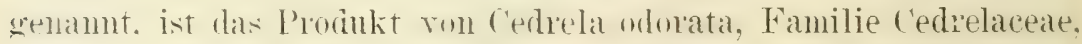
also von dinem baume. dex mit den echten cedern nicht eimmal Familienverwandtschaft besitzt. Lieser Bamm erreicht unter giinstigen Verhältnis-nen eine Höhe ron 2.t Meter bei einem Stammdurchnesicer ron 11.75 Deter' nach ren vielen kleinen Blöcken zu merilen. welche in den Handel kommen, scheint er in vielen Ge-

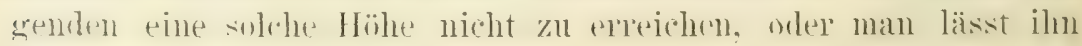
nicht zur Reife kommen.

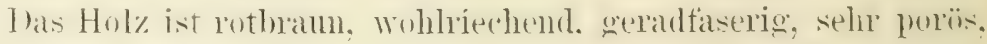
weilh. leicht. ziemlich spröd. nicht stark. sowohl was Bruch- wit

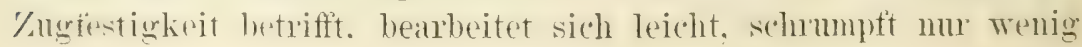


beim florknen. nath diesem Vorgange schrumptt und wirtt es sich nicht. - llie Blïcke sind oft mit erosien kermissen behaftet. Das spezifische Trockengewicht ist etwa 0,440 .

An allswedrhntesten wird dieses $1101 \%$ zn (igarenkistchen

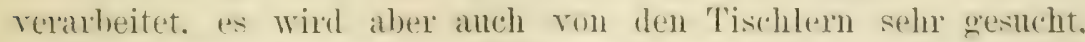
weil es seines angenehmen Wohgertheses wegen sich rorziglich zul Ausfïtterung von Komoden. Kleiderschränken. P'ulten und Luxnskii-tchen eignet. Modelle, spielsachen, schnitzwerke und viele kleine Artikel werten massenhaft ans diesen Holze wefertigt. Ganz besonders emptehlenswert ist dasselbe fïi gelochte Werkzelobebilter. In einen Klotz dieses Holzes werden Lïcher gebohrt. gross genug. um dic schmeideteile ron líeisseln, Bohrer u. s. w. aufzunehmen. In den Löchern schwitzt manseresetzt das feine öl aus. welches dem Holze seinen Wohlgeruch rerleiht, und bewahrt die Werkzeuge vor dem Verrosten.

Da dieses Holz ein jederzeit lebhaft begehrter Handelsartikel ist. sollte der schnellwachsender Baum Beachtumg finden fïr die tropische Forstkultur.

\section{Europäische Hölzer.}

Yit diesem thichnitt wird nur eine kurze Übersicht der wiohtigeren emopäischen Hölzer bezweckt. lediglich zm Abrundumg eines (resamtbildes der Hölzer der Frde. welche für Handel und Industrie Bedeutung haben.

\section{E i c h en h $\ddot{0} \mathrm{l} z \in \mathrm{l}$.}

Lnter den emonaischer Eichenarten spieten (puerens pedun(ulatta (sommereiche) und Qu. sessiliftora (Wintereiche) die weitaus wichtigsten Rollen. Manche Botaniker halten es noch nit Limné mol wollen die heden Bämme nur als spiefarten einer Art be-

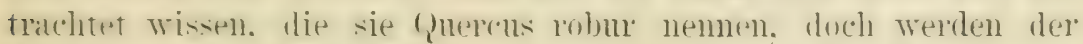

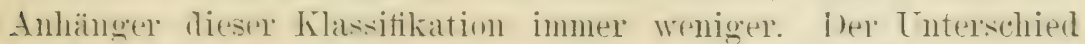
zwischen den beiden Arten besteht darin. diss die sommereiche

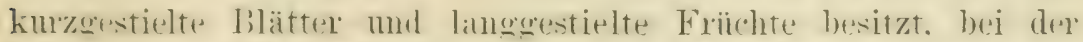

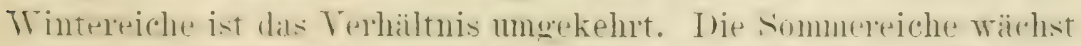
scheller wie die Wintereiche, welche dagegen eine längere Lebens-

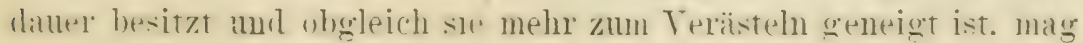




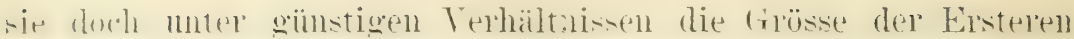

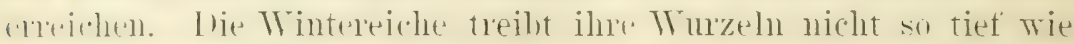
die sumnerefoles. sie berorzugt als Thohmung das Gebirge. Wälnend die and:re anf Torbergen und in somigen Thälerm am fremdigsten gedeiht.

England hesitzt eine Eiche. die manche Botaniker als eine spiedat der Wintereiche betrachten. andere erkemen in iln eine besondere Art. mit dem Samen Qu. pubecens. Dex Volksmund nemnt sie Dumastriche. Die untere seite der Bläter ist etwas flammig. das ist die rinzige antallende ansserliche Abreichung ron der Wintereiche; das Holz aber wird für beträchtlich greringwertiger erachtet, ans diesem Grmde ist die Inmasteiche ein ziemlich seltener Baum.

Lange komuten sich die Forstlente nicht dariber einigen. ob die behauptete bessere (Plialität des Holzes der sommereiche begrindet sei, doch ist der Widersuruch rerstummt. Freilich ist der Cunterschied so unbedentend. dass ihn zuweilen die besten Holzkemer nicht feststellen kümnen. wobei man sich zu erimern hat. dass Borlen mo Klima Alstufungen der pualität berirken. Tnd dann kommt auch der Verrendungsareck in Frage. Das Holz der Wintereidhe ist wenigex zïh und elastisch und leichter spalthar wie dasjenige der commereiche. deshallo wird es zu Kü̈terarbeiten berorzugt ind da es schwerer ist. bildet es einen wertvolleren Bremnstoft. das Terhältnis ist wie 12 zu 11. Las Holz der sommerfiche ist dagegen. Weil von teinerem Giefüge. geschätzter in der Thischlerei und Wagnerei. als Bamaterial ist es jenem etwas. aber nicht viel überlegen.

Ific anch die Vurgleiche im Einzehnen ansfallen mïgen. im allgemeinen wird dem Holze dex sommereidehe der Torlang cingerämont. damit ist diese Eichenart als die mertoullste Emopals und wohl der ganzen Erde anerkamnt.

l) beiden Hïlzer beitzen diese gemenomshattichen Eigens.hatten: die Farbe des leruholzes schwankt zwischen dunkelbaum mud hellgelbbraun. dats letztele ist hat, zäls. dicht. stark.

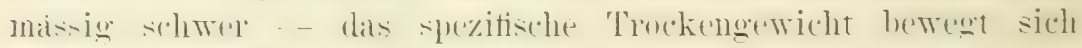
zwischen 11.730 mol 19.900 - als Hartholz leicht zu heabeitou

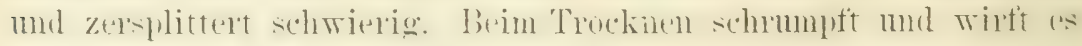
sich. aber nicht in heträchtlichem Masied. folglich kann es nicht 


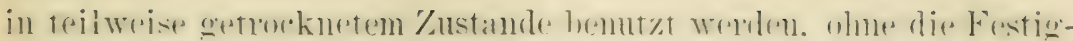
keit des Werkes zu refailnden.

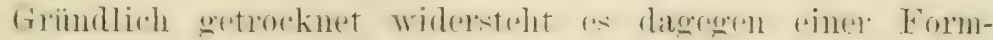

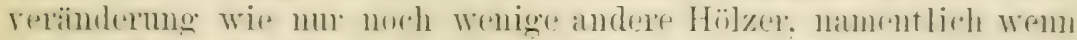

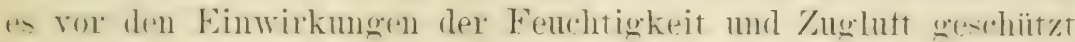

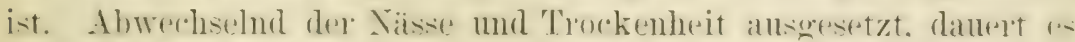

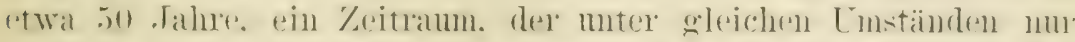

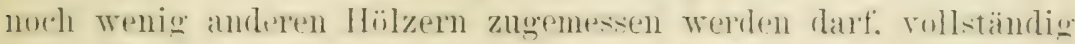

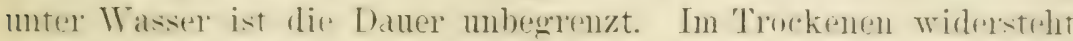

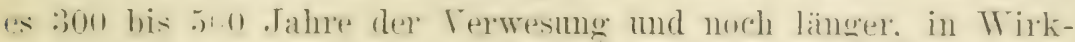

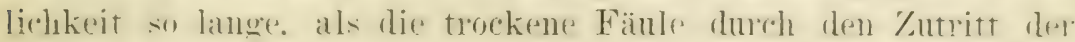
Luft verhindert wirl.

Der Splint ist heller und ron viel geringerer Dauler.

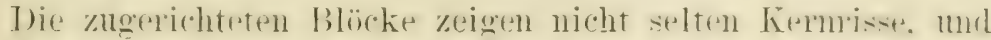

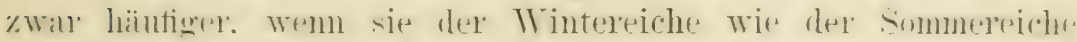
futstammen. Finn andere sichattenseite des Fichemhnlzes ist. dass

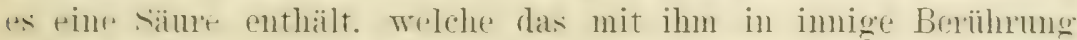
whatehte Fisen zum schnellen Telosten bringt. wäblend gleichzeitig dir hetreffend, Hulzstelle mïrbe wird. - Jiu Verwandmugen

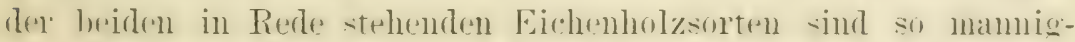

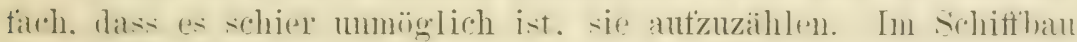

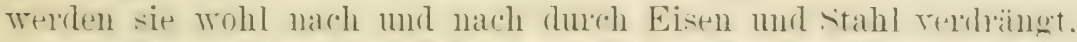

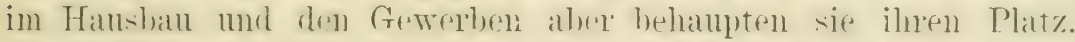

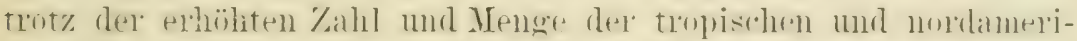

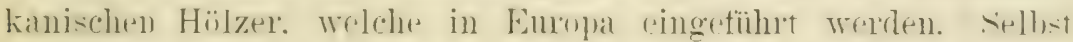
als Luxusholz ist dem lüutig vorkummenden gremaserten Eivhen-

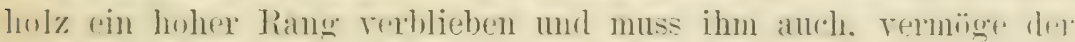
ihm beimohnenden holen Schönheit. vexlleiben.

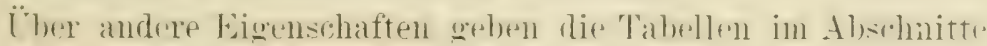
iiber die Holzkunde Auskunft.

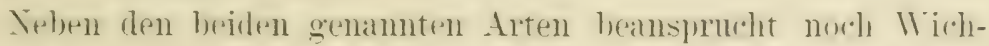

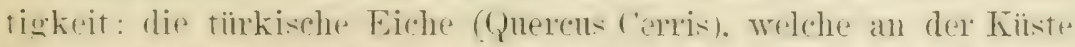

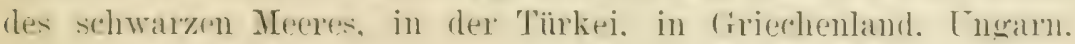
Italien und. Sïlfrankreich rorkommt. Dieser baum ist nalıent

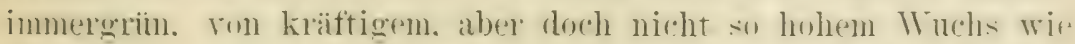

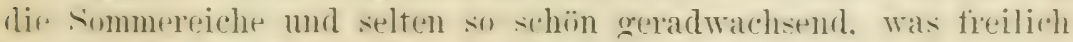
tiïr ren schiftbau als Torteil hetrachtet wird. Dir. Rinde ist

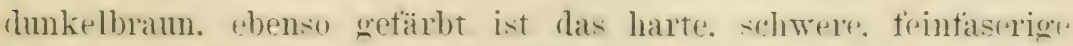

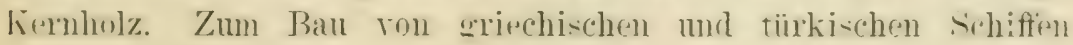


wind is allswerlent reprendet, anf den englischen Werften fand As dateren wenig Anklang. dahex es bei den mehrmals wiederhn|t'n Finführungrersuchen blieb. Als Grünter werden angegeben: bie blïcke zeionen nirht allein die bei allen Eichenhölzern rorkommenden Ke'muisse. sondern auch Oberflächentisse, die möglicherwoise durch sorefiltigeres Trocknen rermieden werden können. was aber natiolich die Käufer in ihrem Urteile nicht beeinflusste. Furner wole geklagt, das Holz sei schwierig zu bearbeiten. weniger damerhaft. Wenm dem Wetter allsgesetzt und weniges elastisch wir das sommor- mol Wintereichenholz. Lagregen wurde willig zugetanden. «e den Letztern gleich zu achten in der Tischlerei. d) dunkle Farde. die Fähigkrit, eine feine Politur anzmehmen. die hervortretenten Markstrahle'n und die häntigen. schönen MLasern lassen es zu M[öbeln sehr geeignet erscheinen.

I) immergüne Fiche viidemopas. anch stemeiche genamnt

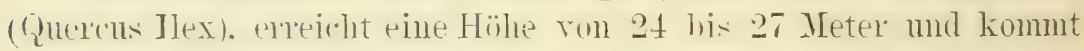

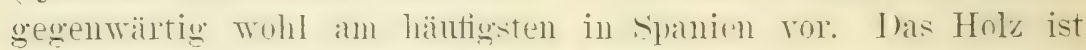

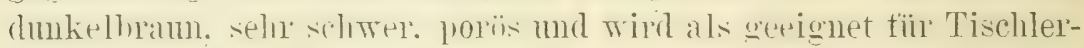
arbeiten wie zur fohlenbremnerei hezeichnet. In Fngland. Wohin

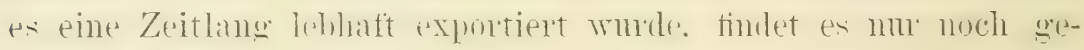
ringe Nachfrage. Wan tadelt an ihm, dass es beim Trocknen

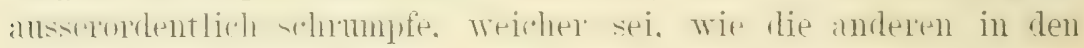

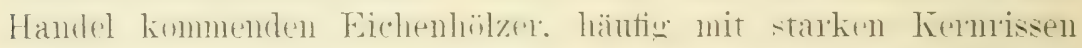

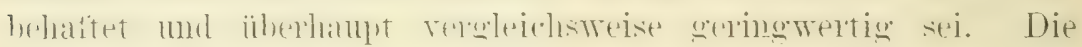

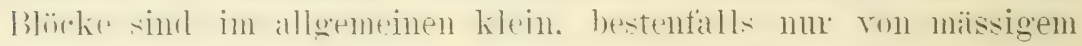

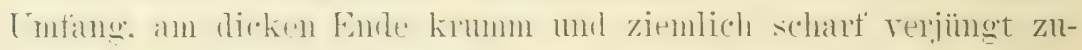
latufend Eigensolatten. dit ahentalls nicht emptehlend sind.

Eine Wohnumerenosin de: immergrimen Eiche ist die

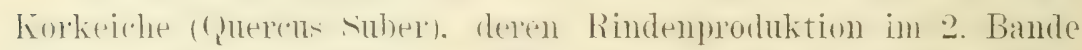
der tropischen derikultm antührlich geschildert ist. Inas Holz int rothram. s.hwer und zäh, la die stämme knuz sind. kamm es al: Bamholz kring Terwendung finden mu weil es sich leicht wirft. auch als Wekholz nicht. Im sichifthan hat es sich als schr dauedhat erwiesen. vorausesestzt, dass es beständig unter Iasser blieh mol nicht mit Fisen. sondern mit himpter verklammert whole. Es borme sut, dats Holz anderer Eichenarten wird aber fïr diesen rwerk höher geschätzt. Die beste Terwendung findet es wohl in der Kohlenbremnerei. demn es liefert ungefähr 18\%, Kohlen. die als vorziiglich gelten. 


\section{Wa $1 \mathrm{ln} u \mathrm{ss}$ h 0 l $\mathrm{z}$.}

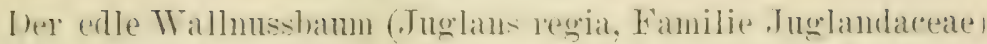

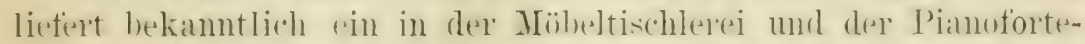

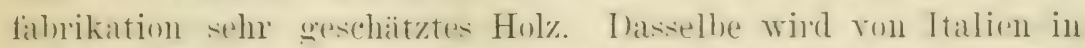

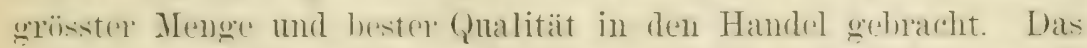
italienische. Wallutssholz ist lichthraun, dicht- und feinfiseriog. oft schön gemasert und schwarz geadert. Es ist hart. schwor. fest und zoigt beim Trocknen kam eine Yeigmg zum Reisen. (iewïlnlich wird ws in Planken expontient. 1,5 bis :3,5 Mreter lang. 1).2.) bis (1.50) J[eter hereit. und 0.10) bis 0.20 Meter dick.

Ton der Küste des schwarzen Veeres wird Wallnussholz in Blicken, 1.8 bis :3,1) Meter lang mel 10.25 his 0.t0 Meter im fievient. expurtist, das im Aussehen rem italienischen sehr ähnlich ist. aber von etwas geringerer Qualität erachtet wird.

leer Verkatuf tindet teilweise nath ferwicht. teilweise nach Mass statt.

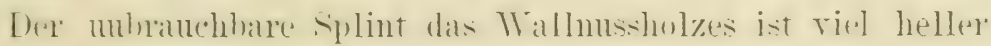
wie das Kernholz und selten ïber 2 Zentimeter dick.

\section{Erlenhol z.}

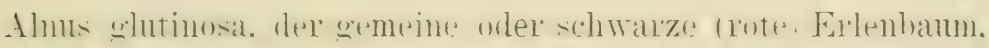

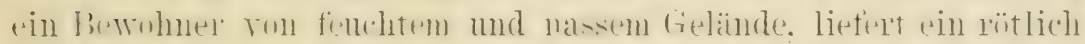

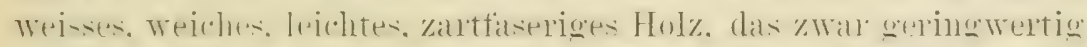

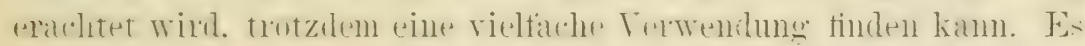

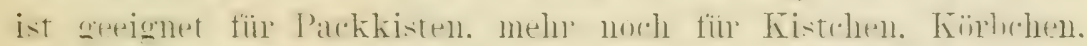

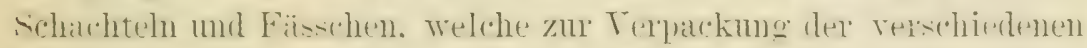

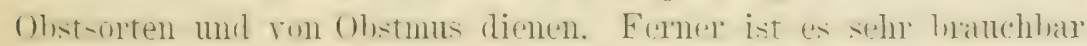
zu spulen und Holzsehuhen. Ferberhaltem mo spielwaren. Zn

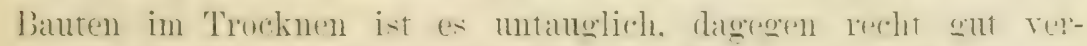

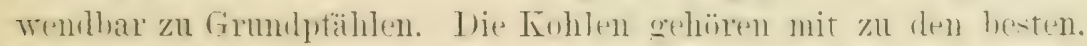
fiir die Fabrikation von Pulver.

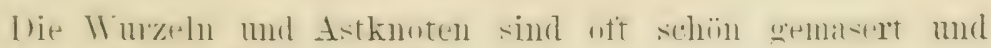

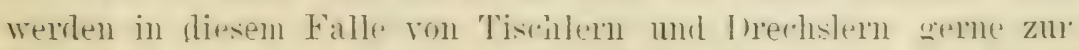
Fertigung kleiner Artikel benutzt.

I) weisse Er!t. (Aluls incana), so genamut wegen ihreer weisen Rirde. kummt seltener wie die schwarze Erle vor. das Holz der beiden Arten stimmt fast überein. 


\section{Eschen holz.}

Der "uropaischen Esche (Fraxinus excelsior') ist schon an mehremen stellen dieses Buches gedacht worden. Das Holz ist strulichweiss. mässig schwer und hart. sehr gleichmässig in der Faser, zäh. elastisch und leicht zu hearbeiten. Dem Zimmermann hiun es hädstens zu untergeordneten Zwecken dienen, seiner bedentenden Biegsamkeit wegen: für den Bau rom Tagen und landwirtschaftlichen (ieräten ist es dagegen mschätzhar. denn grodumpft kamn es in jede Form gebogen werden. ohue Beschädigung der Fasern. Das junge Holz ist rorzüglich geeignet zu Fassreifen. groben Korbwaren. Lanzenschäften und manchen Drechslerartikeln.

Es ist dem Eschenholz eigentumlich, dass kein augenscheinlicher Unterschied zwischen Kernholz und Splint besteht. and (1)sleich der letztere in Wrirklichkeit rorhanden ist. braucht er nicht als unbrauchbar rom Kermholz getremt zu werden. Wrird da: Eschenholz zur Zeit der Saftruhe gefällt und gründlich getrocknet. ist es ausserordentlich dauerhaft. andernfalls gehört es zu ders schnell verderblichen Hölzern.

Zur richtigen Behaudlung des Eschenholzes gehört, dass es sufort nach dem Fällen in Bretter, Bohlen oder Balken rerschnitten wird, demn wenn die Stamme nur eine kurze Zeit rund bleihen. bedecken sie sich mit Rissen, die einen bedentenden Abfall hei der späteren Verarbeitung rerursachen. Das erste Anzeichen des heginnenden Terwesung ist der Farbenwechsel ron graulichweiszul schwärzlichgrau. Es ist deshalb in Erimnerung zu halten, dass

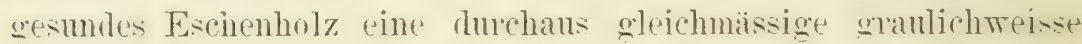
Farbe besitzt.

Über andere Eigensehatten geben die 'labellen im Abschnitte iiber die Holzkunde Auskunft.

5. Buchenholz.

Europa hesitzt nur eine Buchenart. die Rotbuche (Fagne sylvatica), denn die Weissbuche oder Hainbuche ist im wi-senschaftlichen simne keine Buche. Das Holz der Rotbuche ist lichthram. hart. mässig schwer, ron dichtem. Qleichmäsigem trefïgte und feiner Faser. Es läsist sich leicht spalten und zeichnet sich durch viele klfine Poren und dentlich laufende Markstrahlen aus. 


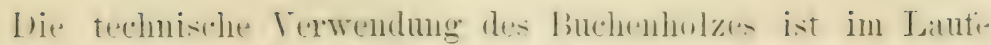

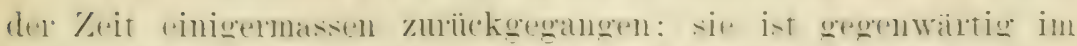

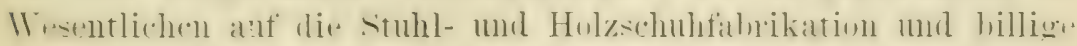

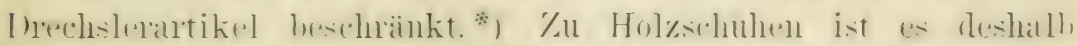

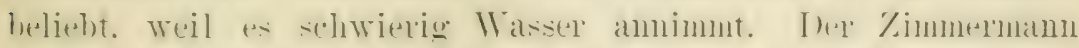

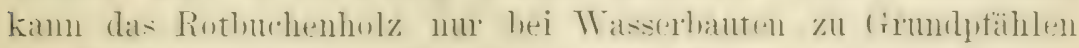

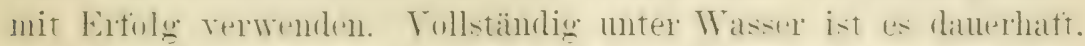

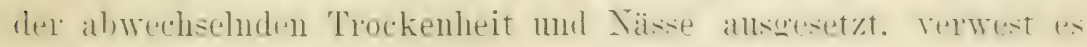

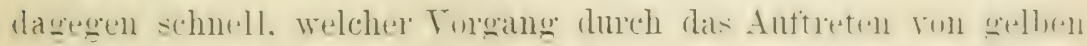

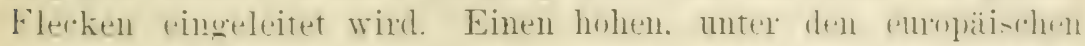

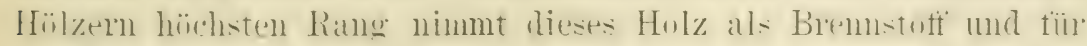
die Kohlenbrennerei ein.

Das spezifische 'l'rockengewicht beträgt etwa 0,705.

6. Birkenholz.

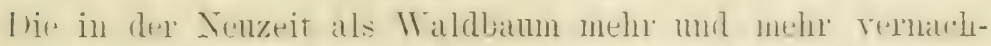

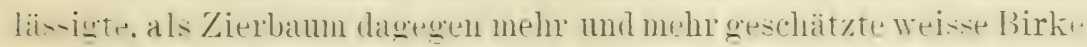
(betula allad produziert ein lichthames. mässig hartes. gerarlfilstiges. Leicht zu bearheitendes Holz. Da es werler statk nurh lantrhaft ist. kann es zu Banzwecken nicht vepwendet werdent. sombern nul zu billigen Tischler- und Drechslelarbeiten. Zun eilen finden sich sehr schön gemaserte stöcke. dit zu elesanten Mïheln

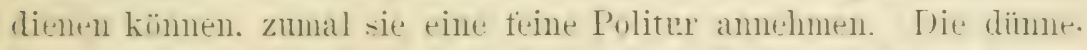

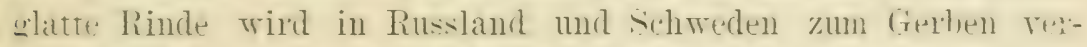
womlet. Das surifiche Trockengewidht des Holzes ist etwal 11.7u1.

7. Kastanienholz.

Der edle Kastanirnbaum (Castanea rescal) ist hereits an anderen stellen besprochen worden. namentich in Bezug auf den schlagholzhetrieb. I as Holz ist hram. mässig hart mul schwer. feinfistrig und ziemlich poris. Tie Markstrahlen kömuen nicht dentlich rerfolgt werden. der splint ist augenscheinlich nicht rom hern-

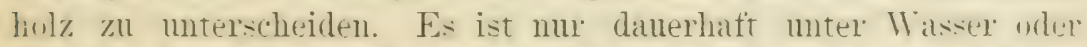
in der Erde. deshall, wird es zu Grundpfählen. schlensen u. s. w. benutzt. gelegentlich findet es anch in der Tischlerei Terwendung. Vergleichstreise ist es rin untergeordnetes Holz, am häutigrten wirel (s) wohl als schlagholz zu Rebptählen und Hoptenstangen benutzt.

* In nicht aussichtslosen Bestrebungen zur erfolsreichen, stïhieren Bunutzung des Buchenholzes in den holzwerarbeitenden frewerhen fehlt as in der netuesten Gegenwart erfreulicherweise nicht. H. H. 


\section{Ulmenholz.}

Funplat besitzt drei Ulmenarten; die eine, die Bergulme (Chmus montanal, hat aber nur eine beschränkte Terbreitung, am häufigsten wird sie in England und schottland unter dem Namen Iyrhelm grefunden. Die gewöhnliche C'lme oder Rüster (J'lmus (ampestris) licfert ein Holz: bram, mässig schwer, hart, zäh, porös nurd rom gewundener Fasermug, welche das Spalten fast mmö̈glich und die Bearbeitung schwirrig macht. Die Markstrablen sind mit nacktem duge nicht zu erkennen. Tenn inmerwainend me II asser oder vollständig trocken gehalten, wird das Thmonholz an Danerhaftigkeit kanm von einem anderen Holz iihertioffen, digegen verwest es ziemlich rasch. wemn abwechselnd der Trockenheit und Xässe ansgesetzt. Wemn die natürliche brame Farbe in Gell, überzugehen beginnt, setzt die Terwesung ein. was schon nach 10 his 12 Innaten stattfinden mag. wemn die frisch gefïllten Blöcke dem Wettex ansgesetzt bleihen. Mit Kernrissen sind die blöke fast nie behattet. dagegen haben si. zuweilen Astlöcher, welche bei der Terarbeitung stören. Der Splint ist gewöhnlich 4 bis 8 Zentimeter dick und ebenso brauchbar wie das Kernholz, der Abfall bei der '/urichtung der Blöcke ist daher mbedentend. Solten kommt dieses Holz in Form von Bohlen mad Brettern zur Terwendung, wem es aber geschieht, sollte die Terschneidmo der Blöcke umittelbar vor dem Verbrauche stattinden, da Bretter und Bohlen sehr leicht zum Trerfen geneigt sind. Wemn es notwendig ist, Llmenholz rorrätig zu halten. bewahrt man es am besten im Wasser auf.

Da sich das T'menholz nicht spaltet. findet es die rorteilhafteste Terwendumg zu Gegenständen, welche starke Stösse anshalten müssen. wie Radnaben. Ambosblöcke, Keile, Hämmer, Maschinenträger l. s. W. Es wird aber auch zu Pumpen. Röhren, Grundpfählen. Drechslerarbeiten und selhst in der Tischlerei benutzt.

Das Holz der Bergume ist lichtbram. etwas porïser und ceradtaseriger wie das der gewöhnlichen Ulme. zäh und nässig liart. Da es sich gedïmpft sehr leicht biegen lässt, ist es in lebhafter Vachfrage für den Boothan. Ausserdem ist seine Verwendung so verschiedenartig wie die des gewöhnlichen Thenholzes. 


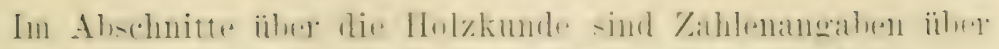

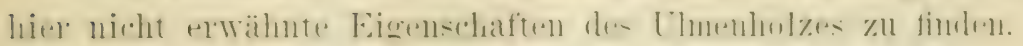

\section{Ha inbuchen holz.}

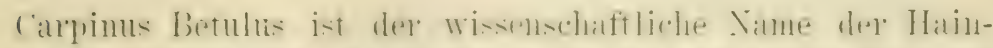

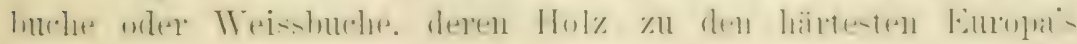
gehört.

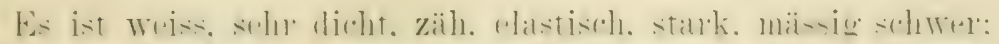

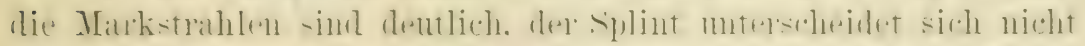

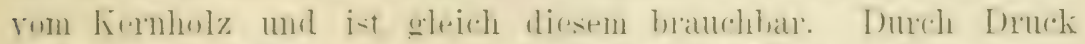

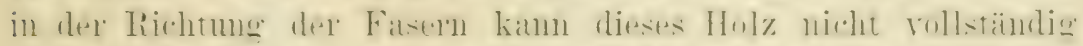

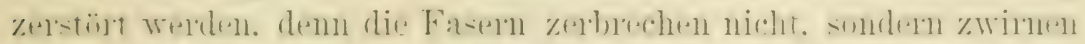

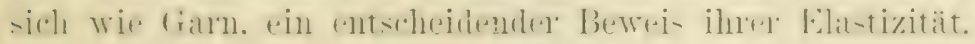

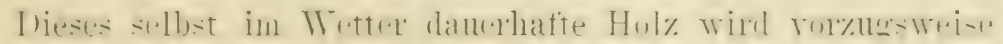

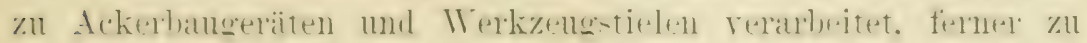

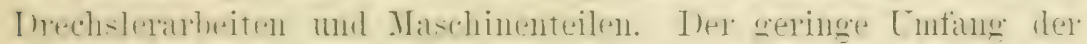

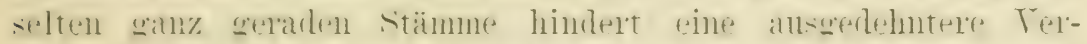

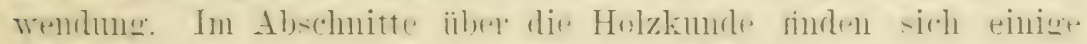

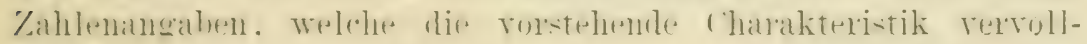
ständigen.

\section{Aspenholz.}

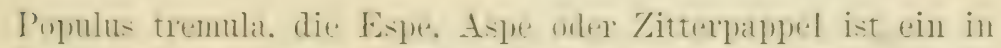

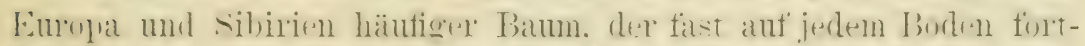
kommt und einen geraden lis zu :30 Metel hohen stamm treiht.

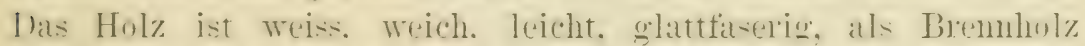

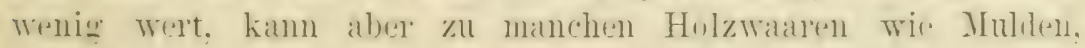
Barktrïgen. spulen und andreren Indechselarbeiten verwendet

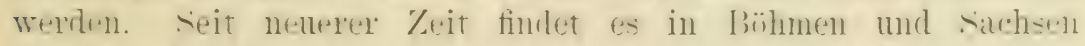
rine ziemlich beträlotliche Bentumg in der syanflechterei. zu

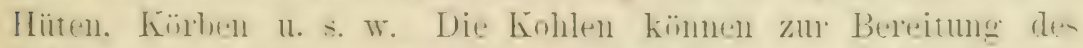

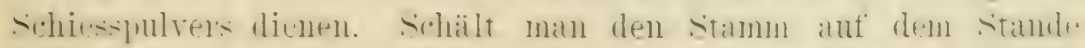

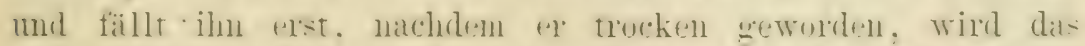

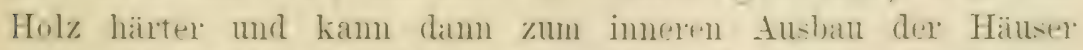
verwendet werden. In diester Hinsicht ist der Bam fïr manche

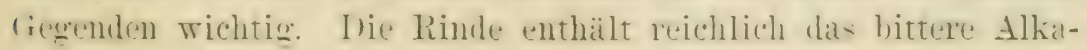
loid Salicin. 


\section{A hornhol\%.}

Europa besitzt 6 Ahornarten, von welchen 3 so zwergig hejben. dass sie von den Waldbäumen allszuschliessen sind. Die :) hanmtïmigen Arten sind: 1. der Feldahorn. Massholder Acer (ampestre). mit mässig starkem Stamm und abgerundeter Krone. seine durchschnittliche Höhe beträgt etwa 10 Meter; 2. der gemeine, weisse Bergahorn (Acer Psendo-P'latants), einer der schönsten Bämme Europa's. der 20 bis 25 Meter hoch wird and a bis 10 Meter astfei bleibt: 3. der spitzahorn (Acer platanoides), der ebenfalleine Höhe von 20 bis 25 Meter erreicht.

Das Holz der drei Arten ist sich sehr ähnlich. es kann im Allgemeinen danin charakterisiert werden. dass es woiss, geradfiserig. zäh, mässig hart mul der Witterung alsgesetzt, ron greringer Danerhattigkeit ist; sorgtaltig getrocknet, besitzt es die schätzensweite Eigenschaft, sich nicht zu werfen noch rissig zu werden. Zu Bauten ist es mutaglich, dagegen ist es ein guter. derm Bucheuholz an Wrert nahe stehender Bremnstoff. In den Gewerben wird es hautsächlich zn Drechslerartikehn, Mulden. Rechen. schaufeln. Togelkätigen. gelegentlich anch zu Fensterahmen mul 'Thiuren verarbeitet.

\section{Ki intel ll lo l \%}

In Dentschland werden die beiden heimischen Arten der (iattung Pinus: P. sylvestris und P. montanal als Kieferm oder Föhren bezeichnet. In einigen Gegenden führt erstere auch den Vamen Fichte. Die ausländischen Arten werden richtig stets Fichten genannt. So die zahleichen nordamerikanischen Arten. die Strandkiefer (P. Pinaster), die Schwarziefer (P. Laricio), die Ziirbelkiefer (P. ('embra) u. $\therefore$. w. Dex in Dentschland allgemein mal richtig Fichte gemannte Bam ist Picea excelsa. Lk. Die (hatrakteristischen Merkmale der Gattmog Pinns (Kiefer) sind: phiemliche Nadelblätter. mämnliche Blütenkïtzchen mit gedrängten schuppen. jede mit 2 Staubbentelfächern auf der immeren Seite. weibliche Bliitenkätzchen kuz, bestehend aus dichten schuppen. jede mit 2- Samenknospen, deren Mumd abwärts gerichtet ist. Frucht ein kegeltörmiger oder rundlicher Zapfen. bestehend ans mehr oder weniger rerholzten dachziegelartig sich deckenden schupper, jede mit ב- geflitgelten simen. Diese grosse Gattung 


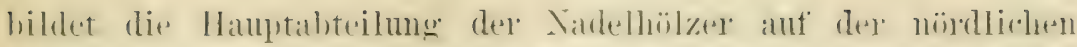

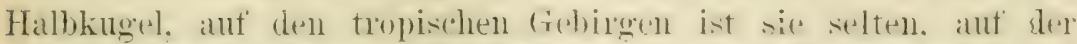
sïdlichen Halbkugel fehlt sie gilnzlich; datalls erhellt wie werlog

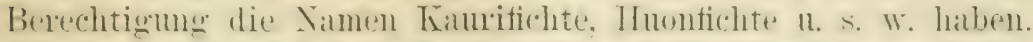

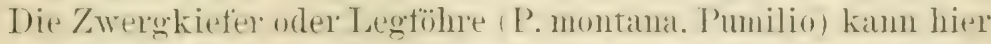

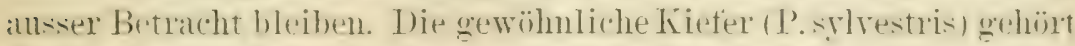
zu den wichtigsten Waldbiumen Dedutschlands. in Notdeleutschland herrscht sie sugall entschieden vor: unbedenklich dillt se als die wertrollste emopäische Art der (rattmo Pints bezeichnet werden. lats Holz ist weiselich. mit einem schwathen. rötlichen Hatuch.

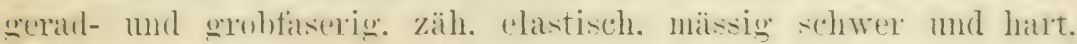

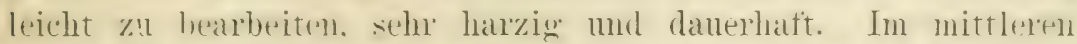
mol nördlichen Europa ist es das am häuforsten gebrauchte Bauholz:

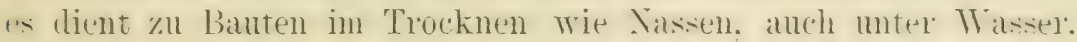

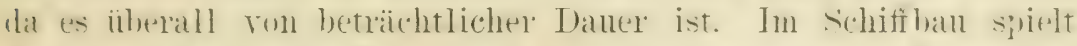
a eine bedentembe liulle und ansehnliche Mengen dienten zu Bahnschwellen und Telegraphenstangen. Za Bohlen. Brettern uni Latten rerschnitten. wird es zu Zwecken rerbrancht. so verschiedenartig. dass sie sich der Antzählung entriehen. Als Bremstoff nimmt es unter den weichen Hölzern winen hohen Rang cin. für die Teerluereitung ist ihm kein anderes emopäisches $\mathrm{Holz}_{\mathrm{n}}$ ehenbiutig: Als Vachteil ist die betrïchtliche Diche des splintes zu bezei"lmen. derselbe ist etwas heller wie das hermbolz und so schwach. dass er vollständig ron den blöcken entfernt werden muss. Wem diese zu Bauzwecken dienen sollen. Bei rlex Verschneidung zu Bretter'n und Bohlen wird es dagegen mit der Futfermung des splints nicht wenan genommen. Fnoten mol Kermrise sind Fehler dieses Holzes. welche seltener oder häutiger auftreten. je nach der sorgfalt. mit welcher der Baum hultivint und die Blöcke getrocknet wurden.

Als ein rorzilgliche spielart dex gewïhnlichen Kiefter wird die Rigakieter (P. sylvestris var, rigensis) in forstmämischen Freisen beztichnet, weil sie vollkommen gedad witchse. ihre dïnneren $\ddot{A}$ ste höher ansetze wie die Grundform und ther wie diese zur Reife gelange. In den Teilen der russischen Ostserprovinzen. fiir welche Riga Verschiftungshafen ist. bildet sie all:gredehnte Wälder. Das mag so sein. Indessen ist an die Thatsache zu erimnern. dass auf dem massgebenden londoner Marktr dats ab Danzig rerschiffte Kefefernholz etwas höher geschätzt wirt. 
wie lats ab Riga verschifte. Die Erklärung wird wohl weniger in der spielart als in den Einflïssen rou Boden und Kilima zu suchen sein.

T̈her weitere Eigenschatten des Kiefermholzes sind die Tahellen im Alschnitte über die Holzkunde nachzulesen.

\section{3. 'T a n n en holz.}

Es lässt sich darüluer streiten. Was als Tamenholz gelten soll. da es neben der Weiss- oder Edeltichte eine Rot- oder Schwarzfichte gibt. Die letztere wird indessen häutiger und richtig Fichte genannt und da sie ron neueren Botanikern einer anderen Gattung wie jent zugeteilt wurde. so sei sie hier nicht als Tamne betrachtet.

Lie Teisstanne (Abies jectinata DC oder A. alla Mill.) wurde von den älteren Botanikern der fiattung Pinus unter dem Samen P. Ticea oder P. Mhies zngeteilt. Fis ist ein schöner his 18 Meter hoher Bamm nit schnurgeradem stamm. pramidentürmiger Krome. weisslicher glatter Rinde und wagerecht wirteligen Zweigen. Die Bläter stehen zweizeilig — das ist besunder's charakteristisch für die Gattung Abies. Dic Kultur dieses bammes ist in dex Tenzeit zuritckgegangen. zu Gunsten ron Bämmen. die wertrolleres Holz liefern. Das Tamnenloulz ist weiss. mit einem rötlichen Hatuch. mässig hart und schwer; poriis. grol)- und geradefaserig. and leicht zu bealbeitell. Im Trocknen ist es zu allen Arten Banholz verwendban: in Nechsel ron Nässe und Trockenheit ist es ron geringer Daner. Die Blïcke zeigen hä̈fig Kermisse.

\section{Fic hten ho l z.}

Die Fichte, häutig. wemn auch falsch. Rot-aler schwarztame bezeichnet. wird jetzt in Thentshland Picea excelsa Lk. grenamnt. Tach anderen Botaniken hiess sie Picea vulgaris. nach noch auderen Alies excelsa. In den älesten Kilasifikationen füht sie die Namen Pinus Abies und I'. I'icear. Tedem Deutschen muss diest Nadelholzart bekannt sein. demn sie liefert das Weihnachtsbïmnchen. ('harakteristisch für die Gattmo Picea ist, dass die kurzen Nadelblätter nicht zu zwei und mehr büscheltörmig stehen wie bei del. Gattung Pinus, anch nicht zweizeili@ wie bei der Gattung Abies. sondern einzeln zerstrent um die Z Z ieige.

I as Holz ist weiss, geradfasurg, zäh, leicht, elastisch. harzien und schwieriger zu bearbeiten wie das der Fiefer. infolge der 
Härte der häntig auftretenden kleinen Asthnoten. Bein Trucknen

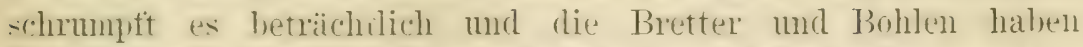

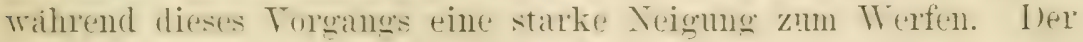
fylint ist dimmer ris bei der Kiefer, aber gerade so wernge brauchbar.

Zu Biluten ist dieses Holz mit Erfolg verwendbar; entwerlew volständig im 'Trocknen older unter. Wasser. abrechselnd dre.

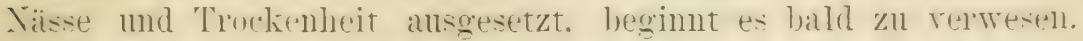

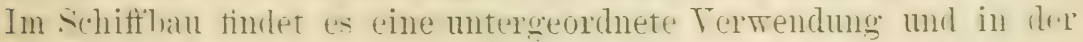
Tischlerei dient « nul zu wrlinären, billigen Arbeitru.

\section{Lärchenholz.}

Larix emopea ist die einzige Lärchenart. welehe Eunpla lw-

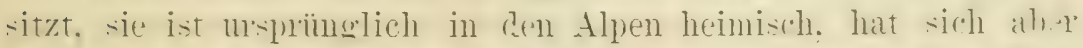

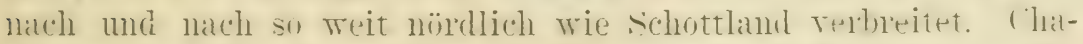
rakteristisch für diesen baum ist. dass seine in Büscheln wentneten. weichen, kurzen Vadelhlatter im Hertst abtallen. a i-t also hein immergituer Jadeholzham. Das Holz ist gelhlichweiss, zäl. stark. elastisch. gerad- mo grobfaserig. Es ist ziomlich leicht zu bearbeiten und sehr danerhaft; als Nachteile sind zu nemnen. dass es stark schrumptt während des Trucknens mul Tejomg zum Werfen zeigt. Die Blöcke zeigen selten Kermiste.

Dar das Lärchenholz ansecerordentlich danteliaft ist, den Techsel ron Vässe mul Trockenleit verträgt und eine bedeutende: Tragklaft besitzt. eignet es sich volzüglich zu Land-. Trasterund schiftbaten. Auscerlem wirt es zu Zäunen, gelenentlich auch fiir landwirtschaftliche Geräte benutzt.

Dem Lärchenbaum entstammt das renetianische Teruentin: seine Rinde ist ein schätzbarer Gerbstoff.

Treitere Eigenschaften des Lärchenholzes sind im . Hhschnitte iiber die Holzkunde in Zahlen dargestellt. 


\section{Sachregister.}

Abneigung gesen Tald

Seite

Acherbaustation Connecticut

8 Borner . . . . . . . . .

A....... .

27t. Boussingault . . . . . . 15:

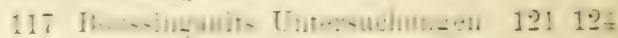

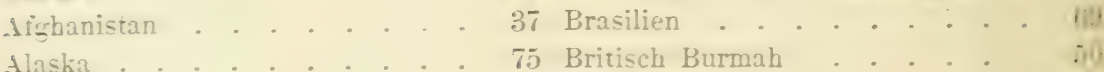

Alsier . . . . . 57 130 Britisch Guiana . . . . . . .

Amazonenthal . . . . . $12 \pm$ Brown, Forsthommissar . . 148 1:0

Amerihanische Wasserstrassen . 88 Buchara . . . . . . . : 17

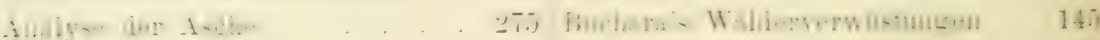

Analyse der Blätter . . . . $27 t$ Bugreaud's Lintersuchungen . . 1\%:

Anum

38 Bulgarien ........ . . .

Arabien . . . . . . 37

Arbordays. . . . . . . . 4

Arcentinieu

Californien . . . T T 129134

ช.Atholl's, Lärchenwald des Herzogs

Aufforstungsversuche im Karst . 28 A-rovitere

Australiens Entwaldungen . . 148

Anstralische Gummibäume zur Auf-

$$
\text { forstung }
$$

Australischer Holzexport.

B sneris Lntersuchungen

Balmoral, Schloss

Baumptlanzungstage

Belgien

Belgiens Holzhandel

Beludschistan.

Fequerel

Ber:amo

Blanqui
$36 \pm 7$

63

(6)

$3 \pm 14$

18

$+$

22

23

37

136

143 Deanforest.

111 | Deutsche liolonien.
Californische Forsthommission . .

Canadische Wälder

Catechu. . . . . . 144.

$59125 \%$

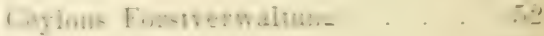

Chevandier's Lntersuchungen . . :

Chili ..... T. 1.1

China . . . . . . .

Cochinchina . . . . . . , . .

Columbia . . . . . 11 it

Congrobectien. . . . . . . in

45 
Deutsche Taldwirtschaft

1617 Genossenschattsmillder.

Dentsch-Ostafrikanische Gesellschatt 58 Gesantwert dernordamerikanischen

Deutschland 3) 1

Deutschlands Waldtinche

16 Griechenland. T) Guatemala .

Ebermeyer, Prof. Dr. .

275 Griana

70

Ecuador

Edinburger Forst-Ausstellung 18224760

Esypten .

Hartig, Professor Dr.

282

Hartigs Cntersuchungen

370

Einfluss des Walles aut die Locomotire

Hamaii

768

Heinan . . . . . . 37

Himalaya . . . . . . .

Einwirkung eler Willder auf das Klima

England

Englische Waldstatistik

Hion's Tntersuchungen ... . 3\%

Hirsebau

Uypinatives

Europa.

Europa's Wa!dtlichen

Export a Holz ron der Pazitikküste

\section{Farhiouleur}

Ferro

Feuerland

Fidschiinseln

Filhot's Analysen . . . . . $\$$ อे

Formosa . . . . . 37

Hochschule für Bodenkwltur in Wien...... . . 31

Hodghinson's Lntersuchungen . . 380 Hōss Aschenuntersuchungen . . . $43 \overline{7}$

Hollündische Folonien. . . . . 7

Holland . . . . . . 2 29

Holzbedart . . . . . . y

Holzversorsung . . . . . . 11

Honduras, Britisch . . . . . it

Hooker. Dr. . . . . . T0 15à

Hudsonsbaigesellschat . . . . 127

Humboldt . . . . . . 15े

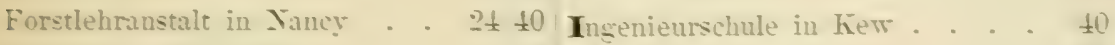

Forstschule für Indien . . . . 40 Irianl . . . . . . . . Is

- in Debra Dun . . . . 50 Indien . . . . . . 30 6 12

- im Schlosse Escurial. . . . - 26 Indiens Hungersnot in Folge ron

- in Erois.

- in Kopenhagen.

Entwaldung . . . . . 117

ลอ Indische Forstrerwaltuns . . . .

31 Indische otfene W"ilder . . . . 41

21 Indische reservierte walder . . \pm 1

5 Indischer Forstschutz . . . . . \pm 1

2: Indisches Forstwesen . . . . . 39

(9) Italien . . . . . . . $=0$

3 . 2 Italiens Waldstatistik . . . .

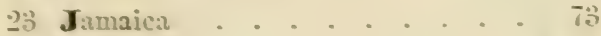

7 J:1рап . . . . . . . . อ3 5

24 Japanische Forstverwaltung . . . 55

Japanische Holztillung . . . .

5y Japanische Priservierung . . . 5

G:ambia .

1516 Tari. 
Jaranische Auftorstung

Seite

Johore

Mittleres Kleinasien

Seite

53

4950 Mahovewüste . . . . . . . 129

36

Kafleepflanzer Ceylons

v. Müller, Baron, Mielbourne

563

Kaiser Julian .

Nanquettes Untersuchungen

353

Kambodscha

Natal

Kampfer

Kapkolonie.

37

Kapländische Aufforstungen

59150

Neuseeländische Aufforstungen

66

Kapländische Pflanzschule

Karpathen .

60

Neuseeländische zur Aufforstung

60

11

Karthago

151

Kautschukgewinnung

Khiwa

37

Kloster Tre fontane

137

De Koninik, Geologe . . . . 208

Konstantinopel

151

Korea

Kugellack

Kulturwald. empfohlene Bäume . . . . . 66

Neuseeländische Forstverwaltung . 66

Neuseeland . . . . . . 56 65

Neusüdwales . . . . . 56163

Nicaragua . . . . . . 125

v. Nördlinger, Forstrat, über technische Eigenschaften des Teakholzes . . . . . . 708

Nordamerika . . . . 346

Nordamerikanische Aufforstungen . 86

Nordamerikanische Eisenbahnen . 81

La Brenne.

Leisten-und Schuhnägel-Fabrikation

Nordamerikanischer Holzbedarf für Telegraphen und Eisenbahnen . 80

Lernüasee

Libanon .

Lybische Wüste.

Nordamerikanischer Holzexport

Nordanerikanische Holzverwertung

Nordamerikanische klimatische und terrestrische 'Veränderungen

$15 \check{5}$

Iadagaskar

Madcira

Minine

Malacea, Halbinsel

Handschurei

Marcus Bull's Untersuchungen

Marcus Bull's Untersuchungen über

Heizwert und Verkohlung

Marsh

Nordamerikanische Pazifikküste, Holzreichtum

Nordamerik. Rindenproduktion

Nordamerikanische Sägemüblenindustrie

Nordamerikanische Sägemühlen-

\section{5}

355 Nordamerikanische Union . . $7 \tilde{5}$

Nordamerik. Wäldervernichtung . 83

419

Tordamerik. Wathasehintzung

Iauritius

Mayr's Untersuchungen, Heinrich Mr. Medlicott, Geologe

370

Nordamerikanische Waldbrände

Nordamerik. Waldreräusserung . S7

147

Ieguscher's Untersuchungen

Nordamerikanische Zäune

Melbourne

Nordchinas Wälderverwüstungen . 146

Forddeutsches Tiefland

Meldrum, Charles, Direktor des

Observatoriums von Mauritius . 149

Oesterreich-Ungarn . . . . . 27

Mesopotamien

37 Palästina . . . . . . 36

Mexiko

974 Paraguay

Mistral

128 Parkhurst 
Seite

Seite

Persien

37 Schweiz .

Peru

72 Schwimmfüssler . . . . . 124

Philipuinen

it r. seatield. Kiefermwald des firafen 18

Plantations

42 Seamann, Botaniker . . . . 154

Po

117 Serbien.

Portugal

26 Seroiens Schweinezucht, eine Ei-

Powell, Mlajor

83, haltung des Waldes. . . . . 33

Privatbesitz

6 Sian

15 Sibirien . . . . . . 35

Privatforsten

Prorence

116 Sidney

11 Sierra Leone . . . . . . 59

Pugetsund Sirocco.

Queensland

563 Sologne.

138

Somaliland . . . . . . 58

Raubwirtschaft .

89 Spanien.

117 Spaniens Entraldung . . . . 109

Rarenna

27 Staatsforsten

42 Stanley . . . . . . . 58

Reisbau.

150 Steinkohlenteer

Réunion, Insel

136 St. Helena.

61152

79 Stiftungsforsten

1516

Rindenextrakt .

Rissmüller's Untersuchungen

274 Stöckhardt, Chemiker 197

Rodriguez

Rohertrize ler nudamerikanischen

61 Sudangebiet 58123 sirdafrika

Wälderausbeute

77 | Südamerika

91268

Ruminien

33 ! Süảasien

34 Südaustralien.

63133

35 ! Südchina

33. Südseeinselı 12 Syrien

Sahara

San Domingo

Tartarei

San Salvador

Tasmanicn

5 63

Santa Cruz

Tibet .

Schelde

Schellack

Türkei

Schiff bau

Tunis.

Sehnalipuriere. Finnen ouler Rutisch-

Colrerfillune der Hulzmarlite.

11 Ueberfüllung europaiischer Holz-

63 märkte . . . . . . . 8 y

Schomburgh, Dr.

Schottland

Schübler's Entersuchungen, Pro-

18 Untersuchungen über die Durchschittstemperatur les Wald-u. fessor

213

Schreden und Norwegen Feldbodens . 


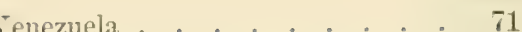

Terfügungsrecht über den Grund-

71

Wald, wilder. . . . . . . 14

besitz

Wallace, Professor . . . . . 122

Verwendung des Eisens . . . . 9 Buchen . . . . . . . . 10

Viktoria . . . . . . 5 61 Weide- und Holzschlagrechte . . 19

Viktorias Aufforstungen . . . 63 Wertheims Untersuchungen . . . 377

- Forstrerwaltung . . . . 693 Westafrika . . . . . . . . . 9 9

- Pflanzschule. . . . . 63 Westaustralien . . . . . . 62

Vülcker, D1. . . . . . . 222 Westerwald . . . . . . . . 127

Togelsgebirge. . . . . . . . . . . 127 Westindien . . 127

Wald, neuer . . . . . 17 Windsorpark, Dr, E., Gerbsäure-Unter-

Waldland, Dichtigkeit desselben . 12 suchungen . . . . . . . . 429

Wald, produktiver . . . . 14 . 15

Waldreichste Länder . . . . 15 Yuma, Fort . . . . . 122123

Waldrente . . . . 68

Waldstatistik . . . . . 14 Zentralamerikanische Republiken . 74

Waldstatistik Böhmens . . . 28 Zöller's Untersuchungen . . . . 274 



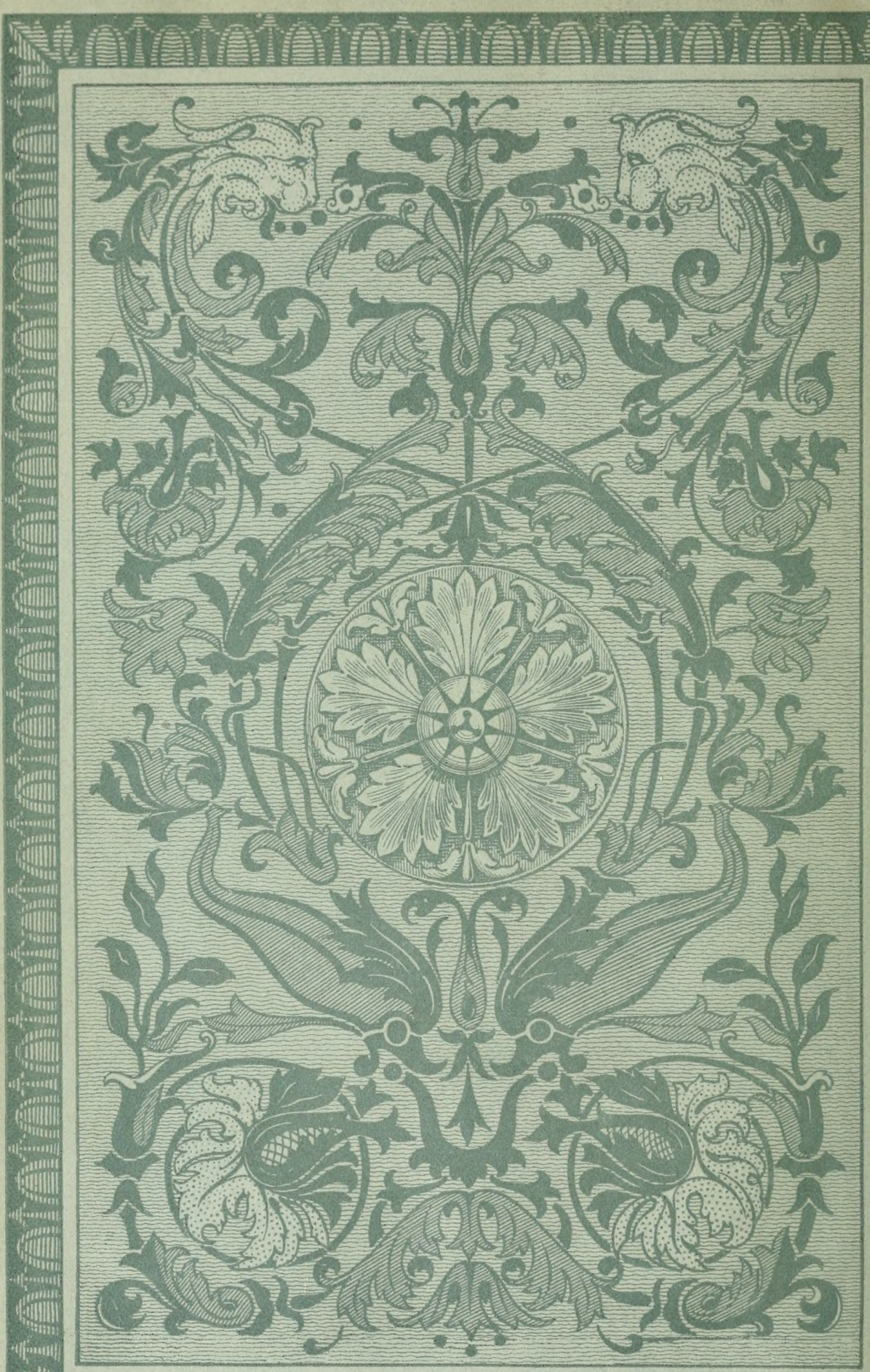




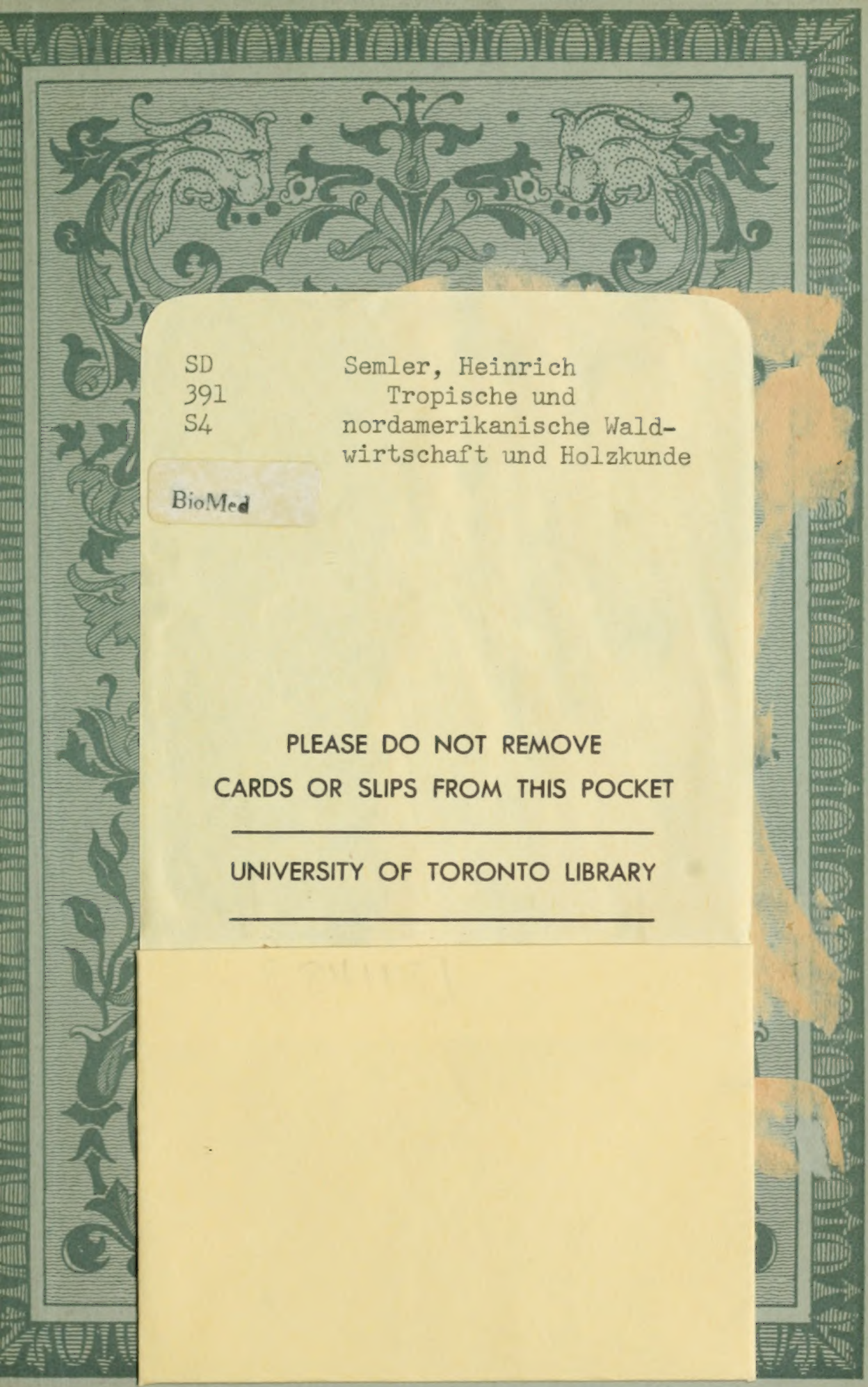


